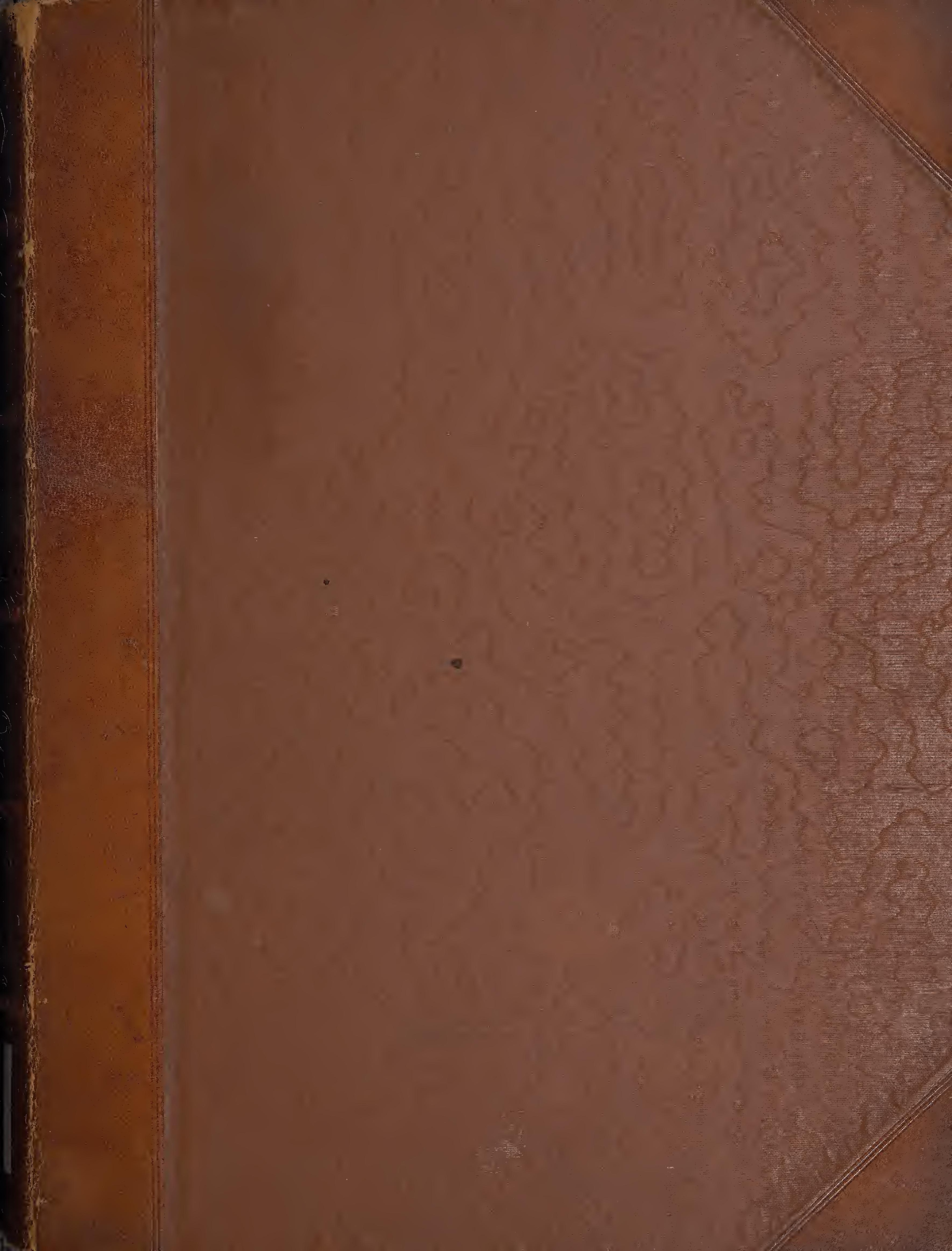



RF?IEST OF

GEORGE T. TURNER 




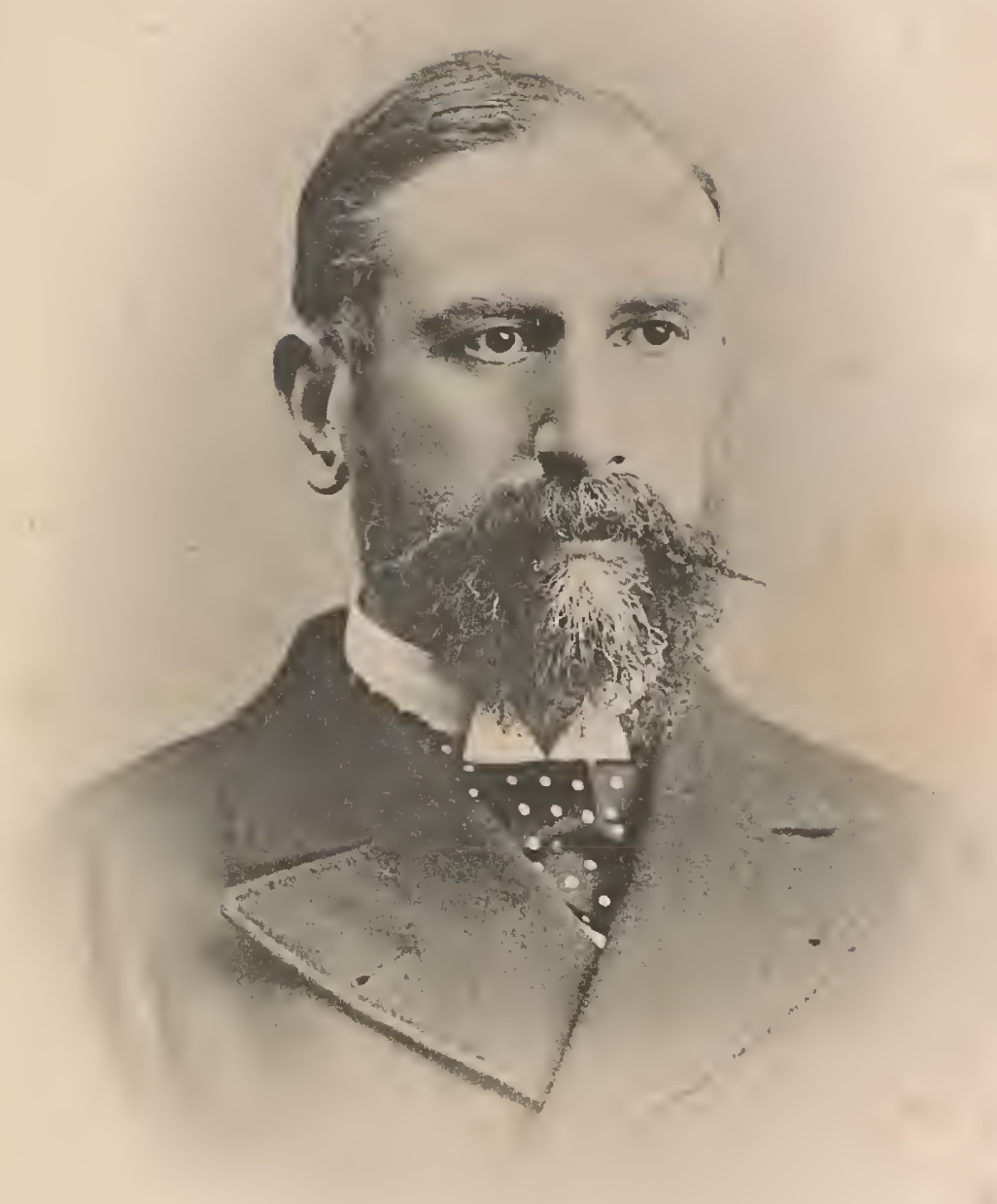

\section{The Earl of Kingston,}

ThE LATE PRESIDENT OF THE PHILATELIC SOCIETY, LONDON. 


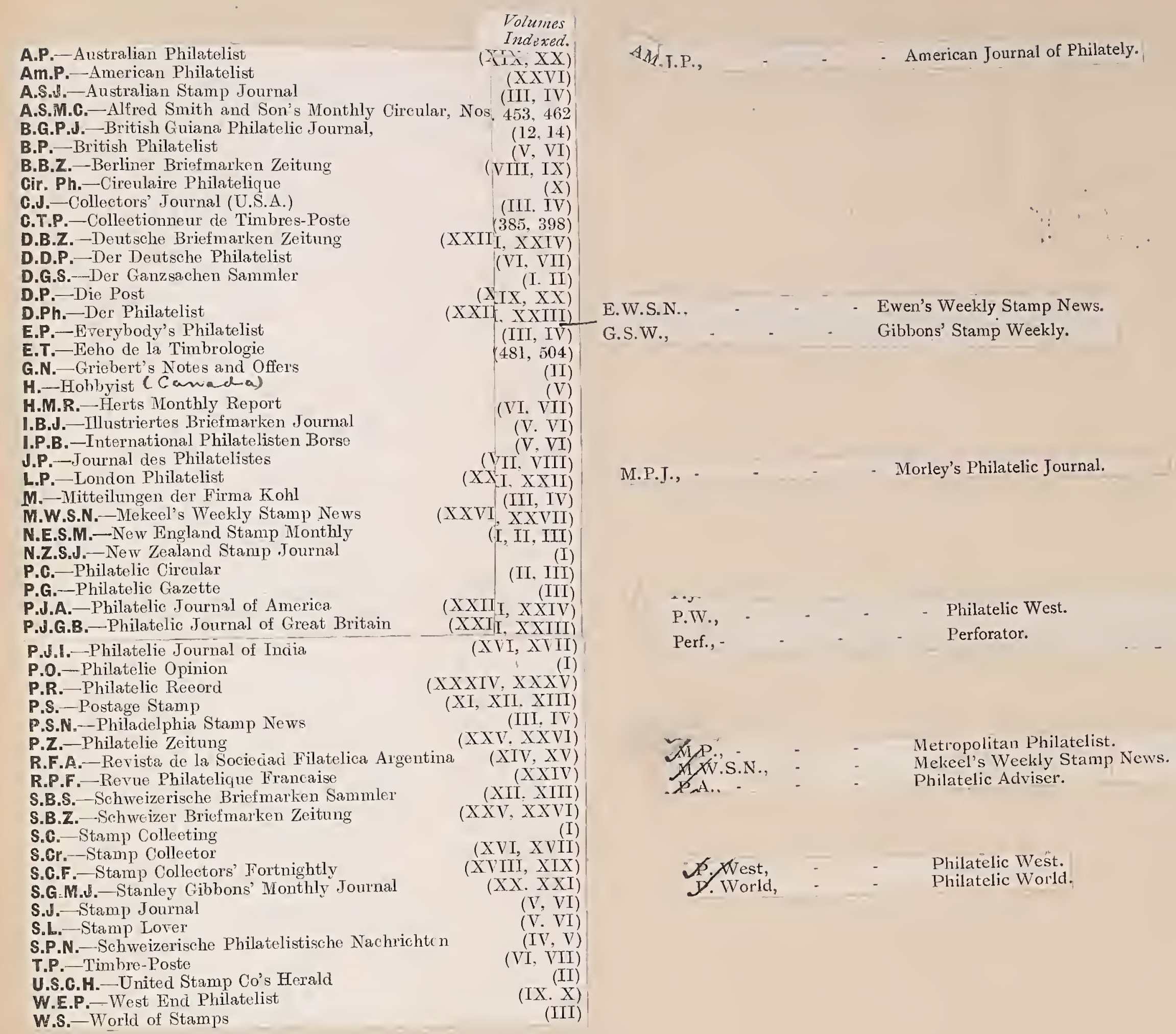

\begin{tabular}{|c|c|c|}
\hline Abbreviation & Periodical & Vols. Indexed \\
\hline $\begin{array}{l}\text { A.P. } \\
\text { Am.P. } \\
\text { A.S.C. } \\
\text { A.S.J. } \\
\text { B.G.P.J. } \\
\text { B.P. } \\
\text { C...P. } \\
\text { C.S.C. } \\
\text { K.P. }\end{array}$ & $\begin{array}{l}\text { Australian Philatelist } \\
\text { American Philatelist } \\
\text { Albemarle Stamp Coliector } \\
\text { Australian Stamp Journal } \\
\text { British Guiana Philatelic Journal } \\
\text { British Philatelist } \\
\text { Collectoro"s Club Philatelist } \\
\text { Canadian Stamp Collector } \\
\text { Rensington Philatelist (for further issues } \\
\text { see : "World-Wide Philatelist"). }\end{array}$ & $\begin{array}{l}\text { XXIX No. } 3-X X X \text { No. } 12 \\
\text { XXXVI No. } 4-\mathrm{XXVIII} \text { No. } 3 \\
\text { IX (finis) } \\
\text { XIII and XIV } \\
\text { Nos. } 33-37 \\
\text { XV No. } 37-X V I I \text { No. } 10 \\
\text { II and III } \\
\text { Nos. 30- } 33 \text { (finis) } \\
\text { II No. } 7-1 V \text { No. } 5\end{array}$ \\
\hline M.P. & $\begin{array}{l}\text { see: Wordd-Wide Philatelist') } \\
\text { London Philatelist } \\
\text { Mekeel's Weekly Stamp News }\end{array}$ & $\begin{array}{l}\text { XXXII and XXXIII } \\
\text { XXXVII and XXXVIII }\end{array}$ \\
\hline N.Z.S.C. & New Zealand Stamp Collector & $\left\{\begin{array}{l}\text { IV Nos. } 3,4 \\
\text { IV. Nos. }\end{array}\right.$ \\
\hline $\begin{array}{l}\text { P.J.G.B. } \\
\text { P.J.I. } \\
\text { P.M. } \\
\text { P.S. } \\
\text { S.A.P. } \\
\text { S.C. } \\
\text { S.Cr. } \\
\text { S.C.F. } \\
\text { S.G.M.C. } \\
\text { S.G.M.J. } \\
\text { S.L. } \\
\text { S.M.J. } \\
\text { V.P.R. } \\
\text { W.E.P. } \\
\text { W.P. }\end{array}$ & $\begin{array}{l}\text { Philatelic Journal of Great Britain } \\
\text { Philatelic Journal of India } \\
\text { Philatelic Magazine } \\
\text { Postage Stamp Philatelist } \\
\text { South African Philatelist } \\
\text { Stamp Collecting } \\
\text { Stamp Collector } \\
\text { Stamp Collectors' Fortnightly } \\
\text { Stanley Gibbors' Monthly Circular } \\
\text { Stanley Gibbons' Monthly Journal } \\
\text { Stamp Lover } \\
\text { Scott's Monthly Journal } \\
\text { Victorian Philatelic Record } \\
\text { West End Philatelist } \\
\text { Wortld-Wide Philatelist (for previous } \\
\text { issues see : "ISensington Philatelist"). }\end{array}$ & 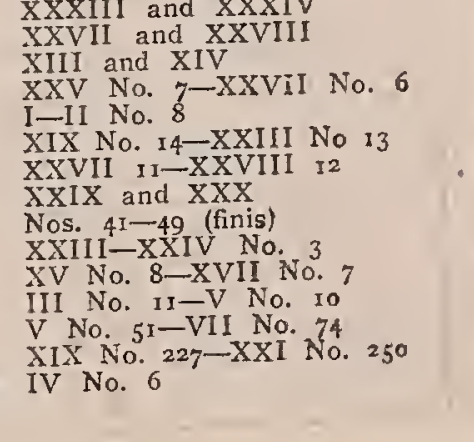 \\
\hline
\end{tabular}






\title{
LIST OF JOURNALS
}

\author{
incorporated in the following \\ Index together with the \\ Abbreviations used to denote them
}

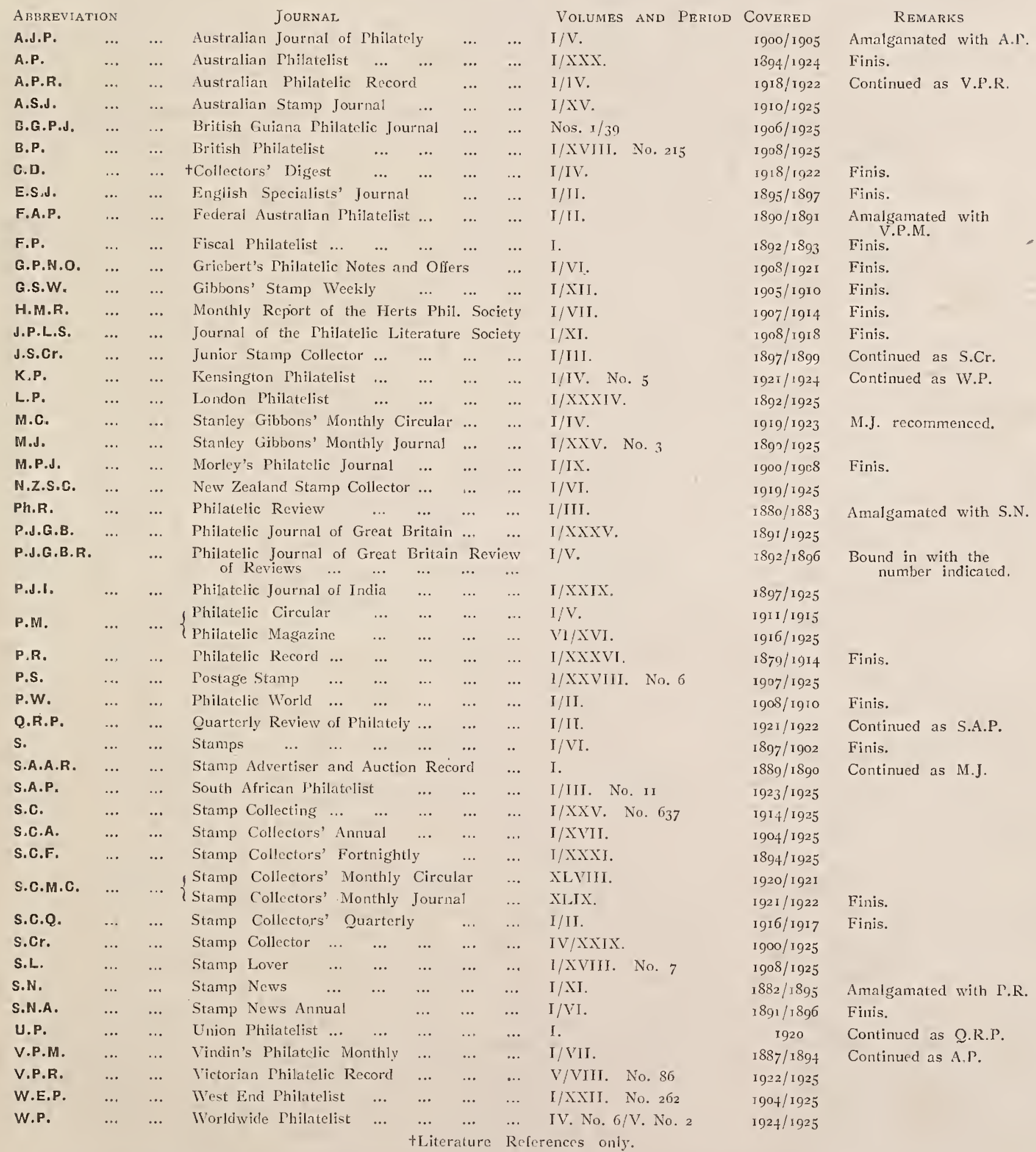

All Journals mentioned have been indexed either to their final issue or to the last issue for December, 1925 


\section{PUBLISHER'S FOREWORD}

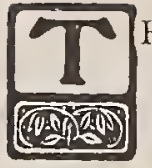

HIS INDEX has been in mind for twenty-two years. Its inception dates from $\mathrm{x} 904$ when, as honorary secretary of the Enterprise (now City of London) Philatelic Society, I prevailed upon three members (A. C. Constantinides, G. H. Simons, and the late H. W. Westcott) to co. operate with me in an attempt to index the contents of the Society's library. We each undertook to index a separate journal, by means of loose slips, according to a carefully agreed. plan. The attempt failed, as all such attempts must fail, owing to the impossibility of obtaining anything like a satisfactory degree of uniformity by this means.

Philatelic Indexing is not so simple as it would seem. It contains so many pitfalls that it would be folly to hope that the present work has avoided them all. In the first place, it involves a library. that must be more than ordinarily comprehensive; and that has been gathered together for this purpose. It also demands some experience in discriminating between academic accuracy and practical utility, since to index every shred of information would be to rival the Doomsday Book, and incidentally to engulf practical sources of knowledge in a sea of petty references, nimety per cent. of which, so far as they are of any use, have been embodied in the more important monographs and articles.

New Issue Chronicles, and Book Reviews, for example, and journals which contain practically nothing else, after careful consideration have been omitted in toto, for this very reason; and also because, so far as reference to them is desired, the period of issue and the indexes to the journals themselves, already provide sufficient guide.

It will be obvious that many handbooks are reprints of, or are based upon, articles by the same, or by other writers; and this involves different degrees of duplication of references which it is impossible to avoid.

The STANDARD INDEX TO PHILATELIC LITERATURE is a natural sequel to the modest Standard Catalogue of Stamp Books, which I published in 1924 ; and which contained, in addition to titles and authors, essential reference facts such as date of publication, number of pages, size of page, whether illustrated, number of plates (if any), of the majority of available works up to that date. All the information included in the Standard Catalogue, revised and amplified, has been incorporated in the Standard Index. But it has been enormously increased by the addition of the principal contents of a round five hundred volumes of periodicals, as detailed on the foilowing page.

The Scheme of Arrangement is strictly alphabetical according to Countries and Colonies. Under each Country or Colony, General References are given first, followed by Special References to particular issues, in the order of Stanley Gibbons' Catalogue. Finally come references to Air Mails, Fiscals, Forgeries, Postal History, Postmarks, Reprints, Stationery, and the like. The letters in brackets refer to the journals according to the Key on page 6; and the figures, to the "whole number" or where this is not indicated on the journal itself, to the volume and part (not to the page) in which the article appears. This has considerably simplified the work of compilation by minimising detail, while it is found in practice that it does not unduly reduce the facility of reference to bound volumes. When journals are unbound, it is a distinct advantage.

While handbooks published in all countries are included, the journals covered are restricted to those published within the British Empire. We are not unmindful of the importance of the leading journals of the United States of America; nor, for that matter, in other parts of the world. But to have included them would have delayed publication without corresponding benefit, for, outside one or tivo private libraries, there are no files of them in this country, and they cannot be regarded as generally available to English readers.

For the same reason, British journals which ceased publication over fifty years ago, although admittedly the original source of much that has appeared since, have not been indexed. They now contain little or nothing that has not been rendered obsolete, or has not been re-published. They are, however, covered to the extent to which special indexes to them have been published, whether in journal or handbook form, these indexes having been catalogued herein; and where such indexes, or lists of journals or works, have special reference to particular countries, they will be found mentioned under such countries.

After several previous experiments had been scrapped, work on the present lines was commenced in I923, and from time to time incomplete portions of it have appeared in the pages of The Philatelic Magazine. It was not, however, until April 1925 that I found an enthusiastic collaborator in L. A. J. Baker, who joined my staff at that time, and threw himself wholeheartedly into the task. Upon him has fallen the brunt of the work, and he is fully entitled to share with myself any credit there may be in the production resulting.

The prices given are those at which Harris Publications Ltd. can supply the handbooks and pamphlets, or in the case of articles, the complete journals containing them, subject to stock, post free.

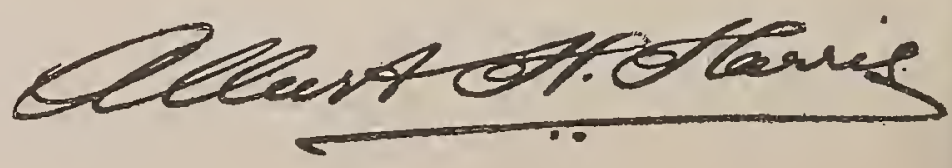






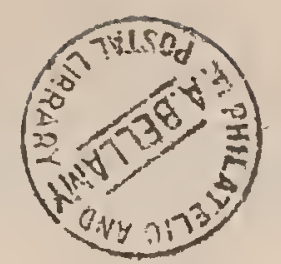

\section{PART II.}

\section{PERIODICALS.}

"A I" PHILATELIST. The "A I" philatelist. A journal for beginners as well as for advanced collectors.

Birmingham, M. P. Ford, I898. $8^{\circ} .7 \frac{1}{4}$ in. No. 1 Jan. $31,1898 . \odot 8 M$.

* The number has a coloured paper wrapper. /mite

$$
\text { Mis. St. Jour. } 81 \text { (11). }
$$

AALESUNDS FRIMAERKEBLAD. Aalesunds Frimaerkeblad. Organ for Aalesunds Philatelistklub.

Aalesund, Norge, Knud Chr. Bolstad, etc., I893-94.

(1) 4. $11 \frac{1}{4}$ in. Nos. 1-3, Oct. 25, Nov. 30, 1893, Jan. 25, 1894.

$\checkmark *_{*}^{*}$ No. 3 was published by Lauritz Math. Holm.

Mis. St. Jour. 87 (6).

ABENDGLOCKEN. A Abendglocken. Zweiter Jahrgang. [Each of the fifty-two numbers of this year contains part of an illustrated catalogue of postage stamps with the title "Briefmarken-album".]

Reudnitz bei Leipzig, A. H. Payne, 1882.

Fol. 121 in. Vol. Ir. nos. 1-52, 1882.

*** There is a title-page and an index to the volume.

ABGAR'S PHILATELIC MONTHLY AND STAMP

( IMART. Abgar's philatelic monthly and stamp mart.

$8^{\circ} .81$ in. No. 1 , Dec. 1894

Calcutta, Stephen Abgar, 1894 .

* * The contents consist entirely of advertisements.

Mis. St. Jour. 107 (3).

AÇORES. Açores.

Angra, Açores, Dias e Lacerda, 1905. ○ Fol. 13 in.' Nos. 1-3, Mar. 15-May 15, 1905.

* * This was the first philatelic journal published in the Azores.

AD TOPICS. Ad topics.

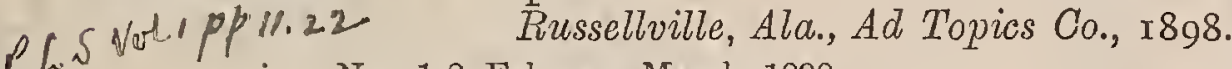
in. Nos. 1-2, February-March, 1898

${ }^{*}$ * Omly partly philatelic. Wanting.

ADHESIVE. The Adhesive. A monthly magazine in the interest of philately.

Rocky Hill, Conn., H. A. Chapman, x900-04. $8^{\circ} .8 \frac{3}{4}$ in. 56 nos. in 5 vols.

Vol. I. Jan.-Des., 1900. Nos. 1-12

" II. " " 1901. " $1-12$.

" III. " " 1902.

"IV. "

"* There is a titie-page and" a list of contents to each of the first our volumes and a paper wrapper to each number. The number or June 1901, is numbered "vol. II. no. 7," in place of "vol. II. no. 6," and the number for June 1902 is numbered "vol. III. no. 5, , instead of "vol. III. no. 6," but the numbering on the wrappers of both these numbers is correct.

A Be Fchateleco Rearstámensual Santo
1900

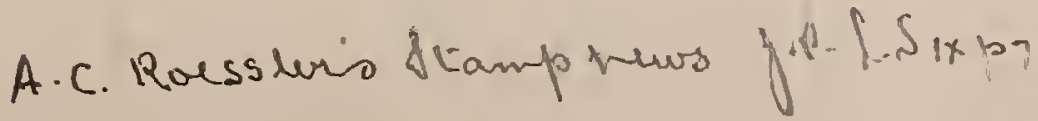

ADMINISTRATIVO, FILATHLICO Y ANUNCIADOR. Administrativo, filatélico y anunciador. Prospectus of a journal to be published by Ramirez Hermanos, Málaga, Spain, on April 19, 1904, but which was never issued.]

Mis, St. Jour. 123 (3).

\section{ADVERTISER. The Advertiser:}

Philadelphia, Pa., E. F. Jordan, ז884-85.

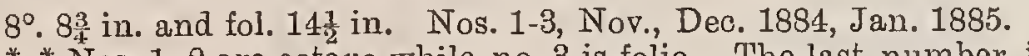
** Nos. 1,2 are octavo while no. 3 is folio. The last number is
only partiy philatelic.
Mis. St. Jour. 1 (9).

ADVERTISER. The Advertiser.

Brooklyn, N. Y., O. Curth, I896. $8^{\circ} .11$ in in. No. 0 and Nos. 1-3, April 8, 30, May 30, June 30, 1896. $8^{\circ} *$ No. No. 0 and Nus. 19 ample of what the journal was intended to be. The contents of all the numbers consist entirely of advertisements. Mis. St. Joun, 107 (12).

[Continued as :]

The Stamp advertiser.

Brooklyn, N. Y., O. Curth, 1896. $8^{\circ} .81$ in. No. 4 , July $25,1896$.

** The contents consist entirely of advertisements.

Mis. St. Jour. 107 (12a).

ADVERTISER. See AymRigan Agents' Advertiser.

ADVERTISER. See P. J. G. B. Advertiser.

ADVERTISER OF WANTS AND OFFERS. The Advertiser of wants and offers.

Handsworth, Birmingham, Philatelic Publishing Co., ז894-ז 903 .

$4^{\circ} .7 \frac{3}{3}$ in. and $8^{\circ} .9 \frac{3}{2}$ in. 161 nos. in 10 vols.

Vol. I. Jan. 20, 1894-Jan. 21, 1895. Nos. 1-16.

"II. Feb. 5, "-Dec. 22, ", " 17-35.

" III. Jan. 7, " " 19, 1896. " $36-55$.

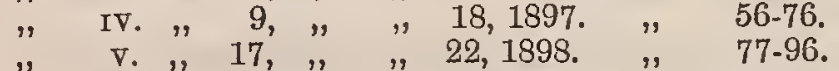

" $\quad \nabla ., " 17, " 14, \quad 22,1898 . \quad " \quad 97-96$.

" VI. " 14, " " 22, $1899 . \quad "$ " $113-125$.

" VIII. " $31, "$ " "21, 1901 . ", 126-137.

"IX. " 29, " " 20, 1902. "138-149.

*"* Xols. I.-vIr. are "quarto and vols. viIr."-x. are octavo. Nos. 128161 are printed on coloured paper and there is a coloured paper wrapper to nos. 38, 39, 41-87, 91-108, and 110-125. The number for "April 23, 1895 " is numbered " 21 " instead of " 22 ". Nos. 77-81 are numbered " 4 th year" in place of "5th year" and no. 77 has " 1897 " instead of "1898". After December, 1903, the journal was amalgamated with the "Philatelic Chronicle and Advertiser".

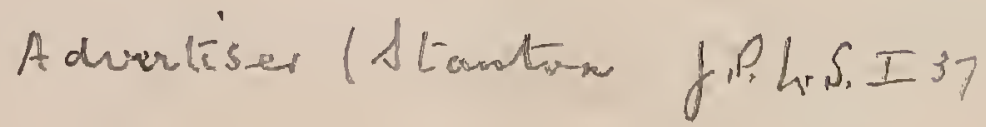


ADVERTISER'S FRIEND. The Advertiser's friend. in. No. 1, November, 1896 Stoughton, Mass., [?] ] 896 * * Only partly philatelic. Wanting.

AFFICHE ARTISTIQUE. See BuLILTIN MENSUEL DE ia Soctéte les Échangistes Réunis.

AFICIONADO FILATÉLICO. El Aficionado filatélico. [Prospectus of a journal to be published by Montesinos Baixet y Ca San Juan, Puerto-Rico, in 1896, but which was never issued.]

Mis. St. Jour. 137 (1).

AGASSIZ ASSOCIATION JOURNAL. The Agassiz Association journal.

Lymn, Mass., Wm. E. Skinner and Co., I885. $8^{\circ} .9 \frac{1}{4}$ in. Nos. 1-2, June-July, 1885

* * Only partly philatelic No, 2 has a coloured paper wrapper. * addition to the bound Not a duplica te of no 1 is bor wrapper. In addition to the bound set a duplicate of no. 1 is bound up in 1rom nos. 1 and 2 are mounted in Stamp Scrap-book, vol. v., pp. $17,18$.

[Continued as :]

-. The Agassiz journal. For curiosity collectors. Iynn, Mass., Wm. E. Skinner and Co., i 885-86. 8. $9 \frac{1}{4}$ in. Nos. 3-10, August, 1885-March, 1886. * Unly partly philatelic. Nos. 3-7 have coloured paper wrappers. In addition to the bound set, parts of no. 3 and nos. 4 and 7 are bound up in Mis. St. Jour. 135 (22a) and cuttings of the philatelic portions from nos. 3-7 are mounted in Stamp Scrapbook, vol. v., pp. 19-34.

AGASSIZ COMPANION. The Agassiz companion. Wyandotte, Kans., Will. H. Plank, r887-88. ․ 9 in Vol. II., nos. 1-9, 12, vol, III., nos. 1, 8, 10 ; JanuarySeptember, December, 1887, January, Augusi, October, 1888. * * Only partly philatelic and each number has a coloured paper * *nly partly philatelic and each number has a coloured paper wrapper. Outings of the philatelic portions of vol. 11., nos. 3-9 and $163-178$ an in 10 , ale apove are bound up in Mis. Si. Jour. 121 (14). The numbers of rol. are not philatelic.

A GASSIZ JOURNAI. See Agassiz Assoctation JoUrnaI. AGENT. The Agent.

Dubruque, Ia., [? ] I896. in. Nos. 1-2

* *nly partly philatelic. Wanting.

AGENT AND COLLECTOR'S SUN. The Agent and collector's sun. Augusta, O., A H. Myers, I884. Fol. $15 \frac{1}{4}$ in. No. 3, April, 1884

* Only partly philatelic. Successox to "Myers' Monthly Echo". Mis. St. Jour. 136 (2).

AGENTS ADVANCE. The Agents advance.

Viroqua, Wis., W. F. Cherington and Co., I895. $16^{\circ} .5 \frac{1}{4}$ in. No. 4, January, 1895.
* Unly partly philatelic.

Mis. St. Jour. 121 (1).

AGENTS' COMPANION. The Agents' companion.

8. 9 in. No. [1], April, 1887

Barre, Vt., F. S. Goldsbury, I 887 .

*.9 in. No. [1], April, 1887 . ** Only partly philatelic. The number bears "No,

Mis. St. Jour. 117 (11).

AGENTS' GAZETTE. See Agents' GazetTe and BudGET OF FUN.

AGENTS' GAZETTE AND BUDGFT OF FUN, The Agents' gazette and budget of fun.

Port Hope, Ontario, Canada, [? John Hooper], I 877. * * Cuttings of the "Stamp Department," etc for March 20th, 1877, are mounted in Stamp Scrap-book, vol. III., pp. 84, 85.

\section{[Continued as:]}

- Agents' gazette.

Port Hope, Ontario, Canada, [? John Hooper], I 877. * Cuttings of the stamp portions from the number for August,

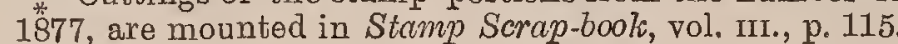

AGENTS WORID. The Agents world.

Passumpsic, Vt., H. A. Beerworth, I 886

Fol. 14 in. No. 1, April, 1886.

** Only partly philatelic. Wanting.

AGUINALDO. Aguinaldo. Revista filatélica.

(-) San Juan, Repriblica Argentina, E. Asdrubal Rodriguez, I897. Hond page of copy pruatid in gelt

C) Fol. $11 \frac{3}{4}$ in. No. 1, Jan. 1, 1897. Mis. St. Jour. 57 (6).

ALABAIMA COLLFCTOR. See SoutherN CoLtmCtor.

(Tuskegee, Ala.)

ALABAIMA PHILATELIST. The Alabama philatelist.

$8^{\circ} .8 \frac{3}{4}-8 \frac{1}{2}$ in., 3 nos. in 2 vols Mobile, Ala., Robt. A. Sheldon, I888-89

Vol. I. Nov.-Dec., 1888 . Nos. 1-2.

$O_{*}$ " Ir. Oct., 1889 . No. 1.

* No. 2, vol. I. and no. 1, vol. Ir. have coloured paper wrappers."

The prospectus of the journal, dated "Oct. 3,1888 ", is bouud up

ATBUTM The Album Vol IIT No 42 November 18 1895. [Contains an article "A chat with a philatelist"; by T. H. L.] London, W.C., Ingram Bros., I 895 Fol. 13 in. Pp. 142, 143.

* * The number has a coloured paper wrapper.

P L.S. Mis. St. Jour. 82 (8)

ALERT. The Alert. f.P. L.S $1 / 12$

Bay City, Mich., James C. McCabe, r885-86.

$8^{\circ} .8 \frac{3}{4}$ in. Nos. 1-6, Aug. 1885-Jan. 1886.

* Only partly philatelic. No. 2 has a supplem ant of two pages, and nos. 3 and 4 were published together. The journal was continued without a philatelic department, and vol. II. no. 2 whole no. 14, September, 1886 , contains a notice of the death of Frank K. Rising, the conductor of that department in nos. 2-6. Nos. 1-4 and no. 14 are bound up in Mis. St. Jour. 117 (19) and the philatelic portions of nos. 1-6 are mounted in Stamp Scrap-book vol. $\vee .$, pp. 34-38.

ALERT. The Alert. of P./.S $S 112$

Davenport, Iowa, R. and H. Kellogg, I 885 $8^{\circ} .8$ in. No. 5 , October, 1885

** Only partly philatelic.

Mis. St. Jour. 121 (9)

[Continued as :]

- Davenport Alert.

Davenport, Iowa, R. and H. Kellogg, 1885-86. $8^{\circ} .8 \frac{3}{4}$ in. No. 6, November, 1885, and vol. II. nos. 5 and 6, June, 15,1886

** Cuttings of the philatelic portions of no. 6 are mounted in Stamp Scrap-book, vol. v., p. 39 and nos. 5 and 6 , vol. II., which were published together, are bound up in Mis. St. Jour. 121 (10).

ALFRED SMITH AND CO.'S MONTHLY CIRCU- B 1600

LAR. Alfred Smith and Co.'s monthly circular. Bath, I 875-93

$4^{\circ} .10$ in. 228 nos. in 19 vols.

[ Ist year.] Jan. 1-Dec. 1, 1875. Nos. 1- 12. 2nd "] " " " $" 1876.0$ " $13-24$. [ 3rd " ] " " " " $\quad 1877 . \quad " \quad 25-36$. 4 th,$] \quad$ ] " $\quad 1878 . \quad, \quad 37-48$. 5th $"] \quad " \quad$ " $\quad 1879 . \quad " \quad 49-60$ 7 th " " , " $\quad 1881 . \quad$ " 8 th " J " " $\quad 1882 . \quad$ " $\quad 85-96$. [10th "] " [11th " ] " ", $1885 . \quad$ " 121-132. [12th "] " " " $1886 . \quad, 133-144$ [13th " ] " " " $1887 . \quad, \quad 145-156$ [14th "] " " " $\quad 1888 . \quad, 157-168$ [15th "] " " " $1889 . \quad, 169-180$. [16th ", " " $\quad 1890 . \quad 181-192$ [17th "] " " $1891 . \quad$ " 193-204. [18th " " " " $\quad 1892 . \quad$ " $205-216$.

* * The "first four years were odited by George Overy Taylor, the remaining years by W. A. S. Westoby Printed on coloured paper with the exception of nos. $26,35,42,49,54$ and 139 , which are on white paper. Nos, 196 and 197 were published together, under the date "April-May, 1891 ". The numbers for November and December, 1892, were wrongly numbered " 214 " and " 215 " instead of " 215 " and " 216 , " respectively.

$$
\text { औ } \quad \text { P } h S 1(35)
$$




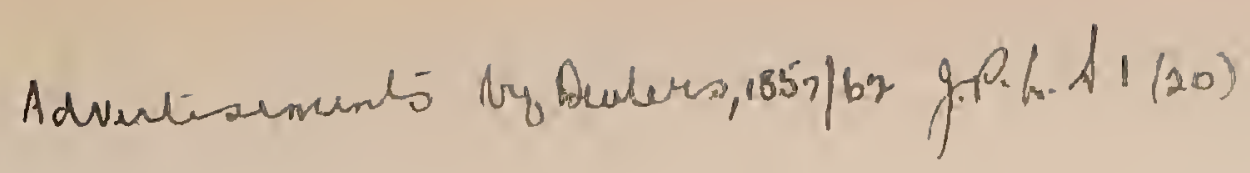

air mail Preanel fowrnal
air Prone ltaomp havs

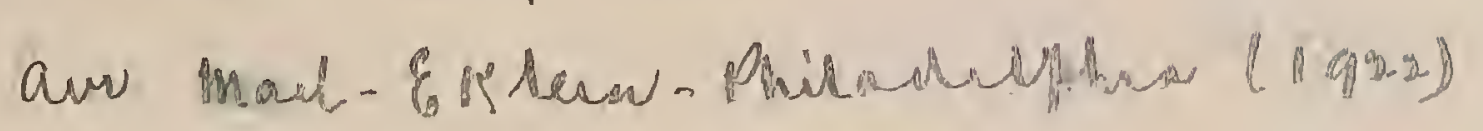

Nos. $1-48(1875-78)$. All privately bound, cloth, in 1 vol.

Nos. 49-144. (1879-86). All privately bound, cloth, in 1 vol.

Nos. 145-216 (1887-92). All privately bound, cloth, in 1 vol.

\section{AT. FRED SMIT
A.S. \& Co.)}

Nos. 217-264 (1893-96). All privately bound, cloth, in 1 vol.

Nos. 265-312 (1897-1900). All privately bound, cloth, in 1 vol

Nos. 313-360 (1901-04). All privately bound, eloth, in $1 \mathrm{vol}$.

Nos. 361-528 (1905-19). Unbound. AFFRED SMITH \& SON'S STAMP COLLECTORS' MONTHLY
CIRCULAR. (London, A.S. \& Co.)

Nos. 529-535 (1920). Unbolind. With index $1875-1910$ by B. T. K. Sinith.

Continued as

STAMP COLLECTORS' MONTHLY CIRCULAR. (LONdOA, A. H.

Narris). 536 -547 (1920-21). Unbound.

STAMP COLLECTORS' MONTHLY JOURNAL. (London, Harris

Publications).
Nos. 548-558 (1921-22). Unbound. 
He romed siamp atvertisior $1896 / 7 \%$ 1ro $/-7,8.9$.

18971013.18

ros 3.7.13. Aruited ai red ink

aet the Yeas Round S.P.L.S 136

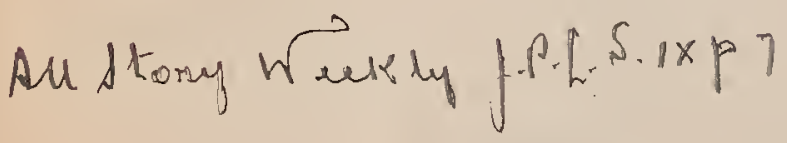


433

ALFRED SMITH

ALFRED SIMITH AND CO.'S IMONTHLY CIRCU. LAR.

[Continued as :]

Alfred Sinith and Son's monthly circular.

Bath, ctc., I 894-

$4^{\circ} .10$ in. vols. xx.- nos. In progress.
[20th year.] Jan. -Dec., 1894. Nos. 229.240.

[21st "] ", $\quad$ ", 1895. " $241-252$.

[22nd " ] " " $\quad$ " $1896 . \quad$ " $253-264$.

[23rd " ] " " " " $\quad 1897 . \quad$ "

24th " " " " $\quad$ " $\quad 1898 . \quad$ " $277-288$

26th "

[27th "] " " " $\quad 1901 . \quad$ " $313-324$.

28th " " " " $\quad 1902 . \quad$ " $325-336$

[30th " ] " " " " 1904. " " $349-360$

[31st " " "15, "15, 1905. " 361-372.

** Edited down "to the time of his death" in Oetober 1899, by W. * Edited down to the time of his death in October, 1899, by W. A. S. Westoby and the subsequent numbers by B. T. K. Smith. There is a title-page and an index to each year commencing with 1895, and commencing with 120. 262 the journal was published in London. Nos. 229-243 are on coloured paper, there is a supple ment of (2) pages to 110. 250 and slip supplements to nos. 233, 236 274 and 275 . The number for January, 1894, is numbered " 228 ",
in place of " 229 " ; that for A pril, 1895 , " 243 " instead of " 244 , and that for May, 1895 , "244" in place of " 245 ". Nos. 382 and 383 were published together.

ALFRED SIMITH AND SON'S MONTHLY CIRCU LAR. See Alfred Smith and Co's Monthly CircuLAR.

ALIANZA FILATÉLICA. La Alianza filatélica. Barcelona, Juan de Solo, r 89r-92 $8^{\circ} .11$ in. 7 uos. in 2 vols

○. 1st year, Nov. 10, Dec. 10, 1891. Nos. 1-2.

${ }_{*}^{2}$ * Analgamated with "Ilustración" Filatélica Hispano.colonial". Mis. St. Jour. 107 (11)

ALL AROUND PHILATELIST. The All around philatelist. Devoted to postage stamp collectors and collecting. $\quad E$. Boston, Mass., Joseph P. Plourd, r899. 8.. 9 in. Nos. 1-2, Mar. 15- tpril 15, 1899.

* * There is a coloured paper wrapper to each number. Amalgamated with the "Bay State Philatelist," June, 1899.

Mis. St. Jour. $92(6)$

ALL - AROUND - STAMP - ADVERTISER. The Allaround-stamp-advertiser. r896-99.

Fol. $15 \frac{1}{2}$ and $17 \frac{1}{2}$ in. 23 nos. in 2 vols.

Vol. I. Mar.-June, Sept. 1896-May, 1897. Nos. 0, 1-12 "II. June-Nov. 1897, Nov. 1898-Feb. $1899 . \quad$ " 13-22. * The contents consist entirely of advertisements. $\sim$ Nos. 4-22 were published by Ant. R. Vallée and nos. 19-22 at Montreal. These last, four numbers measure $17 \frac{1}{2}$ inches and the first eighteen numbers $15 \frac{1}{2}$ inches. Nos. 16 and 17 are printed on coloured
paper. Wanting no. 20.
Mis. St. Jour. 136 (1).

Mis. St. Jour. 136 (1)

ALL THE YEAR ROUND. All the year round. A weekly journal. Conducted by Charles Dickens. With which is incorporated Household Words. No. 169 July 19, 1862. [Contains an article "My nephew's collection ".]

London, W. C., r862.

$8^{\circ} .9 \frac{7}{2}$ in. Pp. 445-448.

* The number has a coloured paper wrapper. A second copy is

f.h.S.yd/10 ALLEGHENY PHILATELIST. See WAVERLY StaMp Co.'s Allegheny Philatelist and Stamp Collectors GUIDE.

ALLEGHENY PHILATELIST AND HERALD EXCHANGE. See Waverly Stamp Co.'s Allegheny Philatelist and Stamp Collectors Guide.

ALLEGHENY PHILALETIST AND STAIMP COLLECTORS GUIDE, See WAVERLY STAMP Co.'s. Alleghent Philatelist and Stamp Collectors GuIde.

algemenes to uzerge Sin Phalatelie

Hans schneide oroshafian (Bavariar)

$$
1910 \text { opl - Septl-? N101 - 11-? }
$$

ALLGEM, ANZEIGER

434

ALLGEM. ANZEIGER. Allgem. Anzeiger. GratisBeilage zu Louis Senf's Illustrirten Briefmarken-Journal Leipzig, Louis Senf, r876-77 $8^{\circ} .10$ in. Nos. 1-10, Sept. 1, 1876-June 1, 1877..Lumus S enf's ** This is a supplement of the A Tllustrirtes Bri

$32 p p$

ALLGEIMEINE DEUTSCHE BRIEFMARKEN-ZEI-

TUNG. Allgemeine deutsche Briefmarken-Zeitung.

4. $9 \frac{1}{4}$ in. Nos. 1-12, July 1-Dec. 15, 1864.

st Roschlau, r864. tho b has adut d eac of

Bauschess' acberoo

18604 sept

** Published fortnightly. There is a supplement of two pages 11. The journal "mas a sol s, 5, 6 and marken-Handel".

ALLGEMEINER ANZFIGER. Allgemeiner Anzeiger. Inb has a " Zeitschrift zur Verbreitung der Postwertzeichen-Sammel- Cuman State stamp kunde. Dortmund, Robert von Gaugreben, 1895. $8^{\circ} .93$ in Nos. 1-4, Feb. 1-May 1, 1895.

* There is a paper wrapper to each number and the sub-title $\checkmark$ ouly appears on the wrappers.

[Continued as :]

Allgemeiner Anzeiger zur Verbreitung der Postwerthzeichen-Sammelk unde.

$8^{\circ} \cdot 10-9 \frac{1}{4}$ in. Vols. II.-III. 24 nos.

(.nd year. Feb. 15-Dec. 15, 1896 . Nos. 1-11.

3rd " Jan. 15- ", ,, 1897. ", 1-13.

** There is a title-page and an index to the third year and a

coloured paper wrapper to each number. Nos. 2-13 of the third year wcre published by Franz Gebhardt at Apolda. The numbers of the second year and no. 1 of the third year measure 10 inches and the succeeding numbers measure 91 inches. $\checkmark$ The number for February 15, 1897, is numbered "No. 1/2", and there are two numbers for May, 1897, one dated " 1 Mai" and the other " 15 Mai". There is an illustrated supplement of two pages, printed on one side only, to no. 13 of the third year, and the title on the wrapper of this number reads "Allgemeiner Anzeiger" für Postwertzeichen Sammler".

\section{[Continued as :]}

- Allgemeiner Anzeiger für Postwertzeichen-Sammler. Apolda, Franz Gebhardt, r898.

$8^{\circ}$. 91 in. Vol. IV. 12 nos.

** There is a coloured paper wrapper to each number. The wrapper of No. 1 is dated in orror " 19.38 ," no. 2 is wrongly numbered "No. 1," except on the wrapper which is correct, no. 10 is dated " 20 Oktober" but the wrapper bears " 25 Oktober" and no. 12 is dated "14 Dezember," while the wrapper has " 20

ALLGEIMEINER ANZEIGER FÜR POSTWERT. ZEICHEN-SAMIMLER. See ALLGEMEINER ANZEIGER.

\section{ALLGEIMINER ANZEIGER ZUR VERBREIT-} UNG DER POSTWERTHZEICHEN-SAIMTMT-

KUNDE. See ALLGEMEINER ANZEIGER.

ALLGEIMEINER BRIEFMARKEN - ANZEIGER. Allgemeiner Briefmarken-Anzeiger.

Hamburg, etc., F. W. Rademacher, etc., I87 I-80. $4^{\circ} .9 \frac{1}{4} \mathrm{in.}$ and fol. 12 in. 207 nos. in 10 vols. 1 st year Oct. 1-Dec. 15,1871 . Nos. 1- 6. 2nd "Jan. 1- i, 1872. ", 7-30.

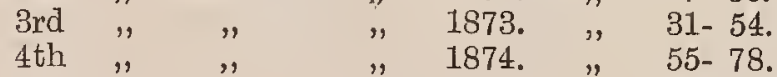
5th " " " " $\quad 1875 . \quad$ "

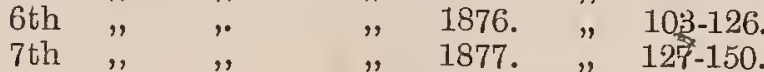

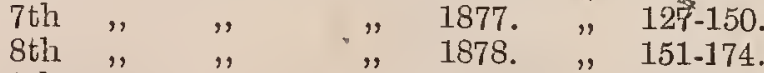

9th " " " "1, 1879. " " 175-195.

10th " " " $1880 ., " 196-207$.

* * The first six numbers are quarto, the remainder folio. Nos. 151.207 were published at Dresden by E. W. Grossmann, and there are title-pages and indexes to the eighth, ninth and tenth year's. There are two editions of the title-page and index of the eighth year. In one, the index only includes the contents of nos. 151-173, in the other, the contents of nos. 151-174 are given. The number for February 15, 1873, is numbered " 33 " instead of " 34 " and no. 127 has "Sechster Jahrgang" in place of "Siebenter Jahrgang". There is a supplement of two pages to no. 4 . Woso hes 2 blank space hoo dritimamore auremparat

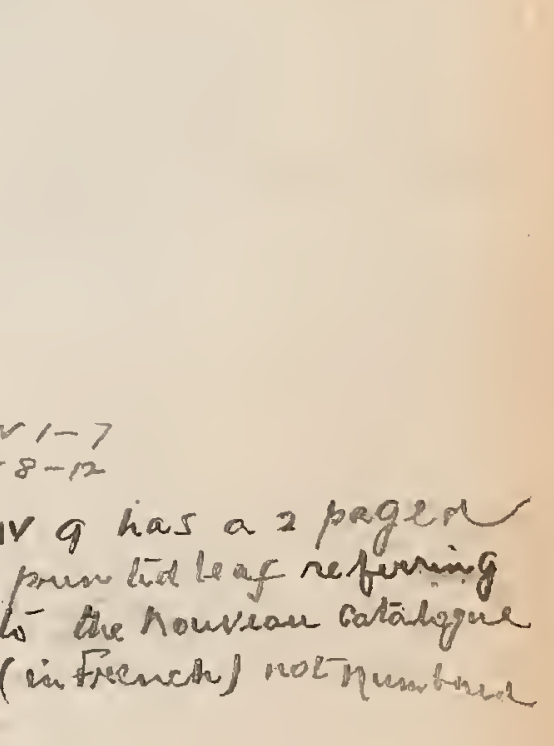

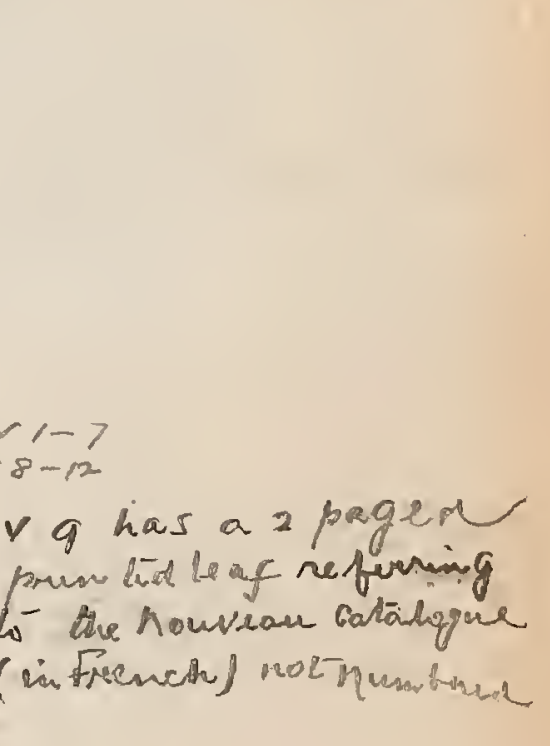

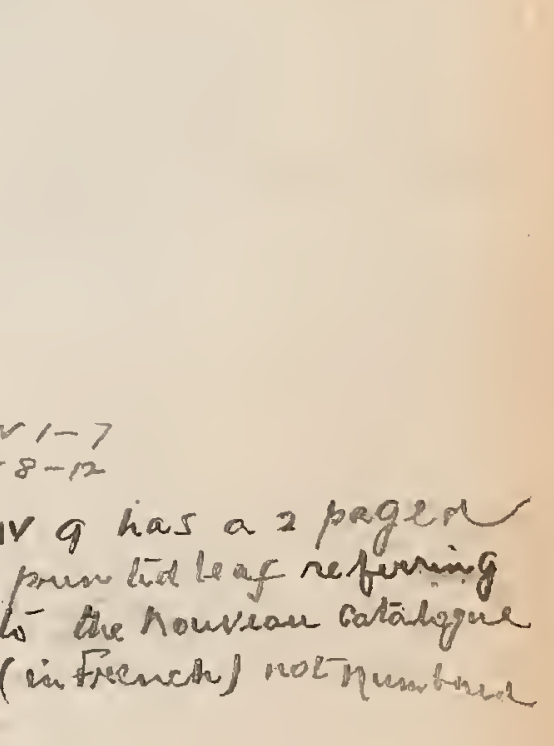

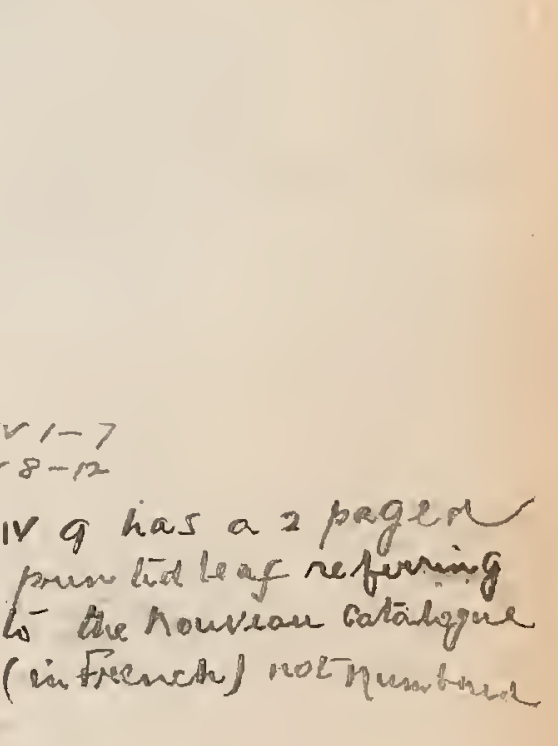

Tho 8 has 7 Cland cllus stampar her mancered $\%$ omange Itract Barlen 


\section{ALLGEIMEINER BRIEFMARKEN - ANZEIGER} [Continued as :]

Dresdner Illustrirtes Briefmarken-Journal.

Dresden, $E . W$. Grossmann, г881-82. Fol. 141 in. Vols. XI.-XII. 13 nos.

11th year. Jan. 1-May 1, Oct. 1-Dec. 1, 1881. Nos. 208-212 and 217-219.

12th year. Jan. 1-A pl. 1, Nov. 1, 1882. Nos. 220-223 and 230 *** The copy of no. 223 in the library has the number altered in pen and ink to " 224 " and the date of the month is changed to were never published.

[Continued as :]

- Deutsche Briefmarken-Zeitung.

Dresden, $E . W$. Grossmann, 1882-9o.

Fol. $14 \frac{1}{2}$ in. and $8^{\circ} \cdot 10-11 \frac{1}{2}$ in. Vols. XII.-XX. 66 nos.

12th year. Dec. 1, 1882. No. 231

13th year: Jan. 1-Dec. 1, 1883 . Nos. 232-243.

14th year Jan 1-Dec. 1, 1884. Nos 244-255.

27th year. [Really 15th year] Jan. 1-Dec. 1, 1885. Nos. 1-12

28th year. [Really 16 th year] Jan. 1-Dec. 1, 1886. Nos. 1-12,

29th year. [Really 17th ycar] Jan. 1-May, July, Oct.-Dec. 1, 1887

29th year. [Really 17th ycar-

30th year. [Rcally 18th year] Jan. 1, May 1, Junc 1, Nov. 1, 1888. Nos. $1,5,6,11$.

31st year. [Really 19th year] Jan. 1, Apl. 1, May 1, 1839. Nos. $1,4,5$.

[Really 20 th year] Nov. 1,1890 . No. 10 .

** 231-255 are folio, nos 1-6 for 1885 are octavo 10 inches, while the remaining numbers are octavo $10^{3}$ to 117 inches There is a supplement of two pages to no. 5. for May, 1887. No other numbers for the years 1887-90 were published.

ALLGEMEINER BRIEFMARKEN-ANZEIGER. Allgemeiner Briefmarken-Anzeiger. Gratis-Beilage zum "Illustrirten Briefmarken-Journal".

Leipzig, Louis Senf, I88x.

$8^{\circ} .12$ in. Nos. 1-2, Feb. 1-Apl. 1, 1881

* * Printed on rose paper and the contents consist entirely of advertisements. Bound up with the "Illustrirtes BriefmarkenJournal" for" 1881.

\section{ALLGEIMEINER BRIEFMARKEN-ANZEIGER} VEREINIGTE ERDBALL IMERCUR, See VEReinigte Erdbali Merkur.

aldiance CoOpérative. See Alutince PhitatéLIQUE.

ALLIANCE PHILATÉLIQUE. L'Alliance philatélique. Fol. $19 \frac{3}{4}$ in. No. 1, May, 1892

Paris, Henri Issanchou, I892.

* * The above was joined to and formed a supplement of "L'Alliance Coopérative," fifth year, no. 5, May, 1892. It is printed on buff päper.

ALLIANCE TIMBROLOGIQUE. Alliance timbrologique. Journal international philatélique.

Paris, Caen [printed], L. Huot, etc., I898-1904. $8^{\circ} .93-10$ in. 72 nos. in 6 vols.

1st year. Feb. 25, Apl. 1-Dec. 1, 1898. Nos. 1-10.

2nd year. Jan. 1-Dec., 1899. Nos. 11-22.

3rd year. Jan. 1900-Feb., 1901. Nos. 23-36.

4th year. Mar. 1901-May, 1902. Nos. 37-51.

5th year. June 1902-Oct., 1903 . Nos. $52-68$.

6th year. Nov. 1903-Feb., 1904. Nos. 69-72.

* * Nos, 61-72 were published by L. Faguais and nos. -72 have * Nos. 61-72 were published by L. Haguais and nos. ${ }^{-72}$ have the title nos. $6,7,11,17,30,45$

[Continued as :]

L'Alliance timbrologique et cartophile. Journal international philatélique.

Paris, Caen [printed], L. Fagnais, I904. $8^{\circ} .10$ in. Vol. vi. 3 nos. 6th year. Mar.-May, 1904. Nos. 73-75
$* *$ Wanting no. 75.

ALLIANCE TIMBROLOGIQUE ET CARTOPHILE. See Alliance timbrologique.
AMATEUR. The Amateur. A monthly magazine, specially devoted to the interests of students, and the admirers of science, art, and literature.

Bridlington, The Amateur Association, 1866. $8^{\circ} .8$ in. No. 1, Jan., 1866.

* The number has a paper wrapper. This journal succeeded "The curiosity collectors' magazine, and journal of the Bridlington Amateur Association". The only philatelic matter it contains, beyond advertisements of stamps on the wrapper, is a piece of poetry entitled "The Stamp Collector".

Mis. St. Jour. 37 (6)

AMATEUR. The Amateur. With which is incorporated "Hull's advertiser". A monthly journal devoted to the interests of amateur authors, stamp, coin and curiosity collectors, dealers, \&c. $8^{\circ} .89$ in. No. 1, February, 1889 Stretford, Manchester, Goss Bros., I889. $*^{*}$ * Wanting.

AIMATEUR. Amateur. Internationale Rundschau für Sammelwesen jeder Art Postwerthzeichen-MünzenWappen-Siegel-Stiche, Urkunden-Kunst-Alterthümer. Wien, J. G. Schöner, I889-9o. $4^{\circ} .93$ in. Nos. 1-4, October, 1889-January, 1890.

* Nos. 3 and 4 were published together, with the date "De(1890" vThe contents are given in Cerme Trencl and Jopligh and nos. $2-4$ contain but little philatelic matter. $\mathrm{VA}$ copy of the prospectus of the journal, printed on coloured paper, is bound up in front of no. 1 .

Mis. St. Jour. 117 (25).

AMATEUR. The Amateur.

$$
\text { Lancaster, Ky. [? ], ז895-97. }
$$

in. 18 nos. in 3 vols

vol. I. 1895-1896. Nos. 1-6.

II. $1896 . \quad " 1-6$.

$U_{*} *$ "IIr. 1896-1897. "Only partly phitalic. 1-6. together. Wanting all nos.

AMATEUR ADVERTISER. The Amateur advertiser. London, W. C., R. C. Seeley, etc., I889.

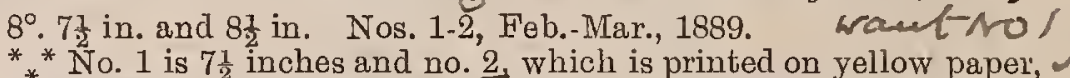
is 8 inches. Both numbers were edited by $B$. Winskill and no. $\checkmark 2$ was also published by him. No. 1 was printed at Knaresborough, Yorks., and no. 2 at Oakham, Rutland. $6 y$. 3 \% Mis. St. Jour. $79(2)$.

AIMATEUR AMERICAN. The Amateur American.

Auburn, N. Y., E. L. Hickok, 1892-93. 8॰. 83 in. No. 9, September, 1892; vol. II., no. 1, February, 1893. ** Only partly philatelic. Vol. II., no. 1, is also numbered $S \& 0$ “"whole no. 13".

AMATEUR AND COLLECTOR. The Amateur and collector. St. Paul, Minn. Elroy C. Wethy, r88o: $8^{\circ} .8_{1}^{3}$ in. Nos. 1-2, Jan.-Feb., $1880 . \quad$ Mis. St. Jour. 24 (10).

AMATEUR BANNER. The Amateur banner.

Toronto, Canada, J. A. Burgess and Co., 1877. * * Cuttings of the "Stamp department," etc., from the numbers for April 5th and May 28rd, 1877, are mounted in Stamp Scrapbook, vol. III., pp. 75-77.

AMATEUR CLIPPER. See COLLECTOR.

(Smyrna, N. Y., I879.)

AMATEUR DE LA TIMBROLOGIE. L'Amateur de la timbrologie. Organe mensuel traitant exclusivement de la timbrologie.

Rio de Janeiro, Antonio Gomes Machado, I89I. (j) Fol. 13 in. Nos. 1-5, May-Sept., 1891.

$V_{*}^{*}{ }^{*}$ Nos. 4 and 5 were published together. Mis. St. Jour. 88 (7).

AMATEUR DES TIMBRES-POSTE. I'Amateur des timbres-poste. Paris, E. Gainsborg, I898-1900. $8^{\circ} .9$ in. 14 nos. in 3 vols. 1st year. (1) Dec., 1898 . No. 1 . 2nd year. Jan.-May, Nov., Dec., 1899. Nos. 2-8. $\checkmark$ 3rd year. Jan.-Mar., Sept.-Dec., 1900. Nos. 9-14. * * No. 14 is dated "Novembre-Décembre, 1900 ". 
. 

437 AMATEUR DES TIMBRES-POSTE

AMATEUR DES TIMBRES-POSTE. Deuxième série $8^{\circ} .9$ in. Nos. 15-23, Jan.-Dec., 1901.

Paris, E. Gainsborg, rgor.

* * Nos. 18, 20 and 21 are dated respectively, "Avril-Mai ;" "Juillet-Aofit;" and "Septembre-Qctobre".

_ Troisième série.

(1) $8^{\circ} .9$ in. Nos. 24-30, Jan.-Dec., 1902. Quatrième série.

8 .9 in. Nos 31-36, Jan.-April, June, October, December, 1903.

* * No. 31 is dated "Janvier-Février". $v$

Cinquième série.

Paris, E. Gainsborg, I904

○ 8․ 9 in. Nos. 37-40, April, Oct., Nov., Dec., 1904.

- Sixième série.

Paris, E. Gainsborg, 1905.

8 $8^{\circ} 8 \frac{3}{4}$ in. Nos. 41-44, Feb., April, June, Aug.-Sept., 1905.

- Septième série.

Paris, E..Gainsborg, etc., I906. 8. $8^{3}-10$ in. Nos. 45-49. Jan., Aug.-Sept., Oct., Nov., Dec., 1906. * * Nos. 46-49 were published by Maurice Lescut. Nos. 47-49 bear "Septième Année" in place of "Septième série" and nos..

AMATEUR EXCHANGE AND IMART. The Amateur exchange and mart. A monthly journal for stamp collectors and others.

London, F. E. Tozer and Co., 1880.

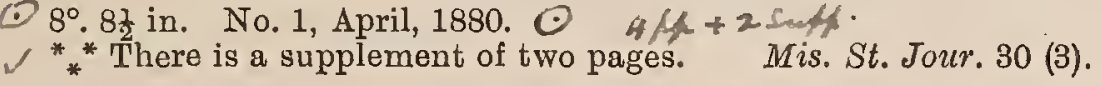

$$
\text { [Continued as :] }
$$

The Amateur stamp exchange and mart. A monthly journal for stamp collectors and others. Ifondon, etc., F. E. Tozer and Co., г 880-8г.

$8^{\circ}$. 81 in. Nos. 2-3, May, 1880-March, 1881. $N 02=1 / 7-10+2 x-1$ * No. 3 was published at Brighton to which place F. E. Tozer " " "Vol. I., No. 2". "There is a supplement of two pages to no. 2. Amarted again in March, 1881 , and in May, 1881, continued as the "Philatelists' Gazette and Stamp Exchange and Mart".

$$
\text { Mis. St. Jour. } 30 \text { (3a). }
$$

AMATEUR HERALD. The Amateur herald.

Watertown, N. Y., [? ] 1878 .

* * Cuttings of the stamp portions from no. 3, dated October

$18 \% 78$, are mounted in Stamp Scrap-book, vol. IV., pp. 12, 13.

AMATEUR JOURN AL. The Amateur journal. $8^{\circ} .9 \frac{1}{4}$ in. No. 1, Feb. $1,1877$.
${ }_{*}^{*}$ Only partly philatelic.

Cincinnati, O., Hof and Lowman, 1877 .

Mis. St. Jour. 18 (9).

AMATEUR MESSENGER. The Amateur messenger.

Plymouth, Mass., Marqueze, Dorr and Co., I 872 . * * Cuttings of the "Philatelhic (sic) department," etc., in the number for March, 1872, are mounted in Stamp Scrap-book, vol. II., p. 43.

AMATEUR PHILATELIC HERALD. The Amateur philatelic herald. Chicago, Ill., L. Mautner, I903. $8^{\circ} .8$ in. Nos. 1-3, May, June 1, August, 1903. Mis. St. Jour. 154 (9).

\section{[Continued as :]}

The Philatelic herald.

Chicago, Ill., L. Mautner, I903. $8^{\circ} .8$ in. No. 4, September 1, 1903 . Wanting.

AMATEUR PRESS. The Amateur press. Troy, Pa., Percy M. Bailey, г888-9o.

$16^{\circ} .5 \frac{1}{2}-6$ in. and $8^{\circ} .9$ in. 24 nos. in 4 vols.

Vol. I. Ji. June-Nov., 1889 . Nos. 1-6.
Vol. III. Dec., 1889-May 10, 1890 . Nos. [13]-18.

Vol. Iv. June-Nov. 15, 1890. Nos. 19-24.

** Only partly philatelic. Nos. $1-18$ are $16^{\circ}$. and the remaining numbers are octavo. Nos. Nos. 1 , have paper wrappers. Wanting vol. I., nos. $1,2,3,4$. Ir. $1,3,4,5,6$.
AMATEURS PRESS

438

AMATEURS PRESS.

__ The Youth's press.

[Continued as :]

Troy, Pa., Percy M. Bailey, I890-9 I.

$8^{\circ} .9$ in. Vols. $\nabla$-vi. 8 nos

Vol. จ. Dec. 15, 1890-May 25, 1891. Nos. 25-30.

Vol. vi. June 25, July 25, 1891. Nos. $31,32$.

** Only partly philatelic.

AMATEUR PRINTERS' JOURNAL AND FOREIGN STAMP GAZETTI. See Amateur Printers' Journal and Philatelists' Gazette.

AMATEUR PRINTERS' JOURNAL AND PHILA'TELISTS' GAZETTE. The Amateur printers' journal and philatelists' gazette.

$4^{\circ} .10$ in. No. 1 , December, 1871 ** Wanting.

\section{[Continued as :]}

The Amateur printers' journal and foreign stamp gazette. A medium of intercommunication for the amateur printing and foreign stamp trade.

Leeds, Yorks., W. Wightman, 1872.

$4^{\circ} .10$ in. Nos. 2-4, January-March, 1872

** Wanting nos. 2, 3 .

AMATEUR RECORD. The Amateur record.

Seneca Falls, N. Y., F. J. Howe, I 876 .

* * Cuttings of the "Stamp and coin dep't," etc., from no. 9 dated May, 1876, are mounted in Stamp Scrap-book, vol. III., pp. 69, 70,

AMATEUR STAMP EXCHANGE AND MART. See Amateur Exchange and Mart.

AMATEUR TIMES. Amateur times. 1876 .

Toronto, Canada, Williams and McMahon, etc.,

$8^{\circ} .10 \frac{1}{4}$ in. Nos. 1 and 4, August and November 15, 1876

** Only partly philatelic. Nos. 1 and 4 are bound up in Mis. St. Jour. 72 (1), and cuttings of the "Stamp department" etc. from no. 4, and of the stamp advertisements from nos. 3 and 5 dated "October" and "December 15, 1876," are mounted in Stamp Scrap-book, vol. III., pp. 63-67. No. 3 was published by Cooper and Williams and nos. 4 and 5 by W. H. Williams.

AIMATEUR TRIBUNE. The Amateur tribune. Mansfield, Penn., H. C. Kinney, I88o. $8^{\circ} .7 \frac{1}{2}$ in. No. 1, Aug. 1880 * Only partly philatelic.

Mis. St. Jour. 41 (3).

AMATEUR WORLD. The Amateur world.

Toronto, C. Boulton, 1877 .

** Cuttings of the stamp portions from no. 1, dated December $1_{\text {st, }}^{*}$ 1877, are mounted in Stamp Scrap-book, vol. xv., p. 9

AMATEUR WORLD. The Amateur world.

Fol. 12 in. Nos. 4-5, Oct.-Nov., 1887 La Rue, O., [? ], т887. ** Only partly philatelic. Nos. 4 and 5 were published together
as one number.
Mis. St. Jour. 121 (21).

AMATEUR WORLD. The Amateur world.

Baltimore, Md., Amateur World Pub. Co., r889-9г. $8^{\circ} .9 \frac{1}{2}$ in. nos. in 3 vols.

Vol. I. Jan.-Dec., 1889. Nos. 1-12.

Vol. II. Jan.- $1890 . \quad$, 1-.

Vol. IrI. Jan.- 1891. ", 1-

"* Only partly philatelic. Nos. have coloured paper Wripers. No. (1), Wanting " 12. Vol. I., all but nos. 2,4 . Vol. II., and Vol III all but no. 8 .

AMATEUR'S JOURNAL. The Amateur's journal. Devoted to amusement, numismatics, philately, minerals, instruction and the interest of its subscribers.

Mechanic Falls, Maine, Poole and Dunscomb, 1880.

$8^{\circ} .9 \frac{1}{2}$ in. Nos. 1-2, August-October, 1880.

*** Only cuttings of the philatelic portions of no. 2 have been preserved and these are mounted, with an advertisement from no. 1, in Stamp Scrap-book, vol, v., pp. 39-41.

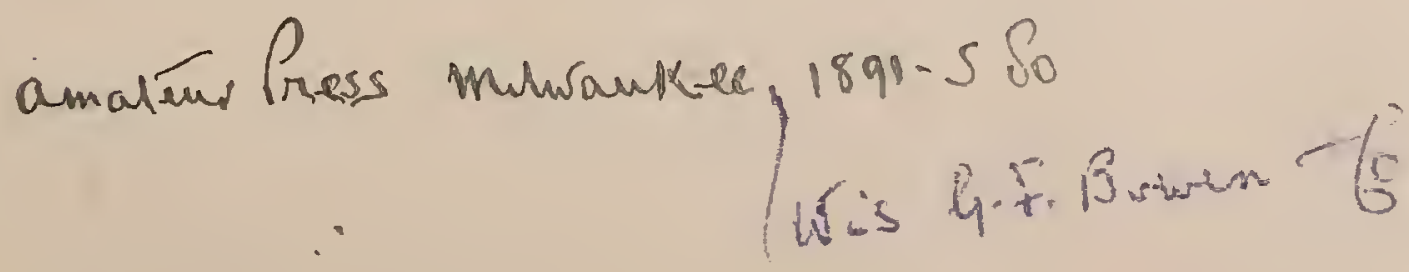


AIMBITION. Ambition. Chicago's little magazine. Chicago, Ill., Clyde A. Dickinson, I898-99. $16^{\circ} .6{ }^{3}-5$ in. Nos. 1- , October, $1898-$ ** The only numbers in the library are nos. 1 and 3, dated, respectively, "October, 1898 " and "March, 1899". The latter has a coloured paper wrapper and is only partly philatelic. No. 1 contains no philatelic matter. $\quad$ Mis. St. Jour. 154 (5).

AIVIRICA FILATELICA. America filatelica. Organo de la "Sociedad filatélica del Ecuador.".

$8^{\circ} .10 \frac{1}{4}$ in. Nos. 1-7, April-October, 1897 ** * There Guayaquil, 1897 Wis. St. Jour. $140(4)$
Manting no. 6.

AIVERICA JUNIOR. America junior. Chicago, Ill., F. R. Anderson, т89 8 . ** Cuttings of the article "Concerning Philately" from no. 1, dated, August 15, 1891, are mounted in Stamp Scrap-book, vol. VI., p. 183.

AIMÉRICA POSTAL. La América postal. Revista filatélica comercial y literaria.

Valparaiso, Córd,ba y Co., I 9oI.

C Fol. 15 in. No. 1, Feb. 15, 1901. Mis. St. Jour. 108 (12)

AMERICA POSTAL. La América postal.

Iquique, Chile, F. H. Liendo y N. Lecaros, etc. I9O2-04.

$8^{\circ} .9-10$ in. 24 nos. in 2 vols

1st year. June 21, 1902-June, 1903. Nos. 1-12.

2nd year. July, $1903-\mathrm{June}, 1904 \mathrm{~T}$

* * Nos. 5-7 were published by F. H. Liendo, N. Lecaros y C. F. Carrillo, no. 8 by U. F. Carrillo, nos. 9- by M. F. Vernal y C. F. Carrillo, no. 12 by M. F. Vernal y C. H. Serra, and nos. 13.24 by $\mathrm{F}$. Vernal. Nos. 9 and 10,13 and 14,15 and 16,17 and 18 and 19 to 24 were severally published together, and there is a and to 24 were severally published together, and there is a 1902. Wauting. no. 11 . Mis. St. Jour. 140 (2)

AIMERICAN. The American. Boys' and girls' monthly. Buffalo, N. Y., [? ] ז87 ז.

* * Cuttings of the stamp portions in no. 1. dated March, 1871, are mounted in Stamp Scrap-book, vol. II., pp. 56, 57 .

AIVERICAN ADVERTISER. The American advertiser. Chicago, Ill., Gustav H. Becker, I904. $8^{\circ} .7 \frac{1}{2}-8$ in. Nos. 1-4, July-Oct., 1904. * Nos. 2 and 3 were published together.

Mis. St. Jour. 111 (1)

AMERICAN AGENTS' ADVERTISER. American agents' advertiser.

Smyrna, N. Y., F. J. Stanton, т89o. Fol. 12 in. Nos. 1-6, June 15-Dec. 5, 1890.

** These six numbers contain no philatelic matter beyond stamp advertisements. No. 6 has a supplemental slip printed on rose paper. There is no number for . Wanting no. 4

[Continued as :]

- The Holiday advertiser.

Smyrna, N. Y., F.J. Stanton, I89o. Fol. 12 in. Vol. Ir., no. 1, Dec. 10, 1890.

* Contains no philatelic matter.

[Continued as ;]

- American agents' advertiser.

Smyrna, N. Y., F. J. Stanton, I89 I. Fol. 12 in. Vol. II., no. 8, Jan. 1891.

* * Contains no philatelic matter beyond stamp advertisements.

[Continued as :]

The Advertiser.

Smyrna, N. Y., F. J. Stanton, I89I-96 Fol. 12 in. Vols. Ir.-X. 51 nos.

Vol. II. Feb.-May, 1891. Nos. 9-12.

Vol. III. June-Aug., Oct.-Dec., 1591. Nos. 13-18.

Vol. Iv. Jan.-May, Sept., Oct., Dec., 1892. Nos. 19.26

Vol. v. April-June, Sept., 1893. 27-30.

Vol. vi. Oct., Nov. 20,30, Dec. 15, 30, 1893, Jan. 15, 1894. Nos. 31-36.
Vol. viI. Jan. 31, Feb. 21, 28, Mar. 24, May 31 [? No. 42], 1894.
Nos. 37- 42. Vol. virI. Aug. 30, Sept. 30, Dec. 10, 31, 1894, Jan. 7, Feb. 2, 1895 Nos. $43-48$

Vol. Ix. Feb. 28, Mar. 6, Apl. 6, May 2, June 26, Sept. 30, 1895. Nos. $49-54$

Vol. x. Nov. 18, Dec. 27, 1895, Jan 31, Feb. 22, Mar. 26, 1896 Nos. $55-59$

* Nos. 9-28 contain no philatelic matter beyond advertisements but nos. 29-59 may be considered purely philatelic. Amalgamated with the "Philatelic Tribune," in July, 1896. Wanting nos. 20, 42 and 43 .

AMERICAN BOY. The American boy.

Detroit, Mich., The Sprague Publishing Co., 1899-

Fol. 1414-15s in. nos. in vols. In progress.

Vol. I. Nov., 1899-Oct., 1900. Nos. 1-12.

"II. " 1900- , 1901. " $1-12$.

" III. " " 1901- ", 1902. " " $1-12$.

" IV. " $1902-", 1903 . \quad$ " $1-12$.

" v. " " 1903- " $1904 . \quad$ " $1-12$.

" vi. " $\quad 1904-" \quad 1905 . \quad " 1-12$.

" vIII. ", 1906- " 1907. " 11.12.

* * Each number contains a philatelic department. No. 9, vol. I.; nos. 8 and 9, vol. III.; no 12, vol. IV., and the numbers of vols. V.-viII. have paper wrappers. Wanting nos. $1,2,6$ of vol. I. and no. 11 of vol. $v$.

AMERICAN BOYS. The American boys.

Middlebury, Vt., M. D. Batchelder, 1884. $8^{\circ} .9$ in. Nos. 1-6, Feb.-July, 1884.

** Only partly philatelic. Nos. 5 and 6 have coloured paper wrappers.

\section{[Continued as :]}

Our American youth.

Middlebury, Vt., etc., M. D. Batchelder and Co., etc., I $884-85$.

8. 9 in. 13 nos. in 2 vols

Vol. I. Aug-Dec., 1884. Nos. 7-12

Vol. II. Jan., Feb., Apl., May, June, [? no. 6], Sept., 1885. Nos.

* * The first twelve numbers are only partly philatelic. Nos. 16, vol. II., were published at St. Louis, Mo., hy M. D. Batchelder and Co., and no. 7, with a coloured paper wrapper, at the same place by C. J. Fuelscher and Co. Nos. 7 and 8, vol. I., and nos. 1 and 2, vol. II., were severally published together, and two numbers were issued in December, 1884, one dated "December," the other "December $30 "$ " It is impossible to give the size of the first twelve numbers from the copies in the library as only the philatelic portions of these numbers have been preserved. Nos. 10 and 12, vol. I., contain no philatelic articles. Wanting no. 6 , vol. II

[Continued as:]

Our American youth and the philatelic chronicle.

St Louis, Mo., C. J. Funelscher and Co., etc. 1885-86.

$8^{\circ} .9$ in. Vol. rr. Nos. 8-11, Oct., Dec., 1885, Jan., Feb., 1886. * * There is a coloured paper wrapper to each number. No. 11 has the name of the publishing firm changed to C. J. Fuelscher. The title on page 1 of each of the four numbers continues to read "Our American youth".

AIMERICAN BOYS. The American boys. Story and stamp paper

Lowell, Mass., T. E. Adams and Co., etc., I897. 8.9 $9 \frac{1}{4}$ in. Nos. 1-6, Jan.-May, August, 1897.

** Nos. 3-6 were published by T. E. Adams and nos. 4-6 have coloured paper wrappers. No. 2 has "Volume 2, no. 1 " instead of "Volume 1, no. 2 ".
Mis. St. Jour. 76 (8).

AIMERICAN BOYS' IMAGAZINE. See PhILAdelphIA MONTHLY.

AIMERICAN COIN AND STAIMP REVIEW. The American coin and stamp review. A monthly journal devoted to the study of philately and numismatics. tion, $\mathrm{I} 87 \mathrm{r}$. Allentown, Pa., The Keystone Stamp Associa$8^{\circ} .8 \frac{3}{4}$ in. Nos. 1-4, May-Aug., 1871. "* The number for August is wrongly numbered " 3 " in place of
" 4 ".
Mis. St. Jour. 27 (1).

Ameincan - Continental Adver tises

1902 I Wol wodp ot punk paplo

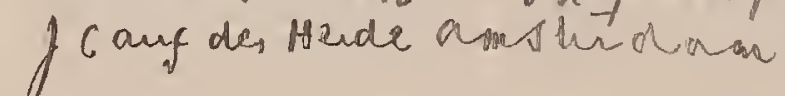





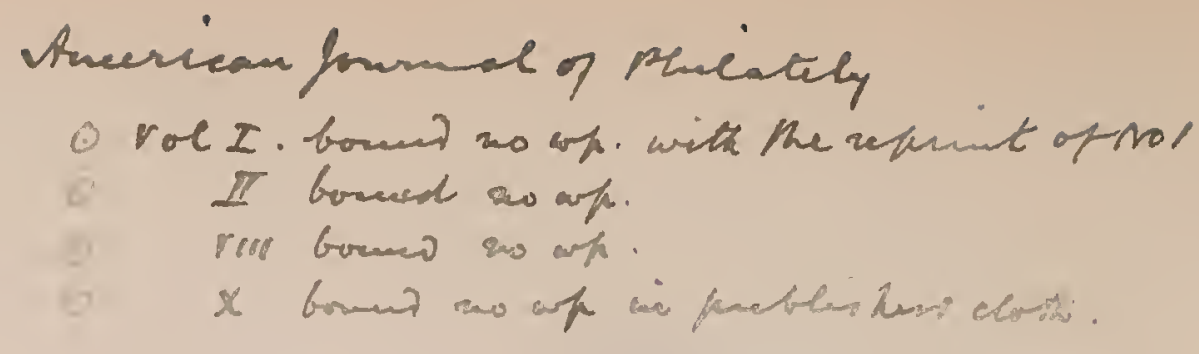

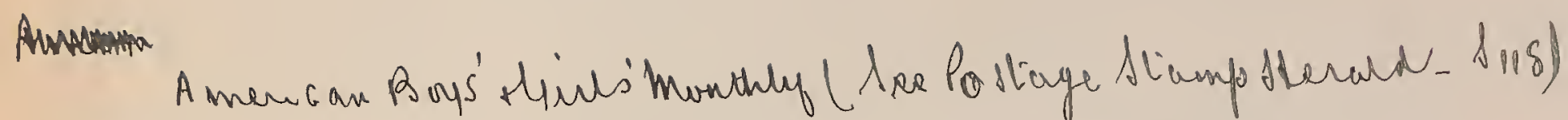


(1) AIERICAN COLLECTOR. The American collector.

Qm $8^{\circ} .9$ in. No. 1 Oct., 1888.

Oak Hill, O., S. Estle Miller, I888.

** Only partly philatelic. The number has a coloured paper wrapper. Bound up in Mis. St. Jour. 22 (6) and a second copy in Mis. St. Jour. 70 (4).

\section{[Continued as :]}

The Philatelic messenger.

Oak Hill, O., S. Estle Miller, 1888-89.

$8^{\circ} .9$ in. and $16^{\circ} .7 \frac{1}{2}$ in. Nos. $2-4$, Dec., 1888, Mar., Sept., 1889. * ${ }^{*}$ No. 3 is $16^{\circ}$. and has a coloured paper wrapper, the two othe numbers are octavo and have no wrappers.

Mis. St. Jour. 22 (6a).

AIMERICAN COLLECTOR. The American collector. New Chester, Pa., [R. M. Miller ], I89o.

$32^{\circ} .3 \frac{1}{4}$ in. Nos. 1-6, Jan.-June, 1890.

* * Nos. $1,3,4$ and 6 have coloured paper wrappers. No. 1 is dated " 1889 ," but the correct year is given on the wrapper. The title on nos. 5 and 6 is given as "The Am. collector".

Mis. St. Jour. 71 (1)

AIMERICAN COLLFCTOR. The American collector.

Piney Creek, Md., etc., The Collector Publishing Co., etc., I $1896-98$.

$4^{\circ} .12$ in. and $8^{\circ} .9$ in. 24 nos. in 5 vols.

Vol. I. July-Dec., 1896. Nos. 1-6.
Vol. II. July-Mar., Aug.-Oct., 1897. Nos. 7-12.

Vol. II. July-Mar., Aug.-Oct., 1897. Nos. 7-19.
Vol. III. Nov., 1897-Jan., 189S, Nos. 13-15.

Vol. III. Nov., 1897-Jan., 1898, Nos. 13.18 .
Vol. IV. Feb.-July 1898. Nos. 16-21.

Vol. IV. Feb.-July, 899 . Nos. 16-21.
Vol. v. Aug.-Oct., 1898. Nos, 22-24.

* * No. 10 was published at New Oxford, Pa., by the Collector Publishing Co., while the succeeding numbers were published at the latter place by J. F. Dodge. Nos. 3.15 bear the words "New the latter place by J. ". Dodge. Nos. 3-15 bear the words "New Series", "no. 10 has "New Oxford, Maryland," in place of "New 20 " instead of "11" : the number for January, 1898, has "Vol. III., no. 2" in place of " no. 3"; 3 and the numbers for May and June, 18ว3, have "Vol. IV. no. 3, or no. 4 " instead of no. 4 and June, 1838, have "Vol. N. no. 3 , or no. 4 "instead of no. 4 and no. 5, respectively. Nos. $1-15$ are quarto and the remainder are
octavo. There is a supplement of four pages to no. 23 . Amalgaoctavo. There is a supplement of four pages to no. 23. A
mated with the "Tri-Monthly Collector," January, 1899.

AIMERICAN.CONTINENTAL ADVERTISER. The American-continental advertiser.

Amsterdam, J. C. Auf der Heide, 1904-05.

Fol. 123 in. Nos. 1-2, Nov. 15, 1904-Feb. 15, 1905.

$\checkmark * *$ Printed on coloured paper. No. ${ }^{2}$ consists of only advertise-

AMERICAN EXCHANGE AND IMART AND HOUSEHOLD JOURNAL. The American exchange and mart and household journal.

Boston, Mass., and New Yort, Percival Gassett, I 88 5-86.

Fol. $12 \frac{1}{1}$ in. nos. in 2 vols.

Vol. I.
Vol. II.

***. Ir. 31 and 32, vol. II., dated April 17, May 1, 15, July 31, and Augus 7, 1886, respectively, and cuttings of the stamp portions from no.
32, vol. II., are mounted in Stamp Scrap-book, vol. v., pp. 41-46.

AIIERICAN GEIM. The American gem. I g०I.

St. Louis, Mo., The American Gem Syndicate,

8.9 in. Vol. III., nos. 11-12, February-March, 1901.

* * Edited by Charles A. Wendemuth. A stamp department was opened in vol. III., no. 11 and continued in no. 12 of that volume, and each of these numbers has a coloured paper wrapper. The other numbers issued of the journal contain no philatelic matter.
Mis. St. Jour. 143 (11)

AIIERICAN HOIME. The American home.

* ** Only vartly I., no. 11.

Waterville, Me., [? ] 1902.
AMERICAN JOURNAL OF PHILATELY. The American journal of philately.

New York, The New York Philatelic Society $y_{\star}$ I 868. $4^{\circ}$. 81 in. Nos. 1-12, March 1-December 1, 1868. * * Special edition printed on camary-yellow wove paper for members of the New York Philatelic Society alone. Nos. 9 and 10 and 11 and 12 were severally published together under the re spective dates "November, 1868," and "December, 1868," and nos. $2-12$ have paper wrappers. Wanting the wrappers to nos.
$2-12$.

The American journal of philately.

New York, The New York Philatelic Society, etc., I868-78.

$4^{\circ} .81$ in. and $8^{\circ} .9 \frac{1}{4}$ in. 156 nos. in 12 vols.

(6) Vol. I. Mar. 1-Dec. 1, 1868. Nos. 1-12.

(6) Vol. II. Jan. 20-Dec. 20, 1869. Nos. 13-24.

Vol. III. Jan. 20.Dec. 20, 1870. Nos. 25-36.

Vol. IV. Jan. 20-Dec. 20, 1871. Nos. $37-48$
Vol. v. Jan.-Dec., 1872 Nos $49-60$.

Vol. I. [Called later vol. vi.] Sept. 3-Nov. 19, 1870. Nos. 1Vol. 12

Vol. VII. Jan. 1-Dec. 15, 1373. Nos. 73-96.

Vol. viII. Jan. 20-Dec. 20, 1874 . Nos. 97-108.

6) Vol. X Jan 20-De. 20, 1876 Nos 121-132

Vol. XI. Jan 20.Dec. 20, 1877. Nos: 133-144.

Vol. XI. Jan $20-$ Dec. 20, 1878, Nos. 145-156.

* * Vols. I.-VII. are quarto and vols. viII.-XII. are octavo. The numbers of vol. I. differ from the "special edition" of this volume in being printed on white paper and also by the fact that no. 1 is a reprint with a note to this effect at the foot of page 8, the two new paragraphs replacing a description of some "Candian IIssays" in the original special edition on yollow paper. The reprint was made in May, 1868, and there is no original no. 1 on white paper. made in May, 1868 , and thore is no original no. 1 on white paper.
Nos. 9 and 10,11 and 12,87 and 88 and 95 and 96 were severally published together under the respective dates " November, 1868 ," "published together under the respective dates " November, 1868," 15, 1873". Each number excepting no. 1 and nos. 73-96 has a paper wrapper, and each volume, excepting vol vi, has a title paper wrapper, and each volume, excepting vol. vI., has a title-
page and an index. Vols. II.-xII. were published by J. W. Scott page and an index. Vols. II.-XII. were published by J. W. Scott and Co. The numbers of vol. VI. Were issued weekly and those of vol. viI. fortnightly. There is an extra number consisting of two pages called "No. $27 \frac{1}{2}$," dated "March 25, 1870," and a supplement of two pages to no. 57, which is only found in the American edition of this number. Vol. III. has a frontispiece with coloured illustrations of the United States stamps of 1870 . Vol. v. Was published at 46 Leadenhall Street, London, E.C., as well as in New York. The wrappers used for the former edition had the subscription price given in English money, many of the advertisements upon them differ from those of the American edition and there are four pages of additional advertisements in cach of the nos. 50, 55 and 57 , which are not found in the latter edition. The wrappers and advertisements of the English edition were printed by Pardon and Son, London, but the contents were printed in New York and correspond exactly with the New York edition. Nos. 52.60 are stated on the wrappers of both editions to be edited by Alfred Turner, but this is believed to have been a pseudonym for J. W. Scott. On the wrappers of nos. $55-60$ of both editions the title reads " The American journal of philately and the stamp collectors' journal "; no doubt referring to an amalgamation with the "Stamp collectors" journal and phila telical opinion " of London. Page 24 of ne 3 has "April 1". in error for "May 1, page "No o nos. 9 and 10 has "October 1 " in

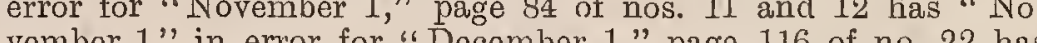

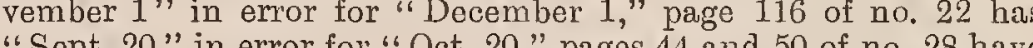
"Sept. 20" in eror for "Oct. 20," pages 44 and 50 of no. 28 have "Mar. "in error" "April 20," page 89 of no. 32 has "1670" in error for "1870," pages 9, 11 and 13 of no. 37 have " 1870 " in "error for "1871, page 29 ol no. 39 has " 1870 "in error for "1871," page 42 of no. 40 in some copies, has "April " in error for "April 20," page 44 of no. 40, in some copies, has "April 6 " in error for "April 20," pages 117 and 120 of no. 46 in some "copies, are printed inverted, the wrapper of no. 99 has in erro "98," pages 55, 56, and 64 of no. 112 have "March 20 " in error for "April 20," page 60 of no 124 has "March 20 " in error " tor "Aphl 20," pago 100 of no. 127 has " June 20 " in erro for "July 20," and pages 5 and 7 ol 10.145 have "1576" in error for "187 " There is a supplement to no. 45 consisting of a catalogue (8 pp.) of an auction sale of stamps to be held by Geo. A. Leavitt and Co., on October 9th, 1871, the pages of which bear the heading "Supplement-American journal of philately". This catalogue is bound up in the volume lettered: "Stamp auctions 1 . Other catalogues of auction sales of stamps by the same firm were presented with nos. $131,143,146,148$ and 153 and
the pages of each of these are headed "The American journal of the pages of 


\section{AMERICAN JOURNAL OF PHILATELY.}

[Continued as :]

The American journal of philately and coin advertiser. Quarterly. $8^{\circ} .91$ in. 28 nos. in 8 vols.

Vol. XIII. Jan., Apl., June, July, Aug., Oct., 1879

Vol. XIv. Jan., Apl., July, Oct., 1880.

Vol. Xv. Jan., Apl., July, Oct., 1881.
Vol. xvI. Jan., Apl., July, Oct., 1882.

Vol. xVI. Jan., Apl., July, Oct., 1882.
Vol. xvir.
Jan., Apl., July, Oct., 1883.

Vol. xviII. Jan., Apl., 1884.

Vol. XIX. Jan., Apl., 1885

ol. Xx. Jan., Mar., 1886

* The two numbers of vol. $x x$. were published, respectively, by the Scott Coin and Stamp Co., Limited, and the Scott Stamp and Coin Co., Limited. There is a paper wrapper to each number. The numbers for June and August, 1879 (the latter printed on rose paper) have "Price 10 cents" above the title, and consist of nothing but advertisements, which are the same in both numbers. The number for January, 1880, has "Vol. xIII." instead of Vol. XIV. and that for January, 1884, has "Vol. XVIr." in place of Vol. XVIIr. The number for April, 1882, has the year given as "1812". There is a supplement of two pages to the number for January, 1884, with the heading "Reference list of U. S. envelopes"

\section{[Continued as :]}

- The American journal of philately. Second series. New York, The Scott Stamp and Coin Co., Limited, I888-1906. 8.91 in. 228 nos. in 19 vols

Vol. I. [Feb.] -Dec., 1888. Nos. 1-12.

II. Jan. -Dec., 1889. " $1-12$.

III. " " $15,1890$.

" IV. " " $\quad 15-, " 15,1891 . \quad$ ", $1-12$.

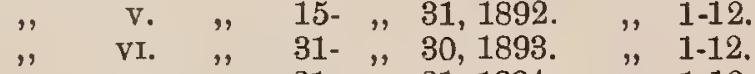

" vII. " $\quad$ 31- ", 31, $1894 . \quad$ " $1-12$.

" Ix. " $1-$ " " $1,1896 . \quad$ " $1-12$

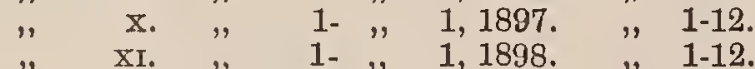

" xII. " 1- " $1,1899 . \quad$ " $1-12$.

" XIII. " $\quad 1-, " 1,1900 . \quad$ " $1-12$.

" xv. " 1- ", 1, 1902. ", $1-12$

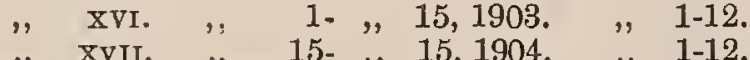

"XVIII. " 15- "28, 1905. ", $1-12$

" XIx. " 28- " 1906. " $1-12$.

* * There is a title-page and an index to each volume and a coloured paper wrapper to each number. The first four numbers of vol. I. are undated except on the paper wrappers. Two numbers were issued in the month of June, 1888, for vol. I., one dated "June," the other "June 15". The wrapper of July, 1893 is wrongly numbered vol. 7, no. 6 , instead of vol. 6, no. 7 , and the wrappers of September and October, 189, are wrongly numbered vol. 8 instead of 10. J. W. Scott edited vol. I. and nos. 1-5 of vol. II., H. L. Calman nos. 6-12, vol. II., vols. III.-XIII. and nos. 1 6 of vol. XIV., John N. Luff no3. 7-12 of vol. XIV., vol. Xv., and nos. 1-8 of vol. XVI. and in conjunction with George L. Toppan nos. 9-12 of vol. XVI., vol. XVII. and nos. 1,2 of vol. XVIII. George L. Toppan edited nos. 3-12, vol. XviII., and nos. 1-6 of vol. xix.

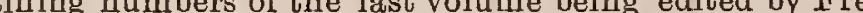
man Putney, Jr. There are two editions of no. 1, vol. I. The contents in the two numbers are not exactly the same and the wrapper of one bears "Vol. I., no. 1 " and of the other "Vol. XII., no $1 "$

\section{AMERICAN JOURNAL OF PHILATELY AND THE} STAMP COLLECTORS' JOURNAL. See AMERIcan Journal of Phinately. (First Series).

AMERICAN MONTHLY. The American monthly. Cobleskill, $N$. Y., Melvin R. King, г898-г 902. Fol. 14 in., $4^{\circ} .11$ in. and $8^{\circ} .9$ in. 17 nos. in 4 vols. Vol. $\mathrm{x}$. $\quad$-Dec, 1898. Nos, 1-6.

Vol. XII. July, Aug., Nov. Dec, 1901. Nos. 1-4. Vol. XIII. March, 1902 , No. 1.

* * Only partly philatelic. The numbers previous to vol. $\mathbf{x}$. are said to be non-philatelic. The numbers of vol, $\mathrm{x}$. are folio, those of vols. XI. and XII. are quarto and the number of vol. XIII. is octayo, nos. 2-5, vol. XI., nos. 3 and 4, vol. XII., and no. 1, vol. XIII. have paper wrappers. The wrapper of no. 2 , vol. XI. is numbered in error " $x_{1}$ " Wanting vol. $x .$, nos, $1,2,3,4,6$ and vol. XII., no, 1
AMERICAN MONTHLY. The American monthly. Coolspring, Del., Basil Perry, r905-06. $4^{\circ} .6 \frac{1}{4}$ in. and $16^{\circ}$. 5 5 in. Nos. 1-3, April, May, 1905, January, 1906

** Only partly philatelic. Nos. 1 and 2 are quarto and no. 3 is results and the vindicator".

AIMERICAN PHILATELIC ASSOCIATION. The American Philatelic Association. Official circular.

Grand Crossing, Ill., I886-87. $8^{\circ} .10 \frac{1}{4}$ in. 4 nos. dated Nov., Dec., 1886, April 21, June 15, ${ }_{\text {"* }}^{1887}$. Bound up with the "American philatelist," vol. I.

[New Series.]

St. Louis, Mo., I 893-95

$8^{\circ} .101$ in. 24 nos. dated monthly from "Septembor, 1893," to

"August, 1895".

AMERICAN PHILATELIC CIRCULAR. See AMERIcan Philatelical Circular.

AMERICAN PHILATELIC GUIDE. The American philatelic guide. New York, H. C. Jones, 1879-80. (6) $8^{\circ}$. 9 in. Nos. $1-10$, Oct., 1879-July, 1880.
$*$ * Nos. 9 and 10 were published together. * Mis. St. Jour. 18 (6).

AMERICAN PHILATELIC MAGAZINE. The American philatelic magazine.

Pittsfield, Mass., W. F. Jillson, I 888 $8^{\circ} .91$ in. Nos. 1-2, Feb.-Mar., 1888.

** Each number has a coloured paper wrapper and contains a frontispiece. Bound up with the two numbers is a letter from the publisher in which he says only the two numbers appeared.
Mis. St. Jour. 14 (6).

AMERICAN PHILATELIC MAGAZINE. The American philatelic magazine.

Omaha, Neb., Sanders and Brown, etc., 1892-1902. $8^{\circ} .8 \frac{1}{4}-9 \frac{1}{1}$ in. 62 nos. in 6 vols.

Vol. I. Oct., 1892-Oct., '1893. Nos. $1-12$

" II. Nov., 1893- ", 1894. ", 13-24.

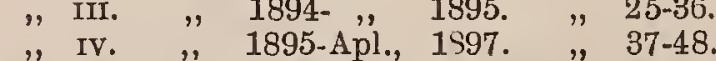

" v. Oct., 1900-Sept., $1901 . \quad$ " $49-60$

"VI. Dec., 1901-Jan., $1902 . \quad$ "61-62.

* * Nos. $12-48$ were published by Parmelee and Brown and nos. 4962 by Frank Brown. There is a coloured paper wrapper to each number. The wrapper of no. 31 has "Vol. III., no. 8," in place
of "no. 7 ".

AMERICAN PHILATELIC NEWS. The American philatelic news.

Newark, N. J., W. A. Jorgensen and Co., 1898 $8^{\circ} .9$ in. Nos. 1-2 April-May, 1898.

** Wantins no. 2.

Mis. St. Jour. $92(3)$

AMERICAN PHILATELIC RECORD. American philatelic record.

Binghamton, N. Y., Record Publishing Co., 1887.

C8. 9 in. Nos. 1-2, Aug.-Sept., 1887.

*** There is a supplement of (2) pp., printed on one side only, to
no. 2 .
Mis. St. Jour. 19 (10). no. 2 .

AMERICAN PHILATELICAL CIRCULAR. The American philatelical circular. A monthly illustrated circular for stamp collectors.

Chicago, Ill., H. Luebker, I874.

$8^{\circ} .8 \frac{1}{2}$ in. Nos. 1-2, Oct. 1-Nov. 1, 1874

* * These two numbers were also published by J. A. Picrce, Chi ago, with his advertisements, etc., in place of those of $\mathrm{H}$. Luebker, and the title of no. 1 is in different type to that of the

[Continued as :]

The American philatelic circular. A monthly illustrated circular for stamp collectors.

Chicago, Ill., H. Luebler, I874-75. $8^{\circ}$. 81 in. Nos. 3-6, Dec. 1, 1874, Jan. 15, Feb. 20, Mar. 25, 1875. * * There is a supplement to no. 4 headed "Supplement to the American Philatelical Circular," (2) pp. Nos. 3-6 were also published by J. A. Pierce, Chicago, and nos. 5, 6 by W. Leckie and Co., Chicago, and no. 4 by E. Herrmann and Co., Chicago, with their advertisements, etc., in place of those of $H$. Luebker.

Mis. St. Jour. 28 (9a), 
AMERICAN JOURNAL OF PHILATELY: WEEKLY EDITION.
(New York, J. W. Scott \& Co.)
Vol. I (1870). Privately bound, half morocco.

American Philatelic fund so 7 



\section{AMERICAN PHILATELICAL CIRCULAR.}

[Continued as :]

The Monthly chronicle. Devoted to stamp collecting and miscellaneous literature.

Chicago, Ill., H. Luebler, I 876-77. 8. 11 in. Nos. 7-10, July 15, Aug. 20, Oct. 1, 1876, Jan. 1, 1877. * * No 10 has the heading "The Monthly chronicle. Devoted to miscellaneous literature "and was published by Locke and Luebker. This number is only partly philatelic and only the philatelic matter has becn retained by being cut out and mounted on plain leaves. A copy of the prospectus of the journal, datrd June 22, 1876, is bound up with nos. 710 .

Mis. St. Jour. 6 (1).

[Continued as :]

- The Family favorite. Devoted to miscellaneous literature. Chicago, $\Pi 7 l ., A$. W. Locke, 1877 .

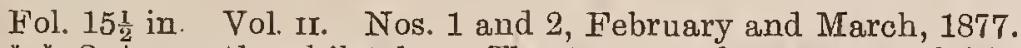
** Only partly philatelic. The two numbers were published together.

Mis. St. Jour. 6 (1a).

AMERICAN PHILATELIST. The American philatelist. [Prospectus of a journal to be published by $\mathbf{W}$. A. Kelsey and Co., Meriden, Conn., on July 1, 1868, but which was never issued.]

Mis. St. Jour. 27 (2a)

AIMERICAN PHILATELIST. The American philatelist. Devoted to the interest of stamp collecting.

Elizabeth, N. J., Tredwell, Rogers and Co., I87 I. $8^{\circ} .83$ in. No. 1, July $1,1871$.

Mis. St. Jour. $27(2)$

AMERICAN PHILATELIST. The American philatelist. Cleveland, O., Johnson E. Wilcox, I875. $8^{\circ} .8 \frac{1}{2}$ in. Nos. 1-3, Jan.-Mar., $1875 . \quad$ Mis. St. Jour. 29 (5). [Continued as :]

The Stamp collector

Painesville, O., Johnson E. Wilcox, I 875-76. $8^{\circ} .81$ in. Nos. 4-6, Nov. 1875, May, June, 1876.

** No. 4 is printed on pale rose paper. Mis. St. Jour. 28 (5a).

AIMERICAN PHILATELIST. The American philatelist. Dayton, O., Collins and Dohme, I 884 . $8^{\circ} .9 \frac{1}{2}$ in. Nos. 1-3, Jan.-Mar., 188t. Mis. St. Jour. 10 (6). ** A prospectus announcing the republication of the above journal successor to Collins and Dohme, who had removed from Dayton to New York, but no number actually appeared.

Mis. St. Jour. 28 (16)

AMERICAN PHILATELIST. The American philatelist. Altoona, Pa., etc., The American Philatelic Association, I887-93.

$8^{\circ} .10 \frac{1}{4}$ in. 73 nos. in 7 vols.

Vol. I. Jan. 10, -May 10, 1887. Nos. 1-5.

" Ir. Oct. 10, 1887-Sept. 10, 1888. Nos. 1-5. 12.

" III. " " 10, 1888- ", 10, 1889. ", $1-12$.

" Iv. " 10, 1889- ", 10, 1890. ", $1-12$.

v. Jan. 13, -Dec. 10, 1891. " $1-12$.

vil. " " 10, -Aug. 10, $1893 . \quad " 1-12$.

*"* Vols. II.--IV. were published at Philadelphia;

* Vols. 1-8. Vt. Louis. 1-s, at Chicago, and nos. 9-12 of vol. VI. and vol. VII., a a coloured paper wrapper, and there are title-pages val. II., has a coloured paper wrapper, and there are title-pages and indexes to December, 1891 ".

\section{[Continued as :]}

The American philatelist and year book of the American Philatelic Association.

Springfield, Mass., etc., The American Philatelic Association, I894-

$80.10 \frac{1}{4}$ in. Vols. VII.- In progress.

Vol. vII., Feb. 5, 189

* * The number has a coloured paper wrapper. This completes vol. VII. of the "American Philatelist," the paging running on from the August, 1895, number. The date of the year of publica". There is a title-page and an index for thę whole volumẹe:
Vol. viII. Dec. 1, 1894. $90 \mathrm{pp}$

" Ix. Feb., 1896. (2) +137 pp. + (1) p.

", x. Nor., ", $73 \mathrm{pp} .+(1) \mathrm{p}$.

" $\quad$ XI, , $1897.84 \mathrm{pp}$

" XII. $1898 . \quad 88 \mathrm{pp}$.

" XIII. 1899. $81 \mathrm{pp} .+(1) \mathrm{p}$.

$94 \mathrm{pp}$., frontispiece.

$\begin{array}{lll}\text { " XV. 1901. } & 83 \mathrm{pp} .+(1) \mathrm{p} . \\ \text { " xVI. 1902. } & 98+(2) \mathrm{pp} .\end{array}$

'XVI. 1902

XVII. 1903

XVIII. 1904.

XIX. 1905 .

Xx. 1906.

* * There is a coloured paper wrapper to each volumo.

$100 \mathrm{pp}$., frontispiece.

$112 \mathrm{pp}$.

$138 \mathrm{pp}$, frontispiece.

126 pp., 2 plates.

AMERICAN PHILATELIST. The American phila telist.

Minden, Neb., etc., The American Publishing Co., etc., I901-02

$8^{\circ} .9$ in. and $4^{\circ} .8$ in. Nos. 1-4, May 1, June 1, July-August, 1901, February, 1902

** Nos. 1-3 are octavo and no. 4 is quarto. The last two numbers were published by Don H. Wimmer; no. 3 at Minden, and
no. 4 at De Soto, Mo.
Mis. St. Jour. 91 (2).

Aiverican Philatgitst. Seo, American PhILatelist AND COLLECTOR.

AMERICAN PHILATELIST AND COLLECTOR. American philatelist and collector.

Marlboro, Mass., F. B. Estabrook and Co., etc., I $89 \mathrm{r}-96$.

$8^{\circ} .8$ and 83 in. 36 nos. in 3 vols.

Vol. 1. Apl., 1891-Mar., 1892. Nos. 1-12

" II. Apl.,-Nov., 1892, Jan., Feb., July, Aug., 1893. Nos.

" IIr. Apl., May., Oct, Nov., Dec., 1894, Jan.-May, Oct., 1895, *an., Feb., 1896. Nos. 25-36.

* * Nos. 1-24 measure eight inches in height and the remaining numbers 83 inches. Nos. 5 aud 6 were published by the Estabrook Publisling Co., nos. 7-9 by the Estabrook Stamp and Pub. Co., nos. 10-21 by F. B. Estabrook Stamp and Publishing Co., no. 22 by F. B. Estabrook and Company, nos. 23 and 24 by F. B. Esta brook, nos. $25-35$ by Estabrook and Leonard, and no. 36 by F. B. Estabrook. No. 1 is dated " 1890 " in place of " 1891 ," and no. 21 has "vol. II., no. 8" instead of "no. 9". Nos. 10-15, and 25-36 have coloured paper wrappers, and nos. 7-36 have the word "The" preceding the title. No. 30 is dated "Jan.-Feb., 1895". , [Continued as :]

The American philatelist.

Marlboro, Mass., F. B. Estabrook, I 896

$8^{\circ} .8 \frac{3}{4}$ in. Vol. IV. No. 37, March, 1896.

* The number has a coloured paper wrapper.

AIMERICAN PHILATELIST AND YEAR BOOK OF THE AIMERICAN PHILATELIC ASSOCIATION. See American PHILATELISt.

(Altoona, $P$ a., I887)

AMERICAN POSTAGE STAMP JOURNAL. [A journal with this title is reviewed in no. 3 of the "Postage stamp reporter," published at Lowell, Mass., for March, 1872; but none such ever appeared and the review in question was nothing more than a skit.]

AIMERICAN STAMP. The American stamp.

Newark, N. J., D. B. Crockett, I889-9o.

$8^{\circ} .10$ in. 2 nos, in 2 vols.

๑Vol. I. Jan., 1889. No. 1

C. ." II. Oct, 1890 .

* There is a coloured paper wrapper to each number. A copy of the elrcular giving the reason for the discontinuance of th journal, issued in January, 1891, is bound up after no. 1, vol. II.
Mis. St. Jour. 60 (4).

AIMERICAN STAMP. The American stamp.

Newark, N. J., David B. Crockett, I 893 . $8^{\circ} .81-8 \frac{1}{2}$ in. Nos. 1-5, Jan. 1-May, $1893 . \quad$ Mis. St. Jour. 64 (6).

AMERICAN STAMP. The American stamp. A semimonthly journal devoted to stamp collecting.

$$
\text { Maywood, Ill., [? ], I } 893 \text {. }
$$

8․ 9 ịn. No. 1, Jạn. 30, 1893,

Mis. St. Jour. 101 (5). 
AIMERICAN STAIMP. The American stamp. A monthly devoted to stamps. $\Upsilon 897$.

Laconia, N. H., Thompson, Saunders and Co., etc., Fol. 12 in. and $8^{\circ} .9$ in. Nos. 1-5, Jan., Feb., June-Aug., 1897. * * Nos. 1 and 2 are folio and are printed on green paper; nos. 3-5 are octavo and have coloured paper wrappers. Nos. 4 and 5 were publislied by the American Stamp and Publishing

AMERICAN STAIVP AND COIN JOURNAL. The American stamp and coin journal. [Prospectus of a journal to be published by the Buckeye Publishing Co., Akron, O., in December, 1879, but which was never issued.]

Mis. St. Jour. 28 (2).

AMERICAN STAMP CIRCULAR. The American stamp circular.

New York, The American Stamp Co., ז877-78. $8^{\circ} .8 \frac{1}{2}$ in. [No numbering.] June, Sept., 1877, April, 1878. * * The above is little more than a price list. In the June num ber under the heading "Salutary" it is stated that this issue is the under company. Wanting the eleventh price list and cireular of the comber and April numbers. St. Jour. 28 (12).

AMERICAN STAIP COLLECTOR'S GUIDE. The American stamp collector's guide. A paper devoted to the science of timbrophily.

Middletown, Conn, Columbian Stamp Co., $\mathrm{x} 870$. $8^{\circ} .8$ in. Nos. 1-5, Apl. 15, May 25, June 25, July 25, Aug. 25, ** Nos. 4 and 5 are numbered in Roman figures.

AMERICAN STAIMP DEALERS' PROTECTIVH ASSOCIATION. BULLETIN. American Stamp Dealers' Protective Association. Bulletin.

[New Oxford, Pa., J. F. Dodge], I896-97. $4^{\mathrm{o}} 11$ in. Nos. 1-14, Sept. 19, Oct. 8, Nov. 5, 11, 16, Dec. 2, 17, 19, 1896, Jan, 4, 11, Mar. 22, May 8, 18, Oct. 9, 1897

Mis. St. Jour. $140(10)$

AMERICAN STAIMP JOURNAL. The American stamp journal. Devoted to philately.

Portsmouth, N. H., etc., American Publishing Co. etc., r889-9r.

$8^{\circ} .9$ in. Nos. 1-10., Nov., 1889-July, 1890, Mar., 1891.
* No. 10 Yas published at Plainfield, N. J., by Warren H. Rice and has a coloured paper wrapper.

Mis. St. Jour. 48 (2)

AMERICAN STAIMP IMERCURY. The American stamp mercury. $8^{\circ} .8 \frac{3}{4}$ in. 20 nos. in 2 vols.

Vol. I. Oct. 25,1867 -Oct., 1868 . Nos. 1-12. *" II. Nov., 1868-June, 1869 . "13-20 have paper wrappers, and nos. 18 and 19 were published together. There is no number for Fobruary, 1868.

[Continued as :]

- The American stamp mercury and numismatist. Boston, Mass., F. Trifet, I869-1870. $8^{\circ} .8 \frac{3}{4}$ in. Vols. Ir.-III., 11 nos.

Vol. Ir. July, 1869-Oct., 1869. Nos. 21-24.

* " There is a title-page and an index to vol. II., and each of the *** There is a title-page and an index to vol. II., and each of the
eleven numbers has a paper wrapper. The number for January, eleven numbers has a paper wrapper. The number for January, "March, April, May, 1870".

\section{[Continued as :]}

The American stamp mercury.

Boston, Mass., F. Trifet, ז870-7 1.

$8^{\circ} .8 \frac{3}{4}$ in. Vols. III.-IV., 8 nos.

Vol. III. Aug.-Dec., 1870. Nos. 32-36.

* * There is a title-page and an index to vol. III., and each num-

** There is a title-page and an index to vol. Im., and each num-

gether, as were nos. $34,35,36$ and nos. $37,38,39$. Nos. 37, 38, 39 have " 1870 " in place of " 1871 ".

AMERICAN STAIIP MERCURY AND NUIMISIMAT-

IST. See American Stamp Merdury.

AMERICAN STAMP NEWS. American stamp news Lowell, Mass., The American Stamp and Publishing Co., $1893-94$.

$8^{\circ} .9$ in. and fol. $16 \frac{1}{4}$ in. Nos. 1-3, Sept. 28, 1893, Junc, July,

** Edited by T. E. Adams. No. 1 is octavo and nos. 2 and 3 are folio. No. 1 has a coloured paper wrapper and nos. 2 and 3 were "Old Fellows' gazette" vol, v., nos. 6 and 7, for June and July, 1894 . Mis, St. Jour. 62 (13).

AIMERICAN YOUNG PEOPLE. American young people.

Johnstown, Pa., Johnstown Stamp and Publishing Co., 1898 .

8. 9 in. Nos. 1-2. May-June, 1898.

${ }_{*}^{*}$ * Only partly philatelic.

Mis. St. Jour. 92 (2).

AIVERICAN YOUTH The American youth. Nashville, Tenn., James J. Hailey, etc., I89o-9x. $8^{\circ} .83$ in. and $4^{\circ} .8$ in. Nos. 1-12, Aug., 1890-Aug., 1891. * * Only partly philatelic. Nos. 1- are octavo and the remainder are quarto. Nos. 7-12 were published by J. J. Hailey and T. J. Darling and nos. 11 and 12 have coloured paper wrappers. [No. 9.] May, 1891, is unnumbered, no. 10 is dated "May-June, 1891 " and no. 11 is numbered in error "volume II. number I." Wanting nos. $1,2,6,8$

AIMI DE LA TIMBROLOGIㅍ. L'Ami de la timbrologie. 8. 91 in. No. 1, Jan., 1900.
$*$ Wanting. Caire, Michel N. Duçi, rgoo.

AMI DES TIMBRES. L'Ami des timbres. Journal catalogue des collectionneurs de timbres-poste, télégraphes et fiscaux. Paris, Ch. Roussin, I874-I 902. $8^{\circ} .10 \frac{1}{2}$ in. 343 nos. in 29 vols.

1st year. Jan. -Dec. 20, 1874. Nos. 1- 12. 2nd " ", 20- " " 1875. " 13- 24.

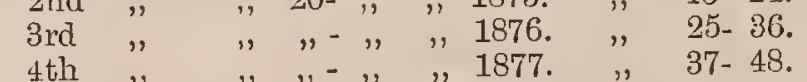

5th " " " " " - ", " " $1878 . \quad$ ", $49-60$.

6th " " " " - " " $1879 . \quad$ " $1880 . \quad 61-72$.

8th " " " " - ", " $1881 . \quad$ "

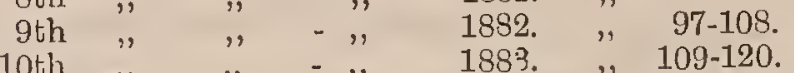

11th " " " - ", 1884. " " $121-132$.

12th " " " - ", 1885. " " $133-144$.

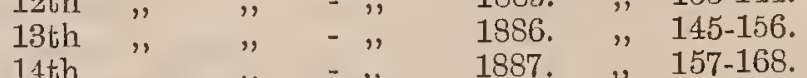

15th " " " $\quad$ - ", $1888 . \quad$ " $169-180$.

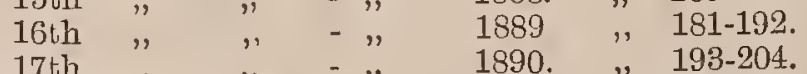

18th " " " - ", $1891 . \quad$ "

19th " " " - " $\quad 1892 . \quad$ " $217-228$.

21 st " " " - " " $\quad 1894 . \quad$ " $241-252$.

22nd " " " - " " $\quad 1895 . \quad$ " $253-264$.

24th " " " - " " $\quad 1897 . \quad ", 277-288$.

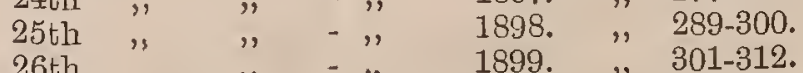

26th " " " $\quad$ - " " $\quad 1890 . \quad$ " $313-324$.

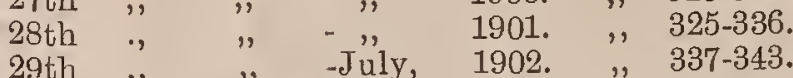

* * The "number for Jannary 20,1876 ," is numbered " 1 " instead of " 25 ," nos. $73,74,75$, have "sixième année " in place of "septième année, the number for September, 1881, has "92" instead of "93," that for June, 1894, has " 24 " in place of " 246 ," and that for December, 1895, has " 274 " instead of " 264 ". No.3. 318-324 have "28e année" in place of "27e année"; 325-336"have "29e havée" insté id of "28e année" and 337-343 have "30e année" in place of " $29 \mathrm{e}$ année". With each number there was published four pages of a catalogue of stamps and this catalogue was in its four pages of a catalogue ournal was discontinued in July, 1902 owing to the death of M. C. Roussin. The illustrations of the owing to the death of $\mathbf{M}$. C. Roussin. The printed apart from the text. There is a supplement of (2) pages to no. 324 .

$$
\text { onect }
$$

AMI DU COLLECTIONNEUR. See ÉTOILE D'TtTaLIE.

AMI DU TIMBROPHILE. L'Ami du timbrophile. Organe international de tous les collectionneurs.

Lisbonne, Netto et Almeida, I888.

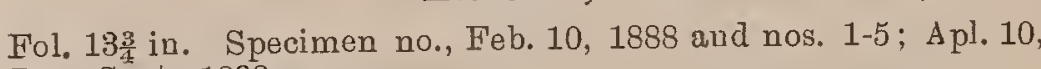
June-Sept, 1888

** Wanting the Specimen number.

Mis. St. Jour. 85 (6) 

L'Annorce Phatatoleque 1)'Grient. L. Taubs Sohn Prinila

I 1910 No, Juent $16 p p$ in grun wop

20 - is 1 -16 in y ellow - fum wp

30 July $1-16$ in blem iop 
A. MIOSCHKAU'S IMAGAZIN. A Moschkau's Magazin für den Sammler von Essais-Privatpost-Wechsel-Stempel-Telegraphen- u. Eisenbahn-Marken. Dresden, etc., Alfred Moschkau, etc., x87x-72. 8 . 91 in. Nos. 1-12, July 15, 1871-June, 1872. * * Nos. 4-12 were published at Oybin and nos. 7-12 also by S. F' Friedmann at Wien. There is a title-page, an index and a frontispiece to the volume, and supplements of two pages each to nos 6, 8, 9 and 11. On nos. 4-6 the sub-title reads " für Deutschland Markensammler. Organ für die Gesammtinteressen der Marken-
kunde" and the same on nos. 7-12 except that the word "Deutschlands" is omitted.

AMOSKRAG JOURNAL. The Amoskeag journal.

Manchester, Mich., Geo. F. Canis, 1873.

* * Cuttings of the "Stamp department," etc., in the number for F'ebruary, 1873, are mounted in Stamp Scrap-book, vol. II., pp. 40,41 .

ANALES DE LA SOCIEDAD FILATÉLICA DE CHILE. See Anales De la Sociedad Filatélic "Santiago".

ANALES DE LA SOCIEDAD FILATÉLICA "SAN TIAGO". Anales de la Sociedad filatélica "Santiago". Santiago de Chile, La Sociedad Filatélica "Santiago," $1892-98$.

$8^{\circ} .101$ and $10 \mathrm{in} .9$ nos. in 4 vols.

(- Vol. I. March. 1892. No. 1.

○ ". III. Nov., 1895. " " 2.

(2) "Iv. Jan.-Dec., 1898. "Nos. 1-6. TL

*"Volume Iv., Was published bi-monthly. $V_{\text {There is a title-page }}$ to each volume, an index to volume IV., and 2 colourcd paper wrapper treach number. WWith volume IV. was also published Vols. I.--IIr. measure $10 \frac{1}{1}$ inches and vol. IV. 10 inches. [Continued as :]

Anales de la Sociedad filatélica de Chile.

Santiago de Chile, La Sociedad Filatélica de Chile, x899- 1904 .

8. 10 in in. Vols. v.-z. 32 nos.

S 81 Vol. v. Jan.-Dec., 1899. Nos. 1-6.

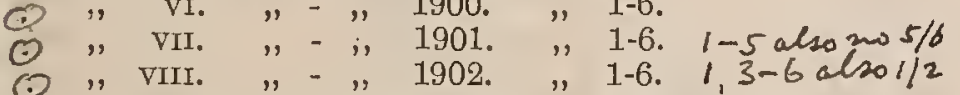

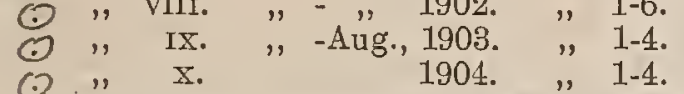

(.) * "* There is a title-page and an" index to each of the vols. V.-viII. a" title-page to vol. $\mathbf{X}$., and'a coloured paper wrapper to each number. With the numbers of vols. $\nabla$.-virI. Was also publishe the "Boletín de los Anales de la Sociedad Filatélica de Chile". $\checkmark$ The numbers of the ninth year consist only of the "Boletín," $\checkmark$ while those of the tenth year consist only of the "Anales". Nos. 5 and 6 , vol. VI.; ; nos. 5 audd 6 , vol. VII.; nos. amd 2, and nos. 4 and 5 , vol. vIrr.; nos. 1 and 2 , and nos. 3 and 4 , vol. IX.; were severally published together, the last two being dated "Enero a
Abril de $1903^{\text {*3 }}$ and " Mayo-Agosto de 1903 " " The four numbers of vol. $\mathrm{x}$. bear no month and only the first has the date "1904".

\section{ANGLO-AMERICAN ADVERTISER AND FOREIGN} STAIMP RECORD. The Anglo-American advertiser and foreign stamp record.

Leicester, Oxford [printed], H. G. B. Collin, I887. $4^{\circ} .10$ in. No. 1, May 7, 1887. Mis. St. Jour. 130 (5).

\section{[Continued as :]}

The Jubilee Commemorator, being the Jubilee number of the Anglo-American advertiser and foreign stamp record.

Leicester, Oxford [printed], H. G. B. Collin, r887. $4^{\circ} .101$ in. No. 2, June 20, 1887.

** The number has a coloured paper wrapper. Wanting.

\section{ANGLO-AIMERICAN PAIMPHLETS FOR STAIMP}

C COLLECTORS. The Anglo-American pamphlets for stamp collectors.

Brighton, etc., H. A. Everett, etc., I88o.

C 8. $7 \frac{1}{4}$ in. Series I. Nos. $1-4$, February, April, June, August,

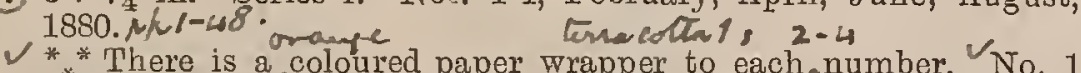
was printed at Bury St. Edmund's and Yo. 4 was published by R. Burnell Spink at Holgate, York, and was printed at Brighton. No 2.3.4 kruntid oy a.m.Robug Mis. St. Pamph. 8 (8).

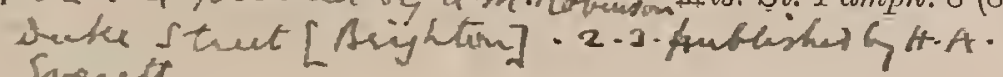
suenet

$$
\text { kj.P.C.J.Voti.p" } 21
$$

ANGLO-AMIERICAN STAMP HERALD AND RE-

(1) VIEW. The Anglo-American stamp herald and review. A monthly journal for philatelists and others.

Fulham, London, S.W., I. W. Harnetty, 1888

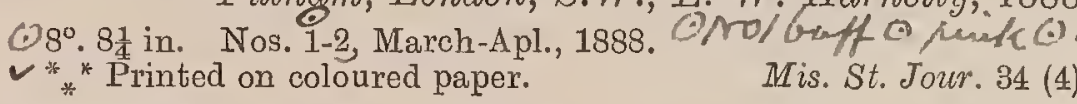

ANNONCE ANVERSOISE. L'Annonce anversoise, Journal philatélique mensuel.

Anvers, Edm. Van der Plassche, I903-04

$8^{\circ} .11$ in. 17 nos. in 2 vols.

1st year. May 15, 1903-A pril 15, 1904. Nos. 1-12.

2nd " " "Sept. "

** The contents" consist entirely of advertisements. NNo. 1 is "*inted on green paper, no. 9 has " $2 \mathrm{e}$ année" in place of "1e année" and nos. 16 and 17 were published together. Wanting nos. 5 and 6.

ANNONCE PHILATHLIQUE. L'Annonce philatélique. Genève, L. Lucien, etc., I895-1903.

$8^{\circ} .9 \frac{1}{2}-10$ in. and fol. $11 \frac{1}{4}-121$ in. 98 nos. in 9 vols.

1st year. Jan. 15, -Oct. 20, 1895. Nos. 1-13.

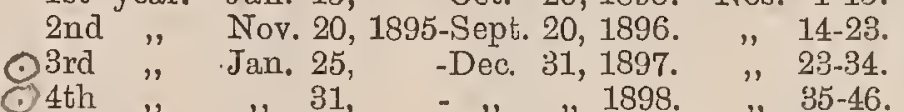

5th " " " $\quad$ " $\quad$ - " " " $1899 . \quad$ " $1899.47-57$.

6th " " ", ",

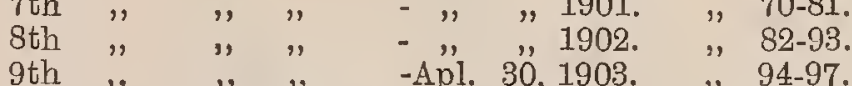
9th "" 10.23 ("September 20, 1896), were" published by Louis JNos. 1-28 are octavo and the remaining numbers are folio. "There are two nos. " 23 ," the second numbered "Ime année " instead of "Irme année" "2nd there arev twoered "IIme annee "instead o "Irme année " and there are two nos. 24 " the first dated " 28 "Irme année" in second " 31 Mars, 1897 " and the first bears "Irme annee "in place of "IIIme annee ". "There is no no. 25 no. 58 bears " 1899 "instead of " 1900 " and no. 82 has "VII.m annee "and "1901" in place of "VIII.me annee " and " 1902 ". The first six numbers were published fortnightly, there is no number for August, 1896, or for $[$ Tos $] 1899.2$ Nos. $29-46$ and 66-97 are printed on rose paper. Nos. 10,26, 37-41, 43-47, 49, each have a supplement and no. 79 has a supplemental slip.
Wanting nos. 52,489, 90, 92. For continuation see "Timbres et cartes".

ANNONCE PHILATRLIQUE. L'Annonce philatélique. Troyes, France, Verdin, etc., I900-

$8^{\circ} \cdot 9 \frac{1}{2}-10 \frac{1}{2}$ in. nos. in vols. In progress.

1st year. Oct., 1900-Jan. 25, 1901. Nos. 1- 4.

$\begin{array}{lll}\text { 2nd " Feb. 28, } & \text {-Nov. 15-30, 1901. " 5-13. } \\ \text { 3rd " Jan. 15, } & \text {-Dec., 1902. }\end{array}$

$\begin{array}{rllll}\text { 3rd " Jan. 15, } & \text {-Dec., } & 1902 . & \text { ", } & 14-25 . \\ \text { 4th } & \text {-Oct, } 20, & 1903 . & \text {," } & 26-35 .\end{array}$

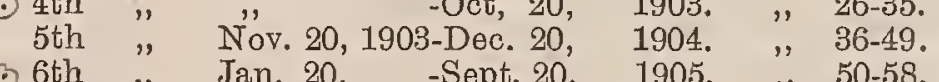

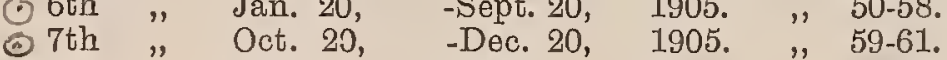

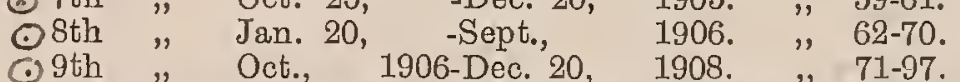

*** Commencing with no. 13 the journal was published by Verdy Nos. 10 and 11,19 and 20,21 and 22,31 and $32,33^{\circ}$ and 34,43 and 44,45 and 46,55 and 56,57 and 58,67 and 68,69 and $70,79^{2}$ and 80,81 andd 82,91 and 92 , and $93^{\prime a n d} 94$, were severally published together, and vhere is a paper, wrapper to each number. No. 12 is dated "Sept.-Octobre, 1901," and there is a supplement of two pages to no. 29 . VThe words " Co-opérative \& Collective" are added after the title on the wrappers of nos. 1-12

\section{ANNONCE PHILATÉLIQUE COOPERATIVE ET} COLLe Ctive. See Annonce Philatélique (Troyes).

ANNONCE PHILATÉLIQUE ET COMMERCIALE. L'Annonce philatélique et commerciale.

Bois-Colombes, J. Minasse, I897-99. $8^{\circ} .93$ in. 23 nos. in 3 vols.

1 st year. Dec. $1,12,24,1897$. Nos. 1-3

2nd " Jan. 1, 8, 15, 22, Feb. 1, 8, 15, 22, Mar. 1, 1898. Nos. 3rd "Jan. 1, 15, Feb. 1, 15, Mar. 1, 15, Apl. 1, 15, May 1, 15, June 1, 1899. Nos. $13-23$. ** The contents consist entirely of advertisements. 'There is a
supplemental slip to no. 1. Wanting no. 11 .

ANNONCE PHILATÉLIQUE TTALIEN ET FRANGAIS. L'Annonce philatélique italien et francais. Prospectus of a journal to be published by Antonio Santini, Ferrara, Italie, in the spring of 1903 , but which was never issued.]
L'aunonce Intermationale f livembing forsy
L'ansonce Cartoph hule

$\&$ Delannoy Paris

[all writtin with a stule]

1902 III Anser

$3-4567$ (twly $\rightarrow$ any

lach 2 or 4 1\% colomed wo

[rcally only putineposteards]

L'annonce Cartó-phole-

que Econtemund from

f Katt Bucharist 
ANNONCE PHILATÉLIQUE SICILIENNE. L'Annonce philatélique sicilienne. Journal mensuel. Catanie, Sicilie, Michele Nocito, 1903-07. Fol, $12 \frac{1}{2}-13 \frac{3}{\text { in. }} 6$ nos. in 3 vols. 1st year. Sept. 1-Nov. 15, 1903. Nos. 1-3. 2nd ", Jan. 1, 1904. Nos. 4, 5.

5th " Jan. 1, 1904. Nos. 1907. No. 6.

* * The contents consist entirely of advertisements. Nos. 4 and 5 were published together.
Mis. St. Jour. 86 (5).

ANNONCE SUISSE. L'Annonce suisse. [Prospectus of a journal to be published at Geneva on April 15, 1900, but which was never issued.]

Mis. St. Jour. 131 (1)

ANNONCE TIMBROLOGIQUE. L'Annonce timbrologique. Organe international mensuel des collectionneurs de timbres-poste et de journaux.

Liége, etc., Armand Dethier, I8goFol. 13 in. nos. in vols. In progress.

1st year. March -Dec. 31, 1890. Nos. 1- 10

2nd " Jan. 31- ", 20, 1891. " 11- 22.

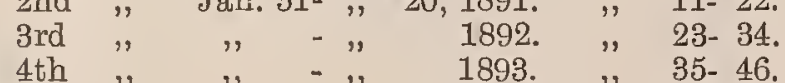

5th " " " $\quad$ th $\quad ", \quad 1894 . \quad " \quad 35-46$.

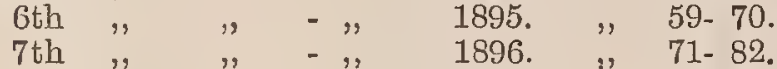

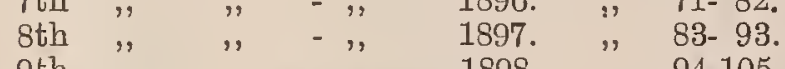

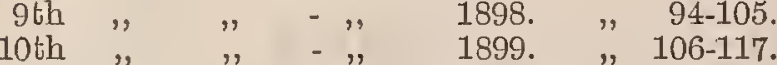

11th " " " $\quad$ - " $\quad 1099 . \quad$ " $1900 . \quad 106-117$.

12th " " - " $1901 . \quad$ " $129-140$.

14th " " " - " $\quad 1903 . \quad$ " $153-164$.

- $\quad 1904 . \quad " \quad 165-176$.

17th " " $\quad$ " , $1906 . \quad$ " $189-200$.

* Commencing with no. 78 the journal has been published at Bruxelles. Nos.78 and 79.90 and 91, 101 and 102, 113 and 114, 124 and 125,136 ańd 137,148 ańd 149, 160 and 161,172 and 173,1 196 and 197, for "Aoutt-Septembre," from 1896-1904, and for 1906 were severally published together as were nos. 179 and 180 . No. 92 is dated "Octobre-Novembre, 1897 , and no. 117 is date " 1985 " no 1903 " is wrongly numbered " 156, " and no 189 bears " $16 \mathrm{~m}$ année" in place of "17me année". A reprint of 50 copies of no. 1 was made in May, 1892. In the original edition of no. 1 the numbers of the third, fifth and seventh pages are placed at the numbers of the third, flth and seventh pages are placed at the left top corner instead of to the right

ANNONCE TIMBROPHILIQUE. LAnnonce timbrophilique. Journal exclusif d'annonces paraissant tous les mois et envoyé gratis et franco à tous les marchands et amateurs qui en font la demande.

Bruxelles, A. Moens Fils, I884-85.

Fol. 13 in. 4 nos. in 2 vols

1st year. May, June and July, Sept., 1884. Nos. 1-3.

2nd year. Jan 1885 . No 1.

** A copy of the prospectus of the journal is hound up in front * A copy

Mis. St. Jour. $82(7)$

ANNONCE UNIVERSELIE. LAAnnonce universelle. Supplément au Schaldis philatélique.

Anvers, Ed. Hulsens, r896.

8. 11 in. Nos. 1-2, Oct.-Nov., 1896. Mis. St. Jour. 110 (7a).

ANNONCE UNIVERSELLE. L'Annonce universelle. Lausanne, Société Lausannoise de Timbrologie, I 903-

$4^{\circ} .11$ in. nos. in vols. In progress.

[1st year.] [Jan.]-Dec., 1903. Nos. [1]-11.

[2nd "] Jan. - ", 1904. "12-22

[3rd ". ] " - "

[4th "The" contents "Noist entirely of adrertisements, and the *" Jeitung". There is no date or number on no. 1 there ane numbers for August "1903, and for the same month of '1904, and 1906. No. 20 is dated "Nov" instead of "Okt." no "25 is wrongly num "24" " and nos 29 and 30 "Okt," nulished towrongly numbered "24," and nos. 29 and 30 were published together, under the date "Aug., 1905 ". No. 2, dated " 15 Fevrier, 1903 , is found on ordinary paper and also on pelure paper, and no. 4 is found on white and also on cream paper. There are two editions of appears on page (4). In the other, this is repla

Bound up with "Schweizer Briefmarken-Zeitung".

1907

1908

$46-57$

1909

$58-6 q$

ho2
ANNONCFN-BEIBLATT ZUIM PHILATELIST. Annoncen-Beiblatt zum Philatelist.

Dresden-Blasewitz, O. Leede, I 903 $8^{\circ} .93$ in. Nos. 1-3, July, September, October, 1903.

** Printed on coloured paper. The three numbers formed sup"Der Philatelist," and are bound up with that journal.

ANNONCEN-BEILAGT ZUIM PHILATELIST. Annoncen-Beilage zum Philatelist.

88.

Dresden, Internationaler Philatelisten-Verein, I886-

Fol. 12 in. and $8^{\circ} .9 \frac{3}{4}$ in. 38 nos. in 3 vols

1st year. [Jan. 1]-Dec, 15, 1886. [Nos. 1-12.]

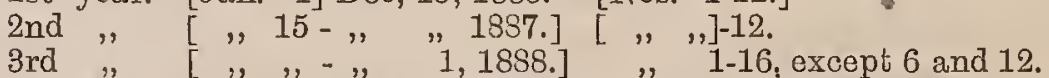
* * This is a "supplement to "Der Philatelist" with which it is bound up. The first and second years are folio and the third year is octavo. The first three numbers of 1886 have merely the title "Annoncen". There are two numbers for March, 1886, one for March 1 and the other for March 15, there is no number fo
October, 1886 , and there is no no. 6 or no. 12 of the third year.

ANNUNCIO PHILATELICO PORTUGUEZ. O Annuncio philatelico Portuguez. Lisboa [? ], I898. \$ 8

C $8^{\circ} .10$ in. Nos. 1-3, May 28, June 28, Aug. 28, 1898.

ANNUNZIO FILATELICO E FILOCARTISTA L Annunzio filatelico e filocartista. (L' Annonçe philatélique et philocartiste.)

$8^{\circ} .7 \frac{3}{4}$ and $9 \frac{1}{2}$ in. 15 nos. in 2 vols

(-) 1st year. May 26-Dec., 1900. Nos. 1-7.

* The numbers of the first year "measure 73 inches and those of the second year 9 1 inches 7 is dated "Novembre-Decembre, , and nos: 3 and 4,9 and 10 , and $13,14,15$, were severally published together. Nos. 8-15 have coloured paper wrappers. Mis. St. Jour. 134 (1) filatelico Italiano. Giornale mensile.

Roma, Gioacchino Guattari, I892-93 Fol. 123 and $13 \frac{3}{3}$ in. "Numero di Saggio," Apl. 20, 1892, and nos. $1-10$; Nov, 30,1892 Jan.-Oct. 1893 .

* * The specimen number measures $12^{3}$ inches and the other numbers, $13^{3}$ inches. The number $12_{4}^{3}$ inches and the other numbers, 13.1 inches. The number 3 for April and May, 1893 Were published together under the nos. 5 and $5 a$, nos. 6 and 7 and dates "Giugno-Luglio, 1893 " and Settembre-Ottobre, 1893". There is a supplement of two pages to no. 4 and one of four pages There is a supplement of two pages to no. 4 and one of four pages
ea.ch to nos. 5 a and 7 . St. Jour. 85 (4).

ANSWERS. Answers. Vol. xIV., No. 356, March 23, 1895. [Contains an article "The boom in English stamps. A talk with a specialist."] London, $B . W$. Young, 1895 . Fol. 12 in. P. 322.

** The number has a coloured paper wrapper.

ANTIQUARY. The Antiquary.

Johnstown, Pa., etc., Johnstown Stamp and Publishing Co., etc., 1898.

$8^{\circ} .9 \frac{1}{4}-8 \frac{3}{4}$ in. No. 1-2, third quarter, fourth quarter, 1898

* Only partly philatelic. No. 2 was published at Saco, Maine, by L. Merner Staebler.

Mis. St. Jour. $144(9)$

\section{ANTVERPIA. Antverpia.}

Anvers, Joseph van Hissenhoven, I897-I 900.

$8^{\circ} 10 \frac{1}{2}$ in. 36 nos. in 3 vols.

(1) 1st year. Sept., 1897-Sept., 1898. Nos. 1-12.

3rd " Oct., 1898- " $1899 . \quad$ " $13-24$

***" Each number has a coloured paper wrapper and the title on the wrappers of nos $\vee 5-36$ reads "Antverpia et Scaldis phila télique réunis". NIn nos. 5-8 "Scaldis philatélique" was given as a separate supplement, but in. nos. 9-36 this supplement was paged up with the rest of the journal. The "Scaldis Philatelique "bears a separate numbering as follows:-

(1) 2nd year. Feb. -Nov., 1898. Nos. 15-24.

(1) 3rd " Dec., 1898- " 1899. (1) 4th " " 1899-Sept., 1900. " "37-46. $\checkmark N o .15$ "has " "3e année" instead of " 2 " année" and nos." 45 and $\checkmark 46$ are numbered in error " 44 " and " 45 ," respectively. Nos. 4 $\sqrt{5} \sqrt{9}$ and 13 of "Antverpia" each have a further supplement of two pages. III ro 25 , Oct. Wes II Qut. No 25 on the araffer.
L'annosaies Jumbropmle clyarofala

ann I 1908 Ap1 nol23689

II 1900 Nolo(whinsupp) 111213 
Annungio Filatelico Intêrnazunale fos.h.Sixp 
Anunciatur be timbers - medellion-1904-582 
ANTVERPIA FT SCALDIS PHILATÉLIQUE REUNIS. See ANTVERPIA.

ANUNCIADOR. Anunciador.

Bogotá, Eugenio Pardo, 1879 . Fol. 13 in. Nos. 1-18, Mar. 1, Apl. 1, May 1, 15, June 1, 15, July 1,15 , Aug. 1, 15 , Sept. 1, 15, Oct. 1; 15, Nov. 1, 15, Dec. 1, 15,

* * Each number consists of a single sheet of coloured paper printed on one side only with the exception of no. 9 , which is printed on both sides. No. 1 is also found with the title "Boletin de Anuncios". This was the first philatelic journal published in Colombia Mis. St. Jour. 86 (12)

ANUNCIADOR. Anunciador.

Bogota, Luis Patiño Orrantia, I 882. $4^{\circ} .10 \frac{1}{2}$ in. and fol. $13 \frac{1}{4}$ in. Nos. 1-4, June 1, 15, July 15, Aug. 11, *** No. 1 is quarto and the other numbers are folio. The title of no. 4 reads "El Anunciador" and each number consists of a
single sheet.
Mis. St. Jour. 85 (1).

ANUNCIADOR FILAT'́fICO. El Anunciador filatélico. Cadiz, Francisco J. Carpintero, I892. Fol. 123 in, and 8०. 83 in. Nos. 1-11, April 5, May 20, June 30, are coloured paper wrappers to nos. 2 and 3 and no. 9 is printed on rose paper. Mis. St. Jour. 107 (15)

ANUNCIADOR FILATELICO. Fl Anunciador filatélico. Revista mensual dedicada a los comerciantes y coleccionistas de sellos.

San José, Costa Rica, Miguel Carranza, I 902.

Mis. St. Jour. $122(5)$

ANUNCIADOR FILATELICO DE VENEZUFLA. El Anunciador filatelico de Venezuela.

Caracas, Venezuela, E. H. Lugo y. A. Ferrer, etc.,

$\$ 82 \quad \mathrm{r} 892-93$

Fol. $13 \frac{3}{4}$ in. 11 nos. in 2 vols.

, 10

3 2nd " " 1, 1893. No. 11.

she fl $V^{*} *$ Nos. 5-8 were published by Arredondo y Forrer and hos. 9-11 by Aurelio Ferrer. This was the first philatelic journal published

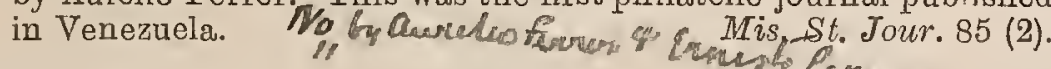

ANUNCIADOR FILOTËLICO. Anunciador filotèlico. Organo de los filotelistas Sud-Americanos.

Bogotá, Colombia, Arturo Rivera, I882.

$4^{\circ} .8 \frac{3}{4}$ in. Nos. 1-5, Apl.-Aug., 1882.

Mis. St. Jour. 89 (4).

ANUNCIADOR PERIODICO FILATELISTA. El Anunciador periodico filatelista.

Santiago, España, Ernesto Carrero, I 896-97.

$S 8$ - $\quad 8^{\circ} .9 \frac{3}{4}$ in. 6 nos. in 2 vols.

1st year. Nov. 1, Dec. 1, 1896. Nos. 1-2.

*** There is a coloured paper wrapper to each number. Wanting

NUNCIADOR TIMBROLŌGICO.

El Anunciador timbrológico. Ferrol, España, Manuel Riva, I895-96.

1st year. Nov. $1, D_{3 c} / 1895$. Nos. $1-2$

2nd " Jan. 1, Mar. 1, July 1, 1893. Nos. $3-5$

ANUNCIATORUL MăRCILOR. Anunciatorul Măr-

(.) Fol. 12 in. No. 1, March $3 / 15,1897$.

* * A copy of the prospectus is bound up with the number.

Mis. St. Jour. 105 (15)

ANVHRS PHILAT氏LIQUE. See ANVERS PHILATHÉLIQUE.

ANVERS PHILATÉLIQUE FT L'UNION DES TIMBROPHILES REUNIS. See ANVERS PHIIATHÉLIQUE. Aug. 5, 20, Sept. 5, 20, Oct. 5, 20, Nov. 5, Dec. 20, 1832.

* No. 1 and nos. 8-11 are folio and nos. 2-7 are octavo. There 8. 10 in. . No. 1, August 15, 1902.

2nd "Jan. 1-Apl. 1, 1897. Nos. 3-6. $8^{\circ} .11$ in. 5 nos. in 2 vols.

Mis. St. Jour. 110 (9) cilor. Jurnal filatelic lunar pentru colectionari şi comercianț̆ de Mărč̆.

ANVERS PHILATHÉEIQUE. Anvers philathélique.

Anvers, P. Puissant, etc., I892-95.

Fol. $16^{3}$ in. and $12 \frac{1}{4}$ in. 29 nos. in 3 vols.

1st year. Sept. 10, 1892-Aug. 15, 1893. Nos. 1-12.

3rd " " 15, 1893- " " $1894 . \quad, 1-12$.

** The first "ighteen numbers measure 163 inches and the $r$

mainder 121 inches. Nos. 2-5 of the third year were published

by William van Aken, and there is a supplement of two pages to each of these four numbers. After no. 5 of the first year the 4 $4 \%$ titie reads "Anvers Philatélique". A copy of the prospectus o the journal, dated August 1, 1892, is bound up in front of no. 1.

\section{[Continued as :]}

Anvers philatélique et l'Union des timbrophiles réunis. $8^{\circ} .8 \frac{1}{2}$ in. Vols. Irr.-IV. 14 nos. Anvers, W. van Aken, I895-96.

(c) 3rd year. Feb. Aug., 1895. Nos. 6-12.

4th ", Sept., 1895-Mar.-Apl., 1896. ", 1-7.

$V_{*}^{*}$ There is a coloured pape" wrapper to each number and a

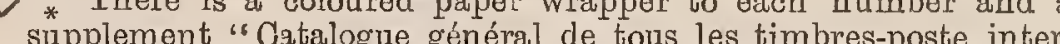
upplement as Onternationaux et locaux, timbres-télegraphe, timbres-taxe, timbres de ournaux, timbres de service et de retour, émis de 1840 à 1895 avec leurs prix réels ou leurs prix de vente, chez J. Nalès.

Compose par J. Nalès... Deuxieme edition, 1895." This catalogue was only completed to the commencement of Gabon. In bers bears the words "nouvelle série " and the numbers 1-14.

ANZEIGER DER WIFIFRILIUSTRIRTFN BRIEF

MARKEN ZEITUNG. See WIENER ILLUSTRIRTE Briefmarken-Zeitung.

APPLFTON'S WFEKLY. See APPLETON'S WEEKLY CIRCULAR.

APPLETON'S WEEKLY CIRCULAR. Appleton's weekly circular. Fol. 15 in.

.
lisher and cannot therefore be considered a philatelic journal. 1.1A.2.3.4.5 [Mar3.10.17.24.31

$$
\text { [Continued as :] }
$$

_- Appleton's weekly. New series.

$8^{\circ} .8 \frac{1}{2}$ in.

$$
\text { Bradford, T. C. Appleton, I906- }
$$

* Like the earlier numbers this consists almost entirely of a price list of stamps, etc., for sale by the publisher and cannot be considered a philatelic journal. No. 2a is dated "April 21st. 1906 ".

ARALDO FILATELICO. L' Araldo filatelico. Saluzzo, Italie, G. Bellino, r905-06. 1st year. [June, 1905]-May 20, [19061. Nos. 1-12. (2) 2nd " June, July, [1906]. Nos. 13-14.

$\checkmark *$ * (No. 2) bears the words "Numero di saggio" and has "no. 2 " attached on a separate piece of paper, or written by hand in pen and ink, in the right upper corner. No. 1 and the "numero di saggio" are folio $16 \frac{1}{2}$ inches, nos. $(3,4,5)$ which were published together, ${ }^{2}$ easure $13^{3}$ inches, and nos $6-14$, which are octavo,

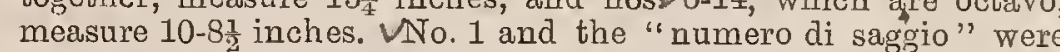
printed by autographic lithography at Torino, no. $3,4,5$ was produced by a hand multiplying press and nos, $6-8$ and no." 11 were printed by autographic lithography at Saluzzo. Nos: 6 and $7 \div 9$ and 10 , and 13 and 14 were severally published fogether. Nos.

¿ 1 and $6-8$ have no date and nos. "11-14 bear the month of issie but no year. No. 8 has "anno $2^{\circ}$ " in place of "anno $1^{\circ}$ Mis. St. Jour. $120 \cdot(15)$

ARALDO FILOTFLICO F NUMISIMATICO. Araldo filotelico e numismatico.

Milano, Maria Rosa Tommasi, I894-95. $8^{\circ} .10$ in. Nos. 1-2, Dec. 1, 1894-Jan. 1, 1895.

*** Each number has a coloured paper wrapper. The title on no 2 and on both the wrappers reads "L' Araldo Filotelico e Numismatico".

\section{[Continued as :]}

L' Araldo timbrologico e numismatico.

Milano, Maria Rosa Tommasi, 1895. 8. $8^{\circ} 10$ in. Nos. 3-8, Feb. 1-July 1, 1895.

**. Each number has a coloured paper wrapper. $\checkmark$ No. 6 is wrongly numbered " 9 " except on the wrapper which is correct and the wrapper of no. 3 has " 1894 " in'place of "1895". Bradford, T. C. Appleton, I 906. Fol. $16 \frac{1}{2}$ or $13 \frac{3}{1}$ in. and $S^{\circ}$. 10-8 $\frac{1}{2}$ in. 14 nos. in 2 vols. of II , $1893 \operatorname{sep} 15$

thu are lavo edetwers orvarutios, one with the 2 glohs at the headenc ghetes, Bhad both, the lavter on thicke

crasupaper a the other without the

\footnotetext{
anumaiador Felatiluco Scusalo Domungu 1907 teat the
}

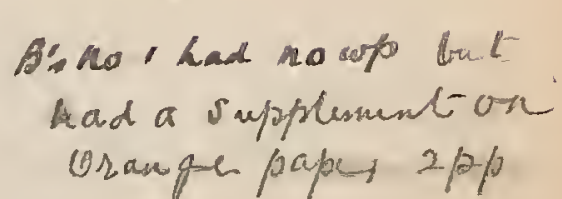

Aad a supplesumb ot

$$
\begin{array}{r}
\checkmark \text { and the wrapper of no. } 3 \text { has " } 1894 \text { "in'place of "1895". } \\
\text { Mis. St. Jour" } 89 \text { (6a). }
\end{array}
$$


455

ARALDO

ARALDO TIIIBROLOGICO E NUMISIMATICO. S ARALDO FILOTELICO E NUMISMATICO.

ARCADE AND MIONTHLY EXCHANGF. The Arcade and monthly exchange.

rot a frow eopt $8^{\circ} .10$ in. Nos. 1-2, Mar.-Apl., 1880 1. Amalgamated with the "Champion exchange, the Aroade, and F'oreign stamp gazette," in May, 1880.

ARChatologist. See Mercurx.

ARCHIVES DES COLLECTIONNEURS. Les Archives des collectionneurs. Revue mensuelle illustrée, paraissant le 15 de chaque mois. Supplément gratuit à la "Revue philatélique française". Méricourt-l'Abbé, H. Douchet, r9o г-०3. $8^{\circ} .10 \frac{1}{3}$ in. 26 nos. in 3 vols.

(1st year. Oct. 15-Dec., 1901. Nos. 1-3.

$\odot$ 2nd " Jan.-Dec. 15, 1902. " $4-14$.

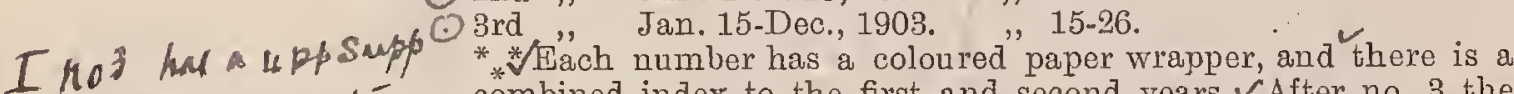
or leaves werth caulis postates shustín

combined index to the first and second years. $\checkmark$ After no. 3 the journal was no longer supplied free to the subscribers of the "Revue philatélique française," but became a distinct publication. Nos. 4 ând 5 were published together under the date "Janvier-Février, 1902"/ho. 9 is dated " 15 Juin-Juillet, 1902," $\checkmark$ nos. (21, 22, 23) and 25 and 26 were severally published together under the respective dates "Juillet-Août-Septembre, 1903," and Philatélie interplanétaire," par J. Suizalloy running through the twenty-six numbers.

[Continued as :]

_ Les Archives des collectionneurs et des curieux. Méricourt-l'Abbé, H. Douchet, r 904 . $8^{\circ} .10 \frac{1}{4}$ in. Vol. IV. 4 nos.

4th year. Jan-Apl., 1904. Nos. 27-30

${ }_{*} *$ Each nunber has a coloured paper wrapper and nos. 27 and

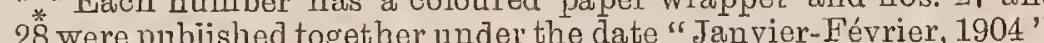
The supplement "La Philatelie interplanetaire," par J. Suizalley The supplement "La Philatelie interplanetaire"

ARCHIVFS DFS COLLECTIONNEURS DES CURIEUX. See ARCHIVES DES COLLECTIONNEURS.

ARGENTINA FILATF́LICA. Argentina filatélica. I 903.

Buenos Aires, D. H. Casa Rahden y M. A. Massa,

(2) $8^{\circ} .8 \frac{1}{2}$ in. Nos. 1-3, Aug.-Oct., 1903.

* There is a coloured paper wrapper to each number. Mis. St. Jour. 84 (1).

ARGFNTINO FILATEIICO. El Argentino filatelico.

Rosario de Santa-F'é, Argentine Republic, A. R. de

Wo 1 has the figure Bousquet, $1894-95$.

usulid is ant Fol. 143. in. Nos. 1-9, Sept. 15-Dec. 15, 1894, Feb. 1, July, Aug.;
Mis. St. Jour. 75 (5).

ARGOS. El Argos. Madrid. Año I. Num. 102. Domingo 31 de Diciembre de 1871. [Contains a letter addressed to Dr. Thebussem from Pascual Lucas de la Encina of Macao.]

*** The letter has been cut out and mounted in Mis. St. Jour. 43 (5).

ARGOSY MONTHLY SALE AND EXCHANGE LIST. The Argosy monthly sale and exchange list.

Belfast, Oxford [printed], W. Nesbitt, I886. $8^{\circ} .7 \frac{1}{2}$ in. No. 1, Apl., 1836.

* * The number has a coloured paper wrapper. The heading on page 3 reads "The Argosy sale and exchange list". The paper
contains nothing but advertisements. Mis. St. Jour. 80 (6).

[Continued as :]

The Argosy monthly sale and exchange list and stamp advertiser. Belfast, W. Nesbitt, 1886. $8^{\circ} .7 \frac{1}{2}-8 \frac{1}{2}$ in. Nos. 2-3, May-June, 1886.

** No. 2 is octavo $7 \frac{1}{2}$ inches, is printed on yellow paper and has a blue paper wrapper. Besides advertisements the number contains a review of stamp journals. No. 3 is octavo $8 \frac{1}{2}$ inches, is printed on white paper and has a rose paper wrapper. It contains, besides advertisements, an article "A few words about stamps" and a review of stamp journals. Amalgamated with "Waugh's monthly exchange list". Wanting no. 3

Mis. St. Jour, 80 (7).
ITS: ARGOSY

456

ARGOSY MONTHLY SALF AND EXCHANGE LIST AND STAMIP ADVERTISER. See ARGOȘY MONTHLY SALE AND EXCHANGE LIST.

ARGOSY SALE AND EXCHANGE LIST. See ARGOSY MONTHLY SALE AND EXCHANGE LIST.

ARGUS. The Argus. No. 15, 763. January 7, 1897. [Contains an article "Stamp frauds. Robbing the post office. Philately up to date. A new use for salts of lemon."] Melbourne, A. MI. Ebsworth, I897 Fol. $25^{\frac{3}{4}}$ in. p. 5.

Mis. St. Jour. 136 (24).

ARGUS PHILATELIST. The Argus philatelist.

$16^{\circ} .5$ in. No. 1, August, 1896. Olean, N. Y., L. Lawrence, r896. * *" Edited by Jas. Wilkinson.

Mis. St. Jour. 96 (3).

ARIZONA PRIDE OF PHILATELY. The Arizona pride of philately.

Tucson, Arizona, T. A. Browne, I885-86. $8^{\circ} .9$ in. Nos. 1-4, Dec. 15, 1885-A pril, 1886

** No. 4 has a coloured paper wrapper with the date "March and April, $1886 "$ ".

ART INTERNATIONAL. L'Art international. No. 2. Mars 1895. [Contains a list of stamps for sale.]

Paris, J. de Lacki, 1895 .

$8^{\circ} .10$ in. pp. $47-49$.

** The number has a paper wrapper. IIis. St. Jour. 141 (4).

ART JOURNAL. The Art journal; art-union monthly journal of the arts. No. exx. June, 1848. [Contains an article "Compound plate printing," with illustrations of essays of postage stamps printed by Charles Whiting.] London, Chapman and Hall, I848.

$4^{\circ} .11^{3}$ in. pp. 194, 195, 1 plate.

* * The number has a coloured paper wrapper.

ARTE FILATÉLICO. El Arte filatélico.

Valencia, Venezuela, J. N. Sénhenn Illas, 189z-94. $8^{\circ} .10^{3}$ and $9 \frac{1}{2}$ in. Nos. 1-2, Nov. 15, 1892-Sept., 1894.

** No. 1 measures 103 inches and no. $2,9 \frac{1}{2}$ inches.

ARTE Y LETRAS. Arte y letras.

$8^{\circ} .9$ in. nos. in 2 vols.

1st year. Sept. 1.-Dec. 1, 1901. Nos. 1-4.

2nd " 1902 .

** Only partly philatelic. There is a paper wrapper to each
number. Wanting no. 5 and any after no. 6 , which is dated Feb. 1,1902 .

ASPEN VIEW PHILATELIST. The Aspen View philatelist. Aspen View, Va., Robt. H. Poarch, I903. in. No. 1, May, 1903

* * Succeoded by the "Philatelic midget," Aspen View, Va., in June, 1903. Wanting.

ATHEN 开UII. The Athenaeum. Journal of English and foreign literature, science, and the fine arts. Nos. 497 and 547. May 6, 1837 and April 21, 1838. [Contain reviews, respectively, of Rowland Hill's " Post Office reform" and "minutes of evidence taken before the Select Committee on postage".]

$4^{\circ} .11 \frac{1}{2}$ in. p. 320 and pp. 281-284. London, John Francis, $1837-38$ Mis. St. Jour. 152 (11).

ATHEิNES-PHILATÉLIQUE. Athènes-philatélique. Athènes, D. Lambadarios, $1894-97$. $8^{\circ} .10$ in. and fol. $13 \frac{1}{3}$ in., 15 nos. in 2 vols.

1st year. Apl.-Oct. 31/Nov. 12, 1894. Nos. 1-7. 2nd "Apl., 1895, Apl. 31, (sic)-June 30/July 12, 1896, end Oct./Nov. 12, end Dec./Jan. 12, 1897. Nos. 8-15. $\checkmark$ ** Nos. $1-11$ are octavo and the remaining numbers are folio $\checkmark$ Nos. 14 and 15 wore published together under the date " F" in Decembre/12 Janvier, 1897 ". Amalgamated with the "Time, St. Jour. 88 (9).
Gaulois," in June, 1897.
Mis. St 
Anstabinis Strmen news.

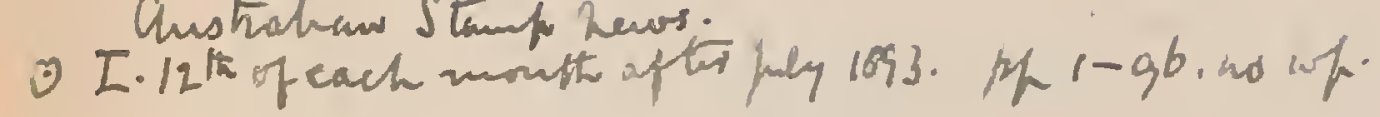

A.P.R. $=$ Australian Philatelic Rẹçord.... III, IV

$$
\text { austiobar Prebationst- }
$$

Errors and Varieties.-The collector of stamp ournals has plenty of varieties and errors to hile he does not usually collect hem as such, it is very necessary to not

void confusion of issues or volumes.

One of the most curious and inexplicable " errors f volume" occurs in the Australian Philatelist, a joinal whe warious ownerships was journal which under various ownerships was published from August, 1894,40 and 30 -being the last three volumes-28, 29 and 30 dited by Mr. E. D. E. Van Weenen. Volumes were indicated in the old-fashioned 1923. The November No, 12 dated October 5, 1923 . The November and Dec. 1923 issues were correctly inscribed as volume XXX, so were those for January, February and March, 1924. But the last seven issues, April to October, Nos. 6 to 12, all have the volume wrongly inscribed as XXIX, not only on the cover, but on the first editorial page as well. How such but on the flinoticed by editor, publisher, public-for one assumes that it post-oflice and pur pointed out for won mo fellah seren monte point for the biophile to can understanc. note is that all nerer complete the last volume of the series! 
ATHENS. The Athens.

Oakland, Cal., the Athens Publishing Co., I899. $8^{\circ} .93$ in. No. 7, September-October, 1899.

** Only partly philatelic. The number has a coloured paper wrapper. Nos. 1-6 were non-philatelic. Mis. St. Jour. 144 (13).

ATLANTIC PHILATELIST'S ADVERTISER. The Atlantic philatelist's advertiser.

New York, R. A. Deglim, r891.

$4^{\circ} .7 \frac{3}{2}$ in. Nos. 1-2, Mar.-Apl., $1891 . \quad$ Mis. St. Jour. 66 (15).

ATLAS. Atlas.

Yonkers, N. Y., etc., Atlas Society, igo г-05. $8^{\circ}: 8 \frac{1}{2}-9$ in. nos. in vols.

Vol. I. Jan.-April-May, 1901. Nos. 1-4.

"* Only partly philatelic. No. 4 is dated "April-May, 1901".

$5.8 \gamma$ volume or number. Those in the library are :-

January, F'ebruary, April, May, July-August, 1902

All March, April, May, 1905.

All of these numbers were published at Now York, and the two last have supplements of four pages.

ATLEE'S STAIMP CIRCULAR, See W. D. ATLEE'S STAMP CIRCULAR.

AUCTION SALE PRICES. See SALE PRTCES.

AURORA. Aurora.

Durango, Mexico, Sociedad Cartófila Mexicana, r 906.

$8^{\circ} .85$
$\forall * *$ in. Nos. 1-
$\forall *$ Only partly philatelic. There is a coloured paper wrapper to

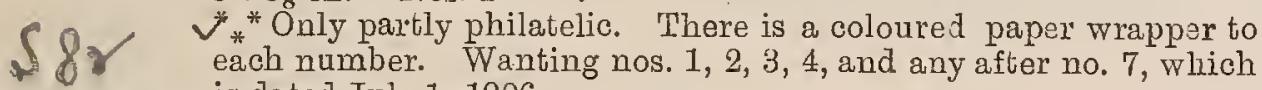
is dated July $1,1906$.

AURORE PHILATKLLIQUE. L'Aurore philatélique.

$8^{\circ} .11$ in. 24 nos. in 3 vols.

1st year. July 1-Nov. 25,1898 . Nos. 1-6.

2nd " Jan. 1- 1- 15, 1899. " 1-12.

3rd " "T" $1-[?$ ? June] 1900.

.** The numbers of the third year were published by $\mathrm{Ch}$. Beniest. There is a coloured paper wrapper to each number. Nos. 5 and 6 of the first year, were published together with the date "25 Novembre, $1898 ; 2$ nos. $4,5,6$, of the second year, together with the date " 1 Juin 1899," and nos. 11 and 12 of the same year, together with the date "15 Novembre, 1899 ". Wanting second year, no. 2 and third year nos. $3,5,6$

AUSTRALIAN JOURNAL OF PHILATELY. The Australian journal of philately. Sydney, Smyth and Nicolle, etc., I goo-05.

8.91 91 in. 59 nos. in 5 vols.
Vol. I. Sopt., 1900-Aug. 7, 1901. Nos. 1-12.

Vol. I. Sopt., 7, 1901-Sept. 19, 1902 . " 13 . $13-24$.

", III. O"ct. 16, 1902- "

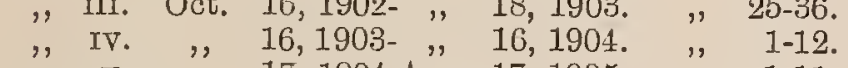

" v. ", 17, 1904-Aug. 17, $1905 . \quad$ "1-11.

* "Edited by James H. Smyth. There is a paper wrapper to each number and a title-page and an index to each volume. There is no number for June, 1902, and no. 2 has a supplement of four pages. Commencing with no. 22 the journal was published by J. H.. Smyth and Co. No. 3 vol. v. has "November 16,

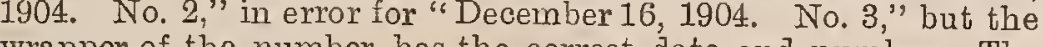
wrapper of the number has the correct date and number. The "title-page and index to vol. v. Were given as a supplement to the

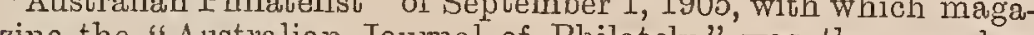
zine the "Australian Journal of Philately" was then amalga-

\section{AUSTRALIAN PHILATELIST OR STAMP AND} CREST PROSPIFCTUS. See PART I LEWIN AND Co. (э. т.) The Australian philatelist or stamp and crest prospectus. [1878], $16^{\circ}$.

AUSTRALIAN PHILATELIST. The Australian philatelist.

Sydney, Fred. Hagen, etc., 1894$8^{\circ} .8 \frac{1}{2}$ in. and $9 \frac{1}{2}$ in. nos. in vols. In progress. Vol. I. Aug. $25,1894-J$ uly 25,1895 . Nos. $1-12$

Vol. vIII. Sept. 2, 1901-Aug. 1, 1902. Nos. 1-12.

"IX. ," 1, 1902-" 1, 1903. "1-12.

" $\quad$ X. " 1, 1903- " 1, 1904. " 1-12.

" xIr. " " $\quad 1,1905-", 1,1906 . \quad$ ", $1-12$.

1, 1906- " 1, 1907. "

* "This journal was a continuation of "Vindin's Philateli Inonthly". There is a title-page and an index to each volume an a paper wrapper to each number. Vol. IV., no. 1, vol. vi., nos. and 6, vol. vII., nos. 2 and 7 and vol. vIII. no. 5 have supplements of two pages, there are two plates of illustrations to vol. $x$. no. 11, and nos. 1, 4 and 7, of vol.XIr. have supplements of two pages. Vols. V. and VI. Were published by Oscar Schulze, and commencing with vol. XII. the journal has been published by Fred. Hagen, Limited, and the size increased to $9 \frac{1}{2}$ inches.

AUSTRALIAN STAIMP COLLECTOR AND PHILA

TFLIC ADVERTISER. The Australian stamp collector, and philatelic advertiser.

Melbourne, T. Webb, т893-96.

$8^{\circ} .83$ in. 29 nos. in 2 vols.

. Nos. 1-13.

" Ir. Jan.-May, Nov., Dec., 1895, Jan.-Sept., 1896. Nos. 13-

* * There is a title-page to vol. r. and a coloured paper wrapper to each number, except no. 13 rol. I. Nos. 11 and 12, vol. I. were published in the same wrapper, with the date "August, Septem ber, 1894 ". Nos. 13 and 14, 16 and 17, 23 and 24, were severally published together. No. 13, vol. I., consists of four pages num bered 93,94, 99, 100, and the paging of nos. 13, 14 vol. II. commences with 93 . the title of the joun the tithiren as "The hustralian stamp collector". A copy of the prospectus of the journal is bound up at

AUSTRALIAN STAIMP COLLECTORS' JOURNAL. The Australian stamp collectors' journal.

Adelaide, South Australia, Fred. Stanley, 1879-80.

$8^{\circ} .8 \frac{1}{2}$ in. Nos. 1-4, Nov. 1, 1879-Feb. 2, 1880.

** This was the first philatelic journal published in South Mis. St. Jour. 30 (18).

AUSTRAIIAN STAMP NEWS. The Australian stamp news.

Gunalda, Queensland, J. E. Newell Bull, i893-94. $4^{2} \cdot 11 \frac{1}{4}$ in. and $8^{\circ} \cdot 8 \frac{1}{2}$ in. 14 nos. in 2 vols.

๑Vol. I. July, 1893-June 12, 1894. Nos. 1-12.

"Ir. " 12 -Aug. 12, 1894. " 1-2.

* " Vol. I. is quartovand vol. rf, octavo, and the two numbers of

vol. II. have coloured paper wrappers. A copy of the prospectus is bound up in front of the first number. This was the first philatclic journal published in Queensland.

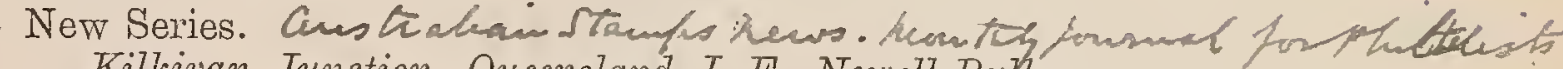
I 898

Kiltivan Junction, Queensland J. E. Newell Bull,

8. 10 in. Vol. rr. 6 nos

OVol. Ir. April-Oct., 1898. Nos. 1-6.

** There is no number for June, 1898. $\checkmark$ No. 3 also bears "No. 17 "." Amalgamated with the "Australian Philatelist," January,
1899.
Mis. St. Jour. $130(4)$.

AUSTRALIAN STAIVP NEWS QUARTERLY. The Australian stamp news quarterly. [Prospectus of a journal to be published by J. E. Newell Bull, Gunalda, Queensland, in December, 1894, but which was never issued.]

I893-94.

AUSTRIA-PHILATEIST. Austria-Philatelist

$8^{\circ} .10 \mathrm{in.} 97$ nos. in 6 vols Prag, P. Rieal, etc., 1893-99.

C. 1st year. Dec. 1, 1893-Dec. 1, 1894. Nos. 1-12, and "Weihnachts-Heft

2nd "Jan. 1-Dec. 1, 1895. Nos. 1-12.

Sth " " "1- " 15, $1896 . \quad$ " 1-24.

5th " " "1- ", 1898. " $1-24$.

C6th " "Nov., $1899 . \quad " 1-11$.

***7h"re is "a title-page and an index to each of the first five years and a paper wrapper to each number with the exception of nos 1 and 2 of the first year. "The wrapper of no. 6 of the first vear bears the word "Festnummer" and nos. 8 and 9 and 10 and 11 of the sixth year were severally published together. Nos. 22-24 of the fourth year, and the numbers of the fifth and sixth years were published by H'ranz Duschek. The journal was published were pightly in 1896 and 1897 and in January, 1898. 
AUXILIARY PHILATrLIST. The Auxiliary philatelist. $32^{\circ} .4 \frac{1}{2}$ in. Nos. 1-2, Jan.-Feb., 1900. Houlton, Me., L. H. Mutch, I goo.

\section{[Continued as :]}

(- The Auxiliary philatelist and philatelic-literature-collector-combined. Houlton, Me., L. H. Mutch, I900. $32^{\circ} .4 \frac{1}{2}$ in. No. 3, Marcb, 1900 .

* The number has a coloured paper wrapper inscribed "The Auxiliary Philatelist, with which is combined the Philatelic Literature collector, no. 16.' Devoted to stamps and stamp literature collecting."

$$
\text { [Continued as :] }
$$

(-) The Universal exchange and auxiliary philatelist. Putnam, Conn., C. W. Chase, I goo. So. 9 in. Vol. II., no. 3, April 1900. Mis. St. Jour. 101 (1b).

$$
\text { [Continued as :] }
$$

- Auxiliary philatelist and universal exchange.

Putnam, Conn., C. W. Chase, I9oo-oI. $8^{\circ} .9$ in. New Series. Nos. 1-4, June, Nov., 1900, Jan., Apl., 1901.

*" No. 1 is also numbered "Vol. II., no. 4," nos. 3 and 4 have "Taper wrappers and no. 4 has the title preceded by the word

UXILIARY FHILATEITST AND PHILATELICIITERATURE-COLLECTOR-COMBINED. See AUXILIARY PHILATELIST.
AUXILIARY PHILATELIST AND UNIVERSAL FXCHANGE. See AUXILIARY PHIATELIST.

AVENIR DES TIMBRRTSPOSTE. L'Avenir des timbresposte. Envoyé gratuitement à tous les collectionneurs et marchands.

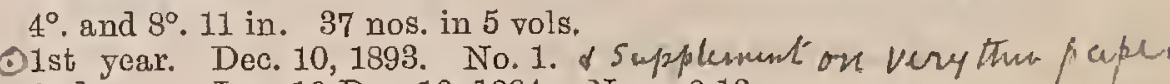

(1) 2nd year. Jan. 10-Dec. 10, 1894. Nos. 2-13

2nd " Jand 10- " 10, 1895. " 14-24.

(1) " " $" 10$ " $10,1895$.

, $20,1397,1096$.

", $25-36$.

35th " " " $20,1897$. No. 37.

remaining numbers are octavo. $\checkmark$ The numbers for September 10 and October 10, 1895, were pub" published together, under the date " 20 Août-Septembre, 1896 ". There is a supplement of two pages to no. 7 and also to no. 2 .

AVERIGUADOR, El Averiguador. Correspondencia entre curiosos, literatos, anticuarios, etc., etc.

Madrid, E. de Mariátegui, I87I-73.

$8^{\circ} .8 \frac{3}{4}$ in. 50 nos. in 3 vols.

Ist year. Jan. 1-Dec. 15, 1871. Nos. 1-24.

2nd $, \quad 15-31,1872$.

3rd " 15-Feb. 28, 1873. " $49-52$.

* * Th"is is not a philatelic journal, but there are a good man articles and notices on philately in its pages. There is a title-page and an index for the first year and also one for the second year. - Each number bears "Segunda época"; the numbers of the first year were published on the 1st and 15th of each month, and those of the second year on the 15 th and 31st. Nos. 50 and 51 containe no philatelic matter and only the philatelic portions of nos. 49 and 52 have been preserved. 
Averill: Adventiver. Postland. Oreforn. $3_{2} \times 0$.

a. B. Averils.

$\odot$ no $1.2 \cdot 3 \cdot 3 \cdot 4.5 \cdot 6.7-891011121314151671819.20$

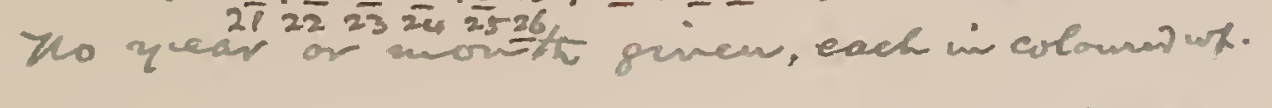

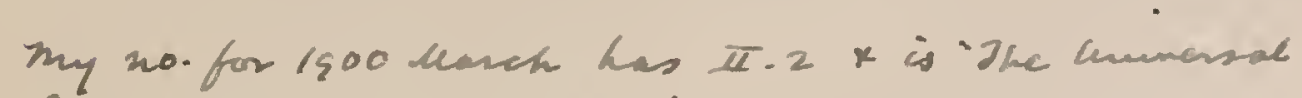

Stohange for stargain Secters rmait orter mese. 
Bargauns-Londow-19o4-S83

Bargains. Liverpool. B. Btallowary.

24 mo. 1908-9I

San. Ihe mar (Mab)

B K K. Stens.
Fron No $11-16$

on surfaced rapar. soll also a varicty on lhicker paper. 
BABY PHILATELIST. The Baby philatelist. Devoted to the interests of philately. Elkhart, Ind., H. O. Smith and Co, I896. $16^{\circ} .5_{9}^{3}$ in. No. 1, Feb., $1896 . \quad$ Mis. St. Jour. 68 (3).

BADGER. The Badger. Milwaukee, Wis., [? ], r8g8. in. No. 1. .

BADGER PHILATELIST. The Badger philatelist 96. Viroqua, Wis., W. F. Cherington and Co., etc., I895-

$16^{\circ} .5 \frac{1}{2}-6 \frac{1}{2}$ in., $24^{\circ} .5$ in'. and $8^{\circ} .8$ in. Nos. 1-8, Aug., 1895-Feb.,

* * No. 1 is $16^{\circ}$., $5 \frac{1}{2}$ inches; no. $2,16^{\circ}$. $6 \frac{1}{2}$ inches; no. $324^{\circ} .5_{\text {f }}$ inches, nos. $4-8$ are octavo, and nos. $1-3$ have coloured paper wrappers. Nos. 3-5 were published by W. F. Cherington and nos. $6-8$ by L. J. Williams. There is a supplement of two pages, printed on coloured pajer, to no. 3, the number for November and December, 1895, is numbered " 4 " instead of " 4 and 5 " and nos. 6 and 7 , which were also published together, have the date " 1886 " instead of " 1896 ". No. 8 is also numbered "whole no. 6".
Mis. St. Jour. $93(15)$.

BADGER STAIMP NOTES. Badger stamp notes. I 905 Milwaukee, Wis., Reim Stamp and Publishing Co.,

8. 9 in. Nos. 1-2, April 25- 1905.

* * Succeeded by the "United stamp journal ". Wanting no. 2.

(5) BADGER STATE ADVERTISER. The Badger State advertiser. Palmyra, Wis., Williams and Co., ז894.

C. $8^{\circ} .8 \frac{1}{2}$ in. No. 1, April, 1894.

BADGER STATE PHILATELIST. The Badger State philatelist.

Delavan, Wis., Carter and Judson, etc., I887-89. $4^{\circ} .9 \frac{1}{4}$ in. and $8^{\circ} .9$ in. 21 nos. in 2 vols.

Vol. I. Dec. 10, 1887-Nov., 1888. Nos. 1-12

*" II. " 1888-Aug., 1889. " 1- 9

* * No. 1 is quarto and the other numbers are octaro. Each number has a coloured paper wrapper with the exception of nos. 1 and 2 of vol. I. Commencing with no. 4, vol. I., the journal was published by N. E. Carter. No. 6, vol. I., is dated "Apr. 15," instead of May, but on the paper wrapper the date is given correctly.

BAKER'S FALLS STAIVP. The Baker's Falls stamp. Sandy Hill, N. Y., The Baker's Falls Stamp and Publishing Co., 1897 .

$8^{\circ} .8 \frac{1}{2}$ in. No. 1 , November, 1897.

* * The number has a coloured paper wrapper, and was edited by Chas. C. Guy. Mis. St. Jour. 147 (5)

$\odot$ BALKAN. Balkan.

Sophia, Bulgarie, J. Willheimer, 1895 O. $4^{\circ} .11 \frac{3}{4}$ in. Nos. 1-3, July 20-Sept. 8-20, 1895 July20 ang S/2 Sept-S/20. St. Jour. 87 (15).

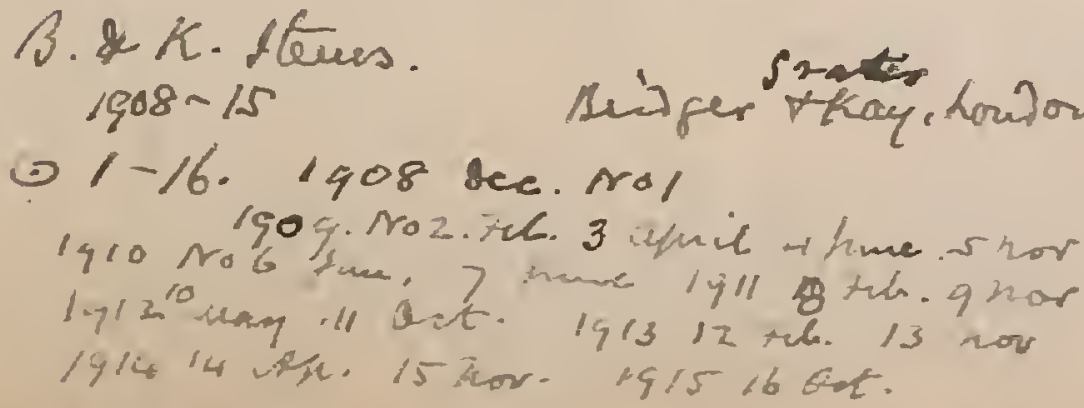

BALTIMORE PHILATELIST. The Baltimore phila telist. Baltimore, Md., J. P. Mackenzie, I88 I-8z

$8^{\circ} .9 \frac{1}{2}-10 \frac{1}{2}$ in. Nos. $1-7$, Nov., 1881-Níay, 1882.
** No. 4 was published by Liebig and Mackenzie.

Mis. St. Jour. 7 (9)

BANGKOK TIMES. The Bangkok times. Vol. IX. No. 416. April 25, 1891. [Contains a paragraph about a one att postage stamp of Siam said to have been in use in 1878. Banglok, T. I. Williamese and C. Thorne, т89г.

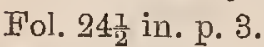

Mis. St. Jour. 136 (23)

BANK NOTES. Bank Notes. The recognised organ of banking throughout the British Isles, India and the colonies. London, W. Speaight and Sons, t9o6$4^{\circ} \cdot 10 \frac{1}{2}$ in. Vols. II.- , nos. In progress.

Vol. II. Feb. 1-Dec. 1906. Nos. 2-12.

* Commencing with No. 2, vol. II., the numbers contain article a coloured paper wrapper "Something about stamps". There i

BARGAIN PHILATELIST. The Bargain philatelist.

* in. No. 1, June-July, [1890].

Smyma, N. Y., F. J. Stanton, [189o]

BARRY'S PHILATELIC IMONTHLY. Barry's philatelic monthly

Melbourne, Vincent A. A. Barry, r887-88. $8^{\circ}$. 83 in. Nos. 1-6: Nov. 1887-April 1888.

***This was the first philatelic journal published in Victoria. Mis. St. Jour. 135 (11)

BARTER. Barter. The sale and exchange journal. Nos 20 and 23 January 12 th and February 2 nd, 1901. [Contain articles "The story of stamp collecting in the nineteenth century," and "How stamps are printed," each by Fred. J. Melville.] Bristol, H. A. Burleigh, т тот. $4^{\circ} .11$ in. pp. 303, 304 and 353.

** There is a coloured paper wrapper to each number.

Mis. St. Pamph. 63 (6)

BATH STAIMP AND COIN GAZFTTE AND ADVER. TISER. The Bath stamp and coin gazette and advertiser.

Bath, London [printed], C. G. Lansley and Co. I 865 .

$4^{\circ} .8 \frac{1}{2}$ in. Nos. 1-2, June 1-July 1, 1865

* Only number 1 is now known of this journal, but W. D. Atlee *riting in "The Philatelist" of July 1,1867 , says that two num-
bers were issued. A second copy of no. 1 is bound up with the late Miss Fenton's working copies of vols. III.-TV. of the "Sth Collector's Magazine," at the end of the advertiseme "Stamp vol. IV. Wanting no. 2.
Mis. St. Jour. 78 (4).

BAY STATE ADVERTISER. The Bay State advertiser. Lynn, Mass., G.W. Bishop, 1886. $8^{\circ} .9$ in. No. 1 , Jan., 1886. Lynn, Mass., G. W. Bishop, 1886.

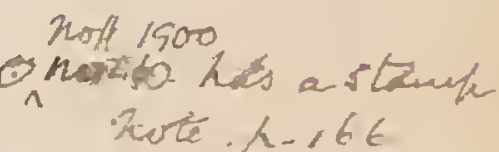


BAY STATE AIMATEUR. Bay State amateur. $8^{\circ} .8 \frac{1}{2}$ in. No. 3, December, 1886. *** Only partly philatelic. The number has a coloured paper
wrapper.
Mis. St. Jour. 121 (7).

BAY STATE COLLECTOR. The Bay State collector. North Leomister, Mass., etc., W. E. Billings, I887. $8^{\circ} .9$ in. Nos. 1-5, Feb.-June, 1887. **Only partly philatelic. Nos. 3-5 were published at Marlboro,
Miass. Wt. Jour. 23 (11).
Manting no. 5. Mis. St. Jour. 23 (11).

BAY STATE IMONTHLY. Bay State monthly. Vol. I. no. 2, November, 1891. [Contains an article on a proposed journal for stamp dealers.]

F'ol. 16童in. p. (1). Plainville, Mass., Bay State Co., т89 Mis. St. Jour. 115 (8)

BAY STATE PHILATELIST. The Bay State philatelist, Boston, Mass., The Drown Stamp and Publishing Co., etc., $1895-96$.

$8^{\circ} .9 \frac{1}{\text { in. }} 14$ nos. in 2 vols.

Vol. I. May, 1895-May, 1896. Nos. 1-12 "II. June -July, 1896. , "13-14.

* * Each number has a coloured paper wrapper. No. 3 is dated "July-August, 1895 " and Nos. 3-14 were published by the Drown Publishing Co. There is a supplement of two pages to no. 1 and supplemental slips to nos. 7 and 13

BAY STATE PHILATELIST. The Bay State philatelist. Melrose Highlands, Mass., Herbert Gile, 1898-1902. $16^{\circ} .5_{4}^{3}$ in. and $8^{\circ} .9-8 \frac{3}{4}$ in. 43 nos. in 5 vols.

Vol. I. May, July, Sept., Nov., 1898. Nos. 1-4.

"II. Jan. July, Sept., -Dec. 1, 1899. "5-16.

" III. "1. 1 - " $1900 . \quad$ " $17-28$.

"IV. " " "M"

* " Nos. $1-4$ are $16^{\circ}$. and the remaining numbers are octaro.

Nos, $1-10,13-15,17-19,21-43$ have paper wrappers and nos. Nos. 1-1, $13-15,17-1,21-43$ have paper wrappers and nos. 29,37 and 38 have supplements. Nos. 11 and 12,14 and

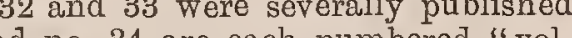
together. "Nos. 32 and 33 , and no. 34 are each numbered "vol, IV., no. 5," instead of "vol. IV., nos. 4, 5," and "vol. IV., no, 6," but the numbering is correct on the wrappers and nos. 42 and 43 are numbered respectively "vol. v., no. 1" and "vol. v., no. 2 , instead of "vol. v., no. 2 "and "vol. v., no. 3," but the numbering on the wroppers is correot. "There are said to be only six-

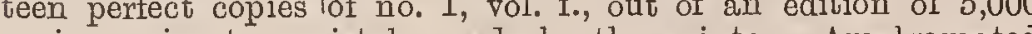
copies, owing to a mistake made by the printer. Amalgamated

BAYERISCHER PHILATELISTEN VEREIN IIÜNCHEN. VEREINSMITTHEILUNGEN. Bayerischer philatelisten Verein München. Vereinsmittheilungen.

$8^{\circ} .9 \frac{1}{4}$ in. 14 nos. in 2 vols.

(1) 1st. year. June 1-Dec, 15, 1883, Nos 1-8.

2. 2nd. "Jan. 1-June 1, 1884. "9-14. deffergat toates gimer ** Jhere are two numbers for December, 1883. No. 7 dated ments of two pages each to nos. 2 and 7.

[Continued as :]

- Vereins-Mittheilungen des Bayerischen philatelistenVereing. Mïnchen, I884-87. $8^{\circ} .8 \frac{1}{2}-9 \frac{1}{4}$ in. and 10 in. Vols. $x_{1}-$-V. 43 nos.

(o) 2nd year. July 1-Dec. 1, 1884. Nos. 15-20.

3 rd "Jan. I 1- ", 1, 1885. "1-12.

4th " " 1- ", 15, 1886. " $1-12$.

5th " " 12. " $15,1887.188 \% " 1-12$.

* * The numbers for" 1884 and 1885 measure $8 \frac{1}{2}-9 \frac{1}{4}$ inches and those for 1886 and 1887, 10 inches. VThere is an extra "Ausstellungs-Nummer" dated " 20 October, 1884 " and there are two supplements to the number for December, 1886, and also to that for December, 1887. No. 5 of the third year bears in error "I. Jahrgang". Continued as "Das Postwertzeichen".

BAYONNE PHILATELIST. The Bayonne philatelist. Bergen Point, N. J., H. M. Oraft, etc., I883-84.

$8^{\circ} .7 \frac{3}{4}$ in. 13 nos. in 2 rols.

Vol. I. Oct. 1883-Sept., 1884. Nos. 1-12

( . "* II. " " 1884 . No. 13 . H. M. Craft.

\section{BAYONNE PHILATELIST.}

\author{
[Continued as :]
}

The Independent philatelist.

New York, etc., W. H. Mitchell and H. M. Craft, etc., г 884-91.

$8^{\circ} .7 \frac{3}{4}$ in. and $9 \frac{1}{4}$ in. Vols. II.-III., 14 nos.

Vol. II. Nov, 1884-Nov., 1885. Nos, 14-23.

(c) ". III. I" 1890-Feb., 1891 , 24-27.

" "Vol. II. is $7 \frac{3}{3}$ inches and vol. III." 91 inches. Nos. $17-27$ were published by W. H. Mitchell, nos. 17-22 at Bayonne City, N. J. no. 23 at Bergen Point, N. J., and nos. 24-27 at Bayonne City., No. 22 is dated "July-Aug., 1885" and no. 23 , "Nov. 1885"."

BAzAR. Der Bazar. Illustrirte Damen-Zeitung. [Contains a number of articles entitled "Briefmarken unc Briefmarken-Sammlungen ".]

Berlin, Louis Schaefer, $1862-64$.

Fol. 15 in. Series of articles. [Nos. 1-23.] October 8, 23, November 8, 23, December 8, 1862 . January 8, 23, F'ebruary 8, March 8, 23, May 8, June 23, August 8, 23, September 8, 23, October 8, 23, November 8, December 8, 1863, February 8, 23 , March 23, 1864.

BAzAR. Der Bazar. Centralblatt für Philatelie. Quakenbriick, etc., G. H. Meyer, etc., г 888-9o. $8^{\circ} .11$ in in. 13 nos. in 2 vols.

(.)1st year. Dec. 10, 1888, Feb. 1-Dec. 8, 1889. "Probe-Nummer" and nos. 2-12.

2ad year. Jan. 8,1890 . No. 1

* * No. 1 of the second year was published by H. Crone at Ankum. NNos. 3-12 and no. 1 of the second year are printed on buff,paper. There are supplements of two pages each to nos. 5 and 6 , one of four pages" to no. 7 , two supplements consisting of six pages to no. 8 and also to no. 10 and two supplements of eight pages to no. second year at Ankum.
s.

BAZAR. The Bazar. Williamsville, Mass., [? ], i892. in. No. 1 .

** Only partly philatelic. Wanting.

BAZAR FƯR BRIEFIMARKENSAIMIMLER. Bazar für Briefmarkensammler.

Heidelberg, Wilhelm Faber und Co., I869-70. $4^{\circ} .10$ in. fol. $133^{3}$ in. and $8^{\circ} .10 \frac{1}{2}-11^{\frac{1}{2}}$ in. Nos. 1-11, July 1, 1869May 15, 1870.

** Nos. 5-11 have paper wrappers, and nos. 2-11 have the article "Der" preceding the title. No. 1 is quarto 10 inches, no. 2 is folio $13 \frac{3}{4}$ inches, and nos. $3-11$ are octavo $10 \frac{1}{2}-11 \frac{1}{2}$ inches.

“B. B." BROWN'S BULLETIN. "B. B." Brown's bulletin. Boston, Mass., Frank P. Brown, I896$8^{\circ} .8 \frac{1}{2}-9 \frac{1}{2}$ in

*** "Ihis is solely a price list of stamps, etc., for sale by the publisher and cannot theretore be considered a philatelic journal. No. 1 is dated "March 24, 1896" and no. 19, "May 15, 1905".

B. B. SCOTT'S IMONTHLY CIRCULAR AND "GENERAL ADVERTISER". B. B. Scott's monthly circular and "General advertiser".

Oxford, B. Scott, Jun., I872-73. $4^{\circ} .9 \frac{1}{2}$ in. and fol. $13 \frac{1}{2}$ in. Nos. $1-3$, Nov. 1, Dec. 1, 1872, Jan. 1, 1873 .

** Each number consists of a single leaf, the whole contents of which are advertisements, mostly of a philatelic nature. No. 1 is quarto in shape while nos. 2 and 3 are folio., No. 3 with the
date "January, 1873" is given in E. B. Jones" "Check List of

date "January, 1873," is given in E. B. Jones' "Che

Mis. St. Jour. 1 (2).

BEAR HILL ADVERTISER. Bear Hill advertiser. Published for the collector and advertiser.

Stoneham, Mass., Frank E. Parks, I903. 8.. 9-91 in. Nos. 1-4, Jan.-April, 1903.

*** Only partly philatelic

Mis. St. Jour. 144 (8).

BEAR'DSLEY'S ADVERTISER. Beardsley's advertiser. $8^{\circ} .7$ in. No. 1, January, 1888.

St. Joseph, Mo., H. C. Beardsley, т888. 

Bélyeg f.P.h.S.1XP7

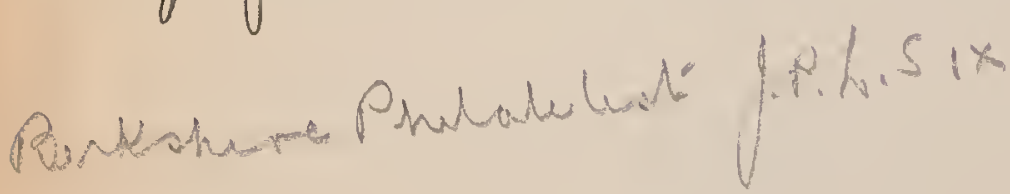




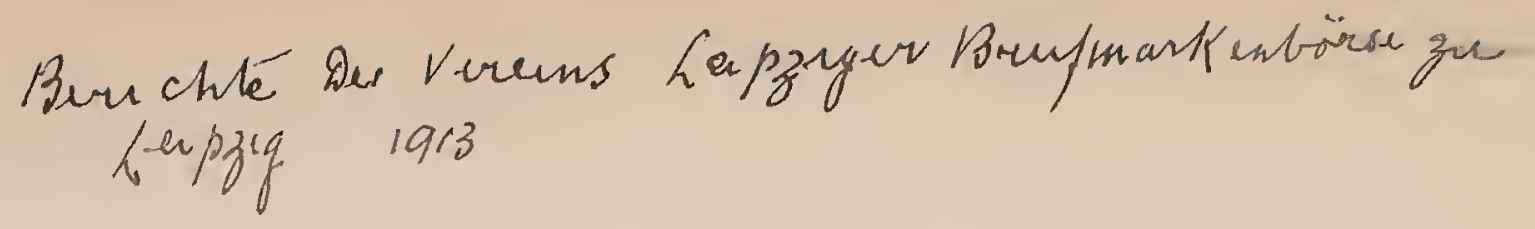

BEE HIVE PHILATELIST. The Bee hive philatelist. 96. New Britain, Conn. Steele Printing Co., etc., I895-

$16^{\circ} .6$ in. 10 nos. in 2 vols

Vol. I. March, Apl., July, Aug. and Sept., Oct., Nov. and Dec., 1895. Nos. $1-4$

" II. Jan.-June, 1896. Nos. 5-10. @ 5-8

* * Each number has a coloured paper wrapper. The wrapper of no. 1 bears the date "January," and no. 5 has " 1895 " instead of "1896," except on the wrapper, which is correct. Nos. 4-10 were published, by D. W. Stcele, Stamp and Publishing Co. The wrapper of no. 1 gives the name of the publishers as D. W. Steele and $\mathrm{Co}$.

Mis. St. Jour. 96 (5)

BEIRA POST. The Beira post. Correio da Beira. Vol. III., no 5, March 7, 1899. [Contains a paragraph on the Mozambique Company's 75 reis carmine stamp surcharged "Provisorio 25".] 899.

Fol. $22 \frac{1}{4}$ in., p. 2.

Mis. St. Jour. $136(22)$

BEITRÄGE ZUR POSTWERTZEICHEN-KUNDE Beiträge zur Postwertzeichen-Kunde. Ausserordentlich Beilage zu Senf's Illustriertem Briefmarken-Journal für vorgeschrittene Sammler.

Nosutwongly paged65-72 for $56-64:$ No9 $8^{\circ} .9 \frac{1}{4}$ in. 67 nos. in 5 vols. Leipzig, Gebrïider Senf, r890-1905. Vol.

ol. I. [July, 1890]-1892. Nos. 1-12.

" II. [Mar.], 1893-1896. " $1-14$

"III. 1896-1899. " $1-13$

$\begin{array}{cccc}\text { IV. } & 1899-1902 . \quad \text { " } & 1-15 . \\ \text { V. } & 1903-1905 . & 1-13 .\end{array}$

* * This is a supplement to the "Illustriertes Briefmarken-Journal," with which it is bound up. There is a title-page and an index to each of the volumes.

BELGIQUE PHILATÉLIQUE, La Belgique philatélique. Journal philatélique pour offres et demandes de timbres-poste.

$8^{\circ} .10$ in. No. 1, March 15, 1899

* * The number has a coloured paper wrapper and the conteats *onsist entirely of advertisements.

BÊLYEGGYU்JTÖ. A Bélyeggyüjtö.

Budapest, Antal Schomann, I9o3-о6.

$8^{\circ} \cdot 9 \frac{3}{4}-10 \frac{1}{2}$ in. 48 nos. in 4 vols.

1st jear. Feb. 1-Dec. 15, 1903. Nos. 1-12.

2nd " Jan. 1- " 1, 1904. " 1-12.

3rd " M" " " $1905 . "$ " $1-12$.

* * There is a title-page and an index to each of the first three years. Nos. 1 and 2,5 and 6,7 and 8,9 and 10,11 and 12 of the third, year and nos. 1-3, 4-6, 7-9 and 10-12 of the fourth yoar wore severally published together.

BÊLYGGYƯJTÖK LAPJA. Bélyeggyüjtök Lapja.

Budapest, Jenö Szatmári, Igo6.

Fol. $13 \frac{1}{2}$ in. and $8^{\circ} .8 \frac{1}{4}$ in. 16 nos. in 2 vols.

1st year. Jan. 6-Jan. [20], 1906. Nos. 1-3.

2nd " "27-Apl. 28. ", " 4-16

* Nos. 1-3 were produced by a type-writer and the remaining

numbers by autographic lithography. No. 3 is wrongly dated

"Január 13" in place of Január 20," nos. 6 and 11 were printed as " 5 " and " 12 " respectively, no. 12 is wrongly numbered " 13 ," no. 13 was printed as "14," no. 11 was wrongly numbered " 15 " and no. 16 was printed as " $15 "$ " Nos. $1-12$ are folio and the remaining nos. are octavo. Wanting nos. 1 and 15 . Mis. St. Jour. 137 (9)

BÉLYEG-UJSÁG. Bélyeg-Ujság.

$8^{\circ} .8 \frac{3}{\text { in }}$ nos in 2 rols.

Budapest, Jenö Széky, 1905-06.

1st year. Feb. 28- , 1905. Nos. 1-
2nd," Jan. 20, 1906.

* * The last number known of the first year is no. 10, dated Nov. 30 , 1905 , and no. 1 of the second year appears to be the last published. Wanting nos. $2,4,5,7,8,9,11$, of the first year and any after no. 1 of the second year.

BÉLYEGVILÁG. Bélyegvilág.

$8^{\circ} .93$ in. 3 nos. in 2 vols.

$$
\text { Nagyvarad, [? ], I899-1900. }
$$

1st year. Nov. 5-Dec. 5, 1899. Nos. 1-2.

2nd " Jan. 5, 1900 . No. 1 .

** The publisher's name is not given. Wanting all but no. 1 of the first year.

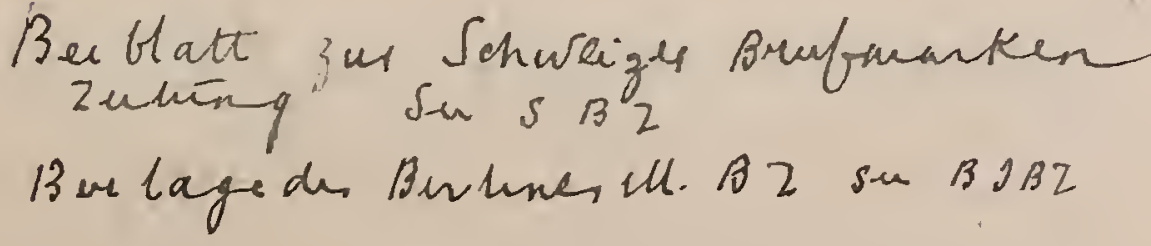

Belge Sonom to Bruges / in Esperantäa Duter also frepet 903 I 1101 Jully
BERLINER BRIEFIVARKEN-ANZEIGFR. Berliner Briefmarken-Anzeiger. Offertenblatt für Hiindler und Sammler der ganzen Welt. Erscheint jeden 5 und 20 im Monat.

Fol. $12 \frac{1}{2}$ in. 18 nos. in 2 vols.

Berlin, Gude und Co., I898-99.

1st year. Oct. 5 -Dec. 20,1898. Nos. 1-6.

2nd " Jan. 5-June 20, 1899 . , 1-12.

Mis. St. Jour. 105 (13)

BERIINER BRIEFMARKEN-ZEITUNG. Berliner Briefmarken-Zeitung. Internationale Zeitschrift für Postwertzeichenkunde. Berlin, Robert Karst, I894-99. $4^{\circ} .11$ in. 63 nos. in 6 vols.

1st year. Oct. 20, 1894-Sept. 22, 1895. Nos. 1-12

2nd ", " 26, -Dcc. 17, 1895. " 1-3.

Brd " Jan. 29, - " 15, $1896 . \quad$ ", $1-12$.

" " 26 - " $31,1897 . \quad$ " $1-12$

- " 12,1899 . " " 1-12.

* There is a title-page and an index to the third year and to each subsequent year and a supplement of two pages to the num ber for December, 1894. Therc arc no numbers for November, 1897, March, 1898, and Septembcr, 1899, but in place of these there are two numbers for December, 1897 , and for the same month of 1898, the first two dated the 10th and 31:t and the last two the 12 th and 31st. $\checkmark$ Nos. 11 and 12 of the sixth year were published together, and no. 5 of this year is numbered in error "No. 6 ".

BERLINER BRIFFMARKEN - ZRITUNG. Berline Briefmarken-Zeitung. Berlin, Philipp Kosack, I905$8^{\circ} .10 \frac{1}{2}$ in. nos. in vols. In progress. 1st year. Apl., June, Aug., Oct., Nov:, 1905. Nos. 1-5. 2nd "J Jan.-June, Aug.-Dec., $1906 . \quad$, 6-16. ** There is a coloured paper wrapper to each number and a supplement of illustrations to nos. 4,6 and 13.

BERLINER ILLUSTRIRTE BRIEFIMAREN ZFITUNG. Berliner illustrirte Briefmarken Zeitung. Bertin, Johs. Braunschweig, etc., x 878-80.

$4^{\circ} .11_{2}^{1}$ in. and fol. 14 in. 27 nos. in 3 vols.

1st year. Oct. 15, 1878-Sept. 15, 1879. Nos. 1-12

2nd " " " 1879- " 1880. "13-24.

3rd " " " " "Dec., 1880 . "

* Nos. 1-17 are quarto and the rest folio. Nos. 6-12 were published by Braunschweig und Harwitz, and the remainder by George Foure. . There is a special supplement to no. 15 with the titl "Philatelistische Börse," which is catalogued separately and there are supplements of two pages to nos. $3,13,17,18,19$, together under the date "August, 1880 " and there is no number for July, 1880.

[Continued as :]

Berliner illustrirte philatelisten Zeitung.

Berlin, Georges Fouré, r88т.

Fol. 14 in. Vol. IrI. 12 nos

3rd year. Jan.-Dec, 1881 . Nos. 28-39

* * Nos. 34 and 35 were published together under the date "Juli-

August, 1881 ". There are supplements of two pages to nos. 28 and 32.

[Continued as :]

Deutsche philatelisten-Zeitung.

Berlin, Georges Fouré, I882-87.

$8^{\circ} .7 \frac{3}{4}$ in. and $4^{\circ} .11 \frac{1}{4}$ in. Vols. IV.-x. 67 nos.

4th year. Jan. -Sept., 1882. Nos. 40- 48.

5th , Oct. 1882-」, 1883. " $49-60$.

6th " " 1883- " $1884 . \quad$ " 61- 72.

8th " [Jan.] -Dec., 25, 1884. " 738 . 73- 75.

9 th " Jan. 25-Dec., 1886. " $87-98$.

10th " "Nov., 1887. " 99-106.

** Nos. 44 and 45,46 rnd 47,56 and 57, 58 ahd 59,69 and 70,71 and 72,76 and 77 , and 78 and 79 were severally published togetl and nos. $76-85$ bear only the year of issue " 1885 ". Nos. $40-86$ are octavo and the remaining numbers are quarto. Nos 87-93 he a supplement "Anzeiger der Deutschen philatelisten-Zeitung" separately paged, but commencing with no. 94 this supplement is amalgamated with the rest of the paper.

BERIINER ILLUSTRIRTE PHIIATHISTEN ZFITUNG. See Berliner imustrirte Briefmarken ZEITUNG. 
BFRITNRT PHILATFLISTFN - GLUB VEREIN SIVITTHEILUNGEN. Berliner Philatelisten-Club Vereinsmittheilunger.

$8^{\circ} \cdot 10-12$ in. nos. in vols. In progress.

1st year. Apl. 1, 1888-Mar. 1, 1889. Nos. 1- 12

2nd " " " -Dec. 1, 1889. " 13- 21

3rd "Jan. 1, - " "1890. " " $22-33$

4th " " " - " " "1891. " " 34- 45.

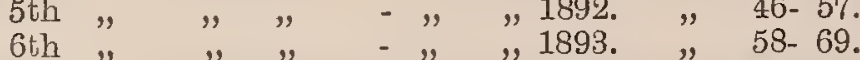

7 th " " " " - - " " " $1894 . \quad$ " $70-81$

8th " " " - " " " 1895 . " $\quad 82-93$

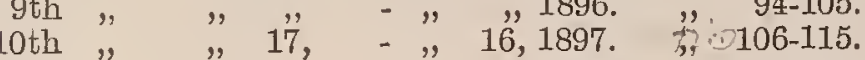

11th " " $" 12, \quad$ - " 14, 1898. "116-125.

12th " $\quad " 15, \quad-" 13,1899 . \quad$ " $126-134$

13 th " " 18, - ", ,1900. " 135-143.

14th " " $17 \quad-\quad " 11,1901 . \quad$ " $144-151$

15th " " $" 15 \quad-\quad " 14,1902 . \quad " 152-159$.

16th " " 18 - " 22, 1903. " $160-167$.

17 th " " 24 - " 2, $24004 . \quad$ " 168-177.

18th " " $25 \quad-\quad$ " $28,1905 . \quad$ " $178-187$.

* 19 th "There is a title-page and an index for the first and second years combined and one for each subsequent year. $v$ No. 10 is numbered in error "Ir. Jahrgang" and there are two "Festnum mer" one dated" "17 Januar, 1890" the other "29 Juin, 1896" Nos. 29 and 30,42 and 43,89 and 90 , and 101 and 102 were severally published togeliher under the respective dates " 1 September 1890," "1 Oktober, 1891," "1 September, 1895," and "1 September, 1896," and there is no number for either August, 1890, or September, 1891. Nos. 1-33 measure 10 inches and the remainin numbers are $11-12$ inches. $n_{0} /-g$ ane $\frac{1}{2}$ Lornged

BERLINER SANIMLER-BÖRSE. Berliner SammlerBörse. [Prospectus of no. 1 of a journal to be published by Albert Wollf, of Berlin, dated August 15, 1897, but of which nothing further was published.]

Mis. St. Jour. 97 (5)

BI-IVONTHLY COLLECTOR. The Bi-monthly collector. McGraw, N. Y., Leon V. Cass, I899-I900. $32^{\circ} .4 \frac{1}{2}$ in., $24^{\circ} .5-5 \frac{3}{2}$ in., $32^{\circ} .4$ in. and $8^{\circ} .8$ in. 9 nos. in 2 vols.

Vol. I. March, 1899-Jan., 1900. Nos. 1-6.

*" II. "July, 1900 . " 1-3. $4-6$, vol. I. and no. 1 * Nos. 1-3, vol, I., are $32^{\circ} .4 \frac{1}{2}$ inches, nos. 4-6, vol. 1. and no. 1 vol. II. are $24^{\circ} .5-5 \frac{3}{4}$ inches, no. 2 , vol. II. is $32^{\circ} .4$ inches and no. 3, vol. II. is octavo 8 inches. Nos. 2 and 3 , "Yol, have coloured September, 1900. Wanting no. 3, vol. I.

BIER-ZFITUNG DESE H. A. B. S. V. Bier-Zeitung des H. A. B. S. V. [Hamburg-Altonaer Briefmarken-Sammler Verein.]

$4^{\circ} .12 \frac{1}{2}$ in. No. 1 , September 3, 1898

Hamburg, I808.

*The nu wrapper inscribed "Ham* The number has a coloured paper wrapper inscribed " Ham of a humorous description.

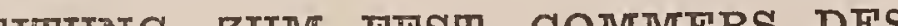
N - ZEITUNG ZUT DFUTSCHEN - PHILATHLISTEN TAGES. Bier-Zeitung zum Fest-Commers des neunten Deutschen-Philatelistentages in der Freien- und Hansestadt Hamburg am 24-26 Juli, 1897.

Hamburq, 1897

Fol. $17 \frac{1}{4}$ in., July, 1897.

* Printed in green on greenish paper. The contents are of a humorous description.

The contents are of a
Mis. St. Jour. 127 (11)

BIJBLAD VAN HET POSTZEGFLBLAD. See PostZEGELBLAD.

BIRIMINGHAM SOCIFTIES' CIRCULAR. See MONTHLY INTELLIGENCER.

BISHOP AND CO'.S STAMP DRUMIMER. See W. F. BISHOP'S QUARTERLY CIRCULAR.

BISHOP'S MONTHLY CIRCULAR. See W. F. BISHOP'S QUARTERLY CIRCULAR.

BISHOP'S MONTHLY JOURNAL. See W. F. BISHOP'S QUARTERLY CIROULAR.

BISHOP'S QUARTHRLY CIRCUIAR. See W. F. BISHOP'S QUARTERLY CIRCULAR.

$$
\begin{aligned}
& \text { Bethle kew or stanen Colcetors }
\end{aligned}
$$

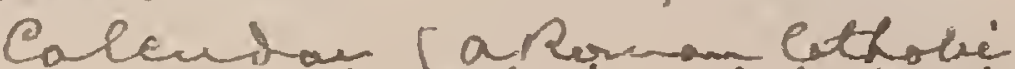

$$
\begin{aligned}
& \text { schoot du titate jomal for hegring } \\
& \text { kas fone reforeuce to stampls. }
\end{aligned}
$$

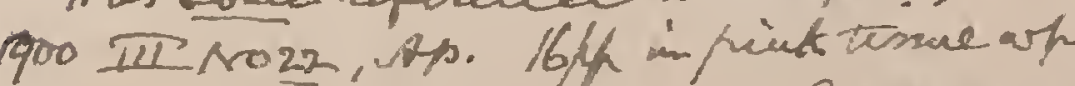

BITS AND CHIPS. Bits and chips.

Utica, N. Y., Frank E. Merritt, Jr., x896-97.

$8^{\circ} .7$ in. and $10 \frac{3}{4}$ iv. 13 nos. in 2 vols

Vol. I. July, 1896-June, 1897. Nos. 1-12

"II. "I. 1897. No. 1

* Most of the numbers contain philatelic matter. The number vol. x., which have coloured paper wrappers, measure 7 inches while no. 12 , vol. $\mathrm{I}$.

BI-WEEKLY STAMP NEWS. The Bi-weekly stamp news. New York, L. Behrens and Co., I905. $4^{\circ} .12$ in. Nos. 1-2, March 15, 29, $1905 . \quad$ Mis. St. Jour. 118 (8).

BLACK HAWK PHILATHLIST. The Black Hawk philatelist. Devoted to the interests of stamp collectors. Rock Island, Ill., L. K. Cleveland, r888. $8^{\circ} .7 \frac{3}{x}$ in. No. 1 , Sept. 1,1888 Mis. St. Jour. 66 (7)

BLACK LIST. The Black list.

(3) $8^{\circ} \cdot 10 \frac{1}{2}$ in. No. 1 , July, 1883. New York, W. F. Smith, r883.

* Published also by C. H. Garrett at Kalamazoo, Mich.

Mis. St. Jonn. 8 (2)

BLADE. The Blade. Mendota, Ill., [? ], I887. $8^{\circ} .8$ in. Nos. 8-9, March-April, 1887.

** Only partly philatelic. Nos. 8 and 9 were published together. Mis. St. Jour. 121 (5).

BLAUE BLATT. Das Blaue Blatt. Le Journal bleu. The Blue journal.

Stolberg, Germany, Pet. Mathes, x899Fol. $14 \frac{7}{4}$ in. and $4^{\circ} .11 \frac{3}{4}$ in. nos. in vols. In progress. 1st year. March 1-Dec. 15, 1899. Nos. 1-20.

2nd " Jan. 5- " 15, 1900. "21-44.

3rd " $\quad " \quad 1-", 15,1901 . \quad " \quad 1-24$.

4th $", \quad " \quad 1-", \quad 10,1902 . \quad " \quad 1-24$.

6th " " $" 1-, 15,1904 . \quad " 1-24$.

O 7th " " $\quad 1-" \quad 15,1905 . \quad$ " $1-24$.

** Only partly philatelic. Nos.11-43 are folio and each of these numbers has a blue paper wrapper, the subsequent numbers are quarto and only no. 14 of the fifth year and nos. 8 and 12 of the sixth year have paper wrappers. The fourth, fifth and sixth years each have a title-page and an index. In the fifth year a supplement "Philatelistische Rundschau" was added to some of the numbers, ten in all being given with dates from Jan. 15-Dec. 15 1903. No. 3 is wrongly numbered "Nr. 2 " and is dated " 15 Februar, 1903 " instead of "15 März, 1903". In the sixth yea four numbers of this supplement appeared from Jan. 15-July 15 1904. Two copies of the prospectus, one on white and one on yellow paper, are bound up in front of no. 1 of the first year.

BLOTS. Blots. Milwaulee, Wis., [? ], ז897.

** On. Nos. 1-2.

582

The the . 1907. pary

BOEK-EN POSTZEGELGIDS. See Post-ZEgeLGIDS,

BOLFTIN DF ANUNCIOS. Boletin de anuncios. Bogotâ, Eugenio Pardo, 1879

Fol. 133 in. No. 1. March 1, 1879

* * Printed on a single sheet of blue paper on one side only. The contents consist entirely of advertisements and correspond in every particular with the contents of no. 1 of "Anunciador" o the same date.

Mis. St. Jour. 86 (11a)

BOLETIN DE CORREOS. Boletin de correos. Año II. Núm. 7. February 15, 1892. [Contains an article "Philatelia" by F. Duro.]

Madrid, Manuel Izquierdo y Gonzales, 1892.

Fol. $11 \frac{1}{4}$ in., pp. 75,76

* * The number has a paper wrapper. Mis. St. Jour. 131 (13).

BOLETIN DE IA SOCIEDAD FILATÉLICA MIEICANA. Boletin de la Sociedad Filatélica Mexicana. México, r889.

Fol. $13 \frac{1}{4}$ in. Nos. 1-7, Apl. 1-Oct. 1, 1889 ** Wanting nos. $3,4,5$ and 7.

$$
\begin{aligned}
& \text { The Nher Chustis Ropetal Sehorl husual }
\end{aligned}
$$

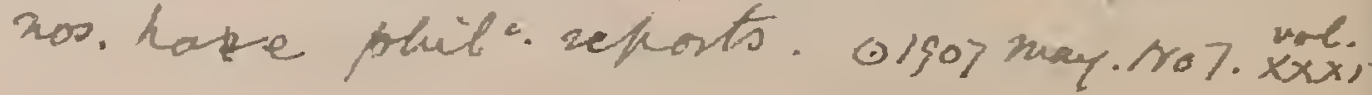


Berner Brig marken Jeitury J.P. L.S IXPT

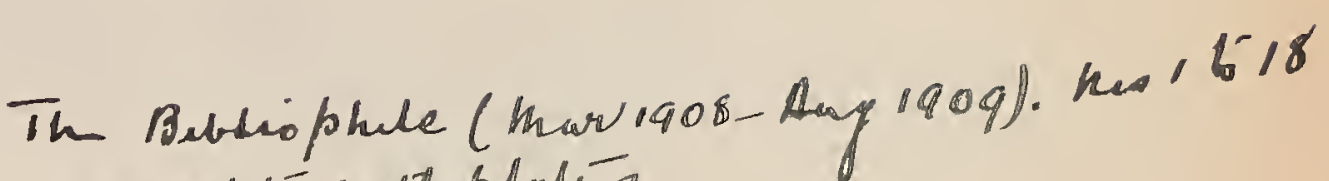
complati worts platés

B.E.V. British sutculte visiter.

sno. heeds. wo anj et rea.

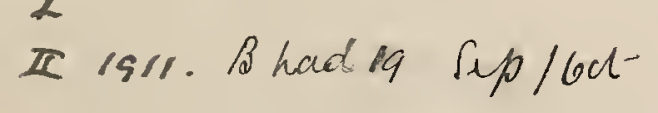

Bieleons Philateki Magagine

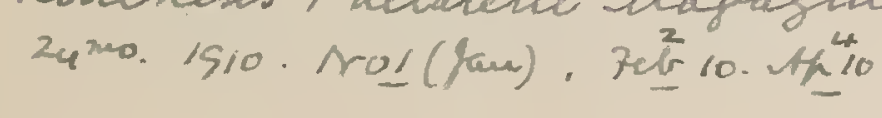

Buming hain Stanf Gowsual

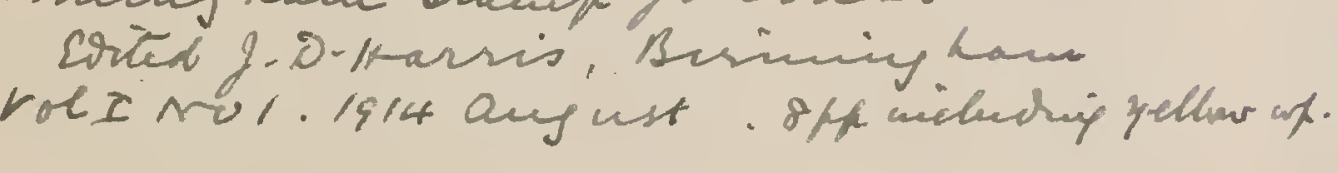


Boston Stiamp therciny 
BOLETIN DE LA SOCIEDAD FILATELICA NA CIONAL. Boletin de la Sociedad Filatelica Nacional. $8^{\circ} .83$ in. 12 nos. in 2 vols.

Guanajuato, Mexico, I889-9 I

(c) 1st year. Mar. 1, 1889. No. 1.

(2) 2nd year. Jan. 4-Nov. 1, 1891. Nos. 1-11.

* $*$ This was the first philatelic journal published in Mexico Mis. St. Jour. 89 (1)

BOLFTIN DE LA SOCIEDAD TIMBROLOGICA SUD AMERICANA. Boletin de la Sociedad Timbro$58 \&$ logica Sud Americana.

$8^{\circ} .8 \frac{3}{4}$ in. Nos. 1 -

** Printed by autographic lithography. The only number in the library is No. 4, dated "15 Agosto, $1892 "$ ". A no. 5 is known with the date "30 Agosto, 1892 ".

BOLETIN DE LOS ANALES DE LA SOCIEDAD FILATFLICA DE CHILE. See ANALES DE LA Sociedad Ftratélica "Santiago".

BOLETIN DE LOS ANALES DE LA SOCIEDAD FILATELICA "SANTIAGO". See ANALES DE LA Soctedad Frmatélica "Santiago".

BOLETIN DFL CÍRCULO FILATÉLICO MATRITENSE. Boletin del Circulo Filatélico Matritense.

$8^{\circ} .10 \frac{3}{4}$ in. 21 nos. in. 3 vols.

(-) 1st year. July-Nov., 1897. Nos. 1- 5

C) 2nd " Jan.-Dec, 189. " " $18-17$.

* * There is a coloured paper wrapper to each number. Succeeded by the "Eco de Madrid"

BOLFTÍN FILATÉLICO. Boletín filatélico. 99.

Manzanares, Spain, Aureliano Ruiz Cabrera, I898-

$58 \% 39$

$8 \frac{1}{2} .14$ nos. in 2 rols

1st year. Jan. 31- 1898. Nos. 1-

2nd " "Feb., 1899. "13-14.

** Each number excepting no. 14 has a coloured paper wrapper

BOLETIN FILATÉLICO UNIVERSAL. Boletín filatélico universal. Revista mensual.

$8^{\circ} .8 \frac{1}{2}$ in. No. 1, June, 1900 .
* The number has a coloured paper wrapper.

Valencia, Ricardo Gregori, I 900.

Mis. St. Jour. 132 (1)

BOLETIN POSTAL DE LOS ESTADOS UNIDOS MEXICANOS. Boletin postal de los Estados Unidos Mexicanos. Numero extraordinario ilustrado conmemorativo de la Independencia Nacional iniciada por Miouel Hidalgo y Costilla el 16 de Septiembre de 1810. [Num. por] 16 de Septiembre de 1890. [Contains an article "Catalogo general y descriptivo de los timbres postales Mexicanos emitidos desde su establecimiento, cubiertas, etc., etc., formado por Joaquin Escalante. Oficial $1^{\circ}$. de la Administración Local de Correos de Guanajuato," in Spanish and also in French.]

Fol. 18 in., pp. 2-12

México, Lino Nava, I89o. * The number has a paper wrapper. Mis. St. Jour. 136 (27).

BOLETIN TIMBROLÓGICO. El Boletín timbrológico. Huelva, Spain, A. Albelda, I goo.

$8^{\circ} .8 \frac{3}{4}$ in. Nos. 1-2, July 15-Aug. 15, 1900.

* * There is a coloured paper wrapper to each number. Mis. St. Jour. 132 (2)

BOLIVIA FILATELICA. Bolivia filatelica. La Paz, Genaro Flores G., etc., rgor. 8․ 93 in. Nos. 1-3, July 8, Nov. 8, Dec., 1901.

* There is a paper wrapper to each number. Nos. $2^{\circ}$ and 3 were publishẹd wy José $M$. Carballo and edited by Moises Ponce de Leon. Mis. St. Jour. 107 (8).

BOLLFTTINO FILATELICO. Bollettino filatelico. Verucchio, Ezio Albini, I892. $4^{\circ} .10 \frac{1}{2}$ in. Nos. 1-3, May 25, July 25, Aug. 25, 1892. * Wanting no. 1.
BOLLETTINO MENSILE. See UNIONE WILATELIOA COMMERCIALE.

BOODLE PHILATELISTE. Ye Boodle philateliste. New York, The B. P. Prublishing Co., r889-9o.

$8^{\circ} .7 \frac{1}{2}$ in. Nos. 1-8, October, 1889-June, 1890

* There is a title-page and an index to the eight numbers, and a coloured paper wrapper to nos. 1-6. No. 4 is dated "January and February, 1890 ". "Wanting no. for May, 1890.

Mis. St. Jour. 149 (2)

BOREKS NEUHEITEN-PREISLISTE, RICHARD. See Richard Boreks Neuheiten-Preisliste,

BÖRSENBLATT FÚR DEN BRIEFIMARKEN-HAN

DEL. Börsenblatt für den Briefmarken-Handel.

Kaufbeuren, Wilh. Reichel und Co., etc., [I864]. Fol. 131 in. Nos. 1-12, Jan. 1-June 15, [1864].

${ }^{*} *$ Nos. 3-12 were published by Wilh. Reichel and thcre is a sup plement of two pages to no. 1. No. 1 also bears the word "Probe $=$ Nummer," but none of the twelve nnmbers have th year of issue "1864" meine deutsche Briefmarken-Zeitung"

BOSTON DAILY GLOBE. Boston daily globe. Boston, Mass., January 25, 1880. [Cuttings of the article "The Postage stamp. Its history and usefulness clearly described. How the mania for collecting spreads so rapidly"... are mounted in Stamp Scrap-book, vol. IV., pp. 33, 34.]

BOSTON JOURNAL OF COMMERCE. Boston journal of commerce. Boston, Mass., January 25, 1879. [Cuttings of the article "A curious business. Stamps and the trade therein," are mounted in Stamp Scrapbook, vol, IV., pp. 26-28.]

BOSTON PHILATELIST. The Boston philatelist. A monthly for stamp collectors. Boston, Mass., E. B. Horn, Jr., I 896

$68^{\circ} .8$ in. Nos. 1-3, May, June, Aug., 1896 ** Nos. 2 and 3 have below the title "(With which is consolidated
Mis. St. Jour. 93 (1)
The Stamp".) Mis. St. Jour. 93 (1)

BOSTON STAIMP BOOK. The Boston stamp book.

Boston, Mass., A. L. Cassino and Co., etc., 1895-98. 8. 73 in. 42 nos. in 4 vols

Vol. I. May 20, 1895-Apl. 20, 1896. Nos. 1-12 "II. June 1, 1896-May 1, 1897. " 1-12. "III. " "1897- "Nov "1898. "1898. 1-12 *"* IV. IVited by Jo" -Nov. 1, 1898. lished by hym John Lolser Kilbon and vols. II.-IV. were also puband the ho have a title-page and an index and there is a paper wrapper to each nnmber. Nos. 9 and 10, vol. 1. are dated " 1895 " in place of 1896, but the correct year is given on the paper wrappers. The number for February, 1898, is num ber "instead of 9 , but on the wrapper the numbering is correct. "The wrapper of no. 2, vol. IV., has "no. 11" in place of no. 2. There to a supplement to vol. IV., no. 2, consisting of 14 pages, printed on one side of the paper only and numbered 1-7.

BOURSE AUX TIMBRES. La Bourse aux timbres. Paris, $F$. Andrè, I 894

$8^{\circ} .10$ in. Nos. 1-7, Sept., 20, 27, Oct., 7, 14, 21, 28, Nov., 4, 1894 *** There are two editions of no. 1 , one printed on white paper like the other numbers, and one printed on yellow paper. Wanting nos. $2,3,4,5,7$.

BOURSE DES TIMBRES. La Bourse des timbres. Die Briefmarken Boerse.

Genève, Kirchhofer et Champion, etc., 1886-88. Fol. $13 \frac{3}{3}$ in. $8^{\circ} .9$ in. and $4^{\circ} .11$ in. Nos. $1-5$, Oct. 31,1886 , Mar. June, Oct. 1887, June, 1888.

* No. 1 is folio, nos. $2-4$ are octavo and no. 5 is quarto. This last number was published by Adrien Champion. The contents of this journal consist entirely of the publishers' price lists of stamps and advertisements. After no. 5 numbers were published with the sub-title "catalogue prix-courant de la maison Adrien Champion " or "Champion \& Cie.," no. 6 of which has the dat Mar. 1, 1889, while nos. 7, 8 and 9 appeared in 1891, 1892 and 1893 respectively. These four numbers are catalogued under the authors names in Part I. Mis. St. Jour. 85 (7). 
BOURSE OFFICIELLE DES TIMBRES-POSTE. La Bourse officielle des timbres-poste. Paraissant tous les Samedis. $\checkmark$ Fol. 13 in. Nos. 1-10, Apl. 18-June 20, 1896 Paris, A. Dages, ז 896. Mis. St. Jour. 108 (5).

BOY PHILATELIST. The Boy philatelist.

Huntingdon, W. Va., Herman D. Jenkins, I901-02. $32^{\circ} .5$ in., $24^{\circ} .5 \frac{3}{4}-6$ in., and $8^{\circ} .6 \frac{1}{2}$ in. Nos. 1-9, Dec. 1, 1901-Aug.,

* ${ }^{*}$ Nos. $1-3$ are $32^{\circ}$., nos. $4-7$ are $24^{\circ}$. a ad nos. 8-9 are octavo.

Mis. St. Jour. 106 (3).

BOYS' AGENCY CIRCUIAR. The Boys' agency circular. Horsham, Sussex, etc., W. Laders, etc., I866. $8^{\circ}$. $7 \frac{1}{4}$ in. Nos. 1, 2, 4, Mar., May, July, 1866.

So ** Only partly philatelic. No. 3 is said not to have been published, although the paging of no. 4 begins with 25 and no. 2 leaves off at 16. No 4 was published by Laders, Rideing and Co. Liverpool. No. 1 was printed at Hull and no. 2 at London. Mis. St. Jour. 42 (3)

BOYS' GLOBE. The Boys' globe. I 887 .

Pittsfield, Mass., W. R. and R. A. Burbank, etc.,

$8^{\circ} .9 \frac{1}{2}$ in. Nos. 1-6, Apl.-Sept., 1887. by W. R. Burbank with the date "July, Aug., Sept.," but no year is mentioned. Each number has a coloured paper wrapper. Mis. St. Jour. 15 (8) and cuttings of the "Philatelic Department" from nos, 2 and 3 are also mounted in Stamp Scrap-book, vol. v., pp. 100, 101.

BOYS' JOURNAL. The Boys' journal. Toronto, Canada, W. F. Taylor, ז877.

* * Cuttings of the "Stamp Department." etc., from nos. 1 and 34 "dated "January" and "March and April," 1877, are mounted in Stamp Scrap-book, vol. III., pp. 115, 116, and vol. $\nabla .$, pp. 15, 16 Nos. 3 and 4 were published together.

BOYS' JOURNAL. The Boys' journal.

Brooklyn, N. Y., John H. Ackerman, I 882.

* * Cuttings of the "Philatelic department," etc., from nos. 2-4, dated July, August and Octoher, 1882, are mounted in Stamp Scrap-book, vol. v., pp. 116-121.

BOYS OF AMIERICA. Boys of America.

Fayetteville, N. C., Nimoeks and MacRae, I892. $8^{\circ} .8 \frac{1}{2}$ in. No. 2, May, 1892.

** Only partly philatelic.

Mis. St. Jour. $121(6)$

BOYS' OF WORCESTER. The Boys' of Worcester.

Worcester, Mass., Ellis and Dickinson, ete., I879. 8. 63 in. Nos, 1-2, Jan.-Feb., 1879.

* * Only partly philatelic. No. 2 was published by tilis and Co. Mis. St. Jour. 68 (26)

BOYS' OWN. The Boys' own. [Philatelic extracts mounted in a folio volume. The articles are headed "Philately" and were written by James M. Chute.] Boston, Mass., Chas. F. Richards, I874-76. Vols. III.- $\mathrm{v}$. 68 nos.

Vol. III. Oct. 31, 1874-Apl. 3, 1875. Nos. 56- 78.

"IV. Apl. $10 \quad$-Oct. 2, "\#" " 79-104.

*" Bound up with "Franle Leslie's Boys" and Girls' Weekly".

[Continued as :]

Munro's girls and boys of America. [Philatelic extracts mounted in a folio volume. The articles are headed "Stamp Department" and were written by James M Chute.] New York, George Munro, 1876-77. Vols. V.-viIr. 69 nos.

Vol. V. Feb. 12 -Mar. 25, 1876. Nos. 124-130.

"VI. Apl. 1 -Sept. 23, $1876 . \quad$ ", 131-156.

" VII. Sept. 30, 1876-Mar. 24, 1877. " 157-182.

* "NIII. Mar. 31, -June 9, "190 contained no philatelic matter. Bound up with

"Frank Lesilie's Boys' and Girls' Weekly".
BOYS' OWN PAPER. The Boys' own paper. No. 17. vol. I, May 10, 1879. [Contains notes on "New postage stamps" and a supplement of four pages "New issues of 1878 , compiled by Mr. J. M. Winch," printed on buff paper.] London, "Leisure Hour" Offee, I879.

Fol. $11 \frac{1}{4}$ in. Pages 270,271 and (4) pp. Mis. St. Jour. 115 (3). *** Other articles on stamp collecting are found in Vol. I., pag

BOYS' OWN PHILATELIST. The Boys' own philatelist. Berlin, Ont., The Ontario Philatelie Co., I897-98. $4^{\circ} .8$ in. 10 nos. in. 2 vols.

c) Vol. I. Dec., 1897-Feb., May,-Aug., 1898. Nos. I- 6. "II. Oct. $1,8,15,22,1898$.

"* Nos. 1-4 have paper wroper of no. 4 bears Philatelic Annual". No. 6 is dated "July-August".

[Continued as :]

The Canadian philatelic weekly Berlin, Ont., Findlay I. Weaver, r 898-99.

$4^{\circ} .8$ in. Vols. Ir.-IV. 10 nos.
Vol. II. Nov. 2, $Z 1898$. Nos. 11-12.

16, 23,30 Dec. $721,28,1898$. Nos. $13-18$

"III. J" 16, 23 , 30, Dec. 121,28 ,

*" Nos. 11, 17 and 19 have paper wrappers.

pisig has wion

[Continued as :]

The Canadian philatelic review.

Berlin, Ont., Findlay I. Weaver, I899.

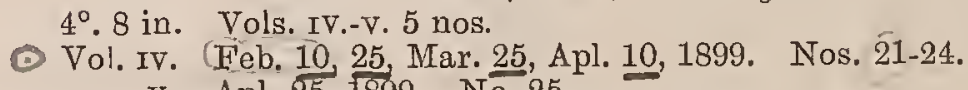

* * No. 22-25 have coloured paper wrappers.

BOY'S PRIDE. The Boy's pride.

in. Nos. 1-3. New York, [?] ], x897.
** Only partly philatelic. Nos. 2 and 3 were published together.
Wanting all nos.

BOYS' STAMP GAZETTE. The Boys' stamp gazette.

$8^{\circ} .8$ in. No. 1, Jan., 1870

Worcester, Mass., Edward S. Lesile, 187o

8.8 in. No. 1, Jan., 1870. Mis. St. Jour. 38 (2).

BOY'S TELEGRAM. The Boy's telegram. A journal devoted to the instruction and amusement of youth in all parts of the world.

London, E. C., Froud and Musgrave, I 866

ㅇ. 71 in. [No. 1.] Sept. 15,1866

* * Only partly philatelic.

Mis. St. Jour. $42(4)$

BOYS' WORLD. The Boys' world.

New York, Matthew White, Jr., I885-86

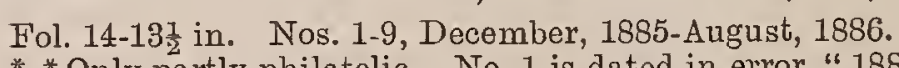

* Only partly philatelic. No. 1 is dated in error " 1886 ," there is an illustrated supploment to no. 6 , and nos. 2-7 have colourod paper wrappers. Cuttings of the philatelic portions from no. 6 are also mounted in Stamp Scrap-book, vol, จ., p. 47.

BOYS' WORLD. The Boys' world.

Haverhill, Mass., The World Publishing Co., I896-97.

$8^{\circ} .8$ in. Vol. II., nos. 1 -

** Only partly philatelic. "Wanting vol. Ir. all but nos. $5,9,11$, S 85

which are dated "Jan. 1," "Jan. 29" and "Feb. 12," 1897, respectively.

BOYS' WORLD. The Boys' world.

Los Angeles, Cal., Neitzke and Brown, I897. $8^{\circ} .8$ in. Vol. IrI., no. 6, January, 1897

* "Contains a "Stamp department" conducted by G. Bentley. A statement on page (4) says "The Boys' world. For boys and girls. Established 1878. Re-established 1894."

Mis. St. Jour. 143 (1)

BRADFORD EXCHANGE LIST AND PHILATELIC

- NEWS. The Bradford exchange list and philatelic

news, Bradford, A. Robinson, I886.

$8^{\circ} .7 \frac{1}{2}$ in. No. 1, May 13, $1886 . \odot$ 4h. Mis. St. Jour. 55 (11).

BRAGA PHILATELICA. Braga philatelica.

Braga, Portugal, José Neves, I 901-02.

$4^{\circ}$. $83-9$ in. Nos. 1-12, July 1901-July, 1902.
** Each number has a coloured paper wrapper. No. 3 is dated

""Setembro-Outubro, 1901," and mos. 10 and 11 were published together.

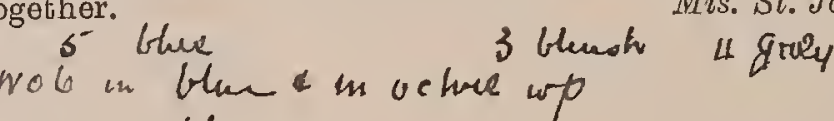

$$
\begin{aligned}
& 7 \text { a vare } \\
& 8 \text { an Hen parple salmox } \\
& \text { a a y ulaw a ther } \\
& \text { ioll ponk, grumesh }
\end{aligned}
$$




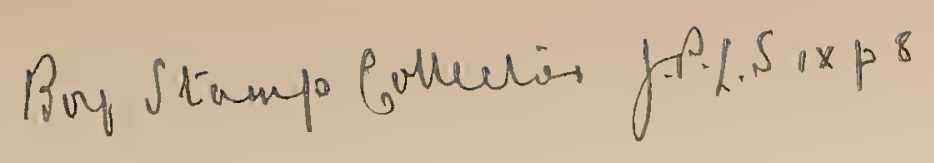

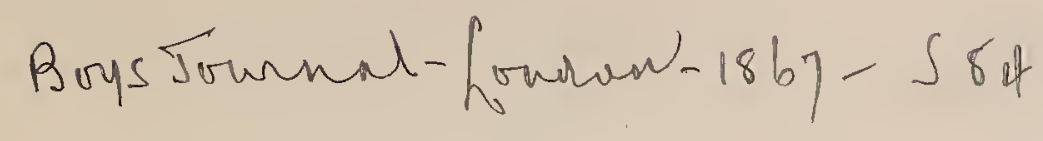

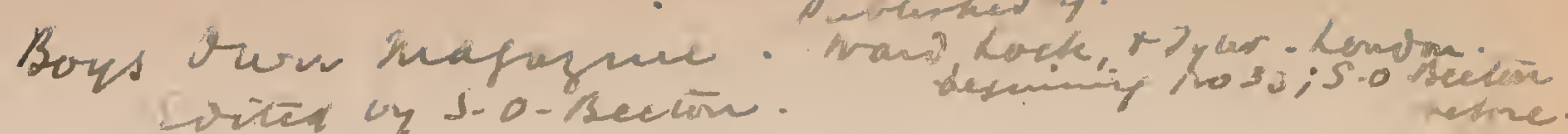

o rolin.irouy-60. 1807 fum-dec.

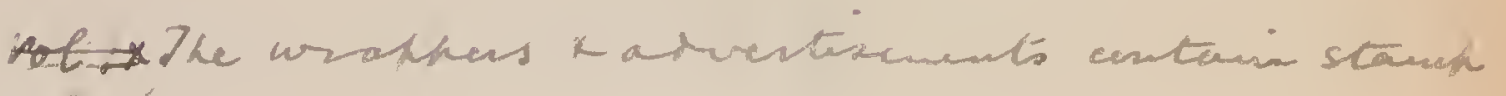
artor.

Burpo Penmy Muquzine

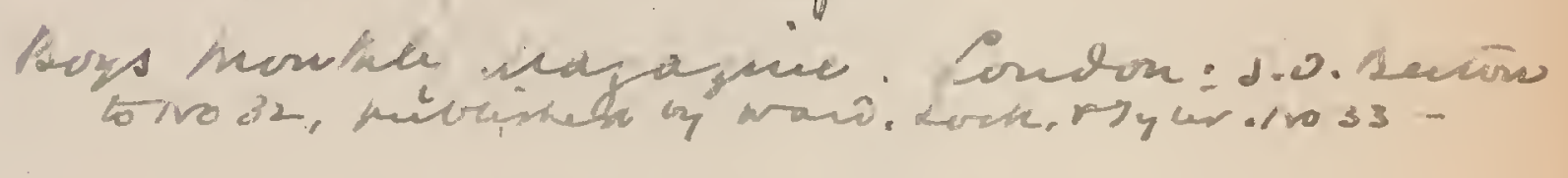

0. III. $1025-36 \cdot[1866]$ hach wat fine 26493132

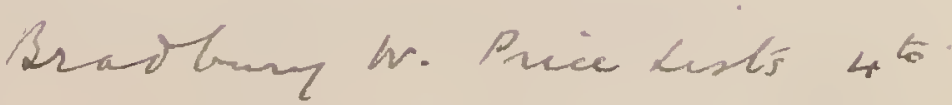


Ball Tithe on to 1171879 angust.

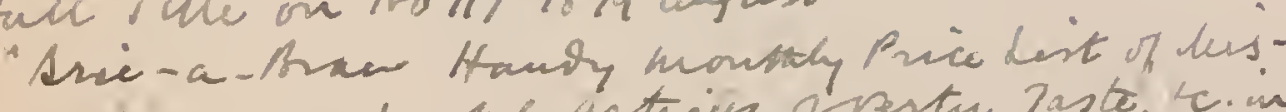

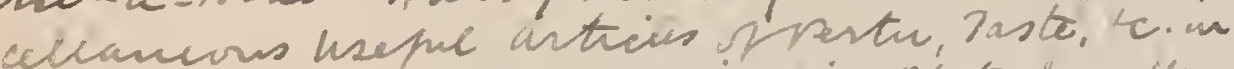
Chuniy Books, Comis, Curvositis, Mlate, tewelery. stamiss. "c. For bale and Baster".

Brica-srae 4 to. Lonoton.

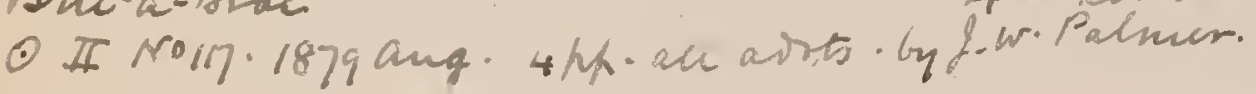


BRASIL-POSTAL. Brasil-postal.

Rio de Janeiro, Alfredo Marques de Souza, I89o-9I $8^{\circ} .9 \frac{1}{2}$ in. and fol. 13 in. 13 nos. in 2 vols. 1st year. July -Dcc., 1890. Nos. 1- 6.

2nd "Jan. 1-July, $1891 . \quad 7-13$. * "Nos. 1-6 are octavo and nos. 7-13 are folio. VNo. 1 has a coloured paper wrapper. Vos. 5 and 6 were published together under the date "Novembro e Desembre de 1890" and nos:10, 11 and 12 were published together under the date "A Aril, Maio e
Junho de 1891 ".
Mis. St. Jour. 86 (17).

๑ BRAZIL PHILATELICO. O Brazil philatelico. Jornal dedicado aos colleccionadores e amadores de sellos postres, estampilhas, telegraphos, etc. São Paulo, Brazil, Luiz Levy, I88z. (C) $8^{\circ} .10 \frac{1}{2}$ in. Nos. 1-3, Jan.-Mar., 1882. * * This was the first philatelic journal published in Brazil.

Mis. St. Jour. 8 (1)

BRAZIL PHILATELICO. Brazil philatelico. No 2 has a var. $8^{\circ} \cdot 9-10 \frac{1}{2}$ in. 23 nos. in 2 vols. Campos, Remijio de Bellido, etc., I892-93. ppq +12 bung Vol. I. Jan. 31-Dec. 31, 1892. Nos. 1-12.

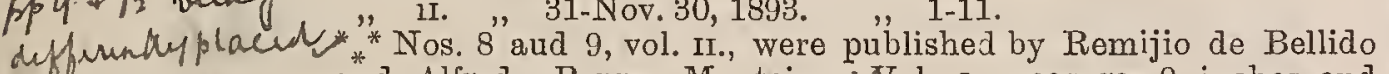
and Alfredo Borges Monteiro. Wol. I. measures 9 inches and

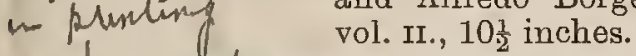

B warlor BRAZIL PHILATELICO. O Brazil philatelico.

Porto Alegre, Theodoro Vielitz Filho, R. Jalowsti et Benjamin Celestino Camozato, etc., r903-05. $8^{\circ} .10 \frac{1}{2}$ in. 20 nos. in 3 vols.

1st year. Dec. 15- 1903. No. 0

2nd " Jan. 15-Dec. 15, 1904. Nos. 1-12.

3 rd " "15-July 15, 1905.

"* After no. 1 of the second year the journal was published by Theodoro Vielitz Filho, Basil Seftou and Benjamin C. Camozato. All the numbers, with the exception of no. 1 of the third year, are printed on yellow paper, and the number of December 15, 190. bears "N-Specimen" struck with an india rubber hand-stamp.
Wanting vol. III., no. 6.
Mis. St. Jour. 131 (8).

mot-it

BRAZIL POSTAL. O Brazil postal. Jornal philatelico e philocartista, apparecendo a 10 de cada mez.

Porto Alegre, Adalberto A. Pinto e J. M. Castello, etc., I904.

8. 10 -11 in. Nos. 1-4, June 10-S'ept. 10, 1904

**" No. 4 was published by João Foernges and Adalberto A. Pinto.

BRIC-A-BRAC. Bric-à-brac.

London, etc., J. W. Palmer and Co., etc., [?]-1 906.

Have hese $\quad 4^{\circ} .81-11 \frac{1}{2}$ in. aud $8^{\circ} .8 \frac{1}{1}$ in. 328 nos. in 32 vols.

II 17

iv. $5-9 \cdot 11$

in $622-z^{2}$

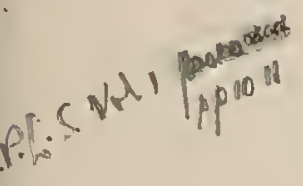

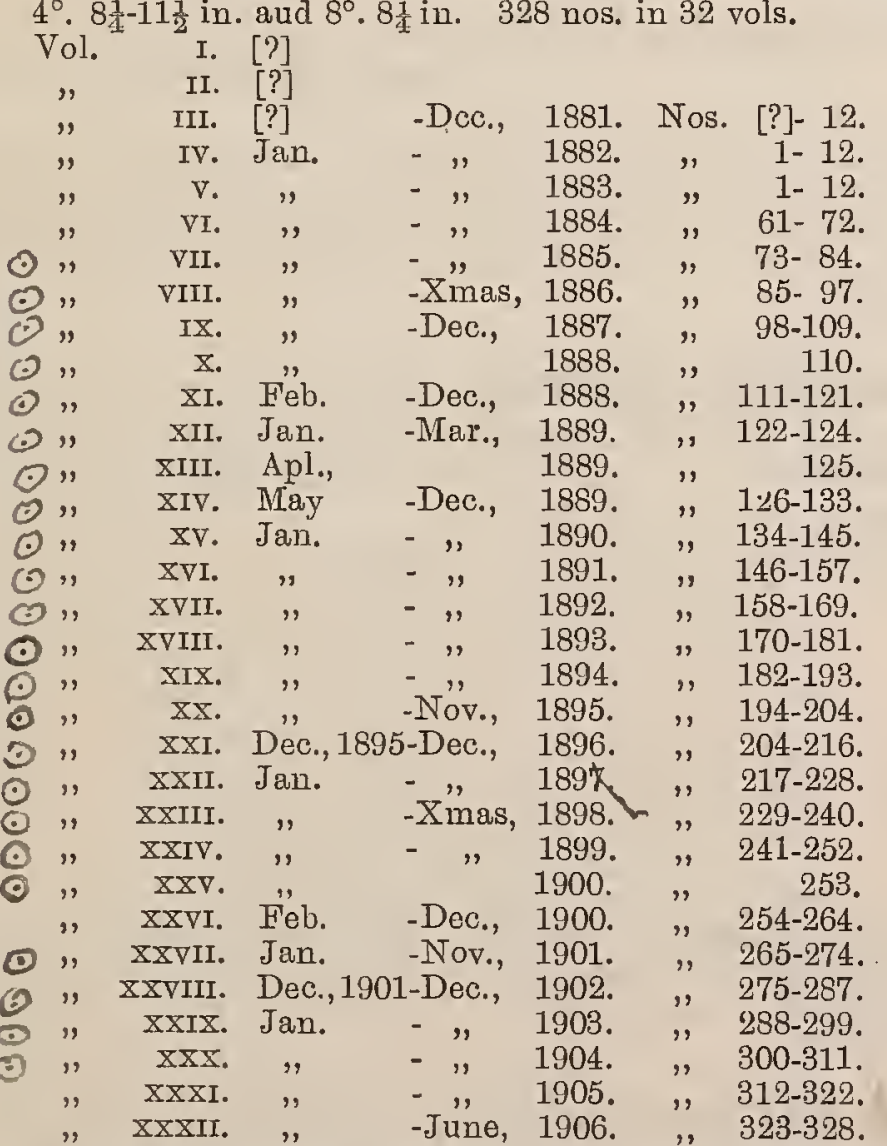

* "* XX XXII.

a copy of the following known except that the library contain consists of $20+(4)$ pages: "No 109, November, 1878 Size, and Hall. Bric-à-Brac, or a collection of varieties on sale for ready money, by J. W. Palmer and Co, Adelphi House, Strand, London, W.C. (Opposite the Vaudeville Theatre.) Gentlemen wishing

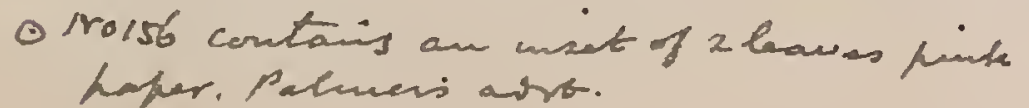

to dispose of books, stamps, coins, jervellery, albums of stamps, etc., or any artiele they may wish no longer to retain, will find, by offering them for sale through this our bi-monthly circular, which is sent to all parts of the United Kingdom and abroad, an expedient way of obtaining sale for them...." Of vols. 1I. and III. the library has (i.) "The Bric-a-brac: handy monthly price list of miscellaneous useful articles of vertu, taste, etc., including books, coins, curiosities, plate, jewellery, stamps,
etc., for sale and [or] barter". Vol. II., nos. 114, 115, A pril, May, etc., for sale and [or] barter". Vol. II., nos. 114, 115, April, May

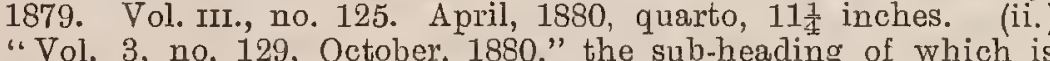
"Vol. 3, no. 129, October, 1880," the sub-heading of which is worded a little differently to that for no. 125 : size quarto 10 inches $8+(2)$ pag 's. (iii.) "Supplement to the Bric-n-Brac: [with the same sub-heading as (i.)]. "Vol. III., no. $130 "$; size quarto $11 \frac{1}{2}$ inches, 4 pages. (iv.) “No.4-131. December, 1880. Ent. Sta Hall. Notice. This is the last catalogue that will be sent to our customers gratis. . . Bric-à-brac. J. W. Palmer and Company's clcarance catalogue of Enolish aud foreign books . . for sale and burtcr ..." quarto $11 \frac{1}{4}$ inches, 8 pages. (v.) "Bric-ì-brac. Handy Vol. 3, no. 12, December 1881," quarto 81 'inches, 4 pages. Of th foregoing the numbers for November, 1878, April and May, 1879 and December, 1880, contain uothing but advertisements. Vol. IV., is quarto $8 \frac{1}{2}$ inches and vols. V.-XXXII. are octavo $8 \frac{1}{4}$ inches. Nos. 269-328 were published by J. W. Palmer at West Hoathly, Sussex. $v$ The numbers of vols. Iv. and v., and nos. 61 and 68 have the same sub-heading as that described for no. 12, vol. III., nos. 69-73 have "The Stamp collector's manual"2 and nos. 74-328, "The collector's manual". Where are thirteen numbers to vol. vIII., no. 97 having the d tte "Special Christmas number, 1886" $\checkmark$ no. 103 has a paper wrapper inscribed "Jubilee double number"

$\sim$ no. 111 bears the heading "Special double number," no. 134 has "vol. 12 ' instead of vol. 15 , there is no no. 236 but no. 235 has the date "July and August. 1898," "Mo. 240 has "vol. 24 " in place of "vol. 23" of "vol. 23 ," no. 242 consists of a singlo leaf, no. 264 is the samc as no. 263 except for the following heading on page 5: "Bric-athe right-haud column the date "November, 1900 " has been the right-haud column the date "November, 1900" has been altered to "November and December, 1900 ". The following numbers

Nos. 183 and 184, "February and March, 1894".

" 204 " 205, "December, 1895-January, is96",

" 207 " 208, “March-April, 1896".

" 225 " 226, "September and October, 1897 ",

" 2250 " 226, "September and October, 1897 ".

" 230 " 231, "Febrilary, March, 1898 ".

" 235 " [236], "July and August, 1898"

"

27. "August and September, 1901 "

275 , 276, "December, 1901, and January, 1902 ".

" 277 " 278, "February and March, 1902".

" 279 " 280, "April and May, 1902". "

" 281 " 282, "June "Just and September, 1902".

" 285 " 281, "August and September, 1902".

" 285 "2 287, "Uctober to December, 1902 ".

" 288 " 290, " January to March, 1903 ".

" 294 " 296, "July to Soptember, 1903 "

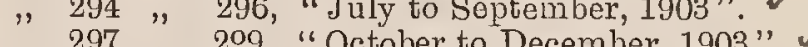

" 300 ", 302, "January to March, 1904". v

" 303 " 305, "April to June, 1904 ". "

" 306 ". 308, "July to September, 1904 ".

" 309 " 311, "Oct. to Dec., 1904

" 312 ", 317 " "Jand 318 to 320 "April to June, 1905" and

pt., 1905 ".

" 321 " 322 and 323 to 328 "Oct. to Dec., 1905 " and "Jan. to June, 1906 ".
Wanting all vols. I. and 1I. ; vol. III., all except no. 12 ; vol. IV. nos. $1,2,3,4,8,10,11,12$; vol. $\nabla .$, nos. $1,2,9$ and nos. 61,95 .

BRICKER'S BULLETIN. Bricker's bulletin.

$16^{\circ} \cdot 5 \frac{1}{2}$ in.

Bellevue, Pa., H. A. Bricker, [1895].

* This is solely a price list of stamps, etc., for sale by the publisher and canuot therefore be considered a philatelic journal. The library contains numbers 3-6, none of which bear any date. Nos 1 and 2 are said to be dated "Spring" and "Summer," respectively.

BRIEFIMARKF. Die Briefmarke. Süddeutsches Tauschund Offertenblatt für Briefmarkensammler.

$8^{\circ} .9$ in. 49 nos. in 4 vols.

Esstingen, Ludwig Schreiber, r894-98.

1st year. June 10, 1894-May 10, 1895. Nos. 1-12.

2nd " " 10, 1895-June 15, 1896. " 1-13.

3rd " July $15,1896-" 15,1897 . \quad, 1-12$

*** There is a" coloured paper wrapper to each number and no. 7 of the third year is dated "1896" instead of 1897 . Nos. 9-14 of "Der Sammlerfreund" were given as a supplement to nos. 1-6 of the third year,
01879 ang 2 No117 IInl 
BRIEFMARKEN-ANZEIGER. Der Briefmarken-Anzeiger. Organ zur Belebung und Erleichterung des Verkehrs zwischen Timbrophilen.

I'riest, Carl v. Cardona, 1866. $8^{\circ} .11 \frac{1}{4}$ in. No. 1, June 20, 1866.

* A no. 2 was printed, but the copies were destroyed. This was the first philatelic journal published in Austria.

Mis. St. Jour. 73 (3).

BRIEFIMARKEN-ANZEIGER. Der Briefmarken-Anzeiger. Gratis-Organ für Philatelisten.

$4^{\circ} .11 \frac{1}{2}$ in. No. 1 , Jamuary 15,1870

Cassel, Arthur Wildt, I870.

*** Printed on buff paper and the contents consist entirely of advertisements. Mis. St. Jour. 3 (6).

BRIEFIMARKEN-ANZEIGER. Briefmarken-Anzeiger. $8^{\circ} .9$ in. 17 nos. in 3 vols. Stettin, etc., Otto Pfaffe, I894-96.

(1) [1st year.] 1894. Xmas. no.

0 [2nd ", ] 1895. Nos. 1-13.

$\checkmark$ ** Printed on yellowish or buff paper and the contents consist entirely of advertisements. Commencing with no. 5 of 1895 the journal was published at Berlin. Nos. 2 and 3 of 1896 were published together and none of the numbers bears the month of publication.

BRIEFIMARKEN-BÖRSE. Die Briefmarken-Börse. Bremen, August Marbes, I892. $8^{\circ} .81$ in. and $4^{\circ} .11$ in. Nos. 1-7, Jan.-[July], 1892.

* * Nos. 1 and 2 are octavo and 3-7 are quarto. Nos. 6 and 7 were published together without date, and consist of one leaf only, and nos. 1-5 have coloured paper wrappers.

Mis. St. Jour. 73 (6)

BRIEFMARKEN BÖRSE Briefmarken-Börse. Internationales Offertenblatt für den gesammten Briefmarkenhandel. Hannover, C. L. H. Thiele, I893. Fol. 12 and 13 in. Nos. 1-2, Sept.-October, 1893.

* * The contents of no. 1 consist entirely of advertisements. No 1 measures 12 inches and no. 2,13 inches. Two copies of different prospectuses one printed on rose paper, are bound up with the numbers. Mis. St. Jour. 124 (7)

BRIFFIMARKEN-BÖRSE. Die Briefmarken-Börse.

Leipzig, Baumbach und Co., etc., I894-I90r. $4^{\circ} .9 \frac{3}{4}$ in. 80 nos. in 8 vols.

[1st year.] Apl. 15, May 1, 15, June 15, Aug. 1, Oct. 1, 1894. [2nd , ] Feb. 1, Mar. 15, May 1, 15, July 15, Sept. 15, Oct. 15, Nov. 15, Dec. 1,1895 . Nos. $1-9$.

[3rd "] Jan. 1, 15, Feb. 15, Mar. 1, 15, Apl. 1, 15, May 1, 15 June 1, 15, July 1, 15, Aug. 1, Sept. 1, 15, Oct. 1 15 , Nov. 1,15 , Dec. $1,15,1896$. Nos. $1-22$

[4th ,"] Jan. 1, 15, Feb. 1, 15, Mar. 1, 15, Oct. 15, Nov. 1, 15, Dec. $1,15,1897$. Nos. $1-11$.

[5th „, Jan. 1, 15, Feb. 1, Mar. 1, 15, Apl. 1, 15, May 1, 15, June 1, 15, July 1, 15, Aug. 1, 15, Sept. 1, 15, Oct. 1, 1898. Nos, $1-18$

[6th "] Jan. 15, Feb. 15, A pl. 15, May 15, June 15, July 15 , Aug. 15, Sept. 15, Oct. 15, 1899. Nos. 1-3 and 5-10. [8th ", ] Mar. 20, May 22, Oct. 24, Nov. 22, 1901. Nos. 1-4 * "This was given as a supplement to "Die Post" and the contents consist entirely of price lists of stamps. Commencing with no. 10 of the sixth year the journal was published by Feodor Reinboth. Owing to a mistake in the numbering there is no no. 4 of the sixth year. No. 3 of the eighth year is printed on page 164 of the journal.

- BRIEFMARKEN-BÖRSE. Briefmarken-Börse des Internationalen Tausch- und Kauf-Verbandes für Semstwomarken-Sammler.

Rüttenscheidt, Rheinland, P. von Tresckow, I895-96. Fol. $12 \frac{3}{4}$ in. 16 nos. in 2 vols.

O1st year. May, 1895- May 15, 1896. Nos. 1-12. O2nd " Aug. 15, -[Nov.] 1896.

$\checkmark_{*}^{*}$ There is no number for March, 1896, nos. 2 and 3 of the secoud *ear were published together ynder the dates " 15 . September und 15 . Oktober, 1896 " and no. 4 of the second year has not the month of issue. Nos. 2 and 3 of the first year have supplements.

BRIEFIMARKEN-BO̊RSE. Die Briefmarken-Börse. Leipzig, Louis Senf, rgor.

$34^{\circ} \cdot 9 \frac{3}{4}$ in. No. 1 , Oct. $1,1901$. "* Given as a supplement to "Die Post," of September 20, 1901.
BRIEFMARKEN - COURIFR. Briefmarken - Courier. Zeitschrift für Philatelie.

Budapest, S. Mattaras, I 904-05. $8^{\circ} .9 \frac{3}{4}-10$ in., fol. $12-12 \frac{1}{2}$ in. and $8^{\circ} .9$ in. 11 nos. in 2 vols.

1st 12 -Dec. 10 . 1904 Nos. $1-5$ 1st year. Aug. 12-Dec. 10, Sept. $15,1905$. Nos. 15 .

** The numbers of the first year measure 93,10 inches, nos. 1-3 * The numbers of the first year measure 9 -10 inches, nos. $1-3$ of the second year are folio and nos. 4.5 and 9 of the second year are octavo 9 inchos. Nos. 2 a 3 , and 4 and 5 of the second year were severally published together and nos. 6,7 and 8 of the second year do not exist. A copy of the prospectus of the journal is bound
up with the above numbers.
Mis. St. Jour. 120 (10).

BRIEFIMARKENFREUND. Der Briefmarkenfreund. Fol. 14 in. No. 1 , Oct. 15,1882
$* *$. Consists of only a single leaf. Leipzig, C. G. Mann, Jr., ז882.

Mis. St. Jour. 120 (9).

BRIEFMARKEN-HÄNDLER, Der Briefmarken-Handler. Organ für die Interessen der Briefmarken Händler.

(.) $4^{\circ} .11 \frac{1}{2}$ in. nos. 1-3 [Jan.-Mar.], 1879. Danzig, P. Kliewer, I 879 .

* * A copy of the prospectus of the journal, dated November, 1878 with "Adressen derjenigen Händler, welche dieses Organ fortdauernd gratis und franco zugeschickt erhalten," are bound up
with the numbers.
Mis. St. Jour. 3 (7).

BRIEFIMARKENHÄNDLER. Der Briefmarkenhändler. Charlottenburg, Berlin, Internationaler Postwertzeichenhändler-Verein, I 896-

$8^{\circ}$. 97 in. nos. in vols. In progress.

1st year. May 28, 1896-Apl. 1,1897. Nos. $1-12$

2nd " " 1, 1897- " 14, 1898. " 1-12.

3rd " " 1, 1898-M" 10, 1899. " $1-12$.

4th " June 15, 1899-June 16, 1900. " " $1-12$.

5th " July 20, 1900-Aug. 20, 1901. ", 1-12.

6th " Sept. 20, 1901-Sept. 12, 1902. ", $1-12$.

7 th " Dct. 20, 1902- ., 7, 1903. ", 1-12.

8 th " " 12, 1903-Oct. 20, 1904. " 1-12.

9th " Nov. 22, 1904-Dec. 31, 1905. " 1-.4.

* * Edited by Paul Lietzow to January, 1905 , and then by Car Stcrnheim. There are no numbers for September, 1898, August, 1899, August, 1900, July, 1901, August, 1902, July, 1904, and nos. 1899 , August, 1900 , July, 1901 , August, 1902 , July, 1904 , and nos. 11 and 12 of the seventh year, nos. 9 and 10 of the ninth year, and nos. 7 and 8 of the tenth year Were severally published "together under the respective dates " " September, 1903," " 31 has "1902" in place "1903" $\checkmark$ The contents consist almost entirely of advertisements.

BRIEFIMARKENSAIMMLR. Der Briefmarkensammler Nïrnberg, Otto Windisch, I864

Fol. 18 in. [No. 1], Nov. 15, 1864

* Printed by autographic lithography with the text in German Firench, English, Italian and Spanish. The number consists of only one leaf. The front page of the number is illustrated in the "Journal of the Philatelic Literature Society" of January, 1909. Wanting.

BRIFFIMARIKEN-SAIMMLER. Der Briefmarken-Sammler. Organ für die gesammten Interessen der Briefmarkenkunde. Loipzig, G. Bauschke, etc., 1866-7 I.

$4^{\circ} .8 \frac{1}{2}-9 \frac{1}{4}$ in. 52 nos. in 6 vols.
1st year. [Jan., Feb. 20, Mar. 31 , May 15, July 2, Aug. 15, Oct. 1 , 1st year. [Jan., Feb. 20,' Mar. 31, May
Nov. 28] 1866 . Nos. 1-8.

2nd " [Jan., Feb. 20, Mar. 25, May 1, June 5, July 10, Aug. 15, [ept. 20, Nov. 1, Dec. 10], 1867. Nos. 9-18.

3rd " [Jan., Feb. 24, Mar. 28, May 1, June 5, July 20, Aug. 25, Oct. 1 , Nov. 5, Dec. 10], 1868. Nos. 19-28.

4th " [Jan., Feb. 20, Apl. 1, May 5, June 10, July 15, Aug. 20, 5th " [Jan., Feb. 25, Apl. 1, May 5 , June 10, July 15, Oct. 15 , 5 th $\quad \quad$ [Jan., Feb. 25, Apl. 1, May 5 , June 10,
$\quad$ Nov. 15, Dec. 15], 1870. Nos. 39-48.

6th " [Jan. 15, Feb. 20, Mar. 25], 1871. Nos. 49-52. * There is an index for the first three years combined. Nos. 44 and 45 and 51 and 52 were severally published together and no. 31 is wron

BRIEFMARKENSAIMMLER. Der Briefmarkensammler. Senf's zweite illustrierte Briefmarken-Zeitung.

Leipzig, Gebrïder Senf, r89o.

8. 91 in. No. 1, Oct. $15,1890$.

* * The number was reprinted with the title reading "Senf's 
Briefmarken SaMmler (Marbes)

BRIEFMATREN-RuMDSCHAU 
British Aruateur Pillativit. R. Rokertion. Edintmess

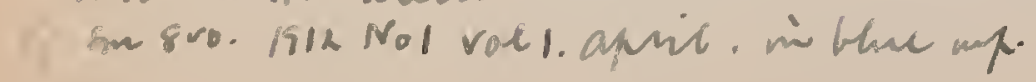




\section{BRIEFMARIS FNSAMMLER. [Continued as :]}

—_ Senf's Briefmarkensammler. Gebrüder Senf's zweite illustrierte Briefmarken-Zeitung. Leipzig, Gebrüder Senf, 189o-9x. 8․ 91 in. Nos. 2-12, Nov. 15, 1890-Sept. 15, 1891.

BRIEFMARKEN SAIMIMLER Der Briefmarken Sammler. Zeitschrift für Postwertzeichenkunde. Bremen, August Marbes, I89o-

S. 11 in. in. nos. in vols. In progress.
1st year. Oct. 1, 1890-Sept. 1, 1891. Nos. 1-12

2nd " " 1, 1891- " 1, 1892. "1-12.

4th " " 1, 1892- " 1, 1898. " 1-12.

5 th " " 1. 1894-Dec. 1, 1895. " $11-15$.

6th ", Jan. 4, - ", 9, 1896 . " $1-12$.

7 th " $"$ " 4, - " 4,1897 . " $1-12$.

9th " $\quad$ 9th $\quad 3, \quad-\quad " 1,1898 . \quad$ " $1-12$

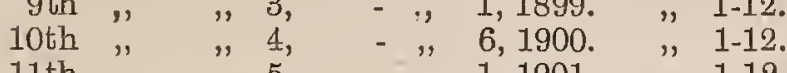

11th " " " $5, \quad-", 1,1901 . \quad$ " $1-12$

12th " " $\quad 4,-" 1,1902 . \quad " 1-12$

14th " " " 2, - " " 1, 1904 " $11-12$.

15th " " 16 , $3, \quad " 1,1905 . \quad " 1-12$

* * There is a titlo * The is a title-page and an index to cach volume, two supple vol. I., no. 1, vol. II., and to nos. 1 and 3 , vol. III.

BRIEFMARKEN - VERKEHR. Briefmarken - Verkeh Erscheint je nach Bedarf, und wird gratis und franco an Sammler und Händler versandt.

New York, A. Paimann, r894-95

(6) $8^{\circ} .9$ in. Nos. 1-8, Apl. 1894, Mar., Apl., 1895.

* * This is nothing more than a price list of the publisher's stock of stamps, etc. No. 1 consists of only one leaf.

Mis. St. Jour. 61 (8).

BRIEFIMARKEN-ZEITUNG FÚR DIE JUGEND. Sec

Part I. Moschiau (Dr. o. o. A.)

B has ppis-s in whitio a houd papu, 2 cditeons

BRIEFWAPPEL. Das Briefwappel.

[Mïnchen], Markus Stempfel, r892.

$8^{\circ} .11$ in. No. 1, Mar. 18, 1892.

* * Produced by autographic lithography. The contents are of a humorous description.

Mis. St. Jour. 73 (1).

BRIGHT AND SON'S MONTHLY PHILATELIC (6) ADVFRTISER AND STAIMP IMARKET JOURNAL. Bright and Son's monthly philatelic advertiser and stamp market journal.

London, W.C., Bright and Son, xgo6-o7.

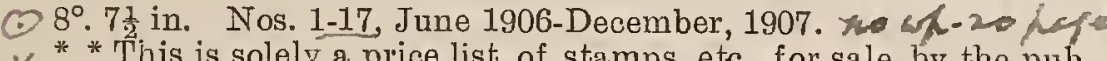
$\checkmark$ ** This is solely a price list of stamps, etc., for sale by the publishers and cannot therefore be considered a phila telic journal. for September, 1907. $1 / 24,-8-1074-17$

BRISTOL COUNTY PHILATELIST. The Bristol County philatelist.

Taunton, Mass., Kirby and Benton, r897-98. $32^{\circ} .41$ in. 15 nos. in 2 vols.

Vol. I. Jan.-Dec., 1897. Nos. 1-12

" II. "-Mar., 1898. "13-15.

Mis. St. Jour. 96 (1).

BRISTOL COUNTY STAMP NEWS The Bristol County stamp news. Official organ of the Bristol County Philatelic Society.

u Taunton, IMass., The Bristol Connty Philatelic Society, 1894.

- $8^{\circ} .73$ in. Nos. 1-8, Jan.-Mar., 1894.

Mis. St. Jour. 66 (14).

BRITISH ALIMANAC. The British almanac and family cyclopaedia, for the year of our Lord 1906. . . . Contain an article "British postage stamps," compiled from papers written by Fred. J. Melville.]

$8^{\circ}, 7 \frac{1}{2}$ in. pp. 209-211,

London, Charles Letts and Co., [rgo6]
BRITISH ALIMANAC. See Companion to the [British] ALMANAC.

BRITISH AMERICAN STAIMP IMERCURY. [A Journal with this title is mentioned in the "American coin and stamp review" of Allentown, Pa., for August, 1871, and a review of it appeared in the "Stamp collector"s record" of Boston, Mass., in February, 1871; but none such ever appeared and the review in question was nothing more than a skit.]

\section{BRITISH AND COLONIAL PHILATELIC ADVER-}

C) TISER. British and colonial philatelic advertiser. Hillsbro', Sheffeld, W. E. Burker, x goo-ox.

\section{(3) $4^{\circ} \cdot 9 \frac{1}{2}$ in. and $8^{\circ} .8 \frac{1}{4}-8 \frac{1}{2}$ in. 15 nos. in 3 vols.}

Vol. I. Feb. ${ }^{2}$-July, 1900 . Tols.

"II. Aug. 31, 1900-Jan. 30, 1901.

III. F'eb. 28 May 25, 1901. " 13-16.

* "Vol. I. is quarto and vols. II. and IIr. are octavo. Each number
has a paper wrapper. "Nos. 7-16 have the word "The" preceding

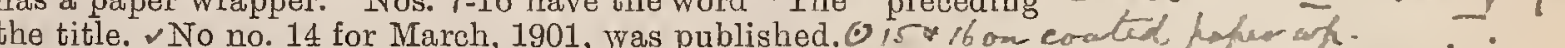

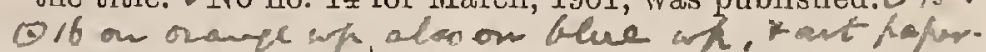

BRITISH AND COLONIAL PRINTER AND STA-

TIONER. The British and colonial printer and stationer. No.'1335. Vol. LVIII., no. 13, March 29, 1906. [Contains an article "Siderography up-to-date," which gives a description of Messrs. Perkins Bacon and Co.'s method of printing stamps from steel plates.] xgo6.

Fol. $17 \frac{3}{3}$ in. p. 6.

Mis. St. Jour. 115 (18).

BRITISH AND COLONIAL STAMP MARKET. The - British and colonial stamp market.

Norwood, London, S.E., Bournemonth [printed], H. L'Estrange Ewen, rgoo-or.

Fol. 15 in. 40 nos. in 2 vols.

$\Xi$ [Vol. I.] October-Dec. 15, 1900. Nos. 1-9.

[" II.] Jan. 5-Sept. 14, 1901.

* This is a supplement published with "Ewen's weekly stamp news," with which it is bound up. Ne. 16 Las Jugy.6

[Continued as :]

E Ewen's colonial stamp market.

Norwood, London, S.E., Bournemouth [printed],

H. L'Estrange Ewen, r9or-oz.

Fol. 15 in. 42 nos. in 2 vols.

C [Vol. II.] Sept. 21-Dec. 28, 1901. Nos. 41-55.

[ " *III.! Jan. 4-July 5, 1902 . " $56-82$

* This is a supplement published with "Ewen's weekly stamp news," with which it is bound up.

\section{[Continued as :]}

Ewen's colonial stamp market, Ltd.

Norwood, London, S.E., Bournemonth [printed]

H. L'Estrange Ewen, etc., r902-05.

Fol. 15 in. 181 nos. in 4 vols

[Vol. III.] July 12-Dec. 27, 1902. Nos. 83-107.

" IV.] Jan. 3- " 26, 1903. " 103-159.

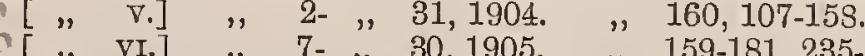

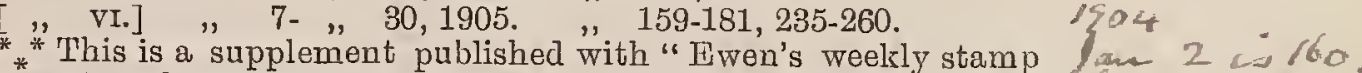
news," with which it is bound up. Commencing with no. 84 it fore 9 - sheje $107-158$

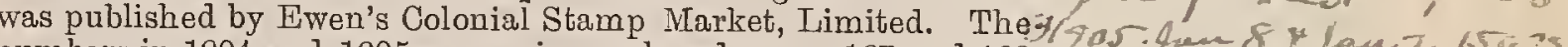

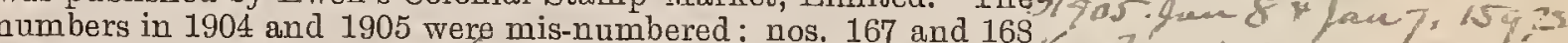

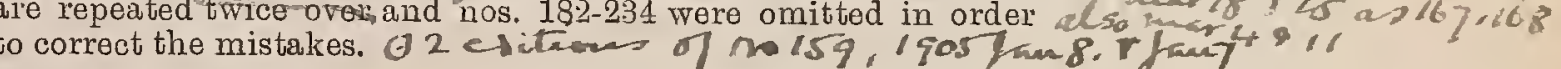

\section{BRITISH AND FOREIGN NOVELTY GAZETTE.}

The British and foreign novelty gazette.

London, S.W., Nottingham [printed], Clark Bennett and Co., I88o.

8. 101 in. Nos. 1-6, July-Dec., 1880 .
* * The contents consist entirely of advertisements. Mis. St. Jour. 78 (18).

$$
\begin{aligned}
& \text { Brufmanken zeitung athens } \\
& \text { I } 1910 \text { No I fas } N 1 \text { jure }
\end{aligned}
$$




\section{BRITISH AND FOREIGN NOVELTY GAZETTE.}

[Continued as :]

- The British and foreign novelty gazette and international stamp review. New Series.

London, S.W., Nottingham [printed], Clark Bennett and Co., etc., r88r.

8. 10 in. New Series. Nos. 1-4. Old Series. Nos. 7-10. Jan., Feb., Apl., June, 1881.

* * Nos. 3 and 4 were published by J. A. Bennett and Co., and the contents of these two numbers consist entirely of advertisements. Mis. St. Jour. 78 (14).

[Continued as :]

- The British and foreign novelty gazette.

London, S.W., J. A. Bennett and Co., I88I. $8^{\circ} .10$ in. New Series. No. 5. Old Series. No. 11. Oct., 1881. ** The number contains a supplement of two pages. The conents consist entirely of advertisements.

Mis. St. Jour. 78 (15).

BRITISH AND FOREIGN NOVELTY GAZETTE AND INTERNATIONAL STAIMP REVIEW. See BRITISH AND FOREIGN NOVELTY GAZETTE.

BRITISH AND FOREIGN PHILATELIC NEWS.

6 The British and foreign philatelic news. A monthly paper devoted to the art of stamp collecting and dealing. Sutton near St. Helens, Lanc., Gibbs and Co., 1887 .

(.) $8^{\circ} .7 \frac{1}{2}$ in. Nos. 1-2, Jan,-Feb., 1837. 0 Mis. St. Jour. 55 (14).

Brit + For.st.atr. Is"I.1) In
BRTTISH AND FORFIGN STATMP AND COIN ADVERTISER. The British and foreign stamp and coin advertiser. Manchester, A. J. Johns, I864.

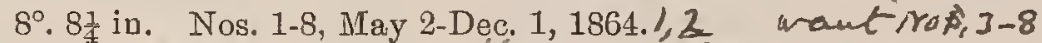
* No. 1 has a title-page. $=$ M 1.2.

BRITISH AUSTRALASIAN AND NEW ZEALAND MAIL. The British Australasian and New Zealand mail. Vol, xir., no. 513, July 26, $1894 . \quad$ Contains an article "Stamps and the man. A chat with Stanley Gibbons, Litd."']

Fol. $13 \frac{1}{2}$ in. pp. 979, 980

* * The number has a coloured paper wrapper.

Mis. St. Pamph. 63 (12).

BRITISH, CONTINENTAL, AND AMERICAN

(- STAIIP, COIN, CREST, AUTOGRAPH, AND GENERAL CURIOSITY COLLECTOR'S IMAGAZINE, AND JOURNAL OF THE BRIDLINGTON AIMATEUR ASSOCIATION. The British, Continental, and American stamp, coin, crest, autograph, and general curiosity collector's magazine, and journal of the Bridlington Amateur Association.

Preston, Preston Curiosity Society, 1865.

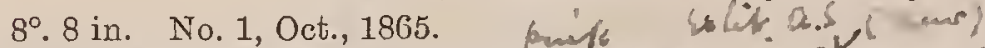

** The number has a coloured paper wrapper and a copy of the prospectus of the journal is bound up with it. Mis. St. Jour. 37 (5).

[Continued as :]

The Curiosity collectors' magazine, and journal of the Bridlington Amateur Association. Specially devoted to the interests of the collector of postage stamps, coins, crests, autographs, and other interesting curiosities.

Preston, Preston Curiosity Society, 1865. $8^{\circ}$. 8 in. No. 2, Nov. 1, 1865 .
* * The above was succeeded in January, 1866, by "The Amateur" 8. 8 in. 0 No. 2 , Nov. 1, 1865 .
** The above was succeeded in January, 1866, by "The Amateur" $\downarrow_{\text {U } 36}$ Mis. St. Jour. 37 (5a).

BRITISH GUIANA PHILATELIC JOURNAL. The British Guiana philatelic journal

Georgetown, The British Guiana Philatelic Society, I906-

$8^{\circ} .9 \frac{3}{4}$ in. Nos. 1- . December, 1906In progress. * * There is a coloured paper wrapper to each number. This was the first philatelic journal published in British Guiana.

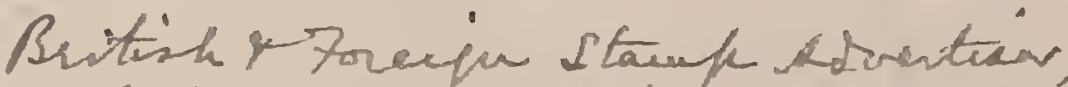
Iffori. o 1311 fuly rol ifh mibue ars

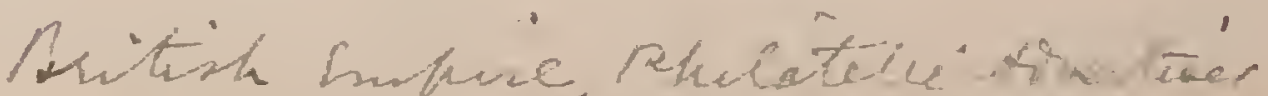

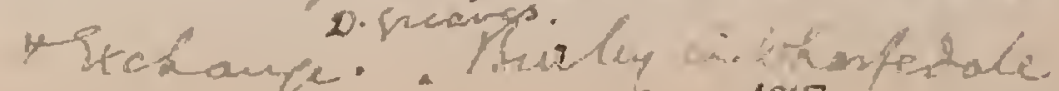

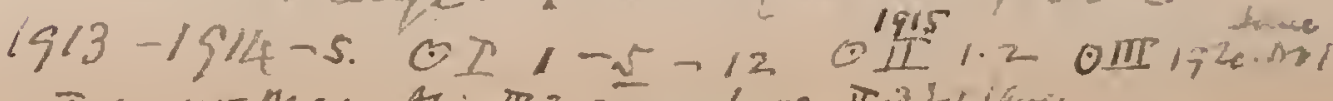

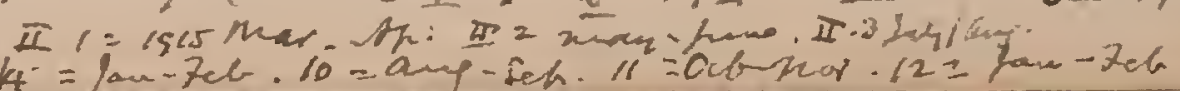
blue. 1891. LETIN.

BRTTISH PHTIATETICAT ADVERTISER The British philatelical advertiser.

Edinburgh, Edwin Reid, [1880] $8^{\circ} .7 \frac{1}{3}$ in. No. 1, Jan., [1880]. $\odot$

* * Succeeded by the "British Philatelist."

Mis. St. Jour. 55 (7)

BRITISH PHILATELIST. The British philatelist. Edinburgh, Edwin Reid, r880.

in. No. 1, Feb. 1880.

* * Advertised in no. 3 of the "Foreign stamp advertiser," New* * Advertised in no. 3 of the "Foreign stamp advertiser," Newcastle-on-Tyne, December, 1879, to appear shortly. According to a note left by 'T. K. Tiffany no. 1 was published in February, 1880. "The Monthly review and advertiser," published by $\mathrm{H}$ "Reid in March, 1880, states that "The British philatelist" an by the "Monthly review and advertiser". Wanting.

BRITISH PHILATELIST. The British philatelist.

London, N.E., The International Stamp Supply Co., 1886.

$8^{\circ} .8 \frac{1}{4}$ in. No. 1-2, Jan. 8-Feb. 8, 1886

Mis. St. Jour. 54 (6)

BRITISH QUARTERLY REVIEW. The British quarterly review. No. xxIx., February, 1852. [Contains a review of the "Report from the Select Committee on newspaper stamps". Ordered by the House of Commons to be printed, 18th July, 1851.]

London, etc., Jackson and Walford, etc., $185^{2}$ $8^{\circ} .8 \frac{1}{2}$ in. pp. $135-162$

* * Published also by Simpkin, Marshall and Co., London, W. Oiphant and Sons, Edinburgh, J. Maclehose, Glasgow, and J. Robertson, Dublin. Mis. St. Jour. 30 (1).

BROOKLYN PHILATELIC ADVERTISER. The Brooklyn philatelic advertiser.

Brooklyn, N. Y., Chas. A. Phildius, r9oz-03. Fol. 11-12-12 in. and $8^{\circ} .9$ in. Nos. 1-7, July 1-Nov. 1, 1902, Feb. 1, July, 1903

* * Nos. 1-6 are folio and no. 7 is octavo. No. 6 is dated in error "1902" but the last figure has an overprinted numeral " 3 " in Mis. St. Jour, 109 (14)

BROOKLYN PHILATELIST. The Brooklyn philatelist. Brooklyn, N. Y., Ashoroft and Dahlfues, I891. 8. 9 in. Nos. 1-6, June-Nov., 1891.

* * There is a coloured paper wrapper to each number. Amalgamated with the "Empire State Stamp Journal" in December,

Mis. St. Jour. $61(2)$

BROOKLYN PHILATELIST. The Brooklyn philatelist.

Brooklyn, N. Y., J. W. Van Ostrand, Jr., I896. c 8. 6-61 in. Nos. 1-2, Mar. 1-Apl., 1896.

* * There is a coloured paper wrapper to each number.

Mis. St. Jour. 68 (4)

BROOKLYN PHILATELIST. The Brooklyn philatelist.

New series.

New York, Metropolitan Publishing Co., 1897 $24^{\circ} .6$ in. No. 1, March, 1897

* * The number has a coloured,paper wrapper. The Metropolitan Publishing Co. were the successors of John W. Van Ostrand, Jr. Mis. St. Jour. $96(7)$

BROOKLYN STAMP. The Brooklyn stamp.

Brooklyn, N. Y., Raymond L. Perry, etc., r893. 8o. 8 in., 9 in., and $7 \frac{3}{4}$ in. Nos. 1-5, 7-9, Apl.-Dec., 1893.

* Nos. 7-9 were published by A. H. Post and G. I. La Mont. No. 1 is octavo 8 inches, nos. 2-8 are octavo 9 inches and no. 9 is octavo 73 inches. No. 1 is dated "March, 1893," but the wor "March," is struck out and "April " written above it in pen and ink. No number 6, for September, 1893, was published and nos. 7 and 8 were published together under the date "Oct. \& Nov. 1893 ". There are coloured paper wrappers to nos. 2,3 and 9.
Mis. St. Jour. 62 (11).

BROWN'S ADVERTISTR. See P. J. G. B. ADVERTISER BROWN'S BULLETIN. See "B. B." Brown's BUL-

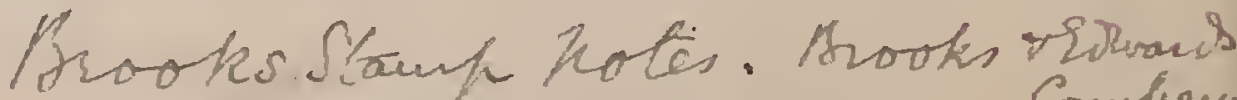

$$
\begin{aligned}
& \text { waut/ 6.7 } \\
& 15 / 6.1 .2-4 \quad-\text { tor } \\
& 15175-8 \text { zeb det-odt } \\
& \text { isto. } 9 \text { Pob-mar. }
\end{aligned}
$$


B1602 Pritisin Phicatensit.

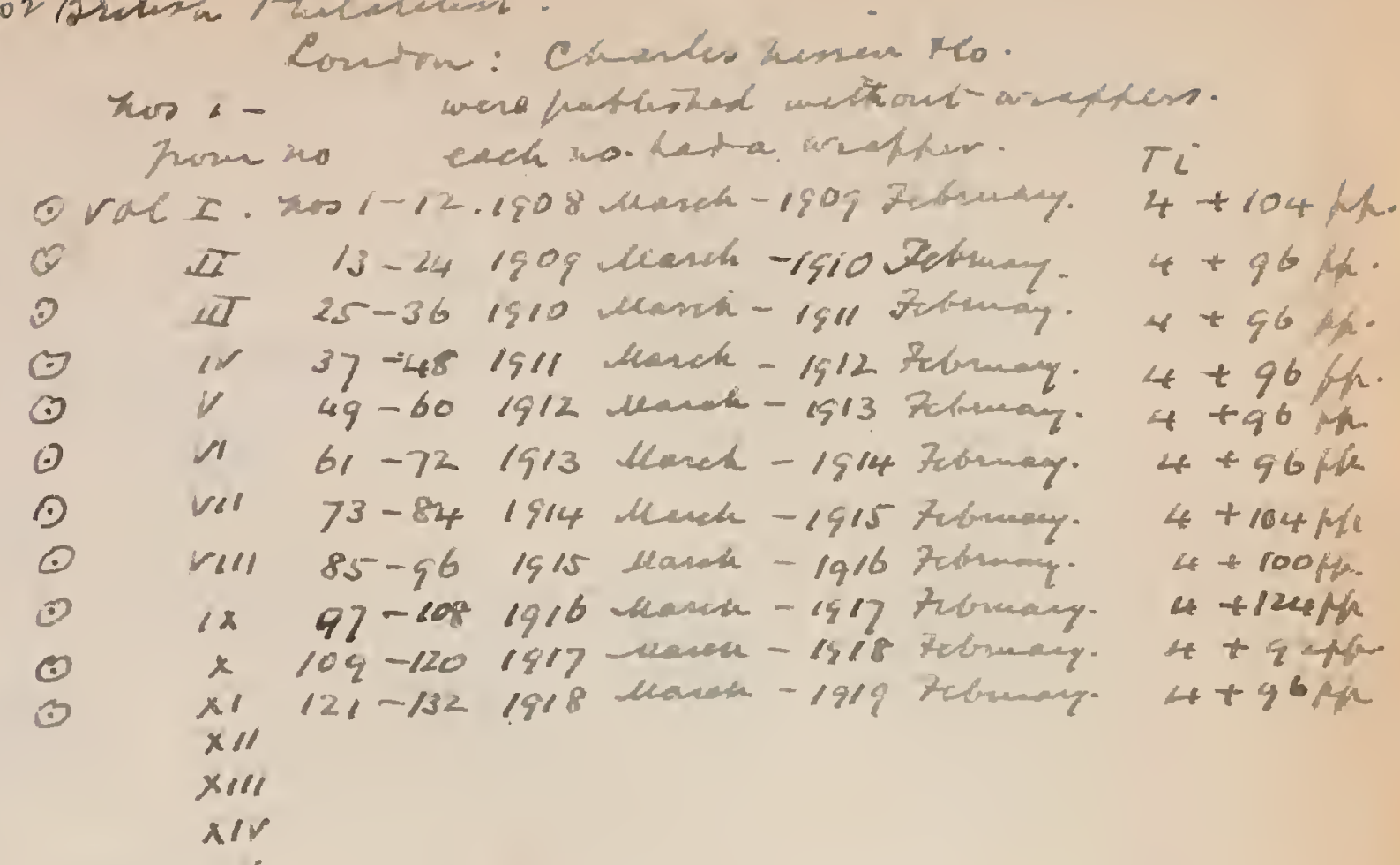

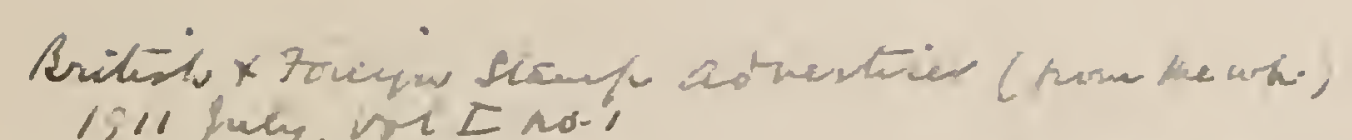

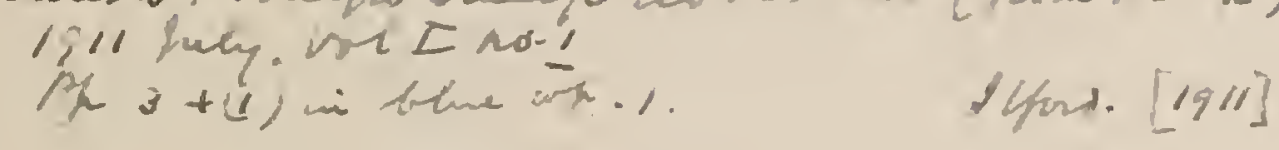

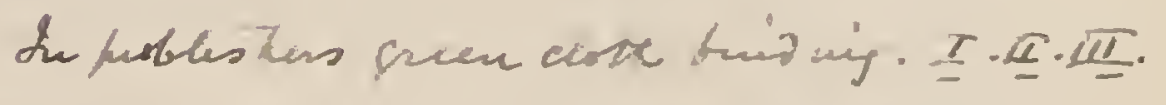

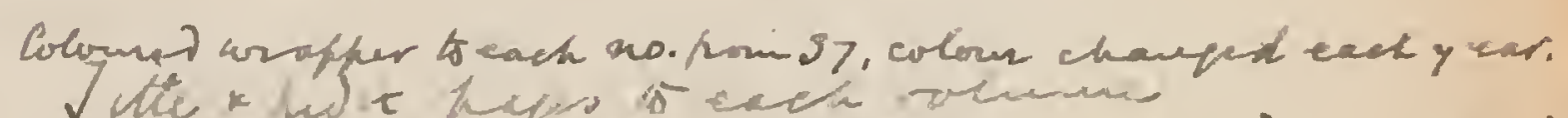

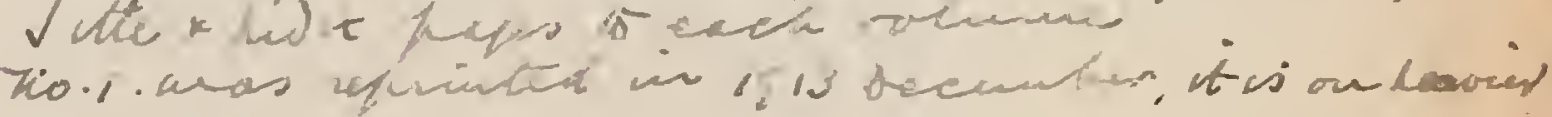
or mose smpaced thater.

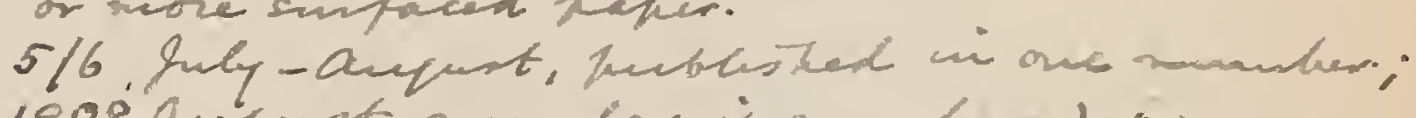
1908 achurt number is mumbers' on

B.S. - - Brown Studies, - - - - Nos. $1-5$

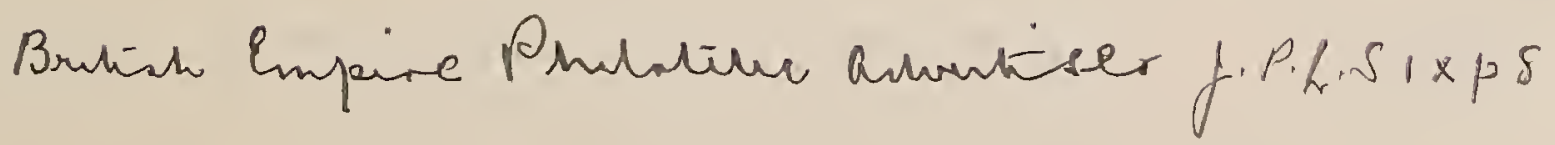

BRITISH GUIANA PHILATELIC JOURNAL. (Demerara, British

Guiana Philatelic Society).
Nos. 1-40 (1906-26). Uniound. All pewhin hed

BRITISH GUIANA PHILATELIST. (Demerara, Victory Plilatelic
Society).

Vol. 1, Nos. 1-3 (1925-26). Unbound.

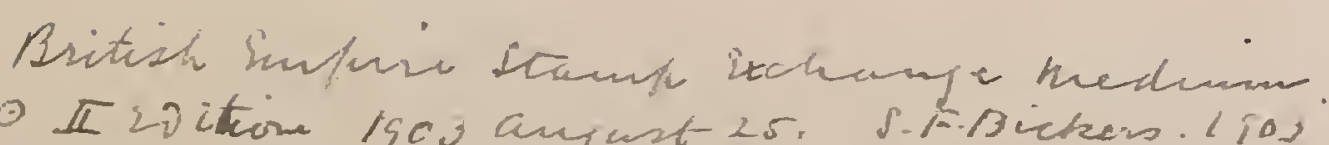

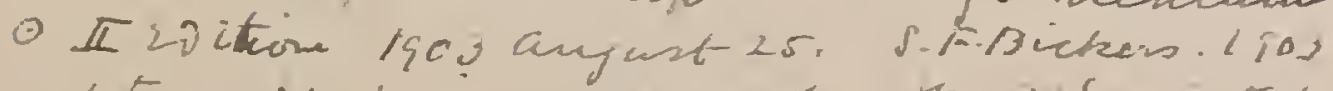

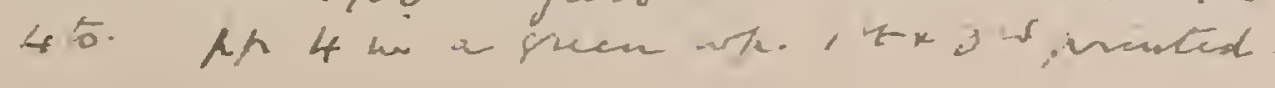

Brooks Pamp hotes.

Cambernell SE.5. Bremas and Lduraus.

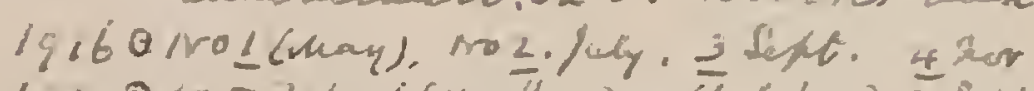

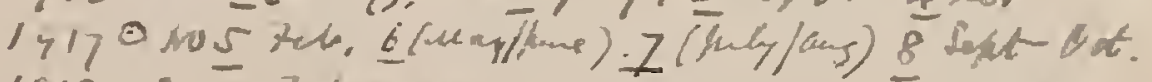

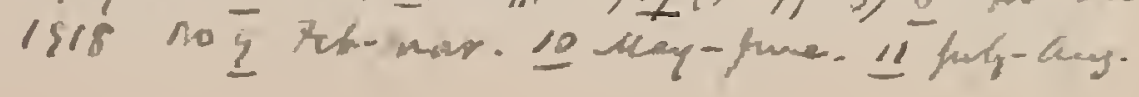



B. S. I. C. WEFRBLAD VOOR DEN POSTZEGEL VERZAMELAAR. B. S. I. C. Weekblad voor den Postzegelverzamelaar.

Amsterdam, The British Stamp Importers Co., r gor-02.

8․ 11 1 in. Nos. 1-28 October, 1901-April 9, 1902.

"* No. 1 has "Proefnummer," no. 6 has " 2 de ProefnummerOplaag 8000," "no. 15 has "3e en laatste gratis ProefnummerOplaag 10,000," and no. 26 has "Einde van den eersten halven Jaargang".

BUCARESTER PHILATELIST. Der "Bucarester Philatelist" Internationales Fachblatt für den Briefmarkenhandel.

Bucarest, A. G. Pancu und J. A. Marcus, 1885 Fol. 12 in. No. 1, Jan. 1, 1885.

Mis. St. Jour. 3 (15)

[Continued as :]

- Der Philatelist, Internationales Fachblatt für den Briefmarkenhandel. Bucarest, J. A. MLarcus, I885. Fol. 12 in. No. 2, Feb., 1885. Mis. St. Jour. 3 (15a).

BUCKEYE AMATEUR GAZETTE. The Buckeye amateur gazette.

Cincinnati, O., Whitmore, Robinson and Co., I877. * * Cuttings of the "Stamp department," ete., from nos. 1 and 2 , dated January and February, 1877, are mounted in Stamp Scrap-book, vol. III., pp. 61 and 83.

BUCKEYE COLLECTOR. The Buckeye collector.

in. Nos. 1-
* Only partly philatelic. Wanting.

BUCKRYE PHILATELIST. Buckeye philatelist. Marietta, O., Buckeye Stamp Co., [188r]. $8^{\circ} .9$ in. No. 1, [Feb., 1881].

** Edited by F. H. Chamberlain.

Mis. St. Jour. 24 (3).

BUCKEYE PHILATELIST. The Buckeye philatelist. Cleveland, O., Frank J. Sommer, I89o. $8^{\circ} .7 \frac{1}{2}$ in. Nos. 1-2, Nov.-Dec., 1890. Mis. St. Jour. 67 (8).

(2) BUCKEYE PHILATELIST. The Buckeye philatelist. A philatelic journal.

Tippecanoe City, O., Paul Cline, r899-r9oo.

@ $8^{\circ} .81-9$ in. Nos. 1-3, Nov., 1899-Jan., 1900.

* * There is a coloured paper wrapper to each number." Nos. 1 and 2 measure 81 inches and no. 3 , 9 inches.

Mis. St. Jour. 93 (16).

BUCKEYE PHILATPLIST. The Buckeye philatelist. Published monthly for stamp collectors.

Columbus, O., The Buckeye Philatelic Publishing Co., r $90 \mathrm{r}$.

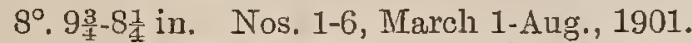

* * Nos, 1-3 measure 93-91. inches, no. 4 measures 81 inches, and nos. 5,6 which were published together" measures 81 inches Each number has a paper wrapper. * Mis. St. Jour. 126 (12).

BUCKEYE STAIIP JOURNAL. The Buckeye stamp journal. Akron, O, Chas. A. Townsend, I881-82. $8^{\circ} .9$ in. Nos. 1-8, Sept., 15, 1881-Mar. 15, June 15, 1882. Mis. St. Jour. 24 (13)

BUCKFYE STATE COLLECTOR. The Buckeye State collector. A monthly journal for collectors.

Portsmouth, O., E. J. Smith, etc., r887-gr. $8^{\circ} .9 \frac{1}{2}$ in. 9 nos. in 2 vols.

Vol. I. Aug. 1, 1887-Feb, 1888. Nos. 1-7. $2-1$

Vol. I. Aug. 1, 1887-Feb., 1888. Nos. 1-7.
"II. Apl. 20, Mary, 20, 1891. Nos. $1-2$.

*"* II. Apl. 20, May, 20, 1891. Nos. 1-2. " " 4 ". " There are coloured paper wrappers to no. 7 and to nos. 1 and 2 of vol. II. The wrapper of no. 7 is wrongly dated "March, and 2 " of vol. II. The wrapper of no. Thashed by the Buckeye Publishing Co."

Vol. I. Mis. St. Jour. 15 (4).

BUCKEYE STATE PHILATELIST. The Buckeye State philatelist.

Wellington, O., E. L. French, I886-9г. $8^{\circ} .9$ in. and 8 in. Nos. 1-3, Dec., 1886, Jan.., 1887, July, 1891. * * Nos. 1 and 2 have coloured paper wrappers and measure 9 inches. No. 3 has no wrapper and measures 8 inches.

Mis. St. Jour. $23(9)$
BUCKEYF STATF PHILATFLIST. The Buckeye Sta te philatelist.

Cincinnati, O., Erwin Fischer, x896-97

$8^{\circ}, 8-9$ in. 3 nos. in 2 vols.

Vol. I. Oct., Nov., 1896. Nos. 1-2.

*"* Ir. March, 1897. No. 1. 1 and 2, vol. I. measure 8 inches and no. 1, vol. Ir. measures 9 inches. The last has a coloured paper wrapper.

Mis. St. Jour. 93 (14).

BUDAPESTER PHILATELISTISCHE CORRFSPONDENZ. Budapester philatelistische correspondenz. Budapest, A. H. Ganz., r895.

$4^{\circ} .11^{\frac{3}{2}}$ in. [No. 1], October, $1895 . \quad$ Mis. St. Jour. $128(6)$

BUDGET. The Budget.

Phitadelphia, Pa., The Budget Co., etc., $\mathrm{x} 896$. 8. 8-9 in. Nos. 1.5, [Apri1], May 30, July 25, Aug. 31, Oct., 1896. * * No. 1 measures 8 inches, bears no date, and is not philatelic. The other numbers measure 9 inches and are partly philatelic. Nos. 2.4 were published by Wm. Clarance Farr, no. 5 by Herbert Stratton, and nos. 4 and 5 have coloured paper wrappers.

$$
\text { Mis. St. Jour. } 119 \text { (5). }
$$

BUENOS AIRES FILATf́LICO. See VIDA EN EI HoGAR.

BUENOS AIRES POSTAL. Buenos Aires postal.

Buenos Aires, Juhel Renoy, I894.

$\circlearrowleft 8^{\circ} .10 \frac{1}{4}$ in. Nos. 1-3, Jan.-Mar., 1894 *** Nos. 2 and 3 were published together under the date "Fev-
rier mars. St. Jour. 57 (4).

BUFFALO AIMATEUR. The Buffalo amateur.

Buffalo, N. Y., Sewell and Cook, $x 875$.

* * Cuttings of the "Stamp Department," etc., from nos. 1, 2 and 4, dated May, June and August, 1875, are mounted in Stamen Scrap-book, vol. III, pp. 52-56.

BUFFALO AMIATEUR. The Buffalo amateur. Buffalo, N. Y., Charles G. Steele, Jr., 1878 . ** Cuttings of the "Stamp corner," etc., from no. 1 dated June, 1878, are mounted in Stamp Scrap-book, vol. IV., pp. 3, 4 .

BUFFALO PHILATELIC IVAGAZINE. The Buffalo philatelic magazine. Printed for circulation only among members of Buffalo Philatelic Society.

Buffalo, N. Y., Buffalo Philatelic Society, Igог. $4^{\circ} .10 \frac{1}{2}$ in. No. 1, May, 1901

* * Produced by a type-writer and edited by J. A. D. Park.

Nis. St. Jour. 109 (4)

BUFFALO PHILATELIC PR刃SS. The Buffalo philate-

lic press. Devoted to the interest of stamp collectors. Buffalo, N. Y., Fischbach and Wemple, r889-9o. (2) $8^{\circ} .912$ in. Nos. 1-3, Dec., 1889-F'eb. 15, 1890

Mis. St. Jonur. 15 (6)

BUFFALO PHILATELIST. The Buffalo philatelist. A monthly paper for stamp collectors. Buffalo N. Y., Clarence J. Manning, etc., x889. $8^{\circ} .11$ in. and $9 \frac{1}{2}$ in. Nos. 1-5, Feb. 1-June, 1889.

** Nos. 1-3 are octavo 11 inches and nos. 4 and 5 octavo $9 \frac{1}{2}$ inches. - The two last were published by Lankler and Manning. No. 5 is printed on coloured paper., $v$ Mis. St. Jour. 72 (2).

[Continued as :]

The Stamp crank. Formerly "The Buffalo philatelist" . A monthly for stamp collectors.

Buffalo, N. Y., Clarence T. Manning, x89o.

$8^{\circ} .10$ in. Vol. II., no. 1, Jan. $1890 . \quad$ Mis. St. Jour. 72 (3).

BUFFALO PHILATELIST. The Buffalo philatelist. Official organ of the Buffalo stamp exchange.

Buffalo, N. Y., Raynor Hubbell, I897.

$8^{\circ} .9$ in. No. 1, March 15, 1897.

*** The number has a paper wrapper. M Nis. St. Jour. 113 (7).

BUGLE. The Bugle. Toronto, Ont., [?], x904. in. No. 1.

** Only partly philatelic, and succeeded by the "Canadian monthly". Wanting. 
BULLETIN. The Bulletin. Official organ of the National Stamp Dealers' Association. Published by the secretary monthly, or as often as deemed advisable.

St. Louis, Mo., etc., National Stamp Dealers' Association, I888-91.

$8^{\circ} .8^{3}$ in. Nos. 1-10, June-Oct., Dec., 18s8, Apl., Dec., 1883, Apl., 1890, F'eb., 1891.

* Nos. 8 and 9 were published at Philadelphia, Pa., and no. 10 at Newmarkct, N.H.

BULLFTIN. The Bulletin. I 894

Newburyport, Mass., Davison Stamp Association,

64.2 in. No. 1., January, 1894.

[Continued as :]

- The Collector. I894.

Newburyport, Mass., Davison Stamp Association,

$16^{\circ} .6 \frac{1}{2}$ in. Nos. 2-3, Feb.-March, 1894.

OBULLFTIN CONFIDENTIEL. Bulletin confidentiel. Organe mensuel de la Société des Amateurs de 'Timbres Français.

Paris, A. Coyette, i $900-$ or.

○ $8^{\circ} .9$ in. Nos. 1-11, April, 1900-Aug., 1901.

* * The above was also published by F. Marconnet at Nancy and the nnmbers were printed at Amiens. Each number has a coloured paper wrapper and nos. 1-4 hare supplements with the title "Etude sur les variétés des timbres de France". WNo. $t$ is dated "Juillet à Octobre, 1900," 1900," and no. 11. "Juin, Juillet, Août, 1901".

BULLETIN DE LA SOCIFT' FRANCGAISE DF TIMBROLOGIF. Bulletin de la Société Française de Timbrologie.

$8^{\circ} .9 \frac{1}{2}$ in. 62 nos. in 5 vols.

Vol. I. 1875-78. Nos. 1-14.

"II. 1879-82. "15-29.

" $"$ II. 1883-86. " 30.44.

[" $\quad$ IV. $1887-94 . \quad " \quad 45-63$.

* "Nos. 1-16 were printed in Brussels and published by J. B. Moens on behalf of the society. Nos. $60,61,62,64,65,66,68,63$ and 70 vere never published. There are title-pages and lists of contents to vols. I.--III. and a coloured paper wrapper to each number, except that nos. 39 and 40,51 and 52 , and 55 and 56 were sererally published together with one wrapper each. No. 23 is wrongly numbered and dated "No. 22, Décembre 1880". combined title-page and an index to vols, rv, and v, were pre sented as a supplement to the "Journal of the Philatelic Litera ture Society" for July, 1909.

BULLETIN DE LA SOCIETTE "L'UNION DES HCHANGISTES". Bulletin de la Société "L'Union des Echangistes".

Paris, A. Lexcellent, I 898-г 901 8. $9 \frac{3}{4}$ in. 46 nos. in 4 vols.

[1st year.] Jan.-July, Sept.-Dec., 1898. [Nos. 1-11.] [2nd "] "-Dec., 1899. [" 1-12.] [3rd "] " " -Aüg., Oct.-Dec., 1900. [ " 1 1-12.] * * The numbers for September and October," 1899, and July and Augnst, 1900 , were severally published together under the respective dates, "Septembre-Octobre, 1899," and "Juillet-Août, 1900 ". The number for October, 1900, is wrongly dated " Novembre, 1900 " and that for February, 1901, has in error "Janvier, 1901" ". This bulletin was distributed with the numbers of the "Philatéliste Français" for the corresponding dates. Wanting the number for October, 1900.

Mis. St. Jour. 117 (20).

BULLETIN DE LA SOCIETR TIMBROPHILE DE BRUXELLES. Bulletin de la Société Timbrophile de Bruxelles.

$8^{\circ} .10 \frac{1}{2}$ in. Nos. 1-2, November, [1883]-January, [1884]

** Only one hundred copies of each number were printed.

Mis. St. Jour. 130 (7).

BULLFTIN DE LA SOCIETTE TIIMBROPHILE DE REIIIS. Bulletin de la Société Timbrophile de Reims. Reims, I898.

8०. 8未 in. Nos. 1-4, [? June] July-August, September, October, * * Nos. 2-4 have coloured paper wrappers. Wanting no. 1 Mis. St. Jour. 145 (3).
BULLFTIN DE T'UNION TIMBROPHILE SUISSE, Bulletin de l'Union Timbrophile Suisse.

(6) $8^{\circ} .9_{\frac{3}{3}}^{3}$ in. No. 1 , July $1,1891$.

Genève, G. Froehlicher, I894 Mis. St. Jour. $5 T$ (2)

BULLRTIN DES ANNONCES TIMBROLOGIQUES.

Bulletin des annonces timbrologiques.

Alexandrie, Egypte, G. T. Pennetty et Fils, I898-99. $8^{\circ} .9 \frac{1}{2}$ in. fol. 13 in. and $8^{\circ} .10 \frac{3}{4}-10 \frac{1}{1}$ in. 15 nos. in 2 vols. 1st year. January -December 31, 1898. Nos. 1-12. 2nd *" 1.3 are 31-March $31,1899 . " 13-15$. inches and the remaining numbers arc octavo $100^{3}-10 \frac{1}{4}$ inches. No. 4 is printed on blue paper and nos. 5-15 have coloured pape wrappers. Wanting no. $6 . \quad$ Mis. St. Jour. 128 (13)

\section{BULLETIN DU COIMIERCE INTPRNATIONAL} ET DE LA TIMBROLOGIE UNIVERSELLE. Bulletin du commerce international et de la timbrologie universelle. Marseille, H. Blanc, [? ] $4^{\circ} .11 \mathrm{in.} 20$ th year. [No number or date.]

* * Only the title appears to be philatelic, with the exception of a stamp advertisement on the last page. Mis. St. Jour. 129 (10).

BULLETIN FISCALISTE. Le Bulletin fiscaliste. Journal exclusivement dédié aux timbres fiscaux.

Paris, Amiens [printed], A. Forbin-L'Hoste, 1904-06. $16^{\circ} .7$ in. 20 nos. in 2 vols.

(1) 1st year. Oct., 1904-Aug., 1905. Nos. 1-10.

(2) 2nd ., 1905-O.t., 1906. 11-20.

***No. 8 is dated "Mai-Juin, 1905," no. 18 "Mai \& Juin, 1906,"

$\checkmark$ and there are no numbers for July and August, 1906.

BULLFTIN MENSUEL DE LA IMAISON THÉODORE CHAMPION ET CO. Bulletin mensuel de la maison Théodore Champion et Co. Paris, I902$8^{\circ} .7$ in. nos. in vols. In progress.

[1st year.] Nov. 25, Dec. 25, 1302. No. 1 and no. 1 bis

[2nd ", Jan. 25-Dec. 25, 1903. Nos. 2-13.

3rd " " " " " 1904. " 14-24.

[4th " "] " " " "- " " " $1905 . \quad$ "

"*The contents consist chiefly of price lists of stamps, but mos of the numbers also include notes on philatelic matters. The number of " 25 Décembre, 1902," has the word " bis " added in pen and ink to "No. 1," and there are two "no. 20," one dated " 2 Juillet, 1904," the other " 25 Août, 1901".

BULLETIN IMENSUEL DE LA SOCIETE ANONYME DES PHILATELISTES DE REIMS. Bulletin mensuel de la Société Anonyme des Philatélistes de Reims.

Reims, $\mathbf{1} 898$

$8^{\circ} .8 \frac{1}{4}$ in. Nos. 1-2, March-April, 1898

${ }_{*}^{*}$ There is a coloured paper wrapper to no. 2

Mis. St. Jour. 145 (2)

BULLETIN MENSUEL DE LA SOCIETR LES FCHANGISTES RÉUNIS. Bulletin mensuel de la Société les Echangistes Réunis.

Fexhe-Slins, lèz-Liége, Liéon Defize, 1896-1900. $8^{\circ} .93$ in. 44 nos. in 4 vols.

1st year. Dec. 1, 1896-Dec. 1, 1897. Nos. 1-11.

2nd ", Jan. 1, - ," 1, 1898 .

3rd " " 1, - " 1, 1899. " 23-33.

th $", \quad, 1$,

"This journal succeeded "La Revue postale". There are no numbers for March and October, 1897, Scptember, 1898, July and October, 1899, and September, 1900 , and nos. 29 and 30 were published together, undcr the date "Août, 1899". Nos 10-44 have coloured paper wrappers and no. 23 both on the first page and on the wrapper has " 2 année" in place of "ze année". There are supplemental slips to nos. 10, 13, 18 and 22 and there is a special supplement with the title " L'Affiche artistique" to nos. 17-44, omitting no. 37. The first number of this supplement has no date or number and those numbered 37-43 were publishcd with nos. 38-44 of the "Bulletin".

[Continued as:]

La Revue postale. Fexhe-Slins, lèz-Liége, ctc., Liéon Defize, г

$8^{\circ} .10 \mathrm{in}$. Vols. vo- nos. Tin progress.

5th year. Jan.-Dec., 1901. Nos. 45- 55 .

6 th ", " - ", 1902. " 56- 67.

7 th " " "- ", $\quad 1903 . \quad$ " $\quad 68-78$.

8th " " " - " 1904. "

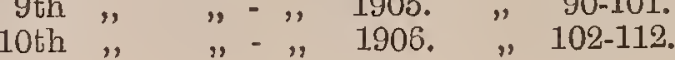

Bulletion insul La mason odon Wartand

$$
\begin{aligned}
& \text { Louny (Bufrum) } \\
& \text { I } 1907 \text { No2 } 3
\end{aligned}
$$


BULLETIN DE L'ACADEMIE DE PHILATElie. (Paris, Academie de Philatélie).

Nos. $1-9$ (1030-

BULLETIN DE LA SOCIETE FRANCAISE DE TIMBROLOGIE. (Paris).

Nos. $1-67$ and 71 (1875-96) (complete set). Privately bound, half

calf, in 4 vols.
BULLETIN DE LASSOCIATION PHILATELIQUE INTER NATIONALE. (Paris, Association, Philatélique Internationale),

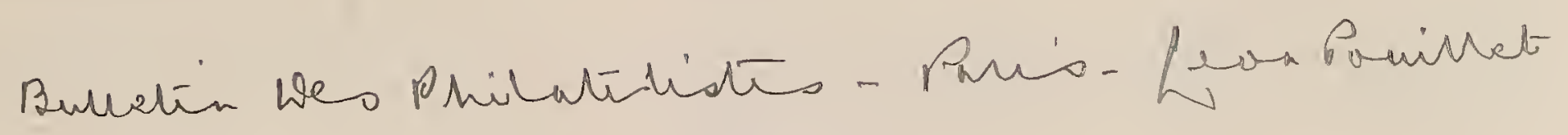

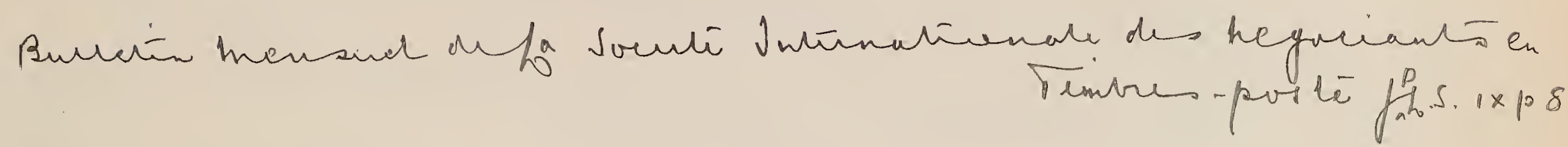


Bulletion of the Fiscal Philaticie Sority:

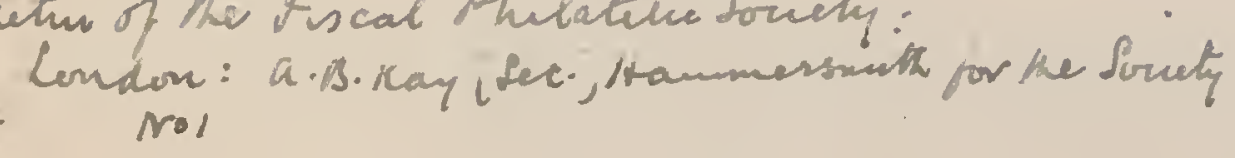

$3160^{3}$ 1908

$$
\begin{aligned}
& \text { rol I. } \operatorname{ros} 1-33 \text { J } \\
& \text { II } 1916-\text { No1. } 19.6-28
\end{aligned}
$$


* * Commencing with no. 57 the journal has been published at Liege. There is a coloured paper wrapper to each number and no. 45 has a supplement "L'Affiche artistique," which is numbered "no. 44". Nos. 63 and 64, 77 and 78, and 94 and 95 were severally published together and there is no number for September, 1901 , or for the same month of 1903 and 1904. "The wrappers of nos. 68 and 69 have " 1902 " instead of "1903," the wrapper of .

BULLETIN IMENSUEL DE LA SOCIETÉ PHILATELIQUE LYONNAISE. Bulletin mensuel de la Société Philatélique Lyonnaise.

S85 Lyon, Société Philatélique Lyonnaise, 1897-98. $8^{\circ} .8 \frac{1}{4}$ in. 20 nos. in 2 vols.

C) 1st year. Mar. 10.-Dec., 1897. Nos. 1-10. a flict un iro

2nd year. Mar. 10.-Dec., 1897. Nos. 1-10.

* * No. 17 js dated "Jüllet-Août" "and no 18 "Septembre-Octo** No. 17 js dated "Juillet-Aont" and no 18 "Septembre-Octo-
bre".

BULLETIN MENSUEL DES NOUVEAUTÉS. Bulletin mensuel des nouveautés. Supplément au catalogue Belin, 1892.

$8^{\circ} .8 \frac{1}{4}$ in. 13 nos. in 2 vols.

( 1 st year. Oct.-Dec., [1892]. Nos. 1-3.

0 2nd "Jan.-Sept. [1893]. "Nos. 1- 4 .

** There is, in addition, a "numéro supplémentaire," without date, which consists of four pages.

[Continued as :]

- Bulletin mensuel des nouveautés. Supplément au catalogue Belin, 1893. Bruxelles, M. Belin, [1893].

$8^{\circ} .8 \frac{1}{4}$ in. 2 nos. in 1 vol.

** Succeeded by the "Revue philatélique Belge"

BUITFTIN MTNSUFT DFS PFTITFS ANNONCRS DU COLIECTIONNEUR. Bulletin mensuel des

$S 85$ petites annonces du collectionneur. Organe universel des collectionneurs de timbres poste, cartes postales illustrées, affiches artistiques, photographies, monnaies, objets anciens, etc., etc. Vienne, France, A. Gay, I899. $8^{\circ} .8 \frac{3}{4}$ in. Nos. 1 -

** Wanting all but nos. 2 and 3, which are dated May and June, 1899.

BULLETIN OF THE NATIONAL PHILATELICAL SOCIETY OF NEW YORK. Bulletin of the National Philatelical Society of New York.

8.9 93 in. Nos. 1-3., Jan., Dec., 1878, Mar., 1879.

New Yorle, I878-79.

* * There is a coloured paper wrapper to each number.

Mis. St. Jour. 11 (2).

BULLETIN OFFICIEL DE L'F́TATINDÉPENDANT DU CONGO. Bulletin officiel de l'état indépendant du Congo. 7e année. No. 1. Janvier, 1891. [Contains "Emission de valeurs postales" and "Création d'une perception à Matadi".]

Bruxelles, I89 I.

$8^{\circ}$. 91 in. pp. 15-17.

Mis. St. Jour. 143 (14).

(.) BULLETIN TIMBROPHILE. Bulletin timbrophile.

$585^{\circ} \odot_{* *}$ in. No. 1, January, 1906.

BULLETIN TRIMESTRIEL DE LA SOCIETÉ LAU. SANNOISE DE TIMBROLOGIE. Bulletin trimestriel de la Société Lausannoise de Timbrologie.

$8^{\circ} .10$ in. 12 nos. in 3 vols.

1st year. Mar., July, Sept., Dec., 1894. Nos. 1- 4.

- 2nd " " " June, " " 1895. " 5- 8 .

$J_{*}^{*}$ Printed by autographic lithography. N้os. 5 and 8 have " $2 \mathrm{e}$ année" omitted. Some lists give an earlier no. 1 with date, Octo-

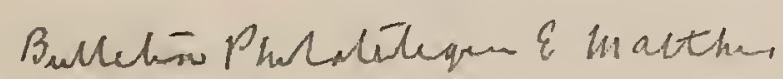

$1907-8$

1908 No $8-18$ fistan

1911

Prato

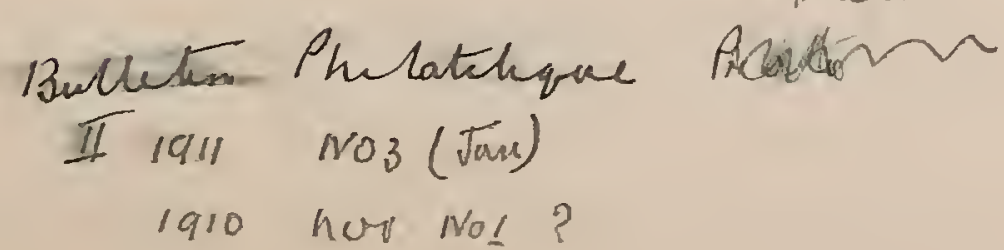

ber, 1889 , but this is a pamphlet with the title "Société Lausannoise de timbrologie. Travaux présentés à la séance du 29 Oct., 89. Par Mr. de Reuterskiöld, $1^{\circ}$. Les filigrammes des timbres de Bavière. $2^{\circ}$. Quelques mots sur les timbres de Norvège, cor non ombré. Lausanne, Octobre 89": printed by autographic lithography. A copy of this is bound up with the twelve numbers of the "Bulletin" and there is another copy bound up in Mis. St. Pamph. 59 (7).

BUND DEUTSCHER UND ÖSTERREICHISCHER PHILATELISTEN - VEREINE. MITTEILUNG. Bund deutscher und österreichischer Philatelisten-Vereine. Mitteilung. Heidelborg, etc., I896-99. Fol. 11 in., $4^{\circ} .11_{2}^{1}$ in., and $8^{\circ} .8 \frac{3}{4}-9$ in. 15 nos. in 4 vols. [1st year.] July 15, Sept. 18, Dec. 15, 1896. Nos. 1- 3. [2nd "] Mar. 23, June 15, [no date], Nov. 7, 1897. " 4- 7. [3rd "] Jan. 16, Mar., May, [no date], 1898. " 8-12. [4th " ] [no date], Feb., May, 1899 . " $13-15$. are octavo. Nos. 1-4 were published at Heidelberg, no. 5 at Karlsruhe and the succeoding numbers at Mannheim. Nos. 6, 11, 12 and 13 are undated. Future numbers were published in the "Vertrauliches Korrespondenz-Blatt philatelistischer Vereine," no. 16 appearing in the number of that journal for September,
Mis. St. Jour. 129 (8)

BUNTE BLÄTTER. Bunte Blätter. Baltimore, Md. No. 43. January 19, 1878. [Cuttings of the article "Aus dem Reiche der Briefmarken," by Albert v. Degen, are mounted in Stamp Scrap-book, vol. IV., pp. 15, 16.]

BUTLER BROS.' STAIMP CIRCULAR. Butler Bros.' stamp circular. Clevedon, Butler Bros., I905-07.

$8^{\circ} .7 \frac{1}{4}$ in. 17 nos. in 2 vols.
Vol. I. Feb. $1905-J a n$. ,

, II. Feb., Mar., to May, Ost., [ ] 1906, June, 1906. Nos. $1-12$. "* No. 10 is wrongly numbered "0" and no. 14, which" is dated "March to May, 1906," bears in error "61"." Wanting nos. 12, 15 16, 17. Thy to is coulect.

BUTLER PHILATELIST. The Butler philatelist.

Butler, Pa., Thomas McKee, I896.

$32^{\circ} .4$ in. Nos. 1-2. June-July, 1896.

Mis. St. Jour. 154 (1)

BUTLERS' PHILATELIC OBSERVER. Butlers' philatelic observer. Canterbury, etc., Butler Bros., I885-86.

$8^{\circ} .8 \frac{1}{4}$ in. 14 nos. in 2 vols.
Vol. I. Mar.-June, Oct., 1885-May, 1886. Nos. 1-12. 1-5. \&-ル "Ir. July, Aug., 1886. Nos. 13-14.0.3

*"* Nos. 1-5 have white paper wrappers, and the remaining numbers Nos. 1-5 have white paper wrappers, and the remaining numbers coloured Nottingham. The wrapper of the number for February, 1886, is
wrongly numbered "10" in place of " $9 "$ ". Mis. St. Jour. 33 (4).

BUYERS' NEWS. The Buyer's' news. Chicago, Ill., C. W. Lehmann, I90I-02.

$16^{\circ} .5$ in. 11 nos. in 2 vols.

Vol. I. Mar., May, July, Sept., Nov., Dec., 1901. Nos. 1-6. "II. Jan., Mar., May, July, Sept., 1902. , 1-5. *"* There is a paper wrapper to each number. Nैo. 1, vol. I., is octavo and measures 9 inches, but is folded and enclosed in a $16^{\circ}$. wrapper measuring 5 inches. No. 4 , vol. I., is numbered in error "No. 1," except on the wrapper which is correct. No. 1, vol. I., has the sub-title "An advertising medium," while the remaining numbers have the sub-title "A Bi-monthly philatelic journal". Mis. St. Jour. 126 (1).

[Continued as :]

The Philatelic world.

Chicago, Ill., C. W. Lehmann, I902-o3.

$16^{\circ} .5$ in. Vols. II.-III. 3 nos.

Vol. II. Noy., 1902. No. 6.

* "* There is a coloured paper wrapper to each number. The title

* " There is a coloured paper wrapper to each number. The title

"The Philatelic world".
Mis. St. Jour. 126 (1a).

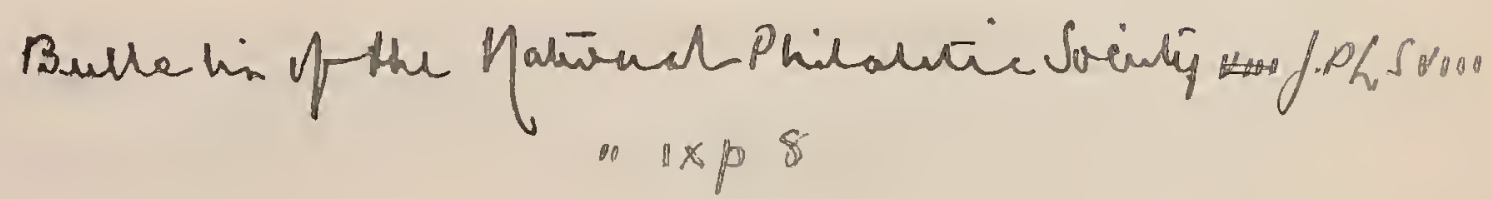


CABINET AND ALBUIM. Cabinet and album. A journal devoted to numismatics and philately.

Chicago, Ill., Wm. A. Fletcher and Co., etc., I89z-93 $8^{\circ} .9$ in. Nos. 1, 1-A, 2-A. March, 1892, Sept., Dec., 1893. * * Printed on rose papel. No. 2-A was published by Fletcher, Rowley and Co. Mis. St. Jour. 46 (1).

CABINET DE NUIMISMATIQUE ET DE TIMBROLOGIE. See Pari I. Michaud et Cie. (v.)

○CADIZ FILATŕfico. Cádiz filatélico. Revista mensual de sellos de correos. Cádiz, Josè Ma. Adam, I893

(1) Fol. 13 in. Nos. 1-3, Aug.-Oct., $1893 . \quad$ Mis. St. Jour. 85 (8)

CÁdIz POSTAL. Cádiz postal. Revista mensual dedicada á los comerciantes y coleccionistas de sellos de correos. Gádiz, Josê Juliá y Fernández, I900-02. $8^{\circ} .10 \frac{1}{4}$ and $8 \frac{1}{4}$ in. 30 nos. in 3 vols.

(3) 1st year. March-Dec., 1900 . Nos. 1-10.

C. 2nd ", Jan. - ", 1901. "11-22.

C. 3rd " "A -Aug., 1902. ", 23-30.

* * Each number has a paper wrapper. Nos. 1-12 are octavo 101 inches and the remaining numbers are octavo 81 inches. Nos. 29 and 30 were published together.

CALIFON PHILATELIST. The Califon philatelist. Califon, N. J., T. G. Kitchin and Co., r892. $48^{\circ} \cdot 3 \frac{3}{4}-3 \frac{1}{2}$ in. Nos. 1-6, July-Dec., 1892.

* * The file of this journal in the library consists of the reprinted set of the six numbers, which was made in March and April, 1893. Mis. St. Jour. $71(4)$

CALIFORNIA COLTECTOR. The California collector. Sacramento, Cal., W. A. Tebowv, I885. S. $77^{3}$ in. No. 1, Sept., 1885.

Mis. St. Jour. 40 (1)

CALIFORNIA COLLECTOR. The California collector. A quarterly journal in the interest of collectors.

San Francisco, Cal., C. F. Rankin, r886.

$8^{\circ} .9$ in. No. 1 , Oct., 1886.

Mis. St. Jour. 23 (8).

CALIFORNIA DEIMOKRAT. California demokrat. October, 13, 1679. [Cuttings of the article "Das Sammeln von Briefmarken," are mounted in Stamp Scrapbook, vol. IV., p. 31.]

CALIFORNIA PHILATELIST. See St. LouIs PHILATELIST.

CALIFORNIA STAMP. The California stamp. A monthly journal devoted to philately. San Francisco, Cal., Charles D. Lowe, r897. $8^{\circ} .8^{3}$ in. Nos. 1-2, Nov.-Dec., 1897. * There is a coloured paper wrapper to each number. Mis. St. Jour. 94 (3).

CALIMAR EXCHANGE. The Calmar exchange. Calmar, Iowa, S. C. Scott, I888. Fol. 22 in. and 16 in. Nos. 1-3, Jan.-March, 1888.

** Only partly philatelic. No. 1 measures 22 inches and nos. 2 and 3,16 inches. Iis. St. Jour. $115(7)$.

CAIMPBELL'S MIONTHLY ADVERTISER. Campbell's monthly advertiser. Calcutta, India, J. Campbell and Co., I896-98. $4^{\circ} .10^{3}$ in. 19 nos. in 2 vols.

Vol. I. Nov., 1896-Oct., 1897. Nos. 1-12.

"Ir. 1897 -May, 1898. " $1-7$

* " Wanting all but no. 1, vol.

CANADA BEAVER. The Canada beaver

Toronto, $R$. Rennie, I876-77.

$8^{\circ} .9$ in. and fol 151 in. Nos. 1-[9], July, 1876-March, 1877.

* Only parbly philatelic. Nos. 1-4 are octavo and the remaining numbers are folio. Nos. 3 and 4 and nos. 7 and 8 were ing numbers are folio. Nos. 3 and " 4 and nos. 7 and 8 were numbered " $10 "$ ". Nos. $1-4$ and the philatelic portions of no: $5-3$ numbered " 10 ". Nound 1 . 4 and the philatelic portions of no: 24 (5), and copies of nos. 6 and 9 are bound up in Mis. St. Jour. 127 (5).

CANADA STAIIP AND COIN JOURNAL. The Canada stamp and coin journal. Halifax, N. S., John R. Findlay, etc., x888-89. $8^{\circ} .83-9$ in. Nos. 1-11, July, 1888-May, 1889. * Nos. 3-11 were published by the Maritime Printing Co. and nos. 4-S have coloured paper wrappers, Mis. St. Jour. 56 (9).

CANADA STAMP JOURNAL. The Canada stamp journal.

** in. No. 1, May, 1892 .

Halifax, N. S., J. R. Findlay, r 892 . jounal is mentioned, as "advertised to be issued," in the "Eastern Philatelist" of F'ebruary, 1892. Wanting.

CANADA STAIMP SHEET. The Canada stamp sheet. Quebec, W. G. L. Paxman, r9oo-or. 8. 9 in. Nos. 1-8, Sept. 15, 1900-Apl. 15, 1901.

[Continued as:]

- The Canada stamp sheet and energy.

Quebec, W. G. L. Paxman, т gог-ог.

$8^{\circ} \cdot 9$ in. Vols. Ir.-IV., 19 nos.

Vol. Ir. Nay 15 -Aug. 15, 1901 . Nos. 9-12.

"IIr. Sept., 15, 1901- " 15, 1902. " 1-12.

"rv. " 15, -Nov. 15, 1902. $\ddot{1}$ 1- 3 .

* " Vol. rrr., no. 9, is dated inside "April 15th, 1902," instead of "May 15th, 1902," but the correct date is given on the front page.

[Continued as :]

- The Canada stamp sheet.

Toronto, etc., C. W. N. Ussher, etc., I903-05.

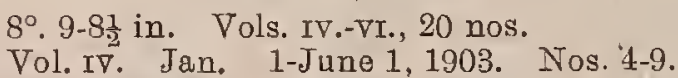

Vol. Iv. Jan. 1-June 1, 1903. Nos. 4-9. 1904. Nos. 1-8, 8, 12

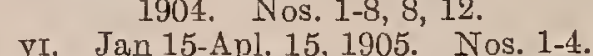

*" vI. Jan 15-Apl. 15, 1905 . Nos. 1-4. * * Nos. 1-4, vol. V., were published at Quebec, by W. G. L. Pax-
man, nos. 5-8 and the second no. 8 of the same volume were published at London, Ontario, and the last tro numbers were published at Quebec, by W. G. L. Paxman. No. 1, vol. V., has the words "Skelolon number "above the title, no. 5, of the same numbers " 8 " to this volume and no numbers 9,10 or 11 .

$$
V / 2 \text { put at Qubere (Pax mun) }
$$




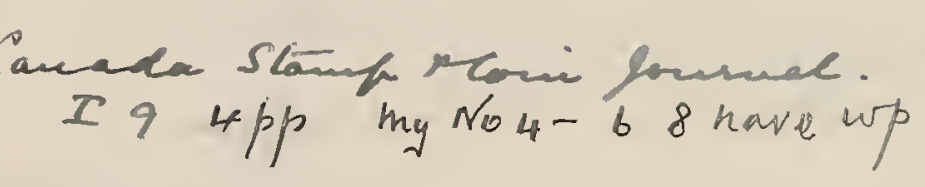

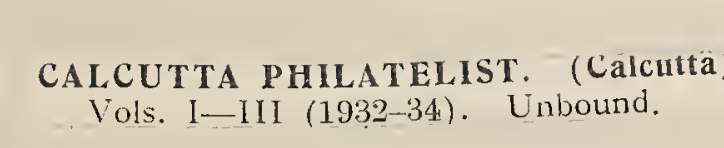




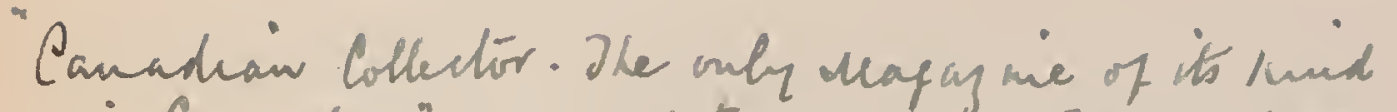

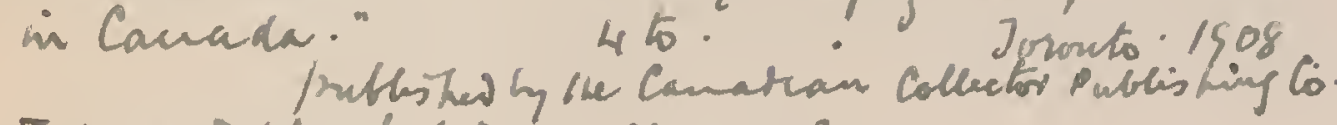
I 1908 soptomber nol. Kor.no?.

Cancuirain Philateri foussal. It Cattermis I. $1888 \mathrm{sec} / 1 \mathrm{ro}$ ] (III)! Canadiàn Philatelist (Tóronto, 1928-29). Vol. 1 (11
parts) 
CANADA STAMP SHEET AND ENERGY. See CANAdA STAMP SHeET.

CANADIAN ADVERTISER. Canadian advertiser. Brantford, Ont., The Canadian Stamp Co., 1806. 16․ 6 in. No. 1, January 18, $1896 . \quad$ Mis. St. Jour. 150 (15).

CANADIAN COLIECTOR. The Canadian collector. Berlin, Ont., Findlay I. Weaver, I 898. Oblong $16^{\circ} .4$ in. No. 1 , Sept., 1898 * The number has a paper wrupper.

Mis. St. Jour. 107 (2) [Continued as :]

The Canadian collector and philatolic Punch. Berlin, Ont., E. A. Giller and Co., I899. Oblong $16^{\circ} .4$ in. Nos. 2-3, Apl.-June, 1899

* There is a coloured paper wrapper to each number. Wanting ** There is a coloured paper wrapper to each number. Wanting
no. 3.
Mis. St. Jour. 107 (2a).

CANADIAN COLLECTOR AND PHILATELIC PUNCH. See Canadian COLLECTOR.

CANADIAN JOURNAL OF PHILATELY. The Canadian journal of philately. A monthly magazine devoted to the science of philately.

Toronto, Henry Ades Fowler, I 893

$8^{\circ} .10$ in. Nos. 1-2, June 1-July 1, 1893.

* * There is a coloured paper wrapper to each number.

o 2 sios Mis. St. Jour. 56 (14)

CANADTAN MONTHLY. The Canadian monthly. Toronto, Ont., [?

], I 904 .

in, Nos. 1.2

CANADIAN PHILATELIC AND CURIO ADVER

TISER. The Canadian philatelic and curio advertiser. Montreal, A. L. Hamilton, I886.

(9) Fol. 12 in. Nos. 1-4, Jan.-Apl., 1886. \% Mis. St. Jour. 5 (1).

CANADIAN PHILATELIC JOURNAL. The Canadian philatelic journal.

Merritton, Ont., The Canadian Publishing Co., I894. $8^{\circ} .8$ in. No. 1, Feb., 1894.

* The number has a coloured paper wrapper. The date of the month "February" is printed on a slip and pasted over the word "January," both in the case of the heading on page 1 and also on the wrapper.

Mis. St. Jour. 56 (4)

CANADIAN PHILATELIC JOURNAL. See CANADIAN philatelist (Nichgara Falls South, Ont.).

CANADIAN PHILATELIC MAGAZINE. The Canadian philatelic magazine.

Halifax, N. S., etc., A. M. Muivhead, etc., I893-г goг. $8^{\circ} .8 \frac{1}{2}-83$ in. and $7 \frac{1}{2}-8 \mathrm{in} .46$ nos. in 7 vols.

Vol. I. Nov., 1893- Apl., 1894. Nos. 1- 5.

II. Sept. 15, 1894- F'eb., 1896. " 1-[12]

" III. Mar., 1896- " ", 1897. " 1-12.

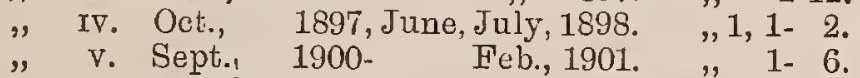

"VI. March- Aug., 1901. " " $1-6$.

* VII. Sept.- Oct. ", " 1- 2.

* Commencing witl no. 1, vol. II., the journal was published at Toronto; nos. 1-3 of this volume by W. S. Weatherston, no. 4 by G. A. Lowe, no. 5 by Walter McMahon and all subsequent numbers by Wm. R. Adams. The numbers of vols. VI. and VII. measure $7 \frac{1}{2}-8$ inches. No. 5 of vol. 1 is dated "March-April, 1894". There are no numbers for December, 1894, February, 1895, and Apriluly, 1895, and vol. IV. has two numbers " 1 ," one dated "October, 1897, " the other "June, 1898 ". There is a paper wrapper to ea sh number with the exception of nos. 1-3, vol. II., and no. 2 , vol. III. Tos, 10-12, vol. II., are numbered 22-24. The number for January, 1896, has a supplement "catalogue of stamps the property of arious parties to be sold by auction in Toronto ... March 5 th, 1896." [by 'T. S. Clark.] Wanting vol. v. nos. $2,5,6$, vI. no. 6 , vit. no. 1 .

CANADIAN PHILATELIC REVIEW. See BoYs' owN PHILATELIST.
CANADIAN PHILATELIC WEFIKLY. The Canadian () philatelic weekly.

London, Ont., I. M. Staebler, I 894.

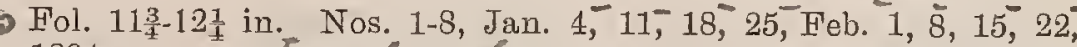
$1894 . \quad$ coned hafor.

* Amalgamated with the "Canadian philatelist" of London, Ont.

CANADIAN PHILATELIC WFEKLY. The Canadian - philatelic weekly.

Toronto, Canadian Philatelic Weelcly Co., ז898-99. $8^{\circ} .10$ in. 5 nos. in 2 vols.

OVol. I. Nov. 12, 19, 26, Dec. 10, 1898. Nos. 1-4.

(5)" II. May $\frac{1}{1899}$. No. 1 .

Mis. St. Jour. $151(7)$

CANADIAN PHILATELIC WEEKLY. See BoYs' ow PHILATELIST.

CANADIAN PHILATELIST. The Canadian philatelist. Quebec, Birt, Williams and Co., I872.

$8^{\circ} .9 \frac{1}{2}$ in. Nos. 1-3, Jan.-Mar., 1872.

* * There is a supplement of four pages to no. 3 headed "(Circular)" and dated "April, 1872". Succeeded by the following.

CANADIAN PHILATELIST. The Canadian philatelist. Quebec, The International Stamp Co., I872-73.

$3^{\circ} .9 \frac{1}{2}$ in. Nos. 1-4, Sept. 1, Oct. 1, Dec. 1, 1872, Jan. 1, 1873.

** There is a supplement of two pages, printed on one side only, to no. 3, and nos. 1-3 have supplemental slip: Bound up with the journal is a copy of the prospectus, dated July, 1872, and also a copy of a circular, dated March 11, 1873, announcing the discontinuance of the magazine.

CANADIAN PHILATELIST. The Canadian philatelist. Whitby, Ont., I. F. Barker, r884-85.

$8^{\circ} .9$ in. Nos. 1-5, December, 1884-April, 1885.

* * Nos. 4 and 5 have coloured paper wrappers and there is a supplement of (2) pages to no. 3. Mis. St. Jour. 24 (18)

[Continued as :-]

-. The Canadian philatelist and numismatist.

$8^{\circ} .9$ in. Nos. 6-7, May-June, 1885.

Whitby, Ont., L. F. Barker, 1885 .

Mis. St. Jour. 24 (18a).

CANADIAN PHILATELIST. The Canadian philatelist. Toronto, G. A. Lowe, I886.

$8^{\circ} .9 \frac{1}{4}$ in. No. 1 , Sept., 1886 per.

Mis. St. Jour. 16 (4).

CANADIAN PHILATELIST. The Canadian philatelist. Niagara Falls South, Ont., The Canadian Philatelic Co., etc., I 888 .

$8^{\circ} .91-9$ in. Nos. 1-6, Jan.-June, 1888

** No. 6 was published by H. E. French, although it has "Published by the Canadian Philatelic Company" beneath the title. Nos. 1 and 2 are printed on buff paper and have coloured paper wrappers." No. 4 for April, is wrongly numbered " 5 "

[Continued as :] is. St. Jour. $56(10)$.

philatelic journal.

The Canadian philatelic journal.
St. Catharines, Ont., H. E. French, r888.
ol. 121 in. Vol. II. No. 1. Whole no. 7, Dec., 1888.

* * Amalgamated with the "Niagara Falls philatelist".

Mis. St. Jour. 56 (10a).

CANADIAN PHILATELIST. The Canadian philatelist. London, Ont., I. M. Staebler, I 89 г-96.

$S^{\circ} .9 \frac{1}{2}$ in. 38 nos. in 4 vols

Vol. I. Apl. 15, July 15, Oct. 15, 1891-July 15, 1892. Nos. 1-12.

" II. Sept. 25, 1892-Aug. 1, 1893. Nos. 13-24.

" III. "\#6. 1, 1893-Mar., 1894, Aug. 1-Dec. 1, 1894. Nos. 25-

IV. Apl. 10-May 10, 1896. Nos. 37, 38.

* " There is a paper wrapper to each number with the exception of nos. 1-4 and 37, 38. No. 17 is dated " 1892 " instead of "1893" but the correct year is given on the wrapper, and no. 38 has "Vol I. "in place of "Vol. IV." Amalgamated with the "Collector" New Chester, Pa., in March, 1895, with the "Oollector," Minneapolis, Minn., in September, 1895, and then restarted in April, 1896. 


\section{CANADIAN}

CANADIAN PHILATELIST AND NUMISIMATIST See Canadian phicateisist (Whitby, Ont.).

CANADIAN WEEKLY STAMP NEWS. The Canadian weekly stamp news.

Toronto, Wm. R. Adams, etc., 1896-97. $4^{\circ} .12$ in. and $8^{\circ} .9 \mathrm{in} .20$ nos. in 2 vols

Vol. I. Aug. 27-Dec. 24, 1896. Nos. 1-10, 12-18.

○ ". II. May 17-June 1, $1897 . \quad " 1-3$.

* The three numbers of vol. 1 . Were published by the Canadian feenly stee peeption of no. 11, which never appeared, are octavo, while all the other
numbers are quarto. No. 15 is wrongly numbered " no. 14 ".J.
Mis. St. Jour. 98 (8).

CANADIAN YOUTH. The Canadian youth. Toronto, Ont., [?

], I904-05.

8. 9-83 in. Nos. 1-5, November, 1904-March, 1905.

* * Only partly philatelic. Nos. 2 and 3 were published together. Amalgamated with the "Dominion Philatelist" May, 1905. Wanting nos. 1,4 .

CANADIANA. Canadiana. A monthly devoted to Canadian papers and stamps.

Mariahilf, Assa, etc., O. H. Tielemans, I902. Fol. 12 in. Nos. 1-12, January-December, 1902 * * Nos. 8 and 9 were published together and no. 12 was published at Winnnipeg. Wanting nos. 8, 9. =any- fort

Meinily is heach.

CAPITAL CITY PHILATELIST. Capital City philatelist.

Augusta, Me., L. M. Hamlen, I884-86. $8^{\circ} .7 \frac{1}{\text { in. and }} 9$ in. 22 nos. in 2 vols.

Vol. I. Dec., 1884-Nov., 1885. Nos. 1-12.

* "No. 1 is 7 18 inches and the remainder are 9 inches. Each number has a coloured paper' wrapper with the exception of nos. 1,2 , and after no. 1 the word "The" precedes the title. Amalgemated with the "Philatelic herald," Portland, Me., in October 1886 .

CAPITAL TRIBUNE. Capital tribune.

Washington, D. C., E. H. Smith, I887. $8^{\circ} .9 \frac{1}{2}$ in. No. 1, November, 1887

Mis. St. Jour. 117 (17)

CAPITOL PHILATELIST. The Capitol philatelist.

Springfield, Ill., The Capitol Philatelist Pub. Co., I893-94.

$8^{\circ} .8 \frac{1}{2}$ in. and $16^{\circ} .6$ in. Nos. 1-5, November, 1853-March, 1894. are octavo and nos. -5 are $16^{\circ}$,

CAFTAIN. The Captain. A magazine for boys and "old boys". London, George Newnes, Limited, I899$8^{\circ} .93$ in. nos. in vols. In progress.

Vol. I. April -Sept., 1899. Nos. 1- 6

"II. Oct., 1899-Mar., 1900. " 7-12.

"II. April 190-Sept., 1900. ", $\quad$ II-18.

" T. $\quad$ v. April -Sept., 1901. " " $25-30$.

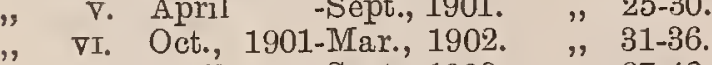

" VII. April -Sept., 1902. " "37-42.

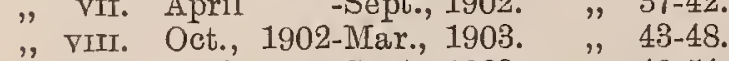

" IX. April -Sept., 1903. ", 49-54.

" IX. April 1903-Mapt., 1901. "

" XI. April -Sept., 1904. " " 61-66.

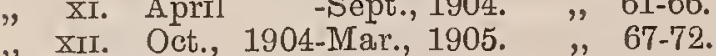

" XIII. April -Sept., 1905. " " 73-78.

"XIII. April 190 -Sept., $1905 . \quad$ "

", Xv. April -Sept., $1906 . \quad$ " $85-90$

"XVI. Oct., 1906-Mar., 1907. " 91-96. ** Each number contains an article on stamp collecting, those

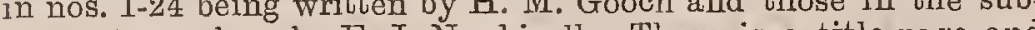
sequent numbers by $\mathrm{E}$. J. Nankivell. There is a title-page and
an index for each volume and a paper wrapper for each number.

CARACAS FILATELICO. Caracas filatelico. Revista filatelica Venezolana.

Caracas, Tomas de Arredondo y B., I894-95.

๑ $8^{\circ} .9 \frac{1}{2}$ in. Nos. 1-11, Apl. 21, 1894-Feb., 1895.

** Nos 4 and 5 and nos. $/ 9$ and 10 were severally published together under the respective dates" " 21 de agosto de 1894 " and " $1{ }^{\circ}$ de enero de 1895 " and the last has " número 9 y 11 " in place of "9 y $10 "$ ".

La Carucature Phitateleque pas le Sagittaire

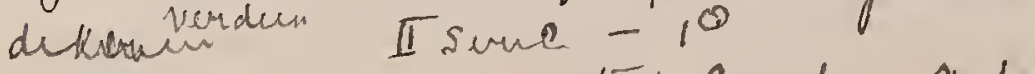

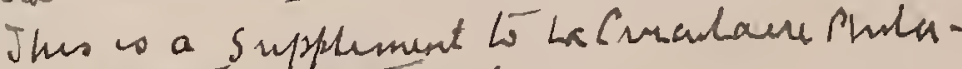

Letepar No75 $1909 \sqrt{a m v e r}$

carctas Portal Contibur srazal

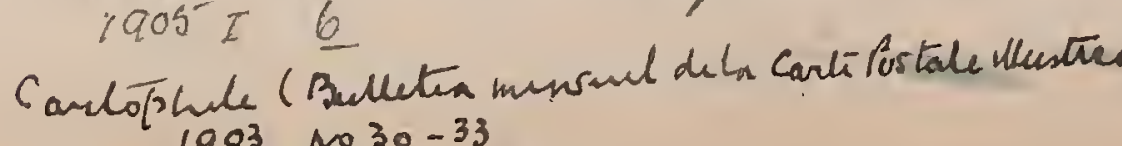

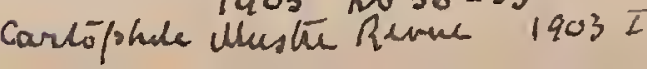

CARD AND STAMP CIRCULAR 492

CARD AND STAIMP CIRCULAR. The Card and stamp circular. Published occasionally, and circulated gratuiously, by F. H. Pinkham, Newmarket, N. H.

Newmarket, N. H., F. H. Pinkham, [1876]. $8^{\circ} .97$ in. [No. $\left.1,1876.\right]$

* * The contents consist entirely of advertisements.

Mis. St. Jour. 18 (11)

CARSON PHILATELIST. The Carson philatelist.

St. Louis, Mo., The Carson Stamp Co., I885-86.

$8^{\circ} \cdot 93-10^{3}$ in. 14 nos. in 2 vols.

Vol. I. Sept., 1885-Aug., 1886. Nos. 1-12

Q "* II. \#" 1886-Dec., $1886 . \quad$ "1, 14 .

*"* Nos. 1-5 are octavo $9 \frac{1}{1}$ inches and the remaining nos. are $10 \frac{1}{4}$ inches. Nos. 4-9 were published by C. H. Mekeel, and no. 5 has a coloured paper wrapper.

CARTE POSTALE. La Carte postale.

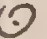
Paris, A. Schoeller, 1890-93.

$4^{\circ} \cdot 10 \frac{3}{x}$ in. and $8^{\circ} \cdot 10 \frac{3}{i}$ in. 45 nos. in 2 vols.

CVol. I. Jan., 1890-Dec., 1892 . Nos. 1-36.

$\Theta_{*}$ "II. II. "Vol. I. is quarto and" vol. II. octavo. 37 Vol. I. was printed by an that autographic process and there is a title-page and an index to this volume. Nos. 25 and 26 were reprinted in September, 1892. Nos. $37-45$ have paper wrappers. $W$ There is an extra leaf of illustrations to no. 41 .

CARTO-PHILATELIQUE-JOURNAL. Le Carto-philatélique-journal.

Paris, Carto-Philatélique-Club, I904.

$8^{\circ} .91$ in. Nos. 1-4, June-September, 1904.
$* *$ Nos. 3 and 4 were published together and there is a coloured paper wrapper to each number. Wanting no. 2

[Continued as:]

Le Carto-Philatélique-Journal et la Revue Philocartiste Internationale réunis.

Paris, Carto-Philatélique-Club, I904-05. S 8B $8^{\circ} .10$ in. 3 nos. in 2 vols.

1 st year. Nov. 1-Dec., 1904. Nos. 5,6

1905. No. 7

The "Revue philocartiste internationale" was non-philatelic. Wanting no. 6 .

CARTO-PHILATELIQUE-JOURNAL ET LA REVUE $6 / 906.2 .1 \cdot$ hes PHILOCARTISTF INTERNATIONALE RE- stempe arte UNIS. See Carto-Philatélique-Journat.

CARTOLINA POSTALE ILLUSTRATA. See FranCoBOLLO.

CASKET. The Casket. A weekly journal.

Toronto, $[?], \mathrm{x} 884$

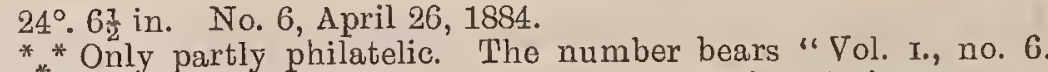
"*." Only partly philatelic. " of the publisher is not given

Mis. St. Jour. 148 (3).

CASSELL'S ILLUSTRATED FAIMILY PAPER. CaS-

6. sell's illustrated family paper. [Contains a number of articles entitled "Postage stamps".]

London, Cassell, Petter and Galpin, I862-67. $4^{\circ} \cdot 103$ in. OFirst series of articles. Nos. 1-36, July 26, Aug. $\frac{2}{9} 9$, $16,23,30$, Sept. $6,13,20,27$, Oct. $\frac{4}{10}$ Nov. $\frac{8}{0}, 15$, Dec. $\frac{13}{21}, 20,1862$ Jan. 10,17 , Aug. $\frac{29}{5}$, Sept. $\frac{5}{18} 12, \frac{19}{26}, 26$, Oct. $10,17,24,31$, Nov.

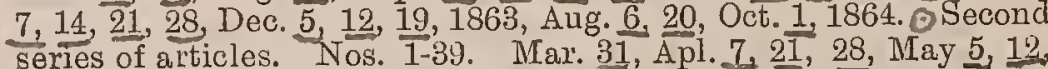
19,26 , June $2,9,16,23,30$, July 7 , 14, Aug. $1,1 \overline{1}, 1 \overline{18}$, 25 , Sept. 1

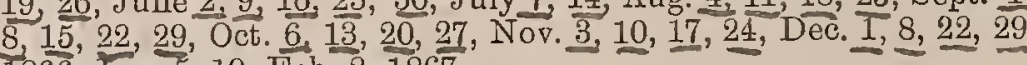
$18 \overline{6}, \sqrt{a n} . \underline{5}, 19, \mathrm{Feb} \cdot 2,1867$.

**" These articles are founded upon a series of papers that were puivlished in "Le Magasin pittoresque," Paris, 1862-66. There is also a further article "Postage currency of the United States" in the number for June 13,1863 . $V$

CAUSERIE PHILATf́LIQUE. Causerie philatélique. Paris, E. Matthey, I906-07.

4․ 11 in. [Nos. 1-7], April 4, May 3, June 7, Nov. 5, Dec. 4, Jan. 3, Feb. 4 , 1907.

* * Produced by a type-writer on one side of the paper only. Probably other numbers exist. . Succeeded by the "Bulletin philatélique ".

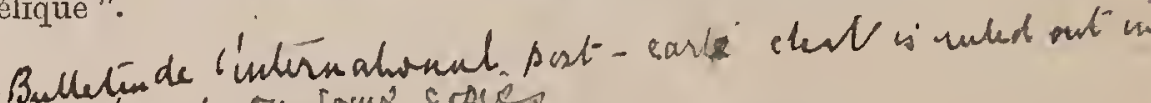
a Carte postale Mus tré
(=pretures porta pands paper)
Pams
1899

La Cartotena postale Mus veata Gussoni-melar

1898 I $1 / 23456789101182$

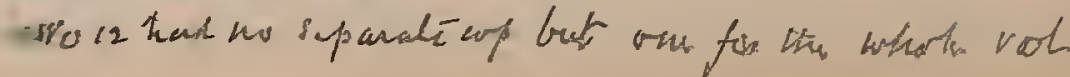


Canadian Stamp Gollector (Brockville, 1921-22). Vol. 2 2/f complete, unbound. in 12 parts

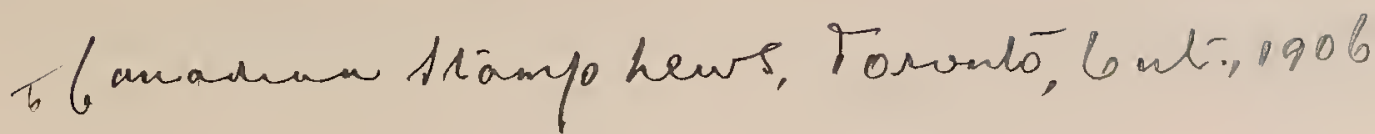
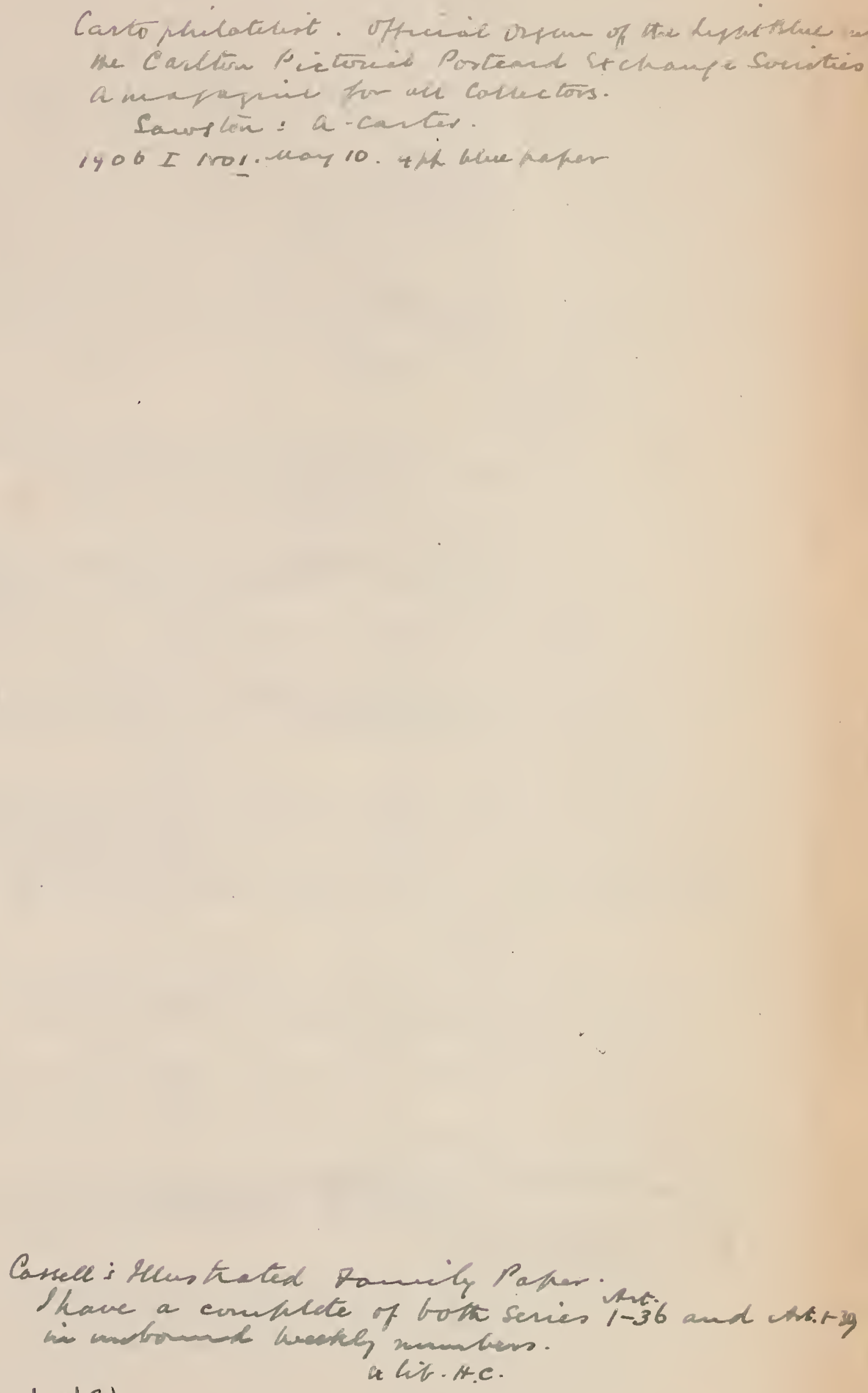

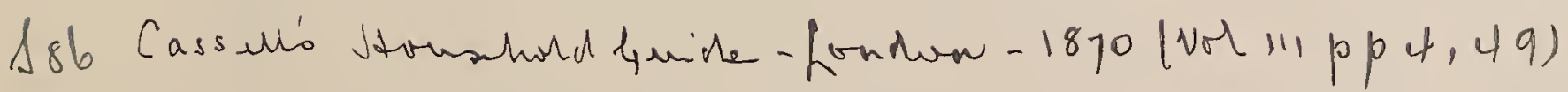


Coylon Collectors Torrespontents' foumal Sro.

O I.1.2. 1915 Out.1916 tan.

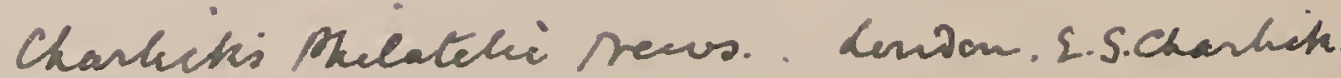
45 .

$1919 / 2 \frac{T}{20}$

Charlichis monthly circulas

1910

1911

1912 
493

\section{CAXTON}

CAXTON. The Caxton. 8.9 $97-9 \frac{1}{2}$ in. 10 nos. in 2 vols.

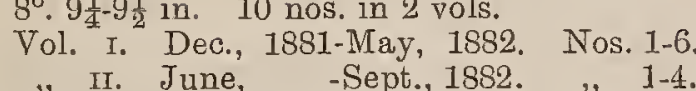
* "* Ir. June, -Sept., 1882. together and there is a supplement of one leaf to no. 2 , vol. I. Mis, St. Jour. 10 (4).

๑ CEARÁ PHILATELICO. Ceará philatelico. 1897.

Ceará, Fortaleza, Brazil, Julio Fabricio Silva e Ca.,

(f) $8^{\circ} .11$ in. No. 1, June, 1897.

${ }_{*}^{*}$ The number has a coloured paper wrapper.

Mis. St. Jour. 130 (12).

CEDAR COUNTY NONPAREIL. The Cedar County nonpareil. St. Helena, Texas, May 3, 1833. [Cuttings of the article "A high-priced stamp," giring an account of the find and purchase of seven "Blattleborc" stamps from the original engraver of the plate, are mounted in Stamp Scrap Book, vol. iv., pp. 93, 94.]

CENTRAL EXCHANGE. The Central exchange. Winchester, Ind., Herbert I. Watts, 1893. $8^{\circ} .83$ in. No. 1, October, 1898 **" Only partly philatelic.

Mis. St. Jour. 117 (14)

CENTRAL PHILATFLIST. The Central philatelist. [Brooklyn, N. Y.], Wm. D. Nichols, I886.

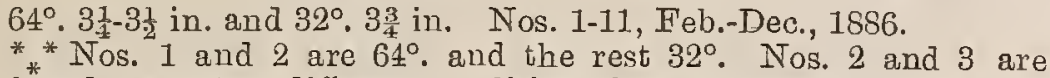
found upon two different qualities of paper, one like that employed for no. 1, the other corresponding to the paper used for nos. 4-11. No. 2 on the latter paper is $32^{\circ}$.
Mis. St. Jour. $71(5)$.

CENTRAL PHILATELIST. The Central philatelist. A monthly journal of philately.

Belvidere, Ill., The Central Philatelic Publishing Co., 1890.

$8^{\circ} .83-8$ in. Nos. 1-7, Feb., Mar., Mar. 15, Apl., May, June, Dec., 1890.

** Nos. 3-7 are rather smaller than nos. 1 and 2. The two num** Nos. 3-7 are rather smaller than nos. 1 and 2 . The two num-
bers last mentioned have coloured paper wrappers. Mis. St. Jour. 46 (6)

\section{ČESKÝ FILATELISTA. Český Filatelista.}

Praha, Klub českých filatelestio, I896-

$8^{\circ} .91$ in. nos. in vols. In progress.
1st year. Feb. 25-Dec. 25,1896 . Nos. 1-11.

2nd "Jan. 25- ", 25, 1897 . " 1-11.

3rd " " , 25- ", 25, $1898 . \quad$ " $1-11$.

4th " " " 25- ", 25, $1899 . \quad " \quad 1-11$.

6th " Jab. 15- " $15,1900 . \quad " 1-11$

7th " Jan. 15-" $15,1901 ., " 1-11$.

8th " " " 15-", 15, 1903. " " $1-11$.

I0th " " $15-" 15,1904 . \quad " 1-11$

11 th " " " 15- ", 15, 1906. "

* * There is " title-page and an index to each ycar commencing and 2 of the fifth and 2 of the severaily published together, withl the dat:s " 25 prosince [December], 1896," "15 unora [February], 1900," and " 15 dubna [April], There is no number for the month of is dated in error " 1896 ". but there are supplements of illustrations to nos. 25 and 8 years, first year, to no 2 of the fourth year, two to 30 . 3 of the ser the year and one to no. 5 of the eighth year. Wanting vol. XI., nos. $8,9,10$ and title-page and index to vol. vI.

CHADWICK. The Chadwick.

Worcester, Mass., Chas. F. Harris, I9o2. $8^{\circ} .8 \frac{1}{2}$ in. Nos. 1-3, May-July, 1902.

** Only partly philatclic. Nus. 2 and 3,were published together Wanting no. 1 .

CHAIR CITY COLLECTOR AND MONTHLY ECHO

See Chair city stamp COLLECTOR.

\section{CHAIR CITY .STAMP COLLECTIOR 494}

CHAIR CITY STAMP COLLECTOR. Chair City stamp collector.

West Gardner, Mass., S. B. Smith, I884. 8․ 8妾 in. Nos. 1-2, June 1-July 1, 1884

Mis. St. Jour. 137 (7).

[Continued as :]

The Chair City collector and monthly echo.

West Gardner, Mass., S. B. Smith, I884-85. Fol. 12 in. and $8^{\circ} .8 \frac{3}{2}$ in. Nos. $3-5$, Oct. 15, Dec. , 1884, Feb. 1885.

** Only partly plilatalic. Nos. 3 and are folio and no. 5 is octavo, with a coloured paper wrapper. The last has the article "The" omitted from the title. Wanting no. 4 .

Mis. St. Jour. 137 (7a).

CHAMBERS'S JOURNAL. Chambers's journal. No. 492. June 6, 1863. [Contains an article "The Stamp mania".]

8. $9 \frac{3}{4}$ in. pp. $353-356$.

London, E.C., W. and R. Chambers, 1863 .

Fifth series. Vol. vr. No. 279, May 4, 1889. [Contains an article "Recent sales of postage stamps".] London, E.C., W. and R. Chambers, I889. $S^{\circ} .10 \frac{1}{1}$ in. pp. 287, 288. Coloured paper wrapper.

Mis. St. Pamph. 64 (7).

CHAMPION EXCHANGE AND MONTHLY AD VERTISER. The Champion exchange and monthly advertiser.

Matfield Green, Brenchley, Kent, etc., W. Morley, I879-80.

$8^{\circ} .7 \frac{1}{2}$ in. Nos. 1-3, December 14, 1879-February 14, 1880

* Only partly philatelic. Nos. 2 and 3 were published at Horsmonden, Staplehurst, Kent.

[Continued as :]

- The Champion exchange and monthly advertiser; and journàl of philatelic literature.

Horsmonden, Staplehurst, Kent, W. Morley, I880. $8^{\circ} .7 \frac{1}{2}$ in. and 10 in. Nos. 4, 5 , March 14, April 14, 1880. *** Only partly philatelic. No. 4 measures $7 \frac{1}{2}$ inches and no. 5 ,
IOI inc. St. Jour. 9 (3a).

$$
\text { [Continued as :] }
$$

- The Champion exchange, the arcade, and foreign stamp gazette : a monthly journal for stamp collectors and advertisers.

Horsmonden, Staplehurst, Kent, W. Morley, г880. $8^{\circ} .10$ in. No, 6, May 14, 1880

* Amalgamated with the "Philatelist's gazette," no. 18.

Mis. St. Jour. 9 (3b).

CHAMPION EXCHANGE AND MONTHLY AD VERTISER AND JOURNAL OF PHILATELIC LITERATURE. See Champion exchange and MONTHLY ADVERTISER.

CHAMIPION TXCHANGE, THE ARCADE AND FOREIGN STAMP GAZHTTE. See Champion EXCHANGE AND MONTHLY ADVERTISER.

CHARITON GAZETTE. See GazetTe.

CHARIVARI. Le Charivari. Quarante-quatrième année. Dimanche, 26 Décembre, 1875 [Contains a caricature of the French postage stamp of 1876.]

Fol. 171 in. p. (3) Paris, Pierre Véron, I 875

CHARLESTON PHILATELIST. The Charleston philatelist. Charleston, S. C., G. J. Ininn, Jr., I887-89. $8^{\circ} .9$ in. 6 nos. in 3 vols.

Vol. I. Oct., 1887, Jan., Apl. 1, July 1, 1888. Nos. 1-4. (1) II. Oct. 1, 1888 . No. 1.

*"* All except the first two numbers have coloured paper wrappers.
Mis. St. Jour. 22 (2).

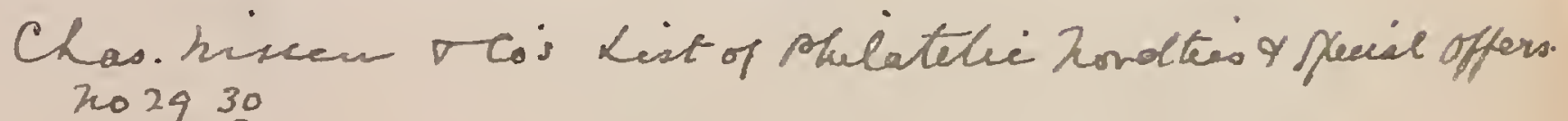


CHAS. PURDOIM MONTHLY CIRCULAR. Chas. Purdom monthly circular.

London, S.W., C. Purdom, I899.

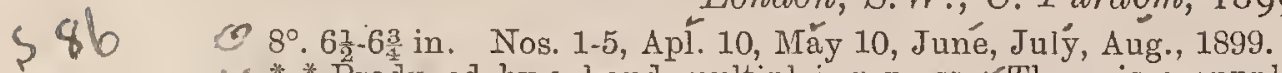

** Produced by a hand multiplying press. "There is a supplement "Philatelic publications" (8) pages to no. 3, and second $\checkmark$ editions of nos. 1 and 2 were issued with the date " 4 th January,

1901 ". Wanting the first editions of nos. 1 and 2.
Mis. St. Jour. 81 (5). [Continued as :]

The Monthly philatelic circular.

London, S.W., C. Purdom, I 899-1900.

2 8 . 7 in. Nos. 6-12, Sepť. 5, Oot. 5 , Nov. 5, Déc. 5, 1899, Jan. 5 , Feb.5, Mar. 5, 1900

$\checkmark * *$ Produced, like its predecessor, by a hand multiplying press.

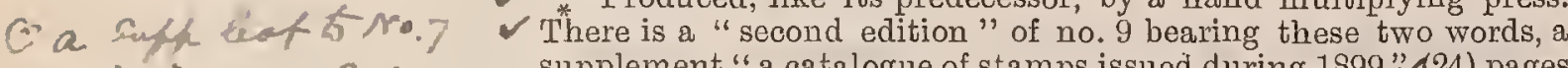

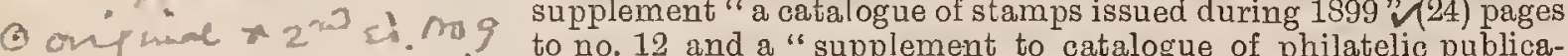

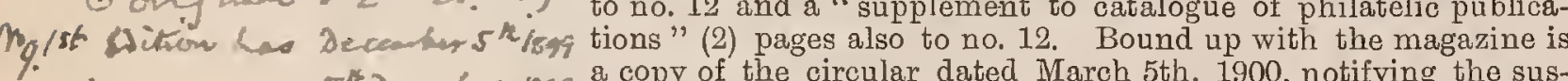

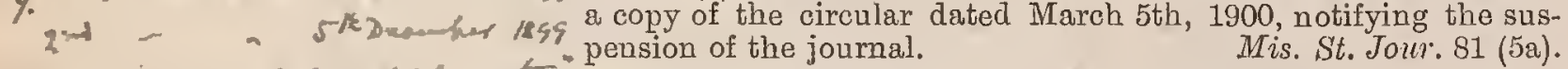

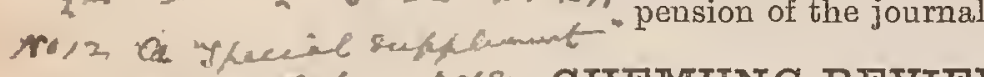

Elmira, N. Y., Chemung Publishing Co., I885-86. $8^{\circ} .7 \frac{1}{2}-8 \frac{3}{4}$ in. Nos. 1-11, Dec., 1885-Nov., 1886.

* Only partly philatelic. There is a coloured paper wrapper to each number, there is no number for January, 1886 and nos. 7 and 8 and 9 and 10 were severally published together.

Mis. St. Jour. 146 (1).

CHESTNUT BURR. The Chestnut burr.

586 Spruce Creek, Pa., [?

], I904.

in. Nos. 1-3.

* Only partly philatelic. Wanting all nos.

CHICAGO HERALD. Chicago herald. Chicago, Ill March 27, 1891. [Cuttings of the article "Fad becomes a trade. Stamp collecting is an industry," are mounted in Stamp Scrap Book, vol. vi., pp. 189-192.]

CHICAGO JUNIOR. The Chicago junior. A monthly philatelic publication devoted to the interests of the juniors.

Chicago, Ill., $R, W$. Cobbe, I 900 . $16^{\circ} .6 \frac{1}{2}-6$ in. Nos. 1-4, May-August, 1900.

** Nos. 1 and 2 measure $6 \frac{1}{2}$ inches and no. 8 measures 6 inches. Wanting no. 4 . Mis. St. Jour. 123 (1)

CHICAGO PHILATELIC. The Chicago philatelic.

$16^{\circ} .6$ in. No. 1, April, 1887 Chicago, Ill., J. E. Hartman, I887. A monthly stamp journal. Chicago, Ill., W. Leckie and Co., I877.

$8^{\circ} .8 \frac{1}{2}$ in. No. 1, June, 1877.

Mis. St. Jour. 28 (13).

CHICAGO PHILATELIST. The Chicago philatelist.

Chicago, Ill., The Oakley Publishing Co., 1893. $8^{\circ} .9 \frac{3}{2}$ in. Nos. 1-7, Jan. 15, Feb. 15, Mar. 15, May 20, June 26, Jul 26, Sept. 25,1893

(oloured paper wrapper to each number $s$ The wrapper of no. 1 is dated "January 15th, 1893," but on the journgl itself the date is wrongly given as "January 5 th, 1883 ".

Mis. St. Jour. 60 (5).

(-) CHICAGO PHILATELIST. The Chicago philatelist A magazine devoted to the interests of stamp collectors. Chicago, Ill., Trask and M' Kay, I899.

(.) $8^{\circ} .9$ in. No. 1, September, 1899.

** The number has a paper wrapper. $\checkmark$ Mis. St. Jour. 135 (15).

CHICAGO PHILATELIST. The Chicago philatelist. Co., I 902 .

Chicago, Ill., The Chas. E. Birr Stamp and Pub.

S०. 9 in. No. 1, July 1,1902

Mis. St. Jour. 123 (8).

CHICAGO STAMP NEWS. Chicago stamp news.

Chicago, Ill., The S. B. Bradt Co., I89I-9z.

$8^{\circ} .8 \frac{1}{2}$ in. 14 nos. in 2 vols.

Vol. I. Nov., 1891-Oct., 1892. Nos. 1-12.

(II.)

Mis. St. Jour. 64 (9).
CHICAGO STAMP NEWS. The Chicago stamp news. Chicago, Ill., L. R. Davis, r 905-06. Fol. 12 in. and $8^{\circ} .9$ in. Nos. 1-9, Angust 15-December, 15, 1905, April-June, November, 1906.

* * Nos. 1-5 are folio and the subsequent numbers are octavo.

Mis. St. Jour. 151 (13).

\section{CHILE FILATELICO. Chile filatélico.}

Santiago, Chile, C. Gutierrez Brieba, Igог. Fol. $15 \frac{1}{1}$ in. and $8^{\circ} .103$ in. Nos. 1-4, Sept. 14-Dec. 14, 1901. ** No. 1 is folio and the other numbers are octavo. $v$ No. 4 has a coloured paper wrapper. Mis. St. Jour. 127 (3).

CHRISTIAN EXCHANGE. The Christian exchange. No. 4, November, 1904. [Contains an article "Notes on stamp collecting ".]

$8^{\circ} .9$ in. p. 2

Cirencester, L. C. T. Gardiner, 1904.\$86 $8^{\circ} .9$ in. p. 2 .
** The number has a coloured paper wrapper.

Mis. St. Jour. 141 (1).

CHRONICLE. The Chronicle.

Philadelphia, Pa., Jay Good, I885-86. 8. 88 in, Nos. 1-3, July, 1885, [? ] July, 1886.
*. Wanting no. 2.

CHUM. The Chum. Sedalia, Mo., [? ], г903. in. Vol. II. no. 6

* * Only partly philatelic. Wanting.

CHUIMS. Chums. Vol. v., no. 218, November 11, 1896, and vol. Ix., July 17, 1901. No. 462. [Contain articles "An afternoon with Mr. M. P. Castle" and "Celebrities shown on postage stamps. The world's miniature portrait gallery. Little known countries-and others," each by M. Z. Kuttner.]

London, E.C., Cassell and Co., Limited, I896-I gor. Fol. $12 \frac{3}{4}$ in. pp. 189 and 759.

Mis. St. Pamph. 63 (11).

CIRCULAIRE DES COLLECTIONNEURS. La Circulaire des collectionneurs.

Roanne, France, E. Deforterey, I 905.

$8^{\circ} .8 \frac{7}{2}$ in. No. 1, May 15, 1905.

** The number consists of but one leaf and the contents are only partly philatelic.

CIRCULAIRE FISCALE CENTENNALE DE J. GOUTIER. Circulaire fiscale centennale de $J$. Goutier, 1789-1889.

$4^{\circ} .11 \frac{1}{4}$ in. [Nos. 1, 2], 1889.

** The contents consist entirely of advertisements. One of the numbers was given as a supplement to the "Paris-Poste". Mis. St. Jour. 82 (5a). " " " $107(18)$

CIRCULAIRE INTER. Circulaire inter.

Poitiers, Camille Caillaud Fils, r905.

* *n. Nos. 1- party partly phiatelic. No. 6 is dated November, 1905 Amalgamated with no. 5 , of the third year (April 1, 1906), of the "Petites annonces cartophiles et philatéliques". Wanting all nos.

CIRCULAIRE IMENSUELIT DE LA LIGUE D' ACHAT TIMBRES POUR COLLECTIONS. See Circulatre Mensuele de la Ligue d'Echange TimBRES POUR COLLECTIONS.

CIRCULAIRE MENSUELLE DE LA LIGUE D ACHAT FT D'ECHANGE TIMBRES POUR COLLECTIONS. See Circulaire Mensuelle de ia ligue d'Echange 'Timbres pour Collections.

CIRCULATRE IMENSUELLE DE LA LIGUE D' ECHANGE TIMBRES POUR COLLECTIONS. Circulaire mensuelle de la Ligue d'Echange Timbres pour Collections.

Spa, Belgique, Estelle Misson, 1899.

$4^{\circ} .11$ in. Nos. 1-8, [? May]-December 20, 1899

$4^{*} *$ There is a supplement of two pages to no. 8 . Wanting nos. 1 $2,3,4,5$.

$$
\begin{aligned}
& \text { La Cirmbare a Passontame Pergreux } \\
& \text { ? पea No12? } \\
& \text { (c) }
\end{aligned}
$$




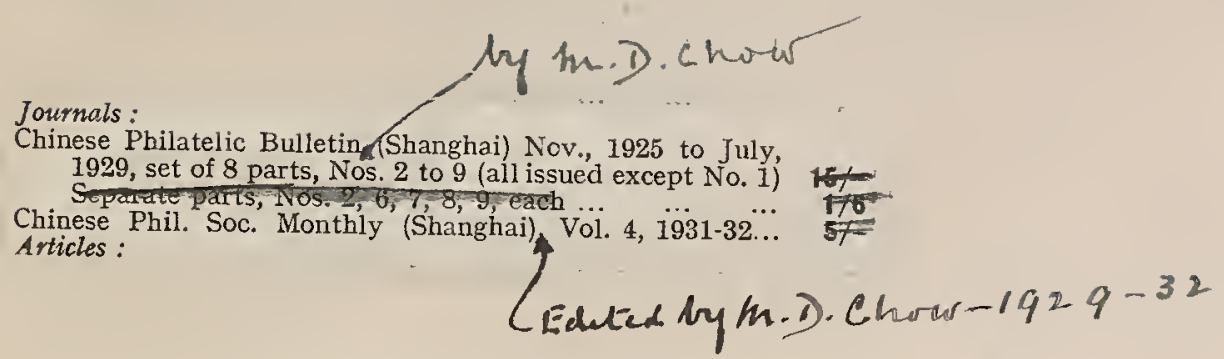

Thustian advocate f.P.L.S Ixp8

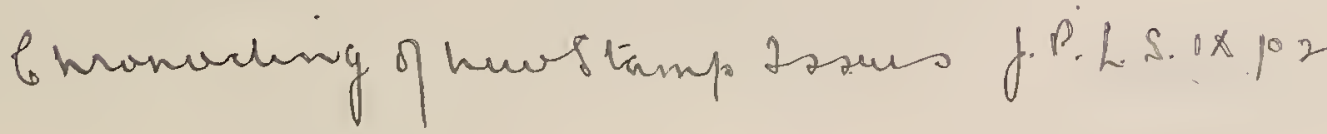


Chubland Supptiment to the "Phitatedie

magazane", 1918-19/hos 158)

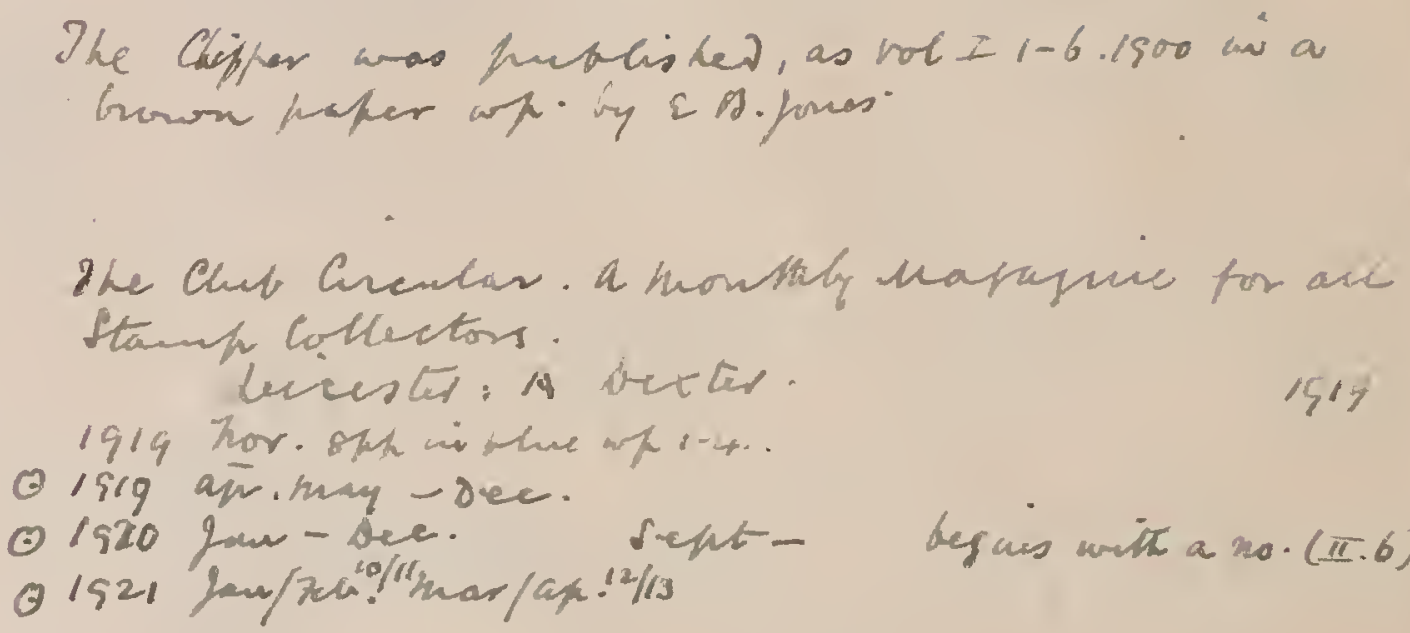

Igig thrie. Moy kat no wh. Mure fuly hat a whito wh

from anpist each number hat a blue arh.

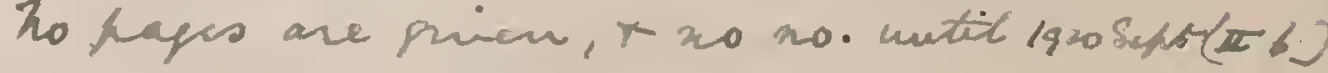

\$ City Phlatelist. No 7

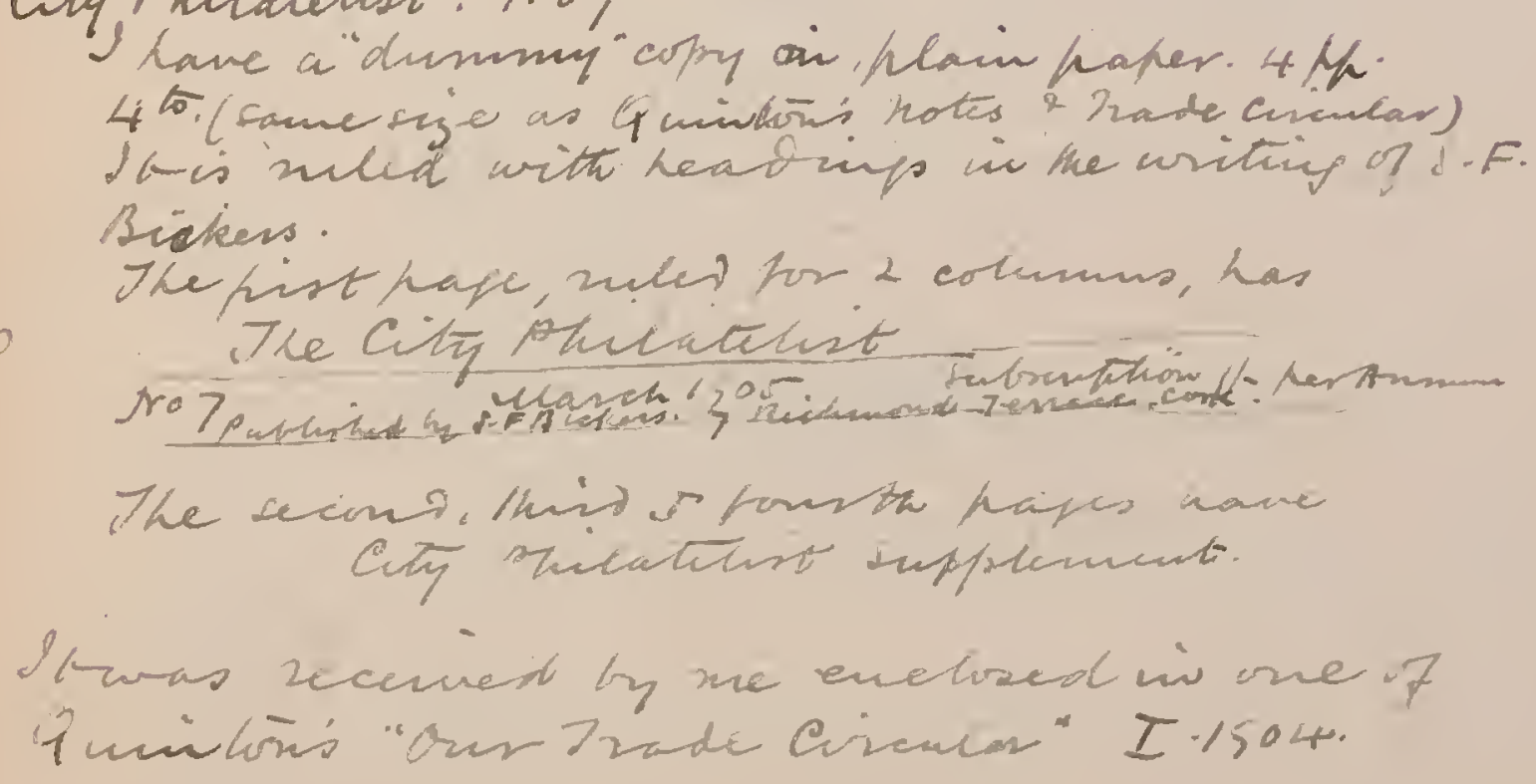

$\$$ hos 3 to 6 contain the whole of the "Catialogue of

Enplish Phulatibie Percole cats" 
CIRCULAIRE IMENSUELLE DE LA LIGUE D' ECHANGE TIMBRES POUR COLLECTIONS

[Continued as :]

Circulaire mensuelle de la Ligue d'Achat et d'Echange Timbres pour Collections.

Spa, Belgique, Estelle Misson, I 900-ог. $4^{\circ} .11-11 \frac{1}{4}$ in. 13 nos. in 2 vols. Q1st year, Jan. 31 -June 30, Sept. 30, 1900. Nos. 9-15.
Q2nd ", Oct. $31,1900-$ March 31,

[Continued as:]

Circulaire mensuelle de la Ligue d'Achat Timbres pour Collections.

Spa, etc., Belgique, Estelle Misson, г 90 I. $4^{\circ} .11-11 \frac{1}{2}$ in. Vol. II.-III. 6 nos.

2 2nd year April 30-June 30, Oct. 15, 1901. Nos. 22-25.

Nov, 30-Dec. 31, Oct. 15, 1901.

*** Nos. 25-27 were published at Brussels and nos"26 and 274 supplements of two pages. No. 23 was also given as a supplement to the "Essor Philatélique" no. 20, June, 1901, but printed on thinner paper than the other copies.

CIRCULAIRE PHILATÉLIQUE. Circulaire philatélique. Le Havre, etc., Ch. Lemierre, I898-Igoz. $8^{\circ} .8 \frac{1}{2}$ in. 44 nos. in 5 vols.

1st year, Oct.-Dec., 1898. Nos. 1-3.)

2nd ", Jan.- " 1899. " 4-14\}

C3rd " " " " $1900 . \quad$ " $15-25.6$.

94th " " " $1901 . \quad " 26-36$.

$\gamma_{*}^{*}$ Nos. $42-44$ were published at Paris, and there is a coloured

Bis the 2 paper wrapper to each number commencing with no. 3. There are

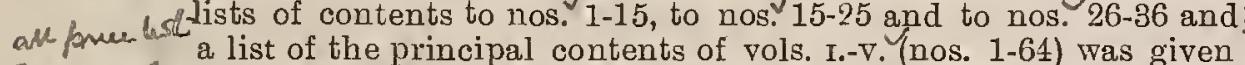

$8 \mathrm{pp}$ hw th in no. 67 (March, 1908). Vommencing with no. 5 the title reads "La Circulaire Philatélique". VNo. 10 is dated "Juillet et Août 1899," no. 21'“Juillet-Août, 1900," no. 32, "Juillet-Août, 1901," no. 41, "Mai-Juin, 1902," and there are no numbers for July, August or September, 1902. VNos. 1-22 do not bear 1e, 2e, or 3e année, but nos. ${ }^{2} 23-33$ have " $3 \mathrm{me}$ année, $V$ nos. $34-43$, " $4 \mathrm{me}$ année" and no. 44 has "5me année". SThere is a supplement of 16 pages with a coloured paper wrapper dated " 20 mai, 1900," and numbered "No. $2 " \cdot \tan 58-70.73 \geqslant 476$ cencenci

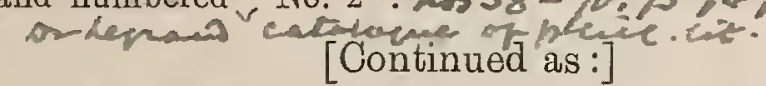

La Philatélie. Revue mensuelle. Ancienne "Circulaire philatélique ".

$8^{\circ} .93$ in. Vols. v.-vI. 8 nos.

5th year, Jan. -Oct., 1903. Nos. 45-51.

6 th "November, 1903. No. 52.

** Each number has a coloured paper wrapper. No. 48 is dated "Avril-Mai," no. 50 "Juillet-Août," and no 51 "SeptembreOctobre," 1903.

[Continued as :]

La Circulaire philatélique. Paris, Ch. Lemierre, I906-

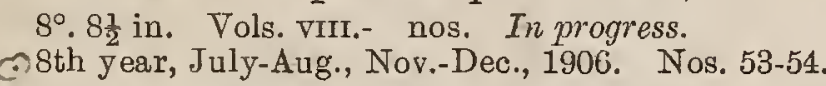

"CIRCULAIRE PHILATÉLISTE". La "Circulaire philatéliste".

Paris, Caen, [printed], B. Vidal, I 897-98. $4^{\circ} .11$ in. fol. $12 \frac{1}{2}$ in. and $8^{\circ} .10$ in. 5 nos. in 2 vols.

C.1st year. Sept. 15, -Dec. 15, 1897. Nos. 1-4.

C. 2nd ${ }_{*}^{*}$ No. 1 is quarto, nos. $2-4$ are folio and no. 5 is octavo.

Mis. St. Jour. 105 (12)

CIRCULAIRE POL BEURDOUCHE. See PoL BeurDoUche Circulaire.

CITY PHILATELIST. The City philatelist. Cork, Ireland, S. F. Bickers, I901-03 $8^{\circ}$. $7 \frac{1}{4}$ in. Nos. 1-6, Oct., 1901, Oct., 1902, Jan., May, Oct., Dec., 1903. 0 2.3.4.6. Cin Rafur 1.5 wnze Mis. St. Jour. 106 (5). CITY STAIMP. The City stamp.

$8^{\circ} .7 \frac{1}{2}$ in. 12 nos. in 2 vols.

Birmingham, J. H. Cooke, I892-94.

OVol. I. Nov., 1892-May, 1893, July, 1893. Nos. 1- 8.

๑) II. Jan., -Apl., 1894.

5 is white ** No. 1 is printed on green paper and nos."2-8 have coloured

* Richard Markes, in no. 5, was reprinted on a single leaf with the

heading "Reprinted from the City stamp". $\odot$

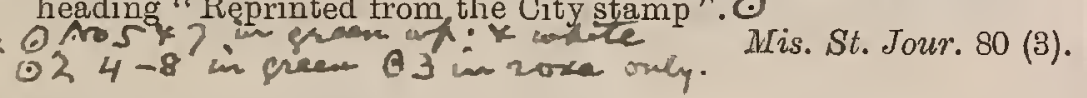

crantare pritatitione

ach yeur $1907 \quad 53=64$

$10-11 \quad 1908 \quad 65^{-}-7$ L

$11-12 \quad 1900 \quad 75-8.2$

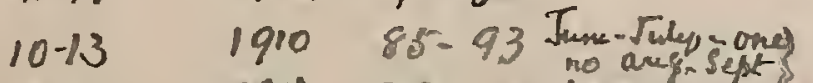

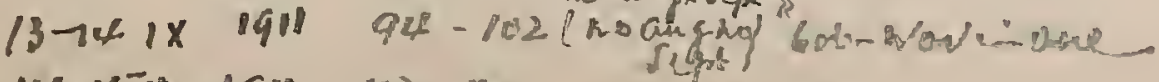

$12-15 \times 1912 \quad 103-112$ many J.ppl-
CLEVELAND PHILATELIST

CLEVELAND PHILATELIST. The Cleveland philatelist.

Cleveland, O., F. E. Gillmore and J. Janowitz, I878. $8^{\circ} .91$ in. Nos. 1-4, June-Sept., 1878.

* Nos. 2-4 were published by F. E. Gillmore and O. S. Hart.

Mis. St. Jour. 10 (1)

CLIPPER. The Clipper. A journal of interesting and instructive literature. Vol. v., no. 49, Oct-Nov., 1889.

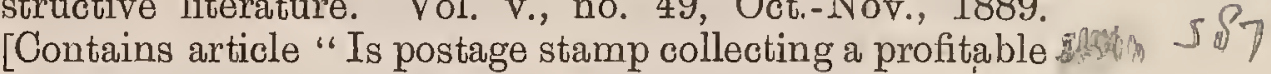
avocation?" from Lynn High School Gazette.]

$8^{\circ} .9$ in. p. [3].

Mendota, Ill., Wells M. Cook, I889.

CLIPPER. The Clipper.

6.) Sioux City, Iowa, Clipper Publishing Co., etc. I 899 -I 900 .

$8^{\circ} .8$ in. 7 nos. in 2 vols.

Vol. I. Dec., 1899-May, 1900 . Nos. 1-6.

"II. June, $1900 . \quad$ No. 7.

*"* Nos. 5-7 were published by E. B. Jones." Amalgamated with

the "Philatelic inter-ocean". Mis. St. Jour. 93 (7).

CLUB HOURS. Club hours. $8^{\circ} .9$ in. Nos. $1-3,[? \quad$ ]-May, 1896.
** Edited by Adolph Boehm and only partly philatelic. No.
has a paper wrapper. Wanting nos. 1, 2 .

CLUB LEDGER. The Club ledger.

Staunton, Ill., E. D. George and L. D. Lillie, I 895.

$8^{\circ} \cdot 9 \frac{3}{4}$ in. No. 1, February, 1895.

4, ** Only partly philatelic.

Mis. St. Jour. 117 (18).

CLUB IMESSENGER. The Club messenger. Official organ of the International Philatelic Society, No. 52. Cherokee, Ia., W. F. Hollinger, I895.

8․ 8-9 in. Nos. 1-2, October 25-December 10, 1895.

Mis. St. Jour. 147 (2)

\section{CLUB PHILATELICO DE SÃO PAULO ... BOLETIN}

official. See Jornal Philatelico.

CLYDE PRESS. The Clyde press.

Clyde, N. Y., Clyde Wayne Co., r886-87.

$8^{\circ} .7 \frac{1}{4} .8$ in. Vol. I., nos. 20, 23-25, 27 ; vol. II., nos. 1, 4-6, 8-12, Sept. 11, Oct. 2, 9, 16, 30, Nov. 6, 27, Dec. 4, 11, 25, 1886, Jan. 8 ,

**, Feb. 10, 1887 . * Only partly philatelic. No. 8, vol. II., has a coloured pape cether with the date "January 8, 1887 " Nos, 23-25, 27, vol. and 1 , 6 and 8-19, vol. II, are bound up in $M$ is. St. Jour. 121 and nos. 1, 4-6 and 8-12, vol. 1., are bound up in Mis. St. Jour. 12 (4) and cuttings of the philatelic portions from no. 20, vol. $x_{\text {. }}$, an vol. $\nabla .$, pp. 99,100 .

COHANN亩T PHILATELIST. The Cohannett philatelist: with which is consolidated the Philatelic sun. Official journal of the Bristol County Philatelic Society. Taunton, Mass., Carlton I. Soule, I895.

$4^{\circ}$. 71 in. No. 1, Sept. 1., 1895 .
* $^{*}$ The number has a coloured paper wrapper. The wrapper has "The Cohannett philatelist. Volume I., Number 1. With which is consolidated the Philatelic sun. Volume II., Number 2. Mis. St. Jour. 66 (12)

COIN AND STAIMP. Coin and stamp. A journal of in formation on currency and postage for bankers, merchants, P. M.'s, and the general public.

Toronto, Greenslade Bros., I 882.

$8^{\circ} .9 \frac{3}{4}$ in. Nos. 1-2, May-June, 1882.

* There is a slip supplement to each number. 2 . 6 k mo Mis. St. Jour. 10 (3).

COIN AND STAIMP. The Coin and stamp.

San Antonio, Tex., Dr. J. B. Breeding, r892.

$8^{\circ} .8 \frac{1}{2}$ in. $\quad$ Nos. 1-2, Jan.-Feb., 1892

* * There is a coloured paper wrapper to each number.

Mis. St. Jour. 64 (5).

COIN AND STAIMP JOURNAL. Coin and stamp journal. Chicago, Ill., Mason and Smith, etc., I865-66.

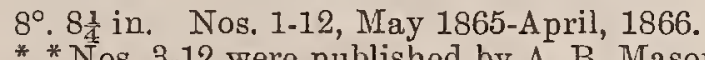

* Nos. 3-12 were published by A. B. Mason. There is a supplement of two pages to no. 5 and no. 7 is wrongly numbered " 4 ". 
COIN AND STAMP JOURNAL. The Coin and stamp journal.

Meriden, Conn., The National Stamp Co., I868. $8^{\circ} .8$ in. Nos. 1-3, Jan.-Mar., 1868.

* No. 3 contains an extra leaf with advertisements printed on one side only and with the heading "The Coin and stamp journal advertiser Mis. St. Jour. 38 (6)

COIN AND STAIMP JOURNAL. Coin and stamp journal.

Kansas City, Mo., etc., W. E. Winner, etc., I875-77. $4^{\circ} \cdot 10^{\frac{3}{4}}$ in. and $8^{\circ} .9 \frac{1}{4}$ in. 32 nos. in 3 vols.

Vol. I. Jan.-Dec., 1875 . Nos. $1-12$.

" III. " "-Ang., $1877 . \quad, \quad 1-12$.

* " Nos. 7-12, vol. II., and nos." 1-8, vol. III., were published at New York, by Joseph J. Casey. Vols. I. and II. are quarto and vol. III. is octavo. The numbers of the last volume have the word "The" preceding the title. No. 4, vol. I., has no number, no. 6, vol. I. is numbered " 5 " in error, and no. 8, vol. II., is dated "July", instead of August. There is an index to vol. I. and also to vol. II. See under "New York Herald" and "Coin Circnlar" for particulars of lawsuit of J. J. Casey versus .M. Kottshofski, the publisher of the "Philatelic Snoozer"

\section{[Continued as :]}

- The Stamp journal. Fearless and independent. New York, Joseph J. Casey, $1877-79$. $8^{\circ} \cdot 91$ in. Vo's. III.-V. 28 nos.

Vol. III. Sept.-Dec., 1877. Nos. 9-12

" IV. Jan. - " 1878. " $37-48$.

** "There is" a tili"e-page and an index to each volume. There is also a special ed tion of vols. IV. and V. measuring 10 inches, printed on buff instead of white paper.

COIN AND STAMP JOURNAL. The Coin and stamp journal. Of Brooklyn. Devoted to the interest of collectors of coins and postage stamps.

Brooklyn, N. Y., J. B. Streeton, I 878 .

$8^{\circ} .9 \frac{1}{2}$ in. Nos. 1-9, Jan.-Sept., 1878.

* Nos. 7 and 8, July and August, were published together.

Mis. St. Jour. 10 (5)

COIN CIRCULAR. The Coin circular. Titusville, Pa. Vol. II., no. 12, February, 1877. [Cuttings of the article on the lawsuit J. J. Casey versus M. Kottshofski are mounted in Stamp Scrap-book, vol. III., p. 82.]

COIN COLLECTORS' JOURNAL, The Coin collectors' journal.

Middlebury, Conn., etc., C. H. Trask, etc., I892-93. $8^{\circ} .89$ in. Nos. 1-9, January 15, February, March-April, June, Jnly, Oct. and Nov., 1892, Mareh, April, 1898

$S$ S. ** Unly partly philatelic. Nos. $6-9$ were published by the C. H. Trask Stamp and Publishing Company and nos. 8-9 at Torrington, Conn. No. 1 is dated in error "1891". No. 4 is dated in erro "July" and no. 5 "Jnne" and nos. 6 and 7 were published together and have a coloured paper wrapper. Wanting nos. 2, 3.4

COIN COLLECTORS' NEWS, AND BRIC-A-BRAC

CHRONICLE. The Coin collectors' news, and brica-brac chronicle. A journal for coin, stamp, and curiosity collectors.

Bury St. Edmund's, C. H. Nunn, r88o. $8^{\circ} .7 \frac{1}{2}$ in. No. 1 , Jan. and F'eb., 1880.

* *No. 2, dated " March and April, 1880," has the title the "Coin collectors' news" and the contents are confined entirely to numis-
matics.
Mis. St. Jour. 95 (1).

COKF'S MONTHLY ADVERTISING LIST OF FOREIGN STAIIPS, CRESTS, IVIONOGRAIMS, BOOKS, FTC. See William Gharles Cokm's MONTHIY ADVERTISING LIST OF FOREIGN STAMPS, CRESTS, MONOGRAMS, BOOKS, ETC.

COIFCCIONISTA. El Coleccionista. Revista mensual organo en España de la aficion coleccionista.

Málaga, Juan A. Aguirre, I89o-92. Fol. $12 \frac{1}{2}$ in. Nos. 1-10, Sept. 15, 1890-May 15, 1891, Jan. 15, 1892

** Only partly philatelic. Nos. 6 and 7 wero published together under the date "15 de Marzo de $1891 "$. Mis. St. Jour. 109 (17).
COLECCIONISTA. Revista trimestral exclusivamente dedicada á defender y propagar la aficion filatélica. 2a série.

Málaga, Juan A. Agnirre, I 893 . 8. 81 in. Nos. 1-2, Mar. 31-June 30, 1893

Mis. St. Jour. 109 (17a).

COLECCIONISTA. El Coleccionista. Revista mensual de sellos postales.

San José, Costa Rica, Ruben J. Vargas, I 898.

8०.91 in. No. 1, December, $1898 . \quad$ Mis. St. Jour. 133 (4).

COLECCIONISTA. El Coleccionista.

Bogotí, Sociedad Filatélica de Colombia, 1904-06.

$8^{\circ} .10$ in. 28 nos. in 3 rols.

O1st year. Apl. 20-Dec., 1904. Nos. 1- 9

(1) 2nd ", Jan. -Oct., Dec., 1904. Nos. 1-9.

(1) 3rd " " "June, Aug., Oct., 1906. " " $21-28$.

COLECCIONISTA. EI Coleccionista. Revista filatélica y numismática

Rosario de Santa Fé, Rep. Arg., A. M. Guzmàn, I $904-07$.

$8^{\circ} .10 \frac{1}{2}$ in. 12 nos. in 3 vols.

(1)1st year. April-Jnne, Sept., Dec., 1904; Feb., 1905. Nos. 1- 6.

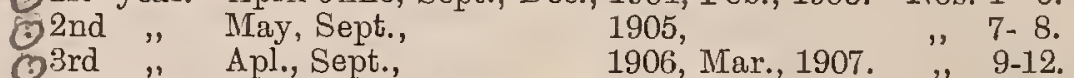
$V_{*}^{*}$ * There is a paper wrapper to each number and a copy of the $\checkmark$ prospectus of the journal is bound np with the numbers. Nos. $\sqrt{11}$ and 12 were publisbed together with the date "Marzo de 1907 ".

COLECCIONISTA ARGENTINO. El Coleccionista argentino. Revista de bellas artes, bibliografia, historia, numismática, filatelia, prensa periódica.

Buenos Aires, Juan Soutomayor, I892-93

O $8^{\circ} .10 \frac{1}{2}$ in. Nos. 1-8, Oct. 12, 1892-Jan., Mar. 28, Apl. 28, Jun int

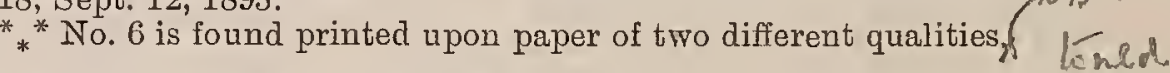

COLECCIONISTA DE SELLOS. El Coleccionista de sellos. Madrid, D. Balbino Cotter Cortés, I87 I. $8^{\circ} .10$ in. Nos. 1-4, Feb 15, Feb. 28, Mar. 15, Mar. 31, 1871. Mis. St. Jour. 43 (2)

COLECCIONISTA DE SELLOS. El Coleccionista de sellos. $8^{\circ} .8-7 \frac{1}{2}$ in. 23 nos. in 2 vols.

1st year. Jan. 31-Dec. 31, 1900. Nos. 1-12. 2nd " " ,-Oct. 31, 1901. "13-23.

*** Nos. 13-23" have paper wrappers. "VNos. 18 and 19 were published together under the date " 15 de Inlio de $1901, " \vee$ no. 20 is called "No. extraordinario" and is dated " 1 " de Agosto de 1901 " $\checkmark a n d$ no. 21 is dated " 31 de Agosto de 1901 ". Nos. 13, 15, 16, 17,
18 and 19 contain pages of a supplement "Las Falsificaciones, 18 and 19 contain pages of a supplement "Las Falsif in Bs apry, pages viry vrrache

- 2a época. Madrid, José G. Caballos, I902-о3. Fol. 123 in. Vols. III., IV., 25 nos.

3rd year. Oct. 15, 30, Nov. 15, 30, Dec. 15, 30, 1902. Nos. 24-29. 4 th "Jan. 15-June 30 , Oct. 1, 8, 16, Nov. 1, 8, 16, 1903 . Nos. ** Nos. 30 and 31,32 and 33,35 and 36,37 and $38,(39,40$ and 41) and 45 and 46 were severally pnblished together, the last having the date " 10 de Noviembre,de 1903 ". Only the numbers of the third year bear " $2 \mathrm{a}$ época".

COLECCIONADOR DE SELLOS. O Colleccionador de sellos.

$8^{\circ} .10$ in. 40 nos. in 4 vols.

Sorocaba, Brazil, Remijio de Bellido, г896-99. 1st year. Jnne:1-Dec. 1, 1896. Nos. $1-7$

$\checkmark 2$ d " Jan. 1-, 15,1897. ", 1-12 and supplemental no. 3rd " " $\quad 25-" \quad 5,1898 . \quad " 1-12$. Q4th " "The is" a coloured paper wrapper to each number. No. 7
of the third year has "Anno II." in error, and nos. 9 and 10 of that year were published together under the date " 30 de Ontubro," there being no number for September, 1898. vNo. 6 of the fourth year bears "N. 5" in error. There is a supplementol number to no. 7 of the second year dated " 25 de Julho de 1897 "\%. vog has a sofk and special supplements with the titles "Erste Südamericanische to 3.38 and special supplements with the titles "Erste Sudamericanische to 2.38 catalogued separately. Peaces in if 16.12 IJ 3.5 .6 .7 9/10

$$
\begin{aligned}
& \text { He coleccoromeste de Targe tas Postales } \\
& \text { Madried } 1901 \text { IIP I Nar } 45
\end{aligned}
$$


Golveurnismo f.P.h.sexp 


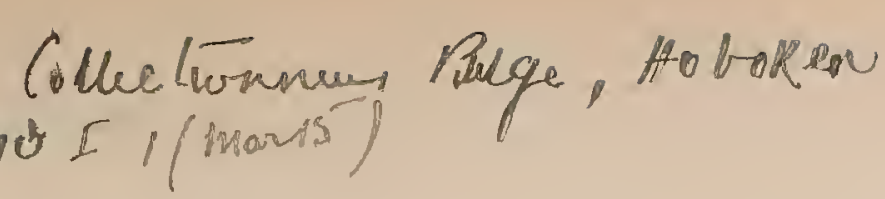

501

\section{COLLECTIONNEUR}

6 COLLECTIONNEUR. Le Collectionneur. Se publie à 3000 copies le 15 de chaque mois. Montréal, J. Le Roux, I886. $8^{\circ} .10 \frac{1}{2}$ in. Nos. 1-2, May-June, $1886 . \quad$ Mis. St. Jour. 8 (6).

COLLECTIONNEUR. Le Collectionneur. Journal bimensuel des collectionneurs d'affiches artistiques, antiquités, armes, autographes, cartes illustrées, cartes postales, gravures, livres, médailles et monnaies, tableaux, timbres, objets d'art, botanique, minéralogie, ornithologie, conchyliologie, etc.

Autun, France, Jean de Kerlecq, rgor-02.

$8^{\circ} .11$ in. 28 nos, in 3 vols.

1st year. Oct. 1-Dec. 15,1901 . Nos. $1-6$.

2nd " Jan. 1-Sept. 15, 1903. " $7-24$.
3rd

* * Each number, commencing with" no. 3 , has a coloured paper wrapper. After no. 8 the nos. 9-23 have "1re année" inside and " $2 \mathrm{e}$ année" on the wrappers and the four last numbers have " $2 \mathrm{e}$ année" on the wrappers in place of "3e année". Wanting first year no. 6 , second year no. 19 and the wrappers to nos. 15 and 20.

COLLECTIONNEUR. Le Collectionneur.

Pskow, Russia, Gesellschaft "Fleiss und Kenntnis," I 902 .

* * in. No. 1, [? ], 1902.

COLLECTIONNEUR. Le Collectionneur.

Le Creusot, France, Cl. Guinot, r905-06. $8^{\circ} .10$ in. 10 nos. in 2 vols.

1st year. May 10-Dec. 10, 1905. Nos. 1- 8.

(3) 2nd Jan. 10-Feb. 10, 1906 . $9-10$

$\checkmark *^{*}$ Only partly philatelic. VNos. "4-10 have coloured paper * Only partly philatelic. Nos. 4-10 have coloured paper wrappers. A copy of the prospectus of the

- Le Collectionneur universel. Revue mensuelle cartophilatélique et littéraire.

Le Creusot, France, Cl. Guinot, I906-

$8^{\circ} .9 \frac{1}{2}$ in. Vols. Ir., nos. In progress.
2nd year. March 10-Dec. 1, 1906 . Nos. 11-19.

* year. March 10-Dec. 1, 1906 . Nos. $11-19$. *ere published together with the date "1er Septembre, 1906" and there is no number for October, 1906.

COLLECTIONNEUR DE TIMBRES. Le Collectionneur de timbres. Journal paraissant chaque mois. Ledeberg-lez-Gand, Charles Vincent, r882. $8^{\circ} .10$ in. Nos, 1-6, Apl.-Sept., 1882

$\checkmark * *$ Nos. 1-4 are without the year of publication.

Mis. St. Jour. 133 (7).

COLLECTIONNEUR DE TIMBRES FISCAUX. Le Collectionneur de timbres fiscaux.

Rouen, A. Dufour, rgoo-or. $8^{\circ}$. 91 in. Nos. 1-4, Nov., 1900, Feb.-April, 1901. $\checkmark{ }_{*}^{*}$ There is a coloured paper wrapper to each number.

Mis. St. Jour. 106 (16).

COLLECTIONNEUR DE TIIMBRS-POSTE. Le Collectionneur de timbres-poste.

Paris, M. Maury Fils, I864 Fol. 12 in. $4^{\circ} .8 \frac{1}{2} \mathrm{in}$. and $8^{\circ} .8 \frac{1}{4}$ in. nos. in vols. In progress. 1st year. July 15, 1864-June 15, 1865. Nos. 1-12.? Ti

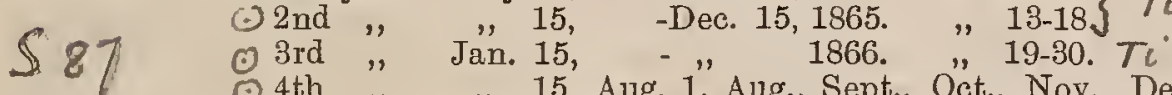
- 4th " " "15, Aug. 1", Aug., Sept., Oct., Nov., Dec., 1867.

$\odot$ Aug.,
Ð Jan., Feb.,

o Dec.,

Jan. -May, June-Oct.,

Jan. 15-Dec

, 15- ,

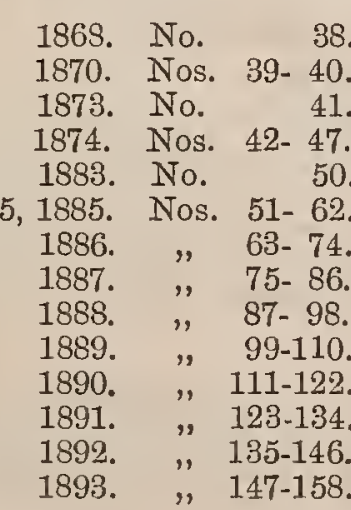

COLLECTIONNEUR

502

\begin{tabular}{|c|c|c|c|c|}
\hline Jan. & -Dec. & 1894. & & 159-170. \\
\hline$"$ & - & 1895. & " & 171-182. \\
\hline " & - " & & $"$ & 183-194. \\
\hline$"$ & - " & 1897. & $"$, & 195-206. \\
\hline " & $-"$ & 1898. & $"$ & $207-21$ \\
\hline$"$ & $-" n$ & 1899. & $"$ & $219-23$ \\
\hline$"$ & - ," & 1900. & ", & $231-24$ \\
\hline ", & $-" n$ & 1901. & ", & $243-25$ \\
\hline$"$ & - ," & 1902. & ", & $255-26$ \\
\hline ", & - ," & $1,1903$. & $"$ & $267-27$ \\
\hline$"$ & $-"$, & ," 1904. & , & $279-29$ \\
\hline$"$ & , - , & $" 1905$. & " & $\begin{array}{l}291-30 \\
303-31\end{array}$ \\
\hline
\end{tabular}

C. $レ$ * " Nos. "̈-8 are folio, nos. $4-47$ are quarto and commencing with no. 50 the journal is octavo. $V$ Nos. 1-3 were reprinted in quarto size, as one number, with the date "15 Septembre, 1864," and mos. 29 and 30 were published together with the date "Novembre et Décembre, 1866 ". No. 32 is wrongly numbered " 33 " and no. Thig is manect, rede thery 33 is wrongly numbered " 32 ". $\sim$ No. 47 is dated "Juin-Octobre, wote 2.33 . The thafur of 1874," and nos. 48-50 are only price lists. There is a title-page 32

and an index for nos. '1-18, óne for nos. 19-30, one for nos. 51-110, one for nos. 111-134;, one for nos. 135.158 , one for nos. 159-18 and then one for each year commencing with 1896. That for 1900 has " numéros 231 à 342 ," instead of "numéros 231 à 242 " There are eight extra unnumbered pages to"no. 101, supplements of eight pages to nos. 110 and 145 , one of six pages to no $122 \mathrm{2}$ and others of two pages each to nos $146,158,167 ; 170,193,205$, 217, 229, 230,241, 253,254,265, 266, 278. Besides these, further supplement, consisting of a catalogue of all the new issues of stamps, etc., that appeared during the year, was given with each December number of the journal commencing with the year 1885. Each number, beginning with no. 125, has a paper wrapper. This was the first philatelic journal published in France. Wanting nos, 48, 49.

COLLECTIONNEUR FRANGGAIS. Le Collectionneur français. Journal mensuel de timbrologie.

$8^{\circ} .10$ in. 2 nos. in 2 vols.

Paris, Louis Martin, I898-99.

C1st year. Oct. 31,1898 . No. 1 .

${ }^{*} *$ "There is a coloured paper wrapper to each number.

Mis. St. Jour. 110 (3)

COLLECTIONNEUR DU VAR. Le Collectionneur du

Var. Journal philatélique mensuel.

Vidauban, Var, France, Léon Rebufel fils, r896.

$8^{\circ} .8 \frac{3}{4}$ in. and 10 in. Nos. 1-3, Mar. 13-May 20, 1896.

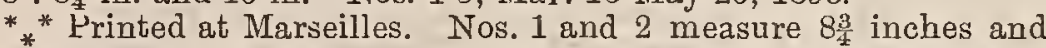
have coloured paper wrappers, no. 3 measures 10 inches and has no wrapper. For continuation see "Indicateur Philatélique et Commercial". $\quad$ Mis. St. Jour. 89 (5)

COLLECTIONNEUR SUISSE. Le Collectionneur suisse. Journal philatélique.

La Chaux-de-Fonds, Victor Renck Fils, I895-96. $4^{\circ} .11 \frac{1}{4}$ in. and $8^{\circ} .8 \frac{3}{4}-9 \frac{3}{4}$ in. Nos. 1-[4], July 15, Aug. 15, Oct. 1895, Jan., 1896.

* * Nos. 1 and 2 are quarto, no. 3 is octavo $8 \frac{3}{4}$ inches and [no. 4] * Nos. 1 and 2 are quarto, no. 3 is octavo 8 inches and [no. 4 ] number for "Janvier, 1896," is unnumbered.

Mis. St. Jour. 57 (5)

COLLECTIONNEUR UNIVERSEL. See COLLECTIONNEUR (Le Creusot)

COLLECTOR. The Collector.

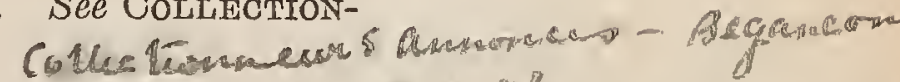

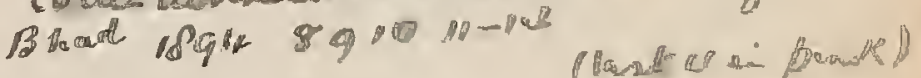
Newburgh, N. Y., D. W. Jagger, 1871-72. $8^{\circ} .911$ in. Nos. 1-6, Nov., 1871-April, 1872.

** Only partly philatelic. Nos. 2, 4 and 6 have supplements of (2) pp.
Mis. St. Jour. 17 (4)

COLLECTOR. The Collector.

Smyrna N. Y., Frank J. Stanton, 1879.

$8^{\circ} .7 \frac{1}{2}$ in. Nos. 1-2, April-LIay, 1879. Mis. St. Jour. 41 (8)

\section{[Continued as:]}

Amateur clipper. An amateur and philatelic journal. Smyrna, N. Y., Frant J. Stanton, 1879 .

$8^{\circ} .7 \frac{1}{4}$ in. 6 nos. in 2 vols. Vol. r. June-Sept., 1879. Nos. $3-6$ * II. Oct., Nov., 1879. " 7-8. * * Only partly philatelic. There is a supplement of two pages of advertisements, printed on one side only, to no. 4.

Mis. St. Jour. 41 (8a) 


\section{COLLECTOR}

Holiday clipper.

[Continued as:]

Smyrna, N. Y., Frank J. Stanton, 1879 $8^{\circ} .7 \frac{1}{2}$ in. Vol. II. No. 9, Dec., 1879. * Only partly philatelic. Mis. St. Jour. 41 (8b)

[Continued as :]

Yankee clipper.

Smyrna, N. Y., Frank J. Stanton, I880-8 I. $8^{\circ} .7 \frac{1}{2}$ in. Vols. II. -IV. 15 nos.

Vol. II. Jan.-Mar., 1880. Nos. 10-12.

rII. Apl.-Sept., " " 13-18.

*" Only partly philatelic. No. 12 is printed on rose paper and * " to no. 14 Yos 17 and 18 pro published tocether under the dat

"Aug.-Sept., 1880". Wanting nos. 19-24. Mis. St. Jour. 41 (8c).

COLLECTOR. The Collector'. A magazine for philatelists. Worcester, Mass., E. A. Welch and Co., I880.

$32^{\circ} 5$ in Nos. 1.2, Feb-Apl., 1880.

** There is a coloured paper wrapper to each number.

Mis. St. Jour. 71 (12)

COLLECTOR. The Collector.

Utica, N. Y., Geo. M. Jones, I884.

$8^{\circ} .9 \frac{3}{x}$ in. No. 4 , October, 1884

Mis. St. Jour. 121 (16)

COLLECTOR. The Collector.

Scranton, $\mathrm{Pa}$, Arthur C. Smith, I884-85

$8^{\circ} .9$ in. Nos. 1-4, Ost., 18s4-Jan., 1885.

* * No 3 and 4 were published together under the date "Decem*er and January, 1885 ". Mis. St. Jour. 24 (2).

COLLECTOR. The Collector. Published in the interests of collectors of coins, stamps, old literature, paintings, antique pottery and porcelain, etc.

Hull, Yorks, G. W. Mortimer, 1884-85

So. 81 in. Nos. 1-8, Dec. 15, 1884-June 15, Aug. 15, 1885.0 2-7

* There is a coloured paper wrapper to each number.

o* Siluming grey 26,87,7 M7 litke Mis. St. Jour. 30 (12)

COLLECTOR. The Collector.

Easton, Md., etc., C. Haddaway, etc., I886-88

8. 9 in. 16 nos. in 2 vols.

Vol. I. Nov., 1886-July, 1887. Nos. 1-9.

Vol. I. Nov., 1886-July, 1887. Nos. $3-9$

* * II. Sept., 1887-Mar., 1888. 2-", vol, I., were published by the Collector Publishing Co. at Easton; no. 3, vol. II., by Geo. D. Morris, at Pittsburgh, $\mathrm{Pa}$. : and nos. 4-9, vol. II., by the last named, at Gambier, 0 . No. 5, vol. I. and nos. 5-7, vol. II., have paper wrappers. bier, $0 . N^{\circ} .5$, vol. I., and nos. 5-7, vol. Ir., have paper wrappers. Nos. 6 and 7, vol. 1. ., were published together under tho date "Decomber and January, 1887-88," and there is a supplement of two merly the Eclipse" beneath the title. "Mis. St. Jour. 70 (8).

COLLBCTOR. The Collector.

Chatham, N. Y., F. P. Vincent, I888.

$8^{\circ} .9$ in. No. 1, September, 1888. Mis. St. Jour. 144 (1).

COLLECTOR. The Collector.

New Chester, Pa., etc., The Collector Publishing Co., I $890-95$.

$32^{\circ} .4 \frac{1}{1}$ in. and $8^{\circ} .7 \frac{3}{4}-9$ in. 51 nos. in 5 vols

Vol. I. July, 1890-Apl., 1891. Nos. 1-10.

" II. Oct., 1891-Sept., 1892. " 11-22.

"III. " 1892-" 1850. " 23-3.

"IV. " 1893-Oct., 1894. " 35-48.

* " V. Nov., 1894-June, 1895. $8^{\circ}$ "Nos. 45.48 were published at * * Vol. I. is $32^{\circ}$. and the lest $8^{\circ}$ "Nos. 45.48 were published at Baltimore, Md. No. 42 is dated "May-June, 1894, "there are no numbers 43 or 44 , and no. 45 has the date cury, 53 have the sub-title "Official organ [or journal] of the Sons of Philatclia" and nos. 52 and 53 also have "W 1,9 10, 12-42, 45-48, porated the Canad an philatelist". Nos. $6,7,9$ ho, $12-42,45-48$, 50-53 have coloured paper wrappers. No. 22 has vol. "For conplace of "II.," but the wrapper is correctly numbered. For con-

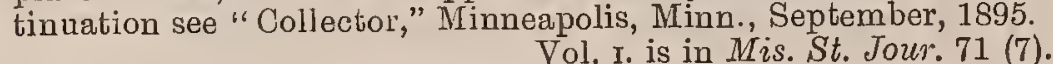

COLLECTOR. The Collector

New York, Alfred Trumble, I890-94.

$4^{\circ} .13$ in. nos. in vols.

* * Some of the numbers only, contain philatelic matter. The library has cuttings of the philatelic portions from no. 19, dated October 1, 1890, and vol. II., no. 18, dated September 1, 1891 mounted in Stanip Scrap-book, vol. VI., pp. 114, 115, 178; and whole numbers: vol. Iv., nos, 10, 18, March 15, September 1, 1893 vol. v., mos. 6, 7, 10, 13, January 15, February, 1 March 15, May 1 1894.

COLLECTOR. The Collector.

Fol. 15 in. nos. in 2 vols.

Pekin, Ill., Fred. E. Lux, I892-93.

Vol. I. 1892-1893. Nos. 1-12.

" II. 1852-1893. Nos. 1-12.

** Only partly philatelic. Wanting all but nos. 9, 10, 11, vol. I. dated respectively July, August and September, 1893.

COLLECTOR. The Collector. A monthly in the interests of stamp collecting.

Minnerpolis, Minn., Eben S. Martin, I895. $8^{\circ} .7 \frac{1}{2}$ in. Nos. 1-3, Sept. 12, Oct. 10, Nov. 14, 1895.

* There is a coloured paper wrapper to each number. Nos. 2 and 3 have above the title, "Canadian philatelist. Vol. III., no. 4. The Collector. Vol. $\nabla .$, no. 6," and "Canadian philatelist. Vol. III., no. 5. The Collector. Vol. v., no. 7," respectively. Mis. St. Jour. 67 (9)

COLLECTOR. The Collector for those who collect stamps. Toronto, Ont., Wm. R. Adams, I897-S81

$8^{\circ} .9$ in. lisher and cannot therefore be considered a philatelic journal.

COLLECTOR. The Collector.

New Oxford, Pa., etc., J. F. Dodge, I899-I goo. $8^{\circ} .8 \frac{3}{4}$ in. 17 nos. in 2 vols.

Vol. I. Sept. 5, 1899-Feb. 20, 1900. Nos. $1-12$ * "II. Mar. 5, Apl. 5, May 5, July 5, Aug. 20, 1900. " 13-17. * * Nos. 14-17 were published at Abbottstown, Pa. The numbers of volume I. were published on the 5th and the 20th of each month. Amalgamated with the "New York Philatelist" in October, 1900.

COLLECTOR. The Collector.

Greenfield, O., Roy Boyd, I902.

$16^{\circ} .4 \frac{3}{4}$ in. No. 1, February, 1902.

Mis. St. Jour. 150 (7)

COLLECTOR. The Collector.

Pittsburg, Pa., R. D. Vroman, I905

$8^{\circ} .8 \frac{3}{4}$ in. No. 1 , March $20,1905$.

** The number has a paper wrapper with "Philately, numismatics, archæology," printed beneath the title

Mis. St. Jour. 123 (6).

COLLECTOR. The Collector.

Q ${ }^{\circ} .9$ in. No. 1,1906

Northfield, Vt., Direct Advertising Co., I 906.

** The month of publication is not given. Mis. St. Jour. 144 (5).

COLLECTOR. See International Stamp.

COLLECTOR. See BuLLETIN (Newburyport Mass.).

COLLECTOR. See Philadelphia collector.

COLLECTOR AND EXCHANGE. The Collector and exchange.

Buffalo, N. Y., H. S. Pickett and Co., etc., I888. $8^{\circ} .9 \frac{1}{2}$ in. Nos. 1-5, Aug. 1-[Dec.], 1888

** Only partly philatelic. Nos. 4 and 5 were published together ** * Only partly philatelic. Nos. 4 and " 5 were published together by Pickett and McLeod with the date "Oct. \& Nov., 1888," in misa
take for "Nov. \& Dec., 1888 ". $\checkmark$ Mis. St. Jour. 15 (7).

COLLECTOR-DEALER. The Collector-dealer. A phila(1) telic miscellany. Southsea, C. S. Quinton, r896-98. C8 $8^{\circ} .8$ in. Nos. 1-9. Dec., 1896, Feb., Mar., May, July-Aug., Nuv., 1897, Jan.-Feb., May-June, Oct.-Nov., 1898. $r^{*} *$ There is a coloured paper wrapper to each numbcr. Of no. 3 there is a second edition dated "March-April, 1897," and the wrapper "April, 1897, "and there is also a second edition of no.

- New Series. Southsea, C. S. Quinton, I899-1900.

(- $4^{\circ} 8$ in Nos. 10-13, Feb, Mar, Oct. 2, 1899, Jan., 1900.

$f^{* *}$ Nos. 10 and 11 have coloured paper wrappers. No/o terma culta

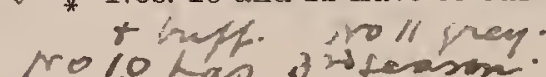

rolo has Jisteasm.

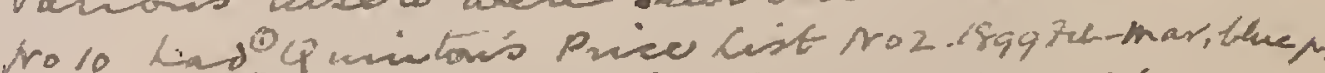

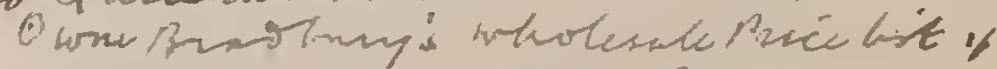

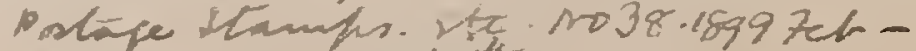

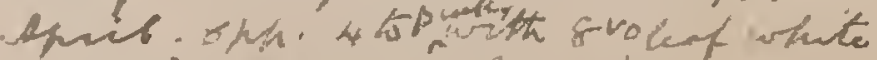
sterial spfers of huw trives

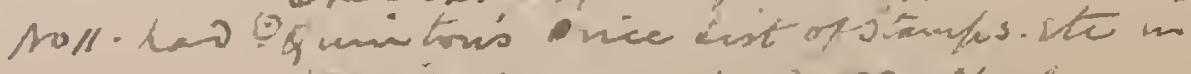

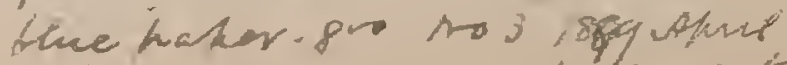



Collectios arvestias

himapool is trolionay.

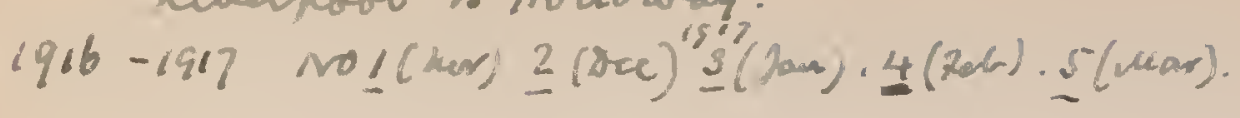

Collectoris Cirincar. To number is sinen, fut doted each mouth $1865 \mathrm{bec}-1866 \mathrm{hor}, 4$ hh each. (as now) a.s 
COLLECTOR'S ADVERTISER. The Collector's advertiser. Wyoming, Ia., E. R. Marshall, I887. in. Nos. 1-2, January-March, 1887. * * Only partly philatelic. Amalganated with the "Western collector," May, 1887. Wanting both nos.

COLLECTORS' ADVERTISER. See UNIVERSAL ADVERTISER.

COLLECTORS' ADVERTISING JOURNAL. The Collectors' advertising journal. A monthly paper for all collectors and dealers. $8^{\circ} .8 \frac{3}{7}$ in. No. 1 , September, $1905 . \odot$ Douglas, I. O. M., A. J. Corlett, I905. $J^{* *}$ Only partly philatelic.

Mis. St. Jour. 126 (8)

COLLECTORS' ADVOCATE. The Collectors' advocate. Devoted to all branches of collecting. $8^{\circ} .8 \frac{1}{2}$ in. No. 1, Jan., 1888

incinnati, O., Chas. Tarvin, I 888. * * Only partly philatelic.

Mis. St. Jour. 26 (7).

[Continued as :]

- The Queen City philatelist and collector's advocate. Cincinnati, O., Chas. Tarvin, 1888. $8^{\circ}: 8 \frac{3}{4}$ in. Nos. 2-3, Feb. and Mar., 1888.

** Only partly philatelic. The two numbers were published together and have a colourcd paper wrapper.

Mis. St. Jour. 26 (7a).

[Continued as :

The Queen City philatelist.

Cincinnati, O., The Quecn City Philatelic Publishing Co., I 888.

$8^{\circ} \cdot 8 \frac{3}{4}$ in. No. 4 , April $30,1888$.

** The number has a coloured paper wrapper with the title "The Queen City philatelist and collector's advocate".
Mis. St. Jour. 26 (7b).

COLLECTOR'S AID. The Collector's aid. Stamps, coins, autographs, etc.

Pendleton, S. C., T. S. Crayton, Jr., I879. $8^{\circ} .8 \frac{1}{2}$ in. No. 1 , Oct., 1879.
$*$ * Printed on yellow paper.

Mis. St. Jour. 28 (3).

COLLECTOR'S AID. The Collector's aid.

Brooklyn, N. Y., G. H. Richmond, x 886-87.

$8^{\circ} .9$ in. Nos. 1-7, Feb. 15, May, Dec. 1, 1886, Jan. 1, Mar. 1, Summer, 1887.

${ }^{*}{ }^{*}$ No. 3 has no date. $\sim$

Mis. St. Jour. 19 (7)

COLLECTORS' AID. See Collectors' companion (Pawnee City, Ncb.).

COLLECTOR'S BARGAIN LIST. The Collector's bargain list. Des Moines, Ia., T. L. Hosmer, I 905. in. No. 1, March, 1905.

** Only partly philatelic. Wanting.

COLLECTOR'S BI-IMONTHLY DIRECTORY. The Collector's bi-monthly directory.

Manchester, Mich., C. J. van Valkenburg, I886-87. $8^{\circ} .9$ in. 7 nos. in 2 vols.

Vol. I. Aug., Oct., Dec., 1886, Feb., Apl., Juue, 1887. Nos. 1-6. ", II. Aug., 1887. No. 1

** Ouly partly philatelic. Each number has a coloured paper
wiapper.
Mis. St. Jour. 23 (7).

COLLECTORS' BUDGET. The Collectors' budget. magazine for stamp, card, coin, and curio collecting. Bradford, Petty and Co., I904. $8^{\circ} .7 \frac{1}{2}$ in. and oblong $8^{\circ} .7$ in. Nos. 1-2, March-May 1, 1904 .

wrent ${ }^{*} *$ * No. 2 has no year given and this number is oblong in shape is printed on coloured paper and has the words "Advertisement Supplement" above the title. Amalgamated with the "Homc and Colonial philatelist" for October, 1904. Mis.,St. Jour. 97 (1).

COTICTORs' 8 M. BUREAU.

COLLECTOR'S CABINET. The Collector's cabinet. 8. 81. in. [No. 1, Dec., 1884.]
** This is nothing but a price list. New York, W. F. Smith, [1884].

Mis. St. Jour. 28 (15).
COLLECTORS' CAPRICE. The Collectors' caprice. Brooklyn, N. Y., Hotchkiss and Dillont, I884-85. $8^{\circ} .7 \frac{1}{2}$ in. 7 nos. in 2 vols.

Vol. III. May, Aug.-Nov., 1884. Nos. 3-7.

* IV. Jan., Feb., 1885. Nos. 1, 2

* * Only partly philatelic. Nos. 6 and 7, vol. III., were published together under the date "Oct. and Nov., 1884". No. 1, vol. IV., is dated " 1884 " instead of " 1885 ". No. 2, vol. IV., was the last published. Probably the numbers previous to vol. III., no. 3, con-
tained no philatelic matter. Mis. St. Jour. 41 (10).

COLLECTOR'S CIRCULAR. The Collector's circular. Preston, Industria and Co., I 865-66.

$4^{\circ} .8 \frac{3}{4}$ in. [Nos. 1-12], Dec. 6, 1865-Nov. 6, 1866 . aet of As

COLLECTORS' CIRCULAR. The Collectors' circular. London, E.C., S. Sherrington Chinn, I 903-04.

$4^{\circ} .12$ in. 33 nos. in 3 vols.

Vol. I. May 30 -Sept. 19, 1903. Nos. 1-13.

" II. Oct. 3, 1903-Mar. 19, 1904. ", 14-26.

* " III. Apl., 2 -June 25, 1904. „ 27-33.

* * Each number has a coloured paper wrapper and contains a

Register of articles "for sale" and "wanted," including stamps. Nos. $12,17,18,19,22,24,25,27,29$ and 31 also contain philatelic notes or articles. Duplicate copies of nos. 25, 27, 29 and 81 are

bound up in Mis. St. Jour. 124 (9). [Continued as :]

The Collectors' illustrated circular.

London, W.C., S. Sherrington Chinn, I 904-05.

$4^{\circ} .123$ in. Vols. IV.-V., 14 nos.

Vol. IV. July 9-Dec. 24, 1904 . Nos. 34-46.

*. vo Jan. 7,1905 . No. 47

* * Each number has a paper wrapper and contains a Register of articles "for sale" and "wanted," including stamps. The title on page 1 of no. 34 reads: "The Collectors' illustrated circular and register of antiques, curios and works of art." on the an numbers the title on the first pagc of reading matter reads. "The collectors' illustrated and register of antiques, curios and works of art". Noz. 34-46 also bear the words "New Series". Nos. $35,37,38,41,43,44,45^{\circ}$ and 46 contain philatelic notes or articles. A duplicate copy of no. 35 is bound up in Mis. St. Jour. 124 (9a). Wanting no. 38 .

COLLECTOR'S COMIMENT. The Collector's comment. "Use not Fame". Succeeding "The Collector's review". A monthly journal for stamp collectors. Denver, Colo., H. A. Babb, etc., I 888.

$8^{\circ} .9 \frac{1}{2}$ in. Nos. 1-3, Oct.-Dec., 1888

* * No. 3 was published by the Colorado Philatelic Company. Mis. St. Jour. 14 (7)

\section{COLLECTOR'S COMMON SENSE, AND ÆX-} CHANGER'S FRIEND. Sce CoMmon SHNSE.

COLLECTOR'S COMPANION. The Collector's companion. Northfield, Vt., G. H. Richmond, I875. $8^{\circ} .9$ in. No. 1 , Jan., 1875

* * The number has a coloured paper wrapper. Bound up with the number is the prospectus of the journal published in Sept.,

COLLECTOR'S COIMPANION. The Collector's com-
panion. Akron, O., Will Clemens and Co., I876. panion. Akron, O., Wili

$16^{\circ} .6$ in. Nos. 1-3, Oct.-Dec., 1876 . **Nos. 2 and 3 were published together under the date "Nov.
and Dec., 1876 ".

COLLECTOR'S COMPANION. The Collector's companion. Issued monthly in the interest of philatelists. Chicago, Ill., J. H. Raymond, etc., I885-86. $8^{\circ} .9$ in. 17 nos. in 2 vols.

Vol. I. Jan.-Dec., 1885. Nos. 1-12.

* " Nos. 11 and 12, vol. I., and the five numbers of vol. Ir. were published by the Collector's Companion Co. Each number has a coloured paper wrapper.

COLLECTORS' COMPANION. Collectors' companion. I 887 .

Pawnee City, Neb., Companion Publišning Co., etc.,

$8^{\circ} .8 \frac{3}{7}$ in. Nos. $1-4$, Feb.-May, 1887

** Only partly philatelic. Ho. 4 was published by Jamos G. MicBride.

COLLECTORS' ' CLUB' PHILATELIST. (New York, Collectors'

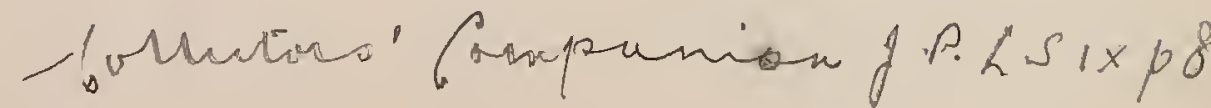




\section{COLLECTORS' COMPANION.}

[Continued as :]

_- Collectors' aid. I 887 .

Pawnee City, Neb., J. G. McBride and Weber, etc.

$8^{\circ} .8_{4}^{3}$ in. Nos. 5-8, June, July-Aug., Sept., Oct., 1887.

* Only partly philatelic. Nos. 7 and 8 were published by James G. McBride and John H. Baird. No. 6 has the number given in Roman numerals. Mis. St. Jour. 25 (6a)

COLLECTOR'S COMPANION. The Collector's companion. A monthly for stamp collectors.

Brooklyn, N. Y., Globe Stamp and Pub. Co., I894. C $8^{\circ} .81$ in. No. 1, Feb., 1894

** The number has a coloured paper wrapper.

Mis. St. Jour. 65 (1)

COLLECTORS COMPANION. The Collectors companion.

Red Creek, N. Y., Walter C. Wendover, r899-1900. 8.9-8 in. Nos. 1-[12], May-August, November, 1899, February, April-August, November, 1900

* * Nos. 2 and 3 were published together and no. 12 is numbered in error "vol. II., no. 2". Nos. 1-11 meesure 9 inches and no. 12 measures 8 inches. Amalgamated with the "Bay State Philatelist," December, $1900 . \quad$ Mis. St. Jour. $125(6)$

COLLECTORS DELIGHT. The Collectors delight. in. Nos, 1-7. Sunbury, Pa., [?

* *nly partly philatelic. Wanting all nos.

COLLECTOR'S ERA. See CoLleCTOR's EXCHANGE.

(Chicago, Ill, I89I.)

COLLECTORS' EXCHANGE. Collectors' exchange.

Lititz, Pa., W. B. Hornberger, 1884 .

* * Cuttings of the stamp portions from no. 2, dated April, 1884 are mounted in Stamp Scrap-book, vol. v., p. 48

COLLECTORS' EXCHANGE. The Collectors' exchange. 89

Springfield, Wis., etc., Frank $H$. Eames, Jr., I888-

$8^{\circ} .8_{4}^{3}$ in. Nos. 1-7, Ang.-Dec., 1888, April, May, 1889. 2-

** Only partly philatelic. Nos. 3-7 were published at Elkhorn,
Wis. St. Jour.
Wis.

COLLECTOR'S EXCHANGE. The Collector's exchange.

in. No. 1, October, 1888

* * Only partly philatelic. Wanting.

COLLECTOR'S EXCHANGE. The Collector's exchange.

$8^{\circ} .9$ in. Nos. 1-2, July-August, 1891

5 \& 1 ** Only partly philatelic. Wanting no. 1

[Continued as :]

- The Collector's era. Moreland, Ill., H. Eilers, ז89 No. 3, September, 1891 *** Only partly philatelic. Wanting.

COLLFCTOR'S EXCHANGE. The Collector's exchange. The best and cheapest advertiser, published monthly. \& London, W., The Acme Stamp Co., I903. $4^{\circ} .10$ in. No. 1, April 1903.

Mis. St. Jour. 109 (2)

COLLECTORS' EXCHANGE. The Collectors' exchange.

Riceville, Ia., The Carpet and Rug Factory Co., I 905 .

$4^{\circ} \cdot 7 \frac{1}{4}$ in, No. 6, September, 1905

* Only partly philatelic. Nos. 1-5 had the title "The Photo artist" and were not philatelic.
COLLECTORS' FORTNIGHTLY SALES CATA LOGUE. Collectors' fortnightly sales catalogue.

Luton, F. O. Baner, I 90I-02.

8 $8^{\circ} .7$ in. [4 nos.] No. 1, November 18 th to December 18 th, $1901 ;$, $1-2$ - [no no.] November 27 to December 27th, 1901 ; $(\mathrm{Nol}$. I. nos. 1-2, $/ \mu /-32$ anuary 9, 24, 1902

* There is a coloured paper wrapper to each number. OIn addition to the above there is a catalogue of a sale dated October 30 th 1901, "Ohich

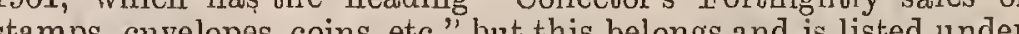
stamps, cnvelopes, coins, etc, "but this belongs and is listed unde
Mis. St. Jour. 114 (8).

COLLECTOR'S FRIEND. The Collector's friend.

Washington, D. C., H. E. Tan), I 904

in Nos. 1-2, A pril-July 1904

* * Only partly philatelic. Wanting both nos.

COLLECTORS' FRIEND. 'See FIRESIDE FRIEND.

COLLECTORS' GAZETTE AND PHOTOGRAPHIC

(- REVIEW. The Collectors' gazette and photographic review. A magazine devoted to stamps, photography, coins and picture post cards.

London, S.W., Bournemouth [printed], The Collectors' Publishing Agency, rgo3.

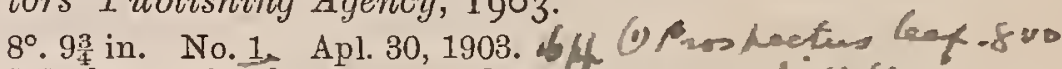
$\checkmark{ }^{*}{ }^{*}$ The number has a coloured paper wrapper. Lict fluce. Mis. St. Jour. 78 (11)

COLLECTOR'S GUIDE. The Collector's guide.

Newport, R. I., etc., Gould and Canfield, etc., 1866 $8^{\circ} .8 \frac{1}{2}$ in. Nos. 1-8, May 15-Dcc. 25, 1866

* * Nos. 3-8 were published by Stephen Gould; nos. 3-5 at New* * Nos. 3-8 were published by Stephen Gould; nos. 3-5 at Newtwo pages, printed on one side only, to no. 5 .

COLLECTOR'S GUIDE. The Collector's guide.

in. Nos. 1-2. Cincinnati, O., [?], I88I.

* Only partly philatelic. Wanting both nos.

COLLECTOR'S GUIDE. The Collector's guide. A monthly stamp journal. Philadelphia, Pa., C. B. Fernald and Co., r88z-83.

(2) $8^{\circ} .97-93$ in. Nos. 1-4, Doc., 1882-Mar., 1883.

* * No. 4 has a coloured paper wrapper and nos. 2 and 3 have supplements of (2) pp. 2 Mis. St. Jour. 10 (10).

COLLECTOR'S GUIDE. The Collector's guide. Peltzer, S. C., W. G. Whilden, Jr., 1885 . in. No. 1, March, 1885.

* * Only partly philatelic. Wanting.

COLLECTOR'S HERALD. The Collector's herald.

Hull, J. Cheeseman, I865-66.

$8^{\circ} 8$ in. Nos. 1-10, Jan.-May, 1865, Jan.-May, 1866.

* *nly partly philatelic. There is a title-page to no. 1 .

COLLECTORS' ILLUSTRATED CIRCULAR. See COLLECTORS' CIRCULAR.

COLLECTORS' ILLUSTRATED IMAGAZINE. The Collectors' illustrated magazine.

Riverside, Cal., E. M. Haight, г888.

$8^{\circ} .9$ in. Nos. 1-2, Jan.-Feb., 1888

* * Both numbers have coloured paper wrappers. There is no philatelic matter in these two numbers beyond one or two stamp advertisements. Mis. St. Jour. 70 (7)

COLLECTOR'S JOURNAL. The Collector's journal. Charlbury, John H. Clifford, I885.

$4^{\circ} .10 \frac{1}{4}$ in. No. 1 , June, 1885

* * Produced by a hand multiplying press. The front page of the * *umber is illustrated in the "Journal of the Philatelic Literature number is illustrated in the "Journal

COLLECTORS JOURNAL. The Collectors journal. Published monthly in the interest of philately.

Lynchburg, Va., The Journal Pub. Co., r886. $8^{\circ} .8 \frac{1}{2}$ in. Nos. 1-5, January-May, 1886 * No. 4 has a coloured paper wrapper. The journal was continued under the title the "Youths' mentor," but ceased to be of a philatelic character. Wanting nos. 1, 2. 


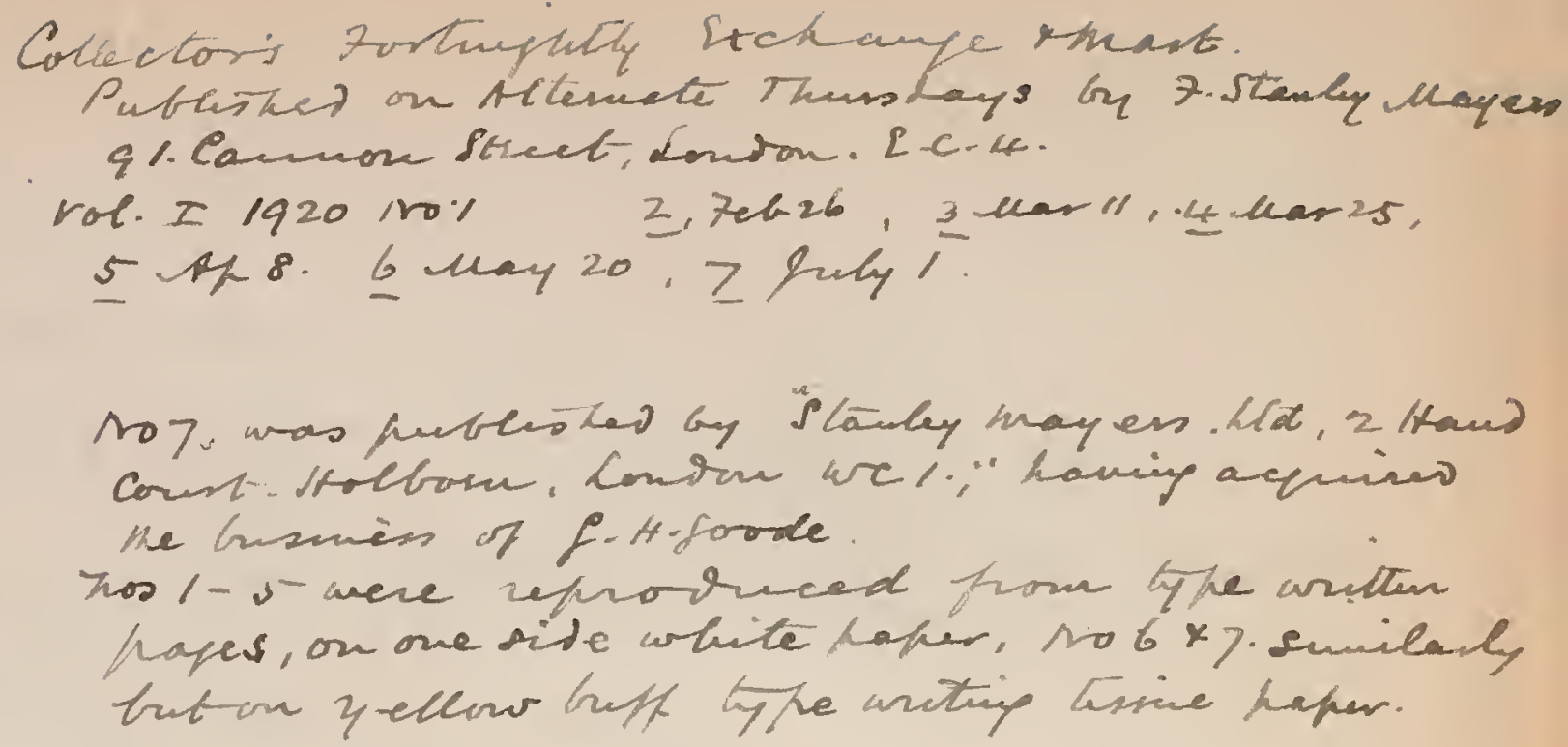

Colection' Aechange. Only aorts.

"Tounal g.p.L.5 $1 \times p 8$ 
Collectoss' fournal (coutinuation of the

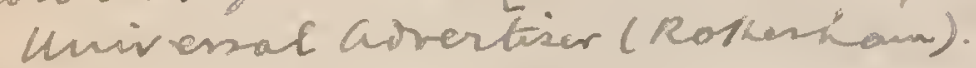
1907

vili IGII. ing g I

$\times 1919$ no 114 bee

Collectors Lebrany A.H-Pike, Antrabo:Ny.

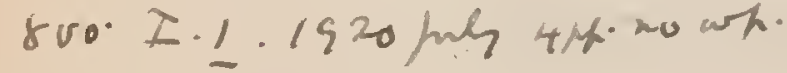

Gollectóris manuscipt Jonrnal, thentbury, 1885

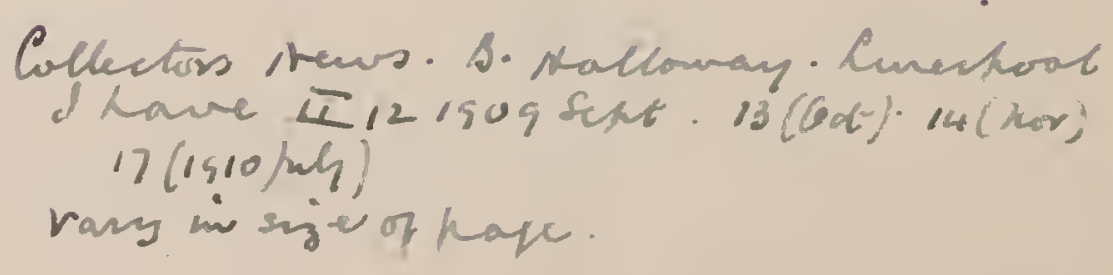

Collections stews. B. Nalloway. Amestool $17(1510 / \mathrm{ml})$ )

ravy in sijer of hafe 
COLLFCTOR'S JOURNAL. The Collector's journal. Brooklyn, N. Y., The Collector's Publishing Co., I $887-88$.

So. 89 in. Nos. 1-2, Aug., 1887-Feb., 1888

* * Only partly philatelic. There is a coloured paper wrapper to no. 1 of which there are two varieties, one being dated "July 1887," the other "August, 1887". Only the philatelic portions of no. 2 consisting of pages 13-16 have been preserved.

Mis. St. Jour. 26 (6).

COLLECTORS' JOURNAL. The Collectors' journal. Published weekly in the interest of collectors of stamps, coins, old books and imiscellaneous antiquities.

Fayette, Iowa, Frank Hammond, I90I. $8^{\circ} \cdot 10 \frac{1}{2}-10 \frac{3}{4}$ in. Nos. 1-4, Nov. 6-Nov. 27, 1901.

Mis. St. Jour. 109 (5).

COLLECTORS JOURNAL. See JOURNAL.

(Diller, Neb., I906.)

COLLECTORS' JOURNAL. See UNIVERSAL ADVERTISER. COLLECTOR'S JOURNAL. See Youth' JOURNAL. COLLECTOR'S LEDGER. See YOUTH'S LEDGER.

COLLECTOR'S LEISURE HOUR. The Collector's leisure hour. A philatelic journal.

Greenland, N. H., A. R. Smith, I 886

$8^{\circ} .10 \frac{1}{2}$ in. Nos. 1-4, Jan.-Apl., 1886. Mis. St. Jour. 59 (3).

COLLECTOR'S LIBRARY TABLE. The Collector's

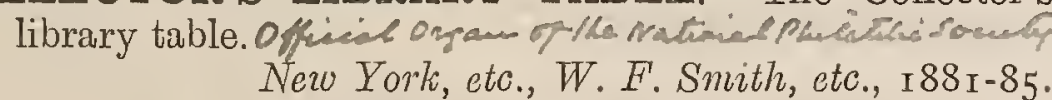
$8^{\circ} .9$ in. 15 nos. in 2 vols.

Vol. I. Oct., 1881-sept. 20, $1882 . \quad$ Nos. 1-12 "II. Nov. 20, 1852-Jan., 1883, Oct., 1885. Nos. 1- 3 * No. 1 was published at Now York by W. F. Smith, nos. 2-12 by H. F. Smith at Waterloo, N. Y., nos. 1, 2, vol. II., by H. M. Rolston at New York and no. 3, vol. Ir., by Smith and Handford at New York. No. 1, vol. II., has the words "And Rogue's gallery" added below the title on page 1. No. 9 has a coloured paper plied in a coloured paper wrapper." On page 3 of vol. I., no. 1 , the plied in a coloured paper wrapper." On page 3 of

Mis. St. Jour. 19 (1)

COLLECTOR'S MAGAZINE. The Collector's magazine. Formerly the American numismatist.

Paterson, N. J., A. Lehmann, Jr., etc., I 888 8?. 88 -9 in. Vol. II., nos. 1-3, July, Aug., Oct., 1888.

** Only partly philatelic. There is a coloured paper wrapper to each number and nos. 2 and 3 were published by the Colloctor' Publishing Co. The title of volume I. was the "American numismatis:," and this contained no philatelic matter.

Mis. St. Jour. 70 (9).

COLLECTOR'S IMAGAZINE. The Collector's magazine. Paterson, N. J., Charles E. Leal, I891. $8^{\circ} .8 \frac{1}{2}$ in. Nos. 1-4, February, March, April, July, 1891.

** Only partly philatelic. Each number has a coloured paper

COLLECTOR'S IMAGAZINE. See Printselier.

COLLECTORS' IMAGAZINE. See UnIVERSAL ADVERTISER.

COLLECTORS' IMEDIUM. The Collectors' medium. London, N., Alex. M. Charlier, I 904

C 80.71 in. Nos. 1-7, May-Nov., 1904. Mr-3LMis. St. Jour. 106 (6)

COLLECTORS' IMISCELLANY. The Collectors' mis-

- cellany. A monthly journal for stamp, coin, and curiosity collectors.

$8^{\circ} .81$ in. Nos. 1-2, Mar.-Apl., 1889

$\checkmark * *$ Both numbers hive coloured paper-wrappers. ssea

Q * Nol hos.

COLLECTOR'S MONTHLY. The Collector's monthly. Philadelphia, Pa., J. M. Faunee, I885-86. $8^{\circ} .9 \frac{1}{4}$ in. Nos. 1-[2]. December, 1885-January, 1886.

* Only partly philatelic. Tach number has a coloured paper wrapper and is numbered "Vol. I., no. 1". Cuttings of the philatelic portions of no. 1 will also be found mounted in Stamp Scrrp-book, vol, v., pp. 13, 14.

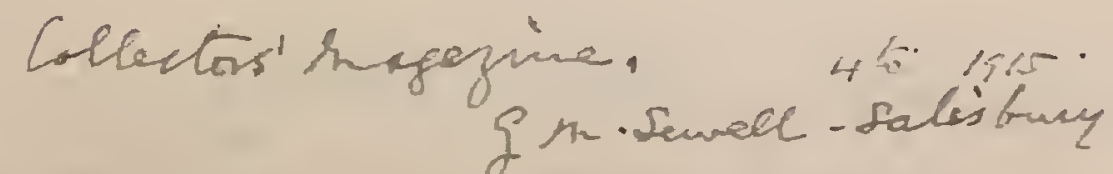

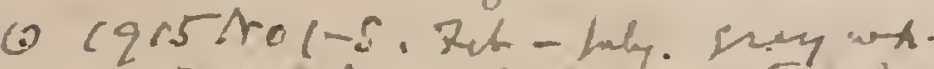

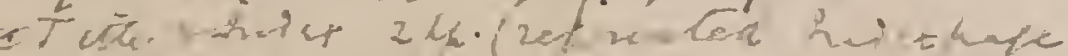

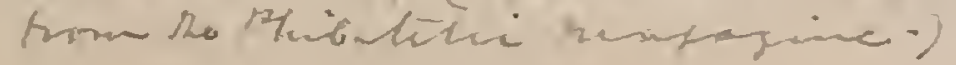

COLLECTORS' MONTHLY. The Collectors' monthly. Lynn, Mass., Bishop and Ellison, I887. $8^{\circ} .9 \frac{1}{2}$ in. No. 1 , May, 1887. Mis. St. Jour. 14 (5).

COLLECTORS' MONTHLY. The Collectors' monthly. Paspebiac, P.Q., Canada, G. P. Le Grand, igoo. $32^{\circ} \cdot 4 \frac{1}{2}$ in. No. 1, Jan. $25,1900$. *" Printed on rose paper.

Mis. St. Jour. 114 (1)

COLLECTORS' MONTHLY RECORD. The Collectors' monthly record. A journal devoted to the interests of philatelists, picture post card and collectors generally. Bolton, Yorkshire, Hardman Bros., I905.

So. 10 in. Nos. 1-3, June-Aug., 1905.

** There is a coloured paper wrapper to each number. frasich reen

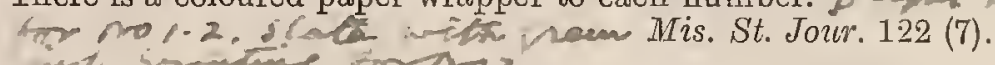

COLLECTOR'S NEWS. Collector's news. In the interest of coin and stamp collectors.

North Adams, Mass., Tunnel City Coin Co., etc., 1875-76.

$24^{\circ} .5 \frac{1}{2}-5$ in. and $8^{\circ} .81$ in. 13 nos. in 2 vols

Vol. I. Sept., 1875-Äug., 1876. Nos. 1-12

*" II. Sept., $1876 . \quad$ No. 1

* Nos. 1-9 are $24^{\circ}$. and the remainder are $8^{\circ}$; nos. $2-9$ were puolished by Adams Coin Co. and nos. 10-12 and no. 1, vol. Ir., by Turner, Richmond and Temple. On nos. 5, 6, 10, 11, and 12 the
title reads "Collectors' news".
MIis. St. Jout. 29 (7).

COLLECTOR'S NEWS. The Collector's news. Postage stamps, coins, autographs, minerals, etc.

Plainfield, N. J., G. B. de Revere, Jr., I879-80. $8^{\circ} .11$ in. Nos. 1-5, Sept., 1879-Jan., 1880.

"." No. 5 has in place of " Postage stamps, coins . . etc.," " Official organ of the National Philatelic Exchange". ". Mis. St. Jour. 6 (2)

COLLECTORS NEWS. The Collectors news. Issued monthly. Useful and interesting to stamp collectors. B̈loomington, Ill., J. C. Becker and Co., ete., 1880. $8^{\circ} .7 \frac{1}{2}$ in. Nos. 1-5, June-Oct., 1880.

* * Nos. 4 and 5 were published by J. C. Becker and G. F. Egert. No. 1 , June, 1880 , is wrongly numbered " 2 "

Mis. St. Jour. 41 (4)

COLLECTORS NEWS. The Collectors news.

Duanesburgh, N. Y., I. B. Moore, I889-9o.

8. $8 \frac{1}{2}-8 \frac{3}{4}$ in. Nos. 1-7, July, 18s9-January, 1890.

** OOnly partly philatclic. Nos. 3-6 have no year given. Want-
ing no. 7 .

COLLECTOR'S NEWS. The Collector's news.

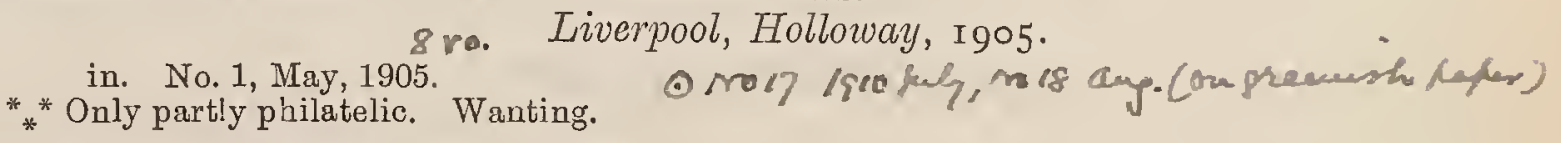

COLLECTORS NEWS. The Collector's news.

in. Nos. 1 -

E. Spokane, Wash., [?

], 1906.

** Only partly philatclic. Wanting all nos.

COLLECTORS' NEWS AND PASTIMES REVIEW.

See "I. P. R." AND ColteCtors' News.

COLLFCTORS NOTE BOOK. The Collectors note book. Devoted to stamps, coins, paper money, curiosities, autographs, books, Indian relics, mineralogy, natural history, etc.

Camden, N. J., Thomas Burnett, etc., I903-05. $8^{\circ} .7 \frac{1}{2}$ in. 15 nos. in 3 vols.

Vol. I. Dec., 1903-May, 1904. Nos. 1-6.

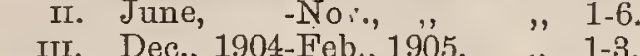

*" "There is a title-page and an index to vol. I. and a pape wrapper to each number. The three numbers of vol, III, vere published by Robert J. Wythe. A copy of the prospectus of the journal is bound up with the numbers.

COLLECTOR'S OWN. The Collector's own.

Concord, N. H., E. B. Crapo, 1875-76.

$8^{\circ} .9 \frac{1}{4}$ in. Nos, 1-2, Dec., 1875-Feb., 1876

Mis. St. Jour. 18 (12).

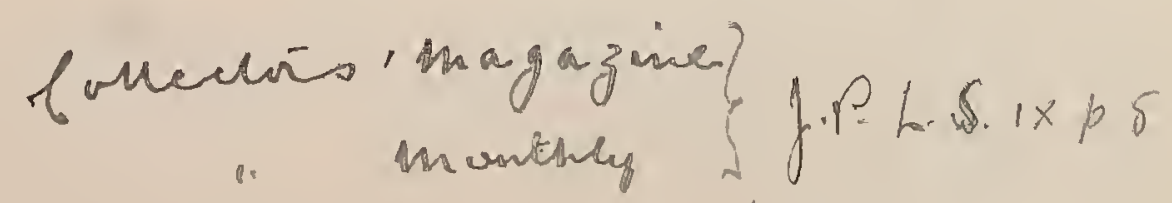


COLLECTORS' OWN. The Collectors' own. Devoted to the interest of stamp collectors.

Syracuse, N. Y., C. C. De Puy, I876-77. $8^{\circ} .97$ in. Nos. 1-6, Nov. 15, 1876-Apl. 15, 1877.

* * There is a slip supplement to no. 1 . Continued as a nonphilatelic journal with the title "Union gem".

Mis. St. Jour. 18 (7).

COLLECTORS' OWN AND PHILATELIC EX6 TRACT. The Collectors' own and philatelic extract. London, S.E., Lawrence and Co., I893. $68^{\circ} .8 \frac{1}{1}$ in. No. 1, July 10, 1893. an tinter hapur. 4 ph. ** Bound up with the number is a copy of the prospectus of the
journal.
Mis. St. Jour. $79(4)$. Mis. St. Jour. 79 (4).

COLLECTOR'S PRESS. The Collector's press.

Richmond, Va., etc., The Antique Publishing and Supply Co., etc., 1892-93.

$8^{\circ} .7$ in. and $4^{\circ} .7 \frac{1}{4}$ in. 7 nos. in 2 vols.

Vol. I. Apl., June, July, Aug., Sept., Dec., 1892. Nos. 1-6.

*" II. Jan., 1893. No. 1.

* * Nos. 1-5, vol. I., are octavo and the two other numbers are quarto. Nos. 2-5, vol. 1., were published by J. C. Weckert, at Richmond, and the remaining two numbers by James $\mathrm{H}$. Sexton, Jr., at Malden, Mass. Each number has a coloured paper
wrapper.
Mis. St. Jour. 67 (4).

COLLECTOR'S QUARTERLY. The Collector's quarterly.

Galveston, Tex., F. P. Cravens, I880. $8^{\circ} .113$ in. Nos. 1-2, July 1-October, 1880.

Mis. St. Jour. 3 (10).

COLLECTORS' REVIFW. The Collectors' review. Toledo, O., Ed. M. Reed and Co., etc., I873. $16^{\circ} .6$ in. Nos. 1-3, Jan., Feb., Apl., 1873.

* * No. 3 was published by Reed, Wheeler and Co. Mis. St. Jour. 68 (17).

COLLECTOR'S REVIEW. The Collector's review. Denver, Colo., H. A. Babb and F. E. Carstarphen, etc., I886-88.

$8^{\circ} .9$ in. 19 nos. in 2 vols

Vol. I. Oct., 1886-Sept., 1887

" II. " $\quad$-Dec., 1887, May-Aug., $1888 . \quad$ Nos. 1-12.

* * No 3-7, vol. II., were published by Charles G." Woodworth. Each number, with the exception of nos. 1-6, has a coloured paper wiapper. Succeeded by the "Collector's comment".

COLLECTOR'S REVIEW. The Collector's review. Denver, Colo., etc., E. W. Plummer, 1893. $8^{\circ} .9$ in. and $10 \frac{1}{2}$ in. Nos. 1-4, Apl. 1, May, June, Sept., 1893. ** Nos. 1-3 are octavo 9 inches and no. 4 is octavo $10 \frac{1}{2}$ inches. The last number was published at Berkelcy, Colo. A copy of the prospectus issued after the publication of no. 3 is bound up with
the four numbers.
Mis. St. Jour. 62 (7).

COLLECTORS' REVIEW. The Collectors' review. Tipton, Staffs., William Haddon, [ I905].

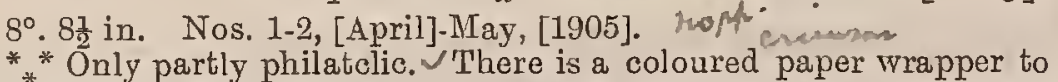
*ach number, no. 1 has no date and no. 2 bears "May " only.
Mis. St. Jour. 112 (4).

COLLECTOR'S REVIEW AND EXCHANGE. The (.) Collector's review and exchange. Tipton, Staffs., Willram Haddon, I904. (c) $3^{\circ} .7 \frac{1}{2}$ in. No. 1 , October, $1904 . \quad 4 \mu$.

${ }^{*}$ ** The contents, which consist entirely of advertisements, are only partly philatelic. Mis. St. Jour. 112 (1).

COLLECTORS' SCIENCE MONTHLY. The Collectors' science monthly.

Battle Creek, Mich., Howes and Spaulding, I886. $8^{\circ} .9$ in. Nos. 1-3, Mar., Apl., Nov., 1886.

** Only partly philatelic. There is a coloured paper wrapper to each number.

Mis. St. Jour. $70: 10)$.

COLLECTOR'S STAMP JOURNAL. The Collector's stamp journal.

Lake Village, N. H., The Belknap Stamp Co., I891. $8^{\circ} .8^{3}$ in. Nos. 1-6, Apl., July-Nov., 1891.

*** No. 1 has a coloured paper wrapper. Mis. St. Jour. 47 (2).

COLLFCTORS' STANDARD. See MoHawk Standard, ADVERTISER AND CHRONICLE.
COLLECTORS' STAR. Collectors' star.

Pawnee City, Neb., Star Publishing Co., I 888 . $8^{\circ} .9$ in. Nos. 1-2, Jan.-Mar., 1888.

*** Only partly philatelic. The title of 2 reads "The Collectors' star".

COLLECTORS' UNIVERSAL ADVERTISER. See UNIVERSAL ADVERTISER.

COLLECTORS' WerkLY. See Hawkexe State col. LECTOR.

\section{COLLECTORS' WEEKLY EXCHANGE AND TRADF}

(2) ADVERTISER. The Collectors' weekly exchange and trade advertiser.

Bayswater, London, W., The Collectors' Supply Agency, I903.

(3) $8^{\circ}$. 111 in. Nos. 1-9, May 9, 16, 23, 30, June 13, 20, 27, July 11 , $18,1903$.

$V^{* *}$ Nos. 5-9 have supplements with the title "Sale and TX-

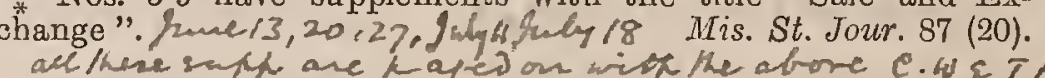

COLLECTOR'S WORLD. The Collector's world. Postage stamps, coins, medals, autographs, minerals, etc. New York, H. W. Oram and Co., etc., I878-79. 8०. 83 in. Nos. 1-12, Sept., 1878-Mar., May, July, Aug., Oct., 1879. * * The sub-title on nos. 8-12 reads "A journal devoted to the interest of stamp collectors " and these numbers were published by C. H. Coster. Nos. 11 and 12 were published together under the date "October, 1879 "

COLLECTORS' WORLD. The Collectors' world. Williamsville, Mass., W. B. Hale, I887-88.

$8^{\circ} .9$ in. 6 nos. in 2 vols.

Vol. I. Nov. 20-Dec. 20, 1887. Nos. 1-2

II. Feb. 20-Apl. 20, 1888.

* * Only partly philatelic Nos. 1 " and 2 have coloured paper wrappers and nos. 3 and 4 were published together unde: the date "February 20, 1888 ". No. 2 and nos. 3 and 4 have added under the title "Pnilatelic bazar. Volume 2. No. 3," and "No. 4," respectively. Mis. St. Jour. 70 (6).

COLLFCTOR'S WORLD. The Collector's world.

Calmar, Iowa, C. Scott, I89 I.

in. Nos. 1-3, January-March, 1891

** Only partly philatelic. Wanting all three nos.

COLLECTORS' WORLD. The Collectors' world. 94. North Leominster, Mass., Walter E. Billinys, I892-

8०. $8 \frac{1}{2}-7 \frac{1}{2}$ in. 9 nos. in 3 vols.

Vol. I. May, July, Sept., Oct. and Nov., Dec., 1892. Nos. 1-6.

"Ir. June, July, 1893. Nos. 7-8.

". Irr. May, 1894. No. 9.

* * No. 2 is octavo $7 \frac{1}{2}$ inches and the remainder are octavo $8 \frac{1}{2}$ inches. Nos. 4 and 5 were published together. Wanting no. 9.

COLLECTORS WORLD. The Collectors world.

$$
\text { Walla Walla, Wash., [? ], } 1906 .
$$

* *n. Nos. $1-3$.

COLLETTORE ITALIANO. Il Collettore Italiano. Rivista mensile di timbrofilia. Torino, Ghiotti Bartolomeo, etc., I88I. Fol. 123 in. Nos. 1-7, Jan. 29-July, 1881.

Nos. 6 and 7 were published together under the date "Giugno e Nos. 6 and 7 were published together under the date "Giugno e Luglio, 1881," and nos. 3-7 were published by Villanis Piet 0 . The front page of the double number 6-7, is illustrated in the "Journal of the Philatelic Literature Society" of April, 1190. .
Wanting nos. 6,7 . Sour. 116 (5).

COLLEZIONISTA. Il Collezionista. Giornale mensile d'annunzi. Fol. $13 \frac{1}{2}$ in. 11 nos. in 2 vols. Torino, G. Oggero, I891-92. (C) 1st year. July 25-Dec. 25, 1891 . Nos. 1- 6 C) 2nd year. Jan. 25-1lay 25,1892 . 11 - 71 . ** Nos. 10 and 11 were published together under the date " 25 M"aggio $1892 "$

$$
\begin{aligned}
& \text { - Colbetors wackly. Rotterham. }
\end{aligned}
$$

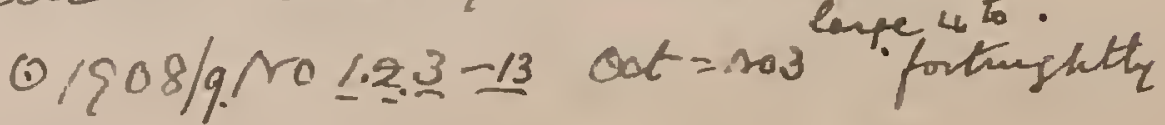




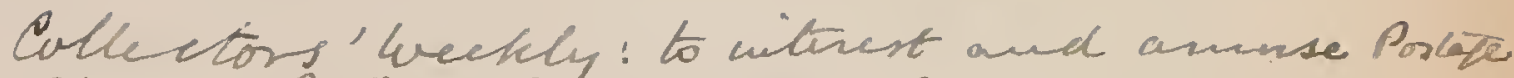
Stomp, Putire Postent, Coni, Cuni, Mhatural Jivis tory Cullectors"

Folio.

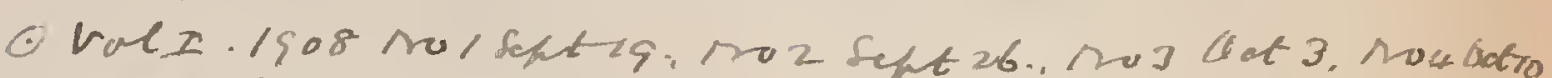

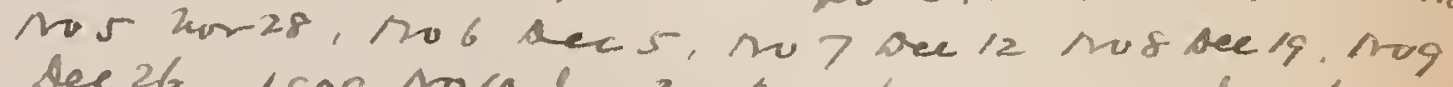
dee 261509 ro/o fane 2 . No/l fang no 12 fan 16 ro/ $\tan 25$ 
The colongiar. tran Jmperial medum of

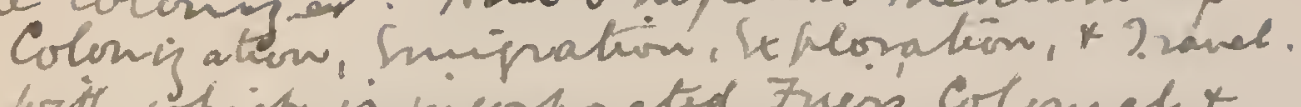
soith which is incoshnated Fuess Colomalt Incipir Refistes.

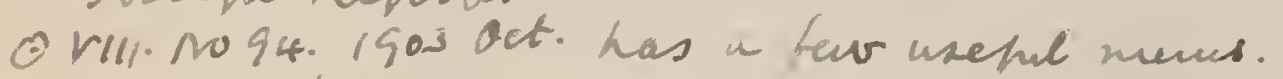
on posts. it.

folomar thagazone fop.h.s axp 8

Colonial stiamp tomentir - S88

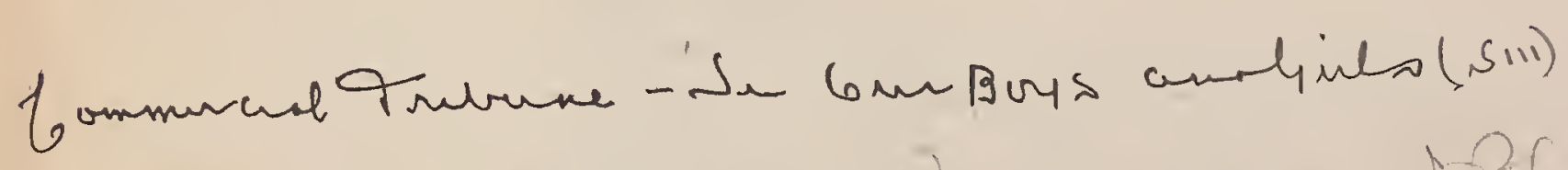

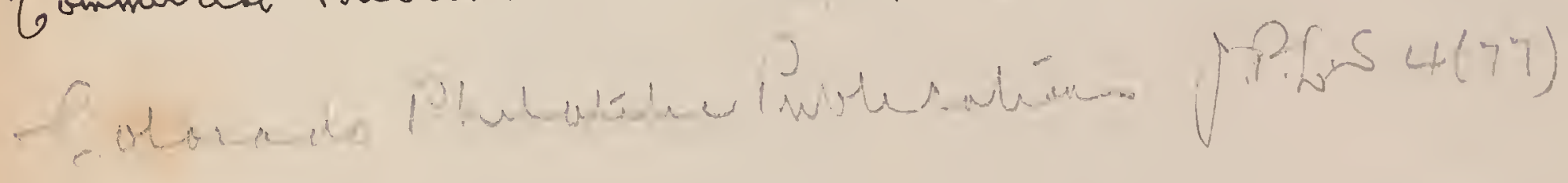


COLLEZIONISTA. Il Collezionista. (Le Collectionneur) (Der Sammler-The Collector-El Colleccionista). Bologna, M. E. De-Sperati, г goo. C) $8^{\circ} .10$ in. Nos. 1-2, Feb., March-A pril, 1900. Mis. St. Jour. 117 (27).

1) Il Collezionista-Le Collectionneur-Der Collezionista. Serie III. Napoli, M. de Sperati, I go6. Fol. 133 in. Nos. 1 (8)-2 (9), November-December, 1906.

CÖLNISCHE BRIFFIMARKEN-ZEITUNG. Cölnische Briefmarken-Zeitung.

4. 113 in. Nos, 1-4, June 1-Sept 1, 1901

Cöln, H. B. Nehrhaupt, r 904

efmarken-Zeitung" Iis. St. Jour. 116 (8)

COLOMBIA POSTAL. Colombia postal. [Two copies of the prospectus, with differentillustrations, of a journal to be published by C. Gastelbondo, Barranquilla, on July 1, 1895, but which was never issued.] Mis. St. Jour. 118 (5)

COLOMBIA POSTAL. Colombia postal. Medellin, Alberto Arango T., r9o4. $8^{\circ} .9 \frac{7}{2}$ in. Nos. 1-4, Feb., A pril, June, 1904

" Nos. 2 and 3 were published together under the date "A bril is date " "wach number has a coloured paper wrapper. No. 4 Mis. St. Jour. 105 (2).

COLONIAL. The Colonial.

Athol, Mass., The Colonial Publishing Co., Igoz. $4^{\circ} 73$ in. and $8^{\circ} .9 \frac{1}{2}$ in. Nos. 1-2, March-April, 1902.

* *nly partly philatelic. No. 1 is quarto, no. 2, octavo and ach number has a coloured paper wrapper.

Mis. St. Jour. 143 (13).

COLONIAL STAMP. The Colonial stamp.

$16^{\circ} \cdot 6$ in. No. 1,1898

Toronto, The Colonial Stamp Co., 1898.

** Printed onlrose paper. The month of publication is not given.

Issued by $H$. W. Garrard trading as the Colonial Stamp Co

There were 250 copies printed of which only $40-50$ copies were cir-
culated and the remainder destroyed.
Mis. St. Jour. 125 (1).

COLONIAL STAIIP ADVERTISER. The Colonial stamp advertiser. [Prospectus of a journal to be published by A. B. Sheraton, St. John, New Brunswick, on October 20th, 1865, but which was never issued.] Mis. St. Jour. 38 (3).

COLUIMBIAN. The Columbian.

Columbus, O., George W. Limn, rgor. $32^{\circ} .43$ in. No. 1, January, 1901

Mis. St. Jour. 94 (1).

[Continued as :]

The Columbus philatelist.

Columbus, O., George W. Linn, rgor-oz.

$12^{\circ} .6$ in. and $8^{\circ} .9$ in. 12 nos. in 3 vols.

Vol. I. Feb.-Sept., 1901. Nos. 2-9.

" Ir. Oct.-Dec., 1901. 1" 1-3.

*" TII. Jan., 1902. No. 1

* those of vol, II. and vol. III.

re octavo, and the numbers of vol. r. have paper wrappers.

Mis. St. Jour. 94 (1a).

The Columbus philatelist.

Columbus, O., George W. Linn, I905-07.

$8^{\circ} .7 \frac{1}{4}$ in. and 9 in. Vols. IV.-VIr. 19 nos.

Vol. IV. Fourth quarter, 1905. No. 1.

" v. F'eb., 1906. No. 1.

" vi. March-Dec., 1906. Nos. 1-10.

*" VII. Jan.-July, 1907. " 1- 7

* Each number has a paper wrapper. The numbers of vols.

$I \nabla$. and $\nabla$. measure $7 \frac{1}{4}$ inches and those of vols $\mathrm{Vr}$. and VIr., 9

inches. Nos. 1 and 2, vol. vII., were published together. Nos. 1 ,

2, 4 and 5 of vol. vIr., each con tain a supplement of four pages of

a philatelic novel : "Polately" by Ad. Reamer. Amalgamated
COLUIMBIAN ERA. The Columbian era

Hinsdale, Ill., The Columbian Era Publishing Co., r $893-94$.

$8^{\circ} .8$ in. Nos. 1-10, [? ]-August, 1894

** Only partly philatelic. Nos. 7 and 10 have coloured paper

COLUMBIAN PHILATELIST. The Columbian philatelist. Windsor, Conn., etc., J. F. Dodge, I896-98 $8^{\circ} .8-8 \frac{3}{4}$ in. 30 nos. in 5 vols.

Vol. I. F'eb. 20, Mar. 20, May 20, Aug. 20, Sept. 20, Oct. 20 1896. Nos. 1-6.

"II. Nov. 20, 1896-Ap]. 20, 1897. Nos. [7]-12

" III. May 20, -Oct. 20, 1897.' ", 13:18

IV. Nov. 20, 1897-Apl. 20, 1898.

* " V. May 20, - -Oct. 20,1898 . "25-30.

* No.1 measures 8 inches and tho remaining numbers $8 \frac{3}{4}$ inches. Nos. 6-30 were published at New Oxford, $\mathrm{Pa}$. and nos. 2-24 hav coloured paper wrappers. No. 3 is wrongly numbered " 2," except on the paper wrapper, which is correct, and nos. 1 and 2 o vol. Ir., do not bear "Whole no. F" or "whole no. 8". Amalgamated with the "Tri-Monthly collector," January, 1899

COLUMBUS PHILATELIST. See CoLumbIaN.

COIMERCIO FILATËLICO. El Comercio filatèlico.

Publicación filatèlica quincenal.

Paranú, Argentine Republic, José G. Sardá, I893.

Fol. 123 in. Nos. 1-3, Oct, 1, 16, Nov, 1, 1893.

Mis. St. Jour. 75 (2)

COMIMRCANT DE TIMIBRES-POSTE. Le Commerçant de timbres-poste. Spécialement réservé aux annonces.

$8^{\circ} .12 \frac{1}{2}$ in. 16 nos. in 3 vols.

Genève, $F$. Serveltaz, r885-87.

1st year. Feb. 1, 1885-Feb., 1886. Nos. 1-12.

0 2nd " Apl. 15, July 1, Dec. 15, 1886. Nos. 1-3.

() 3rd " Mar. 15, 1887. No. 1.

*** There is no number for November, 1885, and nos. 11 and 12 were published together, under the date "Janvier et F'évrier

COMIMERCE CARTOPHILATÉLIQUE. Le Commerce cartophilatélique Saluzzo, Italie, G. Bellino, rgo6-o9. $8^{\circ} .10$ in., fol. $12^{3}$ in. and $4^{\circ} .8 \frac{1}{2}-8{ }_{4}^{3}$ in. 20 nos. in 4 rols. 1st year. Oct.-Nov., 1906. Nos. 1, 2, 3.

2nd " Jan.-Dec., 1907. Nos. 4-12.

4 th " " "-Feb., Apl., June, Aug., Oct., 1908. Nos. 1-[6]

5th " " -Mar., Apl.-June, 1909. Nos. 1-2.

* Nos. 1-3 were published together. This treble number is octavo and was printed by autographic lithography but future numbers were printed in the ordinary way. Nos $4,5,6 ; 7,8,9$; and $10,11,12$, are folio and were, severally, published together. There are no numbers for July or August 1907 and nos. 10, 11, 12 are dated "Settembre-Dicembre 1907". The numbers of 1908 and 1909 arekquarto and are wrongly numbered fourth year and fifth year, respectively, and of the numbers of 1908 only the first, dated "Gennaio-Febbraio," bears a number viz: "n. 1-2". Want-
ing nos. 1 and 2 of 1909.

COMIMERE PHIIATÉLIQUE. Le Commerce philatélique. Campagna, G. Giannuzzi, I goo-or. Fol. $14-13 \frac{1}{2}$ in. 10 nos. in 2 vols.

G1st year. Apl.-Nov. 20. 1900, "Numero di suggio" and nos. 2-8. 2nd'", Dec.-Jan., Feb. 1, 1901. Nos. 9, 10

[Continued as :]

- Le Commerce philatélique et philocartiste.

2nd year. Mar. 1-May 1, 1901. Nos. 11-13.

Campagna, G. Giannuzzi, rgor.

Mis. St. Jour. 108 (15a).

COIMIMERCE PHILATÉLIQUE FT PHILOCAR-

TISTE. See COMMEROE PHILATÉLIQUE.

COIMERCIAL IIONTHLY. The Commercial monthly. in. No. 1

Saratoga Springs, N. Y., [?], r goo.

* Only partly philatelic. Wanting.

COMMERCIO DEI FRANCOBOLLI. Sé PART I. RagoziNo (ETTORE) 
COMMERCIO FILATELICO INTERNAZIONALE. Il Commercio filatelico internazionale.

Bologna, Ubaldo Gregorie Co., etc., I895. Fol. 14 in. Nos. 1-3, Jan. 1-Mar. 1, 1895.

* There is a coloured paper wrapper to each number. No. 3 was published by Ubaldo Gregori. The contents consist entirely of advertisements.

COIMMFRS-ZEITUNG. See Kommers-ZEITUNG (Gössnitz).

COMIMON SENSE. Common sense.

Mexico, N. Y., F. A. Thomas, I887-88. Fol. 12 in. and $8^{\circ} .9 \frac{3}{4}$ in. 15 nos. in 2 vols.

Vol. I. Mar.-July, 1887, Oct. 1887-Apl., 1888. Nos. 1-12.

(. "IT. May-July, 1888. Nos. 1-3.

* * Only partly philatelic. Nos. 1-6 and 11, 12 are folio and the remaining nos. $7,8,9,10$, and vol. II., nos. $1-3$ are octavo. The last seven have coloured paper wrappers.' Cuttings of the philatelic portions from nos. 1-8 and from nos. 10 and 12, vol. I., are also mounted in Stamp Scrap-book, vol. V., pp. 109-115 and in จol. $\nabla I_{.}$, pp. 2-8, and 11-13.

[Continued as :]

Common sense and exchanger's friend.

Mexico, N. Y., F. A. Thomas, I888-89. $8^{\circ} .9 \frac{1}{2}-9$ in. and fol. 12 in. Vol. II., 8 nos.

Vol. II. Dec. 1888-A pl., June, Oct. 1, Nov. 1, 1889. Nos. 15-[22] * Only partly philatelic. Nos. $15-17$ are octavo and the remaining * "Onbers are folio. Nos. 21 and 22 are both wrongly numbered "vol. II., no. 12 ". Nos. 16,17 , have coloured papers wrappers "vol. II., no. 12 " Nos. 16, 17, have coloured papers wrappers with the title the "Collector's common son

COMMON SENSE AND EXCHANGER'S FRIEND. See COMMON,SENsE.

COIMPANION AND PHILATELIC NEWS. The Companion and philatelic news.

Purity and Lorraine, Va., Coleman, Deitrick and G. T. Kesler, 1894

$8^{\circ} .8 \frac{1}{2}$ in. Nos. 1-3, Apl., May, July, 1894

** There is a coloured paper wrapper to each number. The wrappers to nos. 1 and 2 bear no

Mis. St. Jour. 64 (11).

COMPANION TO THE [BRITISH] ALIMANAC. The Companion to the [British] almanac for 1838. [Contains an article "xv. - New System of Twopenny Post".]

$8^{\circ} .7$ in. pp. $115-120$

[London, Charles Knight and Co., I83s.]

* This and the following five extracts are bound up in a volume lettered "Gt. Britain-Articles on Post Office, etc., 1838-77".

- For 1839. [Contains an article "xII.-The Uniform Penny Postage ".]

$8^{\circ} .7$ in. pp. 107-112

[London, Charles Knight and Co., I839.]

—_ For 1840. [Contains an article "vII.-The History of the Post-Office," also tables giving the number of letters passing through the post.]

[London, Charles Knight and Co., I\$40.] $8^{\circ} .7$ in. pp. 62-76 and pp. 190-192.

- For 1841. [Contains two articles "vIr.-Effect of the new Post Office arrangements upon the number of letters," and "XXI.-Minute of the Treasury for the regulation of the Postage ".]

[London, Charles Knight and Co., I84I.] $8^{\circ} .7$ in. pp. 97-106 and pp. 261-263.

- For 1842. [Contains an article "vIrr.-Effect of the Penny Postage on the number of letters and on the revenue of the Post-Office". 8. 7 in. pp. $92-100$

[London, Charles Knight and Co., r842.]

For 1851. [Contains an article "Ocean SteamersForeign Mails".]

$8^{\circ} .7$ in. pp. $52-75$

[London Charles Knight and Co., I851.]
CONEWAGO CURIO. The Conewago curio.

Hanover, Pa., Dodge and Mondorff, etc., I904-06. $8^{\circ} .9 \pm$ in. nos. in 3 vols.

Vol. I. 1904-Nov., 1905. Nos. 1-12.

"II.

*" Only partly philatelic. Commencing with no. vol. I., the "* Only partly philatelic. Commencing with no. vol. I., the journal was published by $F$. L. Dodge. No. 6 , vol. II., is wrongly

\section{CONFIDENTIA. Confidentia.}

Amsterdam, M. Z. Booleman, I904-

$8^{\circ} .10-10 \frac{1}{4}$ in. nos. in. vols. In progress.

1st year. Oct. 1904-Mar., Apl./May, Oct., 1905. Nos. 1-8.

C. 2nd "N Nov., 1905, Jan., Mar., June, 1906. Nos. 9-12.

(1) 3rd "Nov., 1906, May, 1907. Nos. 13-14.

* Nos. 1-7 are printed on green paper and mcasure 10 inches $\checkmark$ and nos. 9-N are on white paper and measure $10 \frac{1}{4}$ inches.

CONNECTICUT PHILATELIST. The Connecticut philatelist. A monthly devoted to philately and philatelists.

Meriden, Conn., The Silver City Stamp Co., 1896. 8. 8-81 in. Nos. 1-2, Mar.-Apl., 1896

* There is a paper wrapper to each number. Edited by W. H.

U* There is a paper wrapper to each number.
Mis. St. Jour. y3 (10).

CONNOISSEUR. The Connoisseur. An illustrated magazine for collectors.

London, Sampson Low, Marston and Co. Ltd., etc., I 90 I-

$4^{\circ} .11$ in. nos. in vols. In progress.

Vol. I. Sept.-Dec., 1901. Nos. 1- 4.

"II. Jan. -Apl., 1902. " 5-8.

" III. May -Aug., 1902. " 9-12.

v. Jan. -Apl., 1903. " 17-20.

"VI May -Aug, 1903. " 217 .

"VI. May -Aug., 1903. " 21-24.

" VIII. Jan -Apl, 1904 " 25-28.

" VIX Jay - Aug., 1904 " $293-36$.

" Lx. May -Aug., 1904. " $33-36$.

" x. Sep. -Apl, 1905. " $" 37-40$.

" XI. Jan. -Apl., 1905. " $41-44$.

" XII. May -Aug., 1905. " 45-48.

$"$ XIII. Sept.-Dec., 1905. " $49-52$.

" xiv. Jas.

" Xv. Mri

* " * "Ech number usually contains uotes or an article on postage * Each number usually contains notes or an article on postage stamps. There is a title-page and an indox to each volume aud a paper wrapper to each number. Commoncing with no. 7, tho journal has been published by Oto Limited. For supplements no. 53 has "vol. XIII." in place of "vol. xIV.".

CONSEILLER DU TIMBROPHILE. Le Conseiller $d u$ timbrophile.

Paris, A. Forbin et Cie., I 892-93. $8^{\circ} .91-93$ in Nos, 1-13, Sept. 15, 1892-Sept, 1893. * * No 1 consists of "Catalogue-Prix-Courant de Timbres-Poste". * 10 and 11 and 12 and 13 were severally published together Nos. 10 and 11 a " 12 and 13 were severally published together supplement of two pages, printed on one side only, to no. 6.

supplement of two pages, printed on one side only, to no. 6.
Mis. St. Jour. 57 (3).

CONSIGLIERE FILATELICO. Il Consigliere filatelico. Palermo, Perniciaro Ermenegildo, I895. Fol. 16 in Nos. 1-4, Jan. 10-Apl. 5, 1895.

* Nos. 3 and 4 were published together. Amalgamated with "Italia Filatelica" in September 1895.

Mis. St. Jour. 108 (17)

CONTINENTAL AND COLONIAL STAIMP ADVER TISFR. The Continental and colonial stamp advertiser. Hecles, Manchester, James Gregson, I863 $8^{\circ} .8 \frac{1}{2}$ in. No. 1 , October $1,1863$.

* * The contents consist entirely of advertisements. Wanting.

CONTINENTAL PHILATELIC MAGAZINE. The

() Continental philatelic magazine.

Amsterdam, C. van Rinsum, r869-70. $4^{\circ} .81$ in. Nos. 1-8, Feb.-July 15, Dec. 15, 1869, Jan. 15, 1870. * "There is a paper wrapper to each number. Nos. 7 and 803,8 full sy the first philatelic magazine published in Holland. 


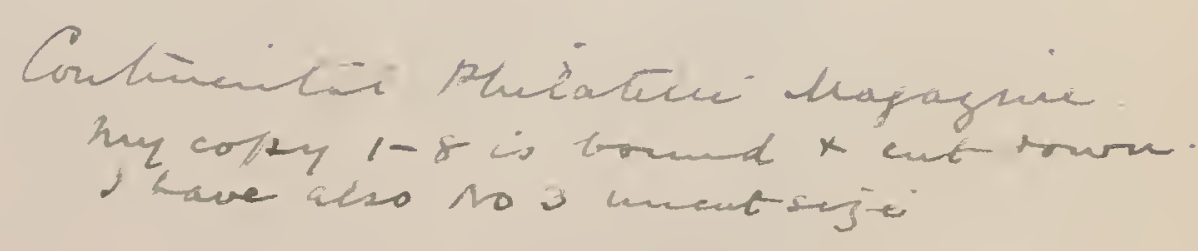


CORPORATION INTERNATIONAL DES NEGOCIANTES EN TIMBRES POSTEA BRUXELLES

Lomapounant-Panis (Not 168, 25.9.1892) - \$89. 


\section{CO-OPERATIVE ADVERTISER}

CO-OPERATIVE ADVERTISER. The Co-operative advertiser. Issued in the interest of common-sense philately and the Co-operative Collectors Company.

Syracuse, N. Y., The Co-operative Collectors Co., I 903 .

$16^{\circ} .6$ in. Nos. 1-3, February 1-April 1, 1903.

* * Wanting all but no. 3 .

CORREIO LUZITANO. Correio Luzitano.

Lisbonne, José Pinto Castello Branco, etc., I888-9o. Fol. $18 \mathbf{1}_{4}-20 \frac{1}{2}$ in. 19 nos. in 2 vols.

(1st year. Sept. 1888-Aug., 1889. Nos. 1-12.

2nd " " 1889-Mar., $1890 ., " 1-7$.

** * The numbers of the second year "were published by Carvalho and Almeida. Besides bearing "anno II " they have "2a serie" and no. 2 is numbered "No. 14 " instead of " 2 ". "The numbers of the first year-with the exception of no. 10 which has "numero dedié ála France "-have the sub-title "Folha politica, Philatelica, Telegrapho-postal, litteraria e noticiosa " and those of the second year have "Follha Philatelica $\theta$ noticiosa". $\vee$ No. 10 is printed in blue and red and nos $Y_{4-7}$ of the second year contain 32 pages of "Um Conto Africano. Parte Primeira. Mussá". Wanting
second year no. 5 . Wis. St. Jour. 127 (18).

CORREO DE CUBA. El Correo de Cuba. Semanario postal y filatélico.

Habana, José Costa, I 900-ог. Eol. 12子 in. Nos. 1-18, Nov, 1, 1900-Mar. 23, 1901.

" * * Nos. 1 -12 have paper: wrappers. Wanting no. 12

CORREO DFL CARIBE. El Correo del Caribe. Publicación mensual. Literatura, bellas artes, filatélia, ecos del exterior. Curazao, Chumaceiro y de Lima, I89I-92. Fol. $13^{3}$ in. 15 nos. in 2 vols. 1st year. F'ob. 10, 1891-Jan. 10, 1892. Nos. 1-12. * ${ }^{*}$ "Th" sub-title on nos. $10-15$ reads "Publicación mensual Dedicada exclusivamente a la filatelia". Nos. 12 "and 14 contain supplements. This was the first philatelic journal published in Curacao. Wanting nos. 4, 11

CORREO FILATELICO. Correo filatélico.

Santiago de Chile, Julian Ramos y Luis Lacoste, etc., 1902-03.

(c) $8^{\circ} .8$ in in. Nos. 1-12, Oct. 15, 1902-Aug. 1903.

** Nos. 3-12 were published by Juliàn Ramos, and nos. 4 and 5 , $V_{6}{ }^{*}$ and 7,8 to 10 , and 11 and 12 were severally published together under the respcctive dates " Febrero 15 de 1903," "Marzo y Abril de 1903" "iJlayo á Julio de 1903," and "Junio á Agosto de 1903 ". Each number has a paper wrapper. Mis. St. Jour. 102 (7).

CORREO ILUSTRADO. El Correo ilustrado. Madrid, D. E. Verdegay, I 896-97. $8^{\circ} .10^{3}$ in. nos. in 2 vols. 1st year. June 25-Dec., 1896. Nos. 1-13.

* * Only one or two of the numbers contain philatelic matter. Wanting nos. 5, 6, 8, 9, 11-26 and any after no. 27 . The last is dated "30 de Julio de 1897 ".

CORREO POSTAL. El Correo postal. Revista mensual filatélica y cartófila.

San José, Costa Rica, Vargas y Benavides, I 906. $8^{\circ} .9 \frac{1}{2}$ in. Nos. 1-6, May 12-October 15, 1906.

Mis. St. Jour. 125 (11).

CORREO SUD-AMERICANO. El Correo Sud-Americano. Buenos Aires, Préus y Cia, etc., I8g6. $4^{\circ} .12$ in. Nos. 1-6, Apl. 1, Apl. 15, May 1, June, July, Sept., 1896 ** Nos. $4-6$ were published by A. Pfaffe and no. 6 is wrongly numbered "9".

CORRESPONDENCIA DE CADIZ. La Correspondencia de Cadiz. Cadiz. Año II. Núm. 172. 6 de Mayo de 1871. CContains a letter addressed to D. Emilio C. de Navasqües from Dr. Thebussem.]

* * *The letter has been cut out and mounted in Mis. St. Jour. 43 (9).

CORRESPONDENZ FÜR DEN BRIEFIMARKEN SAMIMELSPORT. Correspondenz für den Briefmarken-Sammelsport.

Leipzig, C. Crome-Schwiening, r899.

Fol. 18 in. No. 1, July 25, 1899.

* * Produced by autographic lithography on one side of a huge sheet 18 inches by 23 inches. The sheet is headed "Abdruck: honorarfrei gegen Einsendung eines Belegezemplare". Mis. St. Jour. 127 (13).
Cormespondant der Colle tivandu Parum
RHail

CORRESPONDENZ SEYFRIED 518

CORRESPONDFNZ SEYFRIED. Correspondenz Seyfried.

Prag, Franz Seyfried, I 892-93.

Fol. 121 in. Nos. 1-9, Oct. 15, 1892-Feb. 15, 1893.

* * Published fortnightly.

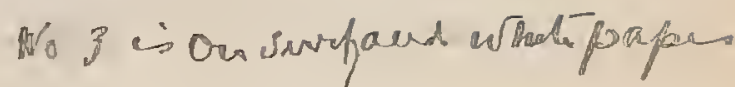

[Continued as :]

Oesterreichische Correspondenz.

Prag, Franz Seyfried, 1893.

Fol. 121 in Nos. 10-22, Mar. 1-Oct. 1, 1893.

* * Nos, 10-19 were published fortnightly, no. 20 is dated " 10 A * Nosust, 1893," no. 21 "1 September, 1893" and no. 22 " 1 Oktober, $1893 "$ ".

CORRIERE DEI FRANCOBOLLI. Corriere dei francobolli. Organo del commercio timbrofilo.

Trieste, Deposito Timbrofilo, etc., I875-79.

Fol. $13 \frac{1}{2}$ in. and $4^{\circ} .10 \frac{1}{2}-10 \frac{3}{3}$ in. 52 nos. in 5 vols.

1st year. Mar. 23-Aug. 21, Oct. 1, 1875-Mar. 1, 1876. Nos,

Oㄹnd " Apl. 1, 1876-Mar. 10, 1877. Nos.1-12.

$63 r d "$ Apl. 14, 30, May 15, June 12, July 15, Sept. 10, Oct. (1) 4th "Jan. 18, Feb. 1, Mar. 29, Apl. 19, May 5, 17, June 17 , July 2 , 20, Aug. 31 , Sept. 25 , Oct. 16 , Nor. 1, Dec. 15,1878 . Nos. $1-14$.

(1) 5th "Jan. 21, Feb. 25, Apl. 8, 1879. Nos. 1-3.

* * The first year is folio, the second quarto $10 \frac{1}{2}$ inches and the remaining years are quarto $10^{3}$ inches. The second, third, fourth and fifth years were published by Teodoro di L. Mayer. Nos.(5 and 6) 7 Y and 9 land (10 and 11) be the third year were severally published together under the respective dates July 15 . September 10 , and Oogether under the respective dates July 15, September 10, and the first year, one of 4 "pages each to nos. $7,8,9,11$ and 12 of the the first year, one of 4 pages each to nos. $7,8,9$, 11 and 12 of the second year, one of six pages to no. and one of four pages each to nos. 3,4, $(5$ and 6$)$, of the third year. The last ten supplements bear a different date to the corresponding numbers of the journal, the dates of publication being: October 22, December 1 and 30 , 1876, February 23, March 31 , April 21 May 8 and 31 , June 27 and July 31, 1877. A copy of the prospectus of the second year, dated March, 1876, andvalso one of the third year are bound up at the commencement of each of these two years. There is a second edition of no. 1 of the first year with the words "Seconda Edizione" at the foot of page 1 and also a second edition of no. 11 of the fourth year with the original article on page 1 omitted and a notice to this effect in its place. The latter number, as originally issued,

CORRIERE DEI FRANCOBOLLI. Il Corriere dei francobolli. Torino, Vittorio Durani e C., I894-95. $8^{\circ} .9 \frac{3}{x}$ in. 4 nos. in 2 vols.

O1st year. Nov. 1894. No. 1.

* * For continuation see "San MLarino Corriere dei Francobolli ". Mis. St. Jour. 108 (18).

CORRIERE DELLA SERA. Corriere della Sera. Anno xIx. Num. 136. Maggio 19-20, 1894. [Contains an article "Le Esposizioni Riunite. La Mostra Fila telica."] Fol. 223 in. pp. 2-3. Milano, [? ], I894 Mis. St. Jour. $136(12$

CORRIERE FILATELICO ITALIANO. Corriere filatelico Italiano. Firenze, Enrico Pestelli, I892-93. Fol. $14 \frac{1}{2}$ in. 10 nos. in 2 vols.

O 1st year. Mar.-Nov., 1892. Nos. 1-8.

$V^{2}{ }^{2}$ * No." 8 is dated "Octobre-Novembre, 1892 ".

Mis. St. Jour. 108 (11)

CORRIERE FILATELICO ROMAGNOLO. Corriere filatelico Romagnolo.

Imola, Bologna, Agostino Bertazzini, I 9or-02.

Fol. $12^{3}-12 \frac{1}{4}$ in. 17 nos. in tiwo vols.

(1) 1st year. Apl. 1-Dec., 1901. Nos. 1- 9

(0) 2nd " Jan. 1-Oct, 1902 and 5,6 and 7,8 and 9,10 and 11,12 and 13,14 and $* *$ Nos. 4 and 5,6 and 7,8 and 9,10 and 11,12 and 13,14 and
15 and 16 and 17 , were severally published together and there is nó number for either July or August, 1902. Nos. 1 and $6-7$ are printed on white paper and the remaining numbers are on buff paper and nos. 12-17 bear no year date. No. 1 has the words
"(Saggio) (Spécimen)".

COSMOPOLITAN PHILATELIST. The Cosmopolitan philatelist. Utica, N. Y., J. T. Bessigg, [1898] Oblong $16^{\circ} .4$ in, .No. 1, June [1898]. Mis. St. Jour. 148 (8).
589 


\section{COSMOPOLITAN PHILATELIST}

COSMOPOLITAN PHILATELIST. The Cosmopolitan philatelist. Le Philatéliste Cosmopolite. Der WeltPhilatelist.

c) Fol. 12 $\frac{1}{2}$ in. [No. 1, November, 1901.]

* * The contents consist entirely of advertisements. There is no number or printed date, but the journal bears " 20 Nov., 1901 " impressed by hand in violet ink.

\section{[Continued as :]}

- Le Philatéliste Cosmopolite. The Cosmopolitan philatelist. Der Welt Philatelist.

Amsterdam, Erwin Donath, etc., I 902-04. Fol. 123 in. 29 nos, in 3 vols.

Ist year. Jan. 1, -Nov. 1, 1902. Nos. 2-12.

2.2nd " Dec.1, 1902- " 1, 1903. " 13-24.

* 3rd "The contents of nos. 2-20 consist entirely of advertisements, but with no. 21 the journal became the "Officieel Orgaan der Ver. $\checkmark$. Postzegelverzamel. "Hollandia " te Amsterdam." Nos. 23-30 were published by Firwin Donath en Co.

COSTA RICA. Costa Rica.

New York, Amando Cespedes M., I900.

(16 $16^{\circ} \cdot 6 \frac{1}{2}$ in. No. 1, March, 1900

* * The number has a coloured paper wrapper." Beneath the title on the wrapper is "With which is consolidated "El Filatelico Comercial 'from San Jose, Costa Rica".

Mis. St. Jour. 1.14 (5)

COSTA RICA POSTAL. Costa Rica postal. Publicación filatélica Costarricense de gran circulación en Centro América. San José, Guillermo Fait h., I 894-95. 8०. 9-93 in. Nos. 1-6, Oct. 1-Dec. 1, 1894, Apl. 15, June 2, 1895. $V_{*}^{*}$ Nos. 4 and 5 were published together. This was the first philatelic journal published in Costa Rica.

Mis. St. Jour. 99 (3)

COSTA RICA POSTAL. Costa Rica postal.

San José, Rubén J. Vargas, etc., I $90 \mathrm{I-02.}$ 8०. 10 in. Nos. 1-5, Dec., 1901-April, 1902.

* No. 3 is printed on green paper and nos. 4 and 5 were published by Rubén J. Vargas y Mig. Carranza.

Mis. St. Jour. 105 (3)

6 COTE DES TIMBRES. La Cote des timbres. Bulletin de la hausse el de la baisse des timbres et journal d'annonces. Paris, Tours [printed], J. Barbarin, 1892-93

(1) $8^{\circ} .11$ in. Nos. 1-10, Oct. 25, 1892-June 25, 1893, Dec. 15, 1893. ** A copy of the prospectus is bound up in front of no. 1 .

Mis. St. Jour. 74 (1)

COTE OFFICIELLE DES TIMBRES = POSTE. La Cote officielle des timbres = poste. Publication hebdomadaire paraissant tous les samedis et indiquant la valeur réelle de tous les timbres parus depuis 1840 jusqu'en 1900.

Paris, Th. Lemaire, голг. $8^{\circ} .8 \frac{1}{4}$ in. Nos. 1-3, Oct. 19, 26, Nov. 2, 1901.

* * There is a coloured paper wrapper to each number. The contents consist of a priced catalogue of stamps from "A byssinie to Réelle des Timbres-Poste" nos. 4-29.

Mis. St. Jour. 106 (8).

COTE RELLE DES TIMBRES-POSTE. La Cote réelle des timbres-poste. Publication hebdomadaire. Paraissant tous les samedis et indiquant la valeur réelle de tous les timbres parus depuis 1840 jusqu'en 1900 . Paris, Th. Lemaire, r 9or-02. $8^{\circ} .8 \frac{1}{2}$ in. Nos. 1-29. Oct. 19, 1901-Sept. 27, 1902.

** There is a coloured paper wrapper to each number. Nos. 1-10 consists solely of parts of a "Catalogue Universel. Prix courant de timbres-poste, avec les prix auxquels on peut se les procurer chez Th. Lemaire." Nos. $1-3$ are the same as nos. $1-3$ of "La
Cote Officielle des Timbres-Poste," except for the change of title Cote Officielle des
on the wrappers.

- La Cote réelle des timbres-poste. Journal des philatélistes. Paraissant les 10,20 et 30 de chaque mois et indiquant la valeur réclle de tous les timbres parus depuis 1840. 2e Série.

Paris, Th. Lemaire, I 902-03.

8 $8^{\circ} .8 \frac{1}{2}$ in. Nos. 1-30, Oct. 15, 1902-Sept. 20, 1903.

${ }^{*} *$ There is a coloured paper wrapper to each number. Nos. 24 27 and $29-30$ were severally published together under the respective datẹs " 15 Août, 1903" and "15-20 Septembre, 1903 ".
COTE

520

COTE RÉELLE DES TIMBRES-POSTE. La Cote réelle des timbres-poste. Journal des philatélistes. $3 e$ Série.

Paris, Th. Lemaire, I903-04.

8. $8^{3}$ in $)$ Nos. 1-29, Oct. 5, 1903-Sept. 30, 1904. **There is a coloured paper wrapper to each number. Nos. 15
and 16,17 and 18,19 and 20,23 and 24,25 and 26 , and 27 and 28 were severally published together.

[Continued as :]

Le Journal des philatélistes. Cote réelle des timbres. Paris, Th. Lemaire, 1904-05.

8. $8 \frac{1}{2}$ in. Vols. IV.-v. 20 nos.

(1) 4th year. Oct. 15-Dec. 25,1904 . Nos. 1- 4.

5th ", Jan. 31- " 31, 1905. " 5-20.

* * Each number has a coloured paper wrapper.

Lue Journal des philatélistes. 5me Série.

Paris, Th. Lemaire, I906$8^{\circ} .9 \frac{1}{2}$ in. Vols. VI.- nos. In progress

(.) [6th year,] Jan. 31-Dec. 31, 1906 . Nose severally published together and there is a coloured paper wrapper to each number.

COUNTRY YOUTH. The Country youth

Milwaukee, Wis., W. J. Kenrick and F. Fortune, etc., I $892-93$.

$4^{\circ} .11 \frac{1}{2}$ in. Vols. II.-III. nos.

Vol. II. Jan.- 1892. Nos. 1-

*" III. "Some of the numbers ouly contain philatelic matter. There is a coloured paper wrapper to each number, and nos. 7 and 8 , vol II. and nos. 1 and 2 and 4-6, vol. UI were severally published together. The numbers of vol. III. wcre published by Wm. J. Kenrick. Wanting nos. $3,9,10,11,12$, vol. II.

COURIER. The Courier.

$32^{\circ} \cdot 4 \frac{1}{2}$ in. No. 3 , Nov., 1887

rbana, Ill., Ernest Harms, I 887

* * The contents are mostly, but not entirely, philatelic.

Mis. St. Jour. 69 (4)

COURRIER DES TIMBRES-POSTE. Le Courrier des timbres-poste.

Saint-Etienne, Loire, S. Bossakiewicz, I89I-I 901.

Fol. 13 in. and $8^{\circ} .9 \frac{1}{2}$ in. 125 nos. in 11 vols.

O1st year. June 15 -Dec. 15,1891 . Nos. 1- 7 .

2nd " Jan. 15- " 15, 1892. ", 8- 19

○ 3rd " " 15- " 15,1893 . " " 20- 31 .

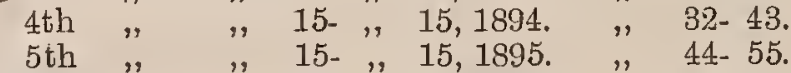

5th " " " $15-, " 15, \quad 1895 . \quad$ " $15,1896 . \quad 44-55$.

O7th " " 15- "15, $1897 . \quad$ "68-79.

Oth " " 15- " 15,1898 . " $\quad 80-91$

Oth " " " $15-\quad 15$ th $15,1899 . \quad$ " $92-103$.

O10th " "15- 10, 10, 1900. " 104-115.

* 11th " $" 10-$ Oct. $10,1901.4116-125$. *** There is an index to nos. 35 to 67 and also one to nos. 68 to
91. Nos. 1-34 are folio and the remainder are octavo, and each number commencing with no. 28 , has a coloured paper wrapper Nos. 15 and 16,51 and 52,65 and 66,75 and 76,89 and 90,99 and 100,111 and 112 , and 122-125, were severally published together under the respective dates " 15 Septembre, 1892," "15 Septembre 1895," "15 Novembre, 1896," "Acût-Septembre' 1897," “OctobreNovembre, 1898," "Août-Septembre, 1899," "Août-Septembre 1900 " and "10, Octobre, 1901". There are supplements to nos. $18,21,36$ and 59, and two supplements to no. 60 . Bound up at the commencement of vol. I. is a copy of the prospectus of the journal. Nos. 122-125 consist of only one leaf within a coloured paper wrapper. There is a second edition of the number for Ma 15,1893 , which has a large numeral " 2 " impressed by a hand stamp at the top of the front page and "3e anne (sic)-no. 24 " is omitted.

COURRIER DU TIMBROPHILE. Le Courrier du timbrophile. Bruxelles, L. Dehenain, etc., I887-90 $8^{\circ} .10^{3}$ in. 46 nos. in 4 vols.

C) 1st year. Feb.-Dec., 1887. Nos. 1-10

c) 2nd " Jan.- " 1888. " $11-22$

3rd " " - " 1889. " 23-34

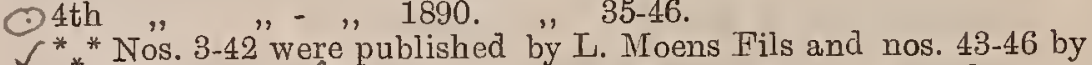
$\checkmark$ ** Nos. $3-42$ were published by L. Moens Fils and nos. $43-46$ by Jeanne Moens. There is no number for April, 1887, and nos. 3
and 4,15 and 16,17 and 18,28 and 29,31 and 32,36 and 37,39 $\checkmark$ and 4,15 and 16,17 and 18,28 and 29,31 and 32,36 and 37,39 and 40 , and 41 and 42 , were severally published together. Where are supplements of tyrelve pages to nos. 31 and 32 , and 39 and 40 , of eight pages to no. 88 and of four pages to no. 33 . A copy of
the prospectus of the journal, dated January 20,1887 , is bound up in front of no. 1 . 


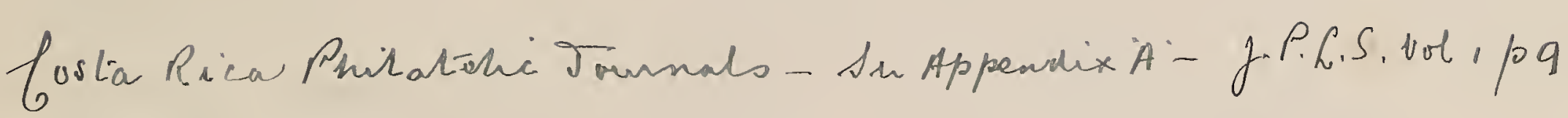

Jommier f. P.h.s oxp8 
Grown Govitisen, tricesté, 1887.589 
521 COURRIER DU TIMBROPHILE COURRIER DU TIMBROPHILE.

[Continued as:]

Lue Courrier timbrophilique.

$4^{\circ} .12 \frac{3}{4}$ in. Vol. $\nabla .12$ nos.

Bruxelles, Jeanne Moens, I89ז.

5th year. Jan.-Dec., 1891. Nos. $47-58$.

** Nos. 52 and 53 , and 54 and 55 , were severally published together.

COURRIER PHILATÉLIQUE. Courrier philatélique. Journal mensuel, paraissant le ler de chaque mois. Saint-Imier, Srisse, Tell Brandt, $\mathbf{8} 884$.

$8^{\circ} .10 \frac{1}{2}$ in. Nos. 1-3, Oct. 1-Dec. 1, 1884.

* *A copy of the prospectus of the journal, dated September, 1884, is bound up in front of number 1 . Wanting no. 3 .

Mis. St. Jour. 7 (2)

COURRIER PHILATELIQUE. Le Courrier philatélique.

$8^{\circ} .10$ in. No. 1, April 15, 1899.

Lille, Albert Lepreux, 899.

* * Printed on green paper and the contents consist entirely of Mis. St. Jour. 110 (2)

COURRIER PHILATELIQUE BELGE. Courrier philatélique Belge. Tongres, Joseph Browwers, I898-I goo. $8^{\circ} .10$ in. 21 nos. in 3 vols.

1st year. Jan.-Dec., 1898. Nos. 1-12.

2nd " 1899 . "13-17.

3rd " Feb., Apl., June, Aug., $1900 . \quad$ " 18-21.

** Nos. 4 and 5, 8 and 9 and ${ }^{*} 10$ and 11 , were severally published together. The numbers of the second year do not bear the month of publication.

COURRIER PHILATELIQUE BELGE. Le Courrier philatélique Belge. Spa, Gaston Fassotte, I 899-1 go2. $8^{\circ} .10^{3}$ in. and $4^{\circ} .13$ in. 26 nos. in 3 vols.

1st year. Dec. $1,1899-$ Nov. 1, 1900. Nos. 1-10.

2nd " "1, 1900- " 1, 1901. "11-22.

3rd $"$ " 1901-Mar. 1, 1902. " 23-26.

** Nos. $1-3$ are octavo and the rest are quarto. No. 4 is dated "Mars et Avril, 1900," no. 8 "Août et Septembre, 1900," no. 1 has in error " 1300 " for " 1901, " nos. 18 "and 19 were published together, no. 21 is wrongly numbered " 20 ," and nos. 23,24 and
25 were published together.

COURRIER TIMBROPHILIQUE. See COURRIER DU TIMBROPHILE.

COURRIER UNIVERSEL. Le Courrier universel. Paris, Ch. Dullekens, I goo-or.

$8^{\circ} .9 \frac{3}{4}$ in. 10 nos. in 2 vols.

1st year. -Dec., 1900. Nos. 1- 5

2nd ", -Sept., 1901. " 6-10.

** Each number has a coloured paper wrapper. A copy of the

prospectus of the journal is included. Wanting nos. $1, \overline{7}, 8,9$.

COURS DES TIMBRES. Le Cours des timbres. Paris, 'E. Chevilliard, 1897 .

$4^{\circ} .10 \frac{7}{2}-11$ in. Nos, 1-3, January 20-March 20, 1897.

* Nos. 1 and 2 (?) were produced by a hand copying press and no. 3 was printed at Amiens in the ordinary way. The contents consist entirely of price-lists of stamps. Wanting no. 2 . Mis. St. Jour. 139 (2).

C. P. S. BULLETIN. C. P. S. Bulletin. Published in the interest of Chicago Philatelic Society.

Chicago, Ill., P. M. Wolsieffer, I 890.

$8^{\circ} .7 \frac{3}{4}$ in. Nos. 1-2, Jan.-Feb., $1890 . \quad$ Mis. St. Jour. 66 (8).

CRAYTON'S OCCASIONAL. Crayton's occasional. Anderson S. C., T. S. Crayton, Jr., I884 8. 9 in. [No. 1] December, 1884

* * The only philatelic matter consists of advertisements.

Mis. St. Jour. 135 (17)

CREAIM CITY PHILATELIST. The Cream City philatelist. Milwaukee, Wis., Chas. Test Taylor, I89x $8^{\circ} .83$ in. No. 1, Feb., 1891. * The number has a coloured paper wrapper

Mis. St. Jour. 47 (4).

\section{CRESCENT}

522

CRESCENT. See Vermont Philatelist.

CRICKET. The Cricket.

Elmira, N.Y., W. A. Turnbull, I894-95. Fol. 12 in. Nos. 1-2, December, 1894-January, 1895. ** Only partly philatelic. Nos. 3, 4 and 5 are also said to exist
Mis. St. Jour. $116(9)$

CRÓNICA FILATÉfICA. Crónica filatélica. Órgano internacional de coleccionistas y negociantes de sellos de correos. $\quad$ Mladrid, Manuel Asenjo Pérez, r895-96. $8^{\circ} .11$ in. 5 nos. in 2 vols.

- Ist year. Dec. $1, \quad 1895$. No. 1.

nd "Jan. 1-Apl. 1, 1896. Nos. 2-5.

* No. 5 has a coloured paper wrapper. Mis. St. Jour. 98 (4).

CROYDON PHILATELIC GAZETTE. The Croydon philatelic gazette.

Croydon, Surrey, Pearce and Stamford, I898. $8^{\circ} .81$ in. Nos. 1-9, Mar.-Nov., 1898.
$7^{*}$ * Printed on coloured paper. Wanting no. 6 .

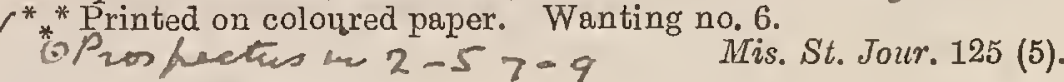

CUBA FILATÉEICA. Cuba filatélica.

Habana, Unión Filatélica Cubana, r 905-06. $8^{\circ} .8 \frac{3}{4}$ in. and $10 \mathrm{in.} 11$ nos. in 2 vols.

1st year. April 1-Dec. 1, 1905. Nos. 1-9.

2nd "J Jan. 1-Feb. 1, 1906.

* * Each number has a coloured paper wrapper. No. 1 measures $8 \%$ inches and the subsequent numbers are 10 inches. Wanting
no. 9 .

CUIMBERLAND COLLECTOR. The Cumberland collector.

Nashville, Tenn., The Cumberland Collector Pub. Co., etc., I886-87

$8^{\circ} .9$ in. Nos. 1-12, May, 1886-A pril, 1887.

** Only partly philatelic. Nos. 8-12 were published by Cheatham, Gray and Martin, and nos. 3-12 have coloured paper wrappers.

Mis. St. Jour. 20 (3)

CUPID ADVERTISER. The Cupid advertiser:

in. Nos. $1-9$

$$
\text { Elkader, Ia., [? ], т894. }
$$

CURIERUL MĂRCILOR POSTALE. Curierul Mărcilor postale. Revista timbrologica.

Pitestü, Románia, I. M. Lazăr, т89т.

80. $9 \frac{1}{4}$ in. Nos. 1-3, Jan. 1-Mar. 1, 1891. Mis. St. Jour. 90 (7).

CURIO. The Curio.

Emporia, Kas., The Curio Publishing Co., ז887. $8^{\circ} .7 \frac{1}{4}$ in. No. 0, May, 1887

** Only partly philatelic.

Mis. St. Jour. 148 (9)

CURIO. The Curio. A monthly devoted to collectors. Benson, Minn., The Curio Co., I889.92.

$8^{\circ} .9$ in. 43 nos. in 8 vols.

Vol. I. Feb.-Apl. 1889. Nos. 1-3.

" Ir. May-July, " " 1-3.

", Iv. Nov., Dec., X"mas, 1889. Nos. 1-3.

" $\mathrm{V}$. Jan.-Mar, 1890 .

" $\mathrm{VI}$. Jpl

" VI. Apl.-Dec. and Xmas, 1890 . Nos. 1-[9]

"VIIr. Feb.-Aug., 1892, Nos, $1-7$

* "Vol Tre.

"

"Jan.-Feb., 1891," and the Christmas number of 1890 is unnum-

ered. The is a supplement of two pages, printed on one side only, to no. 2 , rol. IY.

CURIO. The Curio.

Williamsville, Mass., A. E. Bennett, r892. $32^{\circ} .4 \frac{3}{4}-5$ in. Nos. 1-7, May-Nov., 1892.

* * No. 2 and some of the copies of no. 3 are printed on coloured paper.

Mis. St. Jour. 69 (5).

CURIO. The Curio.

$8^{\circ} .8 \frac{1}{4}$ in. No. 1 , February, 1895 .

Denver, Colo., E. W. Plummer, x 895.

* Only partly philatelic. The number has a coloured paper * Orapper.
Mis. St. Jour. 151 (2). 
CURIO. The Curio. Devoted to coins, stamps and curios in general. Lancaster, Pa., Chas. Steigerwalt, i898-99.

$8^{\circ} .9$ in. Nos. 1-6, [? ] ] June, 1899.
* Only partly philatelic. Wanting all but no. 6.

CURIO EXCHANGE. The Curio exchange.

New Kamilche, Wash., F. Gingrich, 1 900-02. $8^{\circ} .5 \frac{1}{2}$ and 8 in, 10 nos, in 2 vols.

Vol. I. June, Aug., Oct., Dec., 1900, Feb., Apl, 1901. Nos. 1-6. Vol. I. June, Aug., Oct., Dec., 1900, Feb., Apl., 1901. Nos. 1-6. "II. July-Aug.,

* * Only partly philatelic. Nos. 1-4,.vol. I., measure $5 \frac{1}{2}$ inches and the remainiug numbers, 8 inches. No. 2 , vol. I., and nos. $2-4$, vol. the remaining numbers, 8 inches. No. 2, vol. I., and nos. $2-4$, vol. "December, 1900" "but there is a supplement, consisting of a "December, 1900," but there is a supplement, consisting of a No. 3, vol. II., is numbered in Roman numerals, and this and the last number have no year given. Wanting nos. 1,6 , vol. I.

CURIO INFORIMANT. The Curio informant.

Nashville, Tenn., James McBride, I889.

Fol. 12 in. Nos. 1-4, Aug. 1-Nov., 1889.

** Only partly philatelic.

Mis. St. Jour. 72 (8).

CURIOS. Curios.

New Chester, Pa., Curios Publishing Co., I 889 $64^{\circ} .3$ in. Nos. 1-3, August-October, 1889.

** Only partly philatelic. Succeeded by the "American Col-

CURIOSITÉ UNIVERSELLE. La Curiosité universelle. Journal hebdomadaire. Paris, Alex. Geoffray, i889-93. Fol. 123 in. Vols. Irr.-vrr. nos.

3rd year. Sept. 9 , Nov. 18, 1889 . Nos. 138,148

4th " Apl. 7, June 16, July 7, Nov. 17, 1890. Nos. 168, 178, 181,200

5th " Mar. 23, Apl. 27, June 22, 29, July 27, Oct. 5, Nov. 2 , 23,30 , Dec. $7,28,1891$. Nos. $218,223,231,232,236$, $246,250,253,254,255,258$.

6th " Mar. 21, June 27, Aug. 1, Sept. 26, Oct. 3, 10, 1892. Nos. 270, 284, 289, 297, 298, 299

7th "Jan. 30, Mar. 13, 20, 1893. Nos. 315, 321, 322.

* * It was not until the third year that the word "Timbresposte" was added to the heading. Only particulars are given of the numbers in the library, and of these several contain no philatelic matter. Most of the above numbers are bound together in one volume, copies of nos. 254,258, 284 and 297 are bound up in Mis. St. Jour. 115 (5) aind a cutting of the article "Timbrologie," from no. 178, is mounted in Stamp Scrap-book, vol. v1. pp. 119, 120.

CURIOSITY CABINET. See KORIOSITI KABINET.

CURIOSITY COLLECTOR. The Curiosity collector.

in. Nos. 1. Cleveland, O., [? ], $1877-78$

* Only partly philatelic. Wanting all nos.

CURIOSITY COLLECTOR. The Curiosity collector. Devoted to stamps, coins and curiosities. Oberlin, O., The Laurel Stamp Co., I883. $8^{\circ} .9$ in. Nos. 1-3, Feb. 15-May, 1883.

* *No. 3 is dated "April and May, 1883". Wanting no. 2. Mis. St. Jour. 19 (2).

CURIOSITY COLLECTOR. The Curiosity collector. A monthly journal devoted to geology, mineralogy and stamp collecting.

South Amboy, N. J., J. D. Bartlett, 1888-92. $8^{\circ} .83$ in. 28 nos. in 3 vols.

Vol. I. Dec. 1, 1888-Dec., 1889. Nos. 1.12.

"II. Jan.-May; Aug.-Oct; Dec., 1890, Jan., Apl., Nov., 1891. Nos. $1-12$.

"IIr. Jan., Mar., Apl., May, 1892. Nos. 1-4.

" "* The sub-heading on nos. 3-6, vol. I., reads "A monthly journal devoted to the interest of collectors," on nos. 7-12, vol. I., and on no. 1, vol. Ir., "A monthly journal for stamp collectors"; on nos. 2-7, vol. Ir., "A monthly for stamp collectors"; and on the remaining numbers "A monthly journal devoted to the greatest hobby-Philately". There is a title-page and an index to vol. II. After the completion of vols. I. and II. each volume was sold in a coloured paper wrapper with an index to the volume printed on page 2 of the wrapper. No. 12, vol. 1., is dated "Nov. and Dec. 1889," and no. 10, vol. II, is dated in error "Jan., 1890" "instead of "Jan., 1891".
CURIOSITY COLLECTORS' MAGAZINE, AND JOURNAL OF THE BRIDLINGTON AIMATEUR ASSOCIATION. See BRITISH, CoNTINENTAL, AND AMERICAN STAMP, COIN, CREST, AUTOGRAPH, AND GENERAL CURIOSITY COLLECTOR'S MAGAZINE, AND JOURNAL OF THE BRIDLINGTON AMATEUR ASSOCIATION.

CURIOSITY HUNTER. The Curiosity hunter. Rockford, Ill., etc., D. A. K. Andrus, I872-77. $8^{\circ} .8 \frac{1}{2}$ in. 35 nos. in 4 vols.

Vol. 1. Sept., 1872-May, 1873, Oct.-Dec., 1873. Nos. 1-12. $\begin{array}{cccc}\text { Vol. I. Sept., 1872-May, } & 1873 \text {, Oct.-Dec., 1873. Nos. 1-12. } \\ \text { ", II. Jan. } & \text {-July, } 1874 . & \text { " } 1-[8] \text {. }\end{array}$ "rv. Oct. 1, 1876-Sept., 1877. " 1-12. * * Only partly philatelic. There is a title-page and an index to vol. I. Nos. 1-7, vol. IV., were published at Belvidere, Ill., and there is no vol. III. Nos. 3-12, vol. I., have buff paper wrappers, except that nos. 7-9 were published in one wrapper with the date "March April and May, 1873". There is also a buff paper wrapper for each of the numbers of vol. II., except that nos. 6-8 were published in one wrapper with the date "June and July, 1874 " and that nos. 1 and 2,4 and 5 , and 6 and 7 were severally published together. No. 5 , vol. x., is dated "1872" instead of "1873," but the correct year is given on the wrapper. No. 8, vol. II. is numbered " 7 " in place of " 8 " and no. 7 , vol. rV., is numbered in error " 8 ". Nos. 8 and 9 , and 10 and 11, vol. rV., is numbered in exror " 8 ". Nos. 8 and 9 , and 10 and 11 , vol. 17. ., were severally published together, and these numbers bear no year of issue. No. 12, vol. 1V., and the three numbers of vol. V., have

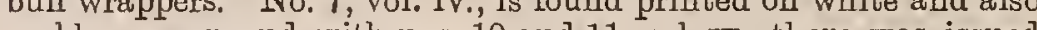
on blue paper, and with nos. 10 and 11, vol. 17 ., there was issued a yellow coloured leaf, printed on one side only, headed "Curiosity

URIOSITY JOURNAL. The Curiosity journal.

New Yort, [? ], 1884.

* ${ }_{*}^{*}$ Only partly philatelic. Wanting all nos.

CURIOSITY REPORTER. The Curiosity reporter. A monthly journal devoted to minerals, stamps, curiosities, etc. Elkader, Ia., Wm. Reinecke, I887. 16․ $6 \frac{1}{2}$ in. Nos. 1-2, March-April, 1887. Mis. St. Jour. 68 (27).

CURIOSITY SEEKER. The Curiosity seeker. 78.

Smithtown Branch, N. Y., Jas. E. Handshaw, i 877 -

8. $7 \frac{1}{2}$ in. Nos. 1-4, Dec., 1877, Jan., Mar., May, 1878.

Mis. St. Jour. 41 (7).

CURIOSITY SHOP. Curiosity shop.

Chicago, Ill., W. S. Haines, etc., 1865. $8^{\circ} .9$ in. Nos. 1-6, July-Dec., 1865

* Only partly philatelic. Nos. 3-6 were published by Haines and Olcott.

CURIOSITY SHOP AND ANTIQUARY. The Curiosity shop and antiquary. Published in the interests of American local archæology and for the benefit of the Ladies' Fair of St. Barnabas Episcopal Church. Irvington, N. Y., Ed. Frossard, I 875 . $4^{\circ} .123$ in. [No. 1], September $17,1875$.
$*^{*}$ Only partly philatelic.

Mis. St. Jour. 116 (11).

CURIOSITY WORLD. The Curiosity world.

Lake Village, N. H., John M. Hubbard, 1886-88.

Fol. 19 in. and $8^{\circ} .9$ in. 30 nos. in 3 vols.

Vol. 1. Sept., 1886-Aug., 1887. Nos. 1-12

, II. ", 1, 1887-Feb. 15, 1888. ", 13-24.

" IIr. Mar. -Aug. 1888. ", 25-30.

* * Only partly philatelic. Nos. 1-24 are folio and nos. 25-30 are octavo. The nos. of vol. II. were published fortnightly and there is a coloured paper wrapper to no. 25 and also to no. 27 .

\section{[Continued as :]}

The Stamp world.

Lake Village, N. H., John M. Hubbard, ı888-9o. $8^{\circ} \cdot 9$ in. Vols. $1 \nabla .-\nabla r ., 18$ nos.

Vol. IV. Sept., 1888-Feb., 1889. Nos. 31-36.

" . March -Aug., 1889. " 37-42 " vi. Sept., 1889-Feb., 1890. " " 43-48. * " Nos. 32-48 have paper wrappers and there is a supplemental slip of four pages to no. 41 . 
Sog furis currotion, hus castle, KER - 190 "Lanio hurs-atrantia, lia - 1905 



\section{CURIOSITY WORLD.}

[Continued as:]

- Hubbard's magazine. Lake Village, N. H., John M. Hubbard, I89o. $8^{\circ}, 9 \frac{1}{4}$ in, Vol. vII., 2 nos.

Vol, viI. Mar., Apl, 1890. Nos. 1-2.

** Each number has a coloured paper wrapper.

CURIOSO AMERICANO. El Curioso Americano. Correspondencia entre literatos, Americanistas, anticuarios, filatelistas, etc., y revista de todo genero de documentos y noticias interesantes.

Habana, Dr. M. Perez-Beato, I899-Igox. $8^{\circ} .10$ in. 17 nos. in 2 vols.

Epoca 3a. July, 15, 1899-Oct., 1900. Nos. 1-12

Q. "' Ano. 2०. Jan. -May, 1901. " 1-5.

" severally publis 1900 , and nos. 1 and 2 and 4 and 5 of 1901 were ". Fpoce "3a" and nos 10 " 11 are dated " Abril i Septiembre de 1900 ". The wrapper of nos. 1 and 2 of 1901 has the date printed "Noviembre y Diciembre de 1900 ," but above this in violet ink is printed "Enero y Febrero de 1901," and the earlier violet ink is printed " date is struck through with a bab in violet. Thenal commenced publication in 1892, but the previous to journal published in Cuba.

CYCLONE. The Cyclone.

Hika, Wis, etc., E. R. Mill, т900-о3.

$8^{\circ} .9$ in. and fol. 12 in. 24 nos. in 3 vols.

Vol. I. Dec., 1900-Dec., 1901. Nos. 1-12.

" II. Jan. 1902 , " 1-10.

*"* Only partly philatelic. Nos. " were published at Ozark Mo., by Fred. Billings, nos. are octavo and nos.
are folio, and nos. Nave coloured paper wrappers. Nos. 7 and 8 of lished together. Wanting nos $1,9,4,5,6,9, \mathrm{vol}, \mathrm{and}$ nos.

CYNOSURE. The Cynosure.

Milwaukee, Wis., [? ], ז897.

in. Nos, 1-4.

** Only partly philatelic. Wanting all nos.

\footnotetext{
140099 fertmins; vo/11 Apul-sept;iscits

1900 July- $\sqrt{\text { aw }}\left(n_{0} 1-7\right)$ an pages $1-16$

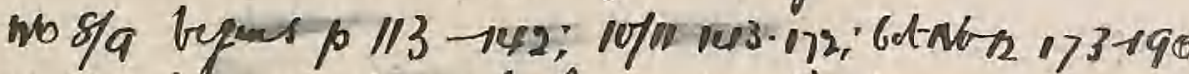

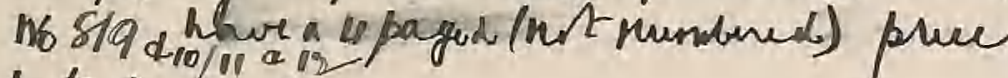

hat of in hazaro

1901 Wora 2 en apper hes hov o dec 1900

but allind woth haver rubbes stants inuroy fibrero de ogor; the matede Enerio y tistrumpo-s
}

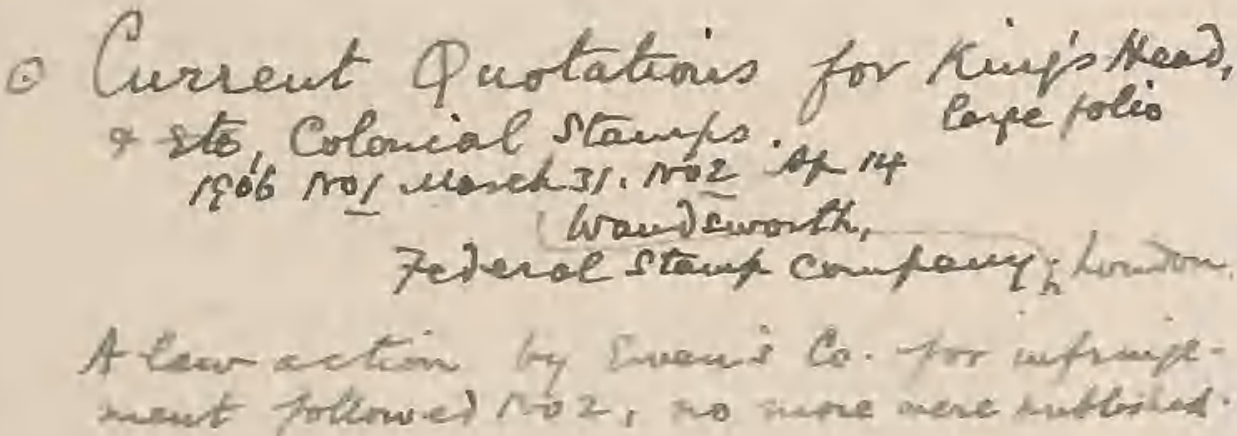


DaGBladvriend. See Presso-Philatélie.

DAHEIM. Daheim. xxx. Jahrgang. No. 21, Februar 24 1894. [Contains an article "Spaniens neueste Geschichte in spanischen Briefmarken".] xxxIIr. Jahrgang. No. 48, August 28, 1897. Beilage. [Contains an article "Die preussischen Oktogone" signed "Lagos".] Leipzig, Velhagen und Klasing, 1894-97. Fol. $12 \frac{3}{4}$ in, p. 336 and p. 4. Mis. St. Jour. $138(2,3)$.

DAILY GLOBE-DEMOCRAT. The Daily globe-democrat. St. Louis, Mo., February 3, 1884. [Cuttings of the article "Two million stamps. Timbrophiles in Paris-The album catalogue," are mounted in Stamp Scrap-book, vol. IV., p. 110.]

DAILY REPORT. The, Daily report. Nos. 1577, 1580 $1604,1616,1619,1631,1634,1707,1710,1748,1749$, $1805,1806,2009$. August 9, 13, September 11, 25, 28, October 12, 16, 1906, January 11, 15, February 28, March 1, May 9, 10, 1907, January 9, 1908. [Contain philatelic articles. The third article was written by Percy C. Bishop, the remainder by B. T. K. Smith.]

London, E.C., The London and Paris Exchange, Ltd., r 906-08.

Fol. 191 in.

DAILY STAIIP ITEM. The Daily stamp item. Published every day in the year except Sunday.

St. Louis, Mo., C. H. Meleeel Stamp and Publisting Co., I896.

$8^{\circ} .11$ in. 285 nos. in 4 vols.

Vol. I. Jan. 1-Mar. 31

" II. Apl. 1-June 30, ", IV. Oct. 1-Nov. 26, and Dec. 31, ", ", 157-235. ** There is a title-page and an index to each" volume. Some copies, but not all, of no. 14 have "Wednesday, January 15, 1896,

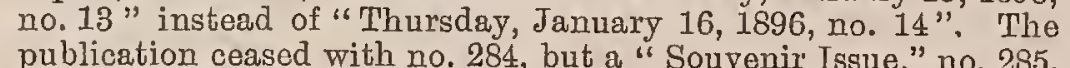
was published on December 31, 1896.

DAILY TRUE AIIERICAN. The Daily True American. Trenton, N. J., January 5, 1885 . [Cuttings of the article "A fortune in oddities. The latest addition to Mr. E. B. Sterling's valuable collection of stamps," are mounted in Stamp Scrap-book, vol. IV., p. 96.]

DAILY UNION. The Daily union. March 21, 1888. [Cuttings of article "Postage prepaid. The progress made in less than half a century. Origin of the idea in 1653-Introduction of the system in England in 1840What the first stamp looked like-Collecting," are mounted in Stamp Scrap-book, vol. VI., pp. 15-16.]
DAKOTA PHILATELIC. The Dakota philatelic.

Beaver, South Dalkota, etc., F. H. Adams, etc., I896-97.

$8^{\circ} .8$ in. and $12^{\circ} .6$ in. Nos. 6-8, 10 and 12, Sept.-Nov., 1896, Jan., Aug., 1897

* *Nos. 1-5 have the title "The Crown" and are not philatelic and nos. 9 and 11 were never published. Nos. 6-8 are octavo and are numbered "volume II."; nos. 10 and 12 are $12^{\circ}$, have "vol. I.," and were published at Sioux Falls, S. D., by J. B. Sessions. Wanting no. 10

DAKOTA PHILATELIC. The Dakota philatelic.

Sioux Falls, S. D., J. B. Sessions, 1898.

$8^{\circ} .10 \frac{1}{2}$ in. No. 1, February 15, 1898.

* * Edited by F. H. Adams. On page 2 the title reads " $T$ The Dakota philatelist". Adams. On page 2 the title reads 140 (9).

DAVENPORT ALERT. See ALERT.

DAWSON'S IMONTHLY. Dawson's monthly. Vol. III., no. 10, November, 1891. [Contains article "philately".] Cape May City, N. J., William S. Dawson, r891. $8^{\circ} .9 \frac{1}{4}$ in. pp. 34,35 .

Mis. St. Jour. 117 (12)

\section{DAYTON PHILATELIST. Dayton philatelist.} 82 .

Dayton, O., Dayton National Stamp Co., etc., r88I-

$24^{\circ} .5 \frac{1}{4}$ in., $16^{\circ} .6 \frac{3}{4}$ in. and $4^{\circ} .10 \frac{1}{4}$ in. 3 nos. in 2 vols.

Vol. I. June, Aug.-Sept., 1881. Nos. 1-2.

* "* II. Jan., 1882. No. 1.

*** No. 2, vol. I., and no. 1, vol. II., were published by John G

Dohme. The last is dated on the first page " 1881 " in error for

" 1882 ". No. 1 is $24^{\circ}$, no. $2,16^{\circ}$, and no. 1 , vol. II., is $4^{\circ}$

Mis. St. Jour. 59 (2).

DEAKIN'S OLD CURIOSITY SHOP. Deakin's old currosity shop.

$8^{\circ} .8 \frac{3}{3}$ in. No. 1, Aug., 1871 .

Chicago, $\Pi l l ., W$. and H. Deakin, $\mathrm{x} 87 \mathrm{I}$. ${ }_{*}^{*}$ * Only partly philatelic.

Mis. St. Jour. 27 (4).

DEALER'S ADVERTISER. The Dealer's advertiser. London, N., P. B. Anderson, 1902-03.

$8^{\circ} .10$ in. Nos. 1-3, Oct., Dec., 1902, Mar., 1903. $4 \mathrm{MP}$ PACA

Mis. St. Jour. 105 (5).

DEALERS' ADVERTISER AND COLLECTORS' EX-

CHANGE. The Dealers' advertiser and collector's' exchange.

Charlbury, Oxfordshire, John H. Clifford, I885-86. $8^{\circ} .8 \frac{1}{4}-8 \frac{3}{4}$ in. and $7 \frac{1}{2}-8$ in. 8 nos. in 2 vols. wawt $3-8$ Vol. 'I. "March, "May 5, June 5, July 5, [? ], 1885. Nos. 1-6. * II. [no date 1886]. * * No. 1 measures $8 \frac{1}{4}$ inches, nos. 2-6, 88 inches, no. 7, $7 \frac{1}{2}$ inches and no. 8, 8 inches. No. 7 has a supplemental slip, and nos. 1,2 , 3 , and 8 contain only advertisements. Wanting nos. $5,6,8$.

Denby Sale, Lecharefe, a herderiment

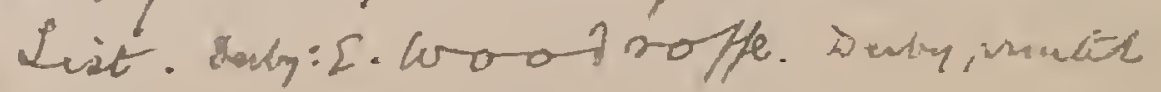

1886 . mar roz, Ap. Mro 3 In beve isp.

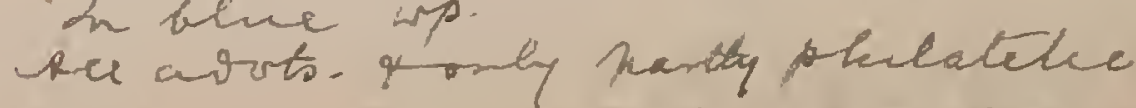

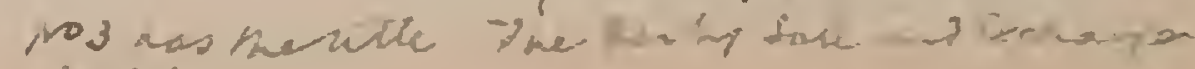

Regisior? 
Darly Express $1 \times p q$ 


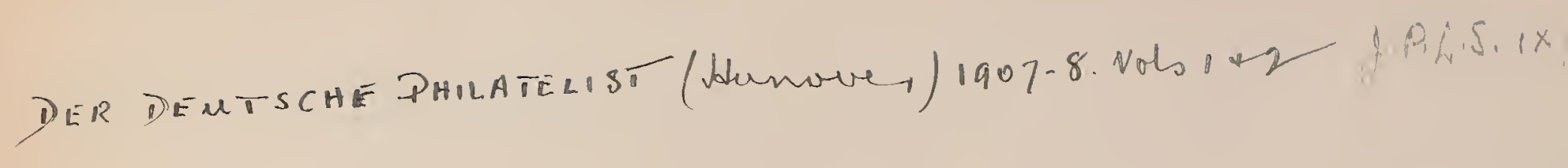

Der Simpulmarkensamonter (Kapsourar, Jungary-1010/N) P.L.C1943-LA

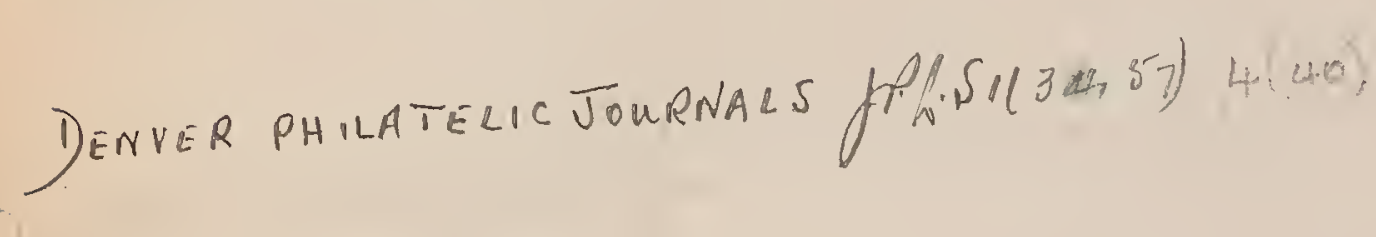


DECORAH PHILATELICAI REVIEW. The Decorah philatelical review.

Decorah, Iowa, R. W. Cooley, I875.

$8^{\circ} .7 \frac{3}{4}$ in. Nos. 1-6, Feb., Apl, June, Aug., Oct., Dec., 1875.

* * There are supplements of two pages to nos. 3 and 4 . No. 2 is numbered in Roman figures.

Mis. St. Jour. 39 (2).

DEFENSA FILATELICA. La Defensa filatelica. Azua, Rep. Dominicana, Noboa y Cia., I 905. $8^{\circ} .11 \frac{1}{2}$ in. No. 1, May 15, 1905. ** Wanting.

DÉLASSEMENTS. Délassements. Journal littéraire et amusant. Châlons-sur-Marne, Ploussard, I902. 8.. 11 in. Nos. 3-4, May-June, 1902.

* Only partly philatelic.

Mis. St. Jour. 131 (11).

DETROIT PHILATELIST. The Detroit philatelist. A monthly journal devoted to philately. Detroit, Mich., W. M. Hewitt, I879.

$8^{\circ} .8 \frac{3}{2}$ in. Nos. 1-3, Aug.-Oct., 1879.

** Nos. 2 and 3 were published together under the date "Sept. and Oct., 1879," and th: $\mathrm{s}$ double number is printed on pink paper. Mis. St. Jour, 24 (9)

DETROIT PHILATELIST. The Detroit philatelist. Detroit, Mich., A. H. Crittenden, etc., I89.2-94. $8^{\circ} .8 \frac{1}{2}$ in. 25 nos. in 3 vols.

Vol. I. Apl, 1892-Mar., 1893. Nos. 1-12

" Ir. Apl., 1893-Apl., 1894. „, 1-12.

* "IIr. May, "No. 1.

* Each number has a coloured paper wrapper, and there is no number for August, 1893. Commencing with no. 11, vol. I., the journal was published by the Crittenden and Borgman Co. No. 1, vol. I., is dated "April, 1882. Number 2," in error for "April, 1892. Number 1," but the wrapper has the correct numbering the wrapper.

DETROIT PHILATELIST. The Detroit philatelist. Detroit, Mich., Wm. H. Kessler, Jr., I 897 .

$8^{\circ} .8 \frac{1}{2}$ in. Nos. 1-5, Apl.-August, 1897.

* * Each number has a paper wrapper, and nos. 3-5 were published together with the date "June, July and August, 1897" The wrappers of nos. 1-2 have below the title "with

Mis. St. Jour. 113 (4)

\section{DEUTSCH - AMERIKANISCHE BRIEFMARKEN} ZEITUNG. Deutsch-Amerikanische Briefmarken Zeitung. German-American stamp journal. Weekly for collectors and dealers.

Yonkers, N. Y., M. Burnham, 1897.

$8^{\circ} .10 \frac{1}{2}$ in. Nos. 1-3, June 1, 8, 15, 1897.

* * Printed on rose paper, and the contents consist entirely of advertisements.

Mis. St. Jour

DEUTSCHE BRIEFMARIEN POST. Deutsche Briefmarken post.

Barmen, etc., Herm. Greeff, etc., I893-95.

Fol. $12 \frac{1}{2}$ in. and $8^{\circ} .10$ in. 27 nos. in 3 vols.

1st year. June 1-Dec. 1, 1893. Nos. 1- 7.

2nd " Jan. 1- " 15, 1894. "1-11.

C3rd ", ", 15-Aüg. 15, 1895. ", 12-20.

* * The first fifteen numbers are folio and the remainder, which were published by C. G. Vogel, at Plauen i. Vogtl ware octavo. There is no number for November, 1894, and nos. 15 and 16,17 . 18 and 19 and 20 were severally published together under 17 and 18 and 19 ate "15 Mai, 1895" "no Juli, 1895" and " 15 " the respective dates 15 Mai, 1895 , " $10 \mathrm{Juli}, 1895$, " and " 15 August, A copy of the prospectus is bound up with the journal.

DEUTSCHE BRIEFIMARKEN-SAMMLER. DE deutsche Briefmarken-Sammler. Organ des BriefmarkenVerkehrs. Hamburg, Gebriuder Spiro, 1864-65. $4^{\circ} .8 \frac{1}{2}$ in. Nos. 1-3, Nov. 20, 1864, Jan. 20, Feb. 20, 1865

Mis. St. Jour. 82 (1).
DEUTSCHE BRIEFMARKEN-SAIMILER. De deutsche Briefmarken-Sammler. Organ für die gesammten Interessen der Briefmarkenkunde.

Aussig, G. Bauschke, r869.

$4^{\circ} .8 \frac{3}{4}$ in. Nos. 1-3, 1869 .

* The numbers only bear the year of publication. Dr. A Moschkau in a list of German philatelic literature published in the "Illustrirtes Briefmarken-Journal " of June 1, 1876, gives six numbers of this journal, but there is reason to believe that this was an error and that three only appeared.

Mis. St. Jour. 132 (8).

DEUTSCHE BRIEFIMARKEN-ZEITUNG. Deutsche Briefmarken-Zeitung. Organ für die gesammten Interessen der Briefmarkenkunde.

Dresden, etc., Die Expedition der Deutschen Briefmarken-Z eitung, etc., I870-73.

$4^{\circ} .8 \frac{7}{2}$ in. 31 nos. in 3 vols.

0 1st year. [Oct. 15], 1870-Sept. 15, 1871. Nos. 1-12.

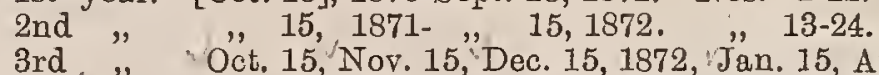
3rd. " Oct. 15, Nov. 15,'Dec. 15, 1872, Jan. 15, Apl. 15, May * 15, June 15, 1873 . Nos. 25-28 and 31-33. * * There is a title-page and an index to the first and also to the second year. Nos. 1-8 havo no month of publication given, and nos. 29 and 30 were never published. There are two editions o nos. 1-15; one published at Dresden by Die Expedition de Deutschen Briefmarken-Zeitung, the other in Leipzig by Alwin Zschiesche. The remaining numbers were published by Die Expedition der Deutschen Briefmarken-Zeitung at Dresden. Some but not all, of the copies of no. 16 are wrongly numbered " 15 " in the notice beneath the sub-title. There is a supplement to no. 1 consisting of sixteen pages of "Probebogen des Briefmarkenkata logs," and supplements of two pages to nos. 14 and 16.

DEUTSCHE BRIEFIMAREN-ZEITUNG. Deutsche Briefmarken-Zeitung. Illustrirte Zeitschrift für Postwertzeichen-Kunde.

Berlin, etc., Dr. Hans Brenducke, etc., I 890

$8^{\circ} \cdot 11^{3}-10_{4}^{3}$ in. nos. in vols. In progress.

O1st year. Oct. 18, 1890-Sept. 1, 1891. Nos. 1-12

20 2nd " " 1, 1891- " 1,1892. " 1-12.

@ 3rd ", " 4 th $1,1892-\quad, \quad 1,1893 . \quad$ " $1-12$.

(3) 5 th " " " $\quad 1,1893-\quad, \quad 1,1894 . \quad$ " $1-12$.

5 6th " " " $1,1894-$ - $, \quad 1,1895 . \quad$ " $1-12$.

(1) 7th " Jan. 8, - " 10, 1896. " " $1-12$.

( ) 8th " " 7, - , 16, 1897. " " $1-12$.

9th " " 13, - " 17, 1898. ", 1-12.

10th ., ", 19, - " 19, 1899. ", 1-12.

11th " " 20, - ", 24, $1900 . \quad$ ", 1-12.

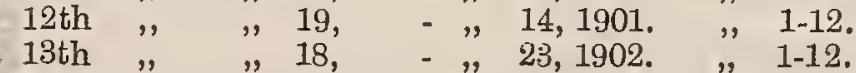

14th " " "27, - "

15 th " " " 20, - " 19, 1904. " " $1-12$.

16 th " " 24, - " 21, 1905. " 1-12.

ith ${ }^{*}$ * Commencing with no. "10, of the seventh year", the journa has been published at Leipzig by Hugo Krötzsch. There is a title-page and an index to each year, except for the sixth and seventh years, for which there is only one for these two year combined. There is also a combined index for the first seven years compiled by Lieutenant Ohrt. There is a supplement to each number with the title "Beiblatt zur' Deutschen Briefmarken Zeitung " and an additional one to no: 2 , first year; nos." 1 and 5 , second year; nos. 2 ' and 5, third year; nos, 5 , 6 and 8 , fourth year, no. 3, fifth year, no. 7, eighth year; nos. 1, 2, 7 and 11, ninth year, no. 1 , tenth year, no. 5 , eleventh year, no. 1 , twelfth year, no. 8 , thirteenth year, no. 4 , fourteenth year, nos. 8 (four) and 10 fifteenth year. Each number, commencing with no. 6 of the third year, has a paper wrapper. Coinmencing with no. 1 of the "Anzeiger" supplement, the first five numbers of which contain humorous, philatelic pictures by A. Reinheimer. The numbers for the first seven years to and including the number for October, 1896, measure 113 inches and the succeeding numbers $10_{\ddagger}^{3}$ inches. Sample copies, for advertisement purposes, of nos. 1 and 12 of the eleventh year were issued, and these two numbers are bound up in Mis. St. Jour. 130 (11).

DEUTSCHE BRIEFMARKEN-ZEITUNG. See ALLGEMEINER BrIEFMARKEN-ANZEIGER.

DEUTSCHE ILLUSTRIRTE BRIEFMARKEN-ZEITUNG. Deutsche Illustrirte Briefmarken-Zeitung. IIlustrirte Zeitschrift zur Förderung der Briefmarkenkunde. Leipzig, Literarisches Museum, I883. 8०. 9 in. Nos. 1-10, Jan. 31, Mar. 31, Apl.-May, June-Dec., 1883. Mis. St. Jour. 58 (3). 


\section{1 \\ DEUTSCHE PAPIER-UND SCHREIBWAREN ZEIT- UNG. See Phitatelisten-Zeitung (Berlin). \\ Dautsche Phipatient $-H$ anomar 1907 \\ DEUTSCHE PHILATELISTEN-ZEITUNG. See BER- Liner Iliustrirte Briefmarken-Zhitung.}

DEUTSCHE STEMPEL-ZEITUNG. Deutsche StempelZeitung. Illustrierte Zeitschrift für Poststempel-Kunde. Diisseldorf, P. Ohrt, I906-07.

8․ 11 in. Nos. 1-2, October, 1906-January, 1907.

* * Future numbers were given as supplements to " Der Deutsche Philatelist". Mis. St. Jour. 151 (11).

DEUTSCHE VERKEHRS-ZEITUNG. Deutsche Verkehrs-Zeitung. No. 6, Februar 11, 1887. [Contains a
Deutscherthess Jach blalt fa Breefmentfer sammles

Berlios

1907 Dee no 1 a cofeculles 6 rogar de

Bour ] Bestenes they thention supplement with article "Das Briefmarkensammeln".]

Fol. 15 in. pp. [51]-52.

Mis, St Jour.
DEUTSCHER PHILATELIST. Deutscher Philatelist.

(.) $4^{\circ}$. 113 in. Nos. 1, 3, March, April, 1896. correspond exactly with ned. 2 one cof the "I Iondoner Philumbers except for the change of the title, name and address of publisher, except for the change of the title, name and address of publisher,
and a few alterations on pages 15 and 23 .

DEW DROP. The Dew drop. Vol. II., no. 4. June, 1886. [Contains article "The United States Mail," which gives a short history of the Post Office in the United States.] Philadelphia, Pa., Geo. Wilson Lutz and H. Douglas Spaeth, I886.

$16^{\circ} .6$ in. pp. [2-3].

Mis. St. Jour. 117 (3).

DIAMOND PHILATELIST. The Diamond philatelist. Unionville, N. Y., E. L. Shove, I895-96. $32^{\circ} .4 \frac{1}{2}$ in. $16^{\circ} .5^{3} \mathrm{in}$. and $8^{\circ} .8$ in. 24 nos. in 4 vols. Vol. I. Jan.-June, 1895. Nos. 1- 6. 123

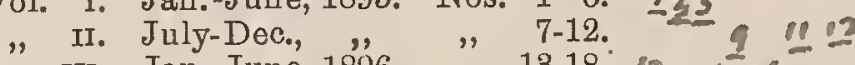

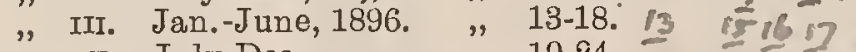

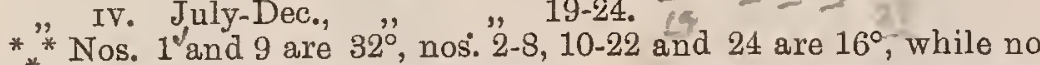
23 is octavo. The number for October, 1895 , is wrongly numbered "Vol. 2. No. 3. Whole no. 9 " in place of "Vol. 2. No 4. Whole no. 10." Thy gis as z=Q Mis. St. Jour. 76 (3).

DIARIO OFICIAL. Diario Oficial. Ano 4. No. 836. Julio 30, 1892. [Contains a postal notice "Direccion G. de Correos " on the issue of a new set of Official stamps.] Asuncion, Paraguay, I892. F'ol. $17 \frac{1}{2}$ in. p. (3). Mis. St. Jour. 136 (7).

DIETETIC RECORD. See Philatelic Record (London).

DIXIE PHILATELIST. The Dixie philatelist. Official organ of the Southern Philatelic Association. Alexander City, Ala., etc., B. Russell, etc., I894-96. $8^{\circ} .7 \frac{3}{4}-8 \frac{3}{4}$ in. 23 nos. in 2 vols.

Vol. I. March, 1894-Feb., 1895. Nos. 1-12

"II. March, A pril and May, Sept., Nov., Dec., 1895, Jan., Apl., ". May, June, July, Aug., 1896. Nos. 1-11.

* * Nos. 3-11, vol. II., were published at Macon, Miss., by Russell and Chappell. Commencing with no. 3, vol. I., each number has a paper wrapper. The number for November, 1895, is numbered " 3 " instead of " 4 ".

DOIMINION BAZAAR. Dominion bazaar. $8 \mathrm{r}$.

Yorlville, etc., Canada, L. B. Greenslade, etc., 1877-

8. 9-101 in. and fol. 14 in. 8 nos.

Vol, May, June, July, 1877. Nos. 1-3.

III. Aug., Sept., Nov., 1879. " " 13 , [14], 16

[ " $"$ IV.] Dec., 1880. No. 6.

" * F. Jan., 1881. partly philatelic." The numbers of vols. I. and Irr. are octavo and those of vols. IV. and $v$. are folio. The numbers of ivol IIT. were published by the Dominion Bazaar Co. at Loronto, and the numbers of vols. IV. and v. wore published by G. Honper also at Toronto. The two last have the title "Dominion
amateur's and fancier's guide to profit, amusement, pet stock and home interests ". The number for September, 1879, is wrongly numbered " 13 ," the same as the August, 1879, number and thers are two distinct editions of number 16, in which some of the contents and advertisements differ. There is a supplement of two pages to no. 3 and also to no. 13 or no. 14 , and a priced catalogue
of postage stamps issued by the Dominion Bazaar in 1881 is bound up with the numbers. Only the stamp portions of no. 2, vol. I., have been preserved and these are mounted in Stamp Scrapbook, vol. III., pp. 121, 122. The other numbers are bound up in Mis. St. Jour. 1 (3).

DOMINION PHILATELIST. The Dominion philatelist. Published monthly in the interests of stamp collecting.

Belleville, Ont., etc., H. F. Ketcheson, etc., I889-97. $8^{\circ} .93-10$ in. 76 nos. in 7 vols.

Vol. I. Jan.-Dec., 1889.

, II. " - " 1890

" III. " - " 1891

"IV.,,- 1892

$\begin{array}{cccc}\text { V. } & \text { VI. } & & 1893 . \\ & \text { VI. } & - & -1894 .\end{array}$

", VII. " " ", 1894.

* "* VII. 1" -Mar. 1895, Dec., 1897. and 11, vol. I., were published by the Dominion Phi-

12, vol. I., to no. 75 , the journal was published by the same Company

at Peterborough, Ont., and no. 76 was published by H. F. Ketche-

son at Belleville, Ont. Fach number beginning with no. 10, vol.

I., has a coloured paper wrapper, with the exception of nos.

66 and 76. No. 51 is wrongly numbered " 50 " and dated " F'ebru-

ary" instead of March, except on the wrapper which is correct. No. 48 has for a supplement "Catalogue of T. S. Clark's fourth auction sale of postage stamps".

DOIMINION PHILATELIST. The Dominion philatelist. Toronto, A. M. Muirhead, etc., I903-05. $8^{\circ} .91$ in. 11 nos. in 2 vols.

Vol. I. Dec., 1903-Dec., 1904. Nos. 1-7.

"II. Jan. -April, $1905 . \quad 1-4$.

* " Nos. were published by the "Dominion Philatelic Association. Nos. 1 and 2 and 3 and 4, vol. II., were severally published together. Wanting all nos. of vol. I.

\section{[Continued as :]}

Dominion philatelist and Canadian youth.

Toronto, Dominion Philatelic Association, 1905-

$8^{\circ} .91$ in. Vols. II.- nos. In progress.

Vol. Ir. May-Dec., 1905. Nos. 5-12.

Vol. II. May-Dec., 1905. Nos. $1-10$.

*" III. Jan.-Oct., 1906 and 6,7 and 8,9 and 10 , and 11 and 12 , vol. II., and nos. 1 and $2,3-5$, and $8-10$, vol. III., were / severally published together.

DOIMINION PHILATELIST AND CANADIAN YOUTH. See Dominion Philatelist (Toronto).

DON QUICHOTTE. Le Don Quichotte. 2me année, no. 69,16 Octobre, 1875. [Contains a caricature of the adopted design for the French postage stamps of 1876.$]$

Fol. $19 \frac{1}{1}$ in. page (1)

Paris, A. Dumon, I 875 . Mis. St. Jour. 115 (16).

\section{DOUGHTY AND PAGE'S FIRST AUCTION SALE} OF PHILATELIC LITERATURE. Doughty and Page's first auction sale of philatelic literature. Muscatine, Iowa, Doughty and Page, 1896. $8^{\circ} .8$ in. No. 1 . October $15,1896$.

* * With prices added by Moses B. Page.

Mis. St. Jour. 93 (2)

[Continued as:]

6

Doughty and Page's philatelic literaturist. Muscatine, Iowa, Doughty and Page, 1896-97. $8^{\circ} .8$ in. Nos. 2-5, Nov. 1, 1896-Jan. 1, Apl. 1, 1897. * * There are two copies of no. $4:$ bound up, one having the prices ture and nos. 2 and 3 are priced in the same way.

$$
\begin{aligned}
& \text { Ac Phlakhst thanows } \\
& 1967 \pm 1-82 \\
& 1908 \text { II } 1-02 \pi
\end{aligned}
$$


Diario De Cániz-Carrz, $1875-S 90$ 
Douphty rPage.

The take of the 6ti sale aras allered by nother staruf from 1897 hor 6 thorro. 


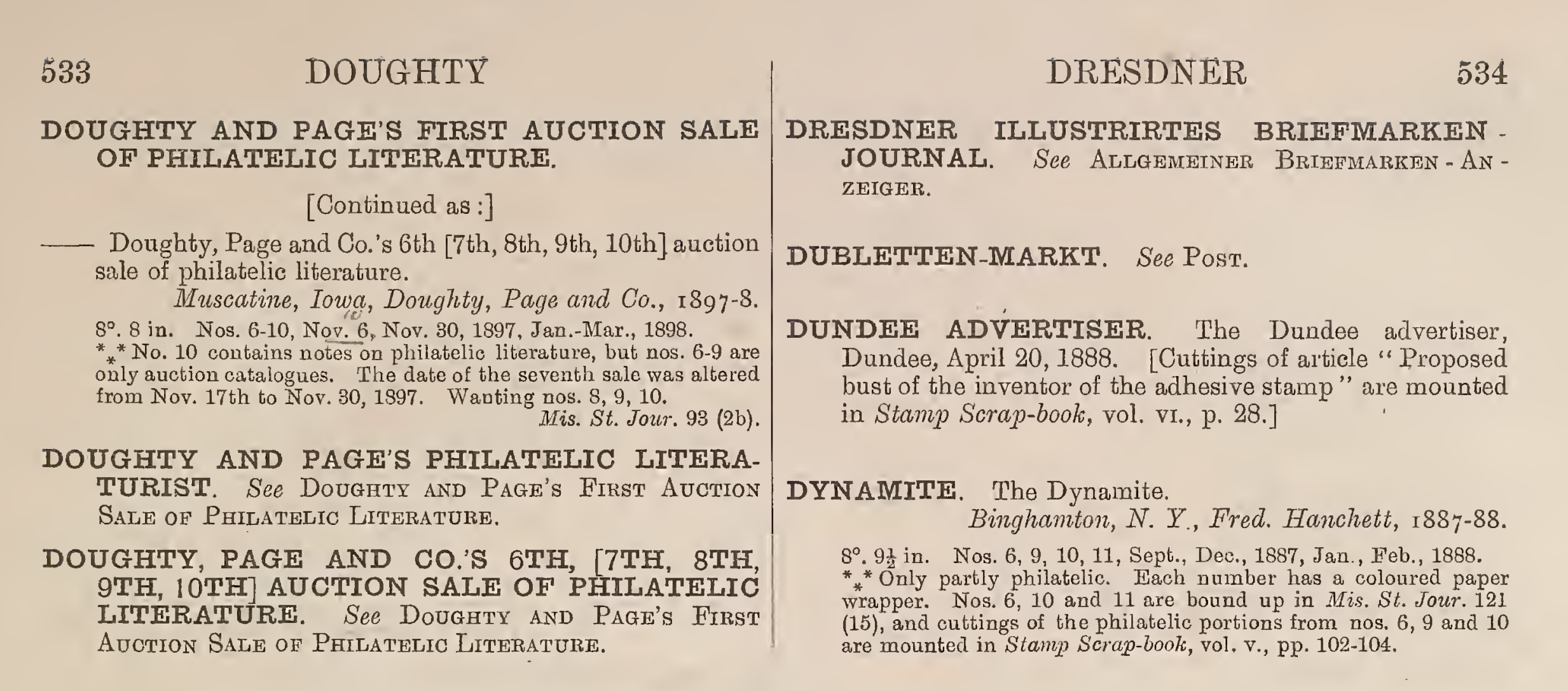


EAGLE. The Eagle. in. 9 nos. in 2 vols.

Uncasville, Conn., O. Walden, ז896-97

Vol, I. June-Dec., 1896. Nos. 1-7.

*"* II. Jan.-Feb., 1897.

EAGLE. The Eagle.

North Wales, Pa., M. Swartley, 1896-97

$32^{\circ} .4$ in. Nos. $1-5$, December, 1896-April, 1897.
* Only partly philatelic. Wanting all five nos.

EAGLE PHILATELIST. The Eagle philatelist. Devoted to the interest of collectors.

Philadelphia, Pa., Hayden and Wesson, 1886. $8^{\circ} .73$ in. Nos. 1-2, Jan.-Feb. 1886.

* * No. 2 has a coloured paper wrapper.

Mis. St. Jour. 40 (6).

EAGLE PHILATELIST. The Eagle philatelist.

Kansas City, Kas., etc., The Eagle Stamp and Publishing Co., etc., х891-93.

$16^{\circ} .6$ in. and $8^{\circ} .8^{3}$ in. 22 nos. in 3 vols.

Vol. I. July, Sept. 1 , Oct. 10, Nov. 10, Dec. 10, Dec. 25, 1891. Nos. $1-6$.

II. Jan 10-June 10,1892 Nos 7-12

III. July 15, 1892, Feb.-May, July-Dec., 1893. Nos. 13-22. * * No 1 is $16^{\circ}$, and the remainder are octavo. Nos. 3-6 were published by M. A. Swanbeck, nos. 7-9 by the W. W. Cox Publishing Company, nos. 10-12 by Swanbeck and Greene, all at Kansas City, no 13 by Roy F. Greene, at Arkansas City, Kas., no. 14 by the Eagle Publishing Company at Arkansas City, nos. by the same Company at Chicago, and nos. 19-22 by 1 . M. Wolcoloured paper wrapper, with the exception ot no. 18 , and no. 6 coloured paper wrapper, with the exception or no. 18, ame numcontains an index to vol. I. No, 1 has in error, no volume numtober-November, 1893," has "no. 20" in error on the wrapper.

EAGLE PHILATELIST. The Eagle philatelist. New Britain, Conn., H. B. Steele and Co., I895. $16^{\circ} .6$ in. No. 1 , Oct. 1895. Mis. St. Jour. 69 (10).

EAGLET. The Faglet. Corry, Pa., R. G. Dawson, rgor. $8^{\circ} .9 \frac{1}{3}$ in. Nos. 1

${ }^{*} *$ Only partly philatelic. Wanting all but no. 2 , which is dated October, 1901

EAST ANGLIAN PHILATELIST. The East Anglian philatelist. (A free and independent monthly magazine) devoted exclusively to stamp collecting.

Norwich, G. T. Bishop, I883-84

$8^{\circ} .10$ in. Nos. 1-6, Oct. 1, 1883-Mar. 1, 1884.
${ }^{*}$ Mis. Stinted on rose paper.

EASTERN BOYS' COIVPANION. The Eastern boys' companion. 1878 .

Gorham, Me., F. L. Perry and F. H. Pintham,

$8^{\circ} .7 \frac{1}{2}$ in. No. 1, August, 1878

${ }_{*}^{*}$. Only partly philatelic. There is a supplement of two pages.
Mis. St. Jour. 117 (5).
FASTERN COLLECTOR. The Eastern collector.

Brooklyn, N. Y., Walls and Hernan, 1885.

$68^{\circ} .9 \frac{1}{4}$ in. No. 1, Jan., 1885.

Mis. St. Jour. 18 (1)

EASTERN COLLECTOR. See EASTERN PRESS.

EASTERN PHILATELIST. The Eastern philatelist.

Fitchburg, Mass., etc., The Eastern Philatelic Publishing Co., etc., 1887-99.

$8^{\circ} .9 \frac{1}{2}$ and $10 \frac{3}{4}$ in. 135 nos. in 22 vols.

Vol. I. Dec., 1887-May, 1888. Nos. 1-6.

"II. July, Seps, Nov., Dec., 1888, Jan., Feb., 1889. Nos. $7-12$.

III. Mar. -Aug. 20, 1889. Nos. 13- 18.

"IV. Sept. 20, 1889-Feb. 20, 1890. " 19- 24.

" $\quad$ v. Mar. 20, -Aug. 10, 1890. " 25-30.

" vi. Sept. 10, 1800-Acb., 1801. " 31- 36.

" vII. Mar. 18. -Ang., 1891. " $37-42$.

" VIII. Sept., 1891-Feb., 1892. " $433-48$.

" IX. Mar. 1892-Fug., 1892. " " 49- 54.

" X. Mept., 1892-An., 1893. " " 55- 60.

" XI. Sent 1893-Feb., 1898. " 61- 66.

", xII. Mar. Mr. -Aug., $1899 . \quad$ " $73-78$.

" xIV. Sept., 1894-Feb., 1895. " "79-84.

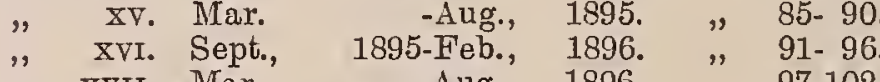

" xvir. Mar. 1806. -Aug., 1896. " 97-102.

" xVIII. Sept., 1896-Heb., 1897. "103-108.

" XIx. Mar. 1897-Aug., 1897. " 109-114.

" Xx. Sept., 1897-Feb., 1898. " 115-120.

" xxI. Mar. Aug., 1898. " 121-126.

*" * Nos. 86-126 are octavo 10 inches and the eremainder are octavo $9 \frac{1}{2}$ inches. Nos. 7 and 8 were published by W. H. Goodrich, nos. 9-11 by the Eastern Philatelic Publishing Co., no. 12 by W. H. Goodrich, no. 13 by the Eastern Philatelic Publishing Co., nos. 14-24 by W. H. Goodrich, all at Fitchburg, Mass. Nos. 25-126 were published by $\mathrm{F}$. H. Pinkham at Newmarket, N. H., and nos. $127-135$ by B. L. Drew and Co., Boston, Mass. There is a coloured paper wrapper to each number.

\section{[Continued as :]}

The Philatelic bulletin and Eastern philatelist.

Salem, Mass., etc., The Naumikeag Stamp and Publisshing Co., I899-1902.

$8^{\circ} .9$ in. Vols. XxiI.-Xxv. 34 nos.

Vol. XXIr. June 25 -Aug. 25, 1899 . Nos. 136-138.

" XXIII. Sept. 25, 1899- " " $1900 . \quad$ "139-150.

" xxiv. " "1900- " "1901. " 151-162.

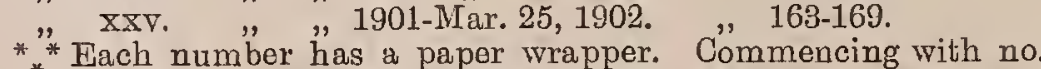
152 the journal was published at Boston, Mass. Amalgamated with the "New York Philatelist," no. 68.

EASTERN PRESS. Eastern press.

Wilmington, Del., Specto and Cole, r888-89.

$8^{\circ} .83$ in. Nos. 1-6, Dec., 1888-May, 1889.

** *nly partly philatelic. Nos. 5 and 6 were published by W. H. Speck. 



\section{EASTERN PRESS.}

\section{[Continued as :]}

Eastern collector

Wilmington, Del., W. H. Speck, r889. $8^{\circ} .9$ in. No. 7, July, 1889.

** Only partly philatelic. The number has a coloured paper ** Only partly philatelic. The number has a coloured paper
wrapper.
Mis. St. Jour. 25 (5a).

FASTERN STAIMP. The Eastern stamp.

Worcester, Mass., Arthur H. Elklund, etc., I892-93. $8^{\circ} .8 \frac{1}{2}$ in. 4 nos. in 2 vols.

Vol. I. Jan., Feb., March, April, 1892. Nos. 1-3.

"II. Jan., 1893. No. 1.

* * No. 1, vol. II., was published by the Argonian Stamp and Pub. Co. No. 3 is dated "March, April, 1892," and has a coloured paper wrapper.

Mis. St. Jour. 65 (9)

EASTERN STAIMP. The Eastern stamp. Duck Pond, Me., Fred. W. Rugg, I 896 $16^{\circ} .51$ in. Nos. $1-3$, Oct.-Dec., 1896.
$* *$ *There is a coloured paper wrapper to each number. Mis. St. Jour. 96 (4).

FCHANGE DE TIMBRES-POSTE. L'Échange de timbres-poste.

Looz, Belgique, Célestin Groenendaels, I893-96. $8^{\circ} .8 \frac{1}{2}$ in. and $4^{\circ} .11 \frac{1}{1}$ in. 44 nos. in. 4 vols.

1st year. May, 1893-May 25, 1894. "No. Spécimen" and 2nd nos. $1-12$.

2nd " June 25, 1894- ", 25, 1895. Nos. 13-24.

3rd " " " 25, 1895- \#, $25,1896 . \quad$ " $25-36$.

**" The specimen number and nos. 1-9 are octavo and the remaining numbers are quarto. There are supplements of two pages, printed on one side only, to nos. 8 and 1.9 .

FCHANGE UNIVERSEL. L'Echange universel. Journal philatélique mensuel. [Prospectus of a journal to be published by M. Nicole, St. André, Eure, but which was never issued.]

Mis. St. Jour. 137 (2)

C FCHAŃGISTE-PHILATÉLISTE UNIVERSEL. L Echangiste-philatéliste universel.

Anvers, Félix Van Coppenolle, r 905-06.

(6) $4^{\circ} .13$ in. Nos. [1-11], October, 1905-May 25-28, July 10, Aug. Sept.-October, Nov.-December, $1906 . \quad$ Mis. St. Jour. 124 (10).

FCHANGISTE UNIVERSEL. LiEehangiste universel. Procure échanges de timbres, cartes, photos, affiches, etc. Paris, M. Ciry, [? 1905]-08.

$8^{\circ}$. 9: in. Nos. 1-10, [? nos. 1, 2, 3] March, Se
Marcl, August, November, 1907, Feb., May, 1908

* * Each number consists of a single leaf printed on one side only, * * and the contents are entirely composed of advertisemonts. Wanting nos. 1, 2, 3 .

ECHO. The Echo. Published in the interest of philatelic literature. $\quad B i g$ Run, Pa., J. M. Thompson, rgoo. $8^{\circ} .8$ in. No. 1. Jan, 1900.

Mis. St. Jour. 112 (3)

(1) F́CHO DE LA PHILATELIE. L'Écho de la philatélie. Journal du collectionneur et du marchand.

Luzarches, Seine et Oise, Charles Caris, 1897-98.

(.) $4^{\circ} .11$ in. Nos. 1-12, Jan. 15, 1897-Jan. 15, 1898.

$\checkmark * *$ There is no number for November, 1897.

Mis. St. Jour. 105 (9)

FCHO DE LA TIIMBROLOGIE. L'Écho de la timbrologie. $\quad$ Dowai, etc., Ed. Frémy Fils, etc., 1887-92. $4^{\circ} .11$ in. 65 nos. in 6 vols.

1st year. Nov. 15-Dec. 15, 1887. Nos. 1- 2. 2nd " Jan. 15- , 15, 1888. "3-14. 3rd " " 15- " 31, 1889. " $15-26$. 5th " " 31- " 31, 1891. " 39-50. $547=822$ ** * Nos. 18-36̈ were published at Paris" by Ed. Frómy nos. 37-51 by Ed. Frémy and A. Hoffmann at the same city, and the remain ing numbers by E.d. Frémy at the same place. Commencing with no. 60 for October 15,1892 , the journal was published fortnightly, and no. 39 has "quatrième année" in place of "cinquième année". Nos. 17-65 were printed at Amiens. There are supplements of two pages to nos. 31,32 and 45 and supplemental slips to nos. $38,50,55,57$ and 63 .
ÉCHO DE LA TIMBROLOGIE

ÉCHO DE LA TIMBROLOGIE. 2e Série.

Paris, etc., Edmond Frémy, etc., I893-

$4^{\circ} .11$ in. Vols, vII.- nos. In progress.

7 th year. Jan. 15-Dec. 31, 1893. Nos. 1- 24

8th " "15-" 31, 1894. " $25-48$

9th " " $15-" 151,1895 . \quad " \quad 49-72$

10th " " $115-"$ " 31, 1896." " $73-96$

11th " " 15- " $31,1897 . " 97-120$

12th " " 15-" $31,1898 . "$ "121-144.

" " $15-"$ " 1,1899 . " 145-168 and 152 bis.

14th " " 15- " 31, 1900. "169-192 and 176 bis.

15th " " 15- " 31, 1901. " 193-216.

16th " " " 15- " 31, 1902. " 217-240.

17 th $"$ " $15-"$ " 31, 1900. " 241-264.

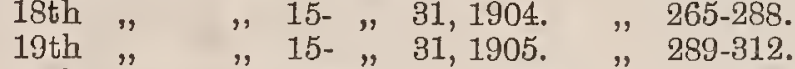

oth " " "15- ", 31, $1906 . \quad$ "313-336.

* "There is a paper wrapper to each number. Nos. 22-68 were published by Edmond Frémy at Douai, and commencing with no. 69 the journal has been published by Yverí and Tellicr, at Amiens, at which place also nos. 1-68 were printed. There aro supplements of two pages to nos. 2 and 6 and a slip supplement to no. 31 Nos. 13 and 14 were published together under the date " 31 Juillot, 1893 ". $\vee$ After no. 96 "2e série "is dropped from the numbering. The two extra numbers " 152 bis," " 176 bis" are dated, respectively, " 7 Mai, 1899" and " 7 Mai, 1900 ".

FCHO DER POSTWFRTZEICHEN-KUNDE. Das Echo der Postwertzeichen-Kunde.

Stuttgart, A. E. Wehrheim, r892-93

Fol. $12 \frac{1}{2}$ in. 11 nos. in 2 vols.

1st year, Nov, Nov., Dec., 1892, Jan.-July, 1893. Nos. 3-12.

2nd " Aug., 1893. No. 1.

*." No nos. 1 and 2 of the first year were published. No. 3 is printed on buff paper and nos. 9 and 10, and 11 and 12, were severally published together. Nos. 9-12 and no. 1, second year,
were printed at Turin.
Mis. St. Jour. 73 (8).

ECHO DU COLLECTIONNEUR. L'Écho du collectionneur. Organe spécial des collectionneurs de tableaux, timbres-poste, antiquités, gravures, armes, monnaies, insectes, journaux, livres, affiches, etc., etc.

Ixelles-Bruxelles, Gaston Neumans, I 897

Q. $8^{\circ} .9 \frac{1}{2}$ in. No. 1 , July 15,1897

***The number has a coloured paper wrappes.

Mis. St. Jour. 90 (12)

ÉCHO DU COLLECTIONNEUR. L'Écho du collec tionneur. Organe mensuel des collectionneurs de timbres-poste, tableaux, gravures, antiquités, armes, monnaies, insectes, journaux, livres, affiches, ex-libris, objets mobiliers, accessoires du costume, etc., etc.

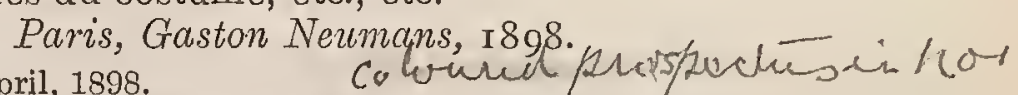

O $8^{\circ} .91$ in. Nos. 1-2, March-April, 1898 .

Mis. St. Jour. 106 (15).

ÉCHO PHILATRLIQUE FT PHILOCARTISTE.

L'Écho philatélique et philocartiste.

Genève, Louis Hetzel, 1900.

(2) 8. 9 in. No. 1, March 1, 1900

*** The contents consist entirely of advertisements.

Mis. St. Jour. 133 (3).

FCHO TIMBROPHILE. See ГJAC'万 [GLAs].

ECLAIREUR DE LA TIMBROLOGIE. L'Éclaireur (1) de la timbrologie. Marseille, D. Samat, i 888 $04^{\circ} \cdot 12^{\frac{3}{2}}$ in. No. 1 , Dec. 25,1888

$V_{*}^{*}$ * The contents consist entirely of advertisements.

Mis. St. Jour. 88 (5).

ECLIPSE. The Eclipse.

Pittsburgh, Pa., Morris and Stewart, etc., I886-87.

$4^{\circ} .10$ in. and $8^{\circ} .9$ in. 10 nos. in 2 vols.

Vol. I. Oct., 1886-May, 1887. Nos. 5-12

"II. June, July, 1887. Nos, 1-2

* * Only partly philatelic. Nos. 5-7 are quarto and the remaining numbers are octavo. Nos. 5 and 6 were published together and commencing with no. 7 each number has a paper wrapper. Nos. 8-12, vol. I., and nos. 1,2 , vol. IT, were published by the Eclipse Publishing Company. Amalgamated with the "Collector," Pittsburgh, Pa., in September 1887. The philatclio department was only started in no. 5. All the numbers given above, with the exception of vol. IT no, 1 are bound up in Mis. St. Jour, 121 (17) and cuttings of the philatelic portions from nos. 10-12, vol. I., and from nos. 1 and 2, vol. II, are mounted in Stamp Scrapbook, vol. v., pp. 121-130. Echangiste-tenwersel Cory-Paris
qvo 1909 Jan to 1
L'Echo Carto - Phelatileque tou Suh. Onest Bordenux ciect with of wh fro

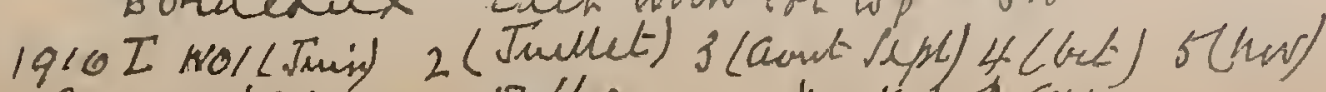

\& cho d'afreque Bollee is punk wh 800
Bcho des Collecitomneurs

(partly phil) 1907 no 810 
$\odot$ ECO DE MADRID. El Eco de Madrid.

$8^{\circ} .10 \frac{1}{4}$ in. and 9 in. 21 nos. in 3 vols.

(2) 1st year. Oct. -Dec., 1900 . Nos. 1- 3.

2nd " Jan.- ", 1901. "4-15.

** Nos. 11 and 12 and 17 and 18 were severally published together, and there is a coloured paper wrapper to each number. Nos. 1-20 are octavo 101 inches and "no. 21 , which is printed on coloured paper and which is merely a price list, is octavo 9 inches. $\checkmark$ The month of publication of no. 21 is not given.

FCO FILATFLICO. El Eco filatelico. Revista mensual dedicada a los coleccionistas de sellos.

La Guaira, J. M. Areledo (hijo) y Ricardo Arteaga G., etc., I892. Carracarho 8

Fol. 13 in. Nos. 1-9, Mar. 30, May 8, 15, June 15, July 15, Aug. 10,17 , Sept. 15 , Oct. 15,1892

* * Nos. 2-6 were published by Arredondo y Arteaga and nos. 7-9 by F. de Arredondo hijo. A no. 10 dated November, 1892, is said to exist, but it seems doubtful if this is really so. Mis. St. Jour. 107 (22).

ECO FILATELICO. El Eco filatelico.

Puerto Plata, Dominican Republic, Ashton y Vitlanueva, I 903

Fol. $15 \frac{1}{1}$ in. and $4^{\circ} .11 \frac{3}{4}-12 \frac{1}{4}$ in. Nos. 1-5, April 1-July, September, 1903.

*** The contents are published in English and Spanish. $\checkmark$ Nos. 1 and 2 are folio and the remaining numbers are quarto. No. 2 bears "Vol. Ir. Año r." in error for "Vol. I. Núm. 2". Wanting no. 1.

ECO POSTAL. El Eco postal. Revista mensual filatélica. Órgano oficial de la Unión Filatélica Valenciana.

Valencia, I 904-

$8^{\circ} .10$ in. nos. in vols. In progress.
[1st year.] Feb.-Dec., 1504. Nos. 1-12. Mh $/-204$

Q [2nd "] Jan. " $1905 . " 13-24$. Mh 205-440

** Each number has a paper wrapper. No. 1 both on page * "Each number has a "Mes de Enero de 1904" obliterated and " and on the wrapper has "Mes de Enero de 1904 " obliterated and "Febrero de 1904" Struck above.

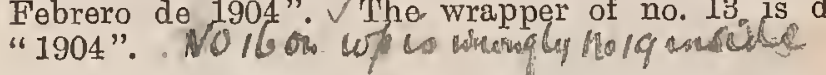

ECOUL IMĂRCILOR. Ecoul Mărcilor. Jurnal philatelic Român. Focşañ̆, Roumanie, Garabet Aslan, I894-95. Fol. 121 -12-12 in. Nos. 1-5, July 25, Sept. 10, 1894, [? no. 3] May 10, [1895].

* *Nos. 4 and 5 were published together with the date " 10 Mai," and this double number consists of only a single sheet. A copy of the prospectus of the journal, dated June, 1894, is bound up in
front of no. 1. Wanting no. 3.

ECUADOR FILATELICO. EI Ecuador filatelico. Guayaquil, Ecuador, Sociedad Filatélica del Guáyas, I $886-87$.

$4^{\circ} .11$ in. and fol. $13+$ in. 14 nos. in 2 vols.

1st year. Jan. 31-Dec., 1886 . Nos. 1-12.

$\checkmark_{*}^{*}$ * Nos.11-12 are quarto and nos. 13,14 are folio. $V_{\text {Nos. }} 1-12$ have paper wrappers. Nos. 4 and 5,9 and 10,13 and 14 were severally published together under the dates "Abril y Mayo, 1886," "Setiembre y Octubre, 1886," and " Enero y Febrero, 1887". $\checkmark N o s .9$ and 10 inside are wrongly dated "Noviembre" and wrongly numbered "8 y 9". This was the first philatelic journal published in Ecuador. Mis. St. Jour. 87 (10).

EDINBURGH REVIEW, OR CRITICAL JOURNAL. The Edinburgh review, or critical journal. No. OXLII., January, 1840. [Contains a review of "1. The Ninth Report of the Commissioners appointed to enquire into the Management of the Post-Office Department. Presented to both Houses of Parliament, 1837. 2. PostOffice Reform-its Importance and Practicability. By Rowland Hill. London: 1837. 3. First, Second and Third Reports from the Select Committee on Postage; together with the Minutes of Evidence, and Appendix. Ordered by the House of Commons to be printed, 1838. 4. Facts and Reasons in support of Mr. Rowland Hill's Plan for a Universal Penny Postage. By W. H. As hurst, 1838. 5. The Post Circular. Nos. I. to XIV. London: 1838. 6. Du Servise des Postes et de la Taxation des Lettres au Moyen d'un Timbre, Paris, 1839.]

London, Longman, Orme, Brown, Green and Long mans, Edinburgh, A. and C. Black, 1840

$8^{\circ} .8 \frac{1}{2}$ in. pp. $545-573$.
*" Bound up with article from the "Quarterly Review".
FDWARDS' PHIIATELIC PRESS IIST Edwards' philatelic press list. Advertiser of philatelists' supplies. $8^{\circ} .8 \frac{1}{\text { in. }} 7$ nos. in two vols. Montreal, John Edwards, [1896]-98.

Vol. I. [March, July, October, December, 1896.] Nos. 1-4. ", II. Sept., 1897, Feb., July, 1898. Nos. 1-3.

*"* All, but no. 1, have coloured paper wrappers. The sub-title no. 2 reads "and advertiser of philatelists supplies," on nos. , 4 "and advertiser of philatelic supplies," and on nos. 1-3 of vol. curios, bric-à-brac and miscellaneous articles".

EFFORT. The Effort.

Boston, Mass., etc., W. T. Wonson, etc., r886-92.

$8^{\circ} .8$ in. $4^{\circ} .7 \frac{1}{1}$ in. and $8^{\circ} .9-9 \frac{1}{2}$ in. 48 nos. in 4 vols.

Vol. I.

", III. Feb., 1890-Jan., 1891. Nos. 1-12.

"IV. $1891-$ 1892. "37-48.

*"* Only partly philatelic. Nos. are octavo 8 inches, nos. are quarto and the numbers of volume IV. are octavo 9$9 \frac{1}{2}$ inches. Nos were published by Farrand H. Borgman, at Detroit, Mich. There is an index to vol. IV., a supplement of two pages to vol. III, no. 5, and coloured paper wrappers to vol. 1 ., no. 9 , vol. III., nos. 7,11 , and to vol. IV., nos. $1-8$ and no. 11 . Wanting nos. 1, 2, 3, 4, 6, 7, 8, 10, 11, 12, vol. I., all nos. of vol. II. and no. 3 , vol. III.

[Continued as :]

The Youth's effort.

Detroit, Mich., F. H. Borgman and Co., I892.

Fol. 11 in. Vol. v. 3 nos,

Vol. $\nabla$. Feb.-April, 1892. Nos. 49-51

* Only partly philatelic. There is a coloured paper wrapper to each number. Wanting no. 50.

FGGS AND STAIMPS. Eggs and stamps.

Comish, Me., Stephen T. Adams, 1894.

$8^{\circ} .81$ in. Nos. 1-2, January-February, 1894.
** Wanting no. 2.

Mis. St. Jour. 152 (4).

ELDER MAGAZINE. See Elder Monthly.

FLDER IMONTHLY. The Elder monthly.

New York, Thomas L. Elder, I 906-07.

$8^{\circ} .10 \frac{1}{4}$ in. 20 nos. in 2 vols.

Vol. I. Mar., 1906-Feb., 1907. Nos. 1-11.

"II. Mar.-Nov., 1907. Nos. 1-9.

** Only partly philatelic. Nos. 4 and 5, 6 and 7 and 8 and 9 , vol. II., were severally published together, each number has a paper wrapper and there is no number for July, 1906. Nos. 5 and 6 , vol. .., are wrongly numbered " 6 " and " 7 " respectively, except on the wrappers which are correct. Continued as the but there is no philatolic matter in these three numbers.

FIDRYN'S ADVERTISER. Eldryn's a tvertiser. Comprises advertisements of sports, games, boys' papers, stamps, coins, curiosities etc., etc., for sale or exchange. London, E., Oatham [printed], H. Copley, r 886. $8^{\circ} .8 \frac{1}{4}$ in. No. 1. Oct., 1886.

** Printed on green paper.

Mis. St. Jour. 79 (3).

ELECTRIC PHILATELIST. The Electric philatelist.

$8^{\circ} .9$ in. 21 nos. in 4 vols. Scranton, Pa., Jay M. Beane, I892-94.

Vol. I. Feb.-July, 1892. Nos. 1-6.

II. Sept., Oct., 1892, Feb.-May, 1893. Nos. 1-6.

", III. June, Oct., Nov., Dec., 1898, Jan., Mar., 1894. Nos. $13-18$.

" IV. Apl., May, June-July, 1894. Nos. 19-21.

*"* A reprint of thirty copies of no. 2, vol. I., was made in July, $18 \% 95$, by H. E. Deats, Flemington, N. J., and two copies of the reprint were printed on Japanese paper. One of these two copies includes an original specimen of the reprinted number.

FIIZABETH DAILY JOURNAL. The Elizabeth daily journal. Elizabeth, N. J., January 31,1879 . [Cuttings of the article "Quite a fortune in old postage stamps," are mounted in Stamp Scrap-book, vol. IV., pp. 24, 25.]

ELUCUBRATIONS CENTENIALES PHILATEIIQUES, 1789-1889. See PARIs-Poste. 



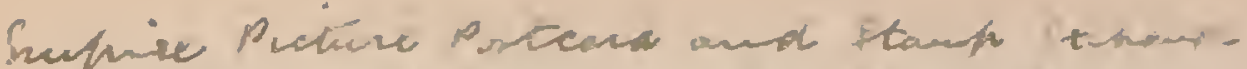

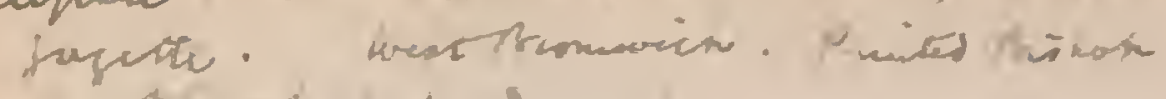

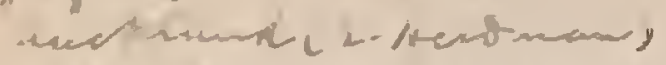

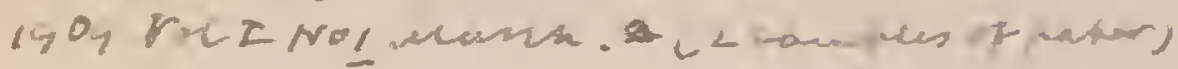

EMCONONTHL If CORCULAR

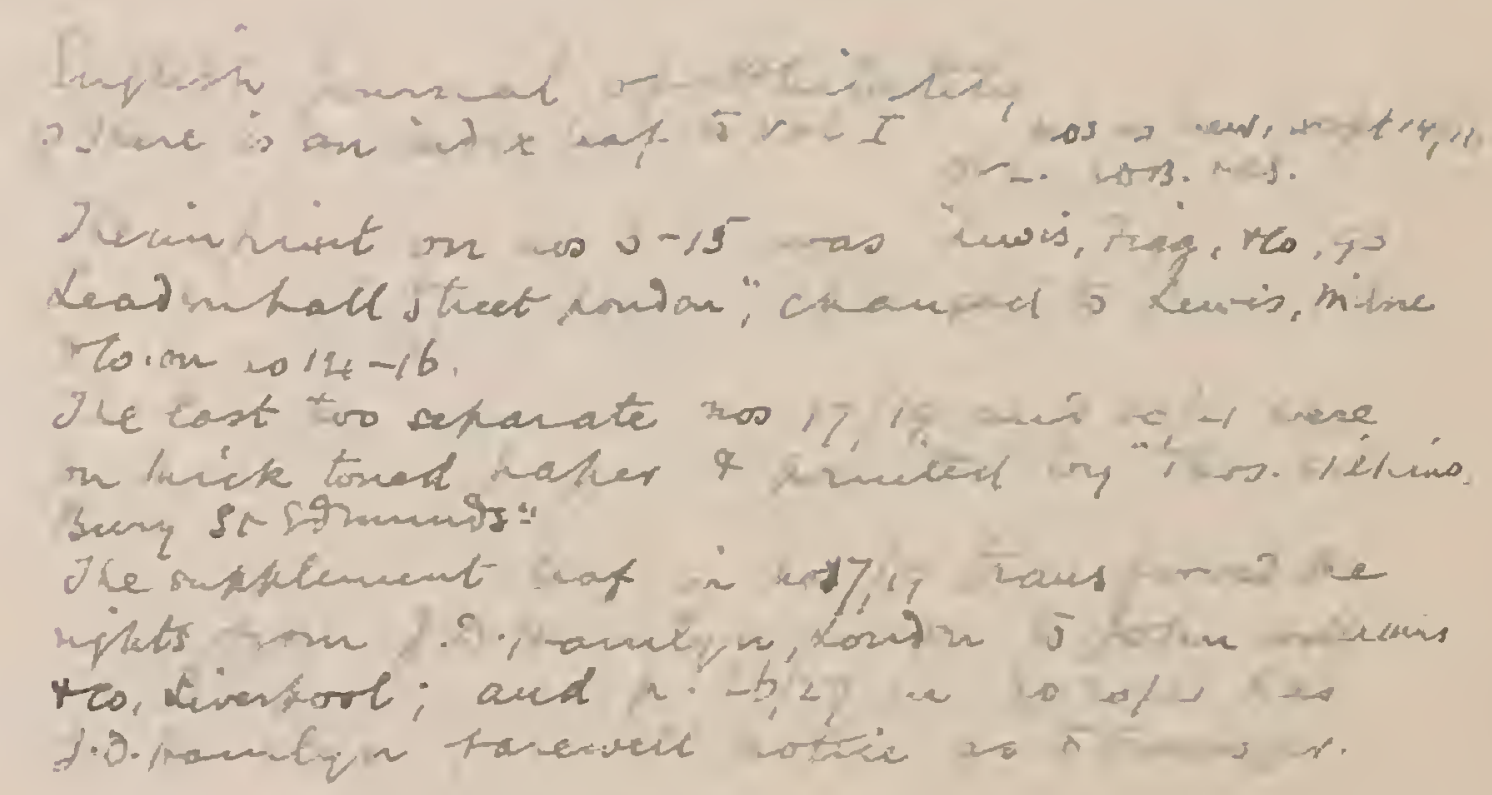

A journal seldom seen to-day is the Engirs A journal seldom seen to philately, which existed from September Journal of Philately, which existed fom launched by
15,1877 , until May 1, 1879. It was lat 15, 1877, until May 1, 1879. It was launched in John D. Hamlyn, of "Holloway, who claimed in "Number One" that "A monthly paper has long been wished for by many dealers, for this country
and we believe we are the only country without such a publication." The contents are still interesting, not the least amusing being the candid if ungrammatical comment, regarding an $A$ journal quoted : "The publishers of this paper should be avoided in business transactions, which are anything but honest."

In No. 5 the name of the editor is given for the first time as J. Hulbert, with J. D. Hamlyn as manager. Publication was regular for thirteen months, supported by two or three pages of advertising. but support then fell off. Nos. "14, 15 and tising; but support then fell of. did Nos. "17, 18 16 ", which contained the announcement that the 19 " which contained the announcementiams \& Co., paper had been bought by John Willast largely and that the late proprietors had "lost largely ever. since the journal has been pumbetter, for new owners evidently did not "dated "From lst a combined No. "20 and " March to lst May, 1879" was the last of this praiseworthy 
541 EMPIRE CITY PHILATELIST

EMPIRE CITY PHILATELIST. The Empire city philatelist. New York, A. M. Crouter, I88z-83. $8^{\circ} .10$ in. 16 nos. in 2 vols.

Vol. I. Apl., 1882-March, 1883. Nos. 1-12. I 3

*" II. $7-12$, vol. I., and nos. 1-4, vol. II., have coloured paper wrappers.

EIMPIRE EXCHANGE GAZETTE. The Empire ex-

- change gazette. (Official organ of the British Exchange Association.)

Ipswich, British Exchange Association, r884-85. C8. $8 \frac{1}{4}$ in. Nos. 1-6, Oct., 1884-Mar., 1885.

$0^{*}$ * The six numbers were afterwards sold together in a coloured paper wrapper. Theses ans /. Mis. St. Jour. 33 (2).

EMPIRE STATE EXCHANGE. The Empire state exchange.

Water Valley, N. Y., Perrine Bros. and Co., r889-9o. $16^{\circ} .6 \frac{1}{2}$ in. Nos. 1-6, Nov., 1889-May, 1890.

* Only partly philatelic. Nos. 2-6 have coloured paper wrappers, and no. 5 is dated "March and April".

Mis. St. Jour. 70 (3)

- New series.

Water Valley, N. Y., etc., Perrine Bros., r89o-92. go. 9 in. 10 nos. in 3 vols.

Vol. I. July-Oct. 1890. Nos. 7-10.

"II. Dec., 1890, Jan., 1891. " 1- 2.

* "* Only partly philatelic. All but no. 7, vol. I., have paper. wrap* Only partly philatelic. All but no. 7, vol. I., have paper wrapN. Y Nos 7-10, vol Rom Roman numerals, and cuttings of the philatelic portions from vol. II., no. 1, are also mounted in Stamp Scrap-book, vol. vi., pp. Mi1
113.
Mis. St. Jour. 70 (3a).

EMPIRE STATE EXCHANGE. The Empire state exchange. Silver Creek, [?], I896. in. No. 1.

* Only partly philatelic. Wanting.

EMPIRE STATE PHILATELIST. The Empire state philatelist. New York, T. C. Watkins, etc., r885-87. $8^{\circ} .7 \frac{3}{4}, 9$ and $9 \frac{1}{2}$ in. 28 nos. in 3 vols.

Vol. I. Jan.-Dec., 1885. Nos. 1-12, but no no. 9 or 11.

"II. " - " 1886. " $1-12$.

*" Nos. 1 and 2 measure $7 \frac{3}{4}$ inches, nos. 3-5, 9 inches, while the remaining numbers measure $9 \frac{1}{2}$ inches. No. 2 , vol. III., bears the title "The Empire State Philatalist, Coin and Curiosity Collector," and the wrapper of this number and also that of no. 3 , vol. III., have the same title. Nos. 10 and 12 of vol. r., all the numbers of vol. II. and no. 1 of vol. III. were published by T. C. Watkins and Co. and the remaining five numbers of vol. III. by the Philatelist Publishing Co. Each number, excepting nos. 6, 7 and 8 of vol. I. has a coloured paper trapper. No. 4, vol. I., is dated "April-May, 1885," no. 7 of the same volume "August
September, 1885," and there is no number for October, 1885 .

\section{[Continued as :]}

The Manhattan journal. Succeeding the Empire state philatelist. A fortnightly journal of literature, art and culture. New York, Manhattan Publishing Co., r888. Fol. $13 \frac{1}{4}$ in. Vol. IV. 5 nos.

Vol. IV. Jan. 14, 28, Feb. 11, 25, Mar. 10, 1888. Nos. 1-5.

** Only partly philatelic. Mis. St. Jour. 59 (1).

EMPIRE STATE STAMP JOURNAL. The Empire state stamp journal. A monthly publication for stamp collectors. 92.

Trumansburg, N. Y., Lincoln Rappleye, etc., r89o-

$8^{\circ} .9$ in. 18 nos. in 3 vols.

$8^{\circ} .9$ in. 18 nos. in 3 vols.
Vol. I. Jan.-Dec, 1890 . Nos. 1-12.

$\begin{array}{rrr}\text { Vol. I. Jan.-Dec, } & 1890 . & \text { Nos. } 1-12 . \\ \text { "II. Mray-Aug., Dec., 1891. } & \text { Io } 1-5 . \\ \text { Jan., 1892. No. } 1 .\end{array}$

* "* No. 5., vol. II., and no. 1, vol. mII., were published by the Empire State Publishing Company. Nos. 3, 4, 5, 6 and 10, vol. I., no. 5, vol. II., and no. 1, vol. III., have coloured paper wrappers. The Stamp Journal and Brooklyn Philatelist".

Mis. St. Jour. 48 (1).

EMPIRE STATE STAMP JOURNAL AND BROOKLYN PHILATELIST. See EMrPIRE State Stamp JOURNAL.

"ENCORE." The Encore.

Braintree, Mass., The Encore Publishing Co., I904.

in. Vol. r1., no. 16, April, 1904.

* Only partly philatelic. Wanting.

ENERGY. Energy. For every one.

Berlin, Ont., Energy Publishing Co., I899.

Fol. 12 in. and $8^{\circ} .8 \frac{1}{2}-8_{4}^{3}$ in. 8 nos. in 2 vols.

Fol. I. June 1, 15 July-Oct., 1899 . No: $1-6$.

* " Ir. Nov. Norly partly philatelic. Ne. Nos. "1 and" 2, vol. I., are folio and the * Only partly philatelic. Nos. 1 and 2 , vol. I., are folio and the
remaining numbers are octavo. Nos. 3-6, vol. I., have paper wrappers.

Philatelic series

Berlin, Ont., F. I. Weaver, rgoo-or.

$8^{\circ} .7 \frac{1}{2}-8$ in. 14 nos. in 3 vols.

Vol. I. Feb. -July, 1900. Nos. 1-6.

Vol. I. Feb. 1900 -July, 1900. Nos. 1-6.

" III. February, March, ", " 1-2

*" "The numbers also bear respectively "Old sevies. Vol. II., nos. 3-6," followed by " nos. 13-22," but the number for March, 1900, 3-6," "Ollowed by " nos. 13-22," but the number for " Mol. " 4 and 6 , vol. I., nos. $1-5$, vol. II., and no. 1 , vol. III., have paper 4 and 6, vol. I., nos. 1-5, vol. Ir., and no. 1, vol. III., have paper May, 1901, under the title the "Canada Stamp Sheet and Energy".

ENGLISH JOURNAL OF PHILATELY. The English $\odot$ journal of philately.

Holloway, London, N., John D. Hamlyn, r877.

$8^{\circ} .9 \frac{1}{2}$ in. Nos. 1-4, September 15-December 15, 1877. - Mas-j-

[Continued as :]

The English journal of philately or stamp collectors magazine.

Holloway, London, N., John D. Hamlyn, r878. $8^{\circ} .9 \frac{1}{2}$ in. Nos. 5-9, January 15-May 15, 1878. W43-80

[Continued as :]

The English journal of philately

Holloway, London, $N$., John, D. Hamlyn, eto., r $878-$ 79.
$8^{\circ} .9 \frac{1}{2}$ in. 12 nos. in 2 vols.

Vol. I. June 15 -Aug. 15, 1878. Nos. 10-12.

* 11. Sept. 15, 1875-May 1, 1879 " 19 " 12 published together under the respective dates "From October to December, 1878" "From 1st Jan. to 1st March, 1879" and "From 1st March to 1st May, 1879". $\checkmark$ Nos. 17-21 were published by John Williams and Co. at Liverpool, and these numbers were printed at Bury St. Edmund's. There is an index for the twelve numbers of vol. I. and a supplement of two pages, printed on one $\checkmark$ side only, to nos. 17-19, dated "March, 1879 ".

\section{ENGLISH JOURNAL OF PHILATPLY OR STAMP} COLLECTORS' MAGAZINE. See ENGLISH JourNAL OF PHILATELY.

FNGLISH SPECIALISTS' JOURNAL. The English specialists' journal.

Swanage, etc., H. L'Estrange Ewen, r895-97.

$8^{\circ} .7 \frac{1}{4}$ in. 17 nos. in 2 vols.

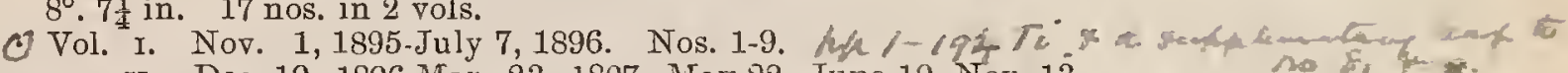
c. "II. Dec. 19, 1896-Mar. 23, 1897, May 22, June 19, Nov. 13, Dec. 18, 1897. Nos. 1-8. ** There is a title-page and an index for the two volumes com-
bined, and a coloured paper wrapper to each number. $v$ Vol. II. was published at Norwood, London, S.E., and all the 17 nos. were printed at Bournemouth. "No. 1, vol. II., is numbered "No. 10 " and all the wrappers of nos. 1-8, vol. II., have the double numbering nos. 10-17 and vol. II., nos. 1-8.

ENGSTROM'S MONTHLY STAMP NEWS. Engstrom's monthly stamp news

$8^{\circ} .6 \frac{1}{2}$ n. No. 1 , October, [1904].

$$
\text { Holdrege, Neb., G. E. Engstrom, [r 904]. }
$$

* The number has a coloured paper wrapper.

Iits. St. Jour. 40 (5).

ENTERPRISE. The Enterprise.

Boston, Mass., J. F. Williams, 1893. * in. No. 1 , October, 1893.

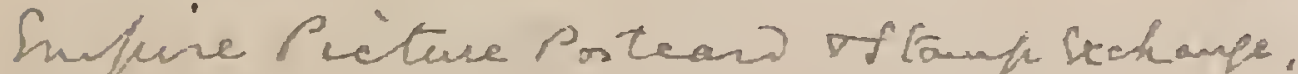

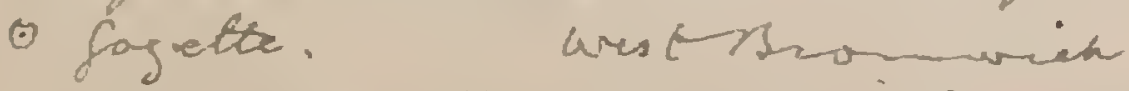

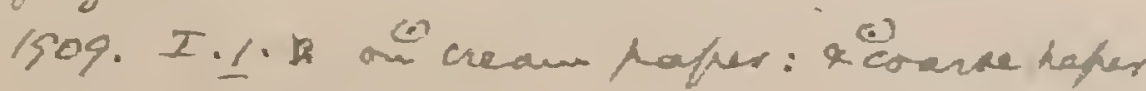

"Enghikis Rudget." Peterbonou

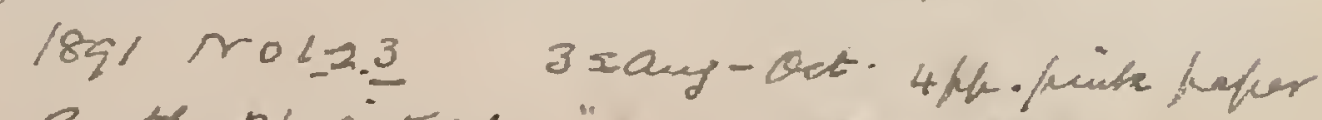$$
\text { Porthy phicitecie. "suet t. arienty }
$$

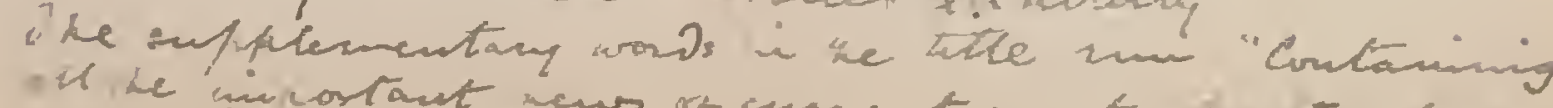

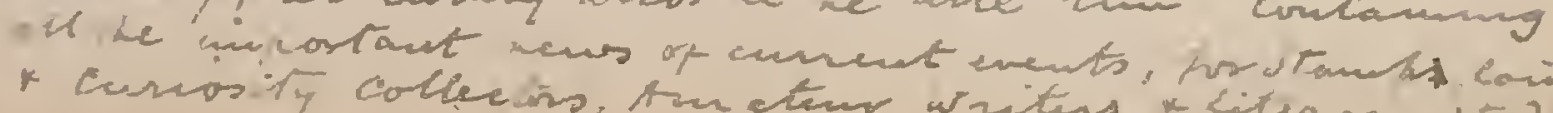


ENTERPRISE. The Enterprise.

* in. No. 1. .

ERA'S MONTHLY. Ëra's monthly.

Benson, Minn., Ernest R. Aldrich, I888.

$8^{\circ} .8 \frac{3}{4}$ in. Nos. 1-4, Sept. 15-Dec., 1888.

* * Nos. 3 and 4 were published together under the date "November-December, 1888 ". Mis. St. Jour. $26(10)$

- [Second series.] in. No. 1, September [1895].
** Wanting.

Benson, Minn., Ernest R. Aldrich, [1895].

ERDBALI. Erdball. Internationales Organ für den Briefmarkenhandel.

Ohrdruf, Aug. Stadermann Jr., I880. Fol. 133 in. Nos. 1-9, April 1-Dec. 6, 1880.

ERNST HAYN'S ILLUSTRIRTES OFFERTENBLATT FỨR BRIEFMARKENSAIMIMLER UND HANDLER. Ernst Hayn's illustrirtes Offertenblatt für Briefmarkensammler und Händler. Berlin, Ernst Hayn, Leipzig [printed], r888.

$8^{\circ} .91$ in. Nos. 1-6, Oct. 1 , Oct. 15, Nov. 1, Nov. 15, Dec. 1, Dec.
15, 1888. 15,1888 .

ERSTE SUDAIMERICANISCHE POSTKARTEN ZEITUNG. Erste Südamericanische Postkarten Zeitung. Officielles Organ des Weltansichtskartenvereines "Brasil".

Sorocaba, Brazil, Alexandre Richtman, [1899]. $8^{\circ} .10$ in. Nos. [1]-2; [Jan.-Feb., 1899].

* "Published with "Colleccionador de Sellos" with which it is bound up.

[Continued as :]

This shoul___Erste Südamericanische Sport und Postkartenzeithowe hem ung. Officielles Organ des Weltansichskartenvereines finen also "clavat. "Brasil".

Sorocaba, Brazil, Alexandre Richtman, [1899].

8. 10 in. Nos. 3-8. [Mar.-Aug., 1899.]

** Published with "Colleccionador de Sellos" with which it is bound up.

ERWIN'S PHILATELIC ADVERTISER. Erwin's philatelic advertiser.

South Bend, Ind., Erwin, I906.

$8^{\circ} .8 \frac{3}{4}$ in. Nos. 1-2, June-July, 1906.

* * Each number has a paper wrapper. Mis. St. Jour. 126 (10).

ESPAÑA FILATÉEICA. España filatélica.

$8^{\circ} .8 \frac{1}{2}$ and 10 in. 11 nos. in 2 vols. Barcelona, Alexandre, r899- 900 .

(1) 1st year. May 15-Dec. 31, 1899. Nos. 1- 7

Q 2nd "J Jan. 31-May 31, 1900 . 8 " 811 . arey there is a/coloured paper wrapper to each number. There is no number for August, 1899, or for April, 1900.

ESPAÑ POSTAL. La España postal. Union Postal Universal. Revista quincenal ilustrada.

Madrid, Ramón Serrano Pingarrón, 1890-9I. Fol. $15 \frac{1}{2}$ in. 24 nos. in 2 vols.

$\$ 91$ 1st jear. Feb. 1-Dec. 15, 1890. Nos. 1-22.

$\Leftrightarrow$ 2nd "Jan. 1-Jan. 15, 1891.

** Only partly philatelic. No. 24 contains an index of the contents of each number, and there is a supplement of two pages to no. 10. Wanting no. 3.

ESP色RANCE. Espérance.

Rotterdam, [R. J. Strang], I898. $8^{\circ} .11$ in. [Nos. 1-2], January-March, 1898. Mis. St. Jour. 129 (5).

ESSEX COUNTY PHILATELIST. The Essex county philatelist.

Lawrence, Mass., Lawrcnce Stamp Co., etc., I 889-92. $8^{\circ} .8 \frac{1}{4}$ in. 31 nos. in 3 vols.

Vol. I. Sept., Nov. 1, 1889-Sept. 15, 1890. Nos. 1-12.

ol. I. Sept., Nov. 1, 1889-Sept. 15, 1890. Nos. 1-12

$\begin{array}{rrr}\text { "Ir. Oct. 15, 1890-Sept., } & 1891 . \\ \text { "IIr. Oct. } & \text {-Dec., } & \text { 1891, Feb, Mar., May, June, }\end{array}$ 1892. Nos. 1-7.

* Nos. 5-12, vol. I., were published by Wm. M. Stuart, nos. 1-2, vol. Ir., by the Eissex County Philatelist Company, and the remaining numbers by the Essex County Philatelic Publishing Company. Nos. 1-8, vol. II., and nos. 1-6, vol. IIr., have paper wrappers. The number for August, 1891, is wrongly numbered "12" in place wrapper bears the date "Jan.-Feb., 1892".

ESSOR PHILATHLIQUE. LiEssor philatélique.

Gendbrugge, Belgiquc, E. Questiaux, I899-г9o6. $8^{\circ} .93-11$ in. 77 nos. in 7 vols.

C 1st year. Nov., 1899-Oct., 1900. Nos. 1-12.

2nd " " 1900- ", 1901. " 13-24.

C 3rd " " 1901- " $1902 . \quad$ " $25-36$.

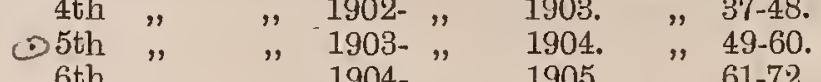

6th " " 1904- " 1905-March, 1906. " $191-72$.

$\sim_{*}^{*}$ * After no." 37 the contents consist of nothing but advertisements. Nos. 10 and $11 ; 21,22$ and $23 ; \cup 33,34$ and $35 ; 45,46$ and $47 ; 57,58$ and $59 ; 68-71$, were severally published together, and nos. 13-37 have coloured paper wrappers. There is a supplement to no. 13-37 have coloured paper wrappers. The title "Circulaire mensuelle de la Ligue d'Achat timbres pour collections, no. 23, 31 Mai, 1901". Commencing with bres pour collections, no, 23, 31 Mai, 1901 ". Commencing with
no. 38 the journal was printed on green paper. Nos. 1-12 measure no. 38 the journal was printed on green paper. Nos. $1-12$ measure "VIe année " in error for "VIIe année". Wanting nos. 44, 75, 76.

झSTRELLA FILATÉLICA. La Estrella filatélica.

Mayaguez, Pto. Rico, Manuel Font y Raul Gomez, r $904-05$ :

$8^{\circ} .10-9 \frac{1}{2}$ in. 8 nos. in 2 vols.

1st year. Sept. 1-Dec., 1904. Nos. 1-4.

2nd "\# Jan. -April, $1905 . \quad$ " 5-8.

Mis St. Jour. 152 (6).

ESTRELLA FILATELICA DE CHILE. La Estrella

filatélica de Chile. Periodico mensual dedicado a los coleccionistas de estampillas.

Santiago, Chile, Cárlos Echeverria y Manuel Cruzat, etc., $1892-93$.

$8^{\circ} .83-10$ in. 11 nos. in 2 vols.

1st year. June -Dec. 20, 1892. Nos. 1- 7

2nd " Jan. 20-Apl. 30, 1893. " 8-11.

* No. 3 was published by Jilberto "Alessandri i Manuel Cruzat and nos. 4-11 by Héctor Pinto and others. Each number, except the last, has a coloured paper wrapper, and no. 8 is numbered
"Núm. 1, año Ir."
Mis. St. Jour. 84 (3).

ESTUDIO. El Estudio. Semanario dedicado á la Escuela y al Hogar. Nos. 38 and 40 . September 15 th and 29th, 1892. [Each number contains a"Sección Filatélica".] $8^{\circ} .111$ in. Montevideo, Domingo Mantovani, 1892.
Mis. St. Jour. 115 (1).

FTNA PHILATELIQUE. L'Etna philatelique. Journal paraissent chaque mois.

Catane, Sicile, Socićté Etna Philatclique, I 897 .

(.) $16^{\circ} .6$ in. - No. 1 , Oct. 15,1897

* The number has a coloured paper wrapper.

ETOILE CARTO-PHILATÉEIQUE. L'Étoile cartophilatélique.

Gondrecourt, France, Emile Défortery, r 905. $8^{\circ} .8 \frac{1}{2}$ in. and $4^{\circ}: 11$ in. Nos. 1.5, March 1-July, 1905.

** Nos. 1- are octavo, nos. are quarto, and nos. 1- have coloured paper wrappers. Wanting no. 4.

ETOILE D' ITALIE. L'Étoile d'Italie. Revue mensuelle. Rome, Léopold Quartini, I876-78. Fol. $12 \frac{1}{2}$ in. $18 \frac{1}{2}$ in. and $25 \frac{1}{2}$ in. Nos. 1-4, March-June, 1876; nos. 5-10, Ost., 1876-Mar., 1877 ; no. 11, May 17, 1877 ; no. 12, July Aug., 1877 ; no. 13 , Sept., 1877 ; No. 14, Jan., 1878; no. 15, Fob. Mar., 1878; no. 16, April-May, 1878.

* *nly partly philatelic. Nos. $1-12$ measure $12 \frac{1}{2}$ inches, nos. 13 14 , and $16,18 \frac{1}{2}$ inches and no. 15 measures $25 \frac{1}{2}$ inches. The

- ispana caulopla Barculouna 


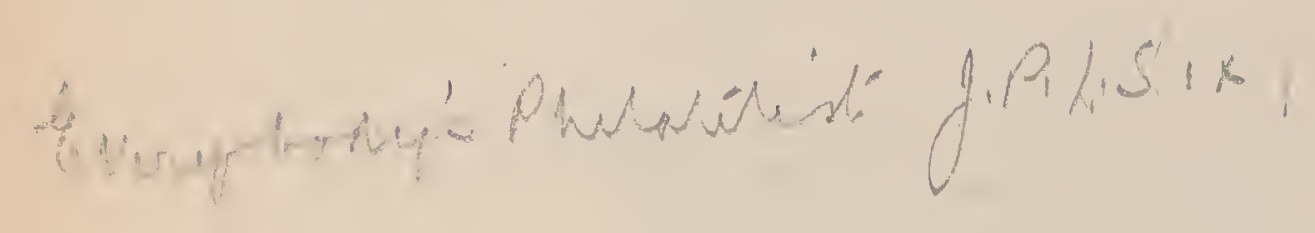


words "Revue mensuelle" are omitted on nos. 11, 12, 13, 14 and 16. A philatelic supplement " $L$ 'Ami du Collectionneur" was published with nos. $5,6,7,8,10,11,12,13,14,15$ and 16 ; no. 10 is dated 10b. Mar., 1877, no. 11, Ap..-May, 1877, nos. $5-8$ and no. " bear the same date as the coresponding numbers of the "Ltoilo ditalie," while "T "lso bears the "Title "La stella d' the following "Prix-courant de lAmi du Collectionneur, 5e Année, No. 28, Mars-Avrit, 1880," octavo 83 inches, published al Rome by L. Quartini. This is found printed on three different coloured papers. It has an article "La Poste des Hotels Suisses," but the contents consisto dvertisements.

Mis. St. Jour. 2 (1) and no. 15 in Mis. St. Jour. 136 (25).

ÉTOILE PHILATÉLIQUE. L'Étoile philatélique.

Padoue, Italie, A. Ravazzolo, I895-I907.

$8^{\circ} .8 \frac{1}{2}-8 \frac{1}{1}$ in. 78 nos. in 7 vols.

1 st year. Oct. 12, 1895-Sept., 1896. Nos. 1-12.

C. 2nd " " 30, 1896- " 30, 1897. " 1-12.

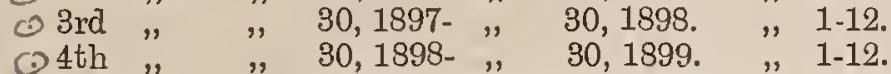

$\odot 5$ th " " 30, 1899-April, 1900 . " $1-7$

6 6th " April, 30, 1905-Mar. 30, 1906. " "1-12

* * Nos. 7 and 8,9 and 10,11 and 12 of the first year,

* *Nos. 7 and 8, 9 and 10, 11 and 12 of the first year, nos. 8 and 9

10 and 11 of the third year, nos. 6 and 7 of the fifth year and nos.

3 and 4 of the seventh year, were severally published together.

The numbers of the first year have paper wrappers and the

wrapper of nos. 7 and 8 is wrongly numbered "No. 6-7". After

the end of the first year the numbers consist entirely of advertisements.

FTOILE PHILATELIQUE BELGE. L'Etoile philatélique Belge. Gand, Alph. Bouquiaux Fils, I 905 . Fol. 11 in. Nos. 1-10, January 25-November, 1905.

* Nos. 8,9 and 10 were published together within a coloured paper wrapper. The date on page 1 is "Aout-Septembre-Octobre" and on the wrapper "Novembre 1905". Amalgamated with "Annonce Philatélique" in February, 1906.

EUREKA. The Eureka.

$$
\text { Sharpsburg, } P \text { a., [? }
$$

], $\mathbf{1 8 9 5}$

* in. Nos. $1-4$.

FUREKA PHILATELIST. The Eureka philatelist. San Francisco, Cal., The Eureka Stamp Co., I88890.

$24^{\circ} .5 \frac{1}{2}$ in. and $8^{\circ} .9$ in. 18 nos. in 5 vols.

Vol. I. Sept.-Dec., 1888. Nos. 1-4.

"II. Jan. -Apl., 1889. " 1-4.

" Irr. May-Aug., " " 1-4.

IV. Sept.-Dec., " ", " 1-4.

*"* V. Jan. -Feb., 1890. Is $24^{\circ}$. and vols. II. $1-2$. were published together and the four numbers of vol. I. and the two numbers of vol. $\nabla$. have coloured paper wrappers. There are supplements of (2) pp. to vol. IIr., nos. 1, 2 and 3, and to vol, rv. nos. 1,2 .

Mis. St. Jour. 22 (4).

EUROPEAN STAMP JOURNAL. The European stamp journal. New York, The European Stamp Co., I872. $8^{\circ} .9 \frac{1}{3}$ in. No. 1, June, 1872

Mis. St. Jour. 17 (3)

EVENEIMENT. L'Événement. Supplément, gratuit au numéro du mercredi I6 mai du journal l'Événement. [Contains an article "Les Timbres Poste" by André Jakson, with illustrations of essays of French stamps.]

Fol. $12 \frac{1}{4}$ in. (8) pp.

Paris, Eidmond Magnier, [1894].

* * Bound up at the end of "Le Questionneur Timbrophilique," for May, 1894.

EVENING POST. The Evening Post. New York. March 21, 1888. [Cuttings of article "A letter-stamping machine, an ingenious device which does the work of five men" are mounted in Stamp Scrap-book, vol. vI. pp. 16, 17.]

EVERGREEN IMONTHLY. The Evergreen monthly. Avon, Washington, [?] ] i 888 * * Only partly philatelic. Wanting.

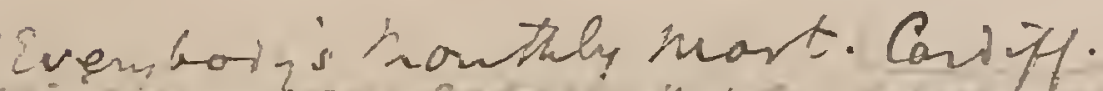

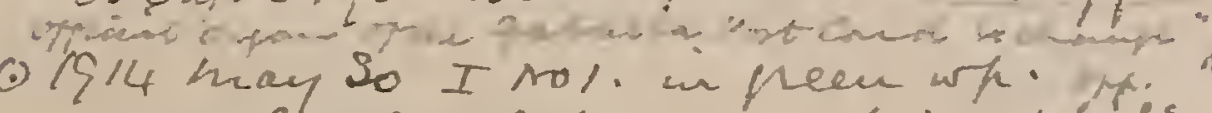

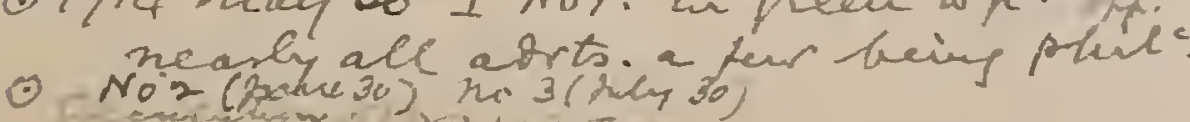

FVERGREEN STATE PHILATELIST. The Evergreen state philatelist.

Hartland, Washington, etc., R. W. French, I894I 900 .

$16^{\circ} .6 \frac{1}{2}$ in. and $8^{\circ} .9$ in. 72 nos. in 13 vols

Vol. I. Jan.-Dec., 1894. Nos. 1-12.

" II. Feb. Jan., 1895. " " $14-19$.

" IV. Aug.-Dec., " ", 20-24.

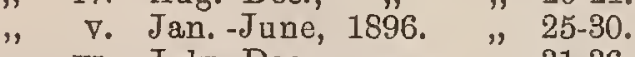

" vi. July-Dec., " "31-36.

" VII. Jan. -June, 1897. " "37-42.

" VIII. July-Dec., " " 43-48.

" IX. Jan. -June, 1898. " 49-54.

" \. Sept.-Dec., " " $55-58$.

" XI. Jan. -June, $1899 . \quad$ " 59-64.

" xII. Oct. -Dec, " \#̈. "

*" Nos. $1-13$ are $16^{\circ}$. and the remainder are octavo. There is a coloured paper wrapper to each number and a supplement of two pages to no. 28. Nos. 39-54 were published at The Dalles, Or. nos. 49 and 50 are wrongly dated " 1897 ," but the correct year is given on the wrappers, no. 53 has "vol. 9 , no. 4 " in place of "vol 9 , no. 5," and no. 72 is dated "May-June, 1900 ".

FVERY BOY'S MAGAZINE. Every boy's magazine. No. 18, July, 1863. [Contains an article "Postage Stamps " by Henry Whymper.]

London, Routledge, Warne and Routledge, I863. $8^{\circ} .7 \frac{1}{2}$ in. pp. $426-432$.

* The number has a coloured paper wrapper. The article was afterwards published in "Every little boy's book," for which see PART r. - Evtery. Mis. St. Jour. 152 (3).

[Continued as:]

Routledge's magazine for boys. With which is incorporated Every boy's magazine. No. 12, December, 1865. [Contains an article "The Stamp-dealer's business"..] [ondon, George Routledge and Sons, I865. 8०. 83 in. pp. 722-724.

** The number has a coloured paper wrapper. Wanting.

- Nos. 26-48. February, 1867-December, 1868. [Each number contains amongst the advertisement pages a monthly report of new issues, etc., under the heading "The Stamp collector". Messrs. Young and Stockall of Liverpool, drew up the reports in nos. 26-36, after which their names are omitted.]

$8^{\circ} .83$ in. 23 nos.

London, George Routledge and Sons, I867-68.

** There is a coloured paper wrapper to each uumber. Wanting all nos.

[Continued as :]

The Young gentleman's magazine. Nos. 1-12, JanuaryDecember, 1869. [Each number contains amongst the advertisement pages a monthly report of new issues, etc. under the heading "The Stamp collector," by Dr. C. W. Viner.] London, George Routledge and Sons, I869. $8^{\circ} .8 \frac{1}{2}$ in. 12 nos. ** There is a coloured paper wrapper to each number. Wanting
no. 12 .

EVERY IMONTH. Every month.

Holyoke, Mass., John B. Sutcliffe, I894-95.

$8^{\circ} \cdot 8 \frac{1}{2}-8 \frac{3}{4}$ in. 18 nos. in 2 vols.

Vol. I. Jan. 20-Dec., 1894. Nos. 1-12.

* * I stamp department was" started with no. 10, the previous numbers having little or no philatelic matter. Nos. 3-12, vol. I. and nos. 1-6, vol. II., have coloured paper wrappers. Wanting nos. $1,2,3,4,5,6$, vol. II

EVORA POSTAL. Evora postal. 96.

Evora, Portugal, Antonio Manuel Torres, etc., I895-

Fol. $13 \frac{1}{2}$ in. and $8^{\circ} .9 \frac{3}{4}$ in. Nos. 1-12, Apl.-Nov. 1, 1895, Jan. 1April, 1896

** Nos. 1-8 are folio and nos. 9-12, which are called "2ême Série," are octavo. Some copies of no. 1 were printed on rose paper. Nos. 3 and 4 were published together under the date "Juin, 1895," and there is no number for July, 1895. Nos. 6-12 were published by Antonio Manuel Torres and Angelo C. Pinto Bastos. This journal was continued in June, 1896, with the subtitle "Fol ha litteraria noticiosa $\theta$ charadistica" and eeased to be of a philatelic character. Wanting nos. 11 and 12. 
FWEN'S COLONIAL STAMP IMARKET. See BRITISH AND COLONIAL STAMP MAREET.

EWEN'S CURRENT STAIMP QUOTATIONS. EWen's current stamp quotations.

Norwood, London, S.E., Bournemouth [printed], Ewen's Colonial Stamp Marleet, Limited, I go6-

Fol. 15 in. nos. in vols. In progress.

[Vol. I.] Jan. 6-Dec. 29, 1906. Nos. 1-62.

$S$ al ** This is a supplement published with " Ewen's weekly stamp 22 and 24 were published separately from the journal.

EWEN'S WEERLY CIRCULAR. See L'ESTRANGE EWEN'S WEEKTY CIRCULAR.

EWEN'S WEEKLY CIRCULAR, L'ESTRANGE. See L'Estrange E'WEN's WEEKLY CIRCUIAR.

EWEN'S WEEKLY STAIMP NEWS. Ewen's weekly stamp news. With which is incorporated Ewen's weekly circular.

Norwood, London, S.E., Bournemouth [printed], $H$. L'Estrange Ewen, etc., 1899-

Fol. 15 in. nos. in vols. In progress.

Vol. I.O Sept. 30, 1899-Jan. 13, 1900. Nos. 1-16. $]$ Ti T. $^{\circ}$

"II.OJan. 20, -Mar. 31, " " "

"IIr.OApl. 7, -June 30, "

IV. O July 7,

V. Oct. 13

vir.o July 6 ,

virr.e Jan. 4,

-Dec. 29 ,

-June 29, 1901.

-Dec. 28

41- 54. $T_{i} \mathrm{C}$

$55-66$.

$67-92.0 \mathrm{Ti}$

Dec. 27 ,

119-144. $07 \mathrm{Ti}$

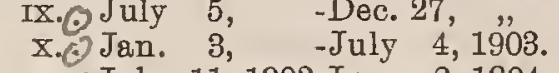

XI. July 11, 1903-Jan. 2, 1904.

xIr. Jan. 9, -July 9, "

XIII. July 16, 1904-Jan. 7, 1905

[XIV.] oJan, 14,

Dec. $30,19 \ddot{6} 6$

145-170. OTi

198-197. OTE

$224-250.0 T$.

251-276. OTi.

$277-327$.

328-379.

* * Commencing with no. 147 the journal has been published by E*wen's Colonial Stamp Market, Limited. There is a combined

(-) title-page and an index to vols. r. and II. and also for vols. III., IV.

- and v., separate titlc-pages and indexes for vols. VI.-XI. and nos.

- $65,117,169,221,274$ and 326 have paper wrappers. The journal has a double numbering: old series continued from "Ewen's weekly circular," and commencing with no. 87 "and so on, and new series commencing with no. 1 and so on. The numbering by volumes was discontinued after the completion of vol. XII. and the issue of title-pages and indexes after vol. xI. Some, but

(1) not all, of the copies of no. 28 are wrongly numbered " 27 "

Nos. $55,56,57$ and 58 are wrongly numbered whole numbers 150 , 151,142 and 143 instead of $141,142,143$ and 144 , and no. 195 is wrongly numbered "194". There is a supplement the "Stamp

- market" to nos. 8, 9 and 10 and supplements with the titles, "British and colonial stamp market"; "Ewen's colonial stamp market"; "Ewen's colonial stamp market, ltd."; and "Ewen's current stamp quotations"; are catalogued under their four respective headings. There is a supplement to no. 348 with the title "Complete catalogue of railway letter stamps," this is

- numbered "No. 2," and there is a supplement to no, $371^{2}$ with the title "The History of railway stamp collecting". A copy of the prospectus is bound up at the end of volume fi. 29

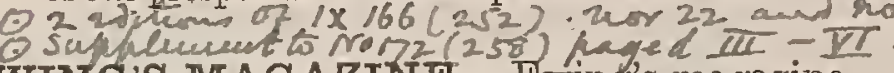

EWING'S IMAGAZINE. Ewing's magazine. Decatur, $\pi l l .$, [?

], 1894 .

in. Vol. II., no. 15

* * Only partly philatelic. Wanting.

EXCELSIOR. The Excelsior.

Fairbury, Ill., C. E. Johnson, I886. $8^{\circ}$. 83 in. No. 3, November, 1886.
** Only partly philatelic.

Mis. St. Jour. 121 (12).

\section{[Continued as :]}

Excelsior monthly.

Fairbury, Ill., C. E. Johnson, I887. $8^{\circ} .8 \frac{1}{4}$ in. No. 4 , January, 1887.

* * Only partly philatelic, There is a supplement of two pages.
EXCELSIOR EXCHANGE JOURNAL 548 EXCELSIOR EXCHANGE JOURNAL. Excelsior ex-
change journal.

Dewsbury, Foreign and Colonial Stamp Co., I887. $16^{\circ} \cdot 6 \frac{3}{4}$ in. No. 1, April 15, 1887.

* * Printed on yellow paper. A note below the title says "with which is incorporated the Philatelist, Stamp review, the Philatelic axchange, Stamp herald, and the South of England philatelist reader," all of which appear to be mythical papers. The only philatelic matter in the number consists of advertisements.

Mis. St. Jour. 135 (4).

FXCELSIOR IMONTHLY. See EXCELSIOR.

FXCELSIOR POSTAL. Excelsior postal. Públicación - filatélica mensual.

Arequipa, Peri, David S. Ruiz N., I9o4. $8^{\circ} .8 \frac{3}{4}$ in. Nos. 1-3, Feb. 1, Mar. 1, July 1, 1904.

** There is a coloured paper wrapper to each number, and a copy of the prospectus of the journal is bound up with the three numbers.

FXCHANGE. The Exchange. Devoted to miscellaneous news, and to the exchanges of collectors of coins, stamps, general curiosities, etc. Adrian, Mich., C. R. Burr, etc., I885-86:

$8^{\circ} .8 \frac{1}{2}$ in. 16 nos. in 2 vols.

Vol. I. Feb.-Dec., 1885. Nos. 1-12.

Vol. I. Feb.-Dec., 1885. Nos. 1-12.

* "* If. Jan.-Apl., 1886. " no. 3 the journal was published by Stebbins and Tripp. There are coloured paper wrappers to nos. $9,10,11,12$, vol. I., and to nos. 1, 2, 3, vol. II. Nos. 10, 11, 12, vol. I., and nos. 1, 2, vol. Ir. to nos. $1,2,3$, vol. II. Nos. $10,11,12$, vol. I., and nos. 1, 2, vol. Ir. Wecember, 1885 is called " nos. 11 and 12 ," but the paper wrapper bears "no, 10 ". No. 4, vol. I1, consists of only one leaf. Mis. St. Jour. 31 (2).

EXCHANGE. The Exchange.

Washington, D. C., J. M. Rjordon, B. Cross and W. J. Carter, 1887.

$8^{\circ}$. 83 in. No. 5, March, 1887.

* * Only partly pbilatelic. The number has a supplement of two pages. The other numbers of this journal contain no philatelic matter.
Mis. St. Jour. 121 (11).

\section{FXCHANGE. The Exchange.}

8․ 83 in. Nos. 1-5, March 1-July 1, 1890.

Detroit, Mich., Jas. H. Collins, I89o.

** Only partly philatelic. Each number has a coloured paper wrapper. Wanting no. 1.

FXCHANGE. The Fixchange.

in. No. 1

$$
\text { Buffalo, N. Y., [? }
$$

], 1890.

* Only partly philatelic. Wanting.

FXCHANGE. The Exchange.

Putnam, Conn., L. E. Richardson, 1899.

* $6^{\circ} \cdot 6$ in. Nos. 1-3, January-[? ], 1899 .

$16^{\circ} \cdot 6$ in. Nos. $1-3$, January-[? ], 1899. * * Each number has a coloured paper wrapper. No. 1 is dated Wanting nos. 2, 3 .

FXCHANGE. The Exchange.

Peekskill, N. Y., C: E. Cooley, I 900-oI.

$16^{\circ} .6$ in., $8^{\circ} .9$ in., and fol. 14 in. 12 nos. in 2 vols.

Vol. I. Feb. July, 1900. Nos. 1- 6.

" II. Aug., 1900-Jan., 1901. " 7-12.

* "* No. 1 is $16^{\circ}$., nos. 2-9 are octavo, nos. 10-12 are folio, and nos.

$1_{-3}^{*}$ and 8 and 9 have paper wrappers. No. 3 is wrongly numbered

"no. 2 " except on the wrapper, which is correct, nos. 5 and 6 were published together, no. 9 is wrongly numbered "Vol. 2 , no. 2 " in place of "Vol. 2, no. 3 ," and there is a supplemental slip to no. 12 .

[Continued as :]

International philatelic review and exchange.

Peekskill, N. Y., C. E. Cooley, rgor.

$16^{\circ} .63$ in. Vol. III. 4 nos

Vol. IIr. Feb.-May, 1901. Nos. 1-4.

* * Each number has a paper wrapper. The journal was amal"*amated with the "New York philatelist" for June 15, 1901.

Mis. St. Jour, 103 (4a)
Excelswor phulaleleque, mi tamal hrége I 1913 not (mas) 


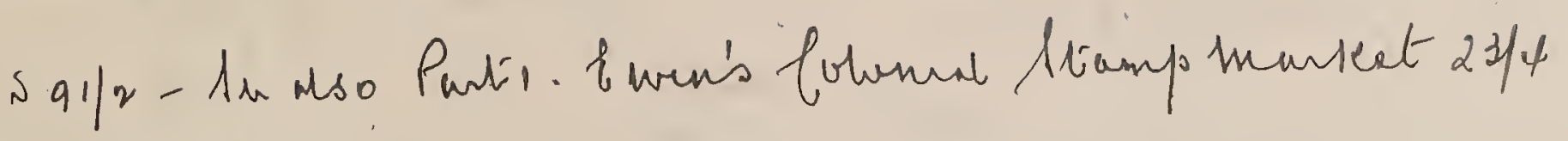

Evin's Qustieningen Fie heucen thanter countrined aso

1906

Sqr tounis Preististe Nor Murken = heutheiten

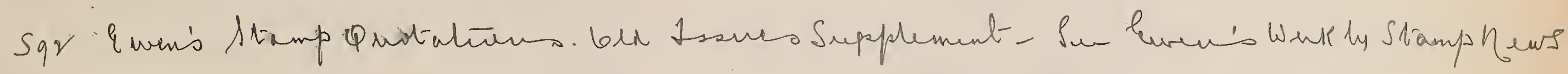

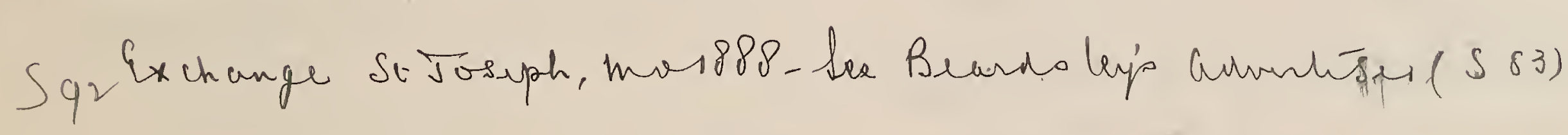


The Exchange. r. reuables. Naiputiurau, irew Realand.

$[1907] 1001$ 2. Lept. $4 \%$. 
549

EXCHANGE

EXCHANGE. The Exchange.

Kirksville, Mo., F. B. Wilson, etc., I 905-06. $4^{\circ} .9 \frac{1}{2}$ in. $16^{\circ} .6$ in. and $8^{\circ} .9-8 \frac{3}{4}$ in. 15 nos. in 3 vols. Vol. I. 1905. Nos. 1-6. "II. April, 1905-Mar., $1906 . \quad$ "June, 1-6. * * Only partly philatelic. No. 6, "vol. II., and the numbers of vol. III. were published by Exchange Pub. Co. and nos. 5 and 6 , vol. II., and nos. 2 and 3 , vol. III., have coloured paper wrappers. Nos. are quarto.
octavo. Wanting all vol. I. and nos. $1,2,3$, vol. II.

EXCHANGE AND IMARKET. See INTERNATIONAT EXCHANGE AND MARKET.

EXCHANGE BULLETIN. The Exchange bulletin.

Erie, Pa., The Exchange Bulletin Publishing Co., 1904 . $\begin{array}{ll}59^{3} & 8^{\circ} .9 \text { in. Nos. 1-3, April, May, July, } 1904 . \\ & \text { *" Only partly philatelic. Each number las a paper wrapper. } \\ \text { Wanting no. 1. }\end{array}$

EXCHANGE CIRCULAR. The Exchange circular. Handsworth, Sheffield, Dodson and Co., [1877]. $8^{\circ}$. 73 in. No. $1,[1877]$.

* Consists of one leaf printed on one side only. T. K. Tiffany by $\mathrm{E}$. F. Herdman in 1890, the date is given as 1877. Wanting.

EXCHANGE DIRECTORY. The Exchange directory. Buffalo, N. Y., W. L. Stark, r8go. $24^{\circ} .5$ in. No. 1, May, 1890. ** Only partly philatelic. The number has a coloured paper
wrapper.
Wis. St. Jour. 117 (1).

EXCHANGE NOTES. Exchange notes. A monthly stamp paper. Poughkeepsie, N. Y., E. Jackson, I892.

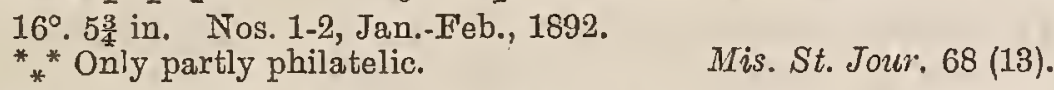

EXCHANGER AND COLLECTOR. See EXCHANGERS' AID.

EXCHANGERS' AID. The Exchanger's' aid.

Canajoharie, N. Y., The Union Exchange Agency, 1885 .

8. $9 \frac{1}{2}$ in. Nos. 1-2, Jan.-Feb., 1885. ** Only partly philatelic. Each number has a coloured paper
wrapper.
Mil. St. Jour. 14 (10).

Miss. St. Jour. 14 (10).

[Continued as :]

The Exchanger and collector.

Canajoharie, N. Y., The Union Exchange Agency, I885.

$8^{\circ} .9 \frac{1}{2}$ in. No. 1, Mar., 1885.

** Only partly philatelic. The number has a coloured paper
wrapper, which has "Vol. I., no. $3 "$. Wis. St Jour. 14 (11).
EXCHANGERS' REGISTER 550

EXCHANGERS' REGISTER. Exchangers' register.

Baldwinsville, N. Y., Register Publishing Co., 1885 .

593 Fol. $11 \frac{1}{4}$ in. No. 2, April, 1885

Miss. St. Jour. 121 (20).

EXPRESS ADVERTISING SHEET. The Express advertising sheet, of purchase, sale, and exchange. Rochdale, J. T. Leach, [1880].

Oblong fol. 10 in. No. 1, May 1, [1880]. * * Consists of a single leaf of rose-coloured paper printed on one side only. The contents include a few stamp dealers' advertisemints.

His. St. Jour. 1 (4).

EXPRESS PHILATHLIQUE ET CARTOPHILE.

- L'Express philatélique et cartophile.

Toulouse, R. Bécanne, r904.

Col. $19 \frac{3}{4}$ in. Nos. 1-5, Jan. 25, Feb. 10, 25, Mar. 10, Ap. 10, 1904.

** A copy of the prospectus of the journal is bound up with it.

[Continued as :]

L'Express philatélique et cartophile illustré.

Toulouse, R. Bécanne, r904-05.

$4^{\circ} .11$ in. 13 nos. in 2 vols.

lIst year. All. 25, May 25, July 25-Dec. 25, 1904. Nos. 6-13.

Jan. 25-May 25, 1905.
** Each number has a coloured paper wrapper.

EXPRESS PHILATÉLIQUE ET CARTOPHILE ILLUSTRE. See EXPRESS PHILATÉLIQUE ET CARTOPILE.

EXPRESS POSTAL. Express postal. Boletin semanario. Orizaba, Mexico, F. J. Bolo y Co., [I904].

Fol. $11 \frac{1}{2}$ in. No. 1, [1904].

* * The number consists of a single leaf of advertisements.

Wis. St. Jour. 137 (4).

EYCHNERS STAIMP COLLECTOR. Eychners stamp collector.

Westernville, N. Y., F. G. Eychner, I904.

$8^{\circ} .8$ in. and 6 in. Nos. 1-2, Jan.-Feb., 1904.

* No. 1 measures 8 inches and no. 2, 6 inches. Wis. St. Jour. 112 (2).

EYE. The Eye.

San Antonio, Texas, The Eye Publishing Co., 1886.

Fol. 11 in. Nos. 1-2, June-July, 1886.

** Only partly philatelic.

Miss. St. Jour. 116 (4).

The Exchoure, rirenables, us a ipukman

$$
\begin{aligned}
& N \text {-tealaud. 4 H. earthy plies } \\
& \text { (c) }[1907] \text { Left }=\text { mon. }
\end{aligned}
$$

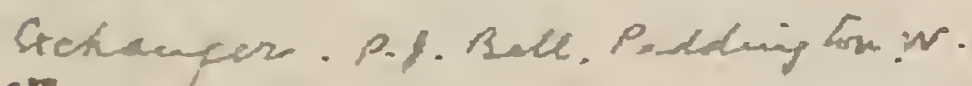

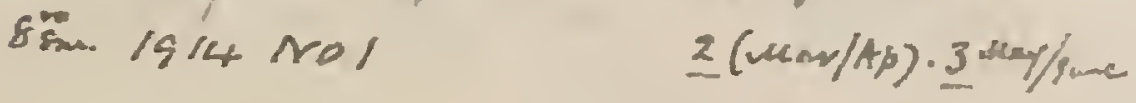




\section{Li: 7 acr sumber I Jourmier leneva Sio

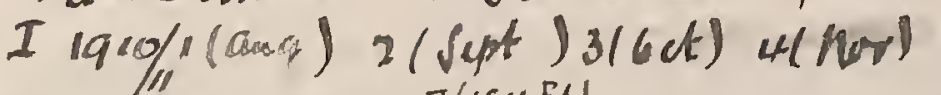 \\ II $17(1912$ fit.ma) $7(1911$ Et $)$ \\ III 1912 \\ 12 (guallet)}

551

FACTS

FACTS. Facts

Riverside, Cal., J. Gilbert and Co., etc., 1895 .

$64^{\circ} .2 \frac{1}{2}$ in. and $32^{\circ} .4 \frac{7}{2}$ in. 7 nos. in 2 vols

Voi. I. March 1-May, 1895. Nos. 1-3.

* "The three numbers of "vol. I. "and nos. 1 and 2 of vol. II. are only partly philatelic. No. 1 is $64^{\circ}$. and the other numbers are $32^{\circ}$. No. 3 was published by Geo. B. Gladden and the subsequent numbers were published by Facts Publishing Co. The four numbers of vol. II. have paper wrappers. Wanting no. 2, vol. I.

[Continued as :]

_- Philatelic facts.

Riverside, Cal., Facts Publishing Co., ז895-96.

$8^{\circ} .7-83$ in. Vols. II.-TV., 11 nos.

Vol. II. Oct. -Dec., 1895. Nos. 5-7.

" III. Jan. -June, $1896 . \quad$ " $1-6$.

* "* Nos. 5, 6 and 7, vol. II., were published together with the date "October-November-December, 1895". The numbering inside reads "Volume 2, no. 5. Whole number 8 ," while the paper wrapper reads "Volume 2, no. 5. Whole number 8," while the paper wrapper
bears "Vol. 2. Nos. 5, 6, 7". No. 2" vol. III-no - 2 vol IY. bear, "whole no. 12 "-" "whole no. 18 ," and nos. 5,6 , 7 , vol. II., nos. $1,2,5,6$, vol. II., and no. 1 , vol. IV., have paper wrappers.

New Series. 98.

Riverside, Cal., etc., Facts Publishing Co., eto., 1897-

$8^{\circ} .9$ in. 13 nos. in 2 vols.

Vol. I. June 10, Aug. -Dec., 1897. Nos. 1-7.

" "II. Jan., Feb., Apl.-July, 1898. " 1-6.

* * Commencing with no. 3, vol. Ir., the journal was published at Winchester, Indiana, by H. I. Watts. No. 1 is dated May, 1897, but over this is struck with a handstamp in violet ink "Jun. 10, 1897," and the paper wrapper is dated "June, 1397 ". No. 4 is dated "October 1, 1897," and no. 5, "October, 1897 ". No. 4, vol. II., is numbered in error "No. 3 ".' Nos. $1,3,4,5,6,7$, vol. I., and nos. 1 and 2, vol. II., have paper wrappers. Succeeded by the "Pacific magazine"

FADS AND HOBBIFS. Fads and hobbies.

Baltimore, Md., Carl Young, I9o6-

Fol. 12 in. Nos. 1 -, May, $1906-$
** Only partly philatelic. In progress.

FAIRIIOUNT EXCHANGE. The Fairmount exchange. Red Lion, Pa., W. O. Smith, I900. in. No. 1, December, 1900.

** Only partly philatelic. Succeeded the "Young collector".

FÄLSCHUNGS-NACHRICHTEN. Fälschungs-Nachrichten.

Gössnitz, S.-A., A. E. Glasewald, I 895-99.

$16^{\circ} .6 \frac{1}{2}$ in. and $8^{\circ} .10 \frac{1}{1}$ in. 54 nos. in 5 vols.

1st year. July -Dec., 1895. Nos. $1-6$.

2nd " [Jan.]-[Dec.], 1896. " 1-12.

3rd " [ " ]-[ "], 1897. " $1-12$.

4th $", \quad["]-["],], 1898 . \quad, 1-12$.

** The numbers of the first year are $16^{\circ}$. and the remainder are octavo. No. 8 for 1898 has the title omitted and the pages unnumbered. It consists of two pages the first of which is headed "Verzeichniss der aus dem Leutzsch'schen Concurse herrïhrenden,
FAMILY FAVORITE

552

vom Deutschen Philatelisten-Verband erworbenen Fohl'schen Fälschungen und dazugehörigem Druckmaterial ". Nos. 8 aud 9 for 1899 were published together. This journal formed a supplement to the "Mitteldeutsche Philatelisten-Zeitung," but after the end of 1899 it was no longer paged separately but was amalga-
mated with that magazine.

FAIMILY FAVORITE. The Family favorite.

Fol. 11 11 in. No. 3, March 20, 1896 .

Norfolk, Va., J. Vickery Langhorne, $x 896$. *** Only partly philatelic.

Mis. St. Jour. 121 (19).

FAMILY FAVORITE. See Amgrtcan PHILATgitgat cirCULAR.

FARGO'S NEW IDEAS. Fargo's new ideas. An ideal publication for the American youth.

Ellwood City, Pa., The C. B. Fargo Co., I9or.

Fol. 12 in. No. 1, Sept., 1901.

** Only partly philatelic. The number has a coloured paper wrapper. Amalgamated with "Leve's New perforator," October,
1901.

FARRAGo. See Fremman's FIRESIDE VIsITOR.

FAVORITE PASTIMES. Favorite pastimes Byron, Ill., Henry H. Huff, г 904. $8^{\circ} .9$ and 7 in. Nos. 1-3, April, June, July-August, 1904. ** Only partly philatelic. Nos. 1 and 2 measure 9 inches and no. 3, 7 inches. The last contains a supplement of two pages measuring six inches. Amalgamated with "Friendship's junior".

FAYETTE STAMP NEWS. See STAMP Tribune (Lexington, $K y$.).

FEDERAL AUSTRALIAN PHILATELIST. The Federal Australian philatelist.

Hobart, Tasmania, A. F. Basset Hull, I890-9 I. $8^{\circ} .8$ in. 8 nos. in 2 vols

Vol. I. Jan., Apl., July 1, Oct. 1, 1890. Nos. 1-4.

* "* II. "There is a title-page and" an index to vol. I. and a coloured paper wrapper to each number. This was the first philatelic journal published in Tasmania and it was amalgamated with "Vindin's philatelic monthly".

FEST-ZEITUNG ZUM ZEHNJÄHRIGEN STIFTUNGSFEST DES DEUTSCHFN PHILATELISTEN-VFRBAND. Fest-Zeitung zum zehnjährigen Stiftungsfest des Deutschen Philatelisten-Verband.

Gössnitz, S.-A., I899.

Fol. $13 \frac{1}{2}$ in. December 30, 1899.

*** The jnurnal is unnumbered and contains a supplement of two pages. The contents are of a humorous description. Mis. St. Jour. 128 (21).

FEST-ZEITUNG ZUM 10. STIFTUNGS-FEST DES VERFINS FƯR BRTFMARKENKUNDE, KIFL. Fest-Zeitung zum 10. Stiftungs-Fest des Vereins für Briefmarkenkunde, Kiel. $8^{\circ} .9 \frac{7}{2}$ in. [October, 1900.]

* * The journal bears no number or date and the contents are of a humorous description.
Mis. St. Jour. 134 (2).

$$
\begin{aligned}
& \text { Tederal Stangh Company's current } \\
& \text { Quotatious. See current. }
\end{aligned}
$$

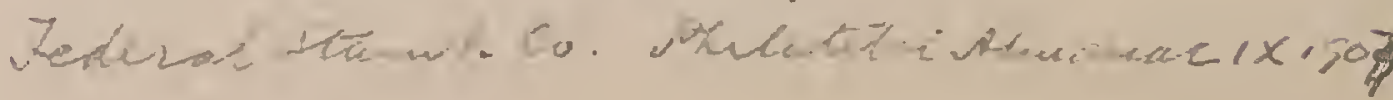




FFUILLE D'AVIS DE BERNE. Feuille d'avis de Berne. Organe de la population romande. Ire année. No. 14. 6 Avril, 1901. [Contains an article "Le nouveau timbreposte" and illustrations of various essays for new Swiss stamps.] Berne, [? ], г90г. Fol. $17 \frac{3}{4}$ in. pp. $[1,2]$ Mis. St. Jour. 127 (14).

FIGARO. Le Figaro. Paris. 9e année. No.40. Octobre 6,1883 . [Cuttings of the article "Les timbres-poste et la timbromanie" by Paul Eudel, are mounted in Stamp
Scrap-book, vol. vI., pp. 165-181]. B had the whole $4 p$

supphin.

$44 e$ année. 3e série. No. 281. Octobre 8, 1898. [Contains an article "Vol des collections nationales de timbres-poste," by Georges Grison.].

Fol. $24 \frac{1}{2}$ in. pp. 1, 2. Paris, A. Périvier, r 898. Mis. St. Jour. 136 (16)

FILATFLIA. La Filatelia. Bollettino mensile della Società Filatelica Italiana con sede in Roma.

$8^{\circ} .11$ in. 35 nos. in 4 vols.
1st . year. July-Dec., 1890. Nos. $1-6$. Roma, т890-93

1st year. July-Dec., 1890. Nos. 1-6.

3rd " " - " 1892. " 19-30.

$S 93^{*}{ }^{\text {th }}$ Nos. 9 and 10,11 and 12,14 and 15,32 and 33,34 and 35, were severally published together. Amalgamated with "Raccogwere severally published together.

FILATELIA. Filatelia. Organo y propiedad de la Sociedad Filatélica de Málaga. Málaga, $1896-98$. $8^{\circ} .10$ in. 25 nos. in 3 vols.

1st year. Jan. 31-Dec., [1896]. Nos. 1-12 2nd " " $31,1898$. [1897]. Nै" $13-24$

* * Nos. $\sqrt{9}, 10,11$ and $12 ; 13,14,15$ and 16 ; and 28 and 24 ; were severally published together. There is a supplement of twelve pages to to. 5, with the heading "El Heraldo Timbrológico Hispano-Americano. Suplemento á Filatelia. Año II. Málaga 15 de Junio de 1896 . Núm. 15 ," and this latter paper was a malganos. 6-25 have paper wrappers.

FILATELIA. Filatelia. Czasopismó illustrowane dla milósników zbierania znaczków listowych.

Kraków, Zygmunt Gessner, т899.

$4^{\circ} .9 \frac{1}{2}$ in. Nos. 1-12, January 1-December 1, 1899.

FILATRLIA. Filatelia.

Buenos Aires, Eustaquio J. Tomé, etc., I9oI-04. $8^{\circ} .8 \frac{7}{2}$ in. 42 nos. in 4 vols.

1st jear. Jan.-Dec., 1901. Nos. 1-12

2nd " " - " 1902. " 13-24.

3rd " " $", \quad$ - $1903 . \quad " \quad[1]-12$.

* " Oommencing "with no. 9 of "the first year the journal was pub. lished by Eustaquio J. Tomé y Alejandro Malaguzzi do Valeri. Nos. 6 and 7,9 and 10,15 and 26,22 and 23 , and of the third year nos. 4 and 5,8 and 9 and 10,11 and 12 were severally published together. The numbers of the fourth year were published bimonthly andeach of the forty-two numbers has a paper wrapper No. 1 of the third year has "número-almanaque, in place of no. 1. There are the following separate supplements, 1. "Catálogo lustrado de todos los sellos postales y telegráficos, emitidos desde 1858 hasta la fecha por la República Argentina," 32 pages; 2 "1903 prix-courant de timbres fiscaux de la République Argentine," 8 pages; $3 \%$ Las Reimpresiones. Datos para su reconocimiento', 4) +24 pages: this work was only continued as far as "Colonias Francesas "; 4. "Catálogo general de los valor'es postales emitidos en la República Oriental del Uruguay. Parte I. Sellos postales," 52 pages ; the work only being completed as far as the issue, December 15, 1892 hay 151894

FILATELIA. Filatelia.

Braila, Roumanie, Victor Goutman, I 905-06.

Fol. $12 \frac{3}{4}$ in. and $8^{\circ} .9 \frac{1}{2}$ in. 7 nos. in 2 vols.

1st year. Feb. 21-Mar. 21, 1905. Nos. 1-5.

2nd "Jan. -Feb. 1906. ", 1-2.

* * The numbers of the first year are folio and contain articles in French, German and Roumanian. The numbers of the second

a 3 year have the contents in French and each has a coloured paper

wrapper. Wanting nos. 1, 3, 5, of the first year.

Tulatcia Puertá Plata 1912 I'
FILATELIA ANTILLANA. Filatelia Antillana. Revista mensual internacional

Mayaguez, Puerto Rico, Jose Prats Tolosa, 1893.

Fol. 12 in. $4^{\circ} .12 \frac{3}{4}$ in. and $8^{\circ} .93$ in. Nos. 1-8, March 10-October, 1893.

* * Nos. 1.2 are folio, no. 3 is quarto and nos. $4-8$ are octaro. No. 1 has a paper wrapper with the title reading "La Filatelia Atbillana" and the article "La" precedes the title on nos. 2-8. Amalgamated with "Ilustración Filatélica Hispano-Colonial". Wanting nos. 7 and 8.
Mis. St. Jour. 152 (13).

FILATELIA BOIIVIANA. La Filatelia Boliviana. Revista mensual internacional.

La Paz, Bolivia, Juan R. de Acuña, r893.

Fol. 13 in. Nos. 1-2, July 16-Aug. 16, 1893

* This was the first philatelic journal published in Bolivia.

Mis. St. Jour. $86(13)$

FILATELIA DE COSTA RICA. Filatelia de Costa Rica San José, Céspedes y Cia, $\mathbf{1 8 9 7 .}$

$16^{\circ} .7$ in. No. 1, May, 1897.

* * The above was given as a supplement to no. 9 of " Fil Filatelico Comercial".

FILATELIA ESPAÑOLA. La Filatelia Española. Revista mensual dedicada á los coleccionistas de sellos.

Vitianueva y Geltri, J. Foradada Canalda, x896-97

$8^{\circ} .11-10 \frac{1}{2}$ in. 4 nos. in 2 vols.

1st year. Oct. 25-Dec., 1896. Nos. 1-3.

2nd " January, 1897. No. 4

Nos. 5 and 6 are said to exist, but it seems doubtful if this is so.

Mis. St. Jour. $151(10)$

FILATELIA ESPAÑOLA. La Filatelia Española, Revista quincenal dedicada exclusivamente a los coleccionistas de sellos. Madrid, [? I igoo. $4^{\circ} .11$ in. No. 1, Feb. 20, $1900 . \quad$ Mis. St. Jour. $105(10)$

FILATELIA ITALIANA. La Filatelia Italiana. Mercuriale mensile dei francobolli degli antichi stati d'Italia. Modena, Fabio Benvenuti, г 90 I. $8^{\circ} .11$ in. Nos. 1-11, January 1-November, 1901. ** Nos. 8 and 9 and 10 and 11 were severally published together.

EILATELIA ROMÂNĂ. Filatelia Română. Jurnal filatelic lunar pentru colectionari si comerciantí de mărcĭ. Bârlad̆, Théodoresco et Cie., i898. $8^{\circ} .9 \frac{1}{\mathrm{a}}$ in. and fol. $13 \frac{1}{\mathrm{x}}$ in. Nos. 1-2, Sept. 25-Oct. 25, 1898.

* No. 1 is octaro and no. 2 folio. Mis. St. Jour. 108 (6).

FILATELIA UNIVHRSAL. Filatelia universal. Revista dedicada a los comerciantes y coleccionistas de sellos y tarjetas postales.

Laguna de Tenerife, Islas Canarias, Domingo $M$. Cabrera, I 903 .

$8^{\circ} .91$ in. and $10_{4}^{3}$ in. Nos. 1-11, January-November, 1908. * * Each number has a coloured paper wrapper. VNos. 6 and 7 and 10 and 11 were severally published together twith the dates "Agosto de 1903" and "Noviembre de 1903". Nos. 1- measure 97 inches and the subsequent numbers measure 103 inches. This was the first philatelic journal published in the Canary Islands. Wanting nos. 3,9 .

FILATELIC FACTS AND FALIACIES. Filatelic facts and fallacies.

San Francisco, Cal., W. Sellschopp and Co., r892I90I.

$8^{\circ} .8 \frac{3}{4}$ in. 108 nos. in 9 vols.

Vol. I. Oct., 1892-Sept., 1893. Nos. 1- 12

"II. $\quad$ I $1893-\quad " \quad 1894 . \quad, \quad 13-24$.

" III. " $\quad 1894-\quad " \quad 1895 . \quad " \quad 25-36$

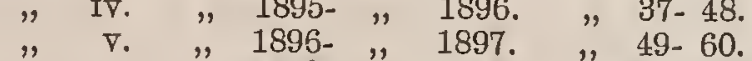

" vi. " $\quad$ vi. $1897-", 1898 . \quad " \quad 61-72$.

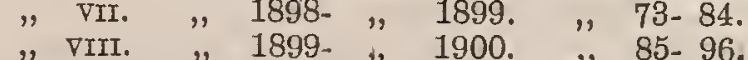

$"$ VIII. " $\quad$ Ix. $1899-"$ " $1900 . \quad " \quad 85-96$.

* * There is "a title-page and an index" to each volume and a paper wrapper to each number. 
FIL.ATELICO. II Filatelico.

Fol, $12 \frac{1}{4}$ in. 6 nos. in 2 vols.

1st year. Nor. 1-Dec. 1, 1897. Nos. 1-2.

** There is a supplement of two pages to no, 2

Mis. St. Jour, 130 (17)

FILATF́LICO AIMERICANO. El Filatélico Americano. Revista mensual.

La Plata, Rep. Arg., Jaime F. Ramon, r897. $8^{\circ} \cdot 10_{4}^{3}$ in. Nos, 1-8, Apl, 1-Nov., 1897.

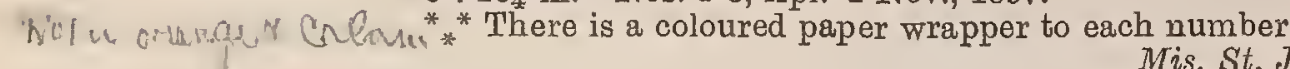
Mis. St. Jour. 84 (5)

FIIATÊLICO ARGENTINO. El Filatélico Argentino. Publicación mensual.

Buenos Aires, J. P. Mendez, 1894.

$8^{\circ} .8 \frac{1}{2}$ in. Nos. 1-2, Sept. 1-Oct. 1, 1894

* * Produced by a hectographic process. Wanting no. 1.

Mis. St. Jour. 107 (7)

FILATÊTICO AZUANO. El Filatélico Azuano.

Azua, Rep. Dominicana, Fco. Cofresi, rgo5.

$8^{\circ} .93$ in. Nos. 1-2, February and March, 1905. 3/4 M/s. that Mis. St. Jour. $122(4)$

FILATÉLICO CARTÓFILO. Ėl Filatélico cartófilo. Revista filatelica mensual.

Santo Domingo, Rep. Dominicana, Miguel A. Mendez y Ca y Daniel Goris, r904-05.

8. 10-11 in. Nos. 1-4, December, 1904-March, 1905.

* Nos. 3 and 4 were published together.

Mis. St. Jour. 124 (1)

FILATÉLICO COIMRCIAL, El Filatélico comercial. San José, Costa Rica, Céspedes y Cia., r896-1902. $8^{\circ} .9 \frac{3}{4}$ in. nos. in 7 rols.

1st year. June-Dec 16, 1896, Mar. 22, 1897. Nos. 1-8.

6 . 2nd" May, July,

3rd ",

4 th "

the "

6 th

${ }^{*}$ * No. 9 contains a supplement with the title " Filatelia de Costa Rica". Nos. 10, 11, 12, 13 and 14, of July, 1897, with "Costa Rica" in March, 1900, and later on was restarted again. Wanting no. 6 and any after 14 except $25,29,32,33$ $37,73,74,76$, the last of which is dated July, 1902 Wraps: 10

FILATËLICO COMERCIAL. El Filatélico comercial. Guayaquil, Ecuador, Gabriel Garcia M., I goI. $8^{\circ} .9 \frac{1}{2}$ in. Nos. 1-3, June-August 1, 1901.

* Each number has a eoloured paper wrapper. Wanting nos. 1,2 .

FILATÉLICO DE VALFNCIA. Fl Filatélico de Valencia Valencia, José Sanchis Garcia, I902.

Fol. $12 \frac{1}{4}$ in. Nos. $1-12$, Jan.-Dec, 1902 .
** Each number has a coloured paper wrapper and nos. 7 and 8 were publlshed together. Wanting nos. 2-12.

Mis. St. Jour. 109 (15).

FILATELICO DEL PERÚ, El Filatélico del Perú.

Arequipa, Peru, Vistor Perron, ז893-94.

Fol, 13 in. and 12 in. Nos, 1-9, May 1-Nov. 30, 1893, Jan. 31 , Apl. 31 (sic) 1894

* * No. 9 measures 12 inches and the other numbers 13 inches.

Mis. St. Jour. 86 (9)

FILATf́LICO DOMINICANO. El Filatélico Dominicano.

Santo Domingo, Rep. Dominicana, B. de Castro Sarda y Genaro Martinez C., etc., I904.

$8^{\circ} .11$ in. Nos. 1-9, February-October, 1904

* * Nos. 2- were published by Martinez and Mendez, nos. by Genaro Martinez C. and nos. 7-9 by Luis E. Alemar y Genaro Martinez C. Nos. 7, 8 and 9 were published together. Wanting nos. 4,5 .
FILATÉLICO ECUATORIANO. El Filatélico Ecuatoriano. Guayaquil, José A. Serrano A., I9o1-02. $8^{\circ} .9_{4}^{3}$ and 81 in. Nos. 1-3, August 31, October 1, 1901, August, 1902 .

**There is a paper wrapper to each number. Nos. 1 and 9 measure 93 inches and no. 3, $8 \frac{1}{2}$ inches. Mis. St. Jour. 122 (3).

FILATÉLICO ESPAÑOL. El Filatélico Español.

Barcelona, T. Remoli, etc., I900-

$8^{\circ} .8 \frac{1}{2}-9 \frac{1}{2}$ in. nos. in vols. In progress.

1st year. Oct.-Dec., 1900. Nos. 1-3.

2ad " Jan." " 1901. " 4-15.

3rd " " " 1902. " 16-27.

4 th " " " 1903. " 28-39.

5th " " " 1904. " $40-51$.

6th " " " 1905. " $\quad$ " $64-63$.

* "There is" a coloured paper" wrapper to each number. Nos. 48 and 49 were published together. Nos. $41-52$ were published by Rafael de Sorarrain and the subsequent numbers by Alfonso Sabadell. Nos. 21-35 contain certain pages of a work "Las Tarjetas postales en España por el Iltre. Sr. D. Francisco Carreras $\dot{y}$ Candi," and nos. 33-75 have a supplement "Catálogo ilustrado de los Sellos Fiscales de España y Colonias". An "Indice de articulos publicados en El Filatélico EspaẼol" (Años I. al VI.) was given with no. 64. A copy of the prospectus of the journal, dated September, 1900, is bound up in front of no. 1.

FILATfLICO ONUBENSE. El Filatélico Onubense. Huelva, Espagne, Carlos Mora, Igoo.

$8^{\circ} .83$ in. Nos. 1-5, January 15-May 15, 1900.

* There is a coloured paper wrapper to each number.

Pruk 1-2-3 Vout blu 4 orants -Mis. St. Jour. 123 (11). FILATÉLICO PORTEÑ̃. El Filatélico Porteño. Valparaiso, Chile, Carlos E. Guzman y Julio $A$. Silva, etc., I902-03.

$8^{\circ} .9 \frac{1}{4}$ in. Nos. 1-11, Oct. 1, 1902-Nov., 1903

* There is a paper wrapper to each number, nos. 4-6 were published by Brandi, Guzman y Silva and nos. 7-11 by Brandi y Silva. No. 5 is dated "Febrero y Marzo de 1903," and nos. 8 and 9 and 10 and 11 were severally published together, under the respective dates "Junio, Julio y Agosto de 1903," and "Setiembre $\begin{aligned} & \text { Octubre y Noviembre de } 1903 \text { ". . Nos. 4-6 contain supplemental } \\ & \text { slips. }\end{aligned}$ Mis. St. Jour. 111 (6).

FILATÉTICO VALENCIANO. El Filatélico Valenciano. Revista mensual. Valencia, José Sanchis, I899-I9or. $4^{\circ} .8 \frac{1}{4}$ in. 27 nos. in 3 vols.

1st year. Jan.-Dec., 1899. Nos. 1-12.

2nd ", " - " 1900. ", 13-24.

** There is a paper wrapper to each number.

FILATELISTA. El Filatelista.

Bogotá, Arturo Arboleda y Augusto Merchan, etc., I900.

$8^{\circ} .9 \frac{3}{4}$ in. Nos. 1-8, Jan. 20-Mar. 20, 1900

* * Nos. 6-8 were published by Augusto Merchan. Nos. 1-6 were published weekly and nos. 7 and 8 on "Marzo 10 " and "Marzo 20," respectively. Wanting no. 2. Mis. St. Jour. 151 (6)

FILATELISTA ED IL FILOCARTISTA ITALIANO See Phimateliste Italien.

FILATEILISTA INTERNACIONAL。 El Filatelista Internacional. [Prospectus dated "Enero 15 de 1898 " of a journal to be published by the International Stamp and Publishing Company, City of Mexico, but which was never issued.]

Mis. St. Jour. 128 (4)

FILATELISTA INTERNACIONAL. See INTERNATIONAL PHILATELIST (Wichita, Kas.).

FILATELISTA ITALIANO. See PhILATELISTE ItalinN, FILATELISTA IMEICANO. El Filatelista Mexicano. r891. Monterrey, Mexico, $M$. L. de la Garza y Cia.

Fol. 11 in. No 1, May 5, 1891.

Mis. St. Jour. 75 (1)

FILATHLISTA MEXICANO. El Filatelista Mexioano. Dedicado á la ciencia de la filatelia.

México, D. F. International Stamp and Investment Co., I900.

8․ 8妾 in. No. 1, Summer Season, 1900. Mis. St. Joutr. 89 (2)

Filutetista: Rzeszow (laticya)

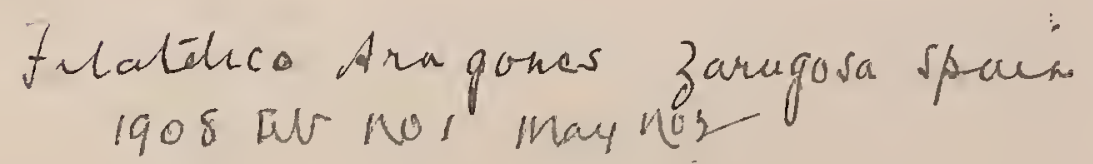





\section{FILATELISTA PENINSÚLAR}

FILATELISTA PENINSULAR. El Filatelista Peninsular. Monitor mensual de los filatelistas. San Sebastiun, Ed. S. Echebarne, I896. Fol. $12 \frac{1}{2}$ in. Nos. 1-3, April 10-June 20, 1896. *** Wanting no. 3. Mis. St. Jour. 107 (21).

FILATELISTA SUD-AIMERICANO. El Filatelista Sud-Americano. Buenos Aires, A. Mettée, etc., r893-96. $8^{\circ} .9 \frac{3}{4}$ in. 70 nos. in 4 vols.

1st year. Jan. 1-Dec. 16, 1893. Nos. 1-24.

2nd " " 1- " 16, 1894. " 25-48.

3rd " " $\quad 16-", 15,1895 . \quad " \quad 49-60$.

* th "There is" a title-p.ege and an index "to vols. I and II. Com-

S 93 mencing with no. 54 the journal was published by Luis Sobrino, and there are coloured paper" wrappers to nos. 61-70. For the first two years the journal was published fortnightly, but for the last two years it was published only monthly.

FILATELISTEN. Filatelisten,

Aalesund, Norge, Martin Ludv. Holm, I894. $4^{\circ} .10_{4}^{3}$ in. Nos. 1-2, May 10-June 10, 1894.

FILOTELICO. El Filotelico. Organo de la Sociedad Filotélica de Santo Domingo.

Santo Domingo, J. A. Vos-Schotborgh, etc., I885-86. $8^{\circ} .101-9 \frac{3}{4}$ in. 14 nos. in 2 vols.

S qul 1st ycar. Jań.-Dec., 1885. Nos. 1-12.

* ${ }^{2}$ * No" 1 is "-Feb., 1886. "Fed in error " $1-2$.

* * No. 1 is "dated in error "Febrero de 1885," nos. 10,11 were published together and nos. 2-12 of the first year and the two numbers of the second year have paper wrappers. Nos. 8-12 were published by David $\mathbb{E}$. Santamaria and the two numbers of the second year by Cárlos Baez i Figueroa. This was the first philatelic journal published in the Dominican Republic.

Mis. St. Jour. 153 (13).

Segunda época. Santo Domingo, José MT. Leyba, I887. 8o. $9 \frac{1}{4}$ in. Vol. II. 1 no.

2nd year. April 1887. No. 1.

* * Edited by Francisco Man Garcia Rodriguez. The number has a coloured paper wrapper.

FILOTELISTA. El Filotelista.

Bogota, J. Joaquin Pérez O., etc., I 880.

$8^{\circ} .9$ in. Nos. 1-7, Jan.-July, 1880.

* * Nos. 6 and 7 were published by G. Michelsen.

Mis. St. Jour. 24 (17).

FILOTELISTA. EI Filotelista. Bogotá, Colombia, Ruiz y Diaz Granados, I883. $8^{\circ} .9$ in. No. 1, June, 1883.

Mis. St. Jour. 91 (2).

FILOTELISTA. El Filotelista. Periodico mensual dedicado a la coleccion de sellos postales.

Panama, Castulo Villamil, r886-87.

8.. 9-91 in. Nos. 1-7, Aug. 1, 1886- Jan., 1887, May, 1887.

** Nos. 3-7 have coloured paper wrappers. Mis. St. Jour. 91 (3).

FINSKA FILATELISTEN. Finska filatelisten.

Helsingfors, Helsingfors Frimärlessamlare Förening, ז894-96.

$8^{\circ} .10$ in. 11 nos. in 2 vols

1st year. Dec., 1894-Dec., 1895. No. 0 and nos. 1-9.

2nd "Jan., 1896. No. 1.

* * There are no numbers for January, July and August, 1895. Wanting no. 8. This was the first philatelic journal published in Russia. Mis. St. Jour. 151 (8).

FIRENZE FILATELICA. Firenze filatelica. Organo dei collezionisti e negozianti.

Fol. 121 in No. 1, MEtroh 10, 1805

FIRESIDE FRIFND. The Fireside friend. Devoted to the interest of collectors.

$8^{\circ} .8$ in. No. 1 , Nov., 1888

Sawens, N. Y., C. E. Curtiss, 1888.

** Only partly philatelic.

Mis. St. Jour. 70 (1).

[Continued as :]

The Collectors' friend.

Sawens, N. Y., C. E. Curtiss, r888-89. $8^{\circ} .81+8$ in. and fol. 16 in. Nos. 2, 3, 3, 4, Dec., 1888, Jan., Jan., Feb., 1889.

"* Only partly philatelic. Nos. 2 and 3 are octavo and nos. 3 friend" folio. On the two last the title reads "The Collector's

Mis. St. Jour. 70 (2).
FIRESIDE PHILATELIST́

FIRESIDE PHILATELIST. The Fireside philatelist,

Mile Run, Pa., P. E. A. Conrade, etc., x895-97.

$32^{\circ} .4$ in. and $24^{\circ} .5 \frac{3}{4}$ in. 12 nos. in 2 vols.

Vol. I. Nov., 1895-Apl., 1896. Nos. 1-6. 4 6

" Ir. May, July, Sept., Nov., 1896, Jan., Mar., 1897. Nos. 1-

* * No. 1 , vol. rI., is $24^{\circ}$. and the other numbers are $32^{\circ}$. Nos. $1-4$, vol. II., were published by P. E. A. Conrade and Co., and inos. 5 , 6 of this volume by the Fireside Philatelic Co There are coloured 6 of this volume by the Fireside Philatelic Co. "There are coloured paper wrappers to nos. 1-4"and to no. 6 vol. I., and to no. 2 vol. II." No. 3, vol. II., is wrongly dated "July"
the front page. $\checkmark$
Mis. St. Jour. 83 (1).

FISCAL PHILATELIST AND REVENUE STAIMP

(-) GUIDE. The Fiscal philatelist and revenue stamp guide. A monthly journal devoted to fiscal collectors.

Tottenham, London, N. Walter Morley and F. G. C. Lundy, 1892-93.

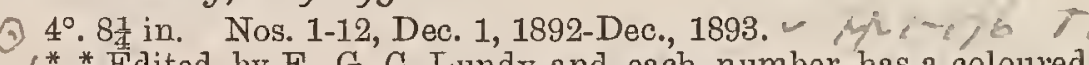

$\checkmark{ }^{*} *$ Edited by F. G. C. Lundy and each number has a coloured

paper wrapper. No. 10 is dated "September-October, 1893".

$\checkmark$ There is a title-page and an index to the volume and a supple-

(5) ment "The Embossed deed stamps of Great Britain - Reprinted

from the "Stamp collector" and the "Fiscal philatelist," 14 pages, w " 727

TCHBURG PHILATELIST. The Fitchburg philatel-

ist. Fitchburg, Mass., C. H. Whitcomb, г888-9x.

$8^{\circ} .8 \frac{1}{2}$ in. 25 nos. in 3 vols.

Vol. I. Dec., 1888-Nov., 1889. Nos. 1-12

"II. Dec, 1889-Dec., 1890. " 1-12.

", III. Jan., 1891. No. 1.

* " There is a supplement of two pages to no. 12, vol. I., containing an index to the volume. There are also supplements of two pages to nos. $2,3,4,5$ and 6 , vol. II., and nos. 1 and 12 of this volume have coloured paper wrappers. No. 8, vol. II., is dated "July and August, 1890," there is no no. 11 to this vol., but no. 12 is dated "Nov. \& Dec., 1890 ". Mis. St. Jour. 49 (1).

FLANDRE PHILATÉLIQUE. La Flandre philatélique. Gendbrugge-lez-Gand, E. Questiaux, I895-96. $8^{\circ} .11$ in., $4^{\circ} .11 \frac{1}{4}$ in. and fol. 13 in. Nos. 1-5, Dec. 1, 1895-Mar. 15,1896 , Oct., 1896.

* No. 1 is octaro, nos. $2-4$ are quarto and no. 5 is folio.

Mis. St. Jour. 88 (3).

\section{FLIEGENDE BLÄTTER. Fliegende Blätter.}

Charlottenburg, Berlin, Paul Lietzow, r gor.

$8^{\circ} .9 \frac{3}{4}$ in. Nos. 1-3, Apl. 18, Nov. 12, Dec. 21, 1901

Mis. St. Jour. $100(2)$.

[Continued as :]

Lietzows Fliegende Blätter.

Friedenau bei Berlin, Paul Lietzow, r904.

$8^{\circ} .9 \frac{1}{2}$ in. No. 4, Jan. 14, 1904.

Mis. St. Jour. 100 (2a).

FLIEGENDE BLÄTTER FUंR DEUTSCHE PHILA-

TELISTEN. Fliegende Blätter für deutsche Philatelisten.

Fol. $13 \frac{3}{2}$ in. [Nos. 1, 2, 1884.]

* * Produced by autographic lithography and printed on one side of the paper only. No. 1 consists of a single leaf and no. 2 of two Mis. St. Jour. 73 (18).

FLORIDA PHILATELIST. The Florida philatelist. A monthly journal for stamp collectors.

Thonotosassa, Fla., D. E. Hazen Stamp and Pub. lishing Co., r892-93.

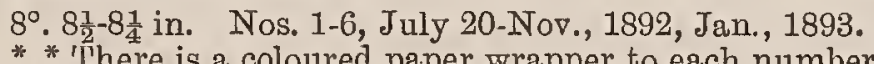

* * I'here is a coloured paper wrapper to each number.

Mis. St. Jour. 65 (10).

FLOUR CITY PHILATELIST. The Flour city philatelist. Minneapolis, Minn., Bell Publishing Co., I889.

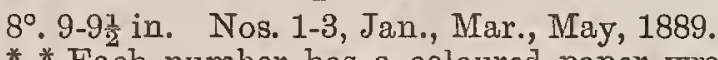
** Each number has a coloured paper wrapper. Nos. 2,3 are
räther smaller than no. 1 . rather smaller than no. 1.

FLY PAPER. See Lake State Stamp.

FOCUS. Focus.

* * Only partly philatelic. Wanting all nos. 
559 FOREIGN STAMP ADVERTISER

FOREIGN STAMP ADVERTISER. The Foreign stamp advertiser. A registry of dealers for collections. Newcastle-on-Tyne, A. M. Paton, 1879. $16^{\circ} .5$ in in. Nos. 1-3, Oct.-Dec., 1879. want mo/ 2 * Nos. 2 and 3 have "A Registry of dealers for collectors" and no. 2 bears no year date. No. 1 was printed at Bury St. Edmund's. Mis. St. Jour. 55 (2).

FOREIGN STAIMP ADVERTISER. The Foreign stamp advertiser. Edinburgh, E. S. Reid, [1880]. $24^{\circ} .5 \frac{1}{4}$ in. Nos. 1-2, [? Nov.]-Dec., [1880].

** The contents consist entirely of advertisements. Wanting ** The contents consist entirely of advertisements. Wanting
no. 1.
IIis. St. Jour. 81 (2).

FOREIGN STAIMP ADVERTISER AND GENERAL IMAGAZINE. The Foreign stamp advertiser and general magazine.

Dalston, London, E. Wm. C. Coke, I873.

$8^{\circ} .8 \frac{1}{2}$ in. No. 1, June, 1873.

** The contents consist entirely of advertisements.

Mis. St. Jour. 30 (2).

FOREIGN STAINP ADVERTISER AND REVIEW. The Foreign stamp advertiser and review. A monthly journal devoted to stamp collecting.

Newcastle-on-Tyne, A. M. Paton, etc., I880.

Hawn 1.2 wath wh $8^{\circ} .10$ in. Nos. 1-7, Jan.-July, 1880. N\%-5 Af 1-40

* * Nos. 3-7 were published by G. R. Beldon. Nos. 2-7 are called "New Series" and nos. 1-4 have coloured paper wrappers. Nos. 6 and 7 were published together. Amalgamated with no. 18 of the "Philatelist's gazette". Wanting nos. 6 and 7.

FOREIGN STAMP COLLECTOR. The Foreign stamp collector. "Truth without Fear".

London, W. Cattell and Green, I886. (9) $8^{\circ} .8^{3}$ in. No. 1, January, 1886. S/W- Mis. St. Jour. 79 (8).

FORTIGN STAIIP COLLECTORS' JOURNAL. The Foreign stamp collectors' journal.

Bury St. Edmund's, C. H. Nunn, x878-82. $8^{\circ} .7 \frac{1}{2}$ in. 48 nos. in 4 vols.

Volo I. Nov., 1878-Oct., 1879. Nos. 1-12, 1- $22 \mu \cdot+T^{\circ}$

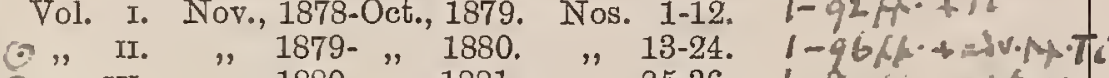

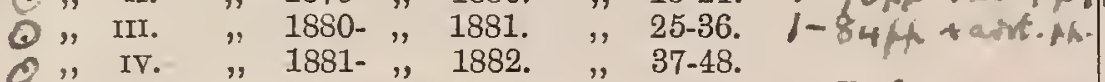

* * There is a title-page and alist of contents to vol. I., a " supplement" of (2) pages to no. 3 an "extra supplement" of (2) pages to no. 17, and paper wrappers to nos. 13-48. Some, but not all, of the numbers for December, 1879, are wrongly numbered " 13 ", in place of 14 , except 9 n the wrappery which always have " 14 ". Nos. 38 and 34,38 and 39 and 45 and 46 were published together under the respective dates "July and Aug. $18 \varepsilon 1$ " "Dec., 1881Jan., 1882," and "July and August, 1882" "The wrapper of nos. 38 and 39 has "No. 38, December. 1881 ".

whith wh. 33-24, grey wh.4 col.an. ps 25-48.

[Continued as :]

- The Stamp collector's journal, coin collector's news, and antiquarian gazette

Bury St. Edmund's, C. H. Numn, r882-84. $8^{\circ} .7 \frac{1}{2}$ in. and $10 \mathrm{in.} V$ ols. V.-VI., 24 nos.

Vol. v. Nov., 1882-Oct., 1883. Nos. 49-60.

"VI. " 15, 1883- "15, 1884 . " 61-72.

* * Vol. $\nabla$. is octaro $7 \frac{1}{2}$ inches and vol. VI., octavo 10 inches.

There is a title-page and a list of contents to vol. vI., and a coloured paper wrapper to each number.

orave 25 is $k$. $49-60$

[Continued as :]

The Stamp collector's journal, and coin collectors' news. A monthly magazine devoted to all branches of philately and numismatics.

Bury St. Edmund's, C. H. Nunn, 1884-85. $8^{\circ} .10$ in. Vol. VII. 12 nos.

Vol. vII. Nov, 15,1884 -Oct. 15,1885 . Nos. $73-84$.

* * There is a title-page and a list of contents to the volume, and a coloured paper wrapper to each number. The number for July, 1885 , is wrongly nnmbered " 80 " in place of " " 81 " but the numbering on the wrapper is correct.
FOREIGN

560

FOREIGN STAMP COLLECTORS' JOURNAL.

[Continued as:]

- The Stamp collectors' journal (with which is incorporated the Stamp dealers' gazette and the Philatelic referee) a monthly magazine devoted entirely to all branches of philately. Bury St. Edmund's, C. H. Nunn, I885-95. $8^{\circ} .10$ in. Vols. VIII.-XviI. 120 nos.

Vol. VIII. Nov. 15, 1885-Oct. 15, 1886. Nos. 85- 96.

"IX. $" 15,1886-", 15,1887$. " $" 97-108$.

" X. " $\quad 15,1887-" 15,1888 . \quad " \quad 109-120$.

" XII. " " 15, 1888- " $15,1889 . \quad$ " $121-132$.

" XIII. " 15, 1890- " 15, 1891. ", 145-156.

" XIV. " 15, 1891- " 15, 1892. " 157-168.

$"$ XV. " 15, 1892- " 15, 1893. " 169-180.

"XVI. " 15, 1893- " 15, 1894. " $181-192$.

*" XVII. " "15, 1894- " 15, 1895. " 193-204.

* * There is a title-page and an index to each volume, and a coloured paper wrapper to each number. The number for May 15,1890 , is wrongly numbered " 132 " in place of " 139 ," but the numbering on the wrapper is correct. No. 174 for April 15, 1893, was published with a wrapper bearing " No. 175. May 15, 1893, , and no. 175 for May 15, 1893, appeared in a wrapper bearing, "No. 174. May 15, 1893". Nos. 144-150 contain supplements with the title "Official gazette for the International Philatelic Union," nos. 19-25. This supplement is catalogued under its own heading.

[Continued as :]

The Stamp collectors' journal. A monthly devoted entirely to all branches of philately.

Bury St. Edmund's, C. H. Nunn, etc., I895-99. $4^{\circ} .8$ in. Vols. XrIII.-XxI. 39 nos.

Vol. xviII. Nov. 15, 1895-Oct. 15, 1896. Nos. 205-216.

" XIX. " $\quad 15,1896-" 15,1897 . \quad "$ 217-228.

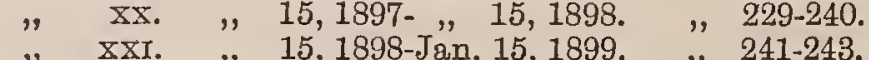

**" There is a title-page and an index to" each volume, and a coloured paper wrapper to each number. Commencing with November, 1897, the journal was published by C. H. Nunn, Graves and Co., and later by C. H. Nunn, Graves and Co., Limited, and commencing with no. 231 the words "(with which is amalgamated Stamp gossip)" are inserted below the title "The Stamp collectors' journal". The numbers for Jannary 15 and February 15,1896 , are wrongly numbered " 20 " and " 21 " in place of " 207 " and "208," respectively, but the numbering on the wrappers is correct, and the wrapper of no. 231 has " 1897 " corrected to " 1898 ". No. 235 is dated "May 16, 1898," but the wrapper bears "May 15, 1898 ".

[Continued as:]

The Stamp collectors' journal and philatelic monthly advertiser (with which is amalgamated Stamp gossip), a monthly magazine devoted entirely to all branches of philately.

Bury St. Edmund's, C. H. Nunn, Graves and Co., Limited, 1899-1901.

$4^{\circ} .8$ in. Vols. xxr.-xxirr. 27 nos.

Vol. XXI. Feb. 15, 1899-Oct., 15, 1899. Nos. 244-252.

" XXII. Nov. 15, 1899- ", 15, 1900. " 253-263.

* * "There are "ititle-pages and indexes to vols." XXI. and XXII., and $a^{*}$ coloured paper wrapper to each number. No. 260 is dated "June and July, $1900 "$.

FOREIGN STAIIP COLLECTORS' NEWS. The Foreign stamp collectors' news

$8^{\circ} .8 \frac{1}{4}$ in. 30 nos. in 3 vols.

Hull, Edwin England, I883-86.

Vol. I. Oct., 1883-Sept., 1884. Nos. 1-12.

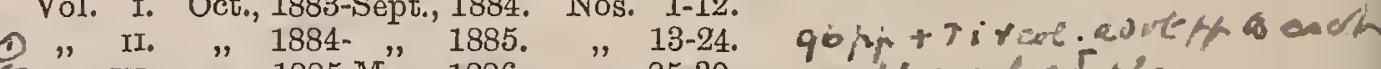

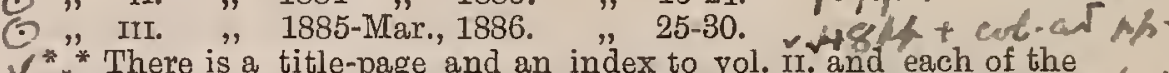
*"* There is a title-page and an index to vol. Ir. and each of the
thirty numbers has a coloured paper wrapper. No. 27 is wrongly that the wh. Les lil numbered "Vol. II.," "vand the paper wrappers of nos. 27-30 bear the words "New Series". $V$ A copy of the prospectus of the journal is bound up in front of no. 1. Amalgamated with the "Philateliç star and coin collector," vol. mr., no. 3.

FOREIGN STAIMP GAZETTE. The Foreign stamp gazette. A monthly devoted to the interest of stamp collectors and dealers 1880

Camden Square, London, Rogers, Wright and Co.,

$8^{\circ} .93$ in. No. $1_{2}$ Mar., 1880.

** There is a supplement of (2) pp. Amalgamated with no. 18 of the "Philatelist's gazette". 
Foreigr folonial Ex change timulat, Theridentead 1880

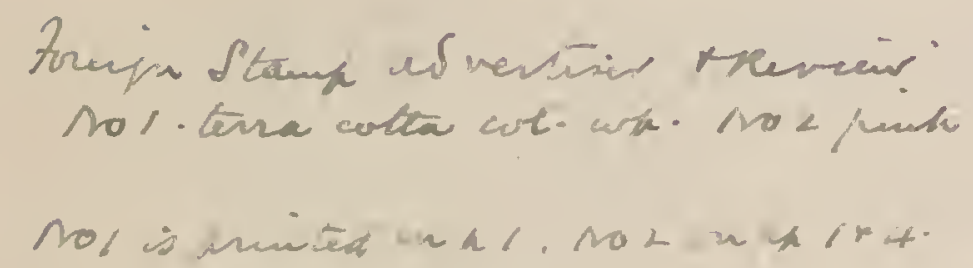

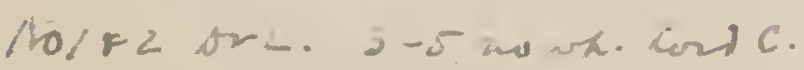

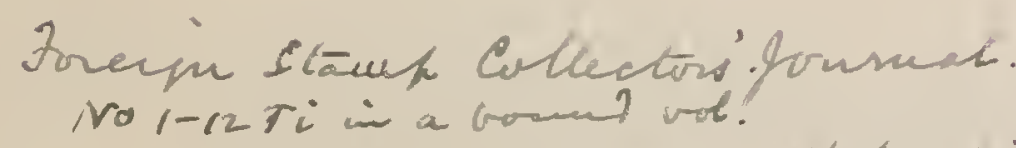

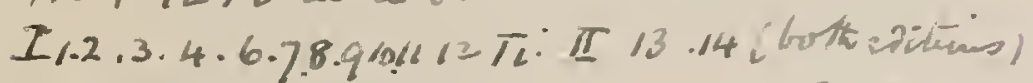

$15-1920.21-24 \pi \sqrt{1}$ III. $25-36$ IV 37-42-44-48

r. 49 -59.

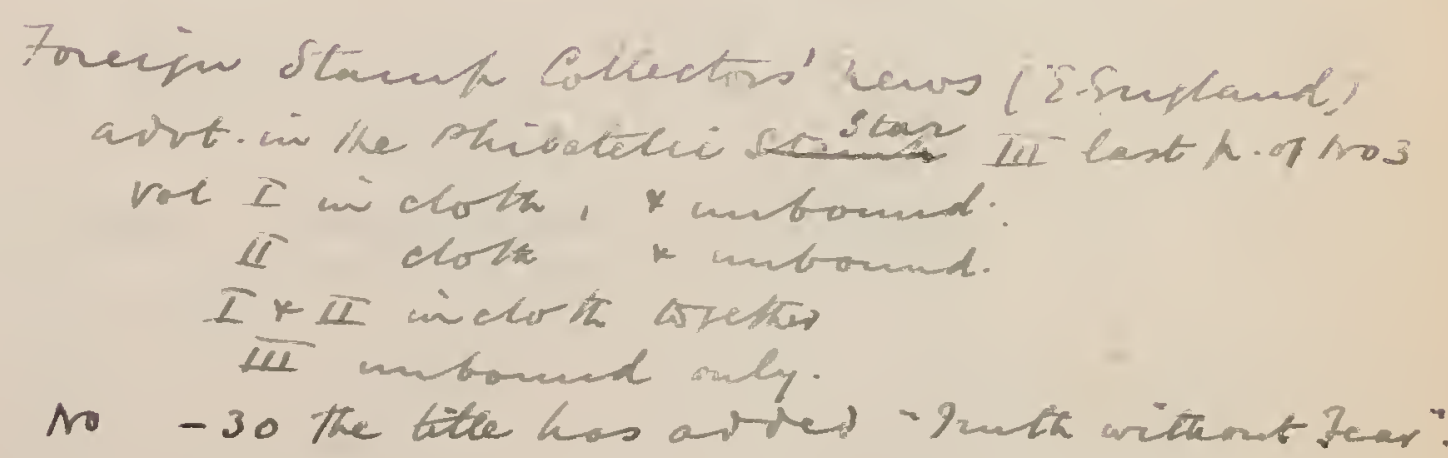



FOREST AND FIELD. Forest and field.

Gilbertsville, etc., N. Y., William Pope, r892-93. 8०. $9 \frac{1}{2}$ in. Nos. 1-

** Only partly philatelic. Nos. were published at Edmeston, N.Y. Wanting all but no. 6 .

- Second series.

Utica, N. Y., Frank E. Merritt, Jr., r894-96.

S q t $4^{\circ} \cdot 10-10 \frac{3}{4}$ in. 28 nos. in 2 vols

Vol. I. Dec. 3, 1894-Nov. 30, 1895. Nos. 1-24.

Vol. I. Dec. 3, 1894-Nov. 30, 1895. Nos. 1-24.

* *nly partly philatelic. Wanting vol. I., nos. 2, 3, 6, 7, 8, 9, 10

FORTNIGHTIY COLLECTOR. The Fortnightly collector. Published every other Tuesday in the interests of stamp collectors.

Smethport, Pa., The J. L. Morrison Co., x9o3.

Fol. 12-111 in. Nos. 1-5, May 11, 25, June 8, October 6, 20, 1903 . ** Succeeded by "Morrison's weekly stamp collector". Wanting nos. $1,2,3$.

FORTNIGHTIY PHILATELIST. The Fortnightly philatelist. Detroit, Mich., A. K. Graves, r902. 80. 9 in. Nos. 1-6, May 15-Aug. 1, 1902. Mis. St. Jour. 94 (7).

FORTNIGHTLY REVIEW. The Fortnightly review. May, 1894. [Contains an article "The Stamp-collecting craze," by $W$. Roberts.]

London, W.C., Chapman and Hall, Ltd., x 894 . $8^{\circ} .10$ in. pp. $661-668$.

* * The number has a coloured paper wrapper.

FORTUNA. Fortuna.

Coepenick, etc., Ernst Wenzel, etc., I888-92. $8^{\circ} .9 \frac{1}{2}$ in. and $4^{\circ} .12$ in. 28 nos. in 5 vols.

1st year. 1888. No. 1 .

2nd ", Jan. 1, Feb. 1, Mar. 15, Oct. 15, Dec. 5, 1889. Nos. 1 , $2,3,7,8$.

3rd "Jan. 15, Mar. 1, Apl. 5, June 1, July 15, Sept. 1,-Dec. 1 , 4 th 1890. Nos. $1-9$

1-10.
5th ., Feb. 1, Apl. 15, May 18, 1892. Nos. 31, 33, 34.

* *ommencing with no. 7 of the third year the size is quarto. Nos. 33 and 34 were published by Josef Bergmann at Oedenburg, Nos. 6 and 7 of the fourth year were published together, with the date "15 Juni, 1891," and nos. 4, 5, 6 of the second year and no. 32 were never published.

\section{[Continued as :]}

___ Illustriertes Briefmarken-Journal "Fortuna". Oedenburg, Josef Bergmann, r892-93.

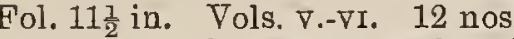

5 th year. July 8, Aug. 12, Oct., Xmas., 1892. Nos. 7-12.

6th "J Jan.-June, 1893. , 1- 6.

* * Nos. 9 and 10 , and 11 and 12 of the fifth year were severally published together under the respective dates "Oktober 1892," and "Weihnachts-Nummer," and there is a prospectus bearing "V. Jahrgang, September 1892. Nr. 9," which consists of a single leaf printed on one side only.

FORTUNA. Fortuna. Hauptvereinsorgan des Briefmarken-Tauschverbandes "Fortuna" zu Baurup.

Baurup, Gravenstein [printed], Wilh. L. Knutz, r895.

$4^{\circ} .8 \frac{1}{2}$ in. No. 1, March, 1895.
* The edition was limited to 150 copies. Wanting.

FORWARD STAMP ADVERTISER. The Forward

Q stamp advertiser. Official organ of the Forward Stamp Exchange. Birmingham, J.H. Coole, ró 5. 8. 71 in. 6 Nos. 1-2, Oct.-Nov., 1905. Mis. St. Jour. $153(2)$

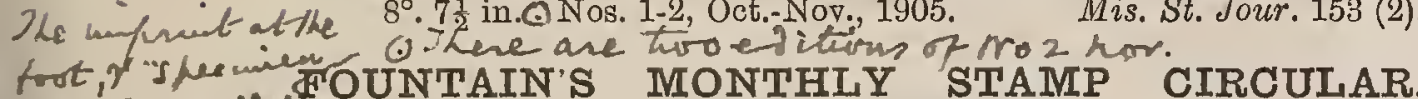
no' heing Fountain's monthly stamp circular.

Fountain's monthly stamp circular.
New York, A. Fountain, $\times 878$. * in. [No.1]

FRANC-PARLEUR PHILATF́LIQUE. Le Franc-Parleur philatélique. Organe périodique absolument indépendant. Paris, Amiens [printed], A. Coyette, x903. $8^{\circ} .9 \frac{\pi}{2}$ in. Nos. 1-3, July, Sept., Nov., 1903.

* No. 3 was never circulated.

ha France Phalidique of tot? Punis

1907 I $18($ ho $)$

1909 III $32($ ma) $33 \times 536$
FRANCO FURTIANISCHES PHILATÉLISTISCHES JUBILÄUIMS BLATT. Franco furtianisches Philatélistisches Jubiläums Blatt.

Frankfurt a. M., [Verein für Briefmarkenkunde zu Frantifurt a. M.], $\times 893$.

Fol. 14 in. 15th year. No. 1, May 6, 1893.

* * Printed on pale rose paper and the contents are of a humorous ** Printed on pale rose paper and the contents are of a humorous
description.
Mis. St. Jour. $128(20)$.

FRANCOBOLLO. Il Francobollo. Milano, Gio. Gussoni, r893-1900.

Fol. 121 -13 in. 89 nos. in 7 vols.

1st year. Mar. 31, -Dec. 31, 1893. Nos. 1-12,

2nd "J Jan. 31, -Mar. 31, May 25-Dec. 31, 1894. Nos.

3rd ", " $\quad$ 13-14. -Dec. 31, 1895. Nos. 25-37.

4th " " " $31, \quad-\quad, \quad 31,1896 . \quad, \quad 38-50$.

5th " " $31, \quad-" 31,1897 . \quad " \quad 51-62$.

7th " Feb. 4, 1899 -Jan. $30,1900 . \quad$ " $\quad 38-87$.

** rhere is a title-page and an index to each year and nos. 5,6 9 and 10,11 and $12,16,35-89$ - have coloured paper wrappers, ex9 and 10,11 and $12,16,35-89$ have coloured paper wrappers, excepting the double no. 67-68, which has a white wrapper. The
wrapper of no. 16 bears the words "Numero speciale dell' Eswrapper of no. 16 bears the words "Numero speciale dell' Essposizione ". There is a supplement to no. 16 and also to no. 27 an illustrative supplement to the double no. 67-68, several supplemental slips, a second edition of nos. 15 and 63 and an "Edizione Economica" of nos. 64, 65, and 73. The numbers for Novembe 30 and December 31, 1893, are numbered, respectively, "9, 10 and " 11,12 ". The number for December 31, 1894, is numbere " 23,24 " and that for March 31, 1895, "27, 28 ". There are two numbers for May, 1896, one dated "15 Maggio," the other "31 Maggio". The number for May, 1898, is numbered "67-68" and there are two :numbers for December, 1898, no. 75 dated "3 Dicembre," the other,' no. 76-77 dated " 31 . Dicembre". There are also two numbers for February, 1899, one dated "4. Febbraio," the other "28. Febbraio" "and there is no number for April, 1899 No. 63 has "Anno V" instead of "Anno VI," except on th [Continued as :]

Il Francobollo e la Cartolina, Monitore dei collettori. Milano, Ditta Giovanni Gussoni, r9oo-or.

$8^{\circ} .8 \frac{1}{4}$ in. Vols. VIII.-IX. 14 nos.

8th year. Feb. 22-Dec. 24, 1900. Nos. 1-13

9 th $"$ " .

* * There is a title-page and an index to the eighth year and a paper wrapper to each number of that year. Nos. 2 and 3, 4 and 5,6 and 7,9 and 10, 12 and 13 were severally published together under the respective dates, " 24. Marzo," "30. Aprile," "6. Giugno, "30. Settembre," "24. Dicembre," and there are no numbers for May, August and October, 1900. The previous titles of the two amalgamated journals were "Il Francobollo" and " La Cartolina Postale Illustrata". Of the latter, one volume of twelve number Was published from December 28,1898 , to January 27,1900 . The librairy contains a copy of this
of a non-philatelic character.

FRANCOBOLLO E LA CARTOLINA. See FrancoBOLLO.

FRANK LESLIE'S BOYS' AND GIRLS' WEEKLY Frank Leslie's boys' and girls' weekly. [Philatelic extracts mounted in a folio volume. The principal article running through the numbers has the title "The Stampcollectors' corner," and was written by Joseph J. Casey.] New York, Frank Lestie, r874-75.

Vols. XVI.-xvirI. 38 nos.

Vol. xvI. Sept. 19 -Oct. 10, 1874. Nos. 413.416

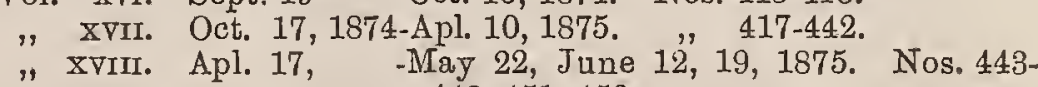
May 22, June

FRANKFURTER BRIEFIMARKEN - ANZEIGER Frankfurter Briefmarken-Anzeiger. Internationales Insertions-Organ.

Frankfurt a. M., Offenbach a. M., [printed], $L$. V. Fleck, r891.

Fol. $12 \frac{3}{4}$ in. No. 1, Apl. 20, 1891. **A copy of the prospectus of the journal is bound up with the
Mis. St. Jour. 73 (15).
Miser.

[Continued as :]

Ludw. Val. Fleck's Frankfurter Briefmarken-Anzeiger.

Internationales Insertions-Organ.

Frankfurt a. M., L. V. Fleck, r89r.

Fol. 1293 in. No. 2. May 10, 1891 
FRANKFURTER BRIEFMARKEN-ZEITUNG. See UNIVERSUM.

FRANKFURTER BRIEFIMARKEN-ZEITUNG IMIT DEII INSERATENTEIL UNIVERSUIM. See UNIVERSUM.

\section{FRANKFURTFR BRIFझMARKENZEITUNG UNI-} VERSUIM. See UnIVERSUM.

FRANKFURTER ZEITUNG UND HANDELSBLATr. Frankfurter Zeitung und Handelsblatt Einundvierzigster Jahrgang. Nr. 231. August 21, 1897. [Contains an article "Briefmarken-Ausstellung in Heidelberg."] Fünfundvierzigster Jahrgang. Nr. 240. August 31, 1900. [Contains an article "Eine Briefmarken-Ausstellung ". Paris.]

Frankfurt a. M., Frankfurter Societäts-Druckerei, I897-I 900

Fol. $22 \frac{1}{4}$ in. p. 1 and p. 1.

Mis. St. Jour. $136(10,11)$

F. RAYMOND AND CO'S IMONTHLY CIRCULAR AND "GENERAL ADVERTISER". F. Raymond and Co.'s monthly circular and "General advertiser".

London, Ont., 1872.

$4^{\circ}$. 8 $\frac{8}{4}$ in. [No. 1], December, 1872.

** The number consists of a single leaf and the contents consist entirely of advertisements.

Mis. St. Jour. 140 (6).

FREEMAN'S FIRESIDE VISITOR. Freeman's fireside visitor.

Mt. Juliet, Tenn., W. H. Freeman, I888. $8^{\circ} \cdot 9 \frac{1}{2}$ in. Nos. 1-2, June-August, 1888

** Only partly philatelic.

[Continued as :]

The Farrago.

Mt. Juliet, Tenn., W. H. Freemann, etc., I888-go. $8^{\circ} .9 \frac{1}{2}$ in. and fol. 12 in. 19 nos, in 3 vols.

Vol. I. Sept. \& Oct., 1888 . Nos. 3 \& 4

$"$ II. Jan.-Dec., 1889. Nos. 1-12.

* " IrI. "May, 1890 . No 1- 5 .

* " Only partly philatelic. Nos. 1-8, vol. II., are folio and the remaining numbers are octavo. There is a coloured paper wrappe to the double number of vol. I., to no. 9, vol. II., and to each subsequent number. Commencing with no. 9 , vol. II., the journel was published by Will. H. Freeman and Co. Nos. 3 and 4, vol. I., nos. 3-6 and 11 and 12, vol. II., were severally published together and there are supplements of four pages to nos. 3-6, vol. II and one of two pages to no. 7, vol. II. Nos. 9-12, vol. II., are also numbered "Whole no. 12-20," respectively. Wanting nos. 3,4 $5,6,10$, vol. II., and nos. 2,4 , vol. III

FREEPORT BREEZE. Freeport breeze. $8^{\circ} .7$ in. No. 2, April 7, 1888 Freeport, Kas., F.R. Gillett, I 888 . * * Only partly philatelic

Mis. St. Jour. 121 (2)

FRIFDI'S ILLUSTRIRTES BRIFFMARKEN - OFFERTENBLATT. Friedl's Illustrirtes BriefmarkenOfferten blatt.

Fol. 13 in. nos. in vols. In progress.

1st year. Nov. 1 , Dec. 10, 1898. Nos. 1- 2.

2nd "Jan. 25, Mar. 25, May, $1899 . \quad$ " 3- 5.

3rd " Jan., Feb., Apl., Nov., $1900 . \quad$ " 6- 9.

Mar., July, Nov.-Dec., 1901.

Mar.-Apl., July-Aug., Oct.-Nov., 1902. " "14-19.

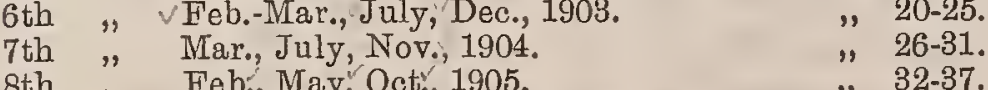

9th " Feb., Apl., Apl.-May, June-July, Aug.-Sept., Oct.-Nov. ** Nos. 12 and 13,14 and 15,16 and 17,18 and 19, 20 and 21,22 and 23,24 and 25,26 and 27,28 and 29,30 and 31,32 and 33,3 and 35,36 and 37,38 and 39,41 and 42,43 and 44,45 and 46 and 47 and 48 , were severally published together. The numbers for 47 and 48 , were severally published fog 1904 and 1905 and FebruJuly and December, 1903, and those
ary, 1906, bear a double number.

FRIEDL'S PHILATEISTISCHE BERICHTE. See Sigmund Friedris Phimatelistische Berrohte.
FRIENDSHIP'S JUNIOR. Friendship's junior. Chiti, N. Y., C. A. Nichols, Jr., I904-05. in. Vols. rV.-V. 7 nos.

Vol. Iv. July-Dec., 1904. Nos. 1-6.

*"* v. Jan., 1905. No. 1 . ing all nos.

FRIMAERKE - HANDLERES OG SAIMERES AVERTISSEIMENTS-HAEFTE. Frimaerke-Handleres og Samleres Avertissernents-Haefte. Aarhus, J. A. Chr. Danielsen, 1894 $8^{\circ} \cdot 81$ in. No. 1, May $15,1894$.

* The number has a coloured paper wrapper. The content consist envirely of advertisements. Mis. St. Jour. 135 (8)

FRIMÄRKS-SAIMLAREN, Frimärks-Samlaren. Stockholm, Emil Braese, I892-93. $8^{\circ} .10$ in. "Profnummer" and nos. 1-12, Dec. 8, 1892-Dec. 30 1893. * *Nos. 7 and 8 , and 10 and 11 were severally published together under the respective dates " 1 Augusti, 1893 " and "5 November, 1893 ," and there is a title-page and an index to the volume. Commencing with January, 1894, the jou

FRIM ̈̈RSSAMLAREN. Frimärkssamlaren. Skandinavisk frimärkstidning. Halmstad, C. I. Bjelke, I897-98.

$8^{\circ} .10$ in. 17 nos. in 2 vols.

1st year. Aug. 30-Dec. 15, 1897. Nos. 1- 5

2nd "Jan. 2- " 1, 1898 .

** Nos. 4 and 5 of the first year and nos. 4 and 5, 6 and 7 and 11 and 12 of the second year were severally published together. No. 3 of the second year is partly numbered $3 \mathrm{~A}$ and partly $3 \mathrm{~B}$ and the double number 11 and 12 is dated November and December, 1898 although it was not printed until 1899. Wanting vol. I., nos. 3 and all vol. Ir., except nos. 1,

FRIULI FILATELICO. Il Friuli filatelico. Giornale mensile filatelico internazionale.

Pordenone, Giacomo Milani, I898.

Fol. $12 \frac{1}{2}$ in. Nos. 1-2, Aug.-Sept., 1898

* There is a coloured paper wrapper to each number.

Mis. St. Jour. 107 (17)

F. TRIFET'S IMONTHLY CIRCULAR. F. Trifet's monthly circular. Boston, Mass., F. Trifet, I874. $8^{\circ} .8 \frac{1}{2}$ in. 12 nos. in 1 vol.

* * Nos. 4 and 5,7 and 8 and 11 and 12 were severally published together and an index to the volume was published with nos. 28 and 29 of the following.

$$
\text { [Continued as :] }
$$

F. Trifet's monthly stamp circular and price catalogue Boston, Mass., F. Trifet, I875-77.

$8^{\circ} .8 \frac{1}{2}$ in. Vols. II.-IV. 35 nos.

Vol. II. Jan-Dec., 1875. Nos. 13-24

, III. " $"-$

IV. "Nov., $1877 . \quad 37-47$

* "An index to vol. II. was published with nos. 28 and 29 and nos. 18 and 19,20 and 21, 22 and 23,26 ana 27, and 32 and 33 were severally published together. The tenth edition of Trifet's "Descriptive price catalogue of the postage stamps of all nations" was issued in parts with vol. II., and Trifet's "Descriptive price catalogue of the revenue stamps of all nations," was issued in parts with vol. III. Some of the numbers are also found printed on coloured paper. On the completion of vol. II. the twelve numbers were supplied in a paper wrapper bearing "Vol. II. Boston, 1875. Nos. 13-24."

\section{[Continued as : ]}

Monthly stamp circular.

Boston, Mass., F. Trifet, I877-79.

$8^{\circ} .8 \frac{1}{2}$ in. Vols. IV.-VI. 18 nos.

Vol. IV. Dec., 1877. No. 48.

" v. Jan.-Dec., 1878. Nos. 49-60.

* " VI. $55 "$ "May, 18 and 60 " and $63-65$ were severally published together. Some of the numbers are also found iprinted on coloured paper. 


\section{Recman's henthly circulas [ourrost-4]}

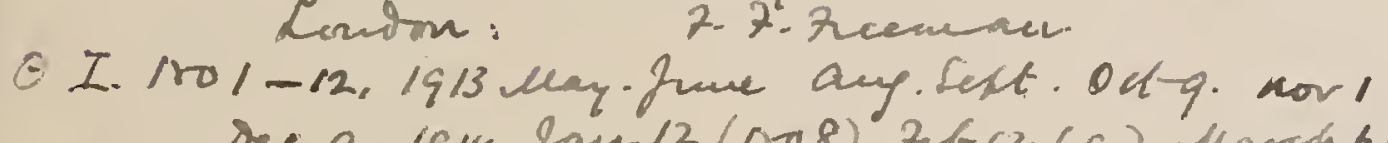

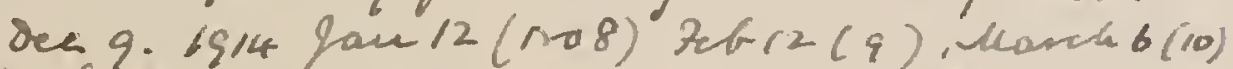

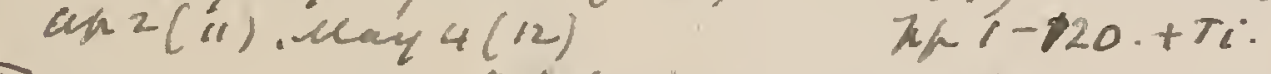

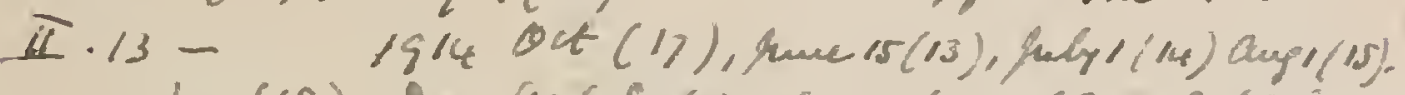

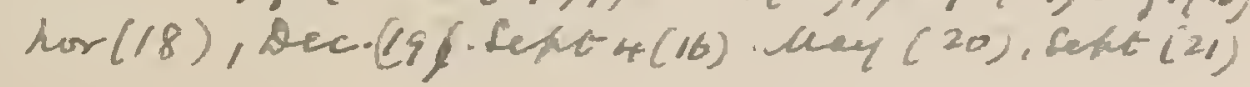

rol $51-12$ hiblished in froen nxime, letterel.

Orange wh. k 1 1 $13-17-20$.

The itte was changed to

"Reenaus Monthly Gorrsual" from sos.

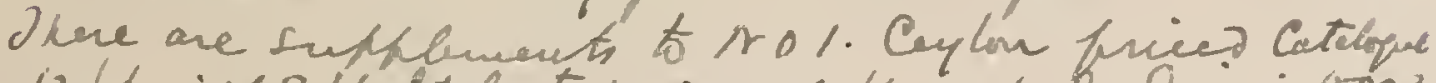

12 ph. jof 8 H. Sthly to no 2 ; If th 9-16 Parinis a cono3.

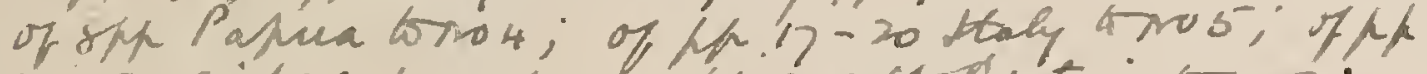

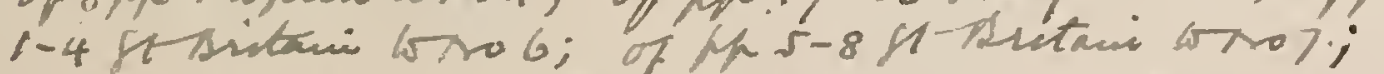

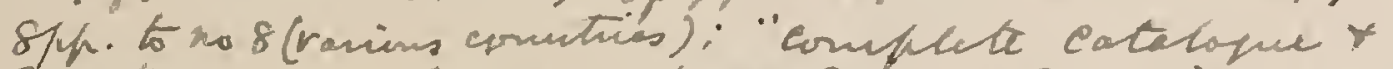

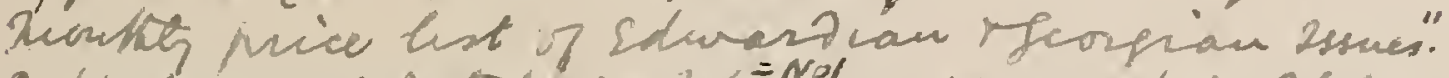

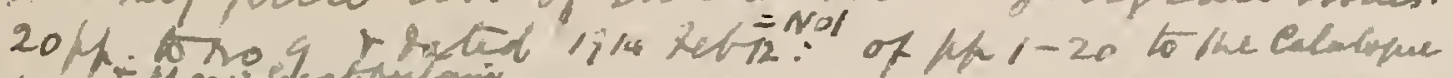

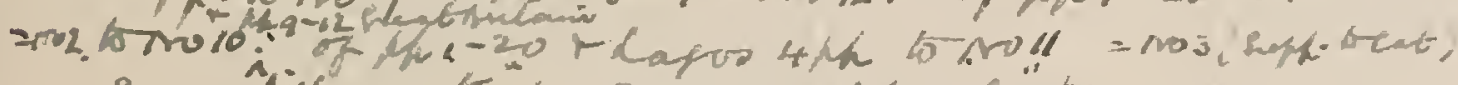

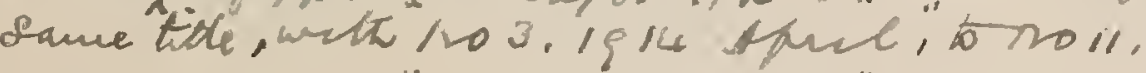

“. .. "No 4, 1514, U ay,"

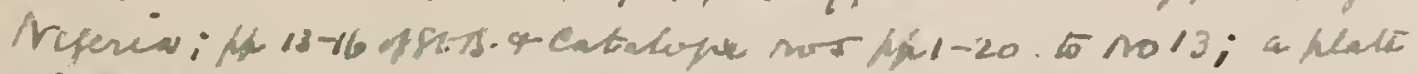

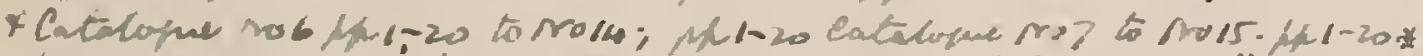

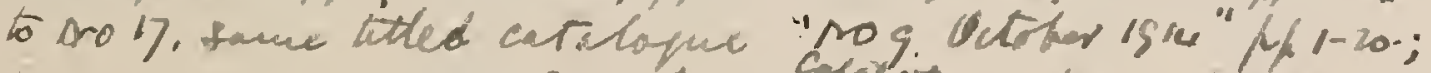

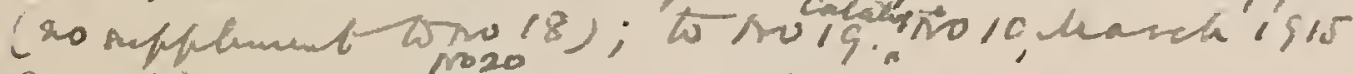

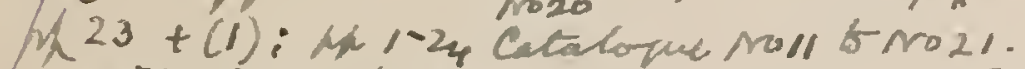

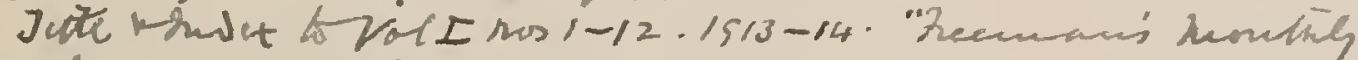

fomar op Picintely.

* or catelopue nop 67 ro is.

Fumaerke- Trebende gPfis ix 



\section{F. TRIFET'S MONTHLY CIRCULAR.}

\section{[Continued as :]}

_ Trifet's monthly.

Boston, Mass., Fr. Trifet, I879-8I.

Fol. $15 \frac{1}{2}$ in. and 23 in. Vols. vI.-VIII. 20 nos,

Vol. VI. Aug. 1879-Feb., 1880 . Nos, 66-72

$"$ VII. Mar.-Sept., Nov., 1880-Mar., 1881. Nos. 73-84.

*"* VIII. May, 1881, No. 85.

** Only partly philatelic. No. 66-74 measure $15 \frac{1}{2}$ inches and the remaining numbers 23 inches. No. 70 is wrongly numbered " 69 ," and there is a supplement of two pages to no. 81 . Nos. 83 and 84 contain no philatelic matter. Nos. 66-73 and 76-85 are bound together in one volume and the philatelic portions of nos. 66-79 and 81 are mounted and bound up after the "Monthly stamp circular," nos. 63-65.

\section{F. TRIFET'S MONTHLY STAMP CIRCULAR AND} PRICE CATALOGUE. See F. TRIFET'S MONTHLY CIRCULAR.
FUNNY FOOLATELIST. The Funny foolatelist. For the benefit of literature collectors.

Mc. Connelsville, O., Page and Adair, [1897].

$8^{\circ}$. 81 in. Vol. 0. No. 0, [Feb., 1897].
* * The number has a coloured paper wrapper

Mis. St. Jour. 93 (9).

FURETEUR. Le Fureteur.

Paris, Louis Dourliac, I900-ог.

Fol. $11 \frac{1}{4}$ in, nos. in 2 vols.

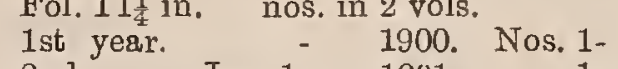

1st year. Jan, 1- 1900. Nos. 1- 1 1-

** Only partly philatelic, There is a coloured paper wrapper to each number. Wanting all nos. of the first year, except no. 2 anded July 1,1901 .
dater no. 13 of the second year. The last is

FYRVÄPPLINGEN. Fyrväpplingen. Tidning för allvar och skämt under Fjerde Nordiska Filatelistkongressen.

$8^{\circ} .91$ in. Nos. 1-4, June 19-22, 1899 ;

Stockholm, x899.

" No. 1 is dated in error " 19 Juli " and no. 4 bears the words Mis. St. Jour. 118 (2). 


\section{GARDEN CITY PHILATELIST}

GARDEN CITY PHILATELIST. The Garden City philatelist. Issued monthly in the interest of stamp collectors. Chicago, Ill., A.J. Mouat, I 886. $8^{\circ} .9$ in. Nos. 1-8, Jan. 15-Aug. 15, 1886.

* * There is a paper wrapper to ench number. A number 9 , dated September 15,1886 , was print d ready for circulation when a fire at the printing works destroyed the entire stock with the exception of one copy, which is in the library of Mr. H. E. Deats of Flemington, N.J.

GAZFTA PHILATELICA. Gazeta philatelica. Organe internationale des philatèlistes.

Rio de Janeiro, Borges Monteiro e Ce., I892. $8^{\circ} .10$ in. No. 1 , November 15,1892

** The contents are published in Portuguese and French.

Mis. St. Jour. 133 (11).

GAZETA POSTAL. Gazeta postal.

Belem, Brazil, Raul d'Azevedo, 1890-94.

Fol. 17 in. nos. in vols.

$\begin{array}{lll}\text { 1st year. } & \text { nos. in } & \text { vols. } \\ \text { 1890. Nos. }\end{array}$

1st year. - $\quad$ - 1891. " "

3rd " $\quad$ - $\quad 1892$.

5th " - 1893.

* Only partly philatelic. No. 31 is dated August 2, 1891, no. 66 is dated February 2, 1893, and no. 94, December 17th, 1893. Wanting nos. 1-30, 32, 34-65, 83, 88, 89, 90, 93 and after 94.

GAZETTE. The Gazette.

Chariton, Iowa, Martin and Voiland, 1886. $8^{\circ} .9$ in. Nos. 1-4, Apl. 1-July 1, 1886.

* * Only partly philatelic. Nos. 3 and 4 have coloured paper wrappers, and these two numbers were published by Fred. B. Voiland.

[Continued as:]

-.... Chariton gazette.

Chariton, Iowa, Fred. B. Voiland, I886-87. $8^{\circ} .9$ in. and fol. $12 \frac{1}{4}$ in. 9 nos. in 2 vols.

Vol. I. Aug. 1, 1886-Jan., 1887, Apl., May, 1887. Nos, 5-12. "II. June, 1887. No.

* * Only partly philatelic. Nos. 9 and 10 are folio and the other numbers are octavo, and nos. 6, 10-12 and no. 1, Vol. Ir., have the article "The" before the title. Mis. St. Jour. 139 (5a)

GAZETTE DES ANNONCES, DU COMMERCE ET DE L'INDUSTRIE. Gazette des annonces, du commerce et de l'industrie. Paraissant chaque samedi en Turc, Français, Grec et Arménien.

Péra, Constantinople, Jacques M. Minasse, 1894. Fol. $13 \frac{1}{2}$ in. Vol. III. 2 nos.

3rd year. August 25, 31, 1894. Nos. 38-39.

* * These two numbers, which are printed on coloured paper, contain an advertisement announcing the publication on Septem"Le Timbre-Poste," which never made its appearance. There are also other philatelic advertisements in the numbers. Wanting
Mis. St. Jour. 128 (19).

Mis. St. Jour. 128 (19).

GAZETTE DES COLLFCTIONNEURS. La Gazette des collectionneurs. Nimes, France, M. H. Merle, I905. Fol. 11 in. Nos. 1-2, September-October, 1905.

** There is a coloured paper wrapper to each number. Mis. St. Jour. 124 (2)

$$
\begin{aligned}
& \text { Gay ette Cartophile (contumiation of } \\
& \text { Gajette des Anatrurste.) }
\end{aligned}
$$

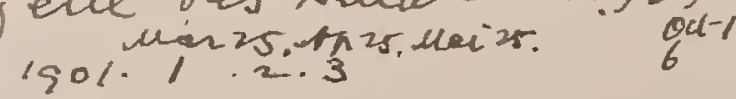$$
\text { supplensents at rol (a Mate): }
$$$$
\text { fajeter des twatems, Aiblioplubs, th }
$$$$
\text { creactionnums. Paris }
$$$$
1900 \text { mar } 25.101 .2 \cdot 3 \cdot 4
$$$$
\text { vil }-1901 / \ln 25
$$$$
r \|-x \mid \text { in stiff pley wreffers }
$$$$
\text { sulpet. an X1 (Mate). }
$$

\section{GAZETTE DES TIMBRES}

GAZETTE DES TIMBRES. Gazette des timbres.

Paris, Pierre Mahé, I872-76.

$8^{\circ} .9 \frac{1}{4}$ in. 48 nos. in 4 vols.

- 1st year. July 15 , 4 vols.

2nd "July-September, 1873-Aug., 1874. Nos. 1-12. \$ 95

3rd " Jan. -Dec., 1875. " " $1-12$

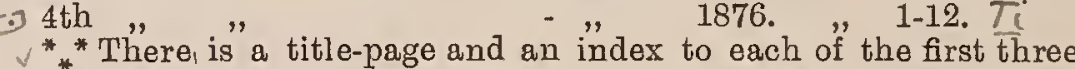

years and a paper wrapper to each of the numbers of the first two

years. $r$ No. 1 of the second year is dated "Juillet-Septembre, 1873," and ryos. 9-12 of the fourth ,year were published together under the date "Août-Décembre, 1876". There are supplements of four pages to nos. 7-10 of the second year, with the title "Notice mensuelle de livres rares et curieux," and four pages of a "Catalogue general des timbres-poste, telegraphes et tiscaux en vente a prix reduits" were given with each of the twelve numbers of the third year and also with nos. 1-8 of the fourth year.

thawe I. II $(1872-4)$ is hepar waphers.

- [Special edition, printed on various coloured paper.] * * Consists of the first two volumes, 24 numbers, like the ordinary edition. The 12 numbers of vol. I. were published in a red wrapper and the edition consisted of 25 copies only. Wanting all.

GAZETTE PHILATELIQUE LYONNAISE. Gazette philatélique Lyonnaise. Iyyon, S. Farges, r 900-04.

$8^{\circ} .8$ in. 45 nos. in 5 vols.

1st year. Oct.-Dec., 1900. Nos. 1- 3.

2nd " Jan.- " 1901. " 4-15.

3rd " "- " 1902. " 16-27.

4 th " " -Nov., 1903. " 28-38.

* * There is" a coloured paper" wrapper to each number. The "wrapper of no. 14 bears in error "13" and nos. 39 and 40 were published together under the date "Janvier, 1904". Nos. 5, 8, 12,16 and 20 have supplements.

GAZETIE TIMBROLOGIQUE. Gazette timbrologique. Revue mensuelle de la Société Timbrophile d'Echanges. Paris, Grenoble [printed], r891-98.

$8^{\circ} .93$ in. 80 nos. in 7 vols.
1 st year. Oct. $15,1891-S e p t .20,1892$. Nos. 1-12.

1st year. Oct. 15, 1891-Sept. 20, 1892. Nos. 1-12.

3rd " " " 20, 1893- " $20,1894 . \quad$ " $25-36$

4th " " " 20, 1894-" " 20, $1895 . \quad " \quad 37-48$.

5th " " "20, 1895-" " 20, 1896. " " $49-60$

6th " " "20, 1896-" " 20, 1897. "

* * th "There is" 20, 1897-July, 1898 . fitle each of the first five * * There is a title-page and an index for each of the first five years, an index to the sixth year, a title-page to the seventh year, and each number has a paper wrapper. "No. is wrongly numbered and cated "Noring, and date are correctly given on the wrapper, and no. numbering! and date are correctly given on the wrapper, and no. 72 is wrongly numbered " 71 "except on the wrapper which has the correct number. No. "Tuin-Juillet, 1898". There is a supplemental slip to no. 5 , 80, "Juin-Juillet, 1898 ". There is a supplemental slip to no. 5 , and 33 , and a separate supplement of a piece of music " Postal and 33 , and a separate supplement of a piece

GAZfTIOPHILE. See Presso-Philatélie.

GAzetrerzamelaAR. See Presso-Philatélit.

GEFN PERS GEFN ZFGELS. See Presso-Philatílie.

I.

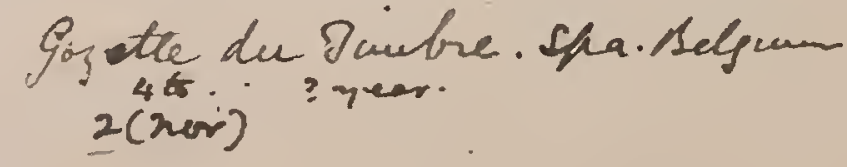

$$
\begin{aligned}
& \text { Sazpetta dec Blatelesti. Nilavo. } \\
& 1909 \text { I.1.2.3.4 } 67 \quad 10.11 .62 .20^{4} \mathrm{fan} .3 \mathrm{ll}
\end{aligned}
$$

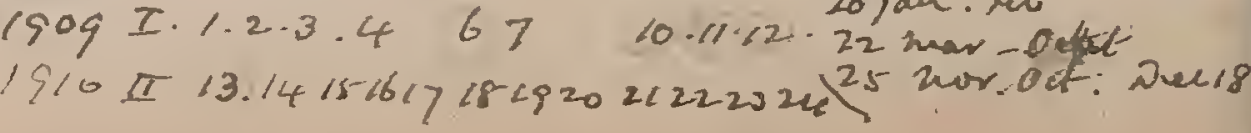





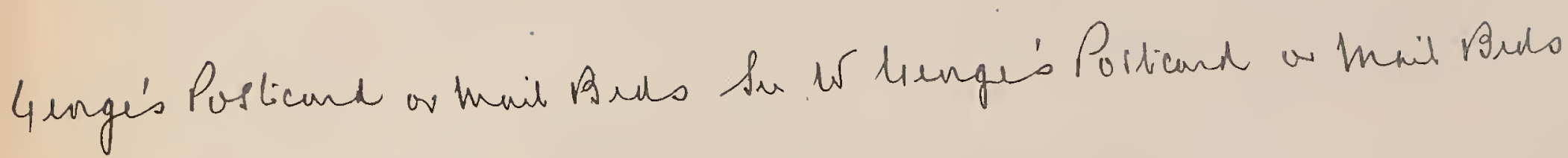

Senuai inculatior. Oevoted to Phiacty.

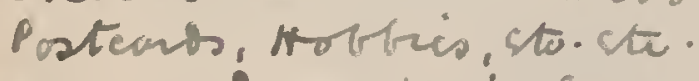

sro. Leven imp inser, 96 hastoume $R^{2}$.

gro 1912 mar.ap. 1ro 1.2. nifmation.

Yenthman's Jomnal (15.4. 1903)

S9' Genilumanos magazine (bet a Dece 1929) 
GEGENWART. Die Gegenwart. Band xuII. No. 39. September 24, 1892. [Contains an article "Der Briefmarkensammler". By Felix von Stenglin.]

Fol. 13 in. pp. 203-204.

Berlin, Theophil Żolling, r892.

GEII. The Gem.

Manchester, N. H., The Gem Publishing Co., etc., I $884-85$.

$8^{\circ} .9$ in. and $4^{\circ} .93-10 \frac{1}{4}$ in. Nos. 1-7, October 1, 1884-April, 1885. * * Only partly philatelic. Nos. 1-3 are octavo, nos. 4-7 are quarto, and nos. 2-7 were published by Thos. H. Crosby.

Mis. St. Jour. 140 (5).

GEIM. The Gem. New Yort, D. M. Dickie, I885. Fol. 16 in. Nos.

* * Cuttings of the stamp portions from nos. 8 and 9, dated September and October, 1885 , are mounted in Stamp Scrap-book, vol. v., pp. 49, 50, and a copy of no. 8 is bound up in Mis. St. Jour. $127(7)$.

GEIM. The Gem.

Hamóburg, Pa., [?

], 1895 .

* * Only partly philatelic. Wanting all nos.

GEIM. The Gem.

Columbus, O., Columbus Novelty Printing Co., I903.

$16^{\circ} .6$ in. Nos. $1-3,[?]$ ]-September, 1903.
${ }_{*}^{*}$ Only partly philatelic. No. 3 has a coloured paper 'wrapper. Wanting nos. 1, 2 .

GEIM PHILATELIST. The Gem philatelist. St. Joseph, Mo., Gem Publishing Co., 1896. $48^{\circ} .4$ in. and $24^{\circ} .6$ in. Nos. 1-3, Jan., Feb., April, 1896.

* Nos. 1-2 are $48^{\circ}$. and have coloured paper wrappers ; no. 3 is $24^{\circ}$. and has no wrapper. No. 3 has no year date given on the
front page.
Mis. St. Jour. $96(6)$

GEIM PRICE LIST. The Gem price list.

$8^{\circ} .81$ in. No. 1 [April 1876.]

Chicago, Ill., A. W. Locke, [1876].

** The number has a supplement of (2) pp.

[Continued as :]

The Philatelic gem.

Chicago, Ill., A. W. Locke, 1876 . $8^{\circ} .9$ in. and 12 in. Nos. 2-6, May-Oct., 1876.

** Nos. 3, 4 were published together with the date "June and July" and no. 6 has the date "September and October". There are supplements of (4) pp, to nos. 2 and 5 , the first with the title
"The Gem Supplement". No. 2 is octavo 9 in. and nos. 3.6 octaro 12 in.

GEMI STAIMP NEWS, See LITTLE GEM STAMP NEWS.

GENERAL-ANZEIGER FÜR PHILATHLIF. GeneralAnzeiger für Philatelie. Internationales InsertionsOrgan.

Iserlohn, eto., Gust. Kirohhoff und Co., etc., r883Fol. $123-12 \frac{1}{4}$ in. nos. in vols. In progress.

1st year, Apl.10-June 15, Aug. 15-Oct. 15, Dec. 1, 1883. Nos. 1-7. 2nd "Jan. 15, Mar. 1-May 15, July 1, Aug. 15, Oct, 1-Dec. 5 , 1884. Nos. 1-9.

3rd "Jan. 10, Feb. 20, Apl,1-June 20, Aug. 1-Oct. 15, Dec. 5 ,

4 th "Jan. 15, Feb. 20, Apl. 1-June 20, Aug. 1-Oct, 15, Dec. 5,

5th 10, FeB. 20, Apl. 1-June 20, Aug. 1-Dec. 5, 1887 Jan. $10, \mathrm{Fe}$

6th "Jan. 15, Feb. 20, Apl. 10-Dec. 10, 1888. Nos, 1-11.

7 th " Jan. 15-Dec. 10, 1889. Nos. 1- 12

8th " " 15- " 10, 1890. " 1-12.

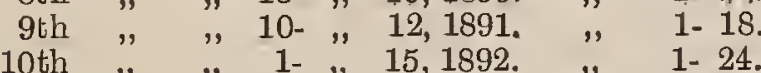

11 th " " " $1-" 15,1893 . \quad$ " $121-24$

12 th " " " 1- " 15,1894 . " " 1- 24.

13 th " " " $\quad 1-", \quad 22,1895 . \quad$ " $171-197$.

5th " " $\quad 5-\quad$ " $21,1896 . \quad$ " 198-232

6th " " 5- " 21, 1898. " "267-299.

17th " " " 5- ", 21, 1899. " "300-333.

18 th " " $\quad 5-$ " $21,1900 . \quad$ " 334-367.

19th " " $\quad 5-", 21,1901 . \quad$ " 368-403.

20 th , " , 5- " 20, $1902 . \quad$ " 404-439.

21 st " " " $\quad 5-\quad " 21,1903 . \quad$ " $440-475$

3rd "5- $" 22,1905$.

24th " " " $5-$ " " 21, 1906. " " $548-583$.

* The contents consist entirely of advertisements. Commencing with the numbor for December, 1887 , the journal has been published by Chr. Sauerland at Hemer i. W. There are supplements to nos. 2, 6 and 9 of the second year and to nos. 1, 2, 3, 4, and 5 of the third year, a "II. Theil" of no. 11, of the sixth year, a "2te Ausgabe" of no. 12 of the seventh year and a "zweite Ausgabe " of no. 12 of the eighth year, dated December 10, 1890, the first edition of this number being dated December 5, 1890 . No. 2 of the fourth year is wrongly numbered "v. Jahrgang no. 2, " no. 221 is dated " 15 September, 1896," in place of " 5 Septem. ber, 1896," no. 239 is dated " 15 Marz, 1897," instead of " 5 Marz, 1897," and no. 478 is dated "5 Februar, 1904," instead of " 25 Januar, 1904". Each number, commencing with no. 1 of the twelfth year, has a coloured paper wrapper. Copies of nos. 284, $392,463,531$ and 571 were also issued in special coloured wrappers inscribed, respectively, "Fest-Ausgabe zu Ehren des II. Deutschen Sammlertages d. Germania-Ringes zu Magdeburg "; " FestAusgabe zum Deutschen Philatelisten-Tag. Berlin 1901 "; "Pforzheim 1903"; "—Regensburg 1905"; "- Nürnberg 1906".

GENERAL STAMP ADVFRTISER. The General stamp advertiser. Amsterdam, C. van Rinsum, r87o. $4^{\circ} .11$ in. No. 1 , June $1,1870.1271$ s cepty.

** A prospectus of the journal is bound up with the above.
Mis. St. Jour. 4 (4).

GENERAL WELT BRIEFIMARKEN BLATT. General Welt Briefmarken Blatt.

Bruxelles, Comptoir Philatélique, 1896.

Fol. $12 \frac{1}{4}$ in. No. 1. Oct. 5, 1896. ** Printed on yellow paper. The contents consist entirely of
advertisements.
Mis. St. Jour. 86 (4).

GENIUS OF YOUTH. Genius of youth. Cincinnati, O., John J. Weissert, I885-86. $8^{\circ} .10 \frac{1}{2}$ in. Nos. 2-4, December, 1885-March, 1886. ** Only partly philatelic. No. 4 is dated "Feb.-March, 1886". Cuttings of the column "The Philatelist, etc.," from nos. 2-4 are mouuted in Stamp Scrap-book, vol. v., pp. 85-92, and the entire numbers are bound up in Mris.' St. Jour. 121 (18).

GEORGE'S PHILATELIC CIRCULAR. See W. GEORGE'S PHILATELIC CIRCULAR.

GERIMAN - AMERICAN STAIMP JOURNAL See Deutsch-Amerikanische Briefmarken Zeitung.

GERMANIA. Germania. Allgemeine Deutsche Philatelisten-Zeitung.

Oybin, Sachsen, Dr. Alfred Moschkau, r883. 4. 121 in. Nos. 1-12, Jan. 10-Dec. 20, 1883.

* * Nos. 7 and 8 were published together with the date " 30 Juli, $18 \% 38$," nos. 9 and 10 together, with the date " 5 November, 1883,"

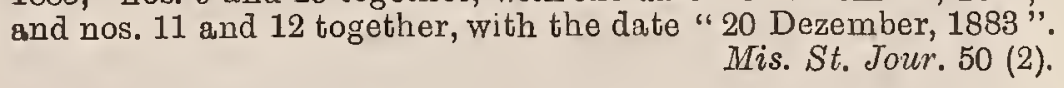

GERIIANIA, BERICHTE. Germania Berichte. Charlottenburg, Germania Ring, I897-

$8^{\circ} .11$ in. nos. in vols. In progress.
1 st year, Nov. 14, Dec. 10,1897 . Nos. $1-2$

2nd ", Feb. 26, Apl. 30, May 31, July 25, Oct. 29, 1898. Nos. 3rd "Jan. 30, June 29, Sept. 29, 1899. Nos. 8-10.

4th "Jan. 29, Aug. 29, Sept. 10, 21, 30, Nov. 25, 1900. Nos. 5th „Feb. 15, Apl. 5, June 30, Aug. 31, Oct. 10, 1901. Nos. 6th "Jan. 10, Feb. 28, Apl. 26, Oct. 26, Nov. 30, 1902. Nos. "22-26.

7th " Feb. 25; May 25, Aug. 15, 22, Nov. 1, 30, Dec. 25, 1903.

Nos. 27-33.
8th "Jan. 31, Feb. 29, May 2, June 21, Aug. 10, Sept. 10, Oct. 10, Nov. 10,'Dec. 10, 1904. Nos. 34-42.

9th "Jan. 10-Dec. 10, 1905. Nos. 43-54.

10th " " 10- " 10, 1906.

* * There is " title-page and an index to nos. 1-14, to nos. 15-37, and to nos. 38-54 with the'words " Erster" "Zweiter" or "Dritter Band". Nos. 1-10, 13 and 14 'have wrappers and advertisement pages with the tit e "Anzeigen der Germania-Berichte" and nos. $11,12,15-22,28,29,32-37,39-66$ have wrappers and advertisement pages with the title "Germania-Berichte Beiblatt für Anzeigen". Nos." 44 and 45 were published together with the date " 25 Februar, 1905 ," and there is no number tor March, 1905. There is a supplement to no, 48 , one to no. 49 and one of two pages to no, 53 ,

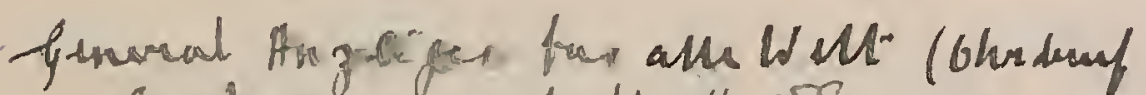

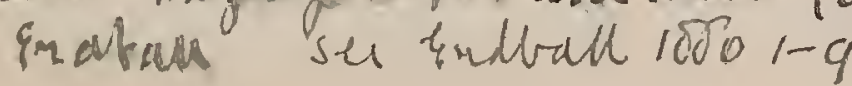


571 GERMANTOWN PHILATELIST

GERIMANTOWN PHILATELIST. The Germantown philatelist.

Germantown, Philadelphia, Pa., The Germantown Philatelist, 1887.

$8^{\circ} .8 \frac{1}{2}$ in. Nos. 1-2, Mar., Apl.-May, 1887.

* * No. 2 was published by Wm. M. Watson

[Continued as :]

_ The Philadelphia philatelist. (Formerly the Germantown philatelist.)

Philadelphia, Pa., Utassy and Hoser, etc., I 888.

$8^{\circ} .8 \frac{1}{2}$ in. Nos. 3-5, Feb., Mar., Apl.-May, 1888.

** No. 4 was published by the Philadelphia Philatelic Publishing

Co. and no. 5 by Geo. W. von Utassy. Mis. St. Jour. 32 (1a).

GIANT. The Giant. Garfield, N. J., [? ], I89o. in. Nos. 1-10.
* Only partly philatelic. Wanting all nos.

GIBBONS AND CO.'S MONTHLY JOURNAL (STANley) See Stanlex Gibbons and Co.'s monthly JOURNAL.

GIBBONS, LIMITED, MONTHLY JOURNAL (STANitex) See Stanley Gibbons and Co.'s monthly JOURNAL.

GIBBONS MIONTHLY JOURNAL (StANLEY) See Stanley Gibbons and Co.'s monthly JouRnal.

GIBBONS STAMP WEEKLY. Gibbons stamp weekly. London, Plymouth [printed], Stanley Gibbons, Limited, I 905 -

$8^{\circ} .10 \frac{1}{2}-10$ in. nos. in vols. In progress.

Vol. I. Jan. 7-June 24, 1905. Nos. 1- 25.

"II. July 1-Dec. 30, " " " $26-52$.

" III. Jan. 6-June 30, $1906 . \quad$ " 53-78.

* "* IV. July 7-Dec. 29, " index to each volume and a coloured paper wrapper to each number:

GIORNALE DEI COLLEZIONISTI DI FRANCO BOLLI E CARTOLINE ILLUSTRATE. II Giornale dei collezionisti di francobolli e cartoline illustrate. $8^{\circ} .9 \frac{1}{4}$ in. No. 1, March, 1901. Napoli, E. Ragozino, г gor. * * The number has a colourel paper wrapper.

Mis. St. Jour. 111 (4).

GIORNALE DEL COLLEZIONISTA. Giornale del collezionista.

Palermo, G. Bonfiglio e Co., r880. $8^{\circ} .12$ in. Nos. 1-2, June 15-July, 1880.

** No. 2 is printed on blue paper. A no. 3 has been given in some published lists of philatelic journals, but only nos. 1-2, exist. A copy of the prospectus is bound up with the two number.

Mis. St. Jour. $107(20)$

GIORNALE FILATELICO ITALIANO. Il Giornale filatelico italiano tratta di filatelia e della collezione Liebig.

$8^{\circ} .10$ in. No. 1, Aug. 10,1899

Biella, Enrico Bussi, I 899

${ }_{*}^{*}$ * The number has a coloured paper wrapper.

GIRL'S REALM. The Girl's realm. Vol. II., December, 1899. [Contains an article "On stamps and stamp collecting," by W. J. Hardy, F.S.A.]

8․ 93 in. pp. 246-249.

London, 1899. Mis. St. Pamph. 63 (3).

GLAD TIDINGS. Glad Tidings. [Contains illustrations of stamps.] Seneca Falls, N. Y., C. B. Howe, 1875 . Fol. 13 in. Vol. 21, no. 11, 1875. Mis. St. Jour. 1 (8)

гЛACъ. ГЛАCЬ [Glas.] . . "Echo Timbrophile".

Philippople, Bulgarie, Première Société Timbrophile Bulgare d'échanges, I 893-94.

Fol. $12 \frac{1}{2}$ in. Nos. 1-6, Oct. 15, 1893-Mar. 17, 1894

* * This was the first philatelic journal published in Bulgaria. Mis. St. Jour. 108 (1).

Scormale dei Colleyconiste sia
GLEANER

GLEANER. The Gleaner.

Poplar Ridge, N. Y., D. Wheeler, 1885 .

* * Cuttings of the stamp portions from vol. Ir., no. 7, dated

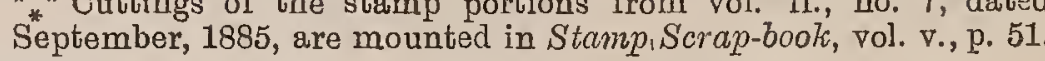

GLOBE. Le Globe. Paraît chaque mois.

Rotterdam, J. H. Hamakers, I896.

Fol. $13 \frac{1}{2}$ in. Nos. 1.2 [Oct.-Nov.], 1896.

* * Neither number bears the month of publieation.

Mis. St. Jour. 108 (7)

GLOBE ILLUSTRE, Le Globe illustré. Journal de la famille. Vol. XI., no. 9, 1 Mars, 1896. [Contains an article "Deux timbres intéressants," with illustrations.] Fol. 15 in. p. $143 . \quad$ Mruxelles, [? St. Jour. 127 (1).

GLOBE-PHILATELISTS ADVERTISER. The Globe philatelists advertiser. [Prospectus of a journal to be published by Shingler and Co., Sheffield, on July 1, 1902 , but which was never issued.]

Mis. St. Jour. 123 (2).

GLOBUS. Der Globus. Internationales Organ für den Briefmarkenhandel. The Globe. International organ of the stamps [sic] trade. Le Globe. Organ international pour le commerce de timbres-poste.

Wien, Max H. Löwinger, I882.

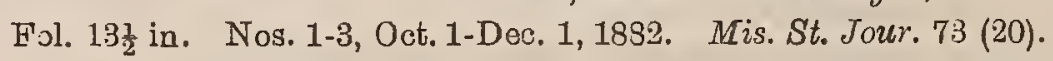

GLOBUS. Globus. Mitteilungen über die gesañte Postwertzeichenkunde. Mit Beiblatt Tauschblatt für Briefmarkensa ̃̃ler. Vereinsblatt des Intern. PostwertzeichenSammler Vereins "Globus". Berlin, r891.

$8^{\circ} .83-9 \mathrm{in}$. Nos. $1-12$, Jan. 1-Dec. $20,1891$.
** Produced by an autographic process. Nos. $4-6$ bear only the ** Produced by an autographic process. Nos. 4-6 bear only the no number, and nos. 11 and 12 were published together under the date December 20,1891. The supplement is catalogued separately. A further supplement with the title "Vereins-Nach-
richten" and the pages numbered 13 to 18 was presented with richten
no. 1.

GLOBUS. Globus. Organ für die Gesamtinteressen der mittleren u. jüngeren Sammler.

Berlin, Intern. Postwertzeichen-Sammler-Verein "Globus," r 892-93.

$8^{\circ} .9 \frac{1}{4}$ in. 18 nos. in 2 vols.

1st year. Feb.-Dec., 1892. Nos. 1-12.

2nd " Jan.-June, 1893. " 1- 6.

* * There is a title-page and an "index to the first year. Nos. 7 and 8 both bear the date "August, 1392," and there is a supplement of illustrations to no. 9. Nos. 2 and 4 of 1893 had supplements with the title "Vertrauliche Vereinsmitteilungen," but these supplements, which are catalogued under their title, were only supplied to members of the society.

GLOBUS. Der Globus. Internationales Organ für den Sammelsport. Wien, $\operatorname{Max} H$. Löwinger, I902. Fol. 121 in. Nos. 1-5, Feb. 1, 20," Mar. 5, 25, Apl. 15, 1902

**" Only partly philatelic.

GLOBUS. See Vertrauliche Vereinsmittwilungen.

GOLDEN DAYS. Golden days. [United States.] Vol. xII., no. 24, May 9, 1891. [Cuttings of the article "A postage stamp man," with portrait of C. H. Mekeel, are mounted in Stamp Scrap-book, vol. v1., pp. 188-189.]

GOLDEN ECLIPSE. Golden eclipse.

Sycamore, Ill., S. H. Paxton and Brother, 1887.

8.. 9 in. Nos. 1-2, February-March, 1887.

** Only partly philatelic. Each number has a coloured paper ** Only partly philatelic. Each number has a coloured paper
wrapper.

GOLDEN ERA. The Golden era.

* in. Nos. 1-2.

Orange, $N . J .,[?$

], 1890.

GOLDEN EXCHANGE. The Golden exchange. in. No. 1 Townsbury, N.J., [? ], I $8 g^{2}$.

* * Only partly philatelic. Wanting. 
Gibbons stamp circulas

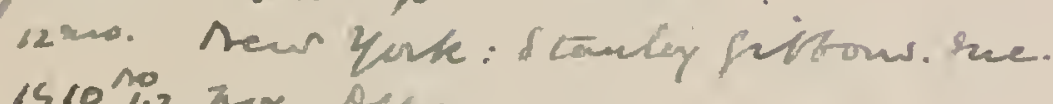

- $1510 \% 2$ tar. Oec

isir hos 3-14. Jan-D-ce.

$191220015-$ tam.

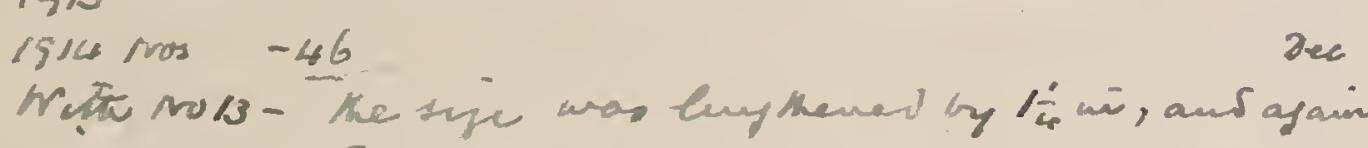
miereased with so.

hior

1915 hor -5

Liconale dei furiosi, Milano, 1906

fibraltar Phelatelist. Officind orpan of the fitrat-

$\tan$ sonits.

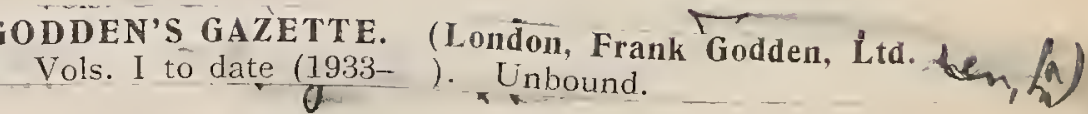

$508-5=1-2.3$

hooiclen. 


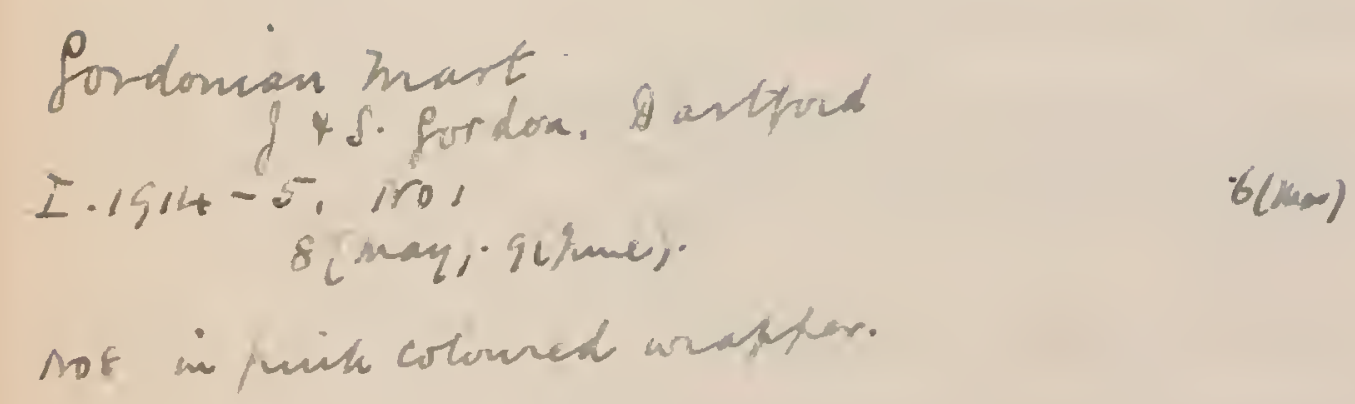

Fucbert. I Ti k $1-150$ on ant, pher.

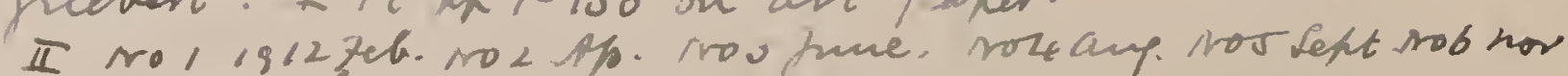

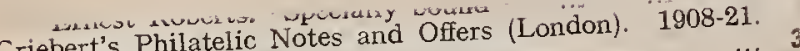
Complete, _unbound

nol 1913 then, 8 March. 9 uny. O11 Aug. 12 hor.

$T i: M /-144$.

GRIEBERT'S PHILATELIC NOTES AND

OFFERS (London). Complete unbound set)

with all indices. Some issues are

lingual (English, French and Germarman.

Hugo Griebert was an earnest student

who published much exclusive rescarch on

. 62 issues.

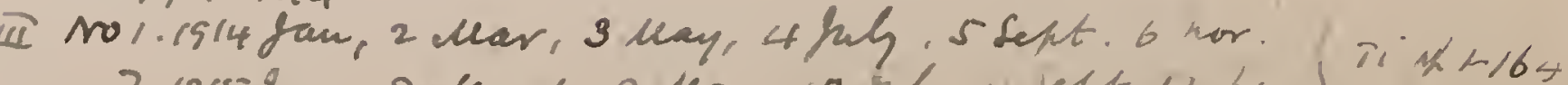

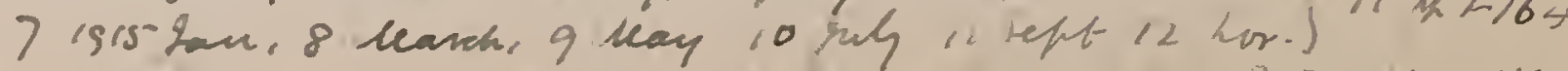

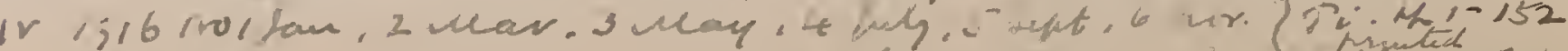
15i, ro 78 mar. 9 May. 10 kil II fept 12 hord cable nes Oct

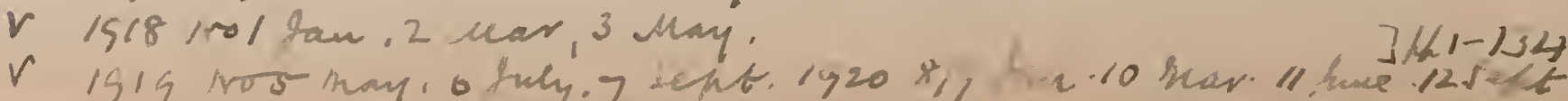


GOLDEN HOURS. Golden hours. For boys and girls. New York, William P. Bunning, I887. 8. 9 in. No. 5, October, 1887 ${ }^{\circ} .9$ in. No. 5, October,
$* *$ Only partly philatelic.

Mis. St. Jour. 121 (13)

GOLDEN PHILATELIST. The Golden philatelist. Patterson's Mills, Pa., Cameron W. Lawton, I895. $32^{\circ} .4 \frac{1}{2}$ in. Nos. 1-4, Jan.-Apl, $1895 . \quad$ 1.2.3

* * There is a coloured paper wrapper to each number. MIis. St. Jour. 71 (9)

GOLDEN STAR. Golden star.

Taunton, Mass., Golden Star Publishing Co., etc., x $89 \mathrm{x}-93$.

$8^{\circ} .9 \mathrm{in}$., $16^{\circ} .7 \frac{1}{2} \mathrm{in} ., 12^{\circ} .7 \mathrm{in}$. and $4^{\circ} .11 \mathrm{in}$., 26 nos. in 5 vols.

Vol. I. June 15 , July 15 , Sept.-Dec,, 1891 . Nos. 1-6.

" II. Jan. -June, 1892. Nos. 1- 6.

"III. July 25-Dec. 25, 1892. " 13-18.

"IV. Jan. -April, $1893 . \quad$ " $19-22$.

*" V. Sept. 1-Dec. 1893. "23-26.

* "Nos. 1 and 2 are octaro, nos. 3-18 are $16^{\circ}$., nos. 19-22 are $12^{\circ}$ and nos. 23-26 are quarto. All but nos. 1 and 2 have the wor "The" preceding the title, and nos. 1,2 and $6-22$ have coloured paper wrappers. Nos, 23-26 were published by L. H. Benton. Nos. 1 and 2 , vol. II., were published together under the date "Jan.-Feb., 1892". The wrapper of no. 14 is numbered "Vol. III., no. 1." Whole no. 13," in place of "Vol. III., no. 2, Whole no. 14," and no. 23 only bears the numbering "Vol. $\nabla .$, no. 1 " Nos. 1.5 are not philatelic, the few following nos. are partly philatelic, while the wrappers of nos. 10-22 bear the words "A monthly for stamp collectors," "Devoted to philately," " A monthly stamp journal," or "A journal for stamp collectors" Nos, 23-26 again are only partly philatalic.

GOLDEN STATE PHILATELIST. See WESTERN COLLECTOR.

GOLDEN STATE SCIENTIST. The Golden State scientist. A monthly journal devoted to zoology, geology, archaeology, botany, numismatics and philately.

$8^{\circ} .8 \frac{1}{2}$ in. No. 1 , Oct., 1886

Riverside, Cal., E. M. Haight, I886.

** The number has a coloured paper wrapper.

Mis. St. Jour. 32 (4).

GOPHER STATE PHILATELIST. The Gopher State philatelist.

Minneapolis, Minn., Lawrence E. Borin, I 900 . $8^{\circ} .9$ in. No. 1, November 1, 1900

* * The number has a coloured paper wrapper. Amalgamated 1901. $\quad$ Mis. St. Jour. 123 (7).

GOSSIP. The Gossip.

Ottawa, Canada, Gossip Publishing Co., 1887. Fol. $13 \frac{3}{4}$ in. and 193 in. Vol. Ir., nos. 1-2, May-June, 1887.

* * Only partly philatelic. No. 1 measures 183 inches and no. 2 $199_{4}^{3}$ inches. The two numbers are bound up in Mis. St. Jour. 136 (5) and cuttings of the philatelic portions from each number are mounted in Stamp Scrap-book, vol. v., pp. 158-163.

GRANITE STATE PHILATELIST. Granite State philatelist. Devoted to stamps, coins and curiosities.

Lake Village, N. H., etc., J. M. Hubbard, r882-84. $8^{\circ} .8 \frac{1}{2}-8 s_{4}^{3}$ in., 26 nos. in 3 vols.

Vol. I. Sept., 1882-Aug., 1883. Nos. 1-12.

$"$ II. " 1883- $" 1884 . \quad " 1-12$

*" "Nos. 7." "12 vol I, and nos. 1-7" vol. . coloured paper wrappers to nos. $5,6,9,10,11$, vol. I., to nos. 1,2 $3,5,6,8,9,10,11$, 12 , vol. II., and to nos. 25 and 26 , vol.

Wrappers and advertisements in Mis. St. Jour. 14 (9).

GRANITE STATE STAMP JOURNAL. The Granite State stamp journal. [Prospectus and sample page of a journal to be published by L. B. Martin Publishing Co., Laconia, N. H., on August 1, 1893, but which was never issued.]

Mis. St. Jour. 83 (5).

GRANT AND CO'S PHILATELICAL CIRCULAR. (James R.) See James R. Grant and Co.'s phitateligal CIRCULAR
GRANT'S MONTHLY PHILATELIST 574

GRANT'S MONTHLY PHILATELIST. Grant's monthly philatelist.

Kansas City, Kas., W. C. A. Grant, x 900.

๑) $8^{\circ} .9 \frac{1}{2}$ in. No. 1 , June, 1900.

* "The number has a coloured paper wrapper.

Mis. St. Jour. $92(9)$

[Continued as:]

Grant's philatelic monthly.

Kansas City, Kas., W: C. A. Grant, rgoo-or. 8․ 91 in. Nos. 2-3, July-Aug., 1900-Jan., 1901.

** There is a paper wrapper to each number

Mis. St. Joutr. 92 (9a)

GRANT'S PHILATELIC MONTHLY. See GRANT'S MONTHLY PHILATELIST.

GRAZER BRIEFIMARKEN-ZEITUNG. Grazer Briefmarken-Zeitung.

Graz, Verein der Briefmarken-Sammler in Graz, I 905 -

$8^{\circ} .11$ in. nos. in vols. In progress

[1st year.] March 15, 1905. No.1.

GRAZER PHILATELIST. Der Grazer philatelist.

Graz, Verein der Briefmarten-Sammler in Graz, $x 892-97$.

$8^{\circ} .10 \frac{1}{2}-11$ in. 6 nos. in 6 rols.

1st year. Mar. 16, 1892. No. 1

2nd " " $15,1893 . \quad " 2$.

3rd " " " $21,1894 . \quad$ " 3

5th " " ", 18, 1896. " " 5.

6 th " " 24, 1897.

* There is a supplement of two pages to no. 3 , and a calendar , and also a supplement of two pages to no. 6 with photographs of two sheets of the first 3 pfennige stamp of Saxony.

Mis. St. Jour. $82(3)$.

GREEN MOUNTAIN BOYS. The Green mountain boys. Montpelier Vt., Tuttle and Dewey, I877. $8^{\circ} .7 \frac{1}{2}$ in. 2 nos. in 2 vols.

Vol. I. Oct., 1877 . No. 6.

Vol. I. Oct., 1877. No. 1.

*"* Only partly philatelic. Vol. II., no. 1, was the last published and nos. 1-5, vol. 1, were non-philatelic. Mis. St. Jour. 41 (12).

GRELOT. Le Grelot. 5e année nos. 229, 230, 29 août, and 5 Septembre, 1875. [Contain facetious designs for postage stamps, by Alfred le Petit and Pepin.]

Paris, J. Madre, $x 875$

Fol. $19 \frac{1}{4}$ in. page (1) of each number. $\quad$ Mis. St. Jour. 115 (17).

GRIFBERT AND CO. MONTHLY SPECIAL OFFERS AND BARGAINS. See Hugo Griebert and Co. MONTHIY SPECIAL OFFERS AND BARGAINS.

GRIIMSBY PHILATELIC ADVERTISER. See GRIMSBY PHILATELIC ADVERTISER OF WANTS AND OFFERS.

GRIMSBY PHILATELIC ADVERTISER OF WANTS AND OFFERS. The Grimsby philatelic advertiser of wants and offers.

Grimsby, T. Robinson and Co., etc., r894-95.

8. 9 in. Nos. 1-5, Sept. 30, 1894-Jan. 20, 1895.

$\checkmark * *$ The contents consist entirely of advertisements. $\checkmark$ The words of wants and offers" are dropped from the title on nos. 2-5. No. 1 is printed on rose paper andyno. 5 was published by A. Moor and Co. This last number is found on coloured paper as well as
on white.

GUAYAQUIL FILATf́rLICO. Guayaquil filatélico.

Guayaquil, Ecuador, José J. de Ycaza, N. r9or-02. $8^{\circ} .9 \frac{3}{4}-10 \frac{1}{4} \mathrm{in.} 11$ nos. in 2 vols.

1st year. July 15, Nov. 1901, Jan.-A pl., 1902. Nos. 1-7:-

2nd May-Aug., 1902. Nos. 8-11.

* * Nos." 8, 9 and 10 were published together and nos. 1-3 and 8-11 have paper wrappers. Wanting no. 2, Mis, St. Jourr. 152 (7)

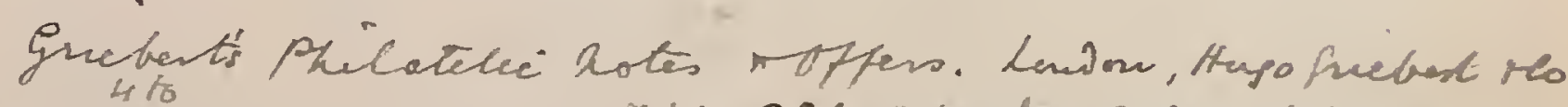

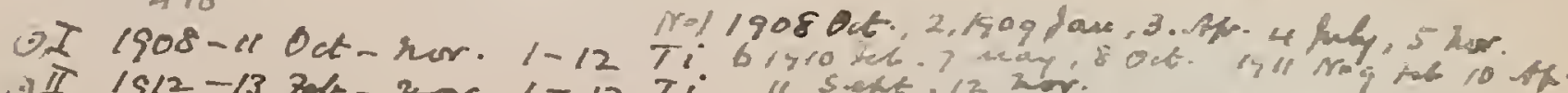


GUAYAQUIL FILATfíliCO. Guayaquil filatélico.

Guayaquil, Ecuador, La Sociedad Filatelica Guayaquil, 1905-06.

Fol. $11-12$ in. 4 nos. in 2 vols.

1st year. Oct. 15, Nov. 15, 1905. Nos. 1-2.

2nd ", Jan. 1 , 1906. "3-4.

Mis. St. Jour. 124 (4).

- GUIA DEL COLECCIONISTA DE SELLOS DF CORREOS. Guia del coleccionista de sellos de correos. Valparaiso, Luis Soleil, etc., I878-84. $8^{\circ} .93-91$ in. 84 nos. in 7 vols.

1st year. Jan. 1-Dec., 1878. Nos. 1-12.

(2nd " " " " 1879. "13-24.

○ 3rd " " " $1880 . \quad$ " 25-36.

O 5 th " " " " " 1882. " " $49-60$

O6th " " " " 1883. " " $61-72$.

7th " " "Th" first" and second years a" octavo

"* The first and second years are octavo 98 inches and the remaining years are octavo 91 inches. Nos. 13-84 were published by 1. . C. Eberharat. Nos. paper and nos. $37-54$ on buff paper. There is a citle-page and an "1883". Nos, yo and 51' 61 and $62,63-65$, 74 and $75,79-81$, and 82-84, were severally published together. Nos. 59 and 60 have "1822" for 1882 and no. 79 has " 1874 " instead of 1884 . V This last

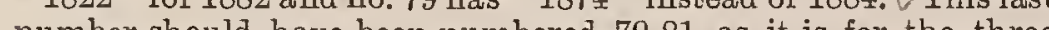
number should have been numbered " " " months "Julio, Agosto i Setiembre". A two-page supplement, printed "o one side only, of lllustrations of stamps was given with no. 36 and a supplement of four pages, one leaf of which is printed on one side only, of illustrations of stamps was presented with nos.
$63-65$. A circular of two pages was published by $\mathrm{E}$. C. Eberhardt 63-65. A circular of two pages was published by $\mathrm{E}$. C. Eberhard
on the discontinuance of the journal and a copy of this is bound on the discontinuance of the journal and a copy of this is bound up at the end of the seventh year, and a copy of the prospectus,
dated January 1st, 1878, is bound up at the commencement of the dated January 1st, 1878 , is bound up at the commencement of the
first year. This was the first philatelic journal published in Chili.

GUIA FILATELICA. Guia filatélica. [Prospectus of a journal to be published by José G. Sardá, Paraná, EntreRios, Argentine Republic, on January 1, 1894, but which was never issued.]

Mis. St. Jour. 131 (15)

GUIA FILATF́LICA MENSUAL. Guia filatélica mensual. Mendoza, Rep. Arg., F. Godoy, r904-o6.

$8^{\circ} .10 \frac{1}{2}$ in. 34 nos. in 3 vols.

1st year. Jan. 1-Dec, 1904. Nos. 1-12.

2nd " " $\quad$. "Oct. 1905. $1906 . \quad 13-24$.

* " There is a coloured paper wrapper to each number and nos. 6 $8^{*}, 9$ and $10,11^{\prime}$ and 12,15 and 16 and 32 and 38 were severally published together. Nos. 6-34 are printed on coloured paper.

GUIDA FILATELICA ITALIANA. Guida filatelica Italiana. Rivista mensile per i raccoglitori di francobolli. Messina, Conte Diego Cumbo, I904-05.

$8^{\circ} .97$ in. 13 nos. in 2 vols.

1st year. May-Dec, 1904. Nos. 1-8.

2nd " Jan.-May, 1905. " 1-5. ** Each number has a coloured paper wrapper.
and 6,7 and 8 of the first year, and nos. 3 and 4 of the second year, were severally published together. Mis. St. Jour. 111 (7).

GUIDA ILLUSTRATA DEL TIMBROFILO. Guida illustrata del timbrofilo.

Bologna, G. Leoni, F. Mignani, F. C. Tonolla, etc., I $876-80$.

Fol. $11 \frac{1}{2}-10 \frac{3}{4}$ in. 51 nos. in 5 vols.

1st year. July 1876-June 1877. Nos. 1-12.

2nd " " $\quad-$ Dec., 1877. " $13-18$.

3rd " Jard II. July-Dec., 1878. Nos. $1-6$.

4th " " Jañ.-D̈ec., 1880, Nos, 1-12. " 1-9.

$$
\begin{aligned}
& \text { Puia del Colveceonita. Malaga } \\
& [1907] \geq-1 \text { ( far })-4 \text { (Aprat) } \\
& \text { fuida Cantofila Mtallaua Mesma } \\
& 1203 . \\
& 1900 \text { II } \% 2.3 / 4.5 .6 \\
& \text { prosplectos in II.1 }
\end{aligned}
$$

* The two earliest years are folio $11 \frac{1}{2}$ inches and the remainder are folio $10 \frac{3}{4}$ inches. Nos. 7-12 were published by Giuseppe Leoni, nos. 13-18 by F. C. Tonolla, nos. 1-6. and Serie II. no. 1, third year, by I. A. Loli e Co., nos. 2-6 Serie II., third year, and nos. 1-6, tourth year, by F. C. Tonolla, nos. 7-9, fourth year, by I. A. Loli, nos. 1 and 2, fifth year, by F.' Mignani and F. C. Tonolla, nos. 3-6, fifth year, by F. Mignani and nos. 7-12 fifth year, by E. Duzzi e Co. There is a title-page and an index to each of the first three and the numbers of the first four years have coloured paper wrappers. The twelve numbers of the fifth year are printed on pale blue paper, and nos. 2 and $5-6$ of this year are also found on thinner and differently coloured papers. The following numbers were severally published together under the respective dates : 1st year nos. 5 and 6. "Novembre-Dicembre 1876."

" " " 7 " 8. "Gennaio-Febbraio 1877."

" " " "

3rd " Serie 2. "Nos. 2 and 3 "Agosto-Settembre 1878,"

" " " " " 4 " 5. "Ottobre-Novembre, 1878."

4 th "N" " " " 8 " 9. "Agosto-Settembre 1879."

"Maggio-Giugno 1880,"

No. $\ddot{10}$, fifth year, has no number, the wrapper of no. 13 is numbered "Anno II. Num. 1," and nos. 1-4, fourth year, alnumbed "Ano nos. 1 and 2 with the date "Gennaio-Febbraio 1879 " and nos. 3 nos. 4 with the "Mos. and 4 with the date "Marzo-Aprile 1897 " (sic).. A supplement "Catalogo dei francosici emessi dal 1818 a tutto.il 1877," consisting in all of 36 pages, was published with nos. 2-6 of the third year, Serie 11., and with nos. 1-9 of the fourth year, omitting nos. 2 and 7. This catalogue, which only consists of the stamps of European countries, was not completed beyond "Svizfor "(Switzerland). A supplement "Calendario del Timbrofilo" with the number for January, 1878. Wanting no. 12, fifth year.

GUIDE CARTO - PHILATHLIQUE UNIVERSEL. Guide carto-philatélique universel.

Smyrne, Turquie, L. Garofalo, I 905-06. $8^{\circ} .8 \frac{1}{2}$ in. fol. $11 \frac{7}{2}$ in. and $13 \frac{3}{4}$ in. Nos. 1-6, June-November, 1905, S q $b$ January, 1906. ${ }^{*}$ * Nos. $1-4$ are octavo, no. 5 is folio $11 \frac{1}{2}$ inches and no. 6 is folio
13 inches. There is no number for October, 1905. Wanting

GUIDE PHILATצLIQUE. Guide philatélique. Organe officiel d'annonces de la Fédération des Sociétés Suisses. Genève, J. Canard, I goz.

$4^{\circ} .11$ in. Nos. 1-12, Jan.-Dec., 1902

* * The contents consist entirely of advertisements. The twelve numbers were also circulated as a supplement to the "Schweizer Briefmarken-Zeitung" for 1902, in which case all the numbers, except nos. 2 and 10, had the words "Supplement d'annonces de la "Schweizer Briefmarken-Zeitung" printed at the top of page 1

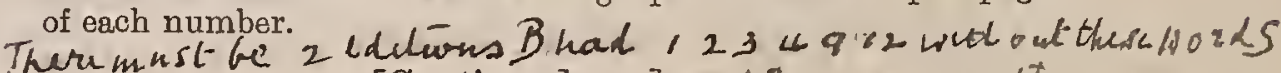
[Continued as:] of $134-12$ w

Le Guide philatélique international.

Genève, J. Canard, I903.

$4^{\circ} .11$ in. Vol. II. 8 nos.

2nd year. Jan. 31-June 30, Oct. 15, Dec. 15, 1903. Nos. 13-20.

GUIDE PHILAT FLIQUE INTERNATIONAL. See Guide PHILATÉLIQUe.

GUTE KAIERAD. Der Gute Kamerad. Spemanns Illustrierte Knaben-Zeitung. No. 1. [October 1, 1887. Contains an article "Neue Briefmarken (1886)" signed H.] No. 10 [an article with the title "Das BriefmarkenSammeln"] and 2 Jahrgang no. 32 [an article "Die Briefmarke".] Stuttgart, W. Spemann, [1887-88]. Fol. $11 \frac{1}{1}$ in. pp. 14, 15, 157, 153, and 509-511.

G. W. WINTERBURN AND CO.'S STAIIP CIRCU-

LAR. G. W. Winterburn and Co.'s stamp circular.

Cincinnati, $0 .$, I $865 \cdot 66$

$8^{\circ} .9$ in. Nos. 1-[2], Nov. 25, 1865-April 20, 1866

* * No. 2 bears no number.

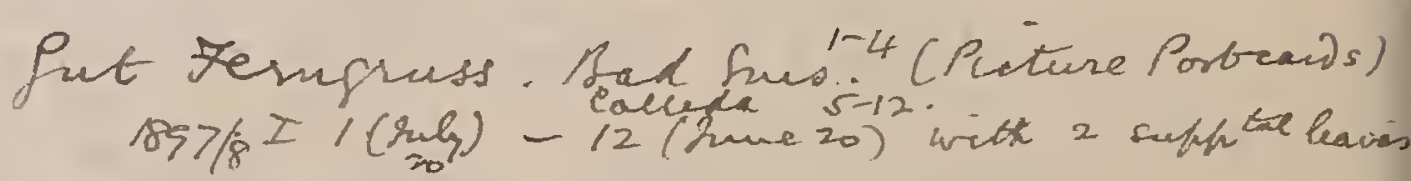

in 2 in blunsh ente 


HABERSTRAW'S STAMP CHRONICLE AND CIR- CULAR. Haberstraw's stamp chronicle and circular. I 893 .

(6) 80. 83 in. No. 1, Jan., 1893 . from a Gomed vol

[Continued as :]

The Stamp chronicle and circular.

Swansea, Egremont, [printed], R. T. Habersiraw, I893. volT

○. $8^{\circ}$. 83. in. Nos. 2-7, Feb.-July, 1893.

"* There is a coloured paper wrapper to each numb 147012 [Continued as:]

The Stamp chronicle and British philatelist.

Swansea, Egremont [printed], R. T. Haberstraw, r893-95.

$8^{\circ} .8^{3}$ in. 19 nos. in 3 vols.

(c) Vol. I. Aug.-Dec., 1893. Nos. 8-12.

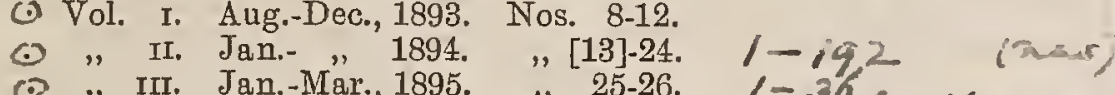

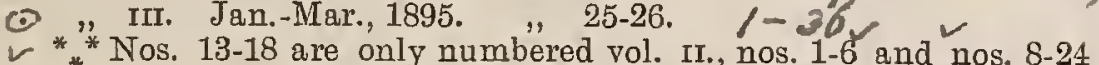
have coloured paper 1895 ".

HALIFAX PHILATELIC IMAGAZINE. The Halifax philatelic magazine.

Halifax, Nova Scotia, Muirhead and Van Malder, etc., I897.

8.9-8 9 in. 9 nos. in 2 vols.

Vol. I. Jan.-June, 1897. Nos. 1-6.

*" II. July, Sept., Oct., 1897. Nos. [7]-9.

* "The numbers of vol. I. and no. 3, vol. II., have coloured paper wrappers. Nos. 4-6, vol. I., were published by the Halifax Philatelic Publishing Co., no. 1, vol. II., by A. M. Muirhead and nos. 2 and 3, vol. II., by A. M. Muirhead and Ed. A. Whalen, No

Mis. St. Jour. 110 (t) I $887-89$.

Halifax, Nova Scotia, The Halifax Philatelic Co.

$8^{\circ} .8 \frac{1}{2}$ in. 31 nos. in 3 vols.

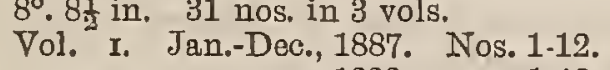

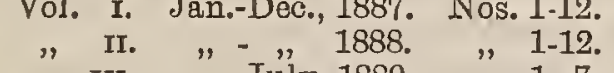

" "III. "J "July, 1889.

to " There is a list of contents to vol. II., a coloured paper wrapper to each number and a sheet of photographic' jllustrations to no.
12 , vol. II. The wrapper of no. 7 , vol. III., is wrongly numbered "12, vol. rI. The wrapper of no. 7, vol. III., is wrongly number

HALSEY STAIMP CO.'S BULLETIN. Halsey Stamp Co.'s bulletin. Published in the interests of stamp collecting generally and especially for the benefit of our patrons. Brooklyn, N. Y., Halsey Stamp Co., r8g6. Fol. 12 in. No. 1, Septo-Oct., $1896 . \quad$ MLis. St. Jour. 87 (24).

HAMBURG-ALTONAER BRIEFMARKEN-SAIMMLER-VEREIN. VEREINS - MITTEILUNGEN. See Vereins-Mittheilunaten des Hamburg-Altonaer BRIEFMARKEN-SAMMUER-VEREINS,
HAMBURGER BRIEFMARIKEN-ZFITUNG. Hamburger Briefmarken-Zeitung. Organ für die Gesammtinteressen der Philatelie.

Hamburg, Alexander Owitch, etc., 1878-79. $4^{\circ} .12 \frac{1}{4}$ in. Probe-No., and nos. 1-12, Nov, 15, 1878, and Jan. 1 Dec. 15, 1879 .

"* Nos. 6-12 were published by Adolph Sternberg and there is a supplement of two pages to the "Probe-No." A copy of the prospectus, dated "1 October, 1878," is bound up in front of the "Probe-No." Mis. St. Jour. 50 (1).

\section{[Continued as :]}

Hamburger Illustrirte Briefmarken-Zeitung.

Hamburg, Adolph Sternberg, I880. $4^{\circ} .12$ in in. vol. II., nos. 1-6, Jan. 15-June 20, 1880 . Mis. St. Jour. 50 (1a).

HAIMBURGER ILLUSTRIRTE BRIEFIMARIENZFitUNG. See Hamburger Brtermarien-Zieitung.

\section{HANDFORD'S QUARTERLY CIRCULAR. See J.T.} HANDFORD'S QUARTERLY CIRCULAR.

HANSA. Hansa. Illustrirte Zeitschrift für Verkehrswerthzeichenkunde. , Bremen, Rudolf Oelrichs, x894. $8^{\circ} \cdot 9$ in in. No. 1, June $25,1894$.

** Only partily philatelic.

Mis. St. Jour. $122(2)$

HARMSWORTH IMAGAZINE. The Harmsworth magazine. September, 1898. [Contains an article "Postage stamps worth fortunes. Latest market prices."] London, E. C., Harmsworth Bros., Ltd., I898 $8^{\circ} .9^{3}$ in. pp. 327,328 * * The number has a paper wrapper.

Mis. St. Pamph. 64 (4)

HARPER'S NEW MONTHLY MAGAZINE. Harper'S new monthly magazine. No. 257. October, 1871 [Contains two articles "New York City post-office" and "Postage stamps and their origin" (the latter written by J. M. Chute).]

New York, Harper and Brothers, $187 \mathrm{x}$ $8^{\circ} .9 \frac{3}{2}$ in. pp. 645-663 and 741-750.

* * The number has a coloured paper wrapper.

Mis. St. Jour. $17(2)$

HARPER'S ROUND TABLE. Harper's round table. I899.

New York and London, Harper and Brothers,

Fol. 111 in. Vol. II. Nos. 18-21. Now series. April-July, 1899 ** These numbers and probably others, contain a department with the heading "Stamps and coins". Each number has a
coloured paper wrapper,

$$
\begin{aligned}
& \text { I. }-19
\end{aligned}
$$

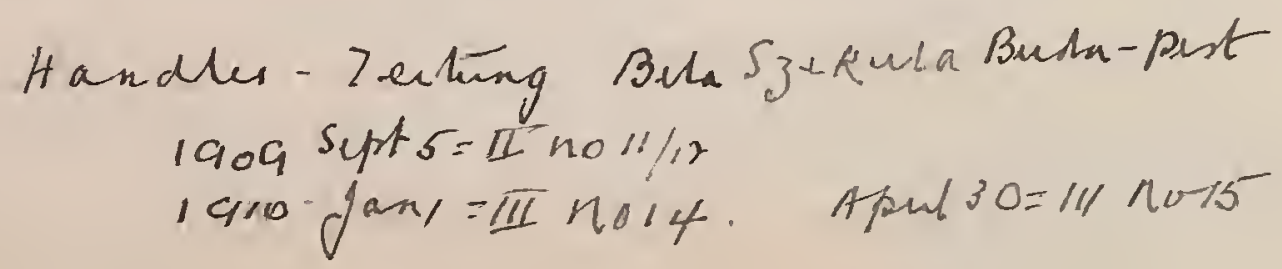


HARPER'S YOUNG PEOPLE. Harper's young people. Vol. I., no. 18, March 2, 1880 ; vol. I., no. 32, June 8, 1880 ; November 9,1880 ; vol. II., no. 68 , February 15 , 1881 ; vol. II., no. 85 , June 14, 1881 ; vol. II., no. 94 , August 16, 1881; vol. II., no. 100, September 27, 1881 vol. III., no. 113, December 27, 1881; vol. III., no. 130, April 25, 1882. [Contain respectively a tale of an Indian postcard "Viầ Brindisi” by Harlan H. Ballard; "A chat about philately" by J. J. Casey; "Stamp collecting," by J. J. Casey; "Chats about philately," IrI.vIII., by J. J. Casey.]

Fol. $11 \frac{1}{2}$ in.

New York, Harper and Brothers, I880-82. NAL. See HaWKESBURY PHTLATELIST.

HAWKESBURY PHILATELIST. The Hawkesbury philatelist. A manuscript journal circulating amongst members of the Hawkesbury District Philatelic Society. Fol. 13 in. No. 1, April, 1901.

Windsor, New South Wales, r gor.

* * Edited by R. M. Fowler and enclosed within a cover designed and sketched by W. B. Greenwell. The title on the cover reads the "Hawkesbury philatelic journal".

[Continued as:]

_ The Hawkesbury District philatelic journal. A manuscript journal circulating amongst members of the Hawkesbury District Philatelic Society.

Windsor, New South Wales, r9o2-03. Fol. 13 in. 7 nos. in 2 vols.

Vol. I. Jan., Apl., July, Oct., 1902. Nos. 1-4.

* * II. Iited b" Miss Joa" 1903.

* * Edited by Miss Joan Newton and each number was enclosed within a cover designed and sketched by W. B. Greenwell. Two copies were made of no. 1, vol. I., which have entirely different wrappers. One of these copies bears vol. I., no. 2, both on the first page and on the wrapper. The other copy has had this numbering altered to "Vol. I., no. 1". Similarly nos. 2 and 3 , vol. I., were originally numbered "III." and "IV." No. 4 bears "Vol.' 'II. no. 1 " on the first page, but"vol. I., no. 4" on the wrapper. No. 2, vol. II., is wrongly lettered "vol. I." on page 1 and no. 3, vol. II., has no volume number on page 1 . "The title on the first page of nos. 2 and 3, vol. II., reads the "Hawkesbury philatelist" and on the wrapper of no. 3, vol. II., the "Hawkesbury philatelic journal". Nos. 2 and 4, vol. I. and no. 2, vol. II., contain illustrated supplements.

HAWKEYE LEDGER. The Hawkeye ledger.

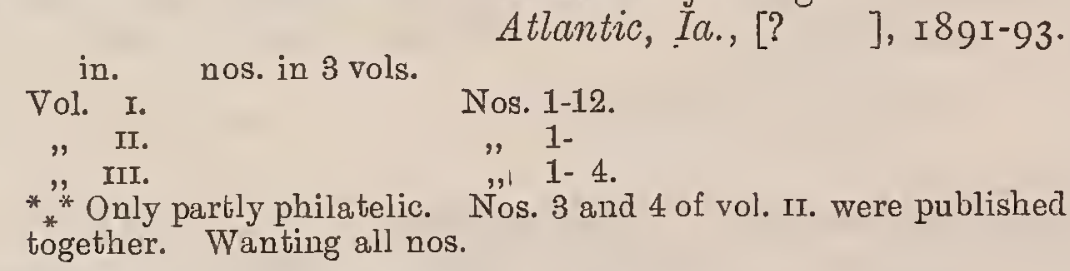

HAWKEYE MONTHLY. The Hawkeye monthly.

* in. Nos. 1-9.

New Hampton, Ia., [? ], I902-03.

(1) Wanting all nine-nos.

HAWKEYE STAIIP. The Hawkeye stamp.

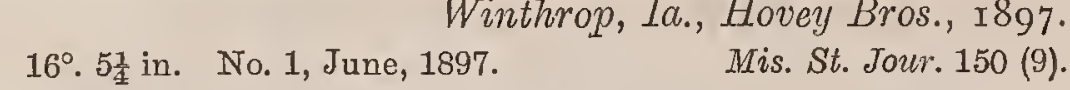

HAWKEYE STATE COLLECTOR. The Hawkeye State collector.

Wyoming, Iowa, Marshall and Tourtellot, r887-88. 8․ 9-93 in. and fol. $14_{4}^{\frac{1}{4}}$ in. Nos. 1-12, Dec. 25, 1887, Jan. 10, Jan. 25, Feb. 10, Mar. 10, Mar. 25, Apl. 10, Apl. 21, Apl. 28, May 12, May 19, May 26, 1888 .

* * Nos. 1-5 have coloured paper wrappers and are ootavo 9 inches in size, while nos. 6,7 are folio and have no wrappers; nos. 8-12 are octavo $9 \frac{3}{2}$ inches and have no: wrappers.

[Continued as :]

The Collectors' weekly.

Wyoming, Iowa, Marshall and Tourtellot, r888. 8०. $9 \frac{3}{1}$ in. Nos. 13-15. June 8, June 16, June 23, 1888.
HAYN'S ILLUSTRIRTES OFFERTENBLATT FỮR BRIFEMARKEN-SAMIMLER UND HANDLER, ERNST. See Ernst Hayn's Illustrirtes OffertenBLATT FÜR BrIEEMARKENSAMMLER UND HÄNDLER.

HEITIMANN'S RATGEBER. Heitmann's Ratgeber. Leipzig, E. Heitmann, I892.

$4^{\circ} .101$ in. Nos. 1-12, April 1-September $15,1892$.
$* *$ Only partly philatelic. The numbers were published fortnightly.

HELVETISCHE PHILATELIE. Die Helvetische Philatelie. Organ für Briefmarkensammler.

Fol. 13 in. No. 2, Dec., 1893

Morges, J. Jaquier, 1893.

* "No. 1 is only a price list. This journal was succeeded by the "Philatélie helvćtique". Bound up with the first year of "Philatélie Helvétique".

\section{HENRY L. WILDEY'S MONTHLY CIRCULAR AND} POSTAGE STAIIP ADVERTISER, Henry L. Wildey's monthly circular and postage stamp advertiser. London, I872-73. $8^{\circ} .10 \frac{1}{2}-11 \frac{1}{2}$ in. Nos. $1-7$, Oct. 15, 1872-Feb. 15, Apl. 25, May 15, 1873.

*** Nos. $1-2$ are octavo $10 \frac{1}{2}$ inches, the rest are octavo $11 \frac{1}{2}$ inches. Nos. 1-5 each consist of a single leaf and nos. 6,7 of two leaves each. The whole seven numbers contain nothing but advertiseeach. The whole seven numbers contain nothing but advertise-
ments.
Mis. St. Jour. 4 (15).

HERALD. The Herald.

Putnzm, Conn., The Herald Co., I90I. $8^{\circ} \cdot 7-73$ in. Nos. 5-7. September-November, 1901. ** Only partiy philatelic. Nos. 1-4, May-August, 1901, are $16^{\circ}$. and are not philatelic. Wanting no. 6. Mis. St. Jour. $154(7)$.

[Continued as :]

The Herald monthly.

Putnam, Conn., The Herald Publishing Co., rgor. $16^{\circ} .6$ in. No. 8. December, 1901.

*** Only partly philatelic.

Mis. St. Jour. 154 (7a).

HERALD EXCHANGE. The Herald exchange. A semimonthly devoted to the interest of stamp collectors.

New York, The Herald Exchange Publishing Co., I 896-I 900.

$8^{\circ} .11$ in. 43 nos. in 8 vols.

Vol. I. Oct. 1, 1896-Feb. 1, 1897. Nos. 1- 6 .

" Ir. Mar. 1, -Aug. 1, 1897. " 7-12.

"III. Sept. 1, 1897-Feb. 1, 1898. " 13-18.

"IV. Mar. 1, -Aug. 1, 1898. " $19-24$.

$" \quad$ v. Sept. 1, 1898-Teb. 1, 1899. " $25-30$.

$"$ VI. Mar. 1, -Aug. 1, 1899. " $31-36$.

$"$ VII. Sept. 1, 1899-Feb. 1, 1900.

*" VIII. March 1900. was only published monthly. No. 42 is wrongly numbered "Vol. VII. No. 2. Whole no. 46," in place of "Vol. vII. No. 6. WWhole no. 42 ". For continuation see "Allegheny philatelist and herald exchange".

HERALD MONTHLY. See HERALD:

HERALDO FILATHLICO. El Heraldo filatélico. Revista mensual. Organo de los coleccionistas de sellos, Puerto-Riqueños.

Mayaguez, Porto Rico, F. Blanes Viale, I894.

$8^{\circ}$. 83 in. Nos. 1-3, May-July, 1894.
** "The title on no. 3 is misspelt "Herlado". Amalgamated with "Ilustración filatélica hispano-colonial".

Mis. St. Jour. 117 (9)

HFRALDO FILATÉLICO ARGENTINO. Heraldo filatélico Argentino. [Prospectus of a journal to be published by Pedro N. Manero, Buenos Aires, in 1904, but which was never issued.]

Mis. St. Jour. 123 (5).

HERALDO FILOTÉLICO. El Heraldo filotélico. Periódico mensual dedicado al adelanto y colección de los sellos de correos.

Bogota, Antonio M. Posada, 1886-87. $8^{\circ} .9 \frac{3}{4}$ in. Nos. 1-4, Oct. 15, 1886-Jan. 16, 1887.

Mis. St. Jour. 142 (4) 



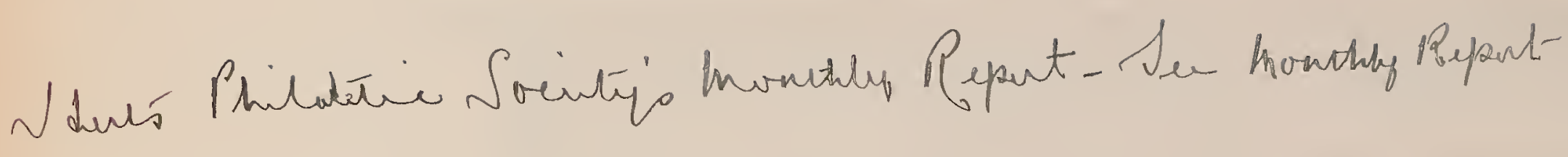

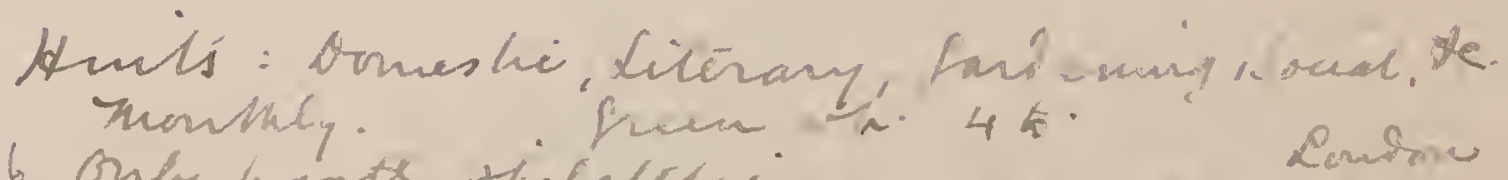

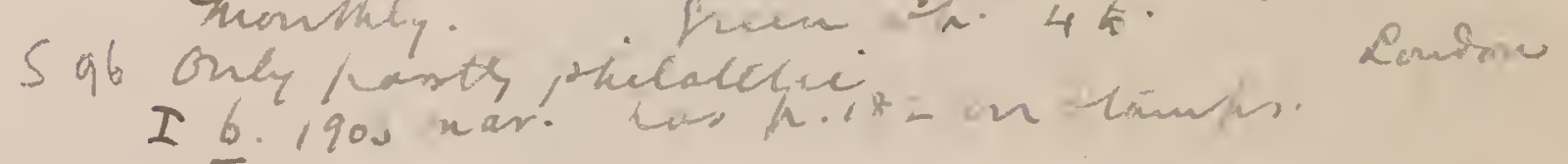

Nobby - Londow - 1905'-S96

Jothy collector and misecllanums adverties, durcted to stamp. Coin, Cinis Mroteard collectass. 16 mo. Rillum m. W.E. Neve. iguglroes 1- $\quad 1910 \quad 7.8 \quad 1911 \quad 9$. 
HERALDO TIMBROLOGICO HISPANO-AIMERI-

CANO. El Heraldo timbrológico Hispano-Americano. Sevilla, A. Pulin, 1895-96.

8. $9 \frac{1}{2}-10$ in. 15 nos. in 2 vols.

1st year. Apl. 1.5-Dec. 15, 1895. Nos. 1- 9 .

2nd Jan. 15.June 15, 1896 . "10-15. * * Nos. 3 t to no. 5 of "Filatelia," Malaga, 1896 with which it is bound up and the jourmal was subsequently amalgamated with "Filatelia". A copy of the prospectus of the journal, dated March 25,1895 , is bound up in front of no 1 .

HERDIMAN'S MISCELIANY. Herdman's miscellany. Sqb Berwick-upon-Tweed, etc., Edward F. Herdman,

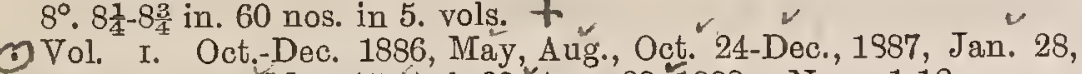

C. Vol. I. Oct.-Dec. 1886, May, Aug., 28, 1888. Nos. 1-12. II. Oct.-Xmas., 1888, Feb. 1.5, Apl. " 13-24. ", III. Oct.-Xmas., 1888, Feb. 15, Apl. $\quad$ Oct., Dec., $1892 . \quad 25-36$.

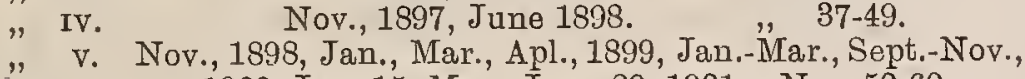

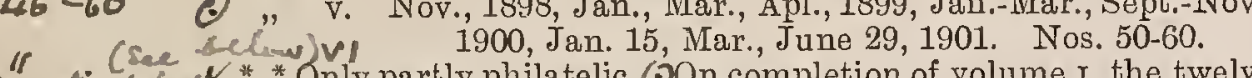

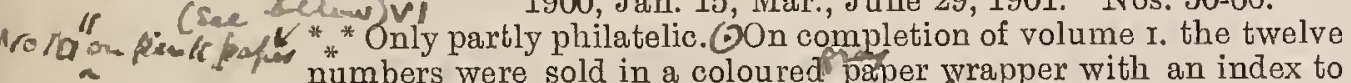
heve 13.14 ange the volume on the second page and nos. $13-16$ have coloured paper

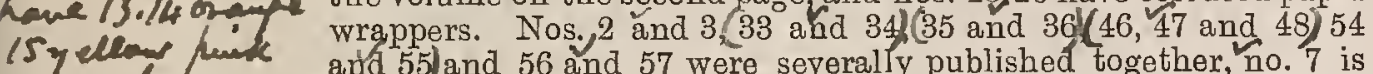
crem.16 205e and 55 and 56 and 57 were severally published together, no. 7 is roll or whitc is numbered "no. 5 ". Nos. 10, and 46,47 and 48 are printed on × lemion coloured paper. Nos. - were published at Sedbergh, Yorkhave $46-48 \mathrm{~m}$ " "Philatelic world," Ashton, Preston, in June, 1999, and then rehick rblue started.in Japuary, 1900. Wanting nos. 18-32, and 37-45.

HERLADO FILATELICO. See HERALDO FILATÉLICO.

HERIMES. The Hermes. International advertiser of philately. New York, M. Isenstein and Co., I885. $4^{\circ} .12$ in. Nos. 1-8, Jan. 1, Feb. 1, Mar. 1, Apl. 1, May 15, July 1, Aug. 15 , Oct. 15,1885 . *** Nos. 4-8 have "The Hermes. International advertiser of
philately and numismatics." Mis. St. Jour. 5 (2).

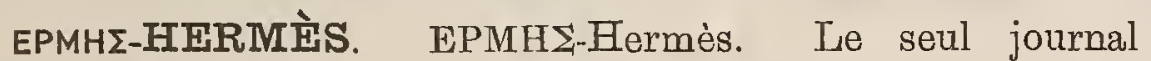

(.) philatélique Grec. Paraissant mensuellement. Athènes, G. N. Calavassi, etc., I89 I-92.

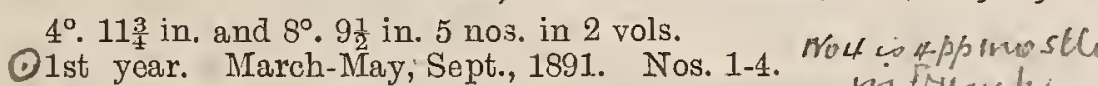

O. 2nd "Tan., 1892. No. 1. 1102 hes a the $\checkmark$ and the other numbers are quarto. "No. 1 second year, was publeapy lottiry lishcd by Fortuné Ivich. This was the first philatelic journal
published in Greece. St. Jour. 87 (19).

HICKSON'S MONTHLY. Hickson's monthly. Lynchburg, Va., Edward Hickson, 1895 . $8^{\circ} .8 \frac{1}{2}$ in. No. 1, September, 1895. * Only partly philatelic.

Mis. St. Jour. 143 (4).

HILL (Rowland) See Rowland HuL.

HINGE. The Hinge. A philatelic monthly. New York, A. P. Mulvey and Co., [1903].

$8^{\circ} .9 \frac{1}{4}$ in. Nos. $1-2$, Feb.-March, [1903].
** Both numbers are dated "1902" in error for " 1903 ". Mis. St. Jour. 101 (10)

HISPALENSE. El Hispalense. Revista de anuncios de los coleccionistas y comerciantes de sellos de correo. Zaragoza, Centro Filatélico Hispalense, [I895]. 8. 10 in. Nos. 1-2, June 15-July 15, [1895]

* * The year date is not given and no. 2 has the title "La Hispalense".

HOBBIES. Hobbies. A weekly journal for amateurs of both sexes. London, E. C., Hobbies Limited, I895-

$\begin{array}{lll}8^{\circ} .93 & \text { in. } & \text { nos. in vols. In progress. } \\ \text { Vol. } \quad \text { I. Oct. } 19,1895 \text {-Apl. 11, 1896. Nos. 1- } 26 .\end{array}$ II. Apl. 18 -Oct. 10, 1896. " $27-52$. Irr. Oct. 17, 1896-Apl. 10, 1897. " " 53- 78. $\begin{array}{rrrr}\text { IV. Apl. } 17 \text {-Oct. } & 9,1897 . & \text { " } & 79-104 . \\ \text { v. Oct. } 16,1897-A p l . & 9,1898 . & & 105-130 .\end{array}$

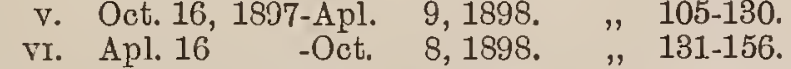
VII. Oct. 15, 1898-Apl. 8, $1899 . \quad$ "157-182. VIII. Apl. 15, -Oct. 7, 1899 . " 183-208. $\begin{array}{llll}\text { IX. Oct. 14, 1899-Apl. 7, } & 7900 . \quad \text { "209-234. } \\ \text { x. Apl. } 14 \quad \text { Oct. } & 6,1900 . \quad \text { 235-260. }\end{array}$

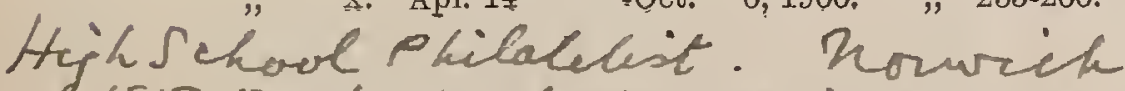

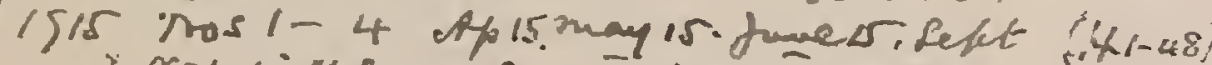

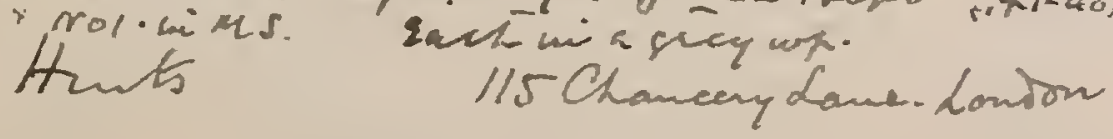

1902-3 I 6(mar, h.182 centimis "Hats to stant buyen "G Grow Plock.

lieriman's heisccle

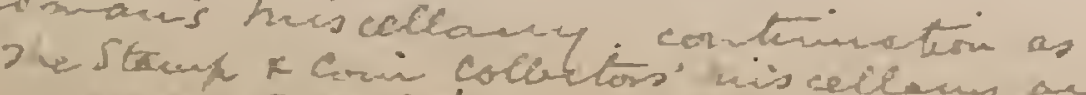

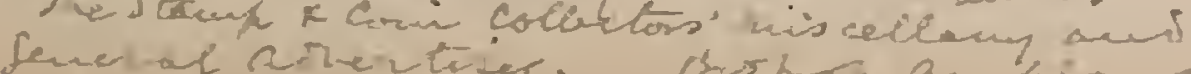

Vol. xI. Oct. 13, 1900-Apl. 6, 1901. Nos. 261-286.

" xrr. Apl. 13 -Oct. $5,1901 . \quad$ Oct. 12,1901 -Apl. $5,1902 . \quad$ 287-312.

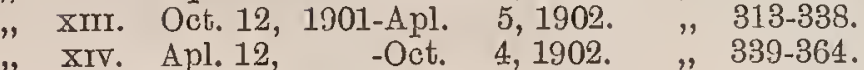
" xv. Oct. 11, 1902-Apl. 4, 1903. " 365-390. " xvr. Apl. 11 -Oct. 3, 1903. " 391-416. " XVII. Oct. 10, 1903-Apl. 2, 1904. " 417-442. " xvIrI. Apl. 9 -Oct. 1, 1904. " 443-468. " XIX. Oct. 8, 1904-Apl. 1, 1905. " 469-494. " xx. Apl. 8, -Sept. 30, 1905. " 495-520. " Xxr. Oct. 7, 1905-Mar. 31, 1306. ", 521-546. " xxIr. Apl. 7 -Sept. 29, 1906. " $\quad 547-572$. * "xxrrr. Oct. 6, 1906* "Each number contains a philatelic article. There is a titlepage and an index to each volume and each number, commencing with no. 27 , has a coloured paper wrapper. No. 381 is wrongly numbered " 380 ". Wanting the title-page and index to vol. rv.

HOBBIES. Hobbies. A magazine for the collector and amateur photographer.

Sioux City, Iowa, W. S. Tripp, Igo6. $8^{\circ} .8_{4}^{3}$ in. Nos. 1-2, Apl. 15-May, 1906.

* Only partly philatelic. Each number! has a coloured paper wrapper.

HOBBY HORSE. The Hobby horse. A journal devoted to philocarty and philately. Bethel, Minn., S. D. Pierce, I905. $16^{\circ} .6 \frac{1}{4}$ in. No. 1, August 2, 1905.

* * Printed on thick green paper. The only thing philatelic about this number is the word "philately" in the title. Future numbers were of a larger size and had the sub-title "Published for post card collectors". They contain no philatelic matter.

Mis. St. Jour. 144 (1.0).

HOLIDAY ADVERTISER. See AMERICAN AGENTS' ADVERTISER,

HOLIDAY CLIPPER. See CoLLECTOR. (Smyrna, N.Y.). HOLIDAY GREETING. The Holiday greeting.

North Attleboro, Mass., W. F. Barden, I886. 8. $9 \frac{1}{4}$ in. [No. 1.] December, 1886

Mis. St. Jour. 117 (15).

HOME AND COLONIAL PHILATELIST. Home and (6) Colonial philatelist. (2) $8^{\circ} .7 \frac{1}{2}$ in. Nos. 1-2, Oct.-Nov., 1904.

* * There is a coloured paper wrapper to each number. Amalgamated with the "Stamp mount," May, 1905.

Mis. St. Jour. 102 (2).

\section{HOME, CONTINENTAL AND COLONIAL SALE}

(. AND EXCHANGF BUDGET. The Home, continental and colonial sale and exchange budget.

London, N. E., A. V. Cartier, I905.

(4) $8^{\circ} .7 \frac{1}{2}$ in. Nos. 1-2, April-May, 1905.

** Only partly philatelic and printed on coloured paper.

HOIME RULE. Home rule.

Pulaski, Tenn., Earl McGrew, I895.

$8^{\circ} .8$ in. No. 1 , August, 1895.
** Only partly philatelic.

Mis. St. Jour. 143 (2).

HOIME WORIER. See HOME WORKER AND PHILATELIST.

HOME WOFKER AND PHILATELIST. The Home worker and philatelist.

Knoxville, Tenn., Moore and Galyon, etc., I895.

Fol. $15 \frac{1}{1}-16 \frac{1}{4}$ in. Nos. $1-2$, Nov.-Dec., 1895.
${ }_{*}^{*}$ No. 2 was published by Charles P. Galyon

[Continued as :]

The Home worker

Knoxville, Tenn., Charles P. Galyon, etc., I 896-98. $8^{\circ} .8 \frac{1}{2}-9 \frac{1}{4}$ in. Vols. IrI.-V. 24 nos.

Vol. Irr. Jan. 1896-Mar., 1897. Nos. 1-12.

" rv. Apl. $\quad$-Dec. 1, $1898 . \quad$ " $1-9$.

* " v. Jan. 1, -Mar. 1, 1898. " 1- 3. * * There is a paper wrapper to each number. There is no volume
rr. and no numbers for F'ebruary and March, 1896, and no. 6 , vol. Ir. and no numbers for February and March, 1896, and no. 6, vol.
rII., is dated "Aug.-Sept., 1896 ". Nos. 5-12, vol. mI., and nos. 1 4, vol. IV., were published by Fenton and Boyd, and the subsequent numbers by Ray Fenton." Amalgamated in April, 1898, with the "Tennessee philatelist" under the title "The Tennessee philatelist and home worker".

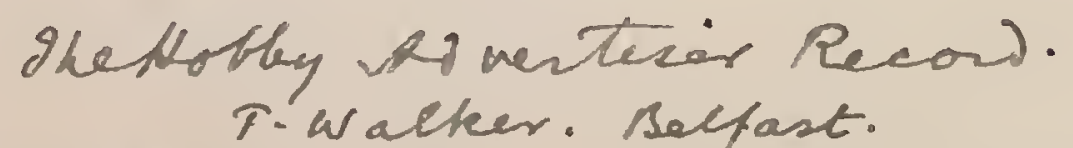

0 lsol angust. all ass. eame temper $8 / 4$. 
HONGKONG PHILATELIC JOURNAL. The Hongkong philatelic journal. A magazine for stamp collectors. Hongkong, E. J. de Frigueiredo, 1895 .

$8^{\circ} .9 \frac{1}{4}$ in. Nos. 1-12, Jan.-Dec., 1895.

* * There is a coloured paper wrapper to each number. This was the first philatelic journal published in Hong-Kong.

HOOSIER PHILATELIST. The Hoosier philatelist. Hanover Centre, Ind., F. N. Massoth, Jr., 1889. $8^{\circ}$. 93.in. Nos. 1-9, Jan.-Sept., 1889.

** There is a coloured paper wrapper to each number. The wrapper of no. 9 has " "The Hoosier philatelist consolidated with
the Stamp collectors" figaro".

HOOSIER STAMP. The Hoosier stamp.

Indianapolis, Ind., etc., W. H. Seaton, etc., I891-94. $8^{\circ} .8 \frac{3}{4}-9 \frac{1}{2}$ in. 17 nos. in 2 vols.

Vol. I. May, June, July, Oct., 1891, Apl. 1, May 1, 1892, Jan.-July, 1803. Nos 1-4, 4-12.

"I Ir. Nov., 1893-Feb., 1894. Nos. 1-4.

*" There are two numbers " 4 " of vol. I., one dated "October, 1891," the other "April 1, 1892 ". The latter and no. 5 were published by Harold van Trump, at Rochester, Ind. Nos. 6-12 vol. 1., and no. 1, val. 1., wero pabcock and Co. at Indianapolis, and nos. 2-4, vol. 11., by Chas. E. Babcock, at the same place. Ther is a coloured paper wrapper to each number, that for no. 5, vol. I., having the year 1892 wrongly given
as " $1890 "$ Mis. St. Jour. 83 (7).

HOPKINS BROS' MONTHLY BARGAINS TO PHILATELISTS, AND LONDON AUCTION RECORD. Hopkins Bros' monthly bargains to philatelists, and London auction record.

Crouch End, London, Egremont [printed], Hopkins Bros., 1894 .

(.) $8^{\circ} .83$ in. No.1, Oct., 1894.

Mis. St. Jour. 79 (10)

[Continued as :]

The London auction record.

Crouch End, London, Egremont [printed], Hoptins Bros., 1894 . want res

8. 83 in. Nos, 2-3, Nov.-Dec., $1894 . \quad$ Mis. St. Jour. 79 (10a).

HOUSEHOLD WORDS. Household words. A weekly (1) journal conducted by Charles Dickens. No. 100. February 21, 1852. [Contains an article "The Queen's head," (by James Hannay and W. H. Wills) which gives a description of the production of the early stamps of Great Britain, printed by Perkins Bacon and Petch.]

(2) $8^{\circ} .9 \frac{1}{4}$ in. pp. $510-513$. London, $185^{2}$.

HUB COLLECTOR. The Hub collector.

Boston, Mass., E. M. Foster, I886.

$8^{\circ} .8 \frac{1}{2}$ in. No. 1, Mar. 12, 1886. Mis, St. Jour. 26 (3).

HUBBARD'S MAGAZINE. See CURIOSITY WORLD.

HUGO GRIEBERT AND CO. MONTHLY SPFCIAI OFFERS AND BARGAINS. Hugo Griebert and Co. monthly special offers and bargains.

$4^{\circ} \cdot 11-11 \frac{1}{2}$ in

** This is solely a price list of stamps, etc., for sale by the publishers and cannot therefore be considered a philatelicl journal. No. 1 is dated "October, 1899". The word "monthly" is dropped from the title on the number issued in "January, 1903," and on

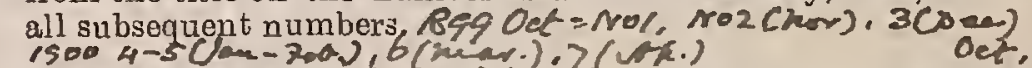

HUGO GRIABRT AND CO. SPECIAL OFFERS AND BARGIANS. See Hugo Griebert and Co. MONTHLY SPECIAL OFFERS AND BARGAINS.

HUNGÁRIA. Hungária.

Budapest, Ödön Alsó, 1903-04.

$8^{\circ} .9 \frac{3}{4}$ in. 8 nos. in 2 vols.

1st year. Oct.-Dec., 1903. Nos. 1-3. $1-5$. II $W_{0} 3=p / 11-66$ ha a plate ** Nos. 4 and 5 of the second year were published together. 4 cor ${ }^{-}$off Wanting all except no. 3 of the second year, which has a coloured lemaney
paper wrapper.

$$
\begin{aligned}
& \text { it wis Trowthly Pavertioer. R. foss. Sketfor } \\
& \text { manchestas. } \\
& \text { arrentizer in The Amateur Atrestiser } \\
& \text { no } 2.1889 \text { manch. } 1.8 \text {. }
\end{aligned}
$$




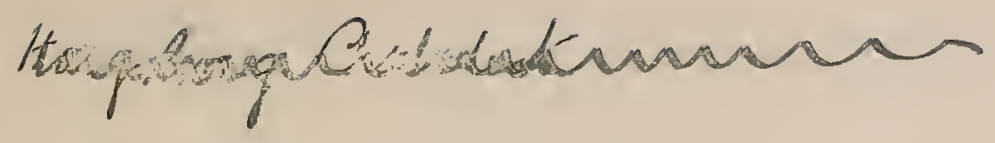 Hangrong Phatitist}

\footnotetext{
Hour flass

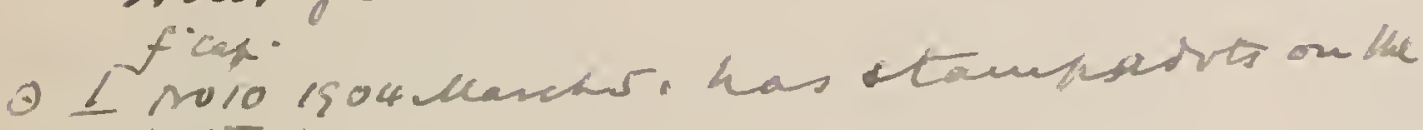

ats $\lambda$-正
} 
IL CORRIERE FILATELICO

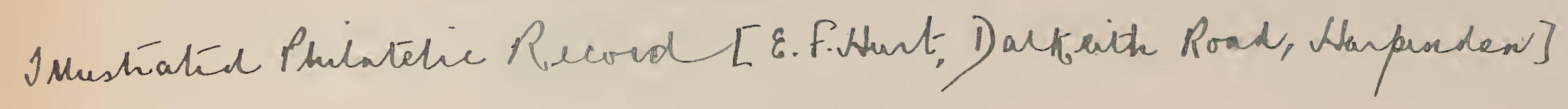

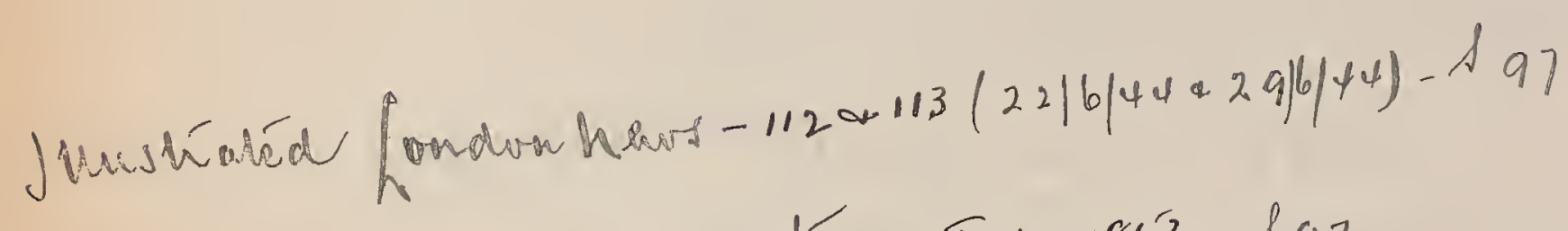

"magazine of art - Tuly, 188'3 - \$97

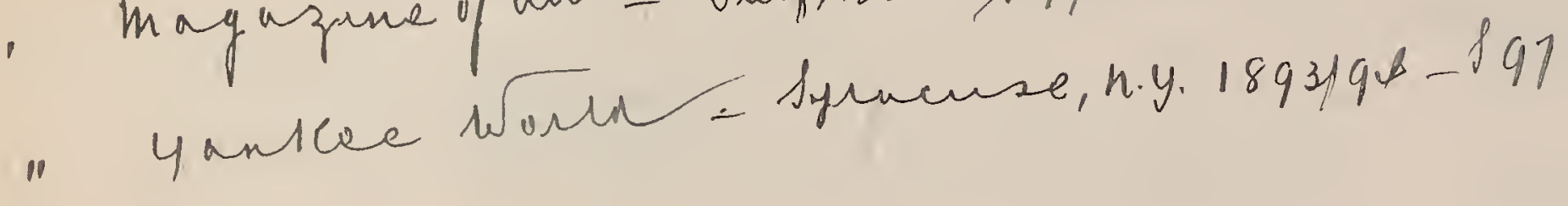


I. C. C. P. See InTermédiatre DES Colimctionneurs DE Cartes Postales Iluustrées et de Tmbres-Poste.

IDÉAL. L'Idéal.

Scorbe-Clairvaux, France, F. Savignaud, I 904 $4^{\circ} .11$ in. Nos. 1-15, Feb. 10-Sept. 10, 25, Oct. 10, 25, Nov. 10, 25, Dec. 10, 25, 1904

** Only partly philatelic. Nos. 1-11 are printed on coloured paper, and nos. 12-15 have coloured paper wrappers and nos. 1-3 pave supplements.

ILLINOIS IIONTHLY. Illinois monthly.

Prophetstown, Ill., Illinois Publishing Co., I 902. $16^{\circ} .6$ in. "[No. ?] March, 1902

* * Only partly philatelic. The number has a paper wrapper, but *ears no volume or number. The library also contains a copy of "The Illinois monthly, Prophetstown, Ill., Vol. I no. VII July, 1901 octovo 7 inches, but this number has no philatelic matter 1901 , octavo 7 inch

ILLINOIS PHILATELIST. The Illinois philatelist Rock Istand, Ill., [C. D. Reimers], 1886. $8^{\circ} .9$ in. Nos. 1-2, Mar.-July, 1886.

Mis. St. Jour. $23(6)$

ILLINOIS PHILATELIST. The Illinois philatelist. Palatine, Ml., Albert G. Smith, I893. 8. 9 in. Nos. 1-2, Apl.-May, 1893

* * There is a coloured paper wrapper to each number.

Mis. St. Jour. 61 (1)

ILLINOIS PHILATELIST. "The Illinois philatelist.for san- Coluscin Kanteakee, Ill., Shirley E. Moisant, I899. $24^{\circ} .6$ in. Nos. 1-4, Sept. 1-Dec., 1899. $/ \quad$ Mis. St. Jour. 96 (9).

ILLUSTRATED NEW YORK IMONTHLY. The Illustrated New York monthly.

Buffalo, N. Y., Ernest C. Fink, I897-98. $8^{\circ} .9$ in. Vol. II., nos. 1-5, November, 1897-Mareh, 1898.

*** Only partly philatelic. Wanting all but vol. II., no. 4, which has a paper wrapper.

ILLUSTRATION. Die Illustration. 15 April, 1890 [Contains an article "Das Jubiläum der Briefmarke. Zur Internationalen Ausstellung der Philatelisten im österreichischen Museum für Kunst und Industrie, April, 1890. Von Ch. Scolik," with illustrations.]

Fol. 153 in. pp. 4-7. Wien, [? St. Jour. 127 (10).

ILLUSTRIERTES BRIFFIMARKEN - JOURNAL "FORTUNA". See Fortuna. (Coepenick).

ILLUSTRIRTE BERLINER WOCHENSCHRIFT DER BÄR. Illustrirte Berliner Wochenschrift Der Bär. xIr. Jahrgang, Nr. 10. Dezember 5, 1885. [Contains an article "Die älteste Berliner Postmarke (Mit einer Abbildung) by Ernst Friedel.]

Fol. $12 \frac{1}{2}$ in. pp. 123-124.

Berlin, Gebrïder Paetel, I885 Mis. St. Jour. 138 (4).
ILLUSTRIRTE BIER - BRIEFIMARKEN - ZFITUNG. See Illustrirte Briefmarken-Bier-Zititung.

ILLUSTRIRTE BRIEFIMARKEN - BIFR-ZEITUNG. Illustrirte Briefmarken-Bier-Zeitung.

Strassburg, Gebrïder Mostrich, [1888]-189o. $8^{\circ} .81$ in. Nos. 1-3, [1888], Dec. 21, 1889, Dec. 20, 1890. ** Printed by autographic lithography. No. 1 has no number o date. The contents are of a humorous deseription. Mis. St. Jour. 58 (7).

[Continued as :]

_ Illustrirte Central-Bier-Briefmarken-Zeitung. Strassburg, Verein Union, [1891].

$8^{\circ} .8 \frac{1}{4}$ in. No. $4,[1891]$

** Printed by autographic lithography. The contents are of a humorous description. The number contains $8+(2) \mathrm{pp}$. Mis. St. Jour. 58 (8) [Continued as :]

Illustrirte Bier-Briefmarken-Zeitung.

Strassburg, Gebriider Mostrich, 1893.

$8^{\circ} .8 \frac{1}{10}$. No. 5, May 13, 1893.

** Printed by autographic, lithography. The contents are of a humorous description.

ILLUSTRIRTE BRIEFMARKEN ZEITUNG. Illustrirte Briefmarken Zeitung. Organ für die gesammte Postwerthzeichenkunde. Leipzig, Ernst Heitmann, I888-1900.

$8^{\circ} .10 \frac{1}{2}$ in. 336 nos. in 13 vols.

1 $10 \frac{1}{2}$ in. 336 nos. in 13 vols.

2nd " "1-" 15, 1889. Nos. 1- $1-24$

3rd " " " $1-", 15,1890 . \quad " \quad 1-24$.

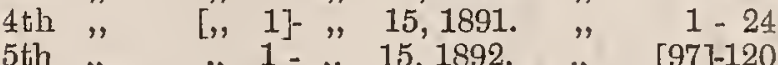

6th " " $\quad 1-" 15,15,1892 . \quad " \quad[97]-120$

7th " " 1- " 1 15, 1893. " $121-144$

Sth " " " 1- " 20, $1895 . "$ " $181-216$

9th " " $" 1-" 15,1896 . \quad " \quad 181-216$.

10th " " $"$ " $" 15,1897 . " \quad 217-240$.

11th " "1-" 15, 1898. " " $241-264$.

12th " " "1 - " 15, 1899. " " 265-288.

13th " " " $1-", 15,1899 . \quad " \quad 289-312$.

* * There is a" title-page and an index to each year, a paper * *aper to a title-page and an index to each year, a papes wrapper to each number, excepting the numbers for the year 1892 , and there are many supplementary pages scattered through the various volumes. VNo. 136 is wrongly numbered " 135 " and no. 298 is wrongly numbered " 297 " $N o .331$ and 332,333 and rester " weverally published together under the

ILLUSTRIRTE CENTRAL-BIER-BRIEFIMARIKENZEITUNG. See IluUstrirte BriefMarken-BierZEITUNG.

ILLUSTRIRTE FRANKFURTER BRIEFIMARKEN ZEITUNG INIT DEII INTERNATIONALEN INSERATENBLATT “UNIVERSUIM". See UNIVERSUM. 
ILIUSTRIRTE FRANKFURTER BRIEFIMARKENZFITUNG IMIT INSERATENTHEIL UNIVERSUIM. See UnIVERSUM.

ILLUSTRIRTE WELT. Tllustrirte Welt. Heft 15, 1893. [Contains an article "Die Fortschritte des Briefmarkensammelns. Von Dr. Hans Brendicke" and a full page of illustrations of postage stamps.]

Stuttgart, Leipzig, Deutsche Verlags-Anstalt, I893. Fol. 1.53 in., pp. 366 and 368.

Mis. St. Jour. 115 (6).

- Illustrirte Welt. Heft 14, 1900. [Contains an article "Wie werden unsre Briefmarken hergestellt? Von Dr. F. Kalckhoff. Mit fünf Abbildungen."]

Stuttgart, Leipzig, Deutsche Verlags-Anstalt, i 9oo. Fol. 153 in., pp. 338, 339.

Mis. St. Jour. 127 (9).

ILLUSTRIRTER BRIEFIMARKEN - ANZEIGER. Illustrirter Briefmarken-Anzeiger.

Leipzig, etc., Alwin Zschiesche, r882-86. Fol. 113.1.12 in. Nos. 1-8, 1832, 1882, 1883, 1884, 1884, 1885, *

** Printed on buff paper. Nos. 2-8 were publislied at Naumburg
a Saale, but were printed in Leipzig.
Mis. St. Jour. 73 (11).

ILLUSTRIRTES BRIEFMARKEN-JOURNAL。 Illustrirtes Briefmarken-Journal. Organ für die GesammtInteressen der Briefmarkenkunde.

Leipzrg, H. Werninck und Co., etc., I874$8^{\circ} .10 \mathrm{in} ., 12 \mathrm{in}$. and $9 \frac{1}{\mathrm{in}}$ in. nos. in vols. In progress. 1st year. Jan. 1-Dec. 1, 1874. Nos. 1- 12.

2nd " " $1-" 1,1875 . \quad "{ }^{\circ} 13-24$.

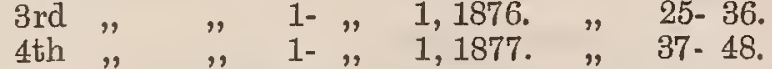

5 th $", \quad " \quad 1-", \quad 1,1878 . \quad " \quad 49-60$.

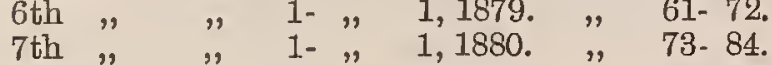

8th " " $\quad 1-\quad " \quad 1,1881 . \quad " \quad 85-96$.

9th " " $\quad 1-", 1,1882 . \quad " \quad 97-108$.

10th " " $" 1-", 1883 . \quad " 109-120$.

11th " " $" 1-" 15,1884 . \quad " 121-144$.

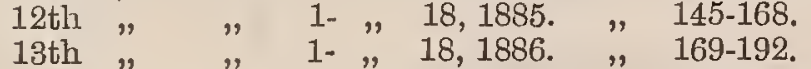

14th " " 8- " 17, 1887. " 193-216.

15th " " 7- " $15,1888 . \quad$ " 217-240.

16 th $" \quad " \quad 5-" 14,1889 . \quad " 241-264$.

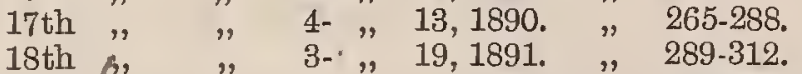

19th " " 2- " 17, 1892. " "313-336.

20th " " $7-", 16,1893 . \quad$ " $337-360$.

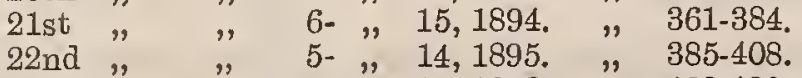

23rd " " " 4- " 19, 1896. "

24th " " 9- " 18, 1897. " $433-456$.

25th " " 2 th $\quad$ 8- $", 17,1898 . \quad, \quad 457-480$.

27 th $"$ " $\quad$ 6- " $15,1900 . \quad$ " $505-528$.

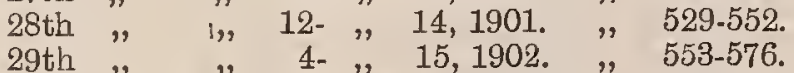

30th " " " 3- " 12, 1903. "

31st " " 2- " 17, 1904. " 601-624.

32nd " " $\quad$ 7- " $\quad 16,1905 . \quad$ " $625-648$.

* * There is a title-page and an index to each year. The first four years are octavo 10 inches, the next six years (1878-83) are octavo 12 inches and the remainder are octavo $9 \frac{1}{4}$ inches, Nos. $7-88$ were published by Louis Senf, and commencing with no. 89 the journal has been published by Gebrüder Senf. From January 1, 1884, it. has been published fortnightly. A copy of the prospectus of the journal is bound up at the end of volume I. there is a "Probenummer" of no. 123, the contents of which are copied from part of the contents of no. 122, some copies of no. 265 were issued with "Probe-Nummer" in red at the top of the front page and there is a "Probenummer" of no. 1, 1904, the contents of which differ in several portions from those of the ordinary no. 1 of that year. $\vee$ Nos. 91 and 92 , and 115 and 116 were severally published together under the respective dates of "Juli-August, 1881" and "Juli-August, 1883". "There are no pages 31,32 of the third "year, no. 124, on page 59, is numbered "Nr. 3 " in place of "Nr. 4," no. 140 is dated "18 Oktober," on page 261 and "15 Oktober" on page 263 , nos. 161 and 162 are wrongly numbered " 165 " and nos. 1 and 2 of 1902 are wrongly numbered " 253 " and " 254 " instead of " 553 " and " 554 " respectively. Nos. 258 and 259 were also published together withi a paper wrapper inscribed "Srinnerung an die II. Internationale Postwertzeichen - Ausstellung des Bayerischen PhilatelistenVereins, München, 1899". There are special supplements with the titles "Allgem. Anzeiger," "Allgemeiner Briefmarken-An- zeiger," “Offertenblatt für Briefmarken-Sammler," "Beiträge lars " " Oer Vereins-Bote" " pat and a reference to "Mercur" should also be made. In 1903 to and a reference to "Mercur" should also be made. In 1903 to Kunde. Fin Hüllfs- und Nachschlacebuch, von Theodor Haas," were included in many of the numbers and in $1906-[$ were "Handed in many of the numbers and in 1906-[ ] parts of the "Handbuch aller bekannten Neudrucke
were presented with some of the numbers. A number of supplewere presented with some of the numbers. A number of supple-
mentary pages, but without separate titles, are also scattered
throughout the various volumes. There is a reprint of no. 286 , throughout the various volumes. There is a reprint of no. 286,
in which many of the illustrations are coloured and much of the in which many of the illustrations are coloured and much of the text part is different and a reprint of no. 289 in which the matter on pages 20-24 differs. Nos. 631 and 632 were also reprinted. I the reprints of these two numbers the advertisements on pages $130,131,151,154,155$ and 170 are totally different, the notice at page 156 also vary.

ILUSTRACIÓN FILATÉLICA. See UnIón FILATÉLICA.

ILUSTRACION FILATELLICA HISPANO AIMERICANA. See UNIÓN FILATÉLICA.

\section{ILUSTRACIÓN FILATÉLICA HISPANO-CO-} LONIAL. See UNIÓN FILATÉLICA.

ILUSTRACION POSTAL.' La Ilustracion postal. No, 2, Dec. 18, 1894. [Contains an article "Filatelia," which gives a chronological list of the order in which the different countries adopted postage stamps, etc.] Madrid, Jose Primo de Rivera y Williams, 1894. Fol. $15_{\frac{1}{2}}^{\frac{1}{2} \text { in., pp. } 6,7 .}$

Mis. St. Jour. 108 (13).

IMPERIAL. The Imperial.

Utica, N. Y., The Imperial Publishing Co., I 905. $8^{\circ} .10$ in. Nos. 1-3, January-March, 1905.

** Only partly philatelic. Nos. 2 and 3 have coloured paper
wris. St. Jour. 143 (15).
wraps. wrappers.

IMPERIAL ARGUS. The Imperial argus. Canadian edition. Vol. Ir., no. 17. October 15, 1902. [Contains an article "The Stamp of merit. Fine art in the postal service," by "Philatelist ".]

London, W.C., The Eilston Press Ltd., I902. $8^{\circ} \cdot 9_{\frac{3}{2}}$ in. pp. $289-296$

**iThe number has a coloured paper wrapper. The article gives a description of Messrs. Perkins, Bacon and Co.'s method of printing stamps and a history of the firm.

Mis. St. Pamph. 63 (4).

INCOGNITO PHILATELIST. The Incognito philatelist.

$16^{\circ} .5 \frac{1}{2}$ in. No. 1, Feb. $29,1896$.

[? Newton, Mass.], I896.

$16^{\circ}$. 51 in. No. $1, \mathrm{Feb} .29,1896$.
* $_{*}$. The number has a coloured paper wrapper. Printed by a type-writing machine. The publishers' address is given as "We, Us and Co., Somewhere City". "Mis. St. Jour. 104 (9).

INDEPENDENCIA E ORDEIM. Independencia e Ordem. II. Anno. Nos. 30, 31. Março 11, 22, 1888. CContain articles "Aux Journaux Philatéliques de tous pays"; "La Société Portugaise des Collectionneurs de Timbres," etc.] Lisboa, José Pedro Germano Manzoni, I888. Fol. 183 in. p. (1) and p. (1).

Mis. St. Jour. 136 (8.)

INDEPENDENT PHILATRLIST. See BAyONNE PHILATELIST.

INDEX. The Index.

Newburgh, N. Y., David W. Jagger, 1872. ** Cuttings of the "Stamp department," etc., in the number for October, 1872 , are mounted in Stamp Scrap-book, vol. II., pp. 42, 43.

INDEX. The Index.

$16^{\circ} .5$ in. Nos. 1-2, [? $\quad$ ]-November $15,1890$.
** Only partly philatelic. Wanting no. 1.

Mis. St. Jour. 154 (2). 
Indian Philatelist. An Indepenisent Montrly for all chroses of Philaterists derotad entind

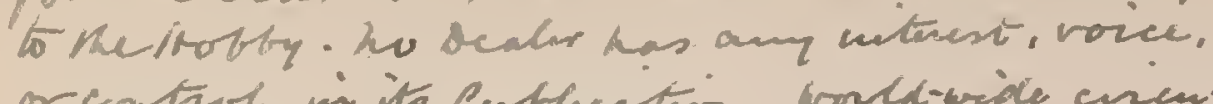

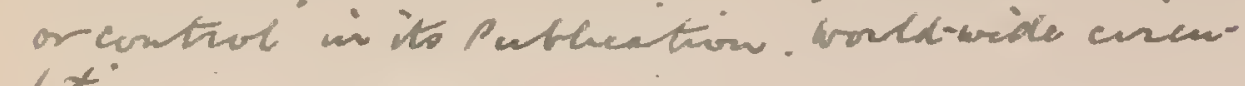
lation. 46 Editer y Ramaseshayya. madras. rolitrol. ISU Ledt. Eluepaperwa.

Indian Philocartist. Srand Corovation oubar tromber. isit ir. No 4. Thape phiciaty

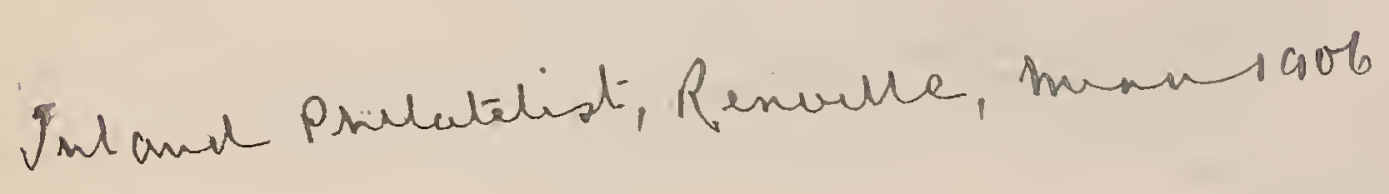

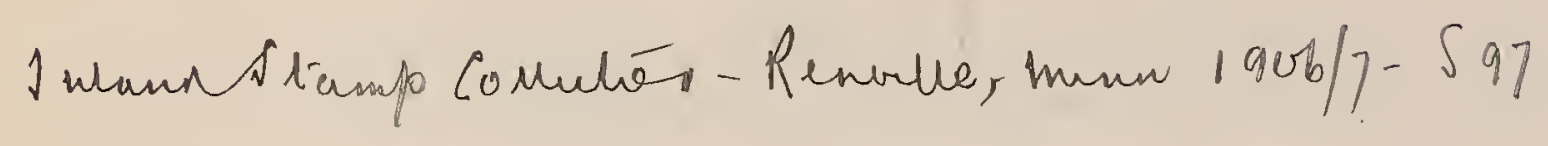

Intermédrave. Bruxelus, 190\%, S97 
INDIAN PHILATEIIST. Indian philatelist. Dadar, Bombay, Julia Ribeiro, I 894-96. $8^{\circ} .93$ in. 23 nos. in 2 vols.

Vol. I. May 1, 1894-A pril 10, 1895. Nos. 1-12

Vol. II. „25-Oct., 1895, Dec., 1895-Apl., 1896. Nos. 1-11

* * There is an index to vol. I., and a coloured paper wrapper to each number. The numbers of volume II., have the word "The" preceding the title and nos. 7-11 of this volume were published at Bombay. This was the first philatelic journal published in India.

INDIAN POSTAGE STAMP NEWS. The Indian post age stamp news. A monthly devoted to philately. $8^{\circ} .9 \frac{3}{4}-10 \frac{1}{4}$ in. 13 nos. in 2 vols. Bombay, P. A. Sakloth, I894-95. Vol. 4 .

$(2$ Vol. I. Sept. 30, 1894-Aug. 25,

number has a coloured paper wrapper.

INDIANA PHILATELIST. The Indiana philatelist. Published monthly in the interest of stamp collecting. $8^{\circ} .9$ in. No. 1, Dec., 1896. Iuncie, Ind., W. Leslie Brand, I896.

* * The number has a paper wrapper. K/ $1-22 M i s$. St. Jour. 92 (5).

INDIANA PHILATELIST. The Indiana philatelist. Goshen, Ind., Bickel and Beber, etc., I 899-1900. 8. $8-9$ in. 8 nos. in 2 vols.

Vol. I. Nov. 15, 1899-Apl., 1900 . Nos. 1-6.

"II. June, Aug., 1900. Nos. 7-8.

* Nos. 3-8 were published by A. J. Bickel. Nos. 3 and 4 and 5 and 6 were severally published together, and nos. 5 and 6,7 and 8 have coloured paper wrappers. There are supplcments of two
pages to nos. 3 and 4 and also to no. 7 . Amalgamated with the "Pages to nos. 3 and 4 and also to no. 7. Amalgamated with the Mis. St. Jour. 93 (12)

INDICADOR DE LOS SELLOS. El Indicador de los sellos.

Madrid, D. Eduardo Gilabert, т87o.

8. 10 in. No. 1 , July 15,1870

** This was the first philatelic journal published in Spain.
Mis. St. Jour. 43 (1).

INDICATEUR PHILATELIQUE ET COMMER CIAL. L'Indicateur philatélique et commercial. Organe spécial de publicité, paraissant fin de chaque mois. Bains-les-Bains, Henri Barbot, 1897. $8^{\circ} .9$ in. Nos. 1-4, Jan.-April, 1897.

* * Printed on rose paper. $v$ No. 3 has added below the title "et "Collectionneur du Var' réunis., Numéro 4,", and no. 4 has " et
"Collectionneur du Var' réunis".
Mis. St. Jour. 112 (7).

INSERATEN BEIBLATT ZUIM SÚDDEUTSCHEN ILLUSTRIRTEN BRIEFIMARKEN-JOURNAI Inseraten Beiblatt zum Süddeutschen illustrirten Briefmarken-Journal. Mïnchen, S. Wolf, [1891]-92. $8^{\circ} .93$ in. Nos. 1-5, [Dec. 15, 1891], Jan. 2, Jan. 18, Feb. 1, Feb.

** The above forms a supplement to Süddeutsches illustrirtes Briefmarkenjournal".

Mis. St. Jour. 58 (10).

INTERCHANGE AND MARKET. The Interchange and market. Weston-super-Mare, W. Spencer, 1872. $8^{\circ} .11 \frac{1}{4}$ in. Nos. 8-9, Mar. 20, Apl. 20, 1872.

** Only partly philatelic. The philatelic department of the paper was only opened in no. 8 , but there are a number of stamp advertisements in the issue of "February 15th, 1872". Cuttings of the stamp portions of nos. 7-9 are mounted in Stamp Scrap.
book, vol. II., pp. 76-89.
Mis. St. Jour. 77 (2).

INTERESSANTES BRIEFMARKENBLATT. Interessantes Briefmarkenblatt.

Hamburg, R. Wiering, I894-96.

$4^{\circ} .11$ in. 36 nos. in 3 vols

Vol. I. Nov. 1, 1894-Apl. 15, 1895 . Nos. 1-12.

" II. May 1, -Oct. 15, 1895. " 13-24.

*" "Published fortnightly.

INTERIMEDIAIRE. L'Intermediaire. Revue Philatelique Internationale.

Constantza, Roumanie, V. Berberianu, rgo6.

$4^{\circ} \cdot 8 \frac{1}{4}$ in. Nos. 1-2, July-August, 1906

* * Produced by autographic lithography. The contents consist entirely of advertisements and of addresses of people wishing to 5 q $\delta$ make exchanges. Wanting both nos.

$$
\begin{aligned}
& \text { Indecatore Flocarlesta Suena Nos } \\
& \text { (Revire Posicando) }
\end{aligned}
$$

Intricantio Alicante

iqoq I $(1+11)$

Susektên-Börse. Lupisy

$1893 \times$ / hor. ro 15 any 1. has artites on stanpso termédiaire de la timbrologie. Journal du collection neur et du marchand.

Paris, etc., E. Gainsborg, etc., I893-1906. $4^{\circ} .11 \mathrm{in.}, 8^{\circ} .9$ in., and fol. $12 \frac{1}{2} \mathrm{in.} 155$ nos. in 14 vols.

1st year, Apl. 20-Dec. 20, 1893 . Nos. 1-9.

2nd " Jan. 20- ", 25, 1894. " 10-21. 1 10, Dec. 15, 1895. Nos. 22-30.

4th " " " 1-Nov. 25, 1896. Nos. 31-41.

5th " Dec. 20, 1596-Nov. 25, 1897. Nos. 42- 53

6 th ", , 20, 1897- " 25, 1898. " " $54-65$.

7 th " " " 25, 1898- " 25, 1899. " " 66- 77

8th " " " 25, 1899- " 25, 1900. " " $78-89$.

10th " " " 25, 1901- " 25, 1902 . " $\quad$ 102-113.

11 th ", ", 25, 1902- ", 25, $1903 . \quad$ " 114-125.

12 th " " 25, 1903- ", 25, 1904. " " 126-137.

13th " " 25, 1904- " 25, $1905 . \quad$ " $138-149$.

* Nos. 1-25 are quarto 11 inches, nos. "26-28 are octavo, while the numbers from 29 onwards are folio $12 \frac{1}{2}$ inches. Nos. $29-57$ were published by C. G. Vogel at Paris and the numbers from 58 onwards were published by the same, but at Caen. Nos. 26-28 have coloured paper wrappers, no. 10 has "Première année" instead of " deuxième année" and no. 67 has " Huitième année" in place of "septième annce". Nos. 31 and 32 are dated, respectively, "1 Janvier, 1896" and " 25 Janvier, 1896 " and there is no number for February, 1896. Nos. 1-29 were printed at Amiens, no. 30 at Mirecourt, and commencing with no. 33 the journal was printed at Caen. No. 112 is found printed on yeliow and also on white paper. 66 has sepheme for scireme

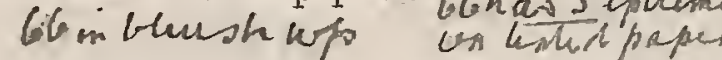

INTERIMÉDIAIRE DES CHERCHEURS ET CURIFUX. L'Intermédiaire des chercheurs et curieux. (Correspondance littéraire, Notes and Queries français.)

Paris, I864-

$8^{\circ} 9 \frac{1}{2}$ in

* * The following is a complete, list of the references to stamps, stamp-collecting and the Post Office. The list was compiled by Mr. P. J. Anderson and was published in the "Journal of the Philatelic Literature Society" of April, 1910.

1864, July 25 (I., 144) “Timares. -Je m'occupe de l'histoire des timbles poste, et désire connaître ce qui a paru sur se sujet. Pour l'illustration de mon ouvrage je fais collection de T.-P. et voudrais échanger avec quelques collectionneurs. S'adresser à Londres, 34, Parliament Street"-King.

1864, Aug. 20 (I., 176). Reply by AD. BO., referring "King" to the articles in the Magasin Pittoresque.

1866, Aug. 10 (rII., 458) "Trmbres-Postz.—à qui en doit-on l'invention?"-V.T.

1866, Sept., 10 (III., 536). A long reply by "A. B. D." claiming the honour for France, in view of the regulation of 1653 . "Il faut toutefois remercier l'Angleterre d'avoir fait revivre pour l'adapter, aux besoins de notre époque, cette mesure s commode." Another short reply by C. R.

1866, Oct. 25 (III., 621). Another long reply by F. Feuillet de Conches, giving a full account of M. de Villayer's plan, and of the famous Pellisson-Scudéry letter.

1874, Nov. 10 (VI1., 625) "Timbres-Poste Oblitérís"-R.N. [Query as to their use "pour une œurre de bienfaisance". 1874, Nov. 25 ( ( III., 627). Replies by O. D. and Jacques D.

1875, March 25 (viII., 164) "Poste AUX LeTTIRES "-Frémusson. [Was the author of Plan de l'administration pour la Poste de Paris, 1760 . M. de Chamousset?]

1879, Sept. 10 (X11., 522) “Timbres DE Dimension "-C.Z. [Mean-

1879, Sept. 25 (XII., 574). Replies by Karl Belton and G. de Bourge.

1881, Jan. 10 (xIV., 13) “ UN TimbRe-Poste \& IDextifier "_Paul Masson. [Turks Islands. One penny.]

1881, Jan. 25 (XI7., 62). Replies by Brieux, Un Timbrophile, and G. G.

1882, Oct. 10 (Xv., 582) “LetTres Afrranchies"-Sus. [Query

1883, Jan. 25 (XvI., 48). Reply by H. B. referring to Journal des Voyages of 22 Oct., 1882

1882, Feb. 25 (xVI, 107) “TRAVAUX RFraTits ì ' Postr "-H. Issan [Query regarding the works of Bermedde, Naudet, Bergier, etc

1883, Feb. 25 (xVI., 111). Another reply by G. I., referring back to the correspondence in vol. III.

1884, March 25 (XVII., 168) "TimbRes DE ContrôLe" -Alphonse $R$.

1884, April 10 (xVII., 220). Reply by B. B.

1885, May 25 (xviII., 293) "A QUOI SERvent Les TIMIBRms-Poste OBLITHB.s?"-

1885, June 25 (xviII., 369). Replies by A. D., Flovil and Oxoniensis.

1885, July 10 (XVirr., 400). Reply by O'Realy, referring to M. P. Eudel's Collections et Collectionneurs.

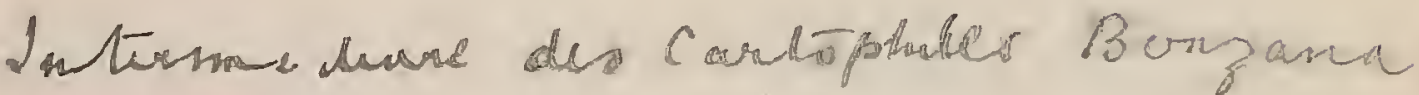

$$
\begin{aligned}
& 1904-5
\end{aligned}
$$

2 leaveserd ho-11

298

598 


\section{INTERIMÉDIAIRE DES CHERCHEURS ET} CURIEUX, etc.

1885, July 25 (xviII., 432). Reply by Un Liseur, quoting lengthy explanation given by M. Georges Delmare in the

Voltaire of 14 th July.
1886, Sept. 10 (XIX., 525). Further reply by CZ

1886, Aug. 10 (XIX., 449) "Poste AUX LeTtregs"-Poggiardo. [Reference to Eustache Deschamps' CEuvres, vol. XI.]

1886, Sept. 10 (IIX., 535) "Poste AUX Letrives"--A. D. [Reference to Du Boulay's Histoire de l'Université de Paris and Brantôme's Vie de Maréchal de Strozzi.]

1886, Sept. 25 (xix., 582) "Postw Aux Letrres "-Alexis Belloc. [Cites the edict of Louis XI., 19 June, 1464.]

1888, Feb. 10 (XXI., 71) "PIARRoN DE CHAMOUSSET"- Henri Issanchou. [The querist desires, for a new edition of his Livre d'or des postes (1885), which is to contain a Bibliography of the subject, information regarding Chamousset, graphy of the subject, informatio

1888, March 10 (XXI., 154). Reply by $L_{e}$ Rosean, who notes Chamousset's CEuvres, 2 vols., 'Paris, 1783

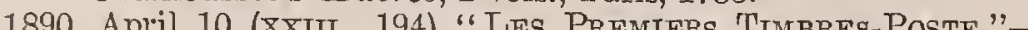
$\mathrm{T}$. Are V. D. [Are copies known to exist of de Valayer's postal covers? The question is put in view of an approachin International Exhibition of stamps.]

1890, May 25 (XXIII., 313). Replies by "Q" (who quotes from the Bulletin of the Société Francaise de Timbrologie), S.

1891, Sept. 10 (xxrv., 659) "Le Premier Service Postal"Alphonse R. [Reference to book of Job, chap. IX.]

1891, Nov. 10 (XXIV., 885). Reply by Joc'h D'Indret, who doubts the interpretation of Alphonse $\mathrm{R}$.

1891, Dec 10 (XXIV, 1000). Further renling by A. X., E. Nilorac (who cites Le Quien de la Neufville's De l'origine des postes chez les anciens et chez les modernes, Paris, 1708) and Malabar.

1892, Dec. 10 (xxiv., 610) "Les Collections de Timbres-Poste" - Prosper de l'Orbize. [A series of queries: What is the most valuable stamp? Who owns the most complete collection? Who was the first in France to collect ?

1893, Feb. (XXVIII., 227). Long and interesting replies by Ed. M. Mahé and Vittorio Mendl. Further queries by Philibert Ténient as to the use made of accumulations of obliterated stamps.

1893, July 20 (XXviII., 51) "L'EMrLoI Des ANCIENS TIMrBRes Poste"-M. J. [Are unused stamps which have been superseded still available for postage? If they are, why should not makers of facsimiles be liable to prosecution?]

1893, Sept. 10 (XXvirI., 275, 370). Replies by Oroel, and G. Kuhnholtz-Lordat (quoting $L$ 'Eclair) and A.

1893, Nov. 30 (XXVIII., 577) "L'ORThogRaPHIE DU MOT 'Poste" sur Les "Timbreas-Poste"-Un Philalethe. ["Poste" or "postes" ?]

1894, Jan. 10 (XxIX., 39). Replies by G. M. (quoting the full discussion by the commission on the new French stamps), T. Pavot and G. F.

1896, March 10 (xxxiII., 281) "Philatílie, Philatíliste"-J. Lt. [Why not "Philotélie" or " téléphilie"?

1896, May 20 (xxxIII., 581). Replies by T. R. and Iatros.

1899, Feb. 28 (XXXIX., 271) "ANCIENAETÉ DU TIMBRAge DeS LETTRES"-Paul Pinson. [Earliest date?]

1899, April 10, etc. (xxxIX., 528, 665, 755, 944). Replies by A Saffroy [1602], "I. C." Effem, Ky, C. P. V.

1899, Oct. 15 (XL., 622) "TimrRes-Poste"-Théophile Gonse. [Best album ?]

1899, Nov. 15 (XL., 830) "ANCIENNEté, ete." Reply by Arm. D.

1900, Oct. 22 (XIII., 676) Le DeUIL et LA Poste"-J. C. Wigg. [Why does the post refuse letters in black-edged envelopes?]

1900, Nov. 7 (xLII., 807). Replies by Charles Yale and La Coussière.

1905, Jan. 10 (LI., 47) "Cherchez LA Figube. - Le Timbre SFRBE" [Face shown when stamp bearing profiles of Kara George and King Peter is inverted.]

1905, July 20 (LII., 57) "TimbRe RenNoIs" -Oroel.

1905, Aug. 10 (LII., 206). Reply by Beaujour, noting similar stamps for Caen, Cherbourg, and Rots.

1906, Feb. 10 (LIII., 165) "CoNTrôLeUr Gérteral des Posteg "Paul Calendini.

1906, F'eb. 20, etc. (LIII., 239, 356). Replies by Th. Courtaux, C, de la Barotte, and A. E., referring to Cheruel's Dictionnaire, Le Quien de la

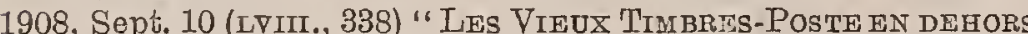
DES COLLECTJONS"-Cerameus. [Why collected ?]

1908, Sept. 30, etc. (LVIII., 489, 822 ; LIX., 97). Replies by Philos, P. B., Dr. A. B., Ch. de R . . y, J. Lt., A. G. C. The last cites a definite object. The orphanage Asile des Billodes, Le Locle, during the last "exercise," had benefited to the Le Locle, during the last "exercise," had benefited to the une œuvre de grande importance moralement."
INTERMEDIAIRE DES COLLECTIONNFURS DF CARTES POSTALES ILLUSTREES ET DE TIMBRES-POSTE. L'Intermédiaire des collectionneurs de cartes postales illustrées et de timbres-poste.

Paris, Charles Hanry, x 90x-02.

$8^{\circ} .10$ in. 16 nos. in 2 vols.

1st year, Sept. 1-Dec. 1, 1901. Nos. 1- 4

2nd "Jan. 1- , 1, 1902 . " 5-16.

* There is a paper wrapper to each number and the sixteen coloured paper wrapper. Nos. 13 and 14 were published together. with 4 pp actuts also $13-16$

\section{INTERIMÉDIAIRE DES COLLECTIONNEURS DE} TIMBRES-POSTE, CARTES-POSTAIES JOURNAUX, LIVRES, GRAVURES, AFFICHES ET IMONNAIES. L'Intérmediaire des collectionneurs de timbres-poste, cartes-postales, journaux, livres, gravures, affiches et monnaies.

Liége, Ch. Smal, I $90 \mathrm{I}-03$

$8^{\circ} .93$ in. 14 nos. in 2 vols.

1st year, Dec., 1901-Dec., 1902. Nos. 1-11.

2nd "Mar. 10- May 10, 1903.

* * No." 2-10 of the first year and the numbers of the second year have paper wrappers. Nos. 4 and 5 , nos. 9 and 10 and nos. 2 and have paper wrappers. Nos. 4 and 5, nos. 9 and 10 and nos. 2 and , of the second year, were severally published together under the 1902" and "10 On the wrappers of "20 Avril, 1902," Novembre, 1902," and "10 Mai, 1903 ". The dates inside each of these numbers are respectively" 5-10 Avril, 1902," "5 Novembre, 1902 " May, August or October, 1902.

INTERIMÉDIAIRE PHILATÉLIQUE. L'Intermédiaire philatélique. Organe mensuel des collectionneurs de timbres-poste.

Paris, J. P. Lelaurain, $\mathrm{x} 893$. $8^{\circ} .10$ in. Nos. 1-3, Sept. 15-Nov. 15, 1893.

Mis. St. Jour. 90 (11)

INTERMIDIAIRE TIMBROPHILIQUE. See TIMBROPHILE. (Marseille).

INTERNACIONAL. O Internacional.

Villa Vicosa, L. da Rocha Mattos Rosario, etc. I 894-97.

$8^{\circ} .10_{4}^{3}$ in. fol. $12-13$ in. and $8^{\circ} .83$ in. 30 nos. in 4 vols.

1st year, Mar. 2, 1894.April, 1895. Nos. 1-13.

2nd " June, 1895- " 1896. " 14-24.

$\begin{array}{llll}\text { 3rd " May, } & \text {-Sept., 1896. } & \text { " } 25-29 . \\ \text { 4th " Sept., 1897. } & \text { No. } 37 .\end{array}$

* * Nos. 1-6 bear Série I. and measure $10 \frac{3}{4}$ inches, nos. $7-13$ bear Serie II. and measure 12-13 inches, and the remaining numbers measure 83 inches. Commencing with no. 14 the journal was publishe by Luiz de Mattos. The first six numbers are not "Section phithe the the "Sear "Journal Philatélique" "Nos 12 and 13 , 15 . 7 the number "Noas. 12 and 13,15 and $16,18-22$ (25 and 24 and 29 were serally published together. There is paper" wrappers.

\section{[Continued as :]}

L'International. Journal philatélique.

Gendbrugge, Belgique, E. Questianx, I900.

$8^{\circ}$. 83 in. Vol. v1., 1 no.

6th year, April, 1900

* "This number bears "No. 2 (nouv. série)" and has a paper wrapper. The number was also published by Luiz de Mattos a Villa Vicosa and the copies sent out by him were put into his old wrappers inscribed "O Internacional te anno".

\section{INTERNATIONAL. See INTERACIONAL,}

INTERNATIONAL ADVERTISER. The International advertiser.

Quebec, The International Stamp Co., 1873. $8^{\circ} .83$ in. [No. 1], May, 1873.

* * The contents consist entirely of advertisements.

Bound up with the "Canadian Philatelist," Quebec, 1872-73.

$$
\begin{aligned}
& \text { butermediare Phlateligie } \\
& \text { Janlou - Q-f.Paies } \\
& 190\rangle \text { Ariel Nol (over furites in suane } 1908 \mathrm{mow}
\end{aligned}
$$

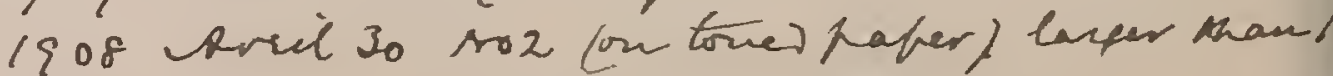



hamational Philatahi auarterts.

foblevithe mich. f.w is anders

$0 / 912 \pm 1$ 
593 INTERNATIONAL COLLECTOR

INTERNATIONAL COLLECTOR. The International collector.

San Francisco, Cal., E. Mendelson and M. Samuels, etc., $1887-89$.

$8^{\circ} .8 \frac{3}{7}$ in. 25 nos. in 5 vols.

Vol. I. June -Nov. 1887. Nos. 1- 6.

"II. Dec., 1887-May, 1888. " 7-12.

" IV. Dec., 1888-May, 1889. " " $19-24$.

" v. June, 1889 . No. 25.

* * Nos. 10-12 were published by Maurice V. Samuels, nos. 13-15 by the California Philatelic Association and nos. 16-25 by the Collector Publishing Co. Nos. 1-12 are only partly philatelic. Each number has a coloured paper wrapper.

INTTRNATIONAL EXCHANGE AND BRITANNIA

() STAIIP GAZETTE. The International exchange and Britannia stamp gazette.

Notting Hill, London, W. Witham, Essex [printed] The Britannia Stamp Association, 1873.

(1) $8^{\circ} .6$ in. No. 1, April 1, $1873 . \quad$ Mis. St. Jour. 55 (3).

INTERNATIONAL EXCHANGE AND MARKET The International exchange and market. A weekly newspaper for all people. New York, [1873]. * "Cuttings of the stamp portions in no. 1 dated "February," [1873], are mounted in Stamp Scrap-book, vol. II., pp. 44, 45.

\section{[Continued as:]}

- The Exchange and market. The swappers journal. A newspaper for all people. New York, [1873] * " Cuttings of the stamp portions in no. 2 dated "February," [1873! and in vol. II., no. 1, dated "October 18," [1873], are mounted in Stamp Scrap-book, vol. II., pp. 46, 47, 48, 49 .

INTERNATIONAL EXCHANGE GAZETTE. The International exchange gazette. (Official organ of the International Exchange Association.)

Ipswich, S. F. Bickers, I887.

$8^{\circ} .8 \frac{1}{2}$ in. No. 1, May, 1887

* Consists of one leaf only, with the prospectus and regulations advertisements of S. F. Bickers and Co. on the back. Wanting.

INTERNATIONAL PHILATELIC ADVERTISER

The International philatelic advertiser. A monthly journal in interest of stamp dealers and collectors.

New York, Krebs Bros., etc., I887-89. $8^{\circ} .11$ in. and 9 in. 20 nos. in 3 vols.

Vol. I. Jau.-Dec., 1887. Nos. 1-12.

"III. ", July, 1888. N". 1-7.

* * All the numbers, excepting the last, have paper wrappers. Nos. 1-12 are octavo 11 inches and the other numbers are octavo 9 inches. Nos. 10, 11, vol. I., and nos. 6, 7, vol. II., were severally published together. Nos. 1-12, vol. I., and nos. 1-4, vol. II., were published by Krebs Bros., nos. 5-7, vol. II., by A. M. Wright, New York, and no. 1, vol. III., by Wright and Ginity, New York. The heading of the last number" reads "The Interna ional philatelic a tvertisel: A monthly paper devoted to the interests of collectors and dealers throughout the rvorld". A prospectus of the journal dated December, 1886, is bound up with vol. I.

$$
\begin{aligned}
& \text { Vol. I. Mis. St. Jour. } 6(6) \text {. } \\
& \text { II., III. ", } 22(1) \text {. }
\end{aligned}
$$

INTERNATIONAL PHILATELIC ADVERTISER

6. The International philatelic advertiser. Published on the 1st and 15th of each month.

London, W., R. Braegger, 1893

() Fol. $12 \frac{1}{2}$ in. Nos. 1-5, Feb. 1, 15, Mar. 1, 15, Apl. 1, 1893. ** The "Philatelic advertiser" in 1894.
by the St. Jour. 72 (12).

INTERNATIONAL PHILATELIC ADVERTISER.

The International philatelic advertiser.

Allegheny, Pa., Herman Lechner, 1900.

598

$$
\text { in. No. 1, April, } 1900 .
$$

* Amalgamated with the "Allegheny philatelist and herald exchange. New Series" in July, 1900. Wanting.

INTERNATIONAL PHILATELIC ADVERTISER. See P. J. G. B. Advertiser.
INTERNATIONAL

INTERNATIONAL PHILATELIC MONTHLY. The International philatelic monthly.

Taunton, Mass., Wm. M. Deane, I892. $8^{\circ} .83$ in. Nos. 1-3, Feb. 29, Mar. 31, May 31, 1892.

** There is a coloured paper wrapper to each number.

Mis. St. Jour. 46 (3).

INTERNATIONAL PHILATELIC REVIEW. The

International philatelic review.

Rochester, N. Y., Review Publishing Co., I899-1900. $16^{\circ} .6 \frac{1}{2}$ in. 14 nos. in 3 vols.

Vol. I. Oct., 1899-Mar., 1900 . Nos. 1-6.

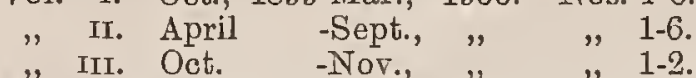

*" "*ach number has a paper wrapper. Nos. 4 and 5, vol. I., were published together and there is a supplement of illustrations to no. 3, vol. I., and also to no. 6, vol. II. Amalgamated with "International philatelic review and exchange," vol. III., no. 1.

INTERNATIONAL PHILATELIC REVIEW AND EXCHANGE. See Exchange. (Peekskill, N.Y.).

INTERNATIONAL PHILATELICAL ASSOCIA TION. The International Philatelical Association. Monthly report. [Headed] private.

West Brighton, I88I-82.

8․ 9 in. [Nos. 1-6.] May, June, July and Aug., Sept., Oct. and Nov., Dec., 1881, and Jan., 1882 . Mis. St. Jour. 78 (7).

INTERNATIONAL PHILATELIST. The International philatelist. The organ of the Institute of Philatelists.

Liverpool, W. H. Rowbotham and Co., ז884. $8^{\circ} .9 \frac{1}{4}$ in. No. 1, Mar. 31, 1884

** Edited by George Henry Readdy. Mis. St. Jour. 79 (15)

INTERNATIONAL PHILATELIST. The International philatelist. A monthly for stamp collectors.

Toronto, W. S. Weatherston, etc., I892-93. 8.. 9-9 in. Nos. 1-8, Oct., 1892-May, 1893.

** Nos. 5-8 were published by George A. Lowe and each of the eight numbers has a coloured paper wrapper.

Mis. St. Jour. 56 (12).

Second series. Toronto, Henry Ades Fowler, 1893. $8^{\circ} .10$ in. Nos. 1-2, Sept. 22-Oct. 23, 1893.

** There is a paper wrapper to each number.

Mis. St. Jour. 56 (13).

INTERNATIONAL PHILATELIST. The International philatelist.

St. Joseph, Mo., etc., H. O. Beardsley, etc., х895-1903. 8 . $9-8 \frac{1}{2}$ in. 48 nos. in 12 vols.

Vol. I. July, Sept.-Oct., Nov., Dec., 1895. Nos. 1-4.

"II. Jan. Apl., 1896. ", 1-4.

" III. May -Aug., " ", 1 -4.

"Tv. Sept. - Sec., " "

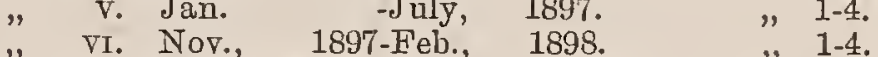

" vII. Mar., May -July "

" VIII. Aug. 15 -Nov. 15, "\# " $1-4$.

" x. Feb., Mar., Mar., Apl., 1901. ", 1-4.

"XI. Feb. 28-Apl. 30, Summer, 1902. " 1-4.

* "* XII. Sept., Oct., Dec., 1902, Jan., 1903. $2-4$, vol. ve, were published by Narvon Ëdwards. There is a paper wrapper to each number down to the end of vol. IX. is a paper wrapper to each number down to the end of vol. IX.
and for nos. 1-3 of vol. XI. and no. 2 , vol. XII., is printed on and tor nos. 1-3 of vol. XI. and no. " , vol. XII., is printed on yellow paper. No. 2, vol. v., is,dated " Feb., Mch., Apr., 1897," no. is wrongly numbered on page 1 , "No. 1 ": no. 1, vol. vII., is dated "March, 1898," on the wrapper and " March-April, 1998" on page "March, 1898," on the wrapper and "March-April, 1898" on page numbers varies in height from 9 to $8 \frac{2}{2}$ inches. There are supplenumbers varies in height from 9 to 82 inches. There are supplements to nos. 2, 3, vol. I., Hos. 1, 4, val. 11, and to nos. 1, 3, vol. Nos. 3 and 4, vol. X., no. 4, vol. XI. and the four nos. of vol. XII. are only price lists. Amalgamated with "Stamp talk," April, are only price lists. Amalgamated with
1899, and re-established in February, 1901.

INTERNATIONAL PHILATELIST. The International philatelist. Wichita, Kas., C.W. Myers, I899-1900. $8^{\circ} .7^{3}-9$ in. Nos. 1-2, October, 1899-Mareh, 1900.

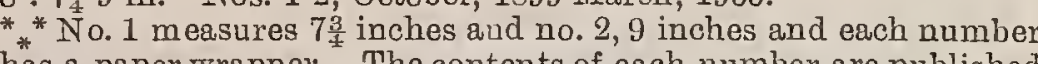
has a paper wrapper. The contents of each number are published in English and Spanish the heading to the latter portion being 


\section{INTERNATIONAL PHILATELTST}

"El Filatelista Internacional". No. 1 is numbered on the wrapper "Old Series. Vol. 10. No. 1. New Series. Vol. 1. No. 1 " and on pages 1 and 11, "Vol. 1. No. 1." No. 2 has no numbering on the wrapper, but bears "Volume 10. Number 1 " on the first page and "Volumen X. Numero Ir." on page (5). The Spanish part of no. 1 is dated "Octubre-Noviembre" Bound up with the "International Philatelist". St. Joseph, Mo., vols.
X.-xIr.

INTERNATIONAL PHILATELIST. The International

(-) philatelist. A journal devoted solely to the interests of philately, and of service alike to dealer and collector.

Northampton, Inuton.[printed], The International Stamp Exchange Co., I902.

8 $8^{\circ} .7$ in. Nos. 1-3, Oct.-Dec., 1902.

${ }_{*}^{*}$ * Nos. 2 and 3 have coloured paper wrappers.

Mis. St. Jour. 81 (12)

INTERNATIONAL POSTAGE STAMP ADVER TISER. See INTERNATIONAL POSTAGE STAMP REVIEW.

INTERNATIONAL POSTAGE STAIMP REVIEW

- The International postage stamp review. An illustrated journal of postage stamp literature and general information. London, E.C., Thomas Wilks, I863. $4^{\circ} .9 \frac{1}{2}$ in. Nos. 1-3, Aug. 1, Aug. 15, Sept. 1, 1863

* There is a supplement of two pages to no. 2 with the titl "The International postage stamp advertiser".

New Series. London, E.C., Thomas Willes, etc., x863. $4^{\circ} .8 \frac{1}{2}$ in. Nos. 1-6, Sept. 15, Oct. 1, Oct. 15, Nov. 1, Nov. 15 , **. Nos. 4 -6 were published by Welfare and Co., Southwark, London, S.E.

INTERNATIONAL STAMP. The International stamp. St. Paul, Minn., etc., Eben S. Martin and Leon $G$. Lambert, etc., $1896-98$.

$8^{\circ} .81$ in. 25 nos. in 3 vols.

Vol, I. Jan 23, July 27, 1896 . Nos, 1-12

.1 Ang. 20, 1896-Doc. $22,1897$.

"Irr. Jan. 22, 1898. No. 25

* "Nos. 13-25 were published by Eben S. Martin, at Minneapolis, Minn. Each number, excepting nos. 19-21, has a paper wrapper. Minn. Each number, excepting nos. 19-21, has a paper wrapper. 13 and $27,1896 "$. It was intended at the end of vol. I. to continue 13 and 27,1896 . It was intended at the end of vol. I. to continuc the journal monthly, but after no. 16 the publication became somewhat irtagular : no. 17 is dated "Dec. 1896, Jan, Fob., 1897," nos. 18-21, Ma1ch 21-June 21, 1397, and nos. 22-24, October 21-December 22,1897 . There are supplements with the title "The col-

INTERNATIONAL STAIMP JOURNAL. The International stamp journal.

St. Louis, Mo., J. Speed, Jr., I 890

$8^{\circ} .87-7 \frac{3}{4}$ in. Nos. 1-3, Sept.-Nov., 1890

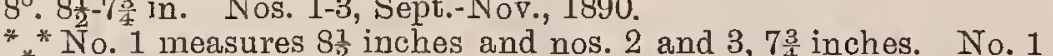
has a paper wrapper.

INTERNATIONAL STAIMP IMART. The International 1) stamp mart. Birmingham, D. Macdonald, rgor. 8. $7 \frac{1}{4}$ in. No. 1, May, 1901.

** The number has a coloured paper wrapper

Mis. St. Jour. 81 (8)

INTFRNATIONAL STAIMP RECORDER AND CURI OSITY IMAGAZINE. The International stamp recorder and curiosity magazine.

Dewsbury, A. Tolson and Co., x868. $8^{\circ} .8$ in. No. 1, May 1, 1868.

* The number has a paper wrapper. Mis. St. Jour. 37 (7).

INTERNATIONAL STAIMP REVIEW AND BRIC A BRAC JOURNAL. The International stamp review and bric à brac journal. I 880.

Battersea, London, S.W. ,Clark, Bennett and Co., $8^{\circ} .9 \frac{1}{2}$ in. Nos. $1-2$, Oct. 15 -Nov. $15,1880$.

**A copy of the prospectus of the journal is bound up in front of no, 1 . Mis. St. Jour. 12 (3).
INTERNATIONALE

INTERNATIONALE ANSICHTSPOSTKARTEN. U. BRIEFIMARKEN-ZEITUNG. Internationale Ansichtspostkarten- u. Briefmarken-Zeitung.

Köln, etc., Frau J. Jacobs, etc., 1899-1900. $4^{\circ} .12 \frac{1}{2}-13 \frac{1}{2}$ in. 25 nos, in 2 vols. INo 2 = Aminil/ M/1-18 1st year. Apl. 1-Dec. 15, 1899. Prospectus and Nos. 2 and 19.

* The prospectus is undated. Nos. 9-19 were published by Rupp u. Strom at Landau, and the numbers of the second year by Arnold Weichelt at Hanover. Wanting no. 6 of the second year.

INTERNATIONALE BIER-PHILATELIST. Der Internationale Bier-philatelist. . . . Festnummer zum Commers am viI. Deutschen Philatelistentage zu Mannheim, am 13, Juli anno domini 1895.

Mannheim, Giwdul Iragisir, 1895 .

Fol. 16 $\frac{1}{2}$ in. 7 th year. No. 28. July 13, 1895.

* The contents are of a humorous description. Mis. St. Jour. 108 (16)

INTERNATIONALE BRIEFIMARKEN-BÖRSE. Internationale Briefmarken-Börse. General-Anzeiger für den Kauf, Tausch und Verkauf und für das gesammte Sammelwesen von Postwerthzeichen aller Länder. Fol. 121 in. 29 nos. in 3 vols.

Leipzig, Theophil Weber, 1893-96.

Dec. 1893. "Probenummer."

[1st year.], Jan.-Dec., 1894.0 Nos. 1-12.

3rd " ] " - " $1895 . \quad 1-12$.

** Printed on buff paper. Nos. 9 and 10 for 1894 were published together. Wanting no. 6 for 1895

INTERNATIONALE BRIEFIARKEN-BÖRSE. Internationale Briefmarken-Börse (Central Offerten-Blatt für Philatelisten). Berlin, N., M. Schrinner, x 894 . Fol. 14 in. No. 1, January 5, 1894.

* * This number is in the nature of a prospectus and the contents *onsist entirely of advertisements. Wanting.

INTERNATIONALE BRIEFIMARKEN-BÖRSE. Internationale Briefmarken-Börse.

Temesvair, Ungarn, Johann Frr. Rácz, I goo.

$4^{\circ} .12 \frac{1}{4}$ in. Prospectus and nos. 1-4, Sept. 1-Dec. 1, 1900.

** The contents consist entirely of advertisements. There is prospectus of the journa dated "1900, 1 September. Nr. 1 " and no. 1 has "r. Jahrgang, 1 September, 1900. Nr. 1 ". The copy of no. 2 in the library has an advertisement cut out of pages 7,8 .

Mis. St. Jour. 137 (12)

INTERNATIONALE BRIEFIVARKEN - ZEITUNG

Internationale Briefmarken-Zeitung. (Offertenblatt fü Philatelisten.)

Schweidnitz, etc., O. Jéran, т888-ı89o go. 11-113 in, 25 nos. in 2 vols

1st year. Dec. 15, 1888, Jan. 15-Dec. 10, 1889. No. 1 and nos. 1-12.

2nd J"Jan. 15-Dec. 15, 1890. Nos, 13-24.

** Nos. 2-19 were published in Berlin and nos. 20-24 at Breslau. Nos. 8 and 9 and 20 and 21 were severally published together. Both the nos. 1 and nos. 2,3 and 13 have supplements of two pages.

[Continued as :]

Internationales Briefmarken-Journal. (Offertenblatt für Philatelisten.)

$$
\text { Brêslau, etc., O. Jéran, r891-94. }
$$

$8^{\circ} .11 \frac{3}{4}$ in. Vols. III.-Vr. 43 nos.

3rd year. Jan. 15-Dec. 1, 1891. Nos. 25-36.

4th " " 15-" 15, 1892. " 37-48.

5 th " " 15- " $" 15,1893 . \quad$ " $49-59$.

** Nos. 40-42 were published at Dresden, "43-46 at Ruaben, 47-50 *t Schweidnitz, $51-57$ at Berlin, 58-63 at Reichenbach and 64-67 at Liegnitz. v No. 32 is numbered in error " 31 ," nos. 35 and 36 at Liegnitz. $v$ No. 32 is numbered in error " 31 ," nos. 35 and 36 and 9 of the fifth year, single number " 56 " 25. A copy of the prospectus of the journal, dated November,

INTERNATONALE BRIEFIMARKGNZEITUNG.See SCHWEIZERISCHE BRIETMARKENZTITUNG.

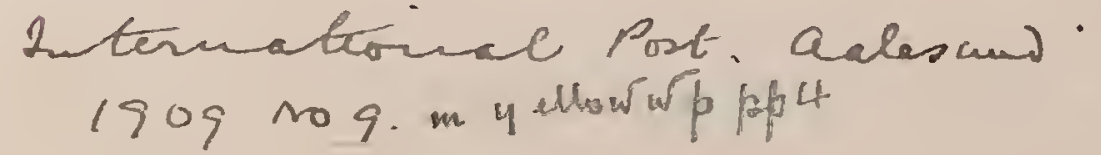

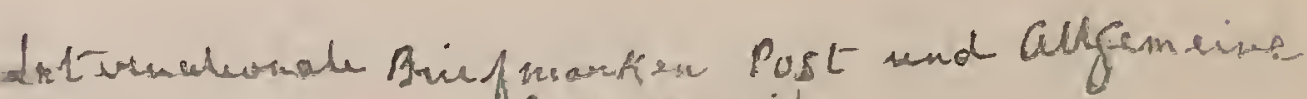
Jausch-Revec Co het wersta 


INTERNATIONAIE BRIEFMARKENZEITUNG "SÜDAIMERIKA". Internationale Briefmarkenzeitung "Südamerika". Organ für die gesammten Interessen des überseeischen Briefmarkenhandels. Czernowitz, Hermann Mittelmann, etc., I892-94. Fol. $13 \frac{1}{2}$ in. 8 nos. in 3 vols.

1st year. July 15 , Oct. 15,1892 . Nos. 1-2.

2nd "Jan. $15 / \mathrm{Apl}$. 15, Oct. 15,'1893. Nos. 1-4.

3rd " Feb. 15, Apl. 25, 1894. Nos. 1-2.

** Nos. 3 and 4 of the second year were published together under numbers of the third year were published by Stephenson und Mittelmann.

Mis. St. Jour. 73 (21).

INTERNATIONALF IMARKEN-BÖRSE. Internationale Marken-Börse. Eine Monatschrift für Brief-MarkenHändler.

Baltimore, Md., Albert von Degen, 1879. $8^{\circ} .11 \frac{1}{2}$ in. No. 1, Jan. 15, $1879 . \quad$ Mis. St. Jour. 72 (4).

INTERNATIONALE POST. Internationale Post. Philatelistisches Inserationsblatt.

Buenos Aires, Luis Husson, г89г.

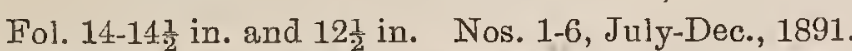

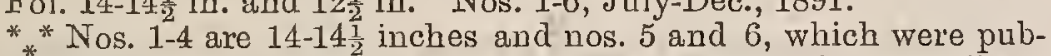
lished together, under the date " November-December, 1891," are $12 \frac{1}{2}$ inches. Bound up with the journal is a copy of the prospectus.

INTERNATIONALE SAM̃I.ER-WARTE. Internationale Sam̃ler-Warte. Central-Anzeiger und Offertenblatt für Philatelie. Roden, Sasar, J. K. Oden, I goo. 8. 93. in. Nos. 1-3, April 1-June 20, 1900.

** No. 3 has a paper wrapper.

INTFRNATIONALFR BRIEFTMARKEN - ANZFI GER. Internationaler Briefmarken-Anzeiger. (Philatelistisches-Insertions-Organ ersten Ranges.) Frankfurt, a M., Max Seligmann, I887.

P $4^{\circ} .11 \frac{3}{4}$ in. and fol. 131 in. Nos. 1-9, Feb.-June 30, Sept. 10, Oct.

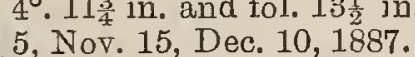

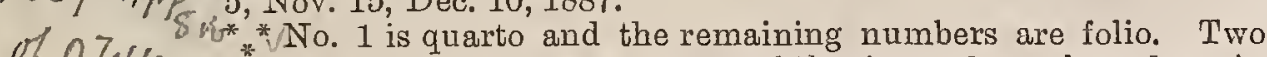
of 0 Telh . Nopies of different prospectuses of the journal are bound up in hen-l laum front of no. 1.
Mis. St. Jour. 73 (19).

u 1106 INTERNATIONALER BRIEFIMARIEN - ANZEIGER. Internationaler Briefmarken-Anzeiger. Insertionsorgan für Händler und Sammler.

$598 \times 893$

Fol. $11 \frac{1}{2}$ in. No. 1, March, 1893.

**" Printed on buff paper

Mis. St. Jour. 73 (10).

INTERNATIONALER BRIEFIMARKEN - ANZEIGER. Internationaler Briefmarken-Anzeiger. Insertions-Organ für Sammler und Händler.

Norrköping, Schweden, Herman Lindberg, I893. Fol. 113 in. Nos. 1-2, [Oct.-Nov.], 1893.

Mis. St. Jour. 73 (9).

INTERNATIONALER BRIFFIMARKEN - ANZEIGER. Internationaler Briefmarken-Anzeiger. [Prospectus of a journal to be published by W. Malende, Leipzig, in January, 1894, but which was never issued.]

Mis. St. Jour. 128 (8)

INTERNATIONALER BRIFFIMARKEN - ANZEIGER. Internationaler Briefmarken-Anzeiger.

Fol. 12 in. No. 1, May 15, 1895.

Ziurich, Fried. Girard, 1895 .

* * The contents consist entirely of advertisements.

Mis. St. Jour. 87 (14)

INTTRNATIONALER BRIEFMARKEN - ANZEIGER. Internationaler Briefmarken-Anzeiger. $Z$ ürich, etc., A. Schneebeli, etc.. I899- 1903.

$4^{\circ} .11$ in. Nos. 1-17, July 15, Sept. 1, Oct., Dec., 1899; Jan., Mar., May, Juue, Sept., Oct., Dec., 1900, Feb., Sept., 1901, Apl., 1902, Mar, Apl., June, 1903.

S.98 ** Nos. 14-17 were published at Luzern by Alb. Bucher-Brun. There is a supplement of 2 pages to no. 6 and one of 4 pages to no. 8. This journal was continued in January, 1907, with no. 18, published by A. Schneebeli at Zürich.

$$
\begin{aligned}
& \text { Incemationale Runtseles fï } \\
& 1510 \text { I.1 (Oct) 4( } \mathrm{dec}) \\
& 1,11 \text { स }
\end{aligned}
$$

Alternationalc téting. Hawhburg.
NTERNATIONAIJR BRIEFIIARKEN - ANZEIGER MERKUR. See Mercur.

INTERNATIONALER PHILATPLISTEN-FREUND. Internationaler Philatelisten-Freund. Insertions-Organ für den gesammten Briefmarkenhandel.

Lyck, Otto Raphael, I882.

Fol. $12^{3}$ in. Nos. 1-2, Jan. 15-Feb. 15, 1882.

** The contents consist entirely of advertisements. No. 1 has only one leaf while no. 2 has two leaves.

Mis. St. Jour. 108 (2).

INTERNATIONALER POSTWERTHZEICHENHÄNDLER-VEREIN. Internationaler Postwerthzeichenhändler-Verein. [Mitteilungen.]

$4^{\circ} .11 \frac{1}{2}$ in. [No. 1.] September 27-October, 4, 1886.

Berlin, I 886.

[Continued as :]

Streng vertraulich. Internationaler Postwerthzeichenhändler-Verein.

$4^{\circ} .11 \frac{1}{2}$ in. 16 nos.
Oct. 18-Nov. 1; Dec. 6, 1886. [Nos. 2-3.] Dec. 20, 1886-Jan. 3, 1887, and report for 1885-86; Jan. 17-31; Feb. 14-28; Mar. 14; Apl. 14; May 2; May 16; June 1-15; July 18; Aug. 1; Aug. 15;
Sept. 19; Sept. 5-Oct. 3; Oct. 17-Nov. 7-21-Dec. 5, 1887. [Nos. 1**.] No. 1 of 1887 has " 20 December, 1887," in error for " 1886 " No. 13 has the words " (Verspätet eingegaugen)" beneath "S Streng vertraulich".

\section{[Continued as :]}

__ Sitzungsbericht... des Internationalen Postwerthzeichen-Händler-Vereins

$4^{\circ} .11_{2}^{\frac{1}{2}}$ in. and $18^{\circ} .99^{3}-10 \frac{1}{4}$ in. 60 nos.

Dec. 19, 1887. [No. 15.]

Jan. 2, Jan. 16, Feb. 6, Feb. 17, Mar. 5, Mar. 19, Apl. 16, May 7 , June 4, July 2, July 16-Aug. 6, Oct. 1, Oct. 15-Nov. 5, Nov. 19, Dec 3 , Dec. 17 , Dec. 27,1888 . [Nos. 1-17.]

Jan. 7, Jan. 21, F'eb. 18, Mar. 4, Mar. 18, Apl. 1, Apl. 15, May 6, June 17, Sept. 23, Oct. 28, Dec. 2, Dec. 16, 1889. [Nos. 1-13.] Jan. 6, 20, H'eb. 3, 17, Mar. 3, 17, Apl. 14, Apl. 28-May 5, May 19June 2, June 16, 30, Sept. 1, 15, Oct. 6, 20, Nov. 3, 17, Dec. 1, 15, 1890. Nos. $1-20$

Jan. 19, Feb. 2, 16, Mar. 2, 16, Apl. 6, 20, May 4, 25, 1891. Nos. 21-29.

*** The numbers for the years 1887, 1888, 1889, and nos. 1-19 of 1800 are quarto and the remaining numbers are octavo. No. 8 of 1890 is dated " 28 April und' 5 Mai, 1890 " and nos. 9 and 10 of that year were published together with the dates " 19 Mai, 1890 " and " 2 Juni, 1890 ".

\section{[Continued as :]}

Mittheilungen und Sitzungsberichte des Internationalen Postwerthzeichen-Händler-Vereins zu Berlin.

8․ $10 \frac{1}{4}$ in. No. 30, June-July, 1891.

Berlin, I89r.

\section{[Continued as :]}

Mittheilungen des Internationalen PostwerthzeichenHändler-Vereins zu Berlin.

Berlin, I89I-

$8^{\circ} .104-91$ in. nos. In progress.

Aug. 24, Sept., Oct.-Nov., Nov., Dec., 1891. Nos. 31-35.

Jan., Feb., Mar., Apl., May, June-July, Sept., Oct., Nov., Dec., 1892. Nos. $36-45$

Jan., Feb., Mar., Apl., May, June 12, July 16, 28, Aug. 26, Sept. 9,23 , Oct. 8 , Nov. 12, 29, Dec. 9,'23, 1893. Nos. 46-61.

Jan. 8, 20 , Feb. 10,'24, Mar. 10, 24, A pl. 7, 21, May 12, 26, June

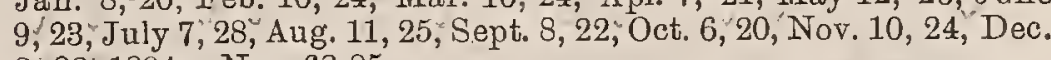
$8,22,1894$. Nos. 62.85 .

Jan. 12, 26, Feb. 9, 23, Mar. 9, 23, Apl. 6, 20, May 11, 25, June 11, 22, July 6,"Aug. 10, 24 ;'Sept. 7, 21; Oct. 12, 26, Nov. 11; 25;'Dec. 8; 20, 1895 . Nos. $86-108$

Jan 11; 25,'Feb. 8, 22,'Mar. 7, 21, 27, Apl. 13, 25, May 9, 28', June 6; 18; July 11, 25; Aug. 11, 22, Sept. 12, Oct. 10, 24, Nov. 6, 21; Dec. $5,19,1896$. Nos. 109-13

Jan. 9,'28,"Feb. 6, 20,"Mar. 6, 19, Apl. 9, 24, May 20, June 3, July 3 , Aug. 4, Sept. 2, 17; Oct 1', 15, 29, Nov. 19,' Dec. 2, 16, 1897. Nos. $138-152$.

Jan. 13, 27, Feb. 16, Mar. 4, 15, 31', Apl. 13,"28', May 12, 26, June 9, 24, July 13, 28,' 'Aug. 18,' 31', Sept. 29, Oct. 20, Nov. 3, 17, 30, Dec. $8, " 22,1898$. Nos. $153-175$

Jan. 10, 16, 25, Feb. 9, 22; Mar. 8, 23, Apl. 13, 26, May 12, 26, June 6,'20,'July 11, 25,'Aug. 9; 31,'Sept. 20, 27, Oct. 11, 25, Nov. 8, 22,' Dec. 13', 1899. Nos. 176-199. 
Jan. 4, 16, 27, Feb., 12, 24, Mar. 17, Apl. 2, 18, 30, May 14, 26 June 16,30, July 14, Aug. 11, 29, Sept. 8, 22, Oct. 14, 29, Nov. 17 Dec. $1,15,1900$. Nos. 200-222. an. 4, 15, 28, Feb. 16, Mar. 4, 16, 30, Apl. 13, 27, May 11, 25 June 17, July 1, 15, Aug. 19, Sept. 2, 24, Oct. 1 , 15, Nov. 19,

Jan. 21, Feb. 4, 18, Mar. 4, 18, Apl 1, 16, 29, May 21, June 4, 18, July 1,16 , Sept. $5,22,30$, Oct. 20 , Nov. 4,18 , Dec. $1,17,1902$ Nos. $246-266$

Jan. 19, 31, Feb. 21, Mar. 4, 18, Apl. 3, 22, May 6, 20, June 3, 17 July 1,15 , Aug. 22, Sept. 4, 18 , Oct. $8,16,30$, , Nov. 20 , Dec. 5,24 Nos. $267-288$

Jan. 21, 30, Feb. 19, Mar. 19, Apl. 16,30, May 21, June 4, 18, July 1, 8, Aug. 17, Sept. 19, Oct. 8, Nov. 6, 24, Dec. 5, 31, 1904. Nos. $289-306$

Feb. 14, 18, Mar. 3, 18, 31, Apl. 22, May 6, 20, June 3, 17, 30, Aug 5,19 , 31, Sept. 16,30 , Oct. 24 , Nov. 4, 18, Dec. $2,16,1905$. Nos $307-327$

Jan. 6, 20, Feb. 3, 17, Mar. 3, 17, 31, Apl. 14, May 5, 19, 31, June 16, 30, Aug. 4, 18, 31, Sept. 22, Oct. 6, 20 , Nov. 3, 17 , Dec. ' 1

* There are separate title-pages for the years 1899-1906, supplements to nos. 173 and 185 and a "Sonder-Ausgabe" to no. 323 (to 1906.

INTERNATIONALES

\section{"CONCORDIA"}

BRIEFIMARKENBLATT

Internationales Briefmarkenblat

"Concordia". Organ für die gesammten Interessen der Postwerthreichenkunde.

B.-Leipa, E. Jäger; I 895 $8^{\circ} .9$ in. Nos. 1-3, Apl. 16, June 20, Aug. 16, 1895

ho/ has a leaf (simp) of Rules 2ppr. Mis. St. Jour. 109 (3). [Continued as :]

Rund um die Erde. Insertions-Organ für BriefmarkenSammler und-Händler.

Friedland, Emil Schicketanz, I 896 $4^{\circ} .10$ in. Vol. II, 5 nos.

2nd year. Mar.-July, 1896. Nos. 1-5. Mis. St. Jour. 109 (3a).

INTERNATIONALES BRIEFMARKEN JOURNAL. See Internationale Briefmarken-Zeitung.

INTERNATIONALES BRIEFIMARKEN - OFFERTENBLATT. Internationales Briefmarken-Offertenblatt. Insertions-Organ für Sammler und Händler. Poessneck i. Th., C. G. Vogel, r892Fol. $12 \frac{1}{4}$ in. nos. in vols. In progress.
1st year. [Jan. 25]- Dec., 1892. Nos. 1- 12. 2nd " " $25-["]$ 1893. " $13-26$.

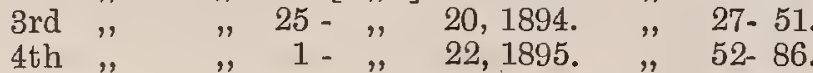
5th " " " $\quad 1$ - " $28,1896 . \quad$ " $\quad 87-126$.

6th " " " 4 - " $27,1897 . \quad$ " $127-177$.

8th " $\quad$ th $\quad 1-\quad " \quad 20,1898 . \quad$ " $178-213$

9th " " " 2 - " 20,1900 . " " 250-283.

10th " , " " 1 - ", 20,1901. ", 284-319.

11th " " $\quad 1-\quad " \quad 20,1902 . \quad$ " $320-355$.

13th " " " 1 - " 20, 1904. " 392-427.

14th " " " 1 - " $\quad 20,1905 . \quad$ " $428-463$.

* * The contents consist" entirely of advertisements. Nos $1-8$ and * 26 have no month of publication given. No. 127 is found with "5. Jahroang" and al'so with " 6 . Jahrgang". The and with nos. 143, one numbered "142" and dated " 20 . April 1897 " (the "as. 14atc as no. 142); a second number the same as the last but " overprinted above in heavy type " " with the last numbered "Nr. $143 \mathrm{~b}$ ". "There are two numbers 149, one dated "10. Juni 1897," the othe "14. Ju "21 " tw" 1897 " tw 150 , one dated " 20 . Juni 1897 " "he other "21. Juni 1897 " two numbers 152 , one dated "1. Jul " Juli 1897 ; two numbers 153 , one dated " 10 . " "20. Jul " 1897, the other "26. Juli 1897 " and with the number "156" overprinted in heavy type "No. 155 "; two numbers 156 one dated "1. August 1897" the other" ". August " 1897", two numb" " 1897 " and two number" 159 , one dated "23. August 1897" the "1. "25. August" 167". Som? of the copies " no. 169 dated 1. November " heavy figure "g" overpinted over the numeral " 8 ," while others have a heavy figure "g " overpin" " 7 " of " 1897 " TThere "and also, in error, over the numeral " 7 " of "1897" "There are two numbers 196, one dated "1. Jul 10. Tul "1898" the other "12 Jul two numbers 197, one dated "10. Juh "1898," the other "12. Juli "
September 1898," the other "21. September 1898"; and two numbers 206 , one dated "10. Oktober 1898," the other "11. Oktober 1898 ". No. 283 is wrongly numbered " 282 " and is dated in error "10. Dezember 1900," but the numbering and the date on the wrapper are correct. No. 356 has " 1902 " in place of " 1903 " No. 440 of " 1 . Mai 1905 " is wrongly numbered " 439 " and no. 465 is wrongly numbered " 565 ". "There are two editions of no. 345 ond "Ausgabe fur Oesterreich-Ungarn" 176 the are two editions of nos. 139, 146, 161, 162,167, 168, 173, 176, 188 are two editions of nos. 139 , $146,161,162,167,168,173$, 271 , (1) . (26. April 1897", (as opies of nos. 448 and 488 were also issued with additional coloured wrappers incer XII Deutsch-Oesterr. Philatelisten-lag " vom 21. bis 24. Juli 1905 zu ischer Philatelistentag in Nïst-Ausgabe 18. Deutsch-Oesterreichischer Phil 1906 ".

INTERNATIONALES OFFERTEN-BLATT FƯR PHILATELIE. Internationales Offerten-Blatt für Philatelie. Brandenburg a. H., F. Meinecke, Jr. I 888. Fol. $12 \frac{3}{4}$ in. F Nos. 1-5, July 1, 25, Aug. 25, Oct. 20, Dec. 10,1888 Mis. St. Jour. $73(16)$

\section{INTERNATION ALES OFFERTENBLATT FU்R PHI}

LATELIE. Internationales Offertenblatt für Philatelie Sonneberg S. M., C. A. Mylius, x896-

Fol. 127 in. nos. in vols. In progress.

1st year. July 1-Dec. 20, 1896. Nos. 1-17.

2nd ", Jan. 1- ", 20, 1897. " $1-36$.

4th " " " 1- " 20, 1899. " "1-36.

5th " " 10- " 20, 1900. " "1-36.

6th " " "1- " 20, 1901. " "1- 8 and 10-36.

7 th " " $10-", 20,1902 . \quad " 1-36$.

8th " " 1- " 20, $1903 . \quad, 1-36$.

9th " " $1-\quad, \quad 20,1904 . \quad, \quad 1-36$.

11 th " " $" 1-, " 15,1906 . \quad$ " $1-24$

* The contents consist mostly of advertisements. There is no number for"August 20, 1896 and no. 13 of that year is dated " 20 November" in mistake for "10. November". No. 23 of the third vear is dated "10. u. 20. Aug. 1898". Nos. 1 and 2 of the fifth year were published together with the date "10 Januar 1900 " some copies being numbered "Nos. 1 u. 2 " and others "No. 2 ", no. 22 of that year is wrongly numbered " 21 " and nos. 23 and 24 of the same vear were published together, with the date "10. August 1900 ". There is no no. 9 of the sixth year, no. 10 of that year is dated " 31 . März 1901," and no. 18 of that year is dated " 1 . Jul 1901 " instead of "20. Juni 1901 ". Nos. 1 and 2 of the seventh year and nos. 10 and 11 of the eighth year were severally published together with the respective dates "10. Januar 1902 " and " 10 . April 1903 ". Wanting 1898, no. 31; 1899, no. 34 and 1900, no. 3.

INTERNATIONALES PUBLICATIONS-ORGAN IM BRIEFIMARKEN. UND ANSICHTSPOSTKAR TENWESEN RESP. DESSEN VERTRIEB UND TAUSCH. Internationales Publications-Organ im Briefmarken- und Ansichtspostkartenwesen resp. dessen Vertrieb und Tausch. Offiz. Organ des Intern. SammlerVerb. "Ratisbona" Regensburg (Deutschland). Organ jeden schlauen Sammlers.

Fol. $12 \frac{1}{2}$ in. No. 1 , July 1,1900

Regensburg, J. Wullinger, x goo. * Contains a supplement of two pages.

Mis. St. Jour. 105 (14)

INTERNATIONALT FRIMAERIEBLAD. Internationalt Frimaerkeblad. Annonceblad for Frimaerkesamlere og Handlere.

Mosi申en, Norge, A. Krantz og Co., I 894 $4^{\circ} .11$ in in. No, 1, September 15, 1894

** The contents consist entircly of advertisements.

Mis. St. Jour. $120(7)$

INTERPOLITAN IMAGAZINE. The Interpolitan magazine. Omaha, Neb., Jessen Bros., I898. $8^{\circ} .9$ in. nos. in 2 vols. Vol. I. July*"* I. July** Some of the numbers only, contain philatelic matter. The
library contain nos. 5, 8, 9, dated "May," "August" and "September, 1898," respectively. Each of these numbers has a paper tember, 189

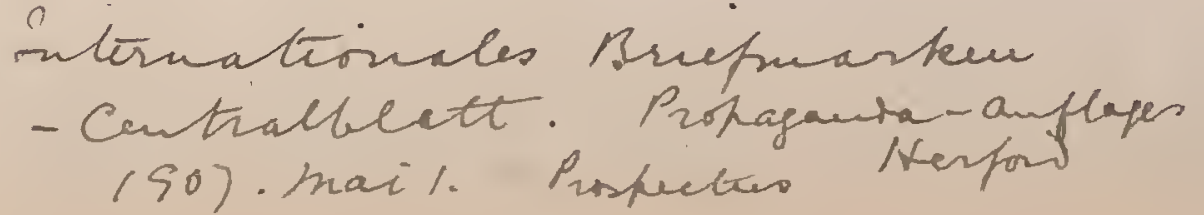

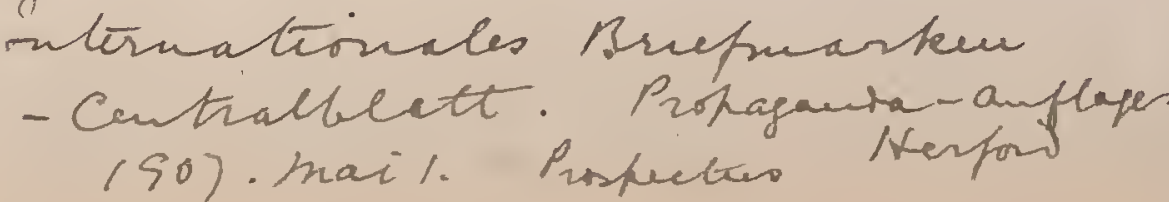



Jquique Filuteloco-1899-5 99

$$
1 \text { sis }(22.11 .1892)-1892-599
$$


INVESTIGADOR AIMERICANO. EI Investigador Americano. Revista de arqueologia, bellas artes, bibliografia, epigrafia, filatelia, filologia, folklorismo, genealogia, heráldica, historia, literatura, milicia, numismática, periodismo. Buenos Aires, José Arturo Scolto, I 903-04. $8^{\circ} .10 \frac{1}{2}$ in. Nos. 1-4, July 15, 1903, March 15, April 23, April 30, 1904.

** There is a coloured paper wrapper to each number. No. 2

INVESTIGATEUR ILLUSTRÉ. L'Investigateur illustré des collections nouvelles ou peu connues. Intéresse les philatélistes, les cartophiles, les amateurs du vieux papier et du bibelot.

$8^{\circ} .10$ in. 13 nos. in 2 vols.

1st year. June-Dec., 1904. Nos. 1-5.

2nd "Jan -Oct, 1905.

** There is a coloured paper" wrapper to each number. Nos. 2 and 3 of the first year and nos. 7 and 8 of the second year are dated respectirely, "' Juillet-Août 1904,", "Sept.-Oct., 1904,"

Mis. St. Jour. 125 (10).

IOWA AMATEUR JOURNAL. The Iowa amateur journal. Keokuk, Ia., M. A. Runner and Co., I876. $4^{\circ} .10 \frac{1}{2}$ in. Vol. Ir. No. 1, October 1, 1876.

* * Only partly philatelic. Vol. I. had the title "The Modoc" and was non-philatelic.

IOWA MIOON. Iowa moon.

Waverly, Ia., Frank Bottcher, I884. Fol. $11 \frac{1}{4}$ in. and $8^{\circ} .83$ in. Nos. 1-3, February, April, May, 1884. ** Only partly philatelic. Nos. 1 and 2 are folio and no. 3 is octaro. The latter contains a supplement.

Mis. St. Jour., 140 (12).

IOWA PHILATELIC WEEKLY. The Iowa philatelic weekly.

Wyoming, Ia., Philatelic Publishing Co., I894. Fol. 12 in. Nos. 1-6, Apl. 5, 12, 20, 27, May 4, 11, 1894

Mis. St. Jour. 72 (11).

IOWA PHILATELIST. The Iowa philatelist.

* $16^{\circ} .5 \frac{1}{2}$ in. No. 1 , June, 1877

Davenport, Ia., A. Schricker, 1877.

* * Printed on pale rose paper with a supplement of two pages on white paper.

Mis. St. Jour. 68 (7).

"I. P. R." AND COLLECTORS' NEWS. The "I. P.

- R." and collectors' news. A newspaper for collectors of stamps, coins, postcards, etc., etc.

Luton, Beds., The Collectors' Press Agency, r 902-03. ○ $8^{\circ} .11 \frac{1}{4}$ in. Nos. 1-3, Nov. 10, Dec. 17, 1902, Jan. 17, 1903.

** There is a "Christmas story supplement" of 8 pages to no. 2. See also "I. P. R. and Collectors news. Advertisement supplement". v6-3 Mis. St. Jour. 77 (3) - New Series.

Luton, Beds., The Collectors' Press Agency, i 903.

$8^{\circ} .11$ in. No. 1, Feb. 7,1903 . Whe number has a coloured paper wrapper. The title on page 1 reads "The I. P. R. a monthly magazine for young and old collectors," and on the front paper wrapper "The I. P. R, and Collectors' news ". $\checkmark$

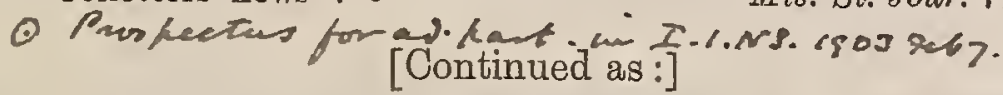

- The Collectors' news and pastimes review, illustrated.

[Devoted to stamp, coin, curio and picture postcard colThw lecting, with seasonable notes on cycling, photography un khe wh and general sport. I (New Series.)

not ine London, W., The Collectors' Supply Agency, I903.

$8^{\circ} .11$ in. Nos. 2-7, Mar. 7, Apl. 4, May 2, June 6, July 4, Aug., 1903.

fach mi vlcue art. Proshectes swogft. in

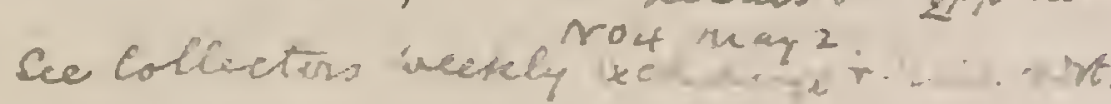

Collectors' newrs weetely sted anye

cicular. Puspetas in Collucters

news, Iso3 Af 4. ans ant in may (bole $x$

Stehange; /8voleaf.
** There is a coloured paper wrapper to each number. There are supplements with the title "Sale and exchange, and miscellaneous advertisements" to nos, 2-4 and two headed "Sale and " exchange, and advertisement supplement" to nos. 5 and 6 . The title on the first page of each number reads "The Collectors" * news. A monthly magazine for young and old collectors." The wrapper of no. 7 does not bear "vol. I." nor the words "New Series ". Amalgamated with "W. H. Regan's monthly circular"

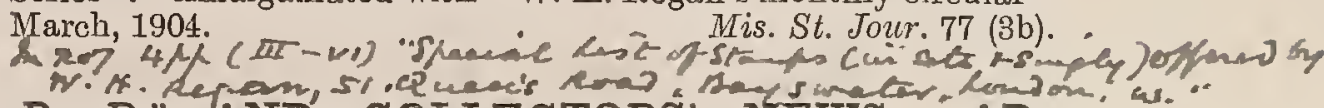

"I. P. R." AND COLLECTORS" NEWS. AD.

6 VERTISEIENT SUPPLEIMENT. The "I. P. R." and Collectors' news. Advertisement supplement. Luton, Beds., The Collectors' Press Agency, I 902. $8^{\circ} \cdot 11 \frac{1}{4}$ in. No. 1 , Nov. $10,1902 . \cdot 2$ dee/7

* *'This is a separate publication to the "'I. P. R.' and Collectors' news," although published by the same agency.

Mis. St. Jour. $77(4)$

IRISH PHILATELIST. The Irish philatelist. [Prospectus of a journal to be published by A. Horneck, Dublin, on March 1st [1898], but which was never issued.]

Mis. St. Jour. 78 (5).

ISLAND HERO. The Island hero. 1873 .

Summerside, Prince Edward Island, S. M. Graves,

$8^{\circ} .9 \frac{1}{2}$ in. Nos. 1-2, May-June, 1873

** Only partly philatelic. Wanting no. 2.

Mis. St. Jour. 135 (21)

ITALIA FILATELICA. Italia filatelica. 95.

Palermo, Giulio Maggiore di S. Barbara, etc., I894-

Fol. $12 \frac{1}{4}$ in. 8 nos. in 2 vols.

1st year. July 1-Nov. 15,1891 . Nos. $1-5$

2nd "Jan. 31, Apl. 15, May, 1895. Nos. 1-3.

** Nos. 2 and 3 of the second year were published by Giovauni Gandolfo Sangiuseppe. Mis. St. Jour. 137 (5).

[Continued as :]

- Italia filatelica e Consigliere Filatelico fusi insieme. Palermo, Joseph E. Marsala, I895-96.

Fol. $12 \frac{1}{4}$ in. Vols. Ir.-rrr., 5 nos.

2nd year. Sept. 20-Dec. 20, 1895. Nos. 9-12

3rd " Jan. 20, 1896. No. 1. Nis. St. Jour. 137 (5a).

ITALIA FILATELICA. L' Italia filatelica. Torino, M. Alliney, I 905.

Fol. $11 \frac{1}{4}$ in., $13^{3}$ in., and $8^{\circ} .10$ in. Nos. 1-10, March 15-Dec. 31,

${ }^{*}{ }^{*}$ *No. 1 , which measures $11 \frac{1}{4}$ inches, vas produced by a hand multiplying press, nos. 2-5 measure $13 \frac{3}{1}$ inches and were printed by autographic lithography and nos. $6-10$ measure 10 inches and are printed in the usual way. Nos. 7 and 8 and 9 and 10 were severally published together with the dates "31 Ottobre, 1905" and " 31 Dicembre, $1905 " .$, Nos. 9 and 10 have a coloured paper
wrapper.
Mis. St. Jour.124 (11).

\section{ITALIA FILATELICA E CONSIGLIERE FILA-}

TELICO FUSI INSIEME. See ITALIA FILATELICA.

ITALIE. L' Italie.

Bisceglie, Italie, G. Carlo de Villagomez, I 905.

$8^{\circ} .8 \frac{1}{4}$ in. [No. 1], March 25, 1905.

** Produced by a hectographic process with the date " 25 Septembre, 1904 " and over the month and year is written "Marzo, 1905 " with pen and ink. The contents consist entirely of stamp
dealers" advertisements.
Mis. St. Jour. $145(6)$.

Stälie phratique Jano

1909 I 1102 (6ct31) No! (sept) No3 (secio)

O Lrish Hattirlist. 1916 see 30 . vol 


$$
\begin{aligned}
& \text { Cackson's montily Crenlar. }
\end{aligned}
$$

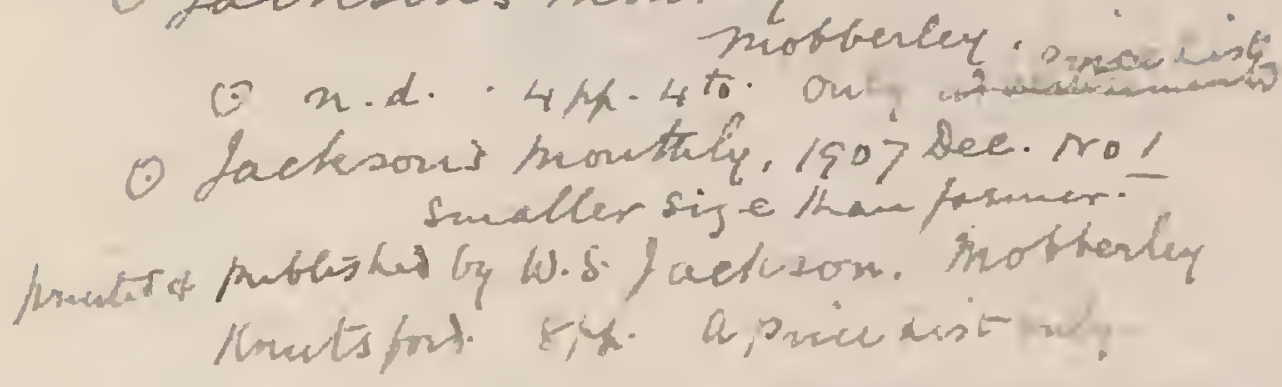

JALISCO FILATELICO. Jalisco filatelico.

Guadalajara, Jal., Mexico, Antonio Arceo, r9o6. Fol. 12 in. Nos. 1-7, May 5-Ost. 6, Oct. 25, 1906.

Mis. St. Jour. 124 (6)

J. ALLAN IMASON AND CO. CIRCULAR. J. Allan Mason and Co. circular. Brooklyn, L. I., I 874-75. $8^{\circ} .8 \frac{1}{2}$ in. Nos. 1-2, Dec., 1874-June, 1875. Mis. St. Jour. 68 (3).

JAIMES R. GRANT AND CO.'S PHILATELICAL

$\odot$ CIRCULAR. James R. Grant and Co.'s philatelical circular. Birmingham, etc., I872-74.

S99 Z679 $4^{\circ} .81$ in. and $8^{\circ} .8$ ia. Nos. 1-10, Fob. 1-June 1, 1872, Sept. 1, 1872, Mar. 20, Aug. 7, Nov. 21, 1873, Doc, 23, 1874. all $r f$.

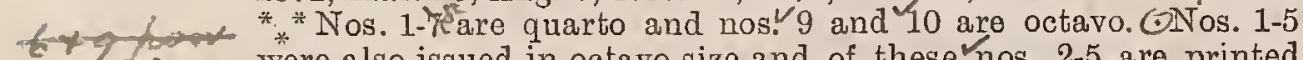
were also issued in octavo size and of these nos. 2-5 are printed on thicker paper. No. 9 was published at Dawlish and'no. 10 at St. Mary Church, Torquay. OTher 3 is a supplement of two pages to no. 6, dated "September 15th, 1872," with the heading "Additions and corrections to James $\mathrm{R}$. Grant and Co.'s circular, of the plates to appear in the "Philatelical patalogue," to no. 9

JERSEY STAIMP. The Jersey stamp.

Avondale, N.J., D. B. Crockett, 1897 . $24^{\circ} .6$ in. Nos. 1-2, Jan.-Feb., 1897.

**No. 2 has a coloured pæuper wrapper. Mis. St. Jour. 96 (8).

JERSEYMAN. The Jerseyman.

Hightstown, N. J., etc., H. E. Deats, r891. $8^{\circ} .10$ in. Nos. 1-3, April, September, December, 1891. * * Only partly philatelic. There is a coloured paper wrapper to each number. Nos. $2-3$ were published at Flemington, N. J Mis. St. Jour. 131 (9).

JOHN GRAY'S POSTZEGELNIEUWS. John Gray's Postzegelnieuws. Utrecht, John Gray and Co., x904-05. $8^{\circ} .11$ in. and $8 \frac{1}{2}$ in. 10 nos. in 2 vols.

1st year. Nov. 1, 1904-July, 1905. Nos. 1-9.

2nd year. Oct., 1905. No.1.

2nd " Oct., 1905. No. 1 . * Nos. 1-3 measure 11 inches and are solely prico lists of stamp atc., for salo by the pusure $8 \frac{1}{2}$ inches and contain philatelic notes. Nos. 7 and 8 were pub-
lished together.
Mis. St. Jour. $130(16)$.

JOHN W. SCOTT'S JUNIOR WEEKLY LETTER. John W. Scott's Junior weekly letter.

New York, The J. W. Scott Co. Ltd., I897. $8^{\circ} .9 \frac{1}{2}$ in. [Nos. 1-5], Mar. 13, 20, 27, Apl. 3, 10, 1897.

Mis. St. Jour. 126 (11)

[Continued as :]

_ John W. Scott's weekly bulletin.

Now York, The J.W. Scott Co. Ltd., I897. $8^{\circ} .9 \frac{1}{2}$ in. [Nos. 6-23], Apl. 17, 24, May 1, 8, 15, 22, 29, June 5, 19 July 3, 17, 31, Aug. 14, 23, Sept. 11, Oct. 2, 16, Nov. 13, 1897. * * Wanting the no. for November 13. Mis. St. Jour. 126 (11a).

JOHN W. SCOTT'S WEEKLY BULLETIN. See JOHN W. SCOTT'S JUNIOR WEEKLY LETTER.
JORNAL PHILATELICO

JORNAL PHILATELICO. Jornal philatelico.

Sð0 Paulo, Brazil, Mr. Copenhagen, г897-г 900. Fol. 121 in. and $8^{\circ} .11$ in. 23 nos. in 3 vols.

Vol. I. Mar. 1-Dec. 1, 1897. Nos. 1-10.

$\begin{array}{rlll} & \text { II. Jan. 1-Nov. 15, } 1898 . \quad \text {, } & 1-10 . \\ \text { III. Mar. 1-May 10, } 1900 . & \text {, } & 1-3 .\end{array}$

*" "There is a paper wrapper to each number and an index to vol. I. The numbers of vol. I. are folio and those of vols. II. and III. are octavo. No. 9 of vol. II. is dated "Setembro-Outubro," and nos. 1 and 2 of vol. II. are further numbered respectively "Anno I. No. 11" and "Anno I. No. 12 "; nos. 3-10 of the same vol. are further numbered respectively "Anno II. No. 13 " -"Anno II. No. 21," no. 9 having "Anno II. No. 19, 20." There is a portrait supplement to no. 3, vol. Ir., and nos. $3-10$ vol. I., and no. 1, vol. II., contain "Club Philatelico de Săo Paulo. Fundado em 24 de Junho de 1896. Bolotin Official," nos. 1-9 These are, however, paged up with the rest of the journal and nos. 8 and 9 are wrongly numbered " 7 " and " 8 ," respectively, and no. 8 is further dated " $1^{\circ}$ de Novembro" in error for " $1^{\circ}$ de Dezembro".

JOTTINGS. Jottings. Part 1, January, 1894. [Contains articles: "Stamp collecting," "Perforation of postage stamps," "The Tapling collection of postage stamps," "Invention of adhesive postage stamps" and "Phila- S qa telic jottings".] Accrington, Henry Garside, I894. $4^{\circ} .10$ in. pp. $9-12$

** The number has a coloured paper wrapper.

Mis. St. Jour. 132 (13)

JOURNAI. Le Journal. Troisième année. No. 596 Mai 16, 1894. [Contrins a number of caricatures of French stamps by A. Mantelet.]

Fol. $24 \frac{3}{4}$ in. p. 2.

Paris, Frornand Xau, I894. Mis. St. Jour. 136 (18).

JOURNAL. The Journal.

Diller, Neb., Earl Pearce, etc., I 906. 8. 7 in. Nos. 1-6, [? ]-June, 1906.

* * Only partly philatelic. Nos. 5 and 6 were publishęd to* *ther and nos. 4-6 were published by the Journal Publishing Co. There is a coloured paper wrapper to each number and the title on that of nos. 5,6 , reads "The Collectors journal ". Wanting nos. 1,2 .

JOURNAL D'ANNONCES DES COLLECTION. NEURS ANVERSOIS. Journal d'annonces des collectionneurs Anversois. Organe mensuel de la Bourse de timbres d'Anvers. Anvers, Alkert Sebus, I892. 4․ 11 in. Nos. 1-3, Apl. 1-June 1, $1892 . \quad$ Mis. St. Jour. 105 (8).

JOURNAL DE LA TIMBROLOGIE FGYPIIENNE. Journal de la timbrologie Figyptienne. Organe des collectionneurs et des marchands de timbres-poste.

Alexandrie, E. Guttmann, I894-95.

Fol. 11 in. 15 nos. in 2 vols.

1st year. June 1, 1894-May, 1895. Nos. 1-12.

2nd "J June -Aug., 1895. "13-15. ** Nos. 9-15 have coloured paper wrappers

$$
\begin{aligned}
& \text { fownal d'annoncees Phelatiliques f Rarbunos } \\
& 1907 \text { Is - nuy }
\end{aligned}
$$

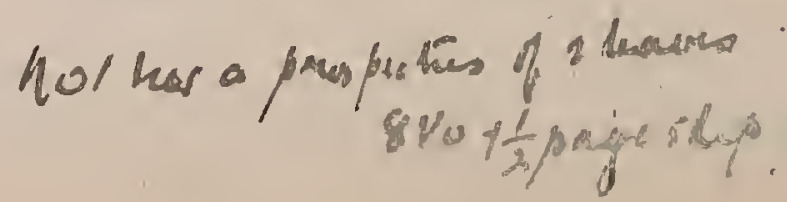




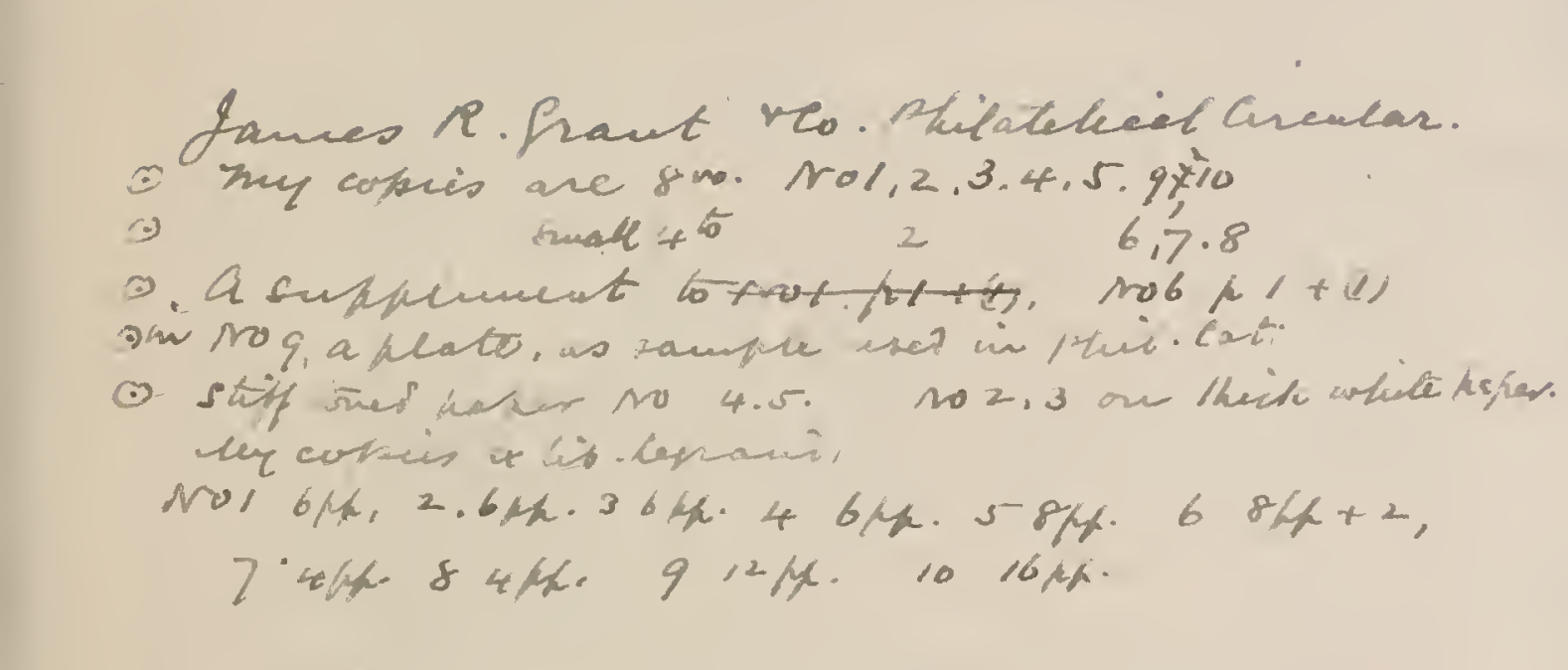

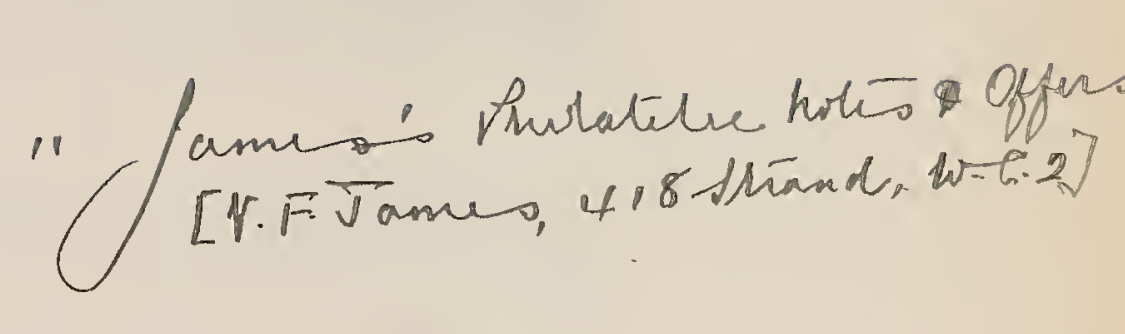


JOURNAL OF THE PHILATELIC LITERATURE SULIEA $x$.

Phitatic Society).

(London, Philater-14). Privately bound, half morocco.

Vols. VIII-XI $(1915-18)$. Unbound.

JournaL PHOLATELIQUE DE BERNE

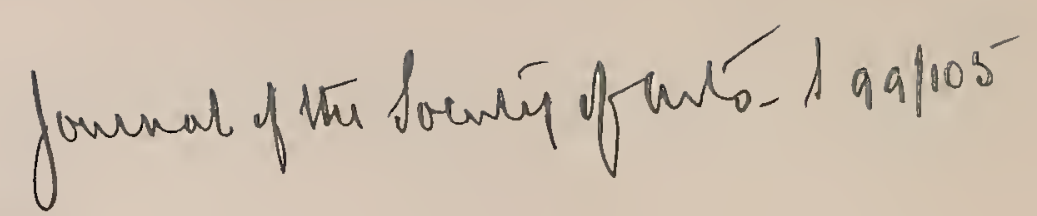


605 JOURNAL DES COLLECTIONNEURS

JOURNAL DES COLLECTIONNEURS. Journal des collectionneurs. Organe mensuel consacré à l'étude des collections historiques, documentaires et artistiques, numismatique, philatélie, iconographie, heraldique, exlibris, armes anciennes, céramique, bibelots et objets d'art, bibliophilie, arts industriels.

$$
\text { Genève, C. Muriset-Gicot, etc., r 904-o\%. }
$$

$4^{\circ} .11 \frac{3}{4}$ in. 39 nos. in 3 vols.

[1st year]. June, 1904-July, 1905. Nos. 1-12.

[2nd "]. Aug., 1905- ", 1906. "13-24.

3rd " 1906-07. Nos. 25-39.

** Commencing with nos. $22-23$ the journal was published by Paul Ch. Stroehlin. Nos. 2 and 3 and 22 and 23 were severally published togother. No. 7 is dated "Décembre, 1904-Janvier, 1905"; no. 8, "Février-Mars, 1905" ; no. 9, "Mars-Avril, 1905" ; no. 13, "Août-Septembre, 1905"; nos. 22-28, "Fin Juin, 1906 ". Nos. 22 and $23,24-30,33,35,36$ and 38 contain supplemental slips and there is a title-page and an index to the second year. The numbers of the third year have no date of publication beyond "1906-07" at the top of each page, with the exception of 1the first page of each number. Pages 319, 320 of no. 26 and page 329 of no. 27 bear " 1905.06 " in error, and page 351 of no. 29 has in mistake "1906.05". There is a copy of the prospectus, dated "2 Avril, 1904". Wanting no. 14

JOURNAL DES CURIEUX. Le Journal des curieux.

Paris, E. L. Perrette et Co., I905-
$8^{\circ} .11 \frac{1}{4}$ in. nos. in vols. In progress.

1st year. Feb., Mar., [? no. 3], June, Sept., Oct., Nov. 20-Dec. 1, 2nd . Jan, $1,20,1$.

Jan. 1, 20, Feb. 1-5, 20-25, Mar. 15, Apl. 1, 15, May 15, June 1, 15, July 1, 20, Oct., Nov., Dec., Dec. 25, 1906. Nos. 8-23.

** Only partly philatelic. There is a paper wrapper to each number. No. 2 has a supplement of illustrations, nos 1, 3, 4 and 6 contain supplemental slips and nos. 22 and 23 have supplements of illustrations. No. 3 has no date.

JOURNAL DES PHILAT贞ISTES. See Cote RÉELLE DES TIMBRES-POSTE.

JOURNAL FÜR MARKENKUNDF. Journal für Markenkunde. Hamburg, Arthur Wiilbern, I894 8०. 93. in. Nos. 1-12, Jan. 15-Dec. 3, 1894.

* * There is a title-page and an index to the twelve numbers, and nos. 4 and 5 and nos. 11 and 12 were severally published together under the respective dates "April und Mai, 1894," and " 3 De-
cember, 1894 ".
Mis. Sour. 91 (5).

JOURNAL OF THE BUFFALO PHILATELIC SOCIETY. The Journal of the Buffalo Philatelic Society. Official organ of the B. P. S.

Buffalo, N. Y. Park and Dougherty Co., I903. 8. 83-81 in. Nos. 1-2, June 15, July-Aug., 1903.

Mis. St. Jour. 106 (13).

JOURNAL OF THE SOCIETY OF ARTS. Journal of the Society of Arts. No. 2, 791. Vol. LIV. May 18, 1906. [Contains an article "The development of watermarking in hand-made and machine-made papers," by Clayton Beadle, with a reference to the Mulready envelopes.] London, George Bell and Sons, Igo6.

$8^{\circ} .93$ in. pp. $684-698$.
$* *$ The number has a coloured paper wrapper.
$*$ * The

Mis. St. Jour. 141 (3).

JOURNAL OFFICIEL DE LA GUADELOUPE. Journal Officiel de la Guadeloupe. No. 25. Mars 26, 1889 [Contains: "Arrêté transformant les timbres-poste de 20,30 et 40 centimes en timbreside 10,15 et 25 centimes".]

Fol. $19 \frac{1}{4}$ in. p. 90.

Basse-Terre, I889.

Mis. St. Jour. 136 (9).

JOURNAL OFFICIEL DE LA NOUVELLE-CALEDONIE ET DÉPENDANCES. Journal Officiel de la Nouvelle-Calédonie et Dépendances. Trente deuxième année. No. 1678. Décembre 26, 1891. [Contains: "No. 1343. Décision. Transformation des timbres-poste de $\mathrm{O}$ fr. 40 centimes en ceux de $\mathrm{O}$ fr. 10 centimes."] Trente troisième année. No. 1700. Mai 28, 1892. [Contains: "No. 466. Décision. Surcharge de timbres-poste de O fr. 30 centimes."]

$4^{\circ} .12 \frac{1}{2}$ in. p. 406 and p. 221 ,

Nouméa, I89i-92. Mis. St. Jour. $138(9,10)$.
JOURNAL

JOURNAL OFFICIEL DU GOUVERNEIMENT ÉGYPTIEN. Journal Officiel du Gouvernement Egyptien. 20me année. No. 12. Janvier 25, 1893. [Contains a postal notice delaying an announced issue of new postage stamps of $3 \mathrm{~m}$. and $2 \mathrm{p}$. t.]

Fol. 13 in. p. 91. Le Caire, 1893 .

J. T. HANDFORD'S QUARTERLY CIRCULAR. J.T. Handford's quarterly circular.

New York, 1879-83. 8. 9 in. Nos. 1[-7], Jan. 1, 1879, Spring, Summer, Autumn, 1881, Spring and Summer, Fall and Winter, 1882, Spring and Summer 1883 .

* No. 1 has "No. 1. Vol. I.," but the subsequent issues are un-

Mis. St. Jour. 24 (14)

JUBILEE COMMEMORATOR, BEING THE JUBILEE NUMBER OF THE ANGLO-AMIERICAN ADVERTISER AND FOREIGN STAMP RECORD. See ANGLO-AMERICAN ADVERTISIR AND FOREIGN STAMP RECORD.

JUBILEE PHILATELIST. The Jubilee philatelist. A monthly magazine devoted to the interests of stamp collectors.

Smith's Falls, Ont., The Jubilee Stamp and Publishing Co., I899- I900.

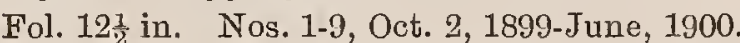
Mis. St. Jour. 88 (1)

[Continued as :]

The Jubilee philatelist and Mount Royal stamp news. A monthly magazine devoted to the interests of stamp collectors.

Smith's Falls, Ont., The Jubilee Stamp and Publishing Co., I 900 .

Fol. $12 \frac{1}{2}$ in. and $8^{\circ}$. $8 \frac{3}{2}$ in. 5 nos. in 2 vols.

Vol. I. July-Sept., 1900 . Nos. 10-12.

Vol. I. July-Sept., 1900. Nos. 10-12.

"* "Nos. 10-12 are folio and nos. 13-14 are octavo and the two last numbers have paper wrappers.

JUBILEE PHILATELIST AND IMOUNT ROYAL STAIIP NEWS. See JUBILEE PHILATELIST.

JUGEND. Jugend. 1 Jahrgang. Nr. 52, 26 Dezember, 1896. [Contains two pages of humorous illustrations and remarks, with the title "Den Philatelisten der 'Jugend ' gewidmet".]

Mïnchen und Leipzig, G. Hirth, I896.

Fol. 12 in. pp. 860, 861.

Mis. St. Jour. 128 (1).

JUNCTION NEWS. The Junction news

Flemington Junction, N. J., H. F. Deats, I885. $64^{\circ} .3 \frac{1}{4}$ in. No. 1, July, 1885 .

** "Contains no philatelic or postal matter beyond an advertisement for "old postage stamps," but the number is included in the library on account of its association with Mr. H. F. Deats.

JUNIOR. The Junior. A monthly magazine for young and old. Bethlehem, Pa., [E.T. Parker], 1902-04. Fol. 12 in. 25 nos. in 3 vols.

Vol. I. Oct., 1902.-Sept., 1908. Nos. 1-12

" II. "1903.- "1904. N" 1-12.

* " " Only partly philatelic. Nos. 3-5, vol. II., have paper wrappers and nos. 10 and 11 of the same volume were published together.

JUNIOR COLLECTOR. The Junior collector. Pittsburg, Pa., Lon. O. Brosie, I897-98. $16^{\circ}, 5 \frac{1}{4}$ in. 12 nos. in 2 vols.

Vol, I. Aug. 10, 1897-Jan. 10, 1898. Nos. 1- 6. *" II. Feb. 10 -July 10," "7-12. * There is a paper wrapper to each number. The numbers of vol, rị. are numbered 1-6 inside and 7-12 on the wrappers. 
JUNIOR PHILATELIST. The Junior philatelist. Ber'wyn, Ill., Willie Porter, 1896. $32^{\circ} .4$ in. No. 1, February, 1896. * "The number has a coloured paper wrapper.

Mis. St. Jour. 104 (4).

New series.

Berwyn, Ill., Willie Porter, I896. $8^{\circ} .8 \frac{3}{4}$ in. and $32^{\circ} .4$ in. Nos. 1-3, April, Aug., Sept., 1896 ** No. 1 is octavo and nos. 2 and 3 , which have coloured paper wrappers, are $32^{\circ}$. Only no. 1 bears the words "New series" Mis. St. Jour. 104 (5).

- [New series.] Berwyn, Ill.,Wm. B. Porter Jr., 1898. $24^{\circ} .5$ in. and $16^{\circ} .61$ in. Nos. 1-3, Feb., June, July, 1898. * * No. 1 is $24^{\circ}$. and nos. 2 and 3 are $16^{\circ}$. and there is a coloured paper wrapper to each number.

JUNIOR PHILATELIST. The Tunior philatelist. Byron, Ill., Henry H. Huff, r903. $16^{\circ} .5 \frac{3}{4}$ in. and $8^{\circ} .8 \frac{1}{2}$ in. Nos. 1-[4], September-December, 1903. * * No. 1 is $16^{\circ}$, and has a coloured paper wrapper. The subsequent numbers are octavo and have no wrappers. Nos. 2 and 3 were published together with the date October-November and the number for December is numbered " 3 " in place of " 4 ". Wanting the number for December.

JUNIOR RECORD. The Junior record. Cincinnati, O., R. L. Zerbe, r882. Fol. $11 \frac{1}{2}$ in. Vol. III., no. 6, September, 1882. ** Onily partly philatelic. $\quad$ Mis. St. Jour. 129 (7). JUNIOR STAIMP COLLECTOR. The Junior stamp collector. The only journal devoted to beginners. Birmingham, Margoschis Bros., r897-99. $8^{\circ} .7 \frac{1}{3}$ in. 36 nos. in 3 vols.

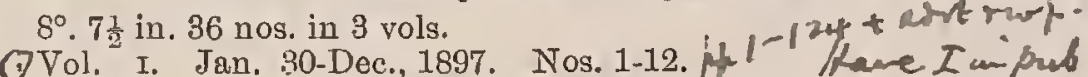

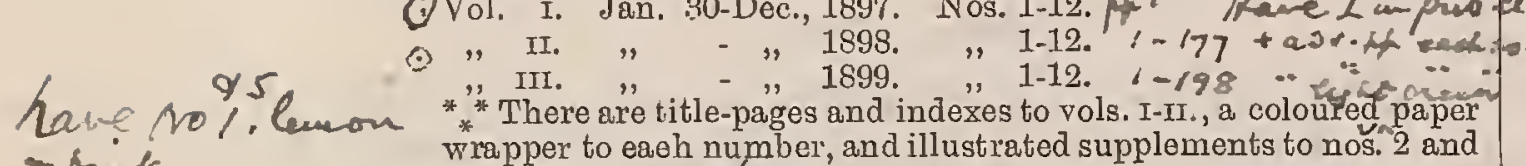
rpink

5105 wrapper to eaeh number, and illustrated supplements to nos. 2 and $\checkmark 12$, vol. Ir., and to no. 2 , vol. III. [Continued as :]

- The Stamp collector. A monthly journal entirely devoted to the interests of philatelists (with which is incorporated the "Junior Stamp Collector").

Birmingham, Margoschis Bros., Igoo$8^{\circ} \cdot 9 \frac{3}{4}$ in. Vols. IV.- nos. In progress,

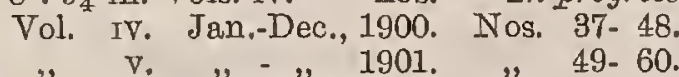

Vol. VI. Jan.-Dec., 1902. Nos. 61- 72.

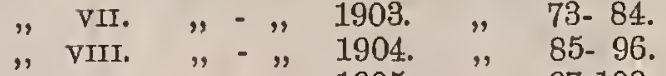

"IX. " - " 1905. " $97-108$.

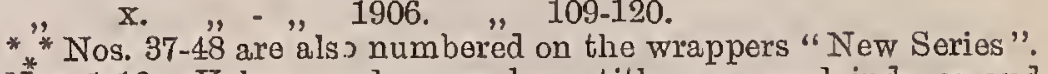
Nos. 1-12. Vols. v. and vir.-x. have title-pages and indexes and there is a paper wrapper to each number. Nos. 40, 45, 46, 61, 7484 , have illustrated supplements. The wrapper of no. 55 bears "vol. v., no. 5," in place of "vol. v., no. 7 ".

JUNIOR SUCCESS. The Junior success.

in. Nos. 1-12 Toronto, Ont., [? ] I904.

* Only partly philatelic. Wanting all nos.

JUNIORS COLLECTOR. The Juniors collector.

Dayton, Texas, etc., Treymond Babcock, etc., Is99I 901 .

$16^{\circ} .6-5$ in. 20 nos. in 3 vols.

Vol. I. Apl. 5, 1899-Mar. 15, 1900. Nos. 1-12. $346 / 7 \quad 8=12$

"II. D" 20, 1900-Jan., 1901. "Nov. ", 1-[2].

* " Commencing with no. 4, vol. II., the journal was published at E1 Paso, Texas, by Juniors' Collector Publishing Co. otherwise F. W. Hartley. Nos. 10,11 , vol. I., and the numbers of vo's. II. and III. have coloured paper wrappers. No. 2, vol. I., was numbered in error " 1 ," nos. 6 and 7, vol. I., were published together and there is no number for either June or July, 1900 . The number for, January, 1901, is numbered vol.' III., no. 1, in error for no. 2. Wanting no. 4, vol. II., and the number for January, 1901

JUVENILE PHILATELIST. The Juvenile philatelist. Denver, Colo., Arnold L. Nell, r906. $8^{\circ} .83$ in. Nos. 1-4, February, March 31, May, June, 1906. 1906 " on the front page and "April 30,1906 " on page 2 . Mis. St. Jour. 146 (4).

J. W. SCOTT CO., L'D., WEEKLY NEWS LETMER. The J. W. Scott Co., L'd., weekly news letter.

New York, I895-97.

$4^{\circ} .12$ in. 84 nos. in 3 vols.

1st year. Sept. 25-Dec. 25, 1895. [Nos. 1-14.]

2nd " Jan. 1- "̈, 26, 1896. [ " 15-66.]

3rd " " 2-May 1, 1897. [ " 67-84.] only. Nos. 20-84 have the sub-title "A private and confidential communication to the 100 leading amateurs of America". 

KENMORE KOLLECTOR, KENMORE, N.Y: USA 
KAUFGESUCHE UND ANGEBOTE VON POST WERTHZEICHEN. Kaufgesuche und Angebote von Postwerthzeichen der Mitglieder des Vereins fü Briefmarkenkunde zu Hamburg von 1885. Hamburg, Italiener, 1899

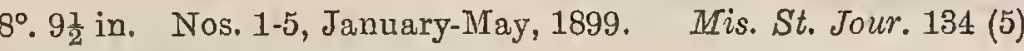

\section{KAUFGESUCHE VEREINS. BÖRSE DER INTER} NATIONALFN VEREINIGUNG VON GANZ SACHENSAIMIIERN ZULEIPZIG. See VEREINS Börse der Internationalen Vereinigung von Ganz- SACHENSAMMLERN ZU LEIPZIG.

KELSEY'S POSTAGE STAIMP REPORTER. Kelsey's postage stamp reporter. How to detect forged stamps. Meriden, Conn., W. A. Kelsey, 1867 . $16^{\circ} .5^{3}$ in. No. 1 , Aug., 1867

* * The number has a coloured paper wrapper.

Mis. St. Jour. 38 (7)

KENTUCKY PHILATELIST. The Kentucky philatelist Kentucky's only stamp paper. Hodgenville, Ky., Watkins and Burba, $189^{6}$ $8^{\circ} .8 \frac{3}{t}$ in. No. 1 , October, 1896.

* * The number has a coloured paper wrapper. A copy of the prospectus is bound up with the paper. Mis. St. Jour. 93 (13).

KENTUCKY STAMP IMAGAZINE. The Kentucky stamp magazine. Published in the interests of collectors. Covington, Ky., Crigler and Stephenson, I888-89. $8^{\circ} .9 \frac{1}{2}$ in. 4 nos. in 2 vols.

Vol. x. May 15, June 15, 1888 . Nos. 1-2.

"I II. Jan. 1, Feb. 15, 1889. " 1-2.

Mis. St. Jonr. $15(1)$

KEYSTONE KURIOSITY KALENDAR. Keystone kuriosity kalendar.

Freeport, Pa., E. E. Hollingsworth, 1887 Fol. 12 in. Vol. Ir., nos. 1-2, May 1-June 1, 1887.

* *nly partly philatelic. The title on no. 2 reads "Keystone kuriosrity kalendar".

KEYSTONE PHILATELIC GAZETTE. The Keystone philatelic gazette.

Altoona, Pa., Mann and Kendig, $x 884-85$ 80.9 in. Nos. 1-8, June, July and August, Sept., 1884-Feb., 1885 * * Nos. 6-8 have coloured paper wrappers.

$$
\text { [Continued as :] }
$$

The Keystone stamp and coin gazette.

Altoona, Pa., Mann and Kendig, r885.

8. 9 in. 10 nos. in 2 vols.

Vol. I. Mar.-June, 1885. Nos. 9-12.

* " Ir. July-Dec., " "Each number has a colourẹd paper wrapper
KEYSTONE PHILATELIC GAZETTE

610 KEYSTONE PHILATELIC GAZETTE.

[Continued as :]

- The Stamp and coin gazette.

Altoona, Pa., Mann and Kendig, I886.

$8^{\circ} .9$ in. Vols. m.-mr. 12 nos.

Vol. Ir. Jan.-June, 1886. Nos. 19-24.

* "* Each number has a coloured paper wrapper.

$S 106$

[Continued as :]

The Philatelic gazette.

Altoona, Pa., etc., Mann and Kendig, etc., I887-9o. $8^{\circ} .9$ in. and $10 \frac{1}{2}$ in. Vols. III.-VI. 35 nos.

Vol.

", IV. July, Aug.-Sept., Oct., 1887-July, 1888. Nos. 37-48.

" IV. July, Aug.-Sept., Oct., 1887 -July, 1888

" v. Sept., 1888-Aug., 1889. Nos. 49-60.

* " There is a paper wrapper to each number. Nos. $49-65$ measure 10 inches and were published by the Western Philatelic Publish$10 \frac{1}{2}$ inches and wero

KEYSTONE PHILATELIST. Keystone philatelist.

Susquehanna Depot, Pa., F. A. Ellis, etc., I874-75. $8^{\circ} .7 \frac{3}{4}$ in. Nos. 1-14, Sept., Nov., 1874-Aug., Nov., 1875.

** Nos. 2-14 were published by T. A. Hayward and nos. 12,13 and 14 were published together under the date "Nov., 1875 ".

$$
\text { Mis. St. Jour. } 39 \text { (3) }
$$

KEYSTONE PHILATELIST. The Keystone philatelist. Allentown, Pa., Claude T. Reno, I896.

$8^{\circ} .8$ in. No. 1, Sept., 1896.

**" The word "Philatelist" of the title is without the final lette "*t". Mis. St. Jour. 93 (3)

KEYSTONE STAMP ADVERTISER. The Keystone stamp advertiser.

Philadelphia, Pa., Lewis W. Colfelt, r89o. $8^{\circ} .8$ in. No. 1, April, 1890.

Mis. St. Jour. 142 (1)

KEYSTONE STAMP AND COIN GAZETTE. See KEYSTONE PHILATELIO GAZETTE.

KEYSTONE STAIMP BULLETIN, The Keystone stamp bulletin.

Titusville, Pa., Keystone Stamp Co., I892. $16^{\circ} .6$ in. Nos. 1-2, November-December, 1892.

** Wanting no. 2.

Mis. St. Jour. 154 (3)

KEYSTONE STAIP NEWS. The Keystone stamp news.

Richland Centre, Pa., The Keystone Stamp News, I 890.

$8^{\circ} .8 \frac{1}{2}$ in. No. 1, March, 1890.

Mis. St. Jour. 65 (8)

KEYSTONE STATE COLLECTOR. The Keystone State collector. A monthly journal for collectors. Spring City, Pa., eto., A.W. Weikel and Co., I888.

$8^{\circ} .9 \frac{1}{2}$ in. Nos. 1-9, Mar.-Nov., 1888.
** Only partly philatelic. Nos. 2-9 were published at Philadelphia, Pa. Wanting no. 9.

\footnotetext{
Arke'heo develezo-Lap. ( La carte rotale illustré).

4 G.

$1859 .(4) 5.1$.

2 sjan.
}

Kensington Philatelist continued as Worldwide Philatelis

London 1921-26. Set of 44 out of 46 issues, lacking onl

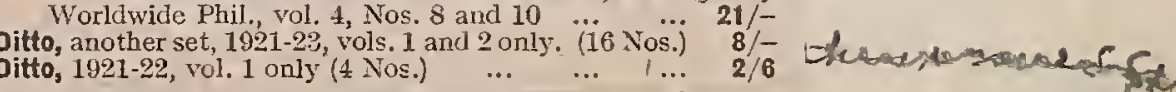

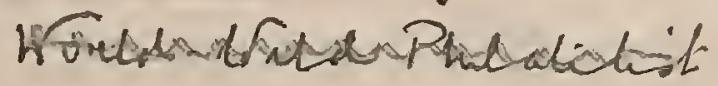


611 KEYSTONE STATE PHILATELIST

KEYSTONE STATE PHILATELIST. The Keystone State philatelist. Philadelphia, Pa., The Keystone State Philatelist Pub. Co., I887.

$8^{\circ} .9 \frac{3}{4}$ in. Nos. 1-8. Jan.-Oct., 1887.

* * There is a coloured paper wrapper to each number. No. 4 is dated "April and May, 1887 " and no. 7, "August and September, Mis. St. Jour. 11 (3)

KID. The Kid.

Beaver City, Neb., Green Bros., I 896-98. $32^{\circ} .4$ in. and $8^{\circ} .8-7 \frac{3}{2}$ in. 49 nos. in 3 vols

Vol. I. 1896-F'eb. 20, 1897, Nos. 1-24. "Ir. Mar. 6, 1897-March, 1898. " 1-23. " III. April, -May-June, " " $1-2$ * * Only some of the numbers of vol. I. and of nos. 1-19, vol. II. are partly philatelic. Nos. 1-5, vol. I., are $32^{\circ}$. and the succeeding numbers are octavo. Nos, 20-23, vol. II., and no. 1, vol. III., have paper wrappers. No. 7, vol. II., is wrongly numbered "No. $6 "$. Wanting vol. I., nos. 1, 2, 3, 4 and vol. II., no. 6 .

KING AND CO.'S WEEKLY TRADE CIRCULAR WHITFIELD. See WHITFIELD KING AND Co.'s WEEkLY TRADE CIRCULAR.

KINGSTON STAIMP ADVERTISER. The Kingston stamp advertiser.

Kingston Hill, Surrey, Charles J. Smith, I 9oo-ог.

500 $8^{\circ} .8 \frac{1}{4}$ in. Nos. $1-6$.

** The contents consist entirely of a price list of stamps and advertisements of the publisher. Wanting all but no. 4 dated March, 1901.

KISSINGER'S PHILATELIC POSTAL CARD. See Philatelic postal card.

KLEINE POSTZEGELVERZAMELAAR. De kleine Postzegelverzamelaar. Maandblad voor jeugdige of Beginnende Verzamelaars. Amsterdam, Mej. A. A. Wijkhuyzen, [? I905].

Hecker oncis creamerlute $16^{\circ} .5 \frac{1}{2} \mathrm{~m}$. [Nos. 1-2.]

the white * The numbers bear no date and are unnumbered. There are 列 The conctuits of there thos are paper and the other on stout yellowish paper. Wanting one no. hevisoly the eacue.

KLEINE VERZAMELAAR. De kleine Verzamelaar.

Den Haag, F. P. B. Van Deventer, x89I-99. $24^{\circ} .5$ in. 2 nos. in 2 vols. 1st year. June, 1891. No. 1 2nd " Jan. 1899. "1. 1

Mis. St. Jour. 117 (2).

KÖLNISCHE BRIEFIMARKEN - ZEITUNG. See CöLNische BRIEFMARKen-ZEITUNG.

KOIMIVERS - ZEITUNG. Kommers-Zeitung zum X. Deutschen Philatelistentage verbunden mit dem II. Bundestage deutschen und österreichischer Philatelistenvereine. (16-19 Juli, 1898.) Gössnitz S.-A., r898. Fol. $12 \frac{1}{2}$ in. July 16, 1898.

* * The journal is unnumbered and the contents are of a humorous description.
KOIMIERS-ZEITUNG

[Continued as :]

Commers Zeitung. XII. Deutscher Philatelistentag. Iv. Bundestag. Fol. $13 \frac{1}{4}$ in. July 29, 1900. ** The journal is unnumbered and the contents are of a humorous description. Mis. St. Jour. 128 (16a)

KOMMERS - ZEITUNG. Kommers-Zeitung zum IV Sammlertage des "Germania-Ringes" ( 8 bis 10 September, 1900).

Fol. $12 \frac{1}{2}$ in. September 8,1900

* * The journal is unnumbered and the contents are of a humorous description.

Mis. St. Jour. 128 (17)

KOSMOS. Kosmos. Prag, Verein "Kosmos Prag," I89I. $8^{\circ} .9 \frac{3}{4}$ in. Nos. 1-[3], Aug. 15-Oct. 25, 1891

* * Produced by a hectographic process. No. 3 is numbered in

RISS KRINGLE. Kriss kringle.

Detroit, Mich., W. T. Ockford, $x 885$.

* * Cuttings of the "Stamp department," etc., from nos. 8 and 9 , dated June and July, 1885, are mounted in Stamp Scrap-book, vol. $\nabla .$, pp. 51-54

KRUMBS. Krumbs Aarwood, Mich., Krumbs Publishing Co., r892-95. $4^{\circ} \cdot 10^{3}$ and 14 in. nos. in 4 vols

V.ol. I. Jan.-Dec., 1892. Nos. 1-12.

V.ol. I. Jan.-Dec., 1892 . Nos. $1-12$.
"I. " - I. $1893 . \quad$ " 1$]-12$

" II. " " - " 1893.

" IV

* "Some only of the numbers contain philatelic matter. Nos. 1 and 2, vol. II., are numbered "vol. I., no. 13 " and "vol. I., no. 14" respectively. Wanting all but the twelve numbers of vol. II., and vol. IV., no. 10, dated "October, 1895 ".

KÛRIOSITI KABINET. De Kûriositi Kabinet. New York, Wm. P. Brown, I870-7x.

$8^{\circ} .10$ in. Nos. 1-12, Sept., 1870-Aug., 1871.
** Printed on buff paper. The first page of each number is printed phonetically. Some of the numbers, if not all, were printed on white paper and only measure $8 \frac{1}{2}$ inches in height: of these the library contains nos. 8, 10 and 12 .

[Continued as :]

The Curiosity cabinet.

New York, Wm. P. Brown, etc., x872-97. $8^{\circ} .8 \frac{1}{2}$ in. Vols. II.-IV., 29 nos.

Vol. II. 1872; Jan., 1873; Apl., June, July, Nov., 1876 ; III. July, Apl., Aug., Sept., 1879; June, Oct., 1884; Feb., Sept.

1886; $1886 ; 1887 ; 1890$. Nos. $1-9,12$.

IV. $1889 ; 1890 ; 1891 ; 1892 ; 1896 ; 1896 ; 1897$. Nos $1-4,6-8$. Nos. 57, 58. Both dated 1897

* * No. 2, vol. II., has the title "Kuriositi Kabinet". From no. 3 , vol. Ir., the publication is practically nothing more than price list. Nos $1,2,3,4,6,7,8,9$ of vol. II., are printed on thin blue paper. Of these nos. $6,7,8$ were also issued on whit paper like nos. 5, 10 and 11 . Nos, 6, 7 and 8, vol. III., were published by the Scott Stamp and Coin Co., Limited. Nos. 6-9, vol III., nos. 1-4, 6, 8, vol. Iv. and no. 57 are solely price lists of coins.
Mis. St. Jour. 28 (1) 


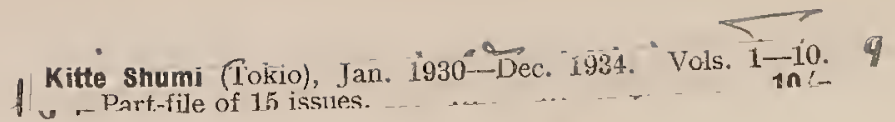

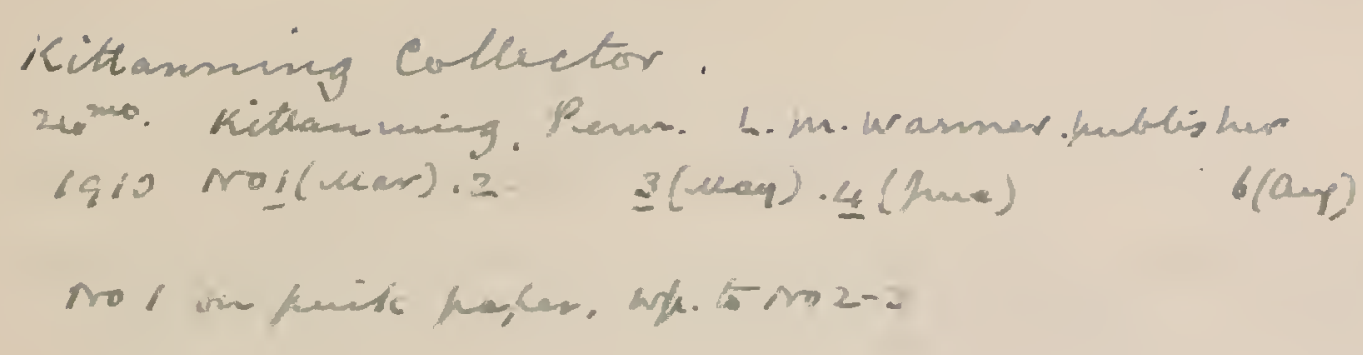

Not \& Cas'sost Cow Gechange Registes. rme 4 \% 1908mar. Treb, ph.1-4, all arto:

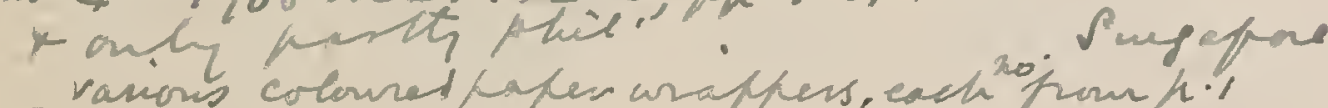
I II 1508 (7) 10.111213 É(new) () III $1509 \cdot \operatorname{fac}-\mathrm{bcc} \cdot 16-2)$ 
ha Phatatidie Fruncarse

LA REVALE POSTALE

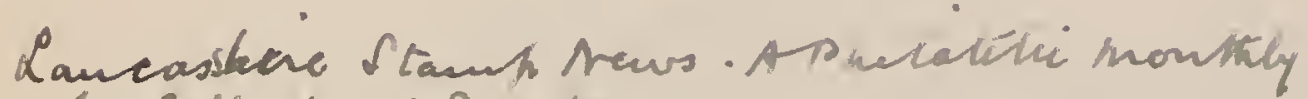

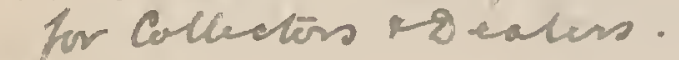

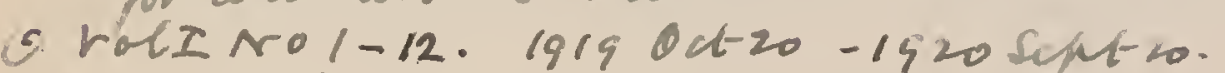

8vo. Colomed poper anspher, sreckero;

urmstion: C.W.ticles

rot.II 1001 - 1920 cict.20-1921 feb.20 
LADIES' HOIME JOURNAL. The Ladies' home journal, Philadelphia, Pa. Vol. Ix., no. 10. September, 1892. [Contains an article "Cancelled postage stamps. The much disputed value of 'a million cancelled postage stamps '."'

${ }_{*}^{*}$ Cuttings of this article are mounted in Stamp Scrap-book, vol. vi., p. 181.

LAKE STATE STAMP. The Lake State stamp. Jackson, Mich., J. Roy Zwick, т898. $8^{\circ} .9$ in., $10 \frac{1}{4}$ in., 7 in, and 73 in. 5 nos. in 2 vols.

Vol. I. A ug.-Oct., 1898. Nos. 1-3.

S $106 \quad$ ** No. 1 measures 9 inches, "no. $2,10 x$ inches, no. 3, 7 inches, no. 1 , vol. II., inches and no. 2, vol. II., 73 inches. The two last have coloured paper wrappers. Wanting no. 1, vol. II.

\section{[Continued as :}

The Fly paper. Jackson, Mich., J. Roy Zwick, I899. in. Vol. II. 1 no

Vol. II. June, 1899 . No 3

* Only partly philatelic. Wanting.

LAKESIDE PHILATELIST. The Lakeside philatelist.

$8^{\circ} .9 \frac{1}{4}$ in. No. 1 , June, 1883.

Chicago, $\Pi l l ., W . F^{\prime}$. Bishop, I883.

* * The number has a paper wrapper. Mis. St. Jour. 18 (18).

LANCASTER STAIMP NEWS. Lancaster stamp news. Lancaster, Pa., Chas. Steigerwalt, 1896. $8^{\circ} .101$ in. No. 1, Jan., 1896. Mis. St. Jour. 87 (8).

LECTURE ILLUSTRÉE. La Lecture illustrée. No. 6, Juin 25, 1896. [Contains an article "Les Grands collectionneurs de timbres-poste," by Jacques Vernay, with portraits of M. de Saulcy, M. Herpin, M. le docteur Legrand, M. Philippe de Ferrari, M. Martial Caillebotte and M. Gustave Caillebotte.]

$8^{\circ} .8 \frac{1}{2}$ in. pp. $561-569$.

Paris, F. Juven et Cie., т896.

Mis. St. Jour. 145 (8)

"No. 397, August 4, 1859. [Contains an article "Something about postage stamps".] $242 \mathrm{~g}$

London, I859.

$8^{\circ} .10$ in., pp. $489-492$.

- No. 579, January 31, 1863. [Contains an illustrated article "Postage stamps".] And no. 605, August 1, 1863, [Contains an illustrated article "Rare and curious postage stamps".]

$8^{\circ} .11$ in., pp. 70-74 and 486-489.

London, I863.

No. 1152, January 24, 1874. [Contains an artiole "Postage stamps and stamp albums".]

* Cuttings of this article are mounted in Stamp Scrap-book, vol. II., pp. 50, 51 .

LEISURE HOUR. The Leisure hour.

in. Nos. $1-5$. Washington, D. C., [? ], I887.
L'ESTRANGE EWEN'S WEFKIY CIRCULAR L'Estrange Ewen's weekly circular. Norwood, London, S.E., Bournemouth [printed], I 897-99.

$4^{0} .93$ in. and fol. 131 in. Nos. 1-77, Oct. 16, 1897-June 3, 1899. * Nos. $1-42$ are quarto and the remaining numbers are folio. There is a supplement of four pages to no. 25 and there are two distinct editions of no. 72. One of these has below the heading on page 1: "Notice. The five labels attached should be returned to me with name and address, and will entitle sender to the 'Weekly circular' for five weeks from date. . ." and beneath this is a row of five green labels, after the design of the railway letter fee stamps of Great Britain. The other edition is minus this

[Continued as :]

Ewen's weekly circular.

Norwood, London, S.E., Bournemouth [printed], I 899 .

Fol. 131 in. Nos. 78-86, June 17-Sept. 23, 1899

** There is a supplement of four pages to no. 80. This cireula was superseded by "Ewen's weekly stamp news".

LEVÉLBÉLYEG FORGALIMI KÖZLÖNY. BRIEFMARKEN VFRKEHRS BLATT. Levélbélyeg F'orgalmi Közlöny. Briefmarken Verkehrs Blatt.

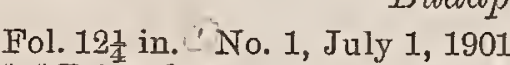

Budapest, Sárkány és F'ekete, Igor

"Printed on green paper and the contents consist entirely of advertisements. $4 / 4$. Mis. St. Jour. 128 (9).

LEVÉLBÉLYEGKYÜJTO゚K LAPJA. Levélbélyeggyüj

tök Lapja-Ungarisches Briefmarken-Offertenblatt.

Fol. 121 in. No. 1, December 1, 1898.

Budapest, Béla Szełula, I 898

* The number has a coloured paper wrapper and the content

LEVศIBF́TYFG-TO̊ZSDF_BRI

Levélbélyeg-Tözsde-Briefmarken-Börse.

Temesvár, Ungarn, Zsigmond Abonyi, I 906 Fol. $12 \frac{1}{4}$ in. nos. in vols. In progress.

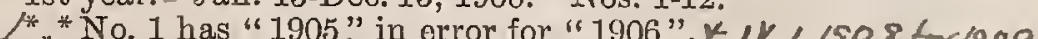

LEVE'S NEW PERFORATOR. See PERFORATOR.

LEWTHWAITE'S IMONTHIY BAZAAR. Lewth waite's monthly bazaar.

Egremont, Cumberland, Wm. Lewothwaite, I894. $8^{\circ} .8_{4}^{3}$ in. Nos. 1-2, September-October, 1894.

** Wanting both numbers.

CIBRE ÉCHANGISTE. Le Libre Échangiste. Journal des transactions philateliques.

$8^{\circ} .8 \frac{1}{2}$ in.ONo 1, April, 1896. Paris-Passy, Noverraz, I 896.
Mis. St. Jour. $90(2)$

LIETZOWS FLIEGENDE BLÄTTER， See FLIEGEND BLÄTTER, 
615 LINCOLNSHIRE PHILATELIST

LINCOLNSHIRE PHILATELIST. The Lincolnshire philatelist.

Grimsby, A. Cooling and Co., I895.

C. $8^{\circ} .8 \frac{3}{4}$ in. No. 1, May 10, 1895 . 44. A ith

$V_{*}^{*}$ *The contents consist entirely of advertisements

Mis. St. Jour. 79 (14)

LITERARY CHIMES, AND STAIMP COLLECTORS TREASURY. Literary chimes, and stamp collector's treasury.

Bradford, Yorks., A. Robinson, I892. $8^{\circ} .83$ in No. 1, August, 1892

* *nly partly philatelic. The number has a coloured paper

ITFRARY COIMPANION The Literary companion. in. nos. in 2 vols. Kansas City, Kas., W. H. Plank, r889-9o.

1889. Nos. 1-

* * Only partly philatelic. Ẅanting all nos.

LITERARY GEIM. The Literary gem.

South Boston, Mass., Curtis and Parker, Igo т. $16^{\circ} .6$ in. Vol. II., no. 6, February, 1901.

* Only partly philatelic. The number has a coloured paper wrapper. Other numbers of the journal contained no philatelic matter.

Mis. St. Jour. 150 (13).

LITERARY PHILATELIST. The Literary philatelist, Devoted to literature and philately.

New York, Harlem Stamp Co., I 903.

8․ 83 in. Nos. 1-2, Jau.-Feb., 1903.

** There is a coloured paper wrapper to each number.

Mis. St. Jour. $106(10)$

LITTLE ADVERTISER. The Little advertiser. A pape devoted to advertising stamps, philatelic supplies, etc.

Newton Center, Mass., Herbert F. Butler, I go I

$8^{\circ} .8$ in. No. 1, March, 1901.

Mis. St. Jour. 106 (12).

LITTLE CLIPPER. The Little clipper.

in. Vols. III.-IV. nos.

$$
\text { Mendota, Ill., [? }
$$

], $1887-89$

S 106 Vol. III.

* * Some of the numbers of vols. III. and IV. contain philatelic matter. Wanting all nos.

LITTLE CURIOSITY NEWS. The Little curiosity news. Devoted to stamps, minerals, and curiosities.

La Hoyt, Iowa, James C. Jay, I885 $16^{\circ} .5 \frac{1}{4}$ in. No. 1 , Oct. and Nov., 1885.

* * The contents consist almost entirely of advertisements. Mis. St. Jour. 68 (9).

LITTLE DRUIMIMER. The Little drummer. Medway, Minn., [?

], I 903. in. No. 1, April, 1903

$\operatorname{sob}$ * Only partly philatelic. Wanting.

LITTLE GEIM STAIMP NEWS. The Little gem stamp news.

Camden, N. J., Wm. P. Shourds, 1898 .

in. No. 1, October, 1898 .
* Wanting.

$$
\text { [Continued as :] }
$$

Gem stamp news.

Camden, N. J., Wm. P. Shourds, 1898.

$8^{\circ} .7 \frac{1}{2}$ in. No. 2, November, 1898.
* * The title on page (2) reads "The Little Gem Stamp Nows," * "The title on page (2) reads "The
and the date is given as "Oct., 1898 ".

\section{[Continued as:]}

The New Jersey philatelist.

Camden, N. J., Wm. P. Shourds, I898. ** Wanting.

Camden, $N$

LITTLE NUGGET. The Little nugget. For philatelist, amateur and advertiser.

Boston, Mass., G. J. Curtis, Igoo. 16 6 in. Nos. 1-12, January-December, 1900.

* * Only partly philatelic. Amalgamated with the "Literary Gem "in January, 1901. Wanting all but nos, 11, 12.

\section{LITTLE SPECTATOR}

616

LITTLE SPECTATOR. The Little spectator.

Mt. Pleasant, Iowa, Stough and Taylor, I878-79. 8. $8 \frac{3}{4}$ in. Nos. 1-6, Oct., 1878-Mar., 1879. *" Only partly philatelic. Nos. 4 and 5 were published together
under the date "Jan. and Feb., 1879 ". Mis. St. Jour. 24 (16).

LITTLE STAIMPIVAN. The Little stampman.

Springfield, Mass., H. T. Belden, I go I-O2. $16^{\circ} .6$ in. Nos. 1-3, July 20, 1901, Feb. 15, Mar. 15, 1902.

** With the exception of the front page of each number, which is printed, the rest of the contents is produced by a type-writer Mis. St. Jour. 125 (2)

LITTLE WAVE. The Little wave.

Alden, Mich., Van Dermark and Wagoner, etc., I $897-98$.

Fol. 12 in. and $8^{\circ} .8 \frac{1}{4}-9$ in. nos. in vols.

* * Some of tho numbers of this non-philatelic journal contain a "Stamp collectors' directory". The library only has vol. III. no. 4, September 1, 1897, vol. III., no. 7, December, 1897, vol. IV., no. 1, July, 1898, and vol. Iv., no. 11, April, 1898 (for "1899"?) no. 1, July, 1898, and vol. IF., no. 11, April, 1898 (for "he and last are printed on rose paper. The last has the title reading: "The Little wave and Kentucky colonel-consolidated".

LITTLE WONDER. The Little wonder.

Aarwood, Mich., Ruth Russell, I895.

(1) $32^{\circ} .41$ in. No. 5 , April, 1895 . Rups publisher, printer and devil and her age is given as twelve. Wanting.

LIVERPOOL AND NEWPORT STAIMP ADVER TISER. See LIVERPOOL STAMP ADVERTISER.

LIVERPOOL STAIVP ADVERTISER. The Liverpool stamp advertiser. Liverpool, F. G. Jones, I863. ○ $8^{\circ} .8 \frac{3}{1}$ in. Nos, 1-3, May 1-July 1, 1863 . Lave mo $2,1 \cdot 3$ [Continued as :]

- The Liverpool and Newport stamp advertiser. Newport, Mon., Stamp and Co., I863-64 $8^{\circ} .8$ in. Nos. 4-14, Aug. 15, 1863-June 15, 1864 . Wme 4 is * * No. 12 for April 15, 1864, is wrongly numbered " 10 ". The title of nos, 13 and 14 reads "The Liverpool and Newport stamp advertiser, with which is incorporated the Newcastle and Gateshead stamp advertiser and review".

LIVERPOOL STAMP COLLECTOR'S JOURNAL

(9) The Liverpool stamp collector's journal. Lave ro/ -3 Liverpool, J. C. Wroe, I865. 4 42,2 $68^{\circ} .8$ in. Nos. 1-3, Apl. 1-June 3, 1865. K/-Mis. St. Jour. 37 (3) LODGE RECORD. The Lodge record. Devoted to fraternity. Benson, Minn., Ernest R. Aldrich, I904-07. $8^{\circ} .9 \frac{1}{2}-10 \frac{1}{2}$ in. nos. in vols.

* Somo of the numbers of this non-philatelic journal contain stamp articles. The library has vol. III., no. 5, Nov. 30, 1905 ; vol. IV., nos. 2-9, 11, 12, Feb. 28-Aug. 31, Oct., Nov., Dec., 1906 ; vol. v., nos. 1-3, Jan.-Mar., 1907

LONDON AND NEW YORK STAIVP COLLECTORS

6) REVIEW. The London and New York stamp collector's' review. London, E.C., John George Boel, I864. A L6

co $8^{\circ} .8 \frac{1}{1}$ in. Nos. 1-2, Jan. 15-Feb. 15, 1864. Mis. St. Jour. 36 (4). thL

LONDON AND PROVINCIAL STAMP COLLECTORS' GUIDE AND ADVERTISER. See LoNDON and Provynciat stamp advertiser.

LONDON AND PROVYNCIAL STAIMP ADVER.

- TISER. The London and Provyncial stamp advertiser. London, A. Murray, I863.

(4) $8^{\circ} .8 \frac{1}{2}$ in. No. 1 , July 1,1863

* *The journal is advertised in "The Boy's own magazine" of August, 1863. The advertisement reads: "The "London and Provincial stamp advertiser'. Nos. 1 and 2 are ready. Both numbers post free for two stamps. They contain articles on the stamp trade, dealers' advertisements. etc..... Address Mirray, stamp trade, dealers advertisements, Wood \& Co., 7 Princes Stret, Bariche "Stamp collectors' wanted." "The following advertise review and monthly advertiser " July 15 and August 15, 1863 , also refers to the same journal: "Wdward Upjohn, Bookseller, supplies foreign stamps at reasonable prices. Mlustrated list $2 \mathrm{~d}$., on 1st August. No. 1 of the 'London and Provincial stamp collectors' guide and advertiser,' with monthly summary, list of similar advertisement, with alteration of a few words, appeared
Siob 5006 



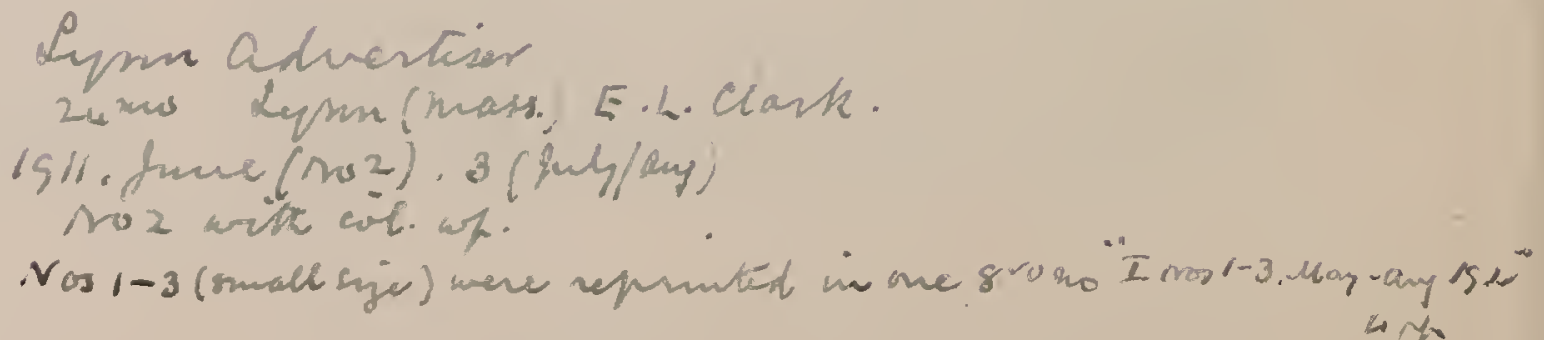


in the "Stamp collector's magazine" of August 1, 1863, and in the "Boy's own magazine" of August, 1863. It will be noticed that the title of the journal is wrougly given in Edward Upjohn's advertisements. No copy of no. 2 is known to exist. The front page of no. 1 is illustrated in the "Journal of the Philatelic Literature Society" of January, 1910. Wanting.

LONDON AND WESTMINSTER REVIRW. The London and Westminster review. No. LXV. March, 1840. [Contains a review by [Sir Henry Cole] of 1 . "On the collection of postage by means of stamps" By Rowland Hill. Printed 13th June, 1839. 2 "Treasury Minute," dated 23rd August, 1839. 3. "Treasury Minute," dated 12th November, 1839.4 "Treasury Minute," dated 26th December, 1839. 5. "A letter" to the Right Hon. the Postmaster General, showing the practicability of the penny postage plan, without having recourse to stamped covers, or abolishing the optional payment of postage." By William Cooper. London, 1839.] London, Henry Hooper, I 840 . $8^{\circ} .9$ in. pp. 491-505. Appendix (7) leaves, four of which contain illustrations of essays for postage stamps.

* * The number has a coloured paper wrapper.

LONDON AUCTION RECORD. See HopkINS Bros' MONTHLY BARGAINS TO PHILATELISTS, AND LONDON AUC TION RECORD.

LONDON GAZETTE. The London Gazette. No. 10537. July 6 to 9, 1765. [Contains a notice of the act "For altering certain rates of postage, and for amending, explaining, and enlarging several provisions in the act of the ninth of Queen Anne, and other acts relating to the Post-Office".] London, E. Owen and T. Harrison, I 765 . Fol. 12 in. pp. (1, 2).

Mis. St. Jour. 140 (13) No. 22111, March 9, 1858. [Contains “Treasury Warrant" altering the rates of British postage.]

Londan, 1858 . Fol. 12 in. pp. 1346-1348. ** There is a complete set of the "London Gazette" in the library at Haigh Hall, Wigan. Mis. St. Jour. 140 (13a)

LONDON PHILATELIC EXCHANGE CIRCULAR

6. London philatelic exchange circular. Devoted entirely to advertisements for the sale and exchange of stamps, with a circulation amongst collectors and dealers all over the world. London, E.C., E. Alexander, I899.

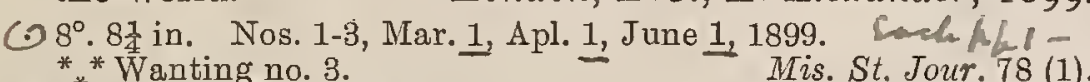

LONDON PHILATELIST. The London philatelist: the monthly journal of the Philatelic Society, London. London, The Philatelic Society, etc., I892-

$8^{\circ} .11 \frac{1}{2}$ in. nos. in vols. In progress.

Vol. I. Jan.-Dec., 1892. Nos. 1- 12.

"II. " - " $\quad 1893 . \quad " \quad 13-24$.

" II. " $"-\quad " \quad 1894 . \quad " \quad 25-36$.

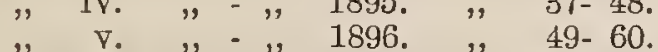

" vi. " " - " $\quad 1897 . \quad$ " $\quad 61-72$.

"VII. " " " $\quad 1898 . \quad " \quad 73-84$.

$"$ VII. $"-", \quad 1899 . \quad " \quad 85-96$.

"

"

" XI. " " $"$ - 1902. " $121-132$.

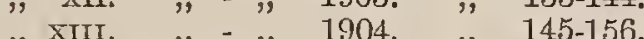

" XIV. " " "

"xv. " $"$ - $" 1906 . \quad$ " $169-180$

* " Edited by M. ". Castle. Each number has a coloured paper wrapper and there is a title-page and a list of contents to each volume. Vol. I. has also an index. Nos. 1-24 were printed in London and the remainder at Plymouth. Vol. Iv. has a suppleLondon and the rerainder at Plymouth. Vol. Iv. has a supple States of America." by the late Gilbert Harrison. Edited and completed by E. D. Bacon, and there is a supplemental erratum completed by L. D. Bacon, and there is a supplemental erratum the tit]e of the publishing society was changed to the Royal Philatelic Society, London.

LONDON SOCIETY. London society. An illustrated magazine. No. 37. January, 1865. [Contajns an article "Coelebs in search of a Mulready envelope".]

$8^{\circ} .9 \frac{1}{4}$ in. pp. 29-41, (1) plate. London, I 865 * * The number has a coloured paper wrapper.
LONDONER BRIEFMARIEN-AUCTIONÄR. Se LONDONER PHILATELIST.

LONDONER PHILATELIST. Londoner philatelist.

(2) raf, matad, H.Declogf. London, W. A. Weisz, 1896. $4^{\circ} \cdot 11 \frac{1}{2}$ in. Nos. 1-3, Feb.-Apl., 1896.

${ }^{*}{ }^{*}$ Nos. 2 and 3 were printed at Köln-Ehrenfeld.

[Continued as:]

(.) Londoner Briefmarken-Auctionär.

$4^{\circ} .11 \frac{1}{2}-11$ in. 5 nos. in 2 vols.

London, W. A. Weisz, 1896-97.

1st year. Nov., 1896. No. 9

2nd "Apl., May, July, Nov., 1897. Nos. 14-17.

* * No other number's were published. No. 9 was printed at Köln-

Lindenthal and nos. 14-17 at Amiens. Mis. St. Jour. 87 (16a)

LONE STAR JUNIOR. The Lone Star junior.

** in. Nos. 1-

San Antonio, Tex., [?], I900.

LONE STAR STATE PHILATELIST. Lone Star State philatelist. Abilene, Tex., Roy B. Bradley, I894-96. $8^{\circ} .9$ in. 76 nos. in 2 vols.

Vol. I. Sept. 3, 1894-Aug. 26, 1895. Nos. 1-52.

*" "Published weekly. Nos. $71-73$ are "dated "1895" instead of "1896".

Second series.

Abilene, Tex., etc., Roy B. Bradley, I896-99.

$8^{\circ} .9$ in. Vols. III.-VII. 35 nos.

Vol. III. Aug., 1896-Jan., 1897. Nos. 1- 6.

"IV. Feb. -July, , , 1- 6

" $\quad \nabla$. Aug. -Dec., ", " 1- 5.

"VI. Jan., Mar.,-July, 1898. " 1- 6.

* " FII. Aug., 1898-Sept., 1899 . " "' 1-12. * * From vol. vi., no. 2-vol. vir., no. 8, the journal was published at Waco, Texas, and from vol. vII., no. 3, at Hillsboro, Texas. There are wrappers to nos. $2,3,5$ and 6 , vol. III., and to each numvol. จ. There are no numbers for June and August, 1899.

LONG ISLAND COLLECTOR. The Long Island collector

Brooklyn, N. Y., Wilbur W. Thomas, etc., 1885-86. $8^{\circ} .8$ in. and $16^{\circ} .7$ in. 5 nos. in 2 vols.

Vol. I. Oct.-Dec., 1885. Nos. 1-3.

Vol. I. Oct.-Dec., 1885. Nos. $1-3$.

* " Only partly philatelic. Vol. I. is $8^{\circ}$. and vol. II. $16^{\circ}$. No. 3 vol. r., and the two numbers of vol. II. were published by the Collectors' Publishing Co. and the two last numbers have coloured lectors Publishing Co. and the two last number paper,wrappers. There is a second copy of no. 1, vol. I, bound up.
in Mis. St. Jour. 41 (11).
Mis. St. Jour. 65 (2).

LONG ISLAND PHILATELIST. The Long Island philatelist. A monthly magazine.

Brooklyn, N. Y., etc., Ashcroft and Ogden, etc., I 892-93.

$8^{\circ} .9 \frac{1}{3}-9$ in. 18 nos. in 2 vols.

Vol. I. Mar. 15, 1892-Feb., 1893. Nos. 1-12.

*" II. "Commencing with no. 3, vol. I., the journal was published at Wै Codhaven, N. Y., and the six numbers of vol. II. were published by Beecher Ogden. There are paper wrappers to nos. 1-4, vol. I. by Beecher Ogden. There are paper wrappers to nos. 1-4, vol. I.,
and to nos. 1-2, vol. II.
Mis. St. Jour. 60 (1)

LUDW VAI FLECK'S FRANKFURTER BRIEFMARKEN-ANZEIGER. See FrankFuRTER BRIEFMARKEN-ANZEIGER.

LUZ FILATÉLICA. La Luz filatélica.

Paris, Th. Lemaire, I905-06. $\odot_{1 \text { st }}^{8^{\circ} .}$ in. 19 nos. in 2 vols. 1st year. Jan.-Dec., 1905. Nos. 1-12. ** There is " coloured paper" wrapper to each number $\checkmark$. 190 * * There is a coloured paper wrapper to each number. Nos.

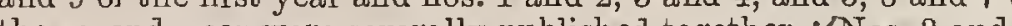
the second year were severally published together. Nos. 3 and

LYON PHILATÉLISTE. Lyon philatéliste. Journal du collectionneur et du marchand de timbres-poste.

$8^{\circ} .9$ in. No. 1, May, 1900. Lyon, $\nabla$. Désage, I 900

** The number has a coloured paper wrapper. solo

a plate of the kapue cthis.

kerig in no $3 \cdot 015$ 


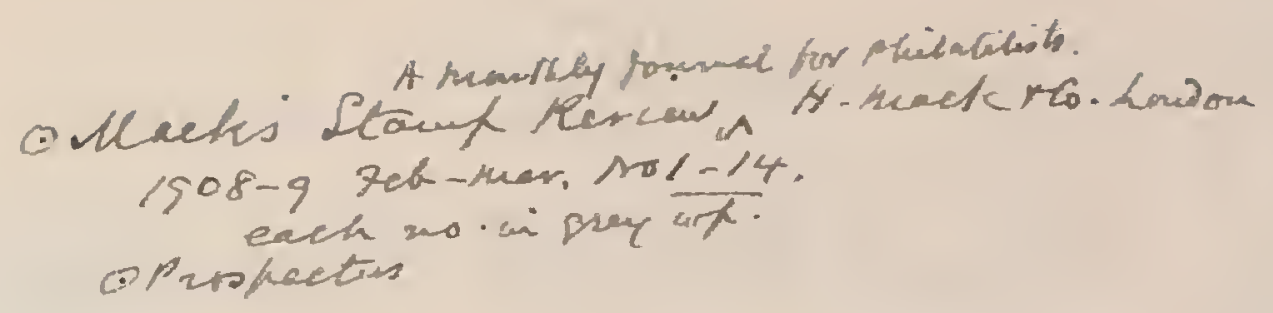

MAANDBIAD DER AFDFFITNG UTRECHT VAN DE FINDHOVENSCHE POSTZEGEL CLUB. Maandblad der Afdeeling Utrecht van de Eindhovensche Postzegel Club. Utrecht, Joh. A. Moesman, I896-97. $8^{\circ} .8 \frac{3}{4} \mathrm{in}$. V"Proefnummer" and nos. 2-9, [no date], and Dec., 1896July, 1897. * Nos. 1-3 were produced by autographic lithography and the remaining numbers were printed by lithography. Nos. 6 and 7 , and 8 and 9 , were severally published together and nos. $4-9$ have
coloured paper wrappers.
Mis. St. Jour. 153 (5).

GIMACANEADOR FILATÉLICO. El Macaneador filatélico. Buenos Aires, Emilio Saint-Germier, I904. $8^{\circ} .8 \frac{1}{2}$ in. $\odot[$ No. 1.] May, 1904.

* * The number bears "No. 2000-anõ el que quiera Mayo 1904". Four copies are said to have been printed on sandpaper.

Mis. St. Jour. 106 (11)

IMC CURDY'S DRUIMIMER. McCurdy's drummer. Westernport, Md., D. E. McCurdy, I906-07.

$16^{\circ} .6-5 \frac{3}{\text { in. }} 5$ nos. in 2 vols.

Vol. I. Sept.-Dec., 1906. Nos, 1-4.

* II. Jan., 1907. No. 1

* * Only partly philatelic. Successor to "McCurdy's International guide".

Mis. St. Jour. 150 (12)

IMC CURDY'S INTERNATIONAL GUIDE. Mc Curdy's international guide.

Westernport, Md., D. E. McCurdy, I906. 16. $5 \frac{1}{4}-6 \frac{1}{4}$ in. 4 nos. in 2 rols.

Vol. I. May-July, 1906. Nos. 1-3.

" II. August, 1906. No. 1

* * Only partly philatelic and the contents consist entirely of advertisements. Nos. 1-3 have coloured paper wrappers. Succeeded
by "McCurdy's drummer".
Mis. St. Jour. 150 (11)

IADRID FILATÉLICO. Madrid filatélico. Revista mensual dedicada á los comerciantes y coleccionistas de sellos de correos. Madrid, Miguel Gálvez, Jiménez, I897$4^{\circ} .11 \frac{1}{4}$ in. and $8^{\circ} .10 \frac{1}{4}$ in. nos. in vols. In progress.

1st year. Jan. 1-Dec. 1, 1897. Nos. 1- 12

2nd " " - " 1898. " 13- 24

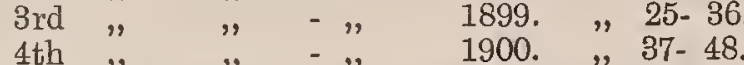

4th " " $\quad$ th $\quad$ th $\quad 1900 . \quad$ " $37-48$.

6th " " " - " $\quad 1902 . \quad " 61-72$

7 th " " "31-" 31, 1904.. "73-84.

8th " " " " " " $1905 . \quad$ " 85-96.

* * Vols. I.-V." are" quarto and the remainder are octavo, and there is a coloured paper wrapper to each number. There are two numbers for April, 1899 and nowe for May of that year these numbers are dated "Abril" and " 23 de Abril". Nos. 59 and 60 68-72, and 79 and 80 , were severally published together, under the respective dates" "Noviembre y Diciembre de 1901" "Agos to 1902 Diciembre, 1902," and "Julio y Agosto de 1904". No. 28 has a folded illustrative plate of a sheet of Philippine stamps, nos. 49-7 have supplements of "Historia de los Sellos de Correos y Telégrafos de Espana. Por Miguel Alená Fernández," pp. 1-200, the work being left incomplete Nos. 79-89 have supplements of "Biblioteca de Mrdrid Filatélico. De la Prisión al Convento. Novela filatélica. Original de Vicente Moreno de la Tejera," pp. 180 and hos. 90-116 have supplements of "Biblioteca de Madrid Fijatélico". El sello maldito, Novela filatélica. Original de Vicente Moreno de la Tejera," pp. 1-317. A copy of the prospectus, dated November 1, 1896, is bound up in front of no. 1.

$10^{12} / 907109-120$ fur-dee

$x 11509.21-132 \ldots$

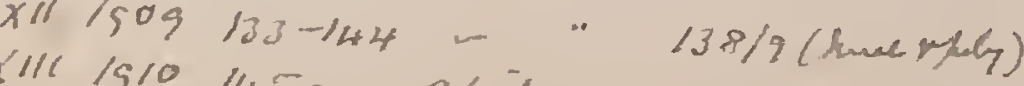

$11161910145-$ apini-

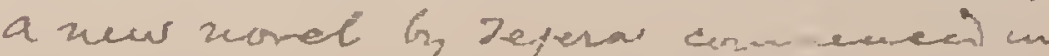

mo 11$) ?-16)\left(\mu /-222, T_{i}\right)$

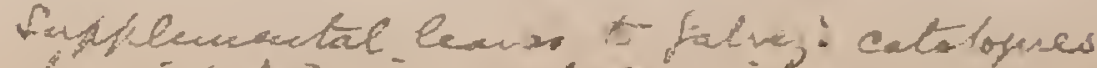

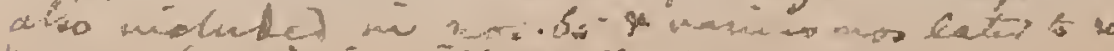

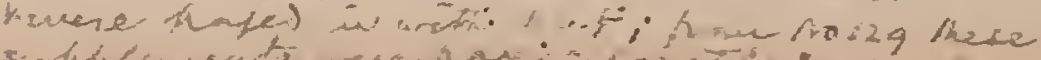

IMAGASIN PITTORESQUE. Le Magasin pittoresque. [Contains a number of articles entitled "Les TimbresPoste," by M. Natalis Rondot.

Paris, Edouard Charton, I862-66. Fol. 12 in. Series of Articles. [Nos. 1-53.] Vol. xxx., pp. 194. 223, 251, 270, 287, 318, 359, 383, 402. June, July, Aug., Aug., Sept., Oct., Nov., Nov., Dec., 1862. Vol. xxxi., pp. 35, 70, 119, 151, 199, 222, 254, 293, 335, 383. Jan., Feb., Apl., May, June, July, Aug., Sept., Oct., Nov., 1863. Vol. Xxxir., pp. 59, 87, 120, 131, 159, 183, 215, 263, 294, 326, 333, 366. Feb., Mar., Apl., Apl., May, June, July, Aug., Sept., Oct., Oct., Nov., 1864. Vol. XxxIr., pp. 47, 87,
$111,159,190,221,263$, 287, 326, 359, 391 . Feb., Mar., Apl., May, June, July, Aug., Sept., Oct., Nov., Dec., 1865. 391. Xxxiv., pp, 46, 86, 126, 158, 191, 223, 254, 308, 338, 367, 391. 1866 .

Apl., May, June, July, Aug., Sept., Nov., Nov., Dec., 1866. ** At the end of the last article the words "La suite au prochain volume" were added in error. These articles formed the basis of two similar series that were pubis.
family paper," London, 1862-67.

IMAGAZIN F'U்RBRIFFIVARKEN-SAIMMLER. Magazin für Briefmarken-Sammler.

Leipzig, Zschiesche und Köder, I863-67.

$4^{\circ} .8$ in. 48 nos. in 4 vols.

1st year. May 1, 1863-Apl. 1, 1864. Nos. 1-12.

2nd " " " 1864- " "1865. " 13-24

3rd " " "1865- " "1866. " 25-36.

* th "There is an index for nos. 1-24, one for nos. $25-36$ and one for Bulye . Tthe

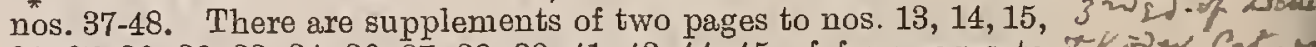

$21,27,30,32,33,34,36,37,38,39,41,43,44,45$, of four pages to 7 kin
nos $18,19,20,26,29,31,42$, of six pages to no. 23 , of eight pages 13.14

nos. $18,19,20,26,29,31,42$, of six pages to no. 23 , of eight pages

to nos. 24,25 , of ten pages to no. 17 , of twelve pages to nos. 22,28 ,
47 , and of fourteen pages to no. 35 . This was the first philatelic journal published in Germany.

IMAGAZINE OF PHILATELY. The Magazine of philately.

Liverpool, etc., The Universal Foreign Stamp Co., etc., $1883-84$.

8. $8 \frac{1}{4}$ in. Nos. 1-12, May-Sept., Dec., 1883, Jan., Dec., 1884. * Nos. 1-5 were edited by G. Henry Readdy, and published by the Universal Foreign Stamp Co. at Liverpool and also at London. Nos. 6-9 were edited and published by George Birtwhistle at Liverpool, London and Manchester, and nos. 10, 11, 12 were edited by George Birtwhistle and published by him and W. H. Rowbotham at Liverpool. Nos. (6, 7 and 8) and 10,11 and 12, were severally published together, dated "December, 1883" and "December, 1884, " respectively, and the former have a coloured paper wrapper.

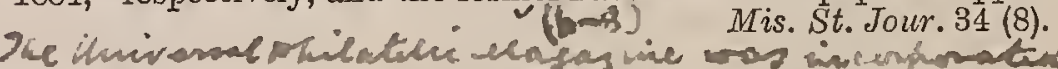
IIAGAZINE PHILATÉLIQUE. Le Magazine philatélique. Auch, Auguste Lecocq, I902-04. $8^{\circ} .10$ in. 27 nos. in 3 vols.

$\odot 1$ st year. July 20-Dec. 20, 1902. Nos. 1- 6

2nd " Jan. "- " " 1903. " 7-18.

* * There is " title-page and an index for the two first years combined and a paper wrapper to each number. Amalgamated with the "Annonce philatélique," Troyes, November, 1901.

IMAGAZINE PHILATELIST. The Magazine philatelist. in. No. 1, December, 1896. Buffalo, N. Y., [? ], I896.

\section{$\sin \operatorname{rob}-0$}




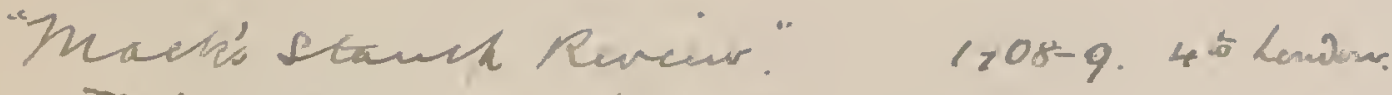

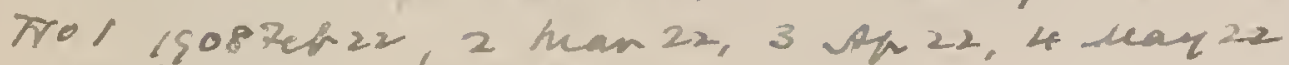
5 hue 22 th hige 22. 7 any.22, 8 Sept 24

9 oct-22, 10. Thor.22. 11. Ree 22 .

$12.1509 \cdot \tan 22,13 \tan 22.14$ Men 22

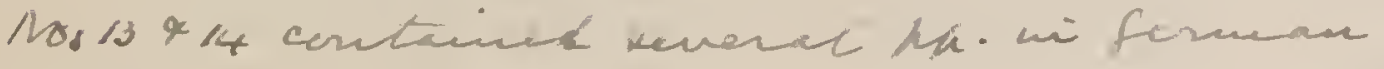

Each wo has a gug wh. w is haget how h.l

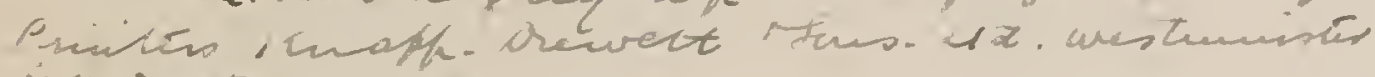
Mary tin en $\pi$ anus. 



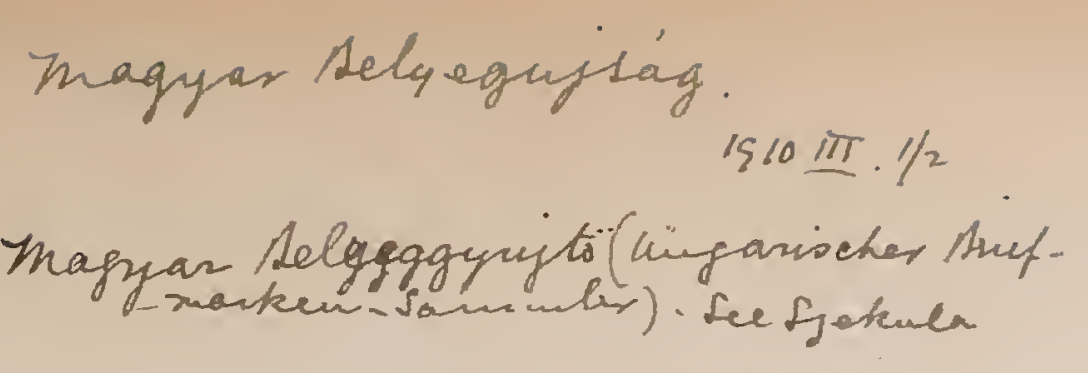

621 MAGYAR BÉLYEGGYU்UTŐ

IMAGYAR BELLYGGGÝ̛̛TÖ. Magyar bélyeggyüjtö.

$8^{\circ} .9$ in. Nos. 1-6, July 1-Dec. 1, 1905.
${ }_{*}^{*}$ *There is a coloured paper wrapper to each number. The jour-

Budapest, Béla Szekula, I905.

** There is a coloured paper wrapper to each number. The jour-
nal was continued in 1907.
Mis. St. Jour. 119 (8).

MAIL BAG. The Mail bag.

Washington, D. C., Albert O. Penney, ז896.

$32^{\circ} \cdot 4 \frac{1}{2}$ in. Nos. 1-5, [? ]-Dec., 1896.

W* Only partly philatelic. No. 5 has a coloured paper wrapper.

MAINE PHILATELIST. The Maine philatelist.

Portland, Me., W. M. Richardson and Co., [1872]. $8^{\circ} .8 \frac{3}{4}$ in. No. 1 , [no date].

** The above consists mercly of two pages, giving the publishers' $*$ * The a bove consists mercly of two pages, giving the publishers'
price list of foreign stamps and list of packets of stamps for 1872 . Mis. St. Jour. 21 (6).

MAINE PHILATELIST. The Maine philatelist. Published at will. Portland, Me., F. I. Perry I 885-86. $8^{\circ} \cdot 9 \frac{1}{4}$ in. Nos. 1-3, Fall and Winter, 1885-86, Jan., 1886, April, ${ }^{*}{ }^{*}$ * This publication is merely a price list of the publisher's stock ** This publication is merely a price list of the publisher's stock
of stamps, albums, etc. No. 1 is printed on coloured paper. Nos. 2 and 3 have "Published quarterly" in place of "Published at 2 and 3 have "Published quarterly" in place of "Published at
will".
Mis. St. Jour. 16 (1).

MALDEN PHILATELIST. The Malden philatelist. A monthly journal devoted to philately.

Malden, Mass., Butler-Sexton Stamp and Publishing Co., 1892.

$8^{\circ} .9$ in. Nos. 1-4, May-Aug., 1892.

${ }_{*}^{*}$ There is a coloured paper wrapper to each number.

Mis. St. Jour. 61 (9).

MALTA ADVERTISER. The Malta advertiser.

Valletta, The Malta Stamp Society, i gor.

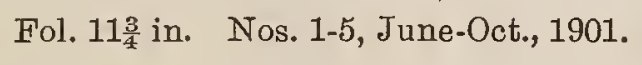

Mis. St. Jour. 107 (13).

MANCHESTER COURIER AND LANCASHIRE GENERAL ADVERTISER. The Manchester courier and Lancashire general advertiser. June 30 , 1899. [Contains a leading article on the Manchester philatelic exhibition.] Manchester, I899. Fol. $25 \frac{1}{2}$ in. p. 6.

Mis. St. Jour. 136 (20).

IMANHATTAN JOURNAL. See EMPIRE STATE PHILATELIST.

MANKATO PHILATELIST. The Mankato philatelist. Mankato, Minn., Carl Sudermann, I894.

in. Nos. 1-5, June-Oct., 1894

** Wanting all five numbers.

[_. [Second series.]

Mankato, Minn., Carl Sudermann, I895. $16^{\circ} \cdot 6$ in. No. 1, January, 1895.

* * The number has a coloured paper wrapper.

[Third series.]

Mankato, Minn., Carl Sudermann, I895.

$32^{\circ} .4$ in. Nos. 1-5, May-September, 1895.

** Wanting no. 5

[Fourth series.]

Mankato, Minn., Carl Sudermann, I8g6.

$16^{\circ} .6 \frac{1}{2}$ in. No. 1 , January, 1896.

${ }_{*}^{*}$ "The number has a coloured paper wrapper.

MaPfir. MaPri. Les Timbres.

Kiew, Pussie, S. D. Solomkine, etc., I896-г901.

Fol. 12 in. and $8^{\circ} .9-10$ in. nos. in 6 vols.

1st year. Mar. 12/24-Dec. 31, 1896. Nos. 1-12.

2nd " Jan. 15-Oct. 1/13, 1897. " 13-24.

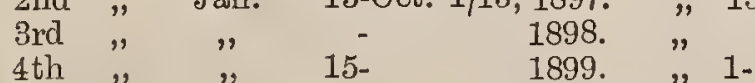

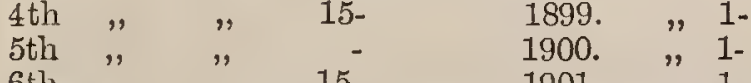

* * Nos. 1-12" were pub'ished in Russian and

French and nos. 6 and 7 were published together. Nos. $13-17$ wore published in two

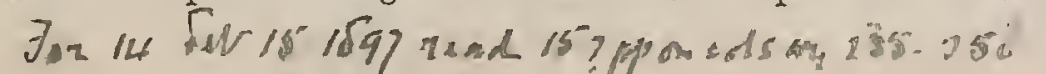

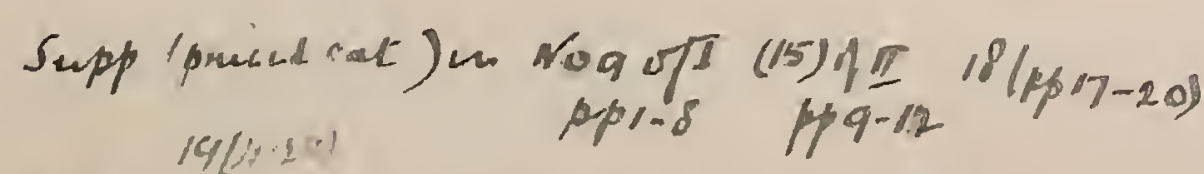

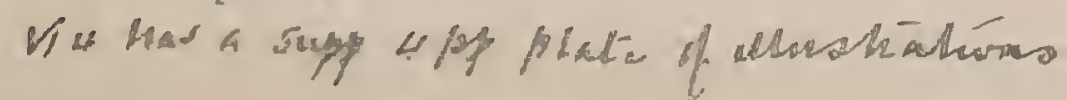

Heail Jzaber. W-E. heare, Hilbum

\section{MARKEN}

622

parts, one measuring 12 inches like the numbers of the first year, and the other measuring 9 inches. Of the third year the only number in the library is no. 29, dated December 24,1898 , which measures 10 inches. Of the fourth year there are copies of nos. $1-6$, measuring $10_{+}^{3}$ inches and the last of which is dated March 31,1899 . Of the,fifth year there is only one number dated May 1 , 1900 , and measuring 91 inches. This is numbered " $40 / 1$ " apparently meaning that it is whole number 40 and no. 1 of the fifth year. Of the sixth year the library has nos. 4, 5, 6, 8, measuring 9 inches, the last of which is dated August 15, 1901. The numbers of the fifth and sixth years were published by C. J. Schulkewicz. Wanting nos. 16 (large size part) 22 ; all vol. Irr. except no. 29 ; rv. all after no. 6 ; v. all but no. 40 ; ซr. nos. 1,2 , 3,7 and after 8 .

МАРКИ И КОЛЛЕКЧІОНЕРЪ. МАРІКИ И КОЛЛЕКЧІОНЕРЪ. Marken und Kollektioneur.

St. Petersburg, Jul. Stauff, I903-

$8^{\circ} .83$
ist
int. noar. in vept. 1903-December, In progress. 1904. "Probenummer" and

2nd ," Jan.-December, 1905. Nos. 1-12.

2nd " Jan.-December, 1905. Nos. 1-12.

** The contents are" published in Russian and German. There is a titlepage to each year. Nos.'5 and 6,7 and 8,9 and 10,11 is a titlepage to each year. Nos.5 and 6,7 and 8,9 and 10,11
and 12,13 and 14,15 and 16,17 and 18,19 and 20,21 and 22 and 23 and 24 of the first year, were severally published together. The dates of the twenty-four numbers of that year are October 10 , The dates of the twenty-four numbers of that year are October 10,
25, November 26, 30, December, 1903-A pril, 1904, Aurgust-Decem25 , November 26,30 , December, 1903-April, 1904, August-Decem-
ber, 1904 . A copy of the prospectus, dated August, 1903, is bound up in front of the "Probenummer".

IMARITIIME PHILATELIST. The Maritime philatelist. Salem, Yarmouth, Nova Scotia, J. J. Wallis, I8gi. $8^{\circ} \cdot 8 \frac{1}{2}$ in. Nos. 1-3, Feb.-Apl., 1891.

"* Each number has a coloured paper wrapper giving the date but no year is mentioned.
Mis. St. Jour. 63 (6).

MARKen-BÖRSE. See Philatelisten-Zeitung. (Stade).

MARKENWART. Der Markenwart. Anzeiger und tauschheft fūr Briefmarkensammler.

Apolda, Max Werner, r895-96.

8. 83 in. Nos. 1-10, April 1, 1895-Jan. 15, 1896.

[Continued as :]

Das Tauschheft. Anzeiger und Tauschheft für Briefmarkensammler.

Reutlingen, Wilhelm Baur, I896.

$16^{\circ} .5 \frac{1}{2}$ in. Vol. Ir., 6 nos.

2nd year. June 1-December, 1896. Nos. 1-6.

* There is no number for November, 1896

IMAROC TIMIBROLOGIQUE. Le Maroc timbrologique.

Journal d'annonces philatéliques.

Tanger, Nissim Abudaram et Cie., I897.

$\circlearrowleft 8^{\circ} .9$ in. Nos. 1-3, Feb. 1-Apl. 1, 1897. *** There is a coloured paper wrapper to each number. This was
the first philatelic journal published in Morocco.

Mis. St. Jour. 112 (9).

IMARSEILLE-POSTAL. Marseille-postal.

Marseille, Maury aîné, I89z-98.

Fol. $12 \frac{3}{4}$ in. and $8^{\circ} .9$ in. 13 nos. in 4 vols.

1st year. Apl. 15-June 15, 1892. Nos. 1- 3.

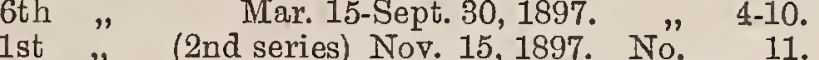

1st " (2nd series) Nor. 15, 1897. No. 11.

* * Nos. 1-11 are folio and nos. 12,13 are octavo $v$ No 3 is dated

"* 1891 " in error.
INis. St. Jour. $108(9)$.

IMARYLAND PHILATELIST. The Maryland philatelist. Church Hill, Md., T. H. Gafford, Jr., I896.

$8^{\circ} .9$ in. No. 1, Nov., 1896.

* * The number has a coloured paper wrapper.

Mis. St. Jour. 94 (5).

IMASON AND CO. CIRCULAR (J. ALLAN). See J. Aluan Mason and Co. circular.

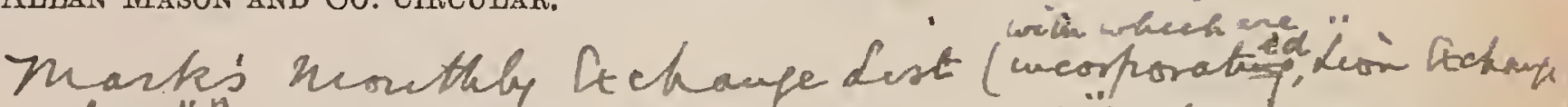

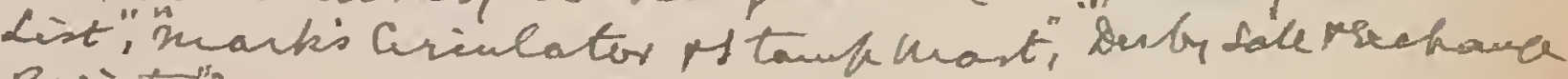
Refisteris)

1886 . I012 frute fors. 
MASON'S COIN AND STAIMP COLLECTORS IMAGAZINE. Mason's coin and stamp collectors' magazine.

Philadelphia, Pa., Mason and Co., etc., r867-7r. $8^{\circ} .8 \frac{3}{4}$ in. 60 nos. in 5 vols.

Vol. I. Apl., 1867-Mar., 1868. Nos. 1-12.

"II. "Dec, 1868. " $1-12$.

- " 1869. "

" V. " - ", 1871. " $1-12$

There is a title-page to each volume and a coloured pape wrapper to each number. Nos. 7 and 8, vol. I., are both dated November, but the wrappers of these two numbers bear, respectively, "October" and "November". Nos. 9-12, vol. II., were mencing with no. 8, vol. II. the wrappers bear the title "Mason" monthly coin and stamp collectors' magaine" and the title-pare of vols. II.-V., have the title given under the same form. Nos. 9 and 10 , vol. I., were published by E. Mason, Jr. and Co., nos. 11 and 12 , vol. I., and nos 1 and 2 vol. II by Mason and Wells, no. 3 , vol. II, by $\mathrm{E}$. Mason, Jre, and all subsequent numbers, by Mason and Co.

\section{[Continued as :]}

_- Mason's coin collectors' magazine.

Philadelphia, Pa., Mason and Co., 1872. $8^{\circ} .8 \frac{3}{3}$ in. Vol. VI., 3 nos.

Tol. $\nabla 1$. Jan - April, 1872 Nos. 1-3.

* There is a coloured paper wrapper to each number, the title on which reads "Mason's monthly coin collectors' magazine". No. 3 is dated "March and April, 1872 ". No. 1 contains the conclusion of the article "Origin of postage stamps," copied from "Harper's magazine," which was commenced in volume $\nabla$. Nos. 2 and

MASON'S COIN COLLECTORS' MAGAZINE. See MASON'S COIN AND STAMP COLLECTORS' MAGAZINE.

MASON'S MONTHLY COIN AND STAMP COL IECTORS' MAGAZINE. See MASON's COIN AND STAMP COLLECTORS' MAGAZINE.

IMASON'S MONTHLY COIN COLLECTORS IMAGAZINE. See MASON's COIN AND STAMP COLLECTORS' MAGAZINE.

MASSACHUSETTS PHILATELIST. The Massachusetts philatelist.

Taunton, Mass., E. E. Ashley, etc., I893. 8०. 9 in. Nos. 1-8, Feb. 25-June, Sept.-Nov., 1893 * . Nos. 4-8 were published by the Philatelic Publishing Co.

Mis. St. Jour. 61 (8)

MATIN. L9 Matin. Dix-Septième année. No. 6028. Août 29, 1900. [Contains an article "Chez les Philatélistes. Une exposition de timbres rarissimes-Le "cours" des timbres-Deux millions sous verre.] $\begin{array}{cc}\text { Fol. } 244^{3} \text { in. p. 2. } & \text { Paris, [? ], I } 900 . \\ \text { Mis. St. Jour. } 136 \text { (17). }\end{array}$

IMEFANICS' MAGAZINE. The Mechanics' magazine. October 17, 1840. [Contains an article describing "Tuck's hermetic envelopes," with an illustration of one of the envelopes having upon it an illustration of the then current one penny black Great Britain stamp: probably the earliest instance of a postage stamp illustration.]

London, E. C., J. C. Robertson, I840.

$8^{\circ} .8 \frac{1}{2}$ in. pp. 388-389

** The number of the "Mechanics' Magazine" for November 7 , 1840 , contains a notice of the same envelopes reprinted from the "Examiner". There is a file of the "Mechanics' Magazine" from its commencement in 1823 until 1858, in the library at Haigh Hall.

IVEDDELELSFR. Meddelelser udgivne af Kjфbenhavns Philatelistklub. Meddelanden utgifna af Lunds Filatelist-Förening. Kjobenhavns, 1899 . $8^{\circ} .10_{\frac{3}{4}}^{3}$ in. No. 1, August 15, 1899. Mis. St. Jour. 131 (5).
MEREEL'S DRUMMMER. Mekeel's drummer.

St. Louis, Mo., C. H. Mekeel Stamp and Publishing Co., r900-or

$12^{\circ}, 6 \frac{3}{4}$ in. and $8^{\circ} \cdot 8 \frac{3}{4}-91$ in. 13 nos in 3 vols

Vol. I. May 1, 15, June 15, July 15, Aug. 1, Sept. 20, 1900

, II. Oct. 27 , Nov. 10, Dec. 25, 1900, June 1, Fall, 1901. Nos $7-11$.

"III. Oct. 1, Nov. 1, 1901. Nos. 12-13.

* Nos. 1-6 are $12^{\circ}$., nos. 7-10 are octavo 83 inches, and nos. 12 and 13 are octavo $9 \frac{1}{4}$ inches. There are two editions of no. 9 one dated December 25, 1900, the other January 1, 1901, and there are two different issues of no. 11 , one with 36 pages, and th other with only 16 pages. The journal was succeeded by

MEKEEL'S NEWS AND TRADE CIRCULAR. Mekeel's news and trade circular.

St. Irouis, Mo., C. H. Mekeel, x $90_{5-}$ $4^{\circ} \cdot 10 \frac{3}{4}-11 \frac{1}{1} \mathrm{in}$ nos. in vols. In progress. [Vol. I.] Nov. 18, Dec. 27, 1905, Feb. 10, Apl. 19, May 25, 31 ,
1906. Nos. 1-6.

MEKEEL'S STAMP COLLECTOR. See Philatelic JOURNAL OF AMERICA.

MEKEEL'S WEEKLY STAMP NEWS. Mekeel's weekly stamp news.

St. Iouis, Mo., etc., C. H. Mekeel Stamp and Publishing Co., etc., r89r-04.

Fol. 163 in. and $13 \frac{3}{4}$ in. 690 nos. in 18 vols.
Vol. $\quad$ I. Jan. $7-$ Dec. 30,1891 . Nos. $1-52$

$"$ II. "6- " 28, 1892. " 53-104.

"III. " 5- " 28, $1893 . \quad " \quad 105-156$.

IV. $\quad 4$ 4- $" 27,1894 . \quad " \quad 157-208$.

" V. J" 3-June 27,

" VII. Jan. 2-June 25, $1896 . \quad$ " 261-286.

" viII. July 2-Dec. 31, " " 287-313.

"IX. Jan. 7-June 24, $1897 . \quad$ " 314-338.

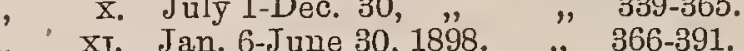

XII, July 7-Dec. 29,

"XIII, Jan 5- "28, 1899. "418-469.

" XIv. "4- " 27, $1900 . \quad$ " 470-521.

" $\quad x \nabla . \quad " 3-\quad " 28,1901, \quad " \quad 522-574$.

"XVII. " "3- " 26, 1903. " 627-678.

XVIII. "2-Mar. 19, 1904 . "679-690.

* "Vols. I.-III." are $16^{3}$ inches and the remainder are $13 \frac{3}{4}$ inches. Nos. 327-553 were published by I. A Mekeel at St. Louis, nos, 554 688 by Mekeel-Redfield-Severn Co., at New, York, and nos. 689 and

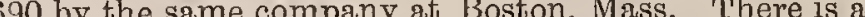
and a list of contents to each of the volumes, I.-IX., and to vol and a list of contents to each of the volumes, 1.-1x., and to vol. XII., lists of contents to vols. X., XI. and XIII., and paper wrappers to nos. $235-338,347-349,358,374,379,382,387,392,418,429,439$ $470,492,496,500,516,517,522,539,567,573,578$ and 636 There is a "Special convention number" for August 19, 1892 numbered "Vol. II. No. 33a," a slip supplement to no. 336 and a supplement to no. 133. Nos. 1 and 2 are dated " 1890 " instead of "1891," nos. 562 and 563 are numbered "Vol. $x \nabla$. . No. $40 "$ and " 41 " instead of " 41 " and " 42 ," respectively, nos. $604-609$ are numbered Vol. XVI. numbers $27-32$ in place of $30-35$, respectively, the wrappers of nos. 274 and 275 are wrongly numbered Vol. VII., numbers 13 and 14, instead of 14 and 15 , respectively, and the wrapper of no. 318 is numbered "Vol. IX., no. 4," of June 25, 1910.

[Continued as :]

Mekeel's weekly stamp news and the weekly philatelic era.

Boston, Mass., Mekeel-Redfield-Severn Co., r 904-05. Fol. $13^{3}$ in. Vols. XVIII.-XIX. 46 nos.

Vol. XviII. Mar. 26-Dec. 31, 1904. Nos. 691-731.

xIx. Jan. 7-Feb. 4, $1905 . \quad " 732.736$

[Continued as :]

Mekeel's weekly stamp news.

Boston, Mass., Mekeel-Redfield-Severn Co., I 905-

Fol. 133 in. Vols. XIX.- nos. In progress.

Vol. XIX. Feb. 11-Dec. 30, 1905. Nos. 737-783.

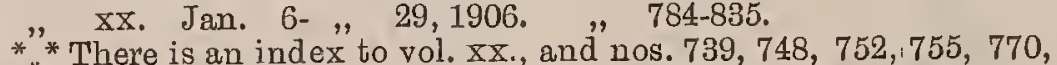
** There is an index to vol. Xx., and nos. 739 , 748, 752,755 , 770 , XIX., no. 26, whole no. 757, is wxongly numbered "XIX. No. 25 , whole No. 756 ," and vol. xx., no. 15 , whole no. 798 is wrongly numbered " $\mathrm{xx}$. No. 14, whole no. 797 ". 


MTREFI'S WHEKIY STANP NEWS AND THE WEEKLY PHILATELIC ERA. See MEKEEL'S WEERLY STAMP NEWS.

IVEITTA PHILATFITC CHRONICLF AND ADVER

TISER. The Melita philatelic chronicle and advertiser. Valletta, Malta, Alfred Muscat, I898-99. $8^{\circ} .10 \frac{3}{4}-11$ in. 24 nos. in 2 vols.

(c) 1st poar. Jon 1-Dec 1, 1898. Nos. 1-12

0 2nd 1 . 1, 1899.

* * Commencing with no. 5, vol. I." each number has a cobloured * Commencing with no. 5, vil. 1., ef the copies of no. 11, of the paper wrapper. Some, but not all, of the "10" in error A copy second year have the wrapper num bound up with the twenty-four nut the phistelic journal published Malta.

IVEIMBERS' EXCHANGE I.IST AND WIDE WORLD ADVERTISER: The Members' exchange list and wide world advertiser.

London, W., Rotherham, [printed] W. E. Neave, T905-06.

$8^{\circ} .8 \frac{1}{2}$ in. and $4^{\circ} .9 \frac{3}{4}$ in. 7 nos. in 2 vols.

Vol. I. Nov., 1905-A pril, 1906. Nos. 1-5. Hunt /-2

6 ," Ir. July, Sept., 1906. Nos. 6-7.

*"* Only partily philatelic. $\sim$ Nos. $1-4$ and nos. 6,7 are octavo and no. 5, which is dated "March and April," is quarto. Wanting
nos. 1-4.

MEIMPHIS PHILATELIST. The Memphis philatelist. Memphis, Tenn., H. Starr Kealhofer, etc., I880-85. $64^{\circ} .2 \frac{3}{4}$ in., $32^{\circ} .4$ in., $16^{\circ} .5 \frac{1}{2}$ in. and $8^{\circ} .63$ in. 4 nos. in 3 vols.

[Vol. I.] Aug., 1880. [No. 1.]

[", II.] Jan., 1882. No.2.

* * No. 1 is $64^{\circ}$. 2 is $32^{\circ}$, Nos. 3,4 . $10^{\circ}$. $8^{\circ}$ No 4 has a coloured paper wrapper and this number was published by E. W. Trancisco. No. 1 bears no number.

Mis. St. Jour. 68 (30).

MEN OF TO-IMORROW. Men of to-morrow.

Albany, N. Y., A. S. Brandow, I 9o4.

Fol. 11 in. Vol. xxxviı. Nos. 1-2; January, February-Mareh,

* 1904.

[Continued as :]

- Young Americans. New series of "Men of to-morrow" Albany, N. Y., A. S. Brandow, I904 Fol. 11 in. Vol. Xxxvir. Nos. 3-10, April-November, 1904 ** Only partly philatelic. Wanting nos. 7, 10.

IVERCANTILE RECORD AND COMIMERCIAL GAZETTE. Mercantile record and commercial gazette. Port Louis, Mauritius. No. 265 new series. No. 8659 old series. August 29, 1878. [Cuttings of the article "Mauritius postage stamps," by Lieut. Evans R.A., are mounted in Stamp Scrap-book, vol. IV., pp. 5559.]

IVERCHANTS' TMAGAZINE AND COIMIMERCIAI REVIEW. The Merchants' magazine and commercial review. January, 1844. [Contains "Art. Ir.-PostOffice reform, and uniform postages," by James M. Wheaton.] New York, Freeman Hunt, I 844 $8^{\circ} .8 \frac{1}{4}$ in. pp. $27-38$

* This and the following postal extracts are bound up in a volume lcttered "Merchants magazine-Postal extracts".

_- March, 1844. [Contains "Art. v.-Post-Office reform," by Hon. W. B. Maclay.]

$8^{\circ} .8 \frac{1}{4}$ in. pp. $250-267$.

New York, Freeman Hunt, I844

February, 1849. [Contains article "The Postal treaty between the United States and Great Britain".]

$8^{\circ} .8 \frac{1}{4}$ in. pp. $225,226$.

New York, Freeman Hunt, I849.

September, 1849 British post-office"; and "The Manufacture of envelopes for letters".] New York, Freeman Hunt, r849. $8^{\circ} .81$ in. [no pagination left on the extracts].
IVERCHANTS' IVAGAZINE AND COIMIMERCIAI

REVIEW. October, 1849. [Contains" Art. III.-The Finance of cheap postage," by Joshua Leavitt.]

$8^{\circ} .8 \frac{1}{4}$ in. pp. $410-414$

New York, Freeman Hunt, I849.

December, 1849. [Contains articles "Postal treaty between Great Britain and the United States" ; and "Art. II.-The Moral and social benelits of cheap postage," by Joshua Leavitt.]

$8^{\circ}$. $8 \frac{1}{4}$ in. pp. $331-334$ and $601-610$

New York, Freeman Hunt, I 849.

- January, 1854. [Contains articles "Postal convention between the United States and Bremen"; and "Law relating to the new receipt stamp in Great Britain ".]

$8^{\circ} .8 \frac{1}{4}$ in. pp. 114-116.

New York, Freeman Hunt, I854.

June, 1854. [Contains article "Postage on printed matter in Cuba".] New York, Freeman Hunt, I854. $8^{\circ} .81$ in. [no pagination left on the extract]

- September, 1854 [Contains "Art. III.-The Genera] post office of the United States," by D. D. T. Leech.]

$8^{\circ} .8 \frac{1}{4}$ in. pp. $305-319$.

New York, Freeman IIunt, I854

December, 1854. [Contains note "Postage in France".] $8^{\circ} .81$ in. [no pagination left on the extract]

New York, Freeman Hunt, I 854

February, 1856. [Contains articles "Franking privilege to members of congress" ; "Sailing of the United States mail steamers and postal regulations for 1856"; "Registered letters and the franking privilege"; and "New Brunswick post-office regulations".]

New York, Freeman Hunt, 1856.

$8^{\circ} .8 \frac{1}{4}$ in. pp. $234-237$.

March, 1856. [Contains articles "United States post office department"; "Revenue from letters and newspapers by ocean steamships"; and "Postal monopoly to be abolished in France".]

New Yort, Freeman Hunt, 1856.

$8^{\circ} .8 \frac{1}{1}$ in. pp. $365-367$.

April, 1856. [Contains articles "Instructions to postmasters and notice to the public" ; and "Postal arrangements between South America and the United States".] New York, Freeman Hunt, I856. $8^{\circ} .8 \frac{1}{4}$ in. pp. $486-489$.

May, 1856. [Contains articles "A postal prohibition in the United States"; and "Of postage on letters between Canada and the United States".]

$8^{\circ} .8 \frac{1}{1}$ in. pp. $615,616$.

New York, Freeman Hunt, I856.

- June, 1856. [Contains articles "Registration of letters between the U. States and Great Britain"; "Letters for California and territories of Oregon and Washington"; "Postage to Foo-Chow, China"; and "The franking privilege".] $8^{\circ} .83$ in. pp. $738-741$.

New York, Freeman Hunt, 1856

July, 1856. [Contains note "The London post office".] New York, Freeman Hunt, I856. $8^{\circ} .8 \frac{1}{4} \mathrm{in}$. [no pagination left on the extract].

August, 1856. [Contains articles "Statistics of the British post-office, 1855-56" ; "Reduction of postage to Egypt"; and "Postage to Van Dieman's land and Western Australia".]

88. 81 in. pp. 244-246.
New York, Freeman Hunt, 1856 . 
IMERCHANTS' MAGAZINE AND COMIMERCIAL REVIEW. September, 1856. [Contains articles "Information for letter writers, etc. Instructions to postmasters"; and "Postage to the East Indies, Java, Borneo, Labuan, Sumatra the Moluccas, and Philippine Islands".] New York, Freeman Hunt, I856. $8^{\circ} .8 \frac{1}{1}$ in. pp. $370-372$.

October, 1856. [Contains articles "Postal reform in the United States" ; "Postage stamps".] New York, Freeman Hunt, 1856 .

$8^{\circ} .8 \frac{1}{4}$ in. p. $493-495$.

- December, 1856. [Contains "Art. II.-The Post-Office as it has been, is, and should be: as a means of modern civilization," by Otis Clapp.]

New York, Freeman Hunt, 1856.

$8^{\circ} .8 \frac{1}{4}$ in. pp. $680-697$.

MERCUR, Mercur. Internationaler Briefmarlien-Anzeiger. Kreuz a.d. Ostbahn, A. Moersig, I877-78. Fol. $12 \frac{1}{2}$ in., $4^{\circ} \cdot 10 \frac{3}{4}$ in., fol. $17 \frac{3}{4}$ in., $8^{\circ} .8 \frac{1}{2}$ in. and fol. $12 \frac{1}{2}$ in. 12 nos. in 2 vols.

1st year. May 15 , July 1-Nov. 15,1877 . Nos. 1-6.

S107 "2nd " Feb. 1, Apl. 1, June 1, Aug. 1, Nov. 1, Dec. 1, 1878. * No. 1 is folio $12 \frac{1}{2}$ inches, nos. $2-4$ are quarto $10^{3}$ inches, no. 5 is folio $17 \frac{3}{2}$ inches, no. 6 is octavo 81 inches and nos. $7-12$ are folio $12 \frac{1}{2}$ inches, No, 6 bears no number and has the title "Weihnachts -Nummer des In:ernetionalen Briefmarken-Anzeigers Mercur". There is a supplement of two pages to no. 8 and one of four pages to no. 10. Nos. $2-5$ and $7-12$ have added to the subtitle " und Gratis-Beilage zu Louis Senf's Illustrirtem Briefmarken-Journal ".

\section{[Continued as:]}

Internationaler Briefmarken-Anzeiger Merkur.

Kreuz, a. d. Ostbahn, A. Moersig, I879-8o.

Fol. 121 in. Vols. III.-IV. 14 nos.
3rd year. Feb. 1, Apl. 1, May 1, Aug. 1-Oct. 1, Dec. 1, 1879. Nos. 3rd year. Feb. 1, A

4th , Jan. 15, Feb. 15, Apl. 15, May 15, July 15, Sept. 15, * Nov. 15, 1880 . Nos. 20-26.

* There are supplements to nos. 14, 16, 17, and 18, two supplements each to nos. $15,20,21$, and 23 , three supplements each to nos. 22 and 25 , four supplements each to nos. $19^{\prime}$ and $24^{\prime}$ and six supplements to no. 26 .

MERCUR. Mercur. Internationales Insertions-Organ für Briefmarken-Händler.

Hemer $i$. Westfalen, Chr. Sauerland, I896. Fol. 12 in. Nos. 1-4, May 5, 20, June 5, July 20, 1896 * * Printed on buff paper and the contents consist entirely of ** Printed on buff paper and the contents consist entirely of
ais. St. Jour. 109 (10).

IMERCURIALE. La Mercuriale des timbres-poste, timbrestélégraphes, cartes-postales, etc.

Paris, Léon Bresson, I893$8^{\circ}$. $9 \frac{1}{2}$ in.

* * This is solely a price list of stamps, etc., for sale by the publishers and cannot therefore be considered a philatelic journal. No. 1 is dated "Janvier, 1893," and numbers were still being published in 1906.

IMERCURIO. El Mercurio. Periódico filotélico: Philatelic monthly.

Lima, Peru, Harold R. Miller, etc., I886-87. $4^{\circ} .11 \frac{1}{2}$ in. Nos. 1-5, Oct. 15, 1886-Jan., Mar., 1887. * Nos. $2-5$ were pubjished by Harold This was the first philatelic journal published in Peru. Mis. St. Jour. 86 (2).

MERCURIUS. Mercurius. Postzegelkundig tijdschrift. Antwerpen, Ed. Hulsens, I903. $8^{\circ} .11$ in. Nos. 1-2, Sept. 15-Nov. 15, 1903

* ${ }_{*}^{*}$ There is a coloured paper wrapper to each number. Mis. St. Jour. 87 (7)
IMERCURY. The Mercury. A monthly magazine for stamp and coin collectors.

London, E.C., etc., F. Pitman, etc., I875. $8^{\circ} .9 \frac{1}{2}$ in. Nos. 1-5, May-July, Sept., Oct., 1875.

* * There is a paper wrapper to each number, Edited by George . Mortim

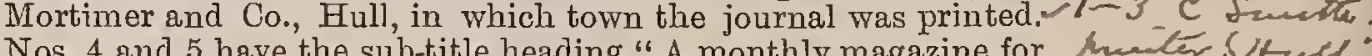
Nos. 4 and 5 hain stamp and coin collectors, and journal of ant

[Continued as :]

$$
\begin{aligned}
& 4 \rightarrow 7 \\
& \text { Henite }
\end{aligned}
$$

The Archaeologist. A medium of intercommunication matas, the

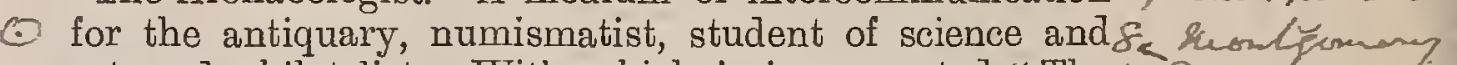
art, and philatelist. With which is incorporated "The/4 Em, hell

Mercury". London, E.C., etc., F. Pitman, etc., I875-76.

$S^{\circ} .9 \frac{1}{2}$ in. 9 nos. in 2 vols.

Vol. I. Nov., Dec., 1875. Nos, $6,7$.

C. "II. Jan.-July, 1876 . Nos. 8-14.

* There is a paper wrapper to each number. Nos. 6 and 7 were sold with the five numbers of the "Mercury" in a blue paper "
wrapper as vol. I. of the "Archaeologist". $v$ No. 14 was published wrapper as vol. I. of the "Archaeologist". $"$ No. 14 was published 7 and 11.

MERCURY IMAILER. The Mercury mailer. Louisville, Ky., F. G. Wattins, Jr., I896-97. $32^{\circ}$. 4 in. Nos. $1-,[?], 1896-[?], 1897$.
* Wanting all but January, 1897, the number on which is $S 108$ omitted.

IMERIDEN ADVERTISER. The Meriden advertiser. Meriden, Conn., [ ], Igo2.

in. No. 1, October, 1902

* *nly partly philatelic. Wanting.

"MERKUR". "Merkur". Fachblatt für Postwertzei1287. chensammler.

Hamburg, Intern. Postwertzeichen-Sammler-Ter.ein "Mertiur," I894. whilcaf presectus Signedin Kroth

$8^{\circ} .9 \frac{1}{4}$ in.๑No. 1, March 10, 1894. Mis. St. Jour. $90(6)$

IMESSENGER. The Messenger.

$$
\text { Cohoes, - N. Y., [? ], r898-1900. }
$$

in. 3 nos. in 2 vols.

Vol. I. May, 1898, Oct., 1899. Nos. 1-2

", II. January, 1900 . No. 1.

* * Only partly philatelic. Wanting all nos.

$$
5108
$$

IVETROPOLIS. The Metropolis.

Corning, N. Y., The Metropolitan Philatelic Associa tion, etc., I $903-04$.

$8^{\circ} .91$ in. and 8 in. Nos. 1-6, Sept. 20, 1903-June, 1904

* * No. 3 measures 8 inches and the other numbers 9 inches and nos. 2-5 have coloured paper wrappers. No. 4 is dated December, 1903-January, 1904" "no. 5, "A pril, 1904 " and no. 6 "May-June, 1904". No. 1, although bearing "Corning, N. Y." is stated to be published by J. W. Stowell and Co. of Federalsburg, is stated to be published by . W. Stowell and Co. of Federalsburg, Md., and no. 6 was published by $H$. D. Munger and $\mathrm{R}$. W
Geauque.

METROPOLITAN PHILATELIST. The Metropolitan philatelist.

New York, National Philatelical Society, etc., I 89o$4^{\circ} .9$ in. and $8^{\circ} .10 \frac{1}{2}$ in. nos. in vols. In progress.
Vol. I. Apl. 1890-Mar. 1891. Nos. 1- 12. Vol. II. Apl. 1891- " 1892.0 " $1-12$ " III. " $\quad$ III. " $\quad 1892-", \quad 1893 . \quad " \quad 1-12$

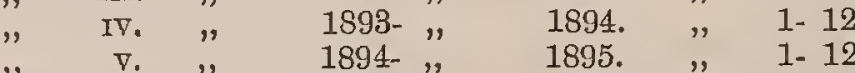
" vi. " $\quad$ v. $\quad 1895-", \quad 1896 . \quad " \quad 1-12$ $\begin{array}{ccccc}\text { VII. } & 1896- & & 1897 . & 1-12 \\ \text { VIII. } & 1897-, & 1898 . & 1-12\end{array}$ Ix. " 2, -Sept. 3, " " $1-26$ IX. S" 2, "̈-Sept. 3, " " " XI. Apl. 1 -Sept. 30, " XI. Apl. 1, -Sept. 30, " "’ " XIII. Ap]. 7, -Sept. 29, " $1-26$. XII. Ap. 6, 1900-Mar. 30, 1901. " " 1- 26 xv. Apl. 6, -Sept. 28, " " " $1-26$. XVI. Oct. 5, 1901-Mar. 29, 1902. " " $1-26$. XVII. Apl. 5, -Sept. 27, ", ", $1-26$. XVIII. Oct. 4, 1902-Mar. 28, $1903 . \quad ", \quad 1-26$. XIX. Apl. 4, -Sept. 26, " " $1-26$ xx. Oct. 3, 1903-Mar. 12, $1904 . \quad ", 1-24$ xxI. Mar. 19, -Aug. 27, ", ", 1- 24 xxII. Sept. 3, 1904-Feb. 11, 1905. " $1-24$ xxiII. Feb. 18, -Dec. 23, 


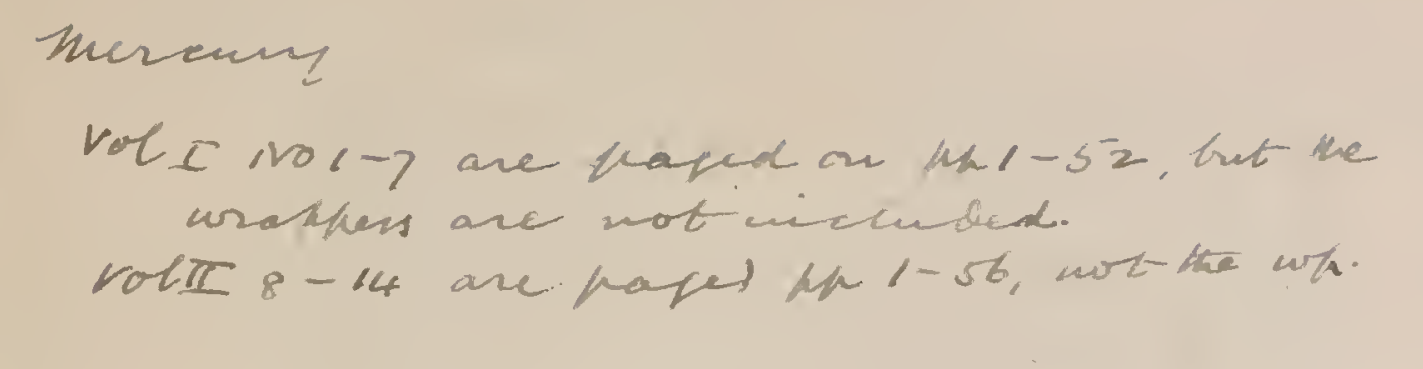


Hudtand Pholatiust. hos as new 1-3.5,-11

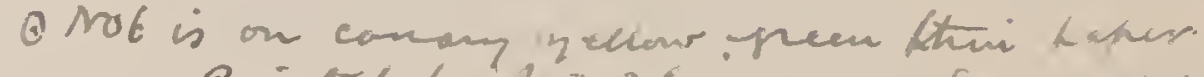

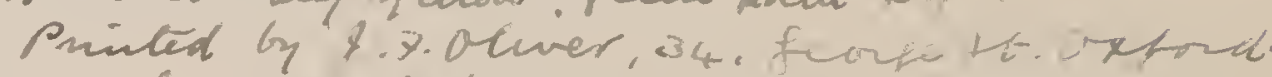
nompar only so stated on hos $1-6$

hos 1-4 werc abo published by Robests or frow the same aidress as his bresiness. 
* * The numbers of vols. I-VIII. were published monthly and are quarto, the remaining numbers have been published either weekl or fortnightly and are octavo. There are titlepages and indexe to vols. I.-VIII. only and there is a paper wrapper to each number of the first eight volumes, and to no. 7 , vol. $x \nabla$. , and to no. 1 , vol. XVI. Nos. 1-10, vol. 1., were published by the Board of Manager of the National Philatelical Society, the Staten Island Philatelic Society, and the Brooklyn Philatelic club. There are two separate numbers of 10. 10, vol. I., owing to a dispute; one published by the Boar, the other by John Walter Scott, and all subsequen numbers have been published " by the latter. "The number for February, 1894, is numbered "No. 2 "in place of "no. 11," an the paper wrappers or the twelve numbers of vol. vill. are numbered 85-96. No. 27, vol. XI., is numbered, in error, "Vol. XII. No. $1 "$.

MEXICO.FILATRLICO. Mexico-filatélico. Organo de la Sociedad Filatélica Mexicana.

Mexico, Sociedad Filatelica Mexicana, i go4-o6. $8^{\circ} .8 \frac{3}{4}$ in. 22 nos. in 2 vols

Vol. I. Jnly 1, 1904-Dec., 1905. Nos. 1-18.

"II. Jan. -Aug., 1906. 1- 4.

* * Nos. 8 and 9,10 and 11,12 and 13,14 and 15,16 and 17 and nos. 3 and 4, vol. II., were severally published together. No, 1 of vol. II., is dated "Enero y Febrero"; no. 2, "Marzo y Abril" and nos. 3 and 4,"Mayo-Agosto". There is a supplement with the title "Al Rededor de los timbres postales de Mexico. Por Joaquin or a labe/ tinol of Escalante" running through the numbers, but this was left inof $2 p$ f journal.

MEXICO POSTAL. Mexico postal. Organo de los filatelistas Mexicanos. prosple turs use $10 \%$ heaf Guanajuato, Mexico, Eduardo Aguirre, 1892-93. $8^{\circ} \cdot 9 \frac{3}{4}$ in. Nos. 1-10, July 1, 1892-Apl. 1, 1893

Mis. St. Jour. $97(8)$

Segunda Epoca

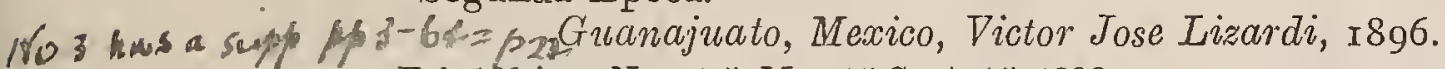
Fol. 121 in. Nos. 1-5, May 15-Sept. 15, 1896.

* * Printed on buff paper.

Mis. St. Jour. 97 (9).

IMERS' MONTHLY ECHO. Myers' monthly echo. Augusta, O., A. H. Myers, I 884 . in. No. 1. ** Only partly philatelic. Succeeded by the "Agent and Collec-
tor's Sun". Wanting.

MICHIGAN PHILATELIC MONTHLY ADVER TISER. The Michigan philatelic monthly advertiser.

$8^{\circ} .8 \frac{3}{1}$ in. Nos. 1-3, Jan.-March, 1899

Detroit, Mich., H. Stange, 1899.

** There is a coloured paper wrapper to each number. The contents consist entirely of advertisements. Wanting no.

Mis. St. Jour. $94(6)$.

MICHIGAN PHILATELIC WEEKLY. The Michigan philatelic weekly. Published in the interest of philately and philatelists.

Ithaca, Mich., W. M. Waterbury, r899. $8^{\circ} .8 \frac{1}{2}$ in. and $4^{\circ} .11$ in. Nos. $1-2$, January $5-16,1899$.

* No. 1 is octaro and no. 2 is quarto. Nos. 3 and 4 are said to * Nist.
No. 1 is octavo and no. 2 is quarto. Nos. 3 and 4 are said to
Mis. Sour. 120 (3).

MICHIGAN PHILATELIST. The Michigan philatelist. Devoted to the interests of stamp collectors.

Detroit, Mich., Union Stamp Co., etc., I877-[79]. $8^{\circ} .8 \frac{1}{2}$ in. 19 nos. in 2 vols.

Vol. I. Apl., 1877-Mar., 1878. Nos. 1-12.

* II. Apl., May, Dec., 1878, Jan.-Apl. [1879]. Nos. 13-19.

* Nos. $10-15$ were published by $\mathrm{E}$. A. Duvernois and 16-19 by $\mathrm{E}$. A. Duvermo 11,13 and $14 ; 16,17,18$ and 19 , were severally published together. Nos. 12-19 were printed on coloured paper, and nos. 16-19 are also found
on white paper.
Mis. St. Jour. 29 (1).

MICHIGAN PHILATELIST. The Michigan philatelist. Manchester, Mich., etc., H. G. Spaulding, r885-86. $8^{\circ} .9$ in. Nos. 1-5, Sept., 1885-Jan., 1886. ** No. 5 was published at Battle Creek, Mich., and nos. 2-5 have
paper wrappers.

Mis. St. Jour. 23 (2).

MICHIGAN PHILATELIST. The Michigan philatelist. Detroit, Mich., W. F. Dessotell, 1892. $8^{\circ} \cdot 8_{\frac{3}{*}-9}$ in. Nos. $1-4$, Jan.-Apl., 1892. Mis. St. Jour. 61 (7).

netico Picatelio. Metieo.

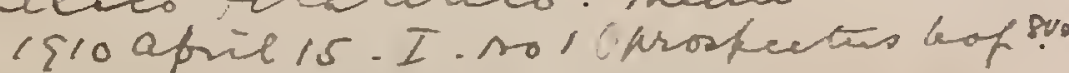

ICHIGAN PHILATELIST. The Michigan philatelist. Devoted to the interests of stamp-collecting. 96.

Coldwater, Mich., Wing, Bailey and Co., etc., I894-

$8^{\circ} .8 \frac{1}{2}$ in. 17 nos. in 2 vols.

Vol. I. Dec., 1894-Dec., 1895. Nos. 1-13.

" II. Jan., April, 1896. " 1- 4

* "Each number has a coloured paper wrapper, and no. 13 and the four numbers of vol. II. wore published by W. C. Bailey and

MICHIGAN PHILATELIST. The Michigan philatelist. $896-99$

Hart, Mich., John C. Brassington and Co., etc.

$8^{\circ} .8$ in -9 in. 7 nos. in 2 vols

Vol. I. July-Nov., 1896, Feb., 1897. Nos. 1-6.

* II. April 15, 1899. No. 1.

* The numbers of vol. I. measure $8 \frac{1}{2}$ inches and no. 1 , vol. II. measures 9 inches. Nos. 4 and 5 were published together, an each number has a paper wrapper. No. 1, vol. II., was pnblishe by John $\mathrm{C}$. Brassington. The wrappers of nos. 1-5 bear the words "New series". In April, 1897, the journal was amalgamated wit the "Detroit philatelist".

MICHIGAN PHILATELIST. The Michigan philatelist.

Ithaca, Mich., Michigan Stamp and Pub. Co., I 898 . $8^{\circ} .7 \frac{3}{4}$ in. No. 1 , June, 1898

** Edited by W. M. Waterbury. The number has a paper
wrapper.

MICHIGAN STAMP. The Michigan stamp.

Clarion, Mich., H. McConnell, I895-96.

$32^{\circ} .4 \frac{1}{2}-4 \frac{1}{4}$ in., $16^{\circ} .5 \frac{3}{4}$ in. and $8^{\circ} .8$ in. 10 nos. in 2 vols.

Vol. I. Feb.-July, 1895. Nos. 1-6.

, II. Aug., Oct., 1895, Jan., Nov., 1896. Nos. 7-10.

* " No. 1 is $32^{\circ}$. $4 \frac{1}{2}$ inches, nos. $2-6$ are $32^{\circ} .4 \frac{1}{4}$ inches, no. 7 is $16^{\circ}$ and nos. 8-10 are octavo. Nos. 5-7 have coloured paper wrappers. Wanting no. 3 .

Mis. St. Jour. $152(1)$

MIDLAND PHILATELIC AND GENERAL ADVERTISER.

Nottingham, The Midland Stamp Co., etc., r 887-88. $4^{\circ} .93$ in. Nos. 1-12, Aug., 1887-July, 1888

* Nos. 5-12 were published by Edward Roberts. Nos. 1 and 6 are also found printed on buff paper. Succeeded by the "Midland philatelist ${ }^{p 1}$. Mis. St. Jour. 45 (3)

MIDLAND PHILATELIST. The Midland philatelist. Nottingham, Oxford [printed], E. Roberts, r889-9o. $8^{\circ}$. 81 in. ONos. 1-4, Mar. 31, June 30, Dec. 31, 1889, Mar. 31 ,

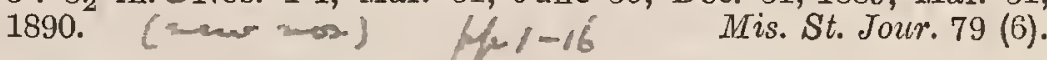

MIDLAND PHILATELIST. The Midland philatelist. Kansas City, Mo., F. R. Hurst, 1895-96. $16^{\circ}$. 6-63 in. Nos. 1-5, Nov., 1895-April, 1896.

* * No. 1 is 6 inches and the remaiuing nnmbers are 63 inches. No. 5 is dated "Mar. and Apl.". and each number has a paper wrapper. The wrapper of no. 2 is wrongly numbered "no. 1 ". Mis. St. Jour. 96 (10).

MIDLAND PHILATELIST. The Midland philatelist [Prospectus of a journal to be published by Coombs and Dworak, Geneva, Nebraska, about December 1, 1889 which was never published, but was consolidated with the "Nebraska philatelist," Pawnee City, Neb. in March, 1890.]

Mis. St. Jour. 76 (1)

MILLION. The Million. Nos. 120-158. rContain 39 articles with the title "Our stamp album". Nos. 1-39; by Harold Frederic.]

London, Geo. Newnes Ltd., I 894-95.

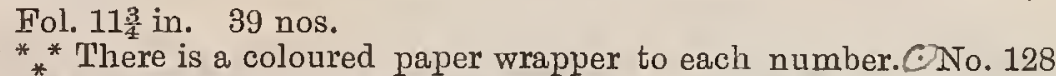
* * Confiscated by the Board of Inland Revenue of Somerset House on account of its containing an illustration of a Great Britain postage stamp.

MILWAUKEE STAMP ADVERTISER. The Milwaukee stamp advertiser.

Milwaukee, Wis., W. and O. Schleif, [I884] Oblong $16^{\circ} .4 \frac{7}{2}$ in. [No. 1, 1884.]

** The contents consist entirely of advertisements.
Mis. St. Jour. 71 (14). 
MINERS' JOURNAL. The Miners' journal. Pottstown, Pa. [? month] 1873. [Cuttings of the article "Philately" are mounted in Stamp Scrap-book, vol. II., pp. 92, 93.]

MINNESOTA PHILATELIST. The Minnesota philatelist. St. Paul, Minn., F. Stahl and Co., r886. 8. 9 in. Nos. 1-2, Jan.-Apl., $1886 . \quad$ Mis. St. Jour. 23 (5).

MINNESOTA PHILATELIST. The Minnesota philatelist. A monthly journal for stamp collectors.

Minneapolis, Minn., The Minnesota Philatelic Co., $1893-94$.

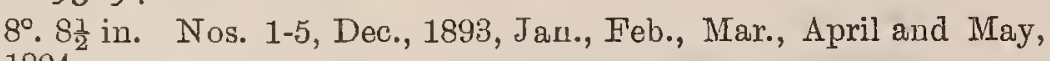
1894 .

**" There is a coloured paper wxapper to each number. Nos. 1-4 were edited by Harry Sylvester Swensen and no. 5 by J. A. Bruederly Jr. No. 2 is wrongly dated "December, 1893," instead of "January, 1894," and no. 3 has " 1893 " in place of "1894," but the wrappers of both these numbers bear the correct dates. Mis. St. Jour. $65(7)$

MINNESOTA PHILATELIST. The Minnesota philatelist.

Minnesota Lake, Minn., Ed. B. Howe, г90г-02. $8^{\circ} 9$ in Nos 1-4, December 1, 1901-March, 1902. * * There is a coloured paper wrapper to each number.

Mis. St. Jour. 147 (8).

IMINNESOTA PHILATELIST. See North Star PHILATELIST.

MINNESOTA STAMIP. The Minnesota stamp. Published monthly for stamp collectors.

Pipestone, Minn., Hart and Ruehlman, I 896. $8^{\circ} .8$ in. No. 1 , Aug., 1896.

**"The number has a coloured paper wrapper.

Mis. St. Jour. 93 (8).

MISCELIANEOUS ADVERTISER OF WANTS AND OFFERS. The Miscellaneous advertiser of wants and offers. Shrewsbury, R. Nixon and Co., rgoo.

(3) $8^{\circ} .71$ in. Nos. 1-2, April-June, 1900.

* * There is a coloured paper wrapper to each number. VTlie contents consist entirely of adrer tisements. -

\section{[Continued as:]}

5108

Shimp advertiser of wants and offers. Shrewsbury, R. Nixon and Co., I900-0r. $8^{\circ} .7 \frac{1}{4}$ in. Nos. 3-8, July-Nov., 1900, Jan., 1901.

* * There is a coloured paper wrapper to each number. The contents consist entirely of advertisements. No. 8 lias " 1900 " in error for "1901". Wanting nos. 3, 4 .

MISCELLANEOUS STAMP ADVERTISER OF WANT'S AND OFFERS. See Mischlianeous ADVERTISER OF WANTS AND OFFERS.

IMISSOURI PHILATELIST. The Missouri philatelist. A monthly magazine devoted to stamp collecting.

St. Louis, Mo., The Conrath Stamp and Pub. Co. etc., I89r-93.

$8^{\circ} .9$ in. 16 nos. in 3 vols

Vol. 1. Oct., 1891-Mar., 1892. Nos. 1- 6

" II. Apl., -Sept., $1892 . \quad$ " 7-12.

" III. Oct., 1892-Jan., 1893. "13-16. * "Nos. 10-16 were published by Ph. Conrath, and there is a coloured paper wrapper to each number. No. 13 is wrongly numbered "Whole no. 1 " and no. 16 is wrongly numbered "Whole no. 15 ".

MISSOURI PHILATELIST. The Missouri philatelist. St. Joseph, Mo., N. G. Wilson, I895-96 8․ 8-81 in. Nos. 1-3, Dec., 1895, Feb., Mar., 1896.

Mis. St. Jour. 93 (11).

IMISSOURI PFILATELIST. The Missouri philatelist. Columbia, Mo., K. S. Heck, I899. $8^{\circ} .9 \frac{3}{4}$ in. Nos. 1-2, Mar.-April, 1899 **"There is a paper wrapper to each number. Wanting no. 1. Mis. St. Jour. $152(5)$.
MITTEILUNGEN AUS DEM PHILAT. SCHÜLRR VEREIN BRUCHSAL. Mitteilungen aus dem Philat. Schülerverein Bruchsal.

Bruchsal, r89r-92.

$4^{\circ} .8 \frac{1}{2}$ in. Nos. 1-5, Apri] 15, Sept. 15, Nov. 15, Dec., 1891, Apri

* * Produced by autographic lithography. The title of nos. 3 "Mitteilungen des Philat. Schuler-Vereins Bruchsal",

Mis. St. Jour. 132 (9)

MITTEILUNGEN DER TAUSCHLEITUNG DES " CHATMRS" Mitteilungen der Tauschleitung des "Chalmers". Leipzig, Der Verein, I893.

$4^{\circ} .87$ in. [No. 1], February 1, 1893.

** Produced by a hectographic process. Wanting.

MITTHEILUINGEN DER TAUSCHVEREINIGUNG FƯR POSTWERTHZEICHEN ZU ELBERFELD. Mittheilungen der Tauschvereinigung für Postwerthzeichen zu Elberfeld.

Elberfeld, r89o-

$8^{\circ} .10$ in. nos. in vols. In progress.

1st year. July 1, 1890-June 1891. Nos. 1-11.

2nd ", " 1891- " $1892 . \quad$ " 1-12.

3rd " " " 1892- ", 1893. " " $1-12$.

4th " " $1893-"$ " $1894 . \quad " 1-12$.

6th " " " 1895- " $1896 . \quad$ " $1-12$

7th " " " 1896- " $1897 . \quad, \quad 1-12$

8th " " " 1897- ", 1898. ", 1, 1a, 2-12

9th " " $\quad 1898-", 1899 . \quad " 1-12$.

11th " " $" 1899-" \quad 1900 . \quad " 1-12$

12th " " " 1901- " 1902.

13th " " " 1902- " $1903 . \quad$ " $1-12$.

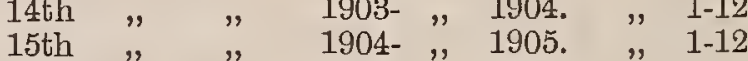

16 th " " " $1905-", 1906 . \quad$ " $11-12$.

* * Nos. 9 and 10 of the second year are wrongly numbered "II. 8," nos. 7-11 of the fourth year are wrongly numbered fifth year; nos. 10 and 11 of the fifth year are numbered " 19 " and " 20 " respectively; no. 9 of the seventh year is wrongly numbered " $7 "$; no. 1a of the eighth year is an extra number of July, 1897 ; no. 2 of the eleventh year has a supplement, and no. 12 of the seventeenth year is wrongly numbered "18 Jahrg". Wanting vol. I., all but 11 ; II. all but 1 ; III. all but 5 ; and IV. no. 7 .

MITTHFILUNGEN DES BRIEFIMARIKENSAIMIMLER-VEREINS MOSEL. Mittheilungen des Briefmarkensammler-Vereins Mosel.

Cochem, etc., r893-I904.

$8^{\circ} .9$ in. and $4^{\circ} .8 \frac{1}{3}$ in. 113 nos. in. 11 vols.

1st year. Jan.-Dec., 1893. Nos. 1-12.

2ad " " - ", 1894. " 1-12

3rd " " - " $1895 . \quad, \quad 1-12$

4th " " $"$ " $1896 . \quad 1-12$

6th " Dec., 1898. No. 1. "

8th " Jan. -Dec. 1900. " 1- 4

9th " " $"$ " $1901 . \quad " 1-12$

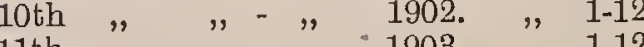

" " " " "

* The numbers of the fourth, fifth and sixth years were published * Kirchberg, and commencing with no. 1 of the eighth year the the $2-4$ of the eighth year and nos. journal was published in Koln. Nos. 2-4 of the eighth year and nos. -5 of the ninth year have the title "Mittheilungen des BriermarkenSammler-Vereins Mosel zu Koin". Nos. 1-9 of the second year and ll the number's of the eighth, ninth, lenth, and eleventh years were produced by autographic lithography. Nos. 10 and 11 of the second year, nos. 2 and 3 and 9 and 10 of the third year, nos. 1 and 2,15 and 6 and 9 and 10 of the fourth year, nos. 5 and 6,7 and 8,9 and 10 and 11 and 12 of the fifth year, and nos. 6 and 7 and 8-10 of the eleventh year were severally published together. There are no numbers of the seventh year, no. 3 of the eighth year is dated März, April und Mai" and no. 4 "Juni-Dezember". Nos. 10 and 11 of the second year are wrongly numbered 14-15, nos. and 8 of the fifth year are wrongly numbered $5-6$ and no. 11 of the welfth year is wrongly numbered 10 . With the exception of nos. 1-9 of the second year, nos. 3-9 and no. 12 of the tenth year, nos. 1-7 of the eleventh year and the twelve numbers of the nos. 2-10 for 1893 .

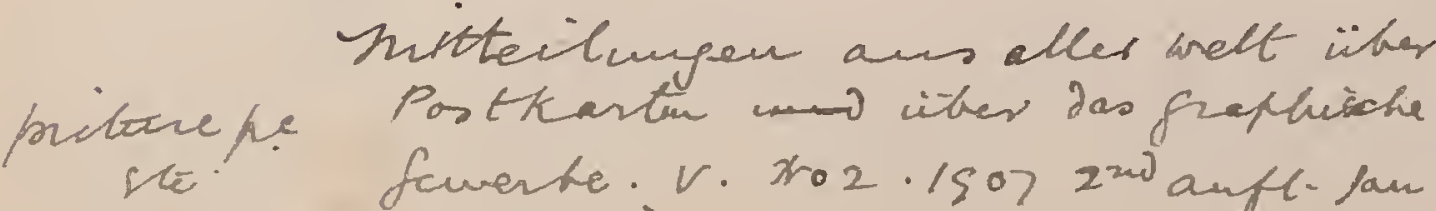
Berlin.
}

Nutteilengen derfirma Pand Kohl $\phi$ f.m.B.H.Chemmits. 810 
Qho 2 has splabers a supplteaf

hous has 4 Pp 


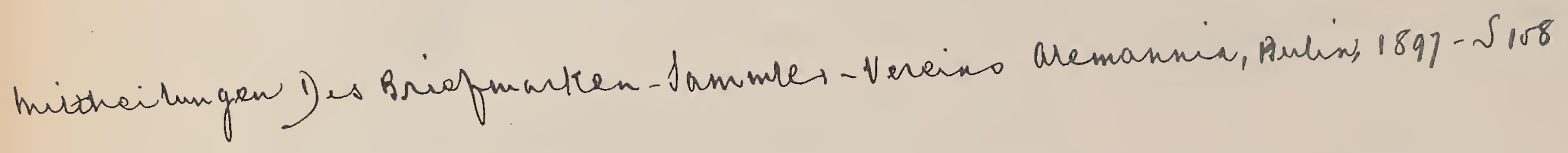




\section{MITTHEILUNGEN DES BRIEFIMARKENSAMM-} LER-VEREINS INIOSEL.

\section{[Continued as :]}

Philatelistische Nachrichten. Vertrauliche Mitteilungen des Briefmarken-Sammler-Vereins "Mosel".

$4^{\circ} .8 \frac{1}{2}$ in. Vols. xIII.- nos. In progress.

13th year. Feb. 25-Dec. 20, 1905. Nos. 1-12.

14 th " Jan. 25- " 28,1906 . " $1-12$.

* Nos. 1 and 2, 3 and 4 and 6 and 7 of the thirteenth year were severally published together and nos. 1 and 2 of that year bear no volume number.

MITTEILUNGFN DES BUNDES DEUTSCHER UND ÖSTERREICHISCHER PHILATELISTENVEREINE, See Bund Deutscher und Osterreichischer Phizatelisten-Vereine. Mitteilung.

MITTEILUNGEN DES DEUTSCHEN POSTWERT( $\mathrm{ZFICHEN} \mathrm{-} \mathrm{KAUF} \mathrm{-} \mathrm{U} \mathrm{TAUSCH} \mathrm{-} \mathrm{VERBANDES}$ LEIPZIG. Mitteilungen des Deutschen Postwertzeichen-Kauf- u. Tausch-Verbandes Leipzig.

Leipzig, Bruno Hofmann, 1898.

$\odot 8^{\circ} .11$ in. and $9 \frac{3}{4}$ in. Nos. 1-4, January 1, April 1, July 1, October

1, ${ }_{*}^{*}$ No. 1 measures 11 inches and nos. 2-4, 93. inches.

MITTEILUNGEN DES DEUTSCHEN SPRACH VEREINS BERLIN. Mitteilungen des Deutschen Sprachvereins Berlin, 6 Jahrgang. Nr. 4-5, 1895. [Contains an article "Philatelie oder Postwertzeichenkunde?" by M. Marcus.]

Berlin, I895.

$8^{\circ} .8 \frac{1}{4}$ in. pp. $55-61$

Mis. St. Jour. 143 (3).

MITTEILUNGEN DESINTERNATIONALEN POSTWERTZEICHEN - HÄNDLER - VEREINS ZU BERLIN. See Internationaler PostwerthzeichenHÄNDLER-V ERELN.

MITTHEILUNGEN DES “IMERKUR”. Mittheilungen des "Merkur" österreichischer Postwertzeichen Sammler Verein in Wien.

$8^{\circ} .9$ in. No. 1, December 26, 1897

* Produced by a hectographic process. The number has the *ords "Extra-Ausgabe" at the top and consists of a single leaf.

[Continued as :]

Mis. St. Jour 135 (16).

Schriftliche Mittheilungen des "Mercur" österreichischer Postwertzeichen Sammler Vereins in Wien.

Wien, 1898 .

$8^{\circ} .9$ in. Nos. 1-4, February 4-May 6, 1898

* * Produced by a hectographic process. No. 2 has!a slip attached with the words "Dieser Nummer der "Mittheilungen" liegt die Tauschordnung, bei Die Redaction". The Tauschordnung consists of (8) pages. Mis. St. Jour. 135 (16a)

MITTHEILUNGEN DES OESTERREICHISCHEN PHILATELISTEN-CLUB. Mittheilungen des Oesterreichischen Philatelisten-Club. Wien, Rud. V. Berger, etc., r886-94. $8^{\circ} .10 \frac{1}{4}$ in. 98 nos. in 9 vols

1st year. Jan, $15-$ Dec, 15,1886 . Nos. $1-12$

2nd ", ", ", , 1887. " $1-12$

3rd " " " " " " $1888 . \quad, 1-12$

5th " " " " "- " " " $1889 . \quad$ " $1890.1-12$.

6th " " " " "- " " ", $1890 . \quad$ " 1891.12.

7th " " ", ", " " 1892. " $1-12$

" " " " " " $" 1893 . \quad$ " 1-12

9th " Mar., Apl, 1894. Nos. 1-2.

* * This journal succeeded the "Mittheilungen des Wiener Philatelisten-Club". Commencing with no. 2 of the first year it was published by the "Oesterreichischer Philatelisten-Club".. There is a title-page and an index for each of the first seven years. Nos. 8 and 9 , and nos. 11 and 12 of 1887, nos. 8 and 9 of 1889 , nos. 8 $w$ and 9 of 1890 , nos. 7 and 8 of 1892, nos. 7 and 8 and nos. 10 and 11 of 1893 were severally published together under the respective
dates ; September u. October, 1887," " 15 December, 1887," "15 $\checkmark 1$ Rusfuct Taschenbuch four Bruphantion. Semond Sunt id 9 11 thsent heaf vert. Kones Glat prosputions soosept

$$
\begin{aligned}
& \text { Vil Wol } 15 \text { Jan } 1891 \text { cownetiod hy } \\
& \delta d=1 \text { st hand prontid figurs } L 1892
\end{aligned}
$$

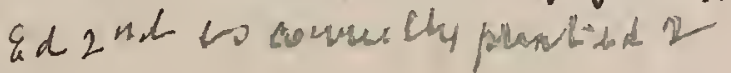

September, 1889," “15 September, 1890," “15 Juli, und 15 August, 1892," "15 August, 1893," and " 15 October und 15 November, 1893 ". There are no numbers for August, 1887, August, 1859, August, 1890, or for July, 1893. No. 4 of the sixth year has a supplemental heliogravure illustration of a specimen of the Two Pence Mauritius "Post Office" stamp. Anvel of V" 1892 has a plate of cape of youth upe 4 died wuth , kred

MITTEILUNGEN DES PHILAT. SCHÜLERVEREINS BRUCHSAL. See MITTLILUNGEN AUS dem Philat. Sohülerverein Bruchsad.

MITTEILUNGEN DES PHILATELISTEN VEREIN "HERIMES," ROSENBERG O.-S. Mitteilungen des Philatelisten Verein "Hermes," Rosenberg O.-S. Rosenberg, O.-S., I896-97.

$4^{\circ} .111$ in. and fol. 13 in. Nos. 1-6, August 18, September 21, October 20, November, December 22,1896, March 10, 1897.

* * Produced by a hectographic process. No. 1 is quarto and the other numbers are folio. The words "Rosenberg O.-S" are dropped from the title on nos. $2-6$, there is a supplement to no. 6 and nos. 2,3 and 6 are printed on buff paper and no. 5 on strawcoloured paper. $\quad$ Mis. St. Jour. 128 (3).

MITTHEILUNGEN DES SCHWEIZ. PHILATELISTEN - VEREINS. Mittheilungen des Schweiz. Philatelisten-Vereins.

$8^{\circ} .9$ in. No. 1, March, 1884.

[Zïrich], Bern, [printed], r884.

MITTEILUNGEN DES VEREINS FÜR FREUNDE DER BRIEFIARKENKUNDE ZU LÜBECK Mitteilungen des Vereins für Freunde der Briefmarkenkunde zu Lübeck. Lïbeck, I886-87.

$8^{\circ} .83-9$ in. 24 nos. in 2 vols. [1st year.] Jan.-Dec., 1886. Nos. 1-12.

** No. 1 was" produced entirely by a hand-copying autographic process, nos. 2-12 of the first year and nos. $1-8$ of the second year were produced in the same way, except that the title of each number was printed. Nos. 9-12 of the second year were produced by a ber was printed. Nos. $9-12$ of the second year were produced by a hectographic process, nos. 9 and 10 having the title printed as be-
fore, but nos. 11 and 12 arc wholly hectographic. Nos. 6 and 7 of the first year were published together. Wanting nos. 1,4 and 9 of 1887 .

\section{[Continued as :]}

Monatliche Mitteilungen des Vereins für Freunde der Briefmarkenkunde zu Lübeck. Lïbeck, I888-93.

$8^{\circ} \cdot 9 \frac{1}{4}-9$ in. Vols. III.-VIII. 48 nos.

[3rd year. Jan.]-Dec., 1888. Nos. 1-10.

[4th "] Jan. - " 1859. " $1-12$.

[5th "] " - " $1890 . \quad$ " $1-12$.

7 th " [no month given] 1892. " "1-

8th " Feb.-Mar.-July., 1893. ", 1- 2

* * Nos. $1-8$ of the third year were produced by a hectographic process and the remainder by autographic lithography. Nos. 6 and 7 of 1888, nos. 5 and 6 and nos. 8 and 9 of 1889, nos. 1 and 2 and nos. 6 and 7 of 1890, and nos. 6 and 7 of 1891, were severally published together under the respective dates "Juni u. Juli, 1888," "MFai u. Juni, 1889," "Aug. und Septbr., 1889," "Jan. und Febr., 1890," "Juni u. Juli, 1890", and "Juni u. Juli, 1891". There is no number for September, 1888, and no. 10 of that year, is dated "Novb. und Decb., 1888". No volume number is given before the issue of April, 1891, which is numbered "Jahrg. VI. no. 4". The volume numbering is then continued to the end. Copies of the eighth, minth, tenth and eleventh year reports of the society are bound up at the end of the third, fourth, fifth and sixth years, respectively, and some other papers connected with the society are also included. Wanting no. 8 for 1891

\section{[Continued as :]}

Verein für Freunde der Briefmarkenkunde Lübeck, Bericht über das Vereinsjahr 1893

Iï̈beck, I893.

$8^{\circ} .9$ in. Vol. viII. 1 no.

8th year [without date or number. No. 3 ]

*** Produced by autographic lithography. From what. is said in the report it is evident that it was intended that this should be no. 3 of the eighth year, and it is so classed by collectors of philatelic literature in Germany. 
MITTHEILUNGEN DES WIENER PHILATELISTEN CLUB. Mittheilungen des Wiener Philatelisten Club.

Wien, Gustav Reitz Edler von Bollheim, I882-85. Wou has a fullpagenotice Fol. 14 in. and $8^{\circ} .101$ in. 50 nos. in 4 vols.

fimudiof far 5 1853 1st year. Aug. 19-Dec. 28, 1882. Nos. 1 and 1- 7.

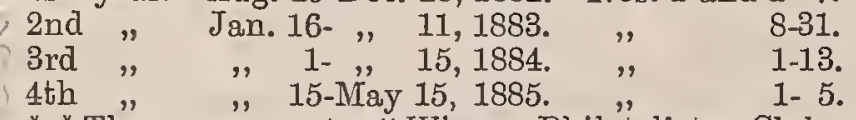

* * The successor to "Wiener Philatelisten-Club. Vertrauliche Mittheilungen ". Nos. 1-31 are folio and were produced by autographic lithography. There are two separate numbers, numbered " 1 " of the first year, one dated August 19, the "other September 15 , and all the numbers of the second year bear "1 Jahrgang, 1882-3". There is a supplement of four pages to no. 8 with the title "Wiener Philatelisten Club. Ehrenmitglieder". There is a title-page and an index to the third and also to the fourth year, and

III ro 2 wangly fafed $/-8$ date " 15 September, 1884". This journal was succeeded by the for $/ 7-24$ (see prefuce Mittheilungen des Oesterreichischon Philatelisten-Club".

IMITTEILUNGEN DES WÜRTTEIMBERGISCHEN PHILATELISTEN - VEREINS STUTTGART. Mitteilungen des Württembergischen PhilatelistenVereins Stuttgurt. Stuttgart, I893-94. Fol. 10 in in. 24 nos. in 2 vols. 1st year. Jan. -Dec., 1893. Nos. 1-12. 5,6 and 7,8 and 9 and 10 and 11 of the second year were severally published together. The numbers of the second year only bear

MITTHEILUNGEN UND SITZUNGSBERICHTE DES INTERNATIONALEN POSTWERTH. ZEICHEN-HÄNDLER-VEREINS ZU BERLIN. See INTERNATIONALER POSTWERTHZEICHENHÄNDLERVEREIN.

MITTELDEUTSCHE PHILATELISTEN-ZEITUNG. Mitmeldeutsche Philatelisten-Zeitung.

Gössnitz, S. A., A. E. Glasewald, I892-1904. $4^{\circ} .11 \frac{1}{2}$ in. and $8^{\circ} .10 \frac{1}{2}$ in. 150 nos. in 13 vols.

1st year. July-Dec., 1892. Nos. 1- 6.

2nd " Jan.- " 1893. " 1-12.

3rd " " "- " 1894. " $11-12$.

4th " " " - " " 1895. "

7th " " "- " " 1898. " " 1-12.

$\delta 106$ 2nd $" \checkmark 1894$.

* Nos. 6 and 7,8 and 9 of the first year and nos. 2 and 3,4 and

6th " " - " " 1897. " $1-12$

MODERNO RACCOGLITORE. Il Moderno Raccoglitore. Torino, Federico Barelli, I 892 Fol. 14 in. $\odot$ Nos. 1-12, Jan.-Dec, 1892. Fol. 14 in. $\varrho$ Nos. 1-12, Jan.-Dec., 1892 .
** There is a supplement of two sheets of "Modelês de Griffes
pour servir d'exemples aux collectionneurs" to no. 6 .

or "hojulo delle tane in Decine" "Mis. St. Jour. 75 (4).

MOHAWK STAMP. The Mohawk stamp.

Utica, N. Y., Bossigg Bros., [I 899].
in. No. 1, [January, 1899].
Tot dated, but issued in January, 1899. Wanting.

Utica, N. Y., Bossigg Bros., [I 899].
in. No. 1, [January, 1899].
* Not dated, but issued in January, 1899. Wanting.

MOHAWK STANDARD. See MOHAWK STANDARD, AD-

VERTISER AND CHRONICLE.

\section{MOHAWK STANDARD, ADVERTISER AND CHRO}

NICLE. The Mohawk standard, advertiser and chronicle. Delta, N. Y., Clarence D. Smith, I886-87.

$8^{\circ} .9$ in. 12 nos. in 1 vol.
Vol. I. Mar., 1886-Feb., 1887. Nos. 1-12.

\section{[Continued as :]}

The Mohawk standard. Published in the interest of collectors. Delta, N. Y., Clarence D. Smith, i 887-88. $8^{\circ} .9$ in. Vols. II.-IIr. 15 nos.

Vol. II. Mar., 1887-Feb., 1888. Nos. 1-12.

* "No. 8, vol. II., is wrongly numbered " " 9 " and nos. 10 and 11 * the same volume were published together under the date "Dec and Jan., 1887-88". There is a coloured paper wrapper to this double number and also to each of the three numbers of volume III.

$$
\text { [Continued as:] }
$$

- The Collectors' standard.

Delta, N. Y., Clarence D. Smith, r888.

$8^{\circ} .9$ in. Vol. III. 3 nos.

Vol, 4-6.

* * There is a coloured paper wrapper to each number.

MOLINE STAMP NEWS. Moline stamp news.

Moline, Ill., L. Mayer, I899-I9oo.

$16^{\circ} .6 \frac{1}{4}$ in. Nos. 1-4, Oct., 1899-Jan., 1900.

* * Amalgamated with the "Ohio Philatelist," February, 1900.

Mis. St. Jour. 150 (17).

MONARCH MIONTHLY. The Monarch monthly.

Chicago, Ill., Monarch Stamp and Pub. Co., I900. $8^{\circ} .8$ in. and $7^{3}$ in. 6 nos. in 2 vols.

Vol. I. July-Sept., 1900. Nos. 1-3.

* " II. Oct.-Dec., " " 1 and 2, vol. II. were published together under the date "October-November, 1900 " and the numbers of volume II. have coloured paper wrappers. No. 3, vol. Ir., measures 73 inches and the other nunzbers, 8.3 inches.

\section{[Continued as :]}

and each year excepting the first, hos a title-page and an index Tos 8 and 9 , for each year commencing with the year 1899 , were published together. There is a supplement " Neueste Privat-PostNachrichten "to each number of the first two years, excepting that for December, 1893, and a supplement " Falschungs-Nachichten" commencing with the number for July, 1895. After the end of 1899 this latter supplement was no longer paged separately but was amalgamated with the magazine. A further supplemen "Philatelia Humoristica. Organ für Possewerthzeichen-kunde," but paged with the magazine, was given at intervals, no. 1 appearing with the number for January, 1901, and no. 12 with the number for October, 1903. In addition there are numerous supplementa slips and each number commencing with no. 1 for 1897 has a coloured paper wrapper. The wrappers of the numbers for the ninth and tenth years bear also twelfth and thirteenth years and those of the thirteenth year bear also seventeenth jear. The higher numbering is given in order to make it appear that the jour" whas whichThe first two yeurs are bound up with vols. III.-VI. of Neneste Privatpost-Nachrichten".

\section{[Continued as :]}

Philatelisten-Zeitung.

Gössnitz, S. A., A. E. Glasewald, I 905 $8^{\circ} .101$ in. Vols. XviII- nos. In progress.

18th year. Jan.-Dec., 1905. Nos. 1-12.

* 19th " " " * Tos. 8 and 9 of each year were published together. The supplements "Failschungs-Nachrich ten" and "Philatelia Humoristica" continue to be paged up with the and "Pho supplements of illustration to no. 1 of 1906.
The Monarch monthly and philatelic news.

Chicago, Ill., Monarch Stamp and Pub. Co., Igor. $8^{\circ} .8 \frac{3}{4}-9$ in. 8 nos. in 2 vols.

Vol. III. Jan. -Feb. 1901. Nos. 1- 2 [should be vol. I., nos. " I. Mar. -June $\quad$ II. July 31-Aug. 31, ", ", $1-2$.

* " Each number has a coloured paper wrapper with the title as ** Each number has a coloured paper wrapper with the titie as reads "The Monarch monthly".

$$
\text { [Continued as :] }
$$

The Monarch philatelist.

Chicago, Mll., Monarch Stamp and Pub. Co., I90 I-о2. $8^{\circ} .9$ in. Vol. Ir. 2 nos.

Vol. II. Dec. 12, 1901-Jan. 12, 1902. Nos. 3-4.

* * There is a coloured paper wrapper to each number.

MONARCH MONTHLY AND PHILATELIC NEWS.

See MoNARCH MONTHLY.

MONARCH PHILATELIST. See MONARCH MONTHLY.

MONATLICHY MITTEILUNGEN DES VEREINS FUंR FREUNDE DER BRIEFIMARKENKUNDE ZU LU்BECK. See MITTEILUNGEN DES VEREINS FÜR Freunde der Briefmarkenkunde zu Lübeck.
5.08 

MONATLICHER BERICHT DER BRIEFMARKENHANDLUNG VON CARL JACOBS. Monatlicher Bericht der Briefmarkenhandlung von Carl Jacobs. Goslar a. Harz, Carl Jacobs, 1876 $4^{\circ} .8 \frac{1}{2}$ in. Nos. 1-6, Mar. 15-June 15, Aug. 15, Sept. 15, 1876. * * Printed on coloured paper. JThis is solely a price list of stamp for sale by the publisher. The six numbers were followed by a seventh, later on in 1876, printed on white paper, without date, and with the title "Siebenter Bericht der Briefmarken-Handlung von Carl Jacobs".

Mis. St. Jour. 58 (6)

MONATS-BERICHT UND SPEZIAL OFFERTE FƯR BRIEFIMARIENHÄNDLER. Monats-Bericht und Spezial-Offerte für Briefmarkenhändler.

Pilsen, L. Stein, I893-94. $4^{\circ} .10$ in. Nos. 1-4, December 1, 1893-A pril 1, 1894.

* Produced by autographic lithography, except the heading, which is printed from ordinary type. No. 4 has the number " 4 " and the date " 1 April " filled in by hand in pen and ink and there is no number for March, 1894. Nos. 3 and 4 have the word "nur" added in front of "für" in the title. The numbers are little more than price lists of stamps, etc., for sale by the publisher.

[Continued as :] Mis. St. Jour. 129 (3)

Special-Offerte No. 5-8 nur für Briefmarkenhändler.

$4^{\circ} .10$ in. Nos. $5-8$, August 1,1894

, ***'This is solely a price list of stamps, etc., for sale by the pub-
lisher.
Mis. St. Jour. 129 (3a).

MONATS - OFFERTEN FỨR BRIEFIMARKEN SAIMMLER VON CARL GEYER UND CO. Monats-Offerten für Briefmarken-Sammler von Carl Geyer und Co.

Aachen, I894$8^{\circ} .9 \frac{1}{4}$ in. $-8 \frac{3}{4}$ in.

* This is solely a price list of stamps, etc., for sale by the publishers and cannot therefore be considered a philatelic journal. No 1 is dated " April, 1894 ".

MONDE COLLECTIONNEUR. Le Monde collectionneur. Journal philathélique (sic) paraissant le 30 de chaque mois.

La Chaux-de-Fonds, Suisse, Arthur Schmidt, etc. I $894-95$

$8^{\circ} .8_{4}^{3}$ in. and $4^{\circ} .11$ in. 20 nos. in 2 vols.

1st year. May $30,1894-\mathrm{Apl}$. 30, 1895. Nos. 1-12

2nd " "30, -Dec. 31,1895 . "13-20.

* * No. 1 is octavo and the remaining numbers are quarto. Nos. 8,9 and 10 were published together. No. 16 is dated " 15 août," no. 17, " 30 août" and there is no number for September, 1895 Nos 5-7 were published by Emile Nicolet fils. Commencing with no. 5 the error of spelling of the word "philatélique" was corrected.

MONDE ILLUSTRE. Lo Monde illustré. Journal hebdomadaire. No. 1859. 12 Novembre, 1892. [Contains an article "Timbres et Timbromanes" by Guy Tomel. Fol. $16 \frac{1}{4}$ in. pp. 310-311.

Paris, Édouard Desfossés, I892. * The number has a paper wrapper. Mis. St. Jour. 115 (10).

MONDE PHILATEIQUE. Le Monde philatélique. Revue internationale du marchand et du collectionneur de timbres-poste. $4^{\circ} .11 \frac{1}{4}$ in. 23 nos. in 3 vols. 1st year. Sept. 1, 1894-Aug. 1, 1895. Nos. 1-12. 2nd ", J" 1, -Nov, 15, 1895. " $13-15$ 3rd " Jan. 15, Aug., 1896. " 16-23. * Nos. 10-23 were published by V. Roegiers-Van Schoorisse. Nos. 13 and 14, 18 and 19,21, 22 and 23 were severally published together, and there is a supplement of two pages, printed on one side only, to no. 6 .

๑ MONDE PHILATELIQUE. Le Monde philatélique. Bisceglie, Italie, Gian Carlo de Villagomez, Igo6. $8^{\circ} .10$ in. ONo. 1 , A pril 25, 1906.

** Although the address of the editor is given as Bisceglie, " "Première annee-Bari" appears above the title and the journal "Premiere annee-Bari" appears above the title and the journal
was printed at Bari.
Mis. St. Jour. 132 (12)

MONDF PHILATÉEIQUE ET CARTOPHILE. L Monde philatélique et cartophile. Montélimar, France, C. Meillon, I904-05. 8.9-10 in. Nos. 1-4, October, 1904-January, 1905 * * Produced by a hand multiplying press. There is a supplement to no. 2 . Wanting no. 1 .

Ravet

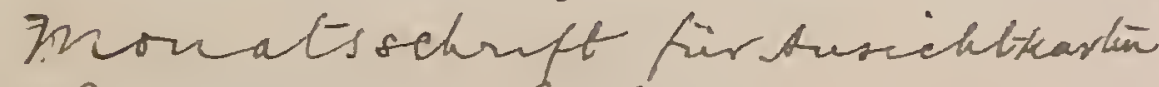

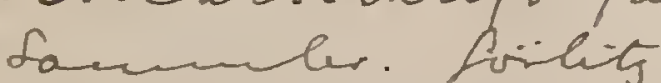

$1856 I \cdot 1 \cdot 2 \cdot 3 \cdot 45 / 67 / 8 \mathrm{~g} / 10 \mathrm{~m} / 12 \mathrm{Ti}$ ird.cower.
MONGTBELIO FILATELICO. Il Mongibello filatelico. Journal mensuel d'offres de timbres-poste.

Catane, Sicile, Joseph Coco, etc., 1898.

$8^{\circ} .10$ in. Nos. 1-6, Apl. 15-Sept. 15, 1898.
* There is a coloured paper wrapper to each number. Nos. 4-6 were published by Mario Distefano Ecora.

Mis. St. Jour. 117 (26)

MONITEUR DES TIMBROPHILES. Le Moniteur des

(.) timbrophiles. Journal du collectionneur, paraissant lo 15 de chaque mois.

Gand, Jules Capelle, т882-83.

$8^{\circ} .10 \frac{1}{2}$ in. 15 nos. in 2 vols.

1st year. OApl, 15-Dec. 15, 1882 . Nos. 1-9.

2nd " OJan. 15-June 15, 1883.

* "There is a title-page and an index to the first year.

IMONITEUR DU COLLECTIONNEUR. Le Moniteur du collectionneur.

Luxembourg, M. Goebel, etc., I89ז-I903.

$8^{\circ} .10 \frac{1}{2}$ in. and $9 \frac{1}{2}$ in. 163 nos. in 13 vols

1st year Jan. $15-\mathrm{Dec} 15$ L 1891 vols. $T_{i}{ }^{\circ}$

2nd " " 15- , 15, 1892. " 1-12. TI $1-190$

C. 3rd " " 15- " 25, 1893. " $112 . T^{\circ}, 1-216$

4 th " " " 25- ", 25, 1894

5th " " - " " 1895.

6th " " - " 1896.

Sth " " " $"$ " " $\quad 1898$

Q) 9th " " " - ", 1899 .

rioth " " " " 15,1900 .

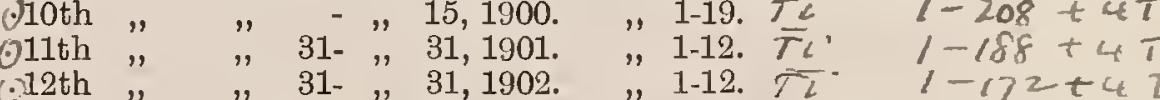

"1-12. Tl. $1-176$

, 1-12. Ti

, 1-12. Tl

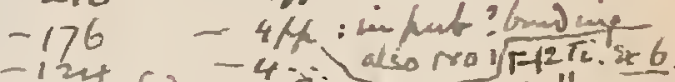

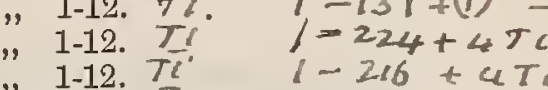

13th " " 31- " 31, 1902. " $1-12.72 .1-172+4 T$

** The first six years measure $10 \frac{1}{2}$ inches and thelast seven years $9 \frac{7}{2}$ inches. Commencing with January, 1895 , the journal was published by Joseph Schock and from January, 1902, it has been published by the Union des Timbrophiles de Luxembourg. There is a title-page and a list of contents for each year and the twelve numbers for 1895 have coloured paper wrappers. VNos. 8 and 9 of 1893 , nos 5 and 6 of 1894 , nos. 8 and 9 of 1895 , nos. 9 and 10 of 1902 , and nos. 6 ond 9 of 1903 "were severally published together under the respective dates: "25 Septembre, 1893," "25 Mai, 25 Juin, 1894," "Août \& Sept., 1895," " 28 Octobre, 1902," and " 30 Septembre, 1903 ". In 1900 the journal was published fortnightly from January to Yune and in November, and once in each of the other months. There is a supplement of (2) pp. to no. 5 for 1899 and a special supplement with the title "Les Petites Affiches du Timbrophile" began to appear with the February number for 1895 This last is catalogued separately.

\section{[Continued as :]}

Le Moniteur du collectionneur et "Les Petites affiches du timbrophile". Journal timbrophile mensuel et fouille d'annonces.

Luxembourg, Union des Timbrophiles de Luxembourg, I 904-05.

$8^{\circ} .10 \frac{1}{2}$ in. Vols. Xrv.-xv, 24 nos.

14th year. Jan. 31-Dec. 31, 1904. Nos. 1-12. Ti 1-5 7-10 12

15 th $"$ "31- "31, 1905. " 1-12. $1-144+T$

is found printed on white paper and also on coarse greyish paper. $\odot$

[Continued as :]

Le Moniteur du collectionneur. Journal timbrophile mensuel.

Luxembourg, Union des Timbro philes de Luxembourg, I $906-$

$8^{\circ} .10$ in. Vols. XVI.- nos. In progress.

6th year. Jan.-Dec., 1906. Nos. 1-12

* There is a title-page and index and nos. 8 and 9 were published together. There is a special supplement with the title "Les Petites Atfiches du Timbrophile". This is catalogued separately.

IMONITEUR DU COLLECTIONNEUR FT “LES PETITES AFFICHES DU TIMBROPHILF" See Moniteur du ColiLectionneur.

MONITEUR PHILATÉfIQUE. Le Moniteur philatélique. Journal mensuel d'annonces.

$8^{\circ} .10$ in. Nos. 1-12, Jan. 15-Dec Gand, Alb. Facon, I896. * The contents consist entirely of advertisements and the jour nal is printed on coloured paper. Nos. 7 and 8 were published
together. Wanting nos. $5,7,8,10$ and 12 .
$S 108$

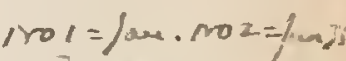

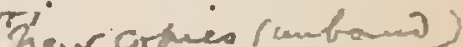

hever corpues (monband)

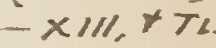

a/ lote of Leaterubarang 6 cinculer I Cof.e.1855 Som 
OMONITEUR PHILATÉLIQUE. Le Moniteur philatélique.

Buccrest, Roumanie, Armand Lerner, etc., I 906. $4^{\circ} .81$ in. GNos. 1-10, January 15-October 25, 1906.

** Nos. 6-10 were published by Michel M. Preda. Nos. 3 and 4, 6,7 and 8 , and 9 and 10 were severally published together. Continued in 1907 under the name "L'Annonce Carto-philatélique".

IMONITEUR TIMBROLOGIQUE DE L'ORIFNT. Le Moniteur timbrologique de l'orient. [Prospectus of a journal to be published by Pierre Taxopoulo et Cie., Braila, Roumanie, at the end of 1900 , but which was never issued.]

Mis. St. Jour. 131 (16).

MONITOR FILATÉLICO. El Monitor filatélico. México, Toscano, Farias y Co., etc., I892-98. Fol. $18 \frac{1}{2}$ in. and $8^{\circ} .9 \frac{7}{4}$ in. 34 nos. in 6 rols.

1st year. Dec. 15, 1892-Dec. 1, 1893. Nos. 1-12.

2nd ", Jan., Feb., May, July, Oct., 1894. Nos. 13-17.

3ri " Jan., Mar., Apl. and May, June and July, Aug. and Sept., 1895. Nos. 18-22.
4th "N Jan., Feb. and Mar., June and July, Aug. and Sept.,
Oct. and Nov 1896. Nos. 23-27.

5th "Dec., 1896 and Jan., 1897, Feb. and Mar., Apl. and May, June and July, Aug. and Sept., Oct. and Nov., 1897. Nos. $28-33$.

6th "Jan and Feb., 1898. No. 34.

** Nos. 1-12 are folio and the remaining numbers are octavo. Nos. 14-20 were published by Regino Farias y Co., and nos. 21-34 by Regino Farias. There are two editions of no. 2, one with the date " 1892 " and the other with " 1893 " there is no number for July, 1893, and no. 14 is wrongly numbered "13" Nos. 30,33 and 34 have coloured paper wrappers.

MONITORUL SOCIETĂTEI FILATELICE ROIMÂNE. Monitorul Societăteǐ Filatelice Române. Le moniteur de la Société Philatélique Roumaine.

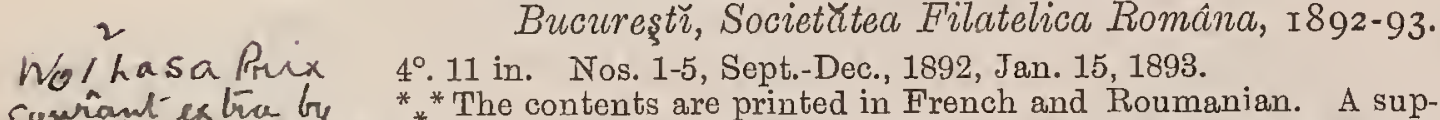
cumiant extha hy ** The contents are printed in French and Roumanian. A supGA Paurn = p 9 ro plement "Catalogul Mărcilor române, arangeat de A. St. Klenck" was given with nos. 3 and 4 , but only eight pages of this was
completed.

IMONTHLY ADVERTISER. The Monthly advertiser. (.) Liverpool, Edward Moore and Co., I862.

O $8^{\circ} .8$ in. No. 1 , December 15,1862 . Britain. A copy of the prospectus is bonnd up in front of the number. caited un A.Penis

[Continued as :]

- The Stamp collectors' monthly advertiser. 1 \% $9-16$

Liverpool, Edward Moore and Co., 1863

C. $8^{\circ} .8$ in. No. 2, January $15,1863$.

[Continued as :]

- The Stamp collectors' review and monthly advertiser. Liverpool, Edward Moore and Co., etc., I863-64.

(6) Vol. I. Feb. 15 -Dec. 15,1863 . Nos. 3-13. M 17-148 T6

c) "II. Jan. 15-June 15, 1864. , 14-19.

* * E. L. Pemberton edited the journal from the commencement of vol. II. No. 19 was published by Alexander Perris. $\checkmark$ A title-page and an index were issued for the numbers of vol. I. on its conclusion and a title-page and an index for vol. II. and a note on "The history of the first English philatelic periodical" were compiled and issued by Mr. P. J. Anderson of Aberdeen in 1879. The six numbers of volume II. have the title given as "The Stamp

sugd "in the tan 1378 ", collector's review and monthly advertiser",

suy "in the year 1r73", collector's review and monthly advertiser".

imas minich for his ond

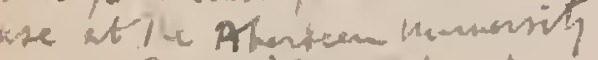

auss. Dnis Dith (II) has ke

wond collevetros?

\section{MONTHLY ADVERTISER}

640

MONTHLY ADVERTISER. The Monthly advertiser. Published on the 15th of each month.

Bury St. Edmund's, T. Wilkin, I879. $8^{\circ} .9 \frac{1}{2}$ in. No. 1, June, 1879.
** Only partly philatelic.

Mis. St. Jour. 12 (4).

IMONTHLY ADVFRTISER. Monthly advertiser.

Newburgh, N. Y., E.R. Hasbrouck, , 886 . $4^{\circ} .12$ in. No. 1 , October, 1886

* * Only partly philatelic.

Mis. St. Jour. 5 (4).

MONTHLY ADVERTISER AND FOREIGN STAIMP GAZETTE: The Monthly advertiser and foreign stamp gazette. Oxford, W. H. Butler, etc., I873. $4^{\circ} .11 \frac{1}{4}$ in. Nos. 1-3, [? June 15], July 15, Sept. 1, 1873. ** Nos. 1 and 2 are stated to have been "conducted by W. H. Buter and F..Millin". The contents consist entirely of advertisements. Wanting no. 1.

Mis. St. Jour. 77 (5).

IMONTHLY AMATEUR AND STAMP NEWS. See SARATOGA AMATEUR NEWS.

MONTHLY ANNOUNCEMENT OF THE NEW FNGLAND STAIMP CO. Monthly announcement of the New England Stamp Co.

4․ 101-11 in. Nos. [1-3], Feb., Mar., June, [1875]

Concord, N. H., [1875]. Mis. St. Jour. 4 (16).

MONTHLY BULLETIN. The Monthly bulletin. Springfueld, $\Pi 1 l$., E. C. Ives, I893. $8^{\circ} .8 \frac{1}{2}$ in. Nos. 1-3, June-Aug., 1893.

* * No. 2 has a coloured paper wrapper. Mis. St. Jour. 63 (1).

MONTHLY BULLETIN. THE POSTAL CARD SOCIETY OF AIIERICA. Monthly bulletin. The Postal Card Society of America. Baltimore, Md., etc., Adolph Lohmeyer, etc., I89498. $8^{\circ} .8 \frac{1}{2}$ in. 48 nos. in 4 vols. Vol. I. March, 1894-Feb., 1895. Nos. 1-12. " II. " $1895-\quad$ " $1896 . \quad$ " $13-24$. ", IV. " " 1897- " 1898. " $37-48$

*" "There is " combined title-page and̆ an index for vols. I. and II. and likewise for vols. III. and IV. Nos. 30 and 31 were published together, and nos. $38-48$ were published at Springfield, Maass., by William C. Stone.

[Continued as :]

The Postal card bulletin.

Sprinafield, Mass., etc., W. C. Stone, etc., I898-99. $8^{\circ} .8 \frac{1}{2}$ in. Vol. V., 9 nos.

Vol. v. March-July, Oct., Nov., 1898, Feb., June, 1899. Nos.

* * * No. 53 is numbered in error " 26 ". No. 57 was' published by Adolph Lohmeyer at Baltimore, Md.

MONTHLY CADET. The Monthly cadet. I 896 .

New Britain, Conn., The Cadet Publishing Co.,

$8^{\circ} .8$ in. Nos. 1-2 [? March]-A pril, 1896 *** Only partly philatelic. No. 2 has a coloured paper wrapper.
Wanting no. 1 .

MONTHLY CHRONICLE. See AMERICAN PHILATELICAL CIROULAR.

MONTHLY CIRCULAR. The Monthly circular. London, R. Evans and Co., 1863 . in. Nos. 1-3, September-November, 1863.

* * Advertisements of this appeared in the "Stamp-collectors' review and monthly advertiser" for September 15 and October 15, 1863 , pages 111,124 , and in the "International postage stamp review" for November 15,1863 , page 39. Succeeded by the "National postage stamp express". Wanting all three nos.

IMONTHLY CIRCULAR. The Monthly circular.

Chicago, Ill., Wm. C. How and Co., r876-77. $12^{\circ} .7$ in. Nos. 1-6, November, 1876-April, 1877. * Nos, 2 and 3 and 5 and 6 were soverally published together. Wanting all six numbers. 
munchty aduntises Reviear Louslow 1880

Hoonthly sulletin. Amiressol stand co. Cheirpo. 1909 (1909) 
Howthly hart and Co-oferative atvertion.

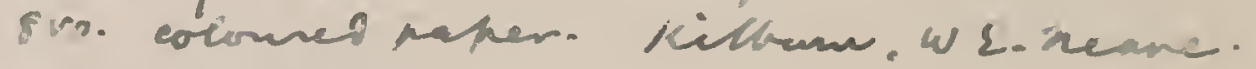
1913 fent/out.

Monthly miver - Baltimose mor-1893-Sosq. 
MONTHLY CIRCULAR. The Monthly circular.

$8^{\circ} .8$ in. No. 1 , January, 1877.

Boston, Mass., M. C. Potter, 1877.

* Printed on yellow paper and consisting of only one leaf.

Mis. St. Jour. 28 (7).

MONTHLY ECHO. The Monthly echo.

siog

Englishtown, Nova Scotia, J. C. MoLean, r883-84.

$8^{\circ} .9 \frac{1}{4}$ in. 8 nos. in 2 vols

Vol. I. Jan.-Aug., 18s3. Nos. 1-6.

Q " II. "Feb., 1884. " 1-2. 3" * Ondy partly " "Jilatelic. Nos. 5 and 6 were published together

$\left\{\begin{array}{l}\text { There are no numbers for May or June, 1883. } \\ \text { Yeo }\end{array}\right.$

Yeos may thenelos Mos

MONTHLY ENTERPRISE. The Monthly enterprise.

S $109 \quad 8^{\circ} .71$ in. Nos. $1-3$.

Syracuse, N. Y., M. C. Howard, I892-93

** Only partly philatelic. No. 2 is dated "January, 1893". Wanting nos. 1, 3.

MONTHIY ETCAETERA. Monthly etcaetera.

Woodstock, Ill., Wm. Southworth and Co., ז885. in. Nos. 1.3, April-June, 1885.

** Only partly philatelic. Wanting all three nos.

IMONTHLY EXCHANGE. The Monthly exchange.

Devoted to the interest of exchangers.

$8^{\circ} .9$ in. No. 1, February, 1885.

Cartisle, $P a ., F$. B. Wallace, I 885

** Only partly philatelic.

Mis. St. Jour. 126 (6)

IMONTHLY EXCHANGE. The Monthly exchange.

Fort Atkinson, Wis., John Miller, Gainesville, Ga.

Bev. Martin, 1896-98.

$32^{\circ} .5-4 \frac{1}{2}$ in. nos. in 2 vols.

Siog Vol. I. Nov., 1896- 1897. Nos. 1-

* * Ir. 1897- 1898. W" 1dated respectively January, March and October, 1897.

MONTHLY EXCHANGE AND JOURNAL OF PHILATELY. The Monthly exchange and journal of philately. Edinburgh, Edwin Reid, [1880]. $8^{\circ} .7 \frac{1}{2}$ in. No. 1, May, [1880].

* * Succeeded by the "Foreign stamp advertiser".

Mis. St. Jour. 55 (9)

MONTHLY EXCHANGE CIRCULAR. Monthly eXchange circular.

Ipswich, The Foreign and Colonial Exchange As sociation, I 883

8०. 88 in. Nos. 1-3, Aug.-Oct., 1883. want Nol

** The contents consist entirely of advertisements with the exception of the insertion of the "Regulations" of the Association. Each number consists of one leaf printed in three columns on either side and was folded up so as to make, as it were, six pages. Wanting no. 1. (Sieut bing lst- no.) Mis. St. Jour. 78 (6).

IMONTHLY GLEANINGS. The Monthly gleanings. Chicago, Ill., J. E. Hartman, I893 8․ 91 in. Nos. 1-6, February-July, 1893.

* * Only partly philatelic. Wanting nos. 1, 2, 4, 5, 6 .

MONTHLY INTELLIGENCER. The Monthly intelligencer. Birmingham, W. Macmillan, I862-63. $8^{\circ} .81$ in. Nos. 1-10, Sept., Nov., 1862-July 1, 1863. Fane 4, 10 ** Only partly philatelic. Nos. 7 and 8 , and probably some of the other numbers, had coloured paper wrappers, on which the title was given as "The Monthly intelligencer and controversialtitle was given as "The Monthly intelligencer and controversialist". This was th

stamp collectors. Bound up with the ten numbers are nos. 1-4 of "The Birmingham and December 1, 1863. This journal contains no philatelic matter beyond stamp advertisements in nos. 1-3.

MONTHLY INTELLIGENCER AND CONTROVERSIALIST. See MONTHIY INTELLIGENCER,
IMONTHLY ITEM. The Monthly item.

* in. Nos. 1-7.

$$
\text { Seattle, Wash., [? ], 1894-95. S109 }
$$

MONTHLY JOURNAL. The Monthly journal.

Cariisle, Pa., Joseph, Jr., and Clinton Bosler, 1886. $8^{\circ} .9$ in. Nos. 1-9, Jan. 20-Sept. 20, 1886.

* *nly partly philatelic. Thore is a coloured paper wrapper to each number, nos. 7, 8, 9 were published together and the wrapper bears the date "July, August and September, 1886 ".

Mis. St. Jour. 23 (4).

IVONTHLY LIGHT. The Monthly light. Washington, D. O., Bogan and Fairchild, [1886] $8^{\circ} .8 \frac{1}{2}$ in. Vol. II. No. 2, February, [1886]

** Only partly philatelic and the number bears no year date. Mis. St. Jour. 143 (8).

MONTHLY OBSERVER. The Monthly observer. Myerstown, Pa., John M. Smeltzer, Jr., I896-97 $4^{\circ} \cdot 10^{3}$ in. and $8^{\circ} .8 \frac{1}{2}-9 \frac{1}{4}$ in. 15 nos. in 2 rols. Vol. I. Feb., 1896-Jan., 1897. Nos. 1-12.

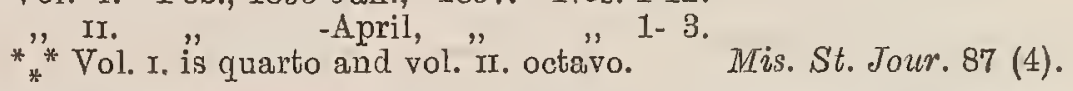

MONTHLY OFFERS AND PHILATELIC RECORD. See MoNTHLY OFERRS TO PHILATELISTS.

IMONTHLY OFFERS TO PHILATELISTS. Monthly offers to philatelists by Fisher, Titley and Co.

Bath, Fisher, Titley and Co., I890-9I. $8^{\circ} .81$ in. Nos. 1-12, Nov., 1890-Nov., 1891.

** Printed on coloured paper No. 2 is dated "Dec., 1890-Jan. 188̈91," no. 3, "Jan.-Feb., 1891" and no. 4, "Feb.-March, 1891 ".

[Continued as :]

Monthly offers and philatelic record. New series. Bath, Fisher, Titley and Co., 1891-92. $8^{\circ} .83$ in. Nos. 13-23, Dec., 1891-Oct., 1892.

** Printed on coloured paper. Nos. 18 and 19 were published together, under the date, "May and June, 1892".

\section{[Continued as :]}

Monthly offers to philatelists. New series.

Bath, etc., Fisher, Titley and Co., I892-98. $8^{\circ} .8 \frac{1}{2}-8 \frac{3}{4}$ in. Nos. 24-84, Nov., 1892-May, 1896, July, 1896, Sept., 1896-May, 1897, July, 1897-F'eb., 1898

* * Nos. 81-84 were published at Reading, and nos. 77 and 78 * *re published together under the date "July and August, 1897 ". Nos. $24-31,33^{2}-35,37$ and $39-47$ were printed on coloured paper.

IMONTHLY PHILATELIC ADVERTISER. The Monthly philatelic advertiser.

Ogden, Utah, [and] New York, The Philatelic Supply and Publishing Co., I896.

$8^{\circ} .8 \frac{1}{4}$ in. No. 1, February, 1896 ** Wanting.

\section{[Continued as :]}

The Philatelic advertiser.

Ogden, Utah, [and] New York, The Philatelic Supply and Publishing Co., 1896.

$8^{\circ} .8 \frac{1}{4}$ in. No. 6, May, 1896

* Only partly philatelic. The number has a coloured paper wrapper. Nos. 2-5 were not published.

\section{IMONTHLY PHILATELIC ADVERTISER. The}

- Monthly philatelic advertiser. Circulated amongst philatelists all over the world.

Derby, Daventry [printed], W. Webster, I 9o1-о2.

O 8․ $7 \frac{1}{4}$ in. Nos. 1-9, Sept., 1901-Mar., April-May, June-July, 1902

$\checkmark$ ** There is a coloured paper wrapper to each number. Incorporated with the "I. P. R. and collectors" news". O P was hect

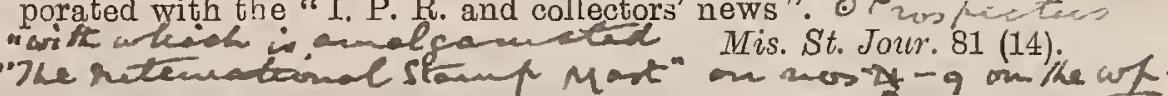

MONTHLY PHILATELIC CIRCULAR. See CHAS. PURDOM MONTHLY CIRCULAR.
$18 / 15 \mathrm{con}$ creen, want yellow

Lure 27 on yeliow rpeen 
IMONTHLY PHILATELIC REFER⿴囗十. See PHILATELIC MONTHLY REFEREE.

MONTHLY PHILATELIST. The Monthly philatelist.

$8^{\circ} .8-8 \frac{1}{2}$ in. 7 nos. in 2 vols.

Yol. I. May-Oct., 1876 . Nos. 1-6.

II. Nov, and Dec., 1876 . No 7

* "Nos. 1-3 are octavo 8 inches and the remainder are octavo $8 \frac{1}{2}$ inches. Nos. 4 and 5 were published together under the date "Aug. and Sept., 1876". Mis. St. Jour. 28 (4).

MONTHIY PHIJATELIST. The Montbly philatelist Holgate, York, R. B. Spink, [1880]

$8^{\circ} .81$ in. Nos. 1-2, Oct.-Nov., [1880]. Mis. St. Jour. 30 (4).

IMONTHLY POST. The Monthly post. Little sticks kindle the fire, large ones put it out.

New York, John V. Drozdowski, I876.

$24^{\circ} .4_{4}^{3}-5 \frac{1}{4}$ in. Nos. 1-4, Sept.-Dec., 1876

* *No. 2 is dated in error " 1886 " and there is an advertisement supplement of two pages to this number. Mis. St. Jour. 68 (1).

MONTHLY POST. See MONTHLY POST AND STAMP WORLD.

MONTHLY POST AND STAMP WORID. The Monthly post and stamp world. A journal of philatelic and general interest.

London, N., Crevee [printed], Smyth and Co., I893-95. $8^{\circ} .9 \frac{3}{1}$ in. 18 nos. in 2 vols.

(6) Vol. I. Oct., 1893-Sept., 1894. Nos. 1-12.

(. "Ir. Oct., 1894-Mar., 1895. " 13-18.

*" Edited by Charles J. Endle. There is a title-page and an index to vol. I, and coloured paper wrappers to nos. 7-18.

[Continued as :]

- The Monthly post; a philatelic circular. London, $\bar{N}$., etc., Crewe [printed], Smyth and Co. I 895-97.

$8^{\circ} .10$ in. Vols. II.-IV. 21 nos

6 2nd year. Apl. -Sept., 1895. Nos. 19-24.

C. 3rd " Oot., 1895- ", $1896 . \quad$ "25-34.

* * No. 33 is "dated "June-July, 1896" 1896 and no. 34 "August-September, $1896 " . \checkmark$ Nos. 35-39 were published at Boscombe, Bournemouth.

[Continued as :]

Smyth and Co.'s philatelic circular. (Originally known as "The Monthly post".)

Boscombe, Bournemouth, Smyth and Co., I897-99.

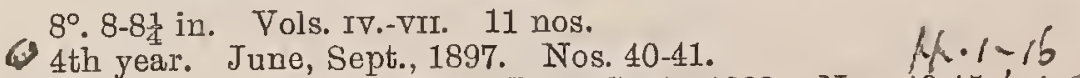

Q 5th " Dec., 1897, Mar., June, Sept., 1898. Nos. 42-45. p.1-32

6th " " 1898, "̈. 0 " " 1899. " 46-49. r-32

** Printed on coloured paper.

\section{[Continued as :]}

Smyth's philatelic circular. (Originally known as "The Monthly post".)

Boscombe, Bournemouth, Chas. J. Endle and Co. I goo-08.

$8^{\circ} .8-8 \frac{1}{2}$ in. Vols. VII.-XV., 35 nos.

- 7th year. Mar., June, Sept., 1900. Nos. 51-53.

(5) 8th " Dec., 1900, Mar., June, Sept., 1901. Nos. 54-57.

" 1901, " " " 1902.

10th " " 1902, " " " 1903.

11th " " 1908, ", " " 1904.

12th "Jan., Apl., July, Oct., 1905.

613 th " " " " " " 1906.

O14th " " " " " " 1907.

** *Nos. 51-57" are printed on "coloured paper

"Eudle's Philatelic Circular".

white hatear 57-10\%.

MONTHLY READER AND STAMP COLLECTOR'S

GUIDE. See STAMrP COLLECTORȘ' ADVERTISTER AND NEW ISSUE RECORD,
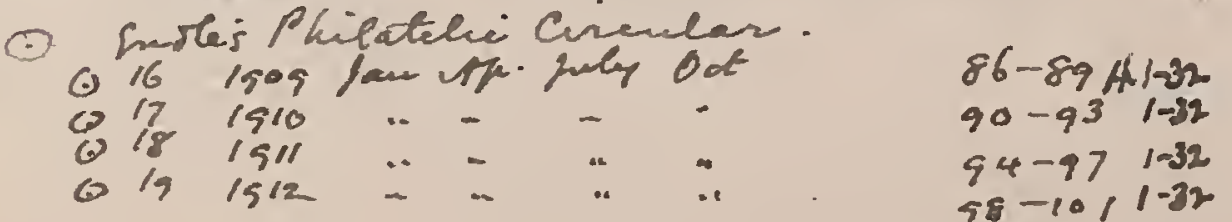

MONTHLY READER AND STAMP COLLECTOR'S GUIDE AND EXCHANGE MEDIUM. See STAMP COLLEOTORS' ADVERTISER AND NEW ISSUE RECORD.

IMONTHLY REPORTER. The Monthly reporter. Montpelier, Vt., Charles F. Buswell, I88I.

* * Cuttings of "Our philatelic corner," etc., from nos. 1-5, dated January 1-May 1, 1881, are mounted in Stamp Scrap-book, vol. IV., pp. 100-107 and 111-116 and in vol. $\nabla ., 59-73$.

MONTHLY REVIEW. The Monthly review. Cincinnati, O., Chas. F. McCann, 1877. * * Cuttings of the article headed "Philately," etc., from the number dated June, 1877, are mounted in Stamp Scrap-book, vol. III., p. 120 .

MONTHLY REVIEW. The Monthly review. Mansfield, Pa., H. C. Kinney, I886-87. $8^{\circ}$. 8-8 $\frac{1}{2}$ in. Nos. 1-12, May, 1886-April, 1887.

MONTHLY REVIEW AND ADVERTISER. The Monthly review and advertiser. A monthly journal for stamp collectors, amateurs, \&c.

Edinburgh, Edwin Reid, [1880].

$8^{\circ} .7 \frac{1}{2}$ in. No. 1. March, $[1880]$

* * Succeeded by the "Monthly exchange and journal of phi**"Succeded by the "Monthly exchange and journal of phi-
laitely".

\section{MONTHLY REVIEW AND STAMP COLLECTOR'S}

- GUIDE. The Monthly review and stamp collector's guide.

Tondon, S.E., The Star Foreign Stamp Co., I89I.

(6) $4^{\circ} .8 \frac{1}{1}$ in. No. 1 , April, 1891.

Mis. St. Jour. 53 (1).

MONTHIY STAMP CIRCULAR. The Monthly stamp circular. A monthly circular devoted to stamp collecting only. New York, $M$. Wineburgh, I876. $8^{\circ} \cdot 8 \frac{1}{2}$ in. No. 1 , March, 1876.

${ }_{*}^{*}$ The number consists of a single leaf. Mis. St. Jour. 18 (13).

[Continued as :]

The Stamp collectors' monthly. Useful and interesting to all stamp collectors.

New York, M. Wineburgh, I876. 8. $9 \frac{1}{4}$ in. Nos. 2-9, Apl. 1-Nov. 1, 1876. Mis. St. Jour. 18 (14).

MONTHLY STAMP CIRCULAR. See F. TRIFET'S MONTHLY CIRCULAR.

MONTHLY STAMP NEWS. The Monthly stamp news. Webster City, Ia., M. Green, I896-98. in. 16 nos. in 3 vols

Vol. I. Nov., 1896-April, 1897. Nos. 1- 6.

" II. May -Dec., "Fe, 1898. Nos. 1- 2.

*"* Wanting all nos.

[Continued as :]

Webster City, Ia., M. Green, I898.

ews.

in. Vol. Irr. 3 nos.

Vol. III. March-[? ] 1898. Nos. 3-5.

MONTHLY STAMP NEWS. Monthly stamp news. Hanley, D. H. Bates, igoz.

$8^{\circ} .7$ in. No. 1, August, 1902.

* * Produced by a hand multiplying press by P. R. Teeton, Stoke on-Trent. A copy is known over-printed "speciman" (sic) with a hand-stamp, but Mr. Bates states that no copies were published. Wanting. 


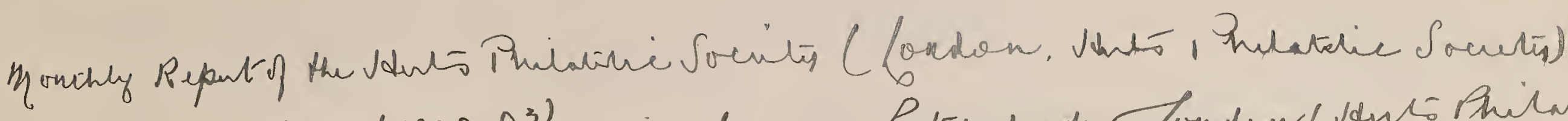

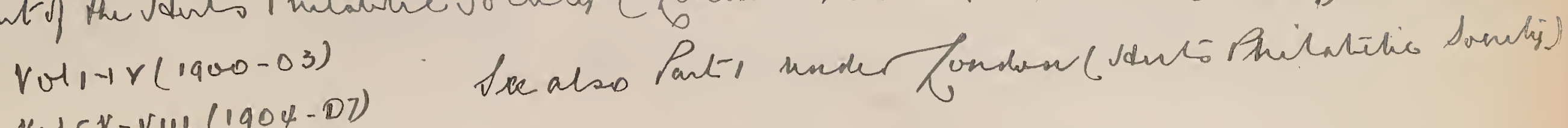
Volst-Vi11 (1904-D7) volix (1908)

Howlinly Post Slainfl wored

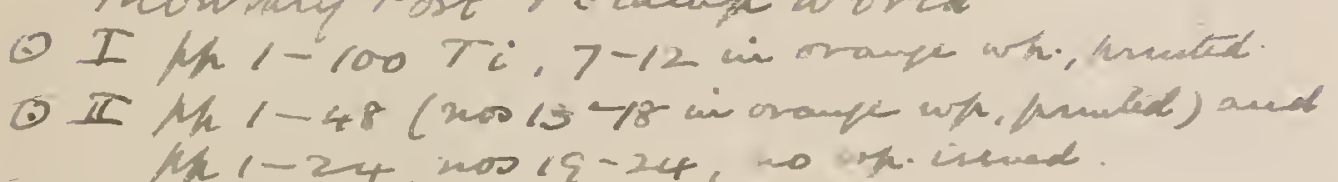

- iाI $h / 1-44$, nos $25-34$. no wh-ninex.

IV $M<-$ 
Tuovtily Alomp hotis.

Horlay: Hivitur fomind.

Mos $1-7$. paped on $1-28$
$8-15$ paged $1-34$

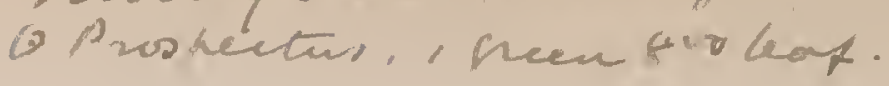

(16)

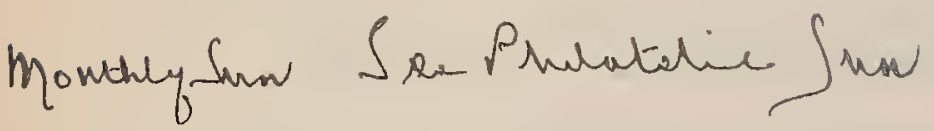


MONTHLY STAIMP NOTES. Monthly stamp notes. For gratuitous circulation.

Southsea, Portsmouth, C. S. Quinton, r901-02. $4^{\circ} \cdot 10 \frac{3}{4}$ in. Nos. 1-7, Jan. 25, Feb. 25, March, April-May, JuneJuly, Aug.-Sept., 1901, Feb., 1902.

\section{[Continued as:]}

Stamp notes.

Southsea, Portsmouth, C. S. Quinton, 1903-06. $4^{\circ} .10 \frac{1}{2}$ in. and $8^{\circ} .8 \frac{1}{4}$ in. Nos. $1-9$ [July], 1903, Sept., Nov., 1903 Feb. Junĕ, Oct., 1904, Fieb" Octe, 1905, Oct., 1906

* * N * Nor 1.8 also bear " M. S. N quarto and no. 9, which has a coloured paper wrapper, is octavg: ind

MONTHLY STAMP WORLD. The Monthly stamp world. Brockton, Mass., Walter J. Hatch, 1899. 16.6 6 in. Nos. 1-3, May-July, 1899.

* * There is a coloured paper wrapper to each number. Wanting no. 3. Mis. St. Jour. 135 (6)

\section{[Continued as :]}

The Philatelic critic.

Brockton, Mass., Walter J. Hatch, xooo. 8. 7 in. Vol. II. 5 nos.

Vol. Ir. Jan.-June, Nov, 1900. Nos. 1-5.

* * Nos. 2 and 3 were published together, with the date "Feb. and Mar. 1900," and nos. 4 and 5 have coloured paper wrappers. No. 4 is dated "Jume, 1900 " on the wrapper and "April-June. No. 4 is dated "June, 1900 " on the wrapper and "April-June.
1900 " on page 1.

MONTHLY VISITOR. The Monthly visitor.

Haverhill, Mass., F. H. Smith, I892-93.

$8^{\circ} .10 \frac{1}{4}$ in., and $10 \frac{3}{1}$ in. Vols. V.-vi. 15 nos.

Vol. V. Jan.-Dec., 1892. Nos. 1-12.

* "* Vr. "Mar., 1893. " 1-3. the remaining numbers of that volume are 8 inches and the numbers of vol. vi. measure $10 \frac{3}{3}$ inches. Nos. $5-8$, vol. v., have coloured paper wrappers and these numbers and nos. 9-12, of the same volume are without the article "The" to the title. The numbers of vols. I.-IV and after vol. vI., no. 3 , are said to contain no philatelio matter. Wanting vol. v., nos. 1, 12, vol vI., nos. 1, 2 .

MONTREAL GEIM. The Montreal gem.

Montreal, J. J. McConkey, x877-78.

in. 11 nos. in 2 vols.

Vol. I. $\quad-1877$. Nos. 1-6.

* "* Only partly philatelic." Succeeded by the "Montreal philatelist". Wanting all nos.

MONTREAL PHILATELIST. Montreal philatelist. Devoted to philatelists and others.

Montreal, J. J. McConkey, 1878.

Fol. 12 in. Nos. 1-[2], February-March, 1878

* *nly partly philatelic. No. 1 is dated "February, 1878" and ** the front page is called "Vol. I. no. 1". On page 3 the title is given as "Montreal Philatelist, formerly the Montreal Gem. Vol. 2. Published monthly. No. 6". No. 2 is dated "March. 1878 " and is numbered "Vol. 3 , no. 1 ". Mis. St. Jour. 3 (13)

IMONTREAL PHILATELIST. The Montreal philatelist A monthly philatelic magazine.

Montreal, The Montreal Philatelic Publishing Co., etc., $\mathrm{I} 898-\mathrm{rg02}$.

$8^{\circ} .83$ in. 48 nos. in 4 vols.

Fol. I. Apl. 15, 1898-May 15, 1899 . Nos. 1-12.

" II. June 15, 1899-June 1900. " 13-24.

" III. July 1900- " 15, 1901. " 25-36.

*" There i" 15, 1901- " 15, 1902. "37-48. * There is a paper wrapper to each number. Nos. 4-15 were published by Rudolph C. Bach, no. 16 by F. W. Wurtele, Trustee, and the re numbers for July and November, 1898, or for October, 1899. No. 7 has "Chistmas and or and nos. 9 and 10 were published together. No. 14 is dated "JulyAugust, 1899 " and should have been numbered " 14 and 15 ". This error was only discovered when the last number of the volume so that there is no number, numbered " 23 ".
IMORLEY'S PHILATELIC JOURNAL. Morley's philatelic journal.

London, S.E., Walter Morley, xgoo-o8.

$8^{\circ} .9 \frac{3}{4}$ in. 108 nos. in 9 vols.

Vol. I. Jan.-Dec., 1900. Nos. 1-12

" II. " - " 1901. " 1-12.

" III. " - " 1902. " $1-12$.

" IV. " - ", 1903. ", 1-12.

"

" vi. ", - ", $1905 . \quad, \quad 1-12$.

" VII. " - " 1906. " 1-12.

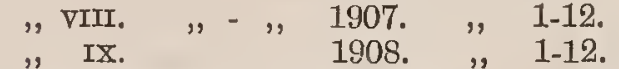

*" There is a title-page, a list" of contents, and an index to each volume and a coloured paper wrapper to each number. Vol. I. was edited by $A$. Preston Pearce and the subsequent volumes by L. W. Fulcher. A supplement "Catalogue of the revenue stamp of South America" was commenced in February, 1901, and was completed in September, 1904, and another supplement " Catalogue of the revenue stamps of the United States, Mexico, and the States of Central America" was started in February, 1905, and completed in vol. IX. The numbers of the last volume were published to-

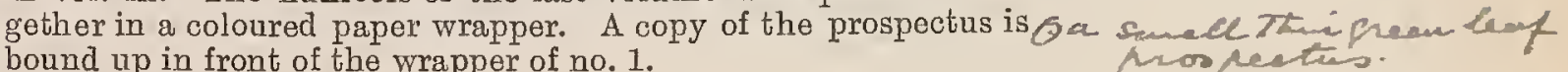

IMORIING CALL. The Morning call. San Francisco, Cal. September 11 and September 18, 1881. [Cuttings of the articles "The Stamp craze. Some interesting particulars as to their collection" ... and "The Stamp craze. An indignant collector resents 'The Call's' in. sinuations," by Mrs. A. G. Craig, are mounted in Stamp Serap-book, vol. IV., pp. 89-91.

\section{MORRISON'S WEEKLY STAIMP COLLECTOR.} Molrison's weekly stamp collector.

Smethport, Pa., The J. L. Morrison Co., etc., x903-

Fol. $12 \frac{1}{2}$ in. 67 nos. in 2 vols

Vol. I. Nov. 24, 1903-Nov. 19, 1904 . Nos. 1 -52

"II. " 26, 1904-Mar. 4, 1905.

* * Nos. 58-67 were published by the Imperial Publishing Co. and nos. 59-64 have" "1904" in error for " 1905 ". No. 53 bears only "Vol. Ir., no. 1 " and nos. 9 and 57 have paper wrappers. Want-
ing nos. 8,10 .

IMORSELS. Morsels.

Milwaukee, Wis., E. F. Daas, I897-98. $8^{\circ} .7 \frac{3}{x}$ in. and $4^{\circ} .12$ in. Nos. 1-7, October, 1897-April, 1898. ** Only partly philatelic. Nos. 1-6 are octavo and no. 7 is quarto. The last contains no philatelic matter. No. 1 has a coloured paper wrapper. Wanting nos. $2,3,4,5,6$.

MOSCHKAU'S MAGAZIN. See A. MoschraU's MagaZIN.

MOUND CITY COLLECTOR. The Mound City collector. Devoted to the interests of philately.

$$
\text { St. Louis, Mo., C. Lang, x88o. }
$$

So. $10 \frac{1}{2}$ in. No. 1 , January, 1880

Mis. St. Jour. 7 (10).

IMOUNT ,ROYAL STAIMP NEWS. The Mount Royal stamp news. $x 900$

Montreal, The Holmes Stamp and Publishing Co.,

$8^{\circ}$.83 in. No. 1, April 1, 1900.

* The number has a paper wrapper. Amalgamated with the "Jubilee Philatelist," July, 1900.

Mis. St. Jour.

MOUNTAIN PHILATELIST. The Mountain philatelist. Official organ of the M.[iddle] A.[tlantic] P.[hilatelic] A.[ssociation] and A.[merican] B.[oys] A.[ssociation]. Mountainville, N. J., Sinnock and Kitchin, 1892. 8. $8 \frac{3}{4}$ in. No. 1, May, 1892. Mis. St. Jour. 47 (3).

IM. P. A. BULLETIN, See Stiamp apVeRTiser. (Hudson, Mass.) 
$\odot$ MULREADY. Le Mulready.

Paris, Adhémar van Weddingen, I892. $8^{\circ} .10$ in. .No. 1, November, 1892.

*** Contains a supplement "Catalogue complet des timbres-poste, avec leurs prix réels, neufs ot oblitérés;" 8 pp. " A copy of the prospectus of the journal is bound up with the number.
Mis. St. Jour. 133 (8).

IMUNDO POSTAL. El Mundo postal. Revista quincenal filatélica y de navegación y comercio. Barcelona, Camilo Mz-Parra, x 897 Fol. 127 in. Nos. 1-4, Aug. 15, Sept. 10, Oct. 30, Dec. 1, 1897. * * There is a coloured paper wrapper to each number. Mis. St. Jour. 97 (11)

IMUNRO'S GIRLS AND BOYS OF AMERICA. See Boys' Own.

IMUSEUIM. The Museum.

Philadelphia, Pa., Edwin At Lee Barber, 1885 . $4^{\circ} .83$ in. Nos. 1-4, May-August, 1885.

* * Only partly philatelic. Each number has a coloured paper wrapper. No. 2 is bound up in Mis. St. Jour. 116 (1) and the philatelic portions of nos. 1-4 are mounted in Stamp Scrap-book, vol. $\nabla .$, pp. 54-58.

IMUSEUIM BULLETIN. Museum bulletin.

Weirs, N. H., C. P. Wilcomb, x886-87. $\mathrm{s} 110$

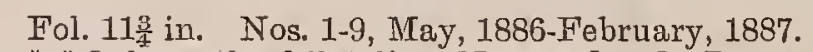

*** Only partly philatelic. No. 9 is dated "January and February, 1887 ". Wanting nos. 1-8.

IIYSTIC WORLD. The Mystic world.

$8^{\circ} .8 \frac{1}{2}-9$ in. 18 nos. in 2 vols.
Vol. r. Oct. 1,1885 -Sept., 1886. Nos. 1-12.

New York, D. J. Hickey, I885-88.

"II. Nov., 1886, Jan., Feb., Apl., Sept., 1887, Feb., 1888.

** Only partly philatelic. Nos. 8 and 11 have supplements of two pages.
Mis. St. Jour. 146 (5). 

NACHRICHTEN AUS DEM BRIEFIMARKENCLUB "IMERCUR". Nachrichten aus dem Briefmarkenclub "Mercur". Mïhlhausen in Thür., I89I. $8^{\circ} .83$ in. No. 1, Jan. 31, 1891.

* * Prcduced by a hectographic process. There is a supplement of two pages, making six pages in all. Mis. St. Jour, 90 (8).

NACHRICHTEN DER PHILATELISTISCHEN BIBLIOTHEK VON ALBERT GOTPSCHALK. Nachrichten der Philatelistischen Bibliothek von Albert Gottschalk. Berlin-Halensee, r904-05. 8. 9 in. INos. 1-17, March 1, 2, Apl. 1, 2, May 1, 12, June 1, 2, 7, 10 , September 15, December 31, 1904, January 6, March 25, June 30,1905 .

* * Produced by a hectographic process. Nos. 11 and 12 and 15 and 16 were severally published together.

NASHVILLE COIN NEWS. The Nashville coin news. Devoted to coins, stamps, and curiosities.

$8^{\circ} .8 \frac{3}{4}$ in. No. 1 , January, 1884. Nashville, Tenn., P. F. Shields, I 884

NATIONAL CAPITAL PHILATELIST. The National capital philatelist.

Washington, J. B. K. Lee, etc., I 886. $8^{\circ} .9 \frac{1}{4}$ and 12 in. Nos. 1-3, Jan.-Mar., 1886. 2

** No. 1 is octavo $9 \frac{1}{4}$ inches and nos. 2,3 measure 12 inches. No. 3 was published by J. B. K. Lee and S. R. Barry.

$$
\text { Mis. St. Jour. } 5 \text { (6). }
$$

NATIONAL COLLECTOR. The National collector.

$8^{\circ} .8 \frac{3}{4}$ in. Nos. 1-2, A pril-May, 1890

Plainfield, N. J., [? ], I89o.

** Only partly philatelic.

Mis. St. Jour. 135 (18).

NATIONAL EXCHANGE. See Youth's EXCHANGE. (Federalsburg, $M d$.)

NATIONAL PHILATELIC NEWS. The National philatelic news, A monthly for all stamp collectors. Indianapolis, Ind.,

8. 91 in. Nos. 1-4, Dec., 1900-Mar., 1901.

** There is a coloured paper wrapper to each number.

Mis. St. Jour. 101 (7).

NATIONAL PHILATELIST. The National philatelist. 3110

8. 9 in. Nos. 1-6, May-Oct., 1879. Mt. Pleasant, Iowa, W. B. Taylor, I879. "**Nos. 3-6 were published together under the date "July-Oct.,
1879 ".
Mis. St. Jour. 24 (15).

NATIONAL PHILATELIST. The National philatelist. New York, National Philatelical Society, r883.

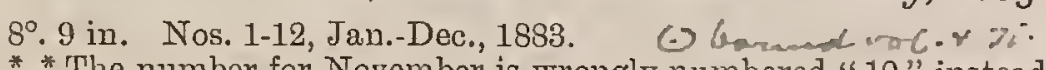
* *The number for November is wrongly numbered " 10 " instead of " 11 ". There is a title-page and an index and nos. 1- $N$ have paper wrappers.

Wrappers and advertisements in Mis. St. Jour. 16 (3).
NATIONAL PHILATELIST. The National philatelist. Washington, D. C., F. MCC. Smith, I888-89.

$8^{\circ} .9$ in. 13 nos. in 2 vols

Vol. I. Feb. 10, Apl. 10, 1888-Feb. 10, 1889. Nos. $1-12$

"II. May, 1889. No.1.

* "No. 1, vol. II., has a coloured paper wrappes.

Mis. St. Jour. 22 (3)

NATIONAL PHILATELIST. See WEs'TERN PHILATELIST. (Humboldt, Kas.)

NATIONAL POSTAGE STAIMP FXPRESS. The National postage stamp express.

London, S.W., R. Evans and Co, $I 864$. $8^{\circ} .83$ in. Nog 1-7, Jan. 15-July 15, 1864 . want Tro 7 of the journal would be published in a corer as "The Quarterly $\checkmark$ postage stamp magazine". ow/wary Mis. St. Jour. 36 (2). NATIONAL SIFTINGS. National siftings.

Beaver Dam, Wis., National Stamp Co., r8gr. in. Nos. 1-3, February-April, 1891.

* * Wanting al] three nos.

NATIONAL STAIMP COLLECTOR. The National stamp collector. A journal devoted to the interests of philately. Official organ of the National Stamp Exchange.

New Orleans, La., The National Stamp Collector's Publishing Co., I897-98.

$8^{\circ}$. $9 \frac{1}{2}$ in. and fol. 12 -123 in. Nos. 1, 3, 4, Dec., 1897-Feb., 1898. be no no. $2 . \quad$ Mis. St. Jour, 118 (9).

NATIONAL YOUTH. See NorTh STAR PHILATELIST.

NATURALIST AND FANCIER. The Naturalist and fancier. Grand Rapids, Mich.,W. A. Gunn, I877. ** Cuttings of "The Stamp and coin collector," no. 1, dated February, from the "Naturalist and fancier," no. 2, dated February, 1877, are mounted in Stamp Scrap-book, vol. III., p. 80.

NEBRASKA PHILATELIST. The Nebraska philatelist, Milligan, Neb., etc., Nebraska Philatelic Publishing Co., etc., I $889-90$.

$8^{\circ} .8 \frac{3}{1}$ in. and $32^{\circ} .5 \frac{1}{2}$ in. Nos. 1-9, May, June, Aug., Nor., 1889. April, 1890

April, 1890. * No. 3 is $32^{\circ}$. and the other numbers are octavo. No, 3 was published at Geneva, Neb., and nos. 4-9 by W. K. Mackey, Pawnee City, Neb.; of the latter nos. $4-8$ were edited by Will $\mathrm{F}$. Weber
and no. 9 by A. $\mathrm{V}$. Dworak. There is a sipplement of two pages to no. 2 and nos. 3-9 have coloured paper wrappers.

Mis. St. Jour. 26 (16).

NEBRASKA PFILATELIST. The Nebraska philatelist. Hastings, Neb., etc., Jas. A. Kennedy, etc., I899-I 900. $8^{\circ} .83$ in. and 10 in. 13 nos. in 2 vols.

Vol. I. Feb. 15, 1899-Mar., 1900, June, 1900. Nos. 1-12. * II. July, 1900 . No. 1.

* * No. 12 and vol. II., no. 1 were published by R. L. Shepard at Omaha, Neb. Nos. 8-11 measure 10 inches and the other numbers about $8 \frac{3}{4}$ inches. Each number, excepting no. 1, has a paper wrapper. No. 4 is dated "May-June 15, 1899 "; no. 7 "September-October 15,1899 "; no. 8, "November-December, 1899 " 
NEBRASKA STAMIP. The Nebraska stamp.

Central City, Neb., Cleve Scott, I892-93.

8․ 8-8 $\frac{1}{2}$ in. Nos. 1-6, Aug.-Oct., 1892, Dec., 1892-Feb., 1893.

* There is a coloured paper wrapper to each number.

Mis. St. Jour. 65 (11).

NEBRASKA STAMP NEWS. Nebraska stamp news. A monthly devoted to stamp collecting.

Fremont, Neb., Edward C. Biggar, I889-9o.

$8^{\circ} .7 \frac{1}{-1} 7$ in. Nos. 1-9, Dec., 1889-Aug., 1890. ** There is a coloured paper wrapper to no. 9 and a supplement
of two pages to no. 6 .
Mis. St. Jour. 67 (1). Mis. St. Jour. 67 (1).

NEBRASKA STAMP NEWS. The Nebraska stamp news. Minden, Neb., Don. H. Wimmer, rgoo. Fol. 12-11 1 in. and $8^{\circ} .88-9$ in. 8 nos. in 2 vols.

Vol. I. Mar. 15-Aug. 15, 1900. Nos. 1-6.

"II. Sept.-October, 1900. Nos. 1-2.

* * Nos. 1 and 2 are folio, the remaining numbers are octavo and nos. 3-5 have coloured paper wrappers. Nos. 1 and 2, vol. Ir., were published together and the last leaf of this double number had some of the advertisements cut off before the number was circulated. A malgamated with the "Monarch Monthly," Decem-
ber, 1900.
Mis. St. Jour. 118 (7).

NEDERLANDSCH TIJDSCHRIFT VOOR POSTZEGELKUNDE. Nederlandsch Tijdschrift voor Postzegelkunde.

Amsterdam, Vereeniging van Postzegelverzamelaars te Amsterdam, I884-

$8^{\circ} .9 \frac{7}{2}-9 \frac{3}{4} \mathrm{in.}$ and $4^{\circ} .11 \mathrm{in}$. nos. in vols. In progress.

1st year. Aug. 8, 1884-July, 1885. Nos. 1- 12.

2nd " " " $\quad 1885-", \quad 1886 . \quad$ " 188.12.

4th " " " 1887- " $1888 . \quad$ " $1-12$.

5th " " " $\quad 1888-", \quad 1889 . \quad " \quad 49-60$.

7th " " "1890-Aug., 1891. " " 73-84.

8th ", Sept., 1891- " 1892. " " 85- 96.

9th " " 1892- " 1893. "

10th " " "1893- " 1894. ", 109-120.

11th " " $\quad$ 1894- " $1895 . \quad$ " $121-132$.

13th " May, 1896-" 1897. " 141-152.

14th " 1897- " 1898. " " 153-164.

15 th " " " $1898-", 1899 . \quad$ " $165-176$.

16th " " $1899-", \quad 1900 . \quad$ " $1900-" 177-188$.

1901- " 1902. " 201-212.

19th " " 1902- " $" 1903 . \quad$ " $213-224$.

21st "1904-Dec., 1904. " "236-243.

22nd " Jä. - " 1905. " "244-255.

* * Vols. I. to "IX. were edited" by A. Е. J. Huart, and the subsequent volumes by J. B. Robert. Nos. 1-5 were printed by autographic lithography and are octavo in size, the remaining numbers being quarto. Commencing with no. 49 the title of the publishing Society was changed to "Nederlandsche Vereeniging van Postzegelverzamelaars". There is an index to each of the first eight zegelverzamelaars . There is an index to each of the firse and an years, with the exception of the first year, a year, and wrappers index to each year, commencing with the ninth year, and wrappers to nos. " $4-48,57$, 97 and to each " Nos. 144-145, 156-157, 168-169, 180-181, 192-193, 204-205, 216-217, $239-240$, 251-252, and 263-264, were severally published together under the date "Aug.-Sept," of the various years. The wrapper of no. 177 is wrongly numbered 176 ; nos. $221-225$ are wrongly numbered " $220-224$," respectively, and the wrappers also, with the exception of the wrapper of no. 225, which is colrect; the wrappers of nos. $232-233$ are wrongly numbered 231 and 232 , respectively; nos. $236-238$ are wrong y numbered $235-237$, respectively, except on the wrappers, which are correct ; the wrapper of no. 237 is dated " Juli" in place of "Juni", and the wrapper
of no. 241 has "No. 4, 5," instead of "No. 6". With no. 133 a of no. 241 has "No. 4, 5" instead of "No. 6 " "With no. 133 " new series was started "Nieuwe Reeks: No. 1 " and this double uumbering has a supplemental slip and no. 5 of the same year has a supplement of (4) pagcs and also a supplemental slip and "ommentement.

NEDERLANDSCHE PHILATEIIST. De Nederlandsche philatelist. Maandblad voor Postzegelkunde.

Amsterdam, Erwin Donath en Co., etc., r904$8^{\circ} .10 \frac{1}{2}$ in. Dos. in. vols. In progress.

2nd " Ja" $\quad$-Dec., $1905 . \quad$ " $1-7$.
NEUE BRIEFMARKEN-ZEITUNG

652

9 ** There is a title-page and an index to each volume and a coloured paper wrapper to each number. Commencing with no. 9 of the first year the journal has becn published by N. Yaar and per which is correet.

NEUE BRIEFIMARKEN - ZPTTUNG. Nene Briefmarken-Zeitung. Vereins-Organ des Interuationalen Tausch- und Kaufverbandes für Semstwomarken-Sammler. Karlsbad, E. Grïneberg, I894. Fol. $12 \frac{1}{2}$ in. Nos. 1-5, Sept. 1, 15, Oct. 1, 15, Nov. 1, 1894. **A copy of the prospectus is bound up with the five numbers. Mis. St. Jour. 129 (21).

NEUE IMARKENBÖRSE. Neue Markenbörse. Philatelistisches Organ.

Nordhausen, Arthur Franke, I896. 8․ 9 in. Nos. 1-2, July 15-August 15, 1896.

* * Printed on buff paper. $\quad$ Mis. St. Jour. 145 (10).

NEUE PHILATELISTISCHE BLÄTTER. Neue philatelistische Blätter zur Wahrung der Sammler vor Fälschungen, etc. Leipzig, Max Böhne, I879-80. $8^{\circ} .10$ in. Nos. 1-3, Oct. 1, Nov. 15, 1879, Jan. 15, 1880 * * No. 3 has for a supplement no. 11 of the "Philatelistischer "* No. 3 has for a supplement no. 11 of the "Philatelistischer mutilated.

Mis. St. Jour. 133 (12).

NEUESTE PRIVATPOST-NACHRICHTEN. Neueste Privatpost-Nachrichten.

Gössnitz, S.-A., A. E. Glasewald, I888-93. $8^{\circ} .6 \frac{3}{4}$ in., $4^{\circ} .8 \frac{7}{2}$ in., $8^{\circ} .9 \frac{3}{4}$ in., and $4^{\circ} .11 \frac{1}{2}$ in. 71 nos. in 6 vols. 1 st year. Jan. -Dec. 15, 1888. Nos. 1-12.

2nd " " 15- ", 20, 1889. , 1-12.

3rd " " " " $"$ "

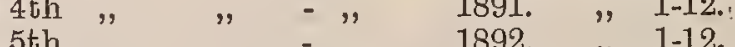

5th " "N" -Nov. 1893. " 1893

* * Nos. 1 and 2 of the first year are "octavo 63 inches, nos. 3-12 ** Nos. 1 and 2 of the first year are octavo 63 inches, nos. 3-12
of that year are quarto $8 \frac{1}{2}$ inches, the numbers of the second year are octavo $9 \frac{3}{4}$ inches and all the subsequent numbers are quarto $11 \frac{7}{2}$ inches. Nos. 8 and 9 of the first year and nos. 3 and 4 of the fifth year were severally published together under the respective dates "August-September, 1888" and "März u. April, 1892". There are title-pages and indexes to the second, third and fourth years, and commencing with July, 1892, the journal was published as ra supplement to "Mitteldeutsche Philatelısten-Zeitung". The first number consists of the first part of a fourth edition of A. E. Glasewald's " Katalog ... deutschen Privatpost-Marken" and the other parts, and supplements thereto, were given with nos. 2-12 for 1888 and with the twelve numbers for 1889. There are also numerous supplemental leaves and slips throughout the volumes.

NEW BOY. The New boy.

New York, The New Boy Publishing Co., I 905-06.

Fol. $12 \frac{1}{4}$ in. Nos. 1-12, March, 1905-April, 1906.

* * Only partly philatelic. Each number has a paper wrapper. Duplicates of nos. 7 and 10, are bound up in Mis. St. Jour. 115 (4).

NEW CENTURY. The New century. Official organ of the U.[nited] S.[tamp] C.[ollectors] A.[ssociation]. Alton, Ill., The Century Pub. Co., I904.

$16^{\circ} .6 \frac{1}{4}$ in. Nos. 1-3, January-March, 1904.

* $6^{\circ} \cdot 6 \frac{1}{4}$ in. Nos. $1-3$, January** Nos. 2 and 3 were published together, and there is a coloured

NEW CURIOSITY TIMES. The New curiosity times. Bath, Stafford Smith and Smith, I865. C $12^{\circ} \cdot 6 \frac{1}{2}$ in. No. 1, Dec. 15,1865 Mis. St. Jour. 42 (2).

NEW ENGLAND JOURNAI, OF PHILATELY. The New England journal of philately.

Boston, Mass., W. W. Learned and Co., etc., 1869. $8^{\circ} .81$ in. Nos. 1-3, Jan.-Mar., 1869.

* Nos. 2, 3 were published by C. A. Lyford. 
NEDERLANDISCHE MAAND BLATT VOOR PHILATELUE

NEUESTE PREETMARKEN UMSC MAU

hurlengtane Phatatile Journel - c.c.P.posog 
Hew Sngland Strimp ciouthly.

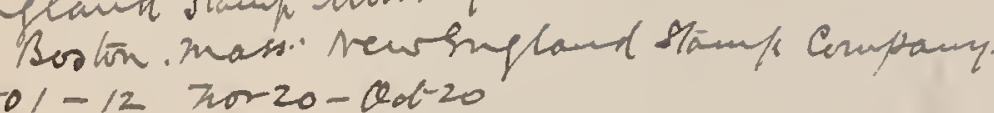

$$
\begin{aligned}
& \text { I } 1911 / 2 \mathrm{rol}-12 \text { norzo- Cod } 20 \\
& \text { II } 1912 / 3 \text { 100 } 1-12
\end{aligned}
$$

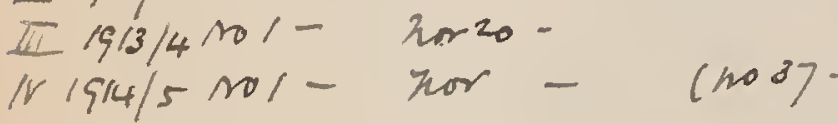

Neur Karen Collector rew it aren. N.Y. 2.0.young.

1909

$1919 \pi 1-2(A)-7.6)$ 
653 NEW ENGLAND PHILATELIST

NEW ENGLAND PHILATELIST. The New England philatelist.

Fitchburg, Mass., W. L. Emory, etc., x884-85. $8^{\circ} .8 \frac{1}{2}$ in. Nos. 1-11, Nov., 1884-Sept., 1885.

* * No. 11 was published by Chas. P. Henry. Nos. 7 and 8 were issued together in a coloured paper wrapper dated "May, 1885 " and there is a coloured paper wrapper to each of the other numbers with the exception of no. 1 .

[Continued as :]

The Philatelist, formerly the New England philatelist. Fitchburg, IIass., Emory and Jewett, [1886]. $8^{\circ} .8 \frac{1}{2}$ in. No. 12 [Jan. 1886].

* The number has a coloured paper wrapper. An index to the printed on the face of the front wrapper of no. 12 .

NEW ENGLAND PHILATELIST. New England philatelist. Brcokline, Mass., G. H. Clark, r889. $8^{\circ} .8^{3}$ in. Nos. 1-2, Nov.-Dec., $1889 . \quad$ Mis. St. Jour. 26 (15).

NEW ENGLAND PHILATELIST. The New England philatelist.

Jamaica Plain, Mass., J. M. Chandler, 1898. $8^{\circ} .9$ in. Nos. $1-3$, Aug.,-Oct., 1898.

"* Amalgamated with the "Bay State philatelist". Wanting nos. 1,3 .

NEW HAIMPSHIRE PHILATELIST. The New Hampshire philatelist. A monthly devoted to the interest of stamp collecting.

Lake Village, N. H., etc., C. L. Simpson and C.S. Gilman, etc., $\mathrm{x} 89 \mathrm{x}-92$.

$8^{\circ} .8 \frac{1}{x}-8 \frac{1}{2}$ in. 13 nos. in 2 vols.

Vol. I. Feb., 1891-Jan., 1892. Nos. 1-12

" II. Feb., 1892. No. 1.

**" No. 1, vol. II., was published at Lakeport, N. H., and this number and nos. 10-12, vol. I., were published by C. L. Simpson. No. 1, vol. I., is undated, but has "Feb., 1891" inserted with pen and ink, and no. 2 of the same vol. is wrongly, numbered, but has the
number corrected in pen and ink to "II." Mis. St. Jour. 63 (7).

NEW IMPRESSIONS. New impressions. A journal without pretensions. Ipswich, A. E. Boswell, r884. $32^{\circ} .4 \frac{1}{2}$ in. No. 1, Jan., 1884.

* * The number has a coloured paper wrapper. J. K. Tiffany states that six numbers are said to have been published, but in a list of philatelic papers for sale by E. F. Herdman in 1890, the latter says only one number appeared. As he wrote two articles in no. 1, both of which were "To be continued," the information he gives should be reliable. An advertisement, however, of A. E.
Boswell appeared in the "East Anglian philatelist" for March, Boswell appeared in the "East Anglian philatelist" for March,
1884 , and also in the "Foreign stamp collectors" news" of the 1884, and also in the "Foreign stamp collectors" news" of the
same month, stating that no. 2 of "New impressions" was "now same month, stating that no. 2 of "New impressions" was " now
ready".

NEW JERSEY COLLECTOR. The New Jersey collector. A monthly journal devoted to philately and cigarette card collecting Plainfield, N. J., W. H. Rice, г 890. $16^{\circ} .5 \frac{3}{2}$ in. Nos. 1-3, Jan.-Mar., 1890.

*** There is a coloured paper wrapper to each number. Succeeded by the "U. S. philatelist".

NEW JERSEY PHILATELIST. The New Jersey philatelist.

Jersey City, N. J., New Jersey Philatelic Society, x $880-82$

S $110 \quad 8^{\circ} .9 \frac{1}{2}$ in. and $11 \frac{1}{4}$ in. 36 nos, in 3 vols.

Vol. I. Jan.-Dec., 1880. Nos. 1-12.

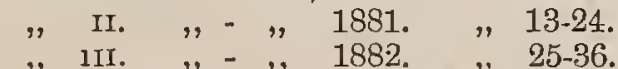

* " No. 1 is $9 \frac{1}{2}$ inches and the "remaining numbers are $11 \frac{1}{1}$ inches. Nos. 3 and 4,18 and 19, 31-33, were severally published together.

NEW JERSEY PHILATELIST. The New Jersey philatelist. Paterson, N. J., Lehmann Bros., etc., I889-9o. 12.6 61 in. and $8^{\circ} .9$ in. Nos. 1-4, Mar., June, 1889, Feb., 1890. ** Nos. 3 and 4 were published by August Lehmann Jr., as one number, under the date "February, $1890^{0}$ ". No. 1 is $12^{\circ}$. and nos. 2-4 octavo, and nos. 1 and 3, 4 have coloured paper wrappers.
NEW JERSEY PHILATELIST

NEW JERSEY PHILATELIST. The New Jersey philatelist.

Califon, N. J., New Jersey Philatelic Publishing Co., etc., $1892-93$.

$8^{\circ} .9$ in. 7 in. and 6 in. Nos. 1-4, Nov., 1892-Feb., 1893 .
$* *$ Nos. 2 and 3 were published by T. G. Kitchin and no. 4 by the Northern Philatelic Publishing Co. Nos. 1 and 3 are octavo 9 inches, no. 2 is octavo 7 inches and no. 4 , octavo 6 inches. The last number has a paper wrapper with the words "Sample copy" at the top of the front page.

NEW JERSEY PHILATELIST. See LITTLE GEM STAMP NEWS.

NEW SOUTH WALES PHILATHLIST. The New

(.) South Wales philatelist. A quarterly journal for stamp collectors. Sydney, D. A. Vindin, 1882-83. C) 80. $91-9 \frac{1}{2}$ in. Nos. $1-2$, Nov. 15, 1882-Jan., 1883.

150seoficis ofrro/. Mis. St. Jour. 56 (16).

NEW SOUTH WALES STAIIP COLLECTORS' IMAGAZINE. The New South Wales stamp collectors' magazine. Sydney, Edward Buckley, etc., x879-8x. 8. 81 in. Nos. 1-3, Nov., 1879, Apl., 1880, Apl., 1881. ** There is a coloured paper wrapper to no. 1 , and nos. 2 and 3 were published by Buckley Blunsum and Co. Pages 13 and 14 of no. 1 were cut out of each number before it was circulated. This was the first philatelic journal published in New South Wales. Mis. St. Jour. 30 (15).

New Series. Sydney, Dawson A. Vindin, I88z.

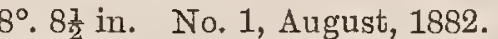

Mis. St. Jour. 30 (15a).

NEW YORK COLLECTOR. The New York collector.

Brooklyn, N. Y., etc., E. A. Hernandez, 1885-86. $8^{\circ} .8-9$ in. Nos. 1-9, September, 1885-May, 1886.

* * Nos. 1-7 are mostly, but not entirely philatelic while nos. 8, 9 have very little philatclic matter. Nos. -9 were published at New York, nos. 5 and 6 were published together, and nos. 2-4 and 8 have coloured paper wrappers. Wanting nos. 5,6 .

Mis. St. Jour. 153 (10).

NEW YORK EVENING POST. The New York evening post. New York. June 7th, 1875. [Cuttings of letter headed "The Slighted dignity of the Philatelical Society," written by Joseph J. Casey, are mounted in Stamp Scrapbook, vol. III., pp. 7, 8.]

NEW YORK HERALD. The New York herald. New York. February 8 and 11, 1877. [Cuttings of articles "Stampy Joe " and "The Berford stamps," are mounted in Stamp Scrap-book, vol. III., p. 60.]

NEW YORK PHILATELIST. The New York philatelist. New York, H. C. Jones, I878-79. $8^{\circ} .913$ in. Nos. 1-7, Dec., 1878-June, 1879. ** No. 5 has the title the "N. Y. philatelist".

Mis. St. Jour. 18 (5).

NEW YORK PHILATrLIST. The New York philatelist. Devoted exclusively to philately.

Waterloo, N. Y., J. G. Murray, x88 I.

$8^{\circ} .11$ in. No. 1 , October, 1881

Mis. St. Jour. 6 (3)

NEW YORK PHILAT'FLIST. The New York philatelist. A monthly paper devoted to stamp collecting. New York, Smith and Lane, x89r. $8^{\circ} .8 \frac{3}{2}$ in. Nos. 1-2, May-June, 1891.

* There is a coloured paper wrapper to each number.

Mis. St. Jour. 46 (5)

NEW YORK PHILATELIST. The New York philatelist. A monthly magazine devoted to philately.

New York, etc., Berniger and Herbst, etc., x896-1903. $8^{\circ} .9 \frac{3}{4}-8 \frac{3}{4}$ in. 79 nos. in 14 vols.

Vol. iI. Oct., 1896-Mar. 15, 1897. Nos. 1- 6.

$"$ II. April 15 -Sept. 15, " " $1-6$.

" III. Oct. 15, 1897-Mar. 15, $1898 . \quad$ " 1- 6.

"IV. Apl. 15 -Sept. 15, " " $1-6$.

" VI. April 15 -Sept 15, $15,1-6$.

" vIl Oct 15,1899 -Mar. 15, 1900 "

"VIIL A pril 15 -Sept 15, "1- 6 .

"VII. Oct. 15, 1900-Mar. 15, 19001. "

" $\quad$ X. Apri1 15 -Sept. 15, " " 


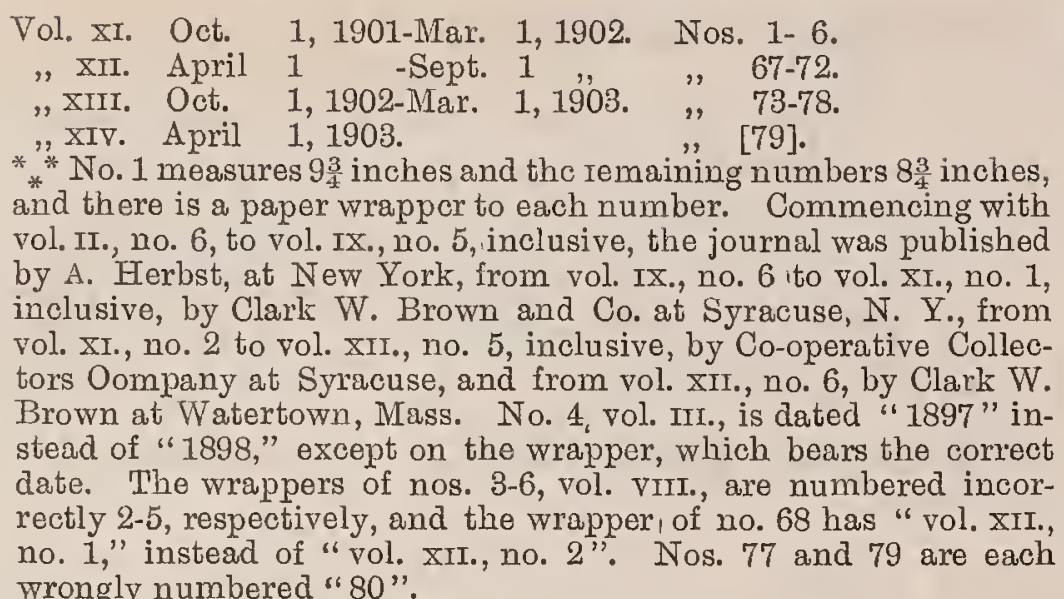

NEW YORK PHILATELIST. See N. Y. PhILATELIST.

NEW YORIK STAMP. The New York stamp. A monthly journal for stamp collectors.

New York, Grevning and Spooner, I892.

$8^{\circ} .83$ in. Nos. 1-3, Apl. 1-June 1, 1892

* * "There is a coloured paper wrapper to each number.

\section{[Continued as :]}

_- The Stamp. A monthly journal for stamp collectors.

Long Branch, N. J., etc., Greoning and Spooner, etc., I892-95.

$8^{\circ} .8 \frac{3}{4}$ in. 39 nos. in 4 vols.

Vol. I. July 1, 1892-Mar. 1, 1893. Nos. 4-12

"II. Apl. 1, 1893-March, 1894. "13-24.

$"$ III. April, 1894-March, 1895. " 25 -December, 1895. 37 .

* "* Each number has a paper wrapper. N้o. 21 is dated "Dec. Jan., 1894," there is no number 23 , and nos. 30 and 31 were published together. Nos. 9-12 were published by Ralph Perkins Spooner at Long Branch, no. 13 by the same at Nerv York, nos. 14-18 by Peugnet and Spooner at New York, nos. 19-41 by Charles W. Grevning at New York, and no. 42 by the last at Morristown, Morris County, N. J.

NEW YORK STAIMP AND COIN NEWS. New York stamp and coin news.

New York, The New York Stamp and Coin Co., etc., I $902-03$

$8^{\circ} .9$ in. Nos. 1-5, Dec., 1902 Jan., 1903, Feb. and Mar., Apl, and May, Aug. and Sept., Nov. and Dec., 1903.

* * Each number has a coloured paper wrapper and nos. 2-5 were published by Greater New York Stamp and Coin Co. otherrise J. F. Negreen. No. 2 is dated inside "March 20, 1903" and no 5 "November 20, 1903 ". The last number contains only advertisements. Only 200 copies of each number are said to have been printed. The copy of no. 3 in the library is wanting pages $1,2,5$ printed 6.

Mis. St. Jour. 147 (7)

NEW YORIK SUN. The New York sun. New York. June 5th, 1871. [A cutting of the article "A new mania Ten thousand collectors of old postage stamps in this City" ... is mounted in Stamp Scrap-book, vol. II., pp. 2, 3.]

NEW-YORK TIMES. The New-York times. New-York August 4, 1890. [A cutting of the article "The price of postage stamps," is mounted in Stamp Scrap-book, vol. vi., pp. 159, 160.]

-CAugust 6, 1890. [A cutting of the article "Postage stamps exhibited. Annual convention of the Philatelic Association," is mounted in Stamp Scrap-book, vol. vI., pp. 153, 154.]

- August 7, 1890. [A cutting of the article "The Phila telic Association. A protest against the registration fee and the duty on stamps," is mounted in Stamp Scrapbook, vol. vi., pp. 154, 155.]

_ August 10, 1890. [A cutting of the article "John's miserable stamps. Collectors consider them bad in every respect," is mounted in Stamp Scrap-book, vol. VI., pp. $160,161$.
NEW-YORK TIMES. September 7, 1890. [A cutting of the article "Postage-stamp collectors. Enthusiasts who spend much money and time on their hobby," is mounted in Stamp Scrap-book, vol. vi., pp. 157, 158.]

August 16, 1891. [A cutting of the article "The Formosa postage stamp," from the Cornhill Magazine, is mounted in Stamp Scrap-book, vol. VI., p. 170.]

August 20, 1891. [A cutting of the article "Work of stamp collectors. The sixth annual convention of philatelists concluded," is mounted in Stamp Scrap-book, vol. VI., p. 167.]

NEW ZEALAND PHILATELIST. The New Zealand philatelist.

Wellington, The British and Continental Stamp Co., I 900.

* No. 1, April, 1900

NEW ZFALAND PHILATELIST. The New Zealand philatelist. With which is incorporated the Sterling monthly.

Nelson, N. Z., The Sterling Stamp Co., I904. $8^{\circ} .8 \frac{3}{4}$ in. 10 nos. in 2 vols

Vol. I. Jan. -May, 1904. Nos. 1-5.

*"* II. June-Oct., " Eumber has a coloured paper wrapper. Bound up with the "Sterling monthly".

NEW ZFALAND STAIVP COLLECTOPS' QUARTERLY. The New Zealand stamp collectors' quarterly. Aucleland, F. A. Henderson and Co., I880.

$8^{\circ} .8$ in. No. 1 , Oct. 1,1880

* * There is a supplement of two pages printed on one side only. This was the first philatelic journal published in New Zealand. Mis. St. Jour. 30 (16).

\section{NEWCASTLE AND GATESHEAD STAIIP ADVER-} TISER AND REVIEW. The Newcastle and Gateshead stamp advertiser and review.

Newcastle-on-Tyne, Joton Burrell and Co., I864. $8^{\circ} .81$ in. Nos. 1-3, Jan. 1-Mar. 1, 1864. 2 ( $/ 4 h$ 5-16) ** * Amalgamated with the "Liverpool and Newport stamp adver-

NEWS AND COURIER. The News and courier. New series, vol. II., no. 711, December 11, 1905. [Contains an article "A new movement in philately," by a Philatelist.] I 905 .

Charleston, S. C., The News and Courier Co., Fol. 223 in. p. 5

Mis. St. Jour. $115(15)$

NEWSPAPER CUTTINGS. [Collection of newspaper cuttings on philately mounted in five volumes lettered "Stamp Scrap-book, vols. II.-vr."]

NEWSPAPER CUTTINGS. [Collection of newspaper cuttings referring to foreign stamps and postal matters made by Judge F. A. Philbrick between the years 1897 and 1903, inclusive, mounted in a folio volume lettered "Newspaper cuttings. F. A. Philbrick. 1897-1903."]

NIAGARA FALIS PHILATELIST. The Niagara Falls philatelist.

Niagara Falls, South, Ont., The Niagara Falls Publishing Co., 1887-89.

8. $9 \frac{1}{4}$ in. Nos. 1-11, Aug., 1887-Jan., 1888, July, Aug. 10, 25, Sept. 10, 25, 1889

* * Nos. 1-6 have paper wrappers.

Mis. St. Jour. 101 (9).

NIAGARA PFILATFLIST. The Niagara philatelist. Buffalo, N. Y., G. C. Andrews, I 896 $32^{\circ} .4$ in. and $8^{\circ} .88^{3}-8 \frac{1}{1}$ in. Nos. 1-4, Feb., March and April, May, $32^{\circ} .4$ in. and 8 " * No. 1 is $32^{\circ}$. and nos. $2-4$ are octavo. Mis. St. Jour. 94 (8).

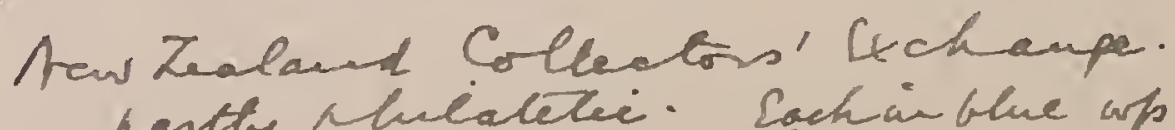
panth Mhialetei. Sach in blue arp orolI $1908 / 9 \mathrm{teb} / \mathrm{m}, 1.2 .94 / 56 / 7.891011 / 12$

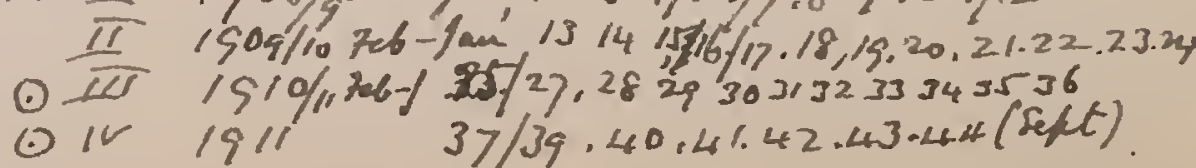




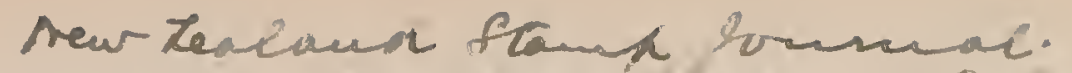

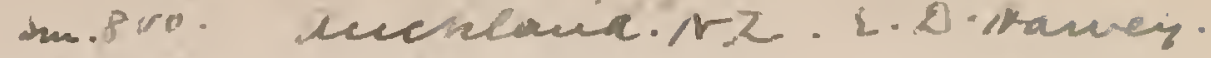

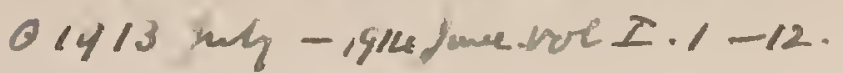

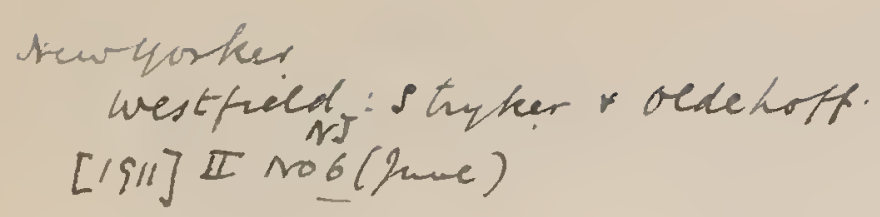

N.Z. Collectors Exchange (Wellington) 1908-11. Nos. 1-48

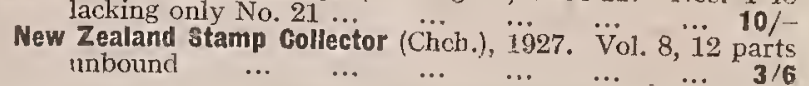

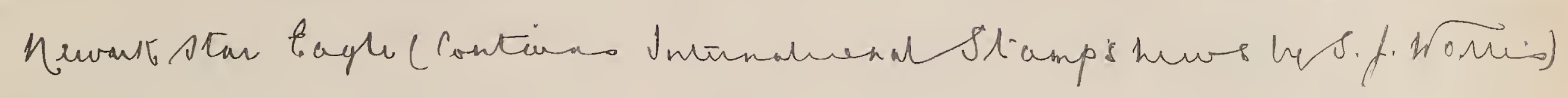

sewarte philatelest

reivark N.J. E.w.Zuss.

8 ro 1912 工 $1-\underline{b}$

1913 II $2 / 3$ (may//mere)

tw wark Stauf hews.

: tewask. Nf. rourask stawfe Clut

$19 / 2$

$1913 \pi$

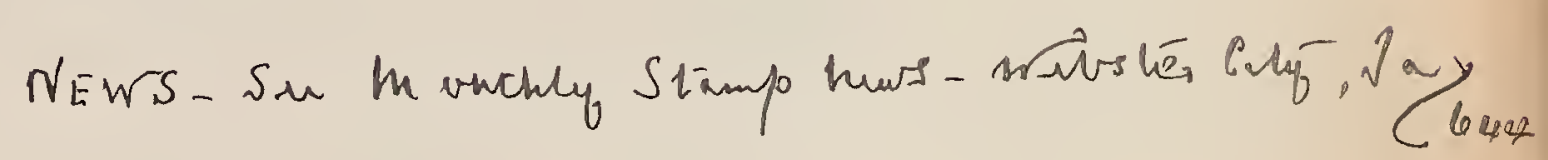




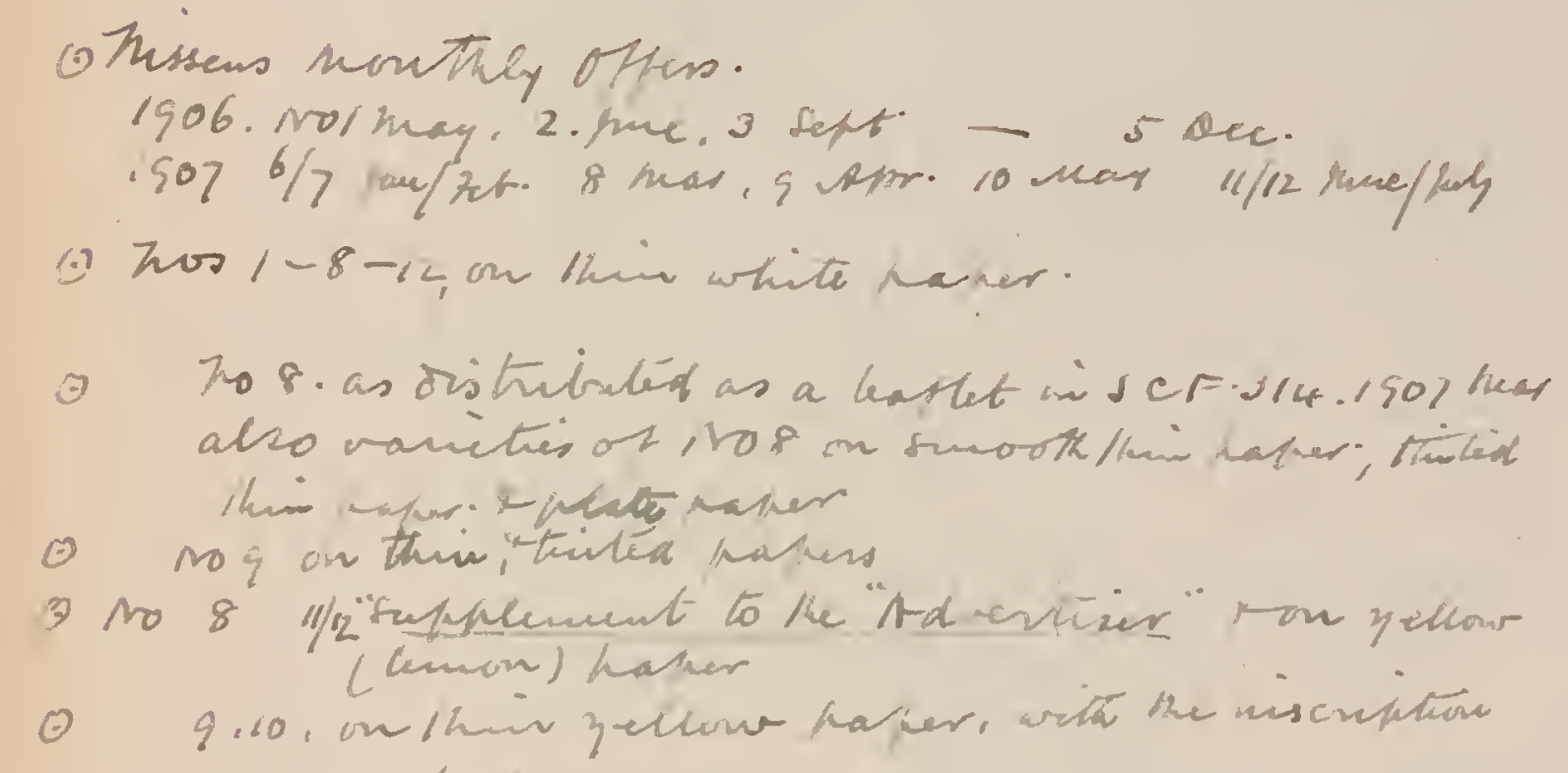

Vol I has extra page numbend 136\% shoing tiabeck frotmanks.

II Nos.497 were is sued in 2 prento, $A 9 B$, the lalter comprising special deatero' offers, not cricludél in pajaination. 
NICHT - ILLUSTRIERTE POSTWERTZEICHEN ZEITUNG. Die nicht-illustrierte PostwertzeichenZeitung. I 894

[Karlsruhe, Verein der Briefmarken-Sammler], $8^{\circ} .9$ in. No. 4, F'ebruary, 1894.

* * The exact heading reads: "Extra-Ausgabe der nicht-illustrierten Postwertzeichen-Zeitung. Streitschrift für VerleumdungsKunde. Offizielles Organ der Vereinigung Kleinsteinbacher Briefmarken-sammler". . . The date is given as "Hornung, 1894. Faschings-Jahrgang " and the publishers as "Neueste
Nachrichten für Stadt und Land".
Mis. St. Jour. 142 (2).

NISSEN'S IMONTHLY OFFERS. Nissen's monthly offers.

London, W.C., Charles Nissen and Co., i 906-o7.

Thave 10 8 on 8.93 in. Nos. 1-12, May, 1906-July, 1907. thin, ruatrias 5 "December, 1906 " " nos. 6 and 7 were published together with

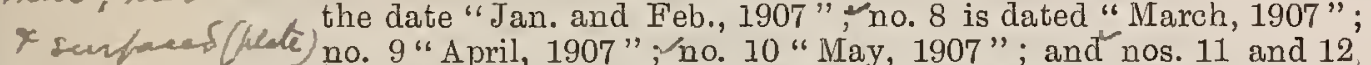
thithopers; 9 an which were published together, "June and July, 1907 ". No no. thai $k$ theite $v 4$ was issued and nos. $1-3$ and no. 5 are solely price lists of stamps, etc., for sale by the publishers. W The eleven numbers were also printed on yellow paper and were presented as supplements to / Mave $8-12$ on the "Stamp and postcard advertiser," or the continuation of that

NORD PHILATÉEIQUE. Le Nord philatélique. Douai, G. Dautricourt, I 899-I 900.

Fol. $12 \frac{3}{4}$ in. and $8^{\circ} .9 \frac{1}{2}$ in. 11 nos. in 2 vols.
1st year. Apl. 8 -Dec. 15,1899 . Nos. $1-7$.

2nd "Jan. 15, Mar. 15, June 1, July 15, 1900. Nos. 8-11. ** Nos. 1-7 and no. 9 are folio, and nos. 8, 10 and 11 are octavo and the three last mentioned have coloured paper wrappers. No 3 and 4 wcre published together with the date " 8 Julllet, 1899 " and there are no numbers for August or September, 1899.

Mis. St. Jour. 108 (10).

NORDDEUTSCHE BRIFFMARKEN-POST. Norddeutsche Briefmarken-Post.

Hamburg, Jul. Helm, I 894-95. $8^{\circ} .9$ in. Nos. 1-12, Nov. 1, 1894-Oct., 1895

* There is a coloured paper wrapper to each number.

Mis. St. Jour. 90 (4)

NORDDEUTSCHES POSTWERTHZFICHEN OFFERTENBLATT. Norddeutsches PostwerthzeichenOffertenblatt.

Sianowo, Westpreussen, Marian Nötzel, I894-95 $4^{\circ} .11 \frac{1}{2}-11 \frac{3}{4}$ in. Nos. $1-8$, Oct. 1, 1894-May 1, 1895

Mis. St. Jour. 87 (17)

○ NORDISK FILATELISTISK TIDSKRIFT. Nordisk Filatelistisk Tidskrift.

Stockholm, etc., F. W. Andréen, etc., I894$8^{\circ} .10 \frac{1}{4}$ in. nos. in vols. In progress.

1st year. Jan. 1-Dec. 15, 1894. Nos. 1- 24

2nd " " 1- " 20, 1895. " 1-24.

3rd " " $\quad 1-\quad " 20,1896 . \quad " \quad 49-68$.

4th " " $\quad 2 \quad 2-" 22,1897 . \quad " \quad 69-88$.

6th " " " 2- ", 30, 1899. " " 109-128.

7 th " " $30-\quad, 31,1900 . \quad$ " 129-140.

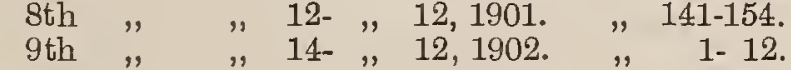

10th " " "12- " 12, $1903 . \quad$ " $1-12$

11 th " " $15-12$ " 12,1904 . " $1-12$.

12 th " " 12- " $12,1905 . \quad$ " $12-12$.

* * No." 1 was published at Stockholm, the next forty-seven numbers at Stockholm and Kristiania, the twenty numbers of the thir year at Stockholm, nos. 69-88 at Christiania, nos. 89-108 at Kj benhavn, nos. 109-128 at Stockholm, nos. 129-140 at Kristiania nos. 141-154 at Kjpbenhavn, the twenty-four numbers of 1902 and 1903 at Lund, the numbers of 1904 and 1905 at Kristiania and those of 1906 at Stockholm. Commencing with no. 2 of the fourth year the journal has been published by the Nordisk Filatelist Forbund. There is a titlepage and an index to each volume and a pape wrapper to each'number. "The wrapper of no. 13 of the secon year is dated " 15 Juni " instead of "1 Juli," and there are no nos. 143 and 144, the number for March, 1901, being numbered " 145 ," and this error in numbering was continued to the end of the year. No. 2 is also called "Nordisk Frimaerkeblad. No. 26 " and "Tidning för Frimärksamlare no. 81 " and this treble numbering is carried on to the end of 1895 when it is dropped. From January, 1897, the spelling of the title is amended to "Nordisk Filatelistis
Tidsskrift". No. 12 of the twelfth year has also "No. 200".
NORDISK FRIMAERKEBLAD. Nordisk Frimaerkeblad. Arendal, etc., $G$. O. Ulleberg, I886-89. $8^{\circ} .10 \frac{1}{4}$ in. 23 nos. in 3 vols

1st year. July $31,1886-J u l y ~ 15,1887$. Nos. 1-12. "nd "Aug," -Dec. 1887. " 13-18.

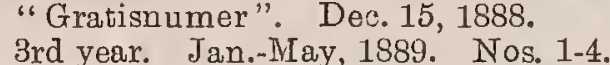

* * There is no number for December, 1886, nos. 14 and 15 , and 16 and 18 were severally published together under the respective dates, "September og Oktober, 1887 " and "December, 1887," and there is no number for March, 1889. The "Gratisnumer" and the four numbers of the third year were published at Skien A copy of the prospectus is bound up in front of no. 1. This was the first philatelic journal published in Norway.

NORDISK F'RIMAERKEBLAD. Nordisk Frimaerkeblad.

$8^{\circ} .10 \frac{1}{4}$ in. 25 nos. in 2 vols

1st year.

1st year. Jan.-Dec., 1892. Nos. 1-12.

* * There is " a title-pagc and an index to tho first year and there * "There is a title-pagc and an index to the first year" and there " $6 \mathrm{~b}$ ". Continued under the title "Nordisk Filatelistisk Tidskrift" in January 1894.

NORDISK FRIMAERKETIDFNDE. Nordisk Frimaerketidende. Kjфbenhavn, Carl Lund, I867-68. $8^{\circ} .8 \frac{1}{4}$ in. Nos. 1-12, Aug. 26-Dec. 20, 1867, Feb. 3, Mar. 3, May 5 , 31 , June 30,1868

** Nos. 8 and 9 and 11 and 12 were severally published together under the respective dates " 5 . Mai 1868" and "30. Juni 1868 " There is a title-page and after the completion of the volume, nos. 1-12. were supplied in a coloured paper wrapper, which has an index on the back page. There is a supplement of four pages (87-90) to nos. 11 and 12 and each number, with the exception of no. 2 , has a separate price list. This was the first philatelic journal published in Denmark. Wanting nos. 11 and 12 and the title-page.

NORDISK FRIMAERKE-TIDENDE. Nordisk Frim aerke Tidende.

Aalesund, Norge, Martin Ludv. Holm, I 895. * in. No. 1, January, 1895

NORDISK FRIMAERKE-TIDENDE. Nordisk Frimaerke-Tidende. Organ for Frimaerkehandlere og Samlere i Skandinavien og Tyskland.

Ydby, etc., Danmark, Nordisk Frimaerkeklub, I9ooOI.

$4^{\circ} .10 \frac{1}{2}$ in. 18 nos. in 2 vols.

1st year. Jan. 15-Dec. 15, 1900 . Nos. 1-12.

2nd " " 15-June 15, 1901.

* "Commencing with no. 5 of the first year the journal was published at Skanderborg. There is a supplement of two pages to no. 4 of the second year.

NORDISK FRIMAFRKEVERDEN. Nordisk Frimaerkeverden. Maanedsskrift for Frimaerkesamlere. I 878 .

Kjфbenhavn, I. E. Jensen og S. Schmidt, etc.

Fol. $14 \frac{1}{4}$ in. Nos. 1-4, Jan. 1-Apl. 15, 1878.

* No. 4 was published by L. E. Jensen. A second copy of no. 1 is bound up in Mis. St. Jour. 1 (11). Mis. St. Jour. 129 (22)

NORTH AIMERICAN PHILATELIST. The North American philatelist. Official journal of the U.[nited] S. [tates] P.[hilatelic] S.[ociety] and G.[olden] H.[ours] P. [hilatelic] A. [ssociation].

Oak Park, Ml., North American Philatelist Co., etc. I890-9 I.

$8^{\circ} .8 \frac{3}{4}$ in. Nos. 1-7, Dec. 1, 1890-Apl., June-August, 1891 * Nos. 2-7 were published by Smith and Kantuer. There is a supplement of two pages to no. 2 and coloured paper wrappers to nos. 3,5 , and 6. The wrapper to no. 5 is dated "April-May, 1891," and no. 7 is dated "July-August, 1891 ".

Mis. St. Jour. 47 (7)

NORTH OF ENGLAND STAMP REVIEW. See North of ENGLAND STAMP REVIEW AND ADVERTISER.

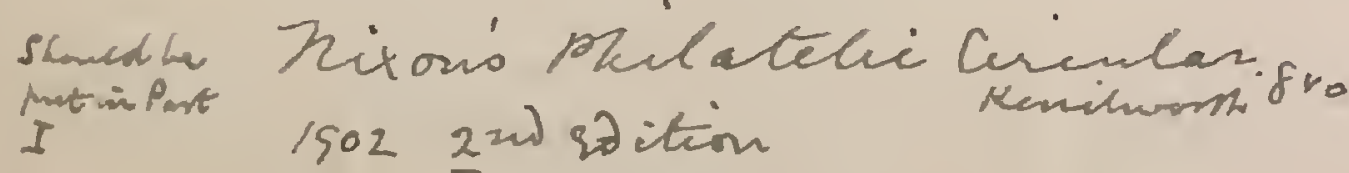


NORTH OF ENGLAND STAMP REVIEW AND ADVERTISER. The North of England stamp review and advertiser.

Barnard Castle, Thos. Dalston and Cò., 1864 $8^{\circ} .8 \frac{1}{4}$ in. Nos. 1-2, July-Aug., 1864. Mis. St. Jour. 36 (3).

[Continued as :]

_ The North of England stamp review. New Series. Barnard Castle, Thos. Dalston and Co., r 864 8․ 81. in. Nos. 1-3, Sept.-Nov., 1864. Mis. St. Jour. 36 (3a).

NORTH STAR PHILATELIST. North Star philatelist. Minneapolis, Minn., North Star Philatelist Co., etc., I $884-85$.

$8^{\circ} \cdot 7-7 \frac{1}{2}$ in. and $8 \frac{1}{2}$ in. $\quad$ nos. in 2 vols.
Vol. I. Jan.-Dec., 1884. Nos. $1-12$.

* " II. - - 1885 . were published by G. W. Achard; nos. measure * inches and nos. inches. No. 10 has a supplemental slip and no. 12 has a "Christmas extra" of four pages. Wanting vol. I., nos. $4,5,6,7,8,9$, and all nos. of vol. II.

- The National youth.

Minneapolis, Minn., G.W.Achard, r885. $4^{\circ} .101$ in. and $8^{\circ} .9$ in. Vol. Ir. nos.

Vol. II. -Dec., 1885. Nos. -12.

* * No: are quarto and nos. are octavo. No 4 is dated

"June, 1885 " on the first page and "June and July 1885 " on the second page. Wanting all but nos. 4,12 .

[Continued as:]

— North Star philatelist.

North Star philatelist.
Minneapolis,

Minneapolis, Minn., G. W. Achard, х887-88.

$8^{\circ} .9-8$ in. Vols. III.-IV. 5 nos.

Vol. III. Jan.-Dec., 1887. Nos. 1-4

* IV. " 1888. No. 1.

* "* Nos. "measure 9 inches and nos. , 8 inches. No. 1, vol. IV., has a coloured paper wrapper. Wanting vol. III., nos. 2, 3.

\section{[Continued as :}

- The Minnesota philatelist.

Minneapolis, Minn., Minnesota Publishing Co., r888. $8^{\circ} .8$ in. and $9 \mathrm{in.}$ Vol. IV. 4 nos.

Vol. Iv. Feb.-June, 1888. Nos. 2-5.

* * No. 2 is dated February, the March and April, and the May and June numbers were severally published together and are numbered, respectively, "No. 3 and 4 " and "No. 4 and 5". The last measures 9 inches the other numbers, 8 inches, and each has a coloured paper wrapper.

NORTH STATE PHILATELIST. The North State philatelist.

McAdenville, N. C., Knox, W. Henry, I896-97. $8^{\circ} .8$ in. Mos. 1-5, Sept., 1896-Jan., 1897.

Mis. St. Jour. 93 (6).

NORTHERN COUNTIES' ILLUSTRATED FAIMILY ALIMANAC, AND GFNERAI ADVERTISER, FOR 1864. The Northern Counties' illustrated family almanac, and general advertiser, for 1864. [Contains an illustrated article entitled "Foreign postage stamps."] $8^{\circ} .7$ in. (1) p. Coloured paper wrapper.

Wick, W. Ras, I864

Mis. St. Pamph. 8 (7).

NORTHERN PHILATELIST. The Northern philatelist. A monthly journal for stamp collectors.

Sandy Hill, N. Y., Charles C. Guy, ז894-95. 8o. 9 in. Nos. 1-7, Sept.-Nov., 1894, Ap]., Sept.-Nov., 1895. 6 * * There is a coloured paper wrapper to each number. Mis. St. Jour. 92 (1).

NORTHERN PHILATELIST. The Northern philatelist. Minneapolis, Minn., Lawrence E. Borin, I gor. $8^{\circ} .9$ in. No. 1 , Oct. 21,1901

* * The number has a coloured paper wrapper.

Mis. St. Jour. 113 (6).
NORTHERN TRADE RECORDER. The Northern - trade recorder. A monthly magazine for stamp, card, coin, curio, sales and wants, etc.

Darlington, The Paragon Publishing Co., I9o6. $04^{\circ} \cdot 10$ in. Nos. 1-2, May and June, July, 1906.

K***No. 2 has a coloured paper wrapper. ${ }^{*}$ Mis. St. Jour. 130 (6).

NORTHUIMBERLAND AND DURHAM STAIMP AD.

VERTISER. The Northumberland and Durham stamp advertiser. I 864 .

Newcastle-on-Tyne, etc., D. James and Co., etc.,

$8^{\circ} .8 \frac{3}{4}$ in. Nos. 1-11, Feb. 15-Dec. 20, 1864 . have /.3.5. aen ** Nos. 5-11 were published for the proprietors by R. Chambers at Gateshead and nos. 8:11 were printed at Gateshead.

NORTHWEST. The Northwest. New Series. Minneapolis, Minn., F. S. George, etc., I893-94.

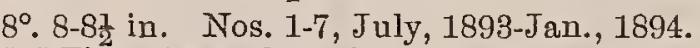

* * There is as. 1-7, July, $1893-J a n ., 1894$. * There is a coloured paper wrapper to each number. Nos. 4-7 were published by the Northwestern Philatelic Publishing Co., and there is a slip supplement to no. 5. The following paragraphs appear in no. 1: "With this issue the Northwest ceases to be an amateur publication. It will be devoted entirely to philately and and 2 are left which will be sent to any who desire them. They do not in any manner relate to philately".

NORTHWESTERN PHILATELIST. The Northwestern philatelist.

Madison, Wis., The Northwestern Philatelist Publishing Co., 1890.

$8^{\circ} .9$ in. No. 1, Nov., 1890

* The number has a coloured paper wrapper.

Mis. St. Jour. 61 (11).

NORTHWESTERN PHILATELIST. The Northwestern philatelist.

Milwaukee, Wis., Northwestern Philatelic Publishing Co., $\mathrm{r} 898$.

in. No. 1, April, 1898.
* Wanting.

NORTHWESTERN PHILATELIST. The Northwestern philatelist.

Elk Point, S. Dak., J. C. Ricard and Ray I. Ellis, etc., I899-I 900 .

$8^{\circ} .9$ in. and 8 in. 9 nos. in 2 vols.

Vol. I. Oct., 1899-Apl., 1900. Nos. 1-6.

* " II. May, -July, " $1-5$ measure 9 inches and the remaining numbers, 8 inches. Each number has a coloured paper wrapper and no. 6 and the three numbers of vol. II. were published by Ray I. Fllis. No. 6 is dated "March-April, 1900 " and there is a two-page supplement with portraits to no. 2, vol II.

Mis. St. Jour. 101 (6).

NOTES AND QUERIES. Notes and queries. A medium of intercommunication for literary men, general readers, etc. No. 40. October 1, 1892. [Contains an article "Cancelling postage stamps," by Andrew W. Tuer.] London, E.C., John C. Francis, 1892.
Mis. St. Jour. $132(7)$.

No. 167. Eighth series. March 9, 1895. [Contains an article "Bibliography of philately," by P. J. Anderson.] $4^{\circ} .8 \frac{1}{2}$ in. p. 192 London, E.C., John C. Francis, I895. an article "Stamp collecting and its literature forty years ago," by P. J. Anderson.

$4^{\circ} .8 \frac{1}{2}$ in. pp. $81-83$

London, E.U., John C. Francis, I 902. Mis. St. Jour. 132 (7b).

No. 17. Tenth series. April 23, 1904. [Contains an article "Stamp collecting and its literature," by P. J. Anderson.] London, E.C., John C. Francis, I904. $4^{\circ} .8 \frac{1}{2}$ in. pp. $322-324$. Mis. St. Jour. 132 (7c).

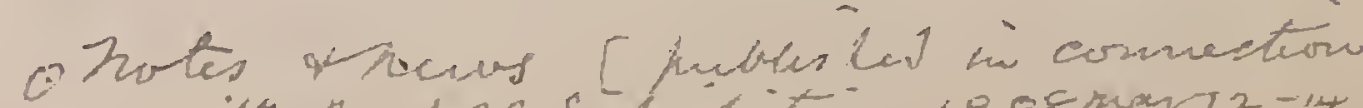 witt the pos sthitition 19 of mant2-14

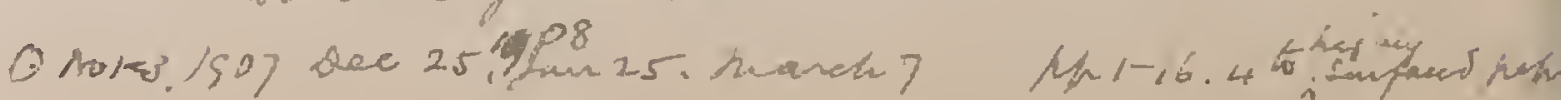

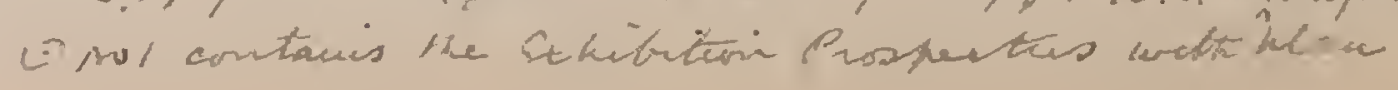


Yoothern Philatichic aduntises - JP.L.S. Vol 1 pq

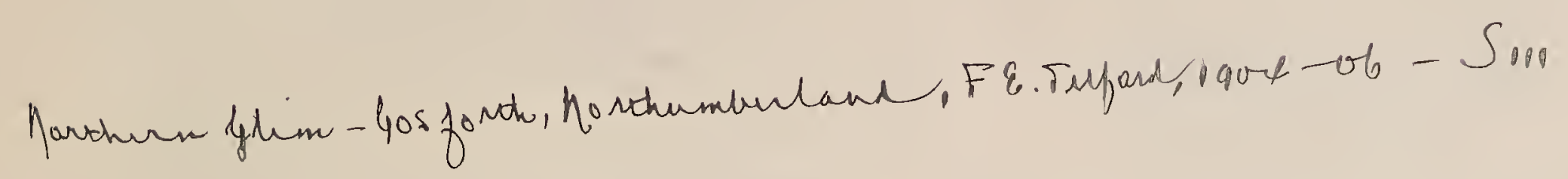



NOTES AND QUERIES. The following is a complete list of the references to-stamps, stamp-collecting and the Post Office to be found in "Notes and Queries". The list was compiled by Mr. P. J. Anderson and was published in the "Journal of the Philatelic Literature Society" of April, 1910 :-

1851, Jan. 4 (1, III., 6) "Origin of Present Penny Postage"E. Venables. [The incident told by Coleridge.]

1851, Jan. 11 (1, III., 27) "Coleridate ANd the Penny Post"C. W. D.

1851, Jan. 25 (1, III., 62) “John Hill's Penny Post in 1659 "E. M. B.

1851, March 8 (1, III., 186) “Edmund Prideaux and the First Post OfFice"-G. P. P. [Who was Prideaux ?]

1851, April 5, etc. (1, III., 266, 308). Replies by Mercurii, Arun, J. B. Colman, J. D. S., and James Crossley.

1853, Jan. 1 (viI., 3) "Chapter IN THe History of our Post OFFICE "-John Bruce. [Proclamations of James I., 1605-09.]

1853, March 12 (1, vit., 258) "Riddles for the Pọt Office "Cuthbert Bede.

1853, July 2 (1, viII., S) "Post Office about 1670 "-P. A. O

1853, Aug. 20 (1, vili., 185) "RIDDles FOR the POST OFFICE"Uneda.

1854, April 15 (1, IX., 350) "Postage System of the Romans"Ardelio. [Where described?]

1854, June 10 (1, IX., 549). Replies by L and Adıeus. [Bergier's Histoire des Grandes Chemins de L'Empire Romain.]

1854, Oct. 7 (1, X., 284) "Errors in Dates of Post Offici STAMPS "-R. H. [Postmarks.]

1854, Dec. $2(1$, x., 442) "Chear Postage"-Alpha.
1854, Dec. $30(1$, x., 523$)$ "Peny Post"-N. E. P. [This spelling

1855, June $9(1$, XI., 442$)$ " History of the Post OFFICE "-James Graves. [Notice of date 1683.]

1855, Aug. 18 (1, XII., 126) "A BookPost QUERy "-Bookseller.

1855, Sept. 8 (1, XII., 185) "History of the Post OfFice"H. T. G. [Where to be found?]

1855, Sept. 29 (1, XII., 255). Reply by James Gilbert, referring to his Official Guide and to the First Annual Report by Lord Canning and Mr. Rowland Hill.

1856, May 3 (2, r., 351) "Inveantion of Postagk Stanips "-W. W. [Quotation from Galignani as to Swedish proposal in 1823.] 1857, May 16 (2, II., 390) "Postagt aNd BILL Stamps"-A. A. D. [Invention of perforation.]

1857, Aug. 20 (2, IV., 170) "Envelopes First Introduced "-Cl. Hopper. 1557, Sept. 5, etc. (2, rv., 195, 279, 397). Replies by Delta, Edward
Foss and Thomas Boys.

1857, Oct. 24 (2, IV., 329) "Collecting Postage Stamps "-A. B. M. [To gain admission to a benevolent institution?]

1857, Nov., 21 (2, rV., 421) "Obliterated Postage Labels" [R57, DReplies by M. C. and J. C. Rickards.] [Removal of obliterations.]

1858, April $10(2, \nabla ., 308)$ "Miss BuRdett Coutts Does Not CoLLECT Postage Stamps." [Reference to newly issued Report of Postmaster-General.]

1859, July 16 (2, viII., 50) "Irish Stamps"-Abhba. [John Bourke's Collection.]

1860, Jan. 21 (2, IX., 47) "Post Office in Ireland"-Abhba. [When established?]

1860, June 23 (2, Ix., 482). As this query contains the earliest reference in print to Stamp Collecting proper, it is given in extenso:-

"Postage Stamps."-A boy in my form one day showed me a collection of from 300 to 400 different postage stamps, English and foreign, and at the same time stated that Sir Rowland Hill told him that at that time there might be about 500 varieties on the whole. This seems a cheap, instructive, and portable museum for young persons to arrange; and yet I have seen no notices of catalogues or specimens for sale, such as there are of coins, eggs, prints, plants, etc., and no articles in periodicals. A cheap facsimile catalogue, with nothing but names of respective states, periods of use, value, etc., would meet with attention. If there be a London shop where stamps or lists of them could be procured, its address would be acceptable to me, and to a score young friends."

"The School, Tonbridge."

"S. F. Creswell."

1862, Feb. 22 (3, I., 149) "Postage Stamps"-I. S. A. [Refers to the "present rage for collecting postage stamps of all countries".]

1862, March 8, etc. (3, r., 195, 277, 357). Replies by F. C. H., Jno. Wm. Phillips, Herus Frater.

1862, May 17 (3, I., 393) "Postagr Stamps "-J. S. A. [Criticises Mount Brown's Catalogue.]

1862, June 14 (3, I., 474) "Postage Stamps"-Delta. [Plate of Mulready's design.]

1862, July 26 (3, Ir., 68) "Penny Post"-R. Turner. [Dockwra's
1862, Aug. 16 (3 II., 125) "Postage Stamps"-Grime. [U. S. stamps used for currency.]

1863, Sept. 26 (3, IV., 247) "The Postal System"-S. Redmond. [References in Job and Esther.]

1863, Oct. 31 (3, IV., 355). Very full replies by Wynne E. Baxter, T. J. Bucktou, W. I. S. Horton, and C. J. Elliott.

1864, May 14 (3, v., 410) Her Majesty's Mails, by William Lewins. reviewed.

1864, May 21 (3, v., 418) "Foreign Postage Stamps "-Stempel.

[Inviting exchange.]
1864, Aug. 20 (3, v., 143) "Penny Postage"-A. de Morgan.

[Seven verses of a squib from a newspaper, which, by a casual date at the back, must be of January, 1840 .... the sixth verse records the author's protest against the usual transfer, namely, that of the merit of the real labourer to the first government which is forced by opinion into adoption of his plan:-

"O RoWLAND HILL, immortal man,

How can we pay you for your plan!

To you our thanks, our pence are due

It was the Emp'ror of Japan
As much as they that gave the U.

niversal Penny Postage."]
nuch as they that gave the

1865, Feb. 18 (3, vil., 132) "Money Post Office Orders "-W. W. 1863, April 1 (3, viI., 257) "Postage Stamps"-Q. [Portrait of Queen Victoria engraved by Heath or Humphrys?]

866, Jan. 13 (3, IX., 33) "The Penny Postage"-F. C. H [Quotation from British Critic of January, 1842.]

1868, July 18 (4, II., 56) "Oriain of EnveLopras"-W. Willey.

1868, Sept. 5 (4, II, 238) "Reply by P.A. I.

1868, Nov. 7 (4, II., 440) "EARTY Post Stamps"-W. Barrett Davis. [Earliest date ?]

1870, Feb. 19 (4, v. 219) "Reducid Postage for Printed MATTER

1870, Oct. 15 (4, vi., 333) "The New Postal Cards".

1873, Jan. 11 (4, Xr., 35) "Post OfFice History "-T.

1873, March 15 (4, XI., 214) "Popular SupERSTItion: Millions of Stamps."-Hyde Clark. ["The little boy ought to be

of full age by this time."]
1873 , Aug. 16 (4, XII., 125) "THE Post OFFICE in 1764 "-Jonathan

Bouchier.
1873, Nov. 15 (4, XiI., 386) "Postagn Portraits" - Everard Home Coleman. [On U. S. stamps.]

1874, Oct. 3 (5, Ir., 269) "Post OFFICE Money ORders in 1791"George Ellis.

1874, Dec. 5 (5, II., 452). Replies by E. H. Coleman and C. W. E. 1875 , Sept. 25 (5, IV., 244) "The Postal Systenc of the UnIted States "-M. M. J.

1876, April 29 (5, v., 348) “The General Post OfFice"-G.P. O. 1877, Oct. 6 (5, viII., 266) "Portraits on American Postage STAMPs "-J. de Boutillier.

1877, Dec. 29 (5, viII., 506) "A Mrstery Solved"-St. Swithin. [Obliterated stamps "sold by thousands to decorate the whitewashed walls of Japanese houses ".]

1879, Jan. 11 (5, XI., 23) "ANother StrVtraL"-Wm. Pengelly. [Blue lines on registered envelopes represent narrow ribbon formerly used.]

1879, July 19 (5, xiI., 48) "Passenger Postage"-F. [Magazine article on.]

1879, July 12 (5, xiI., 26) "ENvelopes "-Anon.

1879, July 26 (5, XII., 74) "ENvELOPES"-E. Walford. [Earliest date with franks.

1879, Sept. 20 (5, XII., 238, 478, 516). Replies by E. McC., F. S. and Henry Campkin.

1879, Aug. 2 (5, XII., 88) “Philately and Philatelist"-Abhba. [Derivation ?]

1879, Aug. 30, etc. $(5$, XII., $172,238,256)$. Replies by B. Whitehead, Edward H. Marshall, E. Walford, C. S. Jerram

1879, Nov. 15 (5, XII., 389) "BLack Stamps "-Hermentrude.

[Market value.]

879, Dec. 13, etc. (5, xII., 474, 515). Replies by Andrew Bryne and $\mathrm{W}$. Lincoln.

1881, Jan. 8 (6, rII., 24) "Stamp on PamphLEts 1712 "-Edward Solly.

1882, Jan. 21 (6, v., 46) “The Pennt Post Anticipated" William Platt. [John Hill's Penny Post, 1659.]

1882, Feb. 4 (6, v., 94). Reply by Henry B. Wheatley, who pro-

1882, Mar. 4 (6, จ., 166) "The Pesry Post, temp. Jac. II."-W. Frazer.

1884, June 28 (6, IX., 508) "CARicatures of the Mulready Entelope br Leech, Phiz and Crotikshank"-P. J. Anderson.

1882, Aug. 2, etc. (6, X., 98, 234, 373, 478; XI., 33, 74, 117, 217). Replies by Hugh Tilsley, E. H. Coleman, Emily Cole, E. Li. Gwillim, Algernon Graves, Cuthbert Bede, E. A. Fry, K. C. B., D. C.

1884, Nov. 15 (6, х., 386) "Ther F'irst (?) Idea of the Penny Post "-H. S. Ashbee. [Reference in Trial of Titus Oates, and in State Poens.]

1884, Dec. 13 (6. X., 468) “Engraver's Proofs of the Penny Postage Stani "-Algernon Graves.

1884, Dec. 20 (6, X., 496) "Birming ham Magazine"-P. J. Anderson. [The Monthly Intelligencer.] 

1885, Jan. 10 (6, xI., 37) “The First Idea of the Penny Post"

1885, Jan. 17 , etc. $(6$, xI., 53, 152). Replies by D., C. A. Ward,

1885, Feb. 14 (6, XI., 126) "OLD ENVELOPE"-Edward Peacock. [Of 1759.$]$

1885, May 23 (6. XI., 406) "Origin of Stamp Coldidcting "-P. J. Anderson.

1885, June 27 (6, xI., 517). Reply by A. H. W. Fynmore.

1885, July 4 (6, XII., 10) "Postal Franks "-G. H. S. Wood.

1885, July 25 ( 6 , XII., 76). Replies by E. Walford and G. F. R. B.

1885, Nov. 28 (6, XII., 429) "John Leech and Mulready"-P. J. Anderson. [Caricature of the envelope said to have ap-

peared in Punch.]
1885, Dec. 19 , etc. $(6$, XII., $505 ; 7$, III., 30, 152; x., 396). Replies by G. F. R. B., Algernon Graves and E. H. Coleman.

1889, Aug. 17 (7, viII., 126) "TwOPENNY PostMEN"-G. S.

1889, Oct. 12 (7, virI., 285) "SECRET CoRRESPONDENCE BY MIEANS of Postage Stamps" - F. Chance.

1889, Nov. 2 (7, VIII., 353). Reply by C. F. S. Warren

1890, Nov. $15(7, \mathrm{x} ., 385)$ "Postage Stamps In 1840 "-St. Swithin.

1891, Jan. 10 (7, Xr., 28) "The Penny Post"-W, Roberts, [Re ference to Heraclitus Ridens, 1681.]

1892, Feb. 13 (8, I., 126) "Envelope:s"-R. B P. [Of 1755.$]$

1892, Feb. 27 (8, I., 172) Reply by Fred Hendriks. [1749.]

1892, Aug. 13 (8, Ir., 127) "Perforation OF Stamps"-E. I. Delevigne. [Date of invention?]

1892, Sept. 3, etc. (8, II., 197, 254, 310, 374). Replies by R. P. Chope, Andrew W. Tuer, Emily Cole, Urban, Este, J. HalesTooke, J. F. Mansergh.]

1892, Oct. 1 (8, iI., 264) "Canceliting Postage Stanips"-Andrew W. Tuer. [Tllustrations of Mr. Whiting s proposed stamps.]

1892, Oct. 8 (8, II., 298) "Penny Post"-H. H. S. [London Gazette, May, 1679-80.]

1893, Feb. 25 (8, mI., 158) "Penny Post '-C. W. Ernst.

1894, June 30 (8, จ., 509) "Philately" - Patrick Maxwell. [Derivation?]

1894, Aug. 4 (8, VI., 93). Replies by P. J. Anderson and W. T.

1894, July 7 (8, VI., 9) “AN EARLY POSTAL COVER"-Jas. B. Morris. [Specimen in Rowland Hill's pamphlet of 1837.]

1894, Aug. 11 (8,

1894, Nov. 10 (8, vi., 368) "Bibliography of Philatioly"I. H. G.

1895, March 9 (8, viI., 192). Reply by P. J. Anderson.

1895, Oct. 19 (8, vill., 306) "HIGH Rates OF Postage"-E. Walford. [£37 10s. on a single letter in 1815.]

1895, Nov. 9 etc. (8, viII., 372; IX., 118). Replies by Robert Blair [ 10 on,

1896, Feb. 1 (8, IX., 88) " ENPELOPES"-B. [When first used in

1896, March 7, etc. (8, IX., 194, 318). Replies by G. L. Apperson and A. C. W.

1896, Nov. 21 (8, X., 415) “MULready's ENvelope Caricatured " - H. G. Griffinhoofe

1896, Dec. 19 (8, X., 499). Reply by E. H. Coleman.

1897, May 29 (8, XI., 424) "THE QUEEN's HEAD UPSIDEDown"May 29 (8, XI.,

1897, June 12 , etc. (8, xI., 476 ; xIr., 18, 113, 238). Replies by George Angus, R. L., Erroll Sherson, Ralph Thomas, H. T. St. Swithin.

1897, Dec. 11 (8, XII., 469) "Stamp Collecting"-Alfred F. Robbins. [Reference in Balzac !]

1898, Feb. 5 (9, I., 115). Reply by W. Roberts. [Reference to his article in Fortnightly Review, May, 1894.

1898, Feb. 12 (9, I., 121) “The Posts IN 1677"-J. A. J. Housden. [Quotes 1rom St. Martin's Le Grand for January.]

1898, April 23 (9, I., 326). Reply by Dunheved.

1898, Nov. 26 (9, II., 425) “ OLD Postag ㅍ STAMPS "-J. K. Laughton. [For the benefit of the Congo Mission !]

1898, Dec. 10 (9, II., 478). Reply by Arthur Mayall.

1899, Sept. 23 (9, IV., 246) "Proposed Interenational Postad CONCESSION"-Ethel Lega-Weekes.

1900, May 19 (9, v., 404) "Stamp ColleCTing "-Alfred F. Robbins. 1900, June 23 (9, 、., 501). Reply by Holcombe Ingleby.

1901, Nov. 23 (9, viII, 419) "The Halfpenny Periodical Post" W. E. A. Axon. [Suggested in 1848.]

1902, March 22 (9, Ix., 228) "Pictorial Postcards "-F. T. Hibgame. [Date of introduction?]

1902, April 12 (9, IX., 288) "Sale of Stamps Forbidden Bx InIAND Revenue"-B. Y.

1902, May 31 (9, IX., 438) "Stamp Collecting "-Alfred F.

Robbins.
1902, Aug. 2 (9 x., 81) "STAMp CJLLECTING AND ITS Literature ForTy YEARS Ago"-P. J. Anderson.

1902, Aug. 30, etc. (9, x., 172, 239, 333, 432, 470). Replies by I C. Gould, H., David Murray, J. S. Curwen, F

1902, Aug. 16 (9, X., 127) "THE INventor OF THE POST CARD"F. T. Hibgame. [Died at Keima, 14 July.]

1902, Sept. 13 (9, x., 212) "Pictorial Postcards "-F. T. Hibgame. [First in 1865.]

1908, March 7 (9, XI., 189) “Posts in EarLy Times"-J. A. J. Housden.
1903, March 28 (9, XI., 256). Replies by W. C. B. and E. H. 1903, Sept. 26 (9, XII., 245) "Enveropes"-Com. Ebor. [Their

1903, Nov. 14, etc. (9; XII., 397, 434, 490; 10, I., 57, 133, 175). Replies by Eleanor C. Smyth (Sir Rowland Hill's daughter), H. G. Hope Thorne George (who refers to the use of stamped envelopes in Australia, before Rowland Hill's scheme), Sir Herbert Maxwell, W. H. Peet, J. A. J. Housden, E. P. Merritt, G. C. W., W. A. Macray, John Pickford.

1904, April 23 (10, I., 322) "Stamp Collecting and its LiteraTURE "-P. J. Anderson.

1904, July 9 (10, II., 38). Replies by Wilmot Corfield, and G. C. W. 1905, May 20 (10, III., 400) "Used Postage Stamps"-Ed.

1906, Sept. 1, etc. (10, VI., 163, 182) "T'He PosT OFFICE" - John C. Francis.

1906, Sept. 29, etc. (10, VI., 232, 251, 273, 315, 354). Replies by Eleanor C. Smyth and Ralph Thomas.

1906, Nov. 17 (10, vi., 400) "OLD Postage Stramps "-Ed.

1906, Dec. 22 (10, vi., 487). Reply by Robert Pierpoint. [Walking stick made of stamps.]

1907, A pril 13 (10, vir., 289) "Postage STAMPs 1830-62"-B. T. K. Smith. [Literary references to.]

1907, Nov. 9, (10, viII., 370) "London Penny Post: Wildiam Dockwra" - - Harry J. Maguire.

1907, Nov. 23 (10, virI., 410). Reply by William Norman.

1907, Nov. 23 (10, viII., 405) "OCEAN Penny Post"-Edward Peacock.

NOTICIERO FILATÉLICO. El Noticiero filatélico.

Mayaguez, Puerto Rico, Espinosa y Salgado, etc., I $900-02$

$8^{\circ} .10-9$ in. 15 nos. in 2 vols.

1st fear. July I-Sept. 1, 1900, Jan. 1-May, 1901. Nos. 1-8.

2nd ", " -Dec., 1901, A pl., 1902. Nos. 9-15.

* Nos. 4-15 were published by Pedro F. Espinosa, and no. 9 is

NOTICIERO FILATf́LICO. El Noticiero filatélico.

Mayaguez, Puerto-Rico, Cesar A. Collado, i 904-05.

$8^{\circ} .9 \mathrm{in}$. and $10 \frac{1}{2} \mathrm{in.} 14$ nos. in 2 vols.

1 st year. July, 1904-July, 1905. Nos. 1-12.

2nd " Aug. -Sept., 1905. "13-14.

* * No". 1 measures 9 inches and the" other numbers $10 \frac{1}{2}$ inches. No. 2 bears "Núm. II." nos. 5 and 6,7 and 8,10 and 11 and 13 and 14 were severally published together. There is no numbe for April, 1905, and nos. 13-14 havo "año 1 " altered in pen and ink to "ar̃o 2 ". Wanting no. $1 . \quad$ Mis. St. Jour. 152 (8).

NOVA SCOTIAN PHILATELIST. The Nova Scotian philatelist.

Amherst, N. S., The Nova Scotian Philatelic Publishing Co., I893-94.

$8^{\circ} .8 \frac{3}{4}-8 \frac{1}{2}$ in. Nos. 1-4, 6-10, Jan., Mar., Apl., May, Aug., Sept. Oct.-Nov., Dec., 1893, Jan., 1894.

** There is a paper wrapper to each number. No no. 5 was pub-

** There is a paper wrapper to each number. No no. 5 was pub-
lished.
Mis. St. Jour. 95 (6).

NOVELTY ADVERTISER AND REVIEW. The

- Novelty advertiser and review.

London, S.W., O. Ventura and Co., I88o.

8. 71 in. No. 1, May 1, 1880 unmert* $t^{*}$ There is a supplement of two pages printed on one side only.
Mis. St. Jour. 55 (5).

NOVELTY GUIDE AND FOREIGN STAIMP COL

LECTOR'S RECORD. The Novelty guide and foreign stamp collector's record. Published half-yearly I 882 .

Glasgow, The British and Foreign Novelty Co.,

$8^{\circ} .7 \frac{1}{4}$ in. [no number]. Winter, 1882.

* This is merely a price list of articles sold by the publishers. Mis. St. Jour. 80 (1)

NOVISSIMA ANTOLOGIA. Novissima Antologia di scienza, filosofia, letteratura, arte $\theta$ filatelia.

Napoli, Nicola Lapegna, I904.

$8^{\circ} .9 \frac{1}{4}$ in. Vol. VIII., 2 nos.

"Anno viII. Fasc. I. [and] II. Nuova Serie-Volume Primo Agosto, 1904 [and] Ottobre-Novembre-Dicembre, 1904."

** Only partly philatelic. There is a coloured paper wrapper to eäch number. 


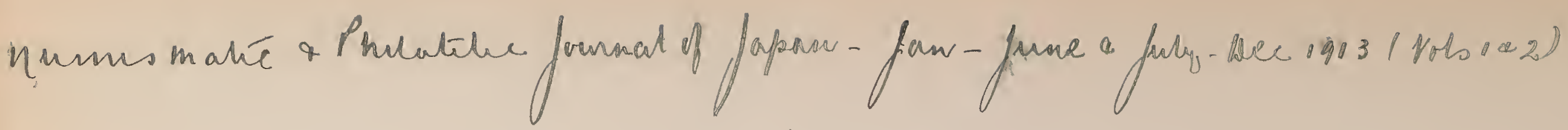


N. P. S. BULLETIN. N. P. S. bulletin. Devoted to the National Philatelical Society's exchange and auction department. Also items of interest both social and philatelic will be published.

New York, G. W. D. Crittenton, I895.

Fol. 12 in. Nos. 1-5, Feb., Mar., May, Nov., Dec., 1895

* Nos. 1 and 2 are printed on pink paper.

Mis. St. Jour. $82(6)$

NUEVA ERA. Ta Nueva era. Semanario politico, literario y noticioso. Año Xv. Numero 688. 28 de Marzo de 1896. [Contains report of the Commission appointed by the Peruvian Philatelic Society to investigate the issue of certain provisional postage stamps at Tùmbez and Piura from March 21st to April 30, 1895.]

Fol. $17 \frac{1}{4}$ in. p. 2.

Pinra, I 896

NUNAL NULIK. See Rivista Filatelica.

NUTMEG STATE PHILATELIST. The Nutmeg State philatelist.

New Britain, Conn., A. C. Hine, r895.

$4^{\circ} .7 \frac{3}{4}$ in. No. 1 , December, 1895 . Mis. St. Jour. 93 (4).

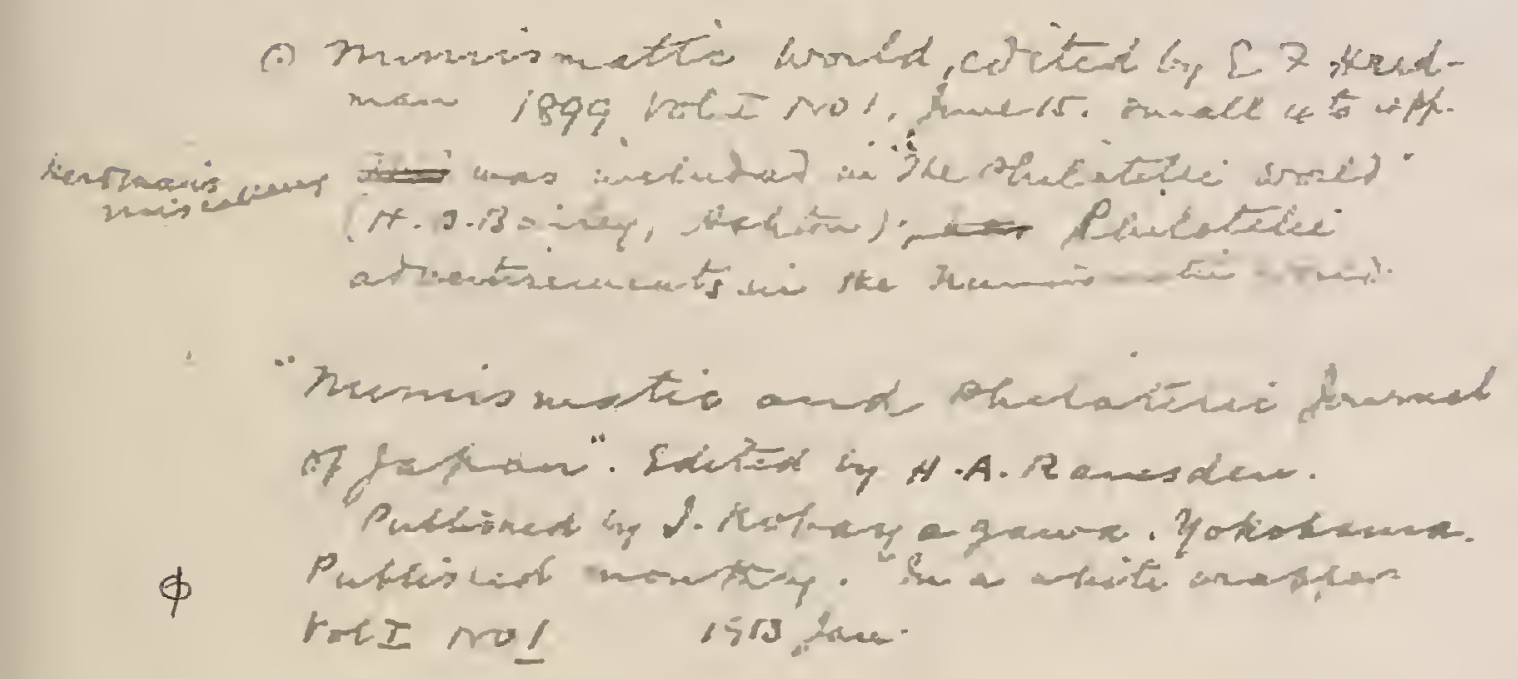

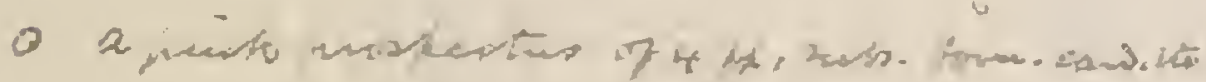

NUTMEG STATE PHILATELIST. Nutmeg State philatelist. Meriden, Conn., K. S. Dalgleish, I9०2. 16.6 6 in. No. 1, October, 1902.

* * Advertised to appear with the title "Silver City philatelist," but the name was afterwards changed. Mis. St. Jour. 114 (4).

N. Y. PHILATELIST. The N. Y. philatelist. A monthly philatelic journal. New York, H. Sabel, ז889-90. $8^{\circ} .83$ in. Nos. 1-8, June 1, 1889-Feb. 1, 1890.

** No. 6 is dated "November-December, 1889 " and there is a supplement of two pages, printed on one side only, to no. 4.

Mis. St. Jour. 60 (2)

[Continued as :]

- The Philatelist.

New York, The Philatelist Co., I890. $8^{\circ} .10$ in. Vol. Ir., nos. 1-5, Mar.-July 15, 1890.

* There is a paper wrapper to each number.

iris. St. Jour. 60 (3)

N. Y. PHILATELIST. See New York Philatelist. 1878-79. 
667 OCCASTONS PHILATELIQUES

OCCASIONS PHILATELIQUES. Les Occasions philateliques. Paraissant 10 fois par an. Ixelles-Bruxelles, C. Matton, I900-03 8․ 93 in. Nos. 1-15, June, Nov., 1900, Mar., Apl., Dec., 1901 Jan.-Feb., Mar., Apl., May, July, Sept., Oct., Dec., 1902, Feb., Mar., 1903

* * The contents'consist entirely of price lists and advertisements No. 4 is wrongly numbered "no. 3". Amalgamated with the "Annonce Philatélique," Troyes, April, 1903

Mis. St. Jour. 90 (13)

OCEANIA PHILATELIC JOURNAL. The Oceania philatelic journal.

Rangitikei, New Zealand, S. J. Howard, I 904-05. $8^{\circ} .81-8 \frac{1}{2}$ in. Nos. 1-5, June, IJuly, September, 1901, May, June, 1905

* * There is a coloured paper wrapper to each number.

Mis. St. Jour. 153 (4)

OCEANIC. The Oceanic 889 .

Honolulu, Hawaiian Islands, Oceanic Stamp Co.

(.) 8'. 9 in. Nos. 1-4, [no. 1, no dáte]. - Maŕ., Apol., Má, 1889.

** This was the first philatelic journal published in the Hawailian
Islands.
Mis. St. Jour. 22 (7). Islands.

ODDS AND FNDS. Odds and ends. I 894.

Boston, Mass., J. F. Williams and R. J. Friery,

8०. 83 in. Vol. IV., nos. 1-5, [? T-Dec., 1894.

* Only partly philatelic. There is a coloured paper wrapper to each number. The first three volumes, part of which were published at Harlem, N. Y., contain no stamp matter. Wanting all but no. 5 , vol. IV.

ODDS AND FNDS. Odds and ends.

Coopersville, Mich., F. A. De Vos, r 900-or. $8^{\circ} .9 \frac{1}{4}$ in. 9 nos. in 2 vols.

Vol. I. Aug.- Dec., 1900. Nos. 1-5.

II. Jan.-Mar., May, 1901.

* "* Only partly philatelic. There is a paper wrapper to each number. Wanting no. 1, vol. II.

OESTERREICHISCHE BRIEFIMARIEN - ZFIT

UNG. Oesterreichische Briefmarken-Zeitung. Wien, Anton Dworacek, I897-99.

$8^{\circ} .9 \frac{1}{2}$ in. 15 nos. in 3 vols.
1 st year. Nov. -Dec. 17,1897 . Nos. $1-2$.

1st year. Nov. -Dec. 17, 1897. Nos. 1-2

2nd " Jan. 15- " $15,1898$.

* * There is a" coloured paper wrapper to each number commencing with no. 1 of the second year.

OESTERREICHISCHE BRIFFIIARIEN - ZEITUNG. Oesterreichische Briefmarken-Zeitung.

Wien, Max Cerbeano, I 905-o6.

Fol. $12 \frac{1}{4}$ in. 22 nos. in 2 vols.

1st year. April 5-Dec. 24, 1905. Nos. 1-15.

2nd "Jan. 1-Apl. 10, 1906. " 1- 7

** Each number has a coloured paper wrapper and nos. 5 and 6 of the second year were published together, under the date " 25 März, 1906".
OESTERREICHISCHE

668

OESTERREICHISCHE CORRESPONDENZ. See Correspondenz Seyfried.

OESTERREICHISCHE PHILATELISTEN - ZEITUNG. Oesterreichische Philatelisten-Zeitung. Internationales Organ für die gesammten Interessen der Philatelie.

Czernowitz, Mährisch-Ostrau [printed], Hermann Mittelmann, I889.

$8^{\circ} .11 \frac{1}{4}$ in. No. 1 , July $1,1889$.

* A copy of the prospectus of the journal is bound up with the number. Mis. St. Jour. 73 (5).

OFFERTENBLATT FƯR BRIFFMARIEN-SAIMILER. Offertenblatt für Briefmarken-Sammler. Gratis Beiblatt zum Illustrirten Briefmarken-Journal.

Leipzig, Gebrïder Senf, I887-

$8^{\circ} .9 \frac{1}{4}$ in. nos. in vols. In progress.

1st year. July-Dec., 1887. Nos. 1- 6.

2nd " Jan.- " $1888 . \quad, \quad 1-12$.

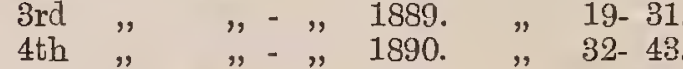

5 th " " - " $1891 . \quad " \quad 44-54$

6th " [ "]- " $18992 . \quad " \quad 55-66$.

8th ". " " - " " $1894 . \quad$ " $189-90$

9th " " - " 1895. " $91-102$

10th " " - " 1896. " "103-114.

11th " " - " 1897. "

12th " " " " " 189s. " " 127-138.

13th " " - " $1899 . \quad " 139-[150]$.

14 th " " " " $1900 . \quad$ " 151-162.

15 th " " " " $1901 . \quad$ " $163-174$.

16 th $" \quad$ " - " $1902 . \quad$ " $175-187$.

17 th " " " " $1903 . \quad$ " 188-199.

18th " " " " 1904. " 199-210.

19th ", " - " 1905. " " 211-221.

20th " " - " 1906. ", 222-233.

* This is a supplement to the "Illustriertes BriofmarkenJournal," with which it is bound up. There are two numbers for January, 1888, none for April, 1888, two numbers for December, 1889, and two numbers for December, 1902. Nos. 11 and 12 for 1891 were published together under the date "Nov.-Dez. 1891," and whole "No. 54". Nos. 1 and 7 for 1892 bear only the num. bers " 55 " and " 61 ," respectively, and neither of them have any date. No. 74 has in error "no. 7," nos. 148-150 are wrongly num bered 147-149, respectivoly. Nos. 189 and 190 hथve " $\mathrm{nr} .3$ " and "nr. 5" in place of " nr. 2" and " nr. 3," there arc two number "199" one dated Dccember, 1903, and the other January, 1904 no. 202 has no date, no. 209 is wrongly numbered " 208 " and there are two nos. "217," one dated July, the other August, 1905 ,

OFFERTENBLAT' FỨR BRIFFMARIENSAIMMLER. Offertenblatt für Briefmarkensammler.

$8^{\circ} .9 \frac{s}{4}$ in. No. 1, January, 1892

München, S. Wolf, I892. ** The above, which consists of a single leaf, forms a supplement to "Süddeutsclies illustrirtes Briefmarkenjournal".

Mis. St. Jour. 58 (11)

OFFERTEN-BLATT FUंR FRFIMARKEN - SAIMIM LER UND HANDLER. Offerten-Blatt für Freimarken-Sammler und Händler.

Jyväskylä, Finnland, Paul Lehmstedt, I896. 8.. 9 in. Nos. 1-3, Jan. 20-Mar. 20, 1896. Mis. St. Jour. 90 (5). 

Friciai tazite.

The un were.

01889 7en. Nol, mavory/An. 2/3, May, ime 4/5 o. high-90.6/9, hor. 10, oev noll. $\mathrm{ph} 1-60$ (c) 1850. Tan No/2, Zet rol3, Marrolu. Ah/may, How

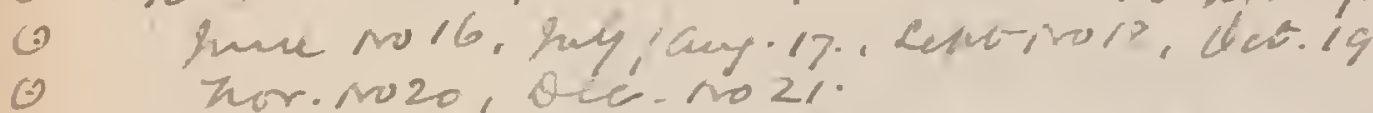

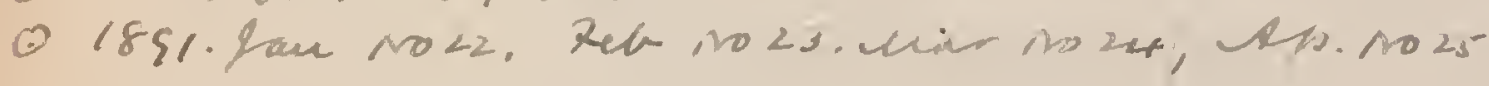

thos 1-11. M5-25 mablithet by C.H. Numn, Aum to. Simumis

nosi2-18 by S. F. Bickess at this wit.

Afor no 13 , each no. Ptarted $h .1$.

hy hos 20-25 have humlix at the head

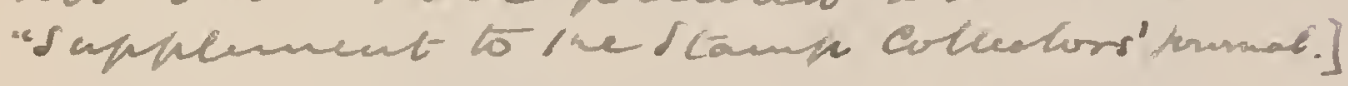

"Oppicial statutes 7 he hlemationac phila thi meion

[c. 18 gimay)

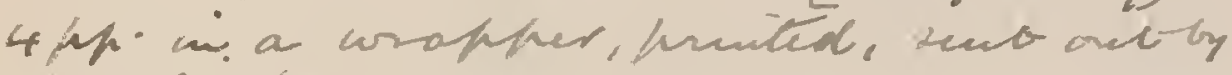
s-ficickess. 
OFFICF INTERNATIONAL DES COLLECTIONNEURS. Office international des collectionneurs.

$8^{\circ} .8 \frac{3}{4}$ in. Nos. 1-6, May-Sept., 1901. Lyon, P. Jaud, i gог.

* Only partly philatelic. Each number has a paper wrapper. No. 3 is dated "Juillet-Août, 1901," nos. 5 and 6 are each dated "Septembre, 1901 " and there is no no. 1.

Mis. St. Jour. 112 (6)

OFFICIAL BULLETIN. Official bulletin.

San Antonio, Texas, The Texas Philatelic Association, $1896-97$.

$8^{\circ} .9 \frac{1}{4}$ in. Nos. 1-7, Oct. 1, 1896-Apl. 1, 1897.

Mis. St. Jour. 92 (12)

OFFICIAL GAZETTE. Official gazette for the International Philatelic Union.

Bury St. Fdmund's, etc., C. H. Nunn, etc., r889-9г. $4^{\circ} .93$ in. Nos. 1-25, Fob., 1889-Mar., 1890, April and May, June, July and Aug., Sept.

te// $*^{*}$ * Nos. 12-18 were published by S. F. Bickers at Bristol, and nos.

C 19 -25 formod supplements to the "Stamp collectors' journal," published by C. H. Nunn, at Bury St. Edmund's. Nos. 2 and 3 ; 4 and $5 ; 6,7,8$ and 9 , were severally published together.

$20-25$ Line ofefflenewt to the Mis. St. Jour. 45 (7). OHIO PHILATELIST. The Ohio philatelist. Cincinnati, O., G. Rodenberg, ז878-8г. $8^{\circ} .8 \frac{3}{4}$ in. Nos. 1-12, Sept., 1878-Feb., 1881.

* Nos. 1 and 2 were published together under the date "September and Octobor, 1878". No. 3 appeared in "May, 1879" and is found printed on white and also on coloured paper: nos. 4, 5, 6 were published together, in "January, 1880 "; nos. 7,8 , together, in "May, 1880 " and nos. 10, 11, 12, together, in "Feb-
luary, 1881 ".

OHIO PHIIATELIST. The Ohio philatelist.

Westerville, O., etc., H. W. Keller, х888-89. $8^{\circ} .81-83$ in. Nos. 1-8, Apl.-Sept., 1888, Jan., June, 1889 * Nos. 4-8 were published at Lancaster, O. No. 1 is octavo 81 inches and the other numbers $8 \frac{3}{4}$ inches. Nos. 4 and 5 were published together under the date "July and August, 1888".

Mis. St. Jour. 26 (8)

OHIO PHILATELIST. The Ohio philatelist. A monthly magazine devoted to the interest of stamp collecting. Cardington, O., H. A. Kreis and Co., 189r-92.

$8^{\circ} .8_{4}^{3}$ in. Nos. 1-4, Aug., Sopt., Oct., 1891, Jan., 1892.

* * There is a colourod papor wrapper to each number. Mis. St. Jour. 46 (9).

OHIO PHILATELIST. The Ohio philatelist. Pearl, O., R. L. Doak, ı899-1 900. $16^{\circ} .6 \frac{1}{4}$ in. $8^{\circ} .8$ in. 7 in. and $8 \frac{3}{4}$ in. 15 nos. in 3 vols.

Vol. I. Sept., 1899-Feb., 1900. Nos. 1-6.

" II. Mar. -Aug. 10, 1900. ", 1-6.

* " Ir. Sept. -Nov. 1900. "1-3. 5 are $16^{\circ}$. is octavo, 8 inches; nos. 1-6, vol. II, are octavo, 7 inches and the numbers of vol. and nos. 2 and 3 , vol. III., were severally published togother.

Mis. St. Jour. 102 (4).

OHIO PHILATELIST. The Ohio philatelist. Cleveland, O., Crowell Stamp Company, I 904. $4^{\circ} .73$ in. No. 1, November, 1904.

Mis. St. Jour. 148 (10).

OHIO STAMP. The Ohio stamp. A monthly journal devoted to the interests of stamp collectors.

Cleveland, O., M. G. Fox, 1893

$8^{\circ} .8^{3}$ in. No. 1, April, 1893

Mis. St. Jour. 63 (9)

OHIO STAIMP JOURNAL. The Ohio stamp journal. * $8^{\circ} \cdot 6 \frac{3}{4}$ in. No. 1 , January, 1877.

Cincinnati, O., Chas. E. Miller, 1877

OHIO STAMP NEWS. Ohio stamp news.

Garrettsville, O., Harris and Sanford, 1892-93.

4. 7 in. Nos. 1-6, June, Sept., Oct., Nov., 1892, Jan., Feb., 1893. Mis. St. Jour. 67 (2)
OHIO STATE JOURNAL. Ohio State journal. [United States.] September 13, 1891. [Cuttings of the article "Curious collections. Stamps rare, old and select, gathered by Columbus lovers of the pastime...." are mounted in Stamp Scrap-book, vol. vi., pp. 187, 188.]

OKLA. PHILATELIST. The Okla. philatelist.

Stillwater, Okla., The Philatelic Mailing Agency, etc., I $90 \mathrm{x}-02$.

$16^{\circ} .61$ in. Nos. 1-6, Dec., 1901, Jan., May 15-Aug., 1902. 1·2 * * There is a paper wrapper to each number. The title on the wrappers of nos. 1 and 2 reads "The Oklahoma philatelist"; nos. 3-5 were published by Dalton and Hale and no. 6 by Clarence Dalton. No. 6 is dated "July 15, 1902" in place of August, ex-
cept on the wrapper, which is correct. Mis. St. Jour. 104 (11).

OKLAHOIMA PHILATELIST. See OKLA. PHILATELIST.

OLD CURIOSITY SHOP. The Old curiosity shop.

Cleveland, O., etc., Clemens and Co., etc., i882-9o.

Fol. 12 in., $8^{\circ} .10 \frac{1}{2}-11$ in. and $8-9 \frac{1}{2}$ in. 57 nos. in 9 vols.

Vol. I. Dec., 1882-June, 1883 . Nos. $1-6$.

$\begin{array}{ccc}\text { II. July } & \text {-Dec., } 1883 . \quad \text { " } & 7-12 . \\ \text { III. Jan. } & -J u n e, 1884 . & 1-6 .\end{array}$

" IIv. and v.] (Numbered I.) June, 1886-May, 1887. Nos. 1-12.

"[Iv. and v.] (Numbered I.) June, $1886-1$.
vI. July-Oct., 1887 . Nos. $31-34$.

" VI. July-Oct., 1887. Nos. 31-34.

" VII. Feb.-May, 1888 .

" IX. Jan.-Dec., 1890. Nos. 1-7.

** Only partly philatelic. Nos. 1-6 were published by Clemens and Co., Cleveland, nos. 7-18 by W. M. Clemens, Cleveland, nos. 19-31 by W. B. Brockway, Jamestown, N. Y., nos. 32-34 by W. M Clemens, Jamestown, nos. 35-37 by C. R. Orcutt, San Diego, Cal. no. 38 by C. R. Orcutt and Co., San Diego, nos. $39-50$ by E. M Haight, Riverside, Cal., nos. 51, 52 by the Collector Publishing Co., San Francisco., Cal., and nos. 53-57 by A. Macdonald, San Francisco. Nos. 1-6, 36-38 and [54-57] are folio and the remaining nos. are octavo. Nos. 27, 28, 44 and 45 contain supplements virl. 7 and nos. 7-13, 31-35, and 38-53 have paper wrappers. No. 6, vol. I., is dated "May and June, 1883," no. 2, vol. Ix., "February March, 1890 " and there are no numbers for June-September, 1890. Wanting Vol. viII., no. 12

Vols. I.-IIT. are bound up in. Mis. St. Jour. 3 (1)

"OLD PUT" PHILATELIST. The "Old Put" philatelist. Putnam, Conn., Clarence W. Chase, I 9o I-02. $8^{\circ} .8-7 \frac{3}{4}$ in. and 10 in. 8 nos. in 2 rols.

Vol. I. Nov., 1901, Jan.-May, 1902. Nos. 1-6.

* " Ir. June-July, 1902. Nos. 1-2.

* * Nos. 1-6 have paper wrappers and measure 8-73 inches. The numbers of vol. II. measure 10 inches and have no wrappers.
Mis. St. Jour. 142 (6).

OLDHAII PHILATELICAL TIMES. The Oldham philatelical times.

Oldham, Greaves, Rothwell and Co., т 885 .

$8^{\circ} \cdot 7 \frac{1}{2}-71$ in. Nos. 1-3, May-July, 1885.

** Wanting no.

Mis. St. Jour. 80 (4)

OLEAN STAIMP. The Olean stamp.

in. Nos. 1-3, April-June, 1897

Olean, N. Y., L. Lawrence, I897.

* Wanting all three nos.

OLHO DE BOI. O Olho de Boi. Jornal commemorativo ao jubileo do primeiro sello postal do Brazil.

Rio Grande, Brazil, Philatelistas rio-grandenses, I 893 .

Fol. 13 in. " Numero unico," July 1, 1893.

Mis. St. Jour. 86 (6).

OLLA PODRIDA. Olla podrida.

Heckatoo, Ark., Sam. G. Smith, ז 886

$8^{\circ} \cdot 8-8 \frac{1}{2}$ in. and fol. 11 in. Nos. 1-3, February-April, 1886.

** Only partly philatelic. Nos. 1 and 2 are octavo, no. 3 is folio and nos. 2 and 3 are numbered in Roman numerals. Cuttings of the philatelic portions of no. 3 are also mounted in Stamp Scrap-
book, vol. v., pp. 14, 15.

OMAHA IMONTHLY PHILATELIST. Omaha monthly philatelist.

Omaha, Neb., Omaha Stamp and Coin Co., I gor-o2. $8^{\circ} .9$ in. 14 nos. in 2 vols.

Vol. I. Jan., Mar., May, June-July, Aug., Sept.-Oct., Nov., Dec., 1901. Jan.-Feb., March-April, 1902. Nos. 1-12.

"II. June-July, Sept.-Oct., 1902 . Nos. 1-2. 
*** No. 4 is dated "June-July, 1901". Nos. 6 and 7 and 10 and 11 were severally published together under the respective dates "Sept.-Oct., 1901," and "Jan.-Feb. 1902" and no. 12 is dated "March-April, 1902 ". Each number has a paper wrapper and nos. 10 and 11 have " 1901 " in place of "1902" except on the wrappers, which have the correct year. Nos. 10-12 and nos, 1, 2, vol. II., have the words "and Numismatist" added lbeneath the
title on the paper wrappers.
Mis. St. Jour. 101 (8).

OMAHA PHILATELIST. The Omaha philatelist. Omaha, Neb., R. L. Shepard, etc., 1896-98.

$8^{\circ} .9$ in. 19 nos. in 5 vols.

Vol, I. Sept.-Dec., 1896. Nos. 1-4.

" II. Jan. -Apl., 1897. ", 1-4.

" IIr. May-Aug., ", " $1-4$.

" IV. Sept.-Dec., ", " $1-4$.

*" Nos. 3 and 4 of vol. I., and nos. 1 and 2 of vol. II. were published by Shepard and Thurston. Each number has a coloured paper wrapper.

ONCE A MONTH. Once a month or, the stamp collector's advertiser. Manchester, C. Gloyn, etc., r863-64.

Howe acao $8^{\circ} .7 \frac{1}{4}-7 \frac{1}{2}$ in. and $4^{\circ} .10 \mathrm{in.}$ Nos. 1-5, Sept. 15, 1863-Jan. 20, 1864. $\pi .4$ un wany $r * *$ Nos. $1-3$ are octavo and nos. 4, 5 , quarto. The last number was published by Gloyn, Alley and Gloyn. Nos. 1-3 consist entirely of advertisements. $\checkmark$ afe $v$.

C-..- [New Series.] Manchester, C. and H. Gloyn, r864. $4^{\circ} .87$ in. Nos. 1-9, Mar. 15, May 1-Dec. 20, 1864. al $\nu f$

** There is a coloured paper wrapper to each number. $\mathrm{A}$ copy of no. 9 is bound up with the late Miss Fenton's working copies of vols. I., II., of the "Stamp collector's magazine".

ONdE A WEEK. Onke a week. No. CCXV. August 8 , 1863. [Contains an arıticle "Timbromanie".] London, E.C., Bradbury and Evans, 1863. 8․ 91 in. pp. 198-195.

** The number has a paper wrapper. Mis. St. Jour. 141 (5).

ONCE IN A WHILE. Once in a while.

Canton, O., T. C. Nighman, Jr., x875-76.

* * Cuttings of the "Stamp collectors' column [or] corner," etc., in vol. I., nos. 1, 2, 3, 4 and 6 and vol. Ir., nos. 1, 2-3, dated respectively, Jan., 'Mar., Apl., May, 1875, Jan., Mar., Apl. and May, 1876, are mounted in Stamp Scrap-book, vol. II., pp. 73, 74 and vol. III., pp. 123-128.

ONE DIME. One dime.

Salem, Ind., Charles W. Peugh, r887-93.

$32^{\circ} .5$ in. and $4^{\circ} .7-6 \frac{1}{4}$ in. 65 nos. in 6 vols.

Vol. I. Dec., 1887-Nov., 1888. Nos. 1-12.

" II. " 1888- " 1889. " $1-12$

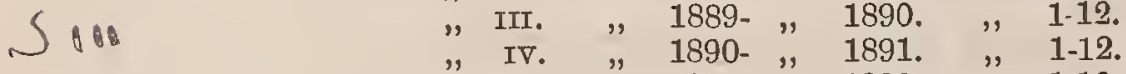

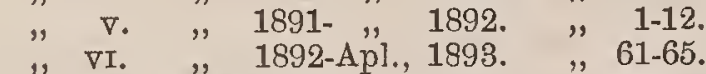

*" Vols. I.-III. and nos. 1-3 of vol. IV. are $32^{\circ}$. and the remaining numbers are quarto. There is a coloured paper wrapper to each number. The wrapper of no. 1, vol. I., gives the place of publication as Kossuth, Ind., as do the wrappers of all subsequent numbers, commencing with no. 4 , vol. IV.

ONEONTA PHILATELIST. The Oneonta philatelist. Oneonta, N. Y., Oneonta Stamp Association, I898. in. Nos. 1-4, April-July, 1898.

* * Wanting all four nos.

ONTARIO PHILATELIST. The Ontario philatelist.

St. Catharines, Ont., Widdicombe and Beatty, etc., 工 $896-98$.

$8^{\circ} .83-9$ in. 19 nos. in 2 vols.
Vol. T. Mar., 1896-A pril, 1897. Nos. 1-12.

,I. Ir. $"$-Sept., 1898. Nos. 1- 7.

*"* II. Nos. 4-12, vol. I., were published by W. A. Beatty and the * Nos. 4-12, vol. I., were published by W. A. Beatty and the seven numbers of vol. II. by R. G. Widdicombe. Nos. 11 and 12 " were published together under the date "March and April, 1897 " and there is a coloured paper wrapper to each number. No. 5 is 1896 ". There is no number for February, 1897. The journal was consolidated with the "Stamp reporter" of St. Catharines, Ont.,
after September, 1898.
Mis. St. Jour. 95 (5).

Mis. St. Jour. 95 (5).

ONTARIO STAIIP JOURNAI. The Ontario stamp journal.

Niagara Falls South, Ont., M. H. Bigger, 1888. $8^{\circ} .8 \frac{3}{4}$ in. No. 1 , October, 1888.

Mis, St. Jour. 56 (5).

OPINION FILATÉEICA CHILENA. La Opinión filatélica chilena.

Santiago de Chile, José Ignacio Vives Solar, etc., I894-95.

$8^{\circ} .10$ in. Nos. 1-10, July 1, 1894-June 15, 1895.

** Nos. 9, 10 were published by Agustin Rojas L. No. 1 has the date " 1884 " altered to " 1894 ," no. 2 has the date "Julio" pasted over with a label bearing "Agosto," and there is no number for December, 1894, or for April, 1895. Mis. St. Jour. 130 (2).

ORANGE CITY PHILATFLIST. Orange City philatelist.

Orange, N. J., W. L. Brower, 1890 .

$8^{\circ} \cdot 8 \frac{1}{2}$ in. Nos. 1-2, January-February, 1890

ORANGT COUNTY PUITATRITR The Orange County philatelist. Published monthly in the interests of stamp collecting.

Middletown, Orange County, N. Y., The Orange County Philatelist Co., I89o. $16^{\circ} .5 \frac{3}{4}$ in. No. 1 , August, 1890.

Mis. St. Jour. 68 (6).

ORIENT. The Orient. Volume III., no. 2, June, 1885. [Contains an article "The Rarest stamp," reprinted from the "Toronto philatelic journal".]

New York, H. W. Warner and F. M. Warner, 1885 . $8^{\circ} .9 \frac{1}{4}$ in. p. (2).

Mis. St. Jour. $143(10)$.

ORIENT PHILATÉLIQUE. L'Orient philatélique.

T.-Severin, Roumanie, Virgite Samboteano, I897. $8^{\circ} .103$ in. [No. 1], March 1, 1897.

* * The contents consist entirely of advertisements.

Mis. St. Jour. 110 (8).

ORIENTAL JOURNAL OF PHILATELY. The Oriental journal of philately. [Prospectus of a journal to be published by A. Woodward, Yokohama, on December 1, 1894, but which was never issued.]

Mis. St. Jour. 123 (4).

ORIENTALISCHE PHILATELIST. Der Orientalische philatelist. Constantinople, J. Melkenstein, I886-87. $8^{\circ} .11 \frac{1}{4}$ in. Nos. 1-6, July 25, Sept. 4, Oct. 8, Nov. 15, 1886, Feb. 5, Mar. 15, 1887.

* * There is a coloured paper wrapper to each number. No. 6 was edited by Robert Hruby.
Mis. St. Jour. 73 (4).

ORIGINATOR. The Originator. An amateur and philatelic publication.

Reading, Pa., H. F. Nickolaus, x 903. $8^{\circ} .9 \frac{1}{2}$ in. Nos. 1-2, January 1, February, 1903

* * Only partly philatelic.

ORTSSTEMPEL. Der Ortsstempel. Festschrift zur Stiftungsfeier des "Philatelisten-Vereins, Essen".

Fol. 13졸 in. 2nd year. No. 1, January 30, 1894. Essen, r 894 . * * Printed by autographic lithography and the contents are of a humorous description.

OTTAWA PHILATELIST. The Ottawa philatelist.

Ottawa, F. I. Chevrier, etc., r892-93. $8^{\circ} .81$ in. Nos. 1-4, [Oct.], 1892-Dec., 1892, April, 1893. * * Nos. 2-4 were published by W. J. Sabourin. No. 1 is dated in error "December, 1892," and nos. 1-3 have coloured paper wrappers. No. 4 has the number in Roman figures. Mis. St. Jour. 56 (2).

OUR ADVERTISER. Our advertiser.

in $N 0,1$. Boston, Mass., [?] 5,11

** Only partly philatelic. The number has no date. Wanting.

OUR AMERICAN YOUTH. See AMERICAN BOYs.

OUR AIMERICAN YOUTH AND THE PHILATELIC CHRONICIE. See AMERICAN BOYs.

OUR BOYS AND GIRLS JOURNAL. Our boys and girls journal. * * Only partly philatelic. Wanting all nos.

Minneapolis, Minn., [? ], rgo4.

$$
\begin{aligned}
& \text { Orumed hansh is hemuthy offers of } \\
& \text { colenwiel postage stempes } \\
& 01910 / 1-6.7 \text { ang. - Law, March } \\
& \text { No/ } 3 \text { is an surpaced firfor }
\end{aligned}
$$

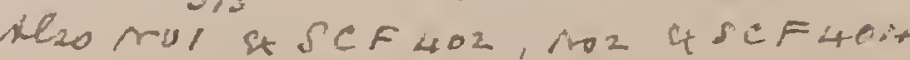

$$
\begin{aligned}
& 4 \text { iS SCF } 498
\end{aligned}
$$

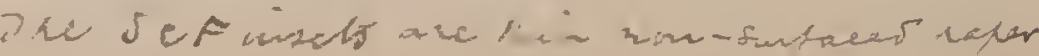




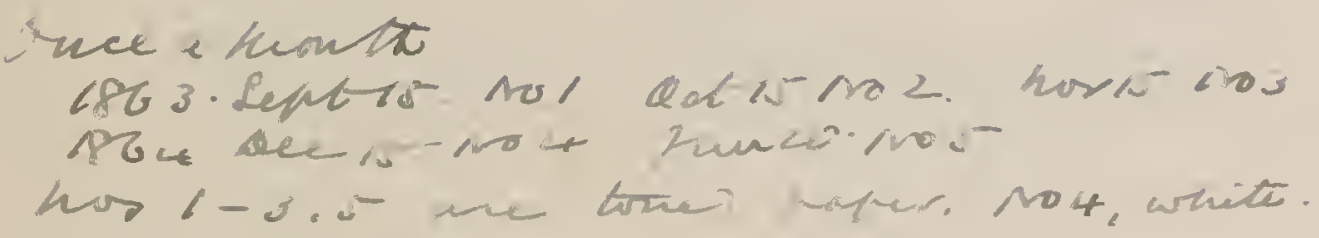

bur adventiser-kansas Chíf, Kas - Floyd Jamption, 1896-S111

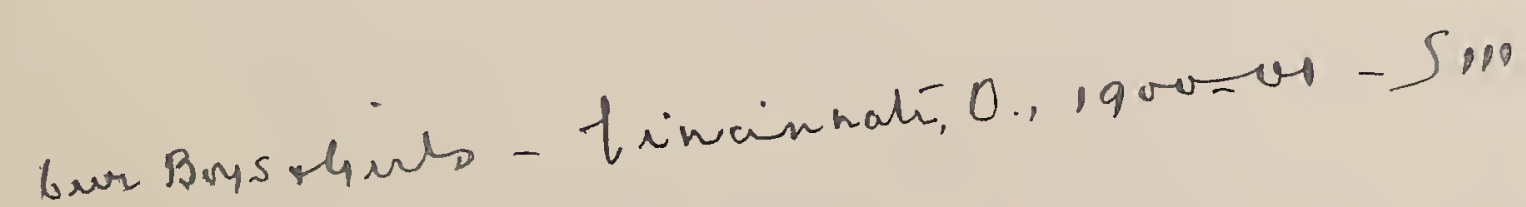


Our inafazuc.

Lonton finited, mablisiced Kilbum

roll. No $10 \quad 1905$ manch

Ouly Martts phiakcic

Our Inaveller.

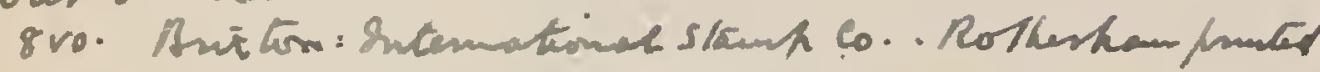

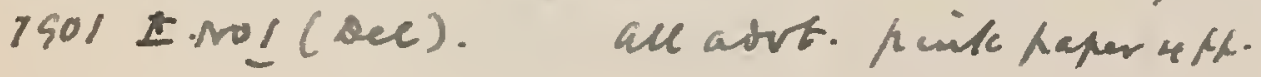


OUR BOYS' MAGAZINE. Our boys' magazine. Vol. xv. No. 169. January, 1901. [Contains an article "Notes on stamp-collecting. The stamps of Japan," by H. M. Gooch.] $8^{\circ} .8 \frac{7}{10}$. pp. $4-6$. London, E.C., The Scripture Union, rgor. * * The number has a coloured paper wrapper. Mis. St. Pamph.64 (1)

OUR CALENDAR. Our calendar. Iowa City, Iowa, etc., Western Philatelic Agency, etc., $\mathrm{r} 892$.

$8^{\circ} .83$ in. Nos. 1-2, January-April, 1892

* No. 2 was published by Howard P. Boyle, at Washington, D. C Mis. St. Jour. 46 (2)

OUR HOIIE AND SCIENCE GOSSIP. Our home and science gossip. Rockford, Ill., [? ], I88I-82. * * Cuttings of the portions headed "Stamp collector" and "Philately," etc., from vol. $\nabla .$, no. 12, dated Novembar, 1881, and from Stamp Scrap-book, vol. IV., p. 100 and in vol. v., pp. 73-75.

OUR HOME COIMPANION. Our home companion.

Jersey City, N. J., Companion Publishing Co., r886. * Cuttings of the philatelic portions from nos. 1-6, dated MarchJune, September and October, 1886, are mounted in Stamp Scrapbook, vol. v., pp. 1-13.

OUR MONTHLY VISITOR. Our monthly visitor.

Fitchburg, Mass., The New England Publishing Association, 1887.

* * Cuttings of the "Philatelic department," etc., from vol. IX., nos. 3, 4, 6, and 7, dated May, June, August and September, 1887 are mounted in Stamp Scrap-book, vol. V., pp. 148-158.

OUR MUTUAL FRIEND. Our mutual friend.

St. Louis, Mo., Paragon Stamp Emporium, 1897. $32^{\circ} .4_{ \pm}^{3}$ in. No. 1 , January, 1897 . Mis. St. Jour. 150 (4)

OUR NEWS. Our news. A bi-monthly journal devoted to amateurdom. Cincinnati, O., G. W. Logan, I88r. $8^{\circ} .7 \frac{1}{4}$ in. No. 1 , September, 1881 ** Only partly philatelic.

Mis. St. Jour. 41 (1)

OUR OWN FIRESIDE. Our own fireside.

Toronto and Whitby, Canada, J.S. Robertson and Bros., I 883

* * Cuttings of the "Philatelic department," etc., from the num bers dated April, May, July and August, 1883, are mounted in Stamp Scrap-boot, vol. rv., pp, 122-127.

OUR PHILATELIA. Our philatelia.

Providence, R. I., George H. Hope, I 896-97. 8․ $9 \frac{1}{4}$ in. Nos. 1-4, Dec., 1896-Mar., 1897. * * Nos. 3, 4 were published together under the date "FebruaryMarch, 1897 ". Mis. St. Jour. 92 (11)

OUR PROGRESSIVE YOUTH. Our progressive youth. Formerly The Wide awake.

New York, Harry K. Zust, ז885-86. Fol. $12-11$ in. and $8^{\circ} .8 \frac{1}{2}$ in. nos. in 2 vols.

Vol. I. 1885 . Nos. 1 -

* "The Jan. -Feb., 1886 . Thers of vol. I. are folio and those of vol. Ir. are octavo. The library contains copies of nos. 7 and 8 , vol. I., and of nos. 1 and 2, vol. Ir., and in addition cuttings of the "Stamp depart ment," etc., from nos. 5 and 6 , vol. I., which were published to- gether with the date May and June, 1885, and from no. 8 of October, 1885 , are mounted in Stamp Scrap-book, vol, $\nabla ., p p$. 75-79. No. 7 is dated July, 1885. No. 1, vol. II. has a pape 75. - No. 7 is dated Jul, advertisements. Wanting vol. I., nos. 1, 2, 3, 4, and after 8 .

OUR STAMP CIRCULAR. Our stamp circular. Cincinnati, O., F. L. Mills, r888.

$8^{\circ} .8 \frac{3}{4}$ in. No. 1, April, 1888

* Printed on yellow paper.

Mis. St. Jour. 147 (4)

OUR STAIMPIC EXCHANGER. Our stampic exchanger Mile Run, Pa., P.E. A. Conrade, r894. $16^{\circ} .5 \frac{1}{4}$ in. Nos. 1-5, [? Jan.]-June, 1894.
$* *$ No. 5 is dated "May and June, 1894". Wanting nos, 1,2 , 3,4 .

$$
\text { [Continued as :] }
$$

The Stampic exchanger

Mile Run, Pa., P. E. A. Conrade, etc., I894-96.

$16^{\circ} .5 \frac{1}{2}$ in. and $32^{\circ} .4$ in. 4 nos. in 2 vols

Vol. I. [? July], Sept., 1894. Nos. 6-7.

II. Oct. Dec., 1896.

* * The numbers of volume I. are $16^{\circ}$. and those of volume Ir. ar $32^{\circ}$. The two numbers of vol. Ir. were published by P. E. A. Conrade and Co. Wanting vol. I. no. 6.

OUR VISITOR. Our visitor.

Kansas City, Kan., George Griffith, т 894-95. $8^{\circ} .83$ in. Nos. 1-6, [? ]-January, 1895.

** Only partly philatic No. 6 has tho sub-title "Official organ * Only partly philatelic. No. 6 has the sub-title " Official organ (596)" and has a coloured paper wrapper. Wanting nos. 1, 2, 3 , 4,5 .

OUR WORLD. See AMATEUR WORLD (Baltimore, Ma.)

OUR YOUNG PEOPLE. Our young people. Milwaukee, Wis., The Young People Co., I899. $8^{\circ} .9 \frac{1}{2}$ in. Vol. vir. nos. 22, 23, May 1, 15, 1899.

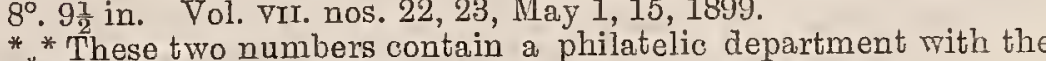
"**These two numbers contain

OUR YOUTH. Our youth.

New York, Phillips and Hunt, r888. ** Cuttings of the philatelic portions from vol. vIr., no. 1, whole no. 157, dated December 1, 1888, are mounted in Stamp Scrapbook, vol. vi. p. 10

OVERLAND IMONTHLY. The Overland monthly. Vol. XII. No. 5. May, 1874. [Contains an article "Cape Horn Post-Office," by Leonard Kip.]

San Francisco, Cal., J. H. Carmany and Co., I 874. $8^{\circ} .9$ in. pp. $424-433$

* * The number has a coloured paper wrapper.

II.s. St. Jour. 21 (9)

OXFORD PHILATELICAL MONTHLY. The Oxford philatelical monthly.

Oxford, Williams, Taphouse and Co., I885. $8^{\circ} .81$ in. Nos. 1-2, June-July, 1885.

* * Succeeded by the "Philatelic Mercury". "Tis. St. Jour. 30 (13). 
P. A. OF I. BULLETIN. The P. A. of I. Bulletin. I889.

Grinnel, Iowa, The Philatelic Association of Iowa, $8^{\circ} \cdot 7 \frac{3}{2}$

Mis. St. Jour. 66 (6) journal.

San Francisco, Cal., H. B. Standerwick and Fred. Lake, 1876 .

* * Cuttings of "Our philatelic corner," etc., from nos. 1, 2, 3, and 4, dated May 15th, June 15th, July 15th and August 15th, 1876, are mounted in Stamp Scrap-book, vol. III., pp. 91-104.

[Continued as :]

— The Pacific journal. 77.

San Francisco, Cal., H. B. Standerwick, etc., ז876-

* * Cuttings of "Our philatelic corner," etc., from nos. 5, 6, 7, and 8, dated October 15th, November 15th, 1876, January 15th and pp. 104-113. Nos. 7 and 8 were published by Wilson, Perrin and
Wilson.

PACIFIC JOURNAL. See Pacific amateur journat.

PACIFIC IMAGAZINE. The Pacific magazine.

in. No. 1, July 1, 1898

$$
\text { Riverside, Cal., [? ], } 1898 .
$$

* Only partly philatelic. Wanting.

PAÍS. El País. Madrid. Diario político y literario. Año I. Num. 164.16 de Agosto de 1870 : Num. 224. 22 de Octubre de 1870: Num. 250. 23 de Noviembre de 1870. [Contain articles by Dr. Thebussem.] ***The three articles have been cut out and mounted in Mis. St. Jour. $43(4,4 a, 4 b$.

PAPIER - UND SCHREIBWAREN-ZEITUNG. See Philatelisten-Zeitung (Berlin).

PARIS-POSTAL. Paris-postal. I $89 \mathrm{I}-92$.

Paris, Amiens, [printed], Ch. Schanpmeier, etc.,

Fol. $12^{3}$ in. Nos. 1-9, June 15-Nov. 20, 1891, Jan. 10-Mar. 15, 1892.

** Nos. 8 and 9 were published by Th. Lemaire and these two numbers are printed on buff paper. Mis. St. Jour. 74 (6)

PARIS-POSTE. Paris-poste. Journal philathélique illustré paraissant le 15 de chaque mois.

Paris, V. Gruat, I887-88.

Fol. 12 in. "Numéro-Spécimen. 15 Octobre, 1887," and nos. 12, Feb. 15-Mar. 15, 1888 .

* * There are several supplements to the above, and also supplements dated " 1 er Mars, 1888, 1er Avril, 1888, 10 Mai, 1888, 3 Juin, 1888, 1er Juillet, 1888, 1er Septembre, 1888," and "1er Octobre, 1888 ". These last seven bear the title " Philat téliques, 1789-1889".

Mis. St. Jour, $82(5)$.

tapess for shilatidists. See the Puilaculist. Limion misugintor.

\section{PARK CITY COLLECTOR}

PARK CITY COLLECTOR. The Park City collector. Bridgeport, Conn., Bennett and Hunt, I888-89. $8^{\circ} .9$ in. Nos. 1-5, Oct., Nov., 1888, Dec., 1888 and Jan., 1889,

*ar., 1889 . ${ }^{*}$ Only partly philatelic. Nos. 3 and 4 were published together.

PATROL. See StaMr DEALERS OWN.

PEARL. The Pearl. "Hic et ubique."

8. 9 in. 15 nos. in 2 vols

Toronto, Pearl Publishing Co., 1876-77.

Vol. I. Jan. -July, 1876. Nos. 6-12.

*" II. Ang., 1876-Mar., 1877. "' was consolidated with the "Pearl" after the issue of no. 5 of the latter journal and henceforth a stamp department was added to the "Pearl," nos. 1-5 of which contain no philatelic matter. There are supplements of (2) pp. to nos. 6,9 and 10 , vol. I., and There are supplements of (2) pp. to nos. 6,9 and 10 , vol. I, and also to nos. 1 and 5, vol. II. and nos. 11 and 12, vol. I., and 3 and 4,
vol. II. were severally published together under the dates "June vol. II., were severally published together under the dates "June latter only bears "No. 3 " in place of "Nos. 3 and 4 ".

PFARL. The Pearl.

Mis. St. Jour. 24 (6).

Syracuse, N.Y., Gray and Coan, I888-89. 8. $9 \frac{1}{4}$ in. Nos. 1-4, Oct., 1888-Jan., 1889.

** Only partly philatolic. No. 3 has a coloured paper wrapper and therc is a supplement of (2) pp. to no. 2 .

$$
\text { [Continued as :] }
$$

- The Pearl magazine.

Syracuse, N. Y., Gray and Coan, I889. $8^{\circ} .9 \frac{1}{4}$ in. No. 5, Feb., 1889 ** Only partly philatelic.

Mis. St. Jour. 16 (8).

PEARL IMAGAZINE. See PEARL. (funterex)

PEARSON'S WEEKLY. Pearson's weekly. Nos. 247, $249,251,253,255,257,259,261,263,265,267,269$, $271,273,275,277,279,281,283,285,287,290,292$, $294,296,298,300$. [Contain 27 articles with the title "Our stamp album". Nos. 1-27; by Harold Frederic.] Fol. $14 \frac{1}{2}$ in. 27 nos. London, C. Arthur Pearson, I895-96. ** * There is a coloured paper wrapper to each number.

PERRLESS REVIEW. The Peerless review. Worcester, Mass., Wm. J. J. Culross, I887. $8^{\circ} .9$ in. Nos. 1-3, January-March, 1887. ** Only partly philatelic.

Mis. St. Jour. 135 (20).

PENINSULAR PHILATELIST. The Peninsular philatelist. Rockford, Mich., H. E. Cowdin, 1886. $8^{\circ} .8$ in. No. 1 , November, 1886. Mis. St. Jour. 145 (4).

PENINSULAR PHILATELIST. The Peninsular philatelist. Devoted to collectors in State and Nation. Grand Rapids, Mich., Kent Phil. Publishing Co., $L t d$., 1889 .

$8^{\circ} .9 \frac{1}{2}$ in, Nos. 1-2, Oct, 15-Nov. 15, 1889.

Mis. St. Jour. 15 (5). 
Pacifir Puratelidt. is angole.

Pacific stoma heurs

$32^{\text {mo }}$ Cardent. Cal. D. 7.0s bom $\operatorname{lgog} I !$ (gan) $\leqslant$ (uar)

PAPERS FóR PHILATELISTS.-See PHILATELIST (Brighton). ( $\left.7 /{ }^{\circ}\right)$

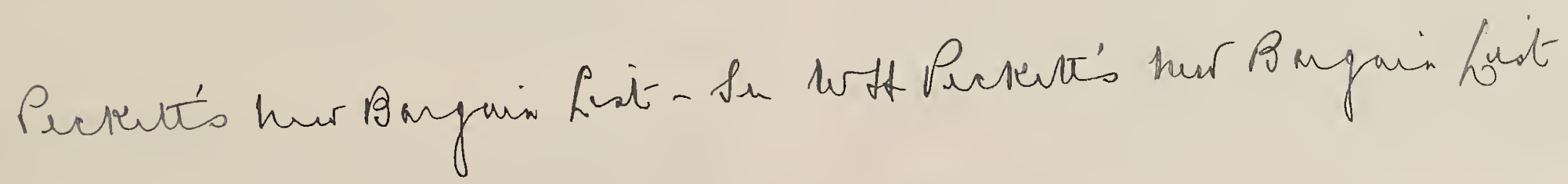


The Puple's arfory 
PENINSULAR PHILATHLIST. See PeninusLar PHILATELIST.

PENINUSLAR (sic) PHILATELIST. The Peninuslar (sic) philatelist. Ft. Meade, Fla., F. F. Crawford, 1895 . $8^{\circ} .9$ in. No. 1 , October $1,1895$.

* * The title on page 2 is given as "Penensular Philatelist".

Mis. St. Jour. 121 (3).

PENNSYLVANIA PHILATELIST. The Pennsylvania philatelist.

Reading, Pa., Harry F. Kantner, etc., I891-98. $8^{\circ} .9$ in. 82 nos. in 14 vols.

Vol. I. Dec. 1891-May, 1892. Nos. 1-6.

" II. June, -Nov., ", " $\quad 1-6$. and "Columbian

number".

Iv. June, number"

IV. June, -Nov., ", " 1 , 16 .

" v. Dec. 1893-May, 1894. " $1-6$

"VI. June 18 Nov., 1894. " $1-6$

VIIT. June 1894-Noy, 1895.6

"III. June -Nov., 18" " $1-6$

$x$-Nov, $1890 ., 1-6$.

"x. Juno 1896-Nov," 18̈7. "

xI. Dune 1896-Nov, $1897 ., 1-6$.

"XIII. Dec. 1897-May, 1898. " " 1-6.

"XIV. June -Aug. " "1-3.

* * Nos. 3-6, vol. II., and vol. "III., were published by the Pennsylvania Philatelic Co., and commencing with vol. IV. the journal was published by Clifford W. Kissinger. There is a paper wrapper to each number, an extra number for May, 1893, headed "Columbian number" and supplements of four pages to no. 2 , vol. virr., no. 6 , vol. IX., and no. 1, vol. x. The year on the wrapper of no. 2 , vol. Ix., was given in error as "1895," but the mistake was corrected to " 1896 ". The journal was consolidated with the "Perforator".

PENNSYLVANIA STAIPP The Pennsylvania stamp Patterson's Mills, Pa., Lawton, Cleaver and Co. etc., $1895-96$.

8․ 8-9 in. Nos. 1-7, Nov., Dec., 1895, Feb., Apl., June, July, Sept., 1896

** Nos. 2-5 were published by Cameron W. Lawton, and nos. 6 and 7 have paper wrappers.

Mis. St. Jour. 94 (9).

PENNY IMAGAZINE. The Penny magazine of the Society for the diffusion of useful knowledge. Monthly supplement. No. 117. December 31, 1833 to January 31, 1834. [Contains an illustrated article "The history and present state of the Post-Office "']

Fol. 11 in. pp. 33-40.

London, Charles Knight, I833. Mis. St. Jour 152 (9)

New series, no. 762. Vol. xiII. February 17, 1844 [Contains an article "Results of penny postage".]

$8^{\circ} .10$ in. pp. 63-64.

London, Charles Knight and Co., 1844

PENNY PICTORIAL IMAGAZINE. The Penny pictorial magazine. Vol. I. No. 9, August 5, 1899. [Contains an article "Millions in stamps," by Victor Buller.] 8. $9 \frac{3}{4}$ in. pp. $432-434$. London, E.C., I899.

* "The number has a coloured paper wrapper.

Mis. St. Pamph. 63 (2)

PENNY POST. The Penny post. Portsmouth, N. H., April 25, 1888. [Cuttings of article "Portsmouth collectors" are mounted in Stamp Scrap-book, vol. vI., pp. $22,23.7$

PENTUCKET PHILATELIST. The Pentucket philatelist.

Haverhill, Mass., The Pentucket Stamp and Publishing Co., I 892

$8^{\circ} .83$ in. Nos. 1-3, Sept. Oct., Nov, and Dec., 1892.

* There is a coloured paper wrapper to each number.

Mis. St. Jour. 63 (14)

PER IITTERAS UNUIM. Per Litteras unum. Verschijnt elke maand. Rotterdam, Henri van der Hoek, I905. $8^{\circ} .9$ in. Nos. 1-3, August 26-October 26, 1905.

* Only partly philatelic and the contents consist entirely of advertisements. Nos. 2 and 3 are printed on buff paper.
PERFORATOR. The Perforator.

Hartford, Conn., etc., Henry A. Chapman, etc., I897-I90I.

$8^{\circ} .8 \frac{1}{4}-9$ in. 52 nos. in 8 vols.

Vol. I. Mar., 1897-Feb., 1898. Nos. 1-12.

" II. " 1898- " $1899 . \quad$ " $1-12$.

III. "Aug., ", " " 1- 6 .

IV. Sept., 1899-Feb., 1900. " " $1-6$.

v. March -Aug., ", " 1- 6 .

vi. Sept. 1900-Eeb., 1901. " " 1- 6.

viI. March, April, " " 1-2.

"XVIII. May-June, July, ", $8 \frac{1}{4}$ inches and

inches and were printed on ellow paper, the remaining numbers measuring 9 inches, were vol. I., and no. 1, vol II., were published by H. A. and W. A. Chapman, nos. 2-6, vol. II., by.J. W. Stowell, at F'ederalsburg, nos. 7-12, vol. II., and nos. 1, 2, vol. III, by Kissinger and Stowel a.t Federas. by Clifford W. by Cliftord W. Kissinger also at Federalsburg, no. 2, vol. VII., and Foderalsburg and the two last at Oswego, N. Y. No. 8, vol. is also numbered "Old series, volume xIV. number 4 " referring is also numbered "Old series, volume XIV. number 4 " referring to a continuation of the "Pennsylvania philatelist," which hac been consolidated with the journal, and this double numbering was continued down to no. 2, vol. VII., and commencing with no. , vol. III., the paper wrappers were numbered vol. XV., no. 1, and so onwards down to nos. 56 and 57 , the wrappers of which have "vol. XVIII., no. 6 " and "vol. XVIII., no. 7," respectively. No. 7 , vol. II, contains a folded sheet of portraits of the officials of the tains two supplomental slips and an add ressod envelope.

[Continued as :]

Leve's new perforator.

Syracuse, N. Y., Ab. Leve, I go I-02.

Fol. 12 in. Vol. xx, 4 nos.

Vol. xx. Oct., Nov., Dec., 1901, Jan.-Feb., [1902]. Nos. 1-4.

* Each number has a paper wrapper and nos. 3 and 4 have no and vol. xx., no. 1

[Continued as:]

The Perforator.

New York, etc., A. Herbst and Wm. A. McDonnell, etc., I902-07.

Fol. $12 \frac{1}{4}$ in. Vols. XxI.-Xxv, 52 nos.

Vol. xxI. May 15 1902-Mar. 25, 1903. Nos. 1-11.

" XxII. April-May, 1903-Apl., 15 1904. " 1-12.

" xxiIr. May 15, 1904-" "1905. " 1-12.

" xxIv. " " " " $\quad$-Sxv. $\quad$ 1905-

*"* XxV. Each number has a paper wrapper. Nos. 11 and 12 , vol. xxIr.

* * Each number has a paper wrapper. Nos. 11 and 12, vol. xxIr. and nos. 1-8, vol. xxIII., were published by A. Herbst and nos. $9-$ 12 , vol. XXIII., and the subsequent numbers by Wm. E. Shoudy, nos. 9-12, vol. xxIII., and nos. 1-3, vol. xxIv., at Syracuse, N. Y., and the succeeding numbers at Federalsburg, Md., with the exception of the last, which was published at Syracuse, N.IY. No.

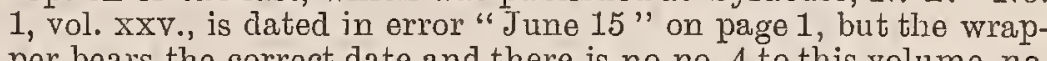
per bears the correct date and there is no no. 4 to this volume, no. 3 being dated "July 15, 1906 " and no. 5, "August-September.15,

PERIODICOPHILE. Le Périodicophile.

$8^{\circ} .9 \frac{3}{4}$ in. 88 nos. in 3 vols. Bruxelles, [?

], I $893-96$.

1st year. July, 1893-June 15, 1894. Nos. 1-32.

1st year. July, 1893-June 15, 1894.
2nd os. 1-32.
3rd July 1, 1894- " " 1895. " 1-30.

** Printed by autographic lithography." The journal gives a list of new papers published throughout the world, including philatelic journals.

PERRY'S FXCHANGE LIST. Perry's exchange list. For the use of everybody who wants to buy, sell or exchange. Syracuse, N. Y., W. R. Perry, I9oz.

$8^{\circ} .101 \frac{1}{2}$ in. No. 1, February 15, 1902

* * Consists of only a single leaf of advertisements.

[Continued as:]

Perry's international advertiser.

Syracuse, N. Y., The Co-operative Collectors Co., I 902 .

$S^{\circ} .8$ in. Nos. 2-11, [? nos. 2, 3, 4], Aug. 30, [? no. 6], Sept. 20, [? no. 8], Oct. $6,20,27,1902$.

"* Succeeded by the "Co-operative advertiser". Wanting nos. 
PERRY'S INTERNATIONAL ADVERTISER. See Perri's exchange List.

PFRU POSTAL. Fl Peru postal. Revista mensual filatélica y cartófila.

$8^{\circ} .10 \frac{1}{2}$ in. Nos. 1-8, Jan. 1-August, 1904

* There is a coloured paper wrapper to each number and nos. 7 and 8 were published together, with the date " Julio y Agosto de

1904". Wanting nos. 4, 5, 6. Mis. St. Jour. $110(6)$

PET PHILATELIST. The Pet philatelist.

$32^{\circ} .4 \frac{1}{2}$ in. Nos. 1-4, Sept.-Dec., 1894

Berlin, Ont., E. Moyer, r 894

* There is a coloured paper wrapper to each number.

Mis. St. Jour. 71 (8)

PETIT BLEU DU IMATIN. Le Petit bleu du matin. Bruxelles, 7. Goossens, etc., 1895 -1 906.

Fol. 24 in. 356 nos. in 11 vols.

Jan. 2 -Dec. 30, 1895. 19 nos.

" 4 - 2, 1896. 14,

Mar. 14 -Sept. 26, 1897.8

Mar. 31, June, 11, Nov, 20, 1899. 3 nos.

Jan. 8-Dec. 29, 1901. 43

, 5- , 28, 1902. 50

4- " $" 27,1903.51$,

$2-", \quad 25,1904.52$

$1-\quad " \quad 31,1905 . \quad 54$

* Each ninted on blue paper, contains a philatelic article by Armand Dethier, those in February and March, 1898, giving a history of all the philatelic societies of Belgium, with portraits of the principal Bclgian collectors. From 1899 the by Francois Kevels. No philatelic articles appeared in the year 1900.

PETIT CARILLON PHILATEILIQUE. Le Petit carillon philatélique.

Tarbes, Hautes-Pyrénées, M. Villeneuve, rgor. $8^{\circ} \cdot 8 \frac{3}{4}-9 \frac{3}{4}$ in. Nos. 1-2, Feb. 28-Mar. 31, 1901

* There is a coloured paper wrapper to each number. No 1 measures 83 inches and no. 2, 93 inches. Mis. St. Jour. 110 (1).

PETTT HABANA. El Petit Habana.

$8^{\circ} .9$ in. Nos. 1 -

Habana, A. del Castillo, r goo.

** Only partly philatelic. Wanting no. 1 and any after no. 3 , which is dated " 29 de Abril de 1900 "

PETIT JOURNAL PHILATÉLIQUE. Le Petit journal philatélique. Das kleine philatelistische Jourmal.

Annemasse, France, M. Federmeyer, r 905$8^{\circ} .8 \frac{3}{4}$ in. and $4^{\circ} .11$ in. nos. in vols. In progress. 1st year. Dec., 1905-Dec., 1906. No. [0] and nos. 1-12. ** No [0] is octavo and the other numbers are quarto. Nos. 9 and 10 and 11 and 12 were severajly published together.

PETIT IMESSAGER. Le Petit messager. Revue populaire. Paraissant à la fin de chaque mois.

Bains-les-Bains, France, Désiré Dusapin, rgor.

S112 8.93 in. No. 1, December, 1901.

* * Only partly philatelic.

Tist (4 pp.) of stamps Mis. St. Jour. 123 (13).

Nouvelle Série. Le Petit messager. Philatélique et littéraire.

Bains-les-Bains, France, Désiré Dusapin, I903-04. 8०. 9 in. Nos. 1-[3], May, June, 1903, February, 1904

* * There is a coloured paper wrapper to each number, No. 3 bears no number and is without the words "Nlle Serie".

$$
\text { Mis. St. Jour. } 123 \text { (13a). }
$$

PETIT MESSAGER UNIVERSRL. Le Petit messager universel.

Bains-les-Bains, France, Désiré Dusapin, r898-99. $8^{\circ} .8 \frac{3}{4}$ in. Nos. 1-11, December 18, 1898-June, 1899.

* * Published weekly to the end of January, 1899, and then monthly. Nos. 9 and 10 have coloured peper wrappers. Wanting nos. 4,6 .

Nouvelle Série.

Bains-les-Bains, France, Déswé Dusapin, rooo. $8^{\circ}$. 83 in. Nos: 1-2, April-May, 1900. Mis. St. Jour. 154 (12a).
PETIT MESSAGER UNIVERSEL. Ire Série.

Bains-les-Bains, France, Désiré Dusapin, rgor. 8. $8 \frac{3}{4}$ in. No. 1, February, 1901

* "Succeeded by the "Petit Messager". Mis. St. Jour. 154 (12b)

PFTIT PHILATELISTE. Le Petit philatéliste.

Lyon, Francisque Bosson, I895-98.

$8^{\circ} .7 \frac{1}{2}$ in. $4^{\circ} .11$ in. and $8^{\circ} .8$ in. 3 nos. in 3 vols.

1st year. Oct., 1895 . No. 1.

[3rd " Nov., 1896. " 1898.2.

* Each number has a paper wrapper, and no. 3 has a supplement of two pages. The numbers vary in size in the order given ment of two pages. The numbers vary in size in the order given
above.
Mis. St. Jour. 109 (7).

PETITE CHRONIQUE. La Petite chronique. Journal internat. de philatélie et de cartophilie.

Lausanne, Suisse, C. Cuerel, r 90 I.

8. $83-9 \frac{1}{2}$ in. [Nos. 1-5], Nay-September, 1901.

${ }^{*}{ }^{*}$ Nos. 1 and 2 measure $8 \frac{3}{4}$ inches and the other numbers $9 \frac{1}{2}$
inches. Wanting the number for May. Mis. St. Jour. $154(15)$.

PETITES AFFICHES DU TIMBROPHILE. Les Petites affiches du timbrophile.

Luxembourg, Joseph Schock, etc., r895-

8. $10 \frac{1}{2}-9 \frac{1}{2}$ in. nos. in vols. In progress.

1st year. Feb. -Dec., 1895. Nos. 1- 12.

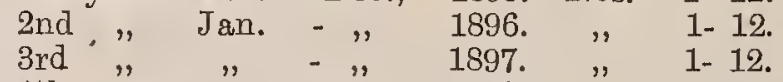

4th " " " - " $\quad 1898 . \quad ", 1-12$.

6th " " " " " $31,1900 . \quad$ " $1-20$.

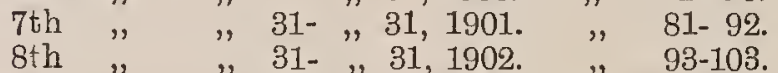

9 th " " " 31- " 31, 1903. " " 104-114.

12th " Jan. -Dec., 1906. " $1-12$.

* "This is a supplement of the "Moniteur du Collectionneur". Commencing with January, 1902, the journal has been published by the Union des Timbrophiles de Luxembourg. Nos. 1 and 2 and nos. 8 and 9 of the first year and nos. 8 and 9 of the twelfth year were severully published together under the respective date "Février, 1895," "Août et Septembre, 1895," and "Août-Septembre, 1906" and nos. 1-9 of the second year are printed on coloured paper. The numbers for the sixth year were published fortnightly, excepting those for the months of July, August, September and October, 1900, for which there is only one number each. There is no number for September, 1902, or for August, 1903. In January, 1904, the journal was amalgamated with th "Moniteur du Collectionneur," but in January, 1906, it again became a separate publication. The numbers of the first two years are bound up with the "Moniteur du Collectionneur" for $1895-96$.

PETITES AFFICHES PHILATELIQUES. Les Petites affiches philatéliques. Paris, [? ], I894. 8.. 83-81 in. Nos. 1-11, January-November, 1894. ** The contents consist entirely of advertisements. Wanting $J_{112}$ ** The contents consist entirely of advertisements. Wanting
nos. 8,11 Mis. St. Jour. 119 (3).

PETITES ANNONCES CARTOPHILES ET PHILA Th́fiques. See Petites Annonces Cartophrles \& Phimatelistes.

PETITES ANNONCES CARTOPHILES \& PHILATELISTES. Les Petites annonces cartophiles \& philatelistes. Gondrecourt, France, Raoul Liè, r 904-05. $8^{\circ} .8 \frac{3}{4}$ in. 6 nos. in 2 vols.

1st year. Sept. 1, 15, Oct. 1, Nov. 1, 15, 1904. Nos. 1-5.

2nd " Oct. 15, 1905. No. 1 .

** No. 1 of the second year is printed on buff paper.

[Continued as :]

Mis. St. Jour. 120 (5)

nces cartophiles et philatéliques.

Gondrecourt, France, Raoul Liè, I 906.

$4^{\circ} .11$ in. Vol. III., 10 nos.

3rd year. March 4, 11, 18 and 25, Apl. 1, 8, 15 and 22, 29, May 6 1906. Nos. 1-10.

** Printed on coloured paper. Nos. 3 and 4 and 7 and 8 wer severally published together and nos. 5-10 have the words "et la Circulaire Inter réunis," below the title.

[Continued as :]

Mis. St. Jour. $120(5 a)$

Les Petites annonces cartophiles \& philatélistes.

Gondrecourt, France, Raoul Liè, rgo6. $8^{\circ} .8^{3}$ in. Vol. IV., 2 nos.

4th year. Sept. 15 , Oct. 1,1906 . Nos. $1-2$ 

Petty's Arverticar Heporter. A masazina durolid prithotice.

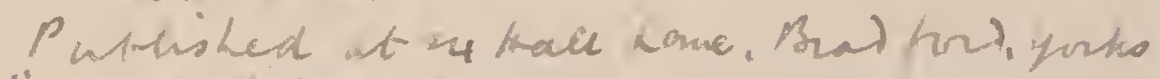
"1903 ictoter. Sopplement", 4/4. 4 to preen haper. $\theta$ J * turracolta 9

This is sally of he reture of a P.oshectus as it efero toho.1 to have illustations raphen on kos 20 . The 1903 december has no number, is annited on hink paper. $7 \mathrm{H}+($ ()) i on the 4 th hage to is callad the "first number."

cunte

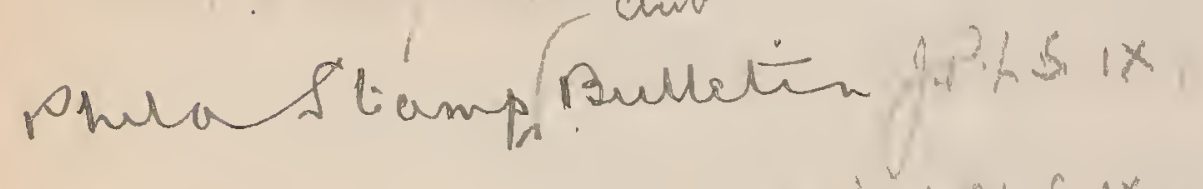

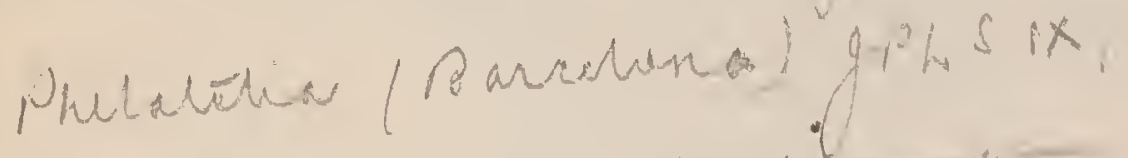

"(hyive syhíga)

"(Pungagar) - " 
PETTY'S ADVERTISER AND REPORTER. Petty's advertiser and reporter.

Bradford, Yorks, Petty and Co., r903-04. $4^{\circ} .10 \frac{1}{2}$ in. Oct., Dec., 1903, no. 2, Jan., [1904].

* * Only partly philatelic. The numbers for October and Decem Oet, greec. craye ber, 1903 are printed on coloured paper. Whe first bears the word "Supplement," neither have any number, while no. 2 has no yea given. Amalgamated with the "Collector's budget," March

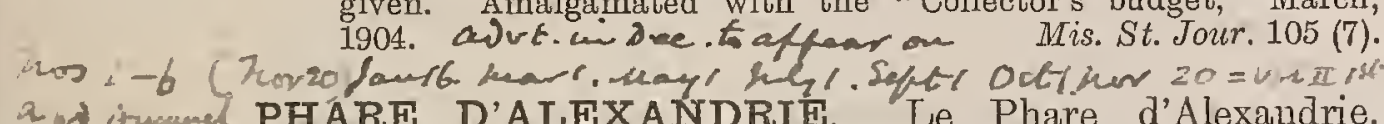
Vingt-deuxième année. No. 33. Février 2, 1895. [Contains a paragraph "Bonne Nouvelle" concerning a new issue of postage stamps.]

Fol. $24 \frac{1}{4}$ in. p. 2. Alexandrie, Dr. Haücalis-Pasha, 1895 Mis. St. Jour. 136 (19)

PHARF DES TIMBROPHILES. Le Phare des timbrophiles. Organe Egyptien philatélique. Paraissant 2 fois par trimestre.

Alexandrie, V. S. Nacamuli et Alfred M. Vais, I 897 .

8․ $9 \frac{3}{4}$ in. Nos. 1-2, May 15-July 1, 1897.

Mis. St. Jour. 117 (24)

PHILADELPHIA COLLECTOR. The Philadelphia collector. $8^{\circ} .8 \frac{1}{2}$ in. No. 1, February, 1885.

** Only partly philatelic. Wanting.

[Continued as:]

The Collector.

Philadelphia, Pa., W. C. Chiles, I885-86.

$8^{c} .8 \frac{7}{2}-9$ in. 13 nos. in 2 vols.

Vol. I. Mar., 1885-Jan., 1886. Nos. 2-12.

*"* Only partly philatelic. Nos. 7 and 8 were published together and nos. 10, 11, 13 and 14 have coloured paper wrappers. No. 14 has in error "whole No. 2". The journal was continued to December, 1887 , but after no. 14 it ceased to contain any philatelic matter.

PHILADELPHIA IVIONTHLY. The Philadelphia monthly.

Philadelphia, Pa., L. C. Heylin, J. H. Langstroth and G. H. Londen, $8870-72$.

$8^{\circ} .9 \frac{3}{4}$ in. and 9 in. 18 nos. in 2 vols.

Vol. I. July, 1870-June, 1871. Nos. 1-12.

II. Sept 1871-Feb., 1872 18.

* "* Only partly philatelic. Vol. I. measures 93 inches, vol. II. 9 inches, and the numbers of vol. II., have coloured paper wrappers. No. 5 of vol. II. has " 1871 " instead of "1872," except on the wrapper, which has the correct year.

[Continued as:]

The American boys' magazine.

Philadelphia, Pa., L. C. Heylin, J. H. Langstroth and G. H. Lionden, $\mathrm{x} \delta_{72}$.

$8^{\circ} .9$ in. Vol. III., 2 nos.

Vol. III. April, May, 1872. Nos. 1-2.

* * Only partly philatelic. Each number has a coloured paper *rapper and no. 2 was published by J. H. Langstroth and G. H. Londen. The title on the wrappers reads "The American boy's magazine".

PHILADELPHIA PHILATELIST. The Philadelphia philatelist. Philadelphia, Pa., [?], r899. in. No. 1, December, 1899.

PHILADELPHIA PHILATELIST. See PHIATELIST (Philadelphia $P a$.).

PHILADELPHIA PHILATELIST. See GERMANTOWN PHILATELIST.

PHILADELPHIA PRESS. The Philadelphia press. July 31, 1892. [Contains an article "New Jubilee stamps. The Post Office Department will issue a complete set in honor of Columbus. To be sold for one year."' Fol. $23 \frac{1}{2}$ in. p. 19.

Plilladelphia, [?], I8g2. Mis. St. Jour. 136 (14).
PHITADETPHTA STATIP NEWS. The Philadelphia stamp news. Philadelphia, Pa., H. M. Porter, r896. 8०. 9-8 $\frac{3}{4}$ in. Nos. 1-5, Jan.-Mar., May, Aug., 1896.

* Nos. 4 and 5 have coloured paper wrappers.

Mis. St. Jour. $92(7)$

PHILAT. LITTERATUR. Die philat. Litteratur. Monatschrift für die Interessen der philat. Litteratur.

Gumbinnen, R. Rose, jun., I894. C $8^{\circ} .8$ in. Nos, 1-2, Jan. 6-Feb. 5, 1894 .

Mis. St. Jour. $102(5)$

PHILAT. SCHU்LFRVEREIN BRUCHSAL. See MrTteilungen aus Dem Philat. Schứlerverein Bruchsal.

PHILATEL. NACHRICHTEN. See PhILATELIstischeR UцK.

PHILATELATSCH. Philatelatsch.

Leipzig, Leipzig Section des Internationalen Philatelisten-Vereins in Dresden, $\mathrm{x} 884$.

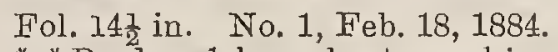

* * Produced by a hectographic process. The contents are of a humorous description.
Mis. St. Jour. 116 (13).

PHILATELIA. Philatelia. Organ für Gesammtinteressen der Postwertzeichenkunde.

Halle a S., etc., Verein Philatelia, etc., r888-9 $8^{\circ} .11$ in. 36 nos. in 4 rols.

1st year. Jan. 1-Dec. 10, 1888. Nos. 1-10.

2nd " " - " 1889. " $1-12$.

4th " " "Feb., 1891. " "

* * Commencing with no. 1 of the "second year the journal was published by the Verein für Briefmarkenkunde zu Braunschwei at Braunschweig. There is a title-page and an index to -each of the three first years. There is no number for April, July or October, 1888, and the number for September, 1888, is numbered " $7 / 8$ ". The two numbers of the fourth year are wrongly numbered "VI. Jahrgang".

PHILATELIA. Philatelia. Internationales Offertenblatt. Organ zur Beschaffung und Verwerthung aller Sammelobjecte.

Fol. 123 in. Nos. 1-2, Oct. 1-Dec. 1, 1890

* * Printed on buff paper. A copy of the prospectus, on white paper, is bound up with the two numbers. Mis. St. Jour. 73 (13).

PHILATELIA. A Philatelia. Revista internacional dos colleccionadores de sellos.

Campos, Brazil, Antonio Epiphanio de Mello e Manoel Lavra, 1894 .

Fol. $12^{\frac{3}{4}}$ in. No. 1, July 15, $1891 . \quad$ Mis. St. Jour. 97 (14).

PHILATELIA. Philatelia. I 896 .

Northampton, Mass., Philatelic Publishing Co.,

$8^{\circ} .6 \frac{3}{4}$ in. Nos. 1-13, March 14-June 27, 1896.

** Edited by J. Arthur Wainwright and published weekly except that the dates May 2, 9 and 16 were missed.

Mis. St. Jour. $148(2)$

PHILATELIA. Philatelia. Revista mensal. Para a defeza dos interesses dos colleccionadores de sellos. Guimarães, Portugal, Lnizz de Freitas, г 902. 8. 91 -91 in. Nos. 1-7, May-November, 1902.

* * Wanting nos. 4,5

PHILATELIA. Philatelia. Illustriertes Organ für die Gesamtinteressen des Briefmarken- und Ansichtskartensports. DDummy copy of a journal to be published by Nuenschwander's Buchdruckerei, Weinfelden, Schweiz, in January, 1903, but which was never issued.]

Mis. St. Jour. 140 (8).

PHILATELIA HUIMORISTICA. Philatelia Humoristica. Organ für Possewerthzeichen Kunde.

Dresden, Internationaler Philatelisten-Verein, x892. $8^{\circ} \cdot 9 \frac{3}{4}$ in. Nos. 1-2, June 15-July 15, 1892. ** This is a supplement to "Der Philatelist" with which it is
bound up.

PHILATELIA HUIMORISTICA. See MitTELDEUTSCHE Philatelisten-Zeitung. 
"PHILATELIAS". "Philatelias". Internationales Central-Organ für das gesammte Sammelwesen. Lïbeck, München [printed], Johs. Duncker, I 897.

$4^{\circ} .113$ in. No. 1 , July 10, 1897.
$*$ * The contents consist entirely of advertis ements.

Mis. St. Jour. $120(6)$

PHILATELIC ACORN. The Philatelic acorn. Or stamp news in a nut shell. Springfield, Mass., J. B. Royce, I 901-02. $8^{\circ} .9$ in. 6 nos. in 2 vols.

Vol. I. [Sept], 1901-January, 1902. Nos. 8-12

** II. March, 1902. No. 2

* No. was the first published, the journal being a continuation is a "s" is numbered in error " 8, and nos. 11 and 12 were published to-
gether. There is no number 1 of vol. II. Wanting no. 9 .

Mis. St. Jour. 154 (14).

PHILATELIC ADVANCE. The Philatelic advance. Berwyn, Ill., Wm. B. Porter, Jr., I 897. $24^{\circ} .5 \frac{1}{4}$ in. No. 1, May, 1897. Mis. St. Jour. 106 (1).

PHILATELIC ADVERTISER. The Philatelic advertiser. New York, I. E. Dickert, I876. $8^{\circ} .9$ in. Nos. 1-3, Sept., Oct., Dec., 1876. 1 Mis. St. Jour. 24 (7).

PHILATELIC ADVERTISER. The Philatelic adver-

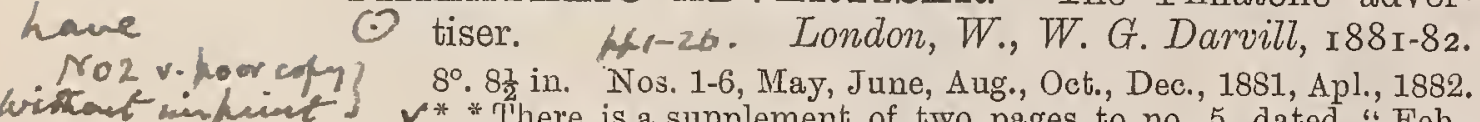

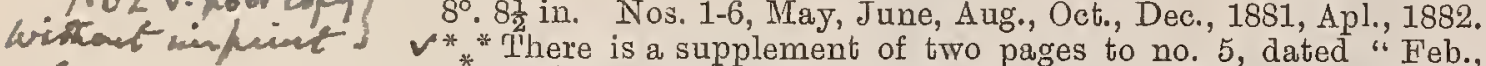
1882 ," and there is a second edition of no. 6, with the date "May, $20 \%$. A copy of the prospectus of the journal is bound up with it. wart rol expecte no Mis. St. Jour. 30 (6).

PHILATEIIC ADVERTISER. The Philatelic advertiser. Philadelphia, Pa., H. S. Jeanes, 1885. $8^{\circ} .91$ in. Nos. 1-5, Feb.-June, 1885 ** There is a supplement of (2) pp. to no. 2

Mis. St. Jour. 18 (2).

6 PHILATELIC ADVERTISER. The Philatelic advertiser. Bloomington, Ill., Rudolph A. Wills, x893. $32^{\circ} .5$ in. No. 1 July, 1893.

* * The number has a coloured paper wrapper. Hay lans.

Mis. St. Jour. 69 (3).

- PHILATELIC ADVERTISER. The Philatelic advertiser. London, W., R. Braegger and Co., etc., I894-95.

(2) $4^{\circ} .11$ in. Nos. 1-10, Sept. 1, 18ษ4-May, July, 1895. ${ }^{*}{ }_{*}^{*}$ Nos. $6-10$ were published by Braegger Brothers. "The contents
consist entirely of advertisements.
Mis. St. Jour. 77 (6).

PHILATFIIC ADVERTISER. The Philatelic advertiser. A monthly journal devoted to stamp collecting.

Tuskaloosa, Ala., Eddins and Davis, etc., I895. 8०. 9 in. Nos. 1-2, Mar.-Apl., 1895.

* No. 2 was published by A. M. Eddins and Co. tiser. $8^{\circ} .9 \frac{1}{4}$ in. 21 nos. in 4 vols.

ol. I. Nov. 5, 1895, Jan. 5, 20, Feb. 5, 20, Mar. 5, 1896 . Nos. "II. Mar. 20, Apl. 5, 20, May, 5, 20, June 5, 1896. Nos. " III. June 20, July 5, 20, Aug. 5, 20, Sept. 5, 1896. Nos. $1-6$

1-6. 20 , Oct. $5,20,1896$. Nos. $1-3$.

* * The contents consist entirely of adverti iements. No. 1, vol. I., bears the words "New Series". Mis. St. Jour. 92 (10).

PHILATELIC ADVERTISER. The Philatelic advertiser.

Philadelphia, Pa., Carl Young, I898-99. 8०.91. in. Nos. 1-6, September 1898-February, 1899 $*$ * The contents consist entirely of advertisements. Wanting all
six nos.

PHILATELIC ADVERTISER. The Philatelic advertiser. Sioux Falls, S. D., Martin E. Nelson, I 904 $8^{\circ} \cdot 7 \frac{1}{2}$ in. Nos. 1-2, January-February, 1904. * * No. 1 is dated in error "1903". Wanting no. 1 Mis. St. Jour. 154 (8).
PHILATELIC ADVERTISER. The Philatelic advertiser.

Ithaca, N. Y., L. M. Mintz and L. Crandall, etc. I 904-06.

Fol. 11 in. 21 nos. in 2 vols.

Vol. I. Nov. 15, 1904 Oct. 15, 1905. Nos. 1-11.

* II. " 15, 1905-Aug. 20, 1906.

* Commencing with no. 5, vol. I., the journal was published by L. M. Mintz. There is no number for March, 1905.

PHILATELIC ADVERTISER. See MoNTHLX PHILATELIC ADVERTISER (Ogden, Utah.).

PHILATELIC ADVFRTISER AND COLIECTORS

6 REFEREF. The Philatelic advertiser and collectors referee. London, W., S. Hellier, I888.

(2) 40.93 in. Nos. 1-10, Jan.-Oct., 1888 . (am ine.r) a-

* * There is a title-page and an index to the ten numbers, which form volume i., Cand a copy of the prospectus of dated November, 1887, is bound up with it.

[Continued as :] 9 The Philatelic advertiser and young men's miscellany.
London, $W ., S$. Hellier, x 888.

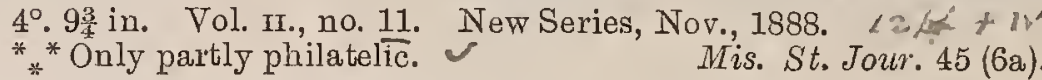

PHILATELIC ADVERTISER AND YOUNG IMEN'S IMISCELLANY. See PhILAtelio advertiser aND COLLECTORS' REFEREE.

PHILATELIC ADVOCATE. The Philatelic advocate. Berlin, Ont., Starnaman Bros., I896-1901. $8^{\circ} .9$ in. and $7 \frac{3}{4}$ in. 61 nos. in 11 vols.

Vol. I. Sept., Nov., Dec., 1896. Nos. 1- 3

II. Jan. -June, 1897.

III. July-Dec.

IV. Jan. -June, 1898

v. July-Dec.,

vi. Jan. -June, 1899

vII. July -Dec.

viII. Jan. -June, $19 \ddot{00}$

IX. July-Dec.

x. Jan. -June, 1901.

* "XI. July -Sept., "

"10-16.

$" \quad 23-28$.

"

$35-40$

$41-46$

" $47-52$

" 53-58.

* There is a paper wrapper to each number. Nos. 1-14 measure inches and the remaining numbers $7 \frac{3}{4}$ inches. There is a second edition of the number for July, 1897, numbered 11. The wrappe of no. 12 is wrongly numbered "vol. 3. No. 2. Whole no. 11 " instead of "vol. 3 , no. 3. Whole no. 12," nos. 13 and 16 are wrongly numbered "14" and "15," respectively, except on th wrappers, which are correct. No. 32 is wrongly numbered " 31 " except on the wrapper, which is correct, and the wrapper of no. 36 is wrongly numbered " 37 ". No. 54 is wrongly numbered " 53 ," except on the wrapper, which is correct. Amalgamated with the "Canada stamp sheet and energy".

PHILATEIIC-AIBUM. Philatelic-album. Journal du collectionneur de timbres.

Marseille, A. F. Pinet, I 899-1900.

$8^{\circ} .9 \frac{3}{4}$ in. 24 nos. in 2 vols.

1st year. [Jan. ]-Dec. 1, 1899. Nos, 1-12.

[2nd "] " $1-, 1,1900$. ", 13-24.

** Edited by "Pierre d"Hure. Nos. 21 " and 22 were published together, but are wrongly numbered "21/21," and nos. 23 and 24 were also published together. Nos. $13-15$, and 17-24 have coloure paper wrappers. The first number has "Première année" but no date, nos. 2-4 have "Premier Février 1899 "_-Premier Mars 1899" "Premier Avril 1899," respectively, while from no. 5 the date is given as " ler Mai," etc.

PHILATELIC AIIIRICAN. The Philatelic American. Atlanta, Georgia, W. B. Symmers, I 885 $8^{\circ} .9$ in. No. 1, Dec. 15, 1885.

* * Edited by D. McD. Parkhurst. The number has a coloured paper wrapper. Mis. St. Jour. 23 (3).

PHILATELIC AND PHOTOGRAPHIC EAST. The Philatelic and photographic east. (Formerly The club bulletin.)

Wastington, D. C., The East Publishing Co., 1903. . S1/2 $8^{\circ} .9$ in. Nos. 1-4, February-May, 1903. $*_{*}^{*}$ Wanting nos. $1,2,3$.

\section{Philatelei Pivertior, Woth.S. Samontson

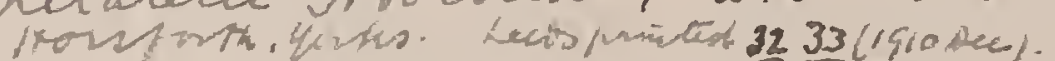

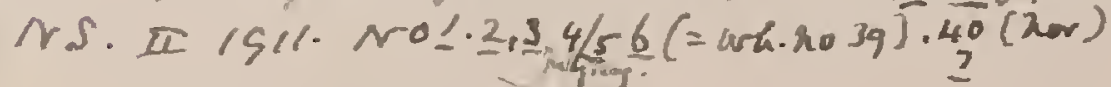 III $1512 \quad 43 \quad 45$.}

on No. 89 " h temational Philatehi Anentiver

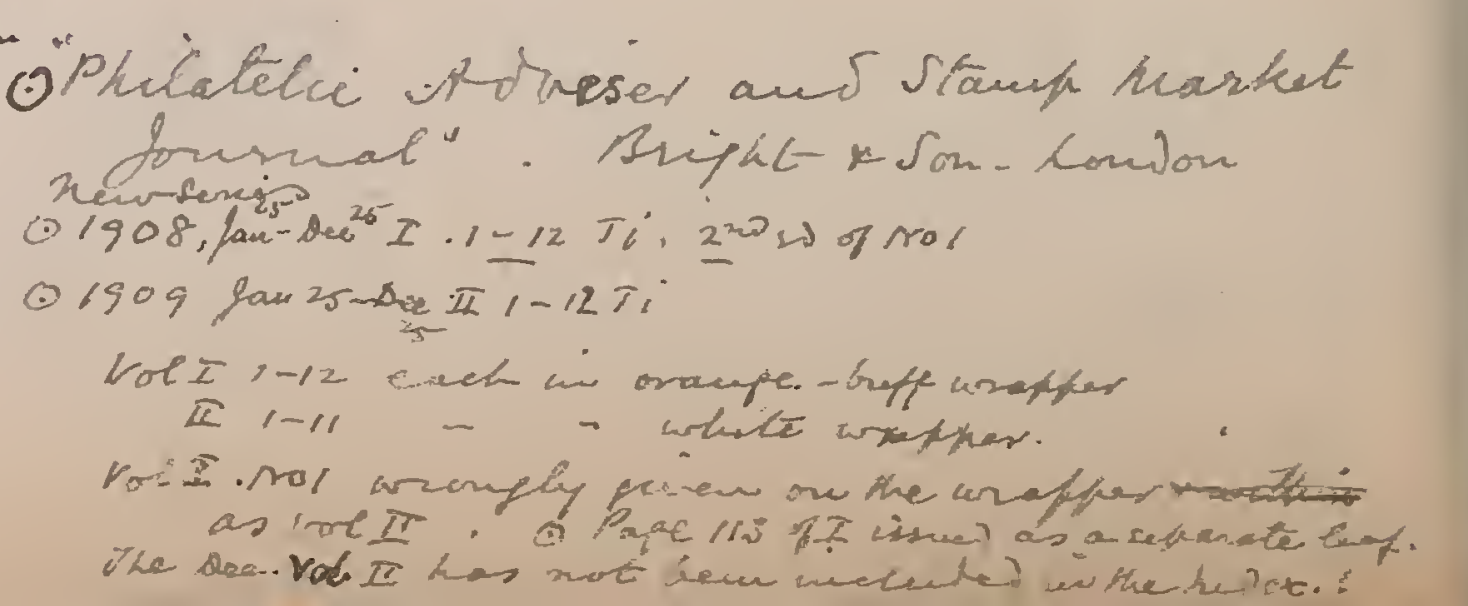


a 
Phlatic Aultitio - Detwert P. Fudnucte 
PHILATELIC AND PHOTOGRAPHIC EAST.

[Continued as :]

- The Philatelic east. A journal of collecting.

Washington, D. C., The East Publishing Co., I 905. $8^{\circ} .9$ in. Nos. 4-7, January-April, 1905.

PHILATELIC ARGOSY. The Philatelic argosy. Buffalo, N. Y., Frank R. Hoyt, I892-93. $24^{\circ} .5 \frac{3}{4}$ in. and $8^{\circ} .9-8 \frac{1}{4}$ in. 11 nos. in 2 vols.

Vol. I. Jan., Mar., May, Sept., Oct., Nov., 1892. Nos. 1-6. * " "II. 1. -May, 1893 . $4-6$, vol. I., and the numbers of vol. II. have paper wrappers. No. 4 , vol. r., is dated "September, 1892" but the wrapper bears "July 1892 ". Bound up with the eleven numbers is a letter from the publisher, dated September 12 th, 1893 , which states that no. 5 ,
vol. II., was the last number issued. Continued as a non-philatelic vol. II., was the last number issued. Continued as a non-philatelic magazine with the title "People's argosy"

Mis. St. Jour. 119 (7).

PHILATELIC BAZAR. The Philatelic bazar. Williamsville, Mass., Wm. B. Hale, I886-87.

$32^{\circ} .4 \frac{1}{4}$ in. 5 in. and $4 \frac{1}{2}$ in. Nos. 1-12, September,1886-1887.

* * No. 2 is dated "September" in error for "October" and nos. -12 bear the date " 1887 " without any month. Nos. 6, 11,
12 are printed on pink paper. For continuation see "Collectors" 12 are printed on pink paper. For
world". Wanting nos. $4,5,7,8$.

PHILATELIC BEACON. The Philatelic beacon. Some ink, paper and light.

Newton, Mass., The Beacon Publishing Co., г888-9т. $8^{\circ} .8 \frac{3}{4}$ in. 31 nos. in 3 vols

Vol. I. Oct. 1, 1888-Sept. 1, 1889. Nos. 1-12.

" II. " 1, 1889- " 1, 1890. " $1-12$. 1 .

*"* "Vols. I." and Ir. have title-pages and indexes and there is a coloured paper wrapper to each number, excepting nos. 10-12, vol. I.

PHILATELIC BROKER. The Philatelic broker

Philadelphia, Pa., Wm..E. Scarlett, 1893.

$8^{\circ} .9$ in. Nos. $1-2$, Sept.-Oct., 1893 .
${ }_{*}^{*}$ * This is solely a list of stamps for which bids are asked and each number consists of a single leaf printed on one side only. Mis. St. Jour. 119 (6).

PHILATELIC BULLETIN. The Philatelic bulletin. Of interest to all classes of stamp collectors.

Salem, Mass., The Naumkeag Stamp and Publishing Co., $\mathrm{x} 897-99$.

$8^{\circ} .9$ in. 21 nos. in 2 vols.

Vol. I. Sept. 25, 1897-Aug. 25, 1898. Nos. 1-12

"Ir. "25, 1898-May 25, $1899 . \quad$. 13-21.

* * There is a paper wrapper to each number and the wrapper of no. 14 bears no date. F'or continuation see "Philatelic bulletin and Eastern philatelist".

PHILATELIC BULLETIN AND EASTERN PHILATELIST. See EASTERN PHILATELIST.

PHILATELIC CALIFORNIAN. The Philatelic Californian. A monthly philatelic magazine.

San Francisco, Cal., etc., California Philatelic Press Club, etc., I893-97.

$8^{\circ} .83$ in. 35 nos. in 3 vols.
Vol. I. Oct., $1893-$ Nov., 1894. Nos. 1-12.

" II. Dec., 1894-Dec., 1895. " $1-12$.

*" III. Jan., 1896-Apl., 1897. " "1-11. "*ach number has a coloured paper wrapper. Nos. 9-11, vol. Cal. No. 9, vol. I., is dated "June, July, Aug., 1894," no. 5, vol. II., is without date, except on the wrapper which has "A pril, II., is without date, except on the wrapper which has "April, gether under the date "December, 1895" "No. 7, vol. III, bears no month no. 8 is dated "October, 1896" "no. 9, "January, 1897" no mon ", wrappers of these five numbers have no month given.

PHILATELIC CANADIAN. The Philatelic Canadian. A monthly stamp paper.

Toronto, Walter McMahon, 1896-97. 8․ 83 in. Tos. 1-4, Dec., 1896-Mar., 1897. ** There is a coloured paper wrapper to each number. Mis. St. Jour. 95 (4).
PHILATELIC CENTURY. The Philatelic century.

Madison, Wis., The Philatelic Century Co., $188 \%$.

$8^{\circ} .9$ in. Nos. 1-4, Apl., May, June, Sept., 1887.

* * Edited by Frank M.' Davis and J. F. Strasilipka.

Mis. St. Jour. 23 (14).

PHILATELIC CHRONICLE AND ADVERTISER.

The Philatelic chronicle and advertiser.

97.

Birmingham, The Philatelic Publishing Co., 1891-

$4^{\circ} .8$ in. 68 nos. in 6 vols.

Vol. I. Oct. 16, 1891-Sept. 17, 1892. Nos. 1-12.

"II. " 17, 1892- " 20, 1893. " 1-12.

" III. " 25, 1893- " 20, 1894. " " 1-12.

" IV. " 20, 1894- ", 23, 1895. " " 1-12.

" V. " "22, 1895-" $\quad 26,1896 . \quad$ " $1-12$.

* ** There is a title-page and an index to each volume and a paper wrapper to each number. The wrappers and advertisement pages of the first twenty-four numbers are paged up with the rest of the contents. No. 2, vol. I., November 16, 1891, has no number and the wrapper of no. 7, vol. I., is wrongly dated "March 22, 1892," instead of "April 16, 1892". The number for "March 25, 1896," is dated in error "February 22nd 1896," on page 41, and the number for "July 18, 1896," is dated in error "June 20th, 1896," on page 73 , but the wrappers of both these numbers have the correct dates.

\section{[Continued as :]}

The Philatelic chronicle and advertiser and philatelic times.

Birmingham, The Philatelic Publishing Co., I897-

S113

I 903

$4^{\circ} .8$ in. and $8^{\circ} .9 \frac{1}{2}$ in. Vols. VI.-xIr. 79 nos.

Vol. vI. June 26, -Sept. 25, 1897. Nos. 9-12

" VII. Oct. 23, 1897- " 21, 1898. " 1-12.

" VIII. " 27, 1898- " 30, $1899 . \quad$ " $1-12$

"IX. " 31, 1899-Dec. 1900. "

", x. Jan.-Dec., 1901. Nos. 1-12.

" XI. " - " 1902. " $1-12$.

*" * Xols. VI.-IX. are quarto and the subsequent volumes are octavo. There is a title-page and an index to each volume, excepting the last, and a coloured paper wrapper to each number. The words "and Philatelic times" are dropped from the title on the paper wrappers of the numbers of vols. X.-XII. The number for "July 20, 1897 " has the wrapper wrongly numbered "Vol. 7. No. 9" in place of "Vol. 6.- No. 10". The wrapper for "Oct. 31, 1899" is wrongly numbered "Vol. 9. No. 13" instead of "Vol. 9. No. 1," and the wrapper of vol. 9. no. 6, is dated "March 6" instead of "March 26".

\section{[Continued as :]}

The Philatelic chronicle and the advertiser of wants and offers.

Birmingham, The Philatelic Publishing Co., I 904-

$8^{\circ} .9 \frac{1}{2}$ in. Vols. XIII.- nos. In progress.

Vol. XIII. Jan.-Dec., 1904. Nos. 162-173.

" XIV. "- " 1905. "174-184.

", xv. " - " 1906. " 185-194.

*" "There is" a coloured paper wrapper to each number with the title "The Philatelic chronicle and advertiser". No. 179 is dated "June-July, 1905," no 190, "June-July, 1906" and no. 192 "Sept.-Oct., 1906".

PHILATELIC CHRONICLE AND ADVERTISER AND PHILATELIC TIMIES. See Philateito CHRONICLE AND ADVERTISER.

PHILATELIC CHRONICLE AND MICHIGAN PHILATELIST. The Philatelic chronicle and Michigan philatelist.

Charlotte, Mich., H. E. William, I899-I90I.

$8^{\circ} .9$ in. 15 nos. in 3 vols.

Vol. I. Nov., 1899-April, 1900. Nos. 1-6.

"II. May, -Oct.,

*" III. Nov, 1900-Jan., 1901. " "1-3. Michigan philatelist" being dropped from the title on the wrappers after the completion of vol. I. No. 3, vol. III., is wrongly dated "1900" in place of "1901," except on the wrapper, which is correct. 
PHILATELIC CHRONICLE AND MICHIGAN PHILATErIIST. [Continued as :] The Philatelic chronicle and philatelic index.

8. 9 in. Vols. III-IVarlotte, Mich., H. E. Williams, rgor. $8^{\circ} .9$ in. Vols. III.-IV. 5 nos.

Vol. III. Feb.-Apl., 1901. Nos. 4-6.

*"* IV. May-June, ", "1-2.

* * Each number has a coloured paper wrapper with the title "The Philatelic chronicle". Amalgamated with the "New York Philatelist," October, 1901, and with "Leve's New Perforator," November, 1901.

PHILATELIC CHRONICLE AND PHILATELIC INDEX. See Phimateitic chronicle and Michigan PHILATELIST.

PHILATELIC CHRONICLE AND THE ADVERTISTR OF WANTS AND OFFERS, See PHILATELIC CHRONICLE AND ADVERTISER.

PHILATELIC CIRCULAR. Philatelic circular.

Susquehanna, Pa., T. A. Hayward, 1876. $8^{\circ} .8 \frac{1}{2}$ in. No. 1, Sept., 1876

Mis. St. Jour. 28 (10).

PHILATELIC CLIPPER. The Philatelic clipper. A monthly magazine devoted to stamp collecting and journalism. Burlington, Kan., C. E. South, r892. $8^{\circ} .8 \frac{3}{4}$ in. No. 5, Feb., 1892.

* * Nos. 1-4 had the title the "Clipper" and were not philatelic. Mis. St. Jour. 63 (5).

PHILATELIC CLIPPINGS. The Philatelic clippings. [Prospectus of a journal to be published by William H. Meredith, Hoboken, N. J., on or about November 15, 1896, but which was never issued.]

Mis. St. Jour. 149 (3).

PHILATELIC COMFORT. Philatelic comfort. Cumberland, Me., J. S. Dunn, x894-95. $4^{\circ} .7 \frac{3}{4}$ in. 18 nos. in 3 vols

Vol. I. Mar. 1 -Aug. 1, 1894. Nos. 1-6.

"II. Sept., 1894-Feb. 1, 1895. " 1-6.

*" III. Mar. 1 -Dec." 1895. an" 1-6., "Vol, nII., no. 1, is dated "March and April," no. 2, May and June," no. 3, "July and August," " no. 4, "September and October," no. 5, "November," and no. 6, "December".

Mis. St. Jour. 66 (4)

PHILATELIC COURIER. The Philatelic courier.

New York, L. Bernnger, 1898

$8^{\circ} .11$ in. Nos. 1-2, Feb.-May, 1898.

Mis. St. Jour. 126 (13)

PHILATELIC COURIER AND STAIMP COLLEC-

TOR'S JOURNAL. The Philatelic courier and stamp collector's journal.

Halifax, N. S., Henry Hechler, r88г-89. Fol. 121 in. 11 nos. in 3 vols. and 7 subsequent supplements. Vol. I. Scpt. 10, 1881, Jan., Apl., Dec., 1882. Nos. 1- 4.

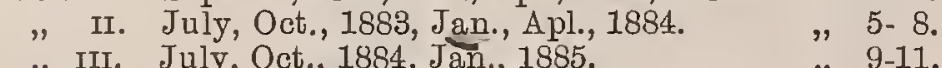
*" III. July, Oct., 1884, Jan., 1885 . There are advertising supplements to nos. 3 and 4 consis * There are advertising supplements to nos. 3 and 4 consisting
of four pages each, and coloured paper supplements of two pages to nos. 10 and 11. There are additional supplements with the following dates, April, July, 1885, March, June, 1887, April, November, 1888, and Aug sti, 1889. The two first are on coloured paper and consist of two pages each, the remainder are on white paper and consist of from four to eight pages. All the supplements consist entirely of advertisements.

$\triangle \quad$ PHILATELIC CRITIC. The Philatelic critic. "Truth $\odot$. without fear". London, N., Edwin England, r887-88. (vol Mrem $4^{0}$. 81 in. Nos. 1-9, Apl., July, Sept., Nov., 1887, Jan., Feb., Mar., ** There is a colour.

${ }^{*}$ * There is a coloured paper wrapper to each number. $V$ Nos. 8

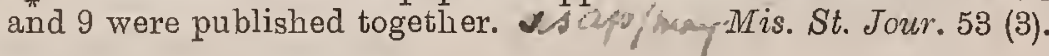

PHILATELIC CRITIC. See Monthly stamp world.

PHILATELIC CURRIFR. The Philatelic currier. Williamsville, Mass., A. E. Bennett, r892. $8^{\circ} .8$ in. Nos. 1-2, Feb.-Mar., 1892. Mis. St. Jour. 63 (11).

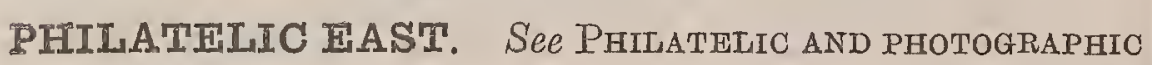
FAST.
PHILATELIC EPOCH. The Philatelic epoch. [Prospectus of a journal to be published by Frank M. Davis, Madison, Wis., on May 1, 1889, but which was never published.]

Mis. St. Jour. 76 (2).

PHILATELIC ERA. The Philatelic era.

Portland, Me., Pickard and Eustis, etc., I889-94. $8^{\circ} .8 \frac{1}{2}-8 \frac{3}{4}$ in. 72 nos. in 8 vols.

Vol. I. Sept. 16, 1889-Feb. 16, 1890. Nos. 1- 6

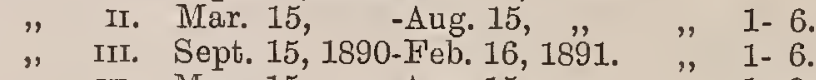

" IV. Mar. 15, -Aug. 15, , , 1- 6 .

"v. Sept., 1891-Aug., 1892. " 25-36.

"VI. " 1892- " 1893. "37-48.

"VII. " 1, 1893-Feb. 15, 1894. " "49-60.

"viIr. Mar. 1, -Aug. 15, 1894. " 61-72.

* ** Commencing with no. 1, vol. III., the journal was published by Pickard and Jewett and commencing with no. 5, vol. IV., by W. W. Jewett. Nos. 4-6, vol. III., and nos. 1-3, vol. IV., have coloured paper wrappers and so have the subsequent numbers commencing with no. 25. Nos. 5 and 6, vol. III., have "1890" instead of "1891," except on the wrappers which have the correct year and there is a supplement of two pages to no. 5 , vol. IV. Commencing with no. 49 the journal was published fortnightly.

[Continued as :]

The Weekly philatelic era

Portland, MLe., etc., W. W. Jewett, etc., x894-1904. $8^{\circ} .83$ in. and fol. 113 in. Vols. IX.-xviII. 494 nos.

Vol. IX. Sept. 1, 1894-Sept. 28, 1895. Nos. 73-124.

" x. Oct. 5, 1895- " 26, 1896. " 125-176.

" XI. " $\quad 3,1896-", 25,1897 . \quad " 177-228$.

" XII. " 2, 1897- " 24, $1898 . \quad " 229-280$.

" XIII. " "1, 1898- " $243,1899 . \quad$ " 281-332.

" XIV. Sept. 30, 1899- " 22, $1900 . \quad$ " $333-384$.

" XVI. " 28 28, 1901- " $" 20,1902 . \quad$ " $385-436$.

" XVII. " "27, 1902- " 19, 1903. " 489-540.

"XVIII. " 26, 1903-Mar. 19, $1904 . \quad$ " 541-566.

* * Nos. 73-124 are octavo and each of these numbers has a coloured paper wrapper. There are no numbers dated June, 1895 , and no. 120 has in error "whole no. 12". Commencine with no. 125 the size of the journal is increased to $11{ }^{3}$ inches. Nos. 144 $196,246,257$, and 400 have paper wrappers no. 46" in place of "no. 49 " and no. 365 has "vol. XIv. no. 3 ;" instead of "no. 33". Nos. 545-566 were published at Boston Mass., by the Philatelic Era Publishing Co. For continuation see "Mekeel's weekly stamp news and the weekly philatelic era".

PHILATELIC ERA. The Philatelic era.

Wymore, Neb., Consolidated Stamp Co., rgor. $8^{\circ} .9$ in. No. 1, August, 1901

Mis. St. Jour. 144 (2).

PHILATELIC EXAIMINER. The Philatelic examiner. Phoenix, Arizona, Chester Mathers, r901-02.

$8^{\circ} .8-9$ in. Nos. 1-5, Sept. 1-Dec. 1, 1901, Mar. 15, 1902 "* * Nos. 1,2 and 4 have coloured paper wrappers. No. 1 is dated
in error "1801," except on the wrapper which has the correct date. Mis. St. Jour. 113 (9).

PHILATELIC EXCHANGE. The Philatelic exchange. Philadelphia, Pa., John Holt, r89r. 16 $6^{\circ} .5 \frac{1}{2}$ in. Nos. 1-6, May-Aug., Oct., Dèc., 1891.

Mis. St. Jour. 69 (7).

PHILATELIC EXCHANGE AND ADVERTISER

() The Philatelic exchange and advertiser. Published on the first of every month.

London, S. E., Lawrence and Co., r89r.

$4^{\circ} .81$ in. No. 1, Dec., $1891 . \quad$ Mis. St. Jour. 53 (4). ILIC EXCHANGE AND IMART. The Phil-

atelic exchange and mart.

$\phi \quad$ [1903]

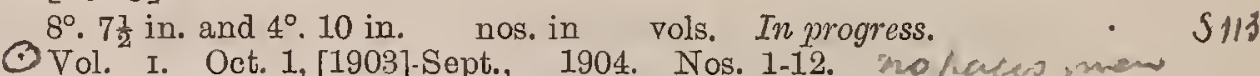

O. II. "II. " $1904-$ " $1905-1,1905 . \quad$ " $13-24$.

", IV. " $\quad$ 1., 1906- " $\quad 1,1906 . \quad$ " $25-36$.

*"* Nos. 10-12 were published by the Philatelic Printing Co. at Marldon and the subsequent numbers by the same Company in

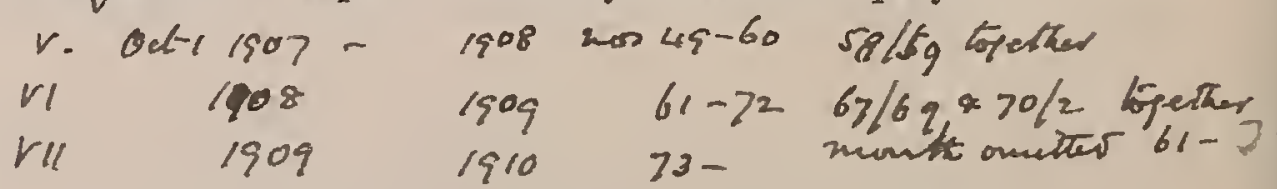


PHILATELIC CIRCULAR. (London, A. H. Harris)

Vols. I-Y (1911-15). Publishers' binding.

PHILATELIC MAgAzINE. (London, A, H. Harris, later Harris

Publications).
Vols. VI-Xi (1916-22). Publishers' binding.

Vols. Xil to date (1923-). Unbound.

Philatire frealna, Bumingham

Lo, Jondon 1881
PHILATELIC CLASSICS. (New York, C. J. Phillips).
Yis. 1-14. (1927-31). Unbound.

Philatiluc Dictionary by Poole Partó 1 2 $\left(A-h_{1}\right)$ $10210 p 1908$

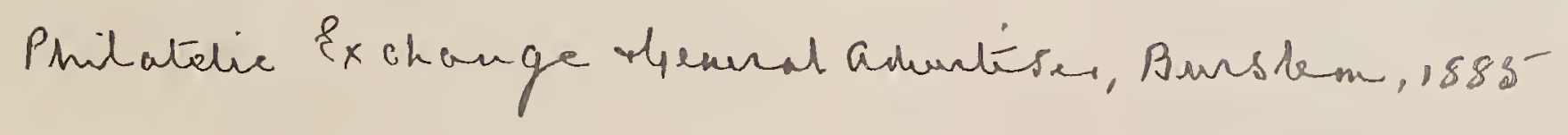

$$
\text { Phlative bachange. Tatedo }
$$

Ph.1-57, hesiles asot - 4p

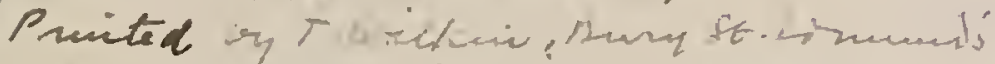

Die unaffer begumine with ros, is ntirele.

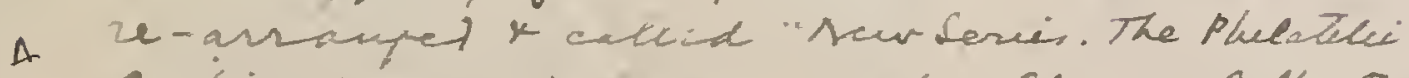

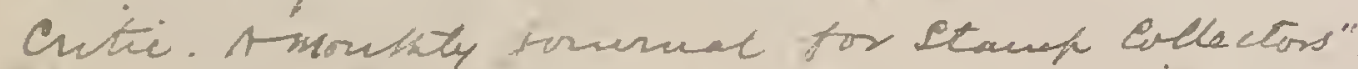

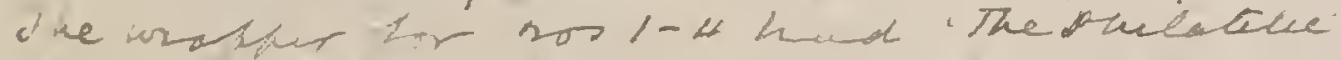

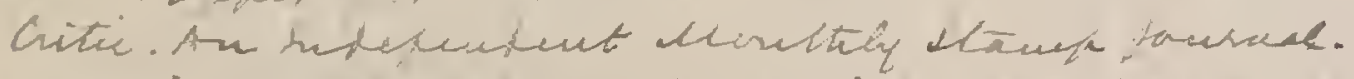

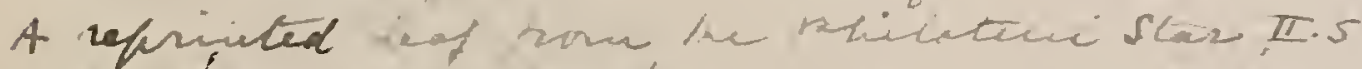

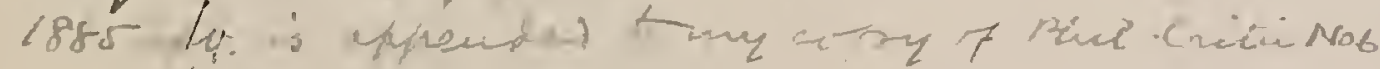

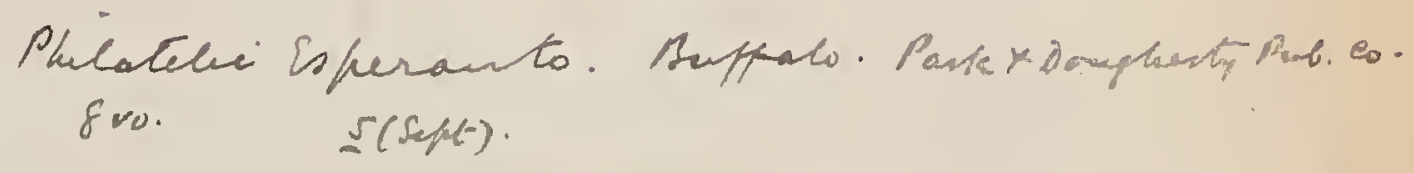

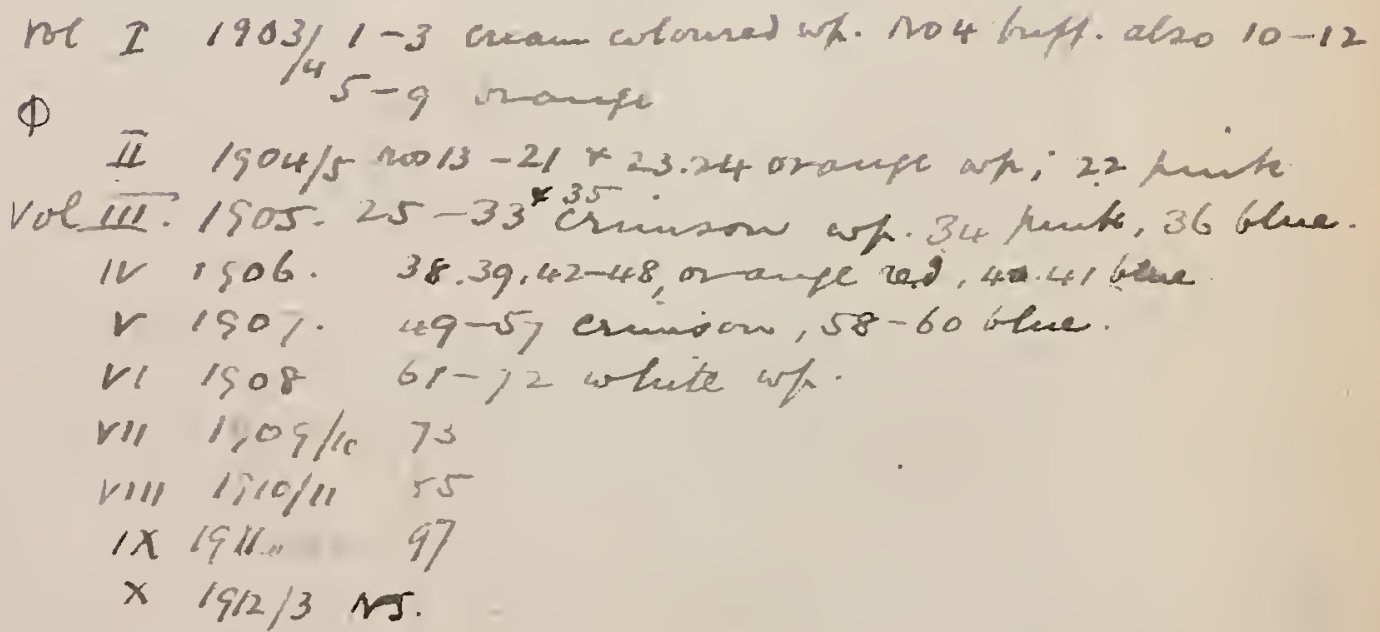


Miniativis chame mert.

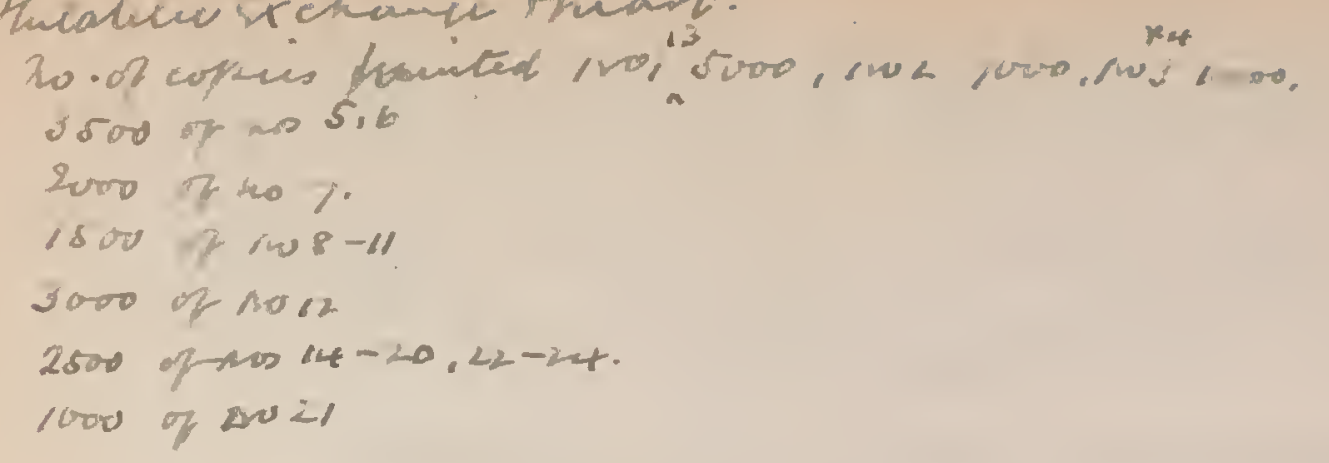

PHUATELIC FACTS, IOWA

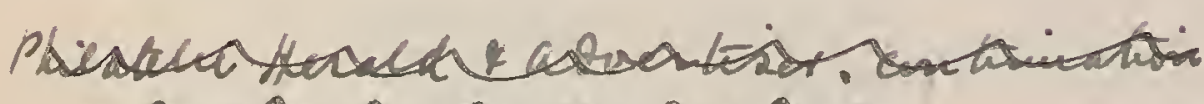
ox rast owa adatis.

Pulativedrapotic - Duquesse. P

Pielatelic Hashes.

i2n. Chomfraign. Le. V. h. Clark.

$191 \%$ I. $\quad=(\mathrm{hm})$

Philatelic l, azeste, Swansera, 18804 PHILATELIC GAZETTF.
Vols. I-Y'111 (1910-18). Privew York, Philaty bound, clicth. Publishing Co., etc.)

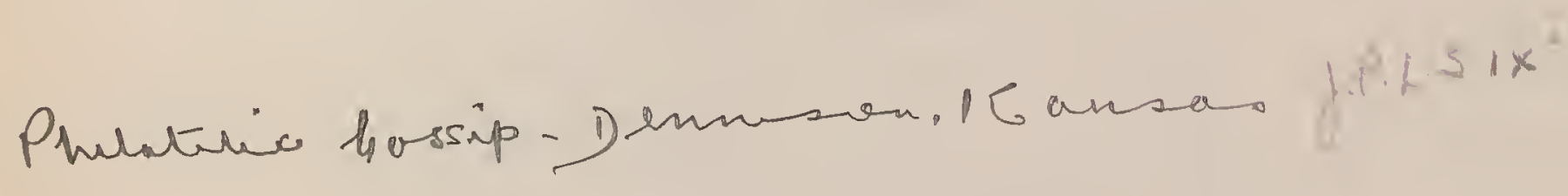




\section{PHILATELIC EXCHANGE LIST}

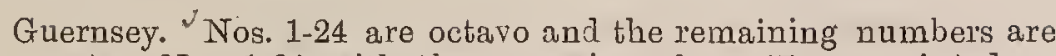
quarto. VNos. 1-24, with the exception of no. 17, are printed on coloured paper, and nos. 1-12 contain advertisements only. Commencing with no. $\mathrm{f}$ t each number has a coloured paper wrapper and the wrapper of no. 38 has "vol. v." in error for "vol. IV."

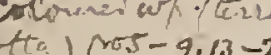
likt Lmf: $1-4$ Nos. 6 and 36 have supplements and nos. 1-4 have no year datc.

PHIL ATELIC FXCHANGE LIST. The Philatelic ex-

- change list.

Pus. Islington, London, N., etc., Percy C. Bishop, etc.,

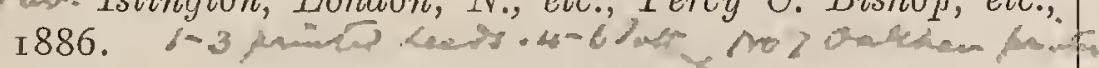
$08^{\circ} .81$ in. Nos. 1-7, Feb.-Aug. 15, 1886.

5113

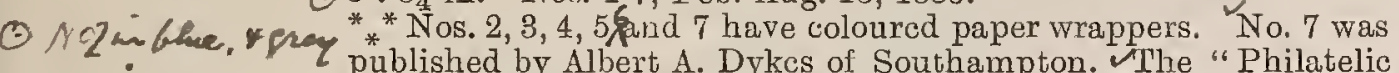

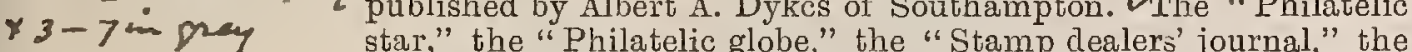
"star," the "Philatelic globe," the "Stamp dealers' journal," the "Foreign stamp collectors" news" and the "Philatelists" own paper" were amalgamated with the last number. \$flu hot

PHILATELIC EXPRESS. The Philatelic express. In the interests of stamp collecting

Portland, Me., J. H. Lyons, I889-9o. $8^{\circ} .8 \frac{1}{4}-8 \frac{1}{2}$ in. Nos. 1-13, May, 1889-June, 1890.

* *There is no number for October, 1889. Mis. St. Jour. 32 (5)

PHILATELIC EXTRACT. The Philatelic extract. The essence of the science. Official journal of the Philatelic Order of Masons. Eldred, Pa., B. G. McFall, i goo. $8^{\circ}$. 7 in. Nos. 1-3, April-July, 1900 .
* No. 3 is dated "June-July, 1900 "

Mis. St. Jour. 148 (4)

PHILATELIC EXTRACT AND ADVERTISER. Phil atelic extract and advertiser.

London, S.E., Lawrence and Co., I892.

(1) 8०. F in. Nos. 1-3, July 20-Sept. 20, 1892, 2na (

The coast Stamp Club" “" of the poofectur Mis. St. Jour. 79 (9)

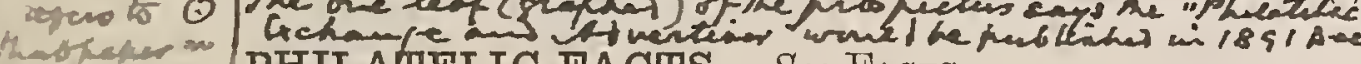
PHILATELIC FACTS. See FAOTS.

PHILATELIC FAVORITE. The Philatelic favorite. Devoted to the interest of stamp collectors. New York, John V. Drozdowski, I 877 . $32^{\circ} .5 \frac{1}{4}$ in. and $8^{\circ} .7 \frac{1}{4}$ in. 8 nos. in 2 vols.

Vol. I. Feb. 15-July 15, 1877. Nos. 1-6.

* "* II. Aug. and Sept., 1877. Nos. 1-2. * Nos. 1-3 are printed on buff paper and are $32^{\circ}$. The other 6 , vol. I., and nos. 1 and 2 , vol. II., were severally published to6, vol. I., and nos. 1 and 2, vol. II., were severally published to-
gether.
Mis. St. Jour. 41 (5).

PHILATELIC FORTNIGHTLY. The Philatelic fortnightly.

Benson, Minn., etc., D. Y. Smith, etc., I887-88. $12^{\circ} .7 \frac{1}{4}-8$ in. and $8^{\circ} .8 \frac{3}{4}-9 \frac{2}{4}$ in. 15 nos. in 2 vols.

Vol. I. Apl. 5-Sept. 15, 1887. Nos. 1-9.

" II. Oct. 1, 1887-Jan. 15, 1888. Nos. 10-15.

* * Nos. 8-15 were published at Bellville, O., by A. B. Burkholder Nos. 1-6 arc $12^{\circ}$. $7 \frac{1}{4}$ inches, no. 7 is $12^{\circ} .8$ inches, nos. $8-15$, excepting no. 9, are octavo $9 \frac{3}{4}$ inches, and no. 9 is octavo $8 \frac{3}{4}$ inches. No. 7 is numbered vol. II. instead of vol. I., and nos. 10-12 are num-
bered vol. II., nos. 1-3, respectively.
Mis. St. Jour. 13 (3).

Second series.

Minneapolis, Minn., W. H. Barnes, 1892-93. Mis. St. Jour. 72 (13) Fol. 12 in. Nos. 1-2, Dec. 15, 1892-Jan. 15, 1893.

PHILATELIC FRAUD REPORTER. The Philatelio fraud reporter. Devoted exclusively to frauds and their exposure. $8^{\circ} .8 \frac{1}{4}$ in. Nos. 1-2, February-March, 1890.

PHILATELIC FRAUD RFPORTER. The Philatelio fraud reporter.

Stromsburg, Neb., Green Bros., etc., I 890-93. $8^{\circ} .81$ in. 26 nos. in 3 vols.

Vol. I. Nov. 1890-Dec., 1891. Nos. 1-12

"II. Jan. - $\quad$ " 1892 . "13-24.

* " Commencing with no. 8 the journal was published by Guy W Green, and nos. 4-21 have coloured paper wrappers dated "Feb., Mar. and Apr., 1891 ".
PHILATELIC FRAUD SPECTALIST 690

PHILATELIC FRAUD SPECIALIST. The Philatelic fraud specialist. Devoted exclusively to frauds and their exposure. Stromsburg, Neb., Green Bros., I89o. $8^{\circ} .8 \frac{1}{4}$ in. No. 1, October, 1890.

* * Bound up with the "Philatelic fraud reporter".

PHILATELIC FKEE LANCE. Philatelic free lance.

$8^{\circ} .11 \frac{1}{4}$ in. 7 nos. in 2 vols.

Bellaire, O., Harry, B. Taylor, I896.

Vol. I. June-Nov., 1896. Nos. 1-6.

* " Each number has a coloured paper wrapper with the title

** Each number has a coloured paper wrapper with the title
preceded by the word "The".

PHILATELIC GAZETTE. The Philatelic gazette.

Ore, Hastings, Sussex, F. Hindell, I893.

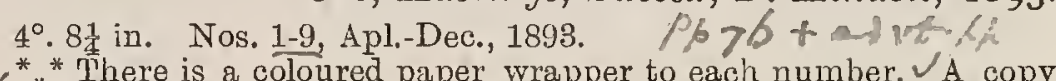

$V^{*} *$ There is a coloured paper wrapper to each number. $V_{A}$ copy

of the prospectus of the journal is bound up in front of no. 1.
Mis. St. Jour. 53 (2).

PHILATELIC GAZETTE. The Philatelic gazette.

Altoona, Pa., The Philatelic Gazette Company, Limited, 1893.

$8^{\circ} .83-9$ in. Nos. 1-3, Apl., May, June-July, 1893.

* There is a coloured paper wrapper to each number.

Mis. St. Jour. $62(2)$

PHILATELIC GAZETTE. The Philatelic gazette.

Philadelphia Fa., The Philatelic Gazette Publishing Co., I 900.

$8^{\circ} .7 \frac{1}{4}$ in. Nos. 1-3, June, July-August, 1900

* Nos. 2 and 3 were published together and there is a coloured paper wrapper to each number. Wanting no. 1.

Mis. St. Jour. $154(6)$

PHILATELIC GAZETTE. See KeYstoNe PHILATELIO GAZETTE.

PHILATELIC GEIM. The Philatelic gem.

Boise, Idaho, W. F. Van Dusen, I go3.

8०. 83 in. No. 1, August, 1903.

** This is said to have never been circulated. Mis. St. Jour. 103 (1).

PHILATELIC GEIM. See GeM PRIOE IIST.

PHILATELIC GLOBE. The Philatelic globe.

London, W., ete., W. G. Darvill, etc., I88 I-85. $8^{\circ} .8 \frac{3}{4}$ in. 13 nos. in 3 vols.

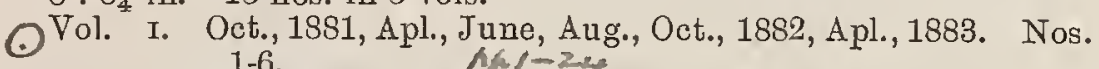
Q." II. Sept.-Nov., 1883. Nos. 1-3. \& $1-20$

(5)." III. Dec., 1884, Feb., Apl., June, 1885. Nos. 10-13. Ah/-2 * * The three numbers of vol. II. were published by Percy R. L. Fisher, London, N.W. and nos. $2-13$ were printed at Stockton-on-
Tees. Pages $7-10$ and 15-18 of nos. 2 and 3 , vol. II., respectively, Tees. Pages $7-10$ and $15-18$ of nos. 2 and 3 , vol. II., respectively,
are headcd the "Numismatic globe," which is stated to be "inare headcd the "Numismatic globe," which is stated to be "incorporated with the philatelic globe ". $\checkmark$ On the resumption of the
publication by W. G. Darvill in 1884 the coin section was dropped. publication by W. G. Darvill in 1884 the coin section was dropped.
There is a supplement of two pages, printed on one side only, to 'There is a supplement of two pages, printed on one side only, to
no. 10.VIn the six numbers of vol. I the publisher's name is spelt "Do. 10.VIn the six numbers of vol. I. the publisher's name is spelt

"Damated," whith the "Philatelic star and coin collector, vol. III gamated with the "Philatelic star and coin collector, vol. III.,
no. 2". Wpthis cech Mis. St. Jour. 79 (7).

145. $15(6), \times 613$

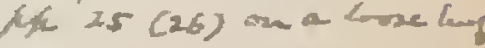

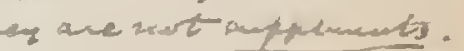

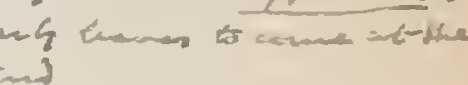

PHILATELIC GLOBE. The Philatelic globe.

La Rue, O., The Globe Publishing Co., I889. $8^{\circ} .9$ in. No. 1, Feb., 1889.

* * The number has a coloured paper wrapper. Both the journal and the paper wrapper are numbered "Vol. II. New series. No. 1, but it is clear from the editorial remarks that this was the first number of a new publication.
fis. St. Jour. 48 (4a).

PHILATELIC GLOBE. The Philatelic globe

Effingham, Ili., The Globe Publishing Co., I891. $8^{\circ} .9$ in. Nos. 1-2, Fcb.-Apl. 15, 1891.

* * No. 2 has a coloured paper wrapper, and both the journal and the wrapper are numbered "No. 11," as if the number was eleven in place of two. $\quad$ Mis. St. Jour. 48 (4).

PHILATELIC GUARDIAN. The Philatelic guardian. A monthly journal devoted to the science and study of philately. Newburgh, N. Y., L. M. Thayer, I 886.

$8^{\circ} .9$ in. No. 1, May, 1886.

2103

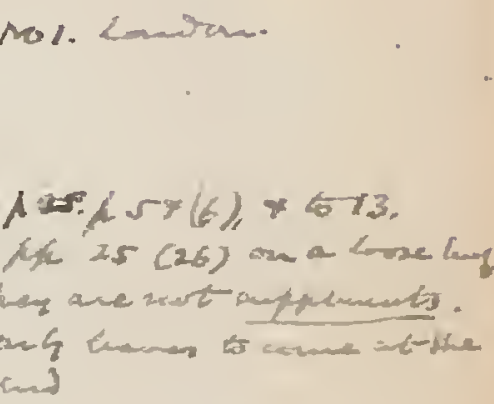


PHILATELIC GUIDE. The Philatelic guide. Concord, N.H., E. B. Crapo, 1874 $8^{\circ} .10 \frac{1}{2}$ in. Nos. $1-8$, May-July, 1874. Mis. St. Jour. 7 (11)

PHILATELIC GUIDE. The Philatelic guide.

[?], British Philatclic Co., 1886.

in. No. 1, June, 1886

* This appears iu J. K. Tiffauy's list of Great Britain philatelic journals in the "Stamp news annual" for 1894, but nothing more seems to be known about it. Wanting.

PHILATELIC HEADLIGHT. The Philatelic headlight. Chicago, Ill, Von Glahn and Busse, I883-84. $8^{\circ} .11$ in. Nos. 1-4, September-November, 1883, October, 1884. * Nos. 2 and 3 were published togother. Mis. St. Jour. 6 (4).

PIILATELIC HERALD. The Philatelic herald.

Forcst Hill, London, S.E., H. F. Pickering and Co., ctc., 1893 .

8․ 81 in. Nos. 1-7, Feb.-Aug., 1893. wrant /.2.7

${ }_{*}^{*}$ * The contents consist entirely of advertisements. Nos. 1 and 2 were lithographed and nos. 5-7 were published by The Belle Stamp Co. Wanting nos. 1,2 .

PHILATELIC HERALD. The Philatelic herald. Cincinnati, O., Burnet Stamp Co., I goz. $8^{\circ} .7$ in. No. 1, January, 1902

* * The number has a coloured paper wrapper.

Mis. St. Jour. 104 (14)

PHILATELIC HERALD. See PoRTLAND PHILATELIC HERALD.

PHILATELIC HERALD. See AMATEỤR PHILATELIC HERALD.

PHILATELIC HERALD AND FOREIGN STAIMP

- ADVERTISER. The Philatelic herald and foreign stamp advertiser. A monthly journal appertaining to stamp collecting. Southport, Joseph Lee and Co., I884-85.

0 8. 81 in. Nos, 1-3, Dec 15, 1884, Feb. 15, Mar. 15, 1885. Car o/

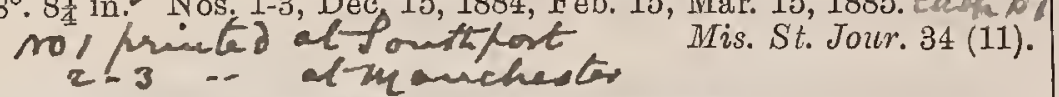
PHILATELIC HERALD AND REVIEW. The Philatelic herald and review.

Cincinnati, O., Horace L. Wood and Co., I874-75. $8^{\circ} .8 \frac{1}{2}$ in. Nos. 1-4, June, July, Aug.-Nov., 1874, Jan., 1875. * * There is a coloured paper wrapper to each number. The wrapper of no. 3 is dated "November, 1874 " and the wrapper of no. 4 is undated.

PHILATELIC HUS'LER. The Philatelic hus'ler. Manchester, Mich., C. J. Van Valkenburg, I 891-92. 8. 9 in. Nos. 1-4, Nov. 25, 1891, Jan. 5, Feb., Mar., 1892 * There is a coloured paper wrapper to each number.

Mis. St. Jour. $46(7)$

PHLATELIC INTER-OCEAN. Philatelic inter-ocean. Waterloo, Ia., J. A. Cook, etc., I899-1907. $8^{\circ} .8$ in. 90 nos. in 10 vols.

- Vol I. July $15, \quad$-Dec. $15, \quad$ 1899. Nos 1- 6

(.) II. Jan. 15, -Apl. 15, 1900. ", 7-10.

(c) " III. Aug., 1900-July, 1901. " 11-22. $17-15,16-22$

(1) "IV. $"$-Dec.

(2) " v. Jan., ${ }^{-J u n e}$

" " vII. Jan

8 " vIII. ,

(3) $" \mathrm{IX}$.

- ,

1904. " " $\quad 50-61$.

1905. " " $62-73$.

* Commencing with no. 11 the journal was published by Cook and Jones. $v^{\prime}$ There is a combined title-page and an index for vols. 4 rut + III.-IV., and one each for vols. V.-VII.V For vol. x. there is an index on the last page of no. 90, and nos. 4 and 6 have coloured paper wrappers. "No. 8 is numbered "No. 1-8" in error for "No. 2-8".

PHILATELIC IOWAN. The Philatelic Iowan. in. No. 1, March, 1897.
** Wanting. Elkader, Ia., [? ] ], т897.

$$
\begin{aligned}
& \text { Phelateleckerales \& avertiver, sm. } 4 \text { to } \\
& \text { f.H. w hitateer (Sheffiel), w. whitson }
\end{aligned}
$$

PHILATELIC ITEIMS. Philatelic items

Dubuque, Iowa, Philatelic Mercantile Agency, I891. $8^{\circ} .8 \frac{3}{4}$ in. [No. 1.] Mar. 1, 1891

* * The number has a coloured paper wrapper. The publication is more of the nature of a pamphlet than a journal and also formed a prospectus of the "Philatelic Mercantile Agency Reference Book," a work that never appeared. Mis. St. Jour. 47 (8).

PHILATELIC JOURNAL OF AIMERICA. The Philatelic journal of America.

St. Louis, Mo., Everett M. Hackett, etc., I 885-95. $8^{\circ} .9 \frac{3}{4}-10$ in. and 11 in. 127 nos. in 14 vols.

Vol. I. Mar., 1885-Feb., 1886. Nos. 1- 12

II. " $1886-, 1887$. " $13-24$

"III. " 1887-Jan. 1, 1888. " " 25- 36.

" IV. Jan. 15, -Dec., I" " $\quad 37-48$.

" V. $\quad$ VI. $\quad-\quad " \quad 1889 . \quad " \quad 49-60$.

" vII. " " 1, - " " $1891 . \quad " \quad 73-84$.

" vIII. " " - " $\quad 1892 . \quad$ " $85-96$.

" Ix. July -Dec., 1893. " 103-108.

" XI. Jan. -June, 1894. " 109-114.

" xII. July -Dec, 1894. " " $115-120$

"xIIr. Jan. -June, 1895. " 121-126.

* "XIv. November, 1895 . No. 127.

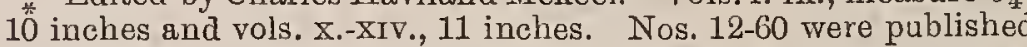
by the Philatelic Publishing Co., and nos. 61-127 by C. H. Mekeel Stamp and Publishing Co. There is a title.page and list of contents or an index to each volume, excepting vol. XIV. list of contents or an index to each volnte, excepting vol. XIV. which has no index or list of contents, and there is a pape for February, 1887, as a sample copy, with the words "Special for February, 1887 , as a sample copy, with the words "Special wdition". This was paged separately land consists of 56 page with a coloured paper wrapper. There are two numbers for December, 1887, one dated " December 1st," the other "December, 15 th". No. 36 is wrongly dated " 1887 " in place of " 1888 ," but has the year correctly given on the wrapper. The numbers for May and June, 1889, are wrongly numbered " 52 " and " 53 ," in stead of " 53 " and " 54 ," but the numbering on the wrappers is correct for both months. Nos. 122, 123, 124 and 125 are wrongly numbered volume "VIII." in place of "XIII.," but in each case "the wrappers give the correct number. "The wrapper of no. 112 has, "Vol. XI. No. IV.," in place of the usual numbering. A Jour. 7 (13).

\section{[Continued as :]}

Mekeel's stamp collector.

St. Louis, Mo., C. H. Mekeel Stamp and Publishing Co., I $90 \mathrm{I}-05$.

8. $9 \frac{1}{2}-10$ in. Vols, Xv.-xix. 172 nos.

Vol. Xv. Dec. 2, 1901-Dec. 27, 1902. Nos. 1- 52.

"XVI. Jan. 5, - ", 28, $1903 . \quad$ " 1- 49.

" XVII. J"4, -June 27, 1904. " 102-127.

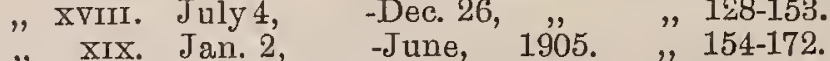

* "* There is a title-page and an index to each volume excepting the last and a coloured paper wrapper to nos. $18,27,40,44,52$ $56,60,65,69,73,147$ and $161-172$. No. 52 is wrongly dated $56,60,65,69,73,147$ and $161-172$. No. 52 is wrongly dated " 1903 inst. A "sample copy" for advertisement purposes was wrapper. A "sample copy" for advertisement purposes was
issued early in 1902 . This is named "volume 15 , number 6 ," but has no date. It consists of (16) pages in a coloured paper but has no date. It consists of (16) pages in a coloured paper
wrapper. There is no number 27 of vol. xvr. (whole no. 79 ). wrapper. There is no number 27 of vol. XVI. (whole no. 99 ) After April, 1905, the two last numbers were published monthly.

PHILATFLIC JOURNAL OF CANADA. The Philatelic journal of Canada. A monthly devoted to stamp collecting.

London, Ont., The Philatelic Journal of Canado Publishing Co., etc., I 892-93.

$8^{\circ} .8 \frac{3}{4}$ in. Nos. $1-4$, Oct., Nov., 1892, Feb., Mar., 1893.
*** Nos. 3 and 4 were published by H. S. Dickson and these two
numbers have coloured paper wrappers.
Mis. St. Jour, 56 (7).

PHILATELIC JOURNAL OF GREAT BRITAIN

The Philatelic journal of Great Britain.

Salisbury, etc., W. Brown, etc., I89I-

$\begin{array}{ll}8^{\circ} .9 \frac{3}{4} \text { in. } & \text { nos. in vols. In progress. } \\ \text { Vol. I. Feb. -Dec. 1, 1891. Nos. 1- } 12 .\end{array}$

"II. Jan. 1- " $10,1892 . \quad$ " $13-24$.

" III. " $\quad 10-", 10,1893 . \quad$ " $\quad \begin{array}{lll}25-36 . \\ \text { IV. }\end{array}$

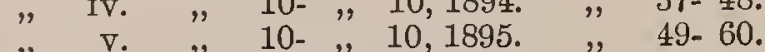

" vI. " " 10- " 10,1896. " " 61- 72

" 


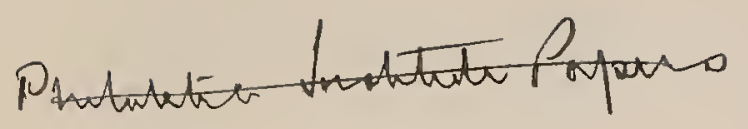

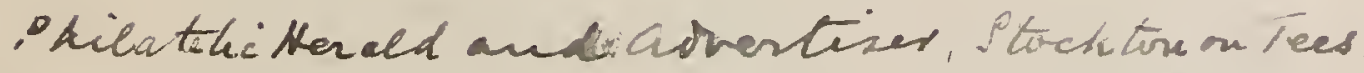
continuation of the Stamp Chot Kersed. q.v.

Phelitui hter beesu

Philatelic Journal Salfard 1882

thos in I FII are not papt.

Ho 4 light ysllow sreen 4 tena cotea wh.

6 bovine wh.

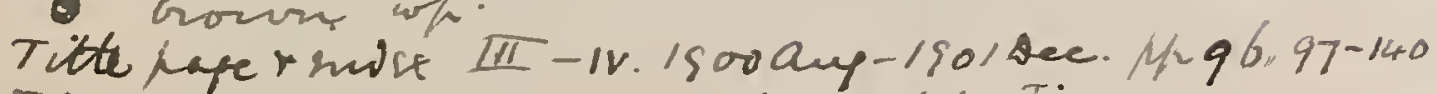

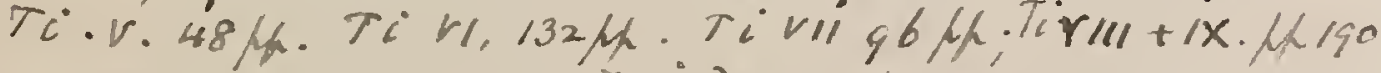

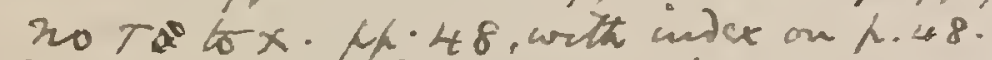

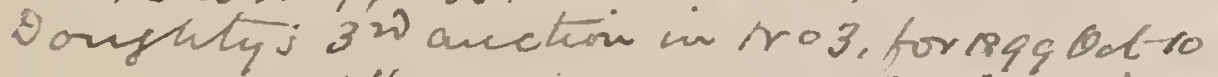

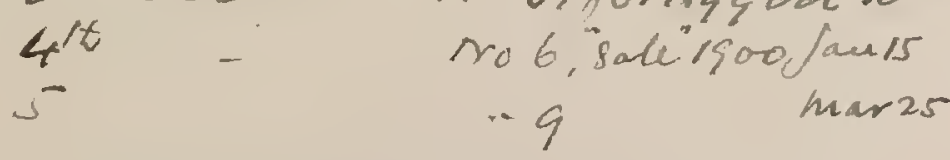

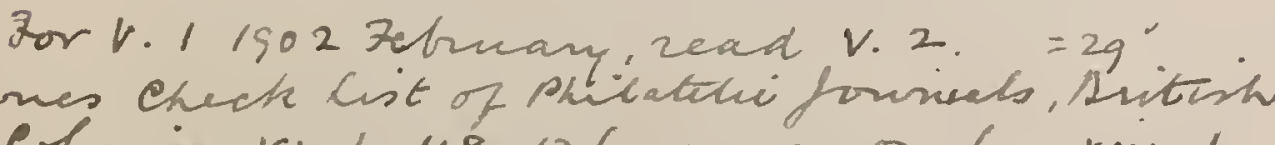

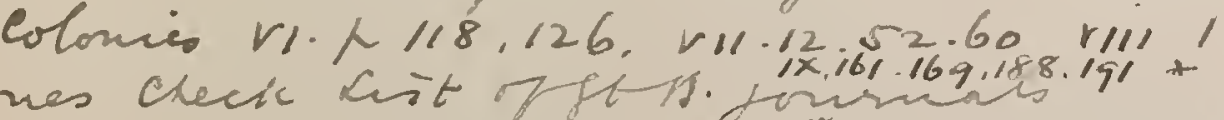

vill.3 $1118,27 \cdot 3+4+3,51 \cdot 83,90,98,106,114,122,130$

$137146.153 . \times 18$

* x. 9 . 


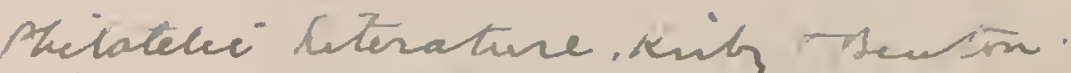

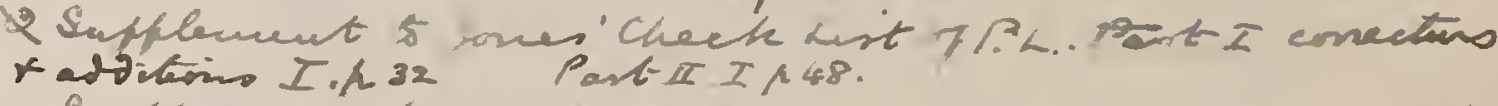

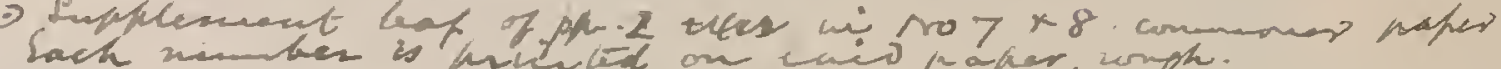

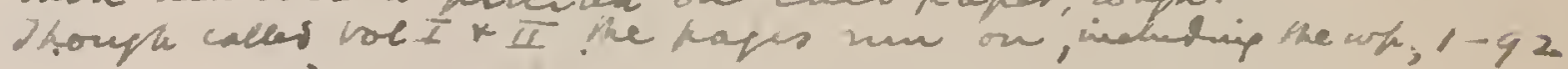

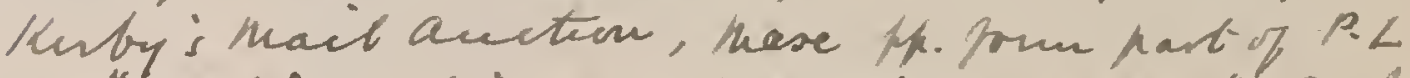

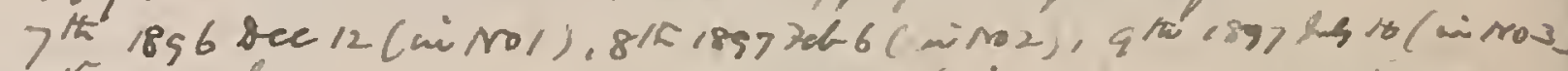

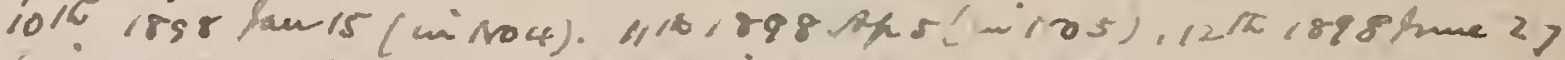

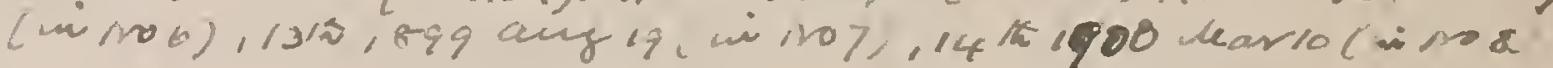

Bentons mail ancteri, hose, th foum hartithe

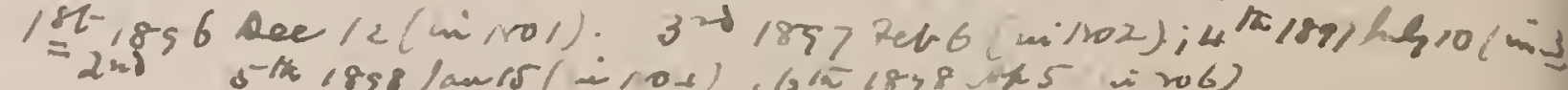

lmes thaci untiri

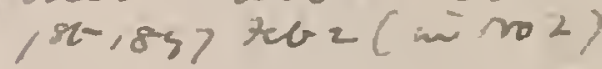

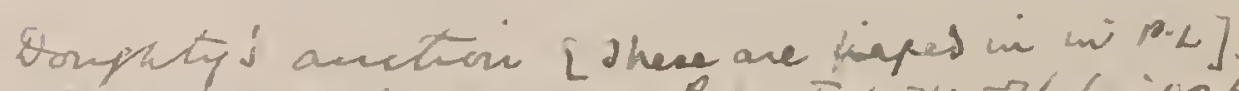

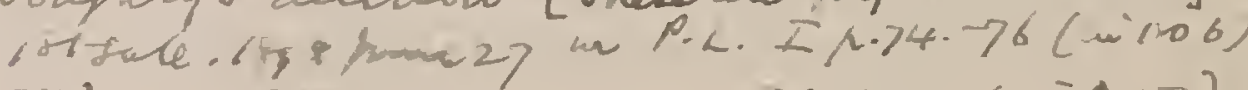

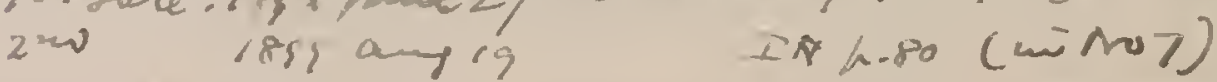

Each no.1-o hat a asapher or hout tite hayo

hese are kafey on arite the ust 7 the nos.

forme visets of towes ats. are incluted. 
Vol. viII. Jan. 15-Des. 15, 1898. Nos. $85-96$
IX.

"IX. " 10-1" 10, 1899. " 97-108.

" $\quad$ X. $\quad$ XI. $10-\quad " \quad 20,1900 . \quad " \quad 109-120$.

" XII. " "31- " 31, 1902. " " 133-144.

" XIII. " 25- " 24, $1903 . \quad$ " $145-156$.

"XIV. " $\quad 25-\quad$ " $25,1904 . \quad " 157 \cdot 168$.

" XVI. " 25- " 25, $1906 . \quad$ " $181-192$.

* * Nos. 109-140 were published in London by Kirkpatrick and Pemberton and commencing with no. 141 the journal has been published by P. L. Pemberton and Co. From January, 1900, it pas been printed in London instead of Salisbury. There is title-prge and an index to each volume, a paper wrapper to each litle-page and an index to each volume, a paper wrapper to each number, and a prefase to vols. 1.-xir. Uommencing with no. 138 the front paper wappor bears the title "Tho Ph"latelic journal of Great Britain, and philavelic review "Leviews". Nos. 11 and 12, vol. I., were published together under the date "Dec. 1 altered to $17-32$ in place of $1-16$, as for the first edition, and there altered to $17-32$ in place of $1-16$, as for the first edition, and there is also a second edition of no. 47, which omits the paragraph found at the bottom of the right-hand column on page 161 of the first edition. There is a supplement to vol. I. with the title "Revenue catalogue: being a compilation of beer, bill, deed, law, revenue, telegraph, tobacco, stamps, etc. Part I. Great Britain and Colonies. Compiled by Fred. Geo. C. Lundy": $4+$ $96 \mathrm{pp}$. A supplement to nos. 4 and 6 with the title "William Brown's priced catalogue of postage stamps"; $16 \mathrm{pp}$. This is only completed up to British East Africa. A supplement to nos. postage stamps," etc. Twelfth edition, $28 \mathrm{pp}$. The last was only completed as far as Mauritius. A supplement to nos. 3335, "Epitome of stamps issued during 1893": (12) pp. on blue paper. Supplements to nos. 37-48, "Epitome of stamps issued from January to December, 1893," (4) pp. and "Epitome of stamp issued from Jan., 1893, to Nov., 1894," (46) pp. on coloured paper. A supplement to nos. 49-53 and 55-57, "Epitome of stamps issued from Dec., 1893 to Aug., 1895," (32) pp. on rose paper. A supplement the "Philatelic review of reviews" commencing with January, 1892. For the years 1892-96 this supplement was paged separately, but from January, 1897, it has been amagamated and paged with the journal. For a fuller account of this supplement se? Philatelic review of reviews. The titlepage, preface and index to vol. I., and also to vol. II., were reprinted in August, 1907

PHILATELIC JOURNAL OF INDIA. The Philatelic journal of India.

Calcutta, The Philatelic Society of India, I897-

$8^{\circ} \cdot 10 \frac{3}{4}$ in. nos. in vols. In progress.

Vol. I. Jan.-Dec, 1897. Nos. 1-12.

" II. " " - " $1898 . \quad$ " $1-12$

" IV. " - " 1900. "

" V. " - " $1901 . \quad$ " $1-12$.

" VII. " - " 1908.

" VIII. " - " 1904. " " $1-12$.

" IX. $\quad$ " - " $1905 . \quad " 1-12$

* Vol. I. was edited by C. F. Larmour and F. N. Schiller, nos. 1-4, vol. II., by C. F. Larmour and W. Corfield, mos. 5-12, vol. II. vols. III.-v., no. 11, and vols. vII. and VIII. by C. Stewart-Wilson and vols. VI., IX. and $x_{.}$, by $\mathrm{E}_{\text {. }} \mathrm{W}_{\text {. Wetherell with the exception }}$ of nos. 2 and 3 , vol. X., which were edited by C. S. F. Crofton. There is a title-paye and a list of contents for each volume and a coloured paper wrapper to each number. The number for April 1899, is wrongly numbered "Vol. III., no. 3 " in place of "no. 4," but the wrapper has the numbering correct. There is a second edition of vol. 1., no. 1, without the coloured paper wrapper, and a second edition of Vol. vill, no. 3 was issued "owing to an unfortunate confusion in the arrangement of Mr. C. Stewart-Wilson's article, entitled Notes on the stamps of Curacao," in the firs edition of that number. There is a supplement of 20 pages, . 7, vol. X., with the title "Sirmoor I." By Sir David Masson.

PHILATELIC JOURNAL OF OHIO. The Philatelic journal of Ohio.

Wooster, O., W. S. Kinzer, 1887-92.

$8^{\circ} .9-8 \frac{1}{2}$ in. and $16^{\circ} .7 \mathrm{in} .19$ nos. in 4 vols.

Vol. I. Oct., 1887, Jan., Mar., Apl., Miry, 1888. Nos. 1-12.

" II. Aug., Nov., 1888, May, June, 1889. Nos. 1, 2, 2, 3

" III. Heb., 1891.

" IV. Dec., 1891, Jan., 1892. Nos. 1, 2.

* * The number for January, 18s8, is $16^{\circ}$. and is numbered "Nos. 2 to 9 ". The other numbers are octavo. It will be noticed that there are two numbers of 701 . II. numbered " $2 "$ "No 1 voll III, has a coloured paper wrapper. Mis. St. Jour. 48 (5).
PHILATELIC KALEIDOSCOPE. The Philatelic kaleidoscope.

Belleville, Mich., W. M. Randall, I 893-94.

$8^{\circ} .83$ in. Nos. 1-8, Oct. 1, 1893-May 25, 1894.

* Nos. 4-6 have coloured paper wrappers and nos. 4 and 5 are wrongly dated " 1893 " instead " 1894 ". Pages 3 and 4 of no. 8 are blank except for an "Explanation," which reads: ". . This issue of the P. K. was printed in Belleville instead of Detroit. Unbeknown to the printer some sneak gained access to the composing room, removed a number of words from the type that should have filled these 2 pages, and inserted filthy words mistake was not noticed until 950 of the edition had been The 950 have been destroyed, the remaining 50 copies of the 1000 were printed like this Next week a new,edition will be got out and mailed Mis. St. Jour. $63(10)$

PHILATELIC LANCET. The Philatelic lancet. 1897.

Poughkeepsie, N. Y., Philatelic Publishing Co.,

* in. No. 1, December, 1897

PHILATELIC LASSO. The Philatelic lasso. Fremont, Neb., E. C. Biggar, I892.

$8^{\circ} .8 \frac{1}{2}$ in. No. 1 , October, 1892.

Mis. St. Jour. 63 (12)

PHILATELIC LFADER. The Philatelic leader.

Scranton, Pa., Geo. E. Pryor, ctc., 1889.

$8^{\circ} .8_{1}^{3}$ in. No. 1, March 10, 1889

** Published also by the Pennsylvania Stamp Collectors' League and edited by H. B. Wilber. Mis. St. Jour. 26 (14).

PHILATELIC LITERATURE. Philatelic literature.

C Taunton, Mass., Kirby and Benton, etc., I896-I goo. $8^{\circ} .8 \frac{1}{4}$ in. 8 nos. in 2 vols.

6 Vol. I. Nov. 21, 1896, Jan. 18, June 22, Dec. 25, 1897. Mar. 21 June 15,"1898. Nos. 1-6.

0." II. July 31,1899, Feb. 17, 1900. Nos. 7-8.

* * Nos. 7, 8 were published by Andrew J. Kirby and there is a supplement of two pages to each of these numbers." A special foreign edition of no. 6 was published: this is wanting in the

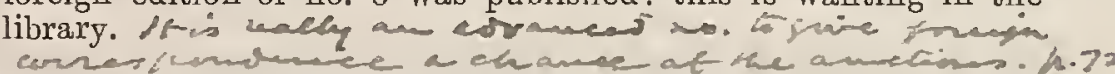

PHILATELIC LITERATURE. Philatelic literature. A monthly magazine. London, C. J. M. Lehner, I goI 8 8 in. Nos. 1-4, Mar. 25-June 25, 1901

$\Omega_{*}^{*}$ Each number has a coloured paper wrapper. Bound up wfofh with the magazine is a copy of a circular letter notifying the discon$\checkmark$ tinuance of the journal and that all interests in the same had been acquired by Mr. F. A. Bellamy of Oxford.

Mis. St. Jour. 81 (7)

PHILATELIC IITERATURE. Philatelic literature. Columbus, O., George W. Linn, I902.

$12^{\circ} .7$ in. No. 1 , July, 1902.

Mis. St. Jour. 114 (7)

PHILATELIC LITERATURE. Philatelic literature.

Red Creek, N. Y., W. C. Wendover, I 903.

$8^{n} .8_{4}^{3}$ in. No. 1, January 10, 1903.

* * Consists of a single leaf of advertisements

Mis. St. Jout. 135 (9)

PHILATELIC ITERATURE COLLECTOR. The - Philatelic literature collector.

St. Joseph, Mo., H. C. Beardsley, r 888.

Q $8^{\circ} .8 \frac{3}{4}$ in. No. 1, Autumn, 1888. $\sim$ Mis. St. Jour. 26 (11).

PHILATELIC LITERATURE COLLECTOR. Phila-

telic literature collector.

Houlton, Me., ëtc., L. H. Mutch, etc., I 896-98.

$24^{\circ} .4 \frac{7}{2}-5 \frac{1}{3}$ in. 15 nos. in 2 vols.

(c) 1st year. May, July, Sept.-Xmas, 1896, Jan., Mar., Apl., June, 1897. Nos. 1-10.

2nd ", Aug., Nov., 1897, Jan., Apl., May, 1898. Nos. 11-15. * There is a paper wrapper to each number. No. 15 was published by John "Bisbee, at Stoughton, Mass., and the title of this number reads "The Philatelic literature collector". Nos. 1 and 10 have supplemental pages. For no. 16 see "Auxiliary Phila IFis. St. Jour. 114 (2) 
PHILATELIC LITERATURE COLLECTOR. The Philatelic literature collector

Westbury, N. Y., W. C. Wendover, I90 I. $32^{\circ} .4-4 \frac{1}{2}$ in. Nos. 1-3, January, Spring, Summer, 1901. Mis. St. Jour. 150 (2)

PHILATELIC IMAGAZINE. The Philatelic magazine. (1) A journal for stamp collectors.

$08^{\circ} .8 \frac{1}{4}$ in. No.1, April, 1885. Liverpool, G. Birtwhistle, 1885

PHILATELIC MAGAZINE. The Philatelic magazine. La Grange, Ill., W. F. Bishop, etc., $1885-87$

$8^{\circ} \cdot 7 \frac{3}{4}$ in. 9 nos. in 2 vols.

Vol. I. Oct. Nov, 1885 . Nos. $1-2$

" II. Jan., Feb., Nov., Dec., 1886, Jan., Apl., June, 1887. * There is a coloured

* There is a coloured paper wrapper to each number and nos. ing Compally.

PHILATELIC MAIL AND EXPRESS. The Philatelic mail and express.

Albany, N. Y., Brett Stamp and Pub. Co., x 893. $16^{\circ} .6$ in. Nos. 1-2, Jan.-Feb., 1893.

** There is a coloured paper wrapper to each number.

Mis. St. Jour. 68 (10)

PHILATELIC MEDIUIM. The Philatelic medium. A monthly pamphlet devoted to the interests of stamp dealers. Cincinnati, O., C. C. Collins, etc., I88 I-82. $8^{\circ} .81-93$ in. Nos. 1-6, Nov. 15, 1881, Jan. 1-May, 1882.

* No. 6 was published by Collins and Co. Mis. St. Jour. 10 (7).

PHILATELIC IMERCANTILE AGFNCY CONFI DENTIAL REPORT. The Philatelic Mercantile Agency, confidential report.

New Oxford, Pa., J. F. Dodge, I898-99.

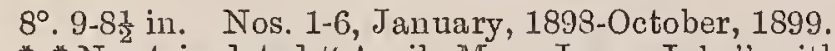

" "No. 4 is dated "April, May, June, July" without any year, no. 5, "Aug., Sept., Oct., Nov., 1898," and no. 6 " "Dec., 1898-Oct. 1893 " On no. 1 "confidential" is spelt " confidencial"

Mis. St. Jour. 126 (7)

PHILATELIC IMERCANTILE AGENCY REFERENCE BOOK. See Philatelic items.

PHILATELIC IMERCURY. The Philatelic mercury (With which is incorporated the Oxford philatelical monthly.) A monthly magazine devoted to philately. Oxford, W. Taphouse and Co., 1886.

4․ 101 in. Nos. 1-2, Mar. 25- Apl. 25, 1886.

$$
x 1,2 \text { iñ low vol sors. }
$$

Mis. St. Jour. 52 (5).

PHILATELIC IMESSENGER. The Philatelic messenger. I 896-99.

Oak Hill, etc., New Brunswick, Matthew R. Knight,

$8^{\circ} .9 \frac{1}{2}$ in. 17 nos. in 3 vols.

Yol. I. Oct. 1, 1896, Jan. 1, Apl. 1, July 1, 1897. Nos. 1-4.

" II. Oct., 1897-Jan. 31, Apl.1-Aug. 15, 1898. Nos. 5-13.

$"$ III. Nov. 15, 1898- 1899. Nos. 14-17.

* Nos. 5-8 were published at Saint Stephen, New Brunswick, nos. 9 and 10 at Oak Hill and nos. 11-17 at Boiestown, New Brunswick. Nos. 5-14 have paper wrappers and nos. 8-13 supplements of two pages. No. 16 is numbered "Volume 3, number 8,"

\section{[Continued as:]}

- The Philatelic messenger and monthly advertiser

Boiestown, New Brunswick, Matthew R. Knight, I 899-I 902 .

$8^{\circ} .9 \frac{1}{4}$ in. Vols. IV.-VIrI. 32 nos.
Vol. Iv. Apl. 15 -June 15, 1899. Nos. 18-20.

"VI. July $15,1899-\quad 1900 . \quad, \quad 21-36$.

vII. Jan. 15, -Dec., 2, $1901 . \quad$ " $37-48$.
vIII. Feb. 1, 1902.

*" "Volume V. was missed. Wanting nos. 19, 20, 24, 29, 36, 41, $42,45,46$.

PHILATELIC IVESSENGER. See AMERICAN COLLECTOR (Oak Hill, O.).

PHILATELIC MESSENGER AND IMONTHLY AD. VERTISER. See Philatelic Messenger.
PHILATELIC IMIDGET. The Philatelic midget.

La Hoyt, Ia., James C. Jay, I888-89.

$24^{\circ} .4 \frac{1}{2}-3 \frac{3}{4}$ in. Nos. 1-12, Apl., 1888-Mar., 1889.

twelve numbers the volume was supplied in a coloured paper wrapper. Mis. St. Jour. 71 (11) [Continued as:]

- The Tiny philatelist.

La Hoyt, Ia., James O. Jay, I889. $24^{\circ} .4 \frac{1}{2}$ in. Vol. II. Nos. 1-4, [April]-July, 1889.

* * There is a coloured paper wrapper to eash number. Mis. St. Jour. 71 (11a)

PHILATELIC MIDGET. Philatelic midget.

Aspen View, Va., etc., Robert H. Poarch, etc., I903. $16^{\circ} .5 \frac{1}{2}-6$ in. Nos. 1-3, June-Sept., 1903.

* *Each number has a paper wrapper. Nos. 2 and 3 have the title "The Philatelic midget" and were published by D. E. MeCurdy, at Westernport, Md. No. 2 has no date and no. is dated "August and September, 1903". Succeeded by the "Union bulletin".
"Mis. St. Jour. 114 (3). PHILATELIC MONTHLY. The Philatelic monthly. Philadelphia, Pa., I. W. Durbin, etc., I875-9 I.

$8^{\circ} .8 \frac{1}{4}$ in. 203 nos. in 17 vols.

Vol. I. Feb., 1875-Jan., 1876. Nos. 1-12.

"II. " -Dec., ", " $1-12$

" III. Jan., - " $1877 . \quad$ " $1-12$.

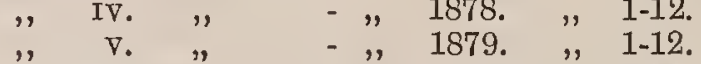

" VI. " " $\quad$ " " $1880 . \quad$ " $1-12$.

" VII. " $\quad$ - " $1881 . \quad " \quad 1-12$

"VIII. " $\quad " \quad 1882 . \quad " 1-12$.

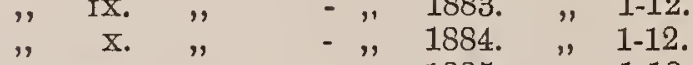

" XI. " - " $1885 . \quad " 1-12$

" XII. " $\quad$ - " 1886. " $1-12$

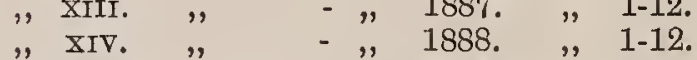

" $\mathrm{xV} . \quad$ " $\quad$ " $\quad 1889 . \quad$ " $1-12$

"XVI. " $\quad$ - " $1890 . \quad$ " $1-12$

* " Nos. 11 and 12, vol. "XILl, and no." 1, vol. xiv., were published by the Durbin Stamp Co. and no. 2, vol. XIV., and all subsequent numbers by Durbin and Hanes. Nos. 11 and 12, vol. II., wer published together under the date "December, 1876". No. 1 vol. vIr., has " 1880 " in place of "1881". No number 7, vol. xiII. was published, and nos. 9 and 10 and 11 and 12 of this volume were severally published together. No. 10. vol. xvi., and all subsequent numbers have colonred paper wrappers. Nos. 1-5, vol. I. were also published with the name of W. M. Pemberton, Ansonia, Conn., at the foot of the last page of each of the five numbers. The five numbers with Pemberton's name are bound up in $M$ is St. Jour. 28 (6).

[Continued as :]

The Philatelic monthly and world.

Philadelphia, Pa., The Bogert and Durbin Co., I892-I 90 I.

$8^{\circ} .8 \frac{1}{2}$ in. Vol. xVIII.-XxVI. 98 nos.

Vol. XviII. Jan. -Dec., 1892. Nos. 1- 12

" xIx. " - " 1893.

"

" XXI. " " $\quad$ - " $1895 . \quad$ " $1-12$.

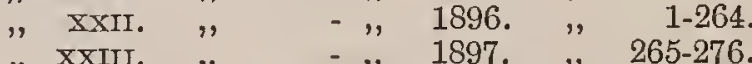

" XXIT. " " - " " $1898 . \quad$ " $277-288$

" Xxv. " "

* "Each number has a coloured paper wrapper.

PHILATELIC IMONTHLY. The Philatelic monthly. Chicago, Ill., Henry Grimsland, I 904-05. 8. 9-8 $\frac{3}{4}$ in. Nos. 1-4, November-December, 1904-Febrnary, 1905

** Nos. 1 and 2 were published together. Wanting no. 3.
Mis. St. Jour. 154 (13).

PHILATELIC IMONTHLY ADVERTISER. The Philatelic monthly advertiser.

Sydenham, London, etc., The Co-operative Stamp Co., $1898-99 . \checkmark$

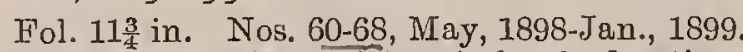

** The contents consist entirely of advertisements. $\checkmark$ Nos. 67 and 68 were published at Forest Gate, London, "and no. 60 was the first number. For continuation see the "Stamp collectors" journal and philatelic monthly advertiser".

PHILATELIC IMONTHLY AND WORLD. See PHILATELIC MONTHLY (Philadelphia, Pa.). 


Incorporating "The Philatelic Circular," "The Collectors' Magazine,"
"The Collectors' Monthly," "The Junior Stamp Magazine," "The Record
of Philately" and "ALFRED SMIITH'S MONTHLY CIRCULAR."
Established at Bath in I875.
Editor and Proprietor:
ALBERT H. HARRIS

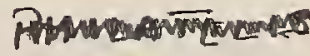

PHAAEELIC NESSEA'EER, CAMADA Do DEFIANCE, 
pheldetie hews. A free montaly fommat sutich derated to stamps. 4 to [homon. a. E. Couphe. $\log$ I. nov I ( $2 \mathrm{~m})$.

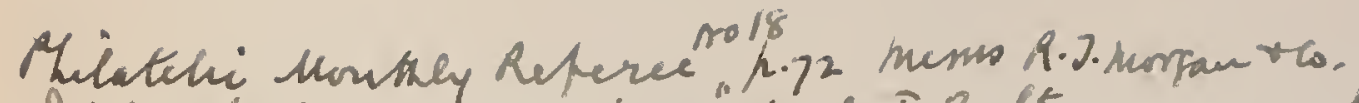

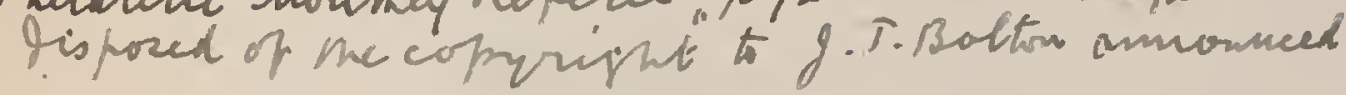
PHILATELIGNEWT, OSSONONG 
697 PHILATELIC MONTHLY NEWS

PHILATELIC IMONTHIY NEWS. Philatelic monthly news. A paper for stamp collectors.

London, E.C., R. Walford White, I892.

- $8^{\circ} .8$ in. Nos. 1-4, Apl. 10-July 10, 1892

** No. 4 has a coloured paper wrapper. Amalgamated with the
"Stamp collector" in July 1892.

PHILATELIC MONTHLY REFEREE. The Philatelic (1) monthly referee.

Norwood, London, S.E., etc., R. T. Morgan and Co., $8^{\circ} .81$ in 19 nos, in 2 vols.

Vol. I. Feb. 25, 1901-Jan. 25, 1902 . Tos 1-12 Ti h $1-148$ tect

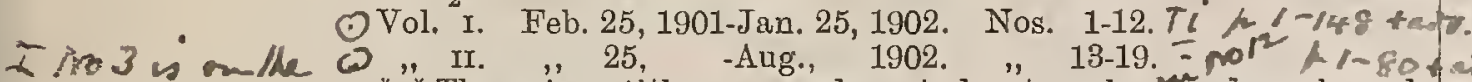

wh. "Shaice $v^{*}$ "* There is a title-page and an index" to vol. I, and a coloured " paper wrapper to each number. $v$ No. 19 was published by J. T. $\checkmark$ " in place of "19" except on the wrapper, which is correctly toum numbered. $v$ Nos. 4 'and 11 have supplements of illustrations of stamps, and no. 19 has a supplement of four pages of advertisements. varions beflets miserted i vol.

42 . 1-18 preyish blue [Continued as :]

15. Emar $O$ The Monthly philatelic referee. 20.21 theik silurean $8^{\circ} .8 \frac{1}{2}$ in. Vol. II. 2 nos. Croydon, J. T. Bolton, 1902.

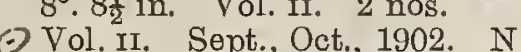

0 Vol. II. Sept., Ot., 1002. Nos. 20-21. H/ $80-107+$ hot * "There is a coloured paper wrapper to each number. Although the title reads "The Monthly philatelic referee." the headings of

rotis-2L the pages of both numbers read "The Philatelic monthly reteree". Both numbers are wrongly numbered "whole no. 9," but the numbering on the wrappers is correctly given. $\checkmark$ There is a supplement of four pages of advertisements to no. 20 .

PHILATEIIC NEBRASKAN. The Philatelic Nebraskan. For stamp collectors.

Omaha, Neb., The Nebraska Philatelic Publishing Co., 1897 .

$32^{\circ} .41$ in. No. 1, January, 1897. Mis. St. Jour. 104. (7).

PHILATELIC NEBRASKAN. The Philatelic Nebraskan. I 897 . Alliance, Neb., Philatelic Nebrastian Publishing Co.,

16. 5-5 $\frac{1}{2}$ in. Nos. 1-2, January 15-February $15,1897$.

12 St. St. Jour. $150(8)$.

PHILATELIC NEWS. The Philatelic news.

8.. 9 in. No. 1, January, 1877.

Toronto, John Kelly, I877.

* * Wanting

PHILATELIC NFWS. The Philatelic news.

Cleveland, $0 .$, Havens and Hamlin, etc., I 878. $8^{\circ}$. $7 \frac{1}{2}$ in. Nos. 1-5, Jan.-May, 1878

** No. 5 was published by Oliver S. Hart. Mis. St. Jour. 41 (6)

PHIJATEIIC NEWS. The Philatelic news. Official journal of the Springfield Philatelic Association. I880.

Springfield, Mass., Springfield Philatelic Association,

$8^{\circ} \cdot 6 \frac{1}{2}$ in. 9 nos. in 2 vols,
Vol. I. Jan.-June, 1880. Nos. $1-6$.

Vol. r. Jan.-June, 1880. Nos. 1-6.

* * After the completion of volume r., the volume was supplied in

a coloured paper wrapper. There is a slip supplement to no. 3 ,

a coloured paper wrapper. There is a slip supplement to no. 3,
vol. 2 .

PHILATELIC NEWS. The Philatelic news. A monthly stamp journal. 86. $8^{\circ} .91-101$ in. 13 nos, in 2 rols.

Vol. I. Apl., 1883-Apl., 1884. Nos. 1-3, 6-12.

* "II. " 1886-June, 1886. " 1-3.

*** There are no nos. 4 and 5, vol. I., but no. 6 , which is dated September, 1883, is stated to be for July, August and September. No. 8 is numbered " 51 " in error and there is no number for December, 1883. Nos. 9-12 were published by W. L. Emory, at Fitchburg, Mass., and the numbers of vol. Ir., by I. C. Greene, at the last-named place. Nos. 2 and 3 , vol. II., were published together and there are coloured paper wrappers to nos. 2-12, vol. I. Amalgamated with the "Philatelic Herald," Portland, Me., in August, 1886.
PHILATELIC NEWS

698

PHILATELIC NEWS. The Philatelic nows.

Chicago, Ill., Harry J. Berry, Jr., I 886.

$8^{\circ} .8$ in. Nos. 1-3, Fcb. 25, Apl. 1, May 1, 1886

${ }^{*}$ * There is a coloured paper wrapper to each number.

Mis. St. Jour, 65 (3).

PHILATELIC NEWS. The Philatelic news.

Cambridgeboro, Pa., H. B. Wilber, etc., I888-go.

$12^{\circ} .7 \frac{1}{2}$ in. and $8^{\circ} .9-9 \frac{3}{4}$ in. 17 nos. in. 3 vols.

Vol. r. Feb.-Aug., 1888. Nos. 1-7.

" Ir. Aug.-Dec., 1889. " 8-12.

" Irr. Jan.-Sept., 1890. " 1- 5.

* Nos. $1-7$ are $12^{\circ}$. and the remainderjoctavo. Nos. 6 and 7 were published together and nos. 11 and 12, vol. Ir., and nos. 1 and 2 , vol. III. have coloured paper wrappers. Vol. III., no. 3, is wrongly numbered vol. II., no. 3 . No. 2 was published by the Philatelic Publishing Co. and no. 8, vol. II., to no. 4, vol. III., inclusive, by H. B. Wilber and Co. There are no numbers for February, April, May, and June, 1890. A copy of the prospectus issued previous to the re-publication of the journal in Angust, 1889, is bound up in front of no. 8.

PHILATELIC NEWS. The Philatelic news. Elizabeth, N. J., Cave and Co., I889. $8^{\circ} .8 \frac{3}{4}$ in. Vol, III. Nos. 1-2, Nov. 1-Xmas, 1889

* * Each number has a coloured paper wrapper, the front wrapper of no. 2 being dated "December, 1889 ". No other numbers appeared. Mis. St. Jour. $63(2)$.

PHILATELIC NEWS. Philatelic news.

Utica, N. Y., Frant B. M. Sheldon, I89o. $16^{\circ} .5 \frac{1}{4}$ in. and $8^{\circ} .9 \frac{1}{2}-9$ in. Nos 1-8, April-November, 1890. * Nos. $1-4$ are $16^{\circ}$. and the remaining numbers are octavo, and nos. 3,4 have coloured paper wrappers. Mis. St. Jour. 140 (11). [Continued as :]

The Utica investigator.

Utica, N. Y., Frank B. M. Sheldon, 189o-91. Fol. $11 \frac{3}{4}$ in. and $8^{\circ} .8 \frac{3}{4}$ in. Nos. 9-11, December, 1890-February 14,1891 .

* * Only partly philatelic. Nos. 9, 10 are folio and no. 11 is octavo. tains no philatelic matter March 2, 1891, but this num is octavo.

PHILATELIC NEWS. See YoUTH'S MAGAZINE.

PHILATELIC NEWSLETTER. The Philatelic newsletter. A monthly journal for stamp collectors. Minneapolis, Minn., Harry S. Swensen, etc., 1895-97. $8^{\circ} .10_{4}^{3}$ in. 19 nos. in 2 vols.

Vol. I. Feb., 1895-April, 1896. Nos. 1-12.

"II. Sept. 15, 1896.-Mar-, 1897. Nos. 1-7.

* * The seven numbers of vol. II. were published by Geo. W. Achard and there is a coloured paper wrapper to each of the nineteen numbers. No. 4, vol. I., is dated "May and June, 1895," there is no number for February, 1896, no. 12 being dated "March and April, 1896". No. 9 is wrongly numbered "no. 8 " and no. 1 , vol. II., is wrongly numbered "no. 7 " and the wrappers of nos. 8 II., has the numeral " 5 " added in pen and ink.

[Second series.]

Minneapolis, Minn., G. W. Achard, 1897. * * Wanting.

PHILATEIIC NONPAREIL. The Philatelic nonpareil. Boston, Mass., Edwin A. Durgin, I889-9o.

$8^{\circ} .9$ in. Nos. 1-3, Nov, 15, 1889-Jan. 15, 1890.

** No. 3 has a coloured paper wrapper. Mis. St. Jour. 22 (8).

PHILATELIC NOTES Philatelic notes.

Norwich, N. Y., F. E. Thorp, 1886.

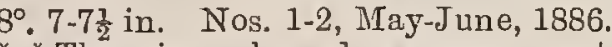

* * There is a coloured paper wrapper to no. 1. The year of publication is wrongly given on each number as " 1885 ," but on the wrapper of no. 1 the date is correct. Bound up with the two numbers is a copy of the prospectus of the journal dated February $24,1886$.

Mis. St. Jour. 67 (3).

PHILATELIC OBSERVER. The Philatelic observer. - A monthly journal for philatelists.

Bournemouth, T. Stevens, I882.

O $8^{\circ} .8 \frac{1}{2}$ in. Nos, 1-2, Jan.-Feb., 1882. $* *$ A copy of the prospectus of the journal is bound up with it.
Mis. St. Jour. $30(9)$ 
PHILATELIC OBSERVER. The Philatelic observer. New York, Wilbur W. Thomas, r 888.

$8^{\circ} .8 \frac{3}{t}$ in. Nos. 1-2, May-June, $1888 . \quad$ Mis. St. Jour. 26 (9).

PHILATELIC PARAGRAPH. The Philatelic paragraph. New York, etc., Max Strakosch, I 896.

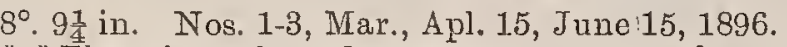

* * There is a coloured paper wrapper to each number. No. 3 was ** Tished at Bellport, Isong Island.
pubis. St. Jour. 92 (8).

PHILATELIC POLITICIAN, The Philatelic politician. Bellaire, O., [Ben. L. Morris], I896.

$48^{\circ} .4 \frac{1}{4}$ in. No. 1 , May $1,1896$.

* * The number has a paper wrapper and this bears the date "April".

Mis. St. Jour $96(2)$

PHILATELIC POST. The Philatelic post. A monthly for stamp collectors.

Smethport, Pa., The Nunundah Stamp and Publishing Co., etc., $\mathbf{1 9 0 0 .}$

$8^{\circ} .8 \frac{1}{4}-8 \frac{1}{2}$ in. Nos. 1-9, Jan.-Sept., 1900

* * Nos. 1-8 have paper wrappers and no. 9 was published by Scott F. Redfield.

[Continued as:]

Redfield's weekly philatelic post.

Smethport, Pa., Scott F. Redfield, I 900-o I. $8^{\circ} .8 \frac{1}{2}-8$ in. and fol. $12^{3}$ in. Vol. II. 32 nos.

$8^{\circ} .8 \frac{1}{2}-8$ in. and fol. $12 \frac{3}{4}$ in. Vol. II. 32 nos.
Vol. II. Oct. 3 1900-May 16,1901 . Nos. $1-32$.

* * Nos. 1-3 are octavo 8 1 inches, nos.14-20 arc octavo 8 inches and the remaining numbers are folio. Nos. 1 -20 have wiappers with the title "Redfield's Weekly philatelic post," but on these numthe title "Redfield's Weekly philatelic post," but on these num-
bers the title inside reads "The Philatelic post". On the wrapper bers the title inside reads "The Philatelic post". On the wrapper of no. 18 the date "January 3, 1901," is given in error for " February 7,1901

PHILATELIC POSTAL CARD. The Philatelic postal card.

Reading, Pa., The Postal Card Publishing Co., r892. $8^{\circ} .61$ in. Nos. 1-2, Oct. 15-Dec. 15, 1892.

* * Printed on the back of the then current one cent United States posteards.

\section{[Continued as :]}

__ Kissinger's philatelic postal card.

Reading, Pa., Clifford W. Kissinger, I893-94. $8^{\circ} .7$ in. 13 nos. in 2 vols.

Vol. I. Feb. 15 -Oct., 1893. Nos. 3-12.

" * Printed on buff card folded in the centre to imitate the then * Printed on buff card folded in the centre to imilatc the then current one cent Unitcd States postal card. Nos. 11 and 12 are both dated October, the first "October 2," and the last "October 0, " the figure before the " 0 " not having printed. This number is headed "Specia

PHILATELIC PRESS. The Philatelic press.

London, E.C., Bluett and Co., 1888. $4^{\circ} .8 \frac{1}{2}$ in. Nos. 1-3, Feb., Mar., May, 1888.

* There is a coloured paper wrapper to each,uumber. Nos. 1 and 2 *were printed at Bury St. Edmund's and no. 3 at Penzance. Mis. St. Jour. 78 (3).

PHILATELIC PRESS. The Philatelic press. Devoted to the interests of stamp collecting.

West Winsted, Conn., H. G. Manchester, I888-89. $8^{\circ} .8 \frac{3}{4}$ in. Nos. 1-8, Oct., 1888-May, 1889.

* Nos. 4-8 are printed on pale rose paper.

Mis. St. Jour. 26 (12).

PHILATELIC PRESS AND GENERAL ADVERTISER. Philatelic press and general advertiser. Anerley, Surrey, F. Sayer, i883-84. $8^{\circ} .8 \frac{1}{2}$ in. and $4^{\circ} .10$ in. Nos. 1-2, Dec., 1883-Mar. 1, 1884.
** No. 1 is octavo and no. 2 quarto. Mis. St. Jour. 30 (11).

PHILATELIC PUCK. Philatelic puck.

San Antonio, Tex., Alamo Publishing Co., I893. $4^{\circ} .9 \frac{1}{2}$ in. No. 1, May, 1893.

* The number has a coloured paper wrapper.

Mis. St. Jour. 59 (7).
PHILATELIC PUCK-LITMRATURIST. The Philatelic puck-literaturist. Devoted to flatelick fools and literature collectors.

8. 10 in. No. 1, April, 1897.

Muscatine, Iowa, Moses B. Page, I897. A quarterly mazine issued in the interests of philately. Manitowoc, Wis., Imperial Stamp Co., r 903. $8^{\circ} .8 \frac{3}{ \pm}$ in. No. 1 , June, 1903.

Mis. St. Jour. 113 (2).

PHILATELIC QUARTERIY ADVERTISER. The

- Philatelic quarterly advertiser. Consisting wholly of advertisements from foreign stamp dealers all over the world. Liverpool, G. and H. Dawson, 1884-85. $8^{\circ} .11 \frac{1}{4}$ in. Nos. $1-2$, Oct. 15,1884 -Jan. $5,1885$.

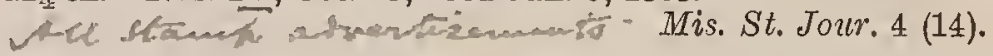

PHILATELIC QUARTERLY AND IMISCELLANE-

$\odot$ OUS ADVERTISER. The Philatelic quarterly and miscellaneous advertiser.

Brighton, Stafford Smith and Co., I877-79. (-) $8^{\circ} .87$ in. Nos. 1-11, Jan.-Mar., Apl.-June, July-Sept., Oct.-Dec., 1877, Jan.-Mar., Apl.-June, July-Sept., Oct.-Dec., 1878, Jan.-Mar. Apl.-June, July-Sept., 1879 . Viner. Nos. $1-8$ are printed on rose paper, nos. 9-11 on buff paper and there is a paper wrapper to each number.

PHILATELIC QUARTERLY REVIEW. The Philatelic quarterly review. London, S.E., Dan Collins, I886.

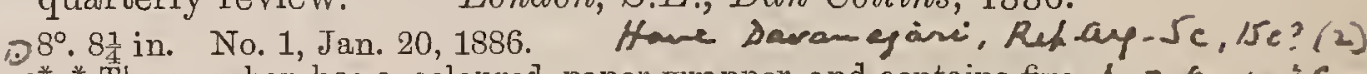
$V_{*}^{*}$ The number has a coloured paper wrapper and contains five has hayancenert photographic illustrations of stamps pasted in by hand which Puma $10 \mathrm{C}$ vary in diffcrent copies of the journal. Two numbers aud a copy of the prospectus are bound up together. Mis. St. Jour. 34 (5).

PHILATELIC RAIL-SPLITTER. The Philatelic railsplitter. [Prospectus of a journal to be published by Cleve Scott, Central City, Neb., on February 1, 1895, but which was never issued.]

Mis. St. Jour. 62 (5).

PHILATELIC RAMBLER. The Philatelic rambler. For the exclusive interests of the publisher.

Loomis, Neb., James A. Anderzen, 1897. $8^{\circ} .8 \frac{1}{2}$ in. No. 1, Season 1897-98.

* * Also numbered "Old series no. 7," the former issues of this series being merely price lists. Mis. St. Jour. $113(1)$.

PHILATELIC RAYS. Philatelic rays. Formerly "The terminal". Stamps, coins, curios, postal cards, postmarks, camera. New York, Rudolf Vlach, i 902. $8^{\circ} .6$ in. No. 3, September, 1902.

* * Nos. 1 and 2 with the title "The terminal" were not phila** Nos. 1 and 2 with the title "The terminal" Were Jour. $135(2)$.
telic.

PHILATEIC RECORD. The Philatelic record.

London, Pemberton, Wilson and Co.. etc., Plymouth [printed], I879-95. $8^{\circ} .8 \frac{1}{4}$ in. 204 nos. in 17 vols

Vol. I. Feb., 1879-Jan., 1880. Nos. 1- 12.

" II. " 1880- " 1881. " 13- 24.

" III. " $\quad 1881-\quad, \quad 1882 . \quad$ " $25-36$.

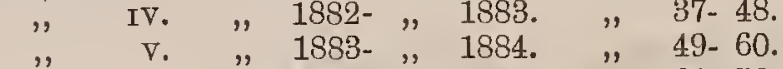

" vI. " " 1884- " $1885 . \quad$ " $61-72$

" VII. " $\quad 1885-"$ " $1886 . \quad$ " $73-84$.

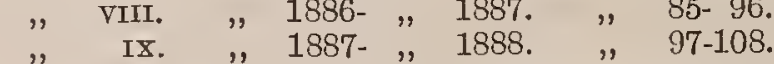

" x. " " 1888-D"̈., 1888. ", 109-1.20.

" xI. Jan., - ", 1889. " 121-132.

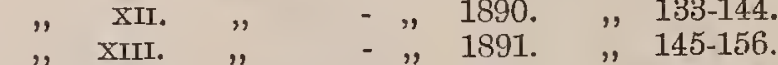

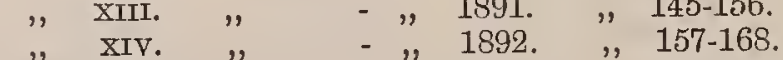

" $\quad$ xIV. " " $\quad$ - " " $1893 . \quad$ " $169-180$

" XVI. " " - " 1894. ", 181-192.

" XVII. " " - " 1895. " 198-204. " *olume and, commencing with no. 25 , a coloured paper wrapper
to each number. Nos. 144-204 were published by Theodor Buhl to each number. Nos. 144-204 were published by Theodor Buhl
and Co. of London. Nos. 32-144 were also published by Stanley Gibbons and Co., London, and part, if not all, of these numbers also by Stafford Smith and Co., Brighton; each of these firms 
PHILATELIC PASTURE, BELLAORE. O

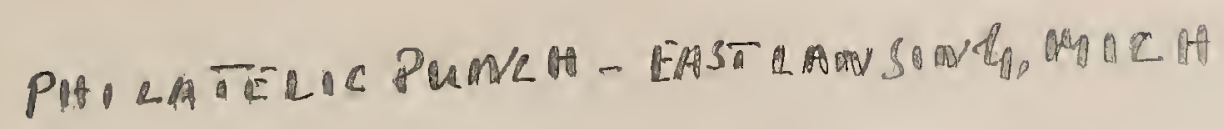

PHORATEROC OPINOOAN'

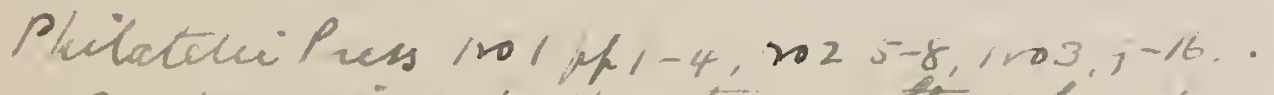
each no. in is iuft or temes cotta wh. whech has atbed the tite afonsuat is Etamk coliersos vedus.
} 


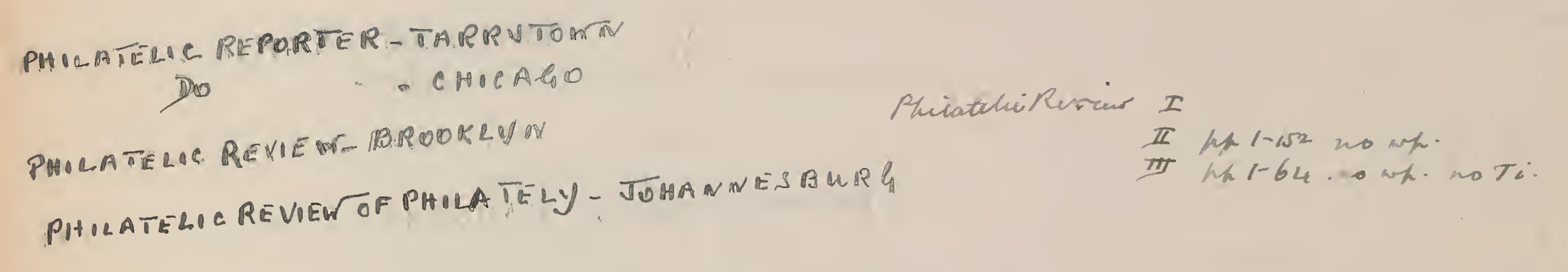


having their own imprint at the end and their name and advertisements instead of those of Pemberton, Wilson and Co., or Theodor Buhl and Co., on the coloured paper wrappers. Nos. 119 and 120 were published together under the date "December, " Japanese post cards in no. 14, slip supplements to nos. 95, 108 159, 171 and 204, a supplement consisting of "A catalogue of telegraph stamps, stamped forms, etc.," to vols. X. and XI., and a supplement consisting of pages 5-12 of "A catalogue of the postage stamps, envelopes, eto., of the United Kingdom during the fifty years that have elapsed since their introduction," to no. 135. The latter catalogue was afterwards completed and published in separate form by W. A. S. Westoby in 1891. A graphic chart of the Departmental stamps of South Australia was presented with no. 15\%. The first seven volumes, with the exception of a fer odd numbers, were edited by Maitland Burnett, while W. A. S Westoby edited vols. VIII.-XVII., omitting the eighteen numbers nos. 7-12, vol. XIr., and M. P. Castle the twelve numbers of rol. XIII.

\section{PHILATELIC RECORD.}

[Continued as :]

The Philatelic record and stamp news.

London, Buhl and Co., Limited, etc., I896-99.

$8^{\circ} .9 \frac{3}{3}$ in. Vols. Xvirr.-xxr. 47 nos.

Vol. xviII. Jan.-Dec., 1896. Nos. 1-12.

$"$ xIx. " - " 1897. ", $1-12$.

" XX. " - " $\quad$ 1898. " $\quad 1-11$.

* * There is a title-page and a list of contents to each volume, an index to vols. Xvrrr. and XIX., and a paper wrapper to each number. Vol. xvIrr. was printed at London, vols xIx. and xx. a Plymouth and vol. XxI. at Bournemouth. Nos. 11 and 12, vol XXI., were published by Sir Isaare Pitman and Sons of London. The August and september numbers of 1598 were published together, as "vol. 20, no. 8 ". The title-page and list of content ofl tour volumes were edity by. J. Johnon of Jomiton in 190 tion of nos. 1-6, vol. XxI., which were edited by Theodor Buhl.

\section{Continued as :}

The Philatelic record.

London, etc., Sir Isaac Pitman and Sons, Limited, etc., I900-

$8^{\circ} .9 \frac{3}{3}$ in. Vols. $x \times 11 .-$ nos. In progress.

Vol. XXII. Jan.-Dec, 1900. Nos. 1-12.

"XXIIr. " - " 1901. " $1-12$

" XXIV. " - " $1902 . \quad " 1-12$

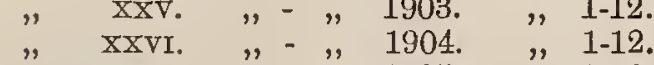

XXVII. " - " 1905. " $1-12$

" Xxvir. " " " 1000. ",

* Commencing with January, 1902, the journal was published by the Philatelic Record Company, Limited, of Manchester. Nos. 1-3, vol. XxII , were printed at Bournemouth and all subsequent numbers at West Norwood, London. There is a title-page and a list of contents to each volume and a paper wrapper to each number. The wrapper of no. 5, vol. xxvil., bears vol. " 28 " in error. (There is a special supplement dated. February $7 \mathrm{th}, 1906$ with the title the "Dietetic record," containing four pages within a coloured paper wrapper. Vol. XxIr. and nos. 1-9, vol. XxIII. were edited by E. J. Nankivell, and the remainder by W. Dorning Beckton.

PHILATELIC RECORD. The Philatelic record. A monthly journal for stamp collectors.

Wellington, O., French and Roser, I885-86. $8^{\circ} .9$ in. Nos. 1-3, Nor., 1885-Jan., 1886 * No. 1 is printed on bluish paper and has a white paper
wrapper.

PHILATELIC RECORD. The Philatelic record.

Springfield, Ill., Colombia Stamp Co., I 893

$8^{\circ} .8 \frac{1}{2}$ in. No. 1, February, 1893.

Mis. St. Jour. 63 (13)

PHILATELIC RECORD. The Philatelic record. Published monthly.

$4^{\circ} \cdot 7 \frac{1}{2}$ in. 7 nos. in 2 vols.

Montreal, Arthur R. Magill, I 90 I.

Vol. I. Jan.-June, 1901. Nos. 1-6

, II. July, 1901. No. 1

* * Each number has a coloured paper wrapper and a notice in each number states that the "Philatclic spectator" has been consolidated with the journal. The "Philatelic record" was subs"quently consolidated with the "Philatelic times" of L'Orignal, Ont.
PHILATELIC RECORD AND STAMP NEWS. See PhILATELid ReCORd (London).

PHILATELIC REFEREE. The Philatelic referee. A magazine for stamp collectors. Published quarterly by F. Bickers and Co., late F. Staunton, Ipswich. $\checkmark$ Ipswich, F. Bickers and Co., 1883 $4^{\circ} .103$ in. QNos. 1-4, Jan. 18, Apl. 18 , Júly 18, Oct. 25, 1883. er in a coloured paper Oa

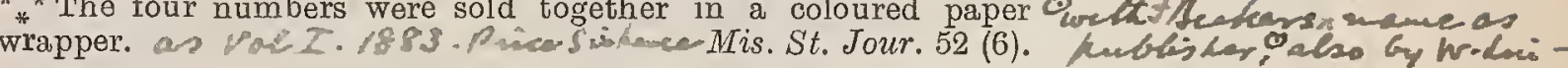
- New series. Ipswich, F. Bickers and Co., x884-85. (68. 8 . 8 in. Vol. II. Nos. 5-8, May 26, Sept. 1, 1884, Feb. 25, Jul M. $1-6$

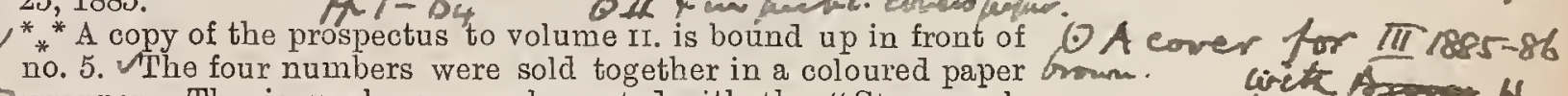

C wrapper $\rightarrow$ The journal was amalgamated with the "Stamp collectors' journal " in November 1885. Mis. St. Jour. 52 (4). PHILATHLIC REPORTER. See U. S. CoRRESPONDING PHILATELIST.

PHILATELIC REVIEW. The Philatelic review. Jersey City, N. J., [? ], 1878. Sond

in. No. 1.

PHILATELIC REVIEW. The Philatelic review. Maidenhead, C. N. Butler and Co., etc., I880-82.

sint $8^{\circ} .8 \frac{3}{2}$ in. and $4^{\circ} .9 \frac{1}{2}$ in. 27 nos. in 3 vols

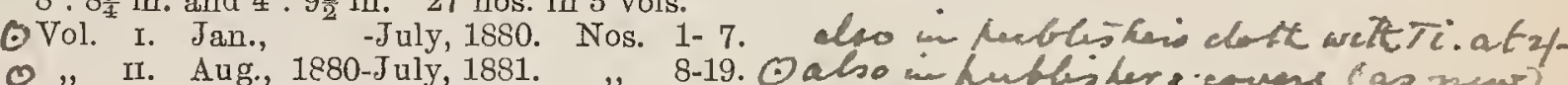
O ". Ir. Aug., 1880-July, 1881. "8-19. Oalso in Rublider eovers (as newow) O." IrI. Sept., 1881-Apl., 1882. "20-27. also in Mubleishers cerrers. * Vol. I. is octavo and vols. II.-III. are quarto. 2 Nos. 17-27 wer published by Nichols, Butler and Co., and nos. 2-7 werc printed at Bray. $\vee$ There is a title-page and an index to volume Ir., and a supplement of coloured illustrations of twenty-three rare stamps was presented with no. 23.2 The imprint at the foot of the last page of no. 25 and'also of no. 26 has " 1881 " in place of " 1882 ". It is stated on page 150 of no. 19 that a titlc-page and an index had been issued for volume I., but the copy of the volume in the
library is without this.

PHILATELIC REVIEW. The Philatelic review. C) Bristol, S. F. Bicleers, 1889

๑24 $24^{\circ}$ in. No. 1, January 25, 1889. 8/א. Mis. St. Jour. 55 (1)

PHLATELIC REVIEW. The Philatelic review. Published quarterly by Philip $\mathrm{H}$. Lee.

Huddersfield, Yorks, P. H. Lee, I89o
$4^{\circ} .93$ in. Nos. 1-2, Júly-October, 1890 * ${ }^{\circ}$. 9 in. Nos. $1-2$ Júly-October, 1890.

ol ot mencuskerat.

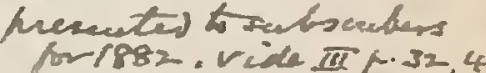
$56.64,24$.

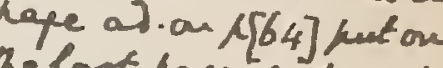
he lont paye of wh. 2 ents

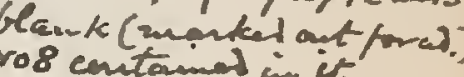

ILATELIC REVIEW. The Philatelic review. $8 \mathrm{gI}$

Hot Springs, Ark., Philatelic Review Publishing Co.

$8^{\circ} .8 \frac{3}{1}$ in. No 1, Feb., 1891

** The number has a coloured paper wrapper. E. B. Jones ** The number has a coloured paper wrapper. E. B. Jones
list for philatelic literature collectors," but it is very doubtful if
list list for philatelic literature collectors," but it is very doubtful if
more than one number was issued.
Mis. St. Jour. 46 (8).

PHILATELIC REVIEW. Philatelic review.

East Boston, Mass., Joseph P. Plourd, 1898 $8^{\circ} .9$ in. Nos. $1-3$, Jan.-Mar., 1898

* * There is a coloured paper wrapper to each number. Mis. St. Jour. 113 (5)

PHILATELIC REVIEW. See REvIEW. Roch hland. 1897

PHILATELIC REVIEW OF REVIEWS. The Philatelic review of reviews. A monthly résumé of periodical literature appertaining to philately.

$8^{\circ} \cdot 9 \frac{3}{4}$ in. 60 nos. in 5 vols. Salisbury, W. Brown, I892-96.

Vol. I. Jan. -Dec. 10, 1892. Nos. 1-12

, II. " $10-, \quad 10,1893 . \quad, \quad 1-12$.

" rrr. " $\quad 10-, " 10,1894 . \quad " \quad 1-12$.

" IV. " $\quad 10-" 10,10,1895 . \quad " 1-12$

* * Vol. r. has a title-page and an index, and there is an index to each of the other volumes printed with the indexes to vols. IIr.-VI. of the "Philatelic journal of Great Britain". Some, but not all of the numbers for Febr:ary, 1892, are wrongly numbered and dated "Vol. I. no. 1. January, 1892." There is no number for November, 1892, but nos. 11 and 12 were published together unde the date "December 10, 1892 ". Page 60 of 1 vol. $\nabla$. is printed a the back of page 176 of the "Philatelic journal of Great Britain". The journal was published as a supplement to the "Philatclic journal of Great Britain" and after December, 1896, it was amalgamated and paged with the latter. 
PHILATELIC REVIEW OF REVIEWS. The Philatelic review of reviews.

Osage, Iowa, H. E. Tuttle and Co., etc., I894-95.

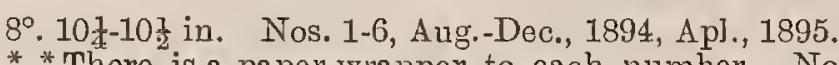
* * There is a paper wrapper to each number. No. 6 was pub lished by the Press Printing Co. Mis. St. Jour. 59 (8).

PHILATELIC SCIENCE. The Philatelic science. 1887 . Georgetown, Mass., The Philatelic Publishing Co.

$8^{\circ} .9$ in. Nos. 1-3, March-May, 1887.

* Nos. 2 and 3 were published together under the date "A pri-

PHILATELIC SNOOZER. The Philatelic snoozer.

New York, M. Kottshofsti and Co., 1877 .

$8^{\circ} .8 \frac{1}{2}-9$ in. Nos. 1-2, Januarÿ-February, 1877.

* A circular dated New York, October, 1878, was issued stating that a no.' 3 would be published on November 10th, but this number never appeared. See under "New York herald" and "Coin circular" for particulars of lawsuit in connection with this "Coinal.
Mis. St. Jour. 118 (3).

PHILATELIC SOUTH. The Philatelic south.

Mapleville, N. C., P. W. Fuller, I904. in. No.
* Wanting.

PHILATELIC SPECTATOR. The Philatelic spectator. Berlin, Ont., Geo. E. Mueller, IS99-1900.

$32^{\circ} .4-4 \frac{7}{2}$ in. and $8^{\circ} .8-8 \frac{1}{2}$ in. 12 nos. in 3 vols.

Vol. I. Oct. -Dec. 1899. Nos. 1- 3.

"II. Jan. -June 22, 1900 . " $4-9$.

"III. July-Oct. " $10-12$.

* "Nos. 1-3 are $32^{\circ}$. and the remaining numbers are octavo and nos. 1-9 and no. 12 have paper wrappers. No. 1 only bears the date "October" the wrapper of no. 7 has in error "whole no 6 " No. 10 is dated "July-Aup, 1900 " and is also numbered "vol 3 no. 1 " and nos. 11 and 12 are also numbered "vol. 3 "no. 3 " and "vol. 3 no 4" respectively Amalsamatod with the "Philatelic record" of Montreal in January, 1901.

Mis. St. Jour. 149 (4)

PHILATELIC SQUEAL. The Philatelic squeal. Boston, Mass., J. M. Randall, I885.

$8^{\circ} .81$ in. No. 1, March, 1885.

Mis. St. Jour. 29 (6)

PHILATEIIC STAR. The Philatelic star.

(-) Stockton-on-Tecs, etc. E. F. Herdman, etc., I88 I-85. $8^{\circ} .8 \frac{1}{2}$ in. 12 nos. in 2 vols. Manen i $2-6$

Dol. I. Mar., 1881, Aug., Oct., Dec., 1883, Feb. 25, Aug. 1, 1884 Nos. 1-6. 1-24 $4+7 i$

(1) ", II. Nov. 1, 1884, Mar., May, July, Sept., Nov., 1885. Nos. 1-6. Mki- K2 + Ti

** There is a title-page, an index and one page of ijlustrations to each volume. $\checkmark$ Nos. 2-6, vol. I., and no. 1, vol. II, were published by the International Philatelic Union, at Ipswich, and nos. 2-6, vol. II., by E. F. Herdman at Berwick-upon-Tweed. A copy of the prospectus is bound up in front of no. 1 and a copy of the prospectus to vol. III. is bound up at the end of vol. II.

$$
\text { Mis. St. Jour. } 30 \text { (7). }
$$

[Continued as :]

(- The Philatelic star and coin collector. 886.

Berwick-upon-Tweed, etc., E. F. Herdman, etc., 4․ 93 in. Vol, III. 3 nos

6 Vol. III. Jan., Mar., May, 1886. Nos. 1-3. Phe Pr. 19 the 3 * There is a coloured paper wrapper to each number. in 0 " in no. 3 that the "Philatelic globe," the "Stamp dealers" journal" and the "Fore " incorporated in in July, 1886. See III $p .17 .25 \%$ Mis. St. Jour. 45 (1)

PHILATELIC STAR. The Philatelic star.

$16^{\circ} .7 \frac{1}{2}$ in. No. 1 , October, 1889

Sawens, N. Y., C. E. Curtiss, I889. Mis. St. Jour. 40 (3).
PHILATELIC STAR. The Philatelic star.

Meriden, Conn., Frank I. Camp, etc., I895. $4^{\circ} .7 \frac{1}{2}$ in. and $16^{\circ} .6$ in. Nos. 1-7, Sept., Oct. 5, Oct. 12, Oct. 19 Oct. 26, Nov. 2, Nov. 9, 1895.

** No. 1 is $4^{\circ}$, the rest $16^{\circ}$. Nos. $2-7$ have coloured paper wrappers and were published by Charles W. Parker. No. 7 ha the date "Nov. 2," and "No. 6 " on page (2) altered in pen and ink to "Nov. 9 " and "No. 7 ". The wrappers of nos. 4,5 and 6 have those numbers in each case printed over No. 3 and the wrapper of no. 7 has that number written in pen and ink over
No. 8 .

PHILATELIC STAR. The Philatelic star.

Madison, N. Y., Judson N. Burton, I 902-07.

$16^{\circ} .5_{\frac{3}{4}}^{3}$ in., $8^{\circ} .9 \frac{1}{2}$ in. and $7 \frac{3}{4}$ in. 53 nos. in 6 vols.

Vol. I. Jan. 10-Dec. 20, 1902. Nos. 1-12.

" II. " 20- " 15, $1903 . \quad$ " $1-12$

" III. " $15-" 15-15,1904 . \quad$ " $1-12$.

" v. Jan. 15, Apl. 7, Apl. 14, [? 49. 50.] 1906. Nos. 46-50.

" V. Jan. 15, Apl. 7, Apl. 14, [? 49. 50.] 1906. Nos. 46-50.

*" VI. 1." 15, Feb. 15, Sept. 15, are 16०., nos. 4-12, vol. I., and nos. 1-3," vol. II., ar * Nos. $1-3$ are $16^{\circ}$, nos. $4-12$, vol. I., and nos. $1-3$, vol. II., are Nos. 1-3, vol. I., and each number commencing with no. 4, vol. II. has. 1 -3, vol. I., and each number wrapper, with the exception of nos. 6 and 7 , vol. III. has a paper Wrapper, with the exception of nos. 6 and 7 , vol. III.,
nos. 7 and 8 , vol. IV. and nos. 47 and 48 . Nos. 7 and 8 , vol. I., were published together. Wanting no. 6 , vol. $\mathrm{N}$., and nos. 49, 50 .

PHILATELIC STAR AND COIN COLLECTOR. See Philatelic star (Stockton-on-Tees).

PHILATELIC SUN. The Philatelic sun. Albany, N. Y., A. H. Brett, I892.

$16^{\circ} .6$ in. No. 1 , February, 1892. Mis. St. Jour. 68 (11)

PHILATELIC SUN. The Philatelic sun. Brushton, N. Y., Chas. H. Smith, I892. $8^{\circ} \cdot 6 \frac{1}{4}$ in. Nos. 1-6, May-Oct., 1892
* Nos. 2-6 have paper wrappers. Mis. $\stackrel{4}{S}$ t. Jour. 68 (12).

PHILATELIC SUN. The Philatelic sun.

Abiline, Tex., Lowry and Bradley, [I894]

* in. No. 1, [August, 1894].

PIIATELIC SUN. The Philatelic sun

Taunton, Mass., Fred. W. Kaupp, etc., I 894-95 $4^{\circ} .7 \frac{1}{2}$ in. 7 nos. in 2 vols.

Vol. I. Sept. 1, 1894-Feb., 1895. Nos. 1-6.

Vol. 1. Sept. 1, 1894-Feb., 1895. Nos. 1-

* " There are coloured paper wrappers to nos. 1, 2, and 4, on which the publisher's name is given as the Sun Publishing $\mathrm{Co}$ No. 1, vol. II., was published by the latter. Amalgamated with No. "Vol. II., was published by the latter. Amalgamated with
the "Cohannett philatelist".

PHILATELIC TIME AND TIDE. See Trme AND TIDE. PHILATELIC TIIIES. The Philatelic times.

Margate, J. Bishop, I88o.

in. No. 1.

* * According to T. K. Tiffany only one number was printed and this was produced by an antographic process. It is very doubtful if the number was circulated. Wanting.

PHILATELIC TIMES. The Philatelic times.

Margate, G. H. F. Gale, I88 I-83 (-) $8^{\circ} .81$ in. Nos. 1-12, Nov., 1881-Aug., 1882, Dec., 1882, Mar., 1883 . ** Nos. 3-12 were printed at Bury St. $\mathrm{E}$ mund's. There is a
white paper wrapper to no. 1 and nos. $2-1 Q$ have coloured paper

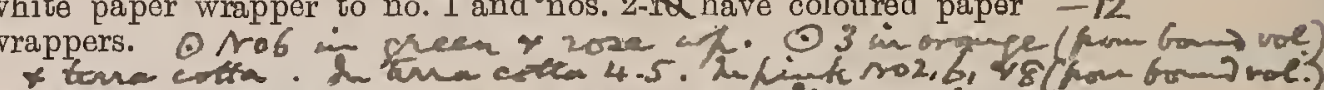

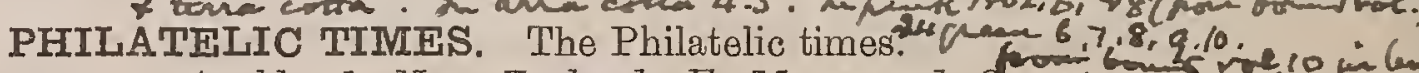

$8^{\circ}$ * 8? in. Nos. 1-4, May, July, Sept., Nov., 1881 .

Auckland, New Zealand, F!. Moore and Co., etc. A. Henderson and Co., both of Auckland. Mis. St. Jour. 30 (17).

PHILATELIC TIMES. The Philatelic times.

London, W.C., Bury St. Edmund's [printed], Bennett and Co., [1889].

Q $4^{\circ} .8 \frac{1}{4}$ in. No, 1 [1889]. Gour lication is not mentioned, but from a review of a number of the "Philatelic jourmal of America" on page 7, it appears that it was probably published in March, 1889. 


$$
\begin{aligned}
& \text { philuteric Roastet-Buster mass., 18q4-J 114 }
\end{aligned}
$$

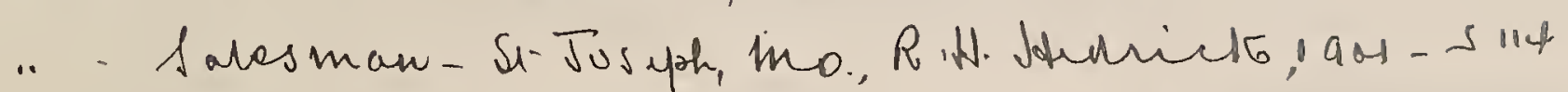

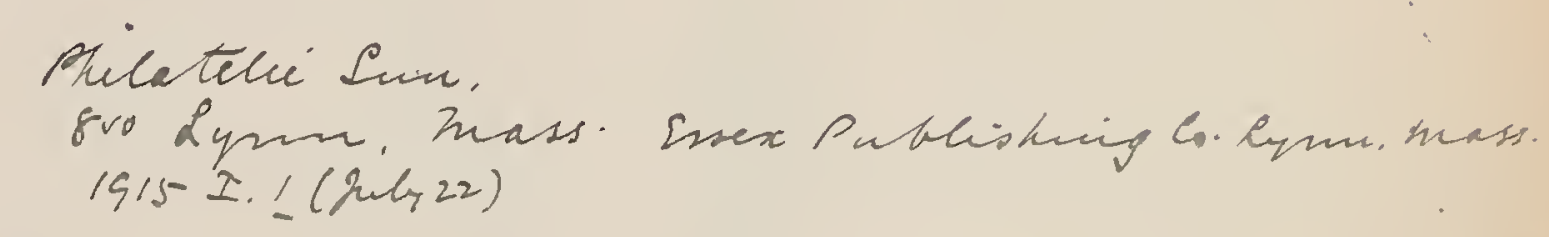

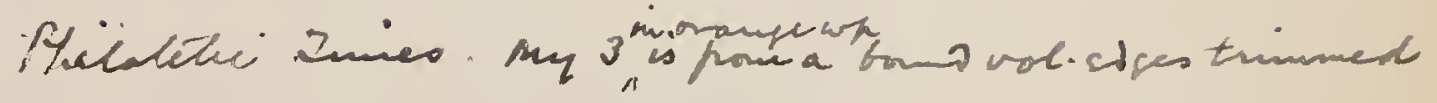




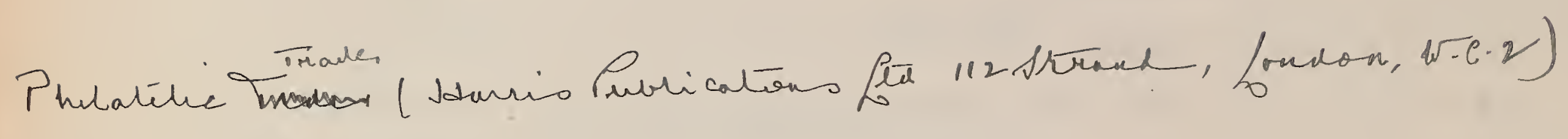


PHILATELIC TIIIES. The Philatelic times.

L'Orignal, Ont., The Philatelic Times Publishing

Co., rgor.

8.. 7 in. Nos. 1-4, March, Apl., JuJy, Sept., 1901.

* There is a paper wrapper to each number. The name of the publishers on nos. 3 and 4 is given as "The Times Publishing Co.". Amalgamated with the "Minnesota philatelist" in January, 1902 Mis. St. Jour. 104 (13).

PHILATELIC TIMES. See StAMP dOLLECTOR.

(Miller's Dale, Buxton, I896.)

PHILATELIC TIMIES AND STAIMP MART. The

$\odot$ Philatelic times and stamp mart. Tewkesbury, etc., Egremont, Cumberland [printed], Robert Croome, etc?, $1894-95$.

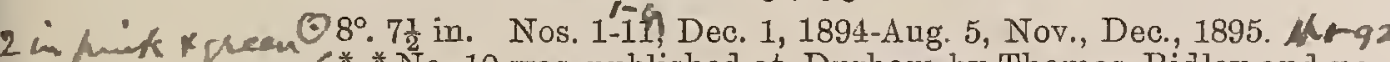
Goff. celus in thents paper wrapper to each number with the exception of the first . Amalgamated with the "Stamp collector" Miller's Dale, Buxton, vith turow from in June, 1896. O Prosfectios Mis. St. Jour. 55 (15) to A.s.

\section{PHILATELIC TRADER. The Philatelic trader.}

Egremont, Cumberland, Wm. Lewthwaite, 1899 . in. Nos. 1-5, [? Jan.-May], 1899

* Wanting all five numbers.

$\odot-$ New series.

Egremont, Cumberland, Wm. Lewthwaite, r 899. $8^{\circ} .7 \frac{1}{2}$ in. 4 nos. in 1 vol.

Vol. I. June-Sept., 1899. Nos. 6-9. not hapel

* * No. 9 has a coloured paper wrapper and has not the words "New series".

[Continued as :]

The Philatelic trader and exchange recorder.

Egremont, Cumberland, Wm. Lewthwaite, I 899-1903. $8^{\circ} .7 \frac{1}{2}$ in. 40 nos. in 5 vols.

- Vol. I. Oct. 16 -Dec. 18, 1899. Nos. 10-12. not Naged

" "Ir. Jan. 31 - " 17,1900 . " $1-12$.

0 "IIr. " $18-, 25,1901 . \quad " 1-12$.

(5) " IV. " " $31-, " 31,1902$

*. v. " 31, 1903 . No. 1 .

* " Each number has a colourod paper wrappex. varionis colen freen II q- III 9. Pivic III.10 - 108.

$$
\text { [Continued as :] }
$$

The Philatelic trader and fraud reporter. $\checkmark$

Egremont, Cumberland, Wm. Lewthuaite, rgo3$8^{\circ}$. $7 \frac{1}{2}$ in. Vols. V.- nos. In progress.

(- Vol. v. Feb. 28-Dec. 19, 1903. Nos. 212. unantrot 7

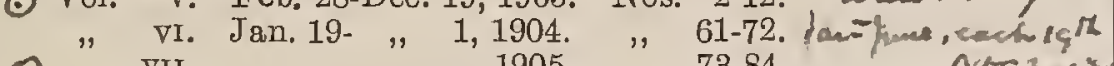

๑ " VII. " - " 1905. " 73-84. Dus.

* " VIII. Each nunber has" a coloured paper wrapper. pintc 6708

cuivison 109 - 131. omange 132 - 16-

PHILATELIC TRADER AND EXCHANGE RE-

CORDER. See PHIUATELTC TRADER.

PHILATELIC TRADER AND FRAUD REPORTER

See Philatelic trader.

PHILATELIC TRIBUNE. The Philatelic tribune. Smyrna, N. Y., F. J. Stanton, r885-87.

$8^{\circ} .8 \frac{1}{2}$ in. and fol. $15 \frac{1}{2}$ in. 20 nos. in 4 vols.

Vol. I. Sept., 1885-'Aug., 1886. Nos. 1-12.

"II. 1886- Feb., 1887. " "13-18.

* "IV. Mar. 15 -April, " 19 an" 19-20.

ifghteen numbers have paper wrappers. Nos. 19 and 20 are bound up with the "Youth's ledger".

$$
\text { [Continued as:] }
$$

_ The Philatelic tribune and ever'ybody's advertiser. Fol. $15 \frac{1}{2}$ in. Vols. IV.-v. 5 nos. Smyrna, N. Y., F. J. Stanton, x887-88.

Vol. Iv. May, June, July-August, 1887, Apl., 1888. Nos. 21-24.

Pifilatu inader

$$
\text { ound up with the "Youth's ledger". }
$$

- $1 x .1907$ kos $q 7-108$

C $\times 1908 \quad 109-120$

(6) $\times 1909 \quad 121-132$

$Q \times 11 \quad 1.910 \quad 133-144$

(i) Xili $1911 \quad 145-156$

XIL $1912157=$

$x \vee \quad 15 / 3$

Xvi / 1914

xurl igis

$x$ vili 1516

$x+1 \times 1517$
PHILATELIC TRIBUNE.

[Continued as :]

The Philatelic tribune and advertiser.

Smyrna, N. Y., F. J. Stanton, I888-go.

Fol, $15 \frac{1}{2}$ in. and $16^{\circ} .6$ in. Vols. V.-VIII. 18 nos.

Vol. V. June, July, Oct.-Nov., Dec., 1888, Jan., 1889. Nos.

"VI. Feb.-July, 1889. Nos. 31-36.

"VII. Aug.-Dec., " " $37-42$.

* Nos. 26-30 are folio and nos. 31-43 are $16^{\circ}$. and nos. 31-38 and $41-43$ hove paper wrappers. There are two numbers for Novem

ber, 1889 (nos. 40 and 41 ). Nos. 26-30 are bound up with the "Youth's ledger"

[Continued as:]

The Philatelic tribune.

Smyrna, N. Y., etc., F. J. Stanton, I890-99.

$16^{\circ} .6$ in. and $8^{\circ} .8 \frac{1}{2}$ in. Vols. VIII.-XXIV. 99 nos.

Vol. VIII. Feb. -June, 1890. No: 44- 48

" IX. July -Dec. $\quad$-June, 1891 " 49-54.

" X. Jan. -June, 1891. " $\quad 55-60$

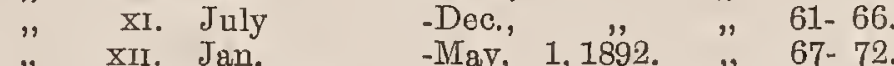

" XII. Jan. $14 \quad$-May, 1, 1892. $\quad$ "Aug, $1, \quad 67-72$,

" XIV. Aug. 14 -Dec. 15, " " 79-84

" XV. Dec. 24, 1892-Mar. 25, 1893. " $85-90$

" xVI. Apl. 20 -Sept. 30 " $\quad$ " 91-96.

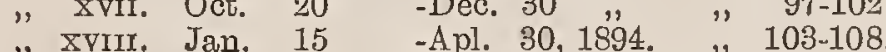

" XVIIr. Jan. 15 -Apl. 30, 1891. " $103-108$.

$"$ xix. Nay 30 -Ot. 30 " "109-114.

$"$ Xx. Nov. 30, 1894-May 31, 1895. " 115-120.

" Xxi. Sept. 25, 1895-Ieb. 11, 1896. " 121-126.

" XXI1. Mar. 7, -Dec. 16 " " 127-132.

" Xxir. Jan. 15 1897-

** Nos. 44-128 are $16^{\circ}$. and nos. $129-142$ are octavo and the octavo numbers were published at Norwich, N. Y. Nos. 44-51, 53, 55, 59 $94,97-100,104,107,116,117$ and 119-142 have paper wrappers and no. 51 has two wrappers one coloured and the other white. Nos. 70-106 were mostly published fortnightly. No. 118 is dated "Feb. Mar., 1895 ". There are no numbers for May, June, August or September, 1896 , or for June, July, August, September or December 1897. No. 140 is dated "Jan. 15, 1898" and no. 141 "Jan. 15 1899 ". Nos. 128-142 are printed on red paper, but the wrappers are white. Nos. 133-135 contain a supplement "The Advertiser". In nos. 136-138, 140 and 141 this forms a part of the journal proper and in nos. 129-131, and no. 142 it forms a part of the wrapper. No. 137 has a supplement "The Amateur photographer".

PHILATELIC TRIBUNE AND ADVERTISER. See Philatelic tribunis.

\section{PHILATELIC TRIBUNE AND FVERYBODY'S AD-}

VERTISER. See PhILATELIO TRIBUNe.

PHILATEIIC TRIUIPH. The Philatelic triumph. Buffalo, N. Y., B. Illing, x881-82.

$8^{\circ} .8 \frac{3}{4}-9 \frac{1}{4}$ in. and fol. 12 in. 10 nos. in 2 vols.

$8^{\circ} .83-94 \mathrm{in}$. and fol. $12 \mathrm{in}$. 10 nos. in 2 vols.

Vol. I. Nov., 1881- 1, 1882. Nos. 12, 13 and 2

* * Nos. 8 and 9,10 and 11 and 12 and 13 were severally published together. No. 3 is folio in size, nos. 8-11 are octavo $88^{3}$ inches and the other numbers are octaro $9 \frac{1}{4}$ inches. Nos. 8-11 and vol. II., no. 2, have coloured paper wrappers. Nos. 4-7 were nover published.
Mis. St. Jour. 18 (19).

PHILATELIC VISITOR. A Philatelic visitor. New York, W. F. Gregory, I89x-99. $8^{\circ} .9$ in. Nos. 1-8, Sept., 1891, Mar., May, Aug., Nov., 1894, Feb., May, 1897,

"* Nos. 2-8 have the title "The Philatelic visitor".

Mis. St. Jour. 113 (11).

PHILATELIC WEERLY. The Philatelic weekly.

Jackson, Mich, The Shaw Stamp and Coin Co., I896. Fol, 121 in. Nos. 1-4, Aug. 18, Sept. 1, 10, 17, 1896. Mis. St. Jour. 88 (2) 
PHILATELIC WEST. The Philatelic west. 98.

Superior, Neb., Brodstone and Wilkinson, etc., I896-

Fol. 11-12 in. and $8^{\circ} .9-8$ in. 30 nos. in 8 vols.

Fol. 11-12 in. and $8^{\circ} .9-8$ in. 30 nos. in 8 vols.
$\begin{aligned} & \text { Vol. I. Jan. } \\ & \text { June } 1896 . \text { Nos. 1-6. }\end{aligned}$

"II. July 1 -Dec. 1, ," " 1 , 1 .

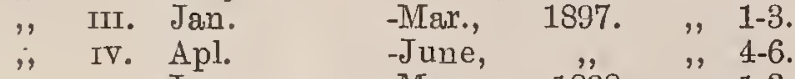

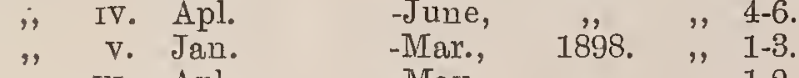

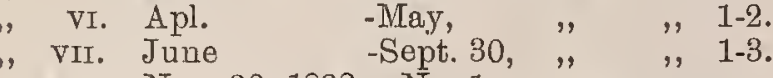

$"$ VII. June 30,1898 . Nop. 1 .

* * Nos. 1-6, vol. I., are folio and the remaining numbers are octavo, and commencing with no. 1, vol. v., the journal was published by Brodstone and Woolston. All but the six numbers of vol. I. have
paper wrappers. No. 4, vol. IV., is numbered "volume 3 ," except paper wrappers. No. 4, vol. IV., is numbered "volume 3," except
on the wrapper, which has "vol. IV.," and no. 1, vol. vII. is dated "June-July, 1898 ".

[Continued as :]

The Philatelic west and camera news.

Superior, Neb., The Brodstone Publishing Co., etc., I 898-I 907 .

$8^{\circ} .9$ in. Vols. VIII.-XXXX. 82 nos

Vol. viII. Dec. 30, 1898-Jan. 31, 1899.

IX. Mar. 31, Apl. 30, June 15, 1899,
X. July 15, Aug. 31, Oct. 31, 1899.

XI. Nov. 30, Dec., 1899-Jan, Feb., 1900.

XII. Mar. 31, May 1, June 30,

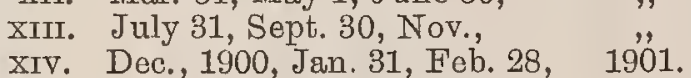

xv Mar 31, Apl 30, May 31,

XVI. June 30 , July 31 , Aug. 31,

XVIr. Oct., Nov., Dec,,

XVIII. Jan., Feb., Mar.,

xx. July, Aug., Sept.,

XXI. Oct., Nov., Dec.,

xxiI. Jan., Feb., Mar.,

xxiII. Apl., May, June,

XXIV. Aug., Sept., Oct.,

xxv. Nov., Dec,., 1903, Jan.,

XXvi. Feb., Mar., May,

xxvII. June, July, Aug.,

XXIX. Dec. 30, 1904, Jan. 31, Feb. 28, 1900 .

xxx. Apl., May 31, July 31 ,

xxxi. Aug. 31, Oct. 31, Dec. 31,

XxxiI. Feb. 28, Mar. 31, Apl. 30,

, XXXIII. May 31, June 30, July 30,

, XXxIV. Aug. 31, Sept. 30, Oct. 31,

* "Each number has a paper wrapper and commencing with no. 3, vol. X., the journal has been published by L. T. Brodstone. The wrapper of vol. XII., no. 1, is dated "April, 1900," that of vol. XIII., no. 1," "August, 1900," that of vol. XIII., no. 2,
"October, 1900," that of vol. XVI., no. 2, "August, 1001," an.
(a) that of vol. xvI., no. 3, "September, 1901". "The wrappers of nos. 2 and 3, vol. XXIII., each bear in error "vol. XVIII. and the wrapper of no. 3 is dated "July, 1903 ". The wrapper of no. 2 , vol. XXVI., is wrongly numbered "vol. XXVII.," that of no. 3, vol. XXviI., is wrongly numbered "vol. 28," and the former is dated "April, 1904". "There is an illustrated supplement of two pages to no. 1, vol. XviII. The wrapper of no. 2, vol. XXviII., is wrongly numbered "vol. 29 ;" no. 1, vol. XxIX., has " no. 3," except on the wrapper, which is correct, and no. 3, vol. XxIx., is dated "February 28, 1905," and on the wrapper " March, 1905". The wrapper of no. 2, vol. xxx., is dated "June, 1905" and the wrappers of nos. 1, 2 and 3, vol. xxxI., are dated, respectively, "September," "November, 1905 " vol. "xxxHI, are numbered in erro and " " 33 ," " which are correct, and no. 3 , vol. XXXIII. is dated "July 30 " "but the wrapper has July 31 , and no. 2, vol. XXXIV., is dated in error "September 31" except on the wrapper which is correct Continued as the "Philatelic west and the collector's world".

PHILATELIC WEST AND CAIMERA NEWS. See Philatelic West.

PHILATELIC WORLD. The Philatelic world. Brooklyn, N. Y., etc., R.R. Bogert, etc., г880-9г. 8. 9 in. and 83 in. 108 nos. in 9 vols.

\begin{tabular}{|c|c|c|c|c|c|c|}
\hline & & & & & No & \\
\hline & II. & Jan. & -Dec., & 1884 & & \\
\hline & III. & & $"$ & 1885. & & \\
\hline & v. & $"$ & & $\begin{array}{l}185060^{\circ} \\
188\end{array}$ & & \\
\hline & $\mathrm{VI}_{\mathrm{g}}$ & , & 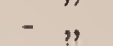 & 1888. & 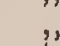 & \\
\hline
\end{tabular}

Vol. VII. Jan. -Dec. 1889. Nos. 73- 84.

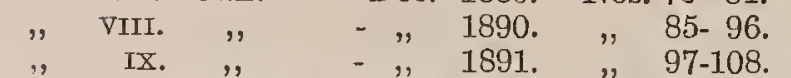

*" Vol. I. häs a title-page and an index and measures 93 inches and the remaining volumes measure 83 inches and have no titlepages or indexes. Commencing with no. 7, vol. IV., the journal was published by $R$. R. Bogert and Co., and commencing with no. 1, vol. II., the numbers were published at New York. Nos. 9092 are wrongly numbered, respectively, 89-91. For continuation
see "Philatelic monthly and world".

PHILATELIC WORLD. The Philatelic world. A monthly journal for stamp collectors. Calcutta, B. Gordon Jones, etc., I894-97. $8^{\circ} .9 \frac{3}{4}$ in. 32 nos. in 3 vols

Vol. I. July 1, 1894-June 15, 1895 . Nos. 1-12.

", II. "15, 1895- " 16, 1896 . "13-24. ** There is a title-page and an index to vol. I., and also to vol. II., and each number has a coloured paper wrapper. There is no number for January, 1897, but the number for February, 1897 is numbered "Vol. III. No. 7 \& 8. Whole no. 31." Commencing with no. 14 the journal was published by B. Gordon Jones and Co. Nos. 1,2 were edited by B. Gordon Jones, nos. 3-9 by C. F. Larmour, nos. $10-24$ by C. F. Larmour and Wilmot Corfield, There is a "Special supplement" of four pages to no. 16 .

PHILATELIC WORLD. Philatelic world. With which Q is amalgamated Herdman's miscellany (Founded 18:6). Ashton, Preston, H. B. Bailey, I899. $4^{\circ} .8 \frac{1}{4}$ in. No. 1 , June $15,1899$.

$S_{*}^{*}$ "The number has a paper wrapper. White Mis. St. Jour. 76 (6). PHILATELIC WORLD. The Philatelic world. Minneapotis, Minn., Ernest R. Aldrich, I 902-04. $8^{\circ} .10$ in. 63 mos. in 3 vols.

Vol. I. Nov. 5-Dec. 31, 1902. Nos. 1- 9.

"I. I. Jan. 7-, 30, 1903 . " $10-61$.

*" * Nos. 24 and 60 have paper wrap" 62-63. "date "A pril 15, 1903," without any number. No. 63 has " 1903 " in error for " 1904 ".

PHILATELIC WORLD. See BuYERS' NEWS.

PHILATHLICAL ADVERTISER. The Philatelical advertiser. Bow, London, G. H. Skuse, I 885 . $8^{\circ} .93$ in. No. 1, January, 1885.

Mis. St. Jour. 9 (9).

PHILATELICAL EXCHANGE AND GENERAL ADVERTISER. - The Philatelical exchange and general advertiser. Stamps, coins, bric-à-brac, etc. Burslem, J. P. Bates and F. C. Midwinter, 1885. $8^{\circ}$. 93् in. Nos. 1-3, April-June, 1885.

* Nos. 2 and 3 were published by J. P. Bates.

Mis. St. Jour. 78 (9).

PHILATELICAI GAZETTE. The Philatelical gazette. 88

$8^{\circ} .7 \frac{1}{2}$ in. Nos. I-2, October-November, 1884.

2al a poor cofy

Mis. St. Jour. 55 (6).

PHILATELICAL JOURNAL. The Philatelical journal. Edited by Edward L. Pemberton.

Birmingham, etc., James $R$. Grant and Co., I87275 .

$4^{\circ} .8 \frac{2}{2}$ in. 16 nos. in 2 vols

$4^{\circ} .8 \frac{1}{2}$ in. 16 nos. in 2 vols.
Vol. I. Jan. 15-Dec. 15, 1872. Nos. 1-12.
[, II.] " 20-Apl. 20, 1875. " $13-16$.

[ "II.] "20-Apl. 20, 1875. Nos. 1-12 There is a front paper wrapper to each number, and a title-nay.ep rospectus $/ 6$ There is a front paper wrapper to each number, and a title-page under the date "November 15, 1872". Nos. 13 and 14 and under the date "November 15,1872 " Nos. 13 and 14 and propplement to no. 5, consisting of a cardboard leaf with photographs of the dies of the first United States envelope stamps attached to one side. B Bound up at the end of no. 16 is a circular of $\mathbf{E}$. L. Pemberton's on rose-coloured paper, dated December 27 , 1877, in which he says he is induced to contemplate the resuscitation of "The Philatelica! journal". 4 i 4 . $8 v_{0}$

PHIT ATELICAL JOURNAL. The Philatelical journal.

in. No. 1, [? Salford, Herbert Fisher, 1884 . ], 1884 .

journals appears in J. K. Tiffany's list of Great Britain philatelic joubts in the "Stamp news annual" for 1894, but it is very doubtrul if any number was published. Wanting.

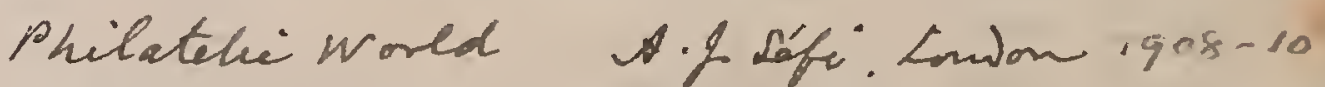

$61908 \%$ I 1 - 6.7i hor-may. Muc pand wA.

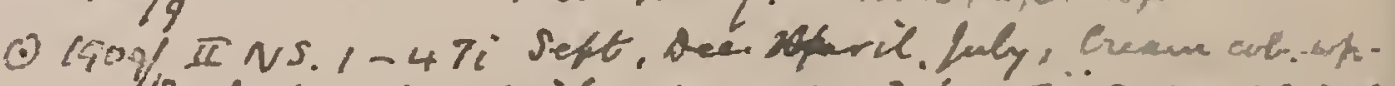

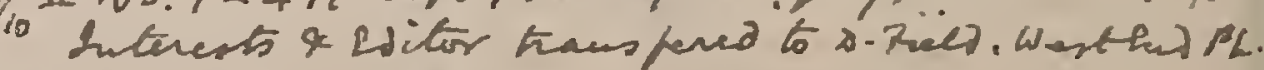

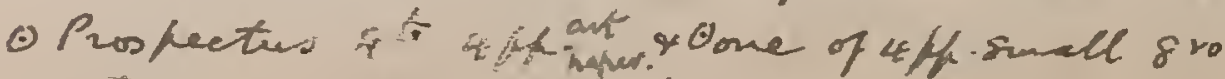

Cireacons inter isog fune.

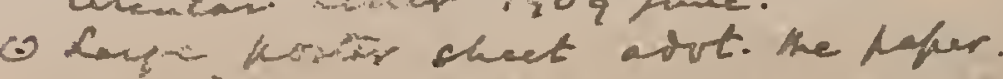

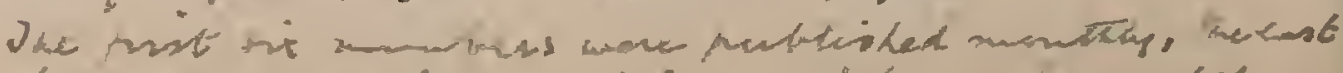

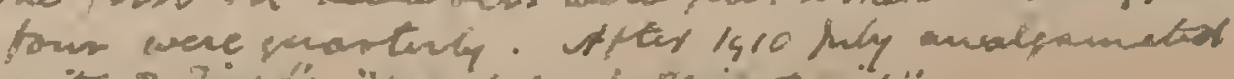

arite $x \cdot$ Fichis "Hast fond privitent". 

PAPERS FOR PHILÁtelists. (Brighton, etc., Stafiord Smith \& Co., etc.)

mprising twenty odd numbers of PHILATELIST, together with "itle page and frontispicce giving an illustration of the One Penny

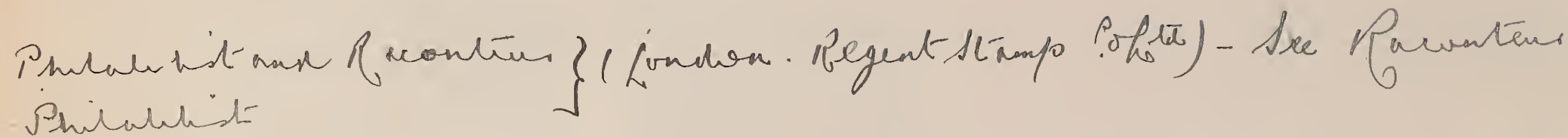


PHILATELICO. O Philatelico. Revista philatelica dedicada aos colleccionadores de cartões postaes e sellos sahindo no dia $1^{\circ}$. de cada mez.

Santa Maria, Brazil, E. di Primio, R. Grott e J. Rocha, I 904-05.

$8^{\circ} .10^{3}$ and $10 \frac{1}{1}$ in. 4 nos. in 2 vols.

1st year. Sept. 1-Nov. 1, 1904 . Nos. 1-3.

2nd "Jan. 1, 1905. "No. 1 .

* Printed on coloured paper. No. 1 of the second year. only measures 10 inches and is narrower than the three numbers of

PHILATELICO AVEIRENSE. O Philatelico Aveirense. Revista mensal dedicada aos colleccionadores portuguezes.

Aveiro, Baptista Moreira, I gor. $8^{\circ} .9$ in. Nos. 1-3, Jan.-Mar., 1901.

* * The title on nos. 2 and 3 reads "O Phylatelico Aveirense".

Mis. St. Jour. 99 (4)

\section{PHILATELICO ELVENSE. Philatelico Elvense.} Elvas, Portugal, Hypolito Jose Pereira, I 90I-о2. $8^{\circ} .8 \frac{1}{2}-8 \frac{1}{4}$ in. 10 nos. in 2 vols.

1st year. Apl. 1-Dec. 1, 1901. Nos. 1-9.
2nd Jan. 1, 1902. No. 10.

* * Nos. 1-8 have coloured paper wrappers.

Mis. St. Jour. 132 (4).

PHILATF́Lite. See Ctroulaire phitatélitque.

PHILATÉLIE. See Poste.

PHILATELIE-BULLETIN. Philatelie-bulletin

1st year. Nov. 1, 15, 1899 . [Nos. 1-2.]

1st year. Nov. 1, 15, 1899. [Nos. 1-2.]
2nd ", Feb. 1, 15, Aug. 1, Sept., Nov., 1900. [Nos. 1-5.]

3rd " Jau.-Feb., March, 1901. [Nos. 1-2.]

S185 4th ", Jan., May, Nov., 1902. [, 1-3.]

* * The contents consist entirely of advertisements. The number for August 1, has no date, but is enclosed in a coloured paper wrapper which bears the date. Wanting numbers dated Feb. 15 Nov., 1900, Jan.-Eeb., 1901 and all nos. for 1902.

PHILATÉLIE HELVÉTIQUE. La Philatélie Helvétique. Journal des collectionneurs de timbres-poste. Morges, J. Jaquier, I 893-97.

Fol. 13 in. and $88^{\circ} .9 \frac{1}{2}-9 \frac{1}{1}$ in. 37 nos. in 4 vols.
1st year. Dec. 1893 , Jan., Feb., Apl., June, Nov., 1894. Nos. 1st year. Dec. $2-7$.

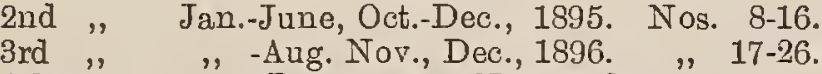
3rd ", ", -Aug. Nov., Dec., 1896.

** Nos. 2-16" are folio and the' remaining numbers are octavo. Nैo. 3 bears " 2 me Année" in error, no. 9 is dated "Janvier" inNo. 3 bears " 2 me Année" in error, no. 9 is dated "Janvier" instead of "Février" and has " numéro 1 " in place of " 9 " and paper wrappers, but there are only four wrappers for the six numpaper wrappers, but there are only four wrappers for the six numbers, as, although scparate, nos. 19 and 20 , and 21 and 22 were severally published together in one wrapper. Nos. 33 and 34,35 are two supplements to no. 9 and one to no. 15. It is stated in no. 3 that no. 1 consisted of a price list published in March, 1893.

PHILATELIE PORTUGAISE. La Philatelie Portugaise. Journal philatelique mensuel.

Lisbonne, Mattos et Cie., I 896-97. 8०. 101 in. Nos. 1-10, Jau. 30, 1896-Feb. 1, 1897.

* * There are no numbers for June, September, October or De-

PHILATEIIESTISCHE (sic) MONATS-BERTCHTH. Philateliestische (sic) Monats-Berichte. Fachblatt für die Interessen deutscher Briefmarkenhändler.

8. $10^{3}$ in. No. 1, April, $1876 . \quad$ Mis. St. Jour. 129 (2).

PHILATELIQUE ORIENTAL. La Philatelique oriental. Corfou, Grèce, C. S. Ioannides, I 905 $\odot$ Fol. $12 \frac{1}{2}$ in. Nos. 1-12, January 1-December 30, 1905. ** The contents, consist entirely of advertisements. Nos. 5 and $6^{*} ; 7,8$ and 9 , and 10,11 and 12 were severally published together with the respective dates " 25 Junie," "25 Septembre" and " 30 Decembre",
PHILATELIST. The Philatelist. An illustrated magazine for stamp collectors.

Brighton, Stafford Smith and Co., etc., I866-76.

$8^{\circ} .8 \frac{1}{2}$ in. 121 nos. in 10 vols.

Vol. I. Dec. 1, 1866-Dec. 1, 1867. Nos. 1- 13

"Ir. Jan. 1, - " 1, 1868. " 14- 25.

" III. Jan. $1, \quad-\quad ", \quad 1,1868 . \quad$ " $14-26$.

"IV. " $1, \quad-", 1,1870 . \quad$ " $38-49$

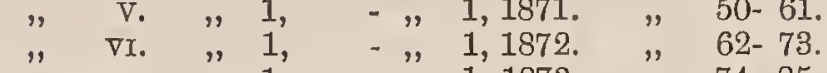

"VII. " " 1, - " $1,1873 . \quad$ " $\quad 74-85$

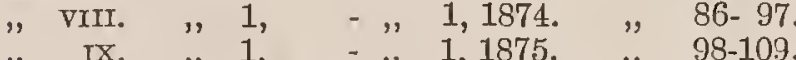

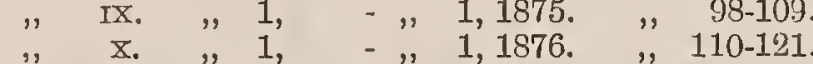

* * Edited by Dr. C. W. Viner. There is a paper wrapper to each number, a title-page and index to each volume and vols. IIr.-X. have froutispieces, consisting of illustrations of stamps. Nos. 1-6 were also published by Hall and Co., London, and nos. 7-97 also by E. Marlborough and Co., London. A portrait and autograph of $H$. Stafiord Smith is inserted as a frontispiece to vol. I. Of the fle in the library. Nos. 1-6 were re-issued in a coloured paper c. wrapper, in 1874, under the titlo "Papers for philatelists "and ar in 1885, in a cloth cover: See PART I. PAPERS. 302

PHILATELIST. Der Philatelist. Organ des Vereins deutscher Philatelisten.

Oybin, Sachsen, Dresden [printed], Alfred Moschkau, I872.

$8^{\circ} .8 \frac{1}{2}$ in. Nos. 1-2, September 1-October 10, 1872

Mis. St. Jour. 58 (2)

PHILATELIST. Der Philatelist.

Dresden, Ermst Petritz, etc., I 880

Fol. 12 in. and $8^{\circ} .93$ in. nos. in vols. In progress.

1st year. June 1-Dec. 1, 1880. Nos. 1- 7 .

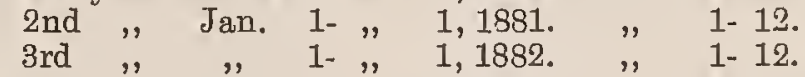

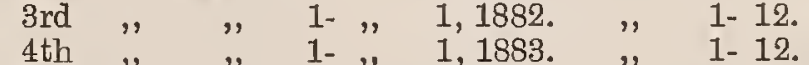

5th " " " 1-" " $1,1884 . \quad$ ", 1- 12.

6th " " 1- " 1, 1885. " $1-12$

8th " " $\quad 1-15, " 15,1886 . \quad$ " $1-12$.

9th " " ", 15- " $15,1888 . \quad, \quad 1-17$.

10th " " " 15-" " 15, 1889. " 1- 18.

11 th " " $15-", 15,1890 . \quad, \quad 1-18$

13th " " "15-" $15,1891 . \quad$ " $1-18$.

13th " " " 15- " $15,1892 . \quad$ " $163-17$.

15th ", ", 15- ", $15,1893 . \quad$ ", $178-189$.

16 th " " $\quad 15-, " 15,1895 . \quad$ " 202-213.

17 th " " $15-, " 15,1896 . \quad$, 214-225.

18th " " 19 th $15-", 15,1897 . \quad$ " $226-237$.

19 th " " " 15- " $15,1898 . \quad$ " 238-249.

20th " " 15- " 15, 1899. " 250-261.

21st " " 22 15- " $15,1900 . \quad$ ", $262-273$.

23rd " " " $15, " 15,1902 . \quad$ ", 286-297.

24 th " ", 15- ," 15, 1903. ", 298-309.

25 th " " 15- " 15, 1904. " 310-321.

26 th " " "15- " 15, $1905 . \quad$ ", 322-333.

27th " "15- ", 15, 1906. " 334-345.

* * The "first eight years are folio and" the remainder are octavo Commencing with Jauuary, 1883, the journal has been published by the Internationaler Philatelisten-Verein of Dresden. There is a titlepage and an index for the first two years combined and on for each subsequent year. There arc two numbers for March, 1886 , one dated March 1, the other March 15, and there is no number for October, 1886. Nos. 178-226 have coloured paper wrappers, nos. 214 and 215 have " 1895 " in place of "1896" except on the wrappers which are correct, and nos. 294 and 295,305 and 306,318 and 319,329 and 330 , and 342 and 343 , were severally published together. There are supplements with the titles "Annoncen-Beilage zum Philatelist " "Philatelia Humoristica," and "Annoncen-Beiblatt zum Philatelist," which are separately listed, aIso see "Vereins-Mittheilungen des Internationalen PhilatelistenVereins Dresden". There is a supplement of ten pages to no. 11 of 1890 and a fow other supplemental pages here and there in some of the volumes, including a supplement of illustrations (2 pp.) to no. 11 of 1906 .

PHILATELIST. The Philatelist. A monthly newspaper devoted to the interests of stamp collectors.

Fol. 19 in. No. 1, July, 1880

Louisville, Ky., C. F. Adams, I880.

Bound up at the end of the "Curiosity World," vol. II.

PHILATELIST. The Philatelist.

New York, J. Holmes, Jr., I884.

8. 9 in, Nos, 1-5, June-Oct. 1884, Mis. St. Jour. 24 (12). 
PHILATELIST. The Philatelist. Philadelphic, Pa., C. Y. Abbott, $1885^{-86}$ $8^{\circ} .8 \frac{1}{\text { in }}$ in. 9 nos. in 2 vols.

Vol. I. Mar., Apl., May, Summer, Winter, 1885. Nos. 1-5. ". II. Spring, Summer, Autumn, Winter, 1886. "1-4. * " No. 5, vol. I., and nos. 1-4, vol. II., have coloured paper wrappers and there is a supplement of two pages to no. 4, vol. T. The pages of nos. 1-4, vol. I, excepting the first page of each o

Mis. St. Jour. 31 (3).

PHILATELIST. "Der Philatelist". Organ für die Gesamt-Interessen der Briefmarkenkunde.

Magdeburg, Richard Skalweit, I886. 8०. 9 in. Nos. 1-6, April 10-September 15, 1886.

** Produced by an autographic process. Nos. 4-6 have the title, notices and representation of the Mulready envelope printed by lithography and the date and number filled in by hand with pen and ink. Some of the copies of no. 4 are numbered in Roman numerals while others bear an Arabic figure. Wanting no.

PHILATELIST. The Philatelist.

Wabash, Ind, Walter Frantelin Slusser, 1892 $32^{\circ} .4 \frac{7}{2}$ in. No. 1, December 10, 1892.

* * The number has a coloured paper wrapper.

Mis. St. Jour. 71 (10)

PHILATELIST. The Philatelist. For the advancement and elevation of philately.

Denver, Colo., Lewis Bishop, 1893 80. 9 in. Nos. 1-4, Apl. 10, May 10, June.25, July and August, 1893

** There is a coloured paper wrapper to each number. Bound up in the same volume is a copy of the prospectus of the journal.

PHILATELIST. The Philatelist. 1896.

Waterville, Wash., Philatelist Publishing Co., etc.

$8^{\circ} .9$ in. Nos. 1-4, March-June, 1896

* Nos. 3 and 4 were published by F. M. Dallam, Jr

Mis. St. Jour. 101 (3)

PHILATELIST. The Philatelist. Issued quarterly.

East Brady, Pa., H. C. Moore, x899-x 900.

$10^{\circ} .5_{2}^{\frac{1}{2}}$ in. and $4^{\circ} .6$ in. Nos. 1-3, July, October, 1899, January, 1900.

** Nos. 1 and 2 are $16^{\circ}$. and no. 3 is quarto. There is a coloured paper wrapper to each number. $\quad$ Mis. St. Jour. 150 (14).

PHILATELIST. Der Philatelist. 02.

Rheinfelden, Schweiz, Philatelisten-Club, etc., r gor-

Fol. $12 \frac{1}{4}-12 \frac{1}{2}$ in. 10 nos. in 2 vols.

1st year. April 15-Dec. 15, 1901 . Nos. 1-8.

1st year. April 15-Dec. 15, 1901. Nos. 1-8.

** Nos. 6-8 and nos. 1, 2, of the second year, were published by the Genossenschaft fiir Hebung und Förderung der Philatelie. There is no number for October, 1301 Mis. St. Jour. 128 (7).

PHILATELIST. The Philatelist. The Magazine of the Philatelic Society of the M. M. S. S. [Manchester Municipal Secondary School.] Manchester, 1906-о7. $8^{\circ} .8$ in. Nos. 1-4, [April, June, October, 1906, September, 1907]. * Produced by a hectographic process and edited by $F$. W. Atack. No. 4 was published by the Philatelic and Geographical Society, and all four numbers are undated. Only some forty copies
or less of each number were made.
Mis. St. Jour. 132 (5).

PhIl atmLisT. See Bucarester Philatelist.

PHillatelist. See New England PhItatelist (Fitchburg, Mass.).

PHILATELIST. See N. Y. PhILATELIST.

PHILATELIST EXCHANGE. Philatelist exchange. Toledo, O., Philatelist Publishing Co., etc., I892. 16. 6-5 $\frac{1}{2}$ in. Nos. 1 and 12. Mar. 30, June, 1892.

** There is a coloured paper wrapper to each number. The title on no. 12 reads "The Philatelist exchange" and this number was published by Edward W. Heck, who edited both numbers. Two copies of no. 1 are bound up one of which has page (4) entirely blank,
PHILATELIST JOURNAI. Philatelist journal.

Nibe, Danmark, A. Petersen, 1894

$4^{\circ} .11 \frac{1}{2}$ in. [Proof number without date of month] and nos. 1-3, April 20-June 15, 1894.

* * The contents consist entirely of advertisements.

Mis. St. Jour. 87 (22).

PHILATELIST-ORIENTAL . Philatelist-Oriental. Insertions Organ für Briefmarken Import et Export.

Galatz, Rumänien, David Steiner, I893.

Fol. 13 in. Nos. 1-2, May-June, 1893.

**A copy of the prospectus of the journal is bound up with the two numbers. Mis. St. Jour. 73 (17)

PHILATELISTA. O Philatelista. Organ dedicado aos colleccionadores de sellos.

S. Paulo, Brazil, Carlos e José Machado de Oliveira I $884-85$.

$8^{\circ} .10 \frac{3}{2}$ in. 9 nos. in 2 vols.

1st year. Mar.-May, July, Sept., Nov., 1884. Nos. 1-6. S II

* * No. 8 has a coloured paper wrapper. 1885 . Mis. "St. Jour. 99 (9).

PHILATELISTA. O Philatelista.

Iisboa, Faustino A. Martins, x887-88.

$8^{\circ} .9 \frac{1}{2}$ in. and fol. $13 \frac{1}{4}$ in. 14 nos. in 2 vols.

1st year. Apl.-Dec., 1887. Nos. 1-9.

2nd "J Jan.-Apl., Aug., 1888. Nos. 10-14.

* * Printed on buff paper. Nos. 1-3 are octavo and theremaining numbers are folio. This was the first philatelic journal published in Portugal.

Serie II. Lisboa, Faustino A. Martins, I893 Fol. $21 \frac{1}{4}$ in. No. 1, June, 1893.

Serie III. Tisboa, Fanstino A. Martins, I894-95 8 . 9 in. Nos. 1-12, Oct., 1894-Apl. 15, 1895.

* After no. 2 the journal was issued fortnightly. There is a süplement of eight proes to no, 12 , a catalogue "Catalogo precocorrente" by F. Hugo, 16 pages, ran through nos. 3 and 4 , and corrente" by F. Hugo, 16 pages, ran through nos. 3 and 4, and rente... por Faustino A. Martins" ran through nos. 5-8.

Serie Iv. Lisboa, Faustino A. Martins, 1895-96. 8०. $9 \frac{1}{4}$ in. Nos. 1-12, May, 1895-Apl., 1896.

PHII ATEIISTA. O Philatelista

Porto Alegre, Brazil, Club Philatelico Porto-Alegrense, 1888 .

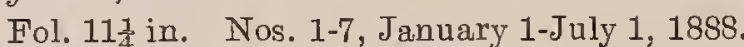

Mis. St. Jour. 87 (8)

PHILATELISTA. O Philatelista

Pernambuco, Brazil, F. Tondella, etc., r89o-9r.

$4^{\circ} .8 \frac{3}{4}$ in. 15 nos. in 2 vols

1st year. Oct. 15 -Dec. 15,1890 . Nos. $1-3$.

2nd "Jan. -Dec., 1891. $1-12$

* * Nos. 7-12, vol. II , were published" by the Sociedade Philatelica de Pernambuco, and nos. 11 and 12 were published together. No. 7 , vol. II., has an illustrated supplement of two pages printed on one side only. $\quad$ Mis. St. Jour. 91 (1).

PHILATELISTA. ANNUNCIADOR. O Philatelista Annunciador.

Porto, Portugal, Joaquim João Covas Junior, I 900. $8^{\circ} .8 \frac{1}{2}$ in. Nos. 1-4, April-July, 1900.

* * Printed on yellow paper. The contents consist entirely of advertisements.
Mis. St. Jour. 132 (3).

PHILATELISTA BRAZILEIRO. O Philatelista Brazileiro. Revista mensal dedicada aos colleccionadores negociantes de sellos.

Rio de Janeiro, J. Costa, I899-1900. $8^{\circ} .10 \frac{3}{4}$ in. Nos. 1.12, July, 1899-June, 1900.

* * Nos. 9 and 10 and 11 and 12 were severally published together, and there is a coloured paper wrapper to each number. Mis. St. Jour. 105 (6).

PHILATELISTA BRAZILEIRO. O Philatelista Brazileiro. Jornal mensal dedicado aos colleccionadores e negociantes de sellos e cartöes postaes.

Pernambuco, L. A. Alves da Silva e A. B. Barboza Vianna, etc., тgo6.

Fol. $13 \frac{1}{4}$ in. Nos. 1-4, May 15-August 15, 1906

* No. 4 was published by José Sotero e Oscar Ramos. Wanting no. 4. 


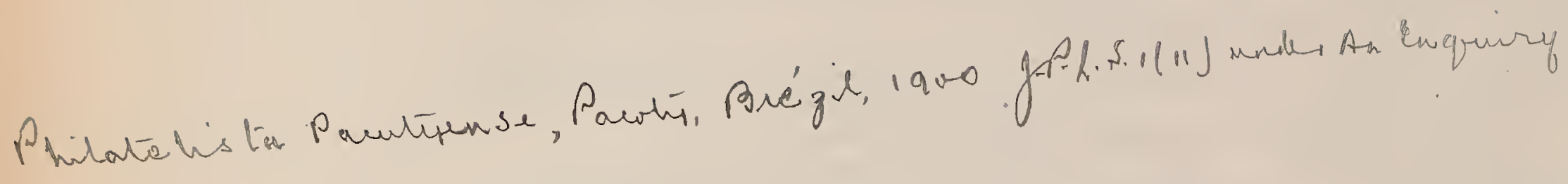

Pintatensta Portuense-1900 S115 
PHILATELISTA CEARENSE. O Philatelista Cearense. Ceará, Brazil, Henrique Silva e Co., I899. $8^{\circ}, 9^{3}$ in. No. 1, August 1, 1899.

** The contents consist entirely of advertisements.

Mis. St. Jour. 130 (8).

PHILATELISTA DE GUIMAR ÃES. O Philatelista de Guimarães.

Guimarães, Portugal, José Joaquim d'Oliveira, 1900. $8^{\circ} .10 \frac{1}{2}$ in. and 10 in. Nos. 1-3, Junc-Aug., 1900.

** No. 1 measures $10 \frac{1}{2}$ inches and nos. 2 and 3 measure 10 inches. No. 2 has a coloured paper wrapper. Mis. St. Jour. 118 (6).

PHILATELISTA DO OCCIDENTE. O Philatelista do Occidente. Porto, Portugal, J. J. Brandão, I898-99. $8^{\circ} .9-9 \frac{1}{4}$ in. 13 nos. in 2 vols.

1st year. Jan.-Dec., 1898. Nos. 1-12.

1st year. Jan.-Dec., 1898. Nos. 1-
20 : 1899. No. 1.

* * Nos. 11 and 12 were published togcther. No. 1 of the second jear has a coloured paper wrapper.

PHILATELISTA LUZO-AFRICANO. O Philatelista Luzo-Africano. Orgão official da "Union Philatelique Soudanaise," Cairo. $8^{\circ} .9$ in. Nos. 1-5, January-May, 1899
** Wanting nos. 1, 2 .

Porto, Portugal, Horacio Leitão, I899.

PHILATELISTA PAULISTANO. O Philatelista Paulistano

S. Paulo, Brazil, Associação Philatelica do Brazil, I $897-1903$.

$8^{\circ} .8$ in. and $9 \frac{1}{2}$ in. 65 nos. in 7 vols.

1st year. July -Dec., 1897. Nos. 1- 5

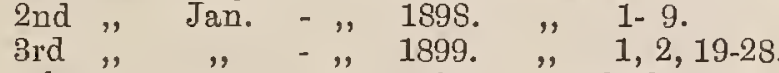

3rd ", " " $\quad$ - ", $1899 . \quad$ ", $1900 . \quad 29-39$.

5th " " - " $1901 . \quad, \quad 40-51$

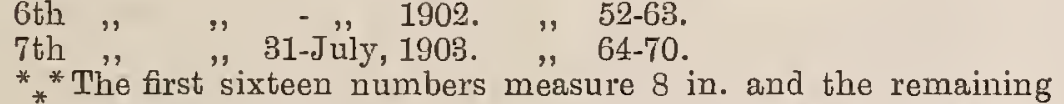
numbers 91 inches. Nos. have coloured paper wrappers. The number for February, 1899, has "Anno III. N. 1 " in place of "Anno III. N. 2". Nos. 25 and 26; 31, 22 and $33 ; 34,35$ and $36 ; 37,38$ and $39 ; 40,41,42,43,44$, and $45 ; 47$ and $48 ; 50$ and $51 ; 53,54$ and $55 ; 56,57$ and $58 ; 60$ and 61 were severally published together. There is no number for August, 1897, nos. 1, 2 and 4 of the second year are dated " Janeiro-Fevereiro de 1898," "Março-Abril de 189S" and "Junho-Julho de 1898," respectively and no. 29 is dated "Janeiro-Fevereiro de 1900". Wanling nos. $37,38,39,62,63,65,66,67,68,69,70$.

PHILATELISTA RIOGRANDENSE. O Philatelista Riograndense. Orgão mensal do "Club Philatelico" Uruguayanense.

Rio Grande do Sul, Brasil, M. Coelho, I897-[987. $8^{\circ}$. 81-9 in. and $11 \mathrm{in}$, and fol. $15-16$ in. Nos. 1-9, June 1-Nov. $1,1897-[1898]$

* * Nos. 1-6 are octavo 81-9 inches and have coloured paper wrappers, no. 7 measures 11 inches and nos. 8 and 9,15 and 16 inches, respectively. No 7,8 and 9 bear no date and no. 8 bas a supplement of tro pages, printed on yellow paper.

Mis. St. Jour. $127(4)$

PHILATHLISTE AFRICAIN. Le Philatéliste Africain. Journal des collectionneurs et marchands de timbres de l'Afrique. Tripoli, Barbarie, Abraham Guez, I893-94. $4^{\circ} .12 \frac{3}{4}$ in and $8^{\circ} .11$ in. Nos. 1-4, Sept.-Oct., 1893, Feb., Feb. 28, Mar.-Apl., 1894

** No. 1 is quarto and the other numbers are octaro. Copies of no. 1 are found printed on both white and buff paper. This number was printed at Amiens, France, and nos. 2-4 at Tunis. This was the first philatelic journal publishcd in Tripoli.

Mis. St. Jour. 74 (5)

PHILATÉLISTE ANVERSOIS. Le Philatéliste Anversois. Anvers, T. Schenck, I896-98. $8^{\circ} .91$ and $10 \frac{1}{2}$ in. 24 nos. in 2 vols.

1st year. Nor. 1896-Oct. 15, 1897. Nos. 1 -12 2nd " " 15, 1897- , 15, 1898. " [13]-24. ** The first twelve numbers measure $9 \frac{1}{4}$ inches and the remaining numbers $10 \frac{1}{2}$ inches, and there is a coloured paper wrapper to each number, with the exception of no. 13. Nos. 13 and 14 are numbered "2e Année. No. 1 " and "No. 2," and the wrapper of no. 15, has "3e Année" in error for " $2 \mathrm{e}$ Année".
PHILATÉLISTE BELGE. Le Philateliste Belge.

Boucherie, Gand, R. Delahaye, I 900.

$8^{\circ} .10 \frac{1}{1}$ in. No. 1, March 1, 1900.

** The contents consist entirely of advertisements.

Mis. St. Jour. 109 (6).

PHILATÉLISTE BELGE. Le Philatéliste Belge. Gand, E. Nicaise, I902.

$4^{\circ} .10^{3}$ in. Nos. 1-4, [May 1]-August 1, 1902.

** No. 1 is printed on rose paper and bears no datc and no. 2 is dated "1er Juin 1902". Wanting no. 1.

PHILATÉLISTE COSMOPOLITE. Sce Cosmopolttan Philatelist.

PHILATÉLISTE D'AIVÉRIQUE. Le Philatéliste d'Amérique. New York, Bernluard Weintraub, I9o. Fol. 14 in. Nos. 1-3, May 15-July, 1901.

**"The contents consist entirely of advertisements. Nos. 2 and 3 were published together. Wanting nos. 2, 3.

PHILATF́LISTE EGYPTIFN. Le Philatéliste Egyptien. Suez, Arugheti et Cie., etc., I894.

$8^{\circ} .10$ in. Nos. 1-2, June 15-July 15, 1894.

** "The printed date on no. 1 is "1er Juin 1894," but this was a) tered in pencil to " 15 Juin 1894 " before the number was circulated. No. 2 was published by M. Arughetti and S. MIanoli. Mis. St. Jour. 118 (4)

PHILATÉLISTE FRANĢAIS, Le Philatéliste Français. Paris, Th. Lemaire, 1892-96.

$8^{\circ} .9 \frac{3}{2}$ in. 36 nos. in 5 vols.

[1st year.] June 15-Dec. 15, 1892. Nos. 1- 7 .

[2nd "] Jan. 15- „" 15, 1893. ", 8-18.

[4th ", ] Jan., Apl. 1895. ", 24-25.

[5th ", ] Feb. -Dec. 1896. "" 26-36.

*** Nos. $19-36$ have coloured paper wrappers, and nos. 14 and 15 17 and 18,19 and 20 , and 21 and 22 were severally published together. There is no number for October, 1893.

IIe série.

$8^{\circ} .9 \frac{3}{4}$ in. Vols. VI.-VII. 22 nos.

[6th year.] Jan.-Dec., 1997. Nos. $37-47$. 7th " " " " 1898. " " 48-58.

* Each number has a paper wrapper. No. 43 is dated "Juillet" .

IIIe série.

Paris, Th. Lemaire, 1899

$8^{\circ} .9 \frac{3}{4}$ in. Vol, viII. 12 nos.

[8th year.] Jan.-Dec., 1899. Nos. 59-70.

* * Each number has a coloured paper wrapper and nos. 67 and 68 were published together.

IVe série.

$8^{\circ} .9 \frac{3}{2}$ in. Vol. Ix. 11 nos.

Paris, Th. Lemaire, Igoo.

[9th year.] Jan.-Dec., 1900. Nos. 71-81.

"** Each number has a coloured paper wrapper and no. 77 is dated "Juillet-Août, 1900". There is a supplement to no. 76 consisting of 16 pages of a price-list of stamps for sale by the publisher contained within a colourcd paper wrapper, and a supplemental slip to no. 72 .

$10 \mathrm{me}$ année.

Paris, Th. Lemuaire, I go1-02.

$8^{\circ} .9 \frac{3}{2}$ in. Vol. x. 13 nos.

10th year. Jan., 1901-March, 1902. Nos. 82-94.

* * There is no number for September or for December, 1901, nos. 93 and 94 were published together, and there is a coloured paper wrapper to each number. There are two extra numbers " 83 bis" dated "Mars, 1901" and " 85 bis" dated "MIai, 1901". These have coloured paper wrappers and. contain price-lists of stamps for sale by the publisher.

PHILATÉLISTE INTERNATIONAL. Le Philatéliste international. Paris, C. Nogent, igoo-02. $8^{\circ} .9 \frac{1}{2}$ in. 27 nos. in 3 rols. 1st year. Jan. 1-Dec. 1, 1900. Nos. 1-11. 2nd " "1-, 1, 1901. "12-21. 3rd " "June 1, 1902. " 22-27. ** "There is" a coloured paper wrapper to each number. No. 16 is wrongly numbered " 15 " except on the wrapper, which is correct, no. 8 is dated "Août et Septembre, 1900," and there are no numbers for July and September, 1901. 


\section{PHILATELISTEE ITALIEN}

PHILATELISTE ITALIEN. Le Philateliste Italien Fermo, Italie, Rodolfo Filippucci, r8g8.

8.. 10 in. Nos. 1-6, March 31-August 31, 1898.

* Nos. 3 and 4 were published together.

Mis, St. Jour. 134 (6).

[Continued as :]

- Il Filatelista: Italiano.

$8^{\circ} .10$ in. 11 nos. in 2 vols.

Fermo, Rodolfo Filippucoi, r898-99.

1st year. Sept. 30 , Nov. 15, Dec. 10, 1898. Nos. 7-9.

2nd J" Jan. 6-Aug., 1899. Nos. 10-17.

* * Nos. 10 and 11 and nos. 15 and 16 were severally published to-

gether", with the respective dates " 6 Gennaio, 1899 " and " Giugno-

lughio, 1899," and there is no number for May, 1899. There is

[Continued as :]

Il Filatelista ed il Filocartista Italiano.

Fermo, Rodolfo Filippucci, $\mathbf{8} 899$.

$8^{\circ} .10$ in. Vol. Ir. 2 nos.

2nd year. Sept.-Oct., 1899. Nos. 18-19.

* * This double number has a coloured paper wrapper.

Mis. St. Jour. 134 (6b).

PHILATÉLISTE LYONNAIS. Le Philatéliste Lyonnais. Organe mensuel de grand format des collectionneurs et marchands de timbres-poste.

Lyon, Comptoir Central des Inventions Modernes, r895-96.

Fol. 18 in. 20 nos. in 2 vols.
1st year. Mar. 25-Dec., 1895. Nos. 1-10

2nd year. Mar. 25-Dec., 1895. Nos. 1-10.

* *Eäited by Jèrome Obst. Nos." 5, 6 and 7 were published together with the date "Juillet, Août et Septembre, 1895," a second no. 7 is dated "Septembre, 1895," nos. 8, 9 and 10 were published together under the date "Octobre, Novembre, Décembre, 1895," nos. 13,14 and 15 were published together with the date "MarsAvril-Mai, 1896," and nos. 18 and 19 were published together with the date "Août-Septembre, $1896 "$ " The first seven numbers
have supplements.
Mis. St. Jour. 127 (15).

PHILATÉLISTg MAROCAIN. Le Philatéliste marocain. Organe des collectionneurs et marchands des timbres-poste. $8^{\circ} .9$ in. Nos. 1-4, January-A pril, 1898.

${ }_{*}^{*}$ There is a coloured paper wrapper to each number.

Mis. St. Jour. 112 (10)

PHILATÉLISTE IMODERNE. Le Philatéliste moderne. Châlons-sur-Marne, Jean Dubernais, r 900-02.

$4^{\circ} \cdot 10^{8}-11$ in. 30 nos. in 3 vols.

1st year. June 10-Dec. 10, 1900. Nos. 1- 7 .

2nd " Jan. "- ", "1901. " 8-19.

3rd " " " "-Nov. 12, 1902. ", 20-30.

${ }^{*}$ * Nos. 14 and 15,26 and 27 , and 28 and 29 were severally published together. Nos. 20-30 have coloured paper wrappers and nos. 16-18 have supplements. Amalgamated with the "Annonce nos. 16-18 have supplements. Amalgam

PHILATELLISTE ROUMAIN. Le Philatéliste roumain. Organe spécial d'insertions pour les timbrophiles, paraissant le 15 de chaque mois (style vieux).

Braila, Roumanie, N. G. Budescu, r895. Fol. 13 in. Nos. 1-3, Jan. 15/27-Mar. 15/27, 1895.

**A copy of a prospectus of the journal is bound up in front of no. 1. Mis. St. Jour. 86 (14).

PHILATÉLISTE SUISSE. Le Philatéliste suisse.

$8^{\circ} .10 \frac{3}{4}$ in. 12 nos. in 2 vols.

Genève, [Th. Geisendorf], r888-89.

1st year. Mar. 1-Aug. 1, Oct. 5-Dec., 1888. Nos. 1-9,

2nd "Jan., Feb., 1889. Nos. 10-12.

"* Nos. 11 and 12 wore published together under the date "Février, 1889," and there is a supplement of two pages of advertisements to no. 2. After completion, the twelve numbers were sup-
plied in a coloured paper wrapper.
Mis. St. Jour. 74 (2).

PHILATEISTE SUISSE. Le Philatéliste suisse.

La Chaux-de-Fonds, E. Nicolet fils, r894. $4^{\circ} \cdot 113$ in. No. 1, December 1, 1894.

* * Printed on rose paper.

Mis. St. Jour. 87 (21)
PHILATELISTE UNNIVERSEL

PHILATELISTE UNIVERSEL. Le Philateliste universel. Journal mensuel de timbres-poste.

Porrentruy, Suisse, A. Boillat, I 886.

$8^{\circ} .12 \frac{1}{2}$ in. Nos. 1-5, June-Oct., 1886.

** Nos. 4 and 5 were published together, under the date "Sep-

tembre et Octobre, 1886". Mis. St. Jour. 2 (3).

PHILATELISTE UNIVERSEL. Le Philatéliste universel. Der Weltphilatelist. The Universal philatelist. Esch-sur-Alzette, Luxembourg, L. Franck, I89o-91. Fol. $12 \frac{1}{2}$ in. and $13 \frac{3}{4}$ in. and $8^{\circ} .10 \frac{1}{4}$ in. 8 nos. in 2 vols.

1st year. May 20, July 10, Aug. 10, Sept., Oct., Dec., 1890. ' Nos. 2nd , Jan., Feb., 1891. Nos. 1-2.

* * No. 1 measures 121 inches, nos. 2-6 and no. 1 , second year, $1 \hat{3}_{4}^{3}$ inches and the number for February, 1891, 101 inches. This last number is numbered "No. 1 \& 2 " "There is a supplementary slip to no. 5. This was the first philatelic journal published in Luxemburg.
Mis. St. Jour. 74 (7).

PHILATELISTEN. Philatelisten. Esbjerg, Danmark, J. Møller, I905-08.

$8^{\circ} .9 \frac{3}{4}$ in. 20 nos. in 3 vols.

1st year. Feb. 10-Nov. 30, 1905. Nos. 1-10.

3rd " Aug. 15-Nov. 15, 1907. ", 11-14.

4th " Jan. 15-July 15, 1908. " "15-20.

* " Nos. 1-6 and nos. 11-20 have coloured paper wrappers and nos. 7 " and 8 were published together. There is no number for April 7 and 8 were published together. There is no number for April
or for May, 1908, but two numbers were published in June 1908 , or for May, 1908, but two numbers were published in June 1908,
one on June 6, the other on June 24. No. 17 for March 20, 1908 one on June 6, the other on June 24. No. 17 for March 20, 1908
is wrongly numbered "16". Nos. 16-18 have supplements with is wrongly numbered " $16 "$. No
the title "Philatelistisk Revue".

PHILATELISTEN-ZEITUNG. Philatelisten-Zeitung.

Stade, Hannover, Hamburg [printed], H. J. Meier, r890-93.

Fol. 12 in. 28 nos. in 3 vols.

1st year. Oct. 30, 1890.Dec., 1891. Nos. 1-12

2nd "Jan. 27, - " 27, 1892. " 1-12.

*** There are title-pages and indexes to the first two years, and "* There are title-pages and indexes to the first two years, and supplements of two pages to nos. 7,8 and 12 of the second year, with the the first year, is dated "Januar-Febr., 1891"; no. 6, "April4, of the first year, is "ated "Januar-Febr., 1891 ; no. 6, "AprilSeptember, or for November, 1891 , and nos. 11 and 12 were pubSeptember, or for November, 1891, and nos. 11 and 12 were published togetiler, under the date "December, 1891 ". Of the second year nos. 10 and 11 were published together under the date " 27 Oct.-Nov., 1892," and of the third year nos. 3 and 4 were published together with the date "Mai-Juni, 1893" and there is no number
for March or April, 1893.

PHILATELISTEN-ZEITUNG. Philatelisten - Zeitung. Journal und Insertionsorgan für Briefmarkenkunde und Briefmarkenhandel. Beiblatt zur Deutschen Papier- und Schreibwaren-Zeitung.

Berlin, Moritz Warschauer, I 904-о6.

Fol. $12 \frac{1}{4}$ in. 38 nos, in 2 vols.

1st year. Dec. 31, 1904-Jan. 20, 1906. Nos. 1-26.

2nd " Feb. 3, -Aug. 11, " " 1-12.

*** Nos. 25 and 26 and the numbers of "the second year hare "Beiblatt zur Papier- und Schreibwaren-Zeitung". Commencing with March, 1905, the journal was published fortnightly, there with March, 1905, the journal was published fortnightly, there and only one for May, 1906. Wanting nos. 2, 13, of the first year.

PHILATELISTEN-ZFITUNG. See MitTELDEUTSCHE Philiatelisten-Zititung.

PHILATELISTISCHE ALT- UND BIERZEITUNG. Philatelistische Alt- und Bierzeitung. Dresden, XI. Deutscher Philatelisten-Tag, r 899

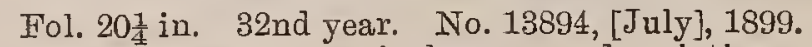

* The contents are of a humorous description.

PHILATELISTISCHE BERICHTE. Philatelistische Berichte.

Rudolfsheim, Wien, S. F. Friedmann, r872-77. $8^{\circ} \cdot 9-9 \frac{1}{2}$ in. 40 nos. in 6 vols.

[1st year.] July 28-Dec. 31, 1872. Nos. 1- 6

[2nd , ] Jan. 31- " 31, 1873 . " 7-15.

[3rd " ] $, 31-", 31,1874$

[4th "] Feb. 28- " 31, 1875 .

[6th "] " " 28- " $31,1877 . \quad$ " $35-40$. 

Phitatelistiche Borsen-hachrichtex Berow 19007 
717 PHILATELISTISCHE BERICHTE

* * Nos. 12-38 were publishcd in Wien; nos. 1-16 were printed in Dresden and the remaining numbers were printed in Wien There are no numbers for February, July and August, 1873, Februry, May, June, September and November, 1874, nor for the may, July, September and November, of the years 1875,1876 and 1877 .

PHILATEISTISCHE BERICHTE. Philatelistische Berichte. Leipzig, Albert Friedemann, I906-

$8^{\circ} .9 \frac{1}{4}$ in. Mos. in vols. In progress.
Vol. I., Apl., June, Sept., Dec., 1906, Jan., Mar., Apl., June, Aug., vols. In progres. Oct., Dec., 1907, Jan., Mar., Apl., May, July, Sept., Oct., Dec. 1908. Nos, $1-19$.

**" There is a title-page and an index to Vol. $\mathrm{I}$.

PHILATELISTISCHE BLÄTTER. Philatelistische Blätter. Organ für die Gesammt-Interessen der Briefmarkenkunde.

Leipzig, Ein Verein von Philatelisten, 1874 . $4^{\circ} .8 \frac{1}{2}$ in. Nos. 1-6. July-Dec., 1874.

** Nos. 5 and 6 were published together under the date "November-December".

PHILATELISTISCHE BIÄTTER. Philatelistische Blätter. Illustrirtes Organ für die Gesammt-Interessen der Briefmarkenkunde.

$8^{\circ} \cdot 9 \frac{1}{2}$ in. No. 1 , [no date]

Brïnn, A. von Tsakovics, [1887].

** The number bears the word "Probenummer" and has 28 pages.

PHILATELISTISCHE BÖRSE. Die Philatelistische Börse. La Bourse des Timbrophiles.

Berlin, G. Frouré, [1879].

$4^{\circ} \cdot 11 \frac{1}{2}$ in. Nos. 1-2, [December 15, 1879]

Illustrirte Briefmarken Z"eitung". The two numbers were published together.

Mis. St. Jour. 120 (4)

PHILATELISTISCHE FACHSCHRIFT FÜR SAIMIMLER VON ELSASS-LOTHRINGER U. OCCUPATIONS-FREIMARKEN UND IHREN ABSTEMPELUNGEN. Philatelistische Fachschrift für Sammler von Elsass-Lothringer $u$. Occupations-Freimarken und ihren Abstempelungen. I 896 .

Mïlhausen, Philatelisten-Verein Miulhausen $i$ Elsass,

$8^{\circ} .10^{3}$ in. No. 1 and nos. 1-5, May, 1896, and May 31-Sept. 30 , 1896

** There is a coloured paper wrapper to each number.

Mis. St. Jour. 122 (11)

PHILATELISTISCHE HERREN-ABEND-ZEITUNG

Philatelistische Herren-Abend-Zeitung. I 898 .

Berlin, Verein der Briefmarken-Sammler zu Berlin,

$4^{\circ} .11 \frac{2}{4}$ in. No. 1 , April $23,1898$.

* * The contents are of a humorous description.

Mis. St. Jour. 129 (12)

PHILATELISTISCHE JUGENDSCHRIFT. Philatelistische Jugendschrift.

Bruchsal, etc., Philatelistischen Schiilerverein Bruchsal, etc., $1892-94$.

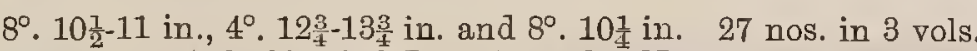
1st year. Apl. 28, 1892-June 1, 1893. Nos. 1-12. 2nd " July 1, 1893- ", 1894. " 1-11. 3rd ",

$5116 * *$ Nos. $1-4$ are octavo $10 \frac{1}{2}-11$ inches, nos. $5-12$ of the first year and the numbers of the second year are quarto and the numbers of the third year are octavo $10 \frac{1}{1}$ inches. Commencing with no. 5 of the first year the journal was printed by an autographic process and published by the "Chalmers" Verband jung: Briefm.-Sammler ; nos. 5-8 at Stutigart and the remaining numbers at Leipzig. Nos. 1-3 of the first year have supplements with the title "TauschOffertenblatt" and no. 4 of the same year has a supplement with the title "Vereins-Bote". There are no numbers for August and October, 1892, or for March and August, 1893 and the numbers of the third year only bear the year date, "1894".
PHILATELISTISCHE

718

PHILATELISTISCHE KORRESPONDENZ. Philatelistische Korrespondenz.

Berlin, Dr. Hans Brendicke, I 905-06. Fol. 13 in., $4^{\circ} .11 \frac{1}{2}$ in. and fol. $13 \frac{1}{2}$ in. No. 1 and nos. 1-9, 1905 and December 15,1905 -April 15,1900 .

* * "There are two numbers " 1 " the first produced by antographic lithography and dated " 1905 " " the other printed like nos. 2-9 and dated "December 15, 1905 ". Each number consists of a singl leaf. No. 1 measures 13 inches, no. 1 with date "December 15 1905 " and nos. $3-9$ measure 111 inches and no. 2 measures 13

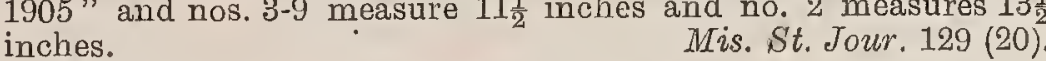

PHILATELISTISCHE LITTERATUR. Die Philatelistische Litteratur. Monatliches Beiblatt zu "Die Post," Kentralblatt für Litteratur-Freunde und Sammler. Leipzig, Baumbach und Co., I895-97. $4^{\circ} .93$ in. 36 nos. in 3 vols. 1st year. Jan. 15-Dec. 15, 1895. Nos. 1-12. 2nd year. Jan. 15-Dec. 15, 1895. Nos. 1-12. 3rd " " $" 15-$ Nov, 15, 1897.

* * "There is no number for March or for December, 1897, but there are two numbers for April and also two for October of that year.

PHILATELISTISCHE LITTERATUR. See PHILAT. LITTERATUR.

PHILATELISTISCHE LITPMRATURSAMIMLER Der Philatelistische Litteratursammler.

Leipzig, Dr. Fiommel, т 9o6Fol. 13 in. and $4^{\circ} .11 \frac{1}{4}$ in. nos. in vols. In progress.
1st year. Oct. 20, Dec. 1, 1906, Feb. 10, May 1, 11, Nov. 20, 1907. Nos. $1-6$.

** Nos. $1-5$ were produced by a type-writing machine and the latter numbers by autographic jithography. No. 1 is folio and the subsequent numbers are quarto. Mis. St. Jour. 137 (10).

PHILATELISTISCHE IMISCELLEN. Philatelistische Miscellen. Monatsschrift für Briefmarkensammler, zugleich Offertenblatt.

Augsburg, etc., M. Liebert, etc., I904-o9. $4^{\circ} .11 \frac{1}{4}-11 \frac{1}{2}$ in. 63 nos. in 6 rols.

1st year. Jan. 1-Dec. 1, 1904. Nos. 1-12.

2nd ", " 1- " 1, 1905. " $1-12$.

4th " " " $" 1-1,1906 . \quad$ " $1-12$.

5th " " " " " $1908 . \quad, 1-12$.

6th " " "Mar., 1909. " "1-3.

* * The numbers of vols. IV.-VI. were published at Berlin by R. FI. Funcke. There is a title-page and an index to vol. IV. only, and a coloured paper wrapper to no. 9, vol IV. only.

PHILATELISTISCHE MITTEILUNGEN. Philatelistische Mitteilungen. Organ des BriefmarlienTausch-Klub Bern. Bern, F. Reinhard, I905$4^{\circ} \cdot 10 \frac{3}{4} \mathrm{in} .2 \%$ nos. in $\&$ vols. Mnowderess.

1st year. Dec. 15, 1905, Jan.-Dec., 1906. [Proof number] and nos. 1-[10].

** Produced by a hand multiplying press. No. 8 is dated "August-September," without any year date, and there are two editions of this number. The second differs from the first in having the contents of pages 2 and 3 transposed. There is no number for November, 1906 and no. 10 dated "Dezember, 1906 " is unnumbered and has a paper wrapper.

PHILATELISTISCHE IMONATS-BERICHTE. Se Philateliestische Monats-Berichte.

PHILATELISTISCHE NACHRICHTEN. See MITTHEILUNGEN DES BRIEGMARKEN SAMMLER-VEREINS MOSEL.

PHILATELISTISCHE OFFERTEN. Philatelistische Offerten. Offres philateliques. Philatelic offers. Insertions-Organ für Briefmarkensammler und-Händler. Berlin, Paul Tavoukdji, 1897 . $8^{\circ} .9 \frac{1}{4}$ in. Nos. 1-2, January 2-February 1, 1897.

** The contents consist entirely of advertisements.

Mis. St. Jour. 111 (3)

PHILATELISTISCHE PRESSE. Philatelistische Presse. Internationales Organ für die gesammten Interessen der Philatelie.

Czernowitz, Czernowitzer Philatelisten Club, I887. $4^{\circ} .11^{3}$ in. Nos. 1-2, November-December, 1887.

Mis. St. Jour. 73 (7) 
PHILATEIISTISCHE RPVUE. Philatelistische Revue. Monatsschrift für die gesamte Postwertzeichenkunde. Revue Philatélique. Revue mensuelle pour la timbrologie. München, Emil Schmuck, [1901] $8^{\circ} .101$ in. Nos. 1-2, November-December, [1901]

* Printed in German and French. A copy of the prospectus of the journal is bound up in front of no. 1. Mis. St. Jour. 131 (7)

PHILATELISTISCHE RUNDSCHAU. Philatelistisch Rundschau. Genf, etc., Hans Kirchhofer, etc., I 903-०5 $4^{\circ} \cdot 10 \frac{1}{2}-11$ in. Nos. [1]-3, May, 1903, December, 1904, November 1905 .

** Nos. 1 and 2 have coloured papor wrappers. No. 1 bears no number and the wrapper has the date "April, 1903". Nos. 2 and 3 were published at Morges by Hans Kirchhofer et Cie.

Mis. St. Jour. 124 (5).

PHILATELISTISCHE RUNDSCHAU. Philatelistische Rundschau.

Pforzheim, Deutscher Philatelisten-Tag, I 903 Fol. 19 in. August 29, 1903.

* * Printed in brown on buff paper and the contents are of humorous description. Mis. St. Jour. 127 (16)

PHILATELISTISCHE RUNDSCHAU. See BLAUE BLATT.

PHILATELISTISCHER BÖRSEN-COURIER. Philatelistischer Börsen-Courier.

Mährisch-Ostrau, Julius Kittl, I886-94

$8^{\circ} .11 \frac{1}{4}$ in., $10 \frac{1}{2}$ in. and 101 in. 144 nos. in 9 vols.

1 st year. July 1 -Dec. 1,1886 . Nos. $1-6$.

2nd ", Jan. 1- " 1, 1887. ", 1-12.

3rd " " $1-", 1,1888 . \quad " 1-12$.

5th " " $" 1-" 1-1,1889 . \quad$ " $1-12$.

6th " "10- " 25, 1891.

7th " " 10- ", 25, $1892 . \quad, \quad 1-24$

8th " " 10- , 25, $1893 . \quad$ " 1-24.

* * Edited by "Karl Cl. Sauer. There" is a title-page and an index for each of the first eight years and no. 6 of the first year, nos. 9 and no. 11 of the second year, no. 3 of the fifth year and nos. 15 and 17 of the eighth year have supplements. The first five years measure 111 inches, the sixth, seventh and eighth years 10 inches and the ninth year $10 \frac{1}{1}$ inches. No. 3 of the ninth year is wrongly numbered " 2 ".

PHIT ATELISTISCHFR

KLADDERADATSCH.

Philatelistischer Kladderadatsch. Organ für die philatelistisch-gebildete Welt. Fest-Nummer für das 111. [v.] Stiftungsfest des Bayerischen Philatelisten-Vereins zu. München.

Mïnchen, $1886-88$. $8^{\circ} .11^{1}$ in. 2 nos. "No. 111, 1886," "No. 222,1888 ". * *The contents are of a humorous description. Published in M̈arch, 1886 and March, 1888 Mis. St. Jour. 4 (17).

PHILATELISTISCHER ULK. Philatelistischer Ulk.

$4^{\circ} .12$ in. April 16, 1887

Rio de Taneiro, [Mïnchen], I88\%.

* * Produced hy a hectographic process and published by the Section Rio de Janeiro des Bayerischen Philatelisten-Vereins in München zum Stiftungsfeste 1887 . The journal boars no number and the contents are of a humorous description.

Mis. St. Jour. 128 (14)

[Continued as :]

Philatel. Nachrichten.

Rio de Janeiro, [München], I887.

Fol. 13 in. No. 2, July 1, 1887.

* * Produced by a hectographic process and published by the Section Rio de Janeiro des Bayerischen Philatelisten-Vereins in München zum Stiftungsfeste 1887. The number consists of two leaves printed on one side only and the contents are of a humor-
ous description.
Mis. St. Jour. 128 (14a).

PHILATELISTISCHER VERKEHR. Philatelistischer Verkehr. Leipzig, Max Böhne, I878-8o. $8^{\circ} .9-91$ in. 11 nos. in 2 vols.

1at year. 1878, 1878, Nov, 15, 1878, Jan. 1, Feb. 15, Apl, 15, May 15, July 1, Sept. 1, Nov. 15, 1879. Nos. 1-10.

** Nos. 1,2 and 11 bear no month and no. 11 was given as a supplement to no. 3 of the "Neue philatelistische Blätter," which
was published on January 15, 1880 . Mis. St. Jour. 133 (2).
PHIL ATFIISTISCHES ANNONCFNBIATT Philatelistisches Annoncenblatt. Internationaler Anzeiger für Ëändler, Sammler und Vereine.

Fuerth, Bayern, H. Uffenheimer, I 896.

Fol. 113 in. Nos. 1-3, January 22-March 22, 1896.

** The contents consist entirely of advertisements.
Mis. St. Jour. 87 (18).

PHILATELISTISCHES BÖRSENBLATT. Philatelistisches Börsenblatt.

Kottbus, Alb. Petersdorf, I 896-97. $8^{\circ} .9 \frac{1}{4}$ in. and fol. $12 \frac{1}{2}$ in. 39 nos. in 2 vols.

1st year. Jan. 15-Dec. 15, 1896. Nos. 1-15.

2nd " " 5- " 15, $1897 . \quad$ "16-39. * Noncing with octavo and the remaining nos. are folio, Comnightly. Nos. 1-10 are printed on rose paper and the remainde are on buff paper. Nos. 31 and 32 and 35 and 36 were severally published together and no. 39 has in error " 1 Jahrg".

PHILATELISTISCHES ECHO. Philatelistisches Echo Leipzig, J. J.Arnd, I 904-07.

$8^{\circ} .10_{4}^{3}$ in. 38 nos. in 3 vols.

1st year. Nov. 15, Dcc. 15,1904 . "Probenumber" 1 and 2.

" "Jan. 15-Dec. 15, 1905. Nos. 1-12.

2nd " " 15- " 15, $1906 . \quad$ " $1-12$

** There is a title-page and an index to each year and nos. 7 and * The fin a tille-page and an index to each year 11 and 12 of the third for the third year have coloured paper wrappers.

PHILATELISTISCHES OFFERTENBIATT. Philatelistisches Offertenblatt.

Budapest, Géza Szekula, [1 905]

8. 9 in. Nos. 1-3, [April-June, 1905]

* *The contents consist entirely of advertisements, and each number has a coloured paper wrapper. The numbers bear no dates. Wanting nos. 1, 2.

PHILATELISTISCHES TAGEBLATT FU்R MITTEL DEUTSCHLAND. Philatelistisches Tageblatt für Mitteldeutschland.

Gössnitz, S.-A., A. E. Glasewald, I89 $8^{\circ} .8 \frac{3}{1}$ in. No. 383 , September 20,1891 * "Contains an "Extra-Beilage" of two pages.

Mis. St. Jour. 145 (9)

PHILATELISTISK REVUE, Philatelistisk Revue (Tillaeg tit "Philatelisten".)

Esbjerg, Danmark, J. Mфller, I 908 $8^{\circ} 9 \frac{1}{2}$ in. Nos. 1-3, Feb. 25, March 25, June 24, 1908. * No. 1 is printed on rose paper. The three numbers are bound up with the "Philatelisten."

PHILATELIST'S BEACON. The Philatelist's beacon. Golden, Colo., Chester Ehle, I902.

$16^{\circ} 6$ in No 1 January, 1909

* The number has a coloured paper wrapper.

PHILATELIST'S COIVPANION. The Philatelist's companion. A monthly magazine. Devoted to stamp col lecting. Williamsport, Pa., Page and Hart, 1873 8.63 in. Nos. 1-2, April-May, 1873.

** Printed on coloured paper. There is a slip supplement to no.

PHIL ATEIIST'S FRIEND. The Philatelist's friend.

$8^{\circ} .8 \frac{1}{2}$ in. No. $1,[1883]$.

Cincinnati, O., F.L. Mills, [1883]

PHILATFLIST'S FRIEND. The Philatelist's friend. Devoted to stamp collectors.

$8^{\circ}$. $7 \frac{1}{2}$ in. No. 1, March, 1890 .

Dixon, Ill., Wm. Trissel, Jr., I89o. ment to the comprehensive check list of philatelic papers and magazines," but it seems doubtful if more than one number issued. 
Pilatelistisches offertenthate. Nela fyehorla.

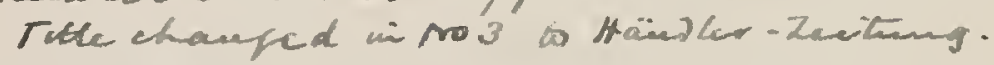

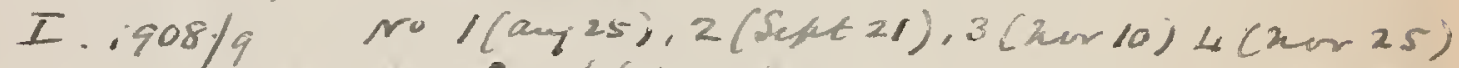

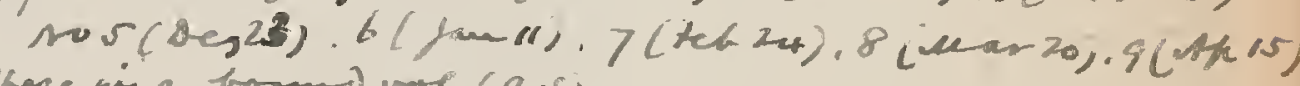
oblonf in chafe wor. (a.s).

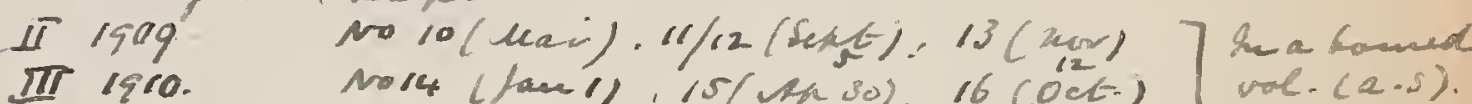


Meantime on March 1st, 1879, a new monthly had raised its head under the name of the Philatelist's Gazette. This was a 4-page effort by R. Loosley, of Maidenhead. Not until No. 5, did its size expand to 8 pages, and at the same time was taken over by A. J \& W. Ashton, of Forest Gate, who ran it until No. 12, after which Wm. Feldwicke, of Brighton took it over for the not very convincing reason that Mr. Ashton "with increasing circula tion, cannot now devote the time which is necastion, "cant nor apare " "suffering from an indisposition", before he was hum to trang from an indisposition which caused " suin to transer the paper to H. A. Everett, also of Brighton. Anticipating criticism, the editorial of May, 1880, states. "We have no doubt that one or two of the inferior class of stamp papers will seize the opportunity of showing off ther blackguardism by making rude remarks on this occurrence."

Mr. Everett increased the size to 12 pages intermittently, improved the contents, and attracted the advertisements of leading dealers of the time, but after 24 numbers had appeared, this journal which had already had four proprietors in two years, came into the possession of a fifth, Messrs. Tozer \& Co., who ran it up to No. 37, when it died in May, 1882 , after showing much promise, and quite a creditable performance.

A.H.H.

Philately in Seorland $1932-33(04$ pants)
Phoniofruphers' a Typist's' Sah alxchange athiscullanevers atumtiser - $1905-6$
Continume as
517
a. an or ensumicte

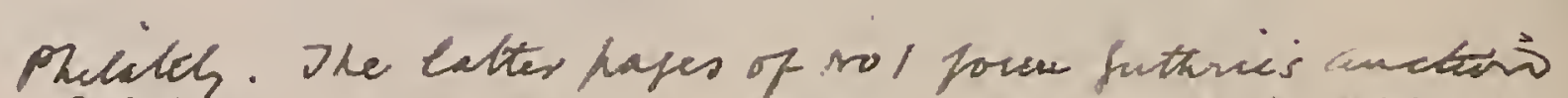

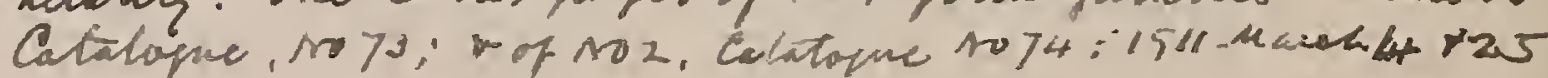

Pistorial Yunes. S11 
721 PHILATELIST'S GAZETTE

PHILATELIST'S GAZETTE. The Philatelist's gazette. A monthly journal for stamp collectors.

Maidenhead, etc., R. Loosley, et

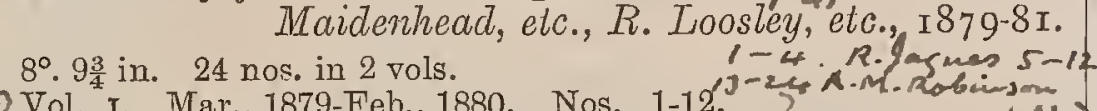

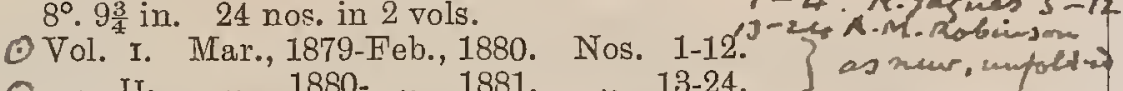

(\% *" II. "There is a title-page and an index to vol. I. Nos. 5 -12 were pulished by $\mathrm{F}$. published by 1 . L. Ashton, at Forest Gate, nos. 13, 14 by W. Feldwick, at Brighton, and nos. $15-24$ by $H$. A. Everett, also at Brighton. $v$ Nos. 1-4 were printed at Maidenhead, nos. 5-12 at Stratford, and nos. 13-24 at Brighton. "No. 18 states that the "Foreign stamp advertiser and review," "The arcade," "The champion exchange" and the "Foreign stamp gazette" have been incorporated with the paper, and the "Amateur exchange the title printed "The Philatelists' gazette". [Continued as :]

- The Philatelists' gazette and stamp exchange and mart. A monthly journal for stamp collectors.

Brighton, F. E. Tozer and Co., I88I-82.

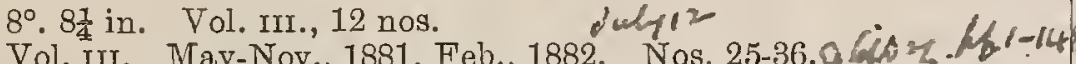

* * Nos. $25,26,27$ and $34,35,36$, we soverally published together under the respective dates May, 1881, and February, 1882. Nos. 25-28 were edited by H. A. Everett, and nos. 30-36 by Phil. Norton. Two editions exist of no. 33 one with the pages
numbered $93-108$, the other 109-124, which is the correct numbering.

[Continued as :]

- The Philatelists' gazette.

West Brighton, F'. E. Tozer and Co., I882.

○ $8^{\circ}$.8 8 in. Vol. IV., no. 1. May, 1882 . K/ $1-16$

PHILATELISTS' GAZETTE AND STAMP EX CHANGE AND IMART. See Phrmatelist's Gazette.

PHILATELISTS' JOURNAL. The Philatelists' journal. Plymouth, Wis., ete., W. G. Karpe, I 883 .

$4^{\circ} .10 \frac{1}{2}$ in. Nos. 1-5, Jan.,-May, 1883.

** Nos. 3-5 were published at Los Angeles, Cal. and nos. 4 and 5 were published together, with the date "April and May, 1883 "

PHILATELISTS' IMAGAZINE. The Philatelists' magazine, a monthly journal for stamp dealers and collectors. Hotk hoor coprias Stoke Newington, London, J. Dickeson, I880. $8^{\circ} .10$ in. Nos. 1-2, November 15-December 15, 1880

** No. 2 is printed on buff paper. Va Lt Dis. St. Jour. $9(6)$.

PHILATELISTS' IMONTHLY ADVERTISER. The

C Philatelists' monthly advertiser. A journal for dealers and collectors.

Lineoln, Bertrand E. Harrison, I goI-02. $8^{\circ} .71$ in. Nos. 1-6, Sept. 21, 1901-Feb. 21, 1902. 2/8t cartons. $6 *^{*}$ * There is a coloured paper wrapper to each number. Sreen ph $1-48$

Mis. St. Jour. 81 (13)

PHILATELISTS' OWN PAPER. The Philatelists' own

(. paper. With which is incorporated "The Southampton stamp advertiser".

Southampton, Albert A. Dykes, Jun., I886.

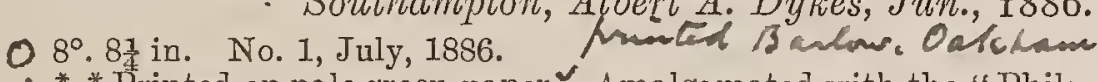
** Printed on pale green paper. A malgamated with the "Phila-
telic exchange list" in August, 1886 . Mis. St. Jour. 34 (2).
Mist

PHILATELISTS' PAPER. The Philatelists' paper. A monthly magazine for stamp collectol's

Southampton, Oxford [printed], A. A. Dykes, r887.

$8^{\circ} .73$ in. Nos. 1-2, October-November, 1887.

** Wanting no. 2.

Mis. St. Jour. 79 (1)

PHILATELISTS” SUPPLEMENT TO “THE

BAZAAR". Philatelists' supplement to "The Bazaar". Issued at intervals during the season.

Iondon, W.C., [L. Upeott Gill], I895-I goo.

Fol. $12 \frac{1}{2}$ in. 35 nos. in 7 vols.

[Vol. I.] Feb. 11, Apl. 8, June 10, 1895. [Nos. 1-3.]

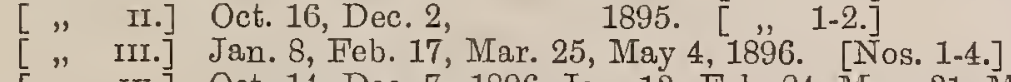
[ ", Iv.] Oct. 14, Dec. 7, 1896, Jan. 13, Feb. 24, Mar. 31, May
12, 1897. Nos. 1-6.
PHILATELIST'S WINDOW

[Vol. v.] Oct. 13, Nov. 10, 1897, Jan. 12, Feb. 9, Mar. 9, Apl. [ , vi.] Oct. 12, Nov. 9, Dec. 14, 1898, Jan. 11, Feb. 8, Mar. 8, Apl. 12, 1899. Nos. 1-[7].

[ " vir.] Oct. 11, Nov. 8, Dec. 13, 1899, Jan. 10, Feb. 14, Mar. * * Edited by the Rev. R. B. Earée. There is an index to vol. v. given at page 15 of vol. vi. and coloured paper wrappers to nos. 1-4, vol. IV. the wrappers being paged in with the rest of the contents. The number for December 14, 1898, is not numbered contents. The number for December: 14, 1898, is not numbered and the numbers for Jan. 11, Feb. 8, Mar. 8, and Apl. 12, 1899 are numbered 3 to 6 , instead of 4 to 7 , respectively. A copy of the prospectus is bound up before the first number. The volume contains the title-page and index compiled by $H$ " Jogar Weston which was published as a supplement to the "Journal of the only 150 copies were printed.

PHILATELIST'S WINDOW. The Philatelist's window. Chicago, Ill., Horn and Co., I 899 8. 8 in. No. 1, September 15, 1899. Mis. St. Jour. 83 (2).

PHILATELY. Philately. A monthly journal devoted to stamps and stamp collecting.

New York, Philately Publishing Co., etc., I889-9o. $4^{\circ} .11^{3}-12$ in. Nos. 1-9, Mar.-Sept., 1889, Feb., Mar., 1890.

* * Nos. 6 and 7 were publishod by Polytechnical News Co., no. 8 by Philately Publishing Co. and no. 9 by Joseph Holmes, and there are coloured paper wrappers to nos. 1, 2, 3,6 and 7. No. 7 is wrongly numbered " 8 " on page 55 , but the wrapper has the numbering correct. A circular with the advertising rates of the journal issued by Wilson and Roberts of Walnut Hills, Cincinnati, O., in April, 1890, is bound up in Mis. St. Jour. 62 (6). Mis. St. Jour. 72 (14)

PHILATELY. 'Philately. Neat, novel, newsy.

Jackson, Mieh., The Philately Publishing Co., I893.

8. 10 in. No. 1 , Ostober, 1893.

Mis. St. Jour. 60 (6)

PHILOCARTIST NEWS AND CAMERA CRAFT,

The Philocartist news and camera craft

Stillwater, Okla., Souvenir Postal Pub. Co., I 905-o6.

$8^{\circ} .8 \frac{1}{2}-9$ in. 14 nos. in 3 vols.

Vol. I. Nov., 1905-Apl., 1906. Nos. 1-6.

" II. May, -Oct., $1906 . \quad$ " $1-6$.

*"* Only partly philatelic. There is a coloured paper wrapper to

each number. Amalgamated with the "Coluinbus philatelist,"

March. 1907. Wanting nos. 1, 3, 4, vol. r.

PHILOIMATH. The Philomath.

Rawlinsville, Pa., James Galen, 1877

* * Cuttings of the stump portions from vol. II., no. 13, dated April, 1877, are mounted in Stamp Scrap-book, vol. irr., p. 77. The previous numbers are not philatelic.

PHILO'S IMONTHLY. Philo's monthly. Published in the interests of philately.

Grand Crossing, Ill., S. B. Bradt, r 888

$8^{\circ} .7 \frac{3}{4}$ in. Nos. 1-4, July-October, 1888.

Mis. St. Jour. 66 (9)

PHILOTELICAL CIRCULAR. Philotelical circular. London, E.C., J. J. Pérez O., I88 I.

$4^{\circ} .10 \frac{1}{2}$ in. Nos. 1-9, Jan.-Sept., 1881

* * Printed by an auto:opyist machine in violet ink, in Spanish on thin paper such as is used for copying letters upon. $v$ Fach number consists of a single leaf printed on one side only. Wantnumber cong. 7 .

5116

PHILOTYPIST OR STAMP AIVATEUR. The Philo(2) typist or stamp amateur.

Ipswieh, Whitfield, King and Co., r882.

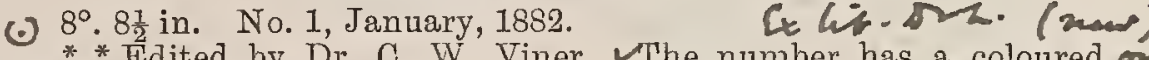

* Eidited by Dr. C. W. Viner. The number has a coloured ompe hoff.

bound up with it.

PHYLATELICO AVEIRENSE. See Phrtaterico AverrENSE.

PICTURE IMAGAZINE. The Picture magazine. No. 8,

(3) August, 1893, [contains an illustrated article "The most valuable stamps in the world".]

London, W.C., George Newnes Limited, I893.

Q $8^{\circ} .11 \frac{1}{4}$ in. p. 119.

** The number has a coloured paper wrapper

Mis. St. Pamph. 63 (7)

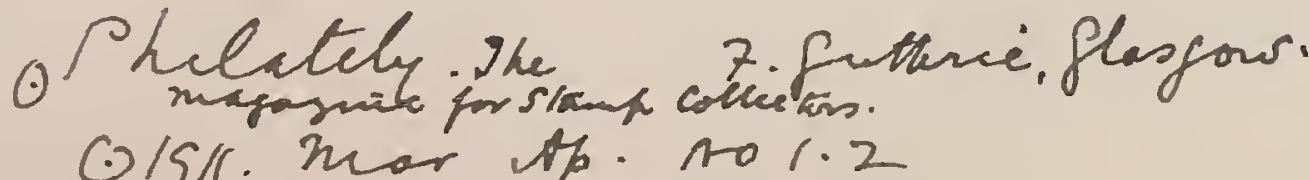


PICTURE POSTCARD. The Picture postcard. A maga zine of philately, travel and art.

London, E.C., E. W. Richardson, etc., I 900-02 $8^{\circ} .93$ in. 24 nos. in 3 vols.

Vol. I. July-Deo., 1900. Nos. 1- 6.

"II. Jan.-" 1901. "7-18.

* " III. "June, 1902. " " 19-24.

a paper wrapper to each Co.

\section{[Continued as :]}

- The Picture postcard and collectors' chronicle. London, E.C., E. W. Richardson, I 902-о\%.

$8^{\circ} .9 \frac{3}{4}$ in. Vol. III.-VIII., 61 nos.

Vol. III. July- Dec., 1902. Nos. 25-30.

" IV. Jan.- ", 1903. " 31-42.

" v. " " $\quad$ 1904. " $\quad 43-54$.

" vI. " $\quad$ - $\quad$ - $\quad 1905 . \quad 1906 . \quad 55-66$.

" VIII. " "Sept. 1907. " $197-78$.

* " Onjy partily philatelic. There is a coloured paper wrapper to each number. No. 83 is dated "May-June, 1907," and no. 85 , "August-September, 1907 ".

PICTURE POSTCARD AND COLLFCTORS CHRONICLE. See PiCturet Postcard.

PIGMY. The Pigmy.

$8^{\circ} .8$ in. Nos. 1

Corning, N. Y., R. D. Van Alstin, I 900-о I.

* * Only partly philat

"January 15, 1901".

PINE AND PALIVETTO. Pine and Palmetto.

New York, etc., Paul Goldsmith and Clarence Whitney, etc., I $884-85$.

$8.9-83$ in. 19 nos, in 2 vols.

Vol. I. March-June, Aug., Nov., 1884-June, 1885. Nos. 1-16. " II. July-Sept. A * Only partly philatelic. Commencing with no. 5, vol. I., the journal was published at Oalland, Cal., and atter no. 14 by Paul Goldsmith alone. Nos. 1-5 have paper wrappers. During the months of December, 1884, to April, 1885, with the exception of February when no number was issued, the journal was published fortnighte. No. 14 "s numbered in error "13 "and no. 16 bears " on page 3 instead of "June 1885, no. 16 ". Wanting nos. 7,8 , vol. I.

PIPESTONE PHILATELIST. The Pipestone philatelist. Pipestone, Minn., Chas. G. Hart, I894.

$32^{\circ} .41$ in. Nos. 1-2, October-November, 1894.

* * Therc is a coloured paper wrapper to each number.

- [New Series.]

8. 9 iu. 14 nos. in 2 vols.

Vol. I. Dec., 1894-Nov., 1895. Nos. 1-12.

* " II. Jan. -Feb., 1896. " " $1-2$.

P. J. G. B. ADVERTISER. The P. J. G. B. advertiser. Salisbury, Wm. Brown, I 896-99.

Fol. $13_{4}^{3}$ in. and $8^{\circ} .97$ in. 36 nos. in 3 vols.

Vo]. I. Oct., 1896-Sept., 1897. Nos. 1-12

"II. "1897- " 1898. "13-24.

* "III. " 1898- ", 1899. " 25-36.

*" "Printed " on buff or yellow paper, and the contents consist entirely of advertisements. Nos. 1-19 are folio and the rest octavo. No. 11 is wrongly numbered " 10 " and no. 25 has " 1889 " for "1898". No. 10 and nos. 32-36 were printed at Bournemouth. Nos. 20-36 were presented frec to subscribers to the "Plilatelic journal of Great Britain".

\section{[Continued as :]}

___ Brown's advertiser.

Salisbury, Boumemouth [printed], Wm. Brown, I 899- I 904 .

$8^{\circ} .9 \frac{1}{2}$ in. Vols. III.-VI., 59 nos.

Vol. III. Oct., 1899-Dec., 1900. Nos. 37-51.

" IV. Jan., 1901- " 1902. " 52-75.

" v. Jan.- - ", 1903. " 76-87.

*" Vrinted" on yellow paper and the contents consist entirely of advertisements. Nos. $37-40$ were presented free to subscribers to the "Philatelic journal of Great Britain".

\section{P. J. G. B. ADVERTISER}

[Continued as :]

The Advertiser, (formerly Brown's.) I 904 .

Salisbury, Bournemouth [printed], S. C. Skipton,

So. $9 \frac{1}{2}$ in. Vol. VI., 2 nos.

Vol. VI. Sept.-Oct., 1904. Nos. 96-97. ** Printed on yellow paper and the contents consist entirely of
advertisements.

\section{[Continued as :]}

The Stamp and postcard advertiser. (Formerly Brown's.)

Salisbury, etc., Bournemouth [printed], S. C. Skipton, etc., 1904-06.

$8^{\circ} \cdot 9 \frac{7}{2}$ in. Vols. VI.-VIII., 20 nos.

Vol. vi. Nov. -Dec., 1904. Nos. 98- 99.

" vII. Jan. $\quad$-Sept., 1905. " 100-108.

* VIII. Oct., 1905-Jume, 1906. " 109-117.

* * Printed on yellow paper and the contents consist entirely of advertisements. Nos. 113-117 were published by C. Nissen and Co., London. Nos. 116 and 117 contain as supplements copies of "Nissen's Monthly Offers," nos. 1, 2, respectively, printed on yellow paper.

\section{[Continued as :]}

The International philatelic advertiser. (Formerly Brown's.)

London, W.C., Bournemouth [printed], C. Nissen and Co., $1906-07$.

$8^{\circ} .9 \frac{3}{4}$ in. Vols. VIII.-IX., 10 nos.

Vol. virI. Sept.-Dec., 1906. Nos. $118-121$.

"IX. Jan.- July, 1907. " [122]-127.

*"* Printed on yellow paper and the contents consist entirely of advertisements with the exception of nos. 122-126, each of which contains a page of philatelic notes. No. 122 is numbered "vol. IX., No. 1," no. 123 is wrongly numbered " 124 " and no. 127 is dated "Juue and Jnly, 1907," and also numbered "vol. IX., nos. 6 and $7 "$. Nos. $118,121,123,12 \pm, 125,126,127$ contain as supplements copies of "Nisscn's monthly offers," nos. 3, 5, 6-7, 8, 9 $10,11-12$, respectively, printed on yellow paper.

PLAIN TALK. Plain talk.

Brooklyn, N. Y., etc., Myers, Van Schaack and Myers, etc., I885-92.

$8^{\circ} .10 \frac{1}{4}$ in. and $11 \frac{1}{4}-11 \frac{1}{2}$ in. 84 nos. in 11 vols.

Vol. I. Apl. 15 -Sept. 15, 1885. Nos. 1- 6

II. Oct.,

"III. Apl.

"IV. Oct.,

" v. Apl.,

" VII. Apl.

$"$ VII. Apl.

" VIII. Jan.

" X. " 1885-Mar., 1886 - "1- 6 886-Nar, 1887. " "

-Sept., 1887. " "25-30

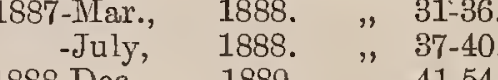

Apl. - ", 1890. ", $55-64$

" 1891. " " 65-76.

" * Only partly philatelic. No. 1 measures $10 \frac{1}{4}$ inches and the remaining numbers $11 \frac{1}{2}-11 \frac{1}{2}$ inches. Nos. 6-84 were published by Plain Talk Publishing Company, and nos. 41-84 at New York. Nos. 20-22, 28-40 and 55-84 have paper wrappers. No. 28 is dated "June" instead of "July," except on the wrapper, which has the correct date, and the wrapper of no. 35 is numbered " 36 " in error. No. 82 is dated "June-July" and no. 83 "September".

PLAINFIELD COLLECTOR. The Plainfield collector. Plainfield, N. J., E. A. Giberga, I889.

$32^{\circ} .5$ in. No. 1 , October, 1889.

* * The number has a coloured paper wrapper. The wrapper is dated August, 1889 . Edited by W. H. Rice. Succeeded by the "New Jersey collector".

POL BEURDOUCHE CIRCULAIRE. Pol Beurdouche circulaire.

Chef-Haut par Rouvres, Vosges, [1899]-1902.

$8^{\circ} .93$ in. Nos. 1-21, [? ]-February 1, 1902.

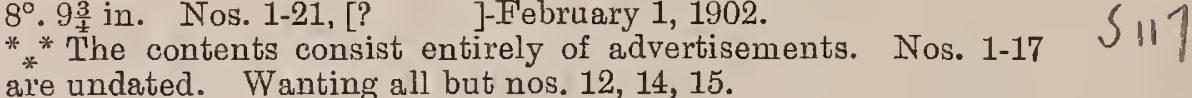

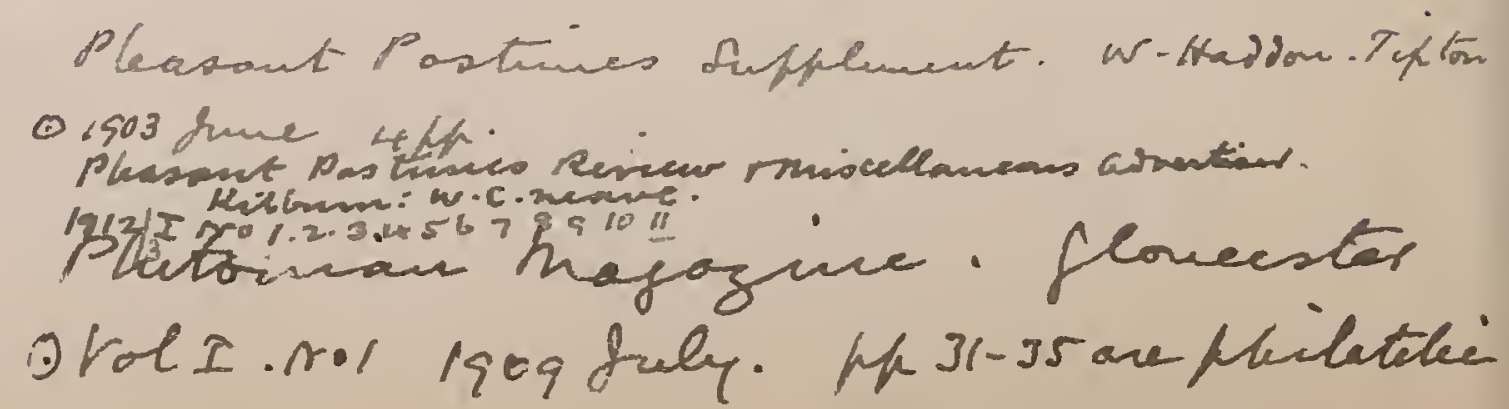


Pouvenir Filitarico Costia Prea 1898

"San Juan, Pmutó Rico 1896 - S118

Post anction stetange. Sale. Poltauction Echarfo. major m. Comolly, seeretary, rimby freen. List ro 2. 1920 elarch, 1203 aquil 
POLSKI FILATELISTA. Polski filatelista. Kraków, Austria, M. M. Urbański, etc., I894-1900. $8^{\circ} .9 \frac{1}{2}$ in. 65 nos. in 6 vols.

1st year. April-Dec., 1894. Nos. 1- 9

2nd "Jan. - " 1895. Nos. 1- 12 .

3rd " " - " " $1896 . \quad$ " $1-12$.

S117 4th " " " - " $1898 . \quad ", 1-12$.

5th " " "-Aug 1899. " 1900.12.

* " Nos. 8 and 9 of the first year, 4 and 5, 6 and $7,8-12$ of the third year and 7 and 8 of the sixth year were severally published together. Nos. 8-12 of the third year were published by Wanda Urbańska and all the subsequent numbers by J. Hechter. No. 2, vol. 1 , is found with the heading printed in gold as well as in black, no. 1, vol. II., is known with the front page printed in gold as well as in black, no. 2, vol. II., has the front page printed in gold, nos. 3 and 4 , vol. Ir., are found with the front pages printed in front page printed in gold and also in black.

POOLE'S IMONTHLY PHILATELIST. Poole's monthly

(6) philatelist. A magazine for stamp collectors. Edited by Bertram W. H. Poole.

Stamford, Lincs., B. W. H. Poole, i 902-04.

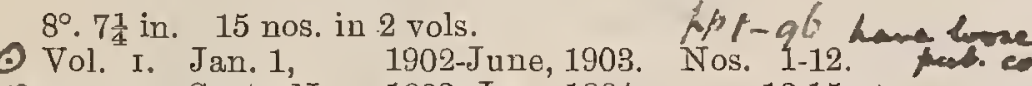

$\vartheta^{0}$." Ir. Sept., Nov., 1903, Jan., 1904. "13-15. $1-24$.

* "There is a title-page and an index to vol. 1 and a coloured C. Chupaper wrapper to each of the fifteen nu vol 1 and

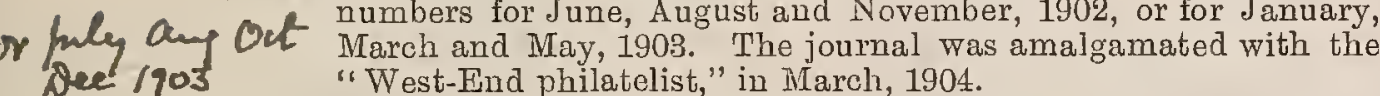

PORTLAND PHILATELIC HERALD. The Portland philatelic herald. Portland, Me., W. W. Jewett, i884. $16^{\circ} .6$ in. Nos. 1-3, October-December, 1884. ** No. 3 has a supplement of two pages headed "Philatelic herald supplement".

\section{[Continued as :]}

- The Philatelic herald.

Portland, Me., etc., W. W. Jewett, etc., I885-88. $8^{\circ} .9$ in. and $11 \frac{1}{2}$ in. Vol. II.-V., 39 nos.

Vol. II. Jan. -Dec., 1885 . Nos. $1-12$.

" III. " - " $1886 . \quad " 1-12$.

" IV. S" vept.-Nov., 1888. ", $21-4$.

* " " Sixteen pages of no. 1 , vol." $\vee$., are said to have been printed but never circulated. Nos. 2-4, vol. 5, were published by the Philatelic Herald Publishing Co. at Freeport, Me. The twelve nos. of vol. rv. measure $11 \frac{1}{2}$ inches and the numbers of the other volumes 9 incles. Nos. $4,6-12$, vol. II., nos. 9, 10, vol. III., and the three numbers of vol. $\mathrm{v}$. have coloured paper wrappers. Nos. 9 and 10 , vol. II., 6 and 7 and 9 and 10 , vol. III. were severally published together. In no. 8, vol. III., it is stated that the "Phi. putelic news" has been incorporated with the journal and in nos. 9,10 of the same volume the incorporation of the "Capital City philatelist" is notified. Vol. IV. Mis. St. Jour. 4 (3).

PORTO PHILATELICO. O Porto philatelico.

Porto, Portugal, M. J. Carvalho, I 893. $4^{\circ} .11 \frac{1}{2}-12 \frac{3}{3}$ in. Nos. 1-4, July 1-Oct. 1, 1893.

** No. 1 is smaller than the other three numbers.

Mis. St. Jour. 97 (13)

PORTO PHILATELICO. Porto philatelico.

Porto, Portugal, Alberto Teixeira d'Azevedo, etc., I898-I 902.

$8^{\circ} .10 \frac{1}{2}-11 \frac{1}{4}$ in. 37 nos, in 4 vols.

Sil] 1st year. Apl. 20, 1898-Apl. 10, 1899. Nos. 1-12.

2nd " May, 1899-Oct. 20, 1900 . "13-24.

3rd ." Nov. 20, 1900-Dec. 20, $1901 . \quad$ " 25-36.

4th J" Jan. 20 ,

* * Nös. 27-37 were published by Alberto B. G. Leal and Delfim Cruz. There is a coloured paper wrapper to each number with the exception of no. 1 and nos. 8 and 9 and 20 and 21 were severally published together. There are no numbers for March and August, 1899. Wanting no. 13.

PORTO RICO STAMP EXCHANGE. The Porto Rico stamp exchange. San Juan, C. Real, I 903 .

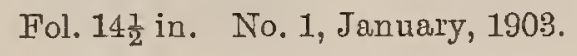
Mis. St. Jour. 116 (14).
PORTUGAL CARTOPHILE ET PHILATELIQUE,

Portugal cartophile et philatélique.

Porto, Portugal, Armando Ribeiro, 1904. Fol. 12: in. No. 1, January, 1904.

\section{- [Continued as :]}

Portugal cartophilo e philatelico.

Porto, Portugal Armando Ribeiro, 1904-06.

Fol. 13-14 in. nos. in 3 vols.

[1st year.] Feb.- Mar., July, 1904. Nos. 2-5.

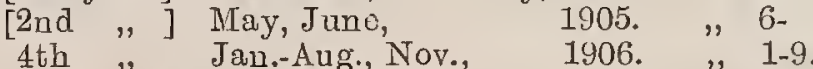

"* "The" numbers of 1906 bear " 4 . anno," although it is only the third year of publication. Nos. 2 and 3 of the first year were published together. No. 1 of the fourth year is dated "JaneiroFevereiro," but bears no year, and no. 4 of the same year has the date " 30 Avril, 1906 " altered in pen and ink to " $30 \mathrm{Mri}, 1906$ ". Wear.

PORTUGAL CARTOPHILO F PHILATELICO. See Portugat Cartophile et Philatélitgue.

PORTUGAL PHILATELICO. Portugal philatelico.

Lisboa, José Pinto Castello Branco e José P. Taborda Ramos, I893-94.

Fol. 181 in. Nos. 1-6, May-Aug., Oct., 1893, Jan., 1894.

Mis. St. Jour. 97 (16).

PORTUGAL PHILATfLIQUT, Le Portugal philatélique. Aveiro, Portugal, Mario Duarte, I895-96. Fol. 13 in. and $8^{\circ}$. 93 in 5 nos. in 2 vols.

1st year. Jan.-Apl., 1895. Nos. 1-4

2nd May, 1896. No. 5.

* * Nos. 1-4 are fol io and no. 5 is octavo.

Mis. St. Jour. 86 (16).

PORVENIR POSTAL. EI Porvenir postal. Revista mensual filatélica.

Guayaquil, Ecuador Eduardo Murrietu, I906-07. $8^{\circ} .93$ in. Nos. 1-4, November, 1906-February, 1907.

${ }^{*}{ }^{*}$ * There is a paper wrapper to each number.

Mis. St. Jour. 133 (10).

POST. Die Post.

Leipzig, Baumbach und Co., etc., I894-

$4^{\circ} .93$ in. nos. in vols. In progress.

1st year. Jan. 1-Dec. 15, 1894. Nos. 1-24.

2nd " " 1- " 15, $1895 . \quad$ " $1-24$

3rd ", " " $1-, ", 15,1896 . \quad$ " $15,1-24$.

4th " " " 1- " $15,15,1897 . \quad$ " $1-1-24$.

5th " "

6th " " " $15-, " 20,1899 . \quad$ " $1-12$.

7th " " 20- "24 20, 1900. " $11-12$.

8th " " 24- " 19, 1901. " 1 1-12.

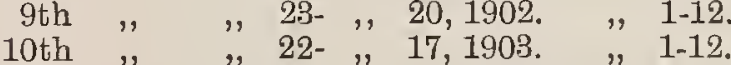

11th ", ", 22- ", 17, $1903 . \quad$ " $11-12$.

12 th " " $\quad 25-" 30,1905 . \quad " 1-13$

13th " " 31-" 25, 1906 . " $1-12$.

* * There is a title-page and an index for each year and a coloured paper wrapper to each number commencing with no. 1 of the second year. Commencing with no. 10 of the sixth year the journal has been published by Feodor Reinboth. No. 23 of the second year is wrongly numbered " 24 " on page 189 . There are supplements with the titles "Die Briefmarken-Börse" and "Philatelistische Litteratur," which are catalogued separately, a further supplement headed " Vereins-Nachrichten," which runs through all the volumes and a supplement with the title "Dubletten-Markt," which was commenced in the number for May, 1906. There are two numbers for December, 1905, "Weihnachten, 1905" and "30 Dezember, 1905," and two editions of no. 1 of that year. In one of these the front paper wrapper is minus "1895" " "No. 1 " at the foot, while the other has this numbering. A sample copy, for advertisement purposes, of no. 5, 1901, was issued and is bound up in Mis. St. Jour. 132 (10).

POST CARD. The Post card.

Roselle, N. J., [G. H. Watson and A. Lohmeyer], I 889 - 90 .

$8^{\circ} .9 \frac{1}{4}$ in. 90 nos. in 3 vols.

Vol. I. Jan. -Dec. 24, 1889. Nos. 1-30.

"II. "2-June 11, $1890 . \quad$ "31-60. 
POST CARD.

\section{[Continued as :]}

-... The Postal card.

Elizabeth, N. J., G. H. Watson and A. Lohmeyer, r892-94.

8.. 81 in. Vols IV.-VI., 27 nos.

Vol. Iv. Feb.-Dec., 1892. Nos. 91-101.

" $\quad$. Jan.-

* " There i" a a title-page and an index to volume Iv., and no num

ber for April, 1892, nos. 92 and 93 both being dated " March".

POST CARD AND STAMP COLLECTORS' JOUR-

NAL. The Post card and stamp collectors' journal.

Adelaide, South Australia, Robt. A. Thompson and Co., etc., 1906-०7.

$8^{\circ} \cdot 93-104$ in. Nos. 1-5, September 6-Dccember, 1906, February, ** There is a coloured paper wrapper to each number and no. 1 has two illustrative supplements. No. 5 was published by Atkinson and Co. Mis. St. Jour. 140 (1).

POST CARD AND STAMP JOURNAL. The Post card and stamp journal, coins, curios, relics, stamps and post cards. I 906 .

Springfield, Ill., The Post Card and Stanı Pub. Co.

8 . 91 in. No. 1, May, 1906

** The number has a coloured paper wrapper.

Mis. St. Jour. 151 (4)

POST CARD NEWS. Post card news.

(.) Leeds, Egremont [printed], W. T. Wilson, I899

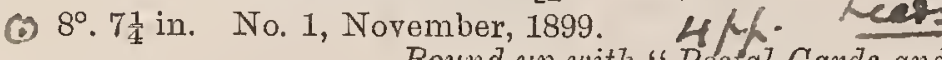

Bound up with "Postal Cards and Covers".

POST CARD NEWS. The Post card news.

Detroit, Mich., The Post Card Publishing Co., 1905. $8^{\circ} .7$ in. No. 1, Miay, 1905

Nis. St. Jour. 125 (4).

POST CIRCULAR. The Post circular.

London, Henry Hooper, $1838-39$

Fol. 14-147 in. and $8^{\circ}$. 8 8 in. Nos. 1-[13]. March 14, 21, 28, Apl. 5, 24, May 4, 11, 25, July 5, 1838, Mar. 28, Apl. 17, 30, June 28,1839 .

** No. 9, which is without year of publication, is octavo and the other numbers are folio. No. 13 is wrongly numbered "No. 14" and nos. 3, 5, 6, 8 and 10 are called double numbers. No. 10 is printed on the back of a large poster with the heading " Petition for an uniform penny postage lie here for signatures" and nos. 4 and 12 contain illustrations of essays for stamps. There are two copies of no. 1, one dated "March 14, 1838" and the othe "March, 1838 ". The latter has the words "Specimen of " above the title and the contents of pages 3 and 4 are entirely differen in the two editions. A second file of the thirteen numbers is bound up in volume Tettered "Papers relating to Uniform Penny Postage, 1838-39" (nos. 5-17)

The editor of the "Post circular," Sir Henry Cole, K.C.B., left a collection of papers and essays of stamps connected with the in troduction of uniform penny postage to the Victoria and Albert Museum. This collection contains two files of the "Post circular," one of which contrins the following additional numbers: a "secon edition " of 1n. 4 dated "April 5, 1838," part of the contents of which differ from the first edition of that number; two edition of no. 7 differing in the make up of the front page, one of whic is perhaps an unissued proof copy; and what is evidently a proof copy of no. 12 with the date "April 29, 1839 ". This file also contains three proof copies of a mo. 15, with two pages each and the date "Sept. 27, 1839" the contents of which are differently arranged in each case, a further copy of no. 15 differing in the make up from the other three, but consisting of two pages an dated "Oct. 11, 1839" and a copy of no. 16, which consists of four pages and has the date "Nov. 20, 1839 ". All the known collections of this paper only contain thirteen numbers and it seems, thcrefore, doubtful whether the nos. 15 and 16 were ever published or circulated. Mr. W. V. Morten has a copy of the second edition of no. 4 in his collection.

POST MAGAZINE. The Post magazine: (Published every Saturday). Combining Ist. A magazine of useful information. 2nd. A post label. 3rd. A sheet of letter paper.

London, Wm. Pateman, I840. $8^{\circ} .10 \frac{1}{4}$ in.

* * Each number consists of a sheet of paper for writing a letter upon and one to three leaves of printed matter of a non-philatelic character. The back of the last leaf of the early numbers contains a rectangular space for the address within an ornamental border in the right upper corner. The space for the address was attached that the whole conten of the placed that the whole contents of the number could be folded up and sent through the post in the form of a letter-sheet. No. 1 i dated "July $25,1840 "$. In 1841 the journal was issued withou a penny stamp attached, at a half-penny a number and this charge was later on raised to one penny. The last number known is no. 153 , dated "October 28,1843 ". As specimens of this in terestiug postal experiment the library contains two differen no. 14 dated "October or date, which are probably imperfect 5, 1840". The two last have the words "Guaranteed weekly supply-Eight thousand," below the title "Post Magazine".

Mis. St. Jour. 7 (7)

POST OFFICE. The Post office. A monthly journal for stamp collectors.

New York, The Post Office Publishing Co., etc., r89199.

$8^{\circ} .9 \frac{1}{4}$ in. 105 nos. in 9 vols

Vol. I. Apl. 15, 1891-March 15, 1892. Nos. 1- 12.

" II. " 15, 1892- ", 1893. ", 13- 24.

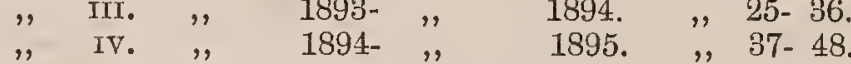

" v. " " $\quad 1895-\quad ", \quad 1896 . . \quad, \quad 49-60$.

1897- ", 1898. " $\quad$ " $73-84$.

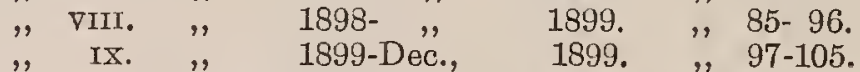

* There is a title-page and an index to each volume and a paper wrapper to each number. Nos. 27-81 were published by Henry Gremmel and the remaining numbers by J.C. Morgenthau and Co. Nos. 1-22 and 30-36 were edited by Alvah Davison, nos. 23 29 by Henry Gremmel, nos. 37-84 by Crawford Capen and the subsequent numbers by J. C. Morgenthau and Co. No. 19 is wrongly numbered "No. 18 "and dated "September 15, 1892," in place of October 15, 1892, but the wrapper has the correct number and date. No. 37 has on the wrapper "Vol. IIr.," in place of vol. IV. There is a supplement of two pages, printed on coloured paper, to no. 15. The title-page and index to the ninth volume was privately printed by H. E. Deats of Elemington, New Jersey, in December, 1900

\section{POSTA- ERRTÉK GYU்JTÖK HIRDETÉSI IAPJA.} ANKƯNDIGUNGSBLATT FÜR PHILATELIE, Posta-Érték Gyüjtök Hirdetési Lapja. Ankündigungsblatt für Philatelie.

Szatmair, Ungarn, A. Siposs, 1898.

4. 12 in. Nos. 1-3, A pril 1C-June 10, 1898

* * The contents consist almost entirely of advertisements.

Mis. St. Jour.129 (17).

POSTA MIONDIALE. La Posta Mondiale. Giornale pei collettori di francobolli e marche.

Livorno, P.R. de Torres, $1873-74$.

$8^{\circ} .97-83$ in. 12 nos. in 2 vols.

1st year. July, Sept.-Dec., 1873 . Nos. 1- 5 .

2nd ", Jan. -Mar., May, May, June, July, 1874. " 6-12 "*."Each number has a plate of illustrations of stamps, etc., printed on one side of the paper only, and the plates of nos. 1-4 ar found in different colours in copies of the same number. Nos. and 10 have two extra pages of advertisements, printed on one side only, no. 9 has an errata slip calling attention amongst other mistakes to the error in the date, May instead of April and no. 12 contains a slip with notice on the suspension of the journal. Some of the copies of no. 3 are wrongly numbered "N. 2 " and
certain of the advertisements on pages 24 of the two editions vary. This was the first philatelic journal published in Italy.

POSTA ROIMÂNÁ. Posta Română. Ziar Philatelic National. Focșanน, Roumanie, Garabet Aslan, r895. Fol. 121 in. No. 1, Apl. 15/27, $1895 . \quad$ Mis. St. Joir. 86 (15).

POSTA UNIVERSALF. La Posta universale. Rivista filatelica internazionale mensile.

Milano, W. von Pecker, r8gr. Fol. 12采 in. "Numero di Saggio" and no. 2, June-July, Sept. 30 "1891. above the title, and this number has a supplemental notice on coloured paper attached to it. 



违

Post-Magagine a Insurance Mantail du Pot magaquie-5118)

Post= Aliamp aroutersec-Soos
Post-fard tocho- Towata Post- fardist - Saration. 
POSTAR WEMB-FOSTORIA.O

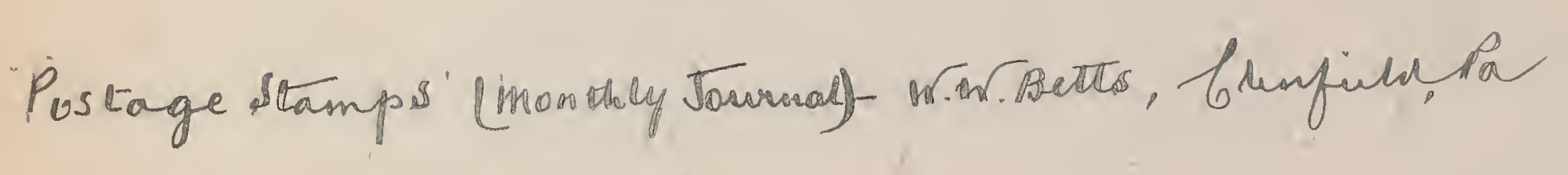

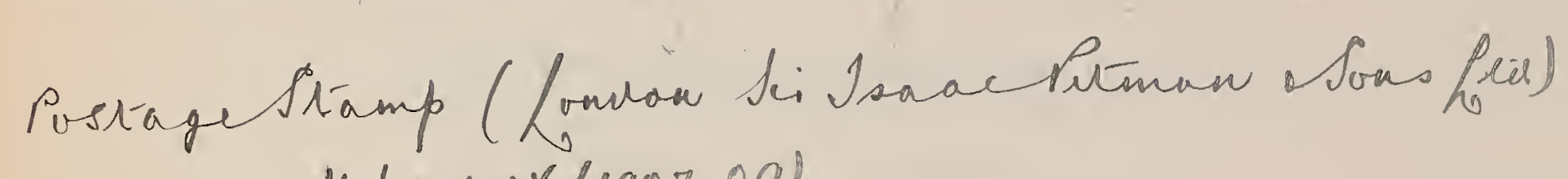
vols $1-18(1907-09)$

Posticage Stamp (week ly) $1908-14$ (Nolso-13)

Postage Sliamps - 8118 


\section{POSTA UNIVERSALE.}

$$
\text { [Continued as:] }
$$

La Poste universelle.

Vienne, ete., W. von Peeker, I892-[94]. Fol. $11 \frac{1}{2}$ in. $4^{\circ} .11 \frac{3}{4}$ in. and $8^{\circ} .7 \frac{1}{4}$ in. Vols. II.-IV. 7 nos. 2nd year. Jan. 20, Feb.-Mar., 1892. Nos. 3-6. $\begin{array}{rrl}\text { 3rd " } & 1893 . & \text { No. 7. } \\ \text { 4th ", } & {[1894 .]} & \text { Nos. 8-9. }\end{array}$

** Nos. 3 and 4 are folio, nos. 5-7 aro quarto, nos. 8, 9 are octavo and nos. 6-9 were published at Trieste. Nos. 3 and 4 bear no year, nos. 5-7 have no month and nos. 8,9 have no month or year. The two last numbers have the numbers attached on small labels. Mis. St. Jour. 116 (7a).

Seconde série.

$4^{\circ} .11 \frac{1}{2}$ in. Nos. 1-2, 1896-1897.

${ }_{*}^{*}$ Neither number bears the month of publication. Mis. St. Jour. 116 (7b).

POSTAGE STAIMP. Postage stamp.

Philadelphia, Pa., Philadelphia Monthly, I87ı-72.

$8 \circ .9$ in. Nos. 1-4, November, 1871-February, 1872.
** Printed on lilac-blue paper.
Mis. St. Jour. 21 (8).

POSTAGE STAIMP. The Postage stamp. Devoted to the interests of collectors.

Pennington, N.J., The Standard Printing Co., г89. $16^{\circ} .6$ in. No. 1, October, 1891. Mis. St. Jour. 66 (5).

$$
\text { [Continued as :] }
$$

The Stamp world.

Pennington, N. J., The Standard Printing Co., I89 I-92.

$16^{\circ} .61$ in. and $4^{\circ} .7 \frac{3}{4}$ in. Nos. 2-4, Nov., 1891-Jan., 1892. * * No. 2 is $16^{\circ}$. and nos. 3 and 4 , which were published together under the date "Dec. and Jan., 1891-2," are quarto.

$$
\text { Mis. St. Jour. } 66 \text { (5a). }
$$

POSTAGE STAIIP. The Postage stamp. Boston, Mass., J. H. Lyons and Co., I896. 8. 8 in. Nos. 1-2, March-April, 1896. Mis. St. Jour. 104 (2).

- [New Series.]

Boston, Mass., J. H. Lyons and Co., I896-97. $16^{\circ} .5 \frac{1}{2}$ in. Nos. 1-6, July-Nov., 1896, Jan., 1897

* * There is a paper wrapper to each number.

Mis. St. Jour. 104 (3).

POSTAGE STAMP. The Postage stamp. [Prospectus dated March, 1896, of a journal to be published by Walter W. Reid, New York, but which was never issued.]

Mis. St. Jour. 104 (1).

POSTAGE STAIMP BAZAAR AND PHILATELIC ADVERTISER. The Postage stamp bazaar and philatelic advertiser. [Dummy copy of a journal to be published by Hewitt and Jay, Lowestoft, Suffolk, on October 1,1894 , but which was never issued.]

OSTAGE STAMP COLLECTORS' IVONITOR.

Postage stamp collectors' monitor; containing an illustrated list of the lately issued stamps; also a descriptive price list of foreign and American postage stamps, for sale by C. M. Seltz. . . . Published bi-monthly.

Boston, Mass., C. M. Seltz, I867.

- $16^{\circ} \cdot 6$ in. [No. 1], June 1, 1867. 16/4. Cx Li as. * * The name C. M. Seltz was a pseudonym for F. H. King. Bound up with C. M. Seltz's "The Postage-stamp collectors' handbook".

POSTAGE STAMP GAZETTE. The Postage stamp gazette. I 882 .

Kensington, London, W., Penry Williams and Co.,

Q8. $8^{\circ}$ in. Nos. 1-4, Mar.-June, 1882 . Crey $/$ / $/-32$ and 4 were published together aper to frer nu journal is bound up with it.
Mis. St. Jour. 34 (7).
POSTAGE STAIVP REPORTER. The Postage stamp reporter. Lowell, Mass., Arthur H. Wheeler, I87 . 8. $9 \frac{1}{4}$ in. [No. 1.] September, 1871.

* * The above consists of only one leaf and the contents are confined to a price list of packets and stamps for sale by the publisher. Mis. St. Jour. 44 (2).

[New Series. $]$

Lowell, Mass., Arthur H. Wheeler, I872-75.

8. 91 in. Nos. 1-7, Jan.-May, 1872, Oct., 1872, Jan. 20, 1875.

* * There is a supplement of two pages, printed on one side only, to no. 5 , the contents of which consist of a price list of packets of stamps.
Mis. St. Jour. 44 (2a).

POSTAGE STAIMP REPORTER. The Postage stamp reporter. An illustrated paper devoted to stamp collecting. Miontpetier, Vt., C. F. Buswell, I877. $8^{\circ} .9 \frac{1}{4}$ in. Nos. 1-8, January-August, 1877.

* Nos. 5 and 6 were published together. Mis. St. Jour. 18 (8).

POSTAGE STAIMPS FOR ADVANCED COLLEC

TORS. Postage stamps for advanced collectors. Brighton, Mass., etc., Warren H. Colson, [1906]$8^{\circ} .8$ in. nos. in vols. In progress.

[Vol. I. Oct., 1906]-May 1, 1907. Nos. [1-8].

* *The numbers of vol. I. bear no numbers and nos. 1 and 2 are undated. Each contains a loose supplement of a calendar of the month of issue with an illustration of a rare stamp.

POSTAI CARD. Sec POST CARD.

POSTAL CARD BULImTIN. See MonTHLY BULLETIN. The Pontal card societry of America.

POSTAL CARD REPORTER. The Postal card reporter. Baltimore, Md., A. Lohmeyer, 1897-99. 8. 9 in. Nos. 1-4, November, 1897, April, December, 1898, Sep-

tember, 1899 .

POSTAL CARDS AND COVERS. Postal cards and

6 covers. A quarterly magazine.

$8^{\circ} .7 \frac{1}{4}$ in. 8 nos. in 2 vols.
(eol. I. Jan., Apl., July, Oct., 1900. Nos, 1.4. $-38 \%$. (9) Vol. I. Jan., Apl., July, Oct., 1900. Nos, 1.4. $1-38$ K.

$\checkmark$ * * There is a title-page and" a list of contents for the two volumes combined and a paper wrapper for each number. All eigh numbers were edited by W. T. Wilson, but nos. $5-8$ were published by Scott and Wilson. WNos. 1-4 were printed at London, N., and

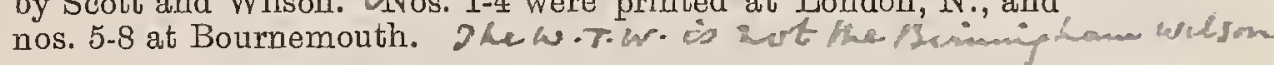

POSTAL GAZETTE. The Postal gazette. A monthly journal devoted to postal and other topics.

New York, B. Batchelor, $1877-78$.

Fol. 141 in. 9 nos. in two vols.

Vol. I. Oct. 1-Dec. 1, 1877. Nos. 6-8.

* " II. Jan. 1-June 1, 1878. " Only partly philatelic. The above are the only numbers con** Only partly philatelic. The above are the only numbers con-
taining philatelic matter.
Mis. St. Jour. 1 (1).

\section{POSTAL, TELEGRAPHIC AND TEIPPHONIC} GAZETTE. The Postal, telegraphic and telephonic gazette. Vol. I. no. 10, October 5, 1883. [Contains a letter signed "St. Martin's-Le-Grand" on the "Origin of adhesive postage stamps" and the claim made on behalf of James Chalmers as their inventor.]$$
\text { Fol. } 13 \text { in. p. } 147
$$$$
\text { London, W. B. Marr, } 1883 \text {. }
$$

Mis. St. Jour. 138 (1).

POSTBLAD. Het Postblad. Vertrouwelijke Mededeelingen voor de Leden van de Nederlandsche Philatelisten Club.

Amsterdam, 1894

$4^{\circ} 8 \frac{1}{2}$ in. Nos. 1-4, 4; [Mar.-Sept.] 1894.

** There are two numbers "4," one bearing " Eerste Blad," the other "Tweede Blad" and all the numbers are without the month
of publication.
Mis. St. Jour. $153(8)$.

$$
\begin{aligned}
& \text { Postape Staind Keraed. Tousen. }
\end{aligned}
$$

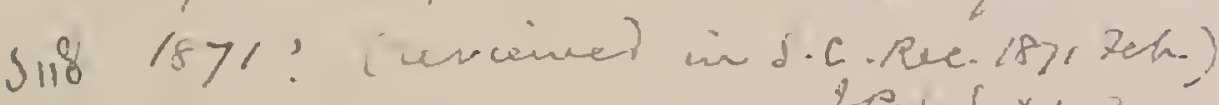

$$
\begin{aligned}
& \text { 2P. L. S X1-30 }
\end{aligned}
$$




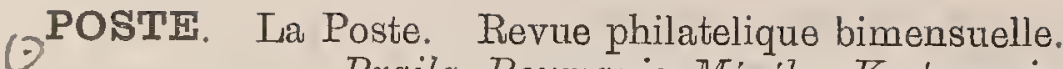
Braila, Roumanie, Ménélas Kostomyris, I 906.

$\checkmark$ Fol. 123 in. No. 1, October, 1906

Mis. St. Jour. 151 (14)

[Continued as :]

- - La Philatélie.

Braila, Roumanie, Ménélas Kostomyris et D - r C. x 906-07.

$8^{\circ} .9 \frac{1}{2}$ in. 5 nos. in 2 vols.

Q 1st year. Nov. 16-Dec. 16, 1906. Nos. 2-3.

Q 2nd ," Jan. -March 1907. , 4-6. ** There is a coloured paper wrapper" to each number. "No. 5 is
dated in error "1997".
Mis. St. Jour. 151 (14a).

POSTF ORIENTALE. Poste orientale. [Prospectus of a journal to be published by J. Dimitracopoulo and $\mathrm{A}$. Rossolimos, Péra, Constantinople, in 1895, but which was never issued.]

Mis. St. Jour. 128 (12).

POSTE UNIVERSELLE. See Posta UNIVERSALE.

POSTILJON. De Postiljon. Eerst Nederlandsch tijdschrift voor postzegelverzamelaars.

Den Haag, H. Croiset, x892-93.

$8^{\circ} .11$ in. 77 nos. in 2 vols.

1st year. Jan. 1-Dec. 17, 1892. Nos. 1-24.

2nd " " 1- , 31, 1893.

* * Nos. 25-58 have coloured paper wrappers and there is a supplemental slip to no. 20. The first philatelic journals published in Holland were rcally the "Continental Philatelic magazine" and "De Timbrophilist" of 1869-70.

POSTILLON. Le Postillon.

Paris, Alfred Montader, x 901

$8^{\circ} .9$ in. nos. in vols. In progress.

[1st year.] Dec. 29, 1901-Dec. 28, 1902. Nos. 1- 53

[2nd " ] Jan. 4, - " 27, $1903 . \quad$ " 54-105.

3rd " " " $3, \quad-$ " $25,1904 . \quad$ " $106-157$

4th " " $\quad 1, \quad-\quad, 31,1905 . \quad$ " $158-210$

* * There is a "title-page and" an index to each year and a supplement of illustrations of stamps to no. 63 and also to no. 137. No. 139 is wrongly numbered "No. 19 ". Nos. 242 and 243 and 246 and 247 were severally published together, and no. 226 is date

POSTIMAN'S KNOCK. The Postman's knock.

St. John, New Brunswick, The Excelsior Stamp Association, etc., r866-70.

$8^{\circ} .73$ in. and 93 in. 21 nos. in 2 vols.

Vol. I. May 1, 1866-April 1, 1867. Nos 1-12.

" II. " 1, -Nov. 1, 1867, Oct., Nov., 1869, Mar., 1870.

Nos. 13-21

1-18 measure $7 \frac{3}{4}$ inches and nos. 19-21, $9 \frac{3}{4}$ inches. Albert C. Killam of Yarmouth, Nova Scotia, was associated in the publication of nos. 1-6, and no. 21 was published by E. A. Craig, who edited the whole twenty-one numbers, and who was the proprietor of the Excelsior Stamp Association. No. 9 has " 1866 " in 21 has a supplemental slip is dated "Ang. and Sept., 1867 . No. (1) $1-18$ by J. W. Scott of New York in April, 1870.

POSTWERTZEICHEN. Das Postwertzeichen.

München, Bayerischer Philatelisten-Verein, I888-89. $8^{\circ} .10 \frac{7}{2}$ in. 24 nos. in 2 vols.

1st year. Jan. 1-Dec. 1, 1888. Nos. 1-12.

2nd ," , 1. , 11, 1889.

* "There is a title-page and an index to each year, and a supplement "Allgemeiner Briefmarken-Anzeiger Vereinigte Erdball Mercur" to each of the twenty-four numbers.

\section{[Continued as :]}

Das Postwertzeichen. Vereinsmitteilungen des Bayerischen Philatelistenverein München.

München, Bayerischer Philatelisten-Verein, x89o. $8^{\circ} .9 \frac{1}{2}$ in. Vol. III. 12 nos.

3rd year. Jan, 1-Dec. 15, 1890. Nos. 1-12,

\section{POSTWERTZEICHEN}

\author{
[Continued as :]
}

- Das Postwertzeichen.

München, Bayerischer Philatelisten-Verein, r89x-

$8^{\circ} .10 \frac{1}{2}$ in. Vols. IV.-[XIII.]. 120 nos.

the year. Jan.-Dec., 1891. Nos. 1-12.

5 th,

6th " " - ", 1893. ", $1-12$.

7th " " - " 1894. , 1-12.

8th " " " " $1895 . \quad, 1-12$.

9th " " - " $1896 . \quad, 1-12$.

10th " " - " $1897 . \quad, 1-12$.

11 th $" \quad$ " - " 1898. " $1-12$.

18th ", [Really 13th.] Jan.-Dec., 1900. Nos. 1-12

* Each year, with the exception of the last, has a title-page and an index and there are coloured paper wrappers to the twenty-four numbers of 1898 and 1899 and also to nos. 1-8 of 1900 . Nos. 6 and 7 , and 11 and 12 of 1892 , nos. 1 and 2,3 and 4,5 and 6,7 and 8,9 and 10,11 and 12 of 1894 , nos. 7 and 8 of 1895 and nos. 7 and 8 of 1896 were severally published together. There is a supplement "Geschichte und Katalog der Postwertzeichen des Königreichs Bayern". Bearbeitet von Comelio Joris und Otto Sedlmayr, to nos. 1-12 of 1891, nos. 1-8 and 10-12 of 1892, nos. 1-3 and no. 7 of 1893 , and there is an illustrative supplement to no. 11,1891 , which was given with no. 12 of that year. No. 12 of the eighth year is also called "XIII Der Vereinsmitteilungen," the nos. of the ninth, tenth and eleventh years likewise "xIV." "xv." or "xvI. Der Vereinsmitteilungen," nos. 1-7 of the twelfth year "xvII. Der Vereinsmitteilungen " and with no. 8 of the last mentioned year "XII. Jahrgang" is dropped, "xVII. Jahrgang" takes its place, and the numbers of 1900 then follow on as "XVIII. Jahrgang". For the earlier years of the "Vereinsmitteilungen" see "Bayerischer Philatelisten Verein München. Vereins-Mitteilungen."

POSTWERTZEICHEN - KUNDF. Die Postwertzei chen-Kunde.

8. $10 \frac{1}{4}$ in. 96 nos. in 8 vols.

1st year. Jan.-Dec., 1890. Nos. 1-12.

2nd " " - " 1891. " 1-12.

3rd " " " - " $1892 . \quad$ " 1893.12.

5th " " - " 1894. " $1-12$.

6th " " " " 1895. " $1-12$.

8th " " " - " $1896 . \quad$ " 1897.12.

** There is a title-page and an index to each year and nos. 7-12, 1893 , and the twelve numbers of 1894,1895 and 1896 have paper wrappers. Nos. 9 and 10 of 1897 were published together. There is a supplement "Allgemeiner Briefmarken-Anzeiger Vereinigte Erdball Mercur" to each number, a supplement of eight pages to no. 8,1890 , one of (6) pages to no. 1, 1892, one of (6) pages to no. 12,1892 , and a supplemental slip to no. 7,1892 . A certain number of copies of no. 4 of the year 1890 were issued with "Verteilt auf der Internationalen Ausstellung offizieller Postwertzeichen zu Magdeburg am 4, bis 12, Mai 1890," printed in red at the top of the first page.

POSTWERTZEICHEN - KUNDE IIV LEIPZIGER HUIMOR. Die Postwertzeichen-Kunde im Leipziger Humor. Zur Nachfeier des x. deutschen Philatelistentages in Gössnitz Festabend in Leipzig, Noth's Festsaal

Leipzig, Ortsverein Leipzig des Deutschen Philatelisten-Verbandes, 1898.

) Fol. 12 in. July 20, 1898

** Published also by "Sektion Leipzig des Internationalen Philatelisten-Vereins Dresden" and edited by C. Crome-Schwiening. The journalis unnumbered and the contents are of a humorous description.

Mis. St. Jour. 128 (18)

POSTWERTZEICHEN-SAIMIMIER. Der Postwertzei chen-Sammler. Offerten-Blatt.

Berlin, Der Internationale Postwertzeichen-HändlerVerein zu Berlin, I899- 1900.

$8^{\circ} .10^{\frac{3}{4}}$ in. "Probe-Nummer" and nos. 1-12, Nov. 25, 1899, Jan. 25-May 30, July 15-Sept. 28, Nov. 10, Dec. 28, 1900.

** The conten ts consist entirely of advertisements. Nos. 7 and 8 and 11 and 12 were severally published together under the re spective dates, "28 August, 1900" and "28 Dezember, 1900". A copy of the prospectus of the journal, dated November, 1899 is bound up in front of the proof number. Mis. St. Jour. 98 (6).

\section{POSTWERTZEICHEN - VEREINSMITTFILUNGEN} DES BAYFRISCHEN PHILATELISTEN VEREIN MÚNCHEN. See PosT'WERTZEICHEN,

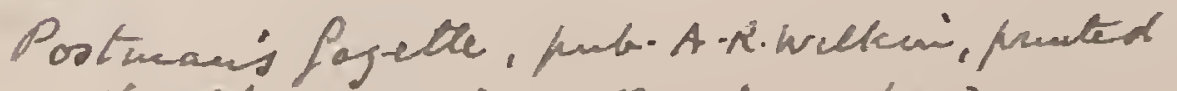

$$
\begin{aligned}
& \text { by churet fied Prants. Lontion. } \\
& 4 \text { to (monstly:) in ax. } \\
& \text { of olegit we to stane collectors } \\
& 1894 \text { III. } 7 \text { (arg4) }
\end{aligned}
$$$$
\text { Poteand Puiges }
$$$$
1807 \text { faw. Noz }
$$$$
\text { Harmécy }
$$ 
Precancel Bses. hebusika

- Laqette (monothey maqa ime) minneapolio, mens

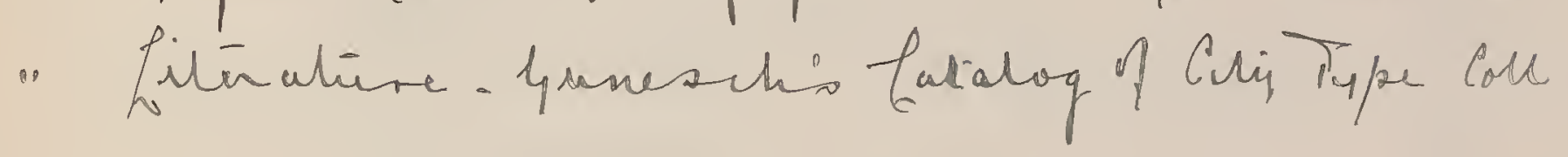




\section{POSTWERTZEICHEN-ZEITUNG}

POSTWERTZEICHEN-ZEITUNG. See NICHT-ILLUSTRIERTe Postwertzeichen-Zeitung.

POST-ZEGEL. De Post-Zegel.

Amsterdam, C. A. D. Steenmeijer, etc., I893-96. Fol. 18-18 $\frac{3}{4}$ in. and 11-138 in. 29 nos. in 4 vols.

[1st year.] Oct. 30-Dec. 18, 1893. Nos. 1-8.

[3rd ", ] May-June, July-Aug., Sept.-Oct., Nov., Dec., 1895. [Nos. 1-5.]

S 118 [4th "] Jan., March, May, 1896. [Nos. 1-3.]

* Nos, 1-21 measure 18-183 inches and nearly every one of these numbers consists of a single sheet. The numbers of the third and fourth years measure 11-133 inches and these were published by Steenmeijer en Cie. The number for March, 1896, was also issued with "Maart" struck through and with "April " struck above it with a hand-stamp. Wanting nos. 1, 2, 10, 17, 19.

POSTZEGEL. De Postzegel. Advertentieblad voor Verzamelaars en Handelaars in Post-, Port- en andere Zegels. Epe, Holland, A. Hooiberg Sr., I 9o6Fol. 14 in. nos. in vols. In progress.

1st year. Jan. 5, 1906-Jan. 5, 1907. "Proefnummer" and nos. $2-51$.

* * Published weekly excepting that there are no numbers for August 31 and September 7,1906 . The contents consist entirely of advertisements.

POSTZEGELBLAD. Postzegelblad. Orgaan der Haagsche Philatelisten-Vereeniging.

Den Haag, etc., P. C. Dozy, I897Fol. $13 \frac{1}{2}$ in. and $4^{\circ} \cdot 10 \frac{1}{2}-11$ in. nos. in. vols. In progress. 1st jear. Oct. 24, 1897-Jan. 9, 1898. Nos. 1-6. 2nd " Jan. 23, 1898- , 15, 1899. " 1-26.

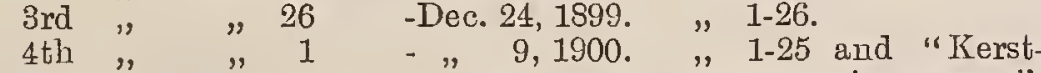
5th " " $6 \quad-$ " 30, 1901. " 1-24. 6th " " $11 \quad-\quad, 31,1902 . \quad, 1-24$. 7th " " $15 \quad-, 15,1903 . \quad, \quad 1-24$.

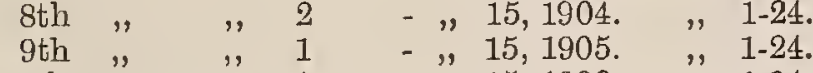
10th " " " " " 15, 1906.

* The numbers of the first three years are folio and were produced by a hectographic process. The remaining numbers are quarto and are printed. Commencing with no. of the year the journal has been published at Utrecht, commencing with the title is precedel by "Het," and commencing with no. 11 of the eighth year each number has a paper wrapper. There is a supplement to nos. 16-17 of the fourth year, to no. 4 of the eighth year, and one with the title "Bijblad van Het Postzegelblad" to nos. $1-11,15,19-23$ of the ninth year and to nos. $2-4,6-9,11,15,19$ and 23 of the tenth year. Nos. 16 and 17 of the fourth year, nos. 15 and 16,18 and 19 of the fifth year, 13 and 14,15 and 16,18 and 19,20 and 21,22 and 23 of the sixth year, 15 and 16 of the seventh year and 12 and 13 of the tenth year were severally published together. No. 4 of the fifth year has in error "6e Jaargang"; no. 6 of the same year is wrongly numbered " 9 "; nos. $15-16$ of tho sam year has "no. 15"; no. 13-14 of the sixth year has "no. 14"; no. 19 of the seventh year has "no. 18". There is a combined titlepage and index for the fourth and fifth years. Wantiug vol. I. all nos.; II. all but $5,7,9,22,25$; III. all but $2,3,4,8,12,15,17$, 18,20 ; VI. $5,9,10,11,13,14,15,16,17,18,19,22,23$; VII. 4,5 ,

OSTZEGELCOURANT. DePostzegelcourant. Speciaal Orgaan voor Postzegelverzamelaars.

Amsterdam, F. H. Brinkman, I 895-97. Fol. $13 \frac{1}{4}$ in. and $8^{\circ} .9 \frac{1}{1}-9 \frac{1}{2}$ in. 20 noz. in 2 vols.

1st year. Aug. 15, 1895-July 15, 1896. Nos. 1-12.

2nd " Aug. 1, 1896-Apl. 1, 1897. , 1- 8 . * * The numbers of the first year are folio and those of the second year are octavo and the last eight have coloured paper wrappers. No. 1 of the second year is dated " 1 September, 1896," no. 2 o the same year " 1 Augustus 1896 " and there is no number for
October, 1896.
Mis. St. Jour. 116 (12).

POST-ZEGELGIDS. De Post-zegelgids

Amsterdam, etc., J. C. auf der Heide S. H. D., etc., I $897-98$.

$4^{\circ} .12$ in., fol. $14 \frac{1}{2}$ in. and $8^{\circ} .10 \frac{1}{2}$ in. 15 nos. in 2 vols.

1:t year. May 1-July, Sept., 1897-Apl. 1898. Nos. 1-12.

2nd year. May, June, July, 1898. Nos. 13, 2, 3.

* "Nos. 1-10 are quarto, nos. 11 and 12 are folio and the numbers of the second year are octavo. The three last numbers were published by J. Th. Smeenk en Co. at Gendringen. Nos. 5 and 6, and 9 and 10 were severally published together under the respective dates "Sept. en Oct. 1897 " and "Januari-Februari 1898" and these numbers, as well as nos. 7 and 8 , are printed on coloure paper. The title on no. 8 is given as "Boek- en
and on nos. 9, 10 "De Boek- en Postzegelgids".

\section{POST-ZEGELGIDS}

POST-ZEGELGIDS. [New Series.]

Amsterdam, J. C. auf der Heide, S. H. D., i 900-06.

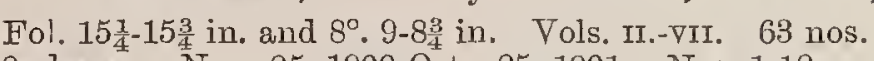
2nd year. Nov. 25, 1900-Oct. 25, 1901. Nos. 1-12. 3rd ", ", 25, 1901- ", 25, $1902 . \quad, 1-12$ 4 th $\quad " \quad$ " 25, 1902- " 25, 1903. " 1-11. 5th " J" 25, 1903-Dec. 1904. ", $1-12$. 7th " " 1, -April 1, 1906. " $1-4$. ** Nos. 2, 6, and 9 of the fourth year are numbered " Kerstnummer," "ILentenummer" and "Zomernummer," respectively, an there is no number for August, 1903. No. 6 of the fifth year is headed "Lente-Nummer 1904" and nos. 11 and 12 of the same year, which were published together, bear "Kerstnummer van d Postzegel Gids". No. 8 of the fifth year is wrongly numbere "no. 7 " and there is no number for March, 1904 or for July, 1904 The numbers of the sixth year are octavo while those of the seveuth year are once more folio. Nos. 7 and 8 and 11 and 12 of the sixth year were severally published together. There is a coloured paper wrapper to no. 1 of the sixth year and there are three large sized separate illustrations tonos. 11 and 12 of the same year. No. 1 o the seventh year is found printed on thin white paper, as well a on thick yollowish paper like the other numbers of this year.

\section{POSTZEGELNIEUWS BRIEFMARIENZEITUNG}

Postzegelnieuws Briefmarkenzeitung.

Velp, bij Arnhem, Holiand, J. A. C. Reinon Kingma, I 900 -

Fol. $12 \frac{1}{2}$ in. and $8^{\circ} .9 \frac{1}{2}-9$ in. nos. in. vols. $1 n$ progress. 1st year. Oct., 1900-Sept, 1901. Nos. 1-12. 2nd " " -Dec. 31, ", " 13-15. 3rd " Jan. $31 \quad$ - " 31, 1902. " 16-27. 4th " " 31 - " 31 31, 1903. " 28-39.

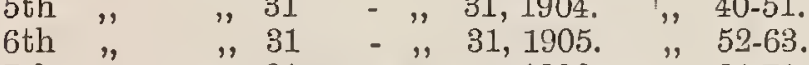
7 th " " " $31 \quad-\quad, \quad 31,1905 . \quad$ " $52-63$.

* * Nos. 1-8 are folio and the subsequent "numbers are octavo and each number commencing with no. 9 has a paper wrapper. Nos. 11 and 12,23 and 24,34 and 35,47 and 48 and 59 and 60 , were severally published together. The wrapper of no. 32 bears in error "31, "but the numbering inside is correct. Nos. 47 and 48 are dated "Aug.-September, 1904 " and there is also a no. 48 dated "September, 1904" the contents of which are exactly the same as those of the double number.

POSTZEGELS. De Postzegels. Weekblad voor postzegelhandelaars en verzamelaars. Verschijnt iederen Zaterdag. Monnikendam, P. Bertoen Junior, I 894

8. $10 \frac{1}{4}$ in. Nos. 1-2, [? ]-September, 1894.
** Wanting no. 1. St. Jour. 153 (12).

POSTZFGELVERZAMELAR. De Postzegelverzamelar. * * Wanting all.

POUL - IMEDJMIOUASSI. Poul-Medjmouassi. Revue mensuelle, philatélique, scientifique et littéraire.

8. 111 in. 25 nos. in 2 vols.

Constantinople, Alimad Ilisān, I 897-98.

[1st year. Aug.-Dec., 1897.] Nos. 1-5.

2nd " Jan.-July 14, Aug. 11, 18, 25, Sept. 1, 8, 15, 22, 29, Oct. 6, 13, 20, 27, Nov. 3, 1898.] Nos. 6-25:

* * 6, 13, 20, 27, Nov. 8, 185.] Nos. 6-25: * * Edited by Muliammad Elkrem and printed in Turkish and each number has a coloured paper wrappe.
July, 1898. Wanting nos. 2, 3, 16, 17.

PRAIRIE STATE PHILATELIST. The Prairie State philatelist. 02.

Chicago, Ill., etc., Prairie State Pub. Co., etc., I 9oo-

$8^{\circ} .8 \mathrm{iu} .16$ nos. in 5 vols.

Vol. I. Maroh ing vols. 1900

Nos. 1- 6

" III. Apl, June, Aug., " [7]-9.

" 1v. Oct., Dec., 1901, Feb., 1902. " " 13-15.

" $\quad$. Apl., 1902. No. 16

* * Nos. 9-16 were published by George F. Dold and of these nos. 12 - 16 were published at Orland, Illinois. Nos. 4 and 5 were published together, no. 7 is only numbered "vol. II., no. 1 " and each number. excepting no. 3, has a paper wrapper. Amalgamated with the "Okla Philatelist," June 15, 1902.

PRESS AND ANGIO-AMERICAN. Press and AngloAmerican, vol. V., no. 21. September 7, 1890. [Cuttings of the article "Interesting records. The stubs of all the revenue stamps issued since the war," are mounted in Stamp Scrap-book, vol. vi., p. 113.] 
PRESSO-PHILATf́tIE. Presso-philatélie.

Anver's, Cercle Presso-Philatélique d'Anvers, r893. $8^{\circ} .6 \frac{1}{2}$ in. [No. 1], November 5, 1893

* Printed on coloured paper. Facsimile copies were also published on other coloured papers with the following titles: "D "Dagbladvriend "; "Le Gazettophile"; "De Gazetverzamelaar";

Mis. St. Jour. 117 (4)

PRINCE FDWARD ISLAND PHILATELIST. The Prince Edward Island philatelist.

Charlottetown, J. L. Jost, r 888

8०. 9 in. No. 1, Ap]., 1888

* The number has a coloured paper wrapper.

Mis. St. Jour. $25(2)$

PRINTSELLER. The Printseller.

$$
\text { London, W.C., [?] ] } 1903 \text {. }
$$

$4^{\circ} \cdot 10^{3}$ in. Nos. 1-2, January-February, 1903.

*.* Both numbers are inon-philatelic and have paper wrappers. The name of the publisher is not given.

[Continued as :]

___ The Printseller and print collector.

$$
\text { London, W.C., [? ], 1903. }
$$

$4^{\circ} .10 \frac{3}{1}$ in. Nos. 3-8, March-August, 1903.

***All six numbers are non-philatelic and have paper wrappers. The name of the publisher is not given.

$$
\text { [Continued as :] }
$$

- The Printseller and collector.

$$
\text { London, W.C., [? ], I903-04. }
$$

$4^{\circ} .10^{3}$ in. 11 nos. in 2 vols

Vol. 1. Sept.-Dec, 1903. Nos. 9-12,

*"* There is a title-page and an index to the twelve numbers of * There is a title-page and an index to the twelvo numbers of
vol. I., and a paper wrapper to each number. Nos. 14-19 each contain an article on philately, but the other. Numbers are nonphilatelic. The name of the publisher is not given.

[Continued as:]

- The Collector's magazine, with which is incorporated the Printseller and collector.

$4^{\circ} .10^{3}$ in. Vols. II.-III. 10 nos

$$
\text { London, W.C., [?] ], I904-05. }
$$

Vol. II. Aug.-Dec., 1904. Nos. 20-24.

" III. Jan.-Hay, 1905. "25-29.

* * There is a title-page and an index to the twelve numbers of vol. II., and each number has a coloured paper wrapper. Each number contains a philatelic article. The name of the publisher is not given.

\section{VR. 1906 yagk, ros $1-$}

PRINTSELLER AND PRINT COLLECTOR. See Printseliter.

PROGRESISTA FILATÉLICO. El Progresista filatélico. San Sebastiún, J. Minondo y $B$, I $4^{\circ}$. $11 \frac{1}{4}$ in. and $8^{\circ} .8 \frac{1}{1}$ in. 8 nos. in 2 vols.

1st year. Aug.-Dec., 1901. Nos. 1-4.

2nd " Jan -Apl, 30, 1902. $5-7$.

** There is a coloured paper wrapper to each number. No. 4 is dated "Noviembre y Diciembre, 1901". Nos. 1-4 and no. 7 are quarto. No. 5 is octavo, no. 6 appeared first in octavo form as "Númcro extraordinario dedicado á la Emisión Conmemorativa" with date "Febrero de 1902" and then in quarto form with the date " 28 de Febrero de 1902". There is no number for March, 1902 , and no. 5 and the first no. 6 do not bear "Año II."

Mis. St. Jour. 129 (14).

PROGRESO FILOTÉLICO. EI Progreso filotélico. Periodico quincenal dedicado al adelanto y coleccion de sellos de correos.

$$
\text { Bogotá, Colombia, L. M. de Castro, I887. }
$$

$8^{\circ} .11 \frac{3}{4}$ in. No. 1, January 1, 1887.

Mis. St. Jour. 5 (7).

PROGRESSIVE AGE. The Progressive age

Hopkinsville, Ky., T. L. Metcalfe, I 888. ** Cuttings of the philatelic portions from nos. $3,4,5,8$ and 9,
dated May, June, July, October and November, 1888 , are mounted in Stamp Scrap-book, vol, vI., pp. 17-22.
PROGRESSIVE PHILATELIST. The Progressive philatelist.

Merrimack, Wis., The Stamp and Coin Exchange, 1890.

8. 10 in. No. 1, January, 1890.

** The number has a coloured paper wrapper.

Mis. St. Jour. 60 (7)

PROPAGANDA FILATÉLICA. La Propaganda filatélica.

$8^{\circ} .103$ in. 62 nos. in 7 vols

1st year. Aug.-Dec., 1899. Nos. 1- 5.

2nd " Jan. - " $1900 . \quad$ " $6-17$.

4th " " - " $1902 . \quad$ " $18-29$.

5 th " " " - " " 1903. " " $42-51$.

7th ", " " -Apl, 1904. " 1905.

** *There are no numbers for "June or September, 1903, for May, July, August or November, 1904, or for March, 1905.

PROPAGANDA INDUSTRIAL. La Propaganda industrial. Santiago de Galicia, F. Vallecillo, $1895-96$. $8^{\circ}$. 939 and 83 in. 14 nos. in. 2 vols.

1st year. -Dec. 30, 1895. Nos. 1- 8

2nd "’ Jan. 15- 1896 . Nos. 9-14

* Only partly philatelic. Nos. 6 and 7 contain philatelic notes, ut the other numbers only a.dvertisements. Nos. 1-6 measure 93

have paper wrappers. Wanting nos. $1,2,3,12,13,14$

[Continued as :]

- La Propaganda industrial filatélica. Santiago de Galicia, F. Vallecillo, r896-97.

$8^{\circ} .812$ in. Vols. II.-III. 2 nos.

2nd year. Nov. 15, 1896. No. 15

3rd " Mar. 1, 1897. "16.

"* M"ostly, but not entirely, philatelic. There is a paper wrap. per to each number.

PROPAGANDA INDUSTRIAL FILATEFLICA. See Propaganda Industrial.

PROPAGANDE PHILATÉLIQUT. La Propagande philatélique. Journal international d'annonces.

$4^{\circ} .11$ in. No. 1, January 25,1899

Gand, Alb. Facon, I899.

* * Printed on blue paper, and the contents consist entirely of advertisements.
Mis. St. Jour. 97 (4).

PROVIDENCE JOURNAL. Providence journal. September 14, 1886. [Cuttings of the article "The now 'letter sheets'. How they have taken with the public. -Some of their merits and defects," are mounted in Stamp Scrap-book, vol. vI., p. 1.]

[? 1890. Cuttings of the article "Postage stamps. Remarkably fine collections in this city," are mounted in Stamp Scrap-book, vol, vI., pp. 135-138.]

October 2, 1892. [Cuttings of the article "A Stamp exhibition. Some really fine, full and interesting collections, are mounted in Stamp Scrap-book, vol. vI., p. 173.]

PUBLIC OPINION AND ROVER. See ROVER (Elk Point, So. Dal.).

PUBLICIDAD. La Publicidad. Periódico independiente de anuncios, noticias é intereses generales.

$$
\text { Málaga, [? ], I903. }
$$

Fol. 15 15. in. Vol. II., nos. 22-24. May 10, July 20, 1903.

* * Each of these numbers contains a "Sección Fijatélica"

Mis. St. Jour. 127 (6).

PUBLICITÉ PHILATÉLIQUE. Publicité philatélique.

Juurnal international d'offres de timbres-poste.

Padone, Italie, Angelo Giudici, etc., I894-95. Fol. $12 \frac{1}{1}$ in. 11 nos. in 2 vols

1st year. Nov. 10-Dec. 10, 1894. Nos. 1-2.

2nd "Jan. 10-Sept. 10, 1895.

** Nos. 1-9 of the second year were published by Antonio Ravazzolo. $\quad$ Mis. St. Jour. 86 (3). 
Provicial Bhistelist ig,2 may is equal to

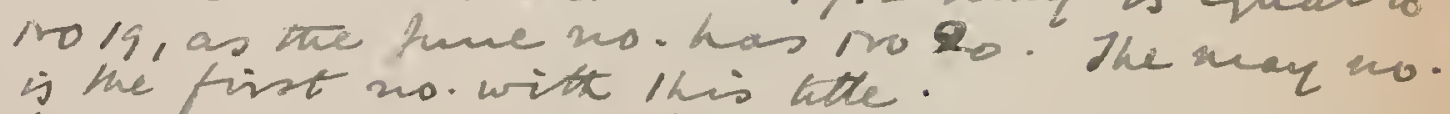

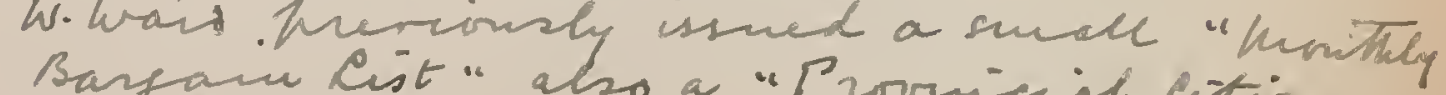
Barfaw Cist" ahs a "Provininil cities. of hose two sesulted in the provincial Philatelsit bering with 1912 may $\left(=N O t_{9}\right)$. 

PUERTO-RICO FILATF́LICO. EI Puerto-Rico filatélico. San Juan, C. Coll y Cuchi, etc., r896-97. $8^{\circ} .10-11$ in. and 9 in. 13 nos. in. 2 vols. 1st year. Apl. 30-Dec., 1896. Nos. 1-9. 2nd * Nos. 11-13 were published by Baixet Perez y Ca., and nos. 2 13 have paper wrappers. No. 1 measures 10 inches, nos. inches, and nos. $10-13,9$ inches. Nos. 7 and 8 and 11 and 12 were severally published together.

PUNCH, Punch, or the London Charivari, Vol, viI, no 157, JuIy 13, 1844. [Contains illustrations of "Punch's Anti-Graham wafers and envelopes "at the back of the Sig front paper wrapper.]
$4^{\circ} .11 \frac{1}{4}$ in. Paper wrapper. Mis. St. Pamph. 63 (9).

Lonaron, W.C., Joseph Smith, I844.
PURDOIM MONTHLY CIRCULAR. See Chas. Purdom Monthly Circular.

PURITAN PHILATELIST. The Puritan philatelist.

Chicago, Ill., Chris. Peterson, I894. $8^{\circ} .8$ in. No. 1, February and March, 1894,

* * The number has a coloured paper wrapper.

Mis. St. Jour. 65 (4)

PUZZLFDOM. Puzzledom. The official organ of the "Moline Puzzle Club".

$8^{\circ} .8$ in. Nos. 1

Moline, Ill., A. W. Rundquist Jr., 1892.

$\sin \theta$

* Only partly philatelic. Each number has a coloured paper

wrapper and no. 2 contains a supplement of two pages with "no.

1 " altered to "no. 2". Wanting all but no. 2, dated "December,

$1892 "$. 
QUAKER CITY PHILATELIST. The Quaker City philatelist.

Philadelphia, Pa., The Quaker City Philatelist Publishing Co., etc., I886-94.

$8^{\circ} .9-9 \frac{1}{2}$ in. 103 nos. in 9 vols.

Vol. I. Jan.-Dec., 1886. Nos. 1- 12.

" II. " - " 1887. ", 1- 12.

" III. " " - " 1888. ", $25-36$.

" IV. $\quad$ v.

" VI. " " - " " $1891 . \quad$ "

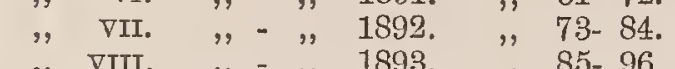

" IX. " "- -July, 1894. " $89.96-96$.

" " "There is a coloured paper "wrapper to each number. No 1 measures 9 inches and the remaining numbers $9 \frac{1}{2}$ inches. With vol. Ir., no. 1, the name of the publishing firm is given as "The Quaker City Philatelic Co. Limited " and commencing with vol. II., no. 2, the name is altered to "The Quaker City Philatelic Publishing Co. Limited".

QUAKER CITY PHILATELIST. The Quaker City philatelist OI.

Philadelphia, Pa., Donald Cadwalador Evans, I900-

$16^{\circ} .7 \mathrm{in}$. and $8^{\circ} .9$ in. 5 nos. in 2 vols.

Vol. I. Nov. 1900-Feb., 1901. Nos. 1-4.

* $\%$ II. April, 1901. No. 1.

* * The numbers of vol. I. are $16^{\circ}$ : and there is a paper wrapper to each number, that of vol. II. is octavo and has no wrapper. Wanting vol. 1 , no. 3 . Mis. St. Jour. 154 (10).

QUARTERLY INTER-CHANGE The Quarterly interchange. A journal for postage stamp collectors. Conducted by Mr. John Chestershire.

Philadelphia, Pa., R. Barrie, 1885. $8^{\circ} .9 \frac{1}{4}$ in. Nos. 1-2, May-Oct., 1885.

** There is a coloured paper wrapper to each number.

Mis. St. Jour. 18 (4).

QUARTERLY PHILATELIC CIRCULAR The Quarterly philatelic circular. The official publication of the Bombay Philatelic Society. Bombay, I896. $4^{\circ} .11$ in. Nos. 1-4, Jan., Apl., July, Oct., 1896.

* * There is a coloured paper wrapper to each number.

Mis. St. Jour. 82 (4).

QUARTERLY POSTAGE STAMP MAGAZINE. See NATIONAL POSTAGE STAMP EXPRESS.

QUARTERLY REVIEW. The Quarterly review. No. wo cxxviII., October, 1839. [Contains a review of "1. Post-office reform: its Importance and Practicability.
QUARTERLY REVIEW

By Rowland Hill, London, 1837, pp. 104. 2. Du Service des Postes et de la Taxation des Lettres au moyen d'un timbre. Par M. A. Piron, Sous-Directeur des Postes, Paris, 1838, pp. 148. 3 First, Second, and Third Reports from the Select Committee on Postage, 3 vols. fol. 1838".] London, John Murray, 1839.

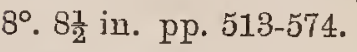

QUARTERLY REVIEW. The Quarterly review.

Galveston, Tex., Cravens and Aguilo, I88I. Go. 12 in. Nos. 1-2, January 28-April 28, 1881.
Mis. St. Jour. 3 (9).

QUEEN CITY COLLECTOR. The Queen City collector. Cincinnati, O., G.W. Logan, I882. 8. 12 in. Nos. 1-5, Jan., Feb., Mar., May, Aug., 1882

"* No. 1 has "1881" for "1882".

QUEEN CITY PHILATELIST. The Queen City philatelist.

Buffalo, N. Y., E. S. A. McLeod and Co., I885. 8. $8 \frac{1}{2}$ in. No. 1, August, 1885.

* * The number has a coloured paper wrapper. Conducted by Edward Samuels.

QUEEN CITY PHILATELIST. The Queen City philatelist. A monthly journal for stamp collectors. $8^{\circ} .71$ in. No. 1, December, 1893.
$* *$ The number has a coloured paper wrapper.
$*$ "The Toronto, H. Beasley, 1893 . Mis. St. Jour. 56 (3).

QUEEN CITY PHILATELIST. See COLLECTORS' ADVOCATE.

QUEEN CITY PHILATELIST AND COLLECTORS' ADVOCATE. See CoLLeCTORS' aDVOCATE.

QUESTIONNEUR TIMBROPHILIQUE. Le Questionneur timbrophilique. Paris, Pierre Mahé, I 892-95. $8^{\circ} .10$ in. 43 nos. in 4 vols.

1st year. June 15-Dec., 1892. Nos. 1- 7.

2nd " Jan. - ," $1893 . \quad$ " $11-12$.

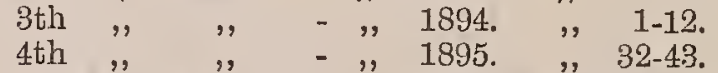

* * There is an index to each year" and a coloured paper wrapper to each number; No. 4 of the second year is dated "Mai" instead of "Avril" and no. 7 of the third year is dated "Juin" in place of "Juillet," except on the wrapper, which has the correct date, 
Quartesty Reviur opphilately.

svo. Rok armestang. 9. Rohertson. Colourat af. I. No, is21 (march 18).

Quintoni Price list. gro. 

RACCOGLITORE. Il Raccoglitore.

Oblong $5^{\circ} .7 \frac{3}{4} \mathrm{in.} \mathrm{Fascicolo} \mathrm{I.,} \mathrm{July,} 1874$.

Firenze, E. Carto Usigli, 1874 .

RACCOGLITORE. Il Raccoglitore.

Firenze, Deposito Centrale Timbrofilo Italiano, I875. $8^{\circ} .10$ in. Nos. 1-7, January-July, 1875.

**" There is a supplement "Catalogo e Guida Generale con prezzo corrente," etc., "Prima edizione" of which (108) pages were published.

[Thick paper edition.]

** Wanting nos. $1,2,3$ and 5 and the title-page, preface and conditions of sale of the catalogue.

RACCOGLITORE ROMANO. Raccoglitore Romano. Roma, Dr. Tommaso Capo, I892-93.

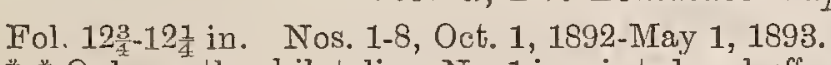

** Only partly philatelic. No. 1 is printed on buff paper. Want$\sin 9$ ing nos. 5,8 .

Mis. St. Jour. $116(10)$

\section{[Continued as :]}

Il Raccoglitore Romano e la filatelia.

Roma, Dr. Tommoso Capo, 1893

Fol. 121 in. No. 9, August 1, 1893.

** Only partly philatelic.

Mis. St. Jour. 116 (10a).

RACCOGLITORE ROMANO F LA FILATELIA. See Raccoglitore Romano.

RAYMOND AND CO.'S MONTHLY CIRCULAR AND "GENERAL ADVERTISER". See F. RaYMond and Co.'s Monthly crroular and "General adverTISER".

RF́CLAIMF FCONOMIQUPr. Réclame economique. Catane, Italie, Placido Montalto, I 902.

\section{$8^{\circ} .8 \frac{1}{2}$ in. [No. 1.] July $16,1902$.}

** Produced by autographic lithography and unnumbered. The contents consist entirely of advertisements.

Mis. St. Jour. 154 (16).

RECLAME ECONOMIQUE. Réclame economique des collectionneurs et marchands de timbres poste.

$8^{\circ} .93$ in. Nos. 1-5, August 25, 1902

Catane, Italie, Placido Montalto, I goz.

** The contents consist entirely of advertisements. The numbers $1-5$ were published together as a number of four pages.

$$
\text { Mis. St. Jour. } 154 \text { (17). }
$$

RÉCLAME PHILATHLIQUE. La Réclame philatélique. Journal du marchand et collectionneur de timbres-poste.

$8^{\circ} .9 \frac{1}{4}$ in. 16 nos. in 2 vols. Le Havre, J. Bouchard, 1895-96.

1st year. Mar. 10, 1895-Feb., 1896. Nos. 1-12.

* * Nos, 6 and 7 were published together and there are supple ments to nos. 11 and 12 and to the four numbers of the second year.
RECLAME PHILATÉLIQUE ET CARTOPHILE. La Réclame philatélique et cartophile. Organe international, paraissant périodiquement.

Hasselt, Belgique, G. Ghuys-Delée, I 903. $4^{\circ} .12$ in. [No. 1.] November, 1903.

**" Printed on buff paper and the number has a coloured paper wrapper.

RÉCLAMI PHILATÉLIQUE ET PHILOCARTISTE UNIVERSELLF. La Réclame philatélique et philocartiste universelle. Revue internationale illustrée des collectionneurs et marchands de timbres-poste, taxe, télégraphe, amateurs, editeurs et marchands de cartes illustrées. Paraissant régulièrement le ler de chaque mois. La Louvière, Belgique, Const. Petit, I9oz. 8o. 11 in. No. 1, March 1, $1902 . \quad$ Mis. St. Jour. 87 (2).

\section{RÉCLAIVE PHILATH́LIQUE GF́F́rRALE. La Ré-} clame philatélique générale. Anvers, [? ], I895. $8^{\circ} .9$ in. No. 1, July 15, 1895. * * The number has a coloured paper wrapper and the contents consist entirely of advertisements. Mis. St. Jour. 90 (3).

RÉCLAIME PHILATÉLIQUE LYONNAISE. La Réclame philatélique Lyonnaise. Feuille exclusivement réservée aux annonces et aux adresses des marchands et collectionneurs de timbres-poste, cartes-vues, affiches, etc., etc. Lyon, C. Colonjard, I 900. $4^{\circ}$. $11 \frac{1}{4}$ in. No. 1, April 15, 1900

* * Printed on coloured paper and the contents consist entirely of advertisements. Mis. St. Jour. 109 (12).

RÉCIAIM巴 PHILATÉLIQUE UNIVERSELIE. La Réclame philatélique universelle. Anvers, G. Verachtert et Co., I899. $8^{\circ} .10 \frac{1}{2}$ in. Nos. 1-5, Jan. 15-May 25, 1899. ** The contents consist entirely of advertisements. There are supplements of two pages to nos.' 1,2 and 3 . Wanting no. 4 . Mis. St. Jour. 99 (8)

RÉCLAIME TIMBROLOGIQUE. La Réclame timbrologique. Anvers, R. Stordiau, etc., I896-98. $8^{\circ} .9 \frac{3}{4}$ in. 19 nos. in. 2 vols.

1st year. Aug., 1896-July, 1897. Nos. 1-12. 1st year. Aug., 1896-July, 1897 . Nos. 1-12.

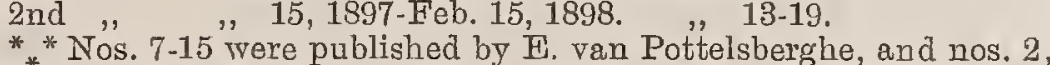
*** Nos. 7-15 vere published by $\mathrm{E}$. van Pottelsberghe, and nos. 2,
3,9 and 10 have supplements of two pages. Nos. I-12 are printed 3,9 and
on coloured paper and no. 5 and nos. $13-19$ have coloured paper on coloured paper and no. 5 and
wrappers. Wanting nos. 11, 16.

RECORD AND REVIEW. The Record and review. New York, Albert R. Rogers, I89o.

8. $9 \frac{1}{4}$ in. Nos. $1-3$, Oct. 15 -Dec. 15,1890

** There is a coloured paper wrapper to each number. The "*apper of no 3 has " 1891 " in place of " 1890 ".
wrapper

RACONTEUR. (London, Robson Lowe Lta.)

Vol. I (1934-35). Unbound.

Continued as

iraconteur and PhILATELIST. (London, Robson Lowe Ltd.

etc.)
Vol. II (exc. No. 3) (1935-36). Linbound.

Continued as

PHILATElist AND RACONTEUR. (London, Regent Stamp Co.

L.t.)

Vol. III (1936-37). Unbound.

Continued as

pHilatelist. (London, Regent Stamp Ce. Ltd.)

Yol, IN to date (1937-) - Linbound. 


\section{RECORD AND RFVIEW}

[Continued as :]

The Record review and auction advertiser. New Yort, Albert R. Rogers, etc., I89I-03. $8^{\circ} .91$ in. Nos. [4]-11, Nov., 1891, Jan., Mar., Apl., Oct., Nov., Dec., 1892, May, 1893.

* * There is a coloured paper wrapper to each number. Nos. 9 11 were published by the J. W. Scott Co. Litd., and nos, 4-6 bear no number.

RECORD REVIEW AND AUCTION ADVERTISER. See RECORD AYD REVIEW.

RECREATION ECHO. Recreation echo. Devoted to shut-ins, postmark and stamp collectors, etc. Knoxville, etc., Tenn., Charles P. Galyon, I 893-94. Fol. $15-16$ and 20 in. 16 nos. in. 2 vols.

Vol. I. Sept., 1893-Aug. 15, 1894. Nos. 1-13. II. Oct 15, Nov. 1, Dec., 1894. ", 1-3. * " Onily partly philatelic. No. 13, vol. I., and the numbers of vol. II., were published at Harriman, Tenn. The numbers of vol. measure 15-16 inches and those of vol. II. 20 inches. Wanting nos. $1,3,4,7,8,11,12$, vol. I., and no. 3 , vol. II

REDFIELD'S WEEKLY PHILATELIC POST. See PhILATELIC POST.

RFFORIME. La Réforme. Treizième année. No. 152 Mai 31 1896. [Contains an article "Nos Philatélistes. Ce que vaut un timbre-poste," by Habert.]

Bruxelles, Champal et Hector Chainaye, I 896. Fol. 23 in. p. (1).

Mis. St. Jour. 136 (15).

REGAN'S IMONTHLY CIRCULAR. See W. H. REGAN's MONTHLY CIRCULAR.

REGAN'S POSTAGE STAIVP CIRCULAR. See W. H. Regan's Monthity Circular.

REGELMÄSSIGFR WOCHEN- UND MARKTBER ICHT DFR HAIMURGER, LÜBECKER UND BREIMER BRIFFIMARIEN-BÖRSE. Regelmässiger Wochen- und Marktbericht der Hamburger, Lübecker und Bremer Briefmarken-Börse.

Hamburg, Theodor Miiller, I872.

$4^{\circ} .11 \frac{1}{4}$ in. Nos. 1-4, Sept. 1, 8, 15, 22, 1872

* * The contents consist entirely of price lists of stamps. The journal was produced by autographic lithography with the exception of the title and notices, which are lithographed from type. The number and date was filled in with a red pencil or in red or black ink before each number was circulated. Wanting no. 4

And a second copy of no. 1 in Mis. St. Jour. 128 (5).

REGENERACIÓN FILATÉLICA. Regeneración filatélica. Barcelona, Ricardo San Antonio, [I 906]. $8^{\circ} .10$ in. No. 1, [April, 1906]

** Contains as a supplement "Ilustración Filatélica" Año II. Núm. IV.

REGISTER. The Register. A journal for photographers, bird fanciers, stamp, coin, post card collectors, etc. Tipton, Staffs, William Haddon, I 903.

(.) $4^{\circ} \cdot 9 \frac{1}{2}-10$ in. Nos. 1-2, January-February, $1903.25 / 16$.

* No. 1 has a colour apo vertisement supplement" above the title. Mis. St. Jour. 109 (1)

REGISTRR OF FACTS AND OCCURRENCES RELATING-TO LITERATURE, THE SCIENCES, AND THE ARTS. Register of facts and occurrences relating to literature, the sciences, and the arts. July, 1863. [Contains an article "The postage stamp mania," by A. R. B.] London, Walter Weldon and Co., I863. $8^{\circ} \cdot 93$ in. pp. $482-485$ ** Wanting
REPORTER. The Reporter.

95

Norwich, Conn., Jaquith and Blackburn, etc., [1892]-

$32^{\circ} .4 \frac{1}{2}$ in., $24^{\circ} .5 \frac{1}{2}-6$ in., $16^{\circ} .6 \frac{1}{4}-5 \frac{1}{2}$ in. $12^{\circ} .7-7 \frac{1}{2}$ in. and $8^{\circ} .8 \frac{3}{4}$ in. 40 nos. in 4 vols.

Vol. I. Aug., [1892]-Aug., 1893. Nos. 1-12.

" II. Sept., [1893]- ", 1894. " 1-12.

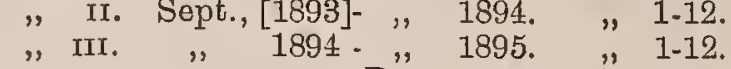

" III. " 1894 - " " $1895 . \quad$ " $1-12$.

*" TV. 1 and 2 are $32^{\circ}$., nos. 1895 . 3 are " $24^{\circ}$., nos. $6-12$ and 1-3, vol * * Nos. 1 and 2 are $32^{\circ}$., nos. $3-5$ are $24^{\circ}$, nos. $6-12$ and $1-3$, vol. II., are $16^{\circ}$, nos. $4-8$, vol. II., are $12^{\circ}$. and the remaining numbers are $8^{\circ}$. Nos. $5-9$, vol. I., and nos. $2-4$, vol. II., were published by Perley H. Jaquith, nos. $10-12$, vol. I., no. 1, vol. I., hos. 5-12, vol II., and all the subsequent numbers by the Reporter Publishing Co. Nos. 3 and 4, vol. I., were published together and are wrongly numbered "No. 5 and 6," and dated in error " 1982 "; nos. 6 and 7, vol. I., nos. 11 and 12, vol. II., nos. 1 and 2 and 3 and 4 , vol. IV., were also published together. Each number, excepting nos. 3 and 4 , vol. I., has a paper wrapper, and the wrapper of no. 6, vol. II., has in error "no. 7". Nos. 1, 2, 5, 8, 9 and 10, vol. I., and no. 1 , vol. Ir., have no year given. There is no number for January, 1893 , and some but not all of the wrappers of no. 1, vol. II., are
wrongly numbered "no. 2 ".

REPUBLICAN, The Republican. St Touis, and Springfield, Mo., May 26, 1876. [Cuttings of the article "The postage-stamp mania " . . are mounted in Stamp Scrapbook, vol. III., pp. 50, 51, 52.]

- April 13, 1882. [Cuttings of the article "Fancy prices paid at a recent sale for St. Louis stamps of the issue of 1845," are mounted in Stamp Scrap-book, vol. IV., p. 84.]

November 27, 1882. [Cuttings of the article "Custer's collection. Current and obsolete postage stamps in great variety"... are mounted in Stamp Scrap-book, vol. IV., pp. 85, 86.]

March 31, 1888. [Cuttings of the article "Stamp and coin article," are mounted in Stamp Scrap-book, vol. vI., pp. 29-33.]

February 7, 1889. [Cuttings of the article "Among the philatelists," are mounted in Stamp-Scrap book, vol. vi., pp. 38-40.]

March 27, 1889. [Cuttings of the article "An odd New York exhibition. Collection of postage stamps," are mounted in Stamp Scrap-book, vol. vi., pp. 40-43.]

April 28, 1889. [Cuttings of the article "Philatelic and numismatic," are mounted in Stamp Scrap-book, vol. vi., pp. 43-47.]

- June 2, 1889. [Cuttings of the article "Stamps and coins," are mounted in Stamp Scrap-book, vol. vi., pp. 51-53.]

June 30, 1889. [Cuttings of the article "For stamp collectors," are mounted in Stamp Scrap-book, vol. VI., pp. 53-55.]

August 23, 1889. [Cuttings of the article "A philatelic conference," are mounted in Stamp Scrap-book, vol. vI. pp. 78-80.]

REVEIL FRANÇAIS. Le Reveil Français. Artistique, littéraire, nationaliste, théatral, sportif, timbrophile.

$8^{\circ} .10$ in. nos. in vols Rowen, Jean de Kerlecq, I897 * *The library only contains nos. 36 and 37 dated respectively, August and September, 1900 , and these bear" "4me année".

REVENUE COLLECTOR. The Revenue collector Published semi-occasionally.

Wyoming, Iowa, E. R. Marshall, I893. $16^{\circ} .6$ in. No. 1 , Winter $1893-4$, Mis. St. Jour. 68 (23)

\footnotetext{
"Red hcoir fay elte". c.m. Canafiet, Calcutta

"Deroted to Pcirtüre Postecus aun Staufis"

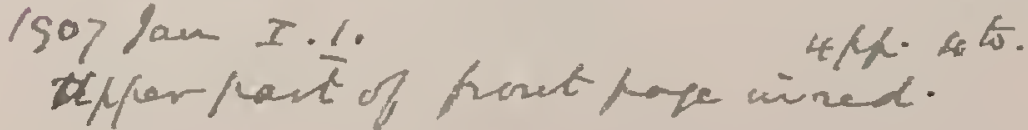


Record of philately (Harpenden), $1935-36 \ldots$ Nos. 1 to 12
(all issued). complete with index. inhorime

RECORD OF THE PHILATELIC STUDENTS' FELLOWSHIP (London, S. R. Turner).

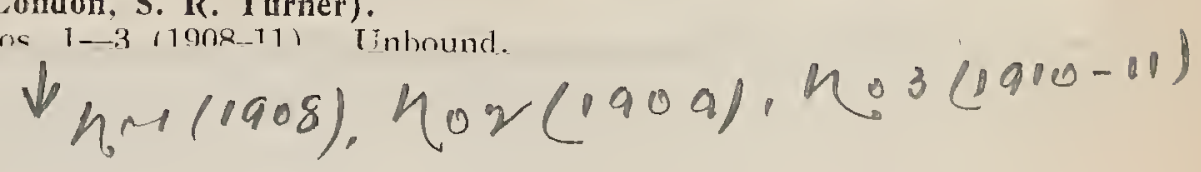

Renpuldis sliamploutbly

Repúvira Currunar. République Cubaine, 1896 -Si lg 
Ruvista Filateluca Ceatro Amuricano, Luctemala, 1899

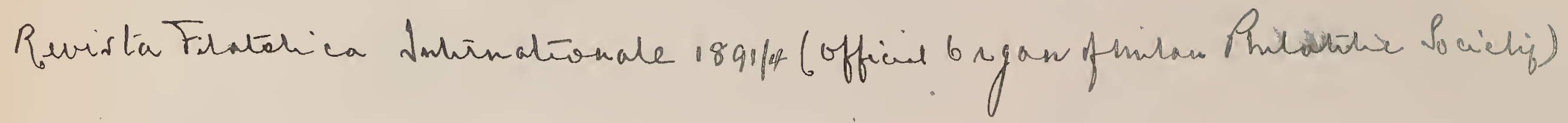

Ruistá Fulateluca d'I latra (La)

- Soe de Bunsos anes 
REVENUE PHILATELIST. The Revenue philatelist. Published in the interest of collectors of revenue stamps. Johnstown, Pa., etc., Johnstown Stamp and Publishing Co., etc., 1898-1906.

$8^{\circ}$. 8 in. Nos. 1-4. First quarter, second quarter, 1898, fourth quarter, 1905, first quarter, 1906.

** Each number has a coloured paper wrapper and nos. 1 and 2 have supplements of illustrations of revenue stamps. Nos. 3 and 4 were published at Saco, Maine, by C. P. Speck. Wanting
no. 4 .

REVIEW. The Review.

Rock Island, Ill., Philatelical Publishing Co., ז887. $8^{\circ} .8 \frac{3}{2}$ in. Nos. 1-2, February-March, 1887.

Mis. St. Jour. 26 (4).

[Continued as:]

The Philatelic review.

Rock Island, Ill., Philatelical Publisting Co., etc., x $887-88$

$8^{\circ} .11 \mathbf{1}^{-}-8 \frac{3}{4}$ in. Nos. 3-6, Apl., May, Dec., 1887, Jan. and Feb., * * No. 3 is octavo 11 inches and nos. 4-6, octavo 83 inches. No. 6 was published by C. D. Reimers. Mis. St. Jour. 26 (4a).

REVIEW OF REVIEWS. The Review of reviews. January 15, 1897. [Contains a page of illustrations, "The Queen's Head," taken from various postage stamps.] London, E.C., Horace Marshall and Son, I897. $8^{\circ} .10 \frac{1}{4}$ in. pp. 14 and 19

* * The number has a coloured paper wrapper.

Mis. St. Pamph. 63 (5)

REVISTA DE ANNUNCIOS. Revista de annuncios Supplemento d'O Colleccionador de sellos.

Sorocaba, Brazil, Remijio de Bellido, $\mathrm{1} 899$

$8^{\circ} .10$ in. [Nos. 1-7]; Feb. 28-Aug. 30, 1899.

** The contents consist entirely of advertisements. Bound up **The contents consist entirely
with "Colleccionador de Sellos".

REVISTA DE CORREOS. Revista de correos.

$$
\text { Madrid, [?], 1868- }
$$

Fol. $11 \frac{1}{1}$ in, 123 in. and $19 \frac{1}{2}$ in. nos. in vols. ** Only some of the numbers contain philatelic matter. The numbers in the library are: Index to "Tomo tercero. 10 enero 1870 \& 31 diciembre,1871"; 5 th year, 1872, nos. 70, 71, 72, 73, 74; 6 th year, 1873 , nos. $75,76,77,84$, 85; 7th year, 1874 , nos. 87 , 88, 89 , $90,91,92,93,94,95-96,97$; 25 th year, 1890 , nos. 912, 913, 914, $915,916,917,923,924,925,926$; 26th year, 1891, nos. 932,933 , $934,935,936,937,938,949,950,951,952,953,954,956,957,958$, $959,962,963,965,966$; 27th year, 1892 , nos. $968,969,973,980$. Of these, the index and the numbers of the fifth, sixth and seventh years measure $11 \frac{1}{4}$ inches; the numbers of the twenty-fifth and twenty-sixth years measure 12 sa inches and those of the twentyseventh year measure $19 \frac{1}{2}$ inches.

REVISTA DE LA SOCIEDAD FILATÉLICA ARGENTINA. Revista de- la Sociedad Filatélica Argentina.

$8^{\circ} .10 \frac{1}{2}$ in. nos. in vols. In progress.

1st year Nov, 1894-Dec., 1895. Nos. 1- 14

2nd " Jan., - ", 1896. ", $15-26$.

3rd " " " $\quad-", \quad 1897 . \quad$ ", $\quad 27-38$.

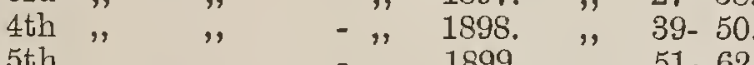

$31196 \mathrm{th}, " \quad " \quad-", 1900 . \quad " \quad 51-62$

7 th " " $\quad$ " $\quad ", \quad 1901 . \quad, \quad, \quad 75-86$.

9th " $\quad-" \quad 1902 . \quad$ " $\quad$ " $\quad 87-98$

10th " May 25 - " 1906. " $111-117$

* * There is a title-page and an index for each year, excepting the second and tenth years for each of which there is only an index and there is a coloured paper wrapper to each number. The title-page for the seventh year has "Ano VI." in error and the wrappor of no. 42 has "Num. 4" for " 42 ". Nos. 11-14, 22-24, $25-26,27-28,39-41,53-54,55-56,57-58,59-60,61-60,63-64,65-66$, and 101-102 wore sevorally publish 5 " 52 ". an " "Toviembre $Y$ Diciem bre de 1906 " and is printed on cols the paper. A supplement "Cotslogo general ilustrado de las ourol pillas fiscales emitidas en la República Argentina las estampor la Sociedad Filatélice Arrentina bajo la direción del Dr. José YTarcó del Pont," was startod in lsoso la direccion del Dr. the succeeding years, 140 pares in oll of the catalogue being ab lished to the end of 1006 pa furth all or the catalogue being pub-

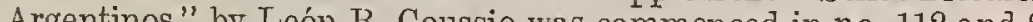
pages of this had appeared at the end of 1906.
REVISTA DE LA SOCIEDAD FILATHLICA CUBANA. Revista de la Sociedad Filatélica Cubana.

Habana, x9o2-o6.

$8^{\circ} .9 \frac{1}{2}$ in. 49 nos. in 5 vols.

1st year. Apl. -Dec. 15, 1502. Nos. 1- 9.

2nd " Jan., 15- ", 15, 1903. ", 1-12.

3rd " "15-" 1904. " $1-12$.

4th " " $\quad$ th $\quad$ Apl., $1905 . \quad$ " 1906.12.

** *There is a combined index for the first and second years and a coloured paper wrapper for each number. Nos. 1 and 2 of the fifth year were published together and the wrapper of this double number bears "Año IV." in error for "Año V.". Wanting III. year nos. 11, 12, IV. year no. 1.

REVISTA DEL MERCADO DE SELLOS DE GUAY AQUIL. Revista del mercado de sellos de Guayaquil. [Guayaquit], Juan MI. Uraga F., I888.

Fol. 123 in. [No. 1], Aug. 31, 1888

** Consists of a single leaf printed on one side. It partakes more of the nature of a price list than a journal.

Mis. St. Jour. 86 (7)

REVISTA FILATELICA. La Revista filatelica.

St Louis, Mo., C. H. Mekeel Stamp and Publishing Co., I892-95.

$8^{\circ} .9-9 \frac{1}{4}$ in. 21 nos. in 3 vols.

Vol. I. May 1-Sept. 1, Nov. 1, Dec. 1, 1892, Jan. 1, Apl. 1, June 1, Oct. 1, 1898, May 1, 1894. Nos. 1-12.

Ir. June 1, Aug. 1, Nov. 1, Dec., 1894 Nos, 13-16.

"III. Jan. 1-MLay, 1895. Nos. 17-21.

* * There is a title-page and an index to vol. I., a title-page and a frontispiece to vol. III., and a coloured paper wrapper to each number. No. 16 is wrongly dated "Noviembre 1,1894 " in place of "Diciembre 1 1894" but the wrapper bears the correct date Nos. 1-12 were edited by Eduardo F. Cottilla and the remaining numbers by I. A. Mekeel.

REVISTA FILATÉLICA. La Revista filatélica, Publicacion mensual dedicada a la Filatelia.

Curazao, Eduardo J. de Villacian, 1893. $8^{\circ} .93-10 \frac{3}{4}$ in. Nos. 1-9, April-December, 1893.

Mis. St. Jour. $130(9)$

REVISTA FILATÉLICA. Revista filatélica.

Panama, Aizpuru y Andreve, r894. $8^{\circ} .11^{3}$ in. Nos. 1-2, October, 1-November, 1894

** There is a paper wrapper to each number and a copy of the prospectus of the journal is bound up with the two numbers. Mis. St. Jour. 116 (2).

REVISTA FILATFLICA. See Revista Filotelica.

REVISTA FILATELICA DE LA CP. SAN JUAN $R$. ARGENTINA. Revista filatélica de la CP. San Juan R. Argentina.

San Juan, E. Asdrubal Rodriguez, 1893.

$4^{\circ} .11 \frac{1}{2}$ in. No. 1, [June], 1893

** Consists of a single leaf printed on one side only.

Wis. St. Jour. 57 (7)

REVISTA FILATÉLICA Y FILOCARTISTA LA UNION POSTAI. See UnIón Postat.

REVISTA FILOTELICA. La Revista filotelica. 89.

Barranquilla, Colombia, G. Schoonewolff Jr., ז887.

$4^{\circ} .8 \frac{3}{4}$ in. 20 nos. in 2 vols.

1st year. Sept., 1887-Aug., 1888. Nos. 1-12

2nd ", ", 1888-Apl., 1889. ", 13-20.

** * Nos. 4 and 5 were published together. Nos. 13-20 have paper wrappers and the title of these eight numbers reads " La Revista Filatelica".

REVISTA IIEDICA. Revista Medica. [Contains a series of articles "El correo en España. Algunas, papeletas, bibliographicas, hilvanadas por el Doctor Thebussem" ] Cadiz, D. F'ederico Joly y Velasco, 1878 . *** These articles have been cut out, pasted on sheets of paper and bound in book form.

REVISTA PHILATÉLICA. La Revista philatélica. Buenos Ayres, Victor Albornoz, I874. $8^{\circ}$. 83 in. Nos. 1-2, August 1-September, 1874.

** Only two copies are now known of no. 1 , while no copy is known of no. 2. This was the first philatelic journal published in the Argentine Republic. Wanting both nos. 
RFVISTA PHILATELICA DO BRASIL. Revista philatelica do Brasil.

Rio de Janeiro, Alph. Bruck, r896-г9oo. $8^{\circ} .10^{\frac{3}{4}}$ in. 48 nos. in 4 vols.

1st year. Jan. -Dec., 1896. Nos. 1-12

2nd " " - " $1897 . \quad, 1-12$

3rd " " " 1899-Jan. 1890. " " $1-12$

** *There is $\approx$ title-page and an index to each of the three first years. Nos. 8 and 9 of the fourth year were published together and no. 12 of the fourth year is dated "Dezembro 1899-Janeiro 1900".

REVISTA PHILATELICA PORTUGUEZA. Revista philatelica Portugueza.

Porto, José Pimenta Junior, I90I-04 $8^{\circ} .10-9 \frac{3}{4}$ in. 29 nos. in 3 vols.

1st year. Jan.-May, 1901. Nos. 1- 5

2nd " " -Dec., 1903. ", $6-17$.

* * "There is" a coloured paper "wrapper to each number. Nos. 13 and $14 ; 25$ and $26 ; 27,28$ and 29 were severally published together. Nos. 6-17 are numbered " $1^{\circ}$. anno $\left(2^{\circ}\right.$. anno). No. 1 (no. 6 " " $10^{\circ}$ anno ( $2^{\circ}$ anno). No. 12 (no. 17)"; and nos. 18-29 are numbered " $2^{\circ}$. anno $\left(3^{\circ}\right.$. anno). No. 13 (no. 18$)$ "." $2^{\circ}$. anno
$\left(3^{\circ}\right.$. anno). No. 22, 23, 24 (no. 27, 28, 29)". Nos. 6-29 were edited $\left(3^{\circ}\right.$.anno). No
by Luiz Braga.

REVISTA POSTAL. La Revista postal. Publicación flatélica mensual.

Buenos Aires, Achard y Cia, etc., I898-99. So. $8 \frac{3}{4}$ in. 9 nos. in 2 vols.

1st year. June 15-Dec., 1898. Nos. 1-7.

2nd "Jan. -Feb., $1899 . \quad, 8-9$.

** Nós. 7-9 were published by Jiménez y Achard. There is a paper wrapper to each number and nos. 5 and 6 , and 8 and 9 were severally published together, the former under the date "Octubre Noviembre de 1898 " and the latter with the date "Enero y
Febrero de 1899 ".
Mis. St. Jour. 84 (2).

REVISTA POSTAL COLOIMBIANA. Revista postal Colombiana.

Bogota, Manuel José Casis, 1904. $8^{\circ} .10$ in. Nos. 1-6, March-August 1, 1904.

Mis. St. Jour. 122 (8).

REVISTA POSTAL DOIMINICANA. Revista postal Dominicana.

Santo Domingo, Enrique A. Curiel, x 905.

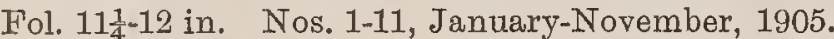

* * Nos. 7-11 were published together with the date " Noviembre de $1905 "$.

Mis. St. Jour. 124 (8).

REVISTA UNIVERSAL, Revista universal. Ilustración

filatélica.
Fol. 113. in. Año x., no. 316. July, 1899

Barcelona, [?], I899.

* The number has a coloured paper wrapper and contains an article with the title "Sociedad Filatélica Hispano-Colonial de
Barcelona".

REVUE DE LA FEDERATION PHILATELIQUE DE

FRANCE. Revue de la Fédération Philatélique de France

Paris, Fédération Philatélique de France, r904$4^{\circ} .10_{4}^{3} \mathrm{in.}$ nos. in $\nabla$ ols. In progress.

1st year. Jan. 1-Dec., 1904. Nos. 1- 9

2nd " " - " 1905. " 10-18.

* * Successor to the" "Union Philatélique". There is a coloured paper wrapper to each number. No. 1 is dated in error on page paper "rapper to each number. " 160 " 1 e année" in place of "1re année" but the date and numbering on each of the respective wrappers is correct. No.17 is dated "Juillet-Aout, 1904 "; no. 8 "Srappers is correct. No.1 " is da. "Novembre-Décembre, 1904" no. 11, "Février-Mars, 1905 "; no. 15, "Juillet-Août, 1905 "; no. no. "1, "Fevrier-Mars, 1905 " no. 15, "Juillet-Aout, 1905 "; no. 16, "Septembre-Octobre, 1905"; no.; "25, "Juillet-Aout, 1306 " no. 26, "Septem"

REVUE FRANGAISE DE LA PHILATÉLIE UNIVERSELLE. Revue Française de la philatélie universelle. Organ mensuel du Cercle Philatélique Chalonnais.

Chalon-sur-Saone, I89I-92.

1st year. Nor. 25, Dec. 25, 1891. Nos. 1-2

1892. 3-7.

* *No. 7 is dated " 25 Mai, 1892 " and has "et 25 Juin" added with a hand-stamp in violet ink. Mis. St. Jour. 135 (10).
REVUE FRANGSAISE DES COLLECTIONNEURS. La Revue Française des collectionneurs.

Paris, Georges Schnebelin, r9o2-

$8^{\circ} .10 \mathrm{in.}$ nos. in vols. In progress.

1st year. Oct. 25-Dec. 25, 1902. Nos. 1- 3

2nd " Jan. - " $1903 . \quad$ " $4-15$.

3rd " " " $\quad$ " $25-25,1904 . \quad$ ", $16-27$.

5 th ", " 25- ", 25, 1906 . ", 40-51.

* There is a coloured paper wrapper to each number and nos.

10 and 11 and 23 and 24 were severally published together.

REVUE GAUIOISF. La Revue Gauloise

Rouen, Jean de Kerlecq, 1899.

8. 93-10 in. Nos. 1-5, April, June-September, 1899.

* * Only partly philatelic. Nos. 1-3 have coloured paper wrappers Mis. St. Jour. 131 (4)

REVUF INTERNATIONALE DE LA PHILATHIIF

See Revue Phimatélique Internationale.

REVUE PHILATELIQUE. Revue philatélique.

Paris, Société Philatélique Française, r890-96.

$8^{\circ} .10 \frac{3}{4}$ in. 65 nos. in 7 vols.

1st year. Apl.-Dec., 1890. Nos. 1- 9

2nd " Jan.- " 1891. " 10-20.

3rd " " - " 1892. " 21-32.

5th " " - " $1893 . \quad$ " $33-44$.

6 th " " " $, 1895 ., 1,55-64$.

* * The third, fourth and sixth years have title-pages and indexes, the fifth year an index only, and there is a coloured paper wrappe to nos. 45-65. No. 16 is dated "Juillet-Aoutt, 1891"; no. 51, "Juillet-Août, 1894" ; no. 52, "Septembre, 1894," but the wrapper bears "Septembre et Octobre, 1894"; no. 60 "JuinJuillet, 1895 " and no. 61, "Août-Septembre, 1895 ". Nos. 40 and 41 were published together and no. 43 is wrongly numbered " 44 ". There are supplements to nos. 35,38 and 44 .

[Continued as :]

Revue philatélique Française.

Paris, Sociétê Francaise de Timbrologie, x896$8^{\circ} .10 \frac{3}{4}$ in. Vols. VII.- nos. In progress.

7th year. Feb. -Dec., 1896. Nos. 66- 75.

Sth " Jan. - ", 1897. " 76-85.

9th " " - " "31, 1898. "

11th " " $" 31-"$ "31, $1899 . \quad " \quad 98-108$.

12th " " " $\quad$ - " " $1,1901 . \quad$ " $120-130$.

13th " " 1- " 1, 1902. " 131-142.

14th " " " $1-" \quad 1,1903 . \quad$ " $143-152$.

16th " " - " " 1904. " $153-163$.

17th " " " $" 1905 . \quad "$ " 164-174.

* * There is a title-page and an index to the seventh year, an index only for each subsequent year, and a coloured paper wrapper to each number. No. 74 is dated "Octobre-Novembre, 1896", no. 83, "Août-Septembre-Octobre, 1897 "; no. 116, "Août-Septembre, 1900 "; no. 150, "Août-Septembre-Octobre, 1908," no. 160 "Aout-Septembre, 1904," no. 171, "Aott-Septembre, 1905," and no. 182, "Aott-Septembre, 1906 " No. 68 is numbered "67" "except on the wrapper, which is correct, no. 80 has "Avrl" in place of "Mai," except on the wrapper, no. 107 has " 106 " except on the wrapper, no. 118 has " 117 " and the wrapper bears " no number. All the numbers of the twellth year have in eror "onzidme annee" and all the numbers of the thirteen th year have "douzieme annee "nos. 143 and 144 of the fourteenth year" and the wrappers o nos. 143-147 have "treizieme annee". The wrapper of no. 131 has "1901" for 1902, the number for September, 1898, is numbered "93," but the wrapper has "no. 93.94 "and where are no number for August, 1898, July, 1899, August, 1901. Nos. 137 and 138 wer published together and the wrapper of no. 164 has " 1904 " in place of "1905". Eight pages of a special supplement "L Philatélie Interplanétaire," written by J. Suizalley, were given with no. 128 and this story was afterwards continued as a supplement to the "Archives des Collectionneurs," the first three num bers of which were also given as supplements to nos. 128-130. There is a special supplement: "Catalogue de Timbres Fiscaux. Rédjgé par M. G. Gilbert. 1re Partie. France et Colonies," which was presented with nos. 150-152 and also a special supplement "Catalogue illustré des Timbres Fiscaux de la Suisse Cantons et Municipalités, par Mm. Gilbert et Koehler," which was presented with nos. 173-185. There are illustrative supplements to nos. $75,101,107$ and 114 and supplemental pages to nos. 116, 120 and 125 
$\varepsilon_{3}$

Revista Postial - Vupurarso,1899-S120

Pevista Postial. Cartagena, Jolambia. 1900 

REVUE PHILATHIQUE. Revue philatélique. Organe de l'Association Philatélique Internationale "Genève" à Budapest. Budapest, Béla Szekula, i905 $8^{\circ} .9$ in. Nos. 1-2, November 10-December 10, 1905. * There is a coloured paper wrapper to each number.

Mis. St. Jour. 117 (10)

REVUE PHILATÉLIQUE BELGE. Revue philatélique Belge. Bruxelles, Mce, Belin, I894-1903. $8^{\circ} .8 \frac{3}{4}$ and $9 \frac{3}{4} \cdot 9 \frac{1}{2}$ in. 114 nos. in 10 vols.

1st year. Jan. -Dec., 1894. Nos. 1-12.

2nd ", "15- " 15, 1895. ", 1-12.

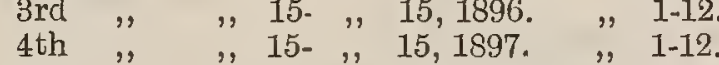

4th " " $\quad 15-, " 15,1897 . \quad$ " 1898.12.

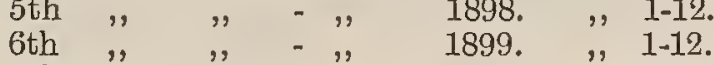

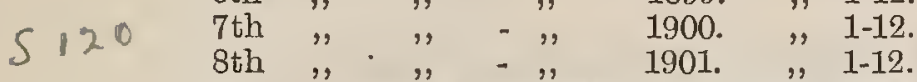

8th " "really 9th" "year.] Jan.-Dec., 1902. Nos. 1-12.

10th " [really 9th year.] Jan.-Dec., 1902. Nos. 1-12.

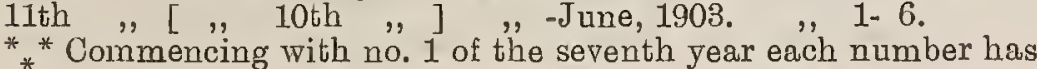
a coloured paper wrapper. Nos. 9 and 10 of the first year, which are wrongly numbered "nos. 8-9," nos. 9 and 10 of the second year, nos. 8 and 9 of the third year, nos. 8 and 9 of the fifth year, nos. 7 and 8 of the sixth year, nos. 8 and 9 of the seventh year nos. 8 and 9 of the eighth year, nos. 8 and 9 of the tenth year and nos. 5 and 6 of the eleventh year were severally published together. No. 11 of the first year is wrongly numbered "no. 10 ," there is no number for August, 1897, but the November number of that year has " nos. 10-11," there is no number for February, 1899, but in place of this there are two numbers for March, one
date i March 1, 1899 the other March 25, 1899. There is a supplemental slip to no. 6 of the second year.

REVUE PHILAT'́LIQUE FRANÇAISE. See REvUE Philatíligue.

REVUE PHILATfLIQUE INTERNATIONALE. Revue philatélique internationale.

$4^{\circ} .12 \frac{3}{4}$ in. 5 nos. in 2 vols.
1st year. Dec. 15,1895 . No. 1 .

Rouen, P. Ozel, I895-96

2nd year. Jan. 1, 15, Feb. 1, 15, 1896. Nos. 2-5.

${ }_{*}^{*}$ A copy of the prospectus of the journal is included.

[Continued as :]

- Revue internationale de la philatélie.

$4^{\circ} .12 \frac{3}{4}$ in. Vol. II., 3 nos.

Rouen, P. Ozel, 1896. $4^{\circ} .12 \frac{3}{4}$ in. Vol. II., 3 nos.
2nd year. Mar. 4, 15, Apl. 5, 1896. Nos. 6-8.

Série Nouvelle.

Rouen, A. Dufour, I899-г90г.

$8^{\circ} .9 \frac{3}{4}$ in. Vol. III.-V., 21 nos.

3rd year. April-Dec., 1899 . Nos. 1- 9.

4th "Jan. -Oct., 1900.

5th ", Feb.-March, Mar.-April, 1901. Nos. 20-21.

* * There is a coloured paper wrapper to each number. The wrapper of no. 14 has "Mai-Juin, 1900," that of no. 15 " 3C Juin, 1900 ," but the dates inside these numbers are respectively " Mai, 1900 ," and "Juin-Juillct, 1900". No. 16 is dated "Juillet-Août, 1900," no. 17 " 31 Aoû", 1900 " and on the wrapper "Août, 1900," no. 18 "Septembre, 1900 " and no. 19 "Octobre, 1900 " and on the wrapper "31 Octobre, 1900".

REVUE PHILATEILIQUE SUISSE. Revue philatélique Suisse. Genéve, Paul Stroehlin, r89r-[93] $8^{\circ} .9$ in. 18 nos. in 2 vols.

1st year. Jan.-[Dec. ?], 1891. Nos. 1-9.

2nd ", 1892-[1893]. " 1-9.

* * "Organe officiel de la Société lausannoise de timbrologie" There is a title-page and an index for each year and a coloured paper wrapper to each number with the exception of the last. Nos. 8 and 9 of the first year and nos. 7 and 8 of the second year were severally published together. After no. 4 of the first year which is dated "Avril, 1891," the numbers bear no month, and although no. 9 of the second year is dated " 1892 " it was not publishcd until 1893. No. 340 and nos. 343-348 of the "TimbrePoste," with the first page of each number headed "Supplément à la Revue Philatélique Suisse," were given as supplements to nos. 4-9 of the first year. This was the first philatelic journal published in Europe to use phototype illustrations. A copy of the prospectus is bound up at the end of volume I., in front of the wrapper to no. 1.

REVUE PHILATHLISTE. Revue philatéliste. Genève, [Th. Geisendorf], I887.

$4^{\circ} .9$ in. Nos. 1-8, April-Nov. 1, 1887

* * Produced by a hand inultiplying press. The journal was ** Produced by a hand inultiplying press. The journal was of the Geneva College. Wanting nos. $1,2,3,4,5,6$.
REVUE POSTALE. La Revue postale. Organe universe] de la timbrologie. $8^{\circ} .10$ in. 32 nos. in 3 vols. 1st year. Nov. 15- Dec. 15, 1893. Nos. 1- 2. 2nd "Jan. 15- ", 15, 1894. " 3-14. 3rd " $" 15$ 1895-July, 15, $1896 . \quad$ " $15-32$ * There is a coloured paper wrapper to each number. No. 3 is wrongly dated "1893" instead of " 1894 " and no. 15 is dated "1894" in place of "1895," but the date on the wrappers in each case is correctly given. The wrappers of nos. 15-17 bear, however, " 2 me année "instead of "3me année" and the wrapper of no. 20 has "No. 19, 15 Mai" in place of "No. 20, 15 Juin". There is no number for September or October 1895, but nos. 23 and 24 werc published together under the date " 15 Novembre 1895 " This journal was succeeded by "Bulletin Mensuel de la Sociéte Échangistes Réunis" in December, 1896.

REVUE POSTALE. La Revue postale. Genève, William Chenevard, I8g8-99. $8^{\circ} .9$ in. 23 nos. in 2 rols. 1st year. Jan.-Dec., 1898. Nos. 1-12. 2nd " "Nov, 1899. N. 1-11.

** There is a title-page and "an index to the first year and a coloured paper wrapper to each number. Nos. 4 and 5 of the first year, nos. 4 and 5 and nos. 10 and 11 of the sccond year were severally published together.

REVUg POSTALE. See BuLtetin Mensuen DE IA Sociḱté les Échangistes Rt́unis.

RHODF ISLAND PHILATEIIST. The Rhode Island philatelist. Newport, R. I., P. Parrish, I889-9I. $8^{\circ} .9$ in. 32 nos. in 3 vols.

Vol. I. Jan.-Dec., 1889. Nos. 1-12

" II. " - " 1890. ", 13-24.

*"* Each number, commencing with no. 13, has a coloured paper wrapper.

RICHARD BOREKS NEUHEITEN - PREISLISTE Richard Boreks Neuheiten-Preisliste.

Braunschweig, I go6-

$4^{\circ} .11 \frac{1}{2}-12$ in.

* * This is solely a price list of stamps, etc., for sale by the publisher and cannot therefore be considered a philatelic journal. No. 1 is dated " 19 Mai, 1906 ".

RICHARDSON'S STAMP COLLECTORS' MAGA

(- ZINE. Richardson's stamp collectors' magazine. San Francisco, Cal., Richardson Bros., [1884]. $8^{\circ} .9$ in. No. 1, [November, 1884].

* The number has a coloured paper wrapper.

Mis. St. Jour. 23 (1)

R. I. PHILATELIST. The R.[ock] I.[sland] philatelist. Rock Istand, Ill., L. K. Cleaveland, I 887 8.. 9 in. No. 1, March, 1887. Mis. St. Jour. 23 (12)

RIVAL PHILATELIST. The Rival philatelist.

[Chicago, Ill., ?

$8^{\circ} \cdot 7_{ \pm}^{3}$ in. Nos. 1-3, August-[October, 1899]. * * Produced by a hand copying press and published anonymously as a skit on "Stampic America," and afterwards amalgamated with that journal. No. 3 bears no date. Wanting no. 1 .

Mis. St. Jour. 145 (5)

RIVISTA DEI FRANCOBOLLI. Rivista dei francobolli. Spoleto, etc., Romolo Mezzadri e Co., I 897. 8. 103 in. Nos. 1-5, Mar., Apl., July-Aug., Oct., Nov., 1897. ** There is a coloured paper wrapper to each number. Nos. 3-5 * ${ }^{*}$ were published at Rome, although the wrapper of no. 3 bears "Sere published at Rome, although the wrapper of no. 3 bears saggio". There is an extra edition of no. 1 printed on thick paper, with a thick buff wrapper.

[Continued as:]

Rivista del francobollo.

Rome, Romolo Mezzadri e Co., etc., I898-

$8^{\circ} .10 \frac{3}{4}$ in. Vols. II.- nos. In progress.

2nd year. Jan.-Dec., 1898. Nos. 1-12.

3rd " " - , 1899. " $1-12$

" - " 1900. " 1-12.

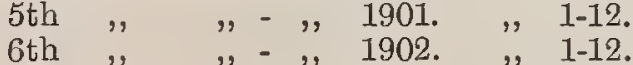

6th " " - " " 1902. " $19051-12$

8th , " " - " " $1906 . \quad$ " 
** Each number has a coloured paper wrapper. Nos. 6 and 7 $9^{*}$ and $10 ; 11$ and 12 of the second year, nos. 1 and $2 ; 5$ and 6 7 and $8 ; 9$ and $10 ; 11$ and 12 of the third year, nos. 2 and $3 ;$ and $5 ; 6$ and $7 ; 8,9$ and $10 ; 11$ and 12 of the fourth year, nos. 1 and $2 ; 3,4$ and $5 ; 6$ and $7 ; 8,9$ and $10 ; 11$ and 12 of the fitth year, nos. $1-4 ; 5-8 ; 9-12$ of the sixth year, nos. 7 and $8 ; 9$ and 10 ; 11 and 12 of the seventh year, nos. 1 and $2 ; 4$ and 5 and 9 and 10 of the eighth year were severally published together. There are supplements to no. 3 of the second year and nos. 11 and 12 of the third year, the last having "Supplemento al N. 9-10" in error for "11-12". Commencing with nos. 9-10 of the second year the jourmal was published by Piero Becchini.

RIVISTTA DEL FRANCOBOLLO. See RIVISTA DEI Francobotiti.

RIVISTA DELLA STAMPA FILOTELICA. La Rivista della stampa filotelica.

Marseille, etc., Luciano Mori, т883-86.
$8^{\circ} .9 \frac{1}{4}$ in. 22 nos. in 2 vols

1st year. Feb. -Dec., 1883. Nos. 1-11.

2nd year. Jan. 1884-Jan. 1886. " 12-22

* * Nos. -22 were published at La"Ciotat and some of the numbers have "Filatelica" in place of "Filotelica". The front page of no. 1 is illustrated in the "Journal of the Philatelic Literature Society" of January, 1909. Wanting all except nos.
$8,9,14,22$.

RIVISTA FILATELICA. Rivista filatelica.

Fol. 13 in. No. 1, February, 1891

Milano, Luigi Cappello, I89.

** This was given as a supplement to no. 8 of the "Nunal Nulik" a volapïk journal. Bound up with "Rivista Filatelica Internazionale".

RIVISTA FILATELICA INTERNAZIONALE. Rivista filatelica internazionale.

Fol. 13-131 Milano, Luigi Cappello, I89T-94. Fol. 13-13 in in. 32 nos. in 4 vols.

1st year. June 16-Oct. 22, Dec. 1, 1891. Nos. 1-6.

2nd ", Jan. 16-June 30, July-Aug., Aug.-Sept., Sept.-Oct., 3rd " Apl.-May, Oct.-Nov., Dec., 1893. Nos. 1-3.
4th " Jan.-
[Dec.], 1894. "1-12. * * After no. 2 of the fourth year the numbers" do not bear the name of the month and nos. 6 and 7,8 and 9 , and 10,11 and 12 of this year were severally published together. No. 11 of the second year consists of a single leaf and this number is headed "Supplemento al numero di Dicembre 1892". The pagination

of no. 1 of the third year follows on no. 10 of the second year,
taking no account of the two pages of no. 11 of the latter year.

RIVISTA FILATELICA ITALIANA. Rivista flatelica Italiana. (Rêvue philatelique Italienne).

Milano, G. Cavallotti, т9от.

Fol. 11 in. Nos. 1-3, January 15-Mar. 15, 1901.

* No. 3 is printed on rose paper and some copies of this num-

ROBINSON'S REVIEW. Robinson's review. A monthly magazine for stamp collectors.

Chicago, Ill., R. Robinson, I 902-03.

8. $9 \frac{1}{4}$ in. Nos. 1-10, March-Nov., 1902, Feb., 1903.

* Nos. 4 and 5 were published together and there is a coloured paper wrapper to each number. $\quad$ Mis. St. Jour. 103 (6).

ROCKY IMOUNTAIN PHILATELIST. The Rocky Mountain philatelist.

Boulder, Colo., E. D. Torrey and F. E. Roth, I893 $8^{\circ} .8 \frac{1}{2}$ in. Nos. 1-2, February-June 10, 1893.

* * There is a coloured paper wrapper to each number.

Mis. St. Jour. 62 (3)

ROCKY IVOUNTAIN STAMP. The Rocky Mountain stamp. A monthly journal devoted to stamp collectors. Denver, Colo., etc., The Rocky Mountain Stamp Publushing Co., etc., 1895-98.

$8^{\circ} \cdot 9-8 \frac{3}{4}$ in. 38 nos. in 4 vols.

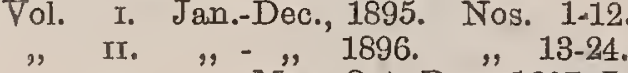

"II. " "-Má, Oct.-Dec., 1897, Jan.-Apl., 1898. Nos. 25-36 "IV. Oct.,

There published by J d Dodge at New Oxford, $\mathrm{Pa}$

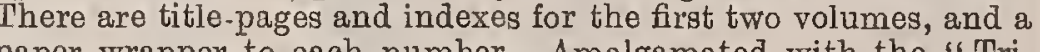
Monthly collector," January, 1899.

ROIIA FILATELICA. Roma filatelica. Bollettino della Società Filatelica Internazionale di Roma.

$8^{\circ} .10$ in. $\dot{8}$ nos. in 2 vols Roma, Giuseppe Lanzi, I896-97.

1st year. Nov. 1-Dec. 1, 1896. Nos. 1-2.

2nd "Jan. 1-Apl. 1, June 1, July 1, 1897. Nos. 3-8.

* Nos. 7 and 8 were published together under the date " 1

Giugno-1 Luglio, 1897 ". Mis. St. Jour. 89 (7).

ROMANIA PHILATPLICA. Romania philatelica. Revista lunara ilustrata. Fol. $12 \frac{1}{2}$ in. No. 1, September, 1893.

Jassy, Alfr. A. Rothenberg, I893.

* * The contents are published in Roumanian and German. Mis. St. Jour. 120 (12)

ROSARIO FILATEIICO. El Rosario filatélico.

Rosario de Santa-F'é, Argentine Republic, Daniel D. Garibaldi y A. MI. Guzman, etc., I893-97.

Fol. $14 \frac{3}{4}$ in., 12 in. and 14 in., $8^{\circ} .10$ in. and $4^{\circ} .10^{3}$ in. 10 nos. in 4 vols.

1st year. July 1-Dec. 1, 1893. Nos. 1-6.

2nd ", ", 1-Oct. 10, 1894. , 1-[2].

[3rd ", ] Sept. 30, 1895. No. 1

* th " Mar. 30, 1897. , 1.

* * Nos. 1-6 measure 14.3. inches; no. 1 of the second year 12 inches, the number for October 10, 1894, 14 inches, that for Sep tember 30,1895, 10 inches and that for March 30, 1897, 10 inches. The last four numbers were published by D. D. Garibaldi No. 1 of the second year was printed by an autographic process. The three numbers for 1894-95 are numbered, "N. 1, 2 Ep."

Mis. St. Jour. 75 (7)

ROTTERDAII PHILATHLIST. Rotterdam Philatelist. Rotterdam, J. T. Vijftigschild, I892-93. $4^{\circ} .11$ in. Nos. 1-6, Sept. 30, 1892-Jan. 20, March 1, 1893.

Mis. St. Jour. 109 (8)

ROUMANIE PHILATÉLIQUE. La Roumanie philatélique. Revue mensuelle. Le plus répandu journal philatélique en Roumanie et dans la Pen. Balcanique. Bucarest, Etienne Constantinovitch, I 904-05.

$8^{\circ} .91$ in. Nos. 1-3, December, 1904-February $28,1905$.
* * There is a coloured paper wrapper to each number. Mis. St. Jour. 123 (12)

ROUMANIE TIMBROPHILE. La Roumanie timbrophile. Journal mensuelle d'annonces.

Bacău, Hermann Rosenberg, I 905. Fol. $12 \frac{3}{4}$ in. and $11 \frac{1}{2}$ in. Nos. 1-10, March-December, 1905. * * The contents consist entircly of advertisements. $\mathbb{N N o}_{\text {. }} 1$ is printed on green paper and nos. 2 and 3,4 and 5 , and 8 and 9 were severally published together. No. 10 measures only $11 \frac{1}{2}$ inches and was produced by a hectographic process. The subtitle on no. 1 reads "Journal mensuel d'annonces". Wanting
mos. 6, 7.
Mis. St. Jour. 137 (13).

ROUND TABLE. The Round table. New York. Vol. III., no. 43, June 30, 1866. [Cuttings of the article "Philately" (by L. H. Bagg) are mounted in Stamp Scrap-book, vol. II., pp. 100, 101.]

ROUTLEDGE'S MAGAZINE FOR BOYS. See EVERT BOY'S MAGAZINE.

ROVER. The Rover. Potsdam, O., [? ], I894-95. ** Onily partly philatelic. Wanting all nos.

ROVER. The Rover. Vol. II., no. 1, December, 1899 [Contains an article "Stamp chat" by C. E. Severn.] $8^{\circ} .10$ in. pp. 46,47 Chicago, Ill., E. and M. Hutchison, 1899

* * The number has a coloured paper wrapper.

Mis. St. Jour. 140 (3)

ROVHR. The Rover.

Elk Point, So. Dak., R. I. Ellis, I900-о I.

$8^{\circ} .8$ in. Nos. 1-5, October, 19C0-February 1901

* * Only partly philatelic. Nos. 1-4 have coloured paper wrappers. 

ROVER

\section{[Continued as :]}

Public opinion and rover.

Tourdes, Ta., E. E. Lovrien, г gor. in. Nos. 10-11, April-May, 1901.

**. Only partly philatelic. Nos. 69 of "Publie opinion" contained no philatelic matter. Wanting both nos.

ROWLAND HILL. Rowland Hill. Philatelistisches Insertions-Organ.

$$
\text { Wien, Löwinger und Knopflmacher, eto., I88 ז-82. }
$$
Fol. $13^{\frac{3}{4}}$ in. 10 nos, in 2 vols.

Vol. r. Apl. 1-Nov. 1, 1881 .

Nos. 1-8.

." II. Jan, 15, July 15, 1882 . " 1-2.

* * Nos. 6-8, vol. 1, and no. 1, vol, II., were published by Max H. Löwinger and no. 2, vol. rr., by Carl Hlauschek. There is a supplement of two pages, printed on one side only, to no. 7 and no. 2, vol. $\mathrm{Mr}$., is wrongly numbered " $\mathrm{Nr} .1$ ".

Mis. St. Jour. 51 (1).

ROYAI IMAGAZINF. The Royal magazine. November, 1903. [The front paper wrapper bears an enlarged illustration of the then current Great Britain four pence postage stamp.]

$8^{\circ} .9 \frac{3}{4}$ in.

London, W.C., O. Arthur Pearson, Ltd., 1903.

* * The number has a paper wrapper. Mis. St. Pamph.64 (3).

ROYAL PHILATELIST. The Royal philatelist.

Sterling, N. Y., Milton E. Marsh, I892. $16^{\circ} 6$ in and $8^{\circ} .8^{3}$ in. Nos. 1-6, Mar.-Aug., 1892.

* * Nos, 1-3 are $16^{\circ}$. and have coloured paper wrappers, nos. 4-6 aie 8. and have no wrappers. No. I is named" "Nol. I., no. 1 , no. 3, Whole no 5 ".
ROYAL PHILATELIST, OR STAIMP COLLECTORS IIONTHLY NEWS. The Royal philatelist, or stamp collectors' monthly news.

Liverpool, A. H. Mahon and Co., r882.

$8^{\circ} .8 \frac{1}{1}$ in. No. 1 , January, 1882.

* * A copy of the prospoctus of the journal is bound up with it * A copy of the prospoctus of the joutnal is bound up with it, and to give the paper the titile " "Amateur Philatelist or the stamp
collector's monthly news".

RUMANISCHER-PHILATELIST. Rumänischer-Philatelist. Insertions Organ für Briefmarken-Händler und Sammier. Bucarest, Oscar D. Perlmunn, I896. Fol. 13 in. Nos, 1-2, April 1-May 1, 1896.

Mis. St. Jour. 97 (15)

RUMÄNISCHES BRIEFIVARKEN - OFFERTEN-

○ BLATT. Rumänisches Briefmarken-Offertenblatt.

(c) $8^{\circ} .8 \frac{1}{1}$ in. No. 1 , March 15,1901

Jassy, Salomon Spiegler, ז 90 т.

* * A copy of two prospectuses of the journal, one in French and the other in German, are bound up with the number.

Mis. St. Jour. 137 (3)

RUND UM DIF ERDE. See INT'ERNationates BRIEF' MARKENBUATT "CoNCORDia".

RURAL NEW-YORKER. The Rural New-Yorker. New York. Vol. 38, nos. 35 and 43, August 30, and Octotober 25, 1879. [Cuttings of the articles "Sale of rare postage stamps" and "Frcts about philately," are mounted in Stamp Scrap-book, vol, IV., pp. 28-30.] 
SÄCHSISCHES POSTWERTHZETCHEN - OFFERTENBLATTr. Sächsisches Postwerthzeichen-Offertenblatt. Bautzen i. S., F. Schmelzer, 1895 .

$8^{\circ}$. 91 in. Nos. 1-3, March 1, Apl. 1, June 1, 1895.

* * The contents consist entirely of advertisement

Mis. St. Jour. 99 (2)

SALE PRICES. Sale prices. Monthly supplement to the Connoisseur. London, W. C., Otto Limited, I901-02. Fol. $13 \frac{3}{2}$ in. 13 nos. in 2 vols.

Yol. I Dec. 20, 1901-Nov, 30, 1902. Nos, 1-19.

Vol. I. Dec. 20, 1901-Nov. 30,190

* * El. II. list of the prices made by the principal lots of stamps and other articles sold by public auction. Although called a supplement to the "Connoisseur" it was an entirely separate publication.

[Continued as:]

- Auction sale prices. Supplement to. the Connoisseur. London, W. C., Otto Limited, I903-o6.

Fol. $18_{4}^{8}$ in. and $8^{\circ} .99$ in. Vols. II.-VIII. 40 nos.

Vol. II. Jan. 30 -May 30, 1903. Nos. 14-18.

", IIT June 30 -Nov. 30, " $19-21$.

", IV. Dec. 30, 1903-MTay 30, 1904. " ", $25-30$.

" $\quad$ จ. June 30 -Nov. 30, ", ", 31-36.

" vi. Dec. 31, 1904-May 31, 1905. " " $37-42$.

" VII. June 30 Jume 30, Sept. 29, Dec."31, 1905. Nos. 50-53 *" There is a title-page and an index to each volume and a coloured paper wrapper to each number. The wrapper of no. 31 has "Vol IV" in place of "Vol. v.," and those of nos. 43 and 44 bear "vol. vI." instead of "vol. VII." Nos. 14-30 are folio and the remaining numbers are octavo. Each number contains allist of the prices made by the principal lots of stamps and other articles sold by public anction. After the end of 1905 the jomrnal was published quarteris. Altinough called a supplement to the "Connoisseur" it was an entirely separate publication. The journal was continued after the end of 1906 , but ceased to contain philatelic matter.

SALESMAN. The Salesman. A paper issued in the interests of philately, and the Consolidated Stamp Company, whenever needed.

Wymore, Neb., The Consolidated Stamp Co., [rgor]. $16^{\circ} .7$ in. No. 1, [September, 1901].

* * The number bears no date. Amalgamated with the "Cyclone," D* Mis. St. Jour. 106 (4).

SAIT CITY PHIIATEIIST. The Salt City philatelist.

Syracuse, N. Y., Salt City Stamp and Publishing Co., etc., $x 89 \mathrm{I}-93$.

$32^{\circ} .4_{4}^{3}$ in. and $16^{\circ} .6-6 \frac{1}{2}$ in. 13 nos. in 2 vols.

Vol. I. Oct, 1891-July, 1892. Nos. 1-10.

IT. Nov., Dec., 1892, Mar. 1893 . Nos. 1-3.

*" II. Nov., Dec., $16^{\circ}$. $6 \frac{1}{3}$ inches. Nos. 8-10, vol. I., and nos. 1-3, vol. II., were published by W. J. Spire. There are coloured paper wrappers to nos. $4-9$, vol. I., and to no. 3, vol. II. This last number has the year wrongly given as " 1892 " instead of "1893," but the date is cor-
rect on the wrapper.
Mis. St. Jour. 64 (1).

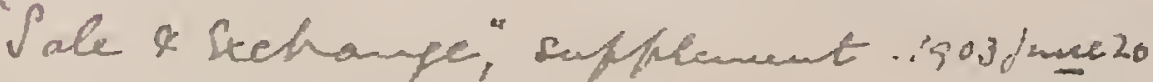

$$
\begin{aligned}
& \text { see "Collector's luectiby Secherpe rhale } \\
& \text { agventiver" 1503 Bayfurater }
\end{aligned}
$$

\section{SALT CITY PHIIATELIST}

\author{
[Continued as :]
}

The Syracuse philatelist.

Syracuse, N. Y., W. J. Spire, I893-94. $16^{\circ} .7$ in. and $8^{\circ} .8 \frac{1}{1}$ in. Vol. II. 4 nos.

Vol. II. May, Aug., Oct., 1893, Jan., 1894. Nos. 4-7.

${ }_{*}^{*}$ No. 4 is $16^{\circ}$. and the remainder are octavo. There are coloured paper wrappers to nos. 4 and 7 , and no. 4 has the year wrongly given as " "892" instead of 1893. The wrapper of this number
is dated "April, 1893".

\section{SAIMMLER. Der Sammler.}

Mïnchen, etc., J. Heinhold, etc., г880-90.

$8^{\circ}$. 11-113 in. 187 nos. in 12 vols

1st year. June-Dec. 15, 1880. Probenummer and nos. 1-6.

2nd "Jan. 15 1881-May 15, 1882. Nos. 7-23.

3rd " June 15, 1882-June 1, 1883. " 24-33.

4th " July 15 -Dec. 10, $1883 . \quad$ "34-39.

5th " Jan. 15 - ", 15, 1884. " " $1-12$.

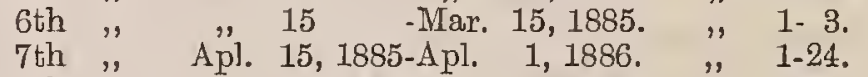

8th ", " 15 1886" $1,1887 . \quad$ ", $1-24$.

9th " " $\quad 151887-, " \quad 1,1888 . \quad, \quad 1-24$.

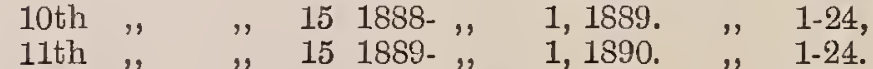

12th ", " 1 -Sept. 15, $1890 . \quad$ ", $1-12$

*** Only partly philatelic and after no. 12 of the twelfth year ceased to contain any philatelic matter. From no. 32 to the on of the sixth year the journal was published by Paul Breithaupt, nos. 1-12 of the seventh year were published by J. Kürschner at Stuttgart and commencing with no. 13 of the seventh year, the journal was published at Berlin by Dr. Hans Brendicke. There is a title-page and an index for the first eleven numbers and the Probenummer, and these numbers are called "I. Jahrgang" on the title-page and the fiftb, seventh, eighth, minth, tenth, eleventh the twe-page and the $15 ; 16,17$ and $18 ; 10$ have a title-page and an index. N 33,35 and 36 , nos. 7 and 8,19 and 20,22 and 23,29 and 30,32 and 3 , year, nos. 7 and 8,9 and 10 of the tenth year and nos. 7 and 8,9 and 10 of the eleventh year, were severally published together. Nos. 29-30 have "II. Jahrgang" in error for "III. Jahrgang". The Probenummer, nos. 1-39, and the numbers of the twellfth year have paper wrappers, the wrappers of nos. 1 and 2 having no numbers. No. 14 of the eighth year, has a supplemental slip; there is a supplement with the title "Anzeicenbeilage" to nos. 19, 21, 23 and 24 of the eighth year; one with the title "Beilage zur Fachzeitschrift "Der' Sammler" to nos. 2, 3, 4, 5, 6, 7-8, 9$10,11,12,14,15,16,18,19,20,21,22,23,24$ of the ninth year; nos. $1,2,3,4,5,9-10,11,13,14,15,16,17,19,20$ of the tenth year; and nos. $1,2,3,5,6,11,12,13,14,15,16,17,18,19,20,21$, 22, 23, 24 of the eleventh year; one with the title "Sonder-Abdruck aus der illustrirten F'achzeitschrift 'Der Sammler,', tenth year, 11-13, 14-15, 16, 18-22, 23-24; eleventh year, 1-2, 2-4, 4-6, 6-10, 11-12, 12-13, 13-14, 14-15, 16-17, 18-20, 20-22, 22-23, 2324 ; and one with the title "Rundschau über neu erschienene schrift "Der Sammler," to nos. 1-11 of the twelfth year.

SAIVIMLER. Der Sammler. Bruchsal, Philatelisten-Schüler-Verein, 1890. $4^{\circ} .8 \frac{1}{2}$ in. [No. 1], May, 1890 4. $4^{\circ}$ in. [No. 1], May, 1890. Wanting. 

Salinday Resient-S121

Scaldis Phiraterique In S chardis Phiruterique S12.1 
SAMIMLER. Der Sammler. Briefmarkenoffertenblatt mit den kostenfreien Beiblättern, Die Ansichtskarte, Der Ganzsachensammler, Die Stempelmarke, Der Münzensammler, Die Siegelmarke, Vereins-Anzeiger.

Passan, H. Schieber, I 905-06.

$4^{\circ} .11 \frac{3}{4}$ in. 2 nos. in 2 vols

[1st year.] [Dec.], 1905. No. 12.

2nd * [Feb.], 1906. "No 1.

a bove are known. No. 12 contains a supplement with the title

"Vereins-Auzeiger". Mis. St. Jour. 129 (15)

SAIMIMLER, See Wertwarte.

SAMMLER-BÖRSE， Sammler-Börse. Internationales Wochenblatt im Dienste aller Sammel-Interessen.

Leipzig, Frankenstein und Wagner, I896-99.

$4^{\circ} .12 \frac{1}{2}$ in. Vols. IV.-VII, 106 nos.

4 th year. July 2-Dec. 31, 1896 . Nos, 1-27.

5th "Jan. 7- " 20, 1897. ", 1-37.

Tth " " 5- " " " 20, 1898. ", 20, 1899.

* * Ouly partly philatelic. From no. 25 of the fifth year the subtitle reads "Internationale Zcitschrift im Dienste aller SammelInteressen" and from no. 19 of the sixth year "Interontionale Interessen "and from no. 19 of the sisuh sear "Internationale Zeitschrift für Philatelie und Ansichts-Postkarten, etc." The $2,11,12,13,18$ for 1896, no. 6 for 1897 , no. 14 for 1898 and nos. $16,17,18$ for 1899 .

SAMIMLER-BÖRSE. Sammler-Börse.

Basel, Arnold Reimer, r 902 .

Fol. 11 in, [Nos. 1-3], January, August, September, 1902.

* Only partly philatelic. Printed on green paper. 'The numbers for August and September contain supplemental slips of red paper. Wanting the number for August, 1902.

SAMIMLER-BÖRSE. Sammler-Börse. Bourse-collectionneur. Collector - purse. Monats - Ausgabe. Edition mensuel. Monthly edition.

Basel, Arnold Reimer, [? I 903]

$16^{\circ} .61$ in

The library only contains one num** Only partly philatelic. The library only contains one numnumber or date.

SAIMIMLFRFREUND. Der Sammlerfreund. Mannheim, Hermann Motz, I895-96. $8^{\circ} .11 \frac{1}{4}$ in. and 9 in. Nos. 1-14, Xmas, 1895, Jan.-Dec. 15, 1896. * * There are two numbers for February, one dated the 15th and the other the 29th. Nos. 9-14 were published with "Die Briefmarke" for July-Dec., 1896, in octavo form, measuring 9 inches,
and are bound up with that jourual.

SAMMLERVEREIN FÜR PRIVATPOSTWERTH ZEICHEN. VEREINS - MITTHEILUNGEN Sammlerverein für Privatpostwerthzeichen. VereinsMittheilungen. 8. 9in. 14. nos. in 2 vols.

1st year. Jan.-Dec., 1894. Nos. 1-12.

$S|\lambda|$ 2nd " " -Feb., 1895. Nos. $1-12$

* * Produced" by a hectographic process with the exception of the heading which is printed. Wanting all but nos. 1,2, 3 of the first year.

SAN IVIARINO. San Marino.

Pistoia, Italie, M. De-Sperati, x895. Fol. 15 in. Nos. 1-S, Jan. 15-Aug. 1̦, 1895 Mis. St. Jour. 75 (6)

[Continued as :

San Marino Corriere dei francobolli.

Torino, Vittorio Durani e Co., I895-98. $8^{\circ} .93 \mathrm{in}$. and fol. $19 \frac{1}{2} \mathrm{in.}$ Vols. II.-Y. 30 nos.

[2nd ycar.] Nov. 30, Dec. 30-J 1390, N1, Sept, 30-Dec. 31, 1896. Nos. $3-12$

[4th " ] "28-Dec. 31, 1897. Nos. 13-24.

5th "Jan. 31 -May 18, 1898.

* * All the numbers are octaro with the exćeption of the last"Anno $\nabla . N, 5,6$ " - which is folio, and no. 1 of 1895 has a coloured 19 and 19. "5-28 del Corriere dei francobolli" and 9-32 del San Marino".

SAN IMARINO CORRIERE DEI FRANCOBOLLI. See San Marino.

SAN MARINO PHILATELIST. San Marino philatelist. San Marino, Otto Bickel, т892-94. $4^{\circ} .11^{\frac{1}{4}} \mathrm{in}, 8^{\circ}, 8 \frac{1}{2} \mathrm{in}$. and $10 \mathrm{in} .28$ nos. in 3 rols. 1st year. Jan.-Dec., 1892. Nos. 1-12. 3rd " [no dates], 1894. ", $1-4$.

* "Nos. 5 and 6 and 7 and 8 of the first year wcre severally published together. No. 10 of the first year, no. 4 of the second year and nos. 1-4 of the third year are octavo, measuring about 8 inches and no, 6 of the second year is octavo 10 inches. Bound up with the journal is a copy of the prospectus dated December, 1891. This was the first philatelic journal published in San Marino.

\section{[Continued as :]}

San Marino postal. Revue Timbrologique et feuille d'annonces.

$4^{\circ} .11$ in. Vol. virr. 5 nos.

Sth year. Feb., 1899, 1899, Nos. 1-5.

* * Printed on buff paper. Nos. 3 and 4 were published together, and nos. 2-5 only bear the date "1899". Mis. St. Jour. 109 (11).

SAN MIARINO POSTAL. See SiN MaRino PhILATELIST.

SANGAMIN PHILATELIST. The Sangamon philate-

list.

$16^{\circ} .5 \frac{1}{4} \mathrm{in}$. Nos. 1-4, Jamuary- [? ] 1897.

* Only three numbers in all were issued, as the second number has " 3 " on the cover and " 2 " inside, and the third number" is numbcred " 4 ". TVanting all but no. 1 .

SANTANDER FILATEIICO. Santander filatelico.

Bucaramanga, Colombia, Inis Fernando Prada $G$. etc., I 905-06.

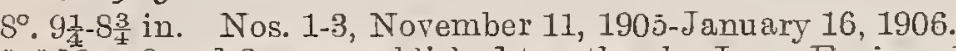

* Nos. 2 and 3 were published together by Jorge Enrique Barco "Joaquin Castro. Copies of this double number have "y 3 " o "Nun. 2 y 3 " struck out with pen and ink.

Mis. St Jour. 125 (8)

SANTO DOIMINGO POSTAL. Santo Domingo postal. Santo Domingo, Pedro E. Perez, etc., I903-05. $S^{\circ} .9 \frac{3}{4}-10 \frac{1}{4}$ in. 15 nos. in 2 vols.

1st year. March 1-Dec., 1903, Sept., 1904. Nos. 1-12.

lst year. March 1-Dec., 1903, Sept., 1904.

* "Nos. 2 and 3 were published by Pedro E. Perez and Enrique *" Curiel,no. 4 by Pedro E. Perez, nos. 5-12 by Pedro E. Percz y Luis E. Mañon and nos. 13-15 by Luis E. Mañon, J. R. Pérez y Luis E. Mañon and nos. $13-15$ by Luis $\mathrm{E}$. Mañon, J.R. Perez Nolasco y Hoo. A. Contin. Nos. "D 15 we severally published together "ith the respecuive dates"

"Deciembre de 1903," "Setiembre de 1904" and "Enero de 1905 "

SARATOGA AIMATEUR NEWS. The Saratoga amateur news.

Saratoga Springs, N. Y., The Crescent Publishing Co., I 900.

in. Nos. 1-4, September-December, 1900. *** Only partly philatelic. Nos. 3 and 4 were published together.
W.

$$
\text { [Continued as :] }
$$

The Monthly amateur and stamp news.

Saratoga Springs, N. Y., The Crescent Publishing Co., I gor.

8०. 9 in. Nos. 5-6, January-February, 1901.

* Only partly philatelic. Wanting mo. 5.

SAYIMION'S IMAGAZINE. Saymon's magazine. A monthly devoted to literature and philately. New York, Joseph Saymon, r 903

$8^{\circ} .9$ in. No. 1, September, 1903.

* "The number has a coloured paper wrapper. Mis. St. Jour. $103(5)$

SCHALDIS PHILATÉLIQUE. Schaldis philatélique.

Anvers, Ed. Hulsens, т896-97.

1st year. July $1,1896-J u n e, 1897$. Nos. 1-12

1st year. July 1, 1896-June, 1897. Nos. 1-12.
2nd Aug., 1897. Nos. 13-14.

" * Nos. 10 and 11 were published together under the date "Mai, 1897 " and nos. 3. 4 and 6-14 have coloured paper wrappers. Nos. " For continuation see "Antverpia". Mis. St. Jour. 110 (7). 
SCHLESWIG-HOLSTEINISCHE BRIFFMARKENZEITUNG. Schleswig - Holsteinische BriefmarkenZeitung.

Baurup, etc., Schleswig-Holstein, With. L. Knutz, etc., I894-95.

$8^{\circ} .9$ in. and $4^{\circ} .11^{3}-11$ in. 16 nos. in 2 vols.

1st year. Sept. 10-Dec. 10, 1894. Nos. 1-4.

2nd "Jan. 25- , 7, 1895. ," 1-12.

* *Nos. 1 and 2 of the first year are octavo and the remaining numbers are quarto. Nos. 3-9 of th ' second year wcre published year were published together.

SCHOOLMATE. The Schoolmate.

Plymouth, Muss., J. H. Marqueze and Co., I873. ** Cuttings of the stamp portions in the numbers for April 1 , II.ay, July nd August, 1873, are mounted in Stamp Scrap-book, vol. I1., pp. 53, 54, 55 .

SCHORERS FAMILIENBLATT. Schorers Familienbla.t. Gegründet 1880. Eine illustrierte Zeitschrift. Nr. 9, 1893, with "Zwreites Blatt" and "Drittes Blatt". [The "Zweites Blatt" contains an article "Die neuen Briefmarken der Vereinigten Staaten von Nordamerika" by C. Lindenberg, with illustrations.]

Berlin, J. H. Schorer A. G., I893.

Fol. 12: in. pp. 41, $42 . \quad$ Mis. St. Jour. 128 (2).

SCHRIFTLICHE IMITTHEILUNGEN DES “ MER-

CUR". See MittheiLUNGen Des "Merkur".

SCHWEIZER BRIEFMARKEN-JOURNAL. Schwoizer Briefmarken-Journal.

Lausanne, Hans Kirchhofer, etc., 1888-93. $8^{\circ} .10 \frac{3}{7}$ in. 61 nos. in 6 vols.

1st year. Nov., 1888, Jan.-Dec., 1889. "Probenummer" and 2nd , Jan.-Dec., 1890. Nos. 1-12.

3rd " " " " 1891. " 1-12.

5th ", Aug.-Dec., 1892. " " $1-7$.

6th ", Jan.- ," 1893.

** There are title-pages and "indexes for the years 1889-92 and an index for 1893. The sixth year was published by the Schweiz. Philatelisten-Verein, Basel, and there is a supplement to no. 2 of that year containing the programme, map, etc., of the Zurich philatelic exhibition held in June, 1893 .

[Continued as :]

Schweizer Briefmarken-Zeitung. $1894-$

Basel, etc., Schweiz. Philatelisten - Verein, etc.,

$8^{\circ} \cdot 10_{4}^{3}$ in. and $4^{\circ} .11$ in. Vol. vir.-

7th year. Jan. -Dec., 1894. Nos. 1-12.

8th " " - " 1895 . " 1-12.

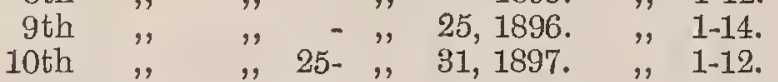

11th ", ", 25-", $1898 . \quad, " 1-12$.

12th " " - " $\quad 1899 . \quad$ " $1-12$.

14th " " "

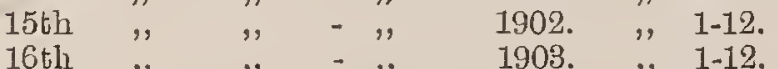

17th ", " - " $\quad 1904 . \quad$ " $11-12$.

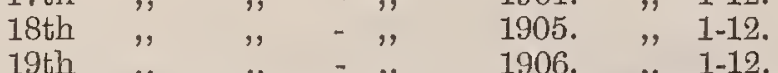

* * Commencing with the eleventh year the size was altered to quarto. The ninth and tenth years were published by the Société Philatélique de Genève and commencing with the eleventh year the journal has been published at Lausanne by the Société Lausannoise de Timbrologie. There are title-pages and indexes to the ninth, fifteenth, sixteenth, seventeenth, eighteenth, and nineteenth years and indexes to the other years. Two numbers were published in the month of March and also in July, 1896, nos. 8 and 9 of the tenth, eleventh, thirteenth, fourteenth, sixteenth, seventeenth and nineteenth years and nos. 7 and 8 of the eighteenth year were severally published together. There are special suppleyear were nith the titles "Guide Philatelique" and "L' Universelle," which will be found catalogued under their respective names, and other supplements to nos. 1-5 and nos $10-11$ of the ninth year, nos. 2-10 of the tenth year, nos. 1-12 of the eleventh year, nos, 1-7 and 9-11 of the twelfth rear. nos $1,3,5$, $6,7,8$, and 12 of the thirteenth year, nos. 1-10 of the fourteenth year, no 3 of the seventeenth year, nos, 10 and 12 of the eighteenth year, and to nos. 17 of the nineteenth year S the eighteenth year, and of thes. 1-7 of the nie neenth year. Separate supple作 zerischer Philatelisten-Vereine were given with
seventh year, no. 7 of the tenth year and in 1900.
SCHWHIZER BRIFFIMARIENN-ZFITUNG. Schweizer Briefmarken-Zeitung. Organ für die Gesammtinteressen der Briefmarkenkunde.

Bern, R. Deyhle et Cie., I879.

$4^{\circ} .102$ in. Nos. 1-6, July 20-Dec. 20, 1879

[Continued as :]

Schweizer Illustrirte Briefmarken-Zeitung. Organ für die Gesammt-interessen der Philatelie.

$4^{\circ} .10 \frac{3}{4}$ in. Vols. Ir.-VIrt. 81 nos.

Bern, R. Deyhle et Cie., r88o-87.

2nd year. Jan. 22-Dec. 22, 1880. Nos. 1-12.

3rd " " $22-\quad$ " 22, $1881 . \quad$ " 1-12.

4th " " $22-"$ " 22, $1882 . \quad " 1-12$.

6th " " ", 22- ," $22,1883, \quad$ " $1884 . \quad 1-12$.

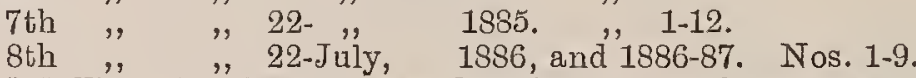

* * * There is " " *** There is a title-page and an index to each year excepting the
last. There is no number for October, 1881 , but nos. 10 and 11 of that year are both dated " 22 November," nos. 7 and 8 of the of that year are both dated " 22 November," nos. 7 and 8 of the seventh year and nos. 5 and 6 , and 8 and 9 of the eighth year
were severally published together and the last bears no date were severally published together and the last bears no date except "virr. Jahrgang,
to no. 2 of the third year.

SCHWEIZFR BRIEFMARKEN - ZEITUNG. See Schweizer Briefmarken-Journal.

SCHWEIZER ILLUSTRIRTE BRIEFIMARKEN ZFITUNG. See Schweizer Briefmarken-Zeitung.

\section{SCHWEIZER POST. Schweizer Post.}

Dïbendorf, etc., J. Thalmann, 1900-05.

$4^{\circ} .11_{\text {a }}^{3}$ in. 61 nos. in 5 rols.

1st year. Dec. 15, 1900, Jan. 15-Dec. 5, 1901. "Probenummer" and nos. 1-12.

2nd "Jan. 15-Dec. 15, 1902. Nos. 1-12

3rd " " 20- " 20, 1903. " 1-12.

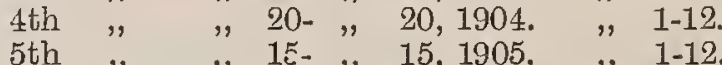

*th On"ly partly philatelic. The "Px"obenummer" and nos. 1-2 bear "Offizielles Organ des Schweizerischen Centralvereins für Ansichtskartensammler"; nos. 3-9 have "Offizielles Organ des Internationalen Gelegenheitskarten-sammler-Verbandes" ; nos. 10-12 of the first year and nos. 1-4 of the second year have the words " und des Briefmarkenklubs des S. C. V." added to those found on nos. 3-9; and the remaining numbers bear "Offizielles Organ des Schweizer. Cen tralvereins für Ansichtskarten-Sammler und des Briefmarkenklubs des S. C. V.". Commencing with no. 12 of the first year the journal was published at Fischenthal and no. 1 of the second year has " 1901 " in error for "1902". The "Probenummer" and nos. 1, 4, 5 of the first year have supplements and no. 9 of the same year has a supplemental slip.

\section{[Continued as :]}

Weltpost.

Fischenthal, J. Thalmann, I go6$4^{\circ}$. $11_{\text {a }}^{3}$ in. Vol. vr.- nos. In progress.

* * Only partly philatelic. Nos. 1-4 bear "Offizielles Organ des Schweizer. Centralvereins für Ansichtskarten-Sammler und des Briefmarkenklubs des S. C. V." and the remaining numbers have "Offizielles Organ des Schweizer. Centralvereins für Ansichtskarten - Sammler und des Briefmarkenklubs Weltpost". Commencing with no. 11 a copy of the "Annonce Universelle," the supplement of the "Schweizer Briefmarken-Zeitung," was presented also as a supplement to this journal.

\section{SCHWEIZERISCHE BRIEFIMARIRNNZEITUNG.} Schweizerische Briefmarkenzeitung

Schwanden, Kts. Glarus, Eduard Riesen, I875. $8^{\circ} .9$ in. Nos. 1-4. [Oct.-Nov.], 1875.

* * This was the first philatelic journal published in Switzerland. Mis. St. Jour. 25 (4).

[Continued as :]

Internationale Briefmarkenzeitung. Schwanden, Kts. Glarus, Eduard Riesen, 1875-76. $8^{\circ} .8 \frac{1}{2}$ in. Nos. 5-7, [Dec.], 1875, [Jan.], 1876.

** Nos. 5 and 6 were published together.

Mis. St. Jour. 25 (4a). 
Solus Phit.revions. Zurich.

$\theta$ Marco lister mil Let iso u hor 1 leaf

Scots Philatelist

Sicilia Frlateliea, Palermo, 1907/8

Lw it's Monthly faunal $(1920 / 30=\operatorname{Vol} 1-$ Vol $\times 1 / 12)$

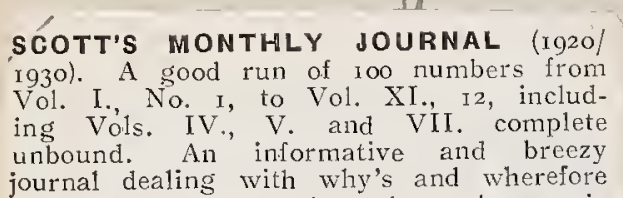

journal dealing with why's and wherefore
of design rather than its microscopic
detail. 


\section{SCHWEIZERISCHE BRIEFIARKENZEITUNG.}

\section{[Continued as:]}

Internationale Briefmarken-Zeitung. Glarus Schwanden-Schweiz. Philatelie, Post- und Telegraphenwesen Zweite Serie.

Schwanden, Kts. Glarus, Eduard Riesen, 1876. $8^{\circ} .8 \frac{1}{2}$ in. Nos. 8-9, [No month], 1876.

*" Nos. 8 and 9 were published together.

Mis. St. Jour. 25 (4b).

\section{SCHWEIZERISCHER PHILATELISTEN - VEREIN} ZÜRICH. VEREINS-IMITTHEILUNGEN. Schweizerischer Philatelisten-Verein Zürich. Vereins-Mittheilungen.

$8^{\circ} .8 \frac{1}{2}$ in. Nos. $1-12$, Nov. 1, 1884-Dec. 1, 1885.
** No. 9 is dated " 1 "Juli-1 September, 1885 ," and nos, 10-12 Ziirich, $1884-85$ were published together" with the date "1 Oktober-1. Dezember 1885 " Nos. 8-12 have the word "Zürich" dropped from the title. Mis. St. Jour. 117 (8)

SCHWINDLER - ADRESSBUCH. Schwindler ${ }_{\text {Adress }}$ buch. $4^{\circ} .107$ in. Nos. 1-15, [1877]

Hamburg, Robert Mayerhofer, 1877 .

* * This consists of a printed prospectus dated "März, 1877" and fifteen numbers written in pen and ink, with the exception of no. 9 , which is in blue pencil, and of nos. 14 and 15 , which are letterpress copies of the original writings. None of the numbers bear any date. The prospectus is found printed on lilac and on yellow paper. Mis. St. Jour. 129 (9)

SCIENCE OBSERVER. The Science observer. A monthly journal devoted to the development of science. Vineland, N. J., A. C. Smith, 1887-88. $8^{\circ} .9$ in. Nos. 1-3, Dec., 1887-Feb., 1888 * * Only partly philatelic and there is a coloured paper wrapper ** Only partly philatelic and there is a coloured paper wrapper
to each number. St. Jour. 22 (13).
Mis.

SCISSORS. The Scissors. Beaver Dam, Wis., F. W. Jillson and Co., I 892. 8. $8 \frac{3}{4}$ in. No. 3, March, 1892 ** Only partly philatelic.

Mis. St. Jour. $143(7)$

SCOTT CO., L'D., WEEKLY NEWS LETTER, J.W See J. W. Scotr Co., L'D., WeEkLy News LeTter.

SCOTTISH NOTES AND QUERIES. Scottish notes and queries. Vol. vili. no. 9. February, 1895. [Contains an article "The Postage stamps of Aberdeen, Dundee, Edinburgh and Glasgow, 1865-69". By P. J. Anderson. With plate of illustrations.] $4^{\circ}$. $8 \frac{1}{2}$ in. pp. 129-144.
* The number has a coloured paper wrapper. Aberdeen, D. Wyllie and Son, I 895

Mis. St. Pamph. 24 (5)

SCOTTISH PHILATELIC ADVERTISER. Scotish philatelic advertiser. Published on the first Monday of every month.

South Queensferry, [T. A. Ferguson], I goo-or.

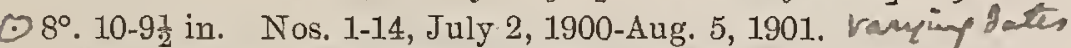

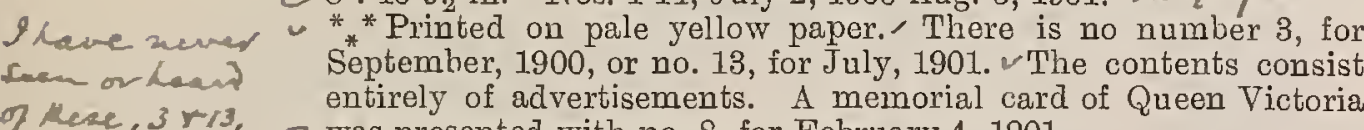

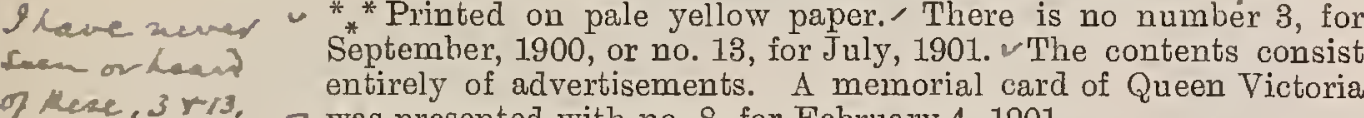

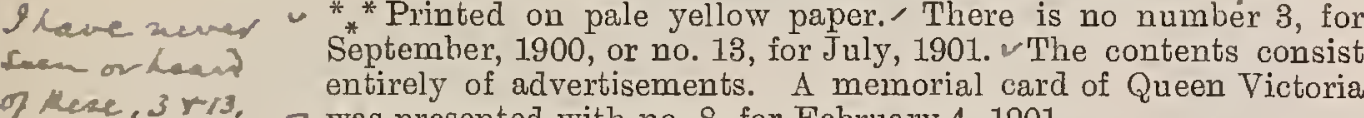

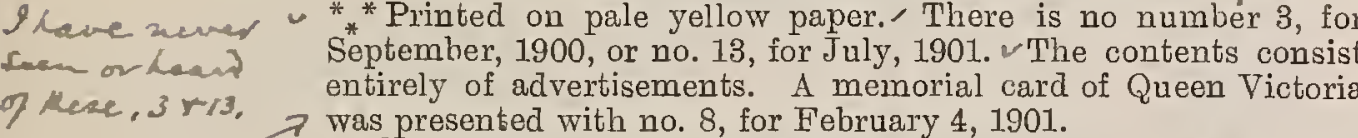

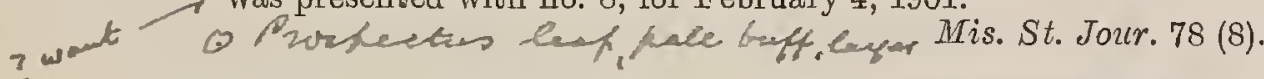

SCOTT'S IMONTHLY CIRCULAR AND "GENERAL ADVERTISER". See B. B. Scotr's MonTHIY CIRcular and "General advertiser ".

SCRAPS. See STAMP FACTS.

SCRIBNFR'S IMAGAZINE. Scribner's magazine. Vol. v. no. 3. March, 1889. [Contains an article "The Railway Mail Service".]

$8^{\circ} .93$ in. pp. $259-277$

New York, C. Scribner's Sons, I889.

* * The number has a coloured paper wrapper.

Mis. St. Pamph. 30 (23).

Serthik Pcetoreil Postcand aw phicater

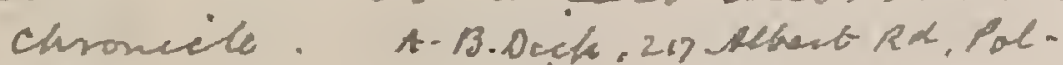
Corkstivils. Flasponer.

I. .1503 oct.

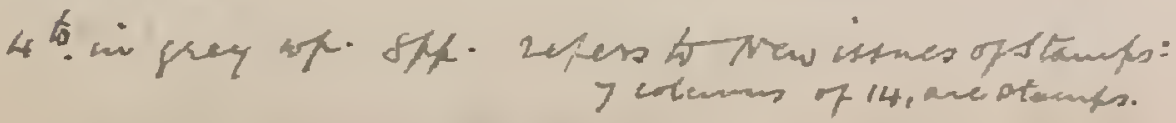

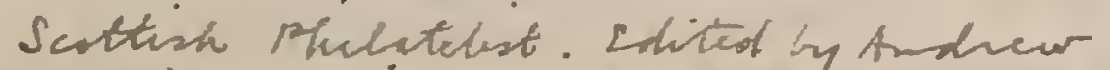

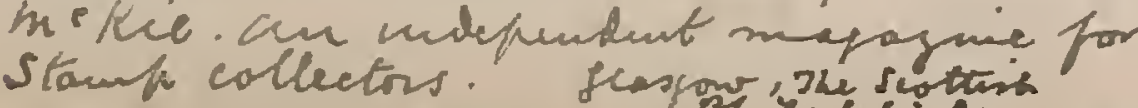

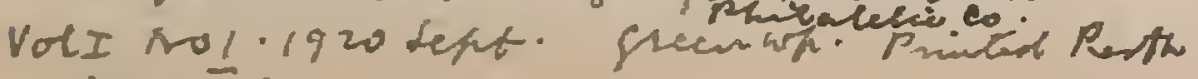
$102(\overline{0 e})$
SCRIBNER'S IMONTHLY. Scribner's monthly. An illustrated magazine for the people. Vol. xvI. No. 1. May, 1878. [Contains an article "The New York PostOffice," by Edward Eggleston.

$8^{\circ} .9 \frac{3}{4}$ in. pp. $59-79$

New York, Scribner and Co., 1878.

* * The number has a coloured paper wrapper.

Mis. St. Jour. 10 (8a).

SELLO. El Sello. Revista mensual de filatelia.

Iquique, Chile, Nicanor Polo, I904-o6.

$8^{\circ} .11$ in. 22 nos. in 2 vols.

1.st ycar. June 1, 1904-May 1, 1905. Nos. 1-12.

2nd ", 1, 1905-Mar. 1, 1906. ", 13-22. * "Nos. 1-17", 20 and 22 have paper wrappers. Nos. 13 and 14

SEIII-ANNUAL STAIMP COLLECTOR. The Semiannual stamp collector. A magazine in the interests of stamp collectors. Schenectady, N. Y., J.W. Jones, 1887. $8^{\circ} .7 \frac{3}{4}$ in. No. 1, Dec., 1887.

* The number has a coloured paper wrapper.

Mis. St. Jour. $65^{\prime}(5)$.

SEIMI-IMONTHLY CARRIHR. The Semi-monthly carrier. Delavan, Wis., J. W. Camp, I 878 . ** Cuttings of the stamp portions from no. 1, dated May 8th,
18 * 78 , are mounted in Stamp Scrap-book, vol. IV., p. 14 .

SENECA PHILATELIST. The Seneca philatelist.

Seneca Falls, N. Y., A.J. Littlejohn and Co., etc., I $895-[96]$.

$8^{\circ} 8 \frac{1}{2}$ in. Nos. 1-7, Sept., 1895-March, [1896].

* Nos. 5-7 were published by the Seneca Philatelist Publishing Co., Limited, and nos. 4-7 have coloured paper wrappers. Nos. 5 and 6 were published together under the date "January and February".
Mis. St. Jour. 64 (12).

[Second series.]

Seneca Fralls, N. Y., Seneca Philatelic Publishing Co., I896.

in. No. 1, November, 1896.

** Wanting.

SENF'S BRIEF'E. Senf's Briefe. An alle Freunde der Briefmarkenkunde Berichte, Auskünfte, Vermittlung von Angebot und Nachfrage.

Leipzig, W. A. Louis Senf und Co., I892. $8^{\circ} .8 \frac{1}{2}$ in. No. 1, May 15,1892

* * Printed on coloured paper.

Mis. St. Jour. 58 (1).

SENF'S BRIEFMARKENSAMIMLER. See BRIEFMARKENSAMMLER (Leipzig, I 89o.).

SENF S IMONATSSCHRIFT FUUR POSTWERTZEICHEN-KUNDE. Senf's Monatsschrift für Postwertzeichen-Kunde. Leipzig, Gebriider Senf, I89o. $8^{\circ} .9 \frac{1}{4}$ in. No. 1 , January, 1890.

* "Conducted by Theodor Haas. The number has a coloured paper wrapper.

Mis. St. Jour. 76 (7).

"SENSE AND NON-SENSE". "Sense and non-sense". St. Louis, Mo., Charles L. Pleasants, I877. ** Cuttiugs of the "Philatelic Department," etc., from no. 5 dated
May 1st, 1:77, are mounted in Stamp Scrap-book, vol. III., p. 79.

SEेVE-ANNONCE. La Sève-Annonce. Organe international des collectionneurs et marchands de timbres-poste. Marseille, Gurt et Modiano, I88I. Fol. 121 in. No. 1, June, 1881.

* * This is headed "Supplément du journal littéraire la Sève". The contents consist entirely of advertisements. Mis. St. Jour. 107 (14).

SHELBYVILLE STAR. The Shelbyville star.

Shelbyville, Ill., Wm. H. Lloyd, х886. * * Cuttings of the stamp portions from a number of which the date and number have not been preserved, are mounted in Stamp Scrap-book, vol. v., pp. 104, 105

SIEGELIMARKF. Die Siegelmarke. Organ für Siegelmarken-sammler. Beilage der "Stempelmarke" Miunster $i . W .$, Ed. Susemihi, I904. 8.9 9 in. No. 1, July, 1904.

Mis. St. Jour. 97 (6a). 
SIGMUND FRIEDL'S PHILATHLISTISCHE BERICHIT. Sigmund Friedl's Philatelistische Berichte. Organ für die interessen des Markenhandels Beiblatt zu "Welt-Post". Wien, Sigmund Friedl, I88z-84 $8^{\circ} .9 \frac{1}{2}$ in. Nos. 1-18, July 15, Sept. 1, 28, Dec. 1, 1882, Jan 15 Mar. 1, Apl. 15, June, Sept. 1, Oct. 15, Dec. 1, 1883, Jan. 15, Mar. 15, M ay 1, July 15, Sept., Nov. 1, Dec. 15, 1884.

$\because *$ A copy of the prospectus of the journal is bound up with it.

SILVER CITY PHILATELIST. See NutMEG STATE PHILATELIST (Meriden, Conn.).

SITZUNGSBERICHT DES INTERNATIONAIEN POSTWERTHZFICHEN - HÄNDLRR VEREINS See Internationaler PostwerthrichenHäNdLeRVEREIN.

SKANDINAVISK FRIMAERKE-JOURNAI. Skandinavisk Frimaerke-Journal.

$8^{\circ} .11 \frac{1}{4}$ in. 8 nos. in 2 vols. Kjфbenhavn, F. Bertini, I876-77. Vol. Oct. 20-Dec. 20, 1876. Nos. 1-3. "II. Jan. 10-Niay, 1877. "4-8. * "The numbers for February-May, 1877 are numbered respectively "Nr. 2 (5), Nr. $3(6), N r .4(7), "$ and "Nr. $5(8)$ ". No. bears the word "Prфvenummer" and there is a supplement of (2)
pp. to no. 6.
Mis. St. Jour. 4 (1).

KANDINAVISK FRIMAERKETIDENDE. Skandinavisk Frimaerketidende. Maanedskrift for Frimaerkesamlere. Kjфbenhavn, Arthur Philipsen, I876-77. $4^{\circ} \cdot 10 \mathrm{x}$ in. 15 nos. in 2 vols.

1st year. Oct. 15-Dec. 15,1876 . Nos. 1- 3 .

2nd , Jan. 15- , 25, 1877.

* * Thore is an index at the end of " no. 12.

SKANDINAVISK FRIMAERKE-TIDENDF. Skandinavisk Frimaerke-Tidende.

Sdnderho, Danmart, etc., Th. Knudsen og $N$. Mdller Kromann, etc., I890-93.

$8^{\circ} .10 \frac{1}{2}$ in. and $4^{\circ} .10 \frac{1}{2}$ in. 36 nos. in 3 vols.

1st year. Oct. 31, 1890-Sept. 30, 1891. Nos. 1-12.

2nd " " " 30, 1891- " $30,1892 . \quad$ " 1892 . $1-12$.

* The numbers of the first year are octavo and those of the two subsequent jears are quarto. There is a title-page and an index to the first year. The numbers of the second and third year were published at Kjфbenhavn by H. Rohde. Nos. 4 and 5,8 and 9 and 10 and 11 of the third ycar were severally published together.

SKANDINAVISK FRIMÄRISTIDNING. Skandinavisk Frimärkstidning. Malmö, Louis Söderberg, I893. $4^{\circ} .11_{\frac{1}{2}}^{1}$ in. Profnummer A, Profnummer B, Feb. 10-Mar. 15, * * The contents consist entirely of advertisements.

Mis. St. Jour. 129 (13)

SKANDINAVISK FRIMÄRKSTIDNING. Skandinavisk Frimärkstidning.

Halberstadt, Paul Lehmstedt, I 896 $8^{\circ} .9 \frac{1}{2}$ in. No. 1, June 20, 1896.

* * This is headed "Probe-Nummer-Prof-Nummer".

Mis. St. Jour. $100(1)$

SKANDINAVISK PHILATEIST TIDENDE. Skandinavisk Philatelist Tidende.

Sdnderho, Danmart, Viborg [printed], N. Mpller Kromann, I 890.

Fol. 13 in. Nos. 1-6, Apl. 25-Sept. 30, 1890

IIis. St. Jour. 75 (3)

SKANDINAVISK PHILATELIST TIDFNDE. Skandinavisk Philatelist-Tidende.

Kobenhavn, Frimaerkeforretningen "Hermes," I 905. $8^{\circ} \cdot 10 \frac{1}{4}-11 \frac{3}{4}$ in. Nos. 1-10, Jan.-May 10, Nov.-Dec., 1905.

* * Nos. 6-10 were published together. Mis. St. Jour". 126 (15)

SKANDINAVISK PHILATHIISTISK OFFERTEBLAD. Skandinavisk Philatelistisk Offerteblad.

$8^{\circ} .83$ in. No. 1, August 1, 1908 Aalborg, Otto C. Jelstrup, r903

**The contents consist entirely of advertisements. Mis. St. Jour. 135 (14)

SIMTH AND CO'S IMONTHLY CIRCUIJAR (ALFRED)

See Alfred Smith and Co.'s Monthly cIRcular.

SMITH AND SON'S MONTHLY CIRCULAR (ALFred) See Alfred Smith and Co.'s monthly cIRcular.

SIMYTH AND CO.'S PHILATELIC CIRCULAR. See MONTHLY POST AND STAMP WORLD.

SMYTH'S PHILATELIC CIRCULAR. See MONTHLY POST AND STAMP WORLD.

SNOWFLAKE. The Snowflake.

in. Nos. 1-2, June-July, 1887.

Evansville, Ind., [?] I 887

* * Only partly philatelic. Wanting both nos.

SNOW-FLAKE. The Snow-flake.

Albany, N. Y., J. A. Helwig, I 904 $16^{\circ} .41$ in. and oblong $16^{\circ}, 3$ in. Nos. 1-3, September, October, [December, 1904].

**No. 3 is oblong $16^{\circ}$, and has a coloured paper wrapper. This number has no date, but the wrapper bears the words "A Merry Christmas to all". Wanting no. 2.

[Continued as :]

- The Snow flake philatelist.

Albany, N. Y., J. A. Helwig, I 905-08.

$16^{\circ} .5 \frac{1}{2}-6$ in. 15 nos. in 3 vols.

Vol. r. Jan., April, June, Sept., Oct., Dec., 1905. Nos. 4, 6, 7,

9, 10, 12.
II. Feb. May, Nov., Dec., 1906, Feb., [? ], Dec., 1907, Dec., 1908. Nos. 1-[8]

"' III. April, 1908 . No. 1.
$*$ "Nos. 5,8 and 11 of vol. I. were never published, and the title on no. 6 reads "The Snow flake". The number for "Dec. 1907 " is wrongly numbered " 4 " and that for December, 1908 bears in error " 6 " instead of " 8 ". Wanting nos. 4, 6 , vol. $x$.

SNOW FIAKE PHILATELIST. See SNOW-FLAKE. (Albany, N. Y.)

SOUTH AFRICAN PHIIATELIST. The South African philatelist.

Johannesburg, Klagsbrun and Epstein, IS95-96.

(6. $4^{\circ} \cdot 10 \frac{1}{2}$ in. Nos. 1-6, Nov. 1, 1895-A pril 1, 1896.

* Printed by a type-writing machine. There is a coloured paper wrapper to each number, an index at the end of no. 6, and the wrapper" of no. 5 bears no. 4 with the numeral altered in pen and ink to " 5 ". This was the first philatelic journal published in the Transvaal.

SOUTH WALES PHILATICAL NEWS. The South Wales philatical news.

Swansea, A. R. Martin and Co., [I884].

$16^{\circ} .7 \frac{1}{4}$ in. Nos. 1-5, Aug.-Dec., [1884]

* No. 5 has beneath the title "(Incorporated with the phila telical gazette)". Wanting nos. 1 and 2. Mis. St. Jour. 153 (1)

SOUTHAIMPTON झXCHANGE LIST. The Southampton exchange list.

$8^{\circ} \cdot 7 \frac{1}{2}$ in. Nos. 1-4, June-September, 1886 .
** Only partily philatelic. Nos. 1 and 2 were printed at Oxford

Southampton, A. Dykes, I886. and nos. 3 and 4 , which are on coloured puper, at Plymouth.
Wanting no. 1.

SOUTHAIIPTON STAIMP ADVFRTISER. The South ampton stamp advertiser.

Southampton, A. Dykes, 1886. $8^{\circ} .7 \frac{1}{2}$ in. Nos. 1-4, Mar.-June, 1886

* * Printed on coloured paper. No. 2 has an advertisement sup pî̀ement of four pages. No. 4 was printed at Oakham, Rutlandshire, and is without the article "The" preceding the title. Succeeded by the "Philatelists' own paper" Iivs. St. Jour. 55 (10)

SOUTHERN CALIFORNIA COLLFCTOR. The Southern California collector. Orange, Cal., Cooper and Cook, I896. $8^{\circ} .7 \frac{1}{1}$ in. Nos. 1-3, Jan.-Mar., 1896. * * There is a paper wrapper to each number. Mis. St. Jour. 67 (6)

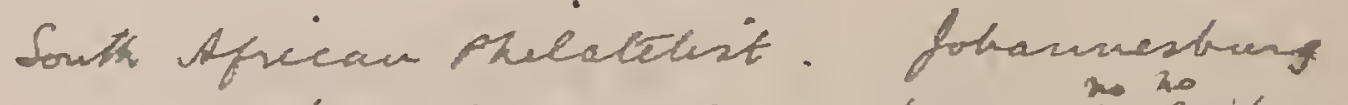

$$
\begin{aligned}
& \text { igro norfigu I. }
\end{aligned}
$$

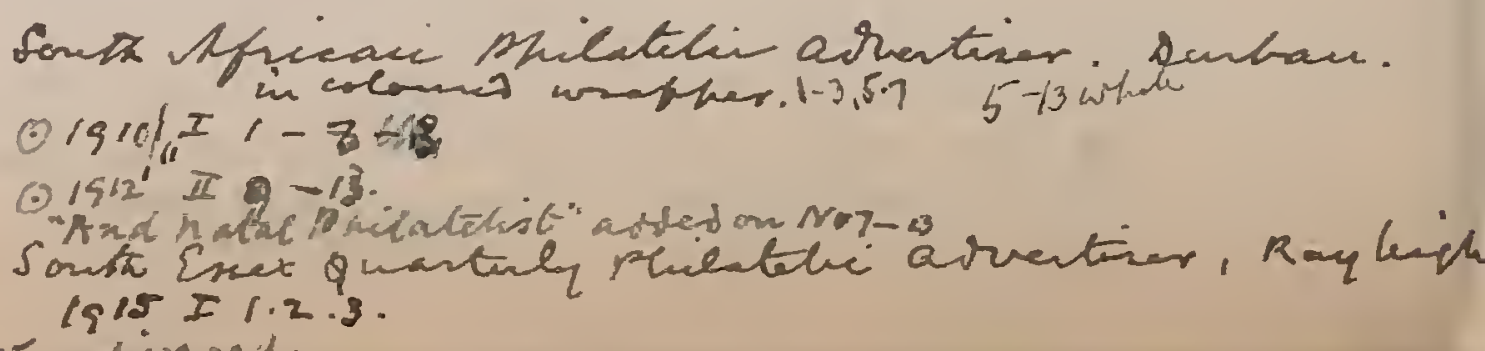



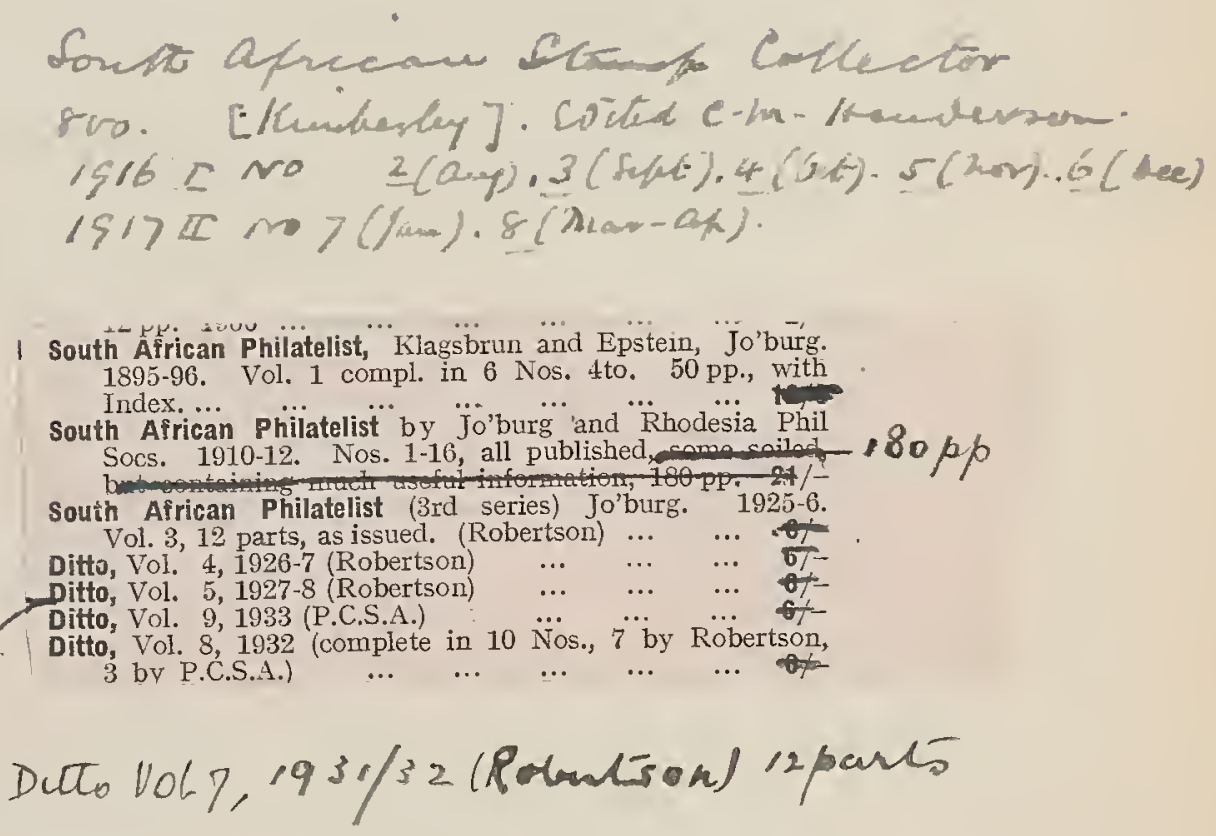
Spindre ily Youth-fowell, mass, 1888-89-S122 
SOUTHERN COLLECTOR. The Southern collector. Nashville, Tenn., J. S. MoHenry, etc., I884-85. 8. 91 in. Nos. 1-3, Oct., 1884, Jan., Mar., 1885. * Only partly philatelic. Nos. 2 and 3 were published by McHenry and Gale and have coloured paper wrappers. Mis. St. Jour. 18 (17).

SOUTHERN COLLECTOR. The Southern collector. Hickory, Miss., T. R. Raines, $\mathbf{1} 887$. $8^{\circ} .9$ in. Nos. 1-4, Mar.-June, 1887. ** Only partly philatelic

Mis. St. Jour. 22 (12)

SOUTHERN COLLECTOR. Southern collector. Tuskegee, Ala., H. P. Simpson, I887. $8^{\circ} .73$ in. Nos. 1-4, Mar., Apl., May 30, June 30, 1887. ** * Only partly philatelic Nos. 2-4 have the word "The" pre** Only partly philatelic, Nos. 2-4 have the word "The" pre-
ceding the title.

[Continued as :]

- The Alabama collector.

Tuskegee, Ala., H. P. Simpson, I887.

$8^{\circ} .73$ in. No. 5, July 30,1887 .

* * Only partly philatelic This number consists of two leaves which are printed on one side only. Mis. St. Jour. 40 (7a).

SOUTHERN CURIOSITY CABINET. The Southern curiosity cabinet.

New Orleans, La., Wm. Wilder and Co., I872. $8^{\circ} .91 \frac{1}{4}$ in. Nos. 1-3, February 1-Aprii 1, 1872.

Nis St. Jour. 17 (5)

SOUTHERN PHILATELIST. The Southern philatelist. Co., 1879 .

Galveston, Texas, Southern Philatelist Publishing

$8^{\circ} .8 \frac{1}{2}$ in. Nos. 1-9, January-September, 1879

* * Nos. 8 and 9 were published togethcr.

Mis. St. Jour. $29(9)$

SOUTHERN PHILATELIST. The Southern philatelist. Charleston, S. C., Luhn and Hadre, etc., I889-96.

$8^{\circ} .9 \frac{1}{4}$ in. 72 nos. in 7 vols.

Vol. I. Oct., 1889-Sept., 1890. Nos. 1-12

" II. "1890- " 1891. " 1-12

" III. " 1891-Dec., 1892. " 1-15.

"IV. Jan. -S" $\quad$ V. $1893 ., " 1-12$.

"v. June -Dept., 1899. " $\quad$ " $1-7$.

" vil. Jan. -Apl., Aug., Sept., 1896. Nos. 1-6.

*"* There is a title-page and an index to vol. III. and also to vol. * There is a title-page and an index to vol. III. and also to vol. rv. and a paper wapper to each number. Nos. 6-12, vol. 1., were published by the Southern Publisting Company, the numbers of

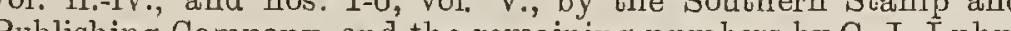
Publishing Company, and the remaining numbers by G. J. Luhn. There is a supplement with portrait to no. 4, vol. IV., and no. 4 , vol. v. is dated "April and May, 1894". A copy of the prospectus is bound up in front of the first number.

SOUTHERN STAMP COLLECTOR. The Southern stamp collector. A journal devoted to the interests of philately.

New Orleans, La., The Southern Stamp Collector Publishing Co., 1897 .

$4^{\circ} .12 \frac{1}{4}$ in. No. 1, September 15, $1897 . \quad$ Mis. St. Jour. 97 (7).

SOUTHERN WEEKLY PHILATELIST. The Southern weekly philatelist.

Houston, Tex., A. M. Rareshide, I894. Fol. 12-121 in. Nos. 1-11, July 19, 26, Aug. 2, 9, 16, 23, Sept. 6 , $13,20,27$, Oct. 3,1894

**. Nos. 1-6 are printed on rose paper. Mis. St. Jour. 72 (15).

SOUTHRON BOY. The Southron boy.

Dallas, Texas, George N. Beach, I875.

* "Cuttings of "The Stamp review," etc., from the numbers fo book, vol. III., pp. $85-89$.

SPANISH AIMERICAN TRADE JOURNAL. The Spanish American trade journal.

St. Louis, Mo., C. H. Mekeel, I89o.

** Cuttings of the philatelic portions from nos. 1 and 4, dated January and April, 1890, are mounted in Stamp Scrap-book, vol. VI., pp. 106-111 and 121-124
SPECIAL-OFFrRTE. See Monats-Bericht und SPEZiatOFFERTE FŬR BRIEFMARKENHÄNDLER,

SPECTATOR. The Spectator. No. 558. March 9, 1839. Second edition. [Contains The Third Report from the Select Committee on Postage. Ordered by the House of Commons to be printed, August 13, 1838.]

London, Joseph Clayton, I839.

Fol. $13 \frac{1}{2}$ in

Boind up in volume lettered "Paper's relating to Unifor"m Penny Postage. 1838-39" (no. 29).

SPINDLE CITY PHILATELIST. The Spindle City philatelist. Lowell, Mass., L. G. Hall, 1885 $8^{\circ} \cdot 7-7 \frac{1}{2}$ in. Nos. 1-3, March-May, 1885.

* * Nos. 1 and 2 are printed on pink paper and measure 7 inches. No. 3 is on white paper and measures $7 \frac{1}{2}$ inches.

Nis, St. Jour, 41 (2)

SPRINGFIELD PHILATELIST. The Springfield philatelist. 96.

$32^{\circ} .4_{4}^{3}$ in., $8^{\circ} .9$ in., and $4^{\circ} .10^{3}$ in. 21 nos. in 3 vols.

Vol. I. Jan., June 1, Sept.-Nov., 1894. Nos. 1-5.

, II. " -Dec., 1895. Nos. [6]-17.

*III. "Apl. $1896 . \quad 18-21$.

* Nos. 1-3 are $32^{\circ}$., nos. 12-15, are quarto and the remainin numbers are octavo. Nos. 5-7 and 9-15 were published by Schmitt and Hamilton, nos. 16 and 17 by Schmitt, Hamilton and Booth and the remaining numbers by Schmitt and Booth. Nos. 7-11 and nos. 16-21 have paper wrappers.

SPY GLASS. The Spy glass. $189 \mathrm{I}$. Arkansas City, Kans., Greene and Balliet, etc.

$8^{\circ} .8 \frac{1}{2}-8 \frac{1}{1}$ in. Nos. 1-3, September-November, 1891.

** Only partly philatelic. No. 2 was published by Roy F. Greene, and no. 3 by Greene and Ball. Each number has coloured paper wrapper. Mis. St. Jour. 64 (2)

ST. LOUIS PHILATELIST. The St. Louis philatelist. St. Louis, Mo., E. F. Gambs, I876-82.

S. $8 \frac{1}{2}$ in. 22 nos, in 5 vols.

Vol. I. Sept. 1876-July, 1877. Nos. 1-11.

" II. Aug.-Dec., 1877, May, 1878, Jan., Nov., 1879. Nos. 12-19.

III. Oct., 1s80. No. 20

"IV. June, $1881 . \quad$ "21.

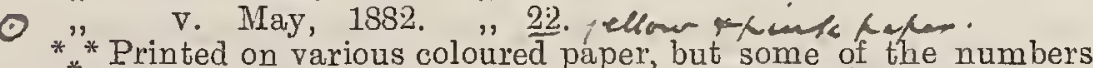
** Printed on various coloured paper, but some of the numbers and 910 and $11 ; 12,13$ and 14 ; and 15 and 16 were severally published together, and there is a supplement of two pages to no.

\section{[Continued as :]}

The California philatelist.

San Francisco, Cal., E. F. Gambs, I883-99.

$8^{0} .8 \frac{1}{2}$ in. Vols. VI.-[XVI.]. 12 nos.

Vol. VI. June, 1883 .

" VII. April, 1884

" VIII. 1885.

"IX. $\quad 1886-87$.

[x.] Winter season 1891-92, " 27.

"[XII.] " " $"$ " 1892-93. " " 30

"[XIII.] " " $\quad$ " 1895.

"[XIV.]

"IXvi.] Fall and Winter season, 1899-1900. No. 34

*"* Many of the numbers are found printed on white as well as coloured paper, but no. 29 is only found on white paper. There is no real no. 28, but a supplement to no. 27, dated June 10 1889 , although it bears " no. 27 ," was called no. 28 by the publisher.

ST. LOUIS POST-DISPATCH. St. Louis post-dispatch September 9, 1888. [Cuttings of the article "Curiosities in stamps. Some rare and costly relics of the postal service," are mounted in Stamp Scrap-book, vol. vI., pp. 80-82.]

July 5, 1889. [Cuttings of the article "Astounding facts about stamps," are mounted in Stamp Scrap-book, vol. vi., pp. 85, 86.]

$$
\begin{aligned}
& \text { "Shecealints' aud Collectors' } \\
& \text { circular" G.w-Lcwell. Salisbuny. } \\
& \text { 1916. Seft. rol, 4to.6/4-copy on } \\
& \text { okin white, } k \text { on greenish blue }
\end{aligned}
$$


ST. LOUIS POST-DISPATCH. August 31, 1889. [Cuttings of the article "American postage stamps. The first issue and its successors-Some rare specimens," are mounted in Stamp Scrap-book, vol. vi., pp. 87, 88.]

- November 10, 1889. [Cuttings of the article "Making postage stamps," are mounted in Stamp Scrap-book, vol. VI., pp. 100, 101.]

- December 1, 1889. [Cuttings of the article "Stamp counterfeiting," are mounted in Stamp Scrap-book, vol vI., pp. 102, 103.]

- January 12, 1890. [Cuttings of the article "Penny postage. Wonderful results in fifty years from Rowland Hill's great postal plan," are mounted in Stamp Scrapbook, vol. vi., pp. 131-135.]

- March 1, 1890. [Cuttings of the article "Postage stamp designs. The recent changes and why they were decided upon," are mounted in Stamp Scrap-book, vol. vI., pp. 118, 119.]

_-_ Vol. 43. No. 209. March 5, 1892. [Contains an article "Held here. Rosondo Fernandez of Madrid, Spain, arrested in St. Louis. Wanted in Galveston for selling counterfeit Spanish stamps."

St. Louis, Mo., The Pulitzer Publishing Co., I892 Fol. $21 \frac{1}{2}$ in. p. 2 Mis. St. Jour. 136 (13)

ST. LOUIS TIMES. The St. Louis times. St. I.ouis, Mo., October 12, 1877. [Cuttings of article "Philately. Something about stamp-gathering as a business and pastime"... are mounted in Stamp Scrap-book, vol. III., pp. 130-132.]

ST. NICHOLAS. St. Nicholas. Scribner's illustrated magazine for girls and boys. Vol. IIr. No. 1. November, 1875. [Contains an article "Postage-stamp collecting," (by J. J. Casey).]

8. $9 \frac{3}{4}$ in. pp. $49-51$

* The number has a coloured paper wrapper.

Mis. St. Jour. 10 (8)

STAATS COURANT DER ZUID-AFRIKAANSCHE REPUBIIEK. Staats Courant der Zuid-Afrikaansche Republiek. Vol. xII. No. 275. April 28, 1869. [Contains a notice on the issue of the first postage stamps in the Transvaal.]

Fol. $13 \frac{1}{2}$ in. (2) pp

Pretoria, 1869 Mis. St. Pamph. 63 (10).

STAFFORD SIITH AND CO.'S ILLUSTRATED IMONTHLY STAMP AND CREST CIRCULAR. See Stafford Smith and Co.'s Monthly stamp and CREST CIRCULAR.

STAFFORD SIMITH AND CO'S MONTHLY STAMP AND CREST CIRCULAR. Stafford Smith and Co.' monthly stamp and crest circular. Brighton, I870$4^{\circ} \cdot 101$ in.

* * This is solely a price list of stamps, etc., for sale by the publishers and cannot therefore be considered a philatelic journal. No. 1 is dated "February 1, 1870 " and no. 23 (the last in the library) "Decmber 1, 1871". The title on the later numbers is

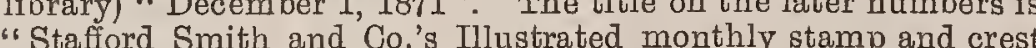

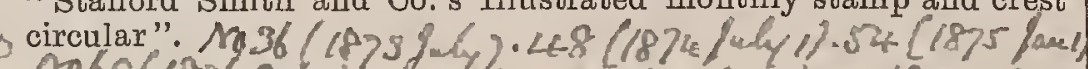

STAMP The Stamp. 1856, $1887 / 8,1859 / 9 ., 1890,1893$ London, H. Wernincts and Co., 1873 . $8^{\circ} .10$ in. Nos. 1-5, July 1, July 16, Aug. 1, Aug. 16, Sept. 1 , ** No. 2 has two supplementary slips. Mnine has only!

STAMP. The Stamp. Devoted to the interests of stamp collectors. Chicago, Ill., M. Wendell, I876. 8 . 9 in. Nos. 1-2, October-Novamber, 1876
STAMP. The Stamp.

Denver, Colo., Stamp Publishing Co., etc., I886-89. $8^{\circ} .83$ in. 38 nos. in 4 vols.

Vol. I. Mar., 1886-Feb., 1887. Nos. 1-12

" II. " 1887- " 1888. ", 1-12.

" III. " $\quad$ IV. $1888-, ", 1889 . \quad$ ". $1-12$.

*" * Each number, excepting the first, has a coloured pape wrapper. Nos. 11 and 12, vol. III., and nos. 1 and 2, vol. IV. were published by the Colorado Philatelic Co., and there is a supplement to no. 7 , vol. II.

STAMP. The Stamp.

Stromsburg, Neb., C. A. Green, I892.

$16^{\circ} .51$ in.

** All the library contains of this is the front leaf of what appears to be the coloured paper wrapper of no. 1, which is dated Under the title are the words "A monthly $\mathrm{S}_{12} \mathrm{D}$ collectors magazine. C. A. Green, editor and publisher".

STAMP. The Stamp.

Williamsville, Mass., A. E. Bennett, I893.

$32^{\circ} .41$ in. and $16^{\circ}$. 51 in. Nos. 1-12, January-Degember, 1893.

* * Nos. 1-3 are $32^{\circ}$, the rest $16^{\circ}$. Nos. 8 and 9 , and 11 and

12, were severally, published together under the respective dates

"Aug. and Sept." and "Nov. and Dec." Mis.

STAMP. The Stamp.

Holyoke, Mass., John Gordon, I895 $32^{\circ} .4$ in. No. 1, January, 1895

* The number has a coloured paper wrapper.

[Continued as :]

The Stamp herald.

Holyole, Mass., John Gordon, I895. $32^{\circ} .4$ in. Nos. 2-3, February-March, 1895 . * * There is a coloured paper wrapper to each number. Wanting no. 3 .

STAMP. The Stamp.

Groveland, Mass., C. H. Pike, r895-96.

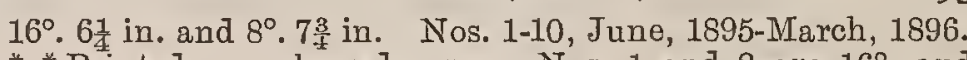

* * Printed on coloured paper. Nos. 1 and 2 are $16^{\circ}$. and the remaining numbers are octavo. Nos. 3 and 4 were published to gether under the date "August and Soptember". Amalgamated

Mis. St. Jour. 67 (7)

STAMP. The Stamp.

Riverside, Cal., G. B. Gladden, Jr., 1897

8. 9 in. No. 1, January 29, 1897.

Mis. St. Jour. 101 (4).

STAMP. The Stamp. For collectors.

$32^{\circ} .4_{4}^{3}$ in. No. 1, May, 1897.

Louisville, Ky., J. Hoehle, I897.

* * Edited by D. Kenner and printed on pink paper. Mis. St. Jour. 150 (5)

STAMP. See New Yori STAMP.

STAMP ADVERTISER. The Stamp advertiser.

Chicago, Ill., Guy C. Ledyard, Jr., I873-75.

$32^{\circ} .4 \frac{1}{2}$ in., $16^{\circ} .6$ in. and $8^{\circ} .7 \frac{1}{2}$ in. 22 nos. in 4 vols.

Vol. I. Mar. Aug., 1873. Nos. 1-6.

" II. Sept., 1873-Feb., 187t. " 1-6.

" III. Mar. -Nov., " " 1.9

"IV. Jan., 1875. No. 1.

* No. 1 is $32^{\circ}$. nos. $2-6$, vol. I, are $16^{\circ}$. and the remaining num bers are octavo. Commencing with no. 4 , vol. II., each number has a coloured paper wrapper. Nos. 2 and 3, vol. III., wer published together under the date "April and May, 1874," but the number only bears "No. 3 ".

STAIMP ADVERTISER. The Stamp advertiser.

Hudson, Mass., Grant and Trowbridge, etc., I88990.

$8^{\circ} .8^{3}$ in. 15 nos. in 2 vols.

Vol. I. Feb. 1889-Jan. 1890. Nos. 1-12.

II. Mar., Aug., Sept., $1890 . \quad 1-3$.

* No. 2 was published by W. F. Trowbridge, nos. 3 and 4 by Grant and Parks and no. 5 to the last number by H. G. Parks. Nos. 6 and 7 , and 10 and 11, were severally published together. There are supplements of (2) pp. to nos. 10 and 11 and also to no. 3, vol. II., the latter having the title "M. P. A. Bulletin". No.5, vol. I., and no. 2, vol. II., have coloured paper wrappers.

Mis. St. Jour. 25 (10) 
Stamp (Denver, Colo.) for the years $1886 / 9$ and $1892 / 4$ boult lettered on spine.

First vol. covers Vol. T., No. 2 (A pril, 1886) to Vol. III., No. 12 (Feb., I889), and second vol. covers Vol. I., No. 4
1892 ) to Vol. III., No. 12 (March, 1895 ) of another paper of the same name. are full of good general artictes interest, but also contain several fine studies. Two handsome vols. $(68$ numbers).

St hurtions - le-lirand 
Stamp Cunt vournal (Fuclos F.H. Vallancey) $\operatorname{vol}(\log 20-23)$

Noln hol

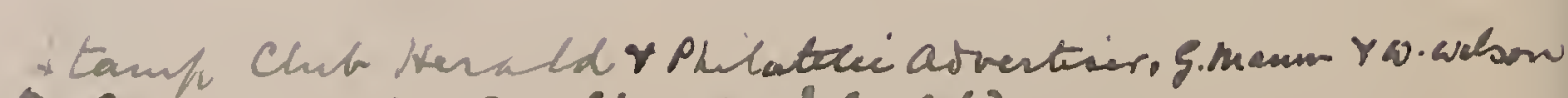
- 8v0.1910. N01.2.3.4 (Jm. af. Jah. oct).
- alno ins.ofnol.
moscley o Stackton-on-Pees

Philative Kerald tarentiser. A monats

joumai turoted is ccamp ollectors. Dozmals

known as "Jhe Ltams clut keraed."

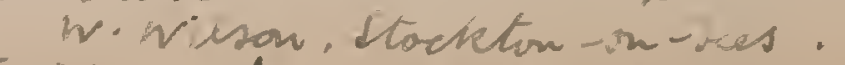


STAMP ADVERTISER. The Stamp advertiser.

S12V in. No.1, September, 1896 New York, [?], x896. * in. Nanting.

STAIMP ADVERTISER. The Stamp advertiser.

(1) Southport, Egremont [printed], Gustav Roberts and Co., 1896-97. have 2 in golenom 3 cemon 4 cannine

(.) 8. 8 8 in. Nos. 2-4, Nov., 1896-Jan., $1897 . \quad$ Ppr-z

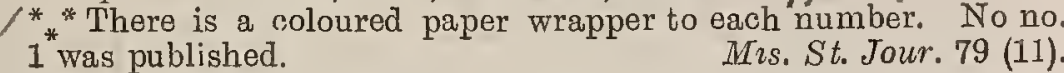

STAMP ADVERTISER. See ADVERTISER (Broolelyn, N. Y.).

STAIMP ADVERTISER. See STAMP COLLIECTOR'S ADVERTISER (Birmingham).

STAIMP ADVERTISER. See STAMP COLTHETORS' DIRECTORY.

STAIMP ADVERTISER AND AUCTION RECORD. The Stamp advertiser and auction record. A monthly magazine and price list for the use of stamp collectors and dealers.

Edgbaston, Birmingham, C. J. Phillips, x889-9o. $8^{\circ} .101$ in. Nos. 1-7, Dec. 14, 1889-June 14, 1890.

* * Edited by C. J. Phillips and each number has a paper wrapper. A copy of the prospectus of the journal is bound up with the seven numbers. The bound volume of the seven numbers subsequently sold by Stanley Gibbons Limited, London, contains a title-page, "contents" list and six extra advertisement pages.

STAMP ADVERTISER AND STAMP COLLECTORS DIRECTORY. See StAMP COLLECTORS' DIRECTORY.

STAIMP ADVOCATE. The Stamp advocate. A monthly paper devoted to philately. Toronto, Wm. Berry, I875. $8^{\circ} .9$ in. Nos. 1,2, and "Summer edition no. 1," Feb. 23, Mar. 23 and June 15.1875.

* *Nos. 1 and 2 are found printed on various coloured paper and the number for June 15 is found on white and also on coloured paper. This journal was consolidated with the "Pearl" in Depaper. This journal was consolidated with the "St. Jour. 56 (11)
cember, 1875 . Sis. Stor.

STAIMP AGE. The Stamp age.

Washington, D. C., The Age Publishing Co., [1904]. $8^{\circ}$. 71 in. No. 1, April, [1904].
$* *$ Edited by Frank J. Stillman

AMP AND COIN COLLECTORS ADVERTISER. The Stamp and coin collectors advertiser.

Leeds, Yorks, John Roper, 1886 $8^{\circ} .8 \frac{1}{\text { in. }}$ in. Nos. 1-6, Feb.-July, 1886.

"* Printed on coloured paper. $\sim$ No. 1 is merely a "dummy" copy without contents. as ismay cofy. Mis. St. Jour. 34 (3).

STAMIP AND COIN GAZETTE. See KEYSTONE PHILATELIC GAZETTE.

STAMIP AND COIN REPORTER. The Stamp and coin reporter. $\quad$ Cobleskill, N. Y., Melvin R. King, 1903. 8․ $9 \frac{1}{2}$ in. Nos. 1-5, November 4, 11, 18, 25, December 23, 1903. ** Nos. 2-5 have paper wrappers.

[Continued as:]

- The Stamp reporter.

Cobleskill, N. Y., Melvin R. King, х904 Fol. 12 in. Nos. 6-12, -April 20, 1904.

* *n nos. the article "The" is dropped from the title. Wanting nos. $6,7,9,11,12$.

STAMP AND COIN TRADER. The Stamp and coin trader. Rockford, Ill., The Globe Stamp Co., I873-74.

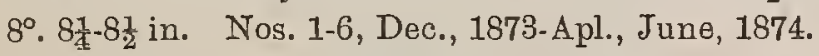

STAIIP AND CURIOSITY CIRCULAR AND COL LECTOR'S VADE IMLCUM. The Stamp and curiosity circular, and collector's vade mecum.

Dewsbury, H. O. Porritt and Co., I867. in. No. 1, April, 1867

* * This journal is reviewed in the "International stamp recorder and curiosity magazine," published by A, Tolson and Co, of Dews-

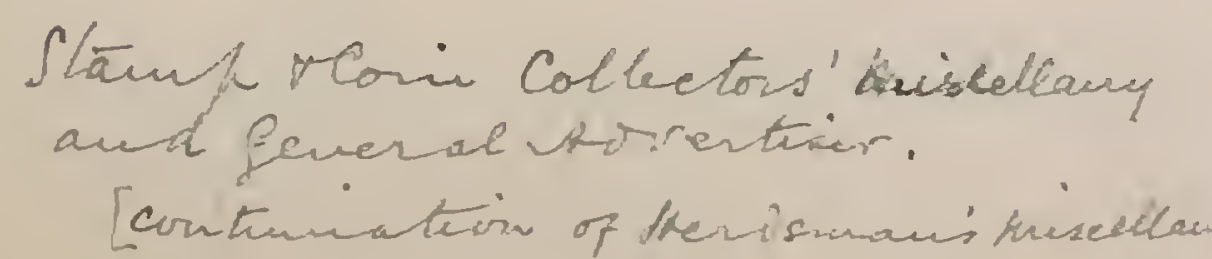

bury, on May 1st, 1868. It is there said to consist of four pages and a list of the contents is added, but the date of issue is not mentioned. In a list of philatelic literature given in the "Philatelist" of November 1, 1869, the date is said to be April, 1867. Wanting.

STAMP AND POSTCARD ADVERTISER. See P. J. G. B. ADVERTISER.

STAMP AND POSTCARD COLLECTOR. Stamp and postcard collector.

Milwankee, Wis., Arthur H. Kraus, I906-07. $8^{\circ} .8 \frac{1}{2}$ in. Nos. 1-4, Decomber, 1906-March, 1907. Mis. St. Jour. 151 (3)

STAIIP ARGUS. The Stamp argus.

St. John, New Brunswick, Robert J. Melvin, etc., 1865 .

$8^{\circ} .9$ in. Nos. 1-5, July 15-Sept. 15 , Nov. 15, Dec. 15, 1865.

$8^{\circ} .9$ in. Nos. $1-5$, July 15 -Sept. 15, Nov. 15, Dec. $15,1865$.
$*$ " Nos. 4 and 5 were published by Ridgeway Jones and the whole five numbers were edited by Edward A. Craig.

STAMP AUCTION RHPORTER. The Stamp auction (6) reporter. Published fortnightly.

1898.

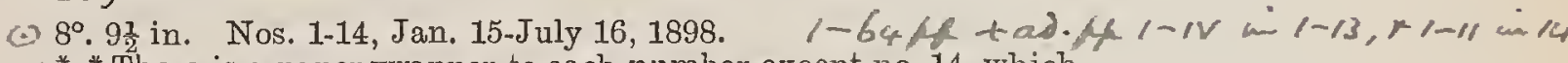

${ }_{*}^{*}$ * There is a paper wrapper to each number except no. 14, which

6.) has only a front wrapper. $\checkmark$ A copy of the prospectus of the jour-

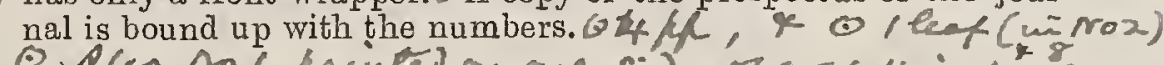

STAIIP BOOK, The Stamp book.

Brockton, Mass., W. J. Hatch, I901-02,

$24^{\circ} .5$ in. 9 nos. in 2 vols.

Vol. I. Jan.-June 30, $1901 . \quad$ Nos. 1-6.

"II. July-Aug., Dec., 1901-Jan., 1902. "1-3.

* * "There is a paper wrapper to each number. "Nos. 2 and 3 , vol. I., and nos. 2 and 3 , v $>1$. II., were severally published together; the latter with the date "December-January, 1901-2". No. 1, vol. II. bears the date "July-August, 1901". No. 6, vol. I., and the double number 2 and 3, vol. II., are printed on coloured paper. No. 5 vol. I., is numbered in error " 4 ," except on the wrapper, which is correctly numbered.

STATIP BULLETIN. The Stamp bulletin La Grange, Ill., W. F. Bishop, x89.

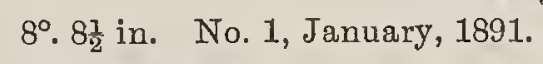
Mis. St. Jour. 64 (3).

STAIMP BUYER. The Stamp buyer.

Middletown, Conn., American Stamp Co., I868.

$8^{\circ} .73$ in. Nos. 1-3, January-March, 1868. Mis. St. Jour. 38 (5).

STAMP CHRONICLE. The Stamp chronicle.

Handsworth, Sheffeld, Dodson and Co., I878 $24^{\circ} .5$ in. Nos. 1-2, April 1-May 1, 1878.

*** Wanting no. 2

Mis. St. Jour. 71 (13)

STAIMP CHRONICLE. The Stamp chronicle.

Nashville, Tenn., Clements Brothers, I89r.

8․ $7^{3}$ in. No. 1, May, 1891.

Mis. St. Jour. 66 (11).

STAMP CHRONICLE AND BRITISH PHILATHLIST.

See HABERSTRAW'S STAMP CHRONICLE AND CIRCULAR.

STAMP CHRONICLE AND CIRCULAR. See HABER STRAW'S STAMP CHRONTCLEE AND CIRCULAR,

STAIMP CIRCULAR. The Stamp circular

Springfield, Mass., Novelty Stamp Co., r874. $8^{\circ} .8 \frac{1}{2}$ in. [? No. 1], 1874

* * This is nothing more than a price list. It appears from the remarks made on page 1 that there was a previous edition of this circular, issued probably in January, 1870. Mis. St. Jour. 28 (8).

STAIMP CIRCULAR. See G. W. Winterburn and Co.'s STAMP CIRCULAR.

STAIIP COLLECTOR. The Stamp collector.

Syracuse, N. Y., L. F. Baum and Co., etc., 1872-73. 8․ 81-9 in. Nos. 1-4, May, June, Sept., 1872, Jan., 1873. ** * No. 4 is 81 inches and nos. 1-3, 9 inches. No. 4 was published by L. F. Baum, and no. 3 was printed on buff paper. No. 4 is dated inside on page 3 " 1872 " in error, and there is a slip supplement to no, 2 headed "Circular". I. -25

$$
\begin{aligned}
& \text { Stanp Nourse. Cuthbertson PCo hivisporol } \\
& 1908 \text { bet }=\text { roi } \cdot \text { Mol (sept) }
\end{aligned}
$$

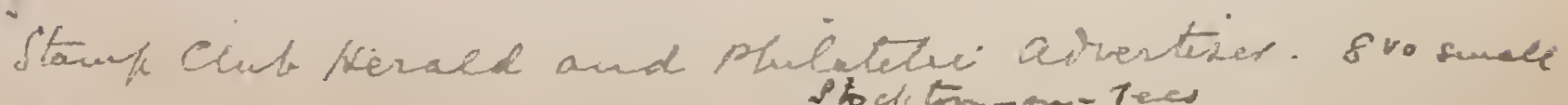

$$
\begin{aligned}
& \text { conthines a shilatelei Hersed yad nesteser, } 4 \text { to } \\
& \text { sill no } 5 \cdot 6-7 \cdot 8
\end{aligned}
$$


STAMP COLLECTOR. The Stamp collector.

New York, A. Fountain, 1879 .

$4^{\circ} .7 \frac{1}{2}$ in. Nos. [1]-[4], Aug., Sept., 1879.

** The four numbers are price lists of stamps offered by the publisher. They bear no number and the two last are without date, Wanting nos. [3, 4].

- [New series.]

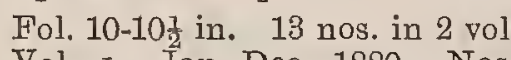

$(129$

Vol. I. Jan.-Dec., 1880. Nos. 1-9.

"II. II. " 1881. No " I-

*" No. 4," vol. I., is dated" "April and May, 1880"; no. 5, "June and July, 1850"; no. 6, "September, 1880,"; no. 7, "October, 1880", while the number for November, 1880, is numno. 2, vol. II., is dated "A pril, 1881". Wanting nos. 3, 4, vol. II.

STAMP COLLECTOR. The Stamp collector. Chicago, Ill., F. J. Abbott, I886 $8^{\circ} .9$ in. Nos. 1-2, July-Aug., 1886.

* * There is a coloured paper wrapper to each number, and a copy of the prospectus is bound up in front of no. 1 .

Mis. St. Jour. 20 (4)

STAIMP COLLFCTOR. The Stamp collector. Ottawa, Ill., Stamp Collector Publishing Co., I888-89. $8^{\circ} .97$ in. Nos. 1-7, July, 1888-Jan., 1889.

* * There is a coloured paper wrapper to each number.

STAIMP COLLECTOR. The Stamp collector. Stretford, Manchester, Robert H. Goss, 880 . $8^{\circ} .8 \frac{3}{4}$ in. Nos. 1-2, May-June, 1889.

** Wanting no. 1 .

Mis. St. Jour. $153(6)$

STAMP COLLFCTOR. The Stamp collector.

Forest Gate, London, E., etc., The International Philatelic Press Agency, I89I-93.

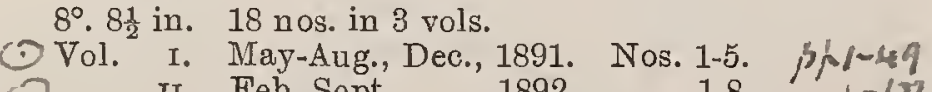

(2) ", II. Feb.-Sept., 1892. ", $1-8 . \quad$ III. Jan.-May.,

V. * " III. Jas. 6-8, vol. II., and nos. 1-5, vol. III., were published at Leadenhall Street, London, E O. $\sim$ Each number has a coloured paper wrapper. vNos. 6 and 7 , vol. II., were published together under the date "July and August" and commencing with this double number it is stated that the "Philatelic monthly news" has been incorporated with the journal. "No. 8, vol. II., is called in error " whole number 17", and nos. 2-4, vol. III., " whole no. 18," " whole no. 19" and "whole no. 20," respectively. There is a paged proof copy of no. 8 , vol, II., bound up with the journal, the contents of which differ somewhat from those of the number as published. Some of the published numbers of no. 8, vol. II., have "whole Some of uh" published numbers of no. 8, vol. 1., have "whole number 1, instead of " 17 ," on page 117 ; the paper is coarser corners of the front wrapper are different.

- (New Series.) With which is incorporated "Witherick's stamp collecting circular".

Leytonstone, London, E., A. E. Witherick, 1896 .

(.) $8^{\circ} .81$ in. Vol. 1v. Nos. 1-3, Oct. 1.Dec. 15, 1896. - 244 -

*** There is a coloured paper wrapper to each number. "These " "There is a coloured paper wrapper to "ach number. "These "whole no 30 " respectively.

Mis. St. Jour. 54 (5).

STAIMP COLLECTOR. The Stamp collector.

$8^{\circ}$. 83 and 61 in. Nos. 1-3, May, 1896, April, 1897, May, 1900.
$*$ * Nos. 1 and 3 measure 8 inches and no. 2, 61 inches. Nos. 2 and 3 are only price lists.

STAMP COLLECTOR. The Stamp collector: with which is incorporated "The Philatelic times and stamp mart". Miller's Dale, Buxton, Tideswell [printed], The Philatelic Syndicate, 1896.

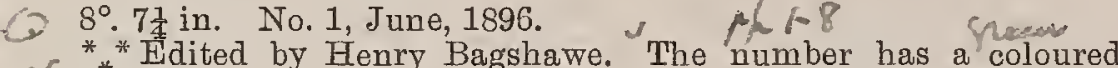
paper wrapper.
JMis. St. Jour. 81 (9).

[Continued as :]

The Philatelic times.

Miller's Dale, Buxton, Tideswell [printed], The Philatelic Syndicate, 1896-97.

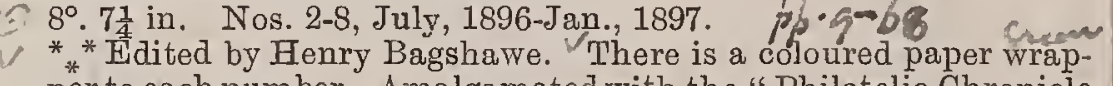
per to each number. Amalgamated with the "Philatelic Chronicle and Advertiser" in June, 1897.

o puspectivo bof
STAMP COLLECTOR

STAIMP COLLECTOR, See AMERICAN PHILATELIST (Cleveland, O.).

STAMP COLLFCTOR. See JUNIOR STAMP COLIECTOR.

STAMP COLLECTOR. See STAMP COLLECTOR'S FIGARO (Chicago, $\pi l$.).

STAIMP COLLECTOR AND EXCHANGE. Stamp collector and exchange. Ipswich, A. E. Stubbs, [? I 884]. "* This is given as a journal in J. K. Tiffany's list in the "Stamp news anuual " for 1894. It is stated in no. 1 of the "International philatelist," Liverpool, March, 1884, that 500 copies Were printed, but only 100 copies were delivered by the printer. This statement, there can hardly be any doubt, refers not to a journal, but to the pamphlet "A guide to the science of philately, entitled ; stamp-collecting and exchange. Especially adapted for the amateur," published by the Foreign and Colonial Stamp Ex1883. See PART I. Foreign AND COLONIAL Stamp EXCHANGe Association.

\section{STAMP COLLECTOR AND IIESSENGER OF THE} ST. FRANCIS XAVIER UNION OF STAMP. COLLECTORS. The Stamp collector and messenger of the St. Francis Xavier Union of Stamp-collectors.

St. Francis, Wis., St. Francis Xavier Union of Stamp Collectors, I894-98.

$8^{\circ} .10$ in. 18 nos. in 5 vols.

Vol. I. Aug., Nov., 1894, Feb., May, 1895. Nos. 1-4.

"II. " " 1895, " " $1896 . \quad 1-4$

"III. Jä., M"ar 1896. Nos. 1-2.

" Iv. Jan., Mar., May, July, Sept., Nov., 1897. Nos. 1-6.

*" V. " Only partly philatelic. Published in the interest of the St. Francis Union of stamp collectors and poor Catholic missions, the object of the Union being to collect cancelled postage stamps, etc. and to convert them into funds for the support of the missions at home and abroad. Each number has a coloured paper wrapper. Wanting vol. rv., no. 5 and vol. v., no 2.

STAMP COLLECTOR CALENDAR. The Stamp collector calendar.

Philadelphia, Pa., Rev. P. M. Barral, I895. $8^{\circ} .11 \frac{1}{4}-10 \frac{1}{2}$ in. Nos. 1-3, March, June, September, 1895.

* * Only partly philatelic. Devoted to the interests of the Bethle*** Only partly philatelic. Devoted to the in
hem A postolic School in Basle and Lucerne.

Mis. St. Jour. 126 (14).

STAMP COLLECTOR'S ADVERTISER. The Stamp

( collector's advertiser. The up-to-date advertiser.

London, E.C., Egremont [printed], [? ], r898.

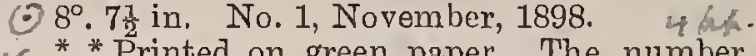

** Printed on green paper. The number was published at $8 \mathrm{a}$ not given. The contents consist entirely of advertisements.

STAMP COLLECTOR'S ADVERTISER. The Stamp collector's advertiser. Up-to-date.

Birmingham, Margoschis Bros., I899.

Q $8^{\circ} .7 \frac{1}{2}$ in. Nos. 1-10, Feb.-Nov., 1899

*** No. 1 is printed on white paper and nos., $2-10$ are on coloured paper. $\vee$ The contents consist entirely of advertisements. [Continued as :]

The Stamp advertiser.

Birmingham, Margoschis Bros., 1899-1902. $8^{\circ} .7 \frac{1}{2}$ in. $9-9 \frac{1}{4} \mathrm{in}$. and fol. $11^{\frac{3}{4}}$ in. 36 nos. in 4 vols.

(1) [Vol. I.] December, 1899 . No. 11

[, II.] Jan.-Dec, 1900. Nos. 12-23.

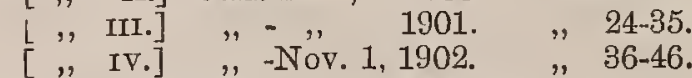

$\checkmark$ **"Printed on coloured paper and the contents consist entirely of advertisements. Nos. 11-20 are octavo $7 \frac{1}{2}$ inches, nos. $21-43$ are octavo 9-91 inches and the remaining numbers are folio $11^{3}$ inches. Nos. 41-45 are wrongly numbered 40-44, respectively. Wanting no. 43 for August, 1902.

[Continued as :]

The Universal stamp advertiser.

Birmingham, Margoschis Bros., I 902-05.

Fol. 11 11 in. and $8^{\circ}, 10$ in. Vols. IV.-VII. 21 nos.

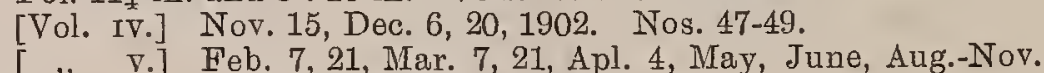

1903. Nos, $50-60$.

$\left[\begin{array}{lll}\text { [" vi.] Jan., Feb., May-Aug., 1904. Nos, 61, 62, } 65-68 . \\ \text { ", vII.] April, 1905. No. 77. }\end{array}\right.$

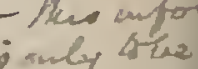 incinat frow}


"THE STAMP COLLECTOR."

Edited by John A. Margoschis and W. Kühn, and
published by Margoschis Bros., Birmingham).

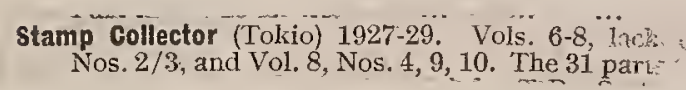

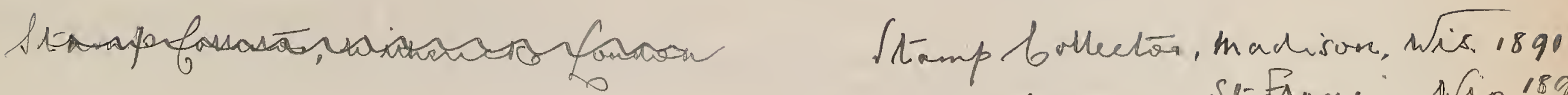


Stanf Coliectios " Chonick of Liturature

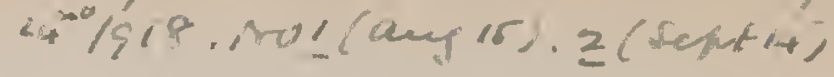

SFamp Collectors' a oventiver.

The fire nos une on from 1894 Zet-

Ime \& the Mh. num on also withenst a heak

thom 1-2b: herefore' Sthould say hat

May " grue ros. Shenld reat 4 Y5."

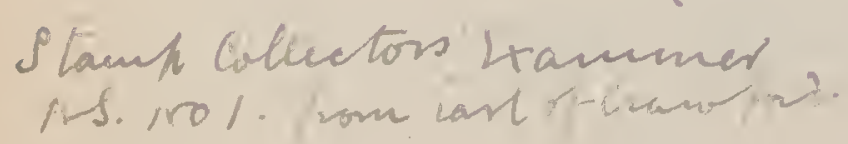


* * Printed on coloured paper and the contents consist entirely of advertisements. Nos. 47-62 are folio and the remaining numbers Wanting no. 66.

STAMP COLLECTORS' ADVERTISER. See STAMP COLLECTORS' ADVERTISER AND NEW ISSUE RECORD.

STAMP COLLECTORS' ADVERTISER AND NEW ISSUE RECORD. The Stamp collectors' advertiser and new issue record. A monthly advertiser for collectors.

Walthamstow, Essex, Wm. Cornish and Co., r894. - $4^{\circ} \cdot 10^{3}-11 \frac{1}{2}$ in. Nos. 1-2, February-March, 1894

** Fidited by Wm. F. Cornish.

\section{[Continued as:}

The Stamp collectors' advertiser. A monthly advertiser for collectors.

Walthamstow, Essex, Wm. Cornish and Co., r894.

(3) $4^{\circ} .111 \frac{1}{2}$ in. Nos. 3, 5, 6, April-June, 1894

* Hidited by W.m. F. Cornish. There is no number 4, the numbers for May and June having been wrongly numbered " 5 " an "6" respectively. Ishould 2 ow say Mis. St. Jour. 87 (12a).

that thay" hyontinued as:]

- The Monthly reader and stamp collector's guide. (With which is incorporated the stamp collector's advertiser.) A monthly magazine of general and philatelic interest.

Walthamstow, Essex, Wm. Cormish and Co., 1894 $8^{\circ} .9 \frac{3}{4}$ in. No. 8, September, 1894 .

* * Conducted by Wm. F. Cornish. The pages are numbered 27 42 , no. 6 of the "Stamp collectors" advertiser" leaving off at pag 26. It would appear from this that there was no no. 7. The number has a coloured paper wrapper, the title on which reads "The Monthly reader and stamp collector"s guide and exchange medium, being a sale and exchange supplement. (With which i incorporated the stamp collector's advertiser.) A monthly maga-

STAIMP COLLECTORS' ANNUAL. The Stamp collectors' annual. London, Charles Nissen and Co., rgo4$8^{\circ} .7 \frac{1}{2}$ in. vols. In progress.

[Vol. I.] For 1904. 136 pp., "errata" slip.

[

$[", \quad$ III. $] \quad$ " $1906.116 \mathrm{pp}$.

[ "

* * Edited by Percy C. Bishop and there is a coloured paper wrapper to each volume. Bound up in Mis. St. Pamph.65(4) 68 (1) 72 (6) 80 (3) and 85 (3).

STAMP COLLECTOR'S ANNUAL FOR 1881. The Stamp collector's annual for 1881.

Brighton, Stafford Smith and Co., r88 r. $8^{\circ} .8 \frac{1}{2}$ in. $132+(2) \mathrm{pp}$., frontispiece.

* * Edited by Dr. C. W. Viner, printed on buff paper and dated "Midsummer, 1881". The number has a coloured paper wrapper. Bound up with "The Philatelic Quarterly and Miscellaneous Advertiser" for 1879.

STAMP COLLECTOR'S ANNUAL 1891 [1892 AND 1893]. See STAMP COLLECTOR'S MONTHLY. (Richmond.)

STAMP-COLLECTOR'S BUDGET. The Stamp-collector's budget. Glasgow, Johnson and Ewing, r868. $8^{\circ} .8 \frac{1}{4}$ in. Nos. 1-2, January 1-February 1, 1868.

Mis. St. Jour. 34 (10)

STAMP COLLECTORS' BUDGET. The Stamp col

( lectors' budget. A guide for young collectors all over the world. Published quarterly.

5123 Hastings, etc., The Empire Stamp Co., rgor-o2.

(.) $8^{\circ} .11$ in. Nos. 1-4, Nov., 1901, Mar., June, Sept., 1902.

** Conducted by H. Noslen. No. 4 was published at Horsmonden

()) and there is a coloured paper wrapper to each number. Tus.

rou has lhe newr aloness an Mis. St. Jour. 77 (1).

STAIMP COLLECTORS BUREAU. The Stamp collector's' bureau. Chicago, $\Pi l l .$, C. H. Mekeel, r881-82.

2. $8^{\circ} .11 \frac{1}{1}$ in. Nos. 1-4, Sept. 1, Dec. 10 [1881], June, 1882.

** Nos. 3 and 4 were published together under the date "June, $1882, "$ and there is a title-page to the volume.

Mis. St. Jour. $72(6)$.

\section{[Continued as: :}

The Collectors' bureau.

Chicago, Ill., C. H. Mekeel and Co., I882.

๑ $8^{\circ} .8 \frac{1}{2}$ in. Vol. II. Nos. 5-6, October-November, 1882

** There is a paper wrapper to each number. .

STAMP COLLECTOR'S CHRONICLE. The Stamp collector's chronicle.

St. John, New Brunswick, Foreign Stamp Depot, $1872-73$.

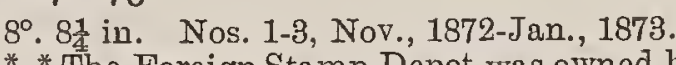

* * The Foreign Stamp Depot was owned by W. Harry Bruce and no. 1 is printed on lilac paper. Wanting no. 3 .

New series. I8 73 .

St. John, New Brunswick, Foreign Stamp Depot,

$8^{\circ} .8 \frac{1}{4}$ in. Prospectus and nos. 1-3, March, and March, June, Sept. 1873 .

** There are paper wrappers to nos. 1-3. Published quarterly by W. Harry Bruce, who owned the Foreign Stamp Depot. The wrapper of no. 3 has "Sept. to Dec., 1873".

STAMP COLLECTORS' COMPANION. The Stamp collectors' companion. A monthly devoted to the interest of collecting.

[Jackson, Mich.], Bert. Wesley, r89r. $4^{\circ} .7 \frac{3}{4}$ in. No. 1, August, $1891 . \quad$ Mis. St. Jour. 66 (16).

STAMP COLLECTOR'S COMPANION. The Stamp collector's companion.

St. Louis, Mo., The Stamp Collector's Publishing Co. I $89 \mathrm{I}-92$

$8^{\circ} .10$ in. Nos. 1-4, Oct. 1, 1891-Jan. 1, 1892.

* There is a coloured paper wrapper to each number. Nos. 1 and 2 were edited by M. Yarnall and nos. 3 and 4 by F. H. Littlefield. Bound up with the "Standard Philatelist".

STAIIP COLLECTORS' DIRECTORY. The Stamp collectors' directory.

Elmira, N. Y., W. A. Turnbull, r896. $8^{\circ} .8$ in. No. 1, July, 1896.

The Stamp advertiser.

Elmira, N. Y., W. A. Turnbull, etc., r896-97.

$8^{\circ} .8$ in. and 9 in. 7 nos. in 2 vols.

Vol. I. Aug.-Oct., 1896. Nos. 2-4.

* "* Nos. 2-5 measure 8 inches and nos. 6-8, 9 inches. The last three numbers were published by the Chemung Stamp Co. and no. 8 is dated "April-May, 1897 ". Wanting no. 8.

[Continued as :]

The Stamp advertiser and stamp collectors' directory.

Ithaca, N. Y., W. A. Turnbull, r 898-99.

$8^{\circ} .8 \frac{3}{4}$ in. Vol. III. 2 nos

Vol. III. May, 1898, May, 1899. Nos. 9-10.

STAMP COLLECTOR'S EXAIINER. The Stamp collector's examiner.

Leamington, A. Parsons and Co., 1865 $8^{\circ} .7 \frac{1}{4}$ in. No. 1, May, 1865.

Mis. St. Jour. 35 (1)

New series,

Leamington, A. Parsons, 1865 .

4. 81 in Nos 1-2, July-August, 1865.48 - 16,1008

** No. 1 was edited by John G. Boel and no. 2 by T. Dalston.

Mis. St. Jout. 35 (1a)

STAMP COLLECTOR'S FIGARO. The Stamp collector's figaro.

Chicago, Ill., etc., E. W. Voûte, etc., r887-9o.

$8^{\circ} .9$ and 93 in. 33 nos. in 5 vols.

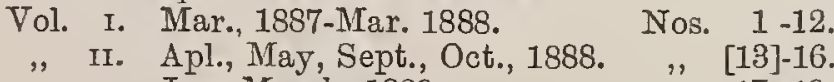

III. Jan.-March, 1889.

$\begin{array}{rrr}\text { IV. Nov., 1889-Oct., } 1890 . \quad \text { " } & 19-30 . \\ \text { ". Nov., Dec., 1890. }\end{array}$

* "No. 14 was published by the Figaro Publishing Company, the numbers of vol. IV. and the two numbers of yol. $\mathrm{v}$., by $\mathrm{F}$. N. 
775 STAMP COLLECTOR'S FIGARO

\section{STAMP COLLECTOR'S FIGARO.}

Massoth Jr. at Hanover Centre, Iudiana. Nos. 1-16, and the two numbers of vol. v., measure about 9 inches and the remaining numbers about $9 \frac{3}{3}$ inches. There is a title-page, a frontispiece, and an index to vol. I., a coloured paper wrapper to each number excepting no. 19, vol. IIr., a portrait of Patrick Chalmers to no. 16 and supplemental slips to nos. 3,5 and 18. No. 12 is dated "March, 1888," but the wrapper bears "February, 1888," no. 19, vol. I ., has in error "Vol. I.," except on the wrapper and no. 24 is wrongly numbered " 23 ," except on the wrapper. There are two varieties of the wrapper of no. 27. One is numbered and dated like nos. 20-30, while the other is the wrapper of no. 26 with the original numbering and date over-printed with foliate ornamentation and "Volume IV., July, 1890, Number 27 " printed in a straight line at the top of the wrapper. No. 19 , vol. III., is said not to have been issued to the public

[Continued as :]

- The Stamp collector. Successor to the Stamp collector's figaro.

Chicago and Hanover Centre, Ind., etc., F. N. Massoth, Jr., etc., x $89 \mathrm{r}$

Vol. v. Jan.-Mar., 1891. Nos. 33-35.

* There is a coloured paper wrapper to each number. No. 35 was published by the Stamp Collector Publishing Co. at Madison, Wis. Wanting no. 35

STAIMP COLLECTOR'S FIGARO. The Stamp collector's figaro.

Wellington, O., The Figaro Publishing Co., I897-98. $8^{\circ} \cdot 9 \frac{3}{4}-10 \frac{3}{4}$ in. Nos. 1-8, November, 1897-[?] ], 1898. * * There is a coloured paper wrapper to each number, but no number for February, 1898. The last number has " 7 " on the wrapper and " 8 " inside. Wanting nos. $6,7,8$.

STAIMP COLLECTORS' FORTNIGHTLY. The Stamp collectors' fortnightly.

London, Bournemouth, [printed], Harry Hilckes and Co., etc., $1894-$

$4^{\circ} .103$ in. nos. in vols. In progress.
Vol. $\quad$ I. Oct. $6,1894-S e p t .21,1895$. Nos. $1-26$.

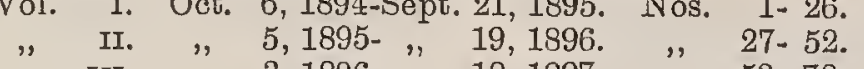

" III. " " 3, 1896- " $18,1897 . \quad " \quad 53-78$

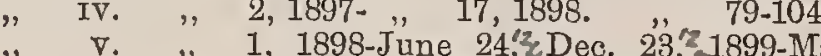

1, 1898-June 24, \&Dec. 23, 1899-Mar. 3, 1900.
Nos. 105-130.

S123 "vi. Mar. 17, 1900-Mar. 2, 1901. Nos. 131-156.

", VI. Mar. 17, 1900-Mar. 2, 1901. Nos. 131-156.

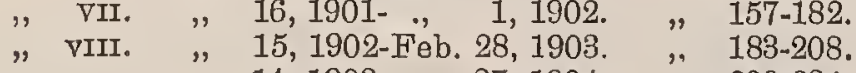

" VIII. " $\quad$ IX. 14, 1903- " 27, 1904. " " $209-234$.

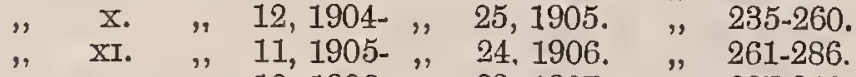

"XII. " 10, 1906-" "23, 1907. " $287-312$

* "There is a title-page and an index to each volume and a coloured paper wrapper to each number. The title-page of vol. vII. bears "October, 1901-March, 1902 "in error for "March, 1901March, 1902" Nos. $1-124$ were edited by Harry Hilckes and Percy C. Bishop and the remaining numbers by Percy C. Bishop. 7 here are tov ing numbers by Plumridge and Co. No. 56 is numbered " 55 " and The ling numbers by Plumridge and Co. No. 56 is numbered " 55 " and Coition ; he $2 x$ dated "October 31,1896 " in place of "November 14, 1896," but hericeome 6 he the number and date on the wrapper is correct. Nos. 86-89have

gof no "204 lns "1902" in place " 1903 " excer on the wrappers; which is correct and the wrapper of no. 217 has " 271 ". "There whe auction is cort and the wrapper of no. 217 has " 271 ". " There are auction supplements to nos. 9-22, illustrative supplements to nos. 23 and 84 and supplements to nos. $42,128-133,147-151,153$ $27-\sqrt{2}$, levelhey are $27-52$, twe the che fort of tar lot

\section{STAIII}

tors' friend.

Margate, The Stamp. Collectors' Co-operative Associa tion, $x 882$.

(9) $8^{\circ} .8 \frac{1}{4}$ in. No. 1, April, $1882 . \quad \%:-4$.
$* *$ Printed on rose paper.

Mis. St. Jour. 54 (9)

STAMP COLLECTORS' GAZETTE. The Stamp col-

(5) lectors' gazette. Liverpool, G. Birtwhistle, r888-89.

2. $8^{\circ} .8 \frac{1}{1}$ in. Nos. 1-3, Nov., 1888, Jan., Feb., 1889. (as mow )

STAMP COLLECTOR'S GAZETTE. The Stamp collector's gazette. A philatelic supporter.

Gainesville, Ga., Martin and Street, 1898 $8^{\circ} .8 \frac{3}{4}$ in. Nos, 1-2, April-May, 1898.
STAMP COLLECTORS' GUARDIAN 776

STAIMP COLIECTORS' GUARDIAN. The Stamp collectors' guardian.

London, E.C., [H. A. McMillan], I899-г 900. 0. $4^{\circ} .103$ in. Nos 1-4, Oct." 10, Nov. 1, Dec, 1, 1899, Jan. 1, 1900. "** There is a coloured paper wrapper to each number. Amalgamated with the "Stamp collectors" fortnightly," no. 128, February
3,1900 . Mis. St. Jour. 52 (7).

STAMP COLLECTOR'S GUIDE. The Stamp collector's guide.

Meriden, Conn., etc., The American Stamp Co., etc., I870-73.

$8^{\circ} .8 \frac{1}{2}$ and $9 \frac{1}{4}$ in. 25 nos. in 3 vols.

Vol. I. Dec. 1870 -Nov., [1871]. Nos. 1-12.

" II. " [1871]-Sept., [1872]. " 1-10

" III. Jan-May, 1873. ", 1-3.

* * The first two volumes are $8 \frac{1}{2}$ inches in height and vol. measures $9 \frac{1}{1}$ inches. Nos. $7-12$, vol. I., and the ten numbers of vol. II. do not bear any year and nos. 7, 8 and 9, vol. I., and nos. 8 and 9 , vol. II., were severally published together. No. 6 was published at New York. nos. 7-12, vol, I., and the ten numbers of three numbers of vol. III., by the American Stamp Co., at Meriden, Conn. The three numbers of vol. III. bear the words "New den, Conn. The three numbers of vol. III. bear the words "New are supplements of two pages to nos. 6 and 7 , and to nos. 8 and 9 , vol. II.

STAMP COLLECTOR'S GUIDE AND WEST OF SCOTLAND CURIOSITY CIRCULAR. Stamp collector's guide and west of Scotland curiosity circular. Glasgow, C. T. Robinson, I872-76.

$8^{\circ} .8$ in. and $16^{\circ} .5_{4}^{3}$ iu. Iro. 1, Feb., 1872, No. 1, Mar., 1872, "Fifth annual issue," 1876.

* * The two numbers, numbered " 1 ," are word for word the same except for the change of the month, and the addition of the word "The" before the title on the March number. They are both octavo in size while the number called "Fifth annual issue" is octavo in size while the number called "Fifth annual issue" is
$16^{\circ}$. The contents of the last named consist wholly of advertise$16^{\circ}$. The contents of the last named consist wholly of advertiseexception of four paragraphs of a philatelic nature.

Mis. St. Jour. 37 (8).

STAIMP COLLECTORS' HERALD. The Stamp collectors' herald.

Walthamstow, Essex, W. Cornish and Co., 1893 .

8.83 in. Nos. 1-5, Jan.-May, 1893 .
${ }^{*}{ }^{*}$ Nos. 1-3 were edited by R. Walford White and there is a coloured paper wrapper to each number. No. 2 is always found very much "cut down".
Mis. St. Jour. 79 (12).

[Continued as :]

The Stamp collectors' herald and philatelic exchange and mart. Walthamstow, W. Cornish and Co., r89.3.

$8^{\circ} .83$ in. Nos. $6-7$, June-Aug., 1893.
$*$ * No. 7 is on coloured paper.

Mis. St. Jour. 79 (12a).

STAIMP COLLECTOR'S HERALD AND BOY'S EIIPORIUIM. See STAMP COLLECTORS' HERALD AND MONTHLY EXCHANGE AND ADVERTISER.

STAMP COLLECTORS' HERALD AND IMONTHLY EXCHANGE AND ADVERTISER. The Stamp collectors' herald and monthly exchange and advertiser. I $87 x$

Hull, Yorks, Yorkshire Stamp and Exchange Agency,

$8^{\circ} .7 \frac{1}{4}$ in. Nos. 1-5, August-December, 1871.

3 * There is a title-page and an index to the five numbers and nos. by C. H. Calvert and C. C. Dixou and nos. 3-5 by C. H. Calvert.

[Continued as:]

The Stamp collector's herald and boy's emporium. New Series.

Hull, Yorks, C. H. Calvert and Co., etc., I872. $8^{\circ} .8 \frac{1}{2}$ in. Vol. II. Nos. 1-4, January-April, 1872. * There is a coloured paper wrapper to each number. Nos. 2-4 were also published by Curtice and Co. of London and all four numbers were edited by Charles H. Calvert. A supplement of two pages with illustrations of stamps, printed on one side only, was presented with no. 3. A second and a third edition were issued of no. 3 and a second edition of no. 4 , the wrapper of the latter 4 have 4 45-64t $\rightarrow$ wh. Mis, St. Jour, 33 (1). 


\section{The \\ Stamp Collectors' Fortmightly \\ AND INTERNATIONAL STAMP ADVERTISER \\ With which is incorporated "Stamps," the "Stamp Collectors' Monthly," the "Young Stamp Collector," and the "Stamp Collectors' Guardian."}



777 STAMP COLLECTORS' HERALD

STAIMP COLLECTORS' HERALD AND PHILATELIC EXCHANGE AND MART. See STAMP COLLECTORS' HERALD.

STAMP COLLECTOR'S JOURNAL. The Stamp collector's journal. Hartlepool, E. C. Hall and Co., $\mathrm{x} 863$.

8 $8^{\circ} .8_{4}^{3}$ in. No. 1, July 1, 1863.84 . Mis. St. Jour. 37 (2).

STAIMP-COLLECTORS' JOURNAL. The Stamp-collectors' journal.

Lake Village, N. H., Harry Cole Quinby and Sydney Conant, etc., 1890 .

$8^{\circ} .73$ in. Nos. 1-12, Jan.-Dec., 1890.

* * Nos. 2-12 have Wellington IJ. Woodworth added to the names of the publishers. Nos. 10 and 11 each consist of a single leaf and there are coloured paper wrappers to nos. 1-9 and to no.
Mis. St. Jour. 66 (1)

STAIMP COLLECTORS' JOURNAL. See FoREIGN STAMP COLLECTORS' JOURNAL.

STAIP COLLECTORS' JOURNAL, AND COIN COLLECTORS' NEWS. See ForEIGN STAMP COLLECTORS' JOURNAL.

STAIMP COLLECTORS' JOURNAL AND PHILATELIC IMONTHLY ADVERTISER. See FORETGN STAMP COLLECTORS' JOURNAL.

STAIMP COLLECTORS' JOURNAL AND PHILA-

(- TELICAL OPINION. The Stamp collectors' journal and philatelical opinion.

$$
\text { London, W.C., Light and Jackson, } 1872 .
$$

(6) $4^{\circ} .81$ in. Nos. 1-4, March 1-June, 1872. hrout all wf. * * There is a paper wrapper to each number. Nos. 3 and 4 were edited by James Foster. Amalgamated with the "American journal of philately and the stamp collectors' journal," July, journal of philately and the stamp collectors' journal," July,
1872. Mis. St. Jour. 35 (3).
S. roms ast.

STAIMP COLLECTOR'S JOURNAL, COIN COLLECTOR'S NEWS, AND ANTIQUARIAN GAZETTE. See Foreign STAMP COLLECTORS' JOURNAL.

STAIMP COLLECTOR'S IMAGAZINE. The Stamp collector's magazine.

Bath, Stafford.Smith and Smith, etc., x863-74. $4^{\circ} .8 \frac{1}{1}$ in. 144 nos. in 12 vols.

Vol. I. Feb. 1-Dec. 1, 1863. Nos. 1- 11

"II. Jan. 1- " 1, 1864. " $12-23$.

III. " $1-", 1,1865 . \quad " \quad 24-35$.

" $\quad$ IV. $\quad$ v. $1-\quad, \quad 1, \quad 1866 . \quad$ " $1, \quad 36-47$.

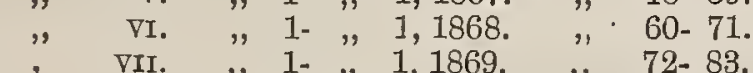

" VIII. ", 1- ", 1, 1870. " " 84- 95.

" Ix. " $\quad 1-, " 1,1871 . \quad, \quad 96-107$.

" $\quad$ x. " "1. " " $1,1873 . \quad$ " $121-132$

" XII. "1- " 1, 1874. " 133-144.

* * Vols. I.-IV. were edited by Dr. C. W. Viner and the remaining volumes by George Overy Taylor. Each number, commencing with no. 12 has a paper wrapper and there is a title-page and index to each volume. Commencing also with no. 12, the title has a hyphen introduced between the words "Stamp collector's." After no. 41 the magazine was published by Alfred Smith and Co., Bath, and all the 144 nos. were also published by $\mathrm{E}$. Marlborough and Co., London. Nos. 119 and 120 were published together under the date "December 1, 1872". Nos. 17, 36, and 52 are found with the front wrapper overprinted "SpecimenJuly, 1863 she tions, the original has the letters "lake" of the name "Blake" in the advertisement of "Oppen's postage-stamp album and cata logue" at the top of page 15 , in small Roman capitals instead of lowercase type and the word "Published" above the advertise ment of the " Postagestamp collector's pocket album" on pae 16 , is misspelt "Pubished". An original copy of no. 1 is bound up at the end of vol. I, and there is a copy of the reprint at the commencement of the volume "Supplementary index" to vol. I., was issued to members of the Philatelic Literature Society in October, 1909

[Vols. I.-IV., bound in two volumes half red morocco.] * * From the philatelic library of the late Miss Adelaide Lucy Fenton of Clifton, Bristol. Her own working copies of these volumes with numerous plain leaves inserted bearing notes an the "large paper" issue of the fifth edition of Mount Brown's
STAMP COLLECTOR'S MAGAZINE 778

"catalogue"; no. 9 of " Once a month," Manchester, December 20, 1864 ; no. 1 of the "Stamp collector's monthly gazette," St. John, New Brunswick, June 1, 1865; no. 1 of the "Bath stamp and coin gazette, and advertiser," Bath, June 1, 1865; severa editions of Stafford Smith and Smith's and Alfred Smith and Co's catalogues of 1863-70, and a printed circular of Spiro Brothers of Hamburg, dated May, 1864. The copy of no. 1 in this set is the reprint.

STAIMP COLLECTOR'S IMAGAZINE. The Stamp collector's magazine.

Boston, Mass., W. L. Terhune, I87x.

$8^{\circ} .9$ in. No. 1, January, 1871.

* ${ }^{*}$ Some copies were printed on white and others on buff paper.

STAMP COLLECTOR'S IMAGAZINE. The Stamp collector's magazine. Illustrated.

Richmond, Surrey, H. Marryat, etc., ז89o.

4. $7 \frac{3}{2}$ in. Nos. 1-4, April-July, 1890.

** Nos. 2-4 were published by H. Marryat and Co. Nos. 1 and 2 have coloured paper wrappers. These two numbers were reprinted, minus the wrappers. The reprints bear the words: "[Reprinted September, 1890.]"

\section{[Continued as :]}

The Stamp collector's monthly.

Richmond, Surrey, etc., H. Marryat and Co., etc., I890-94.

$4^{\circ} .73$ in. 53 nos, in 5 vols

Vol. I. Aug.-Dec., 1890. Nos. 5- 9.

" II. Jan.-" 1891. ", 10-21.

" III. " - " $1892 . \quad$ " 22-33.

" TV. " - -Christmas, 1894. " $1893.46-57$.

*" Nos. 10"-42 were published by "H. A. McMillan and Co. at Kingston-on-Thames, nos. $43-45$ by the same firm at London, E.C., 'and nos. 46-57 by the Philatelic News Agency, London. Nos. 5-45 were printed at Richmond and nos. $46-57$ at Bournemouth. Nos. 1-38 were published on the completion of each year in separate volumes with an index and a title-page reading "The Stamp collector's annual, 1891 [1892 and 1893] being the "Stamp collector's monthly' for 1890 [1891 and 1892]".... A "Special collector's monthly' for 1890 [1891 and 1892]" .... "A "Special 22nd, 1890," and with it portraits of Sir Rowland Hill,and James 22nd, 1890," and with it portraits of Sir Rowland Hill and James by the latter in February, 1838, and the title-page and index deby the latter in February, 1838, and the title-page and index described above. Nos. 49 and 50,51 and 52,53 and 54 and 56 and 57 were severally published together and there is a coloured paper wrapper to each number commencing with no. 15. The wrapper to no. 21 bears the words "with special supplement". This supplement consists of the title-page and index to the volume for 1891, and a similar title-page and index for the 1892 volume was presented with no. 33. The wrappers to nos. 49-54 are neither numbered nor dated, while that for nos. 56 and 57 is, like the journal itself, dated "Christmas, 1094, "Stamp collectors' fortnightly," no. 8, January 12, 1895.

STAMP COLLECTORS' MISCELLANY. The Stamp collectors' miscellany.

Weymouth, D. Dean and Co., 1864-65

C $8^{\circ} .7 \mathrm{in.}$ Nos. 1-11, July 1, 1864-May, 1865 .

STAIMP COLLECTOR'S MONTHLY. The Stamp collector's monthly. Devoted to the interests of stamp collectors.

Newmarket, N. H., F. H. Pintiham, г872-76. $12^{\circ} .6-63$ in. and $8^{\circ} .9 \frac{1}{4}$ in. 17 nos. in 2 vols.

Vol. I. Jan.-Dec., 1872. Nos. 1-12.

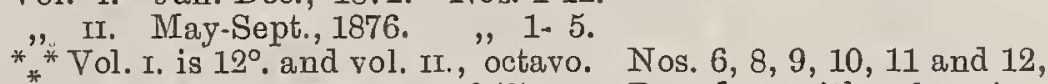
vol. "Notice to subscribers" etc., (2) pp., dated October 12, 1876.

Vol. II. Mis. St. Jour. 18 (10).

STAMP COLLECTORS' MONTHLY. See MONTHLY STAMP CIRCULAR.

STAMP COLLECTOR'S MONTHLY. See STAMP COLLECTOR'S MAGAZINE. (Richmond.) 
๑ STAMP COLLECTOR'S MONTHLY ADVERTISER. The Stamp collector's monthly advertiser. I905.

Christchurch, New Zealand, J. H. East and Co.

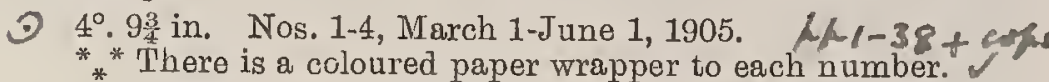

Mis. St. Jour. 122 (6).

STAMP COLLECTORS' MONTHLY ADVERTISER See Monthly advertiser (Liverpool).

STAMP COLLECTOR'S IMONTHLY GAZETTE.

The Stamp collector's monthly gazette.

St. John, New Brunswick, George Stewart, Jr., x $865-67$.

$8^{\circ} .9$ in. 24 nos. in 2 vols

Vol. I. June 1, 1865-May, 1866. Nos. 1-12

"II. I1. 1866- " 1867. "13-24.

* * No. 18 is wrongly numbered "No. 17 " and there is a supple-

ment of two pages to no. 10 and also one of two pages dated "June, 1867". The work has the combined title-page and index for the two volumes printed by J. W. Scott of New York in April, 1870. A second copy of no. 1 is bound up with the late Miss Fenton's working copies of vols. I.-Ir. of the "Stamp collector"s magazine"

STAMP COLLECTORS OWN PAPER. The Stamp Collectors own paper. [Dummy copy of a journal dated "May, 1904" and numbered "No. 3, Vol. I.," proposed to be published by J. H. Cooke, Birmingham, but which never appeared.]

Mis. St. Jour, 154 (18).

STAMP COLLECTOR'S POCKET COIMPANION The Stamp collector's pocket companion.

Manchester, Thorpe and Burns, 1865. $24^{\circ} .51$ in. No. 1, April, 1865.

* * The number has a coloured paper wrapper.

Mis. St. Jour. 42 (1).

STAMP COLLECTOR'S RECORD. The Stamp collector's record. $8^{\circ} .8 \frac{1}{2}$ in. Nos. 1-2, Feb. 15-[? March], 1864.

* *T. K. Tiffany states that S. A. Taylor informed him a no. 2 was printed, but only some five or six copies were circulated and the rest were destroyed. This was the first philatelic journal published in Canada. Wanting no. 2.

_... New Series.

Albany, N. Y., etc., S. A. Taylor, I864-76. Vol. I. Dec. 15, 1864-Feb. 15, Mar. 1, (numbered "Extra,") Apl. 3-Aug. 16, Oct.-Dec., 1865. Nos. 1-11 and

II. Jan.-Dec., 1866. Nos. 13-24.

"III. Jan.-Sept., 1867, May, 1868, May, Sept., 1869. Nos. $25-36$

IV. [1870], [1870], Feb., Dec., 1871, July, 1872, Oct., 1876. Nos. $37-41$ and 44 .

* "Nos. 9-40 were published at Boston and no. 44 at New York. The issue for March 1, 1865, numbered "Extra," consists of a single leaf printed on one side only; , the number for June 1, 1865 , is numbered " 7 " in place of " 6, " and no. 8 has " August" spelt "Augstt". There are no numbers 12,42 or 43. There are two editions of no. 20 with the paragraphs " Answers to correspondents" differently placed on pages 2 and 3 and some copies of no. 23 have pages 2 and 3 entirely blank. Some copies of no. 30 have a different paragraph at the foot of the left hand column of page 3 and have pages 1 and 4 entirely blank. There are two numbers of no. 33 one being exactly the same as no. 32, except for the no. "38" and the date "September". There are also two numbers of no. 38 , one identical, except for the number with no. 37, the other printed on thicker paper and with different contents. Nos. 37 and 38 bear no date or volume number. Three price lists, of one leaf each, were issued by S. A. Taylor, with the heading "The Stamp collector's record" two at Boston (one printed on coloured paper), and the other at New York, and these are bound up with the journal. This was the first philatelic journal published in the United States.

STAMP COLLECTOR'S REVIEW. The Stamp collector's review. Boston, Mass., F. H. King, s866. $8^{\circ} .9 \frac{1}{2}-8 \frac{1}{2}$ in. "Introduetory," no. 1, July, 1866 : No. 1, October, 1866

* "The "Introductory" number "Vol. I. No. 1" dated " July, 1866 ," consists of a single leaf $9 \frac{1}{2}$ inches in height printed on on side only. For continuation see "Star of the East". Mis. St. Jour. $21(2,2 \mathrm{a})$
STAMP COLLECTOR'S REVIEW. The Stamp collector's review. [Prospectus of a journal to be published by the American Stamp Company, Middletown, Conn. on April 5th, 1868, but which was never issued.]

Mis. St. Jour. 38 (4)

STAMP COLLECTOR'S REVIEW. The Stamp collector's review. Devoted to the interests of stamp collectors.

Minneapolis E. D., Minn., Fred. C. Lawrence, I874.

16․ $5 \frac{1}{2}$ in. No. 1, January, $1874 . \quad$ Mis. St. Jour. 68 (8).

STAMP COLLECTOR'S REVIEW. The Stamp collector's review. I 882 .

Davenport, Iowa, etc., J. C. Rasmussen, [1877]-

$8^{\circ} .83$ in. and $99^{3}$ in. 17 nos. in 4 vols.

Vol. I. [Dec., 1877], [Sept., 1878], [Dec., 1879]. [Nos. 1-3.]

"II. Mar. 1880-Jan., 1881. Nos. 1-6 and no. marked "Extra". S 123

" III. Feb.-Dec., 1881. Nos. 1-4.

* " IV. Apl. -Oct., $1882 . \quad$ "1-3.

* * The numbers of vol. Iv. were published at Rock Island, Ill. The three numbers of vol. I. are neither dated nor numbered and no. 1 is printed on blue paper. The three numbers of vol. I. and the first three of vol. II. are octavo $8 \frac{3}{4}$ inches and the remainder are octavo $9 \frac{3}{2}$ inches. There are coloured paper wrappers to no. 4 , vol. III., and to the three numbers of vol. IV.

Mis. St. Jour. 10 (2)

STAMP COLLECTOR'S REVIEW. The Stamp col(?) lector's review. Monthly.

London, E.C., R. Levick, I892.

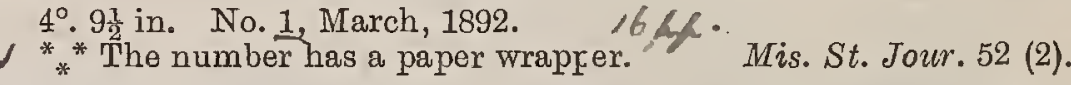

STAMP COLLECTORS' REVIEW AND MONTHLY ADVERTISER. See MONTHLY ADVERTISER (Liverpool).

STAMP COLLECTORS WORLD. The Stamp collectors world. A monthly journal devoted to philately.

Williamsville, Mass., William B. Hale, r888-89. $8^{\circ} .9$ in. Nos. 1-8, November 1, December 10, 1888 , January 10,
1889.

STAMP COURIER AND CUURIOSITY ADVERTISFR Stamp courier and curiosity advertiser.

Dewsbury, Yorks, Abbs and Fryer, $\mathrm{x} 866$ 8. 91 in. Nos. 1-2. October 15-November 15, 1866.

Mis. St. Jour. 52 (1).

STAIMP CRANK, See BuffaLo PhILATELIST.

STAIIP CRITIC. The Stamp critic.

Washington, D. C., The Stamp Critic Co., r89i. $8^{\circ} .9$ in. №. 1, February, 1891.

** The number has a paper wrapper. $\quad$ Mis. St. Jour. 48 (3).

STAMP DEALER. The Stamp dealer. [Prospectus of a quarterly journal to be published by the International Philatelic Press Agency, London, E.C., on April 10, 1893, but which was never issued.]

Mis. St. Jour. 54 (3).

STAMP DEALER'S ADVERTISER. Stamp dealer's advertiser. Liverpool, J. C. Wroe, r866. $8^{\circ} .8$ in. Nos. 1-2, July-August, 1866.

* * No. 1 has four pages numbered 1-4, while the four pages of no. 2 are numbered $5,6,9,10$.

Mis. St. Jour. 37 (4). S123

STAMP DEALERS' ADVERTISER. The Stamp dealers'

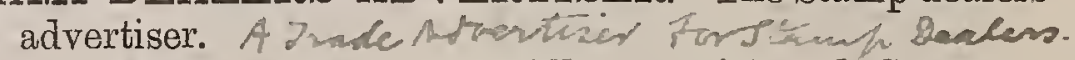
94. Walthamstow, Essex, Wm. Cornish and Co., I893-

(0) $4^{\circ} .11 \frac{1}{1}$ in., 103 in., 10 in. and $9 \frac{3}{2}$ in. Nos. 1-11, December, 1893 Oct., 1894. ** No. 1 is $11 \frac{1}{4}$ inches, nos. $2-7$ are $10 \frac{3}{4}$ inches, no. 8 is 10 inches,
and nos. $9-11$ are 93 inches. There are coloured paper wrappers and nos. $9-11$ are 93
to nos.
3-7 7 and $9-11^{\prime}$ and nos. There are coloured paper wrappers
and 10 were published together under the date, "Aug. and Sept., 1894"." Mis. St. Jour. 77 (7).

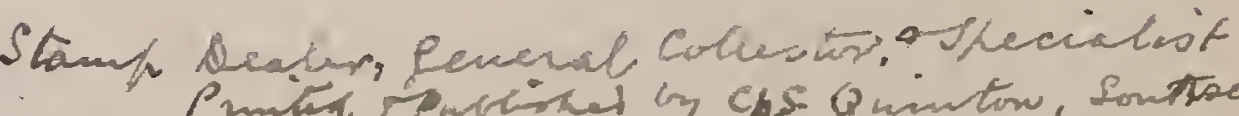

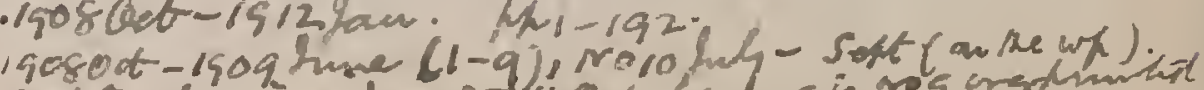

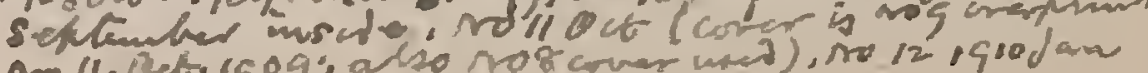

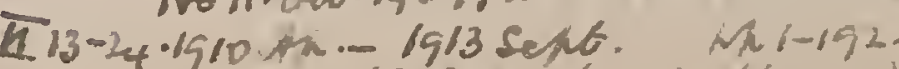

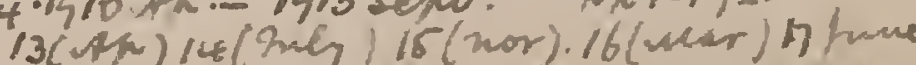

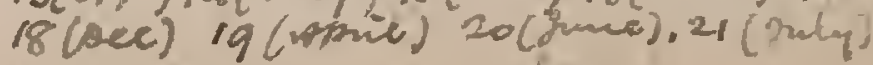
22 (Aev) 23 (Man) 24 (S.to.)

all.25. 1948 Ho 
STAMP COLLECTORS' MONTHLY CIRCULAR.

STAMP COLLECTORS' MONTHLY JOURNAL.

SEe ALFRED SMITH \& CO.'S MONTHLY CIRCULAR.

STAMP COLLECTOR'S QUARTERLY. (London, F. H. Vallancey).

Vols. 1 and II (1916-18). Unbouncl.

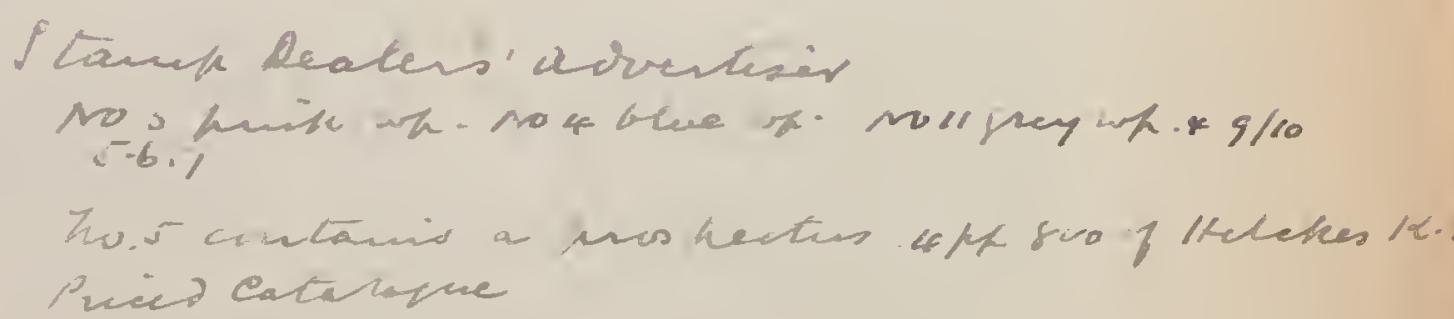


Stand dealess a the

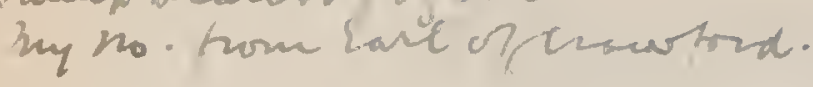

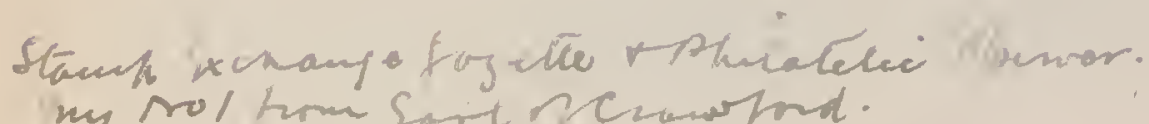
my nol tom sort pevontond.

Stamp Feent. A Reand of the Gonton Branch he S.S.C. Sdited by he decretary [f-Manshall]

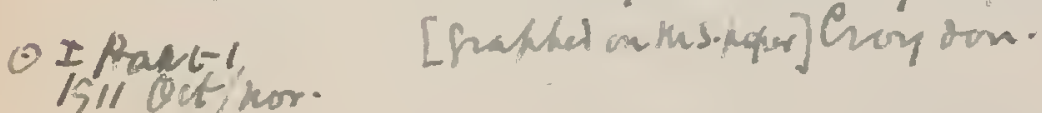

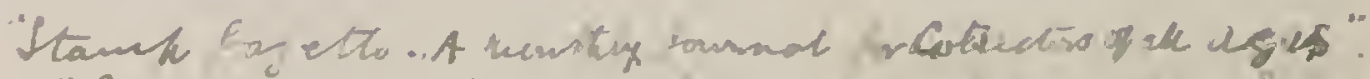

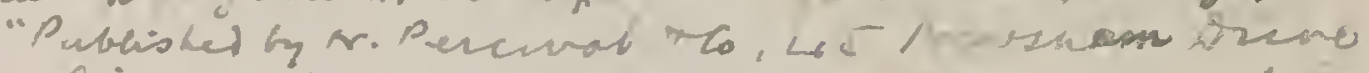

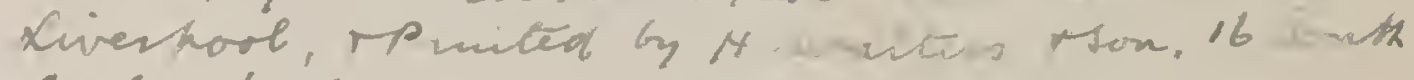
Cas the street.

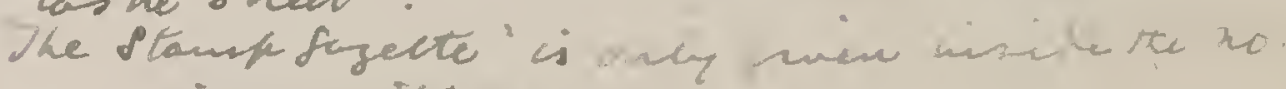
no 4 in a white ind

flamp Jarald thourthly ex change bull 1870 
STAMP DEALER'S AND COLLECTOR'S JOURNAL [A journal with this title is given in the list of American philatelic literature published in the "Philatelist" of London and Brighton for May 1, 1867 ; but it is "said to have been announced, when or where we are unable to learn, but never made its appearance".]

STAMP DEAIERS' GAZETTE. The Stamp dealers' gazette: a monthly journal devoted exclusively to stamp dealers.

Horsmonden, Staplehurst, Kent., W. Morley, I880. $8^{\circ} .9 \frac{1}{2}$ in. Nos. 1-2, September-October, 1880

* No. 2 has an extra leaf of advertisements printed on one side only. A copy of the prospectus is bound up in front of no. 1.
Mis. St. Jour. 12 (2).

- New Series

Bury St. Edmund's, C. H. Nunn, I882

C $8^{\circ} .8 \frac{\pi}{2}$ in. Nos. 1-2, Jan. and Feb;-Mar. and April, 1882.

* * Amalgamated with the "Stamp collectors" jourmal" in November, 1885

Mis. St. Jour. 30 (8)

STAMP DEALERS' JOURNAL. The Stamp dealers'

(-) journal, a journal published in the interest of dealers and collectors of stamps throughout the world.

Nottingham, E. Roberts, I 885-86.

$08^{\circ} .10$ in. Nos. 1-5, June, Aug., Oct., Dec., 1885, Feb., 1886.

, ** The title of nos. 4 and 5 reads "The Stamp Dealers' Journal, published in the interest of dealers and collectors of stamps throughout the world ". No. 5 is numbered in error "No. 4 " Amalgamated with the "Philatelic star and coin collector, vol.

$\begin{array}{ll}\text { III., no. } 2 . & \text { Mis. St. Jour. } 9 \\ \text { STAIMP DEAIERS OWN. The Stamp dealers own. }\end{array}$ I 876 .

Washington, D. C., C. R. Waller and H. Stewart,

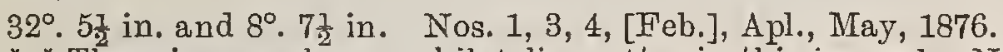

* * There is scarcely any philatelic matter in this journal. Nos. $1^{*}$ and 3 are $32^{\circ}$. and no. 4 is octavo. No. 2 was destroyed when half printed and was never circulated. No. 4 consists of a single leaf, and the back page has the headline "The Patrol". No. 1 has no month or year date. The journal was continued as "The Patrol," nos. 5-6, May-June and July, 1876, but there is no philatelic matter in these two numbers.

Mis. St. Jour. 41 (9, 9a).

STAIMP ECHO. The Stamp echo.

Central City, Neb., Cleve Scott, I892.

$8^{\circ} .8 \frac{1}{2}$ in. No. 1, April, 1892.
$* *$ The number has a coloured paper wrapper.

Mis. St. Jour. 64 (4).

STAMP FXCHANGE. The Stamp exchange.

Lowell, Mass., Arthur H. Wheeler, I87 I 8.913in. [No. 1.] Jan. 1, 1871.

Mis. St. Jour. 44 (1)

STAMP EXCHANGE. The Stamp exchange. A monthly

(6) paper devoted to the advertisements of philatelists residing in all parts of the world.

, Hutson and Co, I886.

(1) $8^{\circ} .7 \frac{1}{2}$ in. Nos. 1-3, September-November, 1886. 4,16

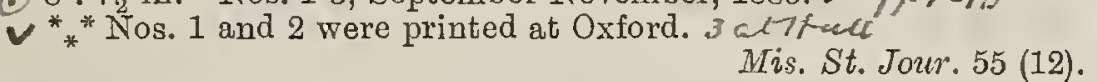

STAMP EXCHANGE. The Stamp exchange.

No. 1, July, 1891

Bloomington, Ind., S. K. Rhorer, r8gr.

STAMP EXCHANGE. The Stamp exchange.

Columbus, Ind., Will E. Marsh, 1897-98.

32. 4 in. Nos. 1-10, Aug., 1897-May, 1898.

** There is a coloured paper wrapper to each number. Wanting nos. $1,2,3,4,6,7,9,10$.

STAIMP EXCHANGE. The Stamp exchange.

Boston, Mass., Ralph W. Tucker, r899.

$8^{\circ} .9$ in. Nos. 1-[5], Apl.-Aug., 1899.

** Each number has a paper wrapper. No. 5 is numbered "volume 1r. number 10" and the wrapper of this number has "vol. II. no. 4. whole no. 10". Whole no. 10 was reached by the amalgamation of "Stamp talk," which issued nine numbers. Copies of the last number are said not to have been circulated and the entire edition is stated to have been destroyed with the exception of some six or eight copies. Mis. St. Jour. 102 (11).
STAIMP EXCHANGE. The Stamp exchange.

Kankaree, Ill., etc., Shirley Ervin Moisant, etc., I 900-02.

$5^{\circ} .9-8$ in. 27 nos. in 5 vols

Vol. I. Jan., Apl., July, Oct., 1900. Nos. 1-4.

" II. Jü June, $1901 . \quad$ ", $1-6$.

" Ill. July -Dec, 15, 1901. "1-6. Nos. 1-6.

" $\quad$ v. July-Oct., Dec., 1902. Nos. $1-5$.

* "*. July-Oct., Dec., 1902 . Nos. 1-5.

** Nos. 5, 6, vol. IlI.. and nos. 1-5, vol. IV., were published by Moisant and Hills, and the subsequent numbers were published at Fort Wayne, Ind., by Exchange Publishing Co. No. 4, vol. I., is numbered in error "No. 3"; no. 6, vol. IV., and no. 1, vol. V., were published together wlth the date "June-July, 1902 " and
nos. 1-3, vol. II., nos. 5, 6 , vol. IV., and the numbers of vol. $\nabla$. have nos. 1-3, vol. II., nos. 5, 6, vol. IV., and the numbers of vol. v. have
coloured paper wrappers. No. 4, vol. v., has in error "vol. vI.," coloured paper wrappers. No. 4 , vol. V., has in error
except on the wrapper, which is correctly numbered.

STAMP EXCHANGE. The Stamp exchange.

Allahabad, India, Mrs. E. A. Freemantle, 1903-04.

$8^{\circ} .10-10 \frac{1}{2}$ in. 12 nos. in 2 vols.

Vol. I. May-Dec., 1903. Nos. 1-8.

* " Printed on coloured paper with the exception of the last

* "Printed on coloured paper with the exception of the last
number.
Mis. St. Jour. 123 (14).

STAMP EXCHANGE GAZETTE AND PHILATELIC

OBSERVER. The Stamp exchange gazette and philatelic observer.

Ipswich, Hamnall, Boswell and Co., I883.

$8^{\circ} .10$ in. Nos. 1-4, January-A pril, 1883

* * Printed on coloured paper. Mar sime, Mis. St. Jour. 9 (7).

STAIIP EXCHANGER'S DIRECTORY. See PART I. Toledo Stamp Co.

STAMP FACTS. Stamp facts.

Butler, Pa., Thomas McKee, r896.

$64^{\circ} .3 \frac{1}{2}$ in. $32^{\circ} .4$ in. and $16^{\circ} .5 \frac{1}{4}$ in. Nos. $1-5$, August-December

${ }^{*}{ }^{*}$ Nos. $1-3$ are $64^{\circ}$., no. 4 is $32^{\circ}$. and no. 5 is $16^{\circ}$

[Continued as :]

Scraps. An amateur monthly devoted to amateur journalism, clubdom and philately.

Butler, Pa., Thomas McKee, I897.

$12^{\circ} .7$ in. No. 6, January, $1897 . \quad$ Mis. St. Jour. 69 (2a).

STAIMP FIEND. The Stamp fiend. Devoted to the interests of stamp collectors.

Cleveland, O., C. C. Hendrictes, 1894 . 8०. 9 in. Nos. 1-2, June-July, 1894.

Mis. St. Jour. 62 (4)

STAIMP GOSSIP. Stamp-gossip. A monthly magazine

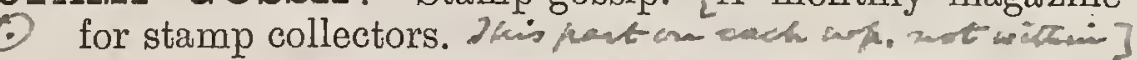
Bury St. Edmund's, J. Graves and Co., I 897.

$08^{\circ} .83$ in. Nos. 1-12, January 1-December 1, 1897. $1 / 1 / 66+a 2-1 / k$ * * There is a coloured paper wrapper to each number. Amalga-

STAMP HERALD. The Stamp herald.

(1) Berwick-on-Tweed, D. Carstairs, [1889] (.) $8^{\circ} \cdot 63$ in. No. 1, January, [1889].

* * The above consists of two leaves only one of which is printed on. The journal is mentioned in a list given in 'Herdman' miscellany" for February 15, 1889, page 32 .

Another copy in Mis. St. Jour. 76 (4)

STAIMP HERALD. The Stamp herald.

Breinigsville, Pa., R. H. Butz, I 903

$16^{\circ} .6$ in. and $8^{\circ} .9$ in. Nos. 1,4 , January-Feb., Mar., Apl., 1903 * No. 1 is $16^{\circ}$. and is printed on rose paper and no. 4 is octavo * * No. 1 is $16^{\circ}$ and is printed on rose paper and no. 4 is octavo and is printed on white paper. The latter is dated "February,
March, April," without any year.
Mis. St. Jour, 107 (5).

STAMP HERALD. See STAMP. (Holyole, Mass.)

STAMP INVESTOR'S GUIDE. The Stamp investor's guide. A quarterly pamphlet in the interest of stamp investors and collectors.

Kingston-on-Thames, H.A. McMillan and Co., I89293.

$8^{\circ} .8$ in. Nos. 1-2, October 20, 1892-March 10, 1893

** Printed on bright rose paper. Mis. St. Jour. 54 (1). 
STAIMP ITEM. The Stamp item.

Memphis, Tenn., Paul W. Prutzman, I89o. $24^{\circ} .5$ in. Nos. 1-4, April-July, $1890 . \quad$ Mis. St. Jour. 68 (2).

STAMP ITEM. The Stamp item.

Hubbardstown, Mass., A. E. Bennett, I897. in. Nos. 1-3, October-December, 1897.
* Wanting all nos.

STAMP ITEM. Stamp items.

Wortendyke, N. J., C. L. Babcock, Jr., I904.

$32^{\circ} .4 \frac{1}{2}$ in. Nos. 1-2, August-September 15, 1904 * *No. 2 has the title "Stamp Items". Wanting no. 1, which
consists of only one leaf.

STAMP JOURNAL. The Stamp journal.

- Middletown, Conn., A. Fountain, 1867.

$8^{\circ} .8$ 8 $^{3}$ in. Nos. 1-3, August-October, 1867. Mis. St. Jour. 27 (3).

STAMP JOURNAL. The Stamp journal.

Cincinnati, O., Roberts and Johnston, $\mathrm{I} 880$.

$16^{\circ} .6 \frac{1}{4}$ in. No. 1, February 1, $1880 . \quad$ INis. St. Jour. 68 (28).

STAMIP JOURNAL. The Stamp journal.

Newburyport, Mass., Carl P. Rollins, I893-95. $24^{\circ} .5-4 \frac{1}{2}$ in. 34 nos. in 3 vols.

Vol. I. March, 1893-Feb. 10, 1894. Nos. 1-12.

"II. " 1894- -D" 18. 1895. " 1.12.

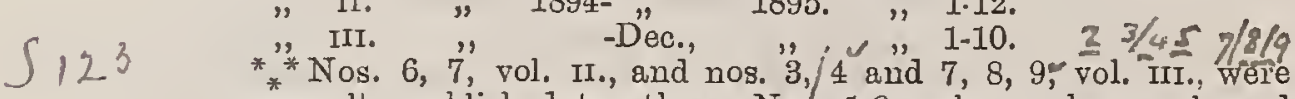
severally published together. Nos. 1-9, vol. III., have coloured paper wrappers. No. 3, vol. I., has the title "The Stamp journal of W. Newbury" and is wrongly numbered "vol. $2 "$. No. 2, vol. II., has a supplement of two pages. Wanting vol. I. nos. 1, 2, 4, $5,6,7,10$. Vol. II. nos. $1,3,4,5,6,7,8,9,10,11,12$.

STAMP JOURNAL. See COIN AND STAMP JOURNAL (Kansas City, Mo.).

STAMP JOURNAL AND PHILATELIST'S GUIDE. The Stamp journal and philatelist's guide. $8^{\circ} .71$ in. November, 1871.
** Edited by Auguste Jacob. Hull, Hy. P. Harker and Co., $\mathrm{x} 87 \mathrm{x}$.

Mis. St. Jour. 42 (8).

STAMP JOURNAL OF W. NEWBURY. See StAMP JOURNAL. (Newburyport, Mass.)

STAIMP-LORE. Stamp-lore.

London, Ont., The Commercial Printing Co., etc., I896-97.

$8^{\circ} .10 \frac{1}{2}$ in. Nos. 1-5, June, July, Nov. 15, 1896-Jan. 15, 1897.

* * Nos. 3-5 were published by the Pritchard Publishing Company and nos. $1,3,4$ and 5 have paper wrappers.

Mis. St. Jour. 87 (1).

STAIMP LORE. Stamp lore. A philatelic monthly. Berlin, Ont., [F. J. Weaver and Co.], x 906. $8^{\circ} .83$ in. 9 nos. in 2 vols.

Vol. I. March-August, 1906. Nos. 1-6.

S "II. September-[? Nov.], 1906. Nos. 7-9.

* * Each number has a coloured paper wrapper. The number for September, 1906, has "vol. I. no. 7 " inside and "vol. II. no. 1 " on the wrapper. Wanting nos. $3,4,5,6,8,9$.

STAMP-LOVERS WEEKLY. The Stamp-lovers weekly. Bethlehem, Pa., E. T. Parker, I 904-05. Fol. 12-113 in. 32 nos. in 2 vols

Vol. I. Sept. 17, 1904-Mar. 11, 1905. Nos. 1-26. " II. Mar. 18, A copy of the prospectus of the journal is bound up with the
a,bove numbers.

\section{[Continued as:]}

The Stamp-love collector. Fol. $11^{\frac{3}{4}-12}$ in. Vols. II.-IV., 54 nos. Vol. II. Apl. 29 -Sept. 9, 1905. Nos. 7.-26. $\begin{array}{llll}\text { "III. Sept 16, 1905-Mar. 10, } 1906 . & \text { "1-26. } \\ \text { " III. Mar. 17, -May 5, 1906. ", } & 1-8 .\end{array}$

STAMP - LOVERS WEEKLY AND IMORRISON'S WEEKLY STAMP COLLECTOR. See STAMP LOVERS WEEKLY.
STAMP IMARKRT. See EWEN'S WEEKLY STAMP NEWS.

STAIIP MEIIORANDA. Stamp memoranda

Providence, R. I., A. B. Slater, Jr., 1893-94.

$32^{\circ} .43$ in. Nos. 1-2, November 20, 1893-June 1, 1894.

** There is a coloured paper wrapper to each number. Mis. St. Jour. 150 (6).

STAIMP IMOUNT. The Stamp mount.

Derby, Daventry, [printed], W. Webster, I903-05. C $24^{\circ} .5 \frac{1}{2}$ in. and $8^{\circ}$. $7 \frac{1}{2}$ in. Nos. 1-5, Sept., Xmas, 1903, April, September, 19C4, May, 1905 . Af 136 . 3 .
$*$ * Nos. 1-4 are $24^{\circ}$. and no. 5 is octavo, and each number has a coloured paper wrapper. Ljut the Mis. St. Jour. 119 (1).

STAMP NEWS. The Stamp news.

Rockford, Ill., Stamp and Coin Co., 1873

$8^{\circ} .8 \frac{1}{2}$ in. No. 1,1873

** Printed in blue ink on white paper without the month of publication. The Stamp and Coin Co. was owned by A. Martin.

STAIMP NEWS. The Stamp news. A monthly journal devoted to philately.

London, Theodor Buhl and Co., I882-95. $4^{\circ} .9 \frac{1}{2}$ in. 115 nos, in 11 vols.

Vol. I. Jan., 1 -Dec., 1882. Nos. 1- 12 ,

"II. " " $\quad 1884 . \quad 13-24$.

"III. " "Nov., 1885. " 25-35.

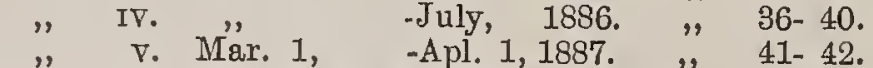

" VI. Dec. 1, 1889-Dec. 1, 1890. " " $43-55$.

" VII. Jan. 1, - " 1, 1891. ", 56- 67.

" VIII. " 1, - " $1,1892 . \quad " \quad 68-79$

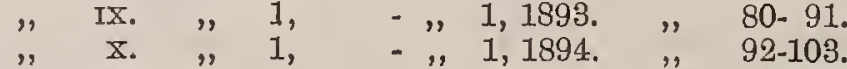

"XI. "X 10, - " $1895 . \quad$ "104-115.

* * There are title-pages and indexes to vols. I., vI.-IX., and xI., but only an index to vol. $x$. ; and, commencing with no. 56 , each number has a coloured paper wrapper. No. 40 is dated "MayJuly, 1886," and there is an advertisement supplement of two pages to no. 43 . The following numbers were severally published together under the given dates:

Nos. 9 and 10, under the date "October, 1882".

" 11 and 12, " " " "December, 1882 "

" 20 and 21, ", " " " "August and September,

"22, 23 and 24, under the date "Oct., Nov., and Dec.,

" 29 to 33, under the date "May to September, 1885".

" 34 and $35, \quad$ " " " "October and November, 1885 ".

" 114 " 115, "1895" " " " "November and December,

Bound up with no. 7 is a copy of the prospectus of the journal and bound up with no. 43 is a copy of the prospectus issued previously to the re-appearance of the journal on December 1, 1889. After December, 1895, the journal was amalgamated with the "Philatelic Record and stamp news".

STAMP NEWS. The Stamp news.

* in. No. 1, November, 1896.

Chicago, Ill., G. F. Dold, I896.

STAMP NEWS. The Stamp news.

], 1899.

in. Nos. 1-2. *" Issued anonymously by " Envelope " from " Stampdom," Pa.
W"anting both numbers.

STAMP NEWS ANNUAL. The Stamp news annual. Being a Christmas number of the "Stamp news".

$40.9 \frac{7}{2}$ in. 6 vols London, Theodor Buhl and Co., I8g $\mathrm{i}-96$.

[Vol. I.] For the year 1891, $100 \mathrm{pp}$.

[" II.] " " " " $1892, \quad 100 \mathrm{pp}$.

"

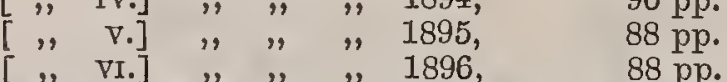

" "There is "a coloured paper wrapper to each volume and vols. III.-V. were printed at Plymouth.

STAIIP NOTES. Stamp notes.

Glencoe, Ill., Gilbert Johnson, I go6. $8^{\circ} .9$ in. Nos. 1-4, August-November, 1906. $8^{\circ} .9$ in. Nos. 1-4, August-November, 1906 .
$* *$ There is a coloured paper wrapper to each number. Wanting $S, 2$.
nos. 1,2 . 


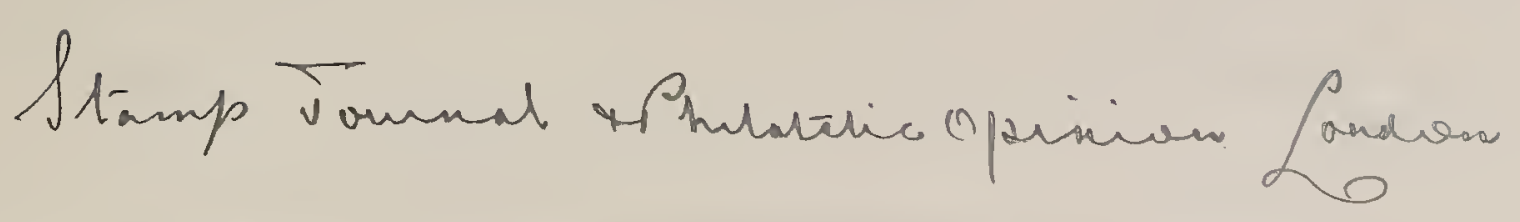


$\Delta$ su vurur 786

stang volís pptias.

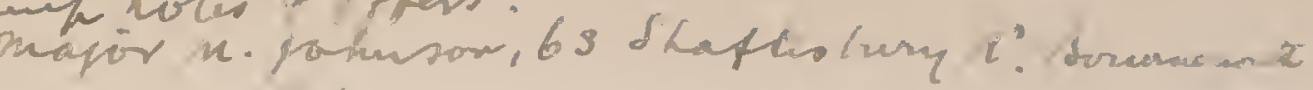

1509 nol. wet.

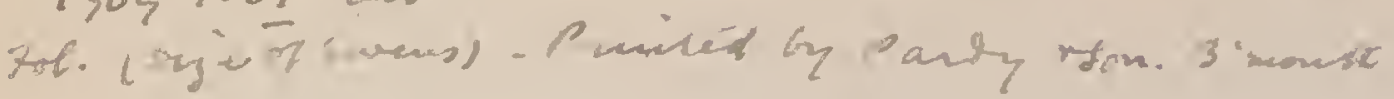

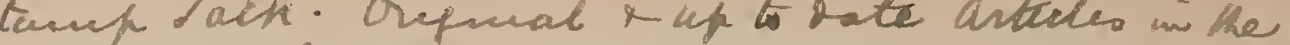

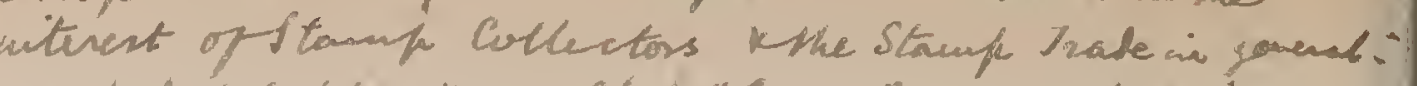

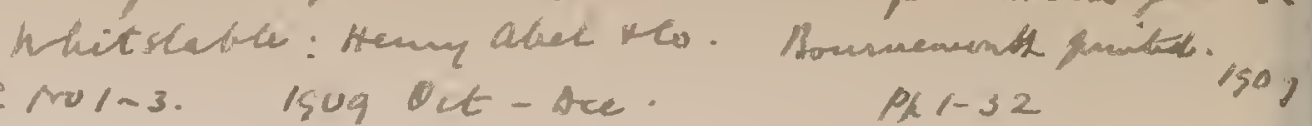

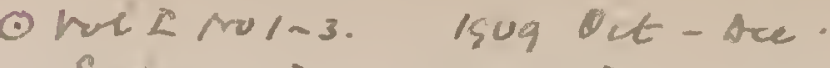
Sach no. in a carmine wh.

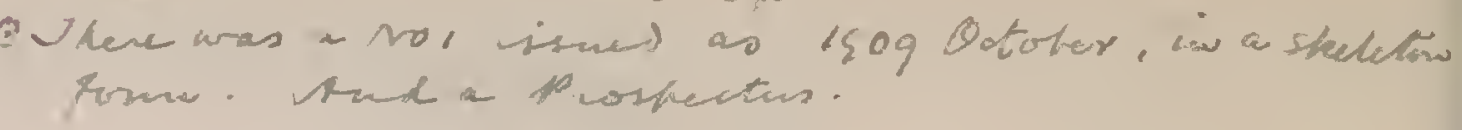

Stamp Recorder.

This was pristid at Rotherham (hriand)

Stamp Ruview, Londur, 1892

Stempotruche aumbires, fordox

Stamp Shopuer. checigo

4

$10 / 11$ 
STAMP NOTES. See MONTHLY STAMP NOTES.

STAMP RECORD. The Stamp record.

$8^{\circ} .8 \frac{1}{1}$ in. No. 1, April 2,1883 .

H. Downey, I883.

STAMP RECORD. The Stamp record.

Denver, Colo., Tedford and Richards, etc., I887. $8^{\circ} .8 \frac{3}{4}$ in. Nos. 1-4, February-May, 1887.

* Nos. 2-4 were published by A. M. Richards.

Mis. St. Jour. 26 (5).

( STAMP RECORDER AND COLLECTORS' EX.

CHANGE. The Stamp recorder and collectors' exchange. Charlestown, Natal,$W$. E. Neave, I904-05.

$04^{\circ} .8 \frac{1}{4}$ in. and $8^{\circ} .8 \frac{1}{2}$ in. Nos. 1-3, Aug., 1904, Jan., 'Apl., 1905. * * There is a coloured paper wrapper to each number. No. 1 is quarto and the remaining numbers are octavo. "This was the frst philatelic journal published in Natal. OP Popecties
Mis. St. Jour. 117 (22).

STAMP REPORTER. The Stamp reporter

Worcester, Mass., E. A. Welch, I879. $16^{\circ} .6$ in. No. 1, April, 1879.

Mis. St. Jour. 68 (18).

STAMP REPORTER. The Stamp reporter.

St. Catharines, Ont., Bradley and Oswald, etc., I897-99.

$8^{\circ} .8 \frac{1}{2}$ in. 18 nos. in 2 vols.

Vol. I. Aug., Oct., 1897-Aug., 1898. Nos. 1-12

1898-Feb., 1899. 1. 1. 6.

* * Nos. 7-12, vol. I., and nos. 2-6, vol. II., were published by George Bradley and no. 1, vol. II., by W. A. Nicholson. There is a coloured paper wrapper to each number, with the exception of no. 2 , vol. II., and nos. 9 and 10 , vol. I., were published together. Only nos. 1 and 2, vol. I., and no. 6, vol. II., bear the year date, excepting on the rvrappers, and nos. 5 and 6 , vol. I., have not the year date even on the wrappers.

- New Series.

St. Catharines, Ont., George Bradley, I899. Fol. 12 in. Nos. 1-6, April 1, 8, 15, 22, 29,'May 13, 1899.

* * The six numbers are also numbered "Old Series, Vol. 2 No. $7 "$ ". "Old Series, Vol. 2, No. 12". Amalgamated with the "Philatelic adrocate," June, 1899.

STAMP REPORTER. The Stamp reporter.

Albany, N. Y., Benj. H. Dayton, xgox.

$16^{\circ} .53$ in. No 1, July, 1901

* * The number has a coloured paper wrapper.

Mis. St. Jour. 104 (10)

STAMP REPORTER. The Stamp reporter. Published monthly. Hamilton, Ont., H. G. Comfort, I903. $16^{\circ} .5 \frac{1}{4}-6 \frac{1}{4}$ in. Nos. 1-3, September-November, 1908.

Mis. St. Jour. 150 (16)

STAMP REPORTER. The Stamp reporter.

* in. No. 1, April, 1904. Albany, N. Y., l?

], I904.

STAMP REPORTER. See STAMP AND COIN REPORTER.

STAMP REPUBLIC. The Stamp republic.

8․ $8 \frac{3}{4}$ in. No. 1 , July, 1887

Binghanton, N. Y., W. O. Morse, 1887 .

Mis. St. Jour. 153 (7)

STAMP REVIEW AND QUARTERLY ADVERTISER

The Stamp review and quarterly advertiser.

Hull, Charles H. Calvert and Co., 1873.

$8^{\circ} .71$ in. Nos. 1-2, March 26-July 1873.
$* *$ There is a coloured paper wrapper to no. 2 and this wrapper *as also used for supplying nos. 1 and 2 together. In the latter case it bad "Nos. 1 and 2. Price twopence" printed at the top of the front page. The pages of no. 1 are not numbered and those of the front page. The pages of no. 1 are not numbered and those
of no. 2 start with " 5 ".
Mis. St. Jour. 42 (7).

STAMP SNAPS. Stamp snaps.

Nutley, N. J., Trade and Barter Co., I898.

$32^{\circ} .4 \frac{1}{2}$ in. No. 1, January, 1898.

* *" The number, which is printed on yellow paper, consists of a single leaf and the contents consist entirely of advertisements.
STAMP SPECIAL. Stamp special.

Putnam, Conn., Clarence W. Chase, I9oo.

$32^{\circ} .4 \frac{1}{2}$ in. No. 1, February, 1900

* * Amalgamated with the "Universal Exchange and Auxiliary ** Amalgamated with the "Universal Exchange and Auxiliary
Philatelist," April, 1900.

STAMP TALK. Stamp talk. Kansas City, Mo., Wm. B. Brown, I 898-99. $8^{\circ} .8$ in. 9 nos. in 2 vols.

Vol. I. Nov. 1898-Apl., 1899. Nos. 1-6.

"II. May 25 -July $25, " 7-9$.

* " There is a paper wrapper to each" number. Amalgamated with the "Stamp exchange," of Boston, Mass. in August, 1899. Mis. St. Jour. $102(6)$.

STAMP TRIBUNE. The Stamp tribune. Harriman, Tenn., etc., S. P. Lev, I 899. $8^{\circ} .8 \frac{1}{2}-9$ in. Nos. 1-12, January-December, 1899.

* * There is a paper wrapper to each number. Nos. 8-12 were published at Cleveland, O. No. 8 is dated in error " 1889 " and no. 11 is numbered "10," except on the wrapper, which has the correct number.

[Continued as :]

Weekly stamp tribune.

Cleveland, O., The Stamp Tribune Publishing Co., I 900-02.

8 . 9 in. Vols. II.-III. 10 nos

Vol. II. Jan. 10-Mar. 7, 1900. Nos. 1-9.

* " Elich number of vol. II. has a paper trapper.

STAMP TRIBUNE. The Stamp tribune.

Lexington, Ky., The T. C. Leaming Co., I901.

$16^{\circ} .51$ in. and $8^{\circ} .81$ in. Nos. 1-2, September-October, 1901.

* * No. 1 is $16^{\circ}$. and no. 2 octavo and each number has a paper

wrapper. The title on the middle page of each number reads "The Stamp tribune and Fayette stamp news".

Mis. St. Jour. 119 (2).

STAMP VISITOR. The Stamp visitor.

* in. No. 1, February, 1895

New York, Robert Stackle, 1895.

S 124

STAMP WORLD. The Stamp world. An illustrated monthly magazine, devoted to stamp collecting. The organ of the New York Philatelic Club. [Prospectus of a journal to be published by Casey, Coster and Freeman, New York, on June 1st 1872, but which was never issued.]

Mis. St. Jour. 59 (4).

STAMP WORLD. The Stamp world.

Cincinnati, O., Collins and Mills, etc., r880-86.

$8^{\circ} .7 \frac{3}{4}-8 \frac{1}{2}$ in. and $9 \frac{3}{4} 10$ in. 68 nos. in 7 vols.

Vol. I. Oct., 1880-Sept., 1881. Nos. 1-12.

" II. " $1881-\quad$ " $1882 . \quad$ " $13-23$.

" III. " 1882- " $1883 . \quad$ " $24-33$.

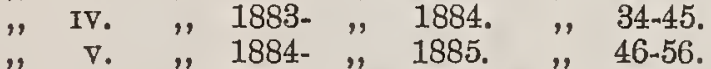

" vI. " " 1885-May, 1886, Sept., 1886 . Nos. 57-65.

" VII. " " -Dec., 1886. Nos. 66-68.

* " Nos. 1-3" measure $7 \frac{3}{4}-8 \frac{1}{2}$ inches and the remaining numbers $93^{3}$ 10 inches. Nos. 20.23 were published by Collins and Co., nos. $24-64$ by F. I. Mills and nos. $65-68$ by Clinton Collins. There is no number for June, 1882, or for January, 1885 and no. 24 is dated "October-November, 1882" and no. 29 "April-May, 1883". Nos. 25 and 36 and nos. 38-68 have coloured paper wrappers. There is a supplemental slip to no. 12 and a supplement of two pages to no. 24. A copy of the prospectus of the journal is bound up in front of no. 1 .

[Continued as :]

- The Stamp world and wise and otherwise.

Cincinnati, 0., Clinton Collins, I887.

$8^{\circ} \cdot 9 \frac{3}{4}$ in. Vol. vir. 2 nos.

Vol, Jan.-Feb., 1887. Nos. 69-70.

** There is a coloured paper wrapper to each number.

STAMP WORLD. The Stamp world.

Indianola, la., C. L. Stanley, I891-92.

$16^{\circ}$.5-5t in. Nos. 1-6, October, 1891-March, 1892. 1 - 15
"*No. 1 is found printed upon paper of two different qualities.

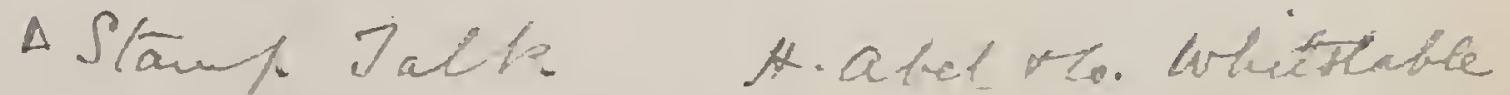

$$
\begin{aligned}
& \text { ISC9. Proshecturs. Dumeng Ro. 19090.tros } \\
& 1509.1201 .2 \cdot 3
\end{aligned}
$$


STAMP WORLD. The Stamp world.

Lynchburg, Va., Gordon H. Hopkins, etc., I893-94. $4^{\circ} .7 \frac{3}{4}$ in. Nos. 1-5, September, 1893-January, 1894.

* * Nos. 3-5 were published by the Stamp World Pub. Co. There are coloured paper wrappers to nos. 1-3; nos. 4 and 5 were published together under the date "December and January, 1893-4,",
and there is a slip supplement to no 1 Mis. St. Jour 66 (2).

STAIMP WORLD. See CURIOSTTY WORLD.

STAIMP WORLD. Sce Postage stamp (Pennington, N.J.).

STAIMP WORLD AND WISE AND OTHERWISE See Stamp World. (Cincinnati, O.)

STAIMPIC AIMERICA. Stampic America.

[East Dubuque, Mll., Albert M. Platt], I899-1900.

Oblong $4^{\circ} .7$ in. $4^{\circ} .8 \frac{1}{2}-8$ in. and $8^{\circ} .8 \frac{1}{2}$ in. 13 nos. in 2 vols.

Vol. I. Mar. 6, 21, Apl. 4, "Eastertide April," May, June and July, Sept., Oct., Nov., 1899, Apl., May, 1900. Nos. $1-12$

"II. June, 1900. No. 1

* Nos. 1-10 are partly printed by a hand copying press and are partly manuscript, and the three last numbers are hectographic with the exception of the front page of each number, which is lithographed. Nos. 1 and 2 each consist of a single folio leaf of 14 inches, which was doubled across the centre making the pages, which are numbered " 1 " to " 4 ," oblong quarto in size. Nos. 3-10 are quarto $8 \frac{1}{2}$ inches, no. 11 is quarto 8 inches and the two last numbers are octavo $8 \frac{7}{2}$ inches. Nos. 6 and 7 were published together and nos. $1,2,4,6-7$, and 8 bear no year date. Of nos. 1 and 2 only two copies each were published, of no. 3, 4 copies, of nos. 4 and 5, 8 copies each, of the double number 6-7 and of no. 8, 9 copies each, and of nos. 9 and 10, 10 copies each. The printing of nos. 1-10 was done at Federalsburg, Md. and no. 11 contains a loose photograph of two cats. Nos. 3,5 and the double number 6-7, have the article "The" preceding the title on the first page of each of these numbers and on the first page of no. 12 the title reads "Ye Stampic America".

STAMPIC AMERICA. Stampic America. A monthly for stamp collectors.

Charlotte, Mich., C. H. Beck Stamp and Publishing Co., 1900 .

$8^{\circ} .9$ in. No. 1, May, 1900.

** Amalgamated with the "Philatelic chronicle and michigan philatelist," November, 1900.

Mis. St. Jour. 113 (8).

STAMPIC EXCHANGER. See OUR STAMPIC EXCHANGER.

STAIMPIIAN. The Stampman.

Pueblo, Colo., etc., D. W. Osgood, r8g6-1 go2. $8^{\circ} .8 \frac{1}{2}$ in., $16^{\circ}$. 61 in., oblong $8^{\circ} .6 \frac{1}{2}$ in., and $8^{\circ} .10$ in. 32 nos, in 6 vols.

Yol.। I. Dec., 1896-Mar., 1897, May, July-Aug., 1897. Nos. 1-6. "II. Sept.-Uct.; 1897-March, 1898. Nos. T-12.

", III. April-June, Aug., Oct., Dec., 1898, Feb., Äpl., June-July, Sept, 1899. Nos. 17-22.

v. Jan., Apl., July, Sept., 1900, Jan., Feb., 1901. Nos. 23VI. June, 1901, Feb., June, Oct., 1902. Nos. 29-32.

* * Nos. 30-32 were published at South Fork, Rio Grande Co. Colorado. Nos. 1-6 are octavo $8 \frac{1}{2}$ inches, nos. 7-16 are $16^{\circ} .6 \frac{1}{4}$ inches, nos. 17-22 are oblong oetavo 61 inches and the remaining numbers are octavo 10 inches. No. 22 bears the words "Supple ment to no. 21 " and nos. $11-24$ and no. 26 are printed on coloured paper.

STAMPIIAN, The Stampman. 903.

Dahlonega, Ga., The Transcript Publishing Co.

$8^{\circ} .9 \frac{1}{2}$ in. No. 1 , August 3,1903

* * The number is headed "The transcript, whole no. 10," and was edited by Mrs. M. E. and John A. Howard. Bound up with it is a copy of the double number 5, 6 of the "Transcript," dated "June 29 " and "July 6,1903, " which is non-philatelic except for an advertisement of the intended publication of the "Stamp-
man".
Mis. St. Jour. $141(2,2 \mathrm{a})$.

STAIMPS. Stamps.

New York, Stamps Publishing Co., 1896-99.

$8^{\circ} .10$ in. 36 nos. in 3 vols.

Vol. I. Oct., 1896-Sept., 1897. Nos. 1-12

" II. " 1897- ", 1898. " 1-12.

" III. Jä., 1897 -Dec. 1899. " 1-12.

* " Edil ed by Crawford Capen. There is a title-page and an index to each volume and a paper wrapper to each number. Wanting the title-page and index to vol. II.
STAMPS. Stamps

Rushden, etc., F. L. Heygate, etc., 1897-1902. $8^{\circ} .7 \frac{1}{4}$ in. and $9 \frac{1}{2}$ in. 63 nos. in 6 vols.

Vol. I. Jan, 30-Dec. 31, 1897. Nos. 1-12. Ti

"II. " $31-\quad, \quad 20,1898$. " $1-12$.

"III. " 25- " 23, $1899 . \quad " 25-36$.

$\nabla$ V 25- 20, 1901 . $249-60$.

" VI. " 25-Mar. 25, 1902. " 61-63.

* * The first twelve numbers measure $7 \frac{1}{4}$ inches and the remainder $9 \frac{1}{2}$ inches. There is a title-page and an index for each of the first five volumes and a paper wrapper for each number. Nos. 49-63. were published by Guilford and Hart, London. Nos. 1-38 were edited by F. L. Heygate, nos. $39 \cdot 60$ by F. L. Heygate and B. W. Warhurst and nos.61-63 by B. W. Warhurst. Amalgamated with the "Stamp collectors' fortnightly," no. 184, March 29, 1902.

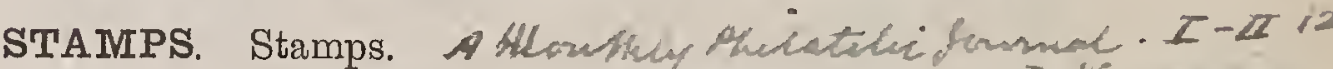
Calcutta, The Calcutta Philatelic Co., 1897-1906. Them the $8^{\circ} .10 \mathrm{in} .59$ nos. in 9 vols.
Vol. I. July 15,1897 -June $15,1898$. Nos. 1-12.

," II. ", 15, 1898- ,, 1899. ", 1-12.

๑ III. ", 1899- , $1900 . \quad$ " $1-6$.

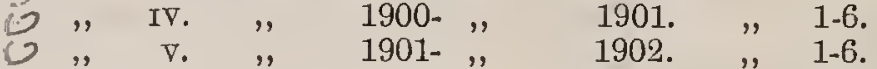

" VI. " 1902- ", $1903 . \quad$ ", $1-6$.

$\begin{array}{ccccc}\text { ", vII. ", 1903-April, } & 1904 . & \text { ", } & 1-5 . \\ \text { vIII. } & \text {-Oct., } & 1904 . & 1-2 .\end{array}$

๑ ", [Ix.] Jän., 1905, Jan., Mar., July, 1906. Nos. [1-4]

* Commencing with vol. III., each number, with the exception of the last four has a paper wrapper. Nos. 9 and 10 and 11 and 12, vol. II., were severally published together and commencing with vol. II, the numbers were published bi-monthly and so continued down to and including vol. viIr., no. 2. The last four num-

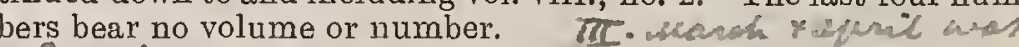
hati: $I-\pi \cdot 2$. 4 , tar 5.

STAMPS. Stamps. in. No. 1, [1899]

New London, Ia., J. H. Shaver, [1899].

MPUS. Stampus. and curio collectors.

Forest City, Iowa, Stampus Publishing Co., I904. $4^{\circ} .8 \frac{1}{2}$ in. Nos. 1, 2, 4, June, July, September, 1904.

* Edited by Philip H. Kelley. No number 3 was published and no. 4 has " 1903 " in error for "1904".

Mis. St. Jour. 148 (12).

STAMIPUS. Stampus.

Garner, Ia., Western Stamp Co., rgo4.

in. Vol. III., no. 1, January, 1904

5122

STANDARD. The Standard. Devoted to the interests of the young people.

Toronto, Jefferis and Co., I878. $8^{\circ} .911$ in. Nos. 1-5, February 15-June, 1878

* * Only partly philatelic. Nos. 3 and 4 were published together.
* Ont in Mis. St. Jour. 18 (15)

STANDARD. The Standard.

Sawens, N. Y., [C. E. Curtiss], 1889. $16^{\circ} .7 \frac{1}{2}$ in. No. 1, April, 1889

** Only partly philatelic. The number has a coloured paper wrapper. Mis. St. Jour. 40 (4).

STANDARD. The Standard. For the youth, by the youth, and of the youth.

$8^{\circ} .8 \frac{3}{4}$ in. No. 1 , September 1,1890

Topeka, Kas., T. J. Darling, I89o. * Only partly philatelic.

Mis. St. Jour. $147(6)$

STANDARD PHILATELIST. The Standard philatelist St. Louis, Mo., The Standard Stamp Co., I89I. $8^{\circ} .10$ in. Nos. 1-9, January 1-September, 1891.

* * Edited by H. Flachskamm. There is a coloured pape wrapper to each number and nos. 8 and 9 were published togethe under the date "August and September, 1891". A copy of the prospectus is bound up with the journal.

STANDARD PHILATELIST. The Standard philatelist. St. Louis, Mo., The Standard Stamp Co., I896-07. Fol. 11 in. Nos. 1-6, August, 1896-January, 1897.

* * No. 2 is dated "September, October, November and December, 1896" and there are no nos. 3-5. Mis. St. Jour. 97 (3) 
Jtampdom $1896 / 7$

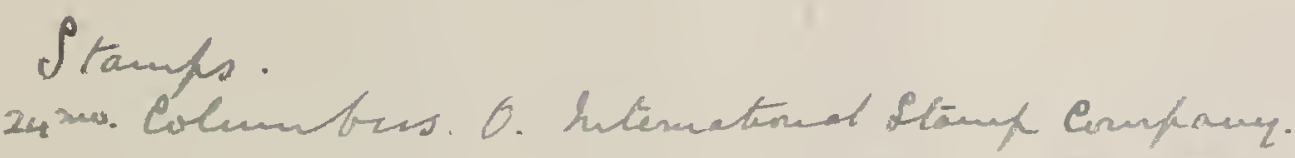

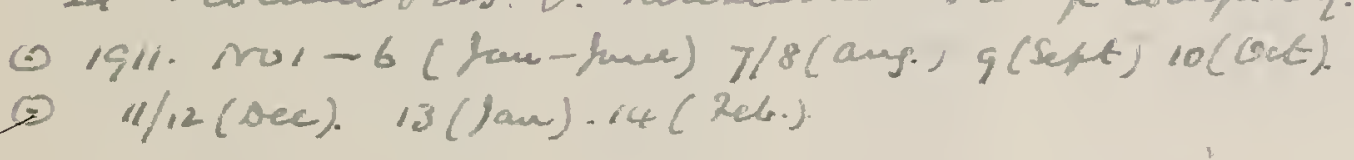

Stamps, New York. 1938 , Apr. -Jun. . Vol. 23 , unbound 
STANLEY GIBBONS \& CO.'s MONTHLY JOURNAL. (London, Stanley Gibbons \& Co.

Vol. I, No. 1 (1890). Bound as below.

STANLEY GIBBONS LTD. MONTHLY JOURNAL. (London, Stanley Gibbons Ltd.)

Vol. I, Nos. 2-12 (1890-91). Privately bound, half calf, together with Vol. I, No.

STANLEY GIBBONS' MONTHLY JOURNAL. (London, S.G. Ltd.)

Vols. II-XXI (1891-1913). Privately bound, half calf.
Vol. XXIl (1914). Unbound.

New Series. Vols. I-IV (1923-27). Unbound.

GIBBONS' STAMP MON'THLY as

NTHY, (London, S.G. Ltd.)

STANLEY GBBONS' MONTHLY CIRCULAR. (London, Stanley Gibbons Ltd.)

Nos. 1 -49 (1919-23). Unbound.

$(12(1927-193819)$ 
STANLEY GIBBONS, LIMITED, MONTHLY JOURNAL. See Stanlex Gibbons and Co.'s monthly JOURNAL.

STANLEY GIBBONS MONTHTY JOURNAL. 'See Stanley GibBons and Co.'s MONTHLY JoURNAL.

STANLEY GIBBONS AND CO.'S MONTHLY JOURNAL. Stanley Gibbons and Co.'s monthly journal.

London, Birmingham [printed], Stanley Gibbons and Co., I8go.

$8^{\circ} \cdot 10 \frac{1}{2}$ in. No. 1 , July 20,1890

** Edited by Charles J. Phillips. The number has a paper wrapper.

\section{[Continued as :]}

Stanley Gibbons, Limited, monthly journal. London, Stanley Gibbons, Limited, г890-9г. $8^{\circ} \cdot 10 \frac{1}{2}$ in. Nos. 2-12, August 20, 1890-June 30, 1891.

* No. 2 was edited by Charles J. Phillips and nos. 3 to 12 by Edward B. Evans. There is a paper wrapper to each number There is a title-page, an index and a frontispiece to the volume.

\section{[Continued as :]}

- Stanley Gibbons monthly journaI. London, Stanley Gibbons, Limited, I89I-I9o8.

8. $10 \frac{1}{2}-11$ in. Vols. II.-XVIn. $20 \pm$ nos.

Vol. II. July 31, 1891-June 30, 1892. Nos. 13- 24.

" III. " " 30, 1892- " 30, 1893. " 25- 36.

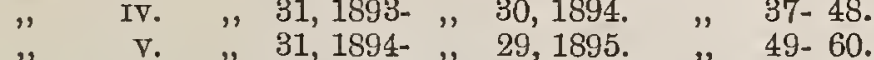

$\begin{array}{ccccc}\text { V. } \quad 31,1894-~ & 29,1895 . \quad \text { " } & 49-60 . \\ \text { vi. } & 31,1895- & 30,1896 . & \end{array}$

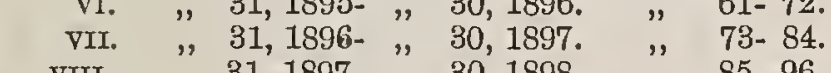

VIII. " $\quad 31,1897-\quad " 30,1898$. " $85-96$.

IX. $\quad " 30,1898-" \quad 30,1899 . \quad " \quad 97-108$.

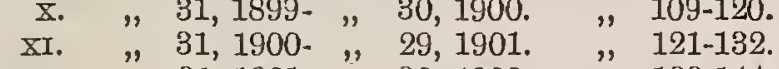

XII. " " 31, 1901- " $30,1902 . \quad$ "

XIII. " "31, 1902- " 30, 1903. " " 145-156.

XIV. " "31, 1903- " 30, 1904. " $157-168$.

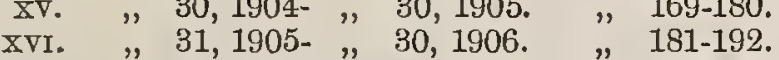

XVII. " 31, 1906- " 29, $1907 . \quad$ ", 193-104.

XVIII. " 31, 1907- " 30, 1908. " 205-216.

* "Edited by Edward B. Evans. Each number has a paper wrapper and there is a title-page and an index to each volume Vols. II.-VIII. have also each a frontispiece. Nos. 143 and 14 were printed at Birmingham, and the remainder at Plymouth. No. 133 is called "Vol. Nir. "No. 1, " but on the wrapper is numbered "138". There is a "Special supplement" of lour pages to no. 63 and a special is ation of no. 128 was printed on thick highly surfaced paper. This edition contains the three illustrations of stamps omitted on pages 173,174 and 175 of the ordinary edition, and which were given on a separate slip in no. 129

STANTON'S EXCHANGE. Stanton's exchange. Smyrna, N. Y., F. J. Stanton, I 887-88 $8^{\circ} 81$ in. Nos. 1-2, June-July, 1887, May-June, 1888 ** Only partly philatelic. Mis. St. Jour. 147 (3)

STANTON'S PHILATELIC INDEX. Stanton's philatelic index. A monthly index devoted to philatelic literature. - Detroit, Mich., W.J.Stanton, I9oo

$8^{\circ} .9$ in. Nos. 1-3, October-December, 1900. $~ 2$

* * There is a supplement of two pages to no. 2. "The index was continued in the "Philatelic Chronicle and Philatelic Index,"
published at Charlotte, Mich., in 1901. Mis. St. Jour. 83 (6).

STAR. The Star.

Dahinda, Ill., Star Publishing Co., 1894. in. Nos, 1-7, [? ]-October, 1894

* *nly partly philatelic. Nos. 6 and 7 were published together, ** Only partly philatelic. Nos. 6 and 7 were published togeth
with the date September. October, 1894 . Wanting all nos.

STAR. The Star. Meriden, Ct., H. H. Parker, I 894-95. in. Nos. 1-2, October, 1894-January, 1895. * * Only partly philatelic. Wanting both nos.

STAR. The Star. A paper for young folks. Oak Park, Ill., Star Publishing Co., I899-1900. Fol. $15 \frac{3}{2}$ in. Vol. vr. Nos. 4, 8, November, 1899, March, 1900. * * These two numbers contain philatelic matter. No. 8 has beentire subscription list".
STAR

[Continued as :]

- The Star monthly.

Oak Park, Ill., Hunter Publishing Co., I goo-o6. ․ 11 $111 \frac{3}{4}$ in. Vol. vI. No. 10. Vol. vrr. No. 1. Vol. IX. ember, 1902, May, 1906

* * These five numbers contain philatelic matter.

STAR. The Star.

Holyoke, Mass., Union Stamp Co., I905-06.

$8^{\circ} .8-8 \frac{3}{4}$ in. and $32^{\circ} .4 \frac{1}{2}$ in. 15 nos. in 2 vols

Vol. I. Feb.-Dec., 1905. Nos. 1-12.

"II. Jan.-Mar., 1906. „" 13-15.

* " Only partly philatelic. No. 2 is numbered "Ir.," nos. 6 and 7 were published together and this double num ber only measures 4 inches; nos. 13 and 14 were also published together. Amalgamated with the "Columbus philatelist," June, 1906. Wanting nos. $4,5,8,9,10,11$.

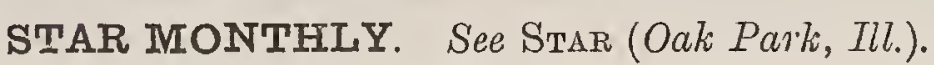

STAR OF THE EAST. The Star of the East.

Boston, Mass., F. H. King and Co., I866.

** Cuttings with the heading "New stamps" in the number for ?? Decembcr], 1866, are mounted in Stamp Scrap-book, vol. II., p. 9. This paper was sent to the subscribers to the "Stamp collector's review" in place of that journal, the publication of which was discontinued with no. 1, dated "October, 1866".

STAR OF PANAIMA. The Star of Panama.

Panama, F. Lawley, 1865

in no. 1. [? May], 1865

* "Reviewed in the "Stamp collector's examiner" for July, 1865. The number is there stated to consist of sixteen pages printed in English and to be illustrated with cuts of European stamps. Wanting.

STAR PHILATELIST. The Star philatelist. Mile Run, Pa., P. E. A. Conrade, $1894-95$ $32^{\circ} .4$ in. Nos. 1-4, November, 1894-February, 1895. $\frac{2}{\text { Mis. St. Jour. } 71(6)}$

STAR STAIMP JOURNAL. The Star stamp journal.

Warrington, Birmingham [printed], The Warrington Foreign Stamp Co., I872.

$8^{\circ} .7 \frac{1}{4}$ in. No. 1 , January, 1872

* * The number has a coloured paper wrapper with the title "The Star stamp journal and monthly exchange and advertiser". A advertisement appeared in no. 8 of the "Interchange and market" for March 20, 1872, which states that no. 2 of the "Star stamp jour"nal " is "now ready" and gives a list of the contents as follows: "An adventure whilst in search of foreign stamps, the stamps of all nations, stamp collecting, forgeries, puzzles, stamp exchange, advertisements, etc." Wanting no. 2 of which no copy is known to exist. Mis. St. Jour. $42(6)$.

STAR STAIMP JOURNAL. The Star stamp journal. A monthly for stamp collectors.

Worcester, Mass., Star Stamp Co., I 893.

$8^{\circ} .10 \frac{1}{1}$ in. No. 1 , October, 1893

* The number has a coloured paper wrapper.

Mis. St. Jour. $59(6)$

STAR STAIMP JOURNAL AND IMONTHLY EX CHANGE AND ADVERTISER. See STAR STAMP JOURNAL (Warrington).

STAR STAMP QUARTERLY. The Star stamp quarterly. Reading, Pa., The Star Stamp Co., I873. $8^{\circ} .9$ in. No. 1, June, 1873. Mis. St. Jour. 21 (7).

STARLIGHT. The Starlight.

Sciota, Ill., John J. Simmons, I 895 8. 8 in. Vol.:II., nos. 11, 12, 15; February 1, 15, April 1, 1895. * * Each of these numbers contains "Philatelic notes" by J. H. Stambaugh of Catlin, Ill.

STELLA DEL FILATELICO E DEL FILOCARTISTA. La Stella del filatelico e del filocartista.

Biella, Italie, Henri Bussi, I9oo.

$8^{\circ} .10 \frac{1}{2}$ in. No. 1, July 1, 1900.

* * The number has a coloured paper wrapper. Mis. St. Jour. 107 (9). 
STELla d'italia. See Étoile d'Italit.

STEIMPELIMARKE. Die Stempelmarke. Organ für Stempelmarkensammler.

Münster $i . W .$, Ed. Susemihl, I904.

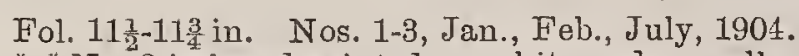

* * No. 3 is found printed on white and on yellow paper and the yellow paper edition contains a supplement "Die Siegelmarke," also printed on yellow paper. This supplement is catalogued
separately.
Mis. St. Joul. 97 (6).

STERLING IMONTHLY. The Sterling monthly. A journal for New Zealand philatelists.

Nelson, N. Z., The Sterling Stamp Co., I903. 8.. 9 in. Nos. 1-7, June-December, 1908.

** There is a coloured paper wrapper to each number. This journal was succeeded by the "New Zealand philatelist".

STRENG VERTRAULICH. INTERNATIONALER POSTWERTHZEICHENHÄNDLER - VEREIN. See Internationaler PostwerthreichenhäNDLERVerein.

SUCKER STATE STAMP. The Sucker State stamp.

Catlin, Ill., R. R. Tilton, etc., I 895 . $8^{\circ} .10$ in. Nos. 1-4, June-September, 1895.

** Nos. 1 and 2 each consist of a single leaf. Nos. 3 and 4 were published by the Sucker State Publishing Co.

Mis. St. Jour. 60 (8).

SƯDDEUTSCHESILLUSTRIRTES BRIEFMARKENJOURNAL. Süddeutsches illustrirtes Briefmarkenjournal. Organ für die gesañte Briefmarkenkunde mit Inseratenblatt. Miinchen, S. Wolf, I891-92. $8^{\circ} .93$ in. Nos. 1-5, Dec. 15, 1891, Jan. 2, Jan. 18, Feb. 1, Feb. $20,1892$.

* "Each number contains a supplement named "Inseraten and a second supplement called "Offertenblatt für Briefmarkenand a second supplement was given with one of the January numbers.

sammler" was given with one of the January numbers.

SÜDUNGARISCHE BRIEFMARKEN - ZEITUNG. Südungarische Briefmarken-Zeitung.

Karansebes, Robert Hulita, etc., I898. $8^{\circ} .10 \frac{1}{4}$ and $8 \frac{1}{2}$ in. Nos. 1-4, Jan. 5-Apl., 1898.

** Nos 1-3 measure 101 inches and no 4 which was published "** Nos. 1-3 measure 10t4 inches and no. 4 , which was published
by Wilhelm Hulita, measures $8 \frac{1}{2}$ inches.
Mis. St, Jour. 99 (7).

SUN. The Sun. Abilene, Tex., W. C. Lowry, I894. $8^{\circ} .8$ in. Vol. rr., no. 51, October $13,1894$.

** This number contains a philatelic column. Wanting.

SUNDAY HERALD. Sunday herald. Boston, Mass. August 12, 1888. [Cuttings of the article "American philatelists. Annual convention to be held in Boston. Many rare and curious stamps to be shown. Curiosities of a stamp collector's album," are mounted in Stamp Scrap-book, vol. vI., pp. 55-58.]

October 18, 1891. [Cuttings of the article "The story of the stamp, as told by assistant postmaster-general Hagen," are mounted in Stamp Scrap-book, vol. vr., pp. $184,185$.
SUNDAY STRAND. The Sunday strand. Vol. IV. No. 19, July, 1901. [Contains an article "Religious postage stamps," by J. A. Kay.]

$8^{\circ} .9 \frac{3}{4}$ in. pp. 76,77 .

London, W.C., George Newnes, Ltd., I901.

* * The number has a coloured paper wrapper.

Mis. St. Pamph. 64 (5).

SUNDAY TIIIES. The Sunday times. Sydney. December 28, 1890. [Cuttings of the article "Philately. Something about stamp collecting. An interview with Mr. Dawson Vindin," are mounted in Stamp Scrapbook, vol. vi., pp. 117, 118.]

SUNSHINE. Sunshine.

Augusta, Maine, E. C. Allen and Co., I887. ** Cuttings of the philatelic portions from the number for Feb-
ruary, 1887, are mounted in Stamp Scrap-book, vol, v., pp. 106, 107.

SVENSK FILATELISTISK TIDSKRIFT. Svensk filatelistisk Tidskrift.

Stockholm, Frimürks amlare-Föreningen i Stockholm, etc., I900-

$8^{\circ} .10$ in. nos. in 10 vols. In pros
1 st year. Jan. 10-Dec. 10,1900 . Nos. $1-12$.

1st year. Jan. 10-Dec. 10, 1900. Nos. 1-12.

2nd " " 10-June 30, Sept. 1-Dec. 18, 1901. Nos. 13-22.

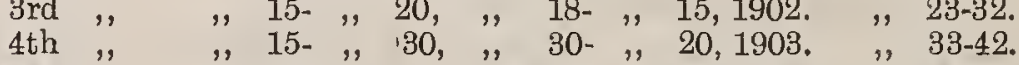

5th " "15. "1, 15, " 15-" $15,1904$.

6th ", ", 15-May 30, July 1, Sept. 15-Dec. 20, 1905. Nos. $53-62$.

7th " "30-June 30, Sept. 18-Dec. 15, 1906. Nos. 63-72. ${ }_{*}^{*}$ * There is a title-page and an index to each year and a paper wrapper to each number. Commencing with no. 13 the journal has been published by the Sveriges Filatelist-Förening Stockholm published by the Sveriges Filatelist-Forening, Stockhom. The
numbers of the third and fourth years were edited by $\mathrm{F}$. W. Andréen numbers of the third and fourth years were edited by $\mathrm{F}$. W. Andreen by Hilmer Djurling. No. 35 is wrongly numbered " 34 ".

SWAP. Swap. Rochester, N. Y., E. D. Lewis, I900-ог. $16^{\circ} .6$ in. 21 nos. in 2 vols.

Voi. I. Jan. 1-Dec., 1900. Nos. 1-12.

* " Ir. "Commencing with no. 4, vol, x., each number has a coloured $*$ * Commencing with no. 4, vol. x., each number has a coloured
paper wrapper. Nos. 5 and 6 , vol. I., were published together paper wrapper. "Nos. 5 and 6, vol. I., were published together under the date "May-June, 1900," according to the inscription on the wrapper, but the journal inside has only "May, 1900, no. 5," no. 1, vol. rr., is dated "1900" in place of "1901,"
and on the wrapper.
Mis. St. Jour. 104 (12).

SYRACUSE PHILATELIST. See SALt City PHILATELIST. SZEKULA BRIEFMARKEN VERIKEHR. Szekula Briefmarken Verkehr. Budapest, etc., Béla Szelulal, rgo1$8^{\circ} .9$ in. nos. in vols. In progress.

1st year. Sept. 10-Dec., 1901. Nos. 1- 4.

2nd ", Jan. 14- ", 20, 1902. " 5-16.

3rd " " 10- ", 15, 1903. " $17-36$.

4th " " $\quad 15-\quad " 20,1904 . \quad " \quad 37-48$.

5th " " $\quad 20-" 20,1905 . \quad " \quad 49-60$.

* * " " " " 20- " 20, 1906. " "61-72. paper wapper. Nos. 4-37 were published at Geneva, and there are two numbers for each of the following months: January-May and August-October, each of the following months: January-May and August-October, 1903. Nos. 45" and the we punumber for September, 1904. The Oktober, 1904 " and there is no number for September, 1904. The per of no. 9 " " $5 / 8$ " instead of " $5 / 9$," and the wrapper of no. 16 per of " no. 9 ". " $5 / 8$ " instead of " 


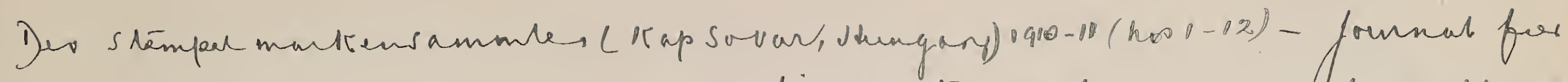

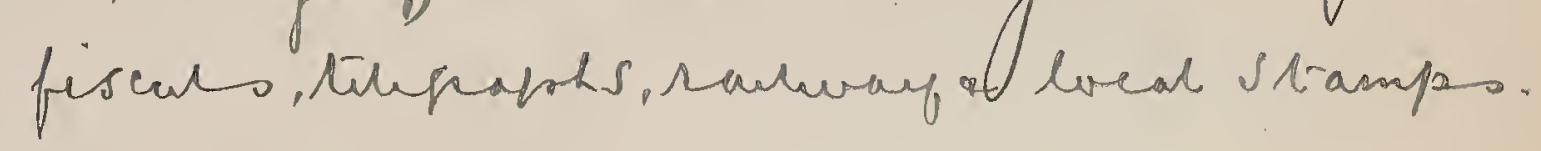





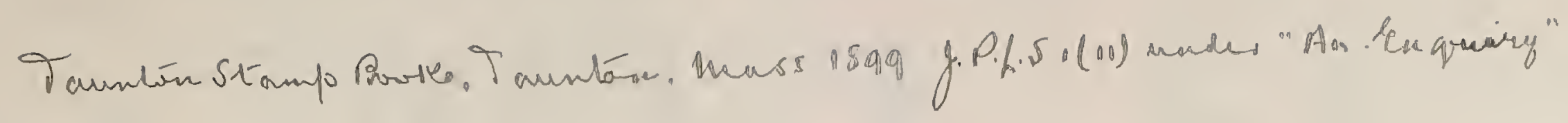

TABLE UNIVERSELLE D'ADRESSES POUR LES PHILOCARTISTES ET PHILATELISTES ET CORRESPONDANT POLYGLOTTE. Table universelle d'adresses pour les philocartistes et philatélistes et correspondant polyglotte.

Fol, 13: in. Vols. III.-IV. Wertheim, Hubert Schmidt, I 901-02. 3rd year. Oct. 1, 1901-Apl. 1, 1902. Nos. 5-9. 4 th May 1

${ }_{*}^{*}$ The previous numbers had the titles: "Table universelle d'adresses pour les collectionneurs de magnifiques cartes postales neurs de magnifiques cartes postales illustrées et correspondan aeurs de magnif "Table universelle d'adresses pour les philocarpolyglotte " or "Table univen ing nos. 6,7 , of the third year and all after no. 3 (October 10, 1892) of the fourth year.

TAG AND STAMP HERALD. Tag and stamp herald. Devoted to the interest of collectors.

Louisville, Ky., F. W. Finzer and Co., I887.

$8^{\circ} .11^{3}$ in. Nos. 1-3, February-April, 1887. Mis. St. Jour. 72 (7)

TAG GAZETTE. The Tag gazette.

$8^{\circ} .7 \frac{1}{2}$ in. Nos. $1-4,[?]$ ]-June, 1887.
$* *$ Only partly philatelic. Nos. 3 and 4 were published together,

Cambridgeboro, Pa., H. B. Wilber, r 887 .

with the date "May-June, 1887". Wanting nos. 1, 2.

TAG PRESS. The Tag press.

Titusville, Pa., Bates and Sharpe, I887.

$8^{\circ} .9$ in. Nos. 1-3, January-March, 1887.

"* Only partly philatelic. No. 1 has the name of the town spelt

TAG WORLD. The Tag world.

Cleveland, O., F. L. Willcutt, I886-87.

$8^{\circ} .9$ in. Nos. 1-9, June, 1886-February, 1887.

** Only partly philatelic. Nos. 4 and 5 and 8 and $\overline{9}$ were severally published together.

Mis. St. Jour. 143 (7a).
Mind

TARJETA POSTAL. La Tarjeta postal.

Barcelona, Hermenejildo Prats, Igor-oz. $8^{\circ} .8 \frac{1}{2}-8 \frac{3}{4}$ in. nos. in 2 vols.

1st year. May -Dec., 1901. Nos. 1-8

2nd " Jan. 31- 1902. ", 9-

* Some of the numbers contain a philatelic section. There is a

coloured paper wrapper to each number. Wanting all but nos. 1, 9.

TARJETA POSTAL ILUSTRADA. La Tarjeta postal ilustrada. Publicación quincenal de novedades postales. Buenos Aires,
$8^{\circ} \cdot 10^{3}$ in. Nos. $1-3$, Nov. 15 , Dec. $1,15,1903$.

* This journal deals with picture postcard collecting and is not philatelic. There is a coloured paper wrapper to each number. Mis. St. Jour. 84 (4).

TARRACO FILATÉLICA. Tarraco filatélica.

Tarragona, Ricardo Besses, I 894.

$8^{\circ} .10$ in. Nos. 1-2, October 1-November 1, 1894.

* * Each number has a supplement of four pages.

TAUSCHBLATT FƯR BRIEFMARITHN-SAMIMLER

Tauschblatt für Briefmarken-Sammler.

Berlin; Intern. Postwertzeichen-Sammler Verein "Globus," I891.

$8^{\circ} .8 \frac{3}{4}-9$ in. Nos. 1-12, January-December, 1891

* * The above formed a supplement to "Globus" and was pro duced in the same way by an autographic process. Nos. 11 and 12 were published together. Wanting no. 5

TAUSCHHETT. See MARKENWART.

TAUSCH-OFFERTENBIATT. Tausch-Offertenblatt. I 892 .

8. $10 \frac{1}{2}-10 \frac{3}{4}$ in. Nos. 1-3, A pril-June, 1892 .
* * These numbers were given as supplements to nos. $1-3$ of the first year of the "Philatelistische Jugendschrift," with which they are bound up.

TAUSCH-VERKEHR. Tausch-Verkehr.

Frantefurt a. M., etc., $A$. Larisch, etc., I88 I-83. $8^{\circ} .9$ in. and $10 \frac{1}{2}$ in. and fol. $13^{3}$ in. Nos. 1-12, Oct. 1, Nov. 1 , Dec. 10, 1881. Feb. 1, Apl. 1, May 15, Aug. 15, Oct. 1, 1882, Jan

20, Apl. 15, June 1, Nov. 1, 1583. no. 12 is octavo $10 \frac{1}{2}$ inches. Nos. 7-11 were published by A. Larisch in the "Vereinigte Erdball Merkur" (nos. 7 and 8 at Frankfurt a. M. and nos. 9, 10 and 11 at Wien) and no. 12 by Larisch und Radesey at Wien in the "Allgemeiner" BriefmarkenAnzeiger Vereinigte Erdball Mereur"

Mis. St. Jour. 22 (11): 51 (2) and Allgemeiner Briefmarken-
Anzeiger Vereinigte Erdball Mercur.

TAUSIG'S BARGAIN ADVERTISER. Tausig's bargain advertiser. New York, M. Tausig, I902-03. $4^{\circ}$. 6-71 in. No. 1 and nos. 1-3, September 1, November 1, 1902,
January 1, February-March, 1903 . * * The contents consist entirely of advertisements. There are "* "The contents consist entirely of advertisements. "No "Nomtwo numbers " 1 ," one dated "September 1 ," the other "November 1 " and the first, which is of the nature of a prospectus, is
printed on yellow paper.
Mis. St. Jour. $148(6)$.

TENNESSEE PHIIATELIST. The Tennessee philatelist. Persia, Tenn., etc., G. J. McLain, I89o. $8^{\circ} .8$ in. Nos. 1-2, February-May, 1890.

* No. 2 was published at Laurel Gap, Tenn.

Mis. St. Jour. $32(6)$

TENNESSEE PHILATELIST. The Tennessee philatelist. Knoxville, Tenn., Carpenter McNutt and Co., I898. $8^{\circ} .9$ in. No. 1 , March 15, 1898.

** The number has a coloured paper wrapper.

[Continued as :]

- The Tennessee philatelist and home worker.

Knoxville, Tenn., Carpenter McNutt and Co., I898. 8. 9 in. Nos. 2-3, April 15-May 15, 1898.

** There is a paper wrapper to each number.

Mis. St. Jour. 92 (4a).

TENNESSEE PHILATELIST AND HOME WORKER

See Tennessee PHILATELIST (Knoxville, Tenn.). 


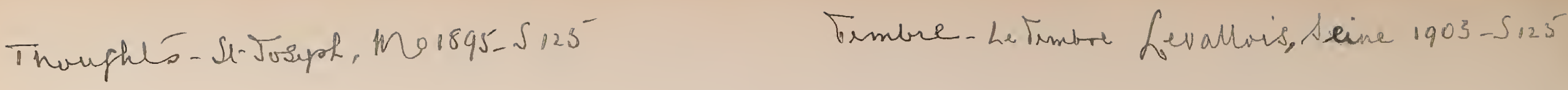

TEXAN PHILATELIST. The Texan philatelist. Abilene, Texas, Walter C. Lowry, 1894-99. $16^{\circ} .6$ in. and $8^{\circ} .9-9 \frac{1}{2}$ in. 59 nos. in 9 pols.

Vol. I. Dec., 1894-May, 1895 . Nos. 1- 6 .

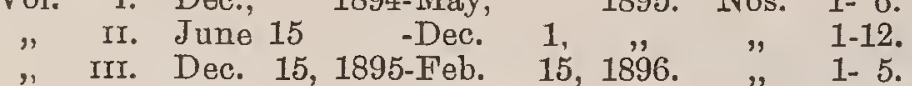

", IV. March -August, $15,1896 . \quad, \quad \begin{array}{r}1-5 . \\ \text { ". }\end{array}$

" v. Sept., 1896-Feb., 1897. ", "30-35.

" vI. March -August, $1897-$ Feb. ", 36-41.

" VII. Sept., 1897-Feb., $1898 . \quad$ " 42-47.

" VIrr. March ${ }^{\text {-August, }}$ IX. Sept., 1898 -Feb., 48-53.

*"* There are paper wrappers to nos. 1 and 2 and nos. $25-58$ and one wrapper for nos. 3-6 combined, and a supplement of two pages to no. 5 , vol. Ir. Nos. 1 and 2 are $16^{\circ}$. and the remaining numbers are octavo.

TEXAS COLLECTOR. The Texas collector.

Webster, Texas, H. V. Demark, 1895 . in. Nos. 1-2, February-March, 1895

*** Only partly philatelic. Wanting both nos.

TEXAS PHILATELIC JOURNAL. The Texas philatelic journal. Paris, Texas, Edgar T. Neville, r887. $8^{\circ} .9$ in. Nos. 1-4, A ugust-November, 1887.

Mis. St. Jour. 23 (15).

TEXAS PHILATELIC JOURNAL. The Texas philatelic journal. Paris, Texas, Edgar T. Neville, r889. $8^{\circ} .83$ in. No. 1, March, 1889.
$* *$ The number has a coloured paper wrapper.

Mis. St. Jour. 26 (13).

TFXAS PHILATELIST. Texas philatelist.

Paris, Texas, E. W. Roberts and Co., r886. $16^{\circ} .6$ in. No. 1, May 15, 1886.

Mis. St. Jour. 68 (19).

TEXAS PHILATELIST. The Texas philatelist. ז886-87.

Paris, Texas, Texas Philatelist Publishing Co., etc.,

$8^{\circ} \cdot 9 \frac{1}{1}-83$ in. Nos. 1-5, November, 1886-March, 1887. ** Nos. 3-5 have coloured paper wrappers and no. 5 was published
by Reuss and Neville.
Mis. St. Jour. 16 (6).

Mis. St. Jour. 16 (6).

TEXAS STAIMP. The Texas stamp. A monthly journal devoted to philately.

Fort Worth, Texas, T. P. Martin Jr. and Co., 1886-87.

$8^{\circ} .9$ in. Nos. $1-6$, Oct., 1886, Feb.-June, 1887.
$* *$ Nos. $2-6$ were published by T. P. Martin Jr.

Mis. St. Jour. 19 (9).

TIDNING FÖR FRIMÄRKSAIMLARE. Tidning för Frimärksamlare. Stockholm, F. W. Andréen, r886-93. $8^{\circ} .9 \frac{1}{2}$ in. 80 nos. in 7 vols.

1st year. Dec. 1, 1886-Dec. 15, 1887. "Profnummer" and 2nd "Jan.115 - " 15, 1888. Nos. 1-12.

3 rd " " $18, \quad-", 14,1889 . \quad$ " 1-12.

4th ", " $18, \quad-, " 16,1890 . \quad$ " $36-48$.

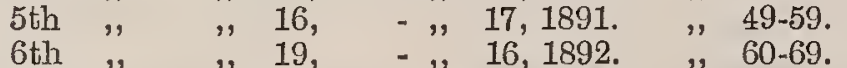

7 th " " " 23, - " 30, 1893. " $70-79$.

* * There is a title-page and an index to each year, excepting the ffrst for which there is only a title-page. Nos. 6 and 7 of the third year and nos. 7 and 8 of the fifth year were severally, published together under the respective dates " 11 Juni, 1889 " and "17 Aug., 1891". The latter bears also the number " 55 ". There are no numbers for July or August, 1892, or for the same months of 1893 and owing to the error in the numbering of the fourth year the number " 44 " was missed. Nos. $72-79$ have coloured paper wrappers and although no. 75 is dated " $30 \mathrm{Juni}$, 1893," the wrapper bears the date " 22 Juli". For continuation see "Nor-
disk Filatelistisk Tidskrift," January, 1894. This was the first philatelic journal published in Sweden.

TIMBRE. Le Timbre. Journal universel illustré de la timbrologie.

Paris, Schmidt et Co., r886. $4^{\circ} .11 \frac{1}{4}$ in. No. 1, June $15,1886$.

** There is a paper wrapper and a supplement of four pages. There are two editions one having "Administration: 48-Rue de Lille-48" and the other " 50 -Rue de Lille-50".

Mis. Șt. Jour, 74 (3 and 3a).
TIMBRE. Le Timbre. Edition Française du Bulletin de la Société Néerlandaise de Timbrophiles.

Amsterdam, Société Néerlandaise de Timbrophiles, I 888-94.

$4^{\circ} .11 \mathrm{in}$. and $8^{\circ} .11 \mathrm{in} .60$ nos. in 5 vols.

1st year. July, 1888-July, 1889. Nos. 1-12. S 125

2nd " Aug., 1889- $\quad$ 3rd $\quad 1890 . \quad$ Oct. $1890-$ Sept. 1891.

3rd " Oct., 1890-Sept., 1891. " $\quad 25-36$

5th ", " "15, 1892-July 20, Dec. 1, 1893̈, [July, 1894]. Nos.

* * Edited by A. E. J. Huart. The first four years are quarto and the fifth year, the twelve numbers of which have coloured paper the fifth year, the twelve numbers of which have coloured paper
wrappers, is octavo, and there is an index to each year. No. 10 is dated "Avril-Mai, 89," no, 40, "1891" instead of "1892" and no. 50 bears " 15 Octobre, 1892 " in place of " 15 Novembre, 1892 ": The wrappers of nos. 52-59 are wrongly numbered, respectively,
$51-58$. No. 60 bears "d'outre-tombe" (posthumous), and the $51-58$. No. 60 bears "d'outre-tombe " (posthumous), and the
leading article is dated at the end " 15 Juillet, 1894". A copy of the prospectus is bound up in front of the first number.

TIIMBRE. Le Timbre. Organe mensuel de la philatélie universelle. Talence, Bordeaux, A. Touron, 1897. $8^{\circ} .9^{3}$ in. Nos. 1-5, June-October $31,1897$.

** There is a paper wrapper to each number. A copy of the pro-
spectus is bound up in front of no. 1 . Mis. St. Jour. $90(10)$.

TIMBRE BELGE. Le Timbre belge.

Namur, Paul Couvreur, [1 901-02].

$8^{\circ} .93$ in. Nos. 1-4, [1901]-Feb., [1902].

** The contents of nos. 3,4 are printed by an autographic process, and these two numbers and no. 1 are printed on coloured paper. No. 4 bears the date "Janvier-Fevricr," but beyond this none of the numbers have any date of year or month of publication. Amalgamated with the "Annonce philatelique " Troyes,
November, 1902.
Mis. St. Jour. 90 (14).

TIMBRE FISCAL. Le Timbre fiscal.

Bruxelles, J. B. Moens, I874-96.

$8^{\circ} .10$ in. 268 nos. in 23 vols.
1st year. Jan. 1 -Dec. 1,1874 . Nos. 1.12

1st year. Jan. 1-Dec. 1, 1874. Nos. 1. 12 .

2nd ", ", 1- ", $1,1875 . \quad$ ", $13-24$.

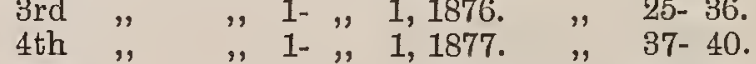

5th " " " $1-, " 1,1878 . \quad ", \quad 41-52$.

6th " " $" 1-" 1,1879 . \quad " \quad 53-64$.

8th ", " " 1- $1-, 1,1880 . \quad$, $1881 . \quad 65-76$.

9th " " $\quad 1-, " 1,1882 . \quad$ " 89-100.

10th " " "1- , 1, 1883. ", 101-112.

11th " " " 1- " $1,1,1884 . \quad$ " $113-124$.

13th " " "1- ", 1, 1886. " "137-148.

14th " " " 1- " $, 1,1887 . \quad$ " $149-160$.

16th " " " $1-, " 1,1889 . \quad$ ", $178-184$

17th $" \quad, \quad 1-, 1,1890 . \quad " 185-196$.

18th ", ", 1- ", $1,1891 . \quad$ ", $197-208$.

20th " " 1- ", 1, 1893. " 221-232.

$21 \mathrm{st}, " \quad$ " $1-" 1,1894 . \quad$ " 233-244.

22nd " " $1-, " 1,1895 . \quad " 245-256$.

* * The" numbers for "1877 were published quarterly. There is a title-page and a list of contents for each year with the exception of 1877 and 1878 for which there is one title-page and one list of contents for the two years combined. Nos. 48 and 49 , and 131 and 132 were severally published together under the respective dates "Août et Septembre, 1878," and "Juillet-Août, 1885". Nos. 1-49 were edited by Dr. Magnus (Dr. J. A. Legrand) and nos. 50-268 by L. Hanciau. After December, 1878 the journal ceased as a separate publication but was continued as a supplement to "Le Timbre-Poste" until January, 1897, when it was amalgamated with the latter inder the title "Le Timbre-Poste et le Timbre fiscal". No. 141 is dated "Avril" instead of "Mai".

[Special edition, printed on various coloured papers.] * * Consists of 268 nos. in 23 vols. like the ordinary edition.

TIMBRE LEVANTIN. Le Timbre levantin. Constantinople, Apiz Yaremdji, etc., I886-88. Fol. $13 \frac{1}{2}$ in. and $8^{\circ} .9 \frac{3}{3}$ in 18 nos in 2 vols.

1st year. I May 25, July 1, Sept. 1-Dec. 24, 1886, Feb. 15-May 31, 1887 . Nos. 1-10.

2nd ," Dec. 25, 1887, Feb. 1-Aug. 15, 1888. Nos. 11, 2-8.

* * Nos. 1 and 2 are folio and the remainder are octavo and nos. 3-10 of the first year have coloured paper wrappers. No.' 4 of the second year is dated " $25 \mathrm{Mai}$ " in place of " $25 \mathrm{Avril}$ " and no. 5 of the same year is dated " 20 Avril" instead of " 20 Mai" and is numbered " 4 " in error for " 5 ". The numbers of the second
year were published by J. Tchakidji et Cie. This was the first year were published by J. Tchakidji et
philatelic journal published in Turkey. 
Timbres = Poskés fourunts Colés Por Evew 1900 - S126 
TIMRE-POSTE Limbre-poste. Journal du collectionneur. Bruxelles, J. B. Moens, x863-1 900 .

Fol. $13^{3}$ in. and $8^{\circ} .97-10$ in. 456 nos. in 38 vols. 1st year. Feb. 15-Dec. 31, 1863. Nos. 1- 12 2nd " Jan. 15-" 15, 1864. " 13- 24. 3rd " " $15-" 15,1865 . \quad " \quad 25-36$. 4th " $\quad " 15-" 15,15,1866 . \quad " \quad 37-48$.

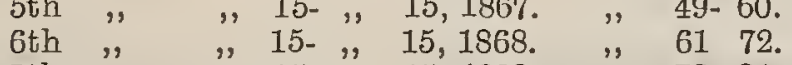
7 th " " 15-" $" 15,1869 . \quad$ " 73- 84.

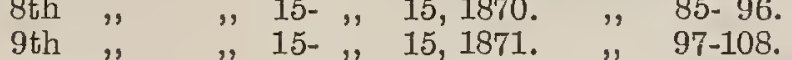
10th " " $" 15-" 1,15,1871 . \quad " 109-120$.

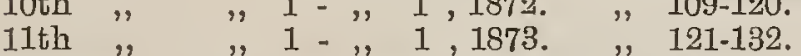

12 th $" \quad$ " $1-", 1,1874 . \quad$ "138-144.

14 th " " $1-1-", 1,1876 . \quad$ " $157-168$.

15 th $" \quad$ " 1 - " $1,1877 . \quad$ " 169-180.

16 th $" \quad " 1-" 1,1878 . \quad " 181-192$.

18th " " " $1-", 1,1879 . \quad$ " 1930.204.

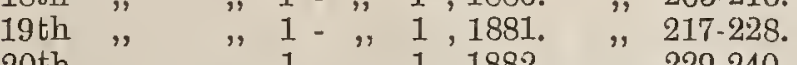

20 th " " 1 - " $1,1882 . \quad$ " 229-240.

21st " " 1 - " $1,1883 . \quad " 241-252$.

28rd " " " 1 - ", $1,1885 . \quad$ " 265-276.

24th " " 1 - " $1,1886 . \quad " 277-288$.

25 th " " $1-" 1,1887 . \quad$ " 289-300.

26 th " " 1 - " $1,1888 . \quad$ " 301-312.

28th " " " 1 - ", 1,1890 . " 325-336.

29th " " 1 - " 1, 1891. " "337-348.

30 th $"$ " 1 - " $1,1892 . \quad, 349-360$.

31 st " " "1 - " $1,1893 . \quad$ "361-372,

32nd " " 1 - " $1,1894 . \quad$ "373-384:

33rd " " 1 - ", 1, 1895. " 385-396.

34th " " "1-", 1, 1896. " "397-408.

35th " "1 - " $1,1897 . \quad$ " 409-420.

36th " " $1-", 1,1898$. " $421-432$.

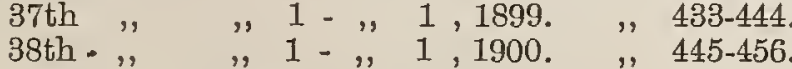

* * Edited by L. Hanciau. Vol. I. is folio and the remainin volumes are octavo. There are two numbers for December, 186 " 15 Decembre" and "31 Decembre". There is a title-page and a list of contents to each volume with the exception of vol. I The last numbers of the year 1900 were issued in advance; number 456, dated "Décembre" being published early in the previou August. There is a "Prix-courant" supplement to nos. 13-24 of LXXXIV. $+(2)$ pages; to nos. $25-30$ of LXXXIV. pages; to nos. $37-47$ of 48 pages; and to nos. $49-60$ of 56 pages; a supplement of (12) pages of illustrations of caricatures, etc., of the Mulready envelop to no 70 ; a "prix-courant" of 24 pages to the seventeenth year and two supplements to the twenty-seventh year, the first: a price list of "Timbres-Poste Ruraux de Russie" 4 pages; the other: a price list of "Timbres de Belgique," etc., 8 pages. "Le Timbre fiscal" was given as a supplement to nos. 193-408 and in January, 1897 , it was amalgamated with the journal under the title "I Timbre-poste et le Timbre fiscal," and was continued thus to the last number of December, 1900. The number for June, 1873, is wrongly numbered " 125 " in place of "126," no. 260 is dated "Juillet" in place of "Aontt" no. 382 "Septembre" instead of "Octobre" no. 408 "Novembre" in place of "Décembre" and no 449 "Avril" instead of "Mai". Nos. 271 and 272 and nos. 450 and 451 wer severally published together under the respective dates " 1885 , Juil let-Août" and "Juin et Juillet 1900". The twenty-fifth year has a "Numéro Jubilaire" of XxxvI. pages. There are paper wrappers to nos. 284-287, to the "Numéro Jubilaire," and to nos. 371-379. No. 340 and nos. 343-348 are found with the first page of each number headed "Supplément à la Revue Philatélique Suisse". These numbers were so printed for circulation with nos. 4-9 of the "Revue Philatélique Suisse" for the year 1891.(ONos. I and were reprinted by Ve J. Van Buggengoudt (sic), in 1863, and not by Beauvais as M. Ph. de Bosredon says in his "Bibliographie Timbrologique de la France et de la Belgique," Bruxelles, 1878 Nos. 13 and 14 were reprinted by $\mathrm{H}$. Thiry-Van Buggenhoud (sic) in 1869 and nos. 15 and 16 by A. Van Buggenhoudt in 1875

6 and the entire first volume was re-arranged and reprinted with a title-page and a list of contents in octavo size in 1867. The reprints of nos. 1 and 2 and 13-16 differ from the original number in the type and the arrangement of some of the articles and certain of the advertisements are entirely different. A copy of the prospectus issued in January, 1897, is bound up in front of tho 409. This was the first philatelic journal published in Belgium.

[Special edition printed on various coloured papers.]

* *This edition consists of 36 vols. viz.: the years 1866-1900 in clusive and the reprinted volume of the year 1863. The volume for the years 1864 and 1865 were not printed on coloured paper. "Numero Jubilaire" of 1887 belonging to this edition printed on thick white wove paper much superior in quality to that of the ordinary edition.
TIMBRE-POSTE, See GazETTE DES ANNONCES, DU COMMERCE ET DE L'INDUSTRIE.

TIMBRE-POSTE ET LE TIMBRE FISCAL. See TIMrRE-POSTE.

TIMBRES ET CARTES. Timbres et cartes. Anciennement l'Annonce philatélique (Ixme année).

Geneve, Louis Moriaud et Cic., I 904.

$4^{\circ} .11$ in. Nos. 1-5, February 25-May 25, Aug. 25, 1904.

* * All five numbers bear the words "Nouvelle série".

TIMBRES POUR COLLECTIONS. Timbres pour collections. Paris, Georges Carion, 1884 $12^{\circ} .6 \frac{1}{1}$ in. Nos. 1-10, January-December, 1884.

* * Nos. 7 and 8 , and 9 and 10 were severally published together the formor under the date "Juillet et Août" and the latter" "Septembre à Décembre".

TIMBRISIMATE. See PRESSO-PHILATÉLIE.

TIMBROFILO. Il Timbrofilo. Guida dei collettori di francobolli. Trieste, Giuseppe I. Morpurgo, I876-77. $8^{\circ} .12$ in. Nos. 1-[6], May 12, June 16, July 21, September 18, November 20, 1876, August 1, 1877.

Mis. St. Jour. $3(12)$

TIMBROFILO. Il Timbrofilo. Torino, L. Morelli, I 904$8^{\circ} \cdot 8 \frac{1}{2}$ in.

** This is solely a price list of stamps, etc., for sale by the publisher and cannot therefore be considered a philatelic journal.

TIMBROFILO QUINDICINALE. See TIMBRofILO (Torino.)

TIMBROFILUL. See TIMBRophILO

TIMBROLOGIA ESPAÑNOL. La Timbrologia española. Revista filatélica universal.

Val de Santo Domingo, Espagne, José Alvarez Janáriz, i 897-99.

$8^{\circ}$. $10-10 \frac{1}{2}$ iu. 14 nos. in 3 vols.
1st year. December, 1897 . No. 1.

2nd ", Jan. 31-Dec. 31, 1898. Nos. 1-12

3rd " Jan. 31-1899.

* * There is a paper wrapper to each number. Nos 6 and 7 of the second year were published together with thos. 6 and 7 of Julio de 1898". There is no number for April, 1898. Wanting nos. $9,10,12$, of the second year.

TIMBROLOGIE. La Timbrologie.

Paris, Georges Carion, 1885 .

$8^{\circ} .10$ in. No. 1, November, $1885 . \quad$ Mis. St. Jour. 90 (15).

TIMBROLOGIE AFRICAINE. La Timbrologie Africaine. Journal d'annonces du commerce de timbresposte. Tripoli, D. Théologo, r893-94. $8^{\circ} .10 \mathrm{in}$, fol. $11 \frac{3}{4}$ in. and $4^{\circ} .11$ in. Proof number, without number or date, and nos. 1-6, October, December, 1893, Narch 20 May 20, 18:4

* "The proof number, which is written entirely by hand in red iuk, is octavo, nos. 1 and 2 are folio and nos. 3-6 are quarto. Nos. 3 and 4 and 5 and 6 were severally published together under the respective dates " 20 Mars, 1894" and "20 Mai, 1894". Nos. 1 and 2 were printed at Tunis and nos. 3-6 at Amiens, Frauce.

Mis. St Jour. 103 (9)

TIMBROLOGIE ANVERSOISE. La Timbrologie Anversoise. Journal et feuille d'annonces. Organe mensuel du marchand et collectionneur.

Anvers, G. Maelfeyt, I892-94.

Fol. 163 in. and $4^{\circ} .11$ in. 20 ncs. in 2 vols.

1st year. June 15, 1892-May 30, 1893. Nos. 1-12.

2nd " $30,1893-J a n .31,1894 . ~ 13-20$

* * Nos. $1-7$ are folio and the remainder" quarto. No, 20 was printed at Amiens, France. Mis. St. Jour. 74 (4)

TIMBROLOGIE EGYPTIENNE. La Timbrologie Egyptienne. Le Caive, Carlo Mosti, I891-92. Fol. $15 \frac{1}{2}$ in. and $8^{\circ} .10$ in. Nos. 1-8, October 15, 1891-May 15, 1892

${ }_{*}^{*}$ Nos. 1-4 are folio and nos. 5-8 are octavo. No. 2 is dated in error " 15 Octobre," but has "Novembre" printed below, and nos. 6 and 7 were published together. This was the first phila-
telic journal published in Egypt.
Mis. St. Jour, 108 (14). 


\section{TIMBROLOGIE MERIDIONALE}

TIMBROLOGIE IMRIDIONALE. Timbrologie méridionale. Montpellier, Emile Portal, 1895. $8^{\circ} .11$ in. Nos. 1-4, March 31, April 30, May-June, 1895. * * There is a coloured paper wrapper to oach number and nos. 3 and 4 were published together. Mis. St. Jour. 98 (2).

TIMBROLOGIE UNIVERSELLE. La Timbrologie universelle. Organe des marchands et collectionneurs de timbres-poste. St. Etienne, Loire, J. Bonnet, I896. 8.9 $9 \frac{3}{4}$ in. No. 1, January 18, 1896. Mis. St. Jour. 100 (5).

TIMBROPHILE. Le Timbrophile. Journal de la collection timbre-postale.

$8^{\circ} .10$ in. 84 nos. in 7 vols.

1st year. Nov. 15,1864 -Oct. 15,1865 . Nos. 1-12.

2nd " " $\quad 15,1865-" 15,1866 . \quad " \quad 13-24$.

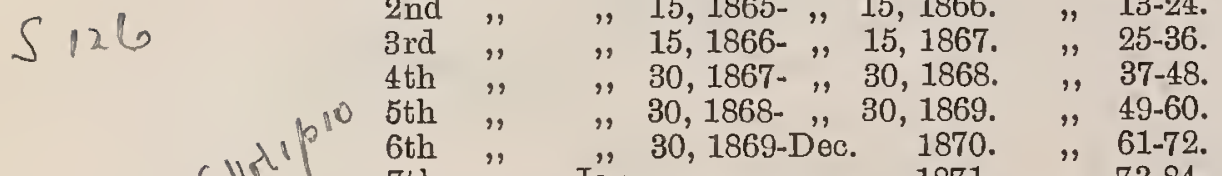

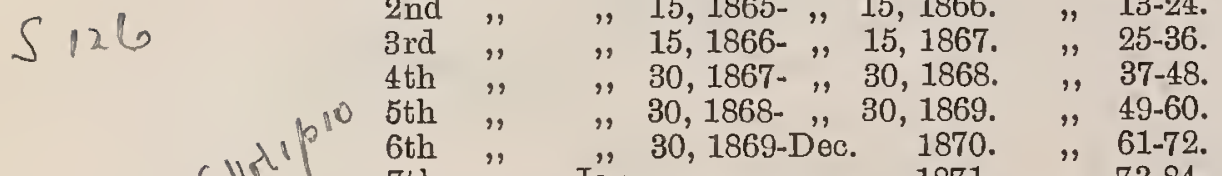

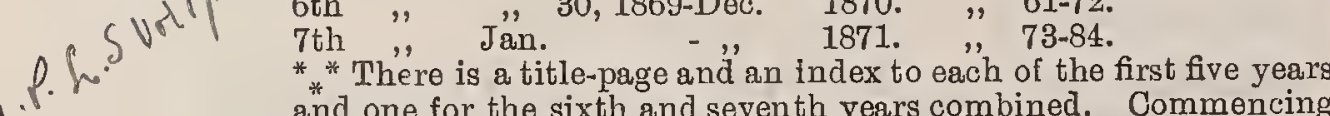
and one for the sixth and seventh years combined. Commencing with no. 38 the sub-title reads "Journal de la collection timbropostale et fiscale". No. 3 is dated " 15 Février" in error for "15 Janvier," no. 10, "15 Juillet" instead of " 15 Aout" and no 31 bears " 15 Avril" in place of "15 Mai". No. 70 is dated "Aotat a Novembre, 1870 "and is called " $6 e$ année, nos. 10 et 11 " "and nos. 71 and 72 were published together with the date "Décembre, $1870 "$ and bearing "6e annee, no. 12 ". Nos. $73-$ $76,77-80,81-82,83-84$ were severally pub ished together under the respective dates "Janvier à Avril, 1871," "Mai à Aout, 1871," "Septembre a "Octobre, 1871 " and "Novembre a Decembre, 1871 ". There are catalogue supplements to no. 1 and to nos. $3-$ 9. No. 3 was reprinted at Brussels. The reprint consists of eight in place of twelve pages and has the error in the date corrected to

_- [Special edition, printed on various coloured papers.] *** Consists of 84 nos. in 7 vols., Iike the ordinary edition. Wanting all.

TIMBROPHILE. Le Timbrophile. Gazette mensuelle d'annonces du commerce des timbres-poste.

Marseille, Alphonse Batifort, 1888 .

S 126 Fol. $12 \frac{3}{4}$ in. Nos. 1-3, January 15-March 15, 1888.
Mis. St. Jour. 108 (8).

[Continued as :]

_- L'Intermédiaire timbrophilique. Gazette mensuelle d'annonces du commerce des timbres-poste.

Marseille, Alphonse Batifort, 1888. Fol. 123 in. Nos. 4-5, A pril 15-May 15, 1888

* * Wanting no. 4.

Mis. St. Jour. 108 (8a)

TIMBROPHILE. Le Timbrophile. Journal mensuel. Marennes, E. Chaput, I899.

8. $9 \frac{1}{2}-10 \frac{1}{2}$ in. Nos. 1-3, September 1-November 1, 1899.

* * Printed on orange-red paper. No. 1 contains a subscription form - "Bulletin d'abonnement au Timbrophile" - which is headed "Supplément au Timbrophile du 1er October, 1899 ". Mis. St. Jour. 140 (7).

TIMBROPHILE ATHÉNIEN. Le Timbrophile Athénien. Le seul journal philatélique grec.

Athenes, D. M. Sacorrafos et Co., etc., I 897-99. $8^{\circ} .10$ in. 19 nos. in 2 vols.

1st year. Sept., 1897-Aug., 1898. Nos. 1-12.

1st year. Sopt., 1809-Aug., 1808. Nos. 1-12.

* * Nos. 6-8 were published by Sacorrafos and Lècatsas and nos.

9-19 by D. M. Sacorrafos. No. 4 bears no number and has th

date "Noël, 1897 " and no. 9 has "No. 8, Avril, 9 Mai, 1898 " with " 8 Avril" struck out in red ink. Nos. 4 and 13-19 have paper wrappers and nos. 6 and 7,11 and 12 and 14 and 15 were
severally published together.
Mis. St. Jour. 105 (4).

TIMBROPHILE BELGE. Le Timbrophile Belge. Bruxelles, J. Rigaux, etc., I 898-I 905.

$8^{\circ} .10 \frac{1}{2}$ in. 96 nos. in 8 vols.

\begin{tabular}{|c|c|c|c|c|c|c|}
\hline & ear. & $F \in$ & $1898-\mathrm{Ja}$ & 99. & os & $1-12$ \\
\hline & ", & " & $1899-$ & 1900 . & ", & $13-24$. \\
\hline & $"$ & & -Dec. & , 1900 & , & 25-36. \\
\hline & " & Jan., &,- & 1901. & " & $37-48$. \\
\hline $6 n$ & $"$ & " & " & 1902 & $"$ & $\begin{array}{l}49-60 . \\
61-72\end{array}$ \\
\hline & $"$ & ", & ", & 1904 . & $"$ & $73-\varepsilon$ \\
\hline & $"$ & $"$ & ," & 1905. & 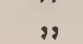 & \\
\hline
\end{tabular}

TIMBROPHILE BRÉSILIEN

800

* * There is a combined index for the first three years, a similar one for the next three years, a similar one for the seventh and eighth years, and a coloured paper wrapper to each number. Nos. 31 and 32,44 and 45,56 and 57,69 and 70,80 and 81, 91 and 92 , and 95 and 96 were severally published together. Nos. 35 and 36 are both dated December, 1900 , and there is an advertisement supplement to no. 26 . Nos. $88-96$ were published by Madame M. Belin.

TIMBROPHILE BRÉSILIEN. Le Timbrophile Brésilien. Organe mensuel du marchand et du collectionneur de timbres-poste.

Petropolis, Brésil, José Mattoso et A. Gredilha, I896.

$4^{\circ}$. 123 in. Nos. 1-[5], January-April, 1896, and no date.
${ }^{*}$ Nos. 2 and 3 were published together and no. 5 is printed on rose paper and bears no number or date. The contents of the lose paper and bears no number consist entirely of advertisements.

Mis. St. Jour. 88 (6).

TIMBROPHILE DE FRANCE. Le Timbrophile de

France. Journal coopératif des annonciers philatélistes. Paris, Geo. Ledoux, I 903-

$4^{\circ} .11 \frac{1}{4}$ in. nos. in vols. In progress.

1st year. Mar. 25-Dec. 25, 1903. Nos. 1- 9.

2nd " Jan. 25- " 25, 1904. " 10-20.

4th " " " 25- ", $25,1905 . \quad$ ", $21-31$.

* * There are" no numbers for August,"1903, August, 1904 or July, 1905 , and nos. $21-23$ are dated in error " 1904 ". No. 38 is dated "25 Juillet et 25 Aoutt 1906". A copy of the prospectus of the journal is bound up in front of no. 1 .

TIMBROPHILE DU LITTORAL. Le Timbrophile du Littoral. Fréjus, France, Gabriel Cisson, r gor-o3. $8^{\circ} .9$ in. 25 nos. in 3 vols.

1.st year. Jan. 15-Dec. 15, 1901. Nos. 1-12.

2nd ", " 15-, 15, 1902. " 13-24.

3rd " " $15-15$ 1903. No. 1.

* * There is" a paper wrapper to each number. The wrapper of no. 1 of the third year is wrongly dated "1902" in place of "1903". Wanting nos. 21, 22, 28, 24.

TIMBROPHILE EGYPTIEN. Le Timbrophile Egyptien. Alexandrie, Isaac $M$. Aboulafia, r 895-96. 8. 9 in. Nos. 1-4, September, October, 1895, June, August 1896. * * There is a coloured paper" wrapper to each number.

TIMBROPHILE GAULOIS. Le Timbrophile Gaulois. Malzéville-lès-Nancy, etc., Madame Ferry, r896r 900.

$8^{\circ} .10$ in. 35 nos. in 4 vols.

1st year. Oct., 25, 1896-Sept., 1897. Nos. 1-12.

1897-June 30, Aug. 15, 1898. Nos. 13-22.

2nd " Se" St. 30, Nov. 15, 30, Dec. 30, 1898-March 31, June 15 3rd " Sept. 30, Nov. 15, 30, Dec. 30, 1898-March 31 , Jun.

4th Dec., 1899, and Jan., 1900. No. 35.

* * Each number has a coloured paper wrapper. Nos. 9-13 bear ** Each number has a coloured paper wrapper. Nos. 9-13 bear the title "Le Timbrophile Gaulois et Athènes Philatélique Reunis" and nos. $22-35$ were published at Moyen "

TIMBROPHILE GAULOIS ET ATHENNES PHILATÉ. LIQUE REUUIS. See Timbrophile Gaulois.

TIMBROPHILE LORRAIN. Le Timbrophile Lorrain. Chef-Haut, Vosges, P. Beurdouche, 1895 $8^{\circ} .10$ in. Nos. 1-7, March 15-September, 1895.

* * There are supplements with the title "Supplément Littéraire du Timbrophile Lorrain" to nos. 3-7, numbered "Livraison" 2-6. Mis. St. Jour. 100 (4)

TIMBROPHILE PARISIEN. Le Timbrophile Parisien. Journal international philatéliste.

Paris, Henri Fidide, I897.

$8^{\circ} .10$ in. Nos. 1-5, May-September, 1897.

* Nos. 4 and 5 were published together in a coloured paper wrapper under the date "Août-Septembre, 1897," but the wrapper 

Tomorophire Promeal - Vidaubar, 1900-S126

Times, wellunglón 1884/5 5126

" Linunbury, Na $1872 / 35127$ 
TIMBROPHILE POITEVIN, Le Timbrophile Poitevin. Poitiers, Raoul Téteix, r895-r9o5.

$8^{\circ} .9 \frac{1}{2}-9 \frac{3}{4}$ in. 99 nos. in 9 vols.

1st year. March 1, 1895-Feb. 1, 1896. Nos. 1-12.

2nd " " 1, 1896- ", 1, 1897. " 13-24.

3rd " " " 1, 1897- " $1,1898 . \quad$ " $25-35$.

4th " " 1, 1898- Jul 1, 1899. Ja " 36-46.

$47-58$.
7 th

7 th " Aug. 15, 190

8th " March-June 15, Sept. 15-Dec. 15, 1903. Nos. 75-82.

9th ", Jan. 15-July 15, Oct. 15, 1904-F'eb. 15, 1905. Nos. $83-94$.

10th "Mar. 15-July, 1905. Nos. 95-99.

*** Each number has a coloured paper wrapper. Nos. 10 and 11 are lithographed, no. 31 is dated "Septembre-Octobre, 1897," there is no number for September, 1898, no. 74 is dated "JanvierFévrier, 1903 " and nos. 98 and 99 were published together.

TIMBROPHILE ROUIMAINE. Le Timbrophile Roumaine. Organe spécial des collectionneurs de timbresposte. Berlad, Georges K. Panaitesco, I897 $8^{\circ} .8 \frac{1}{2}$ in. No. 1, February 9-25, $1897 . \quad$ Mis. S't. Jour. 99 (1).

TIMBROPHILE SUISSE. Le Timbrophile Suisse. Genève, Fernand Monthoux, I897-98. $8^{\circ} .10$ in. Nos. 1-6, December 30, 1897-May, 1898

* Nos. 4-6 have coloured paper wrappers.

Mis. St. Jour. 110 (4)

TIMBROPHILE SUISSE. Le Timbrophile Suisse. Schweizer Anzeiger für Philatélie.

La Chaux-de-Fonds, Th. Breguet fils, , g03-04. $8^{\circ} .103$ in. and $4^{\circ} .12 \frac{1}{2}$ in. Nos. 1-8, September-November, 1903, January-May, 1904.

* * The contents consist entirely of advertisements. Nos. 1-8 are octavo and are printed ou yellow paper, the remaining numbers are quarto and are printed on white paper.

Nis. St. Jour. 120 (13).

TIMBROPHILE TUNISIEN. Le Timbrophile Tunisien. Journal du collectionneur et marchand de timbres-poste. 4. 123 in. Nos. 1-2, January 1-Februar, Borget

Tunis, Borget et Taieb, Igoo.

$4^{\circ} .123$ in. Nos. 1-2, January 1-February 1, 1900. Jour. 128 (10).
Mis. St. Jour.

TIMBROPHILIST. De Timbrophilist. Een geïllustreerd blad voor Postzegel-Versamelaars. Amsterdam, P. Groenendijk, [1869-7o].

$4^{\circ} .81$ in. Nos. 1-9, July 1, [1869]-March 1, [1870]. upright rectangular space for a presentation stamp. Edited by C Van Rinsum and J. Chr. Van Schaick. This was the first

5126 philatelic magine published in Dutch. Wanting nos, $2,3,4$ $5,6,7,8$.

TIMBROPHILIST. The Timbrophilist.

Boston, Mass., C. A. Lyford, etc., I869-74.

$8^{\circ} .9 \frac{1}{2}$ in. 5 nos. in 3 vols.

if Vol. I. [No date], Sept., 1869. Nos. 1 and 7

" II. [No dates.] No. 1 and no. 6.

"III. Sept., 1874. No. 3.

* * No other numbers but those specified were published. No. 3

vol. III., was published by C. A. Lyford and Co., and is called

"Whole number 74".

TIMBROPHILO. Timbrophilo. Jurnal philathelisticu Romän.

Bucuresci, Steinberg si Wortmann, I 88r. Fol. 12 in. Nos, 1-3, Januarie 1/13-Martie 1/13, 1881.

* The contents are published in Roumanian and French. A copy of the prospectus is bound up in front of no. 1. This was the first philatelic journal published in Roumania.

\section{[Continued as :]}

Timbrofilul. Revista mensuala.

Bucuresci, C. MI. Moroin, r89o-[93].

Fol. 123 in. Vols. II.-IV. 15 nos.
2nd year. Nov., 1890, Jan.-July, Oct., Nov.-Dec., 1891. Nos. 413.
3rd ," Mar., Aug., Nor., 1892. Nos. 14-16.

$\begin{array}{lll}3 r d & \text { Mar., Aug., Nor., 1892. Nos. 14-16. } \\ \text { 4th } & \text { Jan., Mar., [1893]. }\end{array}$

* * Some of the contents are published in Roumanian and some in "French No 13 is dated "Noembre-Decembre, 1891," and nos. 15-18 have no year given. Mis. St. Jour. 86 (10).
TIME AND TIDE. The Time and tide.

Bloomdale, O., The Time and Tide Pub. Co., I905. $32^{\circ} .41$ in. No. 1, February, 1905.

* * Only partly philatelic. Wanting.

\section{[Continued as :]}

The Philatelic time and tide.

Bloomdale, O., The Time and Tide Pub. Co., etc., I905. $8^{\circ} .63$ in. and fol. 11 in. Nos. 2-4, March-May, 1905.

** Only partly philatelic. Nos. 2 and 3 measure $6 \frac{3}{x}$ inches and no. 4, 11 inches. The last number was published by Everett $G$ Emerson. Nos, 2 and 3 are printed on rose paper and no. 2 has a yellow wrapper.

\section{[Continued as :]}

The Time and tide.

Bloomdale, O., Everett G. Emerson, I 905-06. $8^{\circ} .8$ in. and 10 in. Nos. 5-12, June, July-Dec., 1905, Jan.-May, June-July, 1906.

* * Only partly philatelic. No. 5 measures 8 inches and the and no. 12 "June-July, 1906 ".

TIMEHRI. Timehri being the journal of the Royal Agricultural and Commercial Society of British Guiana. Vol I., Part II. December, 1882. [Contains an article "Valuable curiosities from the British Guiana Post Office". By Edward C. Luard.]

$8^{\circ} .8 \frac{1}{2}$ in. pp. $251-256$

Demerara, J. Thompson, I 882.

Vol. IV. (new series). Part Ir. December, 1890. [Contains an article "The Post Ottice in British Guiana before 1860". By James Rodway.]

Demerara, J. Thompson, I8go.

$8^{\circ} .8 \frac{1}{2}$ in. pp. $187-213$

* * Each number has a coloured paper wrapper.

TIMES WEEKLY EDITION. The Times weekly edition. March 30, 1894. [Contains an article "Stamp collecting. Its connexion with postal revenues."]

Fol. $18 \frac{1}{2}$ in. p. 259. London, [? ], I 894 . Mis. St. Jour. 136 (6).

TINY COLLFCTOR. The Tiny collector.

Slate Lick, Pa., Herber't Bricker, I $887-88$. $32^{\circ}, 3 \frac{3}{4}$ in. and $16^{\circ}, 5^{3}-6$ in. 4 nos. in 2 vols.

Vol. I. Jan., Summer, Autumn, 1887. Nos. 1-3.

C." II. Spring, 1888. No. $\frac{1}{N_{0}} 1$ is $32^{\circ}$. and the remaining numbers are $16^{\circ}$. No. 2 has no number. Mis. St. Jour. 68 (14).

TINY PHILATELIST. The Tiny philatelist. Cambridgeboro, Pa., H. B. Wilber, I889. $16^{\circ} .6$ in. No. 1, Spring, 1889. Mis. St. Jour. 68 (15).

TINY PHILATELIST. See Philatelic Midget.

TIT-BITS, Tit-Bits. February 6, 1886. [Contains an article "The postage of the world".]

London, George Newnes Limited, I 886.
Fol. 121 in. p. 263.
Mis. St. Jour. 138 (7).

TIZER. The Tizer.

Sandy Hill, N. Y., C. C. Guy, I 900.

in. Nos. 1-3, May-July, 1900.

** Only partly philatelic. Wanting all three nos.

TOLEDO PHILATELIST. The Toledo philatelist.

$24^{\circ} .5_{4}^{3}$ in. No. 1 , September $1,1901$. Toledo, O., J. F. Luwlor, I gor.

** The number has a coloured paper wrapper.

Mis. St. Jour. 106 (2).

TOLEDO STAR. The Toledo star.

Toledo, O., E.S. Ward, I895.

Fol. 12 in. No. 1, January 15, 1895.

* *nly partly philatelic, Mis. St. Jour. 140 (14) 
TORONTO JOURNAL OF PHILATELY. Toronto journal of philately.

Toronto, Toronto Philatelic Publishing Co., 1892. $8^{\circ} .8-8 \frac{7}{2}$ in. Nos. 1-2, May-June, 1892

* * There is a coloured paper wrapper to each number.

Mis. St. Jour. 56 (1).

TORONTO PHILATELIC JOURNAL. Toronto pbilatelic journal. Devoted to the interest of stamp collectors.

$8^{\circ} .11 \frac{1}{2}$ and $9 \frac{1}{2}$ in. 25 nos. in 3 vols

Vol. I. March, 1885-Feb., 1886. Nos. 1-12.

". II. II 1886-June, 1888. " 1-12.

", III. July, 1888. No. 1 .

*" No. 1, vol. r., was publisked by G. A. Lowe, nos. 2-12, vol. I., 4-12, vol. II., and no. 1, vol. III., by the Toronto Philatelic Co. and nos. 1-3, vol. Ir., by H. Morell. $\checkmark$ Vol. I. is octavo $11 \frac{1}{2}$ inches and vols. Ir. and IIr. are octavo $9 \frac{1}{2}$ inches, and there is a coloured paper wrapper to each number of the two last volumes. The magazine was discontinued after May, 1886, until October, 1887; The wrapper of no. 1, vol. III., is dated "July-August, 1888 ". The wrappers of nos. 1-3, vol. Ir., have "The Toronto philatelic journal. A monthly magazine devoted to the interest of stamp col"Tlo to those of nos. 4-12, vol. II., and to. 1, vol. III., have "Loronto philatelic journal. A monthly magazine for stamp collectors". $\quad$ Vol. I. Mr. Mis. St. Jour. $4(2)$.

TORONTO PHILATELIC JOURNAL. The Toronto philatelic journal. Second series.

Toronto, W. S. Weatherston, r894. $8^{\circ} .8^{3}$ in. and $24^{\circ} .4 \frac{1}{2}$ in. Nos. 1-6, January-June, 1894.

** No. 1 is octavo and has a coloured paper wrapper. $*$ The remaining five numbers are $24^{\circ}$. and have no wrappers. No. 6 consists of a single leaf printed on one side only.

Mis. St. Jour. 56 (8).

TORONTO PHILATELIST. The Toronto philatelist. A journal devoted to stamp collecting only.

Toronto, Richardson and James, etc., I877 8. $8 \frac{1}{2}$ in. Nos. 1-3, March-May, 1877

* * No. 3 was published by R. Richardson and there is a supplement of (2) pp., printed on one side only, to no. 2.

Tis. St. Jour. 28 (17).

TORONTO STAMP. The Toronto stamp.

8․ $8^{3}$ in. No. 1, September, 1894

Toronto, John H. Lowe, I 894

TOSCANE PHILATHLIQUE. La Toscane philatélique Journal international d'annonces pour collectionneurs et marchands de timbres-poste.

Livourne, Jean Salsiccioni, 1897.

Fol. 121 in. Nos. 1-2, February 15-March $31,1897$.

Mis. St. Jour. 105 (11)

TOWN CRIER. The Town orier.

New York, The Town Crier Pub. Co., I893-94 $8^{\circ} .8 \frac{3}{4}$ in. 18 nos. in 2 vols.

Vol. I. Mar. 15, 1893-Feb., 1894. Nos. 1-12

* * Only partly philatelic. Edited by Max Strakosch. Nos. 6 and 7 , vol. I., and nos. 2 and 3 and 5 and 6 , vol. rr., were severail published together. Wanting all but nos. 1, 2, 3, vol. I.

TRADER. The Trader. What to buy and where to buy it Washington, D. C., F. O. McCleary, I875-76. $8^{\circ} .8 \frac{1}{2}$ in. Nos. 1-3, November, 1875-January, 1876.

* * Only partly philatelic. Wanting no. 3

Mis. St. Jour. 28 (11a).

TRADER. The Trader.

Washington, D. C., J. Barry and Co., I876.

$8^{\circ} .8 \frac{1}{2}$ in. Nos. 1-2, November-December, 1876

* No. 2 is only partly philatelic. Mis. St. Jour. 28 (11).

TRAMP ADVERTISER. The Tramp advertiser.

Milwaukee, Wis., Western Stamp Co., I 900. in. Nos. 1-2, February-March, 1900.

* * Wanting both nos.

TRANSACTIONS OF THE ASIATIC SOCIETY OF JAPAN. Transactions of the Asiatic Society of Japan. Vol. xxxiv. Part III. October, 1906 . [Consists of "A summarized catalogue of the postage stamps of Japan. By A. M. Tracey Woodward."]

$8^{\circ} .9$ in. 90 pp.
** The number has a coloured paper wrapper.
Mis. St. Pamph. 80 (9).

Yokohama, Japan, I 906

TRANS-ATLANTIC. The Trans-Atlantio I88I.

Richmond, Va., J. H. Huband and H. L. Pinckney,

* * Cuttings of the column "Philately" from no. 1, dated July, 18̂̉, are mounted in Stamp Scrap-book, vol. v., pp. 82, 83.

TRANSCONTINENTAL PHILATELIST. The Transcontinental philatelist.

Waukegan, Ill., The Transcontinental Philatelic Publishing Co., r893-94.

$8^{\circ} .9$ in. Nos. 1-5, December, 1893-April, 1894.

** There is a coloured paper wrapper to each number. Nos. 1 and 2 were edited by E. S. Lawson and nos. $3-5$ by L. O Wainand 2 were edited by E. S. Lawson and nos. 3-5 by L. O Wain-
wright. St. Jour. 62 (8).

TRANSCRIPT. See Stampman. (Dahlonega, Ga.)

TRANS-MISSISSIPPI STAIMP. The Trans-Mississippi stamp. Omaha, Neb., C. R. Pyburn, etc., 1896-97.

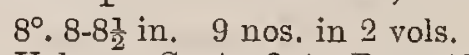

Vol. I. Sept., Oct., Dec., 1896. Nos. 1-3.

", II. Jan.-June, 1897. , 4-9.

* "* Each number has a paper wrapper. Nos. 2-9 were published by the Trans-Mississippi Publishing Co. No. 5 only bears the numbering "vol. II., no. 2" and this number is dated " FebruaryMarch, 1897 " while no. 6 is dated "March, 1897".

Mis. St. Jour. 103 (2).

TRANSVAAL COLLECTORS' QUARTERLY. The Transvaal collectors' quarterly.

Croydon, E. J. Nankivell, 1899

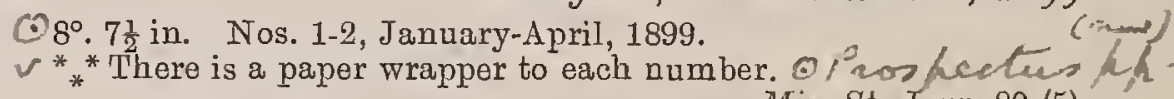
Mis. St. Jour. 80 (5)

TRIBUNE DES COLLECTIONNEURS. La Tribune des collectionneurs. Paris, Ch. Cornet, etc., I 90I-04. $8^{\circ} .93$ in. 33 nos. in 4 vols.

1st year. Mar., 1901-Feb. 15, 1902. Nos. $1-12$

2nd year. Mar., $15, \quad$ - Oct. 31, ", " " $[13]-20$

3rd ", Dec. 15, 1902-Nov., 1903. ", 21 - 21 - 31.

4th " Jan., Feb., 1904.

* * Nos. 14-33 were published by P. Villemont and each number has a coloured paper wrapper. "The wrapper of no. 1 has " 1091 " in error for "1901," no. 13 has " $2 \mathrm{e}$ annce, no. 1" instead of no. 13, there are no numbers for August and November, 1902, or for February and July, 1903, and nos. 18 and 19, 26 and 27 and 30 and 31 were severally published together under the respective dates "30 Septembre, 1902"; "June, 1903 "; and "Octobrebound up in front of no. 1 .

TRIBUNE LITTERAIRE. See Tribune LitTtiraire ET PHILATÉLIQUE.

TRIBUNE LITTÊRAIRE ET PHILATÉLIQUE. La Tribune littéraire et philatélique.

Mâcon, France, [Louis Prudon], I902. $8^{\circ} .9 \frac{1}{4}$ in. Vol. Ir. 4 nos.

2nd year. Aug. 1-Nov. 1, 1902. Nos. 12-15.

* * There is a coloured papor wrapper to each number. Nos. 1 11 had the title " $\mathrm{La}$ Tribune" and were not philatelic.

[Continued as :]

La Tribune littéraire.

Mácon, France, [Louis Prudon], I 902-03. $8^{\circ} .9 \frac{1}{4}$ in. Vols. Ir.-III. 2 nos.

2nd year. Dec. 10, 1902. No. 16

3rd ", Jan. 10, 1903. ", 17.

* "There is a coloured paper" wrapper to each number, that of no. 17 being wrongly dated "1902". Both numbers contuin a loose supplement printed on blue paper and with the title " La Tribune philatélique": The one belonging to no. 16 is dated "1er Décembre, 1902" while that in no. 17 bears "2e Année, no. 17-10 Janvier, 1903 ". 


$$
-
$$

Trata phatatico 



\section{TRIBUNE LITTRRAIRE ET PHILAT F́LIQUE.}

[Continued as:]

- La Tribune philatélique.

8․ 101 in. Vol. II. 2 nos.

Mácon, France, [Louis Prudon], I903. 2nd year. March 10, 1903. Nos. 18-19.

* * Published together. Lilke the supplement to no. 17 this double number baars "2e annés". Mis. St. Jour. 131. (3b).

TRIBUNE PHILATẼLIQUE. See Tribune httTÉRatre ET PHILATELLIQUE.

TRI-CUSPID. The Tri-cuspid. Profundity. Progress. Perseverance. A journal devoted to postage stamp collecting. Statesboro, Ga., Ad. V. Schon, I894-95. 8. 9 in. Nos. 1-S, June 15, July 6, 27, Aug. 17, Sept. 7, 28, Oct.
19, 1894, Jan. 14, 1895.

TRIFET'S MONTHLY. See F. TRIFET'S MONTHLY OIRCULAR.

TRI-MONTHLY COLLECTOR. The Tri-monthly collector. Issued three times a month in the interests of collectors of postage and revenue stamps.

Nerv Oxford, Pa., J. F. Dodge, r899. $8^{\circ} .73-8 \frac{1}{2}$ in. Nos. 1-16, January 3-June 3, 1899.

* * Each number, except no. 11, has a paper wrapper.

"TRINACRTA" "Tripnorin" Giornale mensile d"an nunzi por collezionisti e negozianti di francobolli.

$8^{\circ} .91$ in. 14 nos. in 2 vols. Napoli, Cocorullo e Co., I895-96.

1st

2nd "Jan. 20-Mar. 20, 1896. "1-3.
TUNGURAHUA FILATÉLICO

806

* * Eiach number bears "Organo ufficeial del Circolo Filateilco N"apoletano," and has a coloured paper wrapper. Nos. 7-11 and 1.3 of the second year are printed on coloured paper.

Mis. St. Jour. 100 (3).

TUNGURAHUA FILATÉLICO, El Tuugurahua filatélico. Ambato, Ecubdor, Alfredo Jaramillo P., 1906. $8^{\circ} .8 \frac{1}{2}$ in. No. 1, March 1, 1906.

* * The number bas a papor wrapper. Wanting,

TUNIS-PHILATEIIQUE. Tunis-philatélique. Journal d'annonces pour marchands et collectionneur's de timbresposte. Tunis, René Coscas, I895-96. 4. $11 \frac{1}{4}-113$ in. Nos. 1-4, Oct. 31, Dec. 31, 1895, Jan.-Feb., 1896. * Nos. 3 and 4 were published together. Bound up with the journal is a copy of the prospectus. dated August, 1895. This was the first philatelic journal published in Tunis.

Ifis. St. Jour. 97 (12).

TWENTIETH CENTURY FIRESIDE. Twentieth century fireside.

Kansas City, Mo., R, C. Robinson, I gor. Fol. 15 in. Vol. I. No. 4. New Series No. 1, March, 1901. ** Only partly philatelic. Mis. St. Jour. 136 (3).

20TH CENTURY IMICHIGAN ADVERTISER. SeC 20TH CENTURY MONTHLY ADVERTISER.

20TH CENTURY MONTHLY ADVERTISER, 20th century monthly advertiser. PProspectus of a journal to be published by the Egyptian Stamp Co., Detroit, Mich., on April 20th, 1904, but which was never issued.] *" Although the title is given as above, the prospectus is signed
"20th century Michigan advertiser". Mis. St. Jour. $125(7)$. 


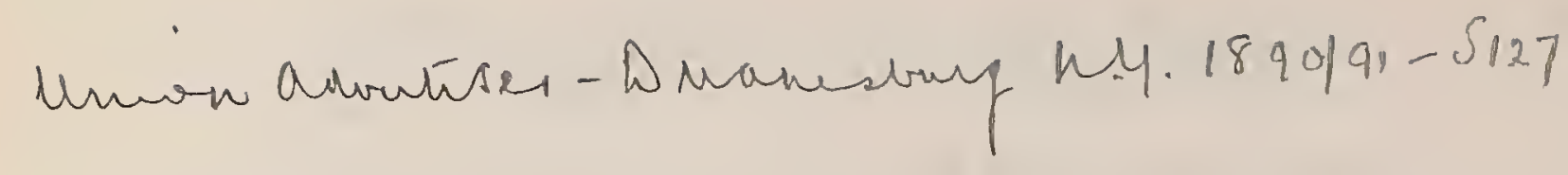

UNGARISCHES BRIEFIMARKEN - OFFERTENBLATT. See LEVÉLBÉLYEGGYÜJTÖK LAPJA.

"UNIÃo CARTO-PHILATELICA." "A' União cartophilatelica." Orgam official da "Paulista".

S127 S. Paulo, Brazil, Sociedad "Paulista," г 905-o6. Fol. $11 \frac{1}{4}$ in. Nos. 1-9, June 15, 1905-February, 1906.

** Nos. 6 and 7 and 8 and 9 were severally published together and there is a coloured paper wrapper to each number. Wanting nos. $3,4,5$.

UNIÁO POSTAL. A Uniáo postal. Orgão philatelico e noticioso. Maranhão, Brazil, J. M. Affonso Rosa, I893.

Fol. $14 \frac{1}{3}$ in. No. 1, Angust 5,1893 .
*** Edited by Sebastiao Nogueira, Ludgero Rodrigues and Ray-
mundo Rodrigues. Wanting.

UNION. Union. Deutsche Briefmarken-Zeitung. Dresden, Alwin Nieske, I877-8I. Fol. $12 \frac{1}{2}$ in. 50 nos. in 5 vols. 1st year. Jan. 1-Dec. 1, 1877. Nos. 1-12. 2nd " "1- " 1, 1878. " $13-24$ 3rd " " $\quad 1-, " 1,1879 . \quad$ " $25-36$.

S127 4th " " "1-" 1, 1, 1880. " " 37-48. ** There are supplements to nos. $6-11,22,26,27,30,34,37,38$, niss und Beschreibung aller Postkarten. Bearbeitet von Mitgliedern des Internationalen Philatelisten-Vereins," was published in parts with the numbers of the journal for 1879 .

UNION. Union. Nur für Mitglieder der " $\mathrm{Ph}$. ." Zittau, "Philatelia Zittau," I889.

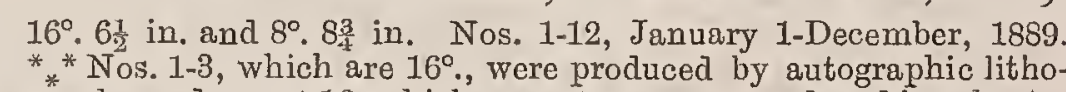
graphy and nos. 4-12, which are octavo, were produced by a hectographic process. There is no number for October, but nos. 10 and 11 were published together under the date November 15. There are supplements to nos. 1 and 9.

UNION. Union.

Arnheim, Holland, etc., I. Keller, etc., I893-94. Fol. $12 \frac{1}{4}$ in. 11 nos. in 2 vols.

1sti year. July 7, Aug. 7, Sept. 8, Nov. 8, Dec. 8, 1893. Nos. 1-5. 2nd "Jan. 8, Feb., Mar., May, June, July, 1894. Nos. [6]$[11]$.

* No. 6 is numbered " 2 Jahrgang No. 1 " and nos. 9-11 bear no number. Nos. 4-8 were published by L. Keller at Pössneck i Thür., and nos, 9-11 by Steenmeijer and Cie. at Amsterdam. INis. St. Jour. 116 (6).

"UNION." “Union." Central-Offertenblatt für den Briefmarkenverkehr des In- und Auslandes.

$4^{\circ} .12 \frac{1}{2}$ in. 'No. 1 , November 12, 1896 Berlin, G.S. Schulz, 1896. ** The contentis consist entirely of advertisements. Mis. St. Jour. 120 (14)

UNION BULLETIN. The Union bulletin

Westernport, Md., D. E. McCurdy, I 903 . * in. No. 1, November $25,1903$.
UNION CHRONICLE. The Union chronicle. Official pamphlet of the Western Philatelic Union,

Long Beach, Cal., Western Philatelic Union, r889. $8^{\circ} .9 \frac{1}{4}$ in. No. 1 , November 15, $1889 . \quad$ Mis. St. Jour. 16 (2).

UNION DES COLLECTIONNEURS. L'Union des collectionneurs.

Chef-Boutonne, Deux-Sèvres, G. de Fommervault, I902-04.

$8^{\circ} .10$ in. 17 nos. in 2 vols.

1st year. Nov. 1, 1902-Oct., 1903. Nos. 1-12.

2nd *" 1-10" have coloured paper wrappers. Amalgamated with the "Annonce Philatélique," Troyes, April, 1904.

Mis. St. Jour. 99 (6).

UNION DES TIMBROPHILES. L'Union des timbrophiles.

$8^{\circ} .10 \frac{1}{2}$ in. 57 nos. in 5 vols.

1st year. Nov. 15,1884 -Oct. 15,1885 . Nos. 1-12.

2nd " " 15, 1885- " 15, 1886. " $13-24$.

3rd ", " " 15, 1886- " $15,1887 . \quad$ " $25-36$. 5th " "Nos, 1888-M"May, 15, June-Aug., Sept.-Oct., 1889.

* * Nos, 2-57 are printed on buff paper, and there is a supplemental slip to no. 55 and also to no. 57 .

Nouvelle serie.

Paris, J. Nalès, r892-94.

$8^{\circ} .10 \frac{1}{2}$ in. 35 nos. in 3 vols.

[1st year.] Jan.-Dec., 1892. Nos. 1-12 and 58-69.

[3rd "] " "

* * Printed on buff paper. Nos, 7 and 8 " 82 . 20 and 21,29 and 30 * Printed on buff paper. Nos. 7 and 8,20 and 21,29 and 30 there is a supplemental slip to no. 24 .

UNION EXCHANGE LIST. Union exchange list. Devoted entirely to the interests of exchangers. Evanston, Ml., G. A. Bogart, I882-84. $8^{\circ} .93$ in. 24 nos. in 2 vols.

Vol. I. June 15, 1882-May, 1883. Nos. 1-16. II

Vol. I. June 15, 1882-May, 1883. Nos. 1-16.

*"* Ir. June, 1883-Jan., 1884. "* Only partly philatelic. Beginning with no. 8, vol. I. each exchange list". Nos. 9 and 10, vol. I., and nos. 6 and 7 , vol. Ir. exchange list". Nos. 9 and 10 , vol. I., and nos. 6 and 7 , vol. Ir.,
were severally published together.

UNIÓN FILATÉLICA. La Unión filatélica. Barcelona, Hermenegildo Prats, etc., 1893-95. $8^{\circ} .10 \frac{3}{1}$ in. and $8 \frac{1}{2}$ in. 23 nos. in 3 vols.

1st year. Jan.-Dec., 1893, Nos. 1-12.

2nd ", "June, Sept.-Dec., 1894. Nos. 13-21.

3rd "1, 1895. Nos. 22-23.

* * Nos. 1-12 measure 103 inches and nos. 13-23, 83 inches. Nos. 22 and 23 were published by Ricardo San Antonio. These two numbers bear the date " 1895 ," but have no month of publication given. Nos. 8 and 9 were published together and no. 21 bears the date " Novbre y Dicbre de 1894 ". There is a supplement of illus trations to no, 1 and other supplements to nos. 3-12. 
Union Filaterica Costakrica 1897

Llmion Philatelist. An hid epentent monthly for alt classes of Philatelists.

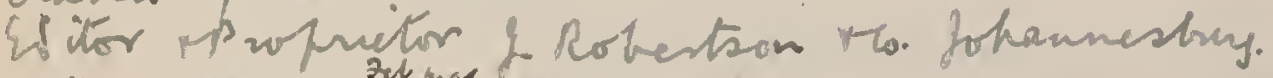
4to.1920.I1.2 than imay)

Mos 1.2 are 8 ro. Union Philatelist (Jo'burg), Nos. 1 and 2 , (contd. as Quarterly 


\section{UNIÓN FILATÉLICA.}

[Continued as :]

Ilustración filatélica Hispano-Colonial.

Barcelona, Ricardo San Antonio, I895-97. $8^{\circ} .8 \frac{1}{2}-7 \frac{1}{2}$ in. Vols. IV.-VIII. 34 nos.

4th year. Apl. 15, -Sept, 1895. Nos. 31-36.

5th " Oct. 1895-Jan., 1896. " 48-50.

6th " Feb. $\quad$-Oct., " $\quad$ "Dec. $51-61$.

8th " $\quad$ Fev. 10, -Dec., " "July, 1897. " 70-75.

* * Nos. 24-30, 37-47 and 76-84 were never published. The first * " Alianza Filatelica" and the second eleven numbers are repre "Ala by the eight " sented by the the three the wrapper. Nos. 31 and 32 bear "vi gño" numbers "IV a no" wat inster "Nos 35 and 36,60 and 61,63-69, 71 and 79 has the corr " 74 , year. " and 73 and 74 , were severally published together. 59 .

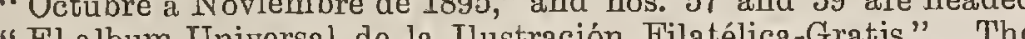

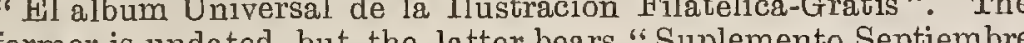
"ormer is udated, but the latter bere

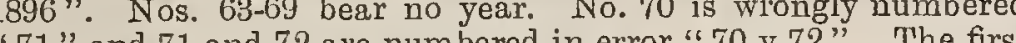
. 71 and 71 and 72 are number 政, also no year given.

[Continued as:]

Ilustración filatélica Hispano Americana.

Barcelona, Ricardo San Antonio, 1897-1900.

$8^{\circ} .8 \frac{1}{2}$ in. Vols. viII.-x. 10 nos.

sth year. 1897, 1897. Nos. 86- 87.

9th year. 1897, 1897. Nos. 86- 87.

10 th " 1898, 1900. " " 106-[108]

* * Nos. 86, 87, 101, 102, 104, 106 and 107 have coloured paper * Nos. 86, 87, 101, 102, 104,106 a 107 bear no month and nos. wrap 105 a d 106 a 103, 105 and 106 have only and bears no number, and " no. 101 has "no. 100 " on the " wrapper, and "Ilustribe " on page " Wanting the number dated " $1900 "$

[Continued as:]

Ilustración filatélica.

Barcelona, Ricardo San Antonio, [1906]

$8^{\circ} .93$ in. nos. in vols. In progress.

UNIÓN FILATÉLICA ESPAÑOLA. Unión filatélica española.

Madrid, Vicente Moreno de la Tejera, 1903-05.

$8^{\circ} .9 \frac{1}{2}$ in. 13 nos. in 3 vols.
1 st year. Dec. $1,15,1903 . \quad$ Nos. $1-2$.

1st year. Dec. 1, 15, 1903. Nos. 1- 2.
2nd ", Jan. 1-Dec., 1904. , 3-12.

* * " " is " 1905. * There is a coloured paper wrapper to

Mis. St. Jour. 144 (12).

UNION PHILATÉLIQUE, L'Union philatélique. Organe hebdomadaire de la Fédération Philatélique de France et des intérêts généraux des philatélistes français. Paris, Fédération Philatêlique de France, I903.

Fol. 13 in. Nos. 1-10, October 4-December 6, 1903.

* * Succeeded by the "Revue de la Fédération Philatélique de Firance".

UNION PHILATELIST. The Union philatelist. Mankato, Minn., Carl Sudermann, I895-96. $24^{\circ} .4$ in. Nos. 1-2, December, 1895-February, 1896.

* * There is a coloured paper wrapper to each number. Mis. St. Jour. 69 (1)

UNI6N POSTAL. La Unión postal.

Barcelona, Leoncio Hernando, i900-02.

$4^{\circ} .8$ in. and $8^{\circ} .9 \frac{3}{4}$ in. 17 nos. in 3 vols.

1st year. Dec. 1900 . No. 1.

2nd ," Jan. 20-Dec. 20, 1901. Nos. 2-13.

3rd " Mar., June, 1902. " 14-17.

* Nos. 1-16" have coloured paper wrappers. Nos. 9, 10 and 11 and nos. 15 and 16 were severally published together. Nos. 1-11 and no. 17 are quarto and nos. 12-16 are octavo. No. 17 has the title on the first page reading "Revista filatélica y filocartista. La Union postal."

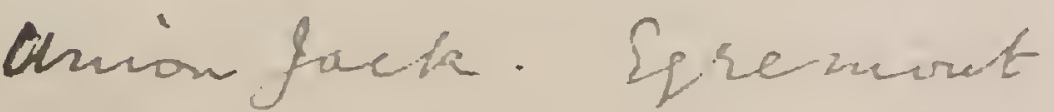

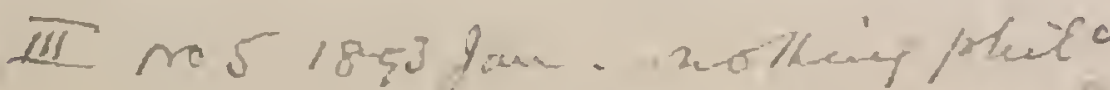

$$
\begin{aligned}
& \text { secefotine asts }
\end{aligned}
$$

UNIÓN POSTAL. La Unión postal. Revista filatélica y filocartista. Barcelona, Leoncio Hernando, I906. $8^{\circ} .9 \frac{1}{2}$ in. Vol. IF. 7 nos.

th year. Jan.-July, 1906. Nos. 1-7.

* There is a coloured paper wrapper to each number. The wrapper of no. 1 has "Año 1 " in error for "Año IV." and nos. and 2 have " 2 a época". Wanting nos. 3,4 .

UNION POSTAL. La Union postal. Publicacion mensual filatelica y cartofila.

Medellin, Florencio Mejia V., etc., I905.

$8^{\circ} .93$ in. Nos. 1-9, January 1-September 20, 1905.

* * Nos. $1-5$ were published by Florencio Mejia V., Timoteo y Juan ** Nos. $1-5$ were published by Florencio Mejia . . Timoteo y Juan Hancisco Jaramilo y Daniel Mesa and nos.

Mis. St. Jour. 122 (1)

UNION POSTALE. L'Union postale.

Berne, L'Union Générale des Postes, etc., 1876.

$4^{\circ} .12 \frac{1}{2}$ in. nos. in vols. In progress.

Vol. $\quad$ x. $\quad$ II. Jan. 1-Dec. 1, 1876. Nos. ${ }_{1-12}$

" III. ", 1-, 1, 1878. " $1-12$.

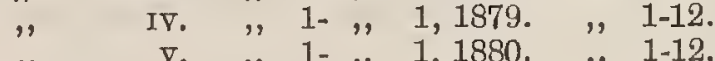

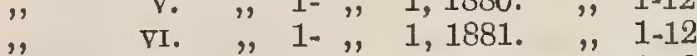

" VII. " 1- " $1,1882 . \quad$ " $1-12$

" VII. " 1 IX. " $1,1883 . \quad$ " $1-12$

" x. " 1- ", 1, 1885. " $1-12$

" XI. " $\quad$ XII. $1-, 1,1886 . \quad " 1-12$

" XIII. ", 1- ", $1,1888 . \quad$ " $1-12$

" XIV. " $\quad 1-", 1,1889 . \quad$ ", $1-12$

" xVI. ", 1-," 1, 1891. ", $1-12$

" xVII. "

" XIX. " 1- ", 1, 1894. ", 1-12

" XX. " $1-\quad, \quad 1,1895 . \quad$ " $1-12$.

" xxII. " 1 " $1,1897 . \quad, 1-12$

" xxIII. ", 1- " $1,1898 ., \quad 1-12$

" XXIV. ", 1- ", 1, $1899 . \quad, 1-12$.

" XXV. " $" 1-", 1,1900 . \quad " 1-12$

" xXVII. ", 1- ", 1, 1902. ", 1-12.

" xxviu. " 1-, 1, $1903 ., " 1-12$

" xxIx. ", 1-,, 1, 1904. ", 1-12.

" xxx. " 1- , 1, $1905 . \quad, 1-12$

* "* Published in French, German and English. In 1878 the name of the organisation was changed to the "Union Postale Universelle". There is a title-page and an index in French, German and Finglish to each volume and a coloured paper wrapper to each and English to each volume and a coloured paper wrapper to each volume. Nos. 1-8, vol. XIX., have coloured paper wrappers and vols.

UNION POSTALE UNIVERSELLE. L'Union postale universelle. Revue Internationale des collectionneurs de timbres-poste. Paris, Victor Robert, $1892-96$. $4^{\circ} .11$ in. 42 nos. in 5 rols.

1st year. Feb. 10-Dec., 1892. Nos. 1-11.

and ," Jan. " " 1893. "12-22.

3rd " " - " 1894. ", 28-33.

4th " M" Merch, June, 1896. " ", $34-40$.

* * No. 19 is dated "Août-Septembre, 1893"; no. 29, "JuilletAoût, 1894"; no. 34, "Janvier-Février, 1895"; and no. 39 "Juillet-Août, 1895". No. 1 bears the words "Supplémen gratuit du Constitutionnel," and there are supplements to nos. 2 12 and 22.

UNIONE FILATELICA COMIMERCIALE. L' Unione Filatelica Commerciale.

Palermo, Girolamo Gargano Ciramy, x9o6.

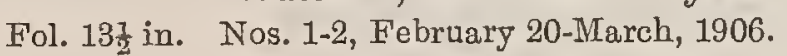

[Continued as :]

- Bollettino mensile dell' Unione Filatelica Commerciale. Palermo, Givolamo Gargano Cirami, rgo7-og. Fol. $12 \frac{1}{4}$ and 14 in. Vols. II.-IV. 28 nos. 2nd year. Jan.-Dec., 1907. Nos. 1-12. 3rd " "- " 1908. " 13-24 * th " Nos. 2 and 3,8 and 9,14 and 15,16 and 17, 18 and 19, 20 and ** Nos. 2 and 3,8 and 9,14 and 15,16 and 17,18 and 19,20 and 21,23 and 24 , and 26 and 27 , were severally published together.
Nos. $1-12$ measure 121 inches and the remaining numbers 14 Nos. $1-12$ measure $12 \frac{1}{2}$ inches
inches. Wanting nos. $6,8,9$. 
UNITED ASSOCIATION PHILATELIST. The United Association philatelist.

Washington, D. C., The United Philatelic Association, [I89I]-92.

$4^{\circ} .7 \frac{3}{4}$ in. Nos. 1-3, December, [1891]-February, 1892.

Mis. St. Jour. 66 (13)

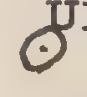
ITED KINGDOM POSTAGE STAMP ADVER TISER. The United Kingdom postage stamp advertiser. Tavistock, Devon, G. Spencer, I863.

(c) $8^{\circ}$. S3 in. Nos. 1-2, June 1-July 1, 1863. Mis. St. Jour. 37 (1).

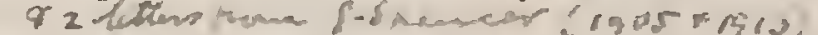

UNITED STAMP JOURNAL. The United stamp journal.

$5128 \quad 8^{\circ}: 9 \mathrm{in}$. Nos, 1-4 [? W J-March 30, 1906. wrapper. Wanting nos, 1, 2, 3.

UNITED STATES IMAIL. The United States mail. The friend of the postmaster's. Vol. vi., no. 5, January, 1891.

$8^{\circ} .9$ in. $40 \mathrm{pp}$.

* This journal is of a postal and not a philatelic character.

Mis. St. Pamph. 30 (9)

_ Vol. viII., no. 9, September, 1892.

$8^{\circ} .91$ in. $27 \mathrm{pp} .+(1) \mathrm{p}$.

New York, E. C. Brown, I892.

* The number has a coloured paper wrapper.

Mis. St. Pamph. 30 (10).

UNITED STATES PHILATELIST. The United States philatelist. $8^{\circ} .8 \frac{3}{4}-97$ in. 8 nos, in 2 vols

Vol. I. May 15, -July 15, 1888. Nos. 1-3.

128 " II. Aug., 1888-Feb., 1889. " 1-5. - 4

* * No. 1 is octavo $8 \frac{3}{4}$ inches and the remainder are octavo $9 \frac{1}{2}$ inches. Nos. 2, 3, vol. I., were published together and have no paper wrapper, while all the other six numbers have coloured paper wrappers.

Mis. St. Jour. 14 (4).

UNIVERS PHILATELIQUE. L'Univers philatélique. Organe mensuel pour les intérêts des collectionneurs. Genève, Ch. Bergeon, etc., I9or.

Fol. 13 in. Nos. 1-5, February-April, June, August, 1901.

* * Printed on blue paper. Nos. 4 and 5 were published by Henri Koch.

UNIVERS PHILATÉLIQUE. L'Univers philatélique. Genève, Hans Kirchhofer, I go3.

$4^{\circ} .10 \frac{1}{4}$ in. [No. 1] June, 1903.

* * The number has a coloured paper wrapper.

Mis. St. Jour. 116 (3).

UNIVERSAL ADVERTISER. The Universal advertiser. Rotherham, The Philatelic Printing Co., 1901-02. $8^{\circ} .7 \frac{1}{4}$ in. 12 nos. in 1 vol.

6) Vol. I. June 1, 1901-Aug., 1902. Nos. 1-12. pape not ferren $\checkmark{ }_{*}^{*}$ Only partly philatelic. Edited by Edward F. Herdman. Each number has a coloured paper wrapper. $V$ There are no numbers for July, 1901, and April and June, 1902.

[Continued as :]

- The Collectors' universal advertiser.

Rotherham, The Philatelic Printing Co., rgo2.

$8^{\circ} .7 \frac{1}{4}$ in. Vol. Ir., 4 nos.

To 1902 . Nos $13-16$

* Only partly philatelic. Edited by Edward F. Herdman and each number has a coloured paper wrapper.

[Continued as :]

The Collectors' advertiser.

Rotherham, The Philatelic Printing Co., etc., r9o305.

$4^{0} .9 \frac{3}{4}$ in. Vols. Ir.-TV. 32 nos.

Vol. II. Feb. -Sept., 1903. Nos. 17-24.

" III. Oct., 1903- ", 1904. " 25-36.

*" "T. " * Only partly philatelic. Each number has a coloured paper
wrapper. Nos. $41-48$ were published by the Philatelic and Cartophilic Printing Co.

\section{UNIVERSAL ADVERTISER.}

[Continued as :]

The Collectors' magazine.

Rotherham, The Philatelic and Cartophilic Printing Co., I $905-06$

$4^{\circ} .9 \frac{3}{4}$ in. Vols. V.-VI., 15 nos.

Vol. v. Oct., 1905-Sept., 1906. Nos. 49-60.

" vi. " -Dec., 1906. " 61-63.

* Only partly philatelic. Each number has a coloured pape wrapper. The magazine was continued in 1907 with the title
the "Collectors' journal".

UNIVERSAL BBIFFIMARKEN - ANZEIGER. Universal Briefmarken-Anzeiger. Universal advertiser for postal stamps. Journal universel pour timbre poste. Charlottenburg, Berlin, E. H. Siegfriedt, I894. Fol. 123i in. Nos. 1-6, January 15-April 15, June 1, July 1, 1894 * * Nos. 1-5 are printed on coloured paper. A copy of the prospectus, printed on white paper, is bound up with the numbers.

UNIVERSAL COLLECTOR. The Universal collector.

Mt. Ayr, Iowa, S. H. Wood, I889-9o. $8^{\circ} .9$ in. Nos. 1-7, Nov. 25, Dec., 1889, Jan.-Feb., Mar., Apl.,

* * Only partly philatelic.

Mis. St. Jour. 25 (1)

UNIVERSAL COLLECTORS' JOURNAL, The Uni versal collectors' journal.

Danvers, Mass., Patterson and Barnard, r886. $8^{\circ} .12$ in. No. 1 , March, 1886

* Only partly philatelic.

Mis. St. Jour. 5 (5)

UNIVERSAL EXCHANGE AND AUXILIARY PHI LATELIST. See AUXILIARY PHILATELIST.

UNIVERSAL EXCHANGE LIST. The Universal exchange list. London, N., Percy C. Bishop, 1886. $8^{\circ} .7 \frac{1}{2}$ in. [No. 1], January, 1886.

* * Only partly philatelic and the contents consist entirely of ad. vertisements. Succeeded by the "Philatelic cxchange list" in

UNIVERSAL EXCHANGE MAGAZINE. Universal exchange magazine.

Belvidere, Ill., James M. Hetherington, I 904-05. $8^{\circ} .8_{4}^{3}$ in. Nos. 1-4, December, 1904-March, 1905.

* * Only partly philatelic. There is a paper wrapper to each number. $\quad$ Mis. St. Jour. 123 (9).

UNIVERSAL PHILATELIC ADVERTISER. The Universal philatelic advertiser.

Frankford, Philadelphia, Pa, The Frankford Stamp and Publisting Co., I89o.

$8^{\circ} .9$ in. No. 1, March 15, 1890.

** The number has a paper wrapper. Mis. St. Jour. 22 (9).

UNIVERSAL PHILATELIC MAGAZINE. The Uni(.) versal philatelic magazine. A monthly journal for stamp collectors.

Liverpool, George Birtwhistle, 1883 . 4. $4^{\circ} .93$ in. Nos. 1-2, September-October, 1883 . fris, St. Jour. 45 (5).

UNIVERSAL PHILATEIIST. See PhILATÉLISTE UNIVERSEL,

Esch-sur-agette.

UNIVERSAL POSTAGE STAMP ADVERTISER. The Universal postage stamp advertiser.

London, Mark T. Cox, I88o.
Fol. 131 in. No. 1, January, 1880.

[Continued as :]

- The Universal postage stamp advertiser and amateurs' chronicle. ... (New Series.)

London, Penry Williams and Co., I88 I-82. Fol. 14色 in. and $4^{\circ} .11 \frac{1}{4}$ in. Nos. 1-4, April 1, June, August, 1881, Jamuary, 1882

$\cup^{*}$ * Nos. $1-3$ are folio while ${ }^{2}$ no. 4 is quarto. There is a supplement to no. 3, dated October, 1881, which consists of a single large sheet, $17 \frac{1}{4}$ inches in height, printed on one side only. The title of no. 4 reads "The Universal postage stamp advertiser".
Mis. St. Jour. 1 (5a). 


813 UNIVERSAT STAMP ADVERTISER

UNIVERSAL STAIVP ADVERTISER. See STAMP COLLECTOR'S ADVEIRISER. (Birmingham).

UNIVERSAL STAMIP COLLECTOR. The Universal stamp collector. A philatelic paper for all.

London, E., Oxford [printed], H. A. Copley, I886-87 C. $8^{\circ} .7 \frac{1}{2}$ in. Nos. 1-2, Novémber, 1886-January, 1887.

Mis. St. Jour. 55 (13)

UNIVERSAL STAIVP GAZETTE. The Universal stamp - gazette. London, E.C., C. L. Howard, I864. 64. $8 \frac{3}{4}$ in. No. 1, September 15, $1864 . \quad$ Mis. St. Jour. 35 (2). Mis. St. Jour. 35 (2).

UNIVERSELLE CORRESPONDANCE. Universelle correspondance. (World's exchange.) Première année. No. 1, 1904, [contains an article "A royal stamp".]

$4^{c} .10 \frac{3}{4}$ in. p. 2.
Mis. St. Jour. 130 (15).

UNIVERSUIM. Universum. Philatelistisches InsertionsOrgan. Frantifurt a.M., H. T. Dauth, I88 I-85. Fol. $14 \frac{1}{2}$ in. and $8^{\circ} .11 \frac{1}{2}$ in. 26 nos. in 4 vols.

1st year. Dec., 1881-Dec., 1882. Nos. 1-8.

2nd " Jan. - ", 1883. "9-15.

3rd " Feb. - ", 1884. " 16-23.

4th " "May, 1885. " 24-26.

* * Nos. $1-15$ are folio 'and the remainder are octavo. No. 9. January, 1883, is given as "II. Jahrgang $\mathrm{Nr} .1$," and no. 10, numbered "16" in ply numbered "

Vols. I.-II. Mis. St. Jour. 1 (10).

[Continued as :]

_- Frankfurter Briefmarkenzeitung Universum. $8^{\circ} .11 \frac{1}{4}$ in. Vol. IV., 6 nos

Franlefurt a. M., H. J. Dauth, I 885 . Nos. 27-32

** Nos. 30 and 31 were published together.

[Continued as :]

Illustrirte Frankfurter Briefmarken-Zeitung mit Inseratentheil Universum.

Frantifurt a. M., H. J. Dauth, I 886-88. $8^{\circ} .10 \frac{3}{4}$ in. Vols. v.-VII., 36 nos.

5th year. Jan.-Dec., 1886. Nos, 1-12.

6th " " - " 1887. " 1-12.

** Nos. 5 and 6 of 1888 were published together and there is a paper wrapper to each number.

[Continued as :]

_ Illustrirte Frankfurter Briefmarken-Zeitung mit dem internationalen Inseratenblatt "Universum".

Franlefurt a. M., H. J. Dauth, I 889-92.

$8^{\circ} .103$ in. Vols. VIII.-XI., 43 nos.

Stl year. Jan.-Dec., 1889. Nos. 1-12.

9th " " - , 1890. ", 1-12.

10th ", " "- " "

** Nos. 5 and" 6,8 and 9,11 and 12 , of 1889,5 and 6,8 and 9,1 and 12 , of 1890,4 and 5,9 and 10,11 and 12 , of 1891,3 and 4 , an 6 and 7 , of 1892 , were severally published together.

[Continued as :]

Frankfurter Briefmarken-Zeitung.

Frankfurt a. M., H. J. Dauth, I 892-93.

$8^{\circ} .10 \frac{1}{2}$ in. Vols. XI.-XII., 6 nos.

11th year. Sept.-Dec., 1892. Nos. 8-12.

* * Nos. 11 and 12 of 1892 were published together. No. 1 of 1893 is called in error " 13 Jahrgang No. 1 ".

[Continued as :]

Frankfurter Briefmarken-Zeitung mit dem Inseratenteil Universum.

Frantifurt a. M., H. J. Dauth, I 893

$8^{\circ} .10 \frac{1}{2}$ in. Vol. xIr., 7 nos.

12th year. Feb.-Sept., 1893. Nos. 2-8.

* * Nos. 2 and 3 , and 5 and 6 were severally published together.
UNIVERSUM

814

\section{UNIVFRSUIM}

\section{[Continued as :]}

Universum. Frankfurt a. M., H. J. Dauth, I893-95. $8^{\circ} .12$ in. Vols. XII.-XIv., 17 nos.

12th year. Nov. 15-Dec. 15, 1893. Nos. 125-126.

13th " Jan.115- " 1894. " 127-136.

* * No." 137 is wrongly dated "Januar-"Februar 1896 ". The title on ithe first pages of nos. 139-141 reads "Frankfurter BriefmarkenZcitung," while on the wrappers is "Universum".

[Continued as :]

- Frankfurter Briefmarken-Zeitung Universum.

Frankfurt a. M., H. J. Dauth, I 895-96.

$8^{\circ}$. $11 \frac{3}{4}$ in. Vols. XIV.-XV., 5 nos.

14th year. Dec., 1895 . No. 142.

** There is a coloured paper wrapper to each number. Nos. 143 and 144 were published together, and nos. 142,143 and 144 , and 145 have special supplements with the title "Liebigbilder-Börse," nos. 1-3; Dec., 1895, Feb., Mar., 1896.

[Continued as :]

Universum. Frankfurt a. M., H.J. Dauth, I896. $8^{\circ} .11 \frac{3}{4}$ in. Vol. $x v,, 3$ nos.

15th year. Sept.-Dec., 1896. Nos. 147-149.

* *In no. 147 the former supplement "Iiebigbilder-Börse" forms a part of the journal and has no separate numbering. No. 149 is printed on yellow paper. Wanting no. 148 .

UNIVERSUIM. Universum. Internationales BriefmarkenOffertenblatt. Budapest, E. Weiszmann, I 893.

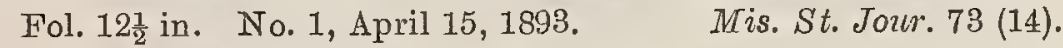

U. S. ADVERTISER. The U. S. advertiser. Published monthly for stamp, coin, curio and picture postcard collectors. Chicago, Ill., Martin H. Bittl, etc., I 906-o7. $8^{\circ} .9$ in. Nos. $1-3$, November, December, 1906, February, 1907.
$*^{*}$ No. 3 was published by Bittl, Press Co. and the sub-title on this number reads "Published in the interests of philately and philatelists".

Mis. St. Jour. 144 (6)

U. S. CORRESPONDING PHILATELIST. The U.S. corresponding philatelist. Official organ of the U. [nited] S.[tates] C. [orresponding] P.[hilatelic] A. [ssociation].

Union Grove, Wis., J. C. Colby, J. Larson, and W. J. Bushey, 1890.

8․ 83 in. INo. 1, May, 1890. Mis. St. Jour. 47 (1).

[Continued as :]

- The Philatelic reporter.

Union Grove, Wis., T. C. Colby, J. Larson, and W. J. Bushey, etc., I890-9 I.

$8^{\circ}$. 83. in. Nos. 2-10, July, Aug., Nov., Dec., 1890, Jan.-May, 1891

* * Nos. 3-5 were published by J. C. Colby, and nos. 6-10 by Colby and Smith. There is a supplement of two pages printed on one side only to no. 5 , the contents of which consist of an advertisement of the Belje City Stamp Co. Mis. St. Jour. 47 (1a).

USEFUL INSTRUCTOR. The Useful instructor.

6

๑ Fol. $12 \frac{1}{4}$ in. Nos. $1-2$, April, May-June, 1887 . Halifax, $N$. S., [? ], I 887 . given." The two numbers are bound up in Mis. St. Jour. 129 (18) and cuttings of the stamp portions in the two numbers are mounted in Stamp Scrap-book, vol. v., pp. 131-146.

U. S. PHILATELIST. The U. S. philatelist. Devoted to stamps, coins and curiosities.

Boston, Mass., E. N. Barker, I 884

$8^{\circ} .10 \frac{3}{4}$ in. No. 1, June, 1884.

Mis. St. Jour. 6 (5)

U. S. PHILATELIST. The U. S. philatelist. A monthly journal devoted to the greatest hobby of the day-philately. Plannfield, N. J., W. H. Rice, I89o. $8^{\circ} .8 \frac{1}{2}$ in. Nos. 1-4, May 1-August, 1890. Mis. St. Jour. 31 (4).

U. S. P. S. BULLETIN. The U. S. P. S. bulletin. Devoted to the interests of the United States Philatelic Society. $16^{\circ} .6$ in. No. 1, May, 1890

Reading, Pa., Harry F. Kantner, I89o.

UTICA INVESTIGATOR. See PhILATELIC News. (Utica, $N . Y$.)

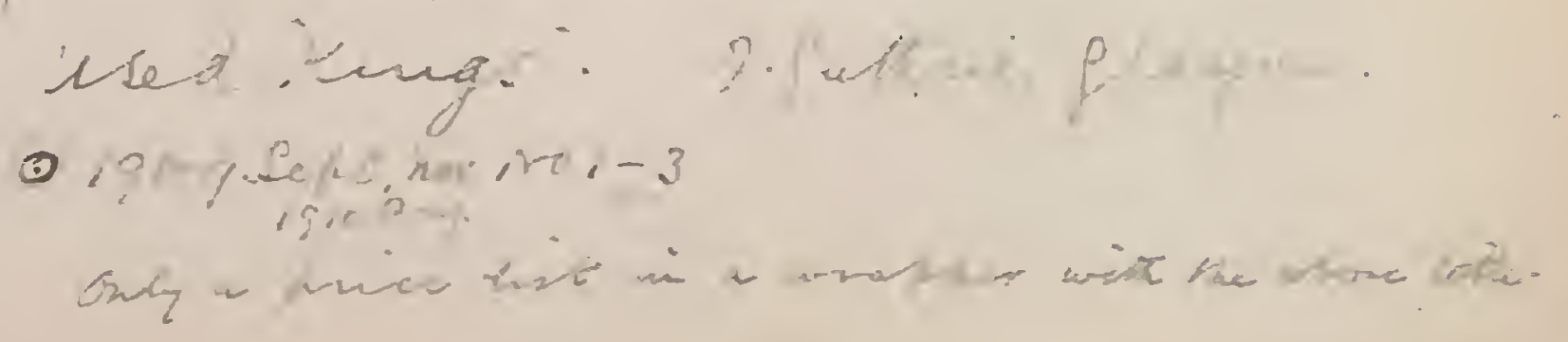




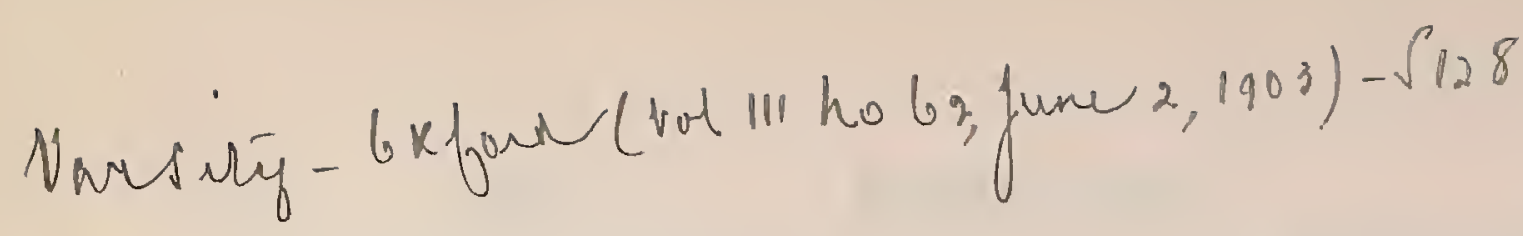

815

\author{
VADE-MECUM
}

VADE-MECUIM DU COLLECTIONNEUR D'EUROPE. Vade-mecum du collectionneur d'Europe. Chieti, Italie, Eugéne Christini, I898-99. Fol. $13 \frac{3}{2}$ in. and $8^{\circ} .9 \frac{1}{2}-9 \frac{3}{4}$ in. 12 nos. in 2 vols.

1st year. 1898, July, Sept., Oct., Nov., 1898. Nos. 1- 5.

2nd " Mar., May-Aug., 1899, Dec., $1899 . \quad$ „6-12

** No. 1 and nos. 6-12 have coloured paper wrappers. No. 1 , which is folio, is headed "Supplement mensuel an Messaggero Abruzzcse"; the remaining numbers are octavo and of these nos. 2-5 are headed "Supplement mensuel au "Svegliarino "and nos. "Domani"." Nos. 1 and 11 are only dated "1898" and "1899" 'Domani'

VALIJA POSTAL. La Valija postal.

Buenos Aires, Manuel M. Casanova, I go5-o6. $8^{\circ} .10 \frac{1}{2}$ in. 31 nos. in 2 vols,

1st year. June 1-Dec. 16, 1905. Nos. 1-14.

2nd " Jan. 2-0ct. 25, 1906 . "15-31.

** Only partly philatelic. Published fortnightly down to July 25,1906 , then monthly. There is a paper wrapper to each number. Nos. 18 and 19 and 22 and 23 were severally published to-
gether.

VALPARAISO FILATELICO. Valparaiso filatélico. Revista bi-mensual.

Valparaiso, Emilio G. Repetto y Ca., I 899. $8^{\circ} .10 \frac{1}{2}$ in. Nos. 1-3, Jan. 1, Miar. 1, July and August, 1899.

* * Each number has a coloured paper wrapper. The contents of no. 1 consist entirely of advertisements. The sub-title on nos. 2 and 3 reads "Revista bi-mestral". No. 1 is only dated on the wrapper and no. 2 is dated "Marzo $1^{\circ}$. de 1899 " on the wrapper
and "Marzo de 1899 " on page 1.
Mis. St. Jour. 130 (3).

VELHAGEN UND KLASINGS MONATSHEFTE Velhagen und Klasings Monatshefte. VII. Jahrgang 1892-93. Heft 2, 'Oktober, 1892. [Contains an illustrated article "Der Briefmarkensport," by Hanns von Zobeltitz.]

Bielefeld und Leipzig, Velhagen und Klasing, 1892. $8^{\circ}$. 10

* * The number has a coloured paper wrapper. A second copy up in Mis. St. Jour. 130 (1).

Mis. St. Jour. 141 (6).

VENFZUFLA POSTAL. Venezuela postal. Publicacion filatélica mensual. Caracas, E. Grintrand, I892-94. $8^{\circ} .9 \frac{1}{2}$ in. 20 nos, in 2 vols.

S128 1st year. Oct. 5, 1892-Dec., 1893. Nos. 1-12.

"2nd *". Jan. 3 of the second year is dated in error "febrero" and numbered " 2 " but the two mistakes are corrected in pencil. There is no number for February, 1893. Wanting first year, nos. $9,10,11,12$.

VENEZUELA POSTAL. Venezuela postal. $\int_{128}$
$8^{\circ} \cdot 91$ in. Nos. 1-2, August 1-September 1, 1903.
** Wanting no. 1. Caracas, [?], I903

VERBANS-IMITTHEILUNGEN， See VOGTLÄNDISCHE Philatelist.

\section{VERBANDS-MITTEILUNGEN 816}

VERBANDS-MITTEILUNGEN DES VOGTLÄNDIS- ? H/ CHEN PHILATELISTEN-VERBANDES. See Vogtiändische Philatelist.

VERBANDS-NACHRICHTEN DES DEUTSCHEN PHILATELISTEN-VFRBAND. See Part I. Gössnitz (Deutscher Phitatelisten-Verband).

VERBANDS-NACHRICHTEN DES INTERN ATIONALEN PHILATELISTEN-VERBANDES ZU IMÄHR.-OSTRAU. Verbands-Nachrichten des internationalen Philatelisten-Verbandes zu Mähr.-Ostrau. Mährisch-Osirau, Austria I 894

$8^{\circ} .10 \frac{1}{2}$ in. $\quad[$ Nos. 1-2, November-December, 1894.$]$

** Neither number bears a number or date.

Nis. St. Jour. 131 (6).

VERBANDS-NACHRICHTEN DES MITTELDEUTSCHEN PHILATELISTEN-VERBANDES. See Part I. Gössmitz (Mittelideutscher PhilatelistenVERBAND).

VERDAD FILATELICA. La Verdad filatélica.

Barcelona, Miguel Marti, т 904 $8^{\circ} .10$ in. Nos. 1-6, July 16, Aug. 5, 20, Oct. 20, Nor., Dec., 1904. * * Each number has a paper wrapper and the wrapper of no. is dated "20 Julio de 1904".

\section{VEREIN BRAUNSCHWEIGER BRIEFIMARKEN-
SAMIMLER. VERFINSIMITTHEILUNGEN.}

Verein Braunschweiger Briefmarken-Sammler. Vereinsmittheilungen. Braunschweig, I 89 I-I 902 .

$8^{\circ} .93-10$ in. 18 nos. in 8 vols

1st year. Jan. 14, May 1, Oct. 1, 1891. Nos. 1-3.

2nd ", July 1, Dec. 1, 1892. $\quad, \quad 4-6$.

4th " Aug. 15, 1895. No. 9

6th ", Jan. 15, Mar. 1, June 16, 1897. Nos. $10-12$.

7th ", Feb. 28, June 16, Dec. 31, 1898. ", $13-15$.

9th " Jan. 20, Nov. 15, 1900.

* * Nos. 4 and 5 were published together with the date " 1 Juli, 1892 ". No. 16 is numbered in error " 17 " and this number consists of a single leaf. Copies of the Society's " Mitgliederliste" for 1892, 1893, 1894, 1895, 1897, 1898 and 1902, of the "Sitzungs bericht über die 2 ordentl. Generalversammlung am 3 Juli, 1889 " and " Jahres-Bericht vom 18 Januar, 1888 bis 3 Juli 1889" and of the "Jahres-Bericht (Juli, 1889-Januar, 1890)," are bound up at the end of the volume.

VFRFIN FÜR FREUNDF DFR BRIFFMARKFNKUNDE LÜBECK, BERICHT ÜBER DAS VER EINSJAHR 1893. See Mitteilungend des Vereins Fưr Freunde Der Briefuarkenkunde ZU LüBër.

VEREINIGTE ERDBALL IMERIKUR. Vereinigte Erdball Merkur. Internationales Organ für die gesammte Philatelie.

188ז -83 .

Fol. 133 in. 24 nos. in 2 vols.

[1st year.] Jan. 6-July 15, Sept. 1, 1881-Jan. 1, 1882. Nos. 1-12, 

817 VEREINIGTE ERDBALL MERKUR

[2nd year.] Feb. 15, Apl. 1, May, 15, July 1, Aug. 15, Oct. 1, 1882-Jan. 20, Mar. 1, Apl. 15, June 1, 1883. Nos. * * 13-24.

* Nos. 16-24 were published by A. Larisch; nos. 16-20 at Mis. St. Jour. 51 (2).

\section{VEREINIGTE ERDBALL IMERKUR.}

\section{[Continued as :]}

Allgemeiner Briefmarken-Anzeiger Vereinigte Eraball Mercur. Wien, etc., Larisch und Radesey, etc., I883-97. $8^{\circ} .10 \frac{1}{2}$ in. Vols. III.-V., XII.-XXI. 153 nos.

[3rd year.] Aug. 1, Sept. 10, Nor. 1, Dec. 10, 1883, Jan. 20, Mar. 1, Apl. 15, June 1, July 15, Sept. 1, Oct. 15, Dec. 5, 1884. Nos. 25-36.

[4th , ] Feb. 1, Mar. 15, May 1, June 15, Aug. 10, Oct. 1, Dec. 5, 1885, Jan. 15, End Mar., End May, End July, Oct. 1,1886 . Nos. $37-48$

[5th , ] Nov. 15, Dec. 15, 1886, Feb. 1, Apl. 1, June, July, Sept., Oct., ,Dec., 1887, Jan., F'eb., Mar., 1888. Nos. $49-60$.

12th year. Apl.-Dec., 18s8. Nos. 61- 69.

13th ", Jan.- ", 1889. " 70-81.

14th ", "- ", 1890. " $82-93$.

15th " " " - " $1891 . \quad$ " 1892 . $106-105$.

17th " " " " " 1893. " "118-129.

18th ", " - ", 1894. ", 130-141.

19th " " " , 1895. " $142-153$.

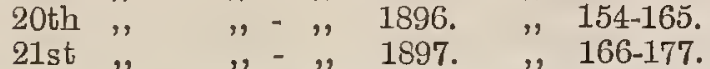

** Nos. 33-177 were published by A. Larisch : nos. 33-52 at Wien and nos. 53-177 at Müuchen. Nos. 58, 59 and 60 are named " 11 Jahrgang". No. 106 is wrongly u umbered " 15 Jahrgang 1891 " in place of " 16 Jahrgang, 1892" and nos. 174 and 175 were pub. lished together under the date "Sept. u. Okt.". From January, 1888, to December, 1889 the journal was continued as a supplement to "Das Postwertzeichen" and from January, 1890, to December, 1897, as a supplement to "Die Postwertzeichen-Kunde".

VEREINS-ANZEIGER. See SAMmLeR. (Passau.)

VEREINS-BERICHTE. Vereins-Berichte.

Oldenburg, Vereinigung Oldenburger Briefmarkenfreunde, 1889 .

$4^{\circ}$. 11-11 $\frac{3}{4}$ in. Nos. 1-6, January 16, 19, 26, February 2, 9, 16, 1889.

*** Produced by autographic lithography. Each number consists of a single leaf and nos. 4 and 5 were published joined to-
gether.
Mis. St. Jour. 137 (8).

[Continued as :]

- Vereins-Berichte der Vereinigung Oldenbg. Briefm. Freunde.

Oldenburg, x 889 .

$4^{\circ} .11 \frac{3}{4}$ in. Nos. 7-11, March 1, April 3, 15, May 1, June 2, 1889. ** Produced by autographic lithography and each number con-
sists of four pages. Wanting no. 11. Mis. St. Jour. 137 (8a).

VEREINS - BERICHTE DER VEREINIGUNG OLDENBG. BRIEFII. FREUNDE. See VEREINSBERICHTE.

VEREINS - BÖRSE DER INTERNATIONALEN VEREINIGUNG VON GANZSACHENSAIMIM LERN ZU LEIPZIG. Vereins-Börse der Internationalen Vereinigung von Ganzsachensammlern zu Leipzig. Leipzig, Fritz Hess, etc., I 893-99. 11 in. 52 nos. in 7 vols.

1st year. Jan. $\quad$-Dec., 1893. Nos. $1-12$.

2nd ", Feb. 1, 1894-Feb. 1, 1895. " 13-24.

4th " Jan. 1, Mar. 1, May 1,"July 1", Aug. 1, Sept. 1, 1896.

5th "Jan. 1, Mar. 1, Apl, 10, Sept. 1, Oct. 1, Nov. 1, 1897.

6th "Jan. 1, Mar. 1, Apl. 1, June 1, [? no. 48] Oct. 1, Dec. 1, 1898. Nos. $44-50$

1899. Nos. $51-52$

* The twelve numbers of the first year are folio in size and were produced by autographic lithography, with the exception of no 3 , which is typewriten. There are three supplemental sheets each to nos. 1,2 , four to 10.3 , six to nos. 4 and 5 , four to no. 6 , two to no. 7,11 and 12 . 11 the supplements, including these to no. 3, are produced by autographic lithography. Nos. 13-52 are octavo and printed, and of these nos. 17-52 were published by Paul Schiffner. No. 29 of September 1, 1895, is wrongly num. bered "28," and there is an extra number with the word "Kaufgesuche" above "Vereins-Börse," etc. This is numbered and dated "v. Jahrgang. Nr. 1. 15 Januar, 1897." There are no numbers for November, 1894, May, August and November, 1895. Wanting nos. 1-12, 13, 14, 24, 25, 48 .

VEREINS-BOTE. Vereins-Bote.

Bruchsal, Philatelistischen Schïlerverein Bruchsal, [1892].

$8^{\circ} .11$ in. [No. 1, July 25, 1892.]

* "This is a supplement of "Philatelistische Jugendschrift," no.

4 " of the first year, with which it is bound up.

[Continued as :]

Vereinsbote des "Chalmers" Allg. Verband junger Sammler. Stuttgart, Verein Stuttgart, [x 892]. $4^{\circ} .11$ in. [No. 2, September, 1892.]

* * Produced by a hectographic process. Wanting.

[Continued as :]

___ Vereinsbote des "Chalmers" Verband jüngerer Briefmarkenşammler. Stuttgart, Verein Stuttgart, [1892]. $4^{\circ} .11$ in. [No. 3, November, 1892.]

** Produced by a hectographic process. Wanting

VEREINS-BOTE. Der Vereins-Bote. Beiblatt zum Illustrierten Briefmarken-Journal. Leipzig, Gebrïder Senf, r892-

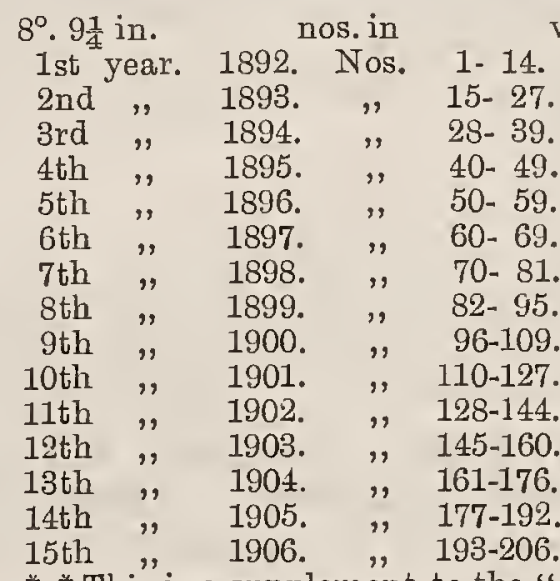

** This is a supplement to the "Illustriertes Briefmarken-Jour nal," with which it is bound up. No. 49 is wrongly numbered " 48 ," nos. $60-66$ are all dated " 1896 " instead of 1897 , no. 67 is numbered "66," no. 72 has "71," no. 75 has " 74 ," no. 76 has "75," no. 92 has " 99 ," no. 108 has " 106," no. 114 has no number no. 142 has " 141 ," nos. $144-151$ are numbered $143-150$ respectively, nos. $152-156$ have respectively " $161-165$, " no. 166 has " 165 ,"
there is no number 164 and nos. 202 and 203 are numbered 199, 200 , respectively.

VEREINSBOTE. Der Vereinsbote. Hauptrereinsorgan des Vereins für Postwertzeichenkunde zu Laibach.

Laibach, Verein fïr Postwertzeichen-Kunde, 1893. $4^{\circ} .11 \frac{1}{4}$ in. Nos. 1-2, January 1-February 1, 1893. * * Produced by a hectographic process. Mis. St. Jour. 129 (11).

VEREINSBOTE DES “CHALIMERS" ALLG. VER BAND JUNGER SAIMIMLER. See VEREINS-Bote. (Bruchsal.)

VEREINSBOTE DES “CHALMERS" VERBAND JÜNGERER BRIFFIMARKENSAIMILER. See Vereins-Bote. (Bruchscul.)

VEREINS-IMITTEILUNGEN. See GLOBUS. (Bertin, 1891.)

VEREINS.IMITTHETLUNGEN DES BAYERISCHEN PHILATELISTEN-VEREINS. See BAYERISCHER Philatelisten Verein München. Vereins-MititheilUNGEN.

VEREINS - IMITTHEILUNGEN DES HAIMBURGALTONAER BRIEFIMARKEN-SAIMIMLER-VEREINS. Vereins-Mittheilungen des Hamburg-Altonaer Briefmarken-Sammler-Vereins. Hamburg, x 897. Fol. 13-12 in. Nos. 1-11, February-December, 1897.

* * The first three issues bear no numbers. 
VEREINS - IMITTHEILUNGEN DES HAIMBURGALTONAER BRIEFMARKEN-SAMIMLER-VEREINS.

[Continued as :]

-_ Hamburg-Altonaer Briefmarken-Sammler-Verein. Vereins-Mitteilungen.

8. $10^{3}-12$ in. Vols. II.- nos. In progress.

3rd ", Mar. 15, Apl. 15, July 15, Sept. 1, Dec. 1, 1899. Nos. $1-5$.

4th "Jan. 1, Mar. 27, May 12, July 27, Oct. 26, Nov. 30

1900. Nos. $1-6$

5th " Jan. 12, Mar. 22, Apl. 26, June 29, Oct. 4, Dec. 2,

6th "Feb. 22, Apl. 25, Jume 27, Sept. 5, Oct. 28, 1902.

" Nos. 1-5.

7 th ,Jan. 16, Mar. 27, June 3, Aug. 28, Oct. 30, 1903.

Nos. $1-5$.

8th "Jan. 15, Mar. 25, May 27, July 29, Sept. 16, Nov. 30,

1904. Nos. 1-6.

9t11 "Feb. 24, Apl. 7, May 26, Aug. 25, Oct. 27, Dec. 29, loth "Jan. 19 , Mar. 9 -

10th " Jan. 19, Mar. 9, Apl. 20, June 15, Aug. 31, Oct. 19
Nov. 23, 1906. Nos. 1-7. * * Nos. 4 and 5 and 8 and 9 of the second year were severally published together, no. 1 of the fourth year is wrongly numbere " 6 " and there is a supplement on coloured paper to no. 6 of the fifth year.

VEREINS - MITTHEILUNGEN DES INTERNA TIONALEN PHILATELISTEN-VEREINS DRESDEN, ETC. Vereins-Mittheilungen des Internationalen Philatelisten-Vereins Dresden, etc.

Dresden, Internationaler Philatelisten-Verein, I89I92.

$8^{\circ} .93$ in. 24 nos. in 2 vols

1st year. July 15 -Dec. 15,1891 . Nos. $1-9$.

2nd Jan. 15- "15, 1892.

* *The above form a supplement of" "Der Philatelist" and are paged up with the numbers for the dates given. After the end of 1892 the separate numbering of the "Vereins-Mittheilungen" ceased. Nos, 10 and 11 are dated "1891" in place of 1892.

VEREINSIMITTHEILUNGEN. VEREIN BRAUNSCHWEIGER BRIEFIMARIEN - SAIMIMLER. See Verein Braunschweiger Briefmarken-Sammuer. VEREINSMITTHEILUNGEN.

VEREINS-NACHRICHTEN. See GLOBUS. (Berlin, 1891.)

VEREINS-NACHRICHTEN. See PosT.

VEREINSNACHRICHTEN. See VEREINSNACHRICHTEN Des Vereins Schlesischer Briefmarkensammier.

VEREINSN ACHRICHTEN DES VEREINS SCHLESISCHER BRIEFIMARKENSAIMIMLER. Vereinsnachrichten des Vereins Schlesischer Briefmarkensammler. [Breslau, Der Verein], 1876-79. $8^{\circ} .9-6 \frac{3}{4}$ in. 41 nos. in 4 vols.

[1st year.] Apl. 19-Dec. 4, 1876. Nos. 1- 8.

[2nd " ] Jan. 31 - " 17, 1877. ", 9-22. [3rd "] [Feb. 6]-[ ", 15], 1878. ", 23-33. [4th "] [Jan. 8]-[Nov. 26], 1879 . " $34-41$. ** Nos. $2-41$ have only the title "Vereinsnachrichten". Nos. $1-$ 36 are produced by autographic lithography and nos. $37-41$ by a hectographic process. Nos. $1,8-41$ are about the same size, no. 2
is wider and nos. 3-7 are much smaller. Nos. 20,21 were pubis wider, and nos.

VFRIMONT PHILATELIST. The Vermont philatelist.

St. Albans, Vt., Chas. E. Foster, I875. $8^{\circ} .7 \frac{3}{4}$ in. and $12^{\circ} .6 \frac{1}{2}$ in. Nos. 1-7, Jan., Feb., Mar. and Apl., May, June, July, Aug., 1875. ** No. 3 is $12^{\circ}$. and the other numbers are octavo. There is a
supplement of two pages to no. 4.
Mis. St. Jour. 39 (1). Mis. St. Jour. 39 (1).

\section{[Continued as :]}

The Crescent. St. Albans, Vt., Chas. E. Foster, 1875. $8^{\circ} .7 \frac{3}{4}$ in. Nos. 8-10, Sept.-Nov., 1875

* * Nos. 8 and 9 were published together under the date "Sept. and Oct., 1875," and there is a supplement of two pages to this double number.
VERORDNUNGS-BLATT DER DIRECTION DER GROSSHERZOGLICH BADISCHEN VERKE HRSANSTALTEN，Verordnungs-Blatt der Direction der Grossherzoglich Badischen Verkehrsanstalten. Nr. Lxx. 29 Dezember 1860. [Contains; "Postwesen. Der Vollzug des Postvereins-Vertrags vom 18 August 1860.]

$4^{\circ} \cdot 10 \frac{7}{2}$ in. pp. $359-456+(14)$ pp.

VERSLAGEN EN HANDELINGEN. Verslagen en Handelingen.

Amsterdam, Nederlandsche Vereeniging van Postzegelverzamelaars, I 892-96.

$8^{\circ} .9 \frac{1}{4}$ in. and $9 \frac{3}{4} \mathrm{in} .46$ nos. in 5 vols.
[1st year. March]-Dec., 1892. Nos. [1]-10.

[2nd "] Jan. - " $1893 . \quad$ " $11-19$.

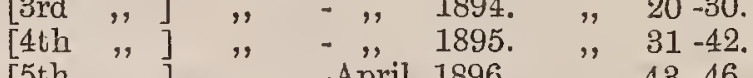

* ${ }^{*}$ th " " " ** Nos. $1-38$ measure $9 \frac{1}{4}$ jnches and the remaining numbers 93 inches. No. 1 bears no number or date and the other number have the title, number and date reading upwards at the left side There are no numbers for June, Septe mber and November, 1893 at the top.

[Continued as :]

Vertrouwelijke Mededeelingen.

Amsterdam, Nederlandsche Vereeniging van Postzegelverzamelaars, I 896-

$8^{\circ}$. 10준-11 in. Vols. V.- nos. In progress.

[5th year.] May-Dec, 1896. Nos. $47-54$.

[6th "] Jan.- " 1897. " $55-66$.

[7th "] " " - ", $1898 . \quad$ " $1899.67-77$.

[9th ", " " - " 1900. " $89-99$.

[10th ", " - " 1901. ", $100-111$.

[11th "] " "- " 1902. " $\quad 112-123$.

[12th " "] " "- " " $1903 . \quad$ " $\quad$ [124]-134.

[14th "] " - " $1905 . \quad$ " $146-157$.

[ * * Nos. 47-127," excepting nos. 62 " and 124 , bear the words "Verslagen en Handelingen " and the number and date, reading up wards at the left side, and the words " Verslagen en Handelingen" are continued below "Vertrouwelijke Mededeelingen" on nos. 128-138. Nos. 50 and 51, 107 and 108, 119 and 120, 158 and 15 and 165 and 166 were severally published together. Nos. 62,12 and 139 have no numbers or dates, and there is no number fo August, 1897, or for this month of $1898,1899,1900$ and 1904 No. 131 is dated "Aug.-Sept. 1908 ".

VERTRAULICHE IMITTHEILUNGEN. Vertrauliche Mittheilungen. Organ des Vereins deutscher Philatelisten zu Dresden. Dresden, I87 I-75. $8^{\circ} .8 \frac{1}{4}$ in. Nos. 1-4, Oct. 15, 1871, Feb. 15, July 1, 1872, Jan. 1,

${ }_{*}^{*}{ }^{*}$ Edited by Dr. Alfred Moschkau. No. 4 was printed at Nossen.
Mis. St. Jour. 34 (1).

VERTRAULICHE MITTEILUNGEN DES SKAN DINAVISCHEN PHILATELISTEN - VEREINS IN KOPENHAGEN. Vertrauliche Mitteilungen des Skandinavischen Philatelisten-Vereins in Kopenhagen. Kopenhagen, Leipzig [printed], I894. $8^{\circ} .10 \frac{1}{2}$ in. No. [0] and nos. 1-7, "1894," May-October, 1894. * The above were given as supplements to the "Illustrierte Briefmarken-Zeitung," but only to members of the Copenhagen Society. Nos. 1-3 only bear the date "1894" and nos. 4, 5, 6 and 7 are dated "Mai," "Mai," "Juli " and "Oktober 1894" respectively. There is also an unnumbered part with "In Sachen Lichtenstein" as the heading to the contents. This part only bears the date "1894" and the whole of the contents were reprinted in no. 3. A second copy of the unnumbered part is bound up in Mis. St. Pamph. 52 (12).

VERTRAULICHE VEREINSIMITTEILUNGEN。Vertrauliche Vereinsmitteilungen.

Berlin, Intern. Postwertzeichen-Sammler - Vereins "Globus," I 893 .

$8^{\circ} \cdot$ 9-9 $\frac{1}{2}$ in. Nos. 1-2, February 15-April, 1893

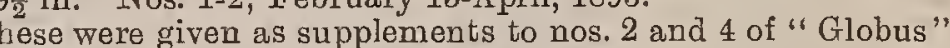
for 1893 , but only to members of the society.

Bound up with "Globus" 1892-93. 

Vuctónan Phitatatic Pecour

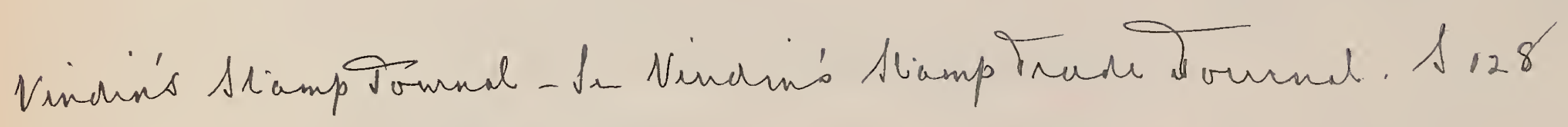

Vest Podket Bhilatalist.

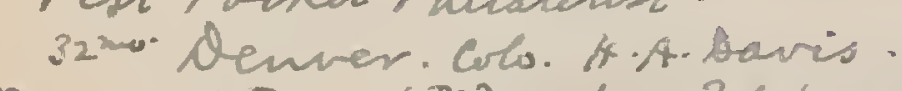

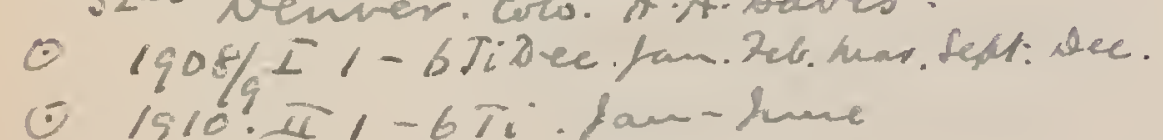

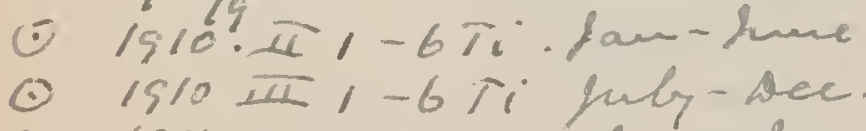

- Isil iv. 19-24Ti Jau-gme.

O igik v. 25-30 Ti. hla-dec.

- islavi $31-36$ Ti. fou -huse. 


\section{VERTRAULICHE VEREINSMITTEILUNGEN.}

[Continued as :]

Globus. Vertrauliche Vereinsmitteilungen des Intern. Postwertzeichen-Sammler-Vereins "Globus" zu Berlin. Berlin, Intern. Postwertzeichen-Sammler-Verein "Globus," I 893.

$8^{\circ}$. $9 \frac{1}{4}$ in. July, November, December, 1893.

* * The three issues bear no number.

Bound up with "Globus" 1892-93.

[Continued as :]

- Vertrauliche Vereinsmitteilungen des Intern. Postwertzeichen-Sammler-Vereins "Globus" zu Berlin

Berlin, Intern. Postwertzeichen-Sammler-Verenn "Globus," I 894-95.

$8^{\circ} .8_{4}^{3}$ in. May, 1894, October, 1895

* * Both issues bear no number and the last has a paper wrapper.

VERTRAULICHES

KORRESPONDENZBLATT

PHILATELISTISCHER VEREINE. Vertrauliches Korrespondenzblatt philatelistischer Vereine.

Strassburg i. Eils., etc., Briefmarkiensammler-Verein "Union," etc., г891-

$8^{\circ} .9 \frac{1}{1}$ in. nos. in vols. In progress.

1st year. Aug.-Dec., 1891. Nos. 1- 5 .

2nd " Jan.- " 1892. " $1-12$.

3rd " " " "1893. " $1-12$.

5th " " " " $1895 . \quad$ " $1-12$.

6th " " " " 1896. " " $1-12$.

8th " " , , 1898. " $11-12$

9th " " " " $1899 . \quad " \quad 1-12$.

10th " " " $1900 . \quad$ " $1-12$.

12th " " " " $1902 . \quad$ ", $1-12$.

13th " " " ", $1903 . \quad$ " 1904.12.

15th " " " " $1905 . \quad " 1-12$.

* * From no. "7, vol." II., to nos. "12, vol. v., inclusive, the journal I.; the twelve numbers of vol. VI by the Verein Mannheimer Briefmarken-Sammler; the twelve number's of vol. vII by the Badischer Philatelisten-Verein Pforzheim; the twenty-four numbers of vols. VIII, and IX, by the Briefmarken-Sammler-Yerein Hannover; the twelve numbers of vol. $x$. by the BriefmarkenClub Haver; the twelve mubering with. X. by the Briefmarkenhas heen published by the Verin fijr Briefmarkenkunde Kiel. Thas been published by une there is a title-page and an index lo each wrapper to each number commencing with no. 1 coloured paper and 2, vol. IV., were published together, there is a supplementary slip to no. 2, vol. rII., and a supplement to no. 11, vol. vIII. There are special supplementary numbers to nos. 2 and 4 , vol. $x$.; nos. $2,3,8$ and 11, vol. XI. ; no. 12 , vol. XII.; no. 10 , vol. XIII.; nos. 2 $2,3,8$ and 11 , vol. XI. ; no. 12 , vol. XII.; no. 10, vol. XIIII.; nos. 2
and 11 , vol. XV.; and to no. 11 , vol. XVI. A copy of the "Bericht uiber das Vertrauliche Korrespondenz-Blatt philatelistischer Vereine pro 1893 " is bound up in Mis. St. Pamph. 52 (9).

VERTROUWELIJKE MEDEDEFLINGEN. See VERS- LAGEN EN HANDELINGEN.

VIDA EN EL HOGAR. La Vida en el Hogar.

Buenos Aires, Dimas Helguera, x897-98. Fol. 14 in in. 64 nos. in 2 vols.

1st year. Mar. 1-Dec. 22, 1897. Nos. 1-40.

2nd "Jan. 1-June 22, 1898 . " 41-64.

* * Only partly philatelic. Each number has a coloured paper wrapper. In no. 33 a philatelic department with the title " Notas Filatélicas de la Vida en el Hogar," was started. Wanting nos. $2-21$.

[Continued as:]

- Buenos Aires filatélico.

Buenos Aires, Dimas Helguera, I898-г900. $8^{\circ} .103$ in. Vols. II.-IV. 62 nos.

2nd year. July 1-Dec. 22, 1898. Nos. 65-88.

3rd " Jan. 1- ", 15, $1899 . \quad$ " 89-118.

4th " "15-Aug. 15, $1900 . \quad$ " 119-126.

* * Each number has a paper wrapper and nos. 89 and 90 were published together under the date "Enero $1^{\circ}$ y 8 de 1899 ".
VIFRTELJAHRS - NACHTR ÄGEＶierteljahrs - Nachträge zum permanenten Handbuch der Postfreimarkenkunde und dem Permanent-Sammelwerk in losen Blättern von Hugo Krötzsch. Mit 19 Lichtdrucktafeln. $8^{\circ} .6 \frac{3}{4} \mathrm{in} .12$ nos. in 3 vols. Leipzig, Hugo Krötzsch, 1894-96.

1st year. Neujahr, Ostern, Johannis, Michaelis, 1894. Nos. 1-4. 2nd ". Neujahr, P角gsten," Johannis", Weihnach ten," 1896. ** There is a combined title-page and an index for the three years.

VILÂGPOSTA. Világposta.

Budapest, Zsigmond F'aludi, I899. $8^{\circ}$. 11 1 in. Nos. 1-4, March-June 20, 1899

Mis. s't. Jour. 130 (13).

VIM ET AIIOREM PHILATECORUM. Vim et amorem philatecorum.

$8^{\circ} .9 \frac{1}{2}$ in.

** "This is solely a price list of stampz, etc., for sale by the publishers and cannot therefore be considered a philatelic journal. No. 1 is headed "N. di saggio" and is dated December 15, 1905 while no. 1 of the second year is dated January 1, 1906.

VINDICATOR. The Vindicator.

Bradford, Me., L. W. Templeton, x905. $24^{\circ} .5$ in. No. 3, May, 1905.

* Only partly philatelic. The number has a coloured paper Mis. St. Jour. 150 (10)

VINDIN'S PHILATELIC MONTHLY. Vindin's philatelic monthly.

Sydney, Dawson A. Vindin and Co., I887-90. $8^{\circ} .81$ in. 29 nos. in 3 vols.

Vol. I. Aug., 1887-May 20, Dec., 1888, Jan., 1889. Nos. 1-12

" II. Feb., 1889-Feb. 20, 1890. Nos. 13-24.

*" Tro Mar. 20, -July 20, $1890 . \quad$ " 25-29.

"." No. 13 is numbered "vol. Ir. no. 1," and no. 20 is dated "Sinted on buff paper.

New Series.

Sydney, Dawson A. Vindin and Co., I890-94. $8^{\circ} .8 \frac{1}{2}$ in. Vols. IV.-VII. 48 nos.

Vol. IV. Aug. 20, 1890-July 20, 1891 . Nos. 1-12.

". v. "

"VI. " $\quad 20,1892-", 22,1893 . \quad " \quad 1-12$

* "* There is " a title-page and a list of contents to each volume and a coloured paper wrapper to each number. In August; 1894, the journal was succeeded by the "Australian Philatelist".

VINDIN'S STAMP TRADE JOURNAL. Vindin's stamp (.) trade journal.

London, W.C., D. A. Vindin and Co., 1894.

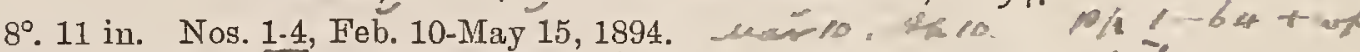
** Conducted by Dawson A. Vindin. J There is a paper wrapper pohite 1 , fleen 2-4 to each number. A copy of the prospectus of the journal, dated. January 16,1894 , is bound up with the four numbers.

(c) No4 hoo "List No/"May25 25 Mis. St. Jour. 72 (5).

VIRGINIA PHILATELIST. The Virginia philatelist. I 89 I.

Staunton, Va., Virginia Stamp and Publishing Co.,

8. $9 \frac{1}{2}$ in. No. 1. January, 1891

*** The number has a coloured paper wrapper. A no. 2 is said to have been printed, but not circulated. Mis. St. Jour. 107 (6).

VIRGINIA PHILATELIST. The Virginia philatelist.

Richmond, Va., Virginia Philatelic Prbblishing Co., I 897 -I 905 .

$8^{\circ} .8_{4}^{3}$ in. 73 nos. in 7 vols

Vol. I. Sept., 1897-Aug., 1898. Nos. 1-12

" II. " $1898-", 1899 . \quad$ " $1-12$

$"$ III. $" 1899-", 1900 . \quad " 1-12$.

" IV. J., Jan.-May, Sept.-Dec., 1902,"Jan.-June, 1903. Nos. 1-12.

", vi. July-Dec., 1900, Jan.-Nov., 1904. Nos. 1-12

", viI. Jan., 1905. No. 1 .

* * There are title-pages and indexes to vols. I.-v. and a paper wrapper to each number. No. 10, vol. IV., is dated "June-July, 1901 " and no. 11 of the same volume "August-September, 1901 ",
Nos. 10-12, vol. v., are dated, respectively, "January-February,"

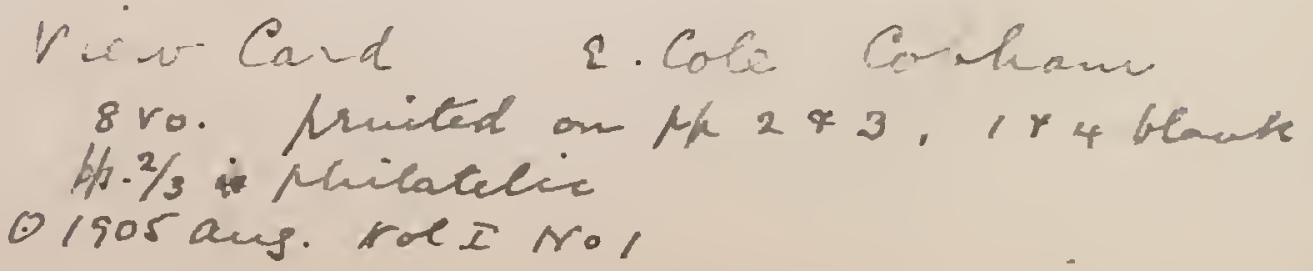


"March-April," "May-June," 1908, and nos. 7-12, vol. VI., respectively, "Jan.-Feb.," "March-April," "May," " June-July," vol. IV., have, iu error, "vol. v." There is a second edition of no. 1 , vol. I., with the words "second edition" at the foot of the no. 1, vol. I., with the words "second edition" at the foot of the front wrapper and a limited "edition de luxe" of no. 1 was also circulated. There are supplemental slips to nos. 1 and 9, vol. IV. and a copy of the prospcctus of the journal is bound up at the "Phmencement of vol. I. The journal was amalgamated with the of no. 1 , and also the edition de luxe of this number.

VITOSCHA. Vitoscha.

Sofia, Bulgarie, [H. S. Tagger et Cie], r896.

$4^{\circ} .11 \frac{1}{2}-12$ in. Nos. 1-5, Mar. 1.July 1, 1896.

** The contents consist entirely of advertisements. Nos. 3-5 *ere published together under the date " 1 Juillet, 1896 "

VLAAMSCHE VERZAIMEAAR. De Vlaamsche Verzamelaar. Antwerpen, Ed. Hulsens, 1899. $8^{\circ} .11$ in. No. 1, Jan. 1, 1899.

* * The number has a coloured paper wrapper.

Mis. St. Jour. 98 (1).

VOGTLÄNDISCHE PHILATELIST. Der Vogtländische Philatelist. Vertrauliche Mitteilungen des Vogtländischen Philatelisten-Verbandes, mit Tausch-Blatt.

Zeulenroda, O. G. König, 1892.

$8^{\circ} .9 \frac{1}{2}$ in. Nos. 1-2, October-November, 1892.

* * Produced by a hectographic process. No. 1 has a supplement of two pages. Mis. St. Jour $133(5)$

\section{[Continued as :]}

- Verbands-Mitteilungen des Vogtländischen Philatelisten-Verbandes von Zeulenroda u. seinem Zweig-Verein Plauen i. V. Zeulenroda, O. G. König, [1892]. 8. 9 in. No. 3, [December, 1892.] Mis. St. Jour. 138 (5a).

[Continued as :]

- - Verbands-Mittheilungen. Mit Anhang: Tausch-Blatt. Zeulenroda, [O. G. König], 1893. $8^{\circ} \cdot 8_{1}^{3}$ in. No. 4, March, 1893. * Produced by a hectographic process.

\section{VOGTLÄNDISCHE PHILATELIST.}

\author{
[Continued as :]
}

- Verbands-Mittheilungen des Vogtländischen Philatelisten-Verbandes zu Zeulenroda und seinen ZweigVereinen Plauen i. V. und Schleiz.

Zeulenroda, O. G. König, [1894]. 80. 9 in. 3rd year, no. 5, [1894]. Mis. St. Jour. 133 (5c).

VOLANUNEL, Volanunel. Světový věstník. No. 1. August 1, 1890. [Contains an article "Ved köoas" on the early postal reformers.] Praha, A. Vitek, I89o. Fol. $11 \frac{1}{2}$ in. pp. 8-9.

* * Printed by autographic lithography with the exception of the title and notices, which are lithographed from type. Mis. St. Jour. 129 (6)

VOII FELS ZUIM IMEER. Vom Fels zum Meer. XVI. Jahrgang. Heft 26, 1897. [Contains an article "Ein Briefmarkenbild" and an illustration "Eine Briefmarkenkopie des "Abendmahls" von Leonardo da Vinci ".]

$4^{\circ} .12$ in. pp. $95-97$.

Stuttgart, W. Spemann, r897.

VOZ. La Voz.

Barranquilla, Colombia, C. Gastelbondo, I888-92. $8^{\circ} .7 \frac{3}{4}-9$ in. and fol. $12 \frac{1}{4}$ in. 37 nos. in 4 vols.

1st year, March 1888-Mar. 1889. Nos. 1-13.

2nd " April 1889- ", 31, 1890. " 14-24.

3rd ", $" 30,1890$-Dec. 25, 1891. " $25-34$.

* * Nos. 1-34 are octavo and the remaining numbers are folio. * Nos. November, December, 1890, March, April, June, July, August, October or November, 1891. Nos. 27 and 28 were published together with the date "Julio 31 de 1890 " and "Julio de 1890 " on the wrapper. No. 29 is dated "Agosto de 1890" on the wrapper and "Setiembre 30 de 1890 " on page 3, and nos. 16-34 have paper wrappers. No. 30 has " 1890 " in error for "1891," except on the paper wrapper, which is correct, and no. 31 has the number on the wrapper altered from " 30 " to " 31 ". The journal was continued for some years, but ceased to contain any philatelic matter after no. 37, beyond stamp dealers' advertisements now and again. Wanting no. 1.

VOZ DEL FILATÉLISTA AMERICANO. La Voz del filatélista Americano. Revista mensual.

Rosario de Santa Fé, Rep. Arg., Ramos y Tarifa, etc., r898.

$8^{\circ} .11$ in. Nos. 1-6, May 31-Oct. 31, 1898. * Noser and no. 6 is numbered in error "Nìm. 5" but the numbering on the wrapper is correct.

Mis. St. Jour. 84 (6) 
+ 
WARD'S PHILATLIC NEWS. (Philadelphia, P. H. Ward, Jr.)

Yo!. I (1930-32). Unbound.

Yol. I1, Xos. 1-4 (1932-34). Unbound.

W. C.Cokk' Mouthly araratisenf fist 
WABASH STAIMP EXCHANGE NEWS. The Wabash stamp exchange news.

Terre Haute, Ind., The Wabash Stamp and Publishing Co., I $905-06$.

$8^{\circ} .9$ in. nos. in 2 vols.

Vol. I. Nos. 1

* "* II.

Nos.

* Wanting all but vol. "II. no. 7, which is dated "May-June, $1906 "$

WAHLZETTEL FƯR BRIEFMARKENSAMIMLER U. BÜCHERFREUNDE. Wahlzettel für Briefmarkensammler u. Bücherfreunde. Leipzig, Emil Enke, 1896. $8^{\circ} \cdot 9 \frac{1}{2}$ in.

**This is solely a price list of stamps, etc., for sale by the publisher and cannot therefore be considered a philatelic journal No. 1 is dated "Januar, 1896 ". Mis. St. Jour. 134 (4).

WAHLZFTTEL FÜR BRIEFIMARKEN-SAIMILER U.-HÄNDLER. Wahlzettel für Briefmarken-Sammler u.-Händler. Leipzig, Hermann Perthus, I 898. $8^{\circ} .93$ in. [Nos. 1-E], May 21, June 1, 11, 21, July 1, 1898. * Printed on green paper and the contents consist entirely of . Wanting the o. for June $21,1898$. Mis. St. Jour. 131 (10)

WAIMSUTTA STAIMP NEWS. Wamsutta stamp news. North Attleborough, Mass., Wamsutta Stamp News Publishing Co., I890-9r.

$8^{\circ} .8 \frac{1}{2}$ in. Nos. 1-3, Dec., 18\%0-Feb., 1891

* * No 3 has a coloured paper wrapper.

Mis. St. Jour. $62(10)$

WASHINGTON PHILATELIST. The Washington philatelist.

Washington, D. C., Schoeni and Co., etc., I892.96. 8०. $8 \frac{1}{2}-7 \frac{3}{4}$ in. 51 nos. in 9 vols.

Vol. I. March, -Aug., 1892. Nos. 1-6.

"II. Sept., 1892-Feb., 1893. " 1-6.

"III. March -Aug., 1893. " "1-6.

" IV. Sept., 1893-Feb., 1894. ", 1-6.

" v. March -Aug., 1894. " $1-1-6$

" vil. March -Aug., 1895. " $1-6$.

"VIII. Sept., 1895-Feb., 1896. " $1-6$.

*"* There is a paper wrapper to each number. From no. 3, vol. I., to no. 5, vol. IV., inclusive, the journal was published by the Washington Philatelic Pub. Co., while all subsequent numbers were published by $\mathrm{H}$. A. Parks.

WATSON'S IMONTHLY STAIMPSONIA. Watson's monthly stampsonia. For philatelic readers and stamp collectors. Philadelphia, Pa., Warren Watson, 1896. Fol. 11 in. Nos. 1-3, Jan. 15, Feb. 15, March-April, 1896 Mis. St. Jour. 97 (2).

WAUGH'S JOURNAL, See WAUGH's MONTHLY EXCHANGE LIST,
WAUGH'S MONTHLY EXCHANGE LIST. Waugh's monthly exchange list. Containing advertisements of foreign stamps, boys' papers, games, bicycles, etc., for sale or exchange.

London, E., Oxford [or] Oakham [printed], $C$. Pollard, etc., I885-86.

$8^{\circ} .7 \frac{1}{2}-8 \frac{1}{4}$ in. Nos. 1-15, [? July], 1885-Sept., 1886.

* * Besides advertisements, the paper contains reviews of stamp journals, etc. Nos. -15 were published by Pollard, Copley an Co. Wanting all but nos. 9 and 11 for March and May, 1886.

\section{[Continued as :]}

Waugh's journal. Containing advertisements of foreign stamps, coins, books, papers, poultry and live stock, games, bicycles, tricycles, etc., etc., for sale or exchange. London, E., Oakham [printed], Pollard, Copley and Co., I 886.

$8^{\circ} .8 \frac{1}{4}$ in. No. 16 , October, 1886.

WAVERLY STAIIP CO.'S ALLEGHENY PHILATE LIST AND STAIIP COLLECTORS GUIDE. The Waverly Stamp Co.'s Allegheny philatelist and stamp collectors guide.

Allegheny, Pa., The Waverly Stamp Co., 1896.

$8^{\circ} .8^{3}$ in. No. 1, July, 1896.

\section{[Continued as :]}

The Allegheny philatelist and stamp collectors guide. Alleghemy, Pa., The Philatelic Prblishing Co., 1896. 8. $8_{7}^{3}$ and 8 in. Nos. 2-3, Aug.-Sept., 1896.

** No. 2 measurss 8 inches and no. 3,8 inches.

[Continued as :]

The Allegheny philatelist.

Allegheny, Pa., Emil N. Kiefer, etc., I897-1900. $8^{\circ} .8 \frac{1}{2}-8 \frac{3}{4}$ in. Vols. II.-VI., 28 nos.

Vol. Ir. Jan. 20, Aug.-Oct., Dec., 1897, Jan., 18:8. Nos, 4-9.

"III. Feb.-Apl., Sept. 20-Nov. 20, 1898. Nos. 10-15.

"II. IV. Dec. 20, 1898-May, 1899. Nos. 16-21.

" v. June 20, -Nov., 1899. " 22-27.

*"* There is a paper wrapper to each number and nos. 13-31 were published by Kiefer Publishing Co. The wrapper of no. 14 is published by kiefer " 13 " andishing Co. The "wrapper of no. 14 is wrongly numbered "13" and no. 21 has " whole no. 21 ," but the wrapper has the correct numbering and date.

[Continued as :]

- The Allegheny philatelist and herald exchange. New Series. Allegheny, Pa., Kiefer Publishing Co., $x 900$. $8^{\circ} .8$ in. Vols. VI.-VIr., 9 nos.

Vol. IV. April, May, 1900. Nos. 32-33.

, V1I. June-Dec., 1900. ," 34-40.

* * Each number has a paper wrapper. Nos. 37 and 38 have "vol. IV." in error for "vol. vII." Besides the numbering given above, each number has "New Series," nos. 1-9 and "Herald Exchange Series," nos, 44-52. 
W. D. ATLEE'S STAMP CIRCULAR. W. D. Atlee's stamp circular. London, $N$., x865-66. $4^{\circ} .9 \frac{3}{4}$ in. [Nos. 1.8], Sept. 10, 1865-Jan. 1, Jan. 15, Apl. 2, May

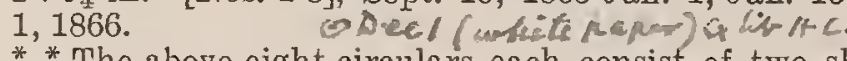

* The above eight circulars each consist of two sheets of blue paper the first only of which is printed on one side. They are not numbered.

WEDNESBURY HERALD, AND SOUTH STAFFORDSHIRE RECORDER. The Wednesbury herald, and South Staffordshire recorder. Vol. xIV., No. 689, March 31, 1888. [Contains an article "A monumental mockery; or, who gummed the stamps?" by J. E. Ryder and a leading article on the same subject, both being written in support of Patrick Chalmers claim that his father James Chalmers invented the adhesive postage stamp.] Wednesbury, Stafford, Robert Ryder, x 888. Fol. 23 in. pp. $(4,5)$.

* Cuttings of these articles are also mounted in Stamp Scrapbook, vol. VI., pp. 23-28.

Mis. St. Jour. 136 (21).

WEEKBLAD VOOR DEN POSTZEGELVERZAIIE LAar. See B. S. I. C. Weekblad yoor den PostzeGELVERZAMELAAR.

WEEKLY BOX OF CURIOS. The Weekly box of curios. Vol. VI., no. 35, December 28th, 1895. [Contains an article "Formosa stamps" by James W. Davidson.]

Yokohama, E. V. Thorn, I895

Mis. St. Jour. 127 (12)

WEEKLY NEWS LETTER. THE J. W. SCOTT CO.

I'D. See J. W. Scott Co., L'D., WEekLy NEWS LetTer.

WEEILY OOLOGIST AND PHILATELIST. Weekly oologist and philatelist. Published every Saturday. Lebanon, Or., F. T. Corless, I891-92

$8^{\circ} .7 \frac{3}{4}$ in. 5 nos. in 2 vols.

Vol. I. Dec. 12, 19, 26, 1891. Nos. 1-3.

II, Jan, 2,9 , 1892 . Nos. $1-3$.

Mis. St. Jour. $66(10)$

WEEKLY PHILATELIC ERA. See PhILATELIC ERA. (Portland, Me.)

WEEKLY PHILATELIST. The Weekly philatelist. New Chester, Pa., R. M. Miller, 1892-94. $8^{\circ} .9$ in. 95 nos. in 2 vols.

Vol. I. Nov, 16, 1892-Nov. 8, 1893 . Nos. 1-52.

" II. ", 15, 1893-Sept., $12,1894 . \quad$, $53-95$

WEEKLY STAIMP TRIBUNE, See STAMP TRIBUNE (Harriman, Tenn.)

WEGWEISER FỬR SAMIMLER. Wegweiser für Sammler. Central-Organ zur Beschaffung und Verwerthung aller Sammelobjekte.

Leipzig, Louis Stefke, I889-99.

\begin{tabular}{|c|c|c|c|c|c|}
\hline $\begin{array}{l}\text { Fol. } 12 \frac{1}{4} \text { lut } \\
\text { st year. }\end{array}$ & Sept. & $\begin{array}{l}\text { nos. in } 1 \\
5-D e c \text {. }\end{array}$ & 18, 1889 & Nos. & \\
\hline 2nd & & & 18,1890 & 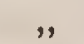 & 1-24. \\
\hline$"$ & ," & 9- , & $18,1891$. & ", & $1-24$ \\
\hline , & ", & 8- " " & 19,1892 . & ", & 1.24 \\
\hline ", & " & 6- " " & 15,1893 & ", & $1-24$. \\
\hline$"$ & ", & & $21,1894$. & ", & $1-2$ \\
\hline$"$ & " & " & $20,1895$. & " & $1-24$ \\
\hline$"$ & ". & 4- $"$ & $25,1890$. & $"$ & 1.2 \\
\hline ," & ", & 12-" & 15,1898 & 11 & $1-24$ \\
\hline & & & & & \\
\hline
\end{tabular}

* The following were severally published nos. 8 and 9,15 and 16 : 5 th 10 , 15 and 16,22 and 23 : 4 th year, near, nos. 7 and 8,23 and $24: 6$ th year, nos. 18 and 19,21 and 22,23 and $24: 7$ th year, nos. 6 and and 20 . 9th and 20: 9 th year, hos. 6 and 7 : Toth year, nos. 8 and $9: 11$ th year, 1806, nos. $5,15,16,17,18,20,22 ; 1898$, nc. $2 ; 1899$, all nos. after 20 .
WEIHNACHTSFFIER. Weihnachtsfeier 1900 im Hamburg Altonaer Briefm. S. V.

Hamburg Hamburg-Altonaer Briefmarken-Sammler Verein, I 900

Fol. 121 in. No. 4, December 15, 1900

* * Produced by autographic lithography and the contents are of a humorous description.

Mis. St. Jour. 129 (19)

WELT PHILATELIST. See COSMOPOLITAN PHILATELIST. (Amsterdam.)

WELTPHILATELIST. See PHILATÉLISTE UNIVERSEL. (Esch-sur-Alzette.)

WELTPOST. See Schweizer Post.

WELT-POST. See WIENER ILLUSTRIRTE BRIEFMAREENZEITUNG.

WELT SPIEGEL. Der Welt Spiegel. Illustrirte Halbwochen-Chronik des Berliner Tageblatts. 26 Oktober, 1902. [Contains two articles "Deutsche Kolonialmarken" and "Englische Kolonialmarken" with illustrations.] Berlin, Rudolf Mosse, x 902 . Fol. 16 in. (1) p. Mis. St. Jour. 127 (8).

WELTWARTE. Weltwarte. Organ der Freien Internationalen Humanistischen Vereinigung "Weltwarte". Leipzig, Otto Weber, 1 905-06. Fol. $12 \frac{1}{4}$ in. Vol. Ir.,
2nd year. Oct., 1905-
1906. Nos. 1 -

* * The numbers of the second year have a supplement with the title "Der Sammler" and this supplement contains philatelic notes. Wanting no. 3 and any after no. 6 .

WERELDPOST. De Wereldpost. Advertentie-Blad voor Postzegel-Handelaars en-Verzamelaars.

Waalwijk, Holland, C. A. Verwiel en Zn., x 905-06. Fol. 141 in. and $4^{\circ} .12-11 \frac{3}{4}$ in. 21 nos. in 2 vols. 1st year. March 10, 1905-Feb. 10, 1906 . Nos. 1-12. 2nd ," ", 10, 1906-Nov. 10, ", , 13-21. * * Nos. 1-9 are folio and the other numbers are quarto, and nos. 1-9 contain nothing but advertisements. Nos. 10 and 11 are printed on coloured paper and the subsequent numbers hav coloured paper wrappers.

WEST-FND PHILATELIST. The West-end philatelist. With which is incorporated Poole's monthly philatelist. London, W., D. Field, r 904-

$8^{\circ} .8 \frac{3}{4}$ in. nos. in vols. In progress.
Vol. I. March, 1904-Feb., 1905. Nos. 1-12.

" II. " $1905-\quad, \quad 1906 . \quad, \quad 13-24$.

* " IIr. Edited by Bertram W. H. Poole." There is a paper wrapper to each number and a title-page and an index to each volume.

WEST OF SCOTLAND FOREIGN STAMP AND PACKET CIRCULAR. The West of Scotland foreign stamp and packet circular.

Glasgow, C. T. Robinson, x 868 in. Nos. 1-2, Mar.-Oct., 1868 * * These two numbers are advertised in "Beeton's boy's own magazine" for March and October, 1868, respectively. The March advertisement reads: "Now ready " the West of Scotland Foreign Stamp and Packet Circular,' containing list of all the cheapest packets and stamps in the market, together with a valuable article for collectors entitled "Seasonable remarks on collecting'. Post, free one stamp....". The October advertisement reads: "Now ready, price 1d., the "West of Scotland Stamp and Packet Circular,' No. 2, containing much information inter esting to stamp collectors, also particulars of new packets, sets etc." It will be noticed that the word "Foreign" is dropped from the title in the advertisement of no. 2. Wanting both nos.

WESTERN ADVERTISER. The Western advertiser. Redington, Neb., F. Gilman, $\mathrm{x} 896$ $16^{\circ} .5 \frac{1}{2}$ in. Nos. 1-2, May-June, 1896. * Only partly philatelic and the contents consist entirely of advertisements. Wanting no. 1.

WESTERN AIMATEUR PRESS. See WESTERN COLLEOTOR. (Sacramento, Cal.) 



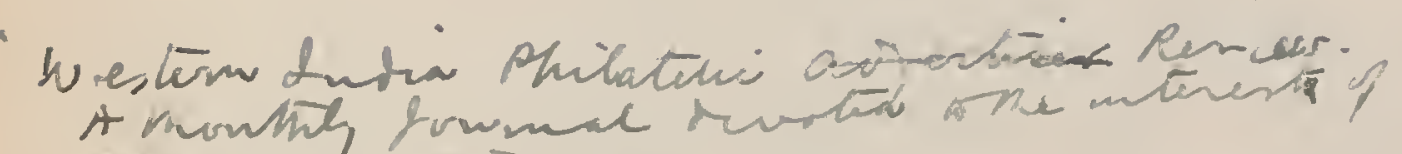

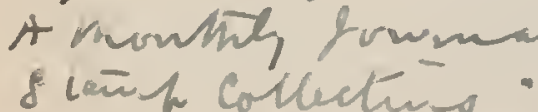

Eiter in s-geridomoke, rublided ty whote

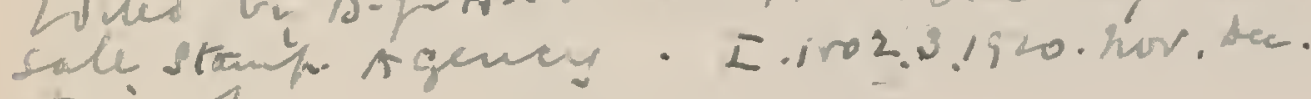
tho nus wh. 
WESTERN COLLECTOR. The Western collector. Sacramento, Cal., E. G. Palmer, 1883 . $64^{\circ}, 3$ in. and $3 \frac{1}{2}$ in. Nos. 1-2, Oct.-Nov., 1883. ** There is a supplement of two pages to no. 1 . Mis. St. Jour. 68 (29).

\section{[Continued as :]}

The Golden State philatelist.

Sacramento, Cal., The|Eureka Pub. Co., I884. $32^{\circ} .4 \frac{1}{2}$ in. No. 3, Feb., 1884 Mis. St. Jour. 68 (29a).

\section{[Continued as :]}

The Western collector.

Sacramento, Cal., The Eureka Pub. Co., etc., I 884.

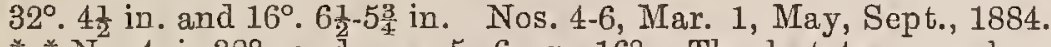
* * No. 4 is $32^{\circ}$. and nos. 5, 6 are $16^{\circ}$. The last two numbers were published by E. G. Palmer 0.4 is dated " "W "1884". The journal was continued under the tith Mis. St. Jour. 68 (29b, 29c)

WESTERN COLLECTOR. The Western collector. Wyoming, Ia., E. R. Marshall, I 887 . Fol. 101-12 in. Nos. 1-2, May-June, 1887. ** Only partly philatelic. Mis. St. Jour. 139, (6).

WESTERN COLLECTOR. The Western collector. A monthly magazine devoted to collectors and amateur journalism. Burlington, Kas., Chas. E. South, I89r. $4^{\circ} .9 \frac{1}{2}$ in. and $8^{\circ} .7 \frac{3}{4}$ in. Nos. 1-2, Apl.-May, 1891.

* * No. 1 is quarto, and no. 2 octavo. Mis. St. Jour. 59 (5)

WESTERN EXCHANGE. The Western exchange.

$16^{\circ} \cdot 6 \frac{1}{4}$ in. and $8^{\circ} \cdot 8 \frac{1}{2}$ in. 8 nos. in 2 vols. Akron, O., J. S. Reese, I 877 .

Vol. I. Jan.-June, 1877. Nos. 1-6.

* " Ir. July, Aug., " " N" 7-8. Nos. $1-6$ are $16^{\circ}$. and nos. 7,8 are octavo.

Mis. St. Jour, 29 (8)

WESTFRN EXCHANGE. The Western exchange.

Central City, Neb., Cleve Scott, I89r-92.

in. Nos. 1-2, December, 1891-January, 1892

WESTERN JOURNAL OF PHILATELY. The Western journal of philately.

Valentine, Neb., Luke.M. Bates, I 893 $8^{\circ} .9$ in. Nos. 1-3, May-July 1893

** There is a slip supplement to no. 1 and each number has a coloured paper wrapper. Bound up with the journal are letters that passed between J. K. Tiffany and Mrs. S. G. Bates in referarticle thereon by J K Tiffany that appeared in the "Philatelic Journal of America " for March, 1894.

Mis. St. Jour. 62 (14).

WFSTERN NEWS. The Western news. Mendota, Ill., [? Hy. C. Thayer], I877

* * Cutlings of the article "U. S. Three Cent. stamps," etc., from no. 5 dated April, 1877, are mounted in Stamp Scrap-book, vol. IIr. p. 79 .

WESTERN PHILATELIC EIMPIRE. The Western philatelic empire. I 89 .

Omaha, Neb., The Omaha Philatelic Publishing Co.,

$\mathrm{S}^{\circ} .10$ in. Nos. 1-4, Mar.-June, 1891

* * There is a coloured paper wrapper to each number.

Mis. St. Jour. $60(9)$

WESTERN PHILATELIC NEWS. The Western philatelic news. Wichita, Kas., Chas. W. Myers, I899. 8. $8 \frac{1}{2}$ in. No. 1 , Sept. 1, 1899

* The number has a coloured paper wrapper. It is printed in English, French and Spanish and was succeeded by the "International philatelist".
WESTERN PHILATEIIST. The Western philatelist. Chicago, Ill., Beifeld and Bell, etc., I872-77. $8^{\circ} .8 \frac{1}{2}$ in. 38 nos. in 6 vols.

Vol. I. Dec. 1, 1872-Feb. 1, April 10, 1873, Mar. 1, Apl. 1, June

. 1,1874 - 1 eb. 1 ,

" II. July 25-Sept. 25, 1874, Jan. 25, Mar. 25, 1875. Nos. 8-

„III. May 1, June 25, Ảug. 18, Oct. 5, Dec. 24, 1875 . Nos.

" III. May 1, Ju

" Iv. Jan 25, Mar. 10, April and May, June and July, Aug. and Sept., 1876. Nos. 18-25.

v. Oct. and Nov., Dec., 1876 and Jan., 1877, Feb., Mar. and Apl., May and June, July and Aug., Sept., 1877.

VI. October, 1877 . No. 38

* * Nos. 20 and 21,22 and 23,24 and 25, 26 and 27,28 and 29 31 and 32,33 and 34 and 35 and 36 were severally published together, and there are supplements to nos. 16,20 and 21,24 and and 25,26 and 27 and 35 and 36 . No. 11 has vol. I. in place of "II.". Nos. 4-12 and 17-38 were published by Joseph Beifeld and nos. 13-16 by J. Beifeld and Co.

WESTERN PHILATELIST, The Western philatelist Devoted to stamp collecting. Council Bluffs, Ia., Ed. L. Howe, [1879]. $8^{\circ} .8 \frac{3}{1}$ in. Nos. 1-3, Sept. 1-Nov. 1, [1879] ${ }_{3}^{*}$ *, Printed on coloured paper. No. 3 is in umbered "Vol. 2 , no.

WESTERN PHILATELIST. The Western philatelist. 1887-88.

Chicago, Ill., Western Philatelic Publishing Co.

$8^{\circ} .9$ in. 17 nos. in 2 vols.

Vol. I. Jan.-Dec., 1887. Nos. 1-12

" II. "-May, 1888. "1- 5.

** There is a title-page, 1 an index and a frontispiece to vol. I. and a coloured paper wrapper to each number.

WESTERN PHILATEIIST. The Western philatelist. Rock Island, Ill., etc., Philatelic Publishing Co., etc., I $889-92$

$8^{\circ} .8 \frac{3}{4}$ in. 16 nos. in 3 vols.

Vol. I. June, Nov., 1889-Mar., May, May, June, July, Aug., Aug., 1890. Nos. 1-12

" II. Sept., 1890. No. 1

", III. June, Aug., Sept., 1892. Nos. 1-3.

* * The three numbers of vol. IIr., were published by C. D. Reimers; no. 1 at Iowa City, Ia., no. 2 at Inglewood, Ill., and no. 3 at Englewood, Ill. There is a paper wrapper to no. 1, vol. r., and there are coloured paper wrappers to nos. 2, 3, 4 and 5 vol. I. to no. 1, vol. II., and to no. 3, vol. III. There is a supplement of two pages, printed on one side only, to no. 1, vol. I., dated Augus 12,1889 , and supplements of two pages, printed on both sides, to nos. 4 :and 15 , vol. I. and to no. 3 , vol. III. No.11, vol. I., is headed Extra" and consists of two pages printed on one side only. Mis. St. Jour. 47 (6)

WESTERN PHILATELIST. The Western philatelist. Devoted to the interests of stamp collecting.

St. Joseph, Mo., Narvon Edwards, I 896

$8^{\circ} .8 \frac{1}{2}$ in. Nos. 1-3, Jan.-Mar., 1896. ** There is a supplement of two pages to no. 1 , and a supple-
mental slip to no. 2.
Mis. St. Jour. 64 (8).

WESTERN PHILATELIST. The Western philatelist.

Humboldt, Kas., S. A. D. Cox, I 898 .

$8^{\circ} .9$ in. No. 1 , July $1,1898$.

* The number has a coloured paper wrapper.

[Continued as :]

The National philatelist.

Humboldt, Kas., S. A. D. Cox, 1898 .

$8^{\circ} .9$ in. Nos. 2-3, Aug. 1-Sept. 1, 1898.

* There is a coloured paper wrapper to each number. Amalgamated with the "Tri-Monthly Collector," January, 1899

Mis. St. Jour. 113 (10a).

WESTERN POSTAL RECORD. The Western postal record. [?] ], I88r-82,

* in. Nos. 1-12, June, 1881-May, 1882.

* * Only partly philatelic. Wanting all.nos. 
WESTERN STAIMP. The Western stamp.

Riverside, Cal., The Western Stamp, etc., I 896. $8^{\circ} .8-8 \frac{1}{2}$ in., and $16^{\circ} .6 \frac{1}{1}$ in. 5 nos. in 2 vols.

Vol. I. Sept, 16, Oct. 1, Oct. 17, Nov., 1896. Nos. 1-4.

* II. Dec., 1896. No. 5.

* No. 5 was published by the Western Stamp Publishing Co. Nos. 1-3 are octavo 8 inches, no. 4 is octavo $8 \frac{1}{2}$ inches, and no. 5 is 16 . 61 inches. No. 1 has the year given wrongly as " 1866 " instead of "1896," there are coloured paper wrappers to nos. 4 and 5, and a supplemental slip to no. 2. ${ }^{\text {Mis. St. Jour. } 64 \text { (7). }}$

WESTERN STAMP BOOK. The Western stamp book. Kansas City, Mo., W. Byron Brown, rgor-oz. $16^{\circ} .6$ in. Nos. 1-2, Dec., 1901-Jan. 1902.

* There is a coloured paper wrapper to each number.

Mis. St. Jour. 107 (1)

WESTERN STAMP BUDGET. Western stamp budget. Chicago, Ill., Western Stamp Co., I89z. $8^{\circ} .83$ in. No. 1, Apl., 1892

Mris. St. Jour. 62 (9).

WESTERN STAMP COLLECTOR. The Western stamp collector.

Chicago, Ill., The Eagle Stamp Co., r873. $8^{\circ} .8$ in. and $8 \frac{3}{3}$ in. No. 1 and nos. 1-3, Apl. 15, May 15, June 15, Sept. 1, 1873

* * The earliest no, 1 measures 8 inches and the three othe numbers, 83 inches. The Eagle Stamp Co. was owned by Fr. Hansen

[Continued as :]

- The Western stamp collector and amateur's bulletin Chicago, Ill., The Eagle Stamp Co., r873. $8^{\circ} .83$ in. No. 4 , Oct. 15,1873 ,

WESTERN STAIMP COLLECTOR. Western stamp collector. Denver, Colo., C. M. Snyder, I 906 . $8^{\circ} .9$ in. and 7䍃 in. Nos. 1-3, April-June, 1906. ** Nos. 1 and 3 measure 9 inches and no. $2,7 \frac{3}{3}$ inches.

Mis. St. Jour. 144 (4)

WESTERN STAIMP COLLECTOR AND AIMATEUR'S BULLETIN See WESTERN STAMP COLLECTOB $($ Chicago, Ill.)

WESTERN STAMP NEWS. The Western stamp news. South Bend, Ind., [? ], r 906. $5129 \quad$ in. No. 1

WEYMOUTH STAIMP AND CREST ADVERTISER. The Weymouth stamp and crest advertiser.

Weymouth, D. Dean, r863-64. 8. $8-9$ in. [? 6] nos. in 2 vols.

[1st year.] Aug. 1-Dec., 1863. Nos. 1-[? 5]. Lave /, 3 (hoor) [2nd ", ] Jan. 15, 1864. No. 1. per. "The Philatelist" of July 1, 1867, notes a number of this nagazine for December, 1863, so that taking into account the numbers in the library, there were probably five, if not six, numbers in all issued.' Wanting all but the front leaf of the number for August 1, 1863, no. 3 for October 1, 1863, and the number for January 15, 1864

- New Series.

Weymouth, D. Dean, r864. $8^{\circ} .7 \frac{1}{2}$ in. Nos. 1-4, Feb. 25-May 25, 1864. * * Nos. 1 and 2 have coloured paper wrappers. Succeeded by the "Stamp collectors" miscellany". Mis. St. Jour. 55 (4).

W. F. BISHOP AND CO.'S STAMP DRUMIMER. See W. F. BISHOP'S QUARTERLY CIRCULAR.

W. F. BISHOP'S MONTHLY CIRCULAR. See W. F. BISHOP'S QUARTERLY CIRCULAR.

W. F. BISHOP'S MONTHLY JOURNAL, See W. F. BISHOP'S QUARTERIY CIRCULAR.

\footnotetext{
Whitfreid Kuig Mes' meckly Irade

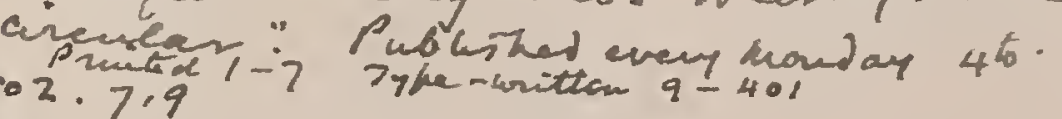

$1903 \quad 59-67$

$190468-75,76,79-82,84,87-91,93-96.99,100$

$1905-104-109$

1906168,170171174176180183188189191192194195
}

W. F. BISHOP'S QUARTERLY CIRCULAR. W. F. Bishop's quarterly circular.

8०. 9 in. No. 1, Jany, 1884.

La Grange, Ill., W. F. Bishop, r884.

\section{[Continued as :]}

W. F. Bishop's monthly circular.

La Grange, Ill., etc., W. F. Bishop, r884-89. $8^{\circ} .9$ in. 6 nos. in 2 vols.

Vol. I. Feb.-May, 1884. Nos. 2-5, 2

*"* II. Oct. -Dec., $1889 . \quad$, 1.2.

*"* Nos. 3-5 vol. r. were published at Chicago.

Vol. I. Mis. St. Jour. 19 (4).

[Continued as :]

W. F. Bishop's monthly journal.

La G Grange, Ill., W. Fr. Bishop, 1890.
in. Vol. II. 2 nos.

Vol, II. Jan.-Feb., 1890. Nos. 3-4. $\quad$ Mis. St. Jour. 26 (1a).

[Continued as:]

W. F. Bishop and Co.'s stamp drummer.

La Grange, Ill., W. F. Bishop and Co., rgoo.

16.. 6 in. Vol. Irr. 1 no.
Vol. III. Fall, 1900, No. 1 .

Mis. St. Jour. 26 (1b).

W. GEORGE'S PHILATELIC CIRCULAR. W.

B George's philatelic circular.

8. 83 in. Publices ineruzingham, W. George, 1899. 3 see

** This is solely a price list of stamps, etc., for sale by the pub-

lisher and colely a price list of stamps, etc., for sale by the pub-

VNo. 1 is dated "March, 1899". W. George also issues another

No. 1 is dated "March, 1899 ". W. George also is

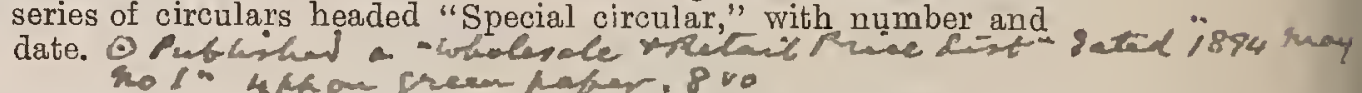

WHITAKER'S MIONTHLY SALE AND EXCHANGE

LIST. Whitaker's monthly sale and exchange list. Manchester, J. Whitaker, I884

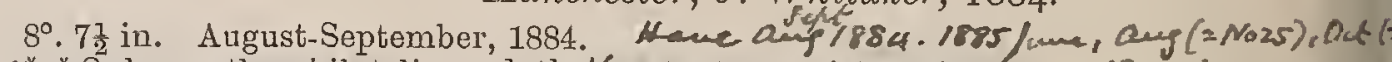

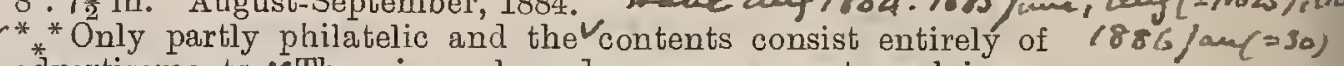
advertisements. Where is a coloured paper wrapper to each issue, which is unnumbered.

Mris. St. Jour. 135 (7).

WHITFIELD KING AND CO.'S WEEKLY TRADE CIRCULAR. Whitfield King and Co.'s weekly trade

A circular.

$8^{\circ} .10 \frac{1}{1}$ in.

Ipswich, r902- Wholewie sta

* * This is solely a price list of stamps, ete., for sale by the pub- 'rearfet: Elishers and cannot therefore be considered a philatelic journal. Thder cer w w

W. H. REGAN'S MONTHLY CIRCULAR. W. H. 1907 Ays-190844

Regan's monthly circular. Bayswater, London, W., W. H. Regan, r904-o6.

$8^{\circ} .8 \frac{1}{2}$ in. 26 nos. in 3 vols.

[Vol. I.] March, 1904-March, 1905. Nos. 1-12. have /. 3.4. $6 . \overline{8} /=$

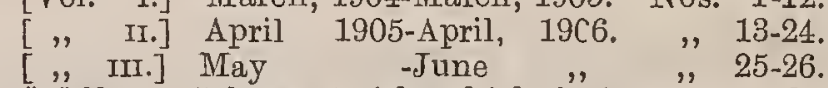

$\checkmark$ *" Nos. 1-5 lave "with which is incorporated the Collectors" news" below the title. $v$ There is no number for August, 1904, or for the same month of 1905 .

[Continued as :]

W. H. Regan's postage stamp circular. Bayswater, London, W., W. H. Regan, rgo6.

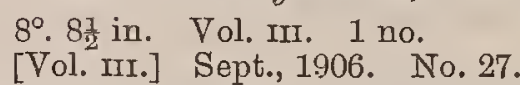

W. H. REGAN'S POSTAGE STAIMP CIRCULAR. See W. H. Regan's MONTHLY CIRCULAR.

WIDE AWAKE. The Wide awake.

New York, Harry K. Zust, r885.

Fol. 11 in. Nos. 3-4, March-April, 1885.

** Only partly philatelic. Nos. 1, 2 , which are rather larger, contain no philatelic matter, and no. 2 is numbered in error " 5 ". Mis. St. Jour. 140 (15).

"M.H.Peckettis New Danfani Lust"

lage 4 to.

[Price insts

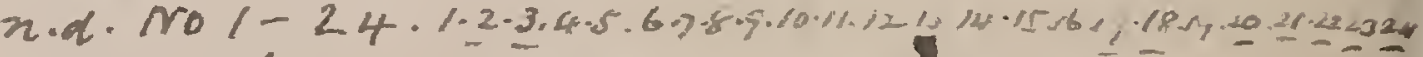
sumell 4 to

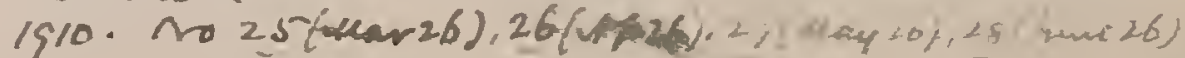

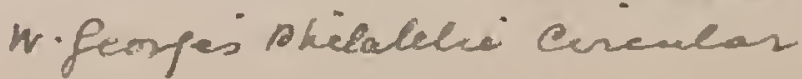

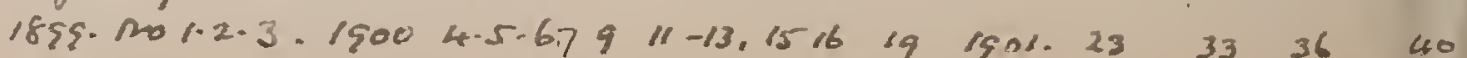
$\begin{array}{llllll}44 & 47 & 58 & 62 & 1902 & 208183\end{array}$

$1903 \quad 128 \quad 136 \quad 149 \quad 1904 \quad 160.164168$

$9052112162192232227232237247 \quad 1906 \quad 258265.282$ 

w. Bishor revistane Denmmer.
III. 1900 . Nol.

W. Jcosers' Philatemi curevelar

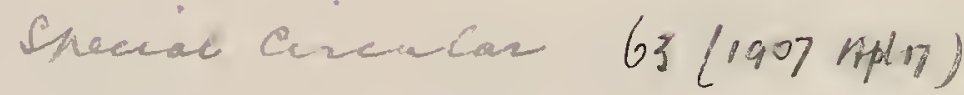

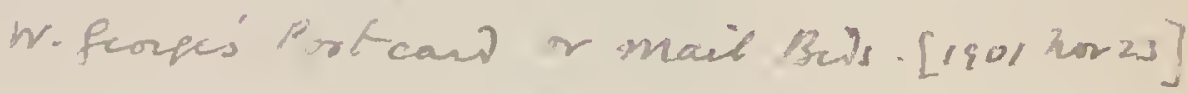

ovkolesale fimph liarket

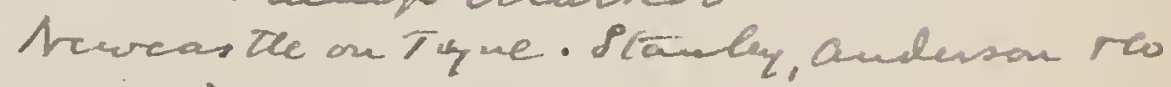

Lask mo. mi a cotemal kaper wat.

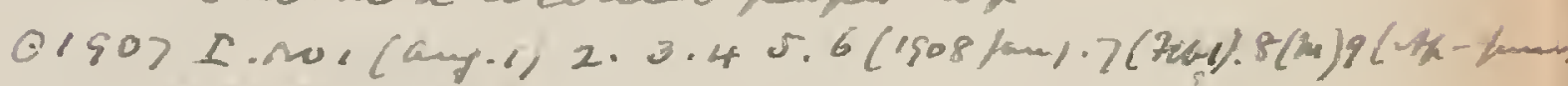

$10\left(\mathrm{hoh}_{2}-\mathrm{sejit}\right)$ 


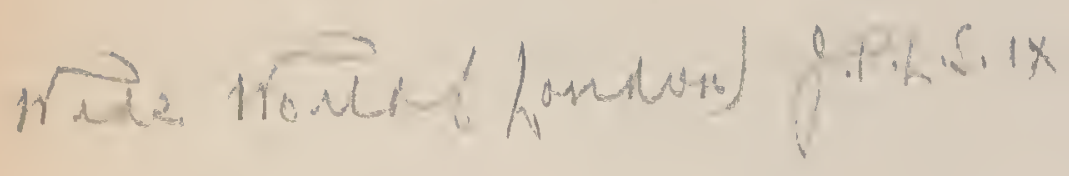


WIDE-AWAKE PHILATELIST. The Wide-awake philatelist. Devoted to philately.

Fitchburg, Mass., Davis and Whitcomb, r89o. 16‥ $5 \frac{3}{4}$ in. No. 1, March, 1890.

Mis. St. Jour. 68 (21).

WIEDLING'S MONTHLY STAMP NEWS. Wiedling's monthly stamp news. Canton, O.,J.E. Wiedling, rgor. $8^{\circ} .83$ in. Nos. 1-4, Ma.y 7-Aug. 7, 1901 * "There is a coloured paper wrapper to each number. Amalgamated with "Lueve's new perforator," November, 1901 Mis. St. Jour. 106 (9)

WIENER BRIEFIMARKEN-JOURNAL. Wiener Briefmarken-Journal. Wien, August von Szabó, г $89 \mathrm{r}$ $4^{\circ} .81$ in. Nos. 1-7, March 1, May 1, July 1, September 1, 1891. * * Nos. 2 and 3,4 and 5 , and 6 and 7 were severally published * "Nos. 2 and 3,4 and 5 , and 6 and 7 were severally published together and there is a coloured paper wrapper to each number. A copy of the prospectus of the journal, dated February 15, 1891,
is bound up with the numbers.
Mis. St. Jour. 132 (6).

WIENER BRIEFIMARKEN-JOURNAL. Wiener Briefmarken-Journal. Illustrirtes Fachblatt für Postwertzeichen-Sammler. $\quad$ Wien, August von Szabo, r893. $4^{\circ} .8 \frac{1}{2}$ in. No. 1, February 18, $1893 . \quad$ Mis. St. Jour. 123 (10).

WIENER BRIEFIMARKEN-ZEITUNG. Wiener Briefmarken-Zeitung. Wien, Heinrich Koch, $880-92$ Fol. 121 in. 132 nos. in 12 vols.

1st year. July 1-Dec. 1, 1880. Nos. 1- 6.

2nd ", Jau. 1- ,, 1, 1881. , 1-12.

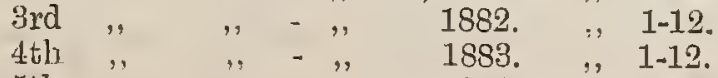

5th , , - . . 1884. ", $1-12$.

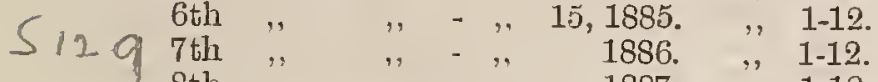

Sth " , - , ", 1.887. ", $1-12$.

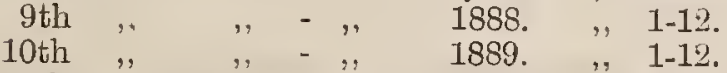

11th ", " -June, $1890 . \quad, \quad 1-6$.

13th " "Tollowing numbers 1892. ", 1-12.

* The following number's were severally published together nos. 7 and 8 , vol. IV.: nos. 7 and 8, vol. v.: nos. 4 and 5, vol. vI. nos. 7 and 8 , and nos. 9 and 10, vol. VII. : nos. 6 and 7 and nos. 8 and 9, vol. vIII. : nos. 7 and 8 and nos. 11 and 12, vol. IX.: nos. 8 and 9 and nos. 11 and 12, vol. X.: nos. 3 and 4 and nos. 5 and 6 vol. XI. : and nos. 1 and 2,3 and 4,5 and 6,7 and 8,9 and 10 and 11 and 12 , vol. XIII. Nos. 5 and 6, vol. XI., are numbered in error "vol. Ix." and there is a supplement of two pages to no. 6 , vol. vi. There were no numbers published of the twelfth year.

WIENER FILATELISTEN - CORRESPONDENZ

Wiener Filatelisten-Correspondenz.

Wien, $K$. Gergel, etc., r gor.

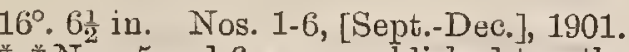

* *Nos. 5 and 6 were published together and no month of publication is given on any of the numbers. Nos. 1-4 were re-issued by R. Tambour, Wien, in a single number with a green paper wrapper bearing "Ir. Auflage". A copy of the prospectus of the
journal is bound up in front of no. 1 . Mis. St. Jour. 135 (3).

WIENER ILLUSTRIRTE BRIEFIMARKEN - ZEI TUNG. Wiener Illustrirte Briefmarken-Zeitung. Wien, Sigmund Friedl, I876-70.

$8^{\circ} .10$ in. and fol. 121 in. 48 nos. in 4 vols.

1st year. Jan. 1.5-Dec. 15,1876 . Nos. $1-12$

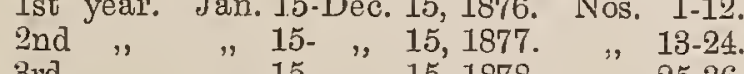

3rd " " 15- " 15,1878 . " $25-36$

* * There is " title-page and an index" to each year, suppleme ts to nos. 13 and 40 , and the numbers of vol. to nos. 13 and to, and the numbers of vol. II. are printed on yellow paper. Vol. 1. is octavo and the three other volumes are folio and a copy of the prospectus of the journal, dated December, 1875, is der with tung". This wrapper for no. 44 consists of only a single leaf.

[Continued as :]

Welt-Post

Wien, Sigmund Friedl, I880-97.

Fol. $12 \frac{1}{4}$ and $11 \frac{1}{2}-11 \frac{3}{4}$ in. Vols. V.-XxII. 131 nos.

5th year. Jan. 15 -Dec. 15,1880 . Nos. $1-12$.

6th " " 15- " 15, 1881. ", $1-12$.

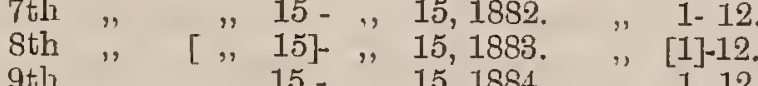

9th ", "15- "15, 1884. ", $1-12$

10th ", " "Mar., May, Aug., Oct., Dec., 1885. Nos. 1-6.
11 th year. Feb., Apl., July, Oct., Dec., 1886. Nos. 7-11.

12th " " " June, Aug., Oct., Dec., 1887. Nos. 12-17. 13th " " " " "Sept.-Oct., ", 1888. " 18-22.

15th " Jan., Apl. 20, June, Äug., Oct., Dec., 1890. " $23-27$.

16th " Feb., May-June, July-Aug., Sept.-Oct., Dec., 1891

Nos. 34-38.
17th , Feb., Apl., June, Sept., Nov., 1892. Nos. 39-43.

1Sth " Jan., Mar., May, Aug., Oct., Dec., 1893. Nos. $39-43$

19th .. Feb., Apl.-May, June-July, Oct., Dec., 189̈4. Nos.

50-54.

20th " Mar., June, Sept., Dec., $1895 . \quad$ Nos. 55-58 22nd " April 1, 15, 1897. $\quad$ ", 59-62. "* "There is a title-page and an index to each year for" $1880-84$ inclusive; there is a supplement to vol. v., no. 12, one to vol. xrv. no. 27, and a supplemental slip to vol. IX. No. 1, vol. vilI., has no number or date, and nos. 5 and 6 and 10 and 11, vol. IX., were severally published togethel: Copies of the prospectuses of the fifth, tenth and eightcenth years ar'e bound up at the commencement of each of these years. The numbers of vols. V.-rx. measure $12 \frac{1}{4}$ inches while those of the remaining volumes measure $11 \frac{1}{2}-11$ inches. Nos. 54-62 and the nine numbers of 1897 have coloured paper wrappcrs. There is very little philatelic matter in th "1897".

WIENER PHILATELISTEN - CLUB. VERTRAU LICHE MITTHEILUNGEN. Wiener PhilatelistenClub. Vertrauliche Mittheilungen. Wien, I88I-82. $8^{\circ} .9-9 \frac{1}{2}$ in. Nos. 1-3, April 15, June 15, 1881, July 1, 1882. "* Succeeded by the "Mittheilungen des Wiener Philatelisten is. St. Jour. 131 (2)

WIENER PRESSE. Separat-Abdruck aus Nr. 24 der "Wiener Presse" vom 15 Juni, 1891. [Consists of an article "Friedl's internationales PostwerthzeichenMuseum in Wien," by Martinez.]

Fol. 183 in.

Wien, Plant und Co., т89 г

Mis. St. Joum. 115 (14)

WILDEY'S IMONTHLY CIRCULAR AND POSTAGE STAMP ADVERTISER. See HENRY L. WILDEY's MONTHLY CIRCULAR AND POSTAGE STAMIP ADVIERTISER.

WILLIAIM CHARLES COKE'S MONTHLY ADVER TISING LIST OF FOREIGN STAIMPS, CRESTS IMONOGRAIMS, BOOKS, ETC. William Charles Coke's monthly advertising list of foreign stamps, crests, monograms, books, etc. Dalston, London, E., W. C. Coke, ז872. $4^{\circ} .10 \frac{1}{2}$ in. Nos. 1-3, Oct.-Dec., 1872

* No. 3 consists of a single leaf printed on one side only and con tains nothing but advertisements. Wanting nos. 1 and 2.

WILSON'S MONTHLY SPECIAL OEFERS AND BARGAINS, W. T. See W. T. WILSON'S MON'THY SPECIAL OFEERS AND BARGAINS.

WINKLER'S IMONTHLY BULLETIN. Winkler's monthly bulletin.

* in. Nos. 1-3, October-December, 1909

], I902.

* Only partly philatelic. Wanting all three nos.

WINTERBURN AND CO.'S STAIMP CIRCULAR, G. W. See G. W. Win'terburn and co.'s stamp cIRCUT. AR.

WISCONSIN PHILATELIST. The Wisconsin philatelist. De Pere, Wis., Archie L. Gowey, 1897. $16^{\circ} .6 \frac{1}{2}$ in. Nos. 1-3, Jan.-March, 1897. * There is a paper wrapper to each numbe.

Mis. St. Jour. 102 (8).

WISCONSIN PHILATELIST. The Wisconsin philatelist. "Wisconsin"s only philatelic magazine"

De Pere, Wis., Gowey Bros. and Co., I 898.
1, Nov., 1898.
Mis. St. Jonr. $102(9)$

WISDOIM. Wisdom

Calmar, Ia., G. P. Jacopson, r889-9o.

in. Nos. 1-9, December, 1889-August, 1890

** Only partly philatelic. Wanting all nos.

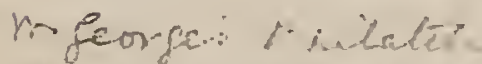




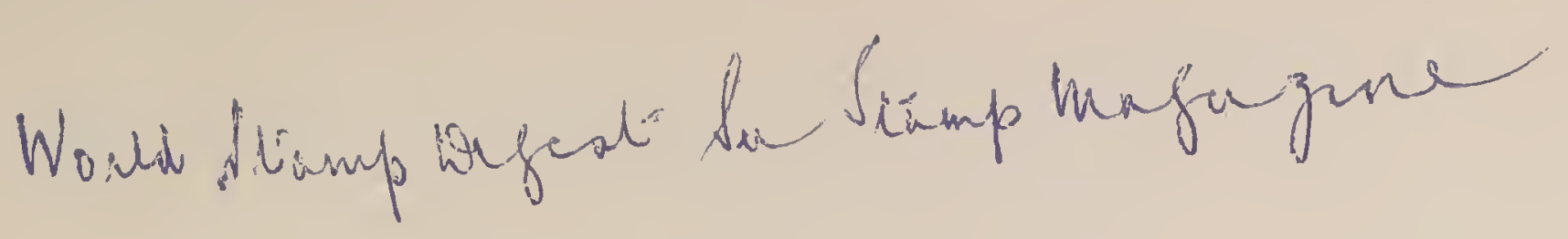

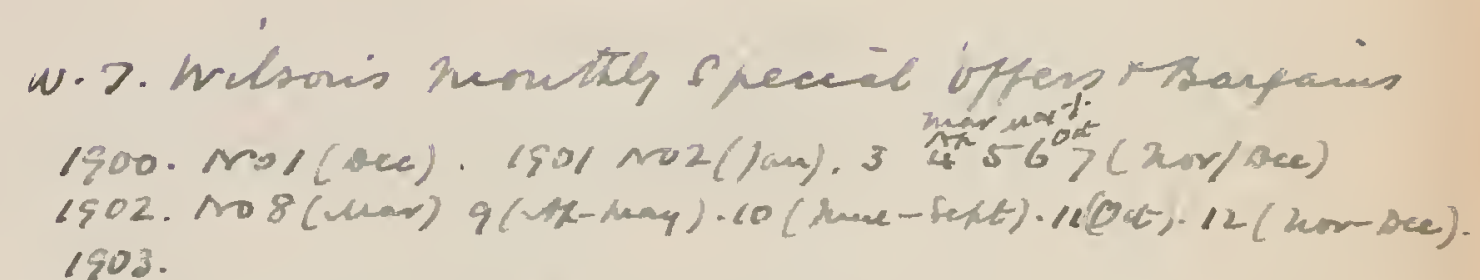

1903.

1504

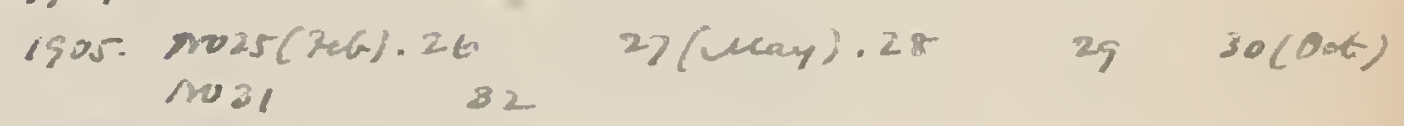

$1506 \cdot 1033$ ( $\mathrm{km} / \mathrm{Fber}) \cdot 34 \quad 35$

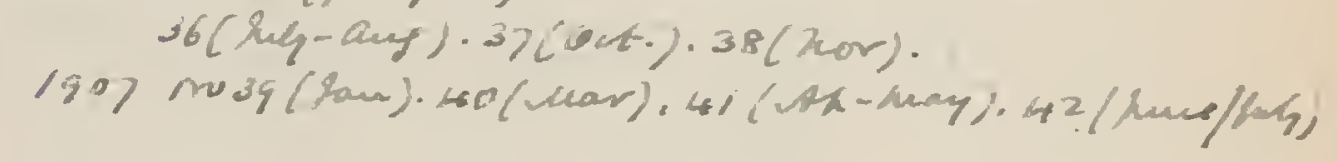

lqo8

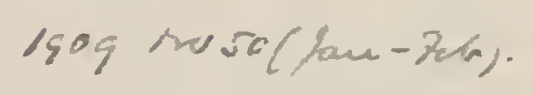

$151005($ taro $)$

1911

$1912 \quad 66$ (may) 67 (any, fofte). 68(dot).

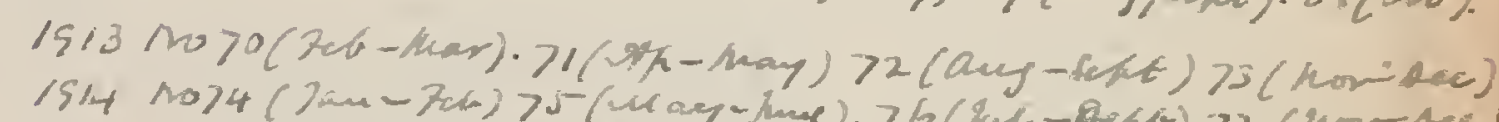

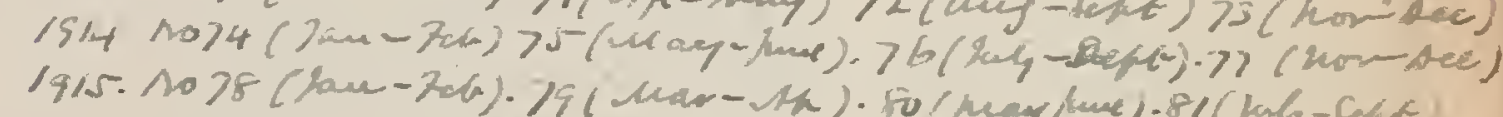

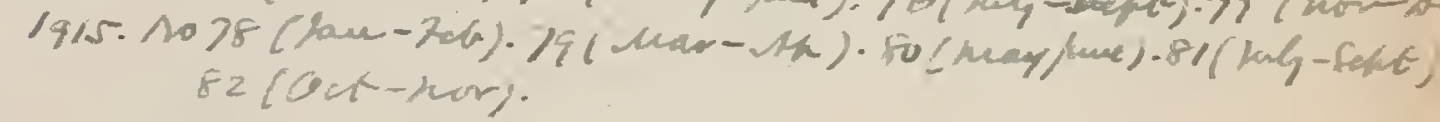

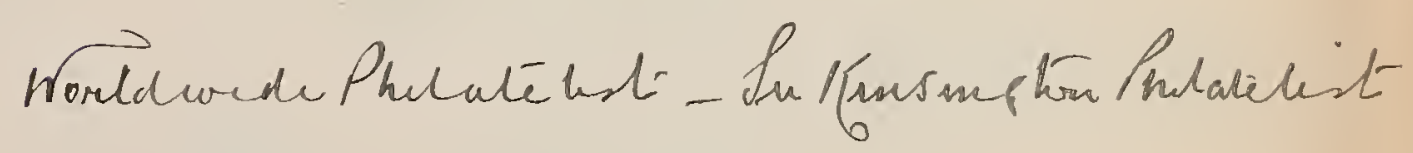


yanked norma

four and 1- vol. hor $(17.5 .94)-1130$ 
YANKEE CLIPPER. See ColleCTOR. (Smyina N.Y.)

YANKEE COLLECTOR. The Yankee collectol. McGraw, N. Y., etc., Leon V. Cass, i goo-o3. $8^{\circ} .9$ in. $32^{\circ} .5$ in. $24^{\circ} .6-5 \frac{1}{2}$ in. and $6 \frac{1}{4}$ in. 13 nos. in 4 vols. Vol. 1. Sept., Dec., 1900. Nos. 1-2.

", Ir. Mar., June, Sept., Dec., 1901. Nos. 3-6. 6 " III. " " " " $1902 . \quad, 1-4$. " "No. 1 is "octavo" no. 2 "is $32^{\circ}$. nos. $3-6$ and" no. 1 , vol. nIr., are $24^{\circ}$.

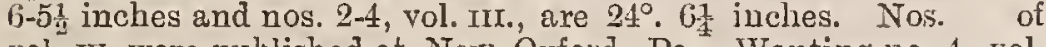
vol. Iv. were published at New Oxford, Pa. Wanting no. 4, vol. III., and all nos. of vol. IV.

YANKEE DOODLE. The Yankee doodle. A paper for stamp and coin collectors and dealers.

Thornton Heath, [Oalcham, printed], W. and $T$. Davey, 1889.

$8^{\circ} .8$ in. No. 1, April 1, 1889.

* * Printed on yellow paper. Wanting.

YANIEE PHILATELIST, The Yankee philatelist. Fitchburgh, Mass., I. C. Greene, I 885. 8. $9 \frac{1}{1}$ in. Nos, 1-2, Aug.-Sept., 1885. Nis. St. Jour. 18 (3).

YANKEE PHILATELIST. The Yankee philatelist. Devoted to the greatest hobby of the day-Philately. Barre, Vt., $H^{7}$ S. Groldsbury, etc., I 889-go.

$8^{\circ} .8 \frac{1}{2}$ iu. 13 nos. in 2 .rols.
Vol. I. Oct., $1889 \cdot$ Oct., 1890. Nos. 1-12.

"II. Nov., 1890. No. 1.

* "No. 2 is dated "Nov.-Dec., 1889 ". Nos. 9-12 were published by the Yankee Philatelist Company and no. 1, vol. r., by W. M. Holden, The last lias a coloured paper wrapper. There is a supplement of four pages to no. 10 . Mis. St. Jour. 49 (2).

YANKEE PHILATELIST. The Yankee philatelist. Boston, Mass., F. Williams, etc., I892-93. 8 . $81-83$ in. 8 nos. in 2 vols.

Vol. I. Nov., 1892-Apl., 1893, July, 1893. Nos. 1-6, 9. , III. Oct., 1893 . No. 5.

** No. 9, vol. I., and no. 5 , vol. III., were published by Cyrus $\mathrm{F}^{*}$. Willard. Each number has a coloured paper wrapper. No other number appeared. Nis. St. Jour. $62(12)$.

YOUNG AMERICAN. The Young American. Portland, Conn., Young American Publishing Co., I 888 .

* * Cuttings of the "Philatelic Department" from vol. III., no. 10े, dated October 15, 1888, are mounted in Stamp Scrap-book, nol. vI., p. 9.

YOUNG AIMERICAN, The Young American.

Kinsley, Kas., L. Lester, I 90 เ. 8. 8s in. Vol. 11, no. 1, October, 1901.

"* This number contains a philatelic department under the title "The Stamp collector". Mis. St. Jour. 144 (3).

YOUNG AIMERICAN. See MEN OF TO-MORKOW.
YOUNG BARBARIAN. The Young barbariall Fort Madison, Iowa, [?], I 886-87. * "Cuttings of the "Philatelic column," etc., from no. 6, dated August 1, 1886, and from vol. II., no. 1, dated January, 1887, are mounted in Stamp Scrap-book, vol. v., pp. 79 and 108, 109.

YOUNG CANADA. Young Canada.

Neil's Harbor, N. S., W. S. McLecun, ז887.

Fol. 12 in. No. 1, July, 1887. *.re also mounted in Stamp Scrap-book, vol. v., pp. 105-106. Mis. St. Jour. $109(16)$.

YOUNG COLLECTOR. The Young collector.

Brooklyn, N. Y., R. C. Smack, I892. $16^{\circ} .6$ in. and $8^{\circ} .10 \frac{1}{-9}-9 \mathrm{in}$. Nos. $1-10$, January-December, 1892.
${ }^{*}$ No. 1 is $16^{\circ}$. and the remaining numbers are octavo. There is
$*$. The no number for April or for and nos -10 have coloured paper wrapper's. Wanting no. 7 .

YOUNG COLLECTOR. The Young collectol:

Kansas City, Mo., Custer Publishing Co., I 905. $8^{\circ} \cdot 7 \frac{1}{1}$ in. No. 1, February, 1905.

* *nly partly philatelic. The number has a coloured paper Mis. St. Jour. 126 (2).

YOUNG COLLECTOR. The Young collector. A monthly stamp paper.

Red Lion, Pa., W. O. Smith, I897. $8^{\circ} .81-83$ in. Nos. 1-12, Jan.-Dec., 1897.

** No. 3 and nos. 5-12 have coloured paper wrappers. No number 11 for" November" was published. Succeeded by "Fairmount exchange".

YOUNG ENGIAND. Young England. Vol, I. nos. 6-10. [Contain articles entitled "The Postage stamps of the world," by Dr. John Edward Gray of the British Museum.] London, W. Tweedie, I862. $8^{\circ} .10$ in. pp. 91-93 : 102-103 : 117-118: 135 : 149-150.

YOUNG FOLISS AT HOME. Young folks at home Dixon, Ill., R. O. Butterfield, I8go. "** Cuttings of the philatelic portions from vol. r., no. 4, dated June, 1890, are mounted in Stamp Scrap-book, vol., vi., pp. 104106

YOUNG GENTLEMAN'S MAGAZINE. See EVERY BOY'S MAGAZINE.

YOUNG IDEA. The Young idea.

Belvidere, Ill., Gront C. Whitney, 1888. *"Cuttings of the philatelic portions from vol. II., no. 8, dated August, 1888, are mounted in Stamp Scrap-book, vol. vi., p. 8.

"YOUNG NATAL". "Young Natal". No. 1, May, 1902. [Contains an article "Stamp collecting" by G. W. Loomis from the "International philatelic review"; "Stamp notes" conducted by "Philatelist" and two advertisement pages headed "The Stamp collector's advertiser".] Newcastle, Natal, [?], I902. $\mathrm{S}^{\circ} .8$ in. pp. 12-14, 25-26. * * The number has a coloured paper wrapper. The name of the publishers is not given.

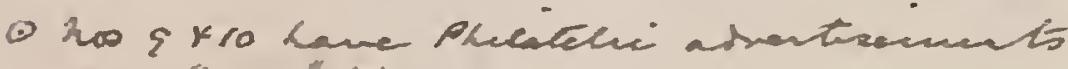
$47: 3$ kang. Eats

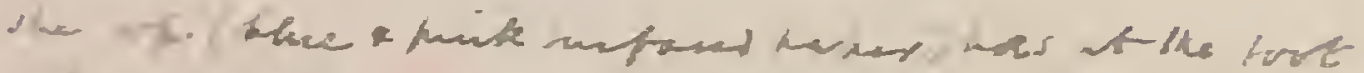


YOUNG NOVA SCOTIA. Young Nova Scotia. I 882 . New Glasgow, Nova Scotia, Mr'Donald and Grant, * * Cuttings of the "Stamp and coin department," etc., from vol. III., no. 3, dated March, 1882, are mounted in Stamp Scrap-book, vol. จ., pp. 107, 108

YOUNG PEOPLE'S COMPANION. The Young people's companion.

St. Lowis, Mo., James W. Sells, ctc., 1900-02. $8^{\circ} .10 \frac{1}{2}-10 \mathrm{in}$. and $9 \mathrm{in.}$ nos. in 2 vols.

Vol. I. June, 1900- 1901. Nos. 1 . Vol. I. June, 1900- 1901- 1902. Nos. 1 . 1 . *" Only partly philatelic. Nos. "1-10, vol. I., measure $10 \frac{1}{2}-10$ inches and the remaining numbers, 9 inches. Commencing with no. 11 , vol. I., the journal was published by Sells and Townsend. Each number has a paper wrapper and the number for November, 1900 , has "No. 7 " on the wrapper and "no. 6" inside. Wanting all but vol. r., 1, 7, 10, 11 and II. 3, 11 .

YOUNG PHILATELIST. The Young philatelist. Albany, N. Y., Fraser Brown, [1892]. $64^{\circ} .3 \frac{1}{2}$ in. Nos. 1-2, [Oct.-Nov., 1892].

* * There is a paper wrapper to each number. At the back of the two front wrappers the name of W. H. Haskell Jr, is given as that of the business manager. Mis. St. Jour. 71 (3).

YOUNG PHILATEIIST. The Young philatelist. A journal for young stamp collectors.

Burton-on-Trent, K. Bucknall, I9०3.

$8^{\circ}$. $\mathrm{C}_{2}$ in. Nos. $1-5$, Feb.-June. 1903 .
** Produced by a hand multiplying press with the exception of o) 1 which is wititten throughout with pen and ink.

YOUNG PHILATFLIST'S ADVERTISER. The Young philatelist's advertiser. Circulated all over the world.

* * Produced by a hand multiplying press. Bound up with the ** Produced by a hand multiplying press. Bou
number is a copy of the prospectus of the journal. Mis. St. Jour. 81 (4).

YOUNG POSTAGE STAMP COLLECTOR. The Young postage stamp collector.

Bangalore, India, F. K. De Cruz, I 905.

$8^{\circ}$. $8 \frac{1}{2}$ in. No. 1 , July, 1905 .
** This publication was intended purely as a skit on the many insignificant stamp journals of the day. It was issued by E. W. Wetherell under the pseudonym " F. K. De Cruz," and only about
ten numbers were printed.
Nis. St. Jour. 112 (5). Wis. St. Joutr. $112(5)$

YOUNG SPORTSMAN. The Young sportsman, Portsmouth, N. H., W. I. Terhune and F. L. Howard, 1872 .

* * Cuttings of the stamp portions in the number for May and July, 1872, are mounted in Stamp Scrap-book, vol II., pp. 36, 39.

YOUNG STAIMP COLLFCTOR. The Young stamp collector London, S.W., F. J. Melville, I 900.

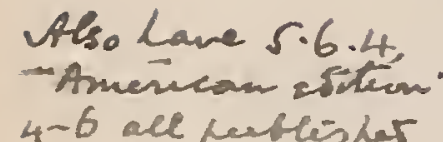

c. $8^{\circ} .93$ in. Nos. 1-6, March-August, 1900 . ** Bound up with the journal is a copy of the prospectus, dated nightly," no. 146, October 13, 1900 . Mis. St. Jour. 78 (10).

YOUNG WORID. The Young world.

Syracuse, N.Y., Robert E. Livingston, 1888.

* * Cuttings of the philatelic portions from vol, III, no.? dated

F'ebruary, 1888, are mounted in Stamp Scrap-book, vol. vi., p. 9.

YOUTH, Youth. Buffalo, N. Y., S. W. Allerton, 1901.

Fol. 16 in. Nos. 1-26, [? ]-December 18, 1901 .
$* *$ Only partly plilatelic. The journa] was continued after no. 26, but ceased to be philatelic. Wanting all but nos. 20, 22, 26.

YOUTH'S ADVOCATE. The Youth's advocate. Colebrooli, Conn., Chavles E. Baglin, I885. **" Cuttiugs of the "Notes" on philately, etc., from vol. IT., no. 1, dated June, 1885, are mounted in Stamp Scrap-book, vol. v., p. so
YOUTH'S BAZAAR AND STAIMP, COIN, AND CURIOSITY IMART. The Youth's bazaar and stamp, coin, and curiosity mart.

London, S.W., Knaresborough, Yor\%s [printed], $H$. Spencer and Co., I 889 .

$8^{\circ} .7 \frac{1}{2}$ in. No. 1, April, 1889.

Mis. St. Jour. 80 (2)

YOUTH'S COIMRADE. 'The Youth's comrade.

Boston, Mass., A. Bullard and Co., 1896

Fol. 133 iu. 11 nos. in 2 vols.

Vol. I. Jan.-June, 1896 . Nos. 1-6.

* " Only partly philatelic. Nos. 1-5, vol. I., bear the words "Neiv Series".

[Continued as :]

The Youth's realm.

Boston, Mass., A. Bullard and Co., I896-1906. Fol. $13 \frac{1}{2}-14_{4}^{3}$ in. Vols. II.-XIr., 114 nos.

Vol. II. Dec, 1896 . No.

" III. Jan.-Dec., 1897. Nos.

$1-12$.

"T. " - " 1898. ", $1-12$.

" $\quad$ VI. $\quad, \quad, \quad, \quad 1900 . \quad, \quad, \quad 1-12$.

, VIII. ", - ". $1901 . \quad$ ", $1902 . \quad 12$.

" $\quad$ Ix.

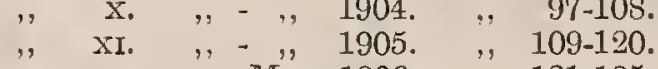

*" XI. "May, $1906 . \quad$ " 121-125. * Only partly philatelic. Commencing witl vol. vII., 110. 11 the size was increased to 143 inches, and the following nos. have paper wrappers vol. II., no. 6 ; vol. III., nos. $2,5,7,10$, 12 ; vol. IV., nos. $1,2,3,4,6,7,8,10,11,12$; vol. V., nos. $2,10,11,12$; 11. vol. vi. are found printed on coloured as well as on white paper.

\section{YOUTH'S EFFORT. See EFFORT.}

YOUTH'S FXCHANGE. The Youth's exchange. Devoted to stamp, coin and literature exchange. Federalsburg, Md., J. W. Stowell, ז89o. $24^{\circ} .5$ in. Nos. 1-3, July-Sept., 1890.

** Thero is a coloured paper wrappor to each number. Wanting $* *$ Thero
nos. 1,3 .

[Continued as:]

National exchange.

Federalsburg, Md., J. W. Stowell, etc., I890-9г. $8^{\circ} .8$ in. Nos. 4-10 and no. 12, Oct., 1890-April, June-July, 1891. * * Only partly philatelic. There is a coloured paper wrapper to each number. No. 12 was published by the Eastern Publishing

Co, and there is no no. 11. Nos. 5-10 and no. 12 have the article "The" preceding the title, except on the wrappers.

YOUTH'S FXCHANGE. The Youth's exchange Norfolk, Va., H. Salomonsky, I 890-91.

Fol. 11 in. Nos. 1-5, September, 1890-January, 1891.

* * Only partly philatelic. Wanting all but no. 2.

YOUTH'S FXCHANGF. The Youth's exchange. Green's Landing, Me., A. A. Goss, I8gI. in. No. 1, June, 1891

** Only partly philatelic. Wanting.

YOUTH'S GAZETTE. The Youth's gazette.

Cleveland, O., E. C. Fox, I 885 .

$8^{\circ} .8$ in. Nos. 1-3, April-June, 1885.

* Only partly philatelic. No. 3 is bound up in Mis. St. Jour. $143(5)$ and the philatelic portions of no. 1 are mounted in Stamp Scrap-book, vol. .., pp. 83, 84. Wanting no. 2.

YOUTH'S GAZETTE AND ADVERTISER. The Youth's gazette and advertiser. A newspaper and review for the rising generation. Published on the 1st and 15th of every month.

London, W., F. May, I869-70. 8. 10 in. Nos. $1-3$, Dec. 1 , Dec. 15,1869 , Jan. 1,1870 * * Only partly philatelic. There is a copy of no. 3 in the Britisl Museum Library, Wanting no. 3. Mis. St. Jour. 78 (12). 


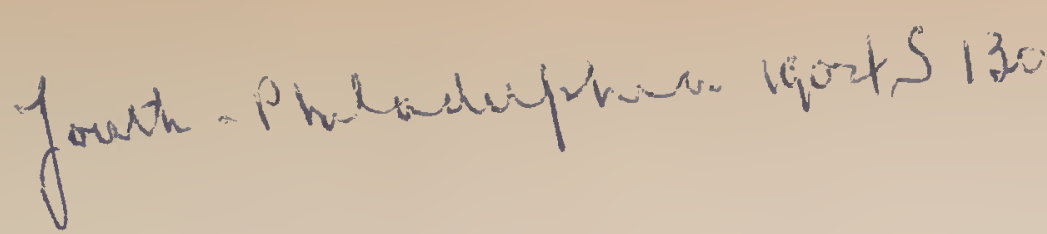

Youth's companion

Young Stank collector.

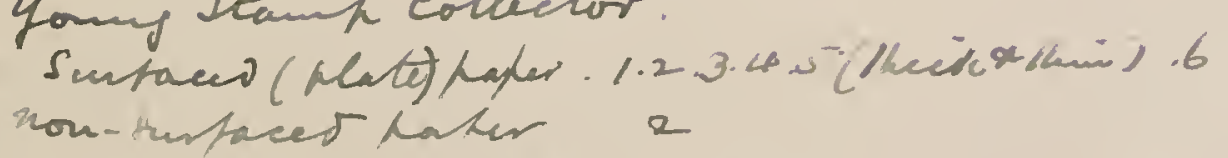

y) American $50.40-6{ }^{2}$

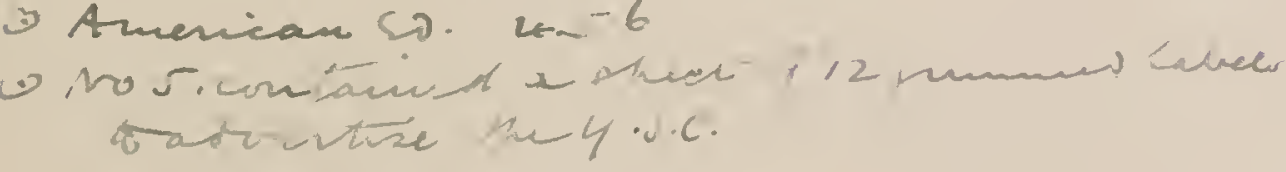


The Yuhbin Kitte (Tokyo, Japan). Vol. 1, Oct.-Dec. 1926.
The 3 parts with T.P.I. Text entirely in Japanese $2 /$ - 
YOUTH'S HERALD. The Youth's herald. Fol. 11] in. Nos. 1-7, [? J-January, 1886.

Decatur, Tex., Chas. Cates Jr., I885-86.

YOUTHS' JOURNAL. The Youths' journal.

Jachison, Mich., Archie W. Shaw, I890-91

$8^{\circ} .9 \frac{1}{2}$ in. Nos. 1-5, December, 1890, January, March, May, June 1891 . S130 "* Only partly philatelic. Each number has a coloured paper "April" is blotted out and "June" is struck below. Wantin nos. $1,2,3$.

\section{[Continued as:]}

The Collector's journal.

Jackson, Mich., The Central City Stamp and Publishing Co., I89I.

$8^{\circ} \cdot 9$ in. Vol. II., 4 nos.

Vol. II. July-Oct., 1891. Nos. 1-4.

* Only partly philatelic. Nos. 8 and 4 wcre published together and no. 1 has a coloured paper wrapper.

YOUTH'S IEADER. The Youth's leader.

Canajoharie, N. Y., Barretit Brothers, I 885 .

Fol. $15 \frac{1}{2}$ in. No. 2, June, 1885

* * Only partly philatelic. Cuttings of the "Philatelic Department" from this number are also mounted in Stamp Scrap-book, vol. . . pp. 81,82 .

Mis. St. Jour. $136(4)$

YOUTH'S LEDGER. The Youth's ledger.

Helmetta, N. J., etc., Alvah Davison, etc., I885-88. Fol. $15 \frac{1}{2}$ in. 28 nos. in 3 vols.

Vol. I. Dec., 1885-Nov., 1886. Nos. 1-12.

" II. " 1886- ", 1887. ", 13-24.

*" III. "̈ 1887-Mar., 1888. "̈ 25-28. * * Only partiy philatelic. Nos. 16-28 were published by the
Youth's Ledger Company at Now York.

[Continued as :]

The Youth's ledger. An interesting monthly for the young; now the Collector's ledger.

Bloomfield, N. .T., The Ledger Co., r888.

8.9 $9 \frac{1}{2}$ in. Vol. TV., 4 nos.

Vol. IV. Apl.-July, 1888. Nos. 1-4.

* * Nos. 3 and 4 have also "whole number 31 " and " 32 " respectively, and there are coloured paper wrappers to all four numbers the title on which reads "The Collector's ledger".

[Continued as :]

_ The Collector's ledger.

Bloomfield, N. J., The Jiedger Co, 1888-89. $8^{\circ} .97$ in. Tol, IV., 8 nos.

Vol. IV., Aug., 1888-March, 1889. Nos. 33-40.

* * There is a coloured paper wrapper to each number. The thit on no. 40 reads "Tho Collectors ledger", There are two editions of no. 33. The second edition has on pp. 68,69 , a notice concerning free subscriptions to members of the American Phiof both editions are in the library.

YOUTH'S LEISURE HOUR. The Youth's leisure hour. Boonville, N. Y., F. C. Johnson, I887-88 $8^{\circ} .9$ in. Nos. 1-7, September, $1887-[?$
* * Only partly philatelic. Wanting all but no. 1.

YOUTH'S MAGAZINE. The Youth's magazine. Scranton, Pa., The Youth's Magazine Publisting Co., I 893 .

$8^{\circ} .83-10$ in. 10 nos. in 2 vols

Vol. I. Jan.-June, 1893. Nos. 1- 6 .

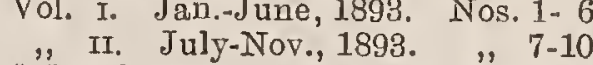

* "* Only partly philatelic. N"os. 5 and 6 were published together, nos. 4-10 have coloured paper wrappers and no. 9 is dated Septem ber-October, 1893 . The wrapper of nos. 5 and 6 only bea s "No 6 ". The philatelic matter in no. 10 is headed "Philatelic news Supplement of the youth's magazine. Volume 1, November, 1893. No. 1." Wauting nos. 1,9.

YOUTH'S PILOT, Youth's pilot.

San Antonio, Texas, Hoefgen and Brotze, I 886. * " Cuttings of the "Philatelic department," etc., from nos. 3-10 dated January 1-August, 1886, are mounted in Stamp Scrap-book vol. $v$., pp. 84-98. Nos. 9 and 10 were published together.

YOUTH'S PRESS. Sče AMATEUR PRESS.

YOUTH'S REALIM. See YoUTH'S COMRADE.

ZƯRCHER BRIEFMARKENBÖRSEN - ZFITUNG. Zïrcher Briefmarkenbörsen-Zeitung.

Zuvich, $\stackrel{F}{F}$. Mentee, I894-I 903 .

$8^{\circ} .8 \frac{1}{4}-9 \frac{1}{2}$ in. and $4^{\circ} .11 \mathrm{in.}$ nos. in 9 vols.
1st year. Oct. 25,1894 -Sept. 25,1895 . Nos. $1-12$

2nd $25,1895-125,1896.2$. Nos. 1-12.

3rd ", " 25, 1896- " $25,1897 . \quad$ ", $1-12$.

4th ", " $1897-, \quad 1898 . \quad$ " $1-12$.

6 th " " " $1899-", \quad 1900 . \quad$ " $11-12$

7th " " "1900 ", 1901. ", $1-12$

8th. " " 1901- ", 1902. ",

* * The title reads "Zürcher Briefmarken-Börsenzeitung" com mencing with vol.IV., no. 1. The numbers of the first three years are octavo and the subsequent numbers are quarto. No. 4 of the fourth year is numbered in error " 3 ". Wanting vol. III., 12 . IV., $3,8,9,11 ;$ v. 1,2 , and any after 3 ; v., all but 11,12 ; vm., 5 ; IX., all but 109

$$
\begin{aligned}
& \text { Youths nespogwie. Lanton. } 1862 .
\end{aligned}
$$

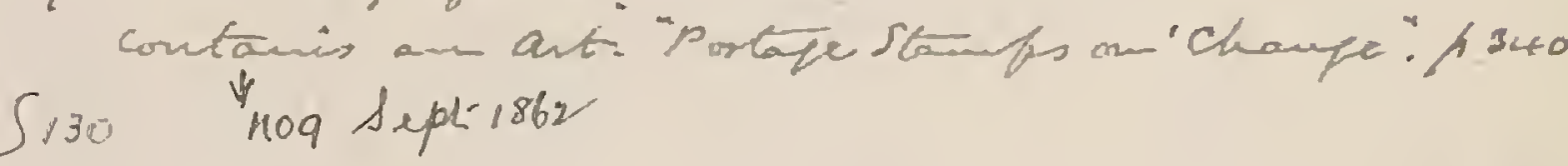


The hrst Philatelic Journals of their respec tive countries :-

rgentine Republic.-Revista Philatelica, Aug., 1884 -Instria.-Brielmarken-Anzeiger, June, 1866.

Bolsium 1863. Vol. I., II.

Bolivia.-Filatelica Boliviana, July, 1893.
Brazil._-Brazil Philatelico, Jan., 1882.

British Guiana-B.G. Phil. Journal, 1906.

Bulgaria.- " Glass," October, 1893. Gazette, June,

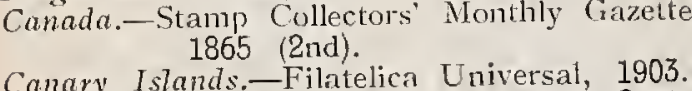

Canary Islands.-Filatelica Universal, 1903. Colombia.-Annunciador, March, 1879 (2nd). Costa Rica.-Costa Rica Postal, Oct.

Cubacao-Con del Caribe, lich, 1891.

Denmark-Nordisk Frimaerketidente, Aus., 1867.

Dominican Republic.-Filotelica, Jan., 1885.

Ecuador.-Ecuador Filatelico, Jan., 1886.

Egypl.-Timbrologic Egvptienne, October 1891.

France.-Collectioneur de Timbre-Poste, July, 1864 .

May, 1863. Vol. I

Great Britain.-Monthly Intelligencer, Sept., 1862.

Crece.-- Hermes, March, 1891. 1887.

Holland-Continental Philatelic Magazine, Feb..

1869.

Hong Kong.-Hong Kong Philatelic Journal, Jan.,

India.-India Philatelist, May, 1894

I taly-Posta Mondiale, July, '1873.

Japan.-Yuraku, 1916. Universal, May, 1890

Luxemburg.-Philateliste Universal, May, Advertises.

Malta.-Malta Philatelic Chronicle and Kanertisen. Mexico-Boletin de L.

- March. 1889. Murocco.- Marco Timbrologique, February, 1897. Mlates New Zealand.-Philatelic Times, Nav 1891 (2nd). Norzoay._Nordisk Frimaerlsblad, July, 1889. Paraguay.-Revista del C. F.d Paraguay, 1923.

Peru.-Percurio October, 1886. Porto Rico.-Filatelia Antillana, March, 1893. Portugal.-Philatelista, Nprit, 1887. Julv, 1893 Queenstand.-Austratian Stamg News, July, 1893.

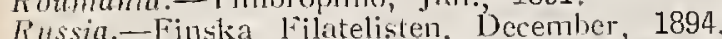

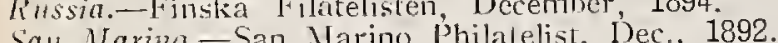
Suuth dustralia - Australian Stame Collectors

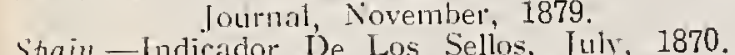
Sriveden,-Tidning for Frimarksamlitre, Dec, 1886. Switserland. - Schweizerische briefmarken Zeitums Tasmania.-Federal Australian Philitelist, Jan. Tripoli-Timbrologie Africane, September, 1893.

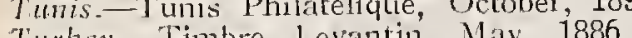
United States.-Stamp Collectors' Record, Dec., 1864 Uruguay.-Revista del C.C. del Uruguay. Venezuela.-Anunciador lialatelico de Venezuela Jan., 1892 .
Victoria_-Barry's Philatelic Monthly, 1st, Nov, 1887; Australian Stamp Collector,
October, 1893. 


\section{APPENDIX A.}

LIST OF PHILATELIC JOURNALS ARRANGED UNDER THE COUNTRIES OF ISSUE IN CHRONOLOGICAL ORDER.

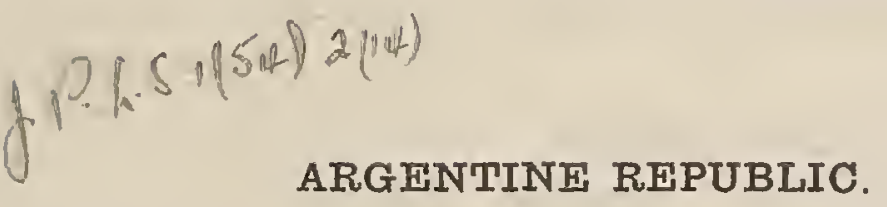

Revista Phimatélica. Buenos Ayres. Aug.-Sept. 1874.

Internationara Post. Buenos Aires. July-Dec. 1891.

Coleccionista Argentino. Buenos Aires. Oct. 1892-Sept. 1893.

Filiatelista Sud-Americano. Buenos Aires. Jan. 1893Nov. 1896.

Revista Filatélica de ua Cp. San Juan R. Argentina. San Juan. June 1893.

Rosario Fituatéuico. Rosario de Santa-Fé. July 1893March 1897.

Comeroio Filuatélico. Paraná. Oct.-Nov. 1893.

Buenos Aires Postal. Buenos Aires. Jan.-Mar. 1894.

Filatélitoo Argentino. Buenos Aires. Sept.-Oct. 1894.

Argentino Fllatelico. Rosario de Santa-Fé. Sept. 1894Oct. 1895.

- Revista de la Sociedad Finatélica Argentina. Buenos Aires. Nov. 1894- (In progress.)

Correo Sud-Americano. Buenos Aires. April-Sept. 1896.

Aguinaldo. San Juan. Jan. 1897.

Filatélico Amerioano. La Plata. April-Nov. 1897.

Voz del Filatélista Americano. Rosario de Santa Fé. May-Oct. 1898.

Revista Postal. Buenos Aires. June 1898-Feb. 1899.

Bunfos Aires Filatúlico. Buenos Aires. July 1898-Aug. 1900.

Firatéria. Buenos Aires. Jan. 1901-Dec. 1904.

Investigador Americano. Buenos Aires. July 1903-April 1904.

Argentina Fildatélica. Buenos Aires. Aug.-Oct. 1903.

Guia Filatélica Mensual. Mendoza. Jan. 1904-Oct. 1906.

Coleccionista. Rosario de Santa Fé. April 1904-March 1907.

Macaneador Filatélico. Buenos Aires. May 1904.

Valija Postat. Buenos Aires. June 1905-Oct. 1906.

\section{AUSTRIA}

Brieguarken-Anzeiger. Triest. June 1866.

Deutsche Briefmarken-Sammler. Aussig. 1869.

Philatelistische Berichte. Rudolfsheim. July 1872-Dec. 1877.

Corriere dei Francoborut." Trieste. March 1875-April 1879.

Wiener Illu ustrirte Briefmarken-Zitung. Wien. Jan. 1876-Dec. 1879

Timbrofilo. Trieste. May 1876-Aug. 1877.

Anzeiger Der Wienerillustrirten Briefmarken-Zitung. Wien. Jan.-Dec. 1879.

.WeLt-Post. Wien. Jan. 1880-1897.

- Wiener Briefmariken-Zeitung. Wien. July 1880-Dec. 1892.

Rowland Hict. Wien. April 1881-July 1882.

Wiener Philatelisten-Cuub. Vertrauliche MittheilUNGEN. Wien. April 1881-July 1882.

Sigmund Friedi's Philatelistische Bhrichte. Wien. July 1882-Dec. 1884.

Mitmheilungen des Wiener Philatelisten-Crub. Wien. Aug. 1882-May 1885.

Grobus. Wien. Oct.-Dec. 1882.

Arigemeiner Briefmarken-Anzeiger Vereinigte Erdbali Mercur. Wien. Aug. 1883-April 1887. (Other numbers were published in Germany).

Fliegende Brätter für Deutsche Phitatelisten. Wien. 1884.

Mittheilungen des Oesterlieichischen PhilatelistenCuub. Wien. Jan. 1886-April 1894.

Philatelistisoher Börsen - Courier. Mährisch - Ostrau. July 1886-Sept. 1894.

Phimatemistische Presse. Crernowitz. Nov.-Dec. 1887.

Philatelistisohe Bliätrter. Brünn. 1887.

Oesterreidhische Philatelisten - Zeimung. Czernowitz. July 1889.

Amateur. Wien. Oct. 1889-Jan. 1890.

Wiener Briefmarken-Tournar. Wien. March-Sept. 1891. 
Kosmos. Prag. Aug.-Oct, 1891.

Poste Untversei.te. Vienne, etc. Jan. 1892-1894. (Nos. 1-2 were published in Ttaly.

Grazfir Phitatelist. Gra\%. March 1892-March 1897.

Fontuna, Oedenburg. April-May 1892. (Nos. 1-31 were published in Germany)

Iludustriertes Briefmarigex-Journal " Fortuna". Oedenburg. July 1892-June 1893.

Tnternationale Briefmarienzhitung. "Südamertika." Czernowitz. July 1892-April, 1894.

Corrmspondenz Seyfrimid. Prag. Oct. 1892-Feh. 1893.

Verminsmotr. Laibach. Jan.-Feb. 1893.

Wiener Briefmariken-Journat. Wien. Feb. 1893.

Oesterreichische Correspondenz. Prag. March-Oct. 1893.

Untversunt. Budapest. April 1893.

- Austria-Philatelist. Prag. Dec. 1893-Nov. 1899.

Monats-Bericht und Speztal-Offerte für BriefmarienHändLER. Pilsen. Dec. 1893-Aug. 1894.

Nicht-ILlustrierte Postwhrtzeichen Zeitung. Karlsrube. Feb. 1894.

Porski Fitratelista. Kraków. April 1894-Árgo 1900

Neut Briefmarken-Zeitung. Karlsbad. Sept.-Nov. 1894.

Verbands-Nachrichten Des ' Internationalen PhilateListen Verbandes $7 U$ Märr.-Ostrau. MährischOstrau. Nov.-Dec. 1894.

Internationales Briefmarkenblatt "Concordia". B.Leipa. April-Aug. 1895.

Budapester Philatetistische Correspondenz. Budapest. Oct. 1895 .

Český Fimatemista. Praha. Feb. 1896- (In progress.)

Rund um die ERDE. Friedland. March-July 1896.

Poste Universelue. Seconde série. Vienne. 1896-1897.

Oesterreichische Briefmarken-Zittung. Wien. Nov. 1897-Jan. 1899.

MittheILUngen des "MertiuR" . Wien. "Dec. 1897.

SÜDUNGarische Briefmarken-Zeitung. Karansebes. Jan.April 1898.

Sohriftlitohe Mittheilungen des "Mercur". Wien. Feb.-May 1898.

Posta-ÉRTÉK Gxüjtör Htrdetési Lapja. Szatmár. AprilJune 1898

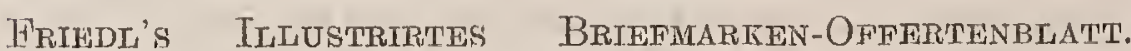
Wien. Nov. 1898. (In progress.)

LmVÉLBÉLXEGGYŨJTör LAPJA， Budapest. Dec. 1898.

Firatelita. Kraków. Jan.-Dec. 1899.

VILÁGPosta. Budapest. March-June 1899.

Béltgavituág. Nagyvárad. Nov.1899-Jan. 1900.

Internationale Briefmarkme-Börse. Temestár. Sept.Dec. 1900.

Levélbéluyeg Forgatmi KözLöny. Budapest. July 1901.

Szerula Brimfmarken Verkerk. Budapest, etc. Sept. 1901- (In progress.)
Wientar Fithathistifin-Correspondenz. Wien. Sept.-Dec. 1901.

Guobus. Wien. Feb.-April 1902.

BĖLIEgGYüITö. Budapest. Feb. 1903-Dec. 1906.

Hungária. Budapest. Oct. 1903-May 1904.

Briefmarken-Courier. Budapest. Aug. 1904-Sept. 1905.

BéLYeg-Ujság. Budapest. Feb. 1905-Jan. 1906.

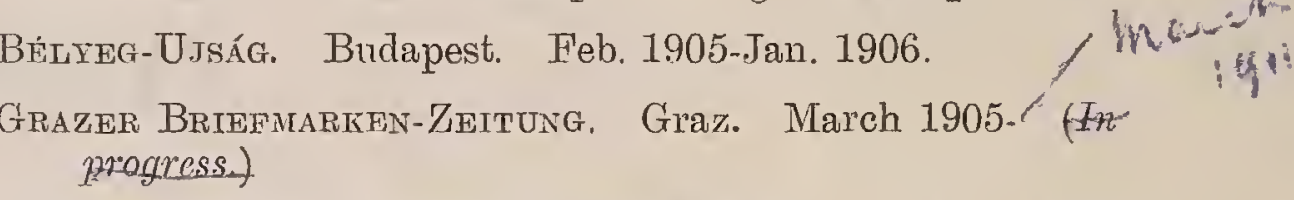

Oesterreichische Briffmarken-Zeitung. Wien. April 1905-April 1906.

Philatelistischess Omfertenblatt. Budapest, April-June 1905.

Magyar Bétyeggyü.rtö. Budapest. July 1905- (In progress.)

Revue Philuatélique. Budapest. Nov.-Dec. 1905.

BÉLIEGGy Ư.TöK LAPsa. Budapest. Jan.-April 1906.

Luevítubéliyeg - Tözsde Briefmarken - Börse. Temesvár. Jan. 1906- (In proyress.)

\section{AZORES}

Açores. Angra. Mar.-May 1905.

\section{BELGIUIM}

Timbre-Poste. Bruxelles. Feb. 1863-Dec. 1900.

Timbre Fiscat. Bruxelles. Jan. 1874-Dec. 1896.

Colimationneur de Timbens. Ledeberg-lez-Gand. AprilSept. 1882.

Moniteur des Timbrophiles. Gand. April 1882-June 1883.

Bulletix de la Soctété Timbrophite de Bruxelles. Bruxelles. Nov, 1883-Jan. 1884.

Annonde Timbrophilique. Bruxelles. May 1884-Jan. 1885.

Courrter du Timbrophite. Bruxelles. Feb. 1887-Dec. 1890.

Annonce Timbrologique. Liége, etc. March 1890- (In progiess.)

Courrier TimbrophiLique. Bruxelles. Jan.-Dec.1891.

Journat d'Annonces des Collectionneurs Anversois. Anvers. April-June 1892.

Timbrologite Anversoise. Anvers. June 1892-Jan. 1894.

Anvers Philathélique. Anvers. Sept. 1892-April 1896.

Bulletin Mensued des Nouvfautés. Bruxelles. Oct. 1892-Dec. 1893.

Echange de Tmmbris-Poste. Looz. . May 1893-Dec. 1896.

Presso-Philatélite. Anvers. Nov. 1893.

- Revue Postale. Liège. Nov. 1893-July 1896.

- Revue Phitiatélique Berger. Bruxelles. Jan. 1894-June 1903.

Monde Phimatílatque. Gand. Sept. 1894-Aug. 1896.

RÉClame Philatélique GÉnérale. Anver's. July 1895.

Frandre Philatílique. Gendbrugge. Dec. 1895-Oct. 1896. 
. 

Moniteur Phitatélique. Gand. Jan.-Dec. 1896. Schaldis Philatélique. Anvers. July 1896-Aug. 1897. Réclame Timbrotogique. Anvers. Aug. 1896-Feb. 1898. Annonce Univfreselte. Anvers. Oct. Avor. 1896, - fan General Wett Briffyarkfin Buatt. Bruxelles. Oct. 1896. Phimatėiste Anversois. Anvers. Nov. 1896-Oct. 1898.

Buluetin Mensuel de la Sociétet les t́changistes réunis. Fexhe-Sluis, lèz-Liége. Dec. 1896-Dec. 1900.

Monither Philatélique. Gand. Jan, 1897-Feb. 1899.

Écho du Collectionneur. Ixelles. July 1897.

Antvarpia. Anvers. Sept. 1897-Sept. 1900.

Courrier Philatélique Belge. Tongres. Jan. 1898-Ang. 1900.

Timprophilis Belge. Bruxelles. Feb. 1898-Dec. 1905. Aurore Philatédique. Anvers. July 1898-[? Jume] 1900. Propagande Philatėlique. Gand. Jan. 1899.

Réclame Philatélique Universelile. Anvers. Jan.-May 1899.

Vlaamsche Verzamelaar. Antwerpen. Jan. 1899.

Beigique Philatélique. Anvers. Mar. 1899.

Circulatre Mensuelte de la Ligue d’hehange Timbres pour Coutanctions. Spa. [? IFay]-Dec. 1899.

Eissor Phitatḱlique. Gendbrugge. Nov. 1899-March 1906. Courrifrer Phitatétique Beige. Spa. Dec. 1899-Mar. 1902.

Circutatre mensuelie de ta Ligue d’achat etr d'echange TIMBRES POUR COLLECTIONS. Spa. Jan. 1900-Mar. 1901.

Phitatimiste Berge. Boucherie, Gand. March 1900.

Conternationat. Gendbrugge. April 1900 .

Occasions Philateliques. Ixelles. June 1900-March 1903.

Revue Postare. Fexhe-Sluis, lèz-Liége. Jan. 1901- (In progress.)

Circulatre Mensuetite de LA Ligue D'AChat timbres Pour CollemCtions. Spa, etc. Apl.-Dec. 1901.

Intermédiatre des CorileCtionneurs de TtMrbres-poste, Cartes-postalems, etc. Liége. Dec. 1901-May 1903.

Timbre Belge. Namur. 1901-Fé.1902. in ay

Réclame Philatétidque eit Philocartiste Universelite. La Louvière. March 1902.

Philatér iste Belge. Gand. May-Aug. 1902

Annonch Anversoise. Anvers. May 1903-Sept, 1904.

Mercurius. Antwerpen. Sept.-Nov. 1903.

Rèclane Philatélique et Cartophile. Hasselt. Nov. 1903- last

Étoire Philatélique Belge. Gand. Jan.-Nov. 1905.

Echangiste Philatéliste Universet. Anvers. Oct. 1905-

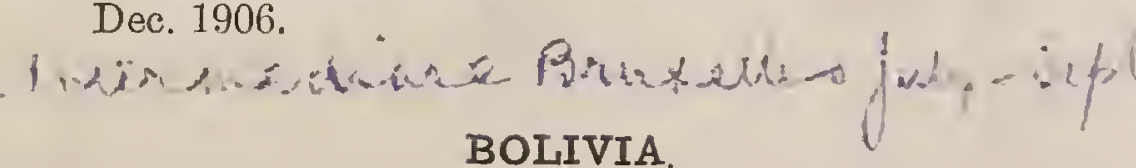
BOLIVIA

Finatelia Bomiviana. La Paz. July-Aug. 1893.

Boutvia Filatelica. La Paz. July-Dec. 1901

\section{BRAZIL}

Brazil Philatalico. São Paulo. Jan.-Mar. 1882.

Philatelista. S. Paulo. March 1884-Aug, 1885.

Philatielista. Porto Allegre. Jan.-July 1888.

Brasit-Postal. Rio de Janeiro. July 1890-July 1891.

Philatelista. Pernambuco. Oct. 1890-Dec. 1891.

Amáteur de ta Timbrotogre. Rio de Janeiro. May-Sept. 1891.

Brazil Phimatelico. Campos. Jan. 1892-Nov, 1893.

Gazeta Philatelica. Rio de Janeiro. Nov. 1892.

Oxнo de Bor. Rio Grande. July 1893.

Untáo Postat. Maranhão. Aug. 1893.

Philatelia. Campos. July 1894.

Revista Philatelica do Brazil. Rio de Janeiro. Jan. 1896-Јаn. 1900.

Timbrophile Brésimien. Petropolis. Jan.-[? May] 1896.

-Coleccionador de Sellos. Sorocaba. June 1896-Aug. 1899.

- Jornal Phicatelitco. São Paulo. March 1897-May 1900.

Chará Philatelico. Ceará. Jume 1897.

Philatelista Riograndense. Rio Grande do Sul. June 1897-1898.

- Philatielista Paulistano. S. Paulo. July 1897-July 1903.

Erste Südamertcanische Postkarten Zeitung. Sorocaba. Jan.-Feb. 1899

Revista de Annuncios. Sorocaba. Feb.-Aug. 1899.

Erste Südamericantsche Sporti und Postrartenzeitung. Sorocaba. March-Aug. 1899.

- Philatelista Brazilieiro. Rio de Janeiro. July 1899June 1900.

Philatelista Cearense. Ceará. Aug. 1899.

- Brazil Philatelico. Porto Alegre. Dec. 1903-July 1905.

Brazir Postal. Porto Alegre. June-Sept. 1904.

Philatelico. Santa Maria. Sept. 1904-Jan. 1905.

Uniño Carto-Philatelica. S. Paulo. June 1905-Feb. 1906.

Philatemista Brazilfiro. Pernambuco. May-Aug. 1906.

\section{BRITISH GUIANA}

British Guiana Philatelic Journal. Georgetown. Dec. 1906- (In progress.)

\section{BULGARIA.}

Г.JACЪ [GLas.] Philippople. Oct. 1893-March 1894.

Batkan. Sophia. July-Sept. 1895.

Vitoscha. Sofia. March-July 1896.

\section{CANADA.}

Stamp Colieftor's Record. Montreal. Feb.-March 1864.

Stamp Cotiector's Monthiy Gazettr. St. John, N.B. June 1865-June 1867. 
Stamp Argus. St. John, N.B. July-Dec. 1865.

Nova Scotian Philatelist. Amherst, N.S. Jan 1893-Jan. 1894.

Postman's Knock. St. John, N.B. May 1866-March 1870.

Canadian Philatelist. Quebec. Jan.-April 1872.

Canadtan Phitatelist. Quebec. Sept. 1872-Jan. 1873.

Stramp Collegtor's Ghrontcle. St. John, N.B. Nov. 1872 Jan. 1873.

F. Raymond and Co.'s Monthly Ciroutar and "Gineral ADVERTISER ". London, Ont. Dec. 1872.

Stamp Collector's Chronicle. New Series. St. John, N.B. March-Dec. 1873.

In'terenational AdVERTiser. Quebec. May 1873.

Stamp Advocate. Toronto. Feb,-June 1875.

Phitateric News. Toronto. Jan. 1877.

Toronto Philatelist. Toronto. March-May 1877.

Montranal Philatelist. Montreal. Feb.-March 1878.

Philatelic Courier and Stamp Colieector's Journat. Halifax, N.S. Sept. 1881-Aug. 1889.

Coln and Stamp. Toronto. May-June 1882.

Canadian Phila'telist. Whitby, Ont. Dec. 1884-Tune 1885.

Toron'io Philaterio Journal. Toronto. March 1885Aug. 1888.

Canadian Philatelic and Curio Adveirtiser. Montreal. Jan.-Apl. 1886.

Coliectionneur. Montreal. May-June 1886.

Canadian Philatelist. Toronto. Sept. 1886.

Halifax Philatelist. Halifax, N.S. Jan. 1887-July 1889. Niagara Falds Philatelis's. Niagara Falls South, Ont. Aug. 1887-Sept. 1889.

Canadian Phicatemistr. Niagara Falls South, Ont. Jan.June 1888.

Prince Edward Istand Philatelist. Charlottetown, P.E.I. April 1888.

Ganada Stamp and Coin Journat. Halifax, N.S. July 1888May 1889.

Ontario Stamp Journat. Niagara Falls South, Ont. Oet. 1888.

Canadian Phitantelito Journal. St. Catharines, Ont. Tec. 1888.

- Dominion Phitua'telis'r. Belleville, Ont., etc. Jan. 1889 Dec. 1897.

Maritime Philatelist. Salem, Yarmouth, N.S. Feb. April 1891.

Canadian Philatelist. London, Ont. Apl. 1891-May 1896.

Canada Stamp Journal. Halifax, N.S. May 1892 . 19

Toronto Journal of Philately. Toronto. May-June 1892.

International Philatelist. Toronto. Oct. 1892-May 1893.

Ottawa Philatelist. Ottawa. Oct. 1892-April 1893.

Phiratelito Journat of Canada. London, Ont. Oct. 1892Narch 1893 1893.

Internatronal Phitamelist. Second series. Toronto. Sept. Oct. 1893.

Canadian Philatelic Magazine. Halifax, N.S. Nov. 1893-Oct. 1901.

Queen City Philatelist. Toronto. Dec. 1893.

Canadian Philatelio Weemuy. London, Ont. Jan.-Feb. 1894.

Toronto Philatelic Journat. Second series. Toronto. Tan.-June 1894

Canadian Philatelic Journal. Merritton, Ont. Feb. 1894.

Pext Phimatelist. Berlin, Ont. Sept.-Dec. 1894.

Tononto Stamp. Toronto. Sept. 1894.

Canadian Advertiser. Brantford, Ont. Jan. 1896.

Ali-Around-Stamp-Advertiser. St. Hyacinthe, etc. March 1896-Feb. 1899.

Enward's Philatelic Press List. Montreal. March 1896-July 1898.

Ontamio Phimatemist. St. Catharines, Ont. March 1896 Sept. 1898.

Stamp LoRe. London, Ont. June 1896-Jan. 1897.

Canadian Weekly Stamp News. Toronto. Aug. 1896-June 1897.

Philatelic Advocate. Berlin, Ont. Sept. 1896-Sept. 1901.

Philatelic Messenger. Oak Hill, etc., N.B. Oct. 1896 Feb. 1902.

Philatelic Canadian. Toronto. Dec. 1896-March 1897.

Halifax Philanelic Magazine. Halifax, N.S. Jan-Oct. 1897.

Stamp Reporter. St. Catharines, Ont. Aug. 1897-Feb. 1899.

Boy's Own Philatelist. Berlin, Ont. Dec. 1897-Oct. 1898.

Colonial Stamp. Toronto. 1898.

Montreat Philatelist. Montreal. April 1898-June 1902.

Canadian Colmector. Berlin, Ont. Sept. 1898.

Canadian Philatelic Weekry. Toronto. Nov. 1898-May 1899.

Canadian Phitantelic Weekuy. Berlin, Ont. Nov. 1898 Jan. 1899

Canadian Phiratemic Review. Berlin, Ont. Feb.-April 1899.

Canadian Colmector and Philatelic Punch. Berlin, Ont. April-June, 1899.

Stamp Reporter. New series. St. Catharines, Ont. AprilMay 1899.

Jubilee Philatelist. Smith's Falls, Ont. Oct. 1899-.June 1900.

Philatelio Spectator. Berlin, Ont. Oct. 1899-Oct. 1900.

Colnectors' Monthly. Paspebiac, P.Q. Jan. 1900.

Energy. Berlin, Ont. Feb. 1900-March 1901. 


Mount Royal Stantp Naws. Montreal. April 1900.

Progreso Frlo'télico. Bogotí. Jan. 1887.

Jubilee Philatelist and Mount Royal Stamp News. Smith's Falls, Ont. July-Dec. 1900.

Canada Stamp Sheet. Quebec. Sept. 1900-Apl. 1901.

Philatelic Record. Montreal. Jan.-July 1901.

Philatelic Trmes. I’Orignal, Ont. March-Sept. 1901.

Canada Stamp Sheet and Energy. Quebec. May 1901. Nov. 1902.

Oanadiana. Mariahilf, Grenfell, Assa, N.W.T., etc. Jan.Dec., 1902.

- Canada Stamp Sheet. Toronto, etc. Jan. 1903-Apl. 1905. Stamp Reporter. Hamilton, Ont. Sept,-Nov. 1903.

- Dominion Philatelist. Toronto, Dec. 1903-April 1905.

- Dominion Philatelist and Canadian Youth. Tolonto. May $1905-$ (In progress.)

Stamp Lorm. Berlin, Ont. March-[? Nov.] 1906.

\section{CANARY ISLANDS.}

Firatielda Univerisatr. Laguna de Tenerife. Jan,-Nov. 1903.

\section{CHILI.}

Gula del Coleccionista de Sellos de Correos. Valparaiso. Jan. 1878-Dec. 1884.

Anales de la Sociedad Filatélica "Santtago". Santiago. Mar. 1892-Dec. 1898.

Estrella Filatélica de Chile. Santiago. Tune 1892April 1893.

Opintón Filatélica Chilnka. Santiago. July 1894-June 1895.

Anates de la Socikdad Filatélica de Chile. Santiago. Jan. 1899-1904.

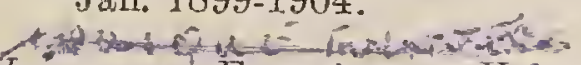

alparaiso Firatélico. Valparaiso. Jan.-Aug. 1899.

América Postal. Valpalaiso. Feb. 1901.

Chile Firatélico. Sautiago. Sept.-Dec. 1901.

America Postal. Iquique. June 1902-June 1904.

Correo Fildatélico. Santiago. Oct. 1902-Aug. 1903.

Firatélico Porter̃o. Valparaiso. Oct. 1902-Nov. 1903.

Sento. Iquique. Tune 1904-March 1906.

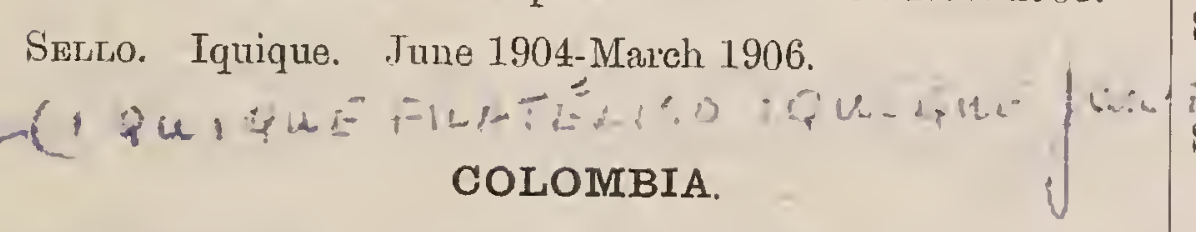

Star of Panam. Panama. [? May] 1865.

Anunctador. Bogotá. Mal.-Dec. 1879.

Boletin de Anuncios. Bogotá. March 1879.

Frrotelista. Bogotí. Jan.-July 1880.

Anunctador Frilotécico. Bogotá. Apl.-Aug. 1882.

Anuncrador, Bogotá. June-Aug. 1882.

Firotelista. Bogotá. June 1883.

Filotelista. Panama. Aug. 1886-May 1887.

Heraldo Ficotécico. Bogoté. Oet. 1886-Jan, 1887.

Revista Filotelica. Barranquilla. Sept. 1887-April 1889.

Voz. Bamanquilla. March 1888-May 1892.

Revista Frratélica. Panama. Oct.-Nov. 1894.

Filatelista. Bogotá. Jan.-March 1900.

Colonibia Postal. Medellin. Feb.-Jume 1904.

Revista Postad Golombiana. Bogotá. March-Aug. 1904.

Colecclonista. Bogotá. April 1904-Oct. 1906.

Union Postal. Medellin. Jan.-Sept. 1905.

Santander Firaterico. Bucaramanga. Nov. 1905-Jan. 1906

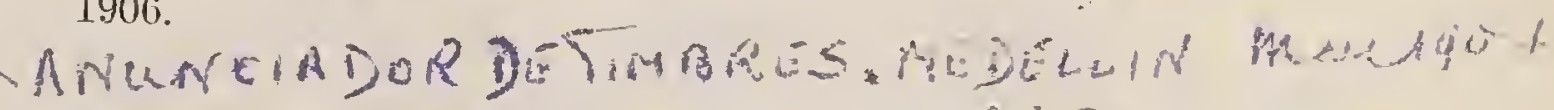

$$
\text { COSTA RICA. JP. L.S. Not } 1 p q
$$

Costa Rica Postad. San José. Oet. 1894 June 1895.

Firatéltco Comercial. San José. June 1896-Jally 1902. - f is is

Fillatelia de Costa Rica. San José. May 1897.

Colnccionista. San José. Dec. 1898.

Costa Rica Postad. San José. Dec. 1901-Apl. 1902.

Anunciador Filatélico. San José. Aug. 1902.

Corrag Postal. San José. May-Oct. 1906.

\section{CUBA.}

Gurioso Americano. Habana. July 1899-May 1901.

Correo de Cuba. Habana. Nov. 1900-March 1901.

-Revista de la Socredad Filatética Cubana. Habana. April 1902-April 1906.

Cuba Filatélica. Habana. April 1905-Feb. 1906.

\section{CURACAO.}

Correo dec Caribe. Curazao. Feb. 1891-April 1892.

Revista Filatélica. Curazao. April-Dec. 1893.

\section{DENMARK.}

Nordisk Frimatrietiddende. Kjpbenhavn. Aug. 1867-June 1868.

Shandinavisk Frimaerke-Journad. Kjøbenhavn. Oct. 1876 May 1877.

Skandinavisi Frimaerketidende. Kj申benhavm. Oct. 1876 Dec. 1877.

Nordisl Frimearkeverden. Kjøbenhavn. Jan.-April 1878.

Skandinavisk Phicatelist Tidende. Sønderho. AprilSept. 1890.

Srandinavisk Frimaerke-Trdende. Sqnderho. Oct. 1890 Sept. 1893.

Vertrauliche Mrttheilungen des Skandinavischen Philatelisten - Vereins in Kopenhagen. Copenhagen. Feb.-Oct. 1894.

Philatelist Journat. Nibe. April-June 1894.

Frimaerke - Handueres og Samleres AvertissementsHaefte. Aarhus. May 1894. 
Nordisk Finametistisk Tidskrift. See SwhDex.

Meddetarser. Kj申benhavns. Aug. 1899.

Nordisk Frimaerke-Tidmane. Yaby. Jan. 1900-June 1901.

Skandinavisk Philatemistisk Offerteblad. Aalbolg. Aug. 1903

Strandinavisk Phiratelist Tmende. Kjф́benhavn. Jan.Dec. 1905 .

- Phimatelisten. Esbjerg. F'eb. 1905-July 1908.

\section{DOMINICAN REPUBLIC.}

$$
1023
$$

Firotelico. Santo Domingo. IR⿴囗十 1885-Feb. 1886.

Firotemico. 2a epoca. Santo Domingo. April 1887.

Santo Domingo Postat. Santo Domingo. March 1903Jan. 1905.

Eco Fildteirico. Puerto Plata. April-Sept. 1903.

Firatético Dominicano. Santo Domingo. Feb.-Oct. 1904. Firatélitco Cartófito. Santo Domingo. Dec. 1904-March 1905.

Revista Postal Dominicana. Santo Domingo. Jan.-Nov. 1905.

Filatelico Azuano. Azua. Feb.-March 1905.

Defensa Firatelica. Azua. May 1905.

\section{ECUADOR}

ECUAdor Fituatelico. Guayaquil. Jan. 1886-Feb. 1887.

Revista det Mercado de Setutos de Guayaquit. Guayaquil. Aug. 1888

America Firatelica, Guayaquil. Apl.-Oct. 1897.

Filatélico Comeroial. Guayaquil. June-Aug. 1901.

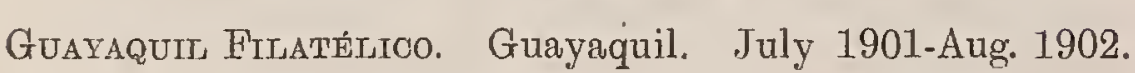

Finatélico Ecuatoriano. Guayaquil. Aug. 1901-Aug. 1902.

Guayaquit Firatélico. Guayaquil. Oct. 1905-Jan. 1906.

Tungurahua Fituatérico. Ambato. March 1906.

Porvenir Postat. Guayaquil. Nov. 1906-Feb. 1907.

\section{EGYPT.}

Trmbromogir Egrptinnne. Caire. Oct. 1891-May 1892.

Journat de la Timbrothogie Egyptienne. Alexandrie. June 1894-Aug. 1895.

Phitatéluiste Egrptien. Suez. June-July 1894.

Timbrophile Egyptien. Alexandrie. Sept. 1895-Aug. 1896.

Phare des Timbrophitues. Alexandrie. May-July 1897.

Butuemin des Annonaes Trmbrotogiques. Alexandrie. Jan. 1898-Mar. 1899.

Ami de ra Tmarologie. Caire. Jan. 1900
FRANCE

Coldectionneur de Timbres-Poste. Paris. July 1864(In progress.)

- Timbrophite. Paris. Nov, 1864-Dec. 1871.

Gazette des Thmbres. Paris. July 1872-Dec. 1876

Ani des Thmbres. Paris. Jan. 1874-July 1902

Bulletin de la Société Francaise de Trmbrojogie. Paris. Oct. 1875-July 1896.

Sìve-Annonoe. Marseille. June 1881.

Rivista detisa Stampa Firotelica., Marseille, etc. Feb. 1883-.Jan. 1886

Tinibres pour Colmections. Paris. Jan.-Dec. 1884

Union des Timbrophites. Paris. Nov, 1884-Oct. 1889.

Timbrologim. Paris. Nov. 1885

Timbre. Paris. June 1886.

Paris-Poste. Paris. Oct. 1887-Oct. 1888.

Écho de la Timbrologie. Douai, etc. Nov. 1887- (In progress.)

Timbrophume. Marseille. Jan.-March $1888 . \quad$ Mh́̈

Intermédatre TIMBRophmique. Marseille. Apmit-May 1888.

Éclatreur de la Timbrorogit. Marseille. Dec. 1888.

Circulaire Fiscate Centennate de J. Goutier. Paris. 1889.

Carte Postale. Paris. Jan. 1890-Sept. 1893.

Revue Philatécique. Paris. April 1890-Jan. 1896.

.Courrier nes Tumbres-Poste. Saint Étienne. June 1891. Oct. 1901.

Paris-Postal. Paris. June 1891-N 1892.

-Gazette Trmbrologique. Paris. Oct. 1891-July 1898.

Revue Franghaise de la Philatelie Universelis. Chalonsui-Saone. Nov. 1891-June 1892.

UnION DES TIMBrophums. Nouvelle serie. Paris. Jan. 1892-10\%. 1894:

Union Postale Univeriselite. Paris. Feb. 1892-June 1896.

Marseim.te-Postat. Marseille. April 1892-Aug. 1898.

Amtitance Phituatítitque. Paris. May 1892.

Bormetin de ra Soctedad Timbrotogica Sud Americana. Paris. [? ] 1892.

- Phiratúriste Français. Paris. June 1892-March 1902.

Questionneur Timbrophitiquk. Paris. June 1892-Dec. 1895.

Conseititifr du Timbrophile. Paris. Sept. 1892-Sept. 1893.

Cote des Timbkes. Paris. Oct. 1892-Dec. 1893.

Muldeady. Paris. Nov. 1892.

INtermédtatre de la Timbrotogie. Paris, etc. April 1893May 1906.

Intermédatre Philatélique. Paris. Sept.-Nov. 1893.

AventR des Timbres-Poste. Paris. Dec. 1893-Jan. 1897.

Petites Afriches Philatétilques. Paris. Jan.-Noy. 1894

Boukse aux Timbres. Paris. Sept.-Nov. 1894. (1) E

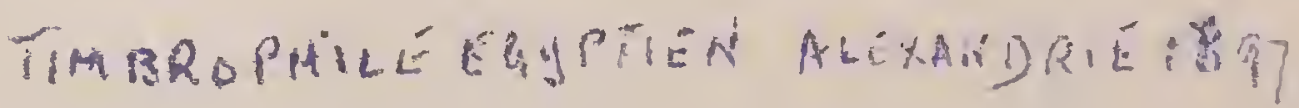




Phicatéliste Lyonnais. Lyon. March 1895-Oct. 1896. RÉclame Philatélique. Havre. March 1895-June 1896. Timbrologie Méridionale. Montpellier. March-June 1895. Timbrophile Lorrain. Chef-Haut. March-Sept. 1895.

- Tindbrophile Poitevin. Poitiers. March 1895-July 1905. Petit Phitatéliste. Lyon. Oct. 1895-1898.

Revue Philatélique Internationale. Rouen, Dec. 1895Feb. 1896.

Timbrologie Universelle. St. Etienne. Jan. 1896.

- Revue Philateilique Française. Paris. Feb. 1896- (In progress.)

Coldegtionneur du Vak. Vidauban. March-May 1896.

Revue Internationale de la Philatelif. Ronen. MarchApril 1896.

Bourse Officielde des Timbres-Poste. Paris. AprilJune 1896.

Lrbre Échangiste. Paris-Passy. April 1896.

Timibrophile Gadrois. Malzéville-lès-Nancy, ete. Oct. 1896-Jan. 1900.

Écho de la Philatélie. Luzarches. Jan. 1897-Jan. 1898.

Cours des Trubres. Paris. Jan.-Mar. 1897.

Indicateur Philatélique et Comnercial. Bains-les-Bains. Jan.-April 1897.

Bulletin mensule de la Société Philatélique Lyonnaise. Lyon. Mar. 1897-Dec. 1898.

Timbrophile Parisien. Paris. May-Sept. 1897.

Trmbre. Talence. June-Oct. 1897.

"Circulatre Philatéliste." Paris. Sept. 1897-Jan. 1898.

Annonce Philatélique eir Connergalale. Bois-Colombes. Dec. 1897-June 1899.

Bulletin De la Société "L'Union Des Échangistees". Paris. Jan. 1898-Dec. 1901.

Aldiance Timbrologrque. Paris. Feb. 1898-Feb. 1904.

Bulletin mensuet de la Société Anonyme des PhilateLISTES DE Reims. Reims. March-April 1898.

Écho du Collectronneur. Paris. March-April 1898.

Bulietin de la Société Tinbrophile de Reins. Reims. [? June]-Oct. 1898.

Circulatre Philatélique. Havre, etc. Oct. 1898-Dec. 1902.

Collectionneur Français. Paris. Oct. 1898-Feb. 1899. Amateur des Thmbres-Poste. Paris. Dec. 1898- (In
progress.)

Penit Messager Universed. Bains-les-Bains. Dec. 1898. Jine 1899. $A:$

Philatelio-Album. Marseille. Jan. 1899-Dec. 1900.

Bulletin mensuel des petttes anNonces du collectionNeUr. Vienne. April-June 1899.

Courrier Philatėlique. Lille. April 1899.

Nord Philatélique. Douai. April 1899-July 1900.

Revue Internationale de la Philatelie. Série nouvelle. Roven. April 1899-April 1901.

Timbrophile. Marennes, Sept.-Nov. 1899.
Pol Beundouche Circulatre. Chef-Haut par Rouvres. [?] 1899-Feb. 1902.

Philatéliste International. Paris. Jan. 1900-June 1902. Buluetin Confrdentiel. Paris. April 1900-Aug. 1901.

Pettit Messager Universel. Nouvelle série. Bains-lesBains. April-May 1900.

Réclame Philatétique Lyonnatse. Lyon. April 1900.

Lyon Philatéliste. Lyon. May 1900.

Philatéliste Modernan. Chálons-sur-Marne. June 1900 Nov. 1902.

Courrier Universel. Paris. [? ] 1900-Sept. 1901.

- Annonce Philatélique. Troyes. Oct. 1900- (In progress.)

.Gazetree Philatélique Lyonnaise. Lyon. Oet. 1900-June 1904.

Collectionneur de 'Timbres Fiscaux. Rouen. Nov. 1900-
April 1901.

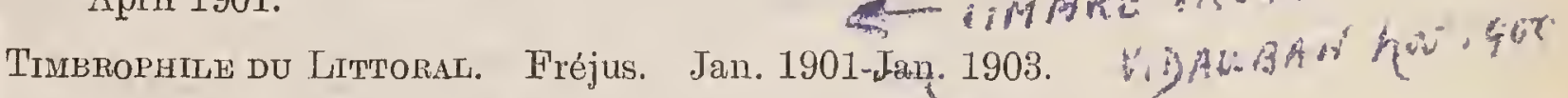

Petit Carillon Philatélique. Tarbes. Feb.-March1901.

Petit Messager Universei. III.e série. Bains-les-Bains.

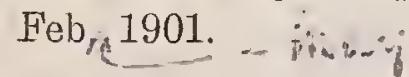

Tribune des Colleotionneurs. Paris. March 1901-Feb. 1904.

Office International des Colledionneurs. Lyon. MaySept. 1901.

Intermédiatre des Coliegtionneurs de Carties Postales Iludstrées et de Timbres-Poste. Paris. Sept. 1901 Dec. 1902.

Archives des Collectionneurs. Méricourt-l'Abbe. Oct. 1901-Apl. 1904.

Coliectionneur. Autun. Oct. 1901-Nov. 1902.

Cote Offictelle des Thmbres-Poste. Paris. Oct.-Nov. 1901.

Cote Réblie des 'Trmbres-Poste. Paris. Oct, 1901-Sept. 1904.

-Postillon. Paris. Dec. 1901- (In progress.)

Magazine Philatélique. Auch. July 1902-Sept. 1904.

Tribune Littérérire eit Philatélique. Mâcon. Aug.-Nov. 1902.

Revue Françatse des Collectionneurs. Paris. Oct. 1902- (In progress.)

Bulletin Mensuel de la Maison Théodore Champion, Paris. Nov. 1902- (In progress.)

Union des Collectronneurs. Chef-Boutonne. Nov. 1902March 1904.

Tribune Littíratre. Mâcon. Dec. 1902-Jan. 1903.

Philatélite. Paris. Jan.-Nov. 1903.

Timbrophile de France. Paris. March 1903-(In pro(gress.)

Tribune Philatél1que. Màcon. March 1903.

Petit Messager. Nouvelle série. Bains-les-Bains. May 1903-Feb. 1904.

Franc-Parleur Philatélique. Paris. July-Nov. 1903.

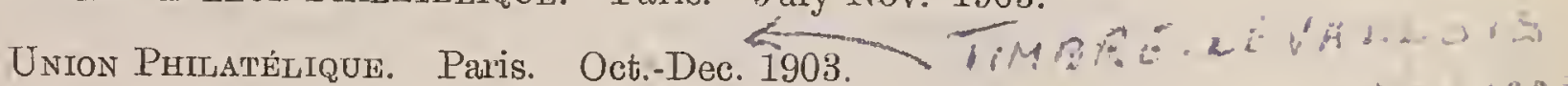




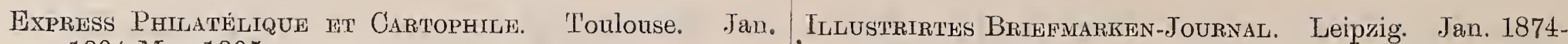
1904-May 1905.

Revue de la Fédération Philatelique de France. Paris. Jan. 1904- (In progress.) Aluiande Thmbrologique et Cartophile. Paris. Mar.-
May 1904.

Carto-Philatélique-Journal. Paris. Jume-Sept. 1904.

Investigateur Illustré. Dijon. June 1904-Oct. 1905.

Petites Annonces Cartophiles eil Philatelistes. Gondrecourt. Sept. 1904-Oct. 1906.

Bulletin Fiscaliste. Paris. Oct. 1904-Oct. 1906.

Journal oes Philatélistes. Paris. Oct. 1904- (In progress.)

Monde Philatéligue et' Car'tophlle. Montélimar. Oct. 1904-Jan. 1905

Carto-Phijatélique-Journal e'T la Revue Philocartis'te Tnternationale Reunis. Paris. Nov. 1904-Jan. 1905.

Luz Filatélica. Paris. Jan. 1905-Itri 1906. Dece

Étoile Carte-Philatéliquh. Gondrecourt. March-July 1905.

Gazetre des Collectionneuks. Nimes. Sept.-Oct. 1905.

Echangiste Universel. Paris. [? 1905]-May 1908.

Petit Journal Phila'lélique. Annemasse. Dec. 1905.

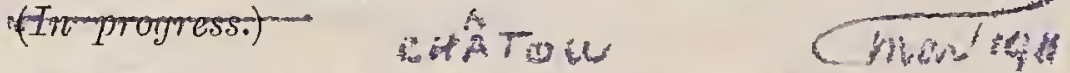

Bulletin Timbrophile. Pontrote. Jan. 1906.

Causerie Phicatélique. Paris. April 1906-Feb. 1907.

Circulaire Philatélique. Paris. July 1906- ( In progress.)

\section{GFRIVANY}

- Magazin für Brijemarken-Sammler. Lueipzig. May 1863 April 1867.

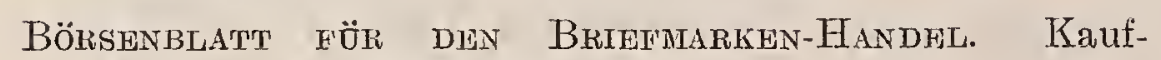
beuren: Jan.-June 1864.

Alugemeine deutsche Briefnarken-Zhitung. Coburg. July-Dec. 1864.

Briefmarkensamalek. Nürnberg. Nov. 1864.

Deutsche Briefmarken-Sammler. Hamburg. Nov. 1864Feb. 1865.

- Briffmarken-Sammlel. Leipzig. Jan. 1866-Mar. 1871.

Bazar für Briefrarkeinsammler. Heidelberg. July 1869May 1870.

Briefmarken-Anzeiger. Cassel. Jan. 1870.

Deutsche Briefmarken-Zeitung. Dresden, etc. Oct. 1870-June 1873.

A Moschikau's Magazin. Dresden, etc. July 1871-June 1872.

- Alugemeiner Briefiarien-Anzeiger. Hambuig, etc. Oct. 1871-Dec. 1880.

Vintiraugiche Mittheilungen. Dresden. - Oct. 1871-Jan. 1875 .

Philatelist. Oybin. Sept.-Oct. 1872.

Regelmässiger WoChen- Und MariKtberioht der HamBURger, LüBECKer und Bremer BriefMartex-Börse. Hamburg. Sept. 1872.

Philatelistische Bü̈tTer. Leipzig. July-Dec. 1874.

Philatelimestische (sic) Monats-Bertohte. Hannover. - April 1876

Vereinsmachrichten des Vereins Sohlesischer Briel'Markensamulfr. Breslau. April 1876-Nov. 1879.

Ajtagn. Anzeiger. Leipzig. Sept. 1876-June 1877.

,Union. Dresden. Jan. 1877-June 1881.

Marcur. Kreuz. May 1877-Dec. 1878.

Philatelis'itscher Verkehr. Leipzig. Sept. 1878-Jan. 1880.

Berlinfar Ileustrirte Briefmarken Zitung. Berlin. Oct. 1878-Dec. 1880 .

Hamburger Briefmarken-Zimung. Hamburg. Nov. 1878 Dec. 1879

Blilefmakkwn-Händeler. Danzig. Jun.-Mar. 1879.

Internationalier Briefmarken-Anzeiger Merkur. Kreuz. Feb. 1879-Nov. 1880.

Neue Philatelistische Brätriei. Leipzig. Oct. 1879Jan. 1880.

Philiatelistische Börse. Berlin. Dec. 1879.

Hanburger Illustrirte Brifharken-Zeitung. Hamburg. Jan.-June 1880.

Erdball. Ohrdruf. April-Dec. 1880.

-Philatelist. Dresden. June 1880- (In progress.)

SammLer. München, etc. June 1880-Sept. 1890.

. Berliner Illuustribte Philatelistefen Zeitung. Berlin. Jan.-Dec. 1881

-Dhesdner Illustriktes Bribanarken-Journal. Dresden. Jan. 1881-Nov. 1882.

Vereinigte Ekdbald Merkur. Frankturt. Jan. 1881-June 1883.

Alugemeiner Bliffmarken-Anzhighr. Leipzig. Feb.-Apl. 1881.

Tausch-Venkehr. Frankfurt, etc. Oct. 1881-Nov. 1883.

UnIVERSum. Frankfurt. Dec. 1881-May 1885.

Deutsche Philatelisten-Zeitung. Berlin. Jan. 1882 Nov. 1887

Internationalel Philatelisten-Freund. Liyck. Jan. Feb. 1882.

Briefmarkenfreund. Leipzig. Oct. 1882.

.Deutsche Briefmarken-Zeitung. Dresden. Dec. 1882 Nov. 1890.

Illustrirter BriefMarken-Anzeiget. Teipzig, etc. 1882 1886.

Deutsche Iluustrikte Brigharaken-Zeitung. Leipzig. Jan.-Dec. 1883.

Germania. Oybin. Jan.-Dec. 1883.

General-Anzeiger für Philatelie. Iserlohn, etc. April 1883- (In progress.)

Bayerischer Philatelisten Verein Mínchen. VereinsMitTheilungen. München. June 1883-June 1884.

Philatelatsch. Leipzig. Feb. 1884. 


Vereins-Mittheilungen des Bayerischen PhilatelistenVereins. München. July 1884-Dec. 1887.

Frankfurter Briefmarkenzeitung Universum. Frankfurt. July-Dec. 1885.

Annoncen-Beilage zun Philatelist. Dresden. Jan. 1886Dec. 1888.

Mitteilungen des Vereins für Freunde der BriefiartienKUNDE ZU LÜBECK, Lübeck. Jan. 1886-Dec. 1887.

Illustrirte Frankfurter Briefmarkigv-Zeitung. Frankfurt. Jan. 1886-July 1892.

Philatelistischer KLadderadatsch. München. Mar. 1886-Mar. 1888

Philatelist. Magdeburg. April-Sept. 1886.

Internationaler Postwerthzeichen-Händeli-Verein. Berlin. Sept.-Oct. 1886.

Streng Vertraulich. Indernationaler PostwerthzeiChen Händler-Verein. Berlin. Oct. 1886-Dec. 1887.

Internationaler Briefmarken-Anzeiger. Frankfurt. Feb.-Dec. 1887.

Philatelistischer Ulis. München. April 1887.

Allgemeiner Briefmarken-Anzeiger Vereinigte Erdball Mercur. München. June 1887-Dec. 1897. (Nos. 2552 were published in Austria.)

OfFertenblatt för Briefararken-SanmeER. Leipzig. July 1887 - (In progress.)

Philatel. Nachrichten. Miüchen. July 1887.

SitzungSBerICht : . Des Internationalen PostwerthZeichen-HändLER-Vereins. Berlin. Dec. 1887-May 1891.

- Illustrirte Briefrarken Zeitung. Leipzig. Jan. 1888Dec. 1900.

Monathiohe Mitteitungen des Vereins für Freunde der BRtefMaRkenKunde zU LÜ̈BeCK. Lübeck. Jan, 1888 . July 1893.

- Neueste Privatpost-Nachrichten. Gössnitz. Jan. 1888Nov. 1893.

- Philatelia. Halle. Jan. 1888-Feb. 1891.

- Postwertzeichen. München. Jan. 1888-Dec. 1900.

Berliner Philatelisten-Club Vereinsuitthemungen. Berlin. Apl. 1888- (In progress.)

Internationales Offerten-Blatt für Philatelie. Brandenburg. July-Dec. 1888.

Ernst Hayn's IluUstrirtes Offentenblatt wÜR BrieFmarisensamuchi UND Handler. Berlin. Oct.-Dec. 1888.

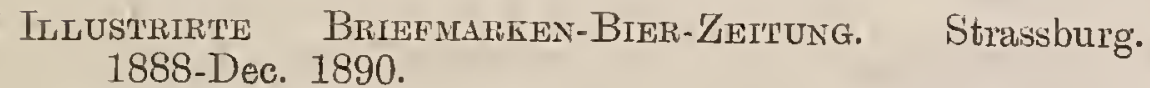

Internationale Briemlarken-Zeitung. Schweidnitz, etc. Dec. 1888-Dec. 1890.

Bazak. Quakenbrück, etc. Dec. 1888-Jan. 1890.

Fontuna. Coepenick. Dec. 1888-Feb. 1892. (Other numbers were published in Austria.)

Union. Zittau. Jan.-Dec. 1889.

Verelns-Bekichte. Oldenburg. Jan.-Feb. 1889.

Vereins-Berichite der Verelnigung Oldengg. Brieny. Freunde. Oldenburg. March-June 1889.
Weqtieiser FŨ̃ SAMMLER, Leipzig. Sept. 1889-[?] 1899.

Postwertzeichen-Kunde. München. Jan. 1890-Dec. 1897.

Sene's Monatsschrlet wür Postwertzetchen-Kunde. Leipzig. Jan. 1890.

Sanimler. Bruchsal. May 1890

Beiträge zur Postwertzeichen-Kunde. Teipzig. July 1890-1905.

Mittheilungen der Tauschvereinigung füri PostwerthZEICHEN ZU ELBERFELD. Elberfeld. July 1890- (In progiess.)

Briefuarien Sammlei. Bremen. Oct. 1890- (In mogress.)

Briefmarkensamuer. Leipzig. Oct. 1890.

Deutsche Brieharien-Zeituna. Berlin, etc. Oct. 1890. (In progress.)

Philatklia. Leipzig. Oct.-Dec. 1890.

Philatelisten-Zeitung. Stade. Oct. 1890-June 1893.

Sene's Brtefmarikensamule. Leipzig. Not, 1890-Sept. 1891.

GLobus. Berlin. Jan.-Dec. 1891.

Internationales Brimamarken-Journal. Breslau, etc. Jan. 1891-Sept. 1894.

NaChrichten aus Dem Brtefmartsenclub "Merour". Mühlhausen. Jan. 1891.

Tauschblatt für Briefmarken-Sammler. Berlin. Jan. Dec. 1891.

Verein Braunschweiger Briefmarken-Samaler. VereinsMitTHEILUNGen. Bramnschweig. Jan. 1891-March 1902.

Frankfurter Briewadrenen-Anzeiger. Frankfurt. April 1891.

Mitreilungen aus dem Phirat. Sohölerverein Bruohsal. Bruchsal. April 1891-April 1892.

Ludw. VaI. Fueck's Frankfurter BriefmarkeyAnzeiger. Frankfurt. May 1891.

Mittheilungen und Sitzungsberichte des Internationalen Postwerthzeichen-Händler-Vereins zU Berlin. Berlin. June-July 1891.

Vereins-Mittheilungen des Internationalen Philatelisten-Vereins Dresden. Dresden. July 1891-Dec. 1892.

Mittheilungen des Internationalen PostwerthizeichenHändler-Vereins zu Berlin. Berlin. Aug. 1891. (In progress.)

Vertrauliohes Korrespondenzblate Philatelistischer Vereine. Strassburg, etc. Aug. 1891- (In progress.)

Philatelistisches Tageblatt für Mttteldeutschland. Gössnitz. Sept. 1891.

Inseraten BeIblate zUII SÜDdeUtschen ILLUSTRIRTen BrIEFMARKEN - Journá. München. Dec. 1891-Feb. 1892.

Süddeu'rsohes Illustrirtes Bitef Markens-Journal. Mïnchen. Dec. 1891-Feb. 1892.

Ildustrirte Central-Bier-Briefuarken-Zeitung. Strassburg. 1891.

BrIEFWARKen-Börse. Bremen. Jal.-July 1892. 
Internatronares Briemmarken Onfemtenhlatt. Poessneck. Jan. 1892- (In progress.)

OfEertenblatt Für Briefmarkensammler. München. Jan. 1892.

VEREINS-Bote. Leipzig. Jan. 1892- (In progress.)

Grobus. Berlin. Feb. 1892-June 1893.

BRIEFWAPPEL. München. Mar. 1892.

Heitmann's Ratgaber. Leipzig. April-Sept. 1892.

Philatelistische Jugendschriet. Bruchsal, ete. April $1892-1894$

Tausch-Offertenblatt. Bruchsal. April-June 1892.

Senf's Brime. Teipzig. May 1892.

Philatelia Humoristrca. Dresden. June-July 1892.

Mrtieldeutsche Philatelisten-Zeitung. Gössnitz. July 1892-Dec. 1904.

Vereins-Вотњ. Bruchsal. July 1892.

Frankeurter Briefmarien-Zeitung. Frankfurt. Sept. 1892-Sept. 1893.

Vereinsbote des "Chadmers". Stuttgart. Sept.-Nov. 1892.

Vogträndische Phwateris't. Zeulenroda. Oct.-Nov. 1892.

Echo DET Postwertzerohen - Kunde. Stuttgart. Nor. 1892-Aug. 1893.

Verbands-Mitieilungen des Vogtüindischen Phitatetisten-Verbandes von Zeulenroda. Zeulenroda. Dec. 1892-1894.

Mittheil ungen des Briemiarkensammler-Vereins Mosel. Cochem, etc. Jän. 1893-Dec. 1904.

Mrtiemungen des Wurttembergischen PhILATElisteñVereins Stuttgart. Stuttgart. Jan. 1893-1894.

Vereins - Börse DER Internationalen Vereinigung Von GanzsaChensammeren zU LmipziG. Leipzig. Jan. 1893Dec. 1899

Mittemungen der Tauschleitung des "Chatimetis". Leipzig. Feb. 1893 Vertrautiche Vereinsmiteilunngen. Berlin. Theb. 1893-
Oct. 1895 .

Internationater BrifhMarken - Anzeiger. Bockenheim, Frankfurt. March 1893.

Franco Furtianisches Phiratelistisches Jubiläums Bratt. Frankfurt. May 1893. I fuds'trirte Bier-Brtefmarken-Zeitung. Strassburg. May
1893. Deutsche Briefmarken Post. Barmen. June 1893-Aug.
1895.

Briefmarken Böuse. Hannover. Sept.-Oct. 1893.

Union. Pössneck. Nov. 1893-Mar. 1894. (Other numbers were published in Holland.)

Universur. Frankfurt. Nov. 1893-Sept. 1895.

Internatonade Briefmarken-Börse. Leipzig. Dec. 1893April 1896.

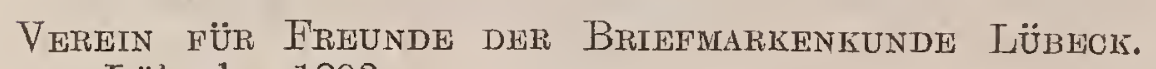
Lï̈beck. 1893.

Internationale Briefmarien-Börse. Berlin. Jan. 1894. Journal für MaRKenKunde. Hamburg. Jan.-Dec. 1894.
Ortsstemper. Essen. Jan. 1894.

Philat. Litteratur. Gumbinnen. Jan.-Feb. 1894.

-Post. Leipzig. Jan. 1894- (In progress.)

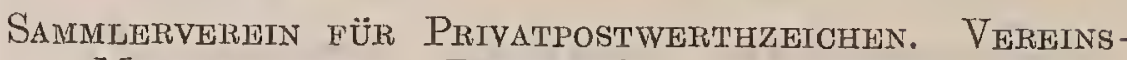
Mittheirungen. Bartenstein. Jan. 1894-Feb. 1895.

Universad Briefmarken-Anzeiger. Charlottenburg. Jan.July 1894.

VierteuJaHRs-NAOHTRäGk. Leipzig. Jan. 1894-Dec. 1896.

"Merkur." Hamburg. March 1894.

Briemmarken-Börsw. Leipzig. Apl. 1894-Nov. 1901.

Briefmarke. Esslingen. June 1894-June 1898.

Hansa. Bremen. June 1894.

Schleswig-Holsteinische Briegmariten-Zeinung. Baurup, etc. Sept. 1894-Dec. 1895.

- Berlinez Briefmarken-Zhitung. Berlin. Oct. 1894-Dec. 1899.

Norddeuisches Postwerthzeichen Offertentati. Sianowo, Oct. 1894-May 1895.

Interessantes Briefmarkenblatt. Hamburg. Nov. $1894-$ April 1896.

Norddeutsche Briefrarken-Pos't. Hamburg. Nov. 1894Oct. 1895.

Briefmafuren-Axzeiger. Stettin, etc. Dec. 1894-96.

Philatelistische Limtenatur. Leipzig. Jan. 1895-Nov. 1897.

Allgemeineir Anzeigler. Dortmund, ctc. Feb. 1895-Dec. 1898.

Fortinuna. Baurup. March 1895.

SR̆chsisches Postiverthzeichen-OFferienthat. Bautzen. March-June 1845.

Markeniwar'. Apolda. April 1895-Jan. 1896.

Briefmarken-Börse. Rüttenscheidt. May 1895-Nov. 1896.

Färschungs-Nachrichten. Gössnitz. July 1895-Dec. 1899.

Internationale Bier-Phitatemist. Mannheim. July 1895.

Fliankfurter Briemarken-Zaitung Universum. Frankfurt. Dec. 1895-June 1896

Sammirirkund. Mannheim. Dec. 1895-Dec. 1896.

Philatelistisches Annoncenbtatt. Fuerth. Jan.-March 1896.

Philatelistisches Börsenblatt. Kottbus. Jan. 1896-Dec. 1897.

Deutscher Phildéreist. Köln-Ehrenfeld. March-April 1896.

BriefMarkenhäNDLER. Charlottenburg. May 1896- (In progress.)

Mercur. Hemer. May-July 1896.

Phitatelistische Fachschirift fïr Sammlir von ElusassLOTHRINGER U. OCCUPATIONS-FREIMARKEN UND IHREN Abstempelungen. Mülhausen. May-Sept. 1896.

Skandinavisk Frimärkstidning. Halberstadt. June 1896.

Tauschrewt. Reutlingen. June-Dec. 1896.

Bund Deutscher und Österreichrscher PhLaftelistenVereine. Mituteiluna. Heidelberg, etc. July 1896 May 1899. 

Internationales Offertenblatt für Philatelie. Sonneberg. July 1896- (In progress.)

Neue Markenbörst. Nordhausen. July-Aug. 1896.

SAMmuer-Börse. Leipzig. July 1896-Dec. 1899.

Mitteilungen des Philatelisten Verein "Hermes". Rosenberg. Aug. 1896-March 1897.

Universum. Frankfurt. Sept.-Dec. 1896.

"Union." Berlin. Nov. 1896.

Phimatelistische Offerten. Berlin. Jan.-Feb. 1897.

Vereins-Mithheilungen des Hamburg-Altonatr BriefMarien-Sammler-Vereins. Hamburg. Feb.-Dec. 1897.

Bier-Zeitung zuni Fest-Commers des Neunten DeutschenPhilatelistentages. Hamburg. July 1897.

"Philatelias." Lübeck. July 1897.

. Germania Berichte. Charlottenburg. Nov. 1897- (In progress.)

Hamburg-Altonaer Briefmaregn-Sammirr-Verein. VeREINs-Mitteilungen. Hamburg. Jan. 1898- (In progress.)

Mitteilungen des Deutschen Postwertzeichen-Kauf- U. Tausch-Verbandes Leipzig. Leipzig. Jan.-Oct.1898.

Philatelistische Herren-Abend-Zeitung. Berlin. April 1898.

Wahtizettel Für BriefMarken-SAMmLer U.-HANDLER. Leipzig. May-July 1898.

Kommers-Zmitung. Gössnitz. July 1898.

Postwertzeichen-Kunde im Leipzeiger Humor. Leipzig. July 1898.

Bier-Zeitung Des H. A. B. S. V. Hamburg. Sept. 1898.

Berliner Briefmarken-Anzeiger. Berlin. Oct. 1898-June 1899.

Fest-Zeitung Zum Zehnjährigen Stiftungsfest des Deutschen Philatelisten-Verband. Gössnitz. Dec. 1898.

Kaufgesuche und Angebote von Postwerthzmichen. Hamburg. Jan.-May 1899.

Internationale Ansichtspostrarten- U. BrIEFMARKen-ZeitUNG. Köln, etc. Apill 1899-March 1900.

Correspondenz Für den BrIeFMarkeN-SAMmelspor't. Leipzig. July 1899.

Philatelistische Alt-und Bierzeitung. Dresden. July 1899.

Postwertzeichen-Sammete. Berlin. Nov. 1899-Dec. 1900.

Internationale SẵLer-Warte. Roden. April-June 1900.

Internationales Publications-Organ im Briefmarken- Und Ansichtspostrartenwesen Resp. Dessen Vertriti und Tausch. Regensburg. July 1900.

Commers Zeitung. Frankfurt. July 1900.

Kommers-Zeitung. Hamburg. Sept. 1900.

Fest-Zeitung zum 10. Stiftungs-Fest des Vereins für Briefiarkenkunde, Kiel. Kiel. Oct. 1900.

Weinnachtsemier. Hambữg. Dec. 1900.

Fuiegende Buätter. Charlottenburg. Aprij-Dec. 1901.

BRIEFMARIEN-BöRSE. Leipzig. Oct. 1901. A Aríl. iquo

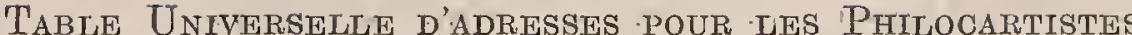
et Philatélistes et Correspondant Polyglotte. Wertheim. Oct. 1901-Oct. 1902.

Phimatelistische Revue. München. Nov.-Dec. 1901.

Annoncen-Beiblatt zum Phinatelist. Dresden. JulyOct. 1903.

Philatelistische Rundschau. Pforzheim. Aug. 1903.

Lietzow's Fliegende Blätter. Friedenau bei Berlin. Jan. 1904.

Philatelistische Miscellen. Augsburg, etc. Jan. 1904March 1909

Stempelmarke. Münster. Jan.-July 1904.

Nachrichten der Philatelistisohen BibliotheK von Azbert GottschalK. Berlin. March 1904-June 1905.

Cülnische Briefmarienn-Zmitung. Cöln. June-Sept. 1904.

Philatelistisches Echo. Leipzig. Nov. 1904-Dec. 1907.

Philatelisten-Zeitung. Berlin. Dec. 1904-Aug. 1906.

Philatelisten-Zeitunng. Gössnitz. Jan. 1905- (In progress.)

Philatelistische Nachrichten. Cöln. Feb. 1905- (In progress.)

Berliner Briefmarien-Zeitung. Berlin. April 1905- (In progress.)

Philatelistische Korrespondenz. Berlin. Déc. 1905April 1906

SAMmLER. Passau. Dec. 1905-Feb. 1906.

Philatelistische Berichte. Leipzig. April 1906- (In progress.)

Deutsche Stempel-Zeitung. Düsseldorf. Oct. 1906Jan. 1907.

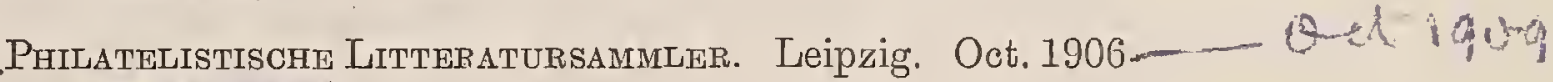
(In progress. $)$

\section{GRFAT BRITAIN}

Monthly Intelligenoer. Birmingham. Sept. 1862-July 1863.

Monthly Advertiser. Liverpool, Dec. 1862.

Stamp Collector's Monthly Advertiser. Liverpool. Jan. 1863-June 1864.

famp Coluector's Magazine. Bath. Feb. 1863-Dec. 1874.

Liverpool Stamp Advertiser. Liverpool. May-July 1863.

- United Kingdom Postage Stamp Advertiser. Tavistock. June-July 1863.

Tondon and Provyncial Stamp Advertiser. London. July 1863.

- Stamp Collector's Journal. Hartlepool. July 1863.

International Postage Stamp Review, London, F.C. Aug.-Sept. 1863.

Liverpool and Newport Stamp Advertiser. Newport, Mon. Aug. 1863-June 1864.

-Weymouth Stamp and Crest Advertiser. Weymouth. Aug. 1863-Jan. 1864.

International Postage Stamp Review. New series. London, E.C. Sept.-Dec. 1863

I. -28 
Monthit Circular. London. Sept.-Nov. 1863.

- Once a Month. Manchester. Sept. 1863-Jan. 1864.

Continfantal and Colonial Stanp Advertiser. Eccles. Oct. 1863.

London and New York Stanip Coliectors' Review. London, E.C. Jan.-Feb. 1864.

Nationat Postage Stanp Express. London, S.W. Jan.July 1864.

Newcastle and Gateshead Stamp Advertiser and Review. Newcastle-on-Tyne. Jan.-Niarch 1864.

Northumberland and Durhan Stamp Advertiser. Newcastle-on-Tyne. Feb.-Dec. 1864.

Weymouth Stamp and Crest Advertiser. New series, Weymouth. Feb.-May 1864.

Once A Month. [New series.] Manchester. March-Dec. 1864.

British and Foreign Stamp and Corn Advertiser. Manchester. May-Dec. 1864.

North of England Stamp Review and Advertiser. Barnard Castle. July-Aug. 1864.

- Stamp Collectors' Misceliany. Weymouth. July 1864May 1865.

North of England Stamp Review. New series. Barnard Castle. Sept.-Nov. 1864.

- Universal Stamp Gazette. London, E.C. Sept. 1864.

Collector's Heraun. Hull. Jan. 1865-May 1866.

Liverpool Stamp Collector's Journal. Liverpool. AprilJune 1865.

Stamp Collector's Pocket Companion. Manchester. April 1865.

Stamp Coliector's Examiner. Leamington, May 1865.

Bath Stamp and Coin Gazette and Advertiseli. Bath. June-July 1865.

Stanir Coltector's Examiner. New series. Leamington. . July-Aug. 1865.

W. D. Atlee's Stamp Circular. London, N. Sept. 1865Nay 1866.

- British, Continental, and Anerican Stamp, Conv, Crest, AUTOGraph, and General CưriostTy Collegtor's Magazine, and Journal of the Bridlington Amateur Association. Preston. Oct. 1865.

- Curiosity Collectors' Magazine, and Journal of the Bridlington Amateur Association. Preston. Nov. 1865.

Coltector's Circular. Preston. Dec. 1865-Nov. 1866.

Boys' Agency Circular. Horsham. March-July, 1866.

Stamp Dealeris Advertiser. Liverpool. July-Aug. 1866.

Boy's Telegram. London, E.C. Sept. 1866.

Stamp Courier and Curiosity Advertiser. Dewsbury, Oct.-Nov. 1866

- Philatelist. Brighton. Dec. 1866-Dec. 1876.

Stamp and Curiosity Circular and Collector's Vade Mecuni. Dewsbury. April 1867.

Stamp-Collector's Budget. Glasgow. Jan.-Feb. 1868.

West of Scotland Foreign Stamp and Packet Circular. Glasgow. March-Oct, 1868 .
International Stamp Recorder and Curiosity Magazine. Dewsbury. May 1868.

Youth's Gazetre and Advertister. London, W. Dec. 1869-Jan. 1870.

Stamp Collectors' Herald and Monthly Exchange and Advertiser. Hull. Aug.-Dec. 1871.

Stamp Journal and Philatelist's Guide. Hull. Nov. 1871.

Amateur Printers' Journat and Phimatelists' Gazette. Leeds. Dec. 1871.

Amateur Printers' Journal and Foreign Stamp Gazette Leeds. Jan.-Mar. 1872.

Philatelical Journal. Birmingham, etc. Jan. 1872-April 1875.

Stamp Collector's Heraed and Boy's Emporium. Hull. Jan.-April 1872.

Star Stamp Journal. Warrington. Jan. 1872.

James R. Grant and Co.'s Philatelical Circular. Birmingham, etc. Feb. 1872-Dec. 1874.

Stamp Collector's Guide and West of Scottland Curiosity Circular. Glasgow. Feb. 1872-1876.

Stamp Collectors' Journal and Philatelical Opinion. London, W.C. March-June 1872.

Hegnry L. Witdey's Monthly Circular and Postage Stamp Advertiser. London. Oct. 1872-May 1873.

Winlian Charleg Coke's Monthly Advertising List of Foreign Stamps, Crests, Monograms, Books, etc. London, E. Oct.-Dec. 1872.

B. B. Scott's Monthly Circular and "Generat AdverTISER". Oxford. Nov. 1872-Jan. 1873.

Stamp Review and Quarterly Advertiser. Hull. MarchJuly 1873.

International Exchange and Britannia Stamp Gazetrte. London, W. April 1873.

Foreign Stanp Advertiser and General Magazine. London, E. June 1873.

Monthly Advertiser and Foreign Stamip Gazette. Oxford. June-Sept. 1873.

Stanp. London. July-Sept. 1873.

Alfred Sumth and Co.'s Monthly Circular. Bath. Jan. 1875-Dec. 1893.

Mercury. London, E.C., etc. May-Oct. 1875.

-Archaeologist. London, E.C., etc. Nov. 1875-July 1876.

-Philatelic Quarterly and Misceldaneous Advertiser. Brighton. Jan. 1877-Sept. 1879.

Exchange Circular. Handsworth, Sheffield. 1877.

- English Journal of Philately. London, N. Sept. 1877 . May 1879.

Stamp Chronicle. Handsworth, Sheffield. April-May 1878.

Foreign Stamp Collectors' Journal. Bury St. Edmund's. Nov. 1878-Oct. 1882.

Bric-À-Brac. London, etc. [? 1878]-June 1906. Whe iflf

. Philatemic Record. London, etc. Feb. 18796 (I7b-93\%O= -gress.)

Philatemlist's Gazetre, Maidenhead, eic. March 1879 May 1882. 


Foreign Stamp Advertiser. Newcastle-on-Tyue. Oct.Dec. 1879.

Champion Exchange and Monthly Advertiser. Matfield Green, Kent. Dec. 1879-Feb. 1880.

British Philatelical Advertiser. Edinburgh. Jan. 1880.

Corn Coluectors' News and Bric-à-Brac Chronicle. Bury St. Edmund's. Jan.-Feb. 1880

Foretgr Stamp Advertiser and Review. Newcastle-onTyne. Jan.-July 1880.

- Phitatedic Review. Maidenhead. Jan. 1880-April 1882.

Universal Postage Stamp Advertiser. London. Jan. 1880.

Angro-American Pamphlets for Stamp Collectors. Brighton, etc. Feb.-Aug. 1880.

British Philatelist. Edinburgh. Feb. 1880.

Arcade and Monthly Exchange. Londion, S.W. MarchApril 1880.

Foreign Stamp Gazette. London. March 1880.

Champion Exchange and Monthly Advertiser; and Journal of Philatelic Literature. Hoismonden, Kent. March-April 1880.

Monthly Review and Advertiser. Edinburgh. March 1880 .

Amateur Exchange and Mart. London. Apl. 1880.

Amateur Stamp Exxchange and Mart. London. May 1880. Mar. 1881.

Champion Exchange, the Arcade, and Foreign Stamp Gazette: a Monthly Journal for Stamp Colmectors and Advertisers. Horsmonden, Kent. May 1880.

Monthly Exchange and Journal of Philateliy. Edinburgh. May 1880.

Novelty Advertiser and Review. London, S.W. May 1880

British and Foreign Novelty Gazette. London, S.W. July-Dec. 1880.

Stamp Dealers' Gazette. Horsmonden, Kent. Sept.-Oct. 1880 .

International Stamp Review and Bric à Brac Journal. London, S.W. Oct.-Nov. 1880.

Monthly Philatelist. Holgate, York. Oct.-Nov. 1880.

Foreign Stamp Advertiser. Edinburgh. Nov.-Dec. 1880.

Phimatelists' Magazine. London, N. Nov.-Dec. 1880.

Phicatelic Trmes. Margate. 1880. [Doubtful if published.]

British and Foreign Novelty Gazette and International Stamp Review. London, S.W. Jan.-June 1881.

Philotelical Circular. London, E.C. Jan.-Sept. 1881.

- Philatelic Star. Stockton-on-Tees, etc. March 1881-May 1886.

Universal Postage Stamp Advertiser and Amateurs' Chrontcle. New series. London. April 1881-Jan. 1882.

International Philatelical Association. Monthly RePoRT. West Brighton. May 1881-Jan. 1882.

Philatelic Advertiser. London, W. May 1881-May 1882.

Stamp Collector's Annual for 1881. Brighton. June 1881.
British and Foreign Novelty Gazette. London, S.W. Oct. 1881 .

-Philatelic Globe. London, W., ete. Oet. 1881-June 1885. -Philatelic Trmes. Margate. Nov. 1881-March 1883.

-Philatelic Observer. Bournemouth. Jan.-Feb. 1882.

Philotypist or Stamp Amateur. Ipswich. Jan. 1882.

Royal Phimatelist or Stant Colmectors' Monthly News. Liverpool. Jan. 1882.

Stamp Dealeris' Gazette. New series. Bury St. Edmund's. Jan.-April 1882.

.STAMP News. London. Jan. 1882-Dec. 1895.

Postage Stanp Gazette. Liondon, W. March-June 1882.

Stamp Colmectors' Friend. Margate. April 1882.

.Stamp Collector's Jounnal. Bury St. Edmund's. Nov. 1882-May 1901.

Novelty Guide and Foreign Stamp Coliector's Record. Glasgow. Winter, 1882.

Philatelic Remeree. Ipswich. Jan. 1883-July 1885.

Stayp Exchange Gazette and Philatelic Observer. Ipswich. Jan.-April 1883.

Magazine of Phildtely. Liverpool, etc. May 1883-Dec. 1884.

Monthly Exohange Circular. Ipswich. Aug.-Oct. 1883.

Universal Phitatelic Magazine. Liverpool. Sept.-Oct. 1883.

East Anglian Philatelist. Norwich. Oet. 1883-Mar. 1884.

Foreign Stamp Collectors' News. Hull. Oct. 1883-March 1886.

Philatelic Press and Genhral Advertiser. Anerley. Dec. 1883-March 1884.

New Impressions. Ipswich. Jan. 1884.

International Philatelist. Liverpool. March 1884.

South Wales Philatical News. Swansea. Aug.-Dec. 1884.

Whitaker's Monthly Sale and Exchange List. Manchester. Aug.-Sept. 1884.

Empire Exchange Gazette. Ipswich. Oet. 1884-March 1885.

Philatelic Quarterly Advertiser. Liverpool. Oet. 1884Jan. 1885.

Philatelical Gazette. Mumbles. Oct.-Nov. 1884.

Coluector. Hull. Dec. 1884-Aug. 1885.

Phrlatelic Herald and Foreign Stamp Advertiser. Southport. Dec. 1884-March 1885.

Philatelical Journal. Salford. [? ] 1884 . [Doubtful if published.]

Philatelical Advertiser. London, E. Jan. 1885.

Butuers' Philatelic Observer. Canterbury, etc. Mar. 1885-Aug. 1886.

Dealers' Advertiser and Collectors' Exchange. Charlbury. March 1885-1886.

Philatelic Magazine: Liverpool. April 1885. 
Philatelical Exchange and General Advertiser. Burslem. April-June 1885.

Ordham Philatelicat Trmes. Oldham. May-July 1885.

Collector's Journal. Charlbury. June 1885.

Oxford Philatelical Monthly. Oxford. June-July 1885.

Stamp Dealers' Journal. Nottingham. June 1885-Feb. 1886.

Waugh's Monthly Exchange List. London, E. [? July] 1885-Sept. 1886.

- British Philatelist. London, N.E. Jan.-Feb. 1886.

Foreign Stanp Collector London, W. Jan. 1886.

- Phicatelic Quarterly Review. London, S.E. Jan. 1886.

- Philatelic Exchange List. London, N. Feb.-Aug, 1886.

Stamp and Coin Colmgctors Advertiser. Leeds. Feb.July 1886.

Philateltc Mercury. Oxford. March-April 1886.

Southanpton Stamp Advertiser. Southampton. MarchJune 1886

Argosy Monthly SaLe and Exchange List. Belfast. April 1886.

Argosy Monthly Sale and Exchange List and Stamp Advertiser. Belfast. May-June 1886.

Bradford Exchange List and Philatelic News. Bradford. May 1886.

Philatelic Guida. [? ]. June 1886. [Doubtful if published.]

Philatelists' Own Paper. Southampton. July 1886.

Stamp Exchange. Hull. Sept.-Nov. 1886.

Eudryn's Advertiser, London, E. Oct. 1886.

Waugh's Journal. London, E. Oct. 1886

Untversat Stamp Collector. London, Fi. Nov. 1886-Jan. 1887.

British and Foreign Philatelic News. Sutton, St. Helens. Jan.-Feb. 1887

Excelsion Exchange Journal. Dewsbury. April 1887.

- Philatelic Critic. London, N. April 1887-May 1888.

Anglo-American Advertiser and Foretgn Stamp Record. Leicester. May 1887.

International Exchange Gazette. Ipswich. May 1887.

Jubinee Commemorator. Leicester. June 1887.

Midland Philatelic and General Advertiser. Nottingham. Aug. 1887-July 1888.

Philatelists' Paper. Southampton. Oct.-Nov. 1887.

- Philatelic Advertiser and Colidector's Referee. London, W. Jan.-Oct. 1888.

Philatelic Press. London, E.C. Feb.-May 1888.

Anglo-American Stamp Herald and Review. London. Mar:-Apl. 1888.

- Phitatelic Advertiser and Young Men's Misceltany London, W. Nov. 1888.

Stamp Collectors' Gazette. Liverpool. Nov. 1888-Feb. 1889.

Philatelic Review. Bristol. Jann, 1889.
Stamp Herald. Berwick-on-Tweed. Jan. 1889

Amateur. Stretford, Manchester. Feb. 1889.

Amateur Advertiser. London. Feb.-Mar. 1889.

Official Gazette. Bury St. Edmund's, otc. Eeb. 1889April 1891.

- Collectors' Miscellany. London, 'W. Mar.-Apl. 1889.

Midland Philatelist. Nottingham. March 1889-March 1890.

-Philatelic Trmes. London, W.C. [? Mar.] 1889.

YankeE DoodLe. Thornton Heath. April 1889.

Youth's Bazaar and Stamp, Coin, and Curiosity Mart. London, S.W. April 1889.

Stamp Collector. Stretford, Manchester. May-June 1889.

Stamp Advertiser and Auction Record. Elgbaston, Birmingham. Dec. 1889-June 1890.

Stamp Collector's Magazine. Richmond, Surrey. AprilJuly 1890.

Philatelic Review. Huddersfield. July-Oct. 1890.

Stanley Gibbons and Co.'s Monthuy Journal. London. July 1890-Jane 1908. I flesth

Stamp Collector's Monthly. Richmond, Surrey. Aug. 1890-Dec. 1894.

Monthly Ofmens to Philatelists. Bath. Nov. 1890-Feb. 1898.

- Stamp News Annual. London. Jan. 1891-Jan. 1896.

Philatelic Journal of Great Britain. Salisbury, etc. Feb. 1891- (In progress.)

Monthly Review and Stamp Collector's Guide. London, S.F. April 1891.

Stamp Collector. Forest Gate. May 1891-May 1893.

Philatelic Chronicle and Advertiser. Birmingham. Oct. 1891 (un (In progress.)

Philatelic Exchange and Advertiser. London, S.E. Dec. 1891.

- London Philatelist. London. Jan. 1892- (In progress.)

- Philatelic Review of Reviziws. Salisbury. Jan. 1892Dec. 1896.

Stamp Collector's Review. London, E.C. March 1892.

Phimatelic Monthly News. London, E.C. April-July 1892

Philatelic Extract and Adpvertiser. London, S.J. Júly. Sept. 1892.

Literary Chimes ani Stamp Collectors' Treasury. Bradford. August 1892 .

Collectors' Universal Advertiser. Rotherham. Sept.Dec. 1892.

Stamp InvestoR's Guide. Kingston-on-Thames. Oct. I892March 1893.

- City Stamp. Birmingham. Nov. 1892-Aṕl. 1894.

Fiscal Philatelist and Revenue Stantp Guide. London, N. Dec. 1892-Dec. 1893

Haberstraw's Stamp Chrontcle and !Ctrcutrar. Swansea. Jan. 1893.

StAMP:COLLECTORs' HERALid, Waithamstow. Jan.-Mayu 1893. 


Intrbinationar Philatelic Advertiser. London, W. Eeb.April 1893.

Phidateilic Higralid. Eorest Hill. Feb.-Aug. 1893.

. Collector-Dealer. Southsea. Dec. 1896-Jan. 1900.

Junior Stamp CoLLeCtor. Birmingham. Jan. 1897-Dec. 1899.

- Stamp Chronicle and Circular. Swansea. Feb.-July 1893. . Stamp-Gossip. Bury St. Eidmund's. Jan.-Dec. 1897.

Philatelic Gazetre. Ore, Hastings. April-Dec. $1893 . \quad$. Stamps. Rushden, etc. Jan. 1897-March 1902.

Stamp Colifectors' Herald and Philatelic Exchange and Smyth and Co.'s Philatelic Circular. Boscombe. June MaRT. Walthamstow. June-Aug. 1893.

Collector's Own and Philatelic Extract. London, S.E. July 1893. 1897-Dec. 1899.

L'Fistrange Ewen's Wegkly Circular. Norwood, London, S.E. Oct. 1897-June 1899.

Stamp Chronicle and British Philatelist. Swansea. Aug. “A I” Philatelist. Birmingham. Jan. 1898. 1893-March 1895.

Monthly Post and Stamp WorLd. London, N., etc. Oct. 1893-Feb. 1897.

Stamp Draleks' Advertiser. Walthamstow. Dec. 1893 Oct. 1894.

Advertiser of Wants and OFfers. Birmingham. Jan. 1894-Dec. 1903.

Alfred Smrth and Son's Monthly Circular. Bath. Jan. 1894- (Iroprogress.)

Stamp Colimetors' Advertiser and New Issue Record. Walthamstow. Feb--March 1894.

Vindin's Stamp Trade Journat. London, W.C. Feb.-May 1894.

Stamp CoLlectors' Adver'iser. Walthamstow. AprilJune 1894.

Grimsby Philatelic Advertiser of Wants and Offers. Grimsby. Sept. 1894-Jan. 1895.

Inwthwalte's Monthis Bazaar. Egremont. Sept.-Oct. 1894.

Monthly Reader and Stamp Collector's Guide. Walthamstow. Sept. 1894.

Philatelic Advertiser. Eondon, W. Sept. 1894-July 1895.

Hopkins Bros." Monthey Bargalns to Philatelists and London Audtion. Record. London, N. Oct. 1894.

Stamp Coliectors' Fortnightil. London. Oct. 1894 (In progress.)

- London Auction Record. London, N. Nov.-Dec. 1894.

- Phillatelic Times and Stamp Mart. Tewkesbury, etc. Dec. 1894-Dec. 1895

. Philatelists' Supplement to "The Bazaar", London, W.C. Feb. 1895-April 1900.

- Lincolnshire Philatelist. Grimsby. May 1895.

English Spegiatists' Journal. Swanage, etc. Nov. 1895Dec. 1897

Londoner Philatedist. London. Feb.-April 1896.

Witherick's Stamp Coldecting Crrcular. London, E. April-Sept. 1896.

Stamp Collector. Miller's Dale, Buxton. June 1896.

- Phimateric Trmes. Miller's Dale, Buxton. July 1896-Jan. 1897.

- P. J. G. B. Advertiser. Salisbury. Oct. 1896-Sept. 1899.

Stamp Collector. Leytonstone. Oct.-Dec. 1896.

- Londoner. Briermakken-Auotionär. London. Nov. 1896 Nov. 1897.

- Stamp Advermiser. Southport. Nov. 1896-Jan. 1897.

. Stamp Auction Reporter. London, N. Jan.-July 1898.

Croydon Philatelic Gazetre. Croydon. March-Nov. 1898.

Philatelic Monthly Advertiser. London, S.F., etc. May 1898-Jan. 1899

Stamp Collector's Advertiser. London, E.C. Nov. 1898

Philatelic Trader. Figremont. [? Jan.] 1899- (In progress.)

Transvaal Collectors' Quarterly. Croydon. Jan.-April 1899.

Stamp Colledtor's Advertiser. Birmingham. Feb.-Nov. 1899.

London Philatelic Exchange Gircular. London, E.C. March-June 1899.

Chas. Purdom Monthly Circular. London, S.W. Apl.Aug. 1899.

Ewen's Weerzy Circular. Norwood, London, S E. JuneSept. 1899.

-Philatelic World. Ashton, Preston. June 1899.

Ewen's Weekly Stamp News. Norwood, London, S.E.

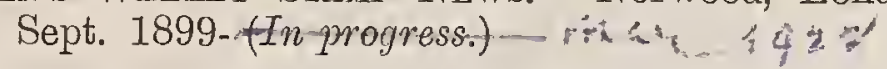

Monthiy Philatelic Cirqular. London, S.W. Sept. 1899-Mar. 1900.

Brown's Advertiser. Salisbury. Oct. 1899-Aug. 1904.

Stamp Collectors' Guardian. London, E.C. Oct. 1899 Jan. 1900.

Post Card News. Leeds. Nov. 1899.

Stanre Advertiser. Birmingham. Dec. 1899-Nov. 1902.

Morley's Philatelic Journal. London, S.E. Jan. 1900 1908.

Postal Cards and Covers. Leeds. Jan. 1900-Oct. 1901.

Stamp CoLlector. Birmingham. Jan. 1900- (In progress.)

British and Colontal Philatelic Advertiser. Hillsbro', Sheffield. Feb. 1900-May 1901.

Smyth's Philatelic Circular. March 1900-Oct. 1908.

Young Stamp Collector. London, S.W. March-Aug. 1900.

Miscelianeous Advertiser of Wants and Offers. Shrewsbury. April-June 1900.

Miscellaneous Stamp Advertiser of Wants and Offers. Shrewsbury, July 1900-Jan. 1901.

Picture Postcard. London, E.C. July 1900-Sept. 1907.

Sgottish Philatelic Advertiser. South Queensferry. July. 1900-Aug. 1901. 
British and Coloniat Stamp Market. Norwood, London, S.E. Oct. 1900-Sept. 1901.

Kingston Stamp Advertiser. Kingston Hill, Surrey. [? ] 1900-[? ] 1901.

Monthly Stamp Notes. Southsea. Jan. 1901-Feb. 1902.

Philatelic Monthuy Referee. London, S.E., etc. Feb. 1901-Aug. 1902.

- Phuatelic Literature. London. March-June 1901. International Stamp Mart. Birmingham. May 1901.

UnIVersal Adveritiser. Rotherham. June 1901-Aug. 1902.

Ewen's Colonial Stamp Market. Norwood, London, S.E. Sept. 1901-July 1902.

Monthly Philateurc Advertiser. Derby. Sept. 1901-July 1902.

Philatelists' Monthly Advertiser. Lincoln. Sept. 1901 Feb. 1902.

City Philatelist. Cork. Oct. 1901-Dec. 1903.

Collectors' Fortnightuy Sales Catalogue. Luton. Nov. 1901-Jan. 1902.

Stamp Coltectors' Budget. Hastings, etc. Nov. 1901Sept. 1902.

Poole's Mon'fhly Philatelist. Stamford. Jan. 1902-Jan. 1904.

Ewen's Colonial Stamp Market, Ltd. Norwood, London. S.E. July 1902-Dec. 1905.

Monthicy Stamp News. Hanley. Aug. 1902.

Monthly Philatelic Referee. West Croydon. Sept.-Oct. 1902.

Dealer's Advertiser. London, N. Oct. 1902-March 1903.

International Phimaterist. Northampton. Oct.-Dec. 1902

"I. P. R." and Collectors' News. Luton. Nov. 1902-Jan. 1903.

"I. P. R." and Colmectors' News Advertisement SuppleMENT. Luton. Nov. 1902.

Untversal Stamp Advertiser. Birmingham. Nov. $1902-$ April 1905.

Register. Tipton. Jan.-Feb 1903.

"I. P. R." and Colledtors' News. New series. Luton. Feb. 1903.

CoLmectors' Advertiser. Rotherham. Feb. 1903-Sept. 1905.

Young Philatelist. Burton-on-Trent. Feb.-June 1903.

Collectors' News and Pastimes Review. London, W. March-Aug. 1903.

Collector's Exchange. London, W. April 1903.

Collectors' Gazette and Photographic Review. London, S.W. April 1903.

Collectors: Weekty Exchange and Trade Advertiser. London, W. May-July 1903.

Young Phimatelist's Advertiser. Burton-on-Trent. June 1903.

- Stamp Notes. Southsea. July 1903-Oct. 1906.

Stamp Mount. Derby. Sept. 1903-May 1905.

- Petry's Advertiser and Reporter. Bradford. Oct. 1903Jan. 1904.

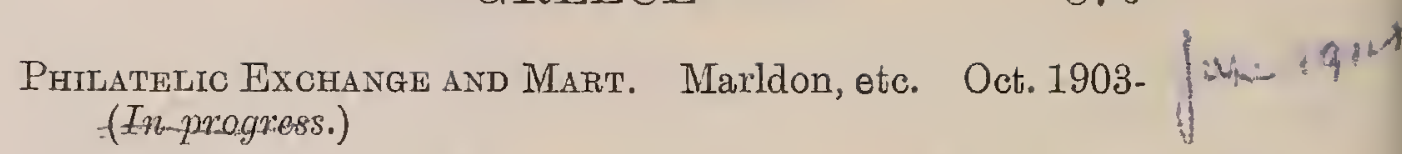

Stamp Coltectors' Annuat. London. Jan. 1904- (In pro- gress.)

Collectors' Budget. Bradford. March-May 1904.

West-End Philatelist. London, W. March 1904- (In progress.)

W. H. Regan's Monthly Gircular. London, W. March 1904-June 1906.

Collectors' Medium. London, N. May-Nov. 1904.

Advertiser. Salisbury. Sept.-Oct. 1904.

Coltector's Review and Exchange. 'Tipton. Oct. 1904.

Home and Colonial Philatelist. Spondon, Derby. Oct.Nov. 1904.

Stante and Postcard Advertiser. Salisbury, etc. Nov. 1904-June 1906

.Gibbons Stamp Weekiy. London. Jan. 1905 (In pro-gress.) -

Butler Bros.' Stamp Circular. Clevedon. Feb. 1905-June 1907.

WorLd's Exchange. Ilford, etc. Feb. 1905-April 1907.

Collectors' Review. Tipton. April-May 1905.

Home, Continental and Colonial Sale and Exchange Budget. April-May 1905.

Collectors' Monthly Record. Bolton. June-Aug. 1905. COLLECTOR MAGAZINE. Rotherham. Oct. 1905 -Dec. 1906.

Forward Stamp Advertiser. Birmingham. Oct.-Nov. 1905.

Members' Exchange List and Wide Worlid Advertiser. London, W. Now1905-Sept.1906. Insas

Ewen's Current Stamp Quotations. Norwood, London,

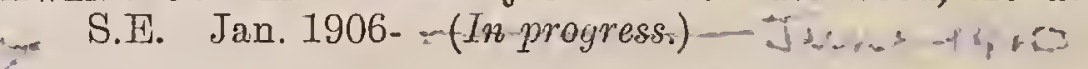

Philatelist. Manchester. April 1906-Sept. 1907.

Nissen's Monthly Offers. London, W.C. May 1906-July 1907.

Northern Trade Recorder. Darlington. May-July 1906. International Philatelio Advertiser. London. Sept. 1906-July 1907.

W. H. Regan's Postage Stamp Crrcular. London, W. Sept. 1906.

\section{GREECE.}

EPMH乏. Hermès. Athenès. March 1891-Jan. 1892.

Athénes-Philatéltque. A thènes. Apl. 1894-Jan. 1897.

Trmbrophile Atrénien. Athènes. Sept. 1897-March 1899.

Philatelique Oriental. Corfou. Jan.-Dec. 1905.

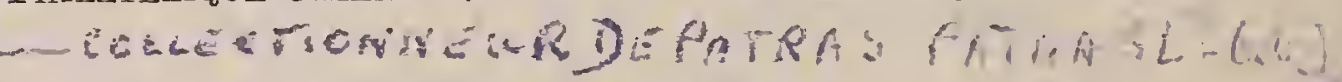

\section{HAWAIIAN ISLANDS.}

Oceanic. Honolulu. [Feb.]-May 1889.

\section{HOLLAND.}

Continental Philatelic Magazine. Amsterdam. Feb. 1869-Jan. 1870.

TinвrophILIST. Amsterdam. July 1869-March 1870. 


General Stamp Advertiser. Amsterdam. June 1870.

Postzegelterzametar. Delft. 1880.

Nederlandsa Thjuschrift voor Postzegethunde. Amsterdam. Aug. 1884- (In progress.)

Timbre. Amsterdam. July 1888-July 1894.

Kleine Verzamelaar. Den Haag. June 1891-Jan. 1899.

Postiujon. Den Haag. Jan. 1892-Dec. 1893.

Verslagen en Handelingen. Amsterdam. March 1892April 1896.

Rotterdalr Philatedist. Rotterdam. Sept. 1892-March 1893.

UnION. Arnheim, etc. July 1893-July 1894. (Nos. 4-8 were published at Pössneck in Germany.)

Post-Zeget. Amsterdam. Oct. 1893-May 1896.

Postblad. Amsterdam. Mar.-Sept. 1894.

Postzegels. Monnikendam. Aug.-Sept. 1894.

Postzegelcourant. Amsterdam. Aug. 1895-April 1897.

Vertrouwelijke Miededeelingen. Amsterdam. May 1896 (In progress.)

GLoвs. Rotterdam. Oct.-Nov, 1896.

MaAndblad der Afopeing Utrecht van de Eindhovensche Postzegel Club. Utrecht. Nov. 1896-July 1897.

Post-Zegetgids. Ansterdam, etc. May 1897-April 1906.

Postzegelilad. Den Haag, etc Oct.1897- (In progress.)

Espérance. Rotterdam. Jan,-March 1898.

Postzegelinieuws Briefmarkenzeitung. Velp bij Arnhem. Oct. 1900- (In progress.)

B. S. I. C. Weekblad voor den PostzegelverzanelaAr. Amsterdam. Oct. 1901-Apl. 1902.

Cosmopolitan Philatelist. Amsterdam. Nov. 1901.

Philatéliste Cosmopolite. Amsterdam. Jan. 1902-May 1904.

Nederlandsche Philatelist. Amsterdam. June 1904(In progress.)

Confidentia. Amsterdam. Oct. 1904- (In progress.)

American-Continental Advertiser. Amsterdam. Nov. 1904-Feb. 1905

John Grap's Postzeqennieurs. Utrecht. Nov. 1904-Oct. 1905.

Wereldpost. Waalwijk. March 1905-Nov. 1906.

Per Litteras Unum. Rotterdam. Aug.-Oct. 1905.

Kleine PostzegelverzamelaAr. Amsterdam. 1905.

Postzeged. Epe. Jan. 1906- (In progress.)

\section{HONG KONG.}

Hong-Kong Philatelic Journat. Hong-Kong. Jan.-Dec. 1895.

\section{INDIA.}

Indian Philatelist. Dadar, Bombay. May 1894-April 1896. Philatelic World. Calcutta. July 1894-March 1897.
- Indian Postage Stamp News. Bombay. Sept. 1894-Sept. 1895.

Abgar's Philatelic Monthly and Stamp Mart. Calcutta. Dec. 1894.

Quarterly Philatelic Circular. Bombay. Jan.-Oct. 1896.

Campbell's Monthly Advertiser, Calcutta. Nov. 1896 May 1898.

- Philatelic Journal of India. Calcutta. Jan. 1897- (In progress.)

-Stamps. Calcutta. July 1897-July 1906.

Stant Exchange. Allahabad. May 1903-April 1904.

Young Postage Stamp Collector. Bangalore July 190 .

\section{ITALY.}

Posta Mondale. Livorno. July 1873-July 1874.

RAcCogltore. Firenze. July 1874.

Raccogurtore. Firenze. Jan.-July 1875.

Guida Illustrata ded Timbrofilo. Bologna. July 1876Dec. 1880.

Am du Collectionneur. Rome. Oct. 1876-1880.

Gionnale dec Coluezionista. Palermo. June-July 1880.

Collettore Italiano, Torino. Jan.--Tuly 1881.

Filatelia. Roma. July 1890-May 1893.

Rivista Filatelica. Milano. Feb. 1891.

Posta Universale. Milano. June-Sept. 1891. (Other numbers were published in Austria.)

Rivista Filatelica Internazionale. Milano. June 1891. Dec. 1894.

Collezionista. Torino. July 1891-May 1892.

Moderno Raccoghitore. Torino. Jan.-Dec. 1892.

Corkikre Filatelico Italiano. Firenze. March 1892-May 1893.

Annunzro Frlatelico Itallano. Roma. April 1892-Oct. 1893.

Bollettino Filatelico. Verucchio. May-Aug. 1892.

Raccoglitore Romano. Roma. Oct. 1892-May 1893.

Franoobollo. Milano. March 1893-Jan. 1900.

Raccoglitore Ronano ei la Filatelia. Roma. Aug. 1893.

Italia Frratelica. Palermo. July 1894-May 1890.

Corriere dei Francobolli. Torino. Nov. 1894-Sept. 1895.

Publicité Philatélique. Padone. Nov. 1894-Sept. 1895.

Araldo Filotelico e Numismatico. Milano. Dec. 1894. Jan. 1895.

Commercio Filatelico Internazionale. Bologna. Jan. March 1895.

Consiguiere Filatelico. Palermo. Jan.-Apl. 1895.

San Marino. Pistoia. Jan.-Aug. 1895.

Araldo Timbrotogico e Numismatico. Milano. Feb.-July 1895.

"Trinacria." Napoli. Feb. 1895-March 1896.

Firenze Frmateuica. Firenze. March 1895. 
Italia Filatelica e Consigliere Filatelico fusi insieme. Palermo. Sept. 1895-Jan. 1896.

Étome Phmatélique. Padoue. Oct. 1895-Feb. 1907.

San Marino Corriere det Francobolili. Torino. Nov. 1895-May 1898.

Roma Filatelica. Roma. Nov. 1896-July 1897.

Toscane PhiLatélique. Livourne. Feb.-March 1897.

- Rivista dei Francoboli. Spoleto, etc. March 1897- (In pragress) the in the i i 11

Etna Philatelique. Catane. Oct. 1897 .

Firatelico. Firenze. Nov. 1897-April 1898.

Peitiateliste Italiten. Fermo. March-A'ug. 1898.

Mongibelio Filatelico. Catane. April-Sept. 1898.

VAde-Mecum du CoLLeCtionneur d'Europe. Chieti. June 1898-Dec. 1899.

Friuli Filatelico. Pordenoné. Aug.-Sept. 1898.

Firatelista Italiano. Fermo. Sept. 1898-Aug. 1899.

Giornale Filatelico Itadiano. Biella. Aug. 1899.

Filatelista ed iL Fillocartista Itadiano. Fermo. Sept.Oct. 1899.

Colimzionista. Bologna, etc. Feb. 1900-Dec. 1906.

Francoboldo e ta Cartolina. Milano. Feb. 1900-March 1901.

Commerce Philatécique. Campagna. April 1900-Feb. 1901.

Annunzio Filatelico e Filocartista. Firenze. May 1900Aug. 1901.

Stelita ded Filatelico e del Fllocartista. Biella. July 1900.

Fidatelia Itadiana. Modena. Jan.-Nov. 1901.

Rivista Ifilatelica Itadiana. Milano. Jan.-March 1901.

Commerce Philatélique et Philocartiste. Campagna. March-May 1901.

Giornale dei Collezionisti di Francobolid e cartoline ILLUstrate. Napoli. March 1901.

Corriere Filatelico Romagnolo. Imola. April 1901-Oct.

Réchame Economique. Catane. July 1902.

RÉclame Economiquéf Catane. Aug. 1902.

Annonce Philatésique Sicilienne. Catanie. Sept. 1903Dec. 1907.

Guida Etíátelica. Itadiana. Messina. May 1904-May 1905.

Itradia Filatelica. Torino. March-Dec. 1905.

Itralte. Bisceglie. March 1905.

Aracdo Filatelico. Saluzzo. June 1905-July, 1906

Untone Filatelioa Commerciade. Palermo. Feb.-March 1906.

Monde Philatélique. Bisceglie. April 1906.

Commerce Cartophitatílique. Saluzzo. Oct. 1906-June 1909.

Bolietrixo Mensile dell' Unione Frlatelica Commerciade. Palermo. Jan, 1907-Apl. 1909:

\section{LUX:FIMURG.}

Philatéliste Universel. Esch-sur-Alzette. May 1890 Feb. 1891.

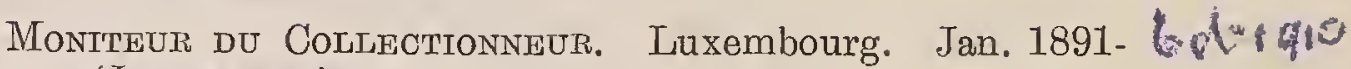
(Itr progress?)

Petites Affiches du Timbrophile. Luxembourg. Feb. 1895- (In-progiesst)

$$
\text { (1) } E-6.9 \% \text { MALTA: }
$$

Medita Philatelic Chronicle and Advertiser. Valletta. Jan. 1898-Dec. 1899.

Malta Advertiser. Valletta. June-Oct. 1901.

\section{IMEXICO:}

Boletin de la Sociedad Filatelioa Nacional. Guanajuato. Mar. 1889-Nov. 1891.

Boletin de la Soctedad Fluatelica Mexicana. Mexico City. April-Oct. 1889.

Filiatelista Mexicano. Monterrey. May 1891.

Mexico Postal. Guanajuato. July 1892-April 1893.

Monitor Ftuatélico. Mexico City. Dec. 1892-Feb. 1898.

Mexico Postal. Segunda Epoca. Guanajuato. May-Sept. 1896.

Filatelista Mexicano. Mexico City. Summer, 1900.

Express Postad. Orizaba. 1904.

Mexico Filatéuico. Mexico City. July 1904-Aug. 1906.

Jalisco Filatelico. Guadalajara. May-Oct. 1906.

\section{IMOROCCO}

Maroc Timbrologique. Tanger. Feb.-April 1897

Philatéliste Marocain. Tanger. Jan.-April 1898.

\section{NATAL}

Stamp Recorder and Collectors' Exchange. Charlestown. Aug. 1904-April 1905.

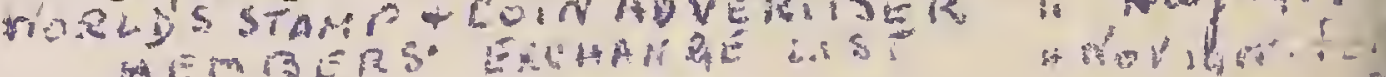
NEW SOUTH WAIES

New South Wales Stamp Collectors' Magazine. Sydney. Nov. 1879-April 1881.

New South Wales Stamp Gollectors' Magazine. New series. Sydney. Aug. 1882.

New South Waligs Philatelist. Sydney. Nov. 1882-Jan. 1883.

-Vindin's Philatelic Monthiy. Sydney. Aug. 1887.July 1894.

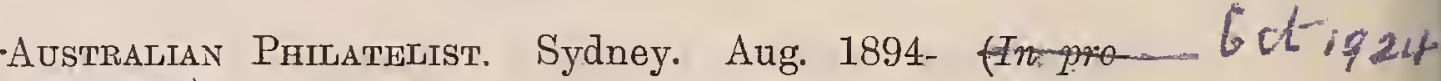
"gress:)

Australian Journat of Philately. Sydney. Sept. 1900 Aug. 1905.

Hawkesbury Philatelist. Windsor. April 1901.

Hawkesbury District Philatelio Journal. Windsor. Jan. 1902-July، 1903. 




\section{NEW ZFEATAND.}

New Zealand Stamp Coluedrors' Quarterly. Auckland. Oct. 1880.

Philatelic Times. Auckland. May-Nóv. 1881.

New Zealand Philatelist. Wellington. April 1900.

Stmrling Monthey. Nelson. June-Dec. 1903 :

New Zgatand Philatelist. Nelson. Jan.-Oct. 1904.

Oceania Philatgelic Journal. Rangitikei. June 1904-June 1905.

Stamp Collector's Monthly Advertiser. Christchuroh. March-June 1905.

\section{NORWAY.}

Nordisk Frimaerkeblad. Arendal, etc. July 1886-May 1889

Nordisk Frimaerkeblad. Kristiania. Jan. 1892:Dec. 1893. Aatesunds Frimaerkeblad. Aalesund. Oct. 1893-Jan. 1894.

Nordisk Firatelistisk Tidskrift. See Sweden.

Filatelisten. Aalésund. May-June 1894.

Internationalt Frinaerkeblad. Mosjфen. Sept. 1894.

Nordisk Frimaerke-Tidende. Aalesund. Jan. 1895.

\section{PERU.}

Mercurio. Lima. Oct. 1886-March 1887.

Fílatélico del Peró. Arequipa. May 1893-ApI. 1894.

Peru Postal. Lima. Jan.-Aug. 1904.

Excelsior Postal. Arequipa. Feb.-July 1904

\section{PORTO RICO.}

Fibatelia Antillana. Mayaguez. March-Oct، 1893.

Heraldo Filatéltco. Mayaguez. May-July 1894.

Puerto-Rico Fildatélico. San Juan. A April 1896-Aprill1897.

Noticiero Filatélico. Mayaguez. July 1900-April 1902.

Porto Rico Stamp Exchange. San Juan. Jan. 1903.

Noticiero Filatélico. Mayaguez.: July 1904-Sept: 1905.

Estrelda Filatélica. Mayaguez. Sept. 1904-Apl: 1905.

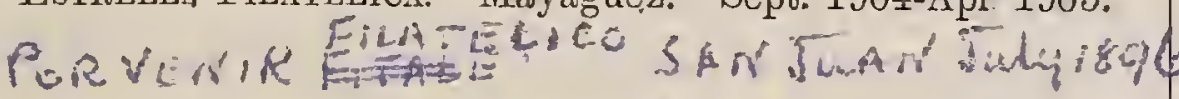

\section{PORTUGAL}

Phithatelista. Lisboa. April 1887-Apl. 1896.

Ami du Timbrophile. Lisbonne. Feb.-Sept. 1888.

Correio Luzitano. Lisbonne. Sept. 1888-March 1890.

Portugal Philatelico. Lisboa. May 1893-Jan. 1894.

Porto Philatelico. Porto. July-Oct, 1893.

Internacional, Villa Vicosa. March 1894-Sejt. 1897.

Portugar Philatélique. Aveiro. Jan: 1895-May 1896.

Erora Postal. Evora. April 1895-April 1896.

Philatelie Pontugaise. Lisbonne. Jan. 1896-Feb.. 1897.
Philatelista do Occidenteg. Porto. Jan. 1898-Jan. 1899 Porto Philatelico. Porto. April 1898-Jam 1902.

Annuncio Philatelico Portuguez. Lisboa. May-Aug. 1898.

Philatelista Luzo-Africano. Porto. Jan.-May. 1899.

Philatelista Annunctador. Porto. April-July 1900.

Philatelista de Guimarães. Guimarães. June-Aug. 1900. Philatelico Averrense. Aveiro. Jan.-March 1901: "

Revista Philatelica Portugueza. Porto. Jan. 1901-Dec. 1904.

Philatelico Elvense. Elvas. April 1901-Jan. 1902.

Braga Philatelica. Braga. July 1901-July 1902.

Philatelia. Guimarães. May-Nov. 1902.

Portugal Cartophime et Philatélique. Porto. Jan. 1904.

Portugal Cartophilo e Philatelico. Porto. Feb. 1904. Nov. 1906.

\section{QUEENSLAND.}

Australian Stamp News. Gunalda, etc. July 1893-Oct. 1898.

\section{ROUIMANIA.}

Timbrophilo. Bucurescĭ. Jan.-March 1881.

Bucarester Philatelist. Bucarest. Jan. 1885.

Phinatelist. Bucarest. Feb. 1885.

Timbrofilud. Bucuresč. Nov. 1890-March 1893.

Curierul Mărcilor. Postale. Pitesti. Jan.-March:1891.

Monitorul Socigrătĭ̌, Filatelice: Române. Bucur'eşty̆. Sept. 1892-Jan. 1893.

Philatelist-Oriental. Galatz. May-June 1893.

Romania Philatelica. Jassy. Sept. 1893:

Ecour Mărcilor. Fócşanĭ. July 1894-May 1895.

Philatéliste Roumain. Braila. Jan.-March 1895.

Posta Română. Focşanl. April 1895.

Rumänischer-Philatelist. Bucarest. April-May 1896.

Timbrophile Roumaine. Berlad. Feb. 1897.

Anunciatorul Mărcilor. Jassy. March 1897.

Orient Philatélique. T.-Severin. March 1897.

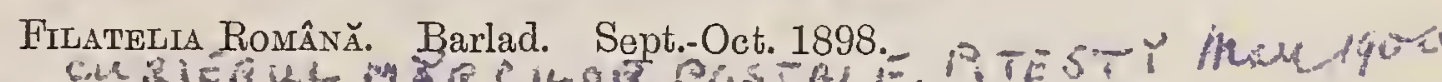

Rumanisches Briendarisen-OFferten-BLAtT. Jassy. March 1901.

Roumanie Philatélique. Bucarest. Dec. 1904-Feb. 1905.

Filatelia. Braila. Feb. 1905-Feb. 1906.

Roumanie Timbrophile. Bacău. March-Dec. 1905.

Montteur Philatélique. Bucarest. Jan.-Oct. 1906.

Intermediaire. Constantza. July-Aug. 1906.

Poste. Braila. Oct. 1906.

Philatélie. Braila. Nov. 1906-March 1907. 


\section{RUSSIA.}

Finska Frlatemisten. Helsingfors. Dec. 1894-Jan. 1896. OfFerten-Blatt für Fremarken-SAMMLER UND HäNDLER. Jyvāskylā. Jan.-March 1896.

марки. Kiew. March 1896-Aug. 1901.

bCemiphai notta (Wsemirnaja Potschta). St. Petersburg. Jan. 1897. Dec. 1898.

MAPKH и KO.IJEKपIOHEP'. St. Petersburg. Sept. 1903 (In progress.)

\section{SAN MARINO.}

San Marino Philatelist. San Marino. Jan. 1892-1894. San Marino Postat. San Marino. Feb.-[? ] 1899.

\section{SOUTH AUSTRALIA.}

Australian Stamp Collectors' Journal. Adelaide. Nov. 1879-Feb. 1880.

Post Card and Stamp Collectors' Journal. Adelaide. Sept. 1906-Feb. 1907.

\section{SPAIN.}

INdiCAdor de LOS SELlos. Madrid. July 1870.

Coleccionista de Seluos. Madrid. Feb.-March 1871.

Coleccionista. Malaga. Sept. 1890-Jan. 1892.

Alianza Filatélica. Barcelona. Nov. 1891-May 1892.

Anunclador Filatélico. Cádiz. Apl.-Dec. 1892.

Unión F'ilatélica. Barcelona. Jan. 1893-1895.

Coleccronista. 2a série. Malaga. March-June 1893.

Cádiz F'tlatélitoo. Cádiz. Aug.-Oct. 1893.

Tarraco Filatélica. Tarragona. Oct.-Nov. 1894.

Heraldo Timbroló́tico Hispano-Americano. Sevilla. April 1895-June 1896.

Ilustración Frlatélica Hispano-Cotontal. Barcelona. April 1895-July 1897.

Hispalense. Zaragoza. June-July 1895.

Anunciador Timbrol6́grco. Ferrol. Nov. 1895-July 1896. Crónica Fillatélica. Madrid. Dec. 1895-April 1896.

Filatelia. Málaga. Jan. 1896-Jan. 1898.

Filatelista Peninsular. San Sebastián. April-June 1896.

Finatelia Espa ̃ola. Villanueva y Geltrú. Oct. 1896-Jan. 1897.

Anunciador Periodico Frlatelista. Santiago. Nov. 1896 Apl. 1897.

Propaganda Industriat F'illatélica. Santiago. Nov. 1896March 1897.

Madrio Finatélico. Madrid. Jan. 1897- (In progress.)

Boletin del Crrculo Fruatélico Matritense. Madrid. July 1897-June 1900.

Mundo Postal. Barcelona. Aug.-Dec. 1897.

Trmbrologia Española. Val de Santo Domingo. Dec. 1897 Jan. 1899.
Ilustración Filatélica Hispano Americana. Barcelona. 1897-1900.

Boletin Filatelico. Manzanares. Jan. 1898-Feb. 1899.

Filatélico Valenciano. Valencia. Jan. 1899-Mameh 1901.

Espa ̃̃a Filatéltca. Barcelona. May 1899-May 1900.

Propaganda Filatélica. Madrid. Aug. 1899-Dec. 1905.

Coleccionista de Sellos. Madrid. Jan. 1900-Oct. 1901.

Fildatélico Onubense. Huelva. Jan.-May 1900.

Fituatelia Española. Madrid. Feb. 1900.

Cádiz Postal. Cádiz. Mar. 1900-Aug. 1902.

Boletin Filatélico Universat. Valencia. June 1900.

Boletin Timbrológico. Huelva. July-Aug. 1900.

Eco de Madrid. Madrid. Oct. 1900-Dec. 1902.

Fillatélico Espa ̃̃ot. Barcelona. Oct. 1900- (In progress.)

Uniб́n Postal. Barcelona. Dec. 1900-July 1906.

Progresista Fífatélico. San Sebastián. Aug. 1901-April 1902

Filatélico de Valencia. Valencia. Jan.-Dec. 1902.

Coleccronista de Sellos. 2a época. Madrid. Oct. 1902Nov. 1903. NatA $A$ A Unrón Fildatíló Española. Madrid. Dec. 1903-Jan. 1905 -Eco Postale. Valencia. Feb. 1904- (In progress.)

Verdad Fituátélica. Barcelona. July-Dec. 1904.

Regeneración Filatélica. Barcelona. April 1906.

\section{SWEDEN}

-Tidning För Frimärissamiare. Stockholm. Dec. 1886-Dec. 1893.

Frimärks-Samtaren. Stockholm. Dec. 1892-Dec. 1893.

Skandinavisk Frimärkstidning. Malmö. Feb.-March 1893

Internationaler Briefmarken - Anzeiger. Norrköping. Oct.-Nov. 1893

- Nordisk Filatelistisk Tidskrift. Stockholm, etc. Jan 1894- (In progress.)

* * The place of publication of this journal has varied between Stockholm, Sweden, Christiana, Norway; Copenhagen, Denmark and Lund, Sweden.

Frimärkssamlaren. Halmstad. Aug. 1897-Dec. 1898.

Frrväpplingen. Stockholm. June 1899.

Svensk Filatelistisk Tidskrift. Stockholm. Jan. 1900 (In progress.)

WinA FELAE- FTSKREN

SWITZERLAND.

Schweizerische Briefmarkenzeitung. Schwanden. Oct. Nov. 1875.

Internationate Briefmarkenzeitung. Schwanden. Dec. $1875-1876$.

Schwetzer Briefmarken-Zeitung. Bern. July-Dec. 1879.

Schweizer Ituustrirte Brief Marten-Zeitung. Bern. Jan. 1880-1887.

Mittheilungen des Schweiz. Philatelisten - Vereins. Bern. March 1884 

Courrier Philatélique. Suint-Imier. Oct.-Dec. 1884.

Journal des Colledtionneurs. Genève. June 1904-1907.

Schweizerischer Phitatelisten-Verein Zürich. VereinsMittheilunagen. Zürich. Nov. 1884-Dec. 1885.

Phimatelistische Mitmeilungen. Bern. Dec. 1905- (In betiqug progress:)

Commerọant de Timbres-Poste. Genève. Feb. 1885-Mar. 1887.

Philateiste Universed. Porrontruy. June-Oct. 1886.

Bourse des Timbres. Genève. Oct. 1886-June 1888.

Revue Phicatéliste. Genève. April-Novi 1887.

Philatefistse Suisse. Genève. March 1888.Feb. 1889.

Schweizer Briefmarken-Journal. Lausanne. Nov. 1888Dec. 1893.

Revue Philatélique Suisse. Genève. Jan. 1891-1893.

Helvetische Phicatelie. Morges. Dec. 1893.

Phicatélie Herivétique. Morges. Dec. 1893-Dec. 1897.

Schweizer Briefmarken-Zeitung. Basel, etc. Jan. 1894(In progress.)

Bulletin Trimestriet de la Socióté Lausannoise de Timbrologie. Lausanne. Mar. 1894-Dec. 1896.

Monde Coure ctionneur. La Chaux-de-Fonds. May 1894Dec. 1895 .

Bulletin de L'Union Timbrophile Suisse. Genève. July 1894.

ZÜrcher Brifhmarkenbörsen - Zeitung. Zürich. Oct. 1894-1903.

Philatéliste Suisse. La Chaux-de-Fonds. Dec. 1894.

Annonce Philatélique. Genève. Jan. 1895-Apl. 1903.

Internationaler Briefmarken-Anzeiger. Zürich. May 1895.

Coldectionneur Suisse. La Chaux-de-Fonds. July 1895Jan. 1896.

Timbrophire Suisse. Genève. Dec. 1897-May 1898.

Revue Postale. Genève. Jan. 1898-Nov. 1899.

Internationaler Briefmarken - ANZeiger. Zürich, etc. July 1899- (a⿶n progress.) fith in +909

Philatelie-Bulletin. Basel. Nov. 1899-Nov. 1902.

Écho Philatélitque et Philocartiste. Genève. March 1900

Univers Philatélique. Genève. Feb.-Aug. 1901.

Philatelist. Rheinfelden. April 1901-Feb. 1902.

Petite Chronique. Lausanne. May-Sept. 1901.

Guide Philateique. Gmève. Jan.-Dec. 1902.

SAmmLer-Börse. Basel. Jaz.-Sept. 1902.

Annonce Universelle. Lausanne. Jan. 1903- (In progress.)

Guide Philatélique International. Genève. Jan.-Dec. 1903.

Philatelistische Rundschau. Genf, etc. May 1903-Nov. 1904.

Univers Philatėlique. Genève. June 1903.

Timbrophire Suisse. La Chaux-de-Fonds. Sept. 1903-May 1904.

Timbres et Cartes. Genève. Feb.-Azg. 1904.

\section{TASMANIA}

Federal Austratian Philatelist. Hobart. Jan. 1890 Oct. 1891.

\section{TRANSVAAL.}

South African Philatelist. Johannesburg. Nov. 1895April 1896.

\section{TRIPOLI}

Philatéliste Africain. Tripoli. Sept. 1893-April 1894.

Trmbrologie Africaine. Tripoli. Oct. 1893-May 1894.

TUNIS.

Tunis-Philatélique. Tunis. Oct. 1895-Feb. 1896

Timbrophile Tunisien. Tunis. Jan.-Feb. 1900.

\section{TURKRY}

Timbre Lefvantin. Constantinople. May 1886-Aug. 1888.

Orientalische Philatelist. Constantinople. July 1886 March 1887.

Pour-Medjmouassi. Constantinople. Aug. 1897-Nov. 1898.

Guide Carto-Philatélique Universed. Smyme. June 1905-Jan. 1906.

\section{UNITED STATES}

Stamp Courector's Record. New Series. Albany, N.Y. etc. Dec. 1864-Oct. 1876.

Coin and Stamp Journal. Chicago, Ill. May1865-April 1866.

Curiosity Shop. Chicago, Ill. July-Dec. 1865.

G.W. Winterburn and Co.'s Stanp Circular. Cincimnati, O. Nov. 1865-April 1866.

Collector's Guide. Newport, R.I., etc. May-Dec. 1866.

Stamp Collector's Review. Boston, Mass. July-Oct. 1866.

Mason's Corn and Stamp Colregctors' Magazine. Philadelphia, Pa. April 1867-Dec. 1871.

Postage Stamp Colitectors' Monitor. Boston, Mass. June 1867.

Kelsey's Postage Stamp Reporter. Meriden, Conn. Aug. 1867.

Stamp Journal. Midaletown, Conn. Aug.-Oct. 1867.

American Stamp Mercury. Boston, Mass. Oct. 1867-Mar. 1871.

Coin and Stamp Journad. Meriden, Conn. Jan.-March 1868.

Stamp Buyer. Middletown, Conn. Jan.-March 1868.

-American Journal of Philately. New York. Mar. 1868 Dec. 1878 
New Eingland Journal of Philately. Boston, Mass: Jan.- J. Allan Mason and Go. Circular. Brooklyn, N.Y. Dec. March 1869.

Trmbrophilist. Boston, Mass. Sept. 1869-Sept. 1874.

Boy's Stanip Gazette. Worcester, Mass. Jan. 1870.

American Stamp Collector's Guide. Middletown, Conn. Apl.-Aug. 1870.

Philadelphia Monthly. Philadelphia, Pa. July 1870-Feb. 1872.

KÛRIOSITI Kabinet. New York. Sept. 1870-Aug. 1871.

Stamp Collector's Guide. Meriden, Conn. Dec. 1870 May 1873.

Stamp Collector's Magazine. Boston, Mass. Jan. 1871.

Stamp Exchange. Lowell, Mass. Jan. 1871. ( $[$ ? J Fin is AMERIOAN CoIN AND STAMP ReVIEW. Allentown, Pa. MayAug. 1871.

Amertcan Philatelist. Elizabeth, N.J. July. 1871.

Dearin's Odd Curtosity Shop. Chicago, Ill. Aug. 1871.

Postage Stamp Reporter. Lowell, Mass. Sept. 1871-Jan. 1875.

Coltemotor. Newburgh, N.Y. Nov. 1871-Apl. 1872.

Postage Stamp. Philadelphia, Pa. Nov. 1871-Feb. 1872.

Stamp Collector's Monthly. Newmarket, N.H. Jan. 1872-Sept. 1876.

Southern Curtosity Cabinet. New Orleans, La. Féb.April: 1872.

American Boys' Magazine. Philadelphia, Pa. Ápril-May 187.2.

Stamp Collectori. Syracuse, N.Y. May 1872-Jan. 1873.

European Stamp Journat. New York. June 1872.

Curiosity Hunter. Rockford, Ill. Sept. 1872-Dec. 1877.

Western Philatelist. Chicago, Ill. Dec. 1872-Oct. 1877.

Matane Philatelist. Portland, Me. 187.2.

Curtosity Cabinet. New York. 1872-1897.

Collectors" Review. Toledo, O: Jan:-A'pl. 1873:

Stamp Advertiser. Chicago, Ill. March 1873-Jan: 1875.

Phidateritst's Companion. Williamsport, Par. April-May. 1873.

Western Stamp Collector. Chicago, Ill. April-Öbt. 1873:

Star Stamp Quarterly. Reading, Pa: June 1873:

Stanp and Corn Trader. Rockford; Ill. Dec. 1873-June 1874.

Stamp News. Rockford, Ill: 1873:

F. Trifhe's Monthly Crrcular. Boston, Mass. Jan.-Dec. 1874.

Stamp Collector's Review. Minneapolis, Minn. Jan. 1874.

Philatelic Guide. Concord, N.H. May-July 1874.

Philatelic Herald and Review. Cincinnati, O. June 1874-Jan. 1875.

Keystone Philatelist. Susquehanna Depot, Pa. Sept. 1874-Nov. 1875.

American Philatelical Circulati: Chicago; Tll: Oet.-Nov. 1874. 1874-June 1875.

American Phitateglic Circular. Chicago; Ill: Dee: 1874 Mar. 1875.

Stamp Crrcular. Springfield, Mass. 1874.

American Philatelist. Cleveland, O. Jan.-Mar. 1875.

Corn and Stamp Journal. Kansas City, Mo, etc. Jan. 1875-Aug. 1877.

ColLeCtor's Gompanion. Northfield, Vt. Jan. 187.5.

F. Trifen's Monthly Stamp Crraular. and Price Catalogue. Boston, Mass. Jan. 1875-Nov. 1877.

Vermont Philatelist. St. Albans, Vt. Jan.-Aug. 187.5;

Deforah Philatelical Review. Decorah, Ia. Feb--Dec. 1875.

Monthly Announcement of the New England Stamp Co. Concord, N.H: Feb.-June 1875.

Philatelir Monthly. Pliliadelphia, Pa. Feb. 1875-Dec. 1891 .

Collmetor's News. North Adams, Mass. Sept. 1875-Sept. 1876.

Crescentr. St. Albans, Vt. Sept.-Nov. 1875.

Stamp Coltector. Painesville, O. Nov. 1875-June 1876.

Trader. Washington; D.C. Nov. 1875:Jan. 1876.

Collector's Own. Concord, N.H. Dec. 1875-Feb. 1876.

Stamp Dealers Own. Washington, D.C. Féb.-May 1876.

Monthly Stamp Circular. New York. Nárch 1876.

Gem Price List. Chicago, IIl: April 1876:

Stamp Collectors: Monthly. New York. April-Nov. 1876. Monthly Philatelist. Erie, Pa. May-Dec. 1876.

Philatelitc Gem: Chicago; Ill. May-Oet. 1876:

Monthly Chrontcle. Cnicago; Ill. July; 1876-Jan: 1877;

Monthly Post. New York. Sept.-Dec. 1876.

Philatelic Advertiser. New York. Sept.-Dec. 1876.

Philatelic Circular. Susquehanna, Pa. Sept. 1876 :

St. Lours Phimatelist. St: Louis, Mo. Sept: 1876-May 1882.

Collector's Companion. Akron, O. Oet.-Dec: 1876.

Stamp. Chicago, Mll. Oct.-Nov. 1876.

Collector's Own. Syracuse, N.Y. Nov. 1876-Apl. 1877.

Monthly Ciroular. Chicago, Tll. "Nov. 1876-April 1877:

Trader. Washingtion; D:C. Nov.-Dèc. 1876.

Card and Stamp Crrcular. Newmarket, N.H. 1876 .

Monthly Circular. Boston, Mass. Jan. 1877.

OHio Stamp Journal. Cincinnati, O. Jan. 1877.

Philatelic Snoozer. New York. Jan.-Feb. 1877.

Postage Stamp Reporter. Montpelier, Vt. Jan.-Aug. 1877.

Western Exohange. Akron; O: Jan.-Aug. 187.7.

Philatelic Favourite. New- York. Feb.-Septi 1877.

Michigan Philatelisst. Detroit, Mich. April 1877-April 1879. 


Amarican Stanp Circular. New æork. June 1877-Apl. 1878.

Chicago Philatelist. Chicago, Ill. June 1877.

Iowa Philatelist. Davenport, Ia. June 1877.

Stamp Journal. New York. Sept. 1877-Dec. 1879.

Curiosity Stemerer. Smithtown Branch, N.Y. Dec. 1877May 1878.

Monthly Stamp Circular. Boston, Mass. Dec. 1877-May 1879

Stantr Coluector's Review. Davenport, Ia., 'ete. 'Dec. 1877Oct. 1882.

Bulletin of the National Philatelical Society of New YoRk. New York. Jan. 1878-Mar. 1879.

Cotn and Stamip Journat. Brooklyn, N.Y. Jan.-Sept. 1878.

Phitatelic News. Cleveland, O. Jan.-May 1878.

Clevveland Philatelist. Cleveland, O. June-Sept. 1878.

Collector's World. New York. Sept. 1878^Oct. 1879.

Fountain's Monthly Stamp Circular. New York. Sept. 1878.

Ohio Philatelist. Cincinnati, O. Sept. 1878-Fèb. 1881.

New York. Philatelist. New York. Dec. 1878-June 1879.

Philatelic Review. Jersey City, N.J. $\sqrt{1878 .}$. Su

American Journal of Phimately and Coin Advertiser. New York. Jan. 1879-Mar. 1886.

Interenationale MaRKen-Bönse. Baltimore, Md. Jan. 1879.

J. T. Handford's Quarterly Circular. New York. Jan. 1879-Summer 1883

Soumhern Philatelist. Galveston, Tex. Jan.:Sept. 1879.

Coluector. Smyrna, N.Y. April-May 1879.

Stamp Reporter. Worcester, Mass. April 1879.

National Phicatelist. Mit. Pleasant, Ia. May-Oct. 1879.

Amateur Clipper. Smyrna, N.Y. June-Nov. 1879.

Detroit Philatelist. Detroit, Mich. Aug.-Oct. 1879.

Stamp-Colnector. New York. Aug.-[ ? ] 1879.

- 'Trifet's Monthly. Boston, Mass. Aug. 1879-May 1881.

Coldector's News. Plainfield, N.J. Sept. 1879-Jæn. 1880.

Western P.hilatelist. ConncilBBluffs, Ia. : Sept.-Nov. 1879.

American Philateltc 'Guide. New York. Oct. 1879-July 1880

Collector's Aid. Penaleton, S.C. Oct. 1879.

Holiday Clipper. Smyma, N.Y. Dec. 1879.

Amateuir and Collector. St. Paul, Minn. Jan.-Feb. 1880.

Mound City Collegtor. St. Louis, Mo. Jan. 1880.

New Jersey Phitateirst. Jersey City, N.J. Jan. 1880Dec. 1882.

Phicatelic News. Springfield, Mass. Jan.-Dec. 1880.

Stamp Collector. [New series.] New York. Jan. 1880[? $] 1881$

YANKeE Clipper. Smyrna, N.Y. Jan. 1880-June 1881.

COLLECTOR, Worcester, Mass. Feb.-April 1880.
Stame Journat. Cincinnati, 0 . Feb. 1880

Coluectors News. Bloomington, Ill. June-Oct. 1880.

Philatelic World. Brooklyn, N.Y. June 1880-Dec. 1891.

Coldectors' Quarterly. Galveston, Tex. July.Oct. 1880.

Philatelist. Louisville, Ky. July 1880.

Amateur's Journay. Mechanic Falls, Me. Aug.-Oct. 1880.

Menphis Phicatelist. Memphis, Tenn. Aug. 1880-Dec. 1885.

Stamp Wortd. Cincinnati, O. Oct. 1880-Feb. 1887.

Quarteriy Review. Galveston, Tex. Jan.-April 1881.

Buakgxe PhiLatelist. Marietta,.O. Feb. 1881.

Dayton Philatelist. Dayton, O. June 1881-Jan. 1882.

Bucheye Stamp Journat. Akron, ○. Sept. 1881-June 1882.

Stamp Collectoris' Bureau. Chicago, Ill. 'Sept. 1881-June 1882

Collector's Library Tabue. New York, etc. Oct. 1881 Oct. 1885.

New Yori Phitatelist. Waterloo, N.Y. Oct. 1881.

Baltimore Philatelist. Baltimore, Mid. Nov. 1881-May 1882

Philatelic Medium. Cincinnati, O. Nov. 1881-May 1882. Philatelic Triumph. Buffalo, N.Y. Nov. 1881-Dec. 1882. Queen City Collector. Cincinnati, O. Jan.-Aug. 1882.

Empire City Phizateelist. New York. April 1882-July 1883.

Union Exchange List. Evanston, Ill. June 1882-Jan. 1884.

Granite State Philatelist. Lake Village, N.H. Sept. 1882-Oct. 1884.

Collectors' Bureau. Chicago, Ill. Oet.-Nov. 1882.

Collector's Guide. Philadelphia, Pa. Dec. 1882-Mar. 1883.

Old :Curiosity Shop. Cleveland, O., etc. Dec. 1882-Dec. 1890.

National Philatelist. New York. Jan.-Dec. 1883.

Philatelist's Journal. Plymouth, Wis. Jan.^May 1883.

Curiosity Collector. Oberlin, O. Feb-May 1883.

Philatelic News. Philadelphia, Pa., etc. April 1883-June 1886

StAMP Recond. Rochester, Ind. April 1883.

California Philatelist. San Francisco, Cal. June 1883Fall and winter season, 1899-1900.

Lakeside PhiLatelist. Chicago, Ill. June 1883.

Buack List. New York. July 1883.

Philatelic Headlight. Chicago, Ill. Sept. 1883-Oct. 1884.

Bayonne Philatelist. Bergen Point, N.J. Oct. 1883-Oct. 1884

Western Collector. Sacramento, Cal. @et.-Nov. 1883.

Philatelist's Friend. Cincinnati, O. 1883.

American Philatelist. Dayton, O. Jan.-Mar. 1884.

NASHVILIE Corn Dims. Nashville, Tenn. Jan. 1884 
North Star Philatelist. Minneapolis, Minn. Jan. 1884Dec. 1885.

W. F. Bishop's Quarterly Circular. La Grange, Ill. Jan. 1884.

American Boys. Middlebury, Vt. Feb.-July 1884.

Golden State Philatelist. Sacramento, Cal. Feb. 1884.

'W. F. Bishop's Monthly Circular. La Grange, Ill., etc. Feb. 1884-Dec. 1889

Western Coluector. Sacramento, Cal. March-Sept. 1884 Chair City Stamp Colfector. West Gardner, Mass. JuneJuly 1884.

Keystone Philatelic Gazette. Altoona, Pa. June 1884 Feb. 1885.

Philatelist. New York. June-Oct. 1884.

U. S. Philatelist. Boston, Mass. June 1884.

Our American Youth. Middlebuly, Vt., etc. Aug. 1884Sept. 1885.

Chair City Collector and Monthly Echo. West Gardner, Mass. Oct. 1884-Feb. 1885.

Collector. Scranton, Pa. Oct. 1884-Jan. 1885.

Portuand Philatelic Herald. Portland, Me. Oct.-Dec. 1884 .

Southern Coldector. Nashville, Tenn. Oct. 1884-March 1885.

Advertiser. Philadelphia, Pa. Nov. 1884-Jan. 1885.

Independent Philatelist. New York, etc. Nov. 1884-Feb. 1891.

New England Philatelist. Fitchburg, Mass. Nov. 1884Sept. 1885.

Richardson's Stamp Collectors' Magazine. San Francisco, Cal. Nov. 1884.

Capital City Phinatelist. Augusta, Me. Dec. 1884-Sept. 1886.

Collector's Cabinet. New York. Dec. 1884.

Milwaukee Stamp Advertiser. Milwaukee, Wis. 1884.

Colmector's Companion. Chicago, Ill. Jan. 1885-May 1886.

Eastern Collector. Brooklyn, N.Y. January 1885.

Empire State Philatelist. New York. Jan. 1885-June 1887.

Hermes. New York. Jan.-Oct. 1885.

Philatelic Herald. Portland, Me. Jan. 1885-Nov. 1888.

Wolverine Collectors Journal. Manchester, Mich. Jan. 1885.

Exchange. Adrian, Mich. Feb. 1885-April 1886.

Monthly Exchange. Carlisle, Pa. Feb. 1885.

Philadelphia Collector. Philadelphia, Pa. Feb. 1885.

Philatelic Advertiser. Philadelphia, Pa. Feb.-June 1885.

ConLector. Philadelphia, Pa. March 1885-March 1886.

Keystone Stamp and Coin GazetTe. Altoona, Pa. MarchDec. 1885.

- Philatelic Journal of Auerica. St. Louis, Mo. March 1885-Nov. 1895.

Philatelic Squeal. Boston, Mass: March 1885.
Philatelist. Philadelphia, Pa. March 1885-Winter 1886. Spindle City Philatelist. Lowell, Mass. March-May 1885.

Quarteriy Inter-Change. Philadelphia, Pa. May-Oct. 1885.

National Youth. Minneapolis, Minn. [? June]-Dec. 1885.

Chronicle. Philadelphia, Pa. July 1885-July 1886.

Queen City Philatelist. Buffalo, N.Y. Aug. 1885.

Yankee Philatelis's. Fitchburg, Mass. Aug.-Sept. 1885

California Collector. Sacramento, Cal. Sept. 1885.

Carson Philatelist. St. Luuis, Mo. Sept. 1885-Dec. 1886.

Maine Philatelist. Portland, Me. Fall 1885-April 1886.

Michigan Philatelist. Manchester, Mich. Sept. 1885-Jan. 1886.

New York CoLlector. Brooklyn, N.Y., etc. Sept. 1885 May 1886.

Philatelic Tribune. Smyrna, N.Y., etc. Sept. 1885-Feb. 1899.

LitTle Curiosity News. La Hoyt, Ia. Oct.-Nov. 1885.

Long Island Collector. Brooklyn, N.Y. Oct. 1885-July 1886.

Our American Youth and the Philatelio Chronicle. St Louis, Mo. Oct. 1885-Feb. 1886.

Philatelic Magazine. La Grange, Ill. Oct. 1885-June 1887.

Philatelic Record. Wellington, O. Nov. 1885-Jan. 1886.

Arizona Pride of Philately. Tucson, Arizona. Dec. 1885 Apl. 1886

Philatelic American. Atlanta, Georgia. Dec. 1885.

Bay State Advertiser. Lynn, Mass. Jan. 1886.

Collectors Journal. Lynchburg, Va. Jan.-May 1886.

Colnector's Leisure Hour. Greenland, N.H. Jan.-April 1886.

Eagle Philatelist. Philadelphia, Pa. Jan.-Feb. 1886

Garden City Philatelist. Chicago, Ill. Jan.-Aug. 1886

Minnesota Philatelist. St. Paul, Minn. Jan.-April 1886.

Monthey Journal. Carlisle, Pa. Jan.-Sept. 1886.

National Capital Philatelist. Washington D.C. Jan. March 1886.

Philatelist. Fitchburg, Mass. Jan. 1886.

Quaker City Philatelist. Philadelphia, Pa. Jan. 1886. July 1894

Stamp and Coin Gazerte. Altoona, Pa. Jan.-Dec. 1886.

Ceentral Philatelist. Brooklyn, N.Y. Fub.-Dec. 1886.

Collector's Aid. Brooklyn, N.Y. Feb. 1886-Summei 1887.

Philatelio News. Chicago, Ill. Feb.-May 1886.

Hub Collector. Boston, Mass. March 1886

Illinois Philatelist. Rock Island, Ill. March-July 1886.

Mohawk Standard. Delta, N.Y. March 1886-May 1888.

-Stamp. Denver, Colo. March 1886-April 1889. 

Universad Collectors' Journal. Danvers, Mass. March 1886.

Cumberland Coluector. Nashville, Tenn. May 1886-April 1887.

Monthuy Review. Mansfield, Pa. May 1886-April 1887.

Philatelic Guardian. Newburgh, N.Y. May 1886.

Philatelic Notes. Norwich, N.Y. May-June 1886.

Texas Philatelist. Paris, Tex. May 1886.

Stame Collector. Chicago, Ill. July-Aug. 1886.

Counectors Bi-Monthey Directory. Manchester, Mich. Aug. 1886-Aug. 1887.

Curiosity World. Lake Village, N.H. Sept. 1886-Aug. 1888.

Philatelic Bazar. Williamsville, Mass. Sept. 1886-1887.

Caltaornia Collector. San Fraucisco, Cal. Oct. 1886.

Collectors' Review. Denver, Colo. Oct. 1886-Aug. 1888.

Golden State Scientist. Riverside, Cal. Oct. 1886.

Monthuy Advertiser. Newburgh, N.Y. Oct. 1886.

Texas Stamp. Fort Worth, Tex. Oct. 1886-June 1887.

American Philatelic Association. Official Circular. Grand Crossing, Tll. Nov. 1886-June 1887.

Peninsular Philatelist. Rockford, Mich. Nov. 1886.

Texas Philatelist. Paris, Tex. Nov. 1886-March 1887.

Bucieye State Philatelist. Wellington, O. Dec. 1886. July 1891.

American Philatelist. Altoona, Pa., etc. Jan. 1887-Dec. 1893.

International Philatelic Advertiser. New York. Jan. 1887-Jan. 1889.

Keystone State Philatelist. Philadelphia, Pa. Jan.-Oct. 1887.

North Star Philatelist. Minneapolis, Minn. Jan. 1887Jan. 1888.

Phitatelic Gazette. Altoona, Pa., etc. Jan. 1887-Jan. 1890.

Tiny Collector. Slate Lick, Pa. Jan. 1887-Spring 1888.

Western Philatelist. Chicago, Ill. Jan. 1887-May 1888.

Witch City Collector. Salem, Mass. Jan.-Feb. 1887.

Bay State Coulector. North Leominster, Mass, etc. Feb.June 1887.

Review. Rock Island, Ill. Feb.-March 1887.

Stamp Recond. Denver, Colo. Feb.-May 1887.

Tag and Stanp Herald. Louisville, Ky. Feb.-April 1887.

Curiosity Reporter. Elkader, Ia. March-April 1887.

Germantown Philatelist. Philadelphia, Pa. March-May 1887.

Philatelic Science. Georgetown, Mass. March-May 1887.

R. I. Philatelist. Rock Island, Tll. March 1887.

Stamp Collector's Figaro, Chicago, Ill., etc. - March 1887. Dec. 1890

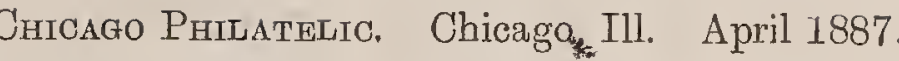

Philatelic Century. Madison, Wis. April-Sept. 1887.

Philatelic Fontnightur. Benson, Minn., etc. April 1837 Jan. 1888.

Philatalic Review. Rock Island, Ill. April 1887-Feb. 1888.

Coluectors' Monthuy. Lynn, Mass. May 1897.

Internationat Collector. San Francisco, Cal. June 1887June 1889.

Stamp Republic. Binghamton, N.Y. July 1887.

Witch City Philatelist. Salem, Mass. July 1887-Feb. 1888.

American Philatelic Record. Binghamton, N.Y. Aug.Sept. 1887.

Coluector's Journal. Brooklyn, N.Y. Aug. 1887-Feb. 1888

Texas Philatelic Journal. Paris, Tex. Aug.-Nov. 1887.

Charleston Philatelist. Charleston, S.C. Oct. 1887-Jan. 1889.

Philatelic Journal of Ohio. Wooster, O. Oct. 1887-Jan. 1892.

Badger State Philatelist. Delavan, Wis. Dec 1887-Aug. 1889.

Eastern Philatelist. Fitchburg, Mass, etc. Dec. 1887 May 1899

Hawkeye State Colleutor. Wyoming, Ia. Dec. 1887-May 1888

One Dime. Salem, Ind. Dec. 1887-April 1893.

Semi-Annual Stamp Coluector. Schenectady, N.Y. Dec. 1887.

Beardsley's Advertiser. St. Joseph, Mo. Jan. 1888.

Collectors' Advocate. Cincinnati, O. Jan. 1888.

American Journal of Philately. Second Series. New York. Feb. 1888-Dec. 1906.

American Phimatelic Magazine. Pittsfield, Mass. Feb.Mar. 1888.

Minnesota Philatelist. Minneapolis, Minn. Feb.-Finem1888

National Philatelist. Washington, D.C. Feb. 1888-May 1889.

Philadelphia Philatelist. Philadelphia, Pa. Feb.-May 1888.

Philatelic News. Cambridgeboro, Pa. Feb. 1888-Sept. 1890.

Queen City Philatelist and Collactor's Advocate. Ci!lcinnati, O. Feb.-Mar. 1888.

Онто Philatelist. Westerville, O. April 1888-June 1889.

Our Stamp Ctrcular. Cincinnati, O. April 1888.

Phitatelic Midget. La Hoyt, Ia. April 1888-March 1889.

Queen City Paitateidist. Cincinnati, O. April 1888.

Kentucky Stamp Magazine. Covington, Ky. May 1888Feb. 1889.

Philatelic Observer. New York. May-June 1888.

United States Philatelist. Calmer, Ia. May 1888-Feb. 1889. 
Bulletin. St. Louis, Mo., etc. June 1888-Feb. 1891. Colledtors' Standard. Delta, N.Y. June-Aug. 1888. Collectors' WeerLy. Wyoming, Ia. June 1888.

Philo's Monthly. Grand Crossing, Ill. July-Oct. 1888.

Stamp Collector. Ottrwa, Ill. July 1888-Jan. 1889.

Collector and Exchange. Buffalo, N.Y. Aug.-Dec. 1888.

Philatelic Literature Collector. St. Joseph, Mo. Autumn $18 s 8$.

Black Hawk Philatelist. Rock Island, Ill. Sept. 1888.

Collector. Chatham, N.Y. Sept. 1888.

Era's Monthly. Benson, Minn. Sept.-Dec. 1888.

Eureira Philatelist. San Francisco, Cal. Sept. 1888-Feb. 1890.

Stamp World. Lake Village, N.H. Sept. 1888-Feb. 1890.

American Collector. Oak Hill, O. Oct. 1888.

Cohlector's Comment. Denver, Colo. Oct.-Dec. 1888.

Park City Collector. Bridgeport, Conn. Oet. 1888-March 1889.

Philatelic Beacon. Newton, Mass. Oot. 1888-April 1891.

Philatelid Press. West Winsted, Conn. Oot. 1888-May 1889.

Alabama Philiatelist. Mobile, Ala. Nov. 1888-Oot. 1889.

Stamp Collectors World. Williamsville, Mass. Nov. 1888 Jan. 1889.

Curiosity Collector. South Amboy, N.J. Dec 1888-May 1892.

EHastern Press. . Wilmington, Del. . Dec. 1888-May 1889.

Fitchiorg Philatelist. Fitchburg, Mass. Dec. 1888-Jan. 1891.

Philatelic Messenger. O O ¿k Hill, O. Dec.1888:Sept. 1889.

Ammrtoan Stantp. Newark, N.J. Jan. 1889 -0ct. 1890.

Flour City Philatelist. Minneapolis, Minn. Jan.-May 1889.

Hoosier Philatelist. Hanover Centre, Ind. Jan.-Sept. 1889.

1- Post Card. Roselle, N.J. Jan. 1889-Dec. 1890.

Rhode Island Phimatelist. Newport, R.I. Jan. 1889-Aug. 1891.

Buffalo Philatelist. Buffalo, N.Y. Feb.-June 1889.

Curio. Benson, Minn. Feb. 1889-Aug. 1892.

Phichtelic Globe. La Rue, O. Feb. 1889.

Stamp Adveritiser. Hudson, Mass. Feb. 1889-Sept. 1890.

New Jersey Philatelist. Paterson, N.J. March 1889 F'eb. 1890.

Philatelic Leadér. Seranton, Pa. March 1889.

Philately. New York. March 1889-March 1890.

Texas Philatelic Journal. Paris, Tex. March 1889.

Tiny Philatelist. Cambridgeboro, Pa. Spring 1889.

Standard. Sawens, N.Y. April 1889.

Tiny Philatelist. La Hoyt, Ia. April-July 1889.
Nmbraska Philatmlist. Milligan, Neb. May 1889-April 1890.

Phimatelic Express. Portland, Me. May 1889-June 1890.

N. Y. Philatelist. New York. June 1889-Feb. 1890.

Western Philatelist. Rock Island, Ill., ete. June 1889Sept. 1892.

Eastern Collector. Wilmington, Del. July 1889.

Curios. New Chester, Pa. Aug.-Oct. 1889.

Essex County Phrtateuist. Lawrence, Mass. Sept. 1889. June 1892.

Philatelic Era. Portland, Me. Sept. 1889-Aug. 1894.

Boodle Philateliste. New York. Oct. 1889-June 1890.

Peninsular Philatelist. Grand Rapids, Mich. Oct.-Nov. 1889.

Philiatelic Star. Sawens, N.X. Oct. 1889.

Pitatnfteld Collector. Plainfield, N.J. Oet 1889.

Southern Philatelist. Charleston, S.C. Oct.1889-Sept. 1896.

Yankeg Philatelist. Barre, Vt. Oct. 1889-Nov. 1890.

American Stamp Journal. Portsmouth, N.H. Nov. 1889Mar. 1891.

New Engrand Phicatelist. Brookline, Mass. Nov.-Dec. 1889.

P. A. of I. Bulletrin. Grinnel, Ia. Nov. 1889.

Philatelic News. Elizabeth, N.J. Nov.-Dec. 1889.

Phitatelic Nonpareil. Boston, Mass. Nov. 1889-Jan. 1890.

Union Chronicle. Long Beach, Cal. Nov. 1889.

Universal Collector. Mt. Ayr, Ia. Nov. 1889-June 1890.

Buffalo Philatelic Press. Buffalo, N.Y. Dec. 1889-Feb. 1890.

Nebraska Stamp News. Fremont, Neb. Dec. 1889-Aug. 1890.

American Collector. New Chester, Pa. Jan.-June 1890.

C. P. S. Bulletin. Chicago, Ill. Jan.-Feb. 1890.

Empire State Stamp Journal. Trumansburg, N.Y. Jan. 1890-Jan. 1892.

New Jersey Collector. Plainfield, N.J. Jan.-March 1890.

Orange City Philatelist. Orange, N.J. Jan.-Feb. 1890.

Progressive PhiLatelist. Merrimack, Wis. Jan. 1890.

Stamp-Collectons' Journal. Lake Village, N.H. Jan.Dec. 1890.

Stamp Crank. Buffalo, N.Y. Jan. 1890.

W. F. Bishop’s Monthly Journal. La Grange, Ill. Jan.Feb. 1890.

Centrat Philatelist. Belvidere, IIl. Feb.-Dec. 1890.

Philatelictridud Reporter. Crete, Neb. Feb.-March 1890.

Tennessee Philatelist. Persia, Tenn. Feb.-May 1890.

Hubbard's Magazine. Lake Village, N.H. March-April 1890.

Keystone Stamp News. Richland Centre, Pa. March 1890.

Philatelist. New York. March-July 1890.

Phicltelist's Friend. Dixon, Ill. March 1890. 


Universal Phiratelic Advertiser. Frankford, Philadelphia, Western Philatelid Empire. Omaha, Neb. March-June Pa. March 1890. 1891.

Wide-aWake Phirateist. Fitchburg, Mass. March 1890.

Keystone Stamp Advertiser. Philadelphia, Pa. April 1890.

Metropolitan Philatelist. New York. April 1890- (In progress.)

Phimatelic News. Utica, N.Y. April-Nov. 1890.

Stamp Item. Memphis, Tenn. April-July 1890.

U. S. Corresponding Phiraterist. Union Grove, Wis. May 1890.

U. S. Phiratemist. Plainfield, N.J. May-Aug. 1890.

U. S. P. S. Buluetin. Reading, Pa. May 1890.

Bargain Phiratelist. Smyrna, N.Y. June-July 1890.

Courector. New Chester, Pa., etc. July 1890-June 1895. Phimateric Reporter. Union Grove, Wis. July 1890-May
1891.

Youth's Exснange. Federalsburg, Md. July-Sept. 1890.

Orange County Philaterist. Middletown, N.Y. Aug. 1890.

Internationat Stamp Journal. St. Louis, Mo. Sept.-Nov. 1890.

StAndard. Topeka, Kas. Sept. 1890.

Index. Chicago, Ill. Oct.-Nov. 1890.

Philatelic Fraud Specialist. Stromsburg, Neb. Oct. 1890.

Record and Review. New York. Oct.-Dec. 1890. National Exchange. Federalsburg, Md. Oct. 1890-July
1891.

Buckeye Phiratelist. Cleveland, O. Nov.-Dec. 1890.

Northwestern Philatelist. Madison, Wis. Nov. 1890.

Phimatelic Fraud Reporter. Stromsburg, Neb. Nov. 1890-Feb. 1893.

North American Philateisist. Oak Park, Ill. Dec. 1890 Aug. 1891.

Wamsutta Stamp News. North Attleborough, Mass. Dec. 1890-Feb. 1891.

ECoLlector's WorLd. Calmar, Ia. Tan A R-MAy

Mekeel's Weekry Stamp News. St. Louis, Mo., etc. Jan. 1891- (In progress.)

Standard Philatelist. St. Louis, Mo. Jan.-Sept. 1891.

Stamp Bulletin. La Grange, Ill. Jan. 1891.

Stamp Collector. Chicago, Ill., etc. Jan.-March 1891.

Virginia Philatelist. Staunton, Va. Jan. 1891.

Cream Citx Philaterist. Milwaukee, Wis. Feb. 1891.

National Siftings. Beaver Dam, Wis. Feb.-April 1891.

New Hampshire Phitatelist. Lake Village, N.H. Feb. 1891-Eeb. 1892.

Philatelic Globe. Effingham, Ill. Feb.-April 1891.

Phimatelic Review. Hot Springs, Ark. Feb. 1891.

Stamp Critic. Washington, D.C. Feb. 1891. Atrantio Phmatelist's Advertiser. New York. Mar.-Apl.
1891.

Philatelic Items. Dubuque, Ia. March 1891.

Ameridan Philatelist and Collector. Marlboro, Mass. Apl. 1891-Feb. 1896.

Collector's Stamp Jouryal. Lake Village, N.H. AprilNov. 1891.

-Post Office. New York. April 1891-Dec. 1899.

Western Colneotor. Burlington, Kas. April-May 1891.

Hoosiek Stamp. Indianapolis, Ind., etc. May 1891-Feb. 1894.

New York Philatelist. New York. May-June 1891.

Phimatelio Exchange. Philadelphia, Pa. May-Dec. 1891.

Stamp Chroniche. Nashville, Tenn. May 1891.

Brooklyn Philatelist. Brooklyn, N.Y. June-Nov. 1891.

Golden Star. Taunton, Mass. June 1891-Dec. 1893.

Fagle Philatelist. Kansas City, Kas., etc. July 1891. Dec. 1893.

Stamp Exchange. Bloomington, Ind. July 1891.

Ohio Philatelist. Cardington, O. Aug. 1891-Jan. 1892.

Stamp Colmectors' Companion. Jackson, Mich. Aug. 1891.

Philatelic Visitor. New York. Sept. 1891-March 1899.

Missouri Philatelist. St. Louis, Mo. Oct. 1891-Jan. 1893.

Postage Stamp. Pennington, N.J. Oct. 1891.

Salt City Philatelist. Syracuse, N.Y. Oct. 1891-March 1893.

Stamp Columctor's Companion. St. Tuouis, Mo. Oct. 1891 Jan. 1892.

Stamp World. Indianola, Ia. Oct. 1891-March 1892.

Worcester County Philatelist. Worcester, Mass. Oct. 1891-Dec. 1893.

Chicago Stamp News. Chicago, Ill. Nov. 1891-Dec. 1892. Philateild HUs'LeR. Manchester, Mich. Nov. 1891-March
1892.

ReCord Review AND AUdTion Advertiser. New York. Nov. 1891-May 1893.

Stame World. Pennington, N.J. Nov. 1891-Jan. 1892. Pennsylvania Philatelist. Reading, Pa. Dec. 1891-Aug.
1898.

United Association Philatelist. Washington, D.C. Dec. 1891-Feb. 1892.

Weekly Oologist and Philatelist. Lebanon, Or., Dec. 1891-Jan. 1892.

Coin and Stamp. San Antonio, Tex. Jan.-Feb. 1892.

Coin Colmector's Journal. Middlebury, Conn., etc. Jan. 1892-April 1893.

Eastern Stamp. Worcester, Mass. Jan. 1892-Jan. 1893.

Exchange Notes. Poughkeepsie, N.Y. Jan.-Feb. 1892.

Michigan Phimatelist. Detroit, Mich. Jan.-April 1892.

Our Calendar. Iowa City, Ia., etc. Jan.-April 1892.

Philatelic Argosy. Buffalo, N.Y. Jan. 1892-May 1893. 
- Philatelic Monthly and World. Philadelphia, Pa. Jan. 1892-May 1901.

Young Collector. Brooklyn, N.Y. Jan.-Dec. 1892.

Ermactric Philatelist. Scranton, Pa. Feb. 1892-July 1894.

International Philatelio Monthi,y. Taunton, Mass. Feb.May 1892.

Philatelic Clipper. Burlington, Kas. Feb. 1892.

Philatelic Currier. Williamsville, Mass. Feb.-March 1892.

Phimatelic Sun. Albany, N.Y. Feb. 1892.

- Postar Card. Elizabeth, N.J. Feb. 1892-Feb. 1894.

Cabinet and Album. Chiçago, Ill. Mar. 1892-Dec. 1893.

Long Island Philatelist. Brooklyn, N.Y., etc. March 1892-Aug. 1893.

Philatelist Exchange. Toledo, O. March-Jume 1892.

Royal Philatelist. Sterling, N.Y. March-Aug. 1892.

Washington Philatelist. Washington, D.C. March $1892-$ May 1896.

Colnector's Press. Richmond, Va. April 1892-Jan. 1893.

Derroit Phiratelist. Detroit, Mich. April 1892-May 1894.

New York Stamp. New York. April-June 1892.

Stamp Echo. Central City, Neb. April 1892.

Weistern Stamp Budget. Chicago, Ill. A pril 1892.

Collectors' Worud. North Leominster, Mass. May 1892-May 1894.

Curio. Williamsville, Mass. May-Nov. 1892.

Malden Philatelist. Malden, Mass. May-Aug. 1892.

Mountain Philatelist. Mountainville, N.J. May 1892.

Philatelic Sun. Brushton, N.Y. May-Oct. 1892.

Revista Filatélica. St. Louis, Mo. May 1892-May 1895.

Ohio Stamp News. Garrettsville, O. June 1892-Feb. 1893.

Carifon Philatelist. Califon, N.J. July-Dec. 1892.

Florida Phiratelist. Thonotosassa, Fla. July 1892-Jan. 1893.

StaMp. Long Branch, N.J., etc. July 1892-Dec. 1895.

Nebraska Stamp. Central City, Neb. Aug. 1892-Feb. 1893.

RFPorter. Norwich, Conn. Aug. 1892-Dec. 1895.

Pentucket Philaterist. . Haverhill, Mass. Sept. - Dec. 1892.

American Philatelic Magazine. Omaha, Neb. Oct. 1892 Jan. 1902.

Filatelio Facts and Faldacies. San Francisco, Cal. Oct. 1892-Sept. 1901.

Philatelic Lasso. Fremont, Neb. Oct. 1892.

Philatelic Postal Card. Reading, Pa. Oct.-Dec. 1892.

Young Philatelist. Albany, N.Y. Oct.-Nov. 1892.

Keystone Stamp Buluetin. Titusville, Pa. Nov.-Dec. 1892.

New Jersey Philatelist. Califon, N.J. Nov. 1892-Feb. 1893 .

Stamp. Stromsburg, Neb. Nov. 1892.

Weekly Philatelist. New Chester, Pa. Nov. 1892-Sept. 1894.

Yankee Philatelist. Boston, Mass. Nov. 1892-Oct. 1893.

Philatelid Fortnightry. Second series. Minneapolis, Minn. Dec. 1892-Jan. 1893.

Philatelist. Wabash, Ind. Dec. 1892.

Americañ Stamp. Newark, N.J. Jan.-May 1893.

American Stamp. Maywood, Ill. Jan. 1893.

Chicago Philatelist. Chicago, Ill. Jan.-Sept. 1893.

Philatelic Mair and Express. Albany, N.Y. Jan.-Feb. 1893.

Stamp. Williamsville, Mass. Jan.-Dec. 1893.

Kissinger's Philatelic Postal Card. Reading, Pa. Feb. 1893-Jan. 1894.

Massachusetts Philatelist. Taunton, Mass. Feb.-Nov. 1893.

Philatelic Record. Springfield, Ill. Feb. 1893.

Rockx Mountain Philatelist. Boulder, Colo. Feb.-June 1893.

Stamp Journat. Newburyport, Mass. March 1893-Deo. 1895.

Brookryn Stamp. Brooklyn, N.Y. April-Dec. 1893.

Collectors' Review. Dénver, Colo., etc. April-Sept. 1893.

Illinors Philatelist. Palatine, Ill. April-May 1893.

Ohio Stamp. Cleveland, O. April 1893.

Philatelic Gazette. Altoona, Pa. April-July 1893.

Philatelist. Denver, Colo. April-Aug. 1893.

Philatelio Puck. San Antonio, Tex. May 1893.

Syracuse Philatelist. Syracuse, N.Y. May 1893-Jan. 1894.

Whatern Journal of Philately. Valentine, Neb. MayJuly 1893.

Monthly Buldetin. Springfield, Ill. June-Aug. 1893.

Northwest. New series. Minneapolis, Minn. July 1893 Jan. 1894.

Philatelic Advertiser. Bloomington, Ill. July 1893.

American Philatelic Association. Official Crroular. [New series.] St. Louis, Mo. Sept. 1893-Aug. 1895.

Amerioan Stamp News. Lowell, Mass. Sept. 1893-July 1894.

Phimatelto Brokrr. Philadelphia, Pa. Sept.-Oct. 1893.

Recreation Echo. Knoxville, Tenn., etc. Sept. 1893Dec. 1894.

STAMP WorLd, Lynchburg, Va. Sept. 1893-Jan. 1894.

Phinatelic Californian. "San Francisco, Cal. Oct. 1893. April 1897.

Philatelic Kaleidoscope. Belleville, Mich. Oct. 1893May 1894.

Philately. Jackson, Mich. Oct. 1893.

Star Stamp Journal. Worcester, Mass. Oct. 1893.

Capitor Phil atelist, Springfield, Ill. Nov. 1893-Mar. 1894. 

Stamp Memoranda. Providence, R.I. Nov. 1893-June 1894. Star Philatelist. Mile Run, Pa. Nov. 1894-Feb. 1895.

Minnesota Philatelist. Minneapolis, Minn. Dec. 1893- Michigan Philatelist. Coldwater, Mich. Dec. 1894-April May 1894.

Revenue Collector. Wyoming, Ia. Winter 1893-4. 1896.

Transcontinental Philatelist. Waukegan, IIl. Dec. 1893April 1894.

Bristol County Stamp News. Taunton, Mass. Jan.-Mar. 1894.

Bulletin. Newburyport, Mass. Jan. 1894.

EgGs and Stamps. Cormish, Me. Jan.-Feb. 1894.

Evergreen State Philatelist. Hartland, Washington, etc. Jan. 1894-June 1900.

Our Stampic Exchanger. Mile Run, Pa. [? Jan.]-June 1894.

Springfield Philatelist. Springfield, Ill. Jan. 1894-April 1896.

Amertcan Philatelist and Year Book of the American Philatelic Association. Springfield, Mass, ete. Feb. 1894- (In progress.)

ColteCtor. Newburyport, Mass. Feb.-March, 1894.

Collector's Companion. Brooklyn, N.Y. Feb. 1894.

Puritan Philatelist. Chicago, Ill. Feb.-March 1894.

Dixie Phizatelist. Alexander City, Ala., etc. Mar. 1894Aug. 1896.

Monthly Bulletin. The Postal Card Society of America. Baltimore, Md., etc. March 1894-Feb. 1898.

Philatelic Comfort. Cumberland, Me. March 1894-Dec. 1895.

Badger State Advertiser. Palmyra, Wis. April 1894.

Briefmarten-Verkehr. New York. Apl. 1894-Apl. 1895.

Companion and Philatelic News. Purity and Lorraine, Va. April-July 1894.

Iowa Philatelic Weekly. Wyoming, Ia. April-May 1894.

Mankato Philatelist. Mankato, Minn. June-Oct. 1894.

Stamp Fiend. Cleveland, O. June-July 1894.

Tri-Cuspid. Statesboro, Ga. June 1894-Jan. 1895- 159 Southern WeEkL PhILATELIST. Houston, Tex. July-Oct. 1894.

Stamipic Exchanger. Mile Run, Pa. [? July] 1894-Dec. 1896.

Philatelic Review ow Reviews. Osage, Ia. Aug. 1894-

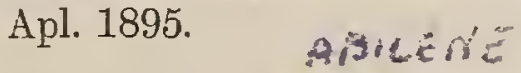

Philatelic Sun. Abriline, Tex. Aug. 1894.

Stamp Collectror and Messenger of the St. Francis Xavier Union of Stamp-colleetors. St. Francis, Wis. Aug. 1894-[? Mar.] 1898.

Lone Star State Philatelist. Abilene, Tex. Sept. 1894Sept. 1899.

Northern Philatelist. Sandy Hill, N.Y. Sept. 1894-Nov. 1895.

Philatelic Sux. Taunton, Mass. Sept. 1894-March 1895.

Weekry Phicatelic Era. Portland, Me., etc. Sept. 1894March 1904.

Pipestone Phimatelist. Pipestone, Minn. Oct. 1894-Feb. 1896.

Thexan Philatelist. Abilene, Tex. Dec. 1894-Feb. 1899.

WoLsigfarer's Specialties. Chicago, Ill. 1894-1895.

Diamond Philatelist. Unionville, N.Y. Jan. 1895-Dec. 1896.

Golden Phitatelist. Patterson's Mills, Pa. Jan.-April 1895.

Mankato Philatelist. Second series. Mankato, Minn. Jan. 1895.

Rocky Mountain Stanip. Denver, Colo., etc. Jan. 1895 Nov. 1898.

Stanp. Holyoke, Mass. Jan. 1895.

Michigan Stamp. Clarion, Mich. Feb. 1895-Nov. 1896.

N. P. S. Bulletin. New York. Feb.-Dec. 1895.

Philatelid Newsletter. Minneapolis, Minn. Feb. 1895March 1897.

Stamp Herald. Holyoke, Mass. Feb.-March 1895.

Stamp Visitor. New York. Feb. 1895.

Bee Hive Philatelist. New Britain, Conn. March 1895June 1896.

Facts. Riverside, Cal. March-Sept. 1895.

Philatelic Advertiser. Tuskaloosa, Ala. March-April 1895.

Stamp Collector Calendar. Philadelphia, Pa. MarchSept. 1895.

Bay State Philatelist. Boston, Mass. May 1895-July 1896.

Boston Stamp Book. Boston, Mass. May 1895-Nov. 1898.

Mankato Phicatelist. Third series. Mankato, Minn. MaySept. 1895.

Stamp. Groveland, Mass. June 1895-March 1896.

Sucker State Stamp. Catlin, Ill. June-Sept. 1895.

International Philatelist. St. Joseph, Mo. July 1895Jan. 1903.

Badger Philatelist. Viroqua, Wis. Aug. 1895-Aug. 1896. Cohannett Philatelist. Taunton, Mass. Sept. 1895.

Collegctor. Minneapolis, Minn. Sept.-Nov. 1895.

ErA's Monthly. Benson, Minn. Sept. 1895.

J. W. Scomt Co., L'D. Weekry News Letrer. New York. Sept. 1895-May 1897.

Philatelic Star. Meriden, Conn. Sept.-Nov. 1895.

Seneca Philatelist. Seneca Falls, N.Y. Sept. 1895-March 1896.

Club Messenger. Cherokee, Ia. Oct.-Dec. 1895.

Eagle Philatelist. New Britain, Conn. Oct. 1895.

Pentnsular Philatelist. Ft. Meade, Fla. Oct. 1895.

Philatelic Facts. Riverside, Cal. Oct. 1895-Aug. 1896.

Fireside Philatelist. Mile Run, Pa. Nov. 1895-March 1897.

Home Worker and Philatelist. Knoxville, Tenn. Nov.Dec. 1895. 
Miduand Philatelist. Kansas City, Mo. Nov. 1895-April 1896.

Pennsylvania Stamp. Patterson's Mills, Pa. Nov. 1895Sept. 1896

Phimatelic Advertiser. St. Joseph, Mo. Nov. 1895-Oct. 1896.

Mrssouri Phimatemist. St. Joseph, Mo. Dec. 1895-March 1896.

Nutmeg State Phunatelist. New Britain, Conn. Dec. 1895.

Union Philatelist. Mankato, Minn. Dec. 1895-Feb. 1896.

Dainy Stamp Item. St. Louis, Mo. Jan.-Dec. 1896.

Gem Philatelist. St. Joseph, Mo. Jan.-April $1896^{\circ}$.

Home Worker. Knoxville, Tenn. Jan. 1896-March 1898.

International Stamp. St. Paul, Minn, etc. Jan. 1896 Jan. 1898.

Lancaster Stamp News. 'Lancaster, Pa. Jan. 1896.

Mankato Phicatelist. Fourth series. Mankato, Minn. Jan. 1896.

Philadelphia Stamp News. Philadelphia, Pa. Jan.-Aug. 1896.

Phinatelic West. Superior, Neb. Jan. 1896- (In progress.)

Southern California Collector. Orange, Cal. Jan-March 1896.

Watson's Monthly Stampsonia. Philadelphia, Pa. Jan.April 1896.

Western Philatelist. St. Joseph, Mo. Jan.-March 1896.

Baby Philatelist. Elkhart, Ind. Feb. 1896.

Columblan Phinatelist. Windsor, Conn. Feb. 1896-Oct. 1898.

Incognito Phinatelist. Newton, Mass. Feb. 1896.

Junior Philatelist. Berwyn, Ill. Feb. 1896.

Monthly Observer. Myerstown, Pa. Feb. 1896.April 1897.

Monthuy Phinatelic Advertiser. Ogden, Utah and New York. Feb. 1896.

Niagara Philatelist. Buffalo, N.Y. Feb.-June 1896.

American Philatelist. Marlboro, Mass. Mar. 1896.

Brooktyn Phiratelist. Brooklyn, N.Y. March-Apl. 1896.

Connecticut Phimatelist. Meriden, Conn. March.-April 1896.

Philatelia. Northampton, Mass. March-June 1896.

Philatelic Paragraph. New York, etc. March-June 1896.

Phildatelist. Waterville, Wash. March-June 1896.

Postage Stancp. Boston, Mass. March-April 1896.

Advertiser. Brooklyn, N.Y. Apl.-June 1896.

Budger. Philadelphia, Pa. April-Oct. 1896.

Junior Philatelist. New series. Berwyn, Ill. April-Sept. 1896.

Boston Phimatelist. Boston, Mass. May-Aug. 1896.

Phicatelid Advertiser. Ogden, Utah and New York. May 1896.
Philatelic Literature Collector. Houlton, Me., etc. May 1896-May 1898.

Philatelio Politician. Bellaire, O. May 1896.

Stamp Colleotor. Arlington, Mass. May 1896-May 1900. Butler Philatelist. Butler, Pa. June-July 1896.

Philatelic Free Lance. Bellaire, O. June-Dec. 1896.

American CoLlmator. Piney Creek, Md. July 1896-Oct. 1898.

Midhigan Philatelist. Hart, Mich. July 1896-April 1899.

Postage Stamp. Boston, Mass. July 1896-Jan. 1897.

Stamp Advertiser. Brooklyn, N.Y. July 1896.

Stamp Collectors' Directory. Filmira, N.Y. July 1896.

Waverley Stamp Co.'s Altegheny Philatelist and Stamp Collectors Guide. Allegheny, Pa. July 1896.

Argus Philatelist. Olean, N.Y. Aug. 1896.

Mrnnesota Staur. Pipestone, Minn. Aug. 1896.

Philatelic Weetriy. Jackson, Mich. Aug.-Sept. 1896.

Stamp Advertiser. Elmira, N.Y. Aug. 1896-May 1897.

Stamp Faots. Butler, Pa. Aug.-Dec. 1896.

Standard Philatelist. St. Louis, Mo. Aug. 1896-Jan. 1897.

Aluegheny Phicatelist. Allegheny, Pa. Aug. 1896-Dec. 1900.

American Stamp Dealers' Protective Association ButLEtin. New Oxford, Pa. Sept. 1896-Oct. 1897.

Dariota Philatelic. Beaver, S.D., etc. Sept. 1896-Aug. 1897.

Halsey Stamp Co.'s Buluetin. Brooklyn, N.Y. Sept.-Oct. 1896.

Kaystone Phuatelist. Allentown, Pa. Sept. 1896.

North State Philatelist. McAdenville, N.C. Sept. 1896Jan. 1897.

Omaha Phuateisst. Omaha, Neb. Sept. 1896-March 1898.

Stamp Advertiseir. New York. Sept. 1896.

Trans-Mississippi Stamp. Omaha, Neb. Sept. 1896-June 1897.

Western Stamp. Riverside, Cal. Sept.-Dec. 1896.

Buckeye State Philatelist. Cincinnati, O. Oct. 1896Mar. 1897.

Eastern Stamp. Duck Pond, Me. Oct.-Dec. 1896.

Heracd Exchange. New York. Oct. 1896-March 1900.

Kentucry Philatelist. Hodgenville, Ky. Oct. 1896.

New York Philatelist. New York, etc. Oct. 1896-April 1903.

Official Buldetin. San Antonio, Tex. Oct. 1896-April 1897.

Stamps. New York. Oct. 1896-Dec. 1899

Doughty and Page's Philatelic Litgeraturist. Muscatino, Ia. Nov. 1896-April 1897.

Maryland Phiuatelist. Church Hill, Md. Nor. 1896.

Monthuy Exchange. Fort Atkinson, Wis. and Gainesville, Ga. Nov. 1896-[?] 1898 

Monthly Stamp News. Webster City, Ia. Nov. 1896-Feb. Virginia Philatelist. Richmond, Va. Sept. 1897-Jan. 1898.

- Philatelic Literature. Taunton, Mass. Nov. 1896-Feb. 1900.

Seneca Philatelist. Seneca Falls, N.Y. Nov. 1896.

Stanp News. Chicago, Ill. Nov. 1896.

- Stampman. Pueblo, Colo., etc. Dec. 1896-Oct. 1902.

Indiana Phicatelist. Muncie, Ind. Dec. 1896.

Magazine Philatelist. Buffalo, N.Y. Dec. 1896.

Our Philatelia. Providence, R.I. Dec. 1896-March 1897.

Mercurf MatLer. Louisville, Ky. [? ] 1896-Jan. 1897.

American Bors. Lowell, Mass. Jan.-Aug. 1897.

Amertcan Stant. Laconia, N.H. Jan.-Aug. 1897.

Bristol County Philatelist. Taunton, Mass. Jan. 1897Mar. 1898.

Jerser Stamp. Avondale, N.T. Jan.-Feb. 1897.

Our Mutual Friend. St. Louis, Mo. Jan. 1897.

Philateltc Nebraskan. Omaha, Neb. Jan. 1897.

Sangamon Philatelist. Springfield, Ill. Jan.-[a. 1897.

Scraps. Butler, Pa. Jan. 1897.

Stamp. Riverside, Cal. Jan. 1897.

Wisconsin Phicatelist. De Pere, Wis. Jan.-March 1897.

Young Collector. Red Lion, Pa. Jan.-Dec. 1897.

Funny Foonatelist. McConnelsville, O. Feb. 1897.

Brooklyn Philatelist. New York. Mal'ch 1897.

Buffalo Phicatelist. Buffalo, N.Y. March 1897.

John W. Scotr's Junior Weekry Letrer. New York. March-April 1897.

Perforator. Hartford, Conn., etc. March 1897-July 1901.

Phis atelic Iowan. Elkader, Ia. March 1897.

Detrort Philatelist. Detroit, Mich. April-Aug. 1897.

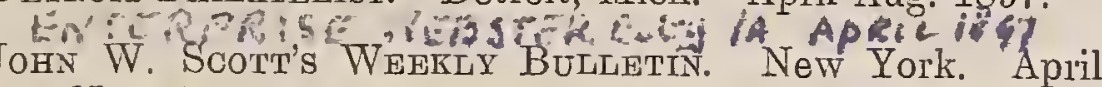
Nov, 1897

Otean Stanp. Olean, N.Y. April-June 1897.

Philatelic Puck-Literaturist. Muscatine, Ia. April 1897.

Philatelio Advance. Berwyn, Ill. May 1897.

Stamp. Louisville, Ky. May 1897.

Deutsch-Amerikanische Brtefmarken Zeitung. Yonkers, N.Y. June 1897.

Hawkere Stamp. Winthrop, Ia. June 1897.

Philatelic Facts. Riverside, Cal. June 1897-July 1898.

Junion CoLlector. Pittsburg, Pa. Aug. 1897-July 1898.

Stamp Exchange. Columbus, Ind. Aug. 1897-May 1898.

Philatelic Buldetin. Salem, Mass. Sept. 1897-May 1899.

Philatelic Newsletter. Second series. Minneapolis, Minn. Sept. 1897.

Southern Stamp CouLector. New Orleans, La. Sept. 1897.

Stamp Item, Fithoretstenn, Mass. Oct.-Dec. 1897.

BaKer's Falds Stamp. Sandy Hill, N.Y. Nov. 1897.

Catifornia Stamp. San Francisco, Cal. Nov.-Dec. 1897.

Postal Card Reporter. Baltimore, Md. Nov. 1897-Sept. 1899.

Stamp Collector's Figaro. Wellington, O. Nov. 1897 [? ] 1898

KrD. Beaver City, Neb. Dec. 1897-June 1898.

National Stamp Colimctor. New Orleans, La. Dec. 1897. Feb. 1898.

Philatelic Lancet. Poughkeepsie, N.Y. Dec. 1897.

Philatelic Rambler. Loomis, Neb. Season 1897-98.

Philatelic Mercantile Agency, Confidential Report. New Oxford, Pa. Jan. 1898-Oct. 1899.

Philatelic Review. East Boston, Mass. Jan.-March 1898.

Stamp Sraps. Nutley, N.J. Jan. 1898.

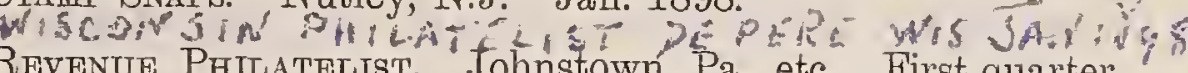
IILAT quarter 1898-first quarter 1906.

Dakota Phicatelic. Sioux Falls, S.D. Feb. 1898.

Juntor Phicatelist. New series. Berwyn, Ill. Feb.-July 1898.

Philatelic Courier. New York. Feb.-May 1898.

News. Webster City, Ia. March-[?] $1898 . \quad$ is 136

Postat Card Bulletin. Springfield, Mass. March 1898 June 1899.

Tennessee Philatelist. Knoxville, Tenn. March-May 1898.

American Philatelic News. Newark, N.J. Apl.-May 1898.

Northivestern Philatelist. Milwaukee, Wis. April 1898.

Oneonta Philatelist. Oneonta, N.Y. April-July 1898.

Stamp ColLector's Gazette. Gainesville, Ga. April-May 1898

. Bay State Philatelist. Melrose Highlands, Mass. May

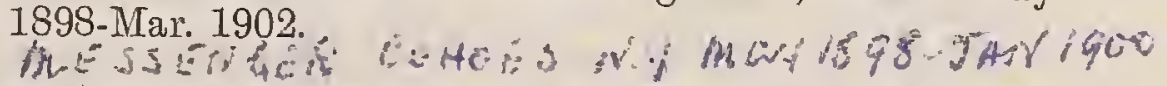

Stamp Advertiser and Stamp Collectors' Directory. Ithaca, N.Y. May 1898-May 1899.

Cosmopolitan Philatelist. Utica, N.Y. June 1898.

Michigan Philatelist. Ithaca, Mich. June 1898.

Western Philatelist. Humboldt, Kas. July 1898.

Lake State Stamp. Jackson, Mich. Aug.-Dec. 1898.

New England Philatelist. Jamaica Plain, Mass. Aug.Oct. 1898.

National Philatelist. Humboldt, Kas. Aug.-Sept. 1898.

Philateltc Advertiser. Philadelphia, Pa. Sept. 1898-Feb. 1899.

Litrue Gem Stamp News. Camden, N.J. Eot. 1898 .

Gen Stanp News. Camden, N.J. Nov. 1898.

Stamp TaLK. Kansas City, Mo. Nov. 1898-July 1899.

Wisconsin Philatelist. De Pere, Wis. Nov. 1898.

New Jersey Philatelist. Camden, N.J. Dec. 1898. 
Exchange. Putzam, Conn. Jan.-[? ] 1899.

Michigan Philatelio Monthuy Advertiser. Detroit, Mich. Jan.-March 1899.

Michigan Philatelic Wreekly. Ithaca, Mich. Jan. 1899.

Mohawe Stamp. Utica, N.Y. Jan 1899.

Stamp Tribune. Harriman, Tenn., etc. Jan.-Dec. 1899.

Tri-Monthly Collector. New Oxford, Pa. Jan.-June 1899.

Nebraska Philatelist. Hastings, Neb. Feb. 1899-July 1900.

Alu Around Philatelist. Boston, Mass. Mar.-Apl. 1899.

Bi-monthly Collector. MaGraw, N.Y. Mar. 1899-July 1900.

Missouri Philatelistr. Columbia, Mo. March-April 1899.

Stanipio America. East Dubuque, Ill. March 1899-June 1900.

Juniors Colmector. Dayton, Tex. April 1899-Jan. 1901.

Stamp Exchange. Boston, Mass. April-Aug. 1899.

Colimetors Companion. Red Creek, N.Y. May 1899-Nov. 1900.

Monthly Stamp World. Brockton, Mass. May-July 1899.

Philatelic Buldetin and Eastern Philatelist. Salem, Mass., etc. June 1899-Mar. 1902.

- Philatelic Inter-Ocean. Waterloo, Ia. July 1899-Aug. 1907.

Philatelist. East Brady, Pa. July 1899-Jan. 1900.

Rival Philatelist. Chicago, Ill. Aug.-Oct. 1899.

Chicago Philatelist. Chicago, Ill. Sept. 1899.

Collector. New Oxford, Pa. Sept. 1899-Aug. 1900.

Iluinois Philuatelist. Kankaku, Ill. Sept.-Dec. 1899.

Ohio Philatelist. Pearl, O. Sept. 1899-Nov. 1900.

Philatelist's Window. Chicago, Ill. Sept. 1899.

Western Philatelic News. Wichita, Kas. Sept. 1899.

International Phitatelic Reviewy. Rochester, N.Y. Oct. 1899-Nov 1900

International Philateuist. Wichita, Kas. Oct. 1899March 1900.

Moline Stamp News. Moline, Ill. Oct. 1899-Jan, 1900.

Northwestern Philatelist. Elk Point, S. Dak. Oct. 1899-July 1900

Buckeye Philatelist. Tippecanoe City, O. Nov. 1899Jan. 1900.

Indiana Philatelist. Goshen, Ind. Nov. 1899-Aug. 1900.

Philatelic Chronicle and Michigan Philatelist. Charlotte, Mich. Nov. 1899-Jan. 1901.

Clipper. Sioux City, Iowa. Dec. 1899-June 1900.

Philadelphia Philatelist. Philadelphįa, Pa. Dec. 1899. Stamps. New London, Ta. $189 \overline{9}$. "n

Stamp News. [? ] 1899.

'AdHesrve. Rocky Hill, Conn. Jan. 1900-Aug. 1904.

Auxiltary Philatelist. Houlton, Me. Jan. 1900-Apl. 1901.

Еоно. Big Run, Pa. Jan. 1900.

\section{UNITED STATES}

908

Littrle Nugget. Boston, Mass. Jan.-Dec. 1900.

Phicateicic Crimic. Brockton, Mass. Jan.-Nov. 1900.

Philatelic Post. Smethport, Pa. Jan.-Sept. 1900.

Stamp Exchange. Kankaree, Ill., etc. Jan. 1900-Dec. 1902.

Swap. Rochester, N.Y. Jan. 1900-Sept. 1901.

Weekry Stamp Tribune. Cleveland, O. Jan. 1900-Jan. 1902.

Exchange. Peekskill, N.Y. Feb. 1900-Jan. 1901.

Stamp Special. Putnam, Conn. Feb. 1900.

Costa Rica. New York. March 1900.

Nebraska Stamp News. Minden, Neb. March-Oct. 1900.

Prairie State Philatelist. Chicago, Ill. March 1900April 1902.

International Phimatelic Advertisgr. Allegheny, Pa. April 1900.

Philatelic Extract. Eldred, Pa. April-July 1900.

Chicago Junior. Chicago, Ill. May-Aug. 1900.

Meneeel's Drummer. St. Louis, Mo. May 1900 Nov. 1901.

Stampio America. Charlotte, Mich. May 1900.

Grant's Monthly Philatelist. Kansas City, Kas. June 1900.

Philatelic Gazerte. Philadelphia, Pa. June-Aug. 1900.

Grant's Philatelic Monthly. Kansas City, Kas. July 1900-Jan. 1901.

Monaroh Monthuy. Chicago, Ill. July-Dec. 1900.

Saratoga Amateur News. Saratoga Springs, N.Y. Sept. Dec. 1900.

Yankee Collector. MeGraw, N.Y. Sept. 1900-Sept. 1903.

W. F. Bishop and Co.'s Stamp Drummer. La Grange, Ill. Fall 1900.

Redfield's Weekly Philatelic Post. Smethport, Pa Oct. 1900-May 1901.

.Stanton's Phicatelic Index. Detroit, Mich. Oct.-Dec. 1900.

Gopher State Philatelist. Minneapolis, Minn. Nov. 1900.

Quaker City Philatelist. Philadelphia, Pa. Nov. 1900. April 1901.

Namional Phmatelio News. Indianapolis, Ind. Dec. 1900 March 1901.

Columbian. Columbus, O. Jan. 1901.

Monaroh Monthey and Philatelic News. Chicago, IIl Jan.-Aug. 1901

Monthly Amateur and Stamp News. Saratoga Springs, N.Y. Jan.-Feb. 1901.

Omaha Monthex Phicatelist. Omaha, Neb. Jan. 1901 Oct. 1902

Philatelio Literature Coliector. Westbury, N.Y. Jan. Summer, 1901.

Stamp Book. Brockton, Mass. Jan. 1901-Jan. 1902.

.Columbus Phitatelist. Columbus, O. Feb. 1901-July 1907.

International Philatelic Review and Exchange. Peekskill, N.Y. Feb.-May 1901. 
- 

Philatelic Chroniche and Phimateric Index. Charlotte, Mich. Feb.-June 1901.

Buckere Philatelist. Columbus, O. March-Aug. 1901.

Buyers' News. Chicago, Ill. Mar. 1901-Sept. 1902.

Litme Advertiser. Newton Center, Mass. March 1901.

Amgrican Phimaterist. Minden, Neb., etc. May 1901-Feb. 1902.

Buffalo Philatelic Magazine. Buffalo, N.Y. May 1901.

Phicatéliste d’Amérique. New York. May-July 1901.

Wiedling's Monthey Stamp News. Canton, O. May-Aug. 1901.

Litmue Stampmay. Springfield, Mass. July 1901-March 1902

Stamp Reporter. Albany, N.Y. July 1901.

Philatelic Era. Wymore, Neb. Aug. 1901.

Phimatelic Acorn. Springfield, Mass. Sept. 1901-March 1902.

Phimatelic Examiner. Phoenix, Arizona. Sept. 1901-March 1902.

Salesian. Wymore, Neb. Sept. 1901.

Stamp Tribune. Lexington, Ky. Sept.-Oct. 1901.

Tolmo Philatelist. Toledo, O. Sept. 1901.

Leve's New Perforator. Syracuse, N.Y. Oct. 1901-Feb. 1902.

Northern Phimatelist. Minneapolis, Minn. Oct. 1901.

Counectors' Journal. Fayette, Ia. Nov. 1901.

"Oud Put" Phimatelist. Putnam, Conn. Nov. 1901-July 1902.

Boy Philatelist. Huntingdon, W. Va. Dec. 1901-Aug. 1902.

Mekeel's Stamp Colmector. St. Louis, Mo. Dec. 1901June 1905.

Minnesota Philatelist. Minnesota Lake, Minn. Dec. 1901-March 1902

Moyarch Philatelist. Chicago, Ill. Dec. 1901-Jan. 1902.

Okla Philatelist. Stillwater, Okla. Dec. 1901-Aug. 1902.

Western Stamp Book. Kansas City, Mo. Dec. 1901-Jan. 1902

Phicateric Herald. Cincinnati, O. Jan. 1902.

- Phimatelic Star. Madison, N.Y. Jan. 1902-Sept. 1907.

Phimatelist's Beacon. Golden, Colo. Jan. 1902.

CoLmector. Greenfield, O. Feb. 1902.

Perry's Exchange List. Syracuse, N.Y. Feb. 1902.

Perry's International Advertiser. Syracuse, N.Y. [? ]-Oct. 1902.

Robinson's Review. Chicago, Ill. March 1902-Feb. 1903.

Fortnightly Phicatelist. Detroit, Mich. May-Aug. 1902.

Perforator. New York, etc. May 1902-Feb. 1907.

Brooklyn Philatelic Advertiser. Brooklyn, N.Y. July 1902-July 1903
Chicago Philatelist. Chicago, Tll. July 1902.

Philatelic Literature. Columbus, O. July 1902

Philatelic Rays. New York. Sept. 1902.

Tausig's Bargain Advertiser. New York. Sept. 1902March 1903.

Nutmeg State Philatelist. Meriden, Conn. Oct. 1902

Philatelic Wortd. Chicago, Ill. Nov. 1902-Mar. 1903.

Phicatelic World. Minneapolis, Minn. Nov, 1902-Jan. 1904.

New York Stamp and Coin News. New York. Dec. 1902. Dec. 1903.

Literary Phimateuist. New York. Jan.-Feb. 1903.

Originator. Reading, Pa. Jan.-Feb. 1903.

Phimatelic Literature. Red Creek, N.Y. Jan. 1903.

Stamp Herald. Breinigsville, Pa. Jan.-April 1903.

Co-operative Advertiser. Syracuse, N.Y. Feb.-April 1903.

Hinge. New York. Feb.-March 1903.

Philatelic and Photographic East. Washington, D.C. Feb.-19ay 1903

Amateur Phimatelic Herald. Chicago, Ill. May-Aug. 1903.

Aspen View Primatelist. Aspen View, Va. May 1903.

Fortinightiy Cochector. Smethport, Pa. May-Oct. 1903.

Journal of the Buffaco Phimatelic Society. Buffalo, N.Y. June-Aug. 1903

Phimatelic Midget. Aspen View, Va., etc. June-Sept. 1903.

Philatelic Quarterly. Manitowoc, Wis. June 1903.

Phimateric Gem. Boise, Idaho. Aug. 1903.

Stampman. Dahlonega, Ga. Aug. 1903.

Junion Philatelist. Byron, Ill. Sept.-Dec. 1903.

Metropolis. Corning, N.Y. Sept. 1903-June 1904.

Phimatelic Herald. Chicago, Ill. Sept. 1903.

Saymon's Magazine. New York. Sept. 1903.

Morrison's Weekit Stamp Coliector. Smethport, Pa. Nov. 1903-March 1905.

Stamp and Coin Reporter. Cobleskill, N.Y. Nov.-Dec. 1903.

Conmectoris Note Book. Camden, N.J. Dec. 1903-Feb. 1905.

Eychners Stamp Coluector. Westernville, N.Y. Jam.-Feb. 1904.

New Century. Alton, Ill. Jan.-March 1904.

Philatelic Advertiser. Sioux Falls, S.D. Jan.-Feb. 1904.

Stramp Reporter. Cobleskill, N.Y. Jan.-April 1904.

Stampus. Gamer, Ia. Jan $1904 . \cdots$

Phicatelic South. Mapleville, N.C. March 1904.

Stamp Age. Washington, D.C. April 1904.

Stamp Reporter. Albany, N.Y. April 1904.

Stampus. Forest City, Ia. June-Sept. 1904. 
American Advertiser. Chicago, Ill. July-Oct. 1904.

Stamp Items. Wortendyke, N.Y. Aug.-Sept. 1904.

Snow-Frake. Albany, N.Y. Sept.-Dec. 1904.

Stanp-Lovars Wemrly. Bethlehem, Pa. Sept. 1904-May 1906.

Enastrom's Monther Stamp News. Holdrege, Neb. Oct. 1904.

Ohio Phimaterist. Cleveland, O. Nov. 1904.

Phicatelic Advertiser. Ithaca, N.Y: Nov. 1904-Aug. 1906.

Phumánelo Monthly. Chicago, Ill. Nov. 1904-Feb. 1905.

Philatelic East. Washington, D.C. Jan.-April 1905.

Snow Flatre Philatelist. Albany, N.Y. Jan. 1905-April 1908.

Star. Holyoke, Mass. Feb. 1905-March, 1906.

True and Tide. Bloomdale, O. Feb. 1905-July 1906.

Young Colueotor. Kansas City, Mo. Feb. 1905.

Bi-Weekry Stamp News. New York. Mar. 1905.

Contrator. Pittsburg, Pa. March 1905.

Philatelic Time and Tidf. Bloomdale, O. Mar.-May 1905.

Badger Stamp Notes. Milwaukee, Wis. Apl.-[? ] 1905.

Chicago Stamp News. Chicago, Ill. Aug. 1905-Nov. 1906.

Mekeel's News and Trade Gircutar. St. Louis, Mo. Nov. 1905- (In progress.)

Phimocartist News and Camera Craft. Stillwater, Okla. Nov. 1905-Dec. 1906

Exchange. Kirksville, Mo. [? ] 1905-June 1906.

Wabash Stamp Exchange News. Terre Haute, Ind. 19051906.

Uniten Stamp Journat. Milwaukee, Wis. [?]-March 1906.

GQLECTURC R'ORLD

WUELAD WALLA WRSH
Juvenime Phimatelist. Denver, Colo. Feb.-June 1906.

Western Stamp Coliector. Denver, Colo. April-June 1906

Post Card and Stamp Journat. Springfield, Ill. May 1906.

Erwin's Phichatelic Advertiser. South Bend, Ind. JuneJuly 1906 A

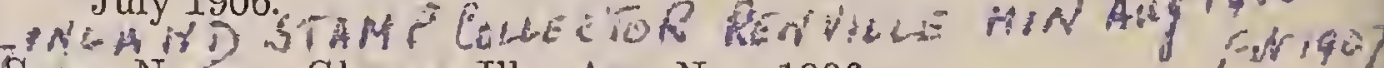

Stamp Notms. Glencoe, Ill. Aug.-Nov. 1906.

Postage Stamps for Advanced Coutectors. Brighton, Mass. etc. Oct. 1906- (In progress.)

U. S. Advertiser. Chicago, Ill. Nov. 1906-Feb. 1907.

Stamp and Postcard Collmotor. Milwaukee, Wis. Dec. 1906-Mareh 1907.

Cousector. Northfield, Vt. 1906.

Western Stamp News. South Bend, Ind. 1906.

\section{VENEZUELA}

Anunciador Fitatélico de Venezuela. Garacas. Jan. 1892-Jan. 1893.

Eco Fitatemico. La Guaira. March-Oct. 1892.

Venezueta Postal. Caracas. Oct. 1892-Aug. 1894.

Arte Firatérico. Valencia. Nov. 1892-Sept. 1894.

Caracas Firaterico. Caracas. Apl. 1894-Feb. 1895.

Venezugia Postar. Caracas. Aug.-Sept. 1903.

\section{VICTORIA.}

Barry's Philatelio Monthuy. Melbourne. Nov. 1887-Apl. 1888.

Australian Stamp Collector and Phitatelic Advertiser. Melbourne. Oct. 1893-Sept. 1896. 

Extra Ludesces.

Heped Sundis H.C. Each year 1895-1908. 241-406.

Enens heckly Stant hews. 1899-1903,2001-223.

$I+I I,\|I+\| r+v, r), r\|\cdot v\| \cdot, \mid x \cdot x \cdot x)$. 
Postage Stamp. Ranhmile sto

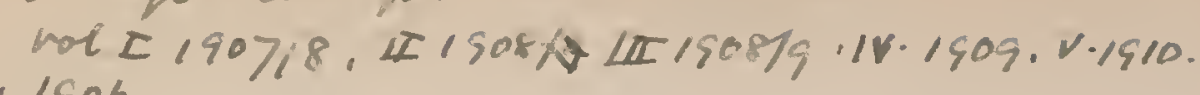
v1.1906 
Stamp Collectors' Iostingith

it $189 \mathrm{c} / \mathrm{F}$. III $1856 / 7 \mathrm{~W} / 897 / 8$. $5111 \cdot 1902 / 3 \cdot 1 \times 1903 / 4$ $x / 41508 / 9$

Stanfu collectors fousual $1 x \cdot 1886 / 7 \times 1887 / 8 \times 1 / 88879 \times 11.1899 / 90 \cdot x 111$ $1890 / 91 . x$ xiv 1851/2 xv $1892 / 3$ xr1 1853/4. xv11 $1894 / 5^{-} x$ vil1 $1855 / 6 \quad x(x \quad 856 / 7 x \times 1857 / 8 x \times 1$ $1858 / 9$

\section{Stanfo Colicetors kapagine. P.fmath to $I-x_{1} .1863-1873$.}

stand cileutions an 1891.1892 .1853

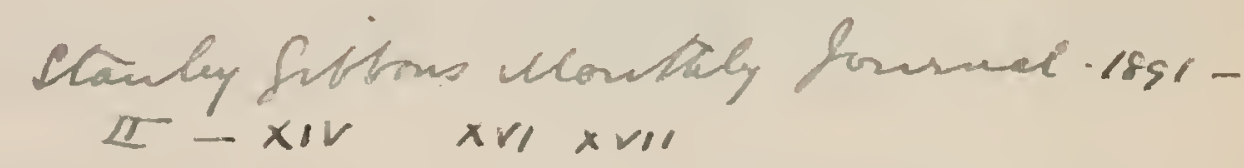

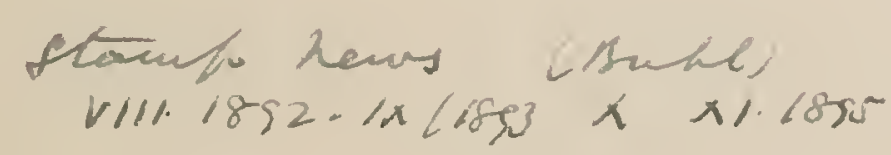




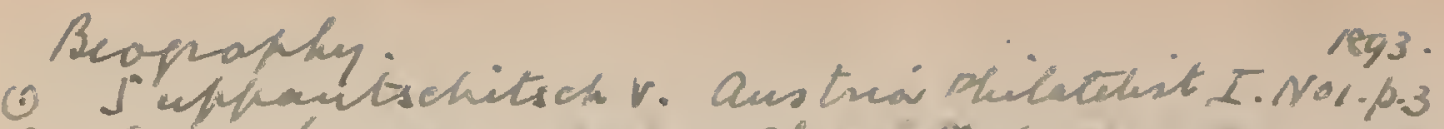

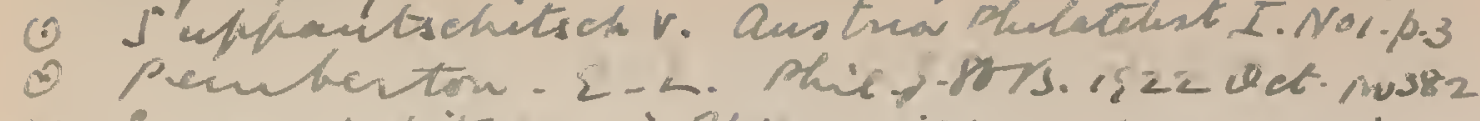

suppoutschitsex. in Phindetisiticher Bören-Cowier

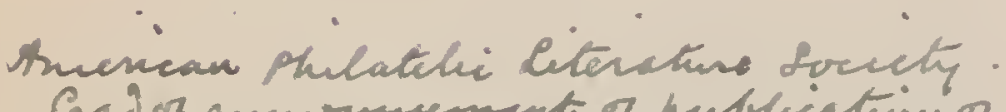

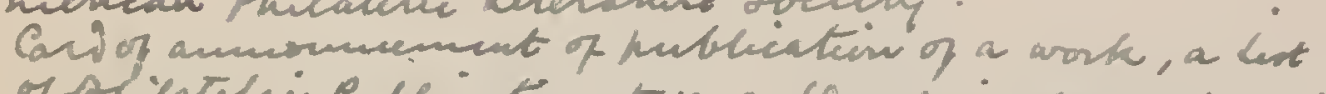

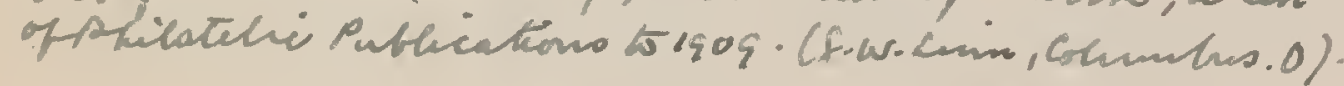

Amencan phelateint rI.M $4 \cdot 162.1892$ M 10

- Mas ar editanial note an a plibatelimin. 




\section{SECTION B.--Special Indexes}

A List of Indeaces of I'hibatelic Literature (J.l'i.s. $\begin{array}{lllllllll}\text { VIII, 4) } & \ldots & \ldots & \ldots & \ldots & \ldots & \ldots & \ldots & 10 / 6\end{array}$

A Bibliography of Works and Arlicles on the Stanp Issuing Countric's of the World, by E. D. Biacon (J.I'L.S. II. $2 / 4$, III. 1/4, IV. 1) ... ... \&4 $4 /-$ r. Japan (J.P.L.S. II. 2) ${ }^{2} \ldots \ldots$ … $\quad \ldots \quad 10 / 6$ 2. New South Wales (J.P.L.S. II. 3) ... $10 / 6$ 3. Queensland (J.P.L.S. II. 4) $\ldots \quad \ldots, 10 / 6$ 4. South Australia (J.P.L.S. III. I) $\ldots .10 / 6$ 5. Tasmania (J.P.L.S. III. 2) $\ldots \quad \ldots \quad$ 10/6 $\begin{array}{llll}\text { 6. Victoria (J.P.L.S. III. 3) } & \text {... } & \text {... } & 10 / 6 \\ \text { 7. Vestern Australia (J.P.L.S. III. 4) } & 10 / 6\end{array}$ $\begin{array}{lll}\text { 7. Western Australia (J.P.L.S. III. 4) } & 10 / 6 \\ \text { 8. New Zcaland (J.P.L.S. IV. 1) } & \ldots & 10 / 6\end{array}$

*Indice Bibliografico Filatelico (fino a tutto il 1924) I Edizione. $14 \mathrm{pp}$. $8 \frac{3}{4} \times 11 \frac{7}{1}$. Torino $1925 \quad \ldots$

* Bibliographie der Wichtigsten Spezialwerke über die Jostwertzeichen einzelner Länder, bearbeitet von Rud. Kraseman. 45 pp. $4 \times 7$. Stockholm 1907

*The Philatelic Index, being an Alphabetieal List of the Principal Articles contained in a seleetion of some of the best-known Philatelie Magazines in the English I anguage up to the end of Igo4, by W A R Jex-Lons

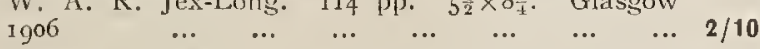

* The Philatelic Index. Comprising the Prineipal Articles in important British Journals to the end of the year 1924, with an Appendix containing many of the leading Monographs in English published since 1908 and therefore not in the published since 1908 and therefore not in the Crawford Catalogue. "The Philatelic Index" by
Mr. W. A. R. Jex-Long, for the 40 years up to $\mathrm{Mr}$. W. A. R. Jex-Long, for the 40 years up to
1004 has by his permission been incorporated in this volume. Compiled by an Index Committec. appointed by the Philatelie Congress of Great Dititain. $248 \mathrm{pp} . \quad 5^{\frac{1}{2}} \times 8 \frac{1}{2}$. (Cambridge) $1925 \quad £ 11 /$ -

American Philatelic Socicty's Philatelic Index, by W. R. Ricketts (S.C.F. 739) $\ldots$... $\quad \ldots \quad \ldots$

* The Philatelic Literature Bibliography Index. Being an $\Lambda$ pluabetically Arranged Index, by Author and Subjeet, of Articles and Notes contained in Philaiclie Publications of all kinds in all Languages, from I863 to IgI2...Compiled by William R. Riclsetts..." $\Lambda$ to KOWPROWSKI". LVI. $+360 \mathrm{pp}$. $8 \frac{\mathrm{t}}{2} \times \mathrm{I}$. Forly Fort 1912/19r5 ...

1862/1889: An Index of English Stamp Magazines, by T. M. Wears (P.J.G.B. $9 / 1 \mathrm{r}, 14 / 16) \quad \ldots, \ldots$

1898: Articles in the Press during, eompiled by G. B.

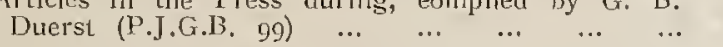

1901 : Index to the Press in (P.J.I. VI. 4) $\ldots$... $\quad \ldots \quad 1 /-$

1903/1904: Index of the Press for (S.C.A. 1905) ... ... $2 / 8$

1906: Literary Index, compiled by P. C. Bishop (S.C.A.

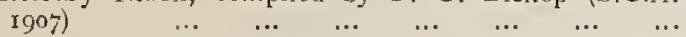

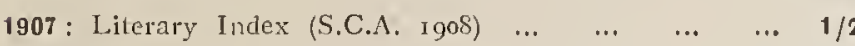

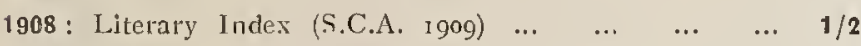

1909 : Literary Index, compiled by P. C. Bishop (S.C.A. 1910) $\quad \ldots \quad$...

1910 : Literary Index, compiled by P. C. Bishop (S.C.A.

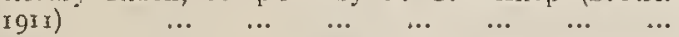

1910/1911 : Literary Index, compiled by D. B. Armstrong

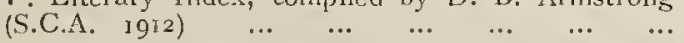

1911/1912: Literary Index, compiled by D. B. Armstrong

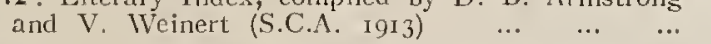

1912/1913 : I.itcrary Index, compiled by D. B. Armstrong

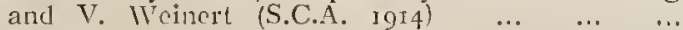

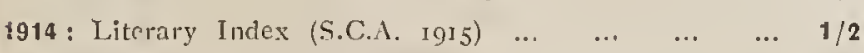

1914/1919 : Literary Index, by P. C. Bishop (S.C.A. 1920) 1/2

1915/1918 : Register of Current Pcriodicals (J.P.L.S. VIII.

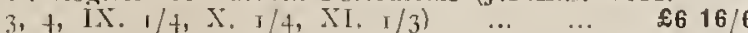

Septembar-December 1916: Literary Index (S.C.Q. 5) ... 1/January-March 1917: Literary Index (S.C.Q. 6) .. $1 /$ -

1917: Annual (IgI7) Edition Collectors' Digest. Reriew-Index-Directory, Published by Index Service Company...23 pp. $\$ \frac{1}{2} \times 10_{\frac{8}{1}}^{\frac{9}{1}}$. Buffalo, N.Y. 1918

"1918/1919: The Collectors" Digest. rgrg Annua?. Index Service Co...6\% pp. $8 \frac{1}{3} \times 11$, Buffalo, N.Y. $(\ln 21)$
1919: General-Index 1019 aller in den deutschP'ost free sprachigen philatelist. Zeitschriften des Jahres spradigen phitentist. Artikel, Notizen und BemerkunI919 enthaltenen Artikel, Notizen und Bemerkun-
fen ete., zusammengestoll von Max B/och. gen ete, zusammengestrll von Max Bloch.
42 1). $6 \frac{1}{3} \times 10$. Teplitz-ichonau 1 yzo $\ldots$...

*1919/1920 : The Collectors' Digest....1921 Annual. pp. $67 / 74.8 \frac{1}{2} \times 11$. Buflalo, N.Y. I92 I $\ldots . \quad \ldots . \quad \ldots \quad 1 / 1$

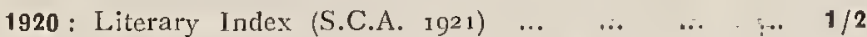

1921: Jhilatelic Press for, compiled by A. H. Pike (C.I), $\begin{array}{lllllllll}\text { IV. 3) } & \ldots & \ldots & \ldots & \ldots & \ldots & \ldots & \ldots & 1 /-\end{array}$

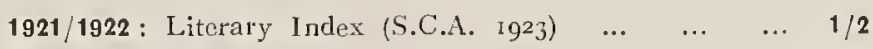

January-Fehruary 1922: By A. H. Pike (C.I). IV. 4) ... 1/-

March 1922: By A. H. Pike (C.D. IV. 5) $\ldots . \quad \ldots \quad 1 /-$

April-May 1922: By A. H. Pike (C.D. IV. 6) $\ldots . \ldots 1 /-$

1923/1924: Literary Index, eompiled by L. A. J. Balsce $\begin{array}{lllllll}\left.\text { (S.C.A. } 19^{2} 5\right) & \ldots & \ldots & \ldots & \ldots & \ldots & \ldots\end{array}$

*Alfred Smilh o Son's Monthly Circular.: Index-Volume to Alfred Smith \& Son's Monthly Cireular 1875/1910. Compiled by B. T. K. Sinith...36 pp.

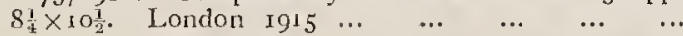

American Joumal of Philately, First Serics, $1868 / 1886$, by E. B. Power (J.P.L..S. I. 4) $\ldots$,.. $\quad \ldots \quad$...

American Stamp Mercury, 1867/1871, by H. E. Weston

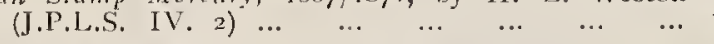

Bazar (Der) 1862/186+. A L.ist of the I'hilatelic References, by 1 . J. Anderson and B. T. K. Snilli (I.T.L.S.S

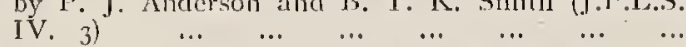

Boston Stamp Book, $1895 / 1898$, by H. E. Weston

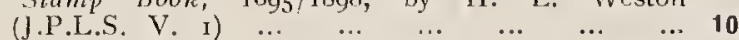

Buenos Aires Postal Annual, $1859 / 1862$, by F. J. Peplow

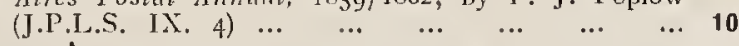

Bulletin de la Société Francaise de Timbrologie, $1875 / 1896$, by B. T. K. Smith (J.P.L.S. II. I, 2) ... £1 1/-

Canadian Philatelist (London, Ontario), $18 \mathrm{gl} / 18 \mathrm{~g} 6$, by H. E. Weston (J.P.L.S. VII. I) $\ldots$. $^{2} \quad \ldots$

Cassell's Illustrated Family Paper, 1862/1867. A List of the Philatelie References, by P. J. Anderson and

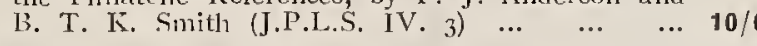

Collectionneur de Timbre-Poste, ${ }_{1} 864 / 1874$ (J.P.L.S. VIII. 1)

Collectors' Magazine, 1915. Complete Index to the Series (P.M. 67)

Continental Philatelic Magazine, $1869 / 1870$, by H. E.

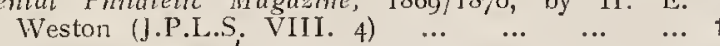

Eastern Philatelist, I887/1902, by H. E. Weston (J.P.L.S.

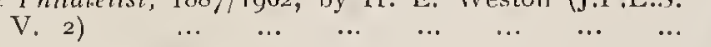

Fiscal Philatelist, $1892 / 1893$ (J.P.L.S. X. 2) $\quad \ldots \quad \ldots 10 / 6$

Gazette des Timbres, $1873 / 1876$, by B. T. K. Smith (J.P.L.S. V. I) $\quad \ldots \quad$... $\quad \ldots \quad$... $10 / 6$

Gibbons' Monthly Circular) see under Stanley Gibbons' Gibbons' Monthly Journal $\}$ Monthly Circular or Journal. Gibbons' Stamp Weekly, 1904/1910 (S.C. 519/521, 546) ... 2/-

Joumal of the Philatelic Literature Socjety. Index to the Plates in Volumes I./VIII., Igos/19i5 (J.P.L.S.

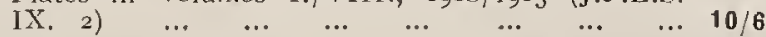

Journal of the Royal Society of Arts, I852/1908, by P. dc

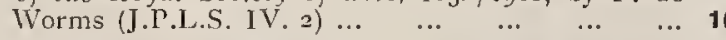

Magasin Pittoresque, $1862 / 1866$. A List of the Philatclic References, by P. J. Anderson and B. T. K. $\begin{array}{lllllll}\text { Smith (J.P.I..S. IV. 3) } \ldots & \ldots & \ldots & \ldots & \ldots & 10 / 6\end{array}$

Mason's Coin and Stainp Collectors' Magazine, 1867/1871,

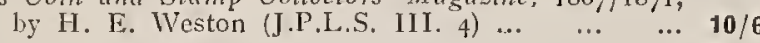
Monthly Joumal, sce under Stanley Gibbons' Monthly Jnl. Morley's Philatelic Journal, Igoo/rgo8 (J.P.L.S. X. 2) ... 10/6

Nederlandsch Tijdschrift voor Postzegclkunde, $188_{4} / \mathrm{rgng}$, by H. E. Weston (J.P.I..S. III. 2) ... $\quad . . \quad \ldots$

19

2

.

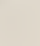


Post free

Neze South Wales Stamp Collertors' Magazine (A.S.J.

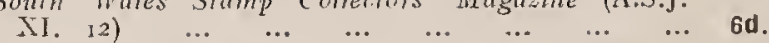

New York Stamp, $1892 / 1895$, by II. E. Weston (J.P.L.S.

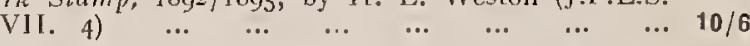

Noles and Quevies, Postage Stamps in the English (1849/1910) and French (186//1910), by P. J.

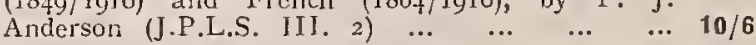

Philatelical Journal, $1872 / 1875$ (J.P.I..S. IX. I) $\quad \ldots \quad \ldots 10 / 6$

l'hilatelic Monthly (and World), i875/1901, hy V. Suppantschitsch (J.P.L.S. IV. 2) $\quad \ldots \quad \ldots y^{\prime} \quad \ldots \quad 10 / 6$

Philatelic Record, Volumes I./XVII., $1879 / 1895$ (J.P.L.S.

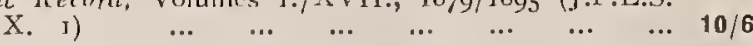

Philatelic Quarterly and Miscellaneous Advertiser, $1877 / 1879$, by B. T. I. Smith (J.P.L.S. 1I. 4) .. 10/6

Philalelic World (Calcutta), I894/1896, by H. E. Weston

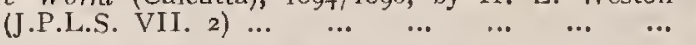

Plitatelist, $1866 / 188 \mathrm{r}$, Index compiled by P. C. Bishop

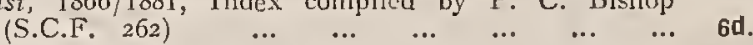

By B. T. K. Smith (J.P.L.S. II. 4) $\quad \ldots \quad \ldots \quad \ldots \quad$ (... $10 / 6$

Posta Mondaile (Leghorn), $1873 / 1874$, by H. E. Weston (J.P.L.S. VI. 3) $\ldots \begin{array}{cccccc}\ldots & \ldots & \ldots & \ldots & \ldots & 10 / 6\end{array}$

Questionneur Timbrophitique, $\mathrm{I} 892 / 1895$, by B. T. K. Smith (J P.I.S. V. T)

Record of the Philatelic Students Fellozeship, ino8/1911

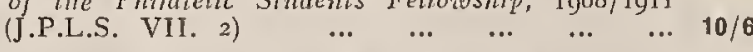

Revure Philatélique Srisse, 1891/1892, by H. E. Weston

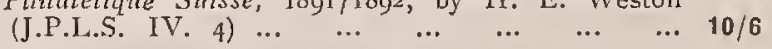

Rocky Monntain Stamp, r895/1898, by H. E. Weston

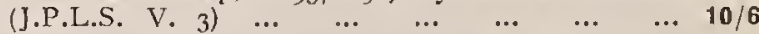

Schweiner Illustrirte Briefmarken-Zeitung, $1879 / 1887$, by H. E. Westun (J.P.T.S. III. 3) $\ldots$... ... $10 / 6$
Stamp Advertiser and Auclion Record, 1889/1890

Slamp Collectors' Houthly Gasette (St. Jo Brunswick) $1865 / 1867$ (J.P.L.S. VI. 4)

Stamp Colleciors Annual, Volumes I./IX., (S.C.A. 1913 , p. 188) ,.. … ‥

Stamp Collectors' Annual for $188 \mathrm{r}$, by B. I (J.P.L.S. II. 4) $\quad \ldots \quad$... $\quad \ldots \quad \quad \ldots$

Slamp Collectors' Figaro (Chicago, rtc.), (J.P.L.S. VIIJ, 3)

Slamp Collectors' Journal. (Bury St. Eslmunds), (.I.P.I.S. IX, 2) …

Stamp Collectors' Magasine, $1863 / 1874$, Index by W. A. R. Jex-Long (S.C.F. 261)

By B. T. K. Smith (J.P.L.S. II. 3, 4) ...

Stamp News, 1882/1895 (J.P.L.S. IX. 3)

Stamps (Rushden), I897/igo2, hy H. E. Westor VI. 2)

Stanley Gibbons' Monthly Circular, 1919/I923. Index to Numbers $1 / 48$ (M.C. 48 ) ...

Index to Numbers $1 / 49$ (S.C. 595)

Stanley Gibbons' Monthly Journal, Volumes I $890 / 1914$ (S.C. $518,519,546,595$ ) ...

Timbrophile, $1864 / 187 \mathrm{r}$, by B. T. K. Smith V. I) $\quad \ldots \quad$... $\quad \ldots \quad$...

Timbrophile Athenien, $1897 / 1899$, by H. I (J.P.L.S. IV. J) -

Times. Philatelic References in the, 1835 B. T. K. Smith (J.P.L.S. IV. I) ‥

F. Trifet's Monthly Circular, 1874/188I, Weston (J.P.L.S. IV. 3) … …

The COPYRIGHT of the whole of the contents of the Standard Index is st served, but publishers of handbooks desiring to include relevant portions $m$ : subject to written permission being first obtained from, and full acknow being given to, the Publishers. 




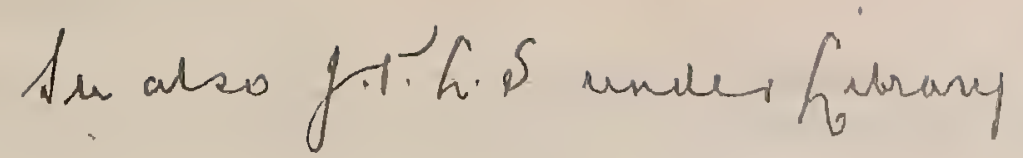

\section{APPENDIX B.}

\section{THE PRINCIPAL SOURCES OF INFORMATION FOR PHILATELIC LITERATURE COLLECTORS.}

(This list was originally published in the "Journal of the Philatelic Literature Society" of January and April, 1908, but has since been revised and augmented.)

\section{I.-SEPARATE WORKS AND ARTICTES.}

Aldrich (e. R.)-See American Philatelic Assoctation.

American Phitatelic Association-Annual reports of the committee on philatelic literature. In The American Philatelist and Year Boole of the American Philatelio Association, Vols. xIII.-XxII. 1899-1908.

$8^{\circ} .10 \mathrm{in}$.

** A good deal of information is contained in these reports about new publications, especially of journals and works issued in the United States and Canada. The second report, that of 1900, was republished in separate form, and this report contains a valuable list of the philatelic periodicals of Switzerland compiled by William Chenevard, of Geneva. The list has the titles arranged alphabetically and the names of the publishers, place, date and numbers issued are given in each instance. The report of 1903 contains a "Bibliography of Scandinavian Papers". This list, which was compiled by Dr. Otto Rommel, first appeared in Nordisk Filatelistisk Tidskrift for February, 1903, and was afterwards reproduced in condensed form by $\mathrm{E}$. R. Aldrich in the number of The Philatelic World, Minneapolis, Minn., for April 15, 1903, of note to the report in The American Philatelist states that the list as there presented, "has been quite fully revised and corrected". The list is dirided under the headings: "Denmark - NorwaySweden - Finland," the titles of the journals are in each instance arranged chronologically, and particulars are given in each case of the name of the publisher and the place, the date and the number of parts issued.

Anderson (P. J.) - Notes on early English philatelic literature. In The Phitatelic Record, London, Vol. vII., Nos. 76, 77, 7. 79, 80, May, June, August, Septomber, 1885; Vol. vIII.,

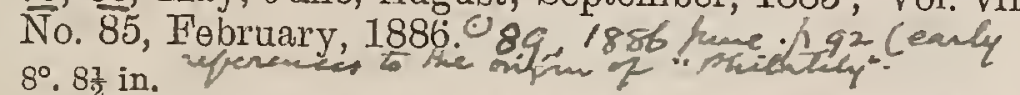
*. $8 \frac{1}{2}$ in.

* * These papers trace out the history of the commencement of English philatelic notices and literature, and are further particuarly valuable as they contain an account of stamp articles in the English non-philatelic magazines of 1860-1864, in addition to a description of the purely philatelic works published during those
years.

Bibliography of philately. In Notes and Queries, London. Eighth series, No. 167, March 9, 1895.

$4^{\circ} .8 \frac{1}{2}$ in.

** A carefully compiled and useful list of works and articles in philatelic journals dealing with philatelic bibliography to the end of 1894 .

- Stamp collecting and its literature forty years ago. In Notes and Queries, London. Ninth series. No. 240, August 2, 1902

$4^{\circ} .8 \frac{1}{2}$ in.

** This and the follorving article may be considered as supplementary papers to those by the same author in The Philatelic Record of 1885 and 1886. Like the earlier articles, these two are of an equally interesting description.
ANDERSON (P. J.) - Stamp collecting and its literature. In Notes and Queries, London. Tenth series. No. 17, April 23, 1904.

$4^{\circ} .8 \frac{1}{2}$ in.
$* *$ A reprint of this was published in The London Philatelist for May, 1904 .

Applaby (R. H.) and Clark (H.)-List of philatelic literature (2) published up to the end of 1902. In The City Philatelist, Cork, Treland, Nos. 3-6, January, May, October, December, 1903.

$8^{\circ} .7 \frac{1}{4}$ in.

* * The above consists of a list of the journals of Great Britain only, and in No. 3 the latter part of the title reads: "to the end of 1901 ". The list gives the title, publisher and address, volume and numbers issued of each journal. The arrangement of the titles is alphabetical, but subject to a chronological order under each letter of the alphabet.

[ATLEe (w. D.)]-English and continental philatelic literature. In The Stamp Collector's Monthly Gazette, St. John, New Brunswick, Vol. II., No. 24 and supplement, May, June, 1867.

$8^{\circ} .9$ in.

** The title of the article in the supplement reads: "English and Foreign Philatelic Literature". The list in the May number

(3) was republished in The Philatelist, London and Brighton, Vol. I., h-118 y20 No. 8, July 1, 1867, under the title "English Philatelic Literature," and the list in the June supplement was embodied by the October 1, November 1, 1867, referred to below. Nos. 11 and 12,

6 English philatelic publications. In The Philatelist, London and Brighton, Vol. I., No. 11, October 1, 1867. $8^{\circ} .8 \frac{1}{2}$ in. $\& / 70-17 /$

** The list is divided into five sections: " Miscellaneous Manuals "Price Catalogues-Albums-Album Tiules-Music," and Was published as a continuation of the article on English philatelic periodicals which appeared in the July number of the same journal.

Continental philatelic publications. In The Philatelist, London and Brighton, Vol. I., No. 12, November 1 , 1867. $8^{\circ} .8 \frac{1}{2} \mathrm{in}$.

** The list contains three sections: "France-Germany--Italy," the two first being subdivided in to "Periodicals-ManualsAlbums-Price Catalogues-Photographs-Music," there being only one entry, that of a manual, under Italy. 
- Atree (w. D.)-Philatelic literature. In The Philatelist, London and Brighton, Vol. IIr., Nos. 9, 11, September 1, November 1, 1869. $2 \%$.124

$8^{3} \cdot 8 \frac{1}{2}$ in.

** These articles contain addenda to the lists published in Vol I. of The Philatelist, and the same arrangement of the journals,
etc., is adhered to.

Philatelic literature in Spain. In The Philatelist, London and Brighton, Vol. v., Nos. 56, 57, July 1 , August 1, 1871 . / $9 /-94, / 12$

$8^{\circ} .8 \frac{1}{2}$ in.

* * A review of the philatelic publications of Spain, including those of a semi-philatelic character and notices of stainp articles in non-philatelic journals.

(3)

- Philatelic literature. In The Philatelist, London and Brighton, Vol. vi., No. 1, January 1, 1872 . $10-14$

$8^{\circ} .8 \frac{1}{2}$ in.

** This article contains a review of philatelic literature and a further addenda to the lists published in Vols. I. and III. of The Philatelist.

- Australian Philatelic Journals. In The Australian Journal of Philately, Sydney. Vol. v., Nos. 1, 5, 8, October 17, 1894, February 16, May 16, 1905./2

$8^{\circ} .9 \mathrm{in}$. Zealand.

- $\mathrm{B}[\mathrm{AGG}]$ (L. H.)-American philatelic literature. In The Philatelist, London and Brighton, Vol. I., No. 6, May 1, 1867. ph 90-92

$8^{\circ} .8 \frac{1}{2}$ in.

** The list contains the journals of the United States and Canada arranged in chronological order under their titles, and these are was compiled by Lymann H. Bagg, of Springfield, Mass.

Bosredon (P. DE)-Bibliographie Timbrologique de la France et de la Belgique. Bruxelles, J. B. Moens, 1878.

$8^{\circ} \cdot 8 \frac{1}{2}$ in. xii. $+74 \mathrm{pp}$. Coloured paper wrapper.

* * This work was reprinted from the Bulletin de la Société Francaise de Timbrologie, Nos. 4-10, July, 1876-January, 1878, and forms the second volume of the Bibliotheque Timbrologique of the Sociéte. The publications of each country are kept separate, and these two divisions are subdivided under eight headings: "I. Catalogues. II, Publications spéciales. III. Journaux speciaux. IV. Albums. V. Articles insérés dans divers ouvrages ou dans divers journaux. VI. Prix Courants, Annonces, Prospectus. VII. Dessins, Caricatures, Vignettes, Photographies. VIII. Morceaux de musique"; and in addition for France: "IX. Documents divers. X. Documents législatifs et Réglementaires." Although published in 1878 this is still a very useful work of reference for the collector who wants information upon the early literature of France and Belgium.

- Boston Phimatelio Societry, Boston, MassachusettsCatalogue of books of philately in the Public Library of the city of Boston.

Boston, Mass., Derby, Conn. [printed], r go3. $8^{\circ} .9 \frac{1}{4}$ in. $31 \mathrm{pp} .+(1) \mathrm{p}$. Coloured paper wrapper.

* * The arrangement is alphabetical, the monographs and catalogues being given under the names of the authors and the journals coming in under the first word of each title, without, as usual, taking account of the article "The" etc., when present. The list is somewhat marred by the fact that it contains no cross references, and no details whatever, not even the date, are given of some of the journals listed.

- Butrer (A.) - English and foreign philatelic literature: A prize essay. In. The Philatelist, London and Brighton, Vol. Iv., No. 10, October 1, 1870 . p. Tas 117

$8^{\circ} \cdot 8 \frac{1}{2}$ in.

** This essay contains a review of the earliest philatelic journals Chenguard (w.) - See American Philatelic Association.

Clark (H.)-See Applebiy (R. H.)

$\Rightarrow$ Deats (H. E.)-Current philatelic magazines.

Flemington, N. J., [1894].

$8^{\circ} .8 \frac{1}{2}$ in. (16) pp. Printed on one side of the paper only.

* * Reprinted from The American Philatelist, Vol. virI., Decem. ber 1, 1894. The list is divided under the heads : "American Philatelic Papers-English Papers-British Colonial-Papers in the French Language-Papers in the German language-Papers in the Spanish Language-Miscellaneous".
EvereTt (H. A.)-Philatelical publications. In The Foreign Stamp Collector's Journal, Bury St. Edmund's, Vol. II., Nos. 17, 18, March, April, 1880.

$8^{\circ} .7 \frac{1}{2}$ in.

** These two articles contain but little information. The last has the words "To be continued " at the end, but no further part appeared.

Figueroa (M. P. DE) under the pseudonym Doctor Thebussem - Literatura philatélica en España. Apuntes para la redaccion de un Catálogo. Sevilla, 1876 . $8^{\circ} .9$ in. xiii. pp. $+(1)$ p. $+32+(2)$ pp. Coloured paper wrapper. * * The work contains an "Ante-scriptum," and has four divisions: - "Seccion primera-Disposiciones legales-Seccion segundaArticulos, Periódicos, Folletos, etc. Seccion tercera-Catálogos y Anuncios-Seccion cuarta-Curiosidades." The contents of the second section are grouped under the years of issue from 1867 to 1876.

Under the pseudonym Doctor Thebussem-Los periódicos filatélicos de España. In Madrid Filatélico, Vol. v., No. 58, October, 1901.

$4^{\circ} \cdot 11 \frac{1}{2}$ in

** The list gives the philatelic journals of Spain under their titles, arranged in chronological order, followed by a chronological

Fontaine (ABeL)-La Prensa Filatélica y Cartófila en la República Argentina. In El Coleccionista, Rosario de Santa Fé, Vol. I., Nos. 2-5, May, June, September, December, 1904.

$8^{\circ} .10 \frac{3}{4}$ in

** This list of the philatelic journals of the Argentine Republic is arranged in chronological order, but is only completed to January, 1897. An earlier and similar list by the same author was published in L'Annonce Timbrologique, Liége, Belgium, Vol. v.,
No. 48, February, 1894.

Catalogue des Journaux Philatéliques et cartophiles publiés dans la République Argentine de 1874 à 1908. In The Journal of the Philatelic Literature Society, London, Vol. I., No 4, Vol. II., No. 1, October, 1908, January, 1909.

$4^{\circ}$. 113 in. Republic.

Fraenkel (н.)_Chronologische Tabelle der deutschen philatelistischen Zeitschriften, 1863-1893. Berlin, 1894.

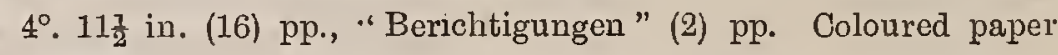

Wrapper: and place, dates of the first and last numbers, number of volumes, and total number of parts issued, etc. of each journal. The list also includes journals published in the German language outside Germany.

Gotrschark (a.)-Die Deutsche philatelistische Litteratur, 1894-97. In "Festschrift zur Feier des zehnjährigen Bestehens des Berliner Philatelisten-Club".

Berlin, 1898.

$8^{\circ} \cdot 11$ in. pp. $100-118$

** This is a review of German philatelic literature for the years named, with a chronological list of the journals which made their first appearance during that period, and tables of the more imyears.

GRAY (DR. J. E.) - A Hand catalogue of postage stamps for the use of collectors.

$8^{\circ} .6 \frac{1}{2}$ in. pp. xv.-xvi.

London, Robert Hardwicke, I862.

** This work contains a list of manuals, catalugues and albums and also articles in non-philatelic magazines.

On Postage stamp catalogues. In The Stamp Collector's Magazine, London and Bath, Vol. I., No. 3, April 1, 1863.

$4^{\circ}$ * 81 in. This is a review of the earliest catalogues with notices of ** This is a review of the earliest catal
stamp articles in non-philatelic magazines. 
Enens weekly Stamen rews.

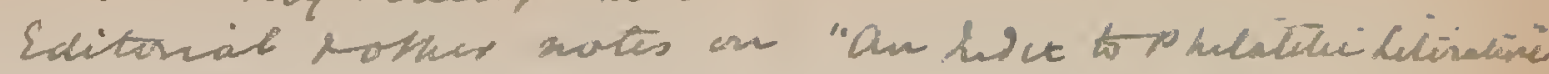

- 1904. func 25 - ang.6 $111.205248(334)-254(340)$. Fin

(c)

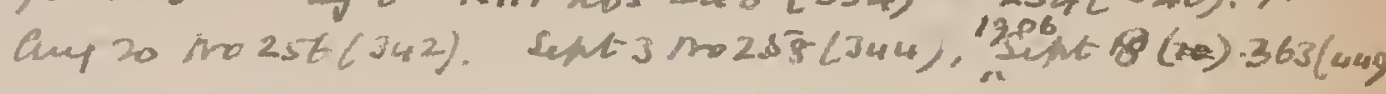
$1 / 4 \cdot \times 11.729 .733 .738 .742 .746 .754 .762 .770,1197$.

Iredrechis Shani. 1894 IIST. Las a hit of Shanish

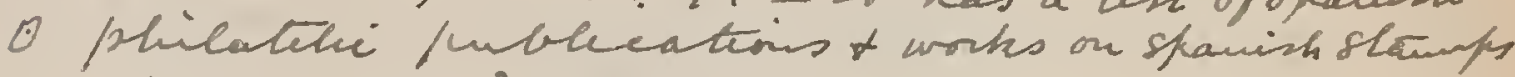
(have a tyren expy)

Deals (H.E.) Philateru Papen wauted ly,

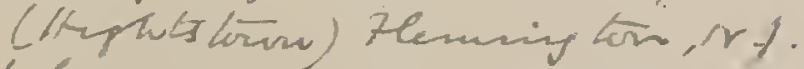

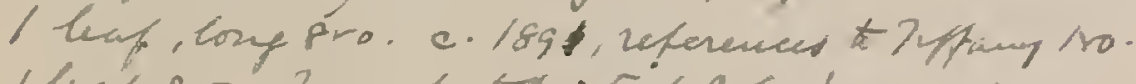

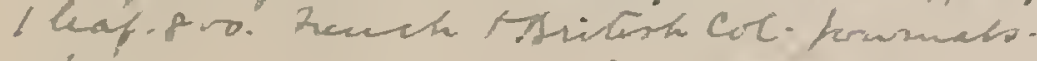

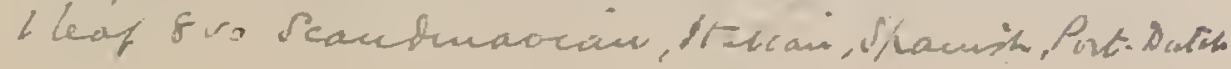

fubous f Emank wately.

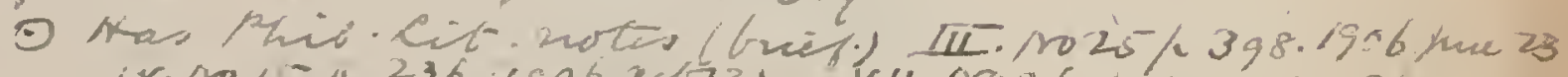

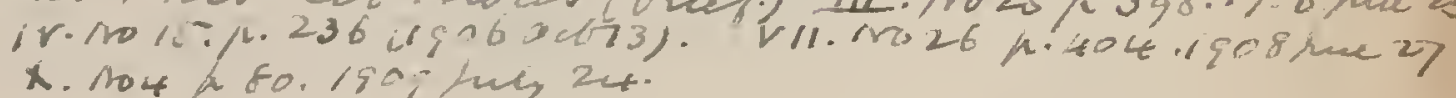




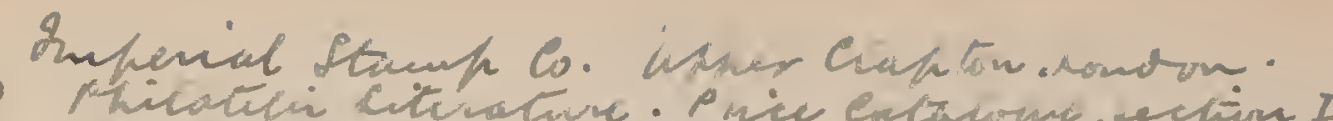

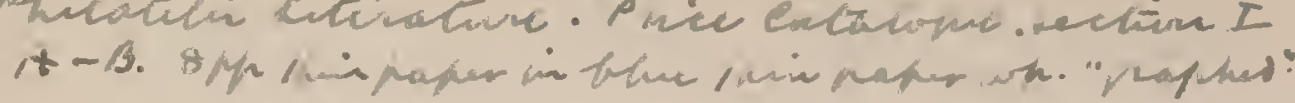

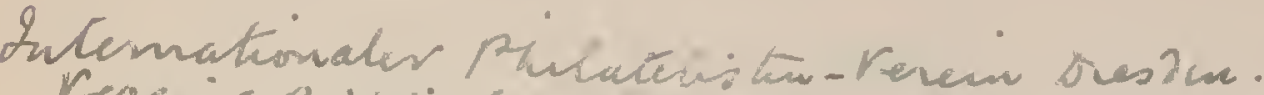

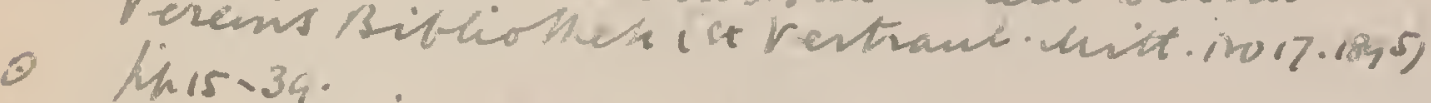

3 Cator soition sigo2. M, - 40
* See Gids voor Philatelistische Literatuur van Nederland en Kolonien, door M. J. van Heerdt Kolfe pp. $43 / 47 \cdot 7 \frac{1}{2} \times 10 \frac{1}{2}$. Rotterdam 193

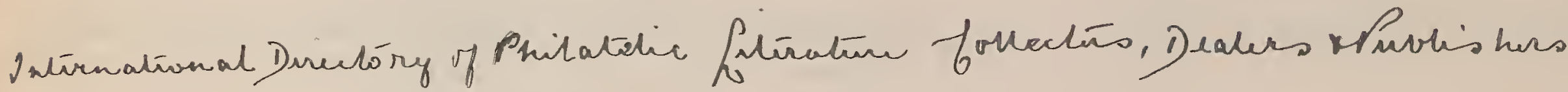

sonom Phlaticust.

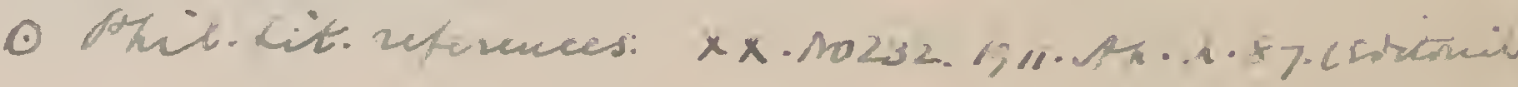


H. (w.) - A Review of our postal literature. In The Stamp Collectors' Review and Monthly Advertiser, Liverpool, Vol. I., No. 3, February 15, 1863.

$8^{\circ} .81$ in.

*** This review gives an account of some of the earliest English philatelic publications and stamp articles in non-philatelic magazines.

JAQUier (J.)-La Presse philatélique suisse. In Schweizer Briefmarken-Zeitung, Lausanne. Vol. xIv., No. 7, July, 1901.

$4^{\circ} .10 \frac{1}{2}$ in.

* The list is arranged in chronological order and contains much valuable information.

Q Johnson (G.)-Stamp Auction catalogues. In The Stamp Collector, Birmingham, Vol. v., Nos. 54, 56, June, August, 1901.

$8^{\circ} .9 \frac{1}{2}$ in.

"* These articles give useful lists of the stamp auction catalogues

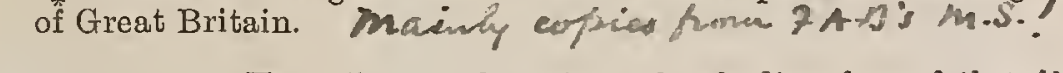

Jones (Е. B.) - The Comprehensive check list for philatelic literature collectors, being a numbered, alphabetically arranged catalogue of nearly 600 United States and Canada philatelic papers and magazines, from 1864 to January, 1895.

Ruthven, Iowa, I 895 .

$8^{\circ} .83$ in. 29 pp. + (1) p. Coloured paper wrapper

* * This and the following lists by the same author are amongst the most uscful works of reference on pliilatelic journals published in English, as they are so compiled that the collector can cross off each individual part as he obtains it, and sees at once exactly what he has and what he has not got. The lists are all arranged on the same principle. i.e. the titles of the journals are grouped under their proper letters of the alphabet, but in each case in chronological order.

- Supplement to the comprehensive check list of philatelic papers and magazines, consisting of two parts. Part one: A list of all known omissions and corrections of all known errors in the original work. Part two: A list of all known United States and Canadian philatelic papers and magazines issued from 1 January, 1895, to 1 January, 1897.

Sioux City, Iowa, r898.

$8^{\circ} .8$ 年 in. 8 pp.

(3rilatelic Literature, Taunton, Mass., Nos. 3-5, June 22, December 25, 1897, and March 21, 1898.

. J Jones' Check list of philatelic journals, British Colonies. A chronological, alphabetically arranged list of all known philatelic periodicals of the British Colonies. From 1864 to 1902 . Giving all numbers issued.

Sioux City, Iowa, I904.

$8^{\circ} .8$ in. $15 \mathrm{pp}$. +(1) p. Coloured paper wrapper.

* * Reprinted from The Philatelic Inter-Ocean, Waterloo, Iowa, Vols. VI.-VIII., November, 1903-January, 1905, with the title changed from "English Colonies" to "British Oolonies".

Jones' Check list of philatelic journals, Great Britain and Colonies. A chronological, alphabetically arranged list of all known philatelic journals of Great Britain and Colonies, from the earliest issued down to the end of the year 1904. Giving name, publisher, place, dates of volumes, with numbers of the issues to each volume. Issued in two parts: the first being the Kingdom of Great Britain, and part two that of the British Colonies.

80. 81 in. 44 pp. Coloured paper wrapper. Sioux City, Iowa, r 907 .

* * The edition was limited to 100 numbered copies. The work consists of the first separately published edition of the author's check list of Great Britain philatelic journals, and the second edition of his check list of the philatelic journals of the British Ocean, Waterloo, Iowa, Vols. viII.-x., January, 1905-February, 1907.

Keystone Stamp Association. A Short review of the philatelic press. In The American Coin and Stamp Review, Allentown, Pa., Nos. 3, 4, July, August, 1871.

$8^{\circ} .8 \frac{3}{3}$ in.

** *The review only gives a list of journals, and these are arranged by their titles under six headings: "American, British, BritishAmerican, French, German, Danish".
KŏNIG (r.) Ueber Philatelistische Literatur (mit Vorlagen). In "Stenographischer Bericht ïber den XvII. Deutschen Philatelistentag und den Ix. Bundestag des Bundes Deutscher und Oesterreichischer Philatelisten-Vereine in Regensburg vom 21-24 Juli 1905". Regensburg, r go5. $8^{\circ} .9$ in. pp. 36-57.

** This Report was presented as a supplement to the number of Vertrauliches Korrespondenz-Blatt philatelistischer Vereine for November, 1905. The article of Herr König was reprinted in Der Philatelist, Dresden, Vol. XXVI., November 1905, and also in the Deutsche Briefmarken-Zeitung, Leipzig, Vol. xvi. November and December, 1905. The article gives an excellent review of philatelic literature describing the various works published on colours, essays, reprints, forgeries, watermarks, fiscal and local stamps; an account of the early handbooks and catalogues, and works on postcards and monographs on stamp issuing countries.

Krasemann (R.) - Bibliographie der wichtigsten. Spezial(-) werke über die Postwertzeichen einzelner Länder. Stockholm, Sveriges Filatelist-Förening, 1907. $8^{\circ} .7 \frac{1}{4}$ in. 45 pp. + (1) p. Coloured paper wrapper.

** The catalogue is interleaved with plain paper, and was reprinted from the numbers of the Svensk Filatelistisk Tidskrift for March-September, 1907. It is a very useful work, especially for philatelic students and writers.

Zweiter, durchgesehener und stark verbesserter (.) Abdruck. Sonderdruck aus " Der Deutsche Philatelist" 1908. Dieser Sonderdruck, von dem nur 100 Exemplare ausschliesslich für den Bedarf des Verfassers hergestellt sind, ist nicht käuflich zu erwerben. Hannover, 1908. $8^{\circ} .10$ in. iv. +40 pp. Paper wrapper.

** This edition contains a few additional items and the names of the publishers of the various works have been added.

Legrand (DR. J. A.)-Catalogue de Littérature Philatélique. Section A. Catalognes des timbres-poste. In La Circulaire Philatélique. Paris, Nos. 58-76, May, 1907-F'ebruary, 1909.

$S^{\circ} .81$ in.

** The works are arranged under the name of the author, or under that of the publisher when no author's name appears, in alphabetical order without regard to the language or country of origin. This is incontestably the simplest and best metbod for reference purposes, but the usefulness of the catalogue is impaired by its being broken up into no less than five divisions, under the headings : " Premiêre Période (1861-1900.)-Supplément Omisheadings: "Premiêre Période (1861-1900.)-Supplément Omis(1861-1900)-Supplément et Omissions (1901-1908)."

See Trfanany (J. K.) Etudes de Bibliographie Timbrologique.

Leont (Giuseppe)-Bibliografia timbrologica dell' Italia. In (-) Guida Illustrata del Timbrofilo, Anno II., Nos. 16, 17, October, November, 1877.

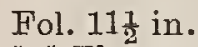

"* These notes are divided under six headings:-“" A. Ca'aloghi. B." Giornali Speciali. C. Articoli inseriti in altri giornali. D. Albums. E. Prezzi-correnti, Annunzi e Pubblicazioni diverse. F. Curiosità."

Lund (CARL) - Udenlandsk Frimaerkelitteratur. In Nordisk Frimaerketidende, Copenhagen, Nos. 5.12, December 20, 1867-June $30,1868$.

$8^{\circ} .81$ in. in " "The list is divided into four divisions:-" "Tidender" "(journals) (sundries), and the three first are further subdivided under Eng(sundries), and the three
lish, French, German, etc.

Marsh (v.) - The International directory of philatelic litera$\odot$ ture collector's, dealers, and publishers London, S.W., V. Marsh, [r904]. $8^{\circ} .71$ in. (2) +65 pp. + (1) p. Coloured paper wrapper. * * Besides a directory the work contains a number of articles on philatelic literature and its collection.

Mitteumann (н.) - Katalog der existierenden BriefmarkenZeitungen. Mährisch-Ostrau, Julius Kittl, I889.

$16^{\circ} .5_{4}^{3}$ in. $32 \mathrm{pp}$. Coloured paper wrapper.

** The journals are listed by their titles under the name of the country to which they belong. 
Moschisau (DR. ALFRED)-Beiträge zur Markenkunde. In Deutsche Briefmarken-Zeitung, Dresden and Leipzig. Vol. I., No. 12. September 15, 1871.

$4^{\circ} .8 \frac{1}{2}$ in.

* Thisl article deals with the early philatelic literature of Germany, and includes notices of stamp articles in non-philateli magazines.

- Die philatelistische Literatur Deutschlands. In $A$. Moschkau's Magazin für Markensammler, Oybin. Supplement to No. 9, March, 1872.

$8^{\circ} .91$ in.

** The list is divided under the headings: "ZeitschriftenHandbücher-Cataloge mit Preisangaben-Albums-MusikDiverse," and each entry of the several divisions is arrangec chronologically either under the name of the author or as in the case of the journals, etc., under the name of the publisher.

- Die philatelistische Literatur Deutschlands. In Illustrirtes Briefmarken-Journal. Leipzig. Vol. I., No. 5, May 1, 1874.

$8^{\circ} .10 \mathrm{in}$.

* This is a supplemental list to that by the same author in $A$. oschteau's Magazin für Markensammler for March, 1872.

- Deutschlands philatelistische Literatur. In Illustrirtes Briefmarken-Journal. Leipzig. Vol. III. Nos. 30, 33 36, June 1, September 1, December 1, 1876 $8^{\circ} .10$ in.

*** The list is divided into nine divisions: "FachzeitschriftenHandbücher und Specialitäten-Preiscataloge-Adress-BücherMarken-Albums-Musik-Kalender-Photog-An - BicherBilderbogen," and each entry is arranged either under the name of the author or that of the publisher.

- Deutschlands philatelistische Literatur. In "Geschichte der Briefmarken und der Philatelie"

Leipzig, Louis Senf, 1878 .

$8^{\circ} \cdot 7 \frac{1}{2}$ in. pp. 36- 49 .

* * This is a reprint of the author's list in the Illustrirtes Briefmarken-Journal for June.to December, 1876, except for a few alterations and additions.

Rommed (DR. o.)-Die philatelistische Literatur des Jahres, 1894. In Der Philatelist, Dresden. Vol. Xvi., Nos. 202-204, January 15-March 15, 1895.

$8^{\circ} .93$ in.

** The list, which is confined to journals, is arranged under eleven headings, formed of the different languages found among the publications. 6 Repmated eofy / 894 , If 1895.

- Zeitungs-Chronik. In Der Philatelist, Dresden. Vols. xIx., etc., Nos. 239, etc., February 15, 1898, etc. $8^{\circ} .99$ in. In progress.

** These articles, which have been running continuously since February, 1898, are amongst the most valuable and useful presentday sources of information for collectors. The article in the number of August 15, 1898, consists of a "Catalog der Schweizer philatelistischen Zeitungen". The January, 1902, number contains a list of the philatelic journals of Spain translated from the Madrid Filatelico of October, 1901, and the number for February, 1902, a list of the philatelic journals of Holland.

-_- Den filatelistiske Tidsskrift-Literatur i Norden. In Nordisk Filatelistisk Tidskrift, Lund. Vol. x., No. 2, February, 1903 .

$8^{\circ} .10 \mathrm{in}$.

** For particulars of this, see note to American Philatelic Association.

- Die philatelistische Zeitungslitteratur der Welt in den Jahren, 1901-1903. In Der Philatelist, Dresden. Vol. xxv., Nos. 312-321, March 15-December 15, 1904. $8^{\circ} .9 \frac{3}{4}$ in.

* The journals in this useful list are divided according to language and then further sub-divided under the name of the country in which they were issued. Only Great Britain and British North American journals are given of those published in English.

Scomt (J. w.)-Philatelic literature of England and America. In The American Journal of Philately, New York. Vol. IV., Nos. 10, 11, October 20, November 20, 1871. $8^{\circ} .8 \frac{1}{4}$ in.

* * The list is confined to journals, and these are divided in a most unusual form, under the name of the town in which they were published, and then arranged by the titles in chronological order.
SupPantschitson (v.)-Die philatelistischen Zeitungen der Vereinigten Staaten von Nordamerika. In Die Postwertzeichen-Kunde. München. Vol. II., Nos. 5-7, May-July, 1891.

$8^{\circ} .10 \frac{1}{4}$ in.

* * These articles consist of an introduction and an alphabetically arranged list of the philatelic journals.

Bibliographie zugleich Nachschlagebuch der gesammten deutschen philatelistischen Literatur seit, ihrem Entstehen bis Ende 1891 nebst einem Abriss der Geschichte der Philatelie mit besonderer Berücksichtigung Deutschland's und einer kurzen Geschichte der deutschen philatelistischen Literatur. . .

$8^{\circ} .9$ in. $748+(4) \mathrm{pp}$.

Mïnchen, A. Lavisch, I892[-94]. * Published in sixteen parts with coloured paper wrappers. The title-page gives a complete summary of this comprehensive and valuable work by an author who has done as much as any one to assist in furthering the study and collection of philatelic litcrature. A supplement, consisting of an index of all the articles and notices in German philatelic journals on postal history and matters con nected with the post office, was published in Die Postwertzeichen Kunde, München, Vol. vIIr., Nos. 1-12, January-December, 1897. The title of this supplement is "Errgänzung der Bibliographie zugleich Nachschlagebuch der gesamten deutschen philatelistischen Literatur seit ihrem Entstehen bis Ende 1891. München, 1892-1893. Verlag von A. Larisch."

Versuch einer Bibliographie der fremdsprachigen philatelistischen Zeitungs-literatur Europa's bis Ende 1891. In Die Postwertzeichen-Kunde. München. Vol. IV., Nos. 2-12, February-December, 1893.

$8^{\circ} .10 \frac{1}{1}$ in

** This useful list of journals is divided under the headings Italian, Roumanian, Dutch, Danish and Norwegian, Swedish, Greek, Spanish, Portuguese, French and English.

Zur Geschichte und Statistik der philatelistischen Zeitungs-Literatur der Erde bis Ende 1893. In Die Postwertzeichen-Kunde. München. Vol. vi., Nos. 2-6, February-June, 1895.

$8^{\circ} .10 \frac{1}{4}$ in.

** This series of articles contains some interesting information on early notices of stamp-collecting in non-philatelic magazines, an account of the earliest published philatelic journals, with lists giving the name of the first journal published in each country; journals of which 50-100 and over 100 numbers have been published; those of the largest and smallest sizes and an alphabetical list of places throughout the world with the number of philatelic journals published in each.

- Katalog der philatelistischen Bibliothek des Oberlandesgerichtsrathes Victor Suppantschitsch in Graz bis Ende 1893.

$8^{\circ} .10 \frac{1}{2}$ in. $34 \mathrm{pp}$. '
** $^{*}$ Reprinted from the Austria-Philatelist, Prag. Vols. II.-IV.

[Graz, I897.] January 1, 1895-July 1, 1897.1 This catalogue of the author's very fine library is useful in many ways for reference purposes.

Die Entstehung und Entwicklung der Philatelistischen Literatur in der zweiten Hälfte des XIx. Jahrhunderts. ... Wien, rgor.

$8^{\circ} .9$ in. 63 pp. + (1) p. Coloured paper wrapper.

* The edition was limited to one hundred and fifty numbered copies. The work gives an excellent review of the philatelic literature of the world for four decades, the sections being: "1861 bis $1870-1870$ bis $1880-1880$ bis $1890-1890$ bis $1900 "$

Eie Seltenheiten der philatelistischen Zeitungsliteratur bis Ende 1900. . . Wien, [1904]. $8^{\circ} .9 \frac{1}{2}$ in. $12 \mathrm{pp}$.

**" Reprinted from Der Philatelist, Dresden. Vols. $\mathrm{x} \times 1 \nabla ., \mathrm{x} \times \nabla$. June, 1903-February, 1904. A very interesting review of the comparative rarity of philatelic journals grouped under the languages : German-French-Italian-Spanish-PortugueseDutch-Scandinavian-English. The journals of Great Britain and of the United States are, however, not included in the "English" group.

Ueber Unregelmässigkeiten bei Herausgabe, sowie über Irrungen und Verstösse in der Nummerirung, Datirung und Paginirung der philatelistischen Zeitungslitera. tur bis Ende 1900. In Der Philatelist, Dresden. Vols. xxvi.-xxix., Nos. 325-362, April 15, 1905-May 15, 1908. $8^{\circ} .9 \frac{3}{z}$ in

** The title fully describes these interesting and useful articles. 
o funt Pricid Catalovie of he steped Sunth

$\therefore$ Phiativi cinary. Paits I - vil completed.

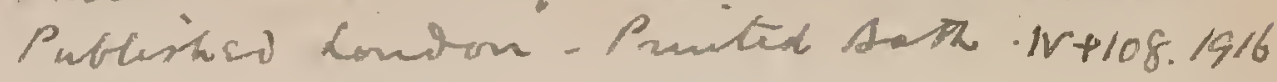

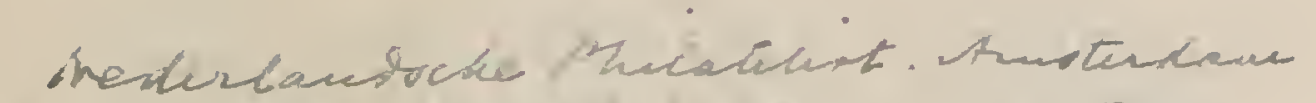

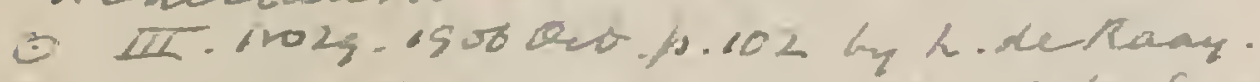

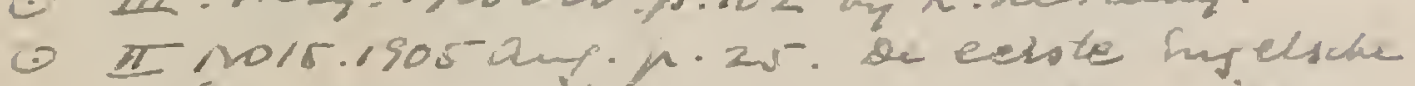

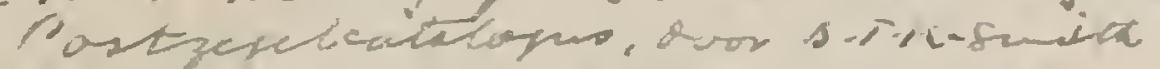
chans. Form the Maintelex Rarn.

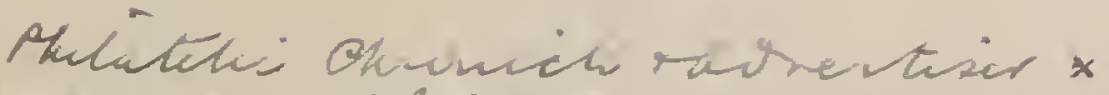

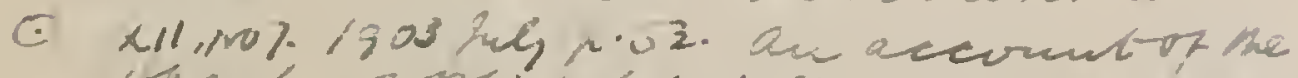

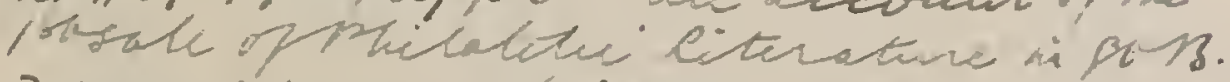

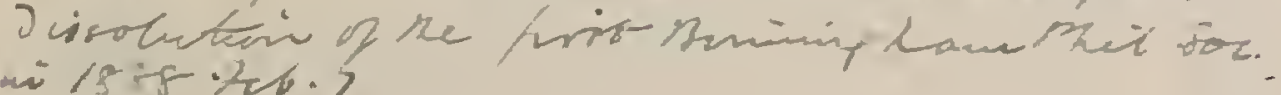

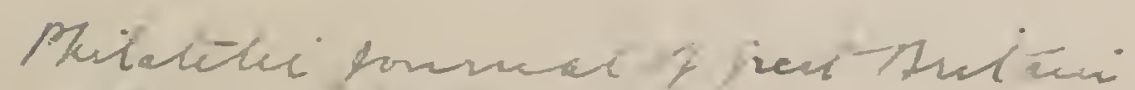

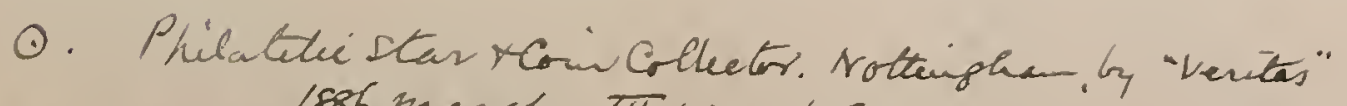
1886 masch. III rio $2 \cdot 6 \cdot 20-21$

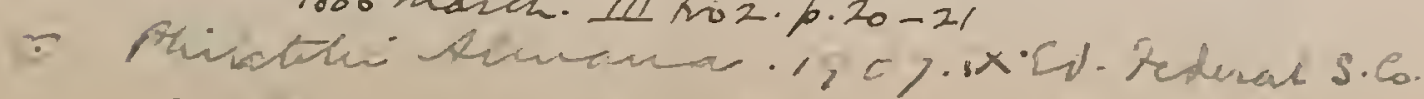

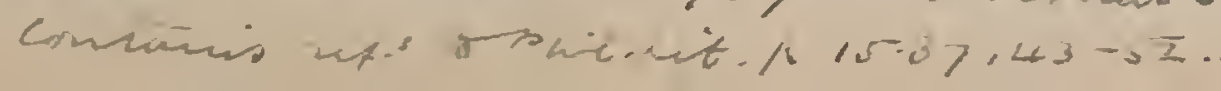

Postape stante. Philatelé hos.

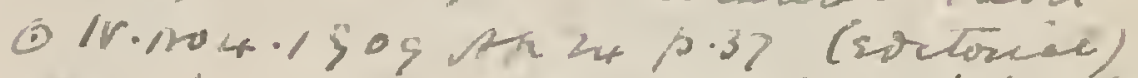

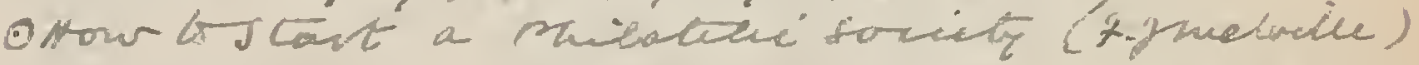
(fuvics a lesit of Dootes). B100-102,136-13\&

Pedfuldis stang weetely. Contains Phil-bit. columus.

0 I. $1020.19070 \mathrm{dt} 31 / 21$. bysig.Power (1) - -26 dec $14 \%$ p. 4 (2)

Orll 10.1910 any 20.2.2. Report of the phit. Lit. Cirmmittie

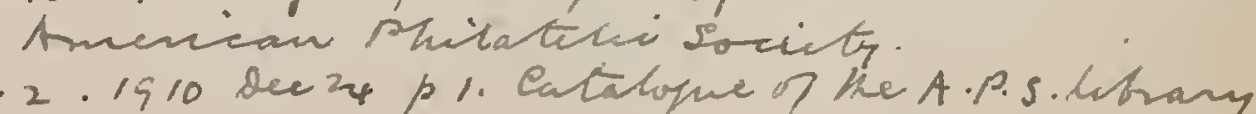

orill. $2.1910 \operatorname{dec} 24$ p 1. Eatalopue of he A.P.S.lutrany

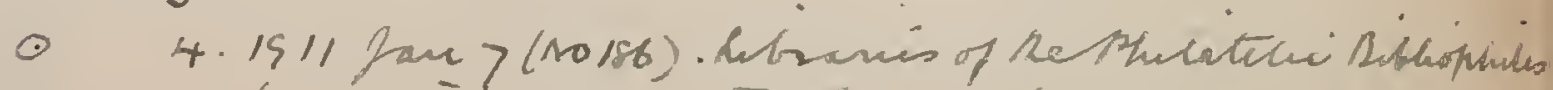
(ufinitad from thes tark Lover, H.Chark). 


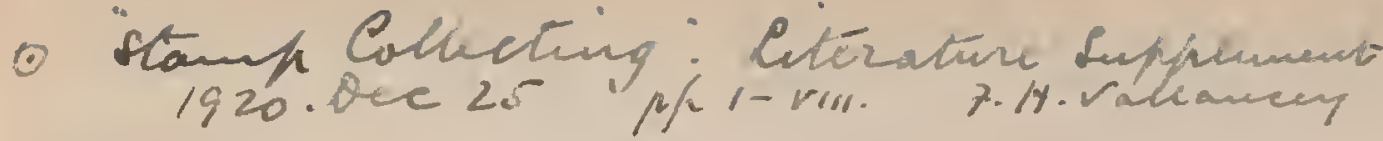

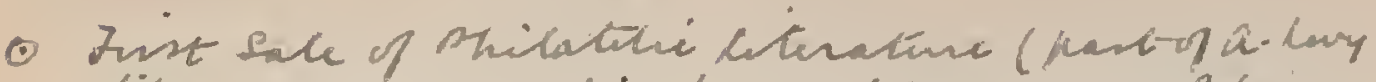

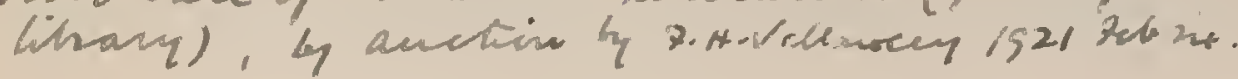

Stang Collectoss' format. Sumn. Philatelical itierative op hreactsitain durving 1884 . Cy T.M. Weass.

D vil. moso.tis7. 1885-qumeis.

Schmerz. Philatehitan - Vereni, tanis. dist of hapers ouplicate (H. Burkhantz)

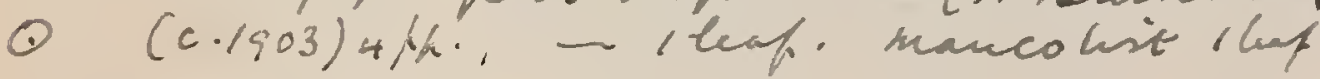

Stank Colectors Donturintly.

How to compile Natalopuc a Phelatevi ditrary, H.D.Roterts.

(1) 1905 hime 3. p57 \& May 20 p. kq

(1) Ast trinil. Lit. 1897 may/ 1.173

Wins. Bibliskccasis der Perecniging. Rotheitam catacopus. $1906 \cdot 1-x+(3) \cdot 820$.

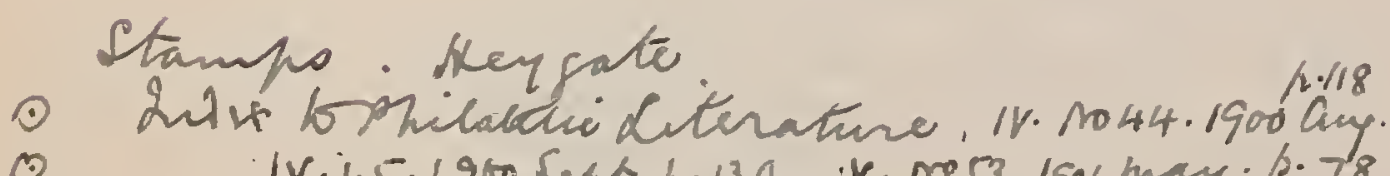

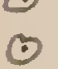

$$
\begin{aligned}
& \text { iv. } 45.1900 \text { Sept.1.13 g. v. no } 53.1501 \text { may. } 1.78 \\
& \text { r. } 54.1901 \text { gme p. } 81 \text { (sDitonil). }
\end{aligned}
$$


Suppantschitsch (v.) - Die philatelistische Literatur Oesterreich-Ungarns im XIx. Jahrhundert. In Der Philatelist, Dresden. Vol. xxxx., Nos. 371-374, February-May, 1909. $8^{\circ} \cdot 9$ in $^{3}$ in.

"** An excellent list of the phjlatelic works and journals pubin the Austrian Empire to the end of 1900.

Thebussem (Dr.)-See Figueroa (M. P. De)

TrFany (Ј. к.)-The Philatelical library. A catalogue of stamp publications. . . .

St. Louis, Mo., Cambridge, Mass., [printed], I874.

$4^{\circ} \cdot 10 \frac{1}{\mathrm{in}}$ in $\mathrm{vi}+(4)+110+(2)$ pp. Coloured paper wrapper.

* The edition was limited to one hundred and fifty numbered

copies. This was the first published bibliography of philatelic parature in a separate form. The work is divided into thre parts: 1. Philatelic journals aud works: 11. Price-lists, circulars, post offic Stanp articles in non-philatellic magazines, works on the post ofleo, ete: "Part 1. is sub-divided into eight divisions under the coun ctes: "American-Danish-Datch-Euglish-French the frst eilant the same "Rission" "and Part IrTe as for Part 1., and the addition of collection, and Part int. has eight headings: "Articles on stamp collecting- - History of postage stamps-History of post office reform-History of the post office-Postal periodicals-Postage stamp games - Postage stamp music - Postage stamp photographs. The usefulness of the work is somewhat impaired by these numerous divisions, by the absence of cross-references and by the lassertion of the journals under the name of the publisher instead of under the title. Notwithstanding these defects the work condains much information as regards details of the early publications that is to be found nowhere else, and it remains to this day one of the most valuable sources of information for the philatelic literature collector.

- Philatelical Journalism in Great Britain. In The Foreign-Stamp Collectors' Journal, Bury St. Edmund's. Vol. IV., No. 41, March, 1882.

$8^{\circ} .7 \frac{1}{2}$ in.

** This is a list of journals published in the years 1878-1881, and is stated to have been compiled by an American correspondent [the late Mr. J. K. Tiffany] the papers are arranged by the name of the publisher under each. year and the titles and numbers
issued are given, but the places of publication are not mentioned.

The Stamp Collector's Library Companion. A chronological catalogue of all publications published wholly or chiefly in the interests of stamp collecting. Brought up to January 1, 1889.... Part I., United StatesPeriodicals. . I 889 .

Chicago, Illi., The Western Philatelic Publishing Co.,

$4^{\circ} .10 \frac{1}{1}$ in. $24+(2)$ pp. Coloured paper wrapper.

* * The title fully described this work, except that the catalogue also includes the names of journals announced for publication,
but which never appeared.
Tifrany (J. к.) -Addenda to the Stamp Collector's Library Companion. ... . I 890 . Chicago, Ill., The Western Philatelic Publishing Co.,

$4^{\circ} \cdot 10 \frac{1}{4}$ in. $6+(2) \mathrm{pp}$.

** Contains a list of corrections to be made in the "Stamp Collector's Library Companion," a table of additional numbers published in 1889 by journals current when the "Companion" was published and a list of new journals issued or announced in the United States during the year 1889.

-... An Addendum to the "Stamp Collector's Library Companion". ... Comprising all papers issued between January, 1890 and January, 1892. In The American Philatelist. Vol. vi., No. 5, May, 10, 1892. $\mu .72-75$ $8^{\circ} .103$ in.

** The list is divided into two divisions: (1) "Additional numbers issued by journals in existence at time last addendum was published "; (2) "New journals issued in 1890 and 1891 ".

- Etudes de Bibliographie Timbrologique. In L'Annonce Timbrologique, Liége. Vol. III., No. 24, February, 1892.

Fol. $12 \frac{1}{2}$ in.

*** This article contains a list of journals published in French to the end of 1891, arranged under their titles in chronological order, with the name of the publisher, place, number of parts issued, etc. The list was drawn up by Mr. J. K. Tiffany and was included by Dr. Legrand in his "Etudes de Bibliographie Timbrologique," with notes thereon by the latter.

The Stamp publications of Canada. In The American Philatelist, St. Louis, Mo. Vol. vir., No. 1, January 10, I893.

$8^{\circ} .10 \frac{3}{4}$ in.

*** This interesting and valuable article gives a review of the philatelic publications of Canada and a chronological list of the journals with particulars of the parts issued to the end of 1892 .

English Stamp publications. In "The Stamp News Annual, for the year 1894".

London, Theodor Buhl and Co., 1894.

$4^{\circ} .93$ in. pp. $40-48$

"* Consists of an introduction followed by a list of the journals arranged under the titles in chronological order, with the inclusion of the names of journals advertised to be published, but which never appeared. The list is completed to October, 1893.

\section{II.-JOURNALS.}

Auxiliary Phifatelist and Phifatelic-Literature-CotLeotor Combined. See Philatelic Ltterature ColLECTOR, Houlton, Maine.

The Echo. Published in the interest of philatelic literature Biy Run, Pa., J. M. Thompson, No. 1, January, I900. $8^{\circ} .8$ in.

The Journal of the Phtratelic Literature Societr. London, Nos. 1- . January, 1908 $4^{c} .11 \frac{3}{4}$ in. Published quarterly. In progress.

Philatelic Ltmerature. Taunton, Mass., Kirby and Benton, 2 vols., 8 numbers.

$8^{\circ} .8 \frac{1}{1}$ in. Vol. I., November 21, 1896, January 18, June 22 , December 25, 1897, March 21, June 15, 1898, Nos. 1-6. Vol. II. July 31, 1899, February 17, 1900. Nos. $7-8$. * Nos. 7-8 were published by Andrew J. Kirby and each of these numbers has a two-page supplement.

- Philatelic Literature. A monthly magazine. London, C. J. M. Lehner, Nos. 1-4, March 25-June 25, 1901.

tha sutgo. 7 iu. Coloured paper wrapper to each number.
Philatelio Literature. Columbus, Ohio, George W. Linn, - No. 1, July, 1902. $8.7 \mathrm{in.}$

Philatelio Literature. Red Creek, New York, W. C. Q Wendover, No. 1, January 10, 1903 $8^{\circ} \cdot 8 \frac{3}{4}$ in. ** The number consists of a single leaf and contains advertise-
ments only.

The Phimatelic Literature Collector. St. Joseph, Mo. ○ H. C. Beardsley, No. 1, Autumn, 1888. $8^{\circ} .8 \frac{3}{4}$ in.

Philatelic Literature Coliector. Houlton, Maine, L. H. Mutch, 2 vols., 15 numbers. $16^{\circ} .4 \frac{1}{2}-5 \frac{1}{4}$ in. Vol. I., May, July, September-Christmas, 1896,
January, March, April, June, 1897, Nos. 1-10. Vol. II., August, November, 1897, January, April, May, 1898, Nos. 11-15. November, 1897, January, April, May, 1898, Nos. $11-15$.
* Each number has a paper wrapper, and nos. 1 and 10 each
have a two-page supplement. No. 15 was published by John have a two-page supplement. No. 15 was published by John the title" "Auxiliary Philatelist and Philatelic-Titerature Collector combined," Houlton, Maine, $32^{\circ}$. 4 in. The number has a coloured paper wrapper with the 
title "The Auxiliary Philatelist. With which is combined the Philatelic Literature Collector, No. 16. Devoted to stamps and stamp literature collecting." Future numbers bore the title "The Universal Fixchange and Auxiliary Philatelist," or "Auxiliary Philatelist and Universal Exchange".

The Phicatelic Literature Collector. Westbury, New York, W. C. Wendover, Nos. 1-3, January, Spring, Summer, 1901. $32^{\circ} .4-4 \frac{1}{2}$ in. der philat. Litteratur. Gumbinnen, R. Rose,jun. Nos. 1-2, Jan. 6, Feb. 5, 1894

$8^{\circ} .7 \frac{3}{1}$ in.

Die Philatelistische Litteratur. Leipzig, Baumbach $\rightarrow$ and Co., 3 vols., 36 numbers.

$4^{\circ} .9 \frac{3}{4}$ in. 1st year, January 15-December 15, 1895. Nos. 1-12. 2nd year, January 15-December 15, 1896. Nos. 1-12. 3rd year, January 15-November 15, 1897. Nos. 1-12.

" "This was presented as a supplement to the numbers of "Die Post" for 1895-97. There is no number for March or for Decem ber, 1897, but there are two numbers for April, and also two for October of that year.

Der Philatelistische Litteratursammler. Leipzig, $D r$. Rommel, Nos. 1- October 20, 1906- In progress.

* Nos. 1.5 are type-written while the subsequent numbers are produced by autographic lithography. No. 1 measures 13 in. and the other numbers $11 \frac{1}{2}$ in.

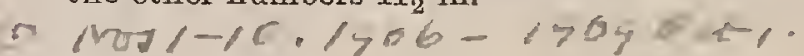


SECTION I.

\section{(BIBLIOGRAPHICAL)}

\section{(A) BIBLIOGRAPHIES}

1 CARNEGIE LIBRARY OF PITTSBURG. Books in the Library of the American Philatelic Society. (Pittsburg, Carnegie Library, 1910). C 73 2 CHECK

ENGLISH OF THE PHILATELIC PUBLICATIONS IN THE EANGUAGE FOR THE YEAR 1909. Compiled and arranged for the American Philatelic Literature Society by W. R.

3 AMERICAN PHILATELIC SOCIETY. Coloured paper wrapper. Committee on Philatelic Literature. 14th Annual Report of the tions and corrections by Philatelic Society, 1913) Publichers

4 - 16th Report. (1915). 40 pp. Coloured paper wrapper.

PHILATELIC LITERATURE, 1862-1865. B 108 pp. 32 plates. Edition of P.L. 19 uope

6 PHILATELIC LITERATURF COLPaper wrapper. scences and Extracts from a Diary scences and Extracts from a Diary. By P. J. Anderson. $47 \mathrm{pp}$.

7 SCOTTISH PHILATELIC LITERTIUE,

And

8 SECOND ROUGH LIST OF SPECIMENS OF PHI, 1923.) LITERATURE FROM THE ABERDEEN UNIVERSITY LIB= RARY. By P. J. Anderson. 47 pp. (1913). Coloured paper

9 BIBLrapper.

Writings, General, Special and - Vol. VII. A Bibliography of The Philass, General, Special and Periodical, Forming the Literature of

10 CATALOGUE OF THE PHILAT Press, 19II). Bound cloth.

OF CR WF THE PHLATELIC LIBRARY OF THE EARL G. B. E. Bacon. (London, 1911). Bound half morocco.

11 - Another copy. Interleaved. Contains numerous manuscript notes by E. D. B. Bound half morocco.

2 - Supplement. (London, 1926) Coloured paper wrapper. Contain manuscript notes by E. D. B and a copy of "Addantains "Lont. . ". by E. D. Bacon: presented as a supplement to the

13 STORY OF "STAMP COLLECTING", By P C Bishop (Loton, nd.) Author's edition of 50 . Bishop. (London,

14 BIBLIOGRAPHIE TIMBROLOGIOUE Coloured paper wrapper. BELGIQUE. By P. de Bosredon. 74 PP. FT DE LA ( Col-

15 CHRONOLOGISCHE TELISTEN ZCETCHEN PHILA. (Berlin, 1894). Coloured paper, 1863-1893. By H. Fraenkel. 7 pp.

16 PHILATELIC LIBRARY. By F J. Melvile.

Paper wrapper. Paper wrapper. STOCKHOLERIGES FILATELIST=FORENINGS BIBLIOTEK (Stockolm,

18 LITERATURA PHILATELIC paper Wrapper.

cion De Un Catalogo. By Dr. Thebussem. 33 pp. (Seville, 1876 ). Coloured paper wrapper. erature; Bibliour countries (as ); and Library

rticular period; early journals;

1 in their appropriate

p2.8

ipal Complete Wo Post free (S.C.A. I912) ... $1 / 2$ ipal Complete Works ipar Complete Work $1 / 2$ th Annual Report of Literature. Being a
Vorks (throw (English Language Iuly I9xi, to Augus W. R. Ricketts with 1
$\frac{1}{4} \times 6 \frac{1}{2}$. A. Nast and

Society. 15th Annual In to the r 4 th Annual

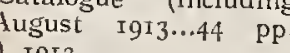
the Most Importan $\begin{array}{llll}\text { conpiled by R. E. R. } & \\ \ldots & \ldots & \ldots & \ldots\end{array}$ ciety. 16th Annual logue to January igrs
iville, Ind.) I 915 .. Melville (S.C.F. 752) F. J. Melville (S.C.A.

... $3 / 9$

Melville (S.C.F. 779) 6d. Short Papers for the
ille (S.L. I., I/4; II.,

. I. $_{11} \cdots \quad \ldots \quad \ldots 6 /$ I. 2) $\ldots \quad \ldots \quad$ 1/ S.L. II. IO)
ton (S.L. VI. ... $\quad$... $\quad \ldots$ I/ $\begin{array}{lll}\text { Collectors," etc., by } \\ \text { ivIt, 6) } & \ldots & \text {... }\end{array}$ s, by F. J. Melville llography, by $\quad$ F. $\quad$ J. 10/6 iijou bibliography, by $5 \frac{1}{2} \times 8 \frac{1}{2}$. London 1925 .
1 y (1864) (J.P.L.S. VI. $\begin{array}{lllll}\ldots & \ldots & \ldots & \ldots & 10 / 6\end{array}$ $\begin{array}{llllll}\text { sy B. T. K. Smith } & \\ \ldots & \ldots & \ldots & \ldots & 10 / 6\end{array}$ 



\section{SECTION I. \\ (BIBLIOGRAPHICAL)}

\section{(A) BIBLIOGRAPHIES}

1 CARNEGIE LIBRARY OF PITTSBURG. Boolss in the Library of the American Philatelic Society. (Pittsburg, Carnegie Library, 1910). $20 \mathrm{pp}$.

2 CHECK LIST OF THE PHILATELIC PUBLICATIONS IN THE ENGLISH LANGUAGE FOR THE YEAR 1909. Compiled and arranged for the American Philatelic Literature Society by W. R. Ricketts. (Columbus, 1911). 89 pp. Coloured paper wrapper.

3 AMERICAN PHILATELIC SOCIETY. 14th Annual Report of the Committee on Philatelic Literature. By W. R. Ricketts, with additions and corrections by C. A. Nast and E. R. Aldrich. (American Philatelic Society, 1913). Publishers' boards.

4 - 16th Report. (1915). 40 pp. Coloured paper wrapper.

5 EARLY ENGLISH PHILATELIC LITERATURE, 1862-1865. By P. J. Anderson and B. T. K. Smith. 108 pp. 32 plates. Edition of 120. (London, 1912). Coloured paper wrapper.

b PHilatelic Literature COLlecting IN 1864-79. Reminiscences and Extracts from a Diary. By P. J. Anderson. $47 \mathrm{pp}$. (London, 1919). Coloured paper wrapper.

7 SCOTTISH PHILATELIC LITERATURE, 1863-1923. By P. J. Anderson. (Article in "The Philatelist," No. 8. November, 1923.)

8 SECOND ROUGH LIST OF SPECIMENS OF PHILATELIC LITERATURE FROM THE ABERDEEN UNIVERSITY LIB= RARY. By P. J. Anderson. 47 pp. (1913). Coloured paper wrapper.

9 BIBLIOTHECA LINDESIANA.-Vol. VII. A Bibliography of The Writings, General, Special and Periodical, Forming the Literature of Philately. (Aberdeen University Press, 1911). Bound cloth.

CATALOGUE OF THE PHILATELIC LIBRARY OF THE EARL OF CRAWFORD, K.T. By E. D. Bacon. (London, 1911). Bound half morocco.

11 - Another copy. Interleaved. Contains numerous manuscript notes by E. D. B. Bound half morocco.

12 - Supplement. (London, 1926). Coloured paper wrapper. Contains manuscript notes by E. D. B. and a copy of "Addenda to the "Supplement. .." by E. D. Bacon; presented as a supplement to the "London Philatelist," March, 1938.

STORY OF " STAMP COLLECTING." By P. C. Bishop. (London, nd.) Author's edition of 50. $16 \mathrm{pp}$. Coloured paper wrapper.

BIBLIOGRAPHIE TIMBROLOGIQUE DE LA FRANCE ET DE LA BELGIQUE. By P. de Bosredon. 74 pp. (Brussels, 1878). Coloured paper wrapper. The front cover is loose.

CHRONOLOGISCHE TABELLE DER DEUTSCHEN PHILA. TELISTEN ZEITSCHRIFTEN, 1863-1893. By H. Fraenkel. 7 pp. (Berlin, 1894). Coloured paper wrapper.

16 Philatelic LibRaRY. By F. J. Melville. (London, nd.) 20 pp. Paper wrapper.

17 KATALOG SVERIGES FILATELIST=FORENINGS BIBLIOTEK STOCKHOLM, MALMÖ, NORRKOPING OCH BORAS. $28 \mathrm{pp}$. (Stockholm, 1908). Coloured paper wrapper.

LiteRATURA PHILATELICA EN ESPAÑA. Apuntes Para La Redaccion De Un Catalogo. By Dr. Thebussem. 33 pp. (Seville, 1876). Coloured paper wrapper. 
PHILATELICAL LIBRARY. A Catalogue of Stamp Publications. Attempted by J. K. Tiffany. 111 pp. (St. Louis, 1874). Bound half morocco.

STAMP COLLECTOR'S LIBRARY COMPANION. By J. K. Tiffany. 24 pp. (Chicago, 1889). Coloured paper wrapper.

21 - Addenda. 6 pp. (1890). Paper wrapper.

22 GRATIS STAMPS DISTRIBUTED BY THE "STAMP COL" LECTOR'S MAGAZINE." By Sir John Wilson. (Reprinted from "The London Philatelist"). 16 pp. 2 plates. (London, 1934). Coloured paper wrapper.

\section{(B) INDEXES}

25 STANDARD INDEX TO PHILATELIC LITERATURE, 1879-1925. Edited by A. H. Harris. $146 \mathrm{pp}$. In parts as issued. Unbound.

25 a - Ditto. Bound.

26 BIBLIOGRAPHI DER WICHTIGSTEN SPECIALWERKE UBER DIE POSTWERTZEICHEN EINZELNER LÄNDER. By R. Krasemann. 45 pp. (Stockholm, 1907). Coloured paper wrapper.

27 - 2nd Abdruck. 40 pp. (Hanover, 1908). Paper wrapper.

28 PHILATELIC INDEX. Being an Alphabetical List of the Principal Articles Contained in a Selection of Some of the Best Known Philatelic Magazines in the English Language up to the End of 1904. By W. A. R. Jex Long. 114 pp. (Glasgow, 1906). Publishers' binding.

29 - Compiled by an Index Committee Appointed by the Philatelic Congress of Great Britain. (June, 1925). 248 pp. Publishers' binding.

30 REPERTOIRE BIBLIOGRAPHIQUE DE LA PRESSE PHILA= TELIQUE MONDIALE. By F. P. Renault D'Oultre-Seille. ler Semestre, 1929. 47 pp. Coloured paper wrapper.

31 - 2e Semestre. 47 pp. Coloured paper wrapper.

32 AMERICAN PHILATELIC SOCIETY PHILATELIC INDEX. Compiled by W. R. Ricketts, assisted by C. W. Kissinger. pp. $1-154$. (Extracted from the "American Philatelist" from February, 1911, to August, 1912).

33 BIBLIOGRAPHIE ZUGLEICH NACHSCHLAGEBUCH DER GESAMMTEN DEUTSCHEN PHILATELISTISCHEN LITERA= TUR SEIT IHREM ENTSTEHEN BIS ENDE 1891. Nebst Einem Abriss Der Geschichte Der Philatelie Mit Besonderer Berücksichtigung Deutschland's Und Einer Kurzen Geschichte Der Deutschen Philatelistischen Literatur. By V. Suppantschitsch. $748+1$ pp. (Munich, 1892). Bound half calf.

34 LIST OF ARTICLES ON POSTAGE STAMPS, \&c. By F. H. Vallancey. $64 \mathrm{pp}$. (London, 1922). Coloured paper wrapper. (Also many other catalogues, lists, etc., by the same author). 




\section{BIBLIOGRAPHY}

The distinction between Sections " $A$ " and " $B$ " hereunder is that

SECTION "A" consists of General Works dealing with Philatelic Literature; Bibliographies of the works of any particular firm or person, or of particular countries (as distinct from publications dealing with the stamps of such countries); and Library Catalogues.

SECTION "B" contains Indexes to Philatelic Literature for any particular period; Special Indexes, or Index-Volumes to periodicals; Historical Studies of early journals; and Summaries of the Contents of journals.

Bibliographies or Indexes dealing with certain issues of stamps or certain countries will be found in their appropriate places in the body of this work.

\section{SECTION A.-General References}

Literature.

Post free

for the Novice and Specialist (P.S. 544) $\quad \ldots \quad$... 6 d.

Notes on Early, by P. J. Anderson (S.C.F. 437) … 6d.

Principal Sources of Information for Collectors, by E. D. Bacon (J.P.L.S. I. I, 2) ... ... £1 $1 /$ -

* - See Catalogue of the Fnilatelic Library of the Earl of Crawford, K.T., by E. D. Bacon. Columns $913 / 9^{24}$. Ioxi4. London rgi $\ldots$... $22 /-$

Delights and Perplexities of Collecting, by P. C.

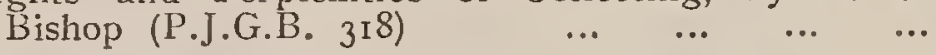
A Short Survey, by H. Clark (S.Cr. I20) _.. … 6d

Some Advantages of, by L. A. Gibbens (S.C.F. 756) Ed. Importance of, by R. Gibbons (A.S.J. XIV. I2) 6d.;

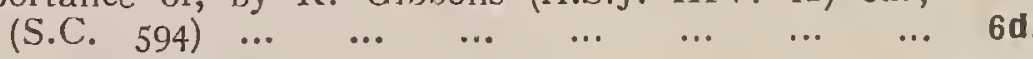

By B. S. H. Grant (S.L. XVI. I0) $\ldots$... ... $1 /-$

Postal and Philatelic Literature, by R. H. Halliday (P.J.G.B. I 70)

The Lure of by E. B. Hill (S.C. 292)

Sources of Information for the Student, by F. J.

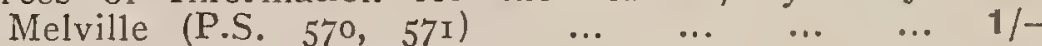

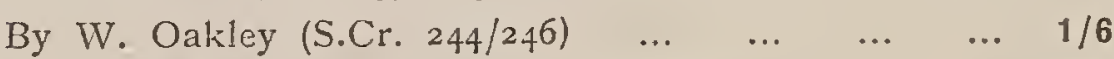

Philatelic Encyclopæedia, by A. Palethorpe (P.S. 77) ... 6d.

\section{Argentine.}

Catalogue des Journaux Philatelique et Cartophiles publies dans la Republique Argentine de 1874 à 1908, par Abel Fontaine (J.P.L.S. I. 4, II. I) £1 $1 /$ -

\section{Auction Catalogues.}

British (to I90I), by G. Jolnnson (S.Cr. 54, 56) $\ldots$. 1/-

Australasia.

Australian Philatelic Journals (A.J.P. V. I, 5, 8) ... 3/-

Bibliographies.

tThe Earliest Philatelic Bibliography (J.P.L.S. V. 2) $10 / 6$

1894: English Literature of, by W. R. Wallace (S.N.A, V.) ...

*1899/1900: Second Annual Report of the Committec on Philatelic Literature of the Anerican Philatelic Association for the year ending August 3I, Igoo. i 8 pp. $8 \times 10 \frac{7}{2}$. (Flemington, N.J., I 900) ..

*1909. A Check List of the Philatelic Publications in the English Language for the year Ig09...compiled.. by W. R. Ricletts...87 pp. $4 \frac{3}{t} \times 7$. Columbus, Ohio, IgII ..

tFound in Dr. Gray's Catalogue, First Edition, 1862

tThe first, third to thirteenth (inclusive), seventeenth and all subsequent editions were published in the American Philatelist.
1910/1912: Check List of Principal Complete Works published, compiled by H. Clark (S.C.A. I912) ...

1911/1912: Check List of Principal Complete Works published, compiled by H. Clark (S.C.A. I913) ...

* American Philatelic Society. I4th Annual Report of the Committee on Philatelic Literature. Being a Catalogue of all Separate Works (throughout the world) and the Periodicals (English Language the Periodicals (English Language only) that have appeared July IgI I, to August Ioth, rg12. Compiled by W. R. Ricketts with additions and corrections by C. A. Nast and E. R. Aldrich...r59 pp. $4 \frac{1}{4} \times 6 \frac{1}{2}$. (Jeffersonville,

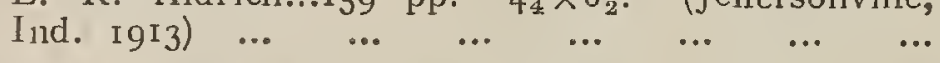

*1912/1913: American Philatelic Society. I5th Annual Report...Being an Addendum to the I4th Annual Report...continuing the Catalogue (including Foreign Periodicals) to August I9I3...44 pp.

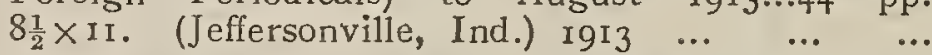

1913 : Tentative Check List of the Most Important Complete Works published, compiled by R. E. R.

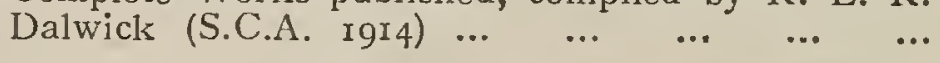

*1914: American Philatelic Society. I6th Annual Report...Being an Addendum to the r $5^{\text {th }}$ Annual Report...continuing the Catalogue to January igI5

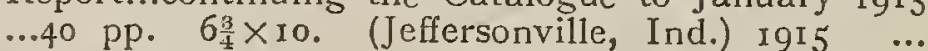

1923: Stamp Books of, by F. J. Melville (S.C.F. 752) 1923/1924: Stamp Books of, by F. J. Melville (S.C.A. $\begin{array}{lllllllll}\text { 1925) } & \ldots & \ldots & \ldots & \ldots & \ldots & \ldots & \ldots & 3 / 9\end{array}$ 1924 : Stamp Books of, by F. J. Melville (S.C.F. 779) 6d. The Stamp Lovers' Library. Short Papers for the

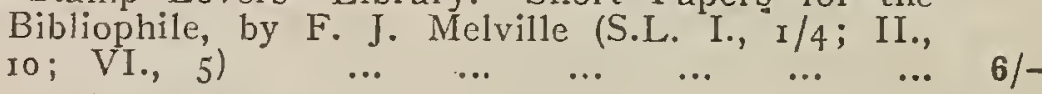
I. Mr. Mount Brown (S.L. I. I) $\ldots$ I/2. M. Pierre Mahé (S.L. I. 2) $\ldots . \quad \ldots \quad$ I/3. Dr. Gray (S.L. I. 3, 4) 4r. Frederick Booty (S.L. II. Io) $2 /-$

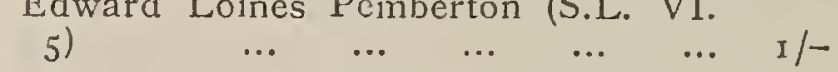

F. Sooty: "Aids to Stamp Collectors," etc., by B. T. K. Smith (P. R. XXVII. 6) $\ldots$. … $1 /$ -

Dr. Gray: and his Catalogues, by F. J. Melville

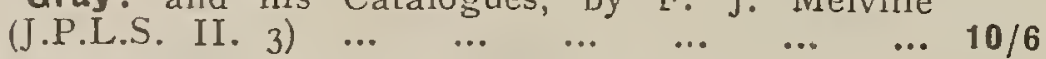

G. A. Higlett: A Bijou Bibliography, by F. J. Melville (S.L. XVI. 7) $\ldots \begin{array}{llllll}\ldots & \ldots & \ldots & \ldots & \ldots & 1 /-\end{array}$

The Higlett Booklets. A Bijou bibliography, by Fred. J. Melville. 9 pp. $5 \frac{7}{2} \times 8 \frac{1}{2}$. London $19^{2} 5$. Illus. Lallier's Philatelic Bibliography (i 864 ) (J.P.L.S. VI. 4) $\quad \begin{array}{llllllllll} & \ldots & \ldots & \ldots & \ldots & \ldots & \ldots & \ldots & \ldots & 10 / 6\end{array}$

P. Mahé: Publications of, by B. T. K. Smith

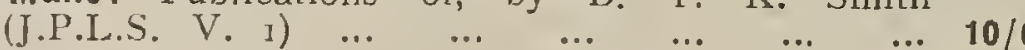


Bibliographies (continued).

Post free

J. Moens: Larly Publications of (J.P.L.S. VII. I) 10/6 $\triangle$ Note on J. B. Moens' Catalogue Prix-Courant of I 868 , by H. E. Weston (J.P.L.S. V. 4) ... .. $10 / 6$

Mount Brown: Notes on his Catalogues, first published in 1862 , by F. Hagen (A.P. XVI. 7/9) ... $3 /$ -

E. L. Pemberton: Publications of, by F. J. Peplory P.L.S. III. 2) $\ldots$

F. A. Philbrick: Writings of, by E. D. Bacon (J.P.L.S. IV. 2) $\quad \ldots \quad$...

Alfred and Stafford Smith: Publications of, by B. T. K. Smith (J.P.L.S. II. I, 2) ... \&1 1/

Société Francaise de Timbrologie: Publications of the, $1875 / 1896$, by B. T. K. Smith (J.P.L.S. II. $1,2)$

Binding,

On the Binding of Literature, by F. J. Peplow (J.P.L.S. I.

\section{British Empire}

*...A Chronological, Alphabetically Arranged List of al known Philatelic Periodicals of the British Colonies. Fron 1864 to 1902 . Giving all Numbers E. B. Jones...13 pp. $5 \frac{1}{4} \times 7^{\frac{3}{4}}$. Sioux City, Iowa 1904

*...A Chronological, Alphabetically Arranged List of al known Philatelic Journals of Great Britain and Colonies from the earliest issued down to the end of the year Ig04...E. B. Jones...43 pp. $5 \frac{1}{2} \times 8$. Sioux City, Iowa, 1907 ..

Canada.

PERIODICALS, see under UNITED STATES

Collecting,

1864/1879: By P. J. Anderson (J.P.L.S. XI. I/3)

Guriosities.

By, H. Clark (S.L. V. 5)

Fiction.

Philately in, by F. J. Melville (P.S. 488)

German Empire.

* Chronologisehe Tabelle der deutschen philatelistischen Zcitschriften $1863 /$ I 893 . Zusammengestellt von $\mathrm{H}$. Fraenkel. ${ }_{5}$ pp. $8 \frac{1}{2} \times 11 \frac{1}{4}$. Berlin $1894 \ldots . .$.

*Bibliographie zugleich Nachschlagebuch der gesammten deutschen philatelistischen Literatur seit ihrem Entstehen bis Ende I801 nebst einem Abriss der Geschichte der Philatelie mit besonderer Berücksichtigung Deutschland's und einer kurzen Geschich Literatur verlasst und bearbeitet von Victor Suppantschitsch ...749 p1. $5 \frac{3}{4} \times 8 \frac{3}{4}$. München $1892(-94) \quad \ldots \quad$..

\section{Great Britain.}

Notes on Early English Literature, by P. J. Anderson (P.R. 76, 77, 79, 80) $\quad \ldots \quad \ldots \quad \ldots \quad \ldots$

English Stamp Publications, by J. K. Tiffany (S.N.A. IV.)

Pionecr British Press, by P. C. Bishop (S.C.F. 246,

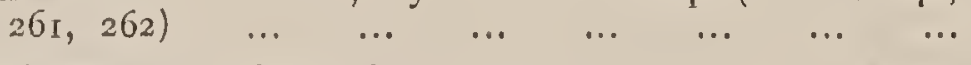

1862/1865 : English Literature, by P. J. Anderson and B. T. K. Smith (J.P.L.S. IV. I/4) ‥ £2 2/Early English Philatelic Literature, $1862 / 1865$, by P. J. Anderson and B. T. I. Smith. 96 pp.t 32 plates. $5 \frac{1}{2} \times 8 \frac{3}{4}$. London Igr ... … £2 $2 /$ 1863/1923: Scottish Literature, by P. J. Anderson

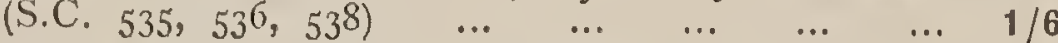
See also under BRITISH EMPIRE.

Holland.

Rise and Development of Philately in, by H. E. Weston (J.P.L.S. VIII. 2)

Ideal Handbook

By W. B. Haworth (S.C.F. 728 )

\section{Library(ies).}

*A Collectors' Catalogue of Philatelic Literature, $\begin{array}{lllllll}\text { compiled by } & \text { P. } & \text { C. } & \text { Bishop. } & 39 & \text { pp. } & 4 \frac{3}{4} \times 7^{\frac{1}{4}} \\ \text { London rgr }\end{array}$

By G. L. Campbell (P.R. XXIX. 6, 8, 9) $\ldots . \quad \ldots \quad 3 /-$

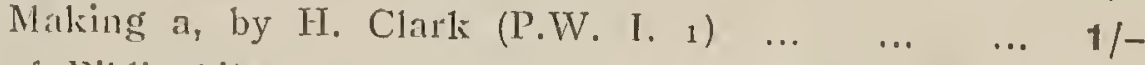

of l3ibliophiles, by H. Clark (S.L. III. 7) $\ldots . \quad \ldots \quad 1 /-$

*The Philatelic Library, by Fred. J. Melville. 20 pp. $4 \frac{3}{4} \times 7 \frac{1}{4}$. London 1924

Its Uscs and How to Form it, by W. H. Poole (G.S.W. $132 / 134$ )
How to Compile and Catalogue a, by H. D. Roberts

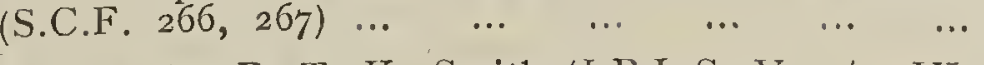

Notes in a, by B. T. K. Smith (J.P.L.S. V. 2/4, VI. I/4, VII. 4, VIII, 2/4, IX. 2/4, X. I, 2) ...

*Die Entstehung und Entwicklung der Philatelistische Literatur in der zweiten Hälfe des XIX. Jahrhunderts von Victor Suppantschitsch...6 3 pp. $5 \frac{1}{2} \times 9$. Wien I 901

Aberdeen University Library: Philatelic Works in the (J.P.L.S. I. 4 )

British Museum: Philatelic Works in the, by B. T. K. Smith (J.P.L.S. I. 2) $\quad \ldots \quad$...

Herbert Clark Library (J.P.L.S. III. I) $\quad \ldots \quad \ldots \quad 10 / 6$

* Crawford Library: Catalogue of the Philatelic Library of the Earl of Crawford, K.T., by E. D. Bacon. X. pp. +924 columns. ro XI4. London $\begin{array}{lllllllll}\text { IgI I } & \ldots & \ldots & \ldots & \ldots & \ldots & \ldots & \text { क }\end{array}$

* - Supplement...by E. D. Bacon...136 columns. 10 X 14. London 1926

- Notes on the (and additions), by V. Suppantschitch (J.P.L.S. V. 3, 4, VI. I) … ... \&1

- Complete Files of Periodicals Issued since. the publication of the, in the Library of Mr. W. R. King (J.P.L.S: XI. 1, 3)

By E. D. Bacon (J.P.L.S. I. 3)

Emilio Diena Library (J.P.L.S. II. 2) ...

* Herts. Philatelic Society Library: Catalogue of Handbooks, Journals, etc., in the Library of the Herts. Philatelic Society at Christmas igro.. compiled...by the Editor of the Monthly Report of the Herts. Philatelic Society...53 pp. $5 \frac{1}{4} \times 8$ London (I9II)

* Second Edition...on 3ist March r913...63 pp $5 \frac{1}{2} \times 8 \frac{1}{2}$. London 1913

Junior Philatelic Society Library: +By A. B. Creeke

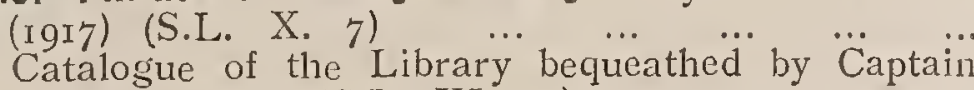
L. W. Crouch (S.L. XI. I0) ...

Fred. J. Melville Library (J.P.L.S. III. 3)

Royal Philatelic Society Library: By C. W. G Crawford (L.P. 368, 369)

By L. W. Fulcher (J.P.L.S. I. I)

*Alfred Smith Philatelic Library: Priced Catalogue of the Alfred Smith Philatelic Library. $106 \mathrm{pp}$ $6 \frac{1}{2} \times 8 \frac{1}{2}$. London $1913 / 1915$

Victor suppantschitch Library (J.P.L.S. II. I)

* Katalog der philatelistischen Bibliothek des Ober" landesgerichtsrathes Victor Suppantschitsch...bis Ende $1893 \cdots 34$ pp. $7 \times 10 \frac{1}{2}$. Graz (I897)

Die Seltenheiten der philatelisten Zeitungsliteratur bis Ende 1900, von Hofrath V. Suppantschitsch.. I2 pp. $6 \times 9 \frac{1}{4}$. (Leipzig I904) ...

*Sveriges Filatelist-Forenings: Bibliotelis-Katalog Biblioteket i Stockholm I922. Nr. 5. $9^{2} \mathrm{pp}$. $5 \frac{1}{2} \times 8 \frac{3}{4}$. Stockholm 1922

Miscellanea.

Autographs and Documents, by H. E. Weston (J.P.L.S. IX. 4)

Illustrated Music Titles; some Postal and Philatelic Examples, by W. E. Imeson (S.L. V. 5)

Stamp Catalogues.

Development of, in England, by F. J. Peplow (P.R. XXXI. I1, I2)

Earliest English, by B. T. I. Smith (P.R. XXVII. 6)

Earliest, by B. T. K. Smith (P.R. XXX. 4, 5) See also under BHBLIOGRAPHIES.

\section{United States of America.}

American Literature, by H. Clark (S.L. VI. 5)

*...A Numbered, Alphabetically Arranged Catalogue of nearly 600 United States and Canada Philatelic Papers and Magazines, from I 864 to Jan. I 895 . E. B. Jones...24 pp. $5 \frac{1}{2} \times 8 \frac{3}{4}$. Ruthven, Iowa 1895

* - Supplement...to January Ist, I $897 \ldots$ E. B. Jones... 8 pp. $\quad 5 \frac{1}{2} \times 8 \frac{1}{2}$. Sioux City, Lowa (1898)

*The Stamp Collector's Library Companion. A Chronological Catalogue of all publications published wholly or chiefly in the interests of stamp collectins. Brought up to January 1, 1889 , by John K. Tiffany...Part I. United StatesPeriodicals. 24 pp. $7 \frac{7}{4} \times 10$. Chicago 1889

* Addendum... by John K. Tillany. 6 pp. $7^{\frac{1}{4}} \times 10 \frac{1}{2}$. Chicago 1890

+Earlier Catalogues were published by Mr. Crecke but are not listed here.

\section{$1 /$} $8 /-$

.

- 








